

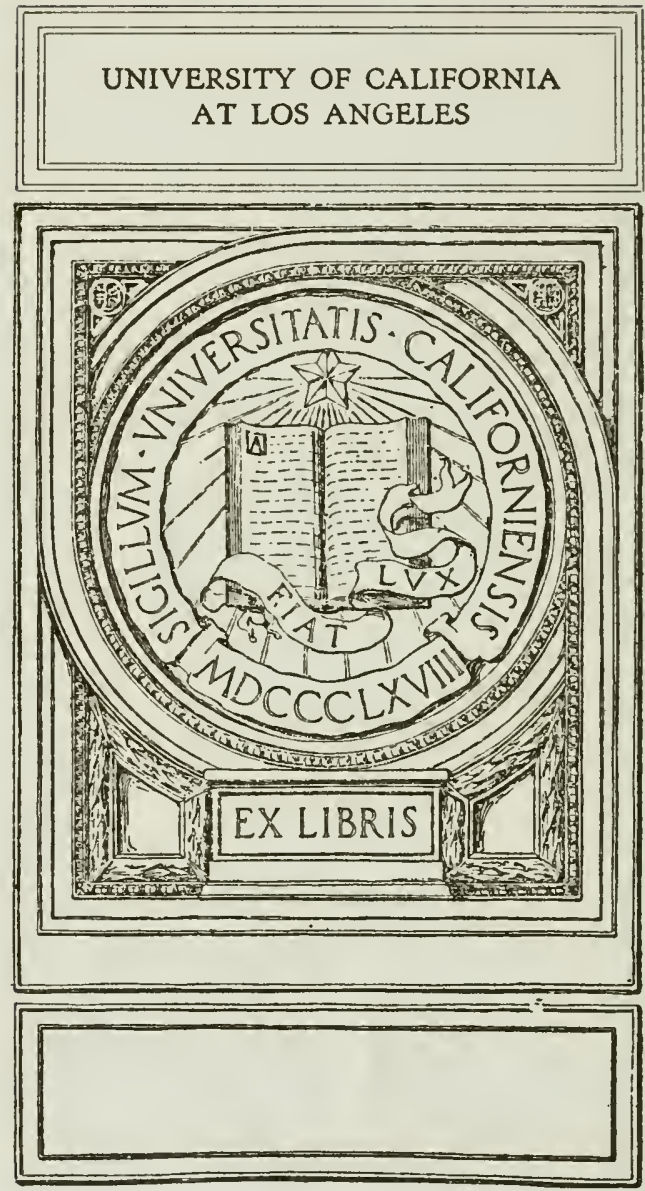






\title{
SOUTH CAKOLINA.
}

RESOURCES AND POPULATION.

INSTITUTIONS AND INDUSTRIES.

\author{
PUBILIIED BY THE;
}

\section{STATE BOARD OF AGRICULTURE}

OF SOUTH CAROIINA.

Governor HUGH S. THOMPSON, Chairman.

A. P. BUTLER, Commissioner. 



\section{TABLE OF CONTENTS.}

\section{PART I.}

CHAPTER I. INTRODUCTORY. Lochtion. Area: Mans, Gexerle Feate Rivers. Regions. Agriculture: Small Grain, Rice, Indigo, Indian Corn, Cot Sea Istand Cotton, Remarks. Diacira of Crops, 16 tito to 1880. pl. 1

CHAPTER II. COAST REGION. Lochtrox: Area, (haracteristics. GEnLo subsidence, Erosion, Sedimentation, Formation of Islands, Topography, Pursi Features, Tides. Solls: Uplants. Bays, Salt-Marshes. Axulsws: Error, Oceurr of Marls, \&c. Curmate: Health. Sritistics. Proncctross. Cotron: Three Kind Seeds, Ilybrids, Origin, Inprovement, and Characteristics of Sea Isianct. FAR: Number, Value of Land. L.nor: Tenures, Credits, Diagram, Enclostre's, Draina Plows, Hoes, Fallows. Cutcere: Of Seal Island ('otton. Exemes: ()t the Pla Handling. SEED: Santees and Mains. LnMTs: of Culture. Cons of Producti Yield, Itemized Statenent of Expenditures......................................1]. 1t-:

('HAPTER III. LOWER PINE IBLT, OR SAVANXA REGION. LOCATI Pursical-Features, Rivers, Lakelets, Elevation, Drainage, Irrigration, Freshet. Geolocis: C'retaceons, Buhnstone, Santee Marls, Ashley and Cooper Marls. Pros. phates: Oecurrence, Characters, Fossils, Changes, Origin, Extent. Mining. Sons: Uplands, Analyses, Swamps. Growril. Climate: Health. Stitistics. Pronlcrioxs: Rice Culture, Oats, firasses. Ares: In Cotton. Firus: Labor, Wages, Rerits. Value of Land, Credits. Tuldace: Fallowing, Rotation of C'rops, Manures. (uтrox: Culture, Iranding. Cost : Of Proulnction. Disasters to the Plant. Abstract of Township Cor-

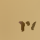
:n1 H. $+4-i 11$.

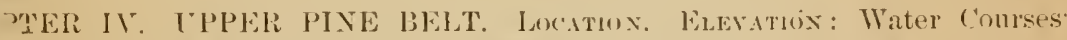
i: Creticeons, Mincene, amb Encene Marls, Bulırstone. Solls: Analyses. Pee

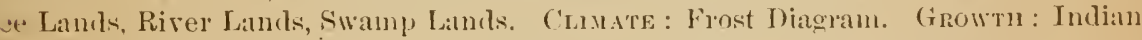

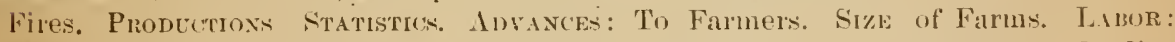
Wages, Rent, Value of Land. T.ıbs: Exhiliting Proluction in Relation to Creclits, Size of Farms, those liented and those Worked by Owners. Exclostres: Inainage, Fallows, Rotation, Tillage, Growth on Lands Lying Ont, Manures. CotTox: Cultnre, Handling. Ratro: Of Lint to Seed Cotton. Shrpesce. Crrass, Liee, Rust. Cos'r : Of Production. Ditto in 18ts. Anstrict ; of Township Correspontence........pp. it-1(n).

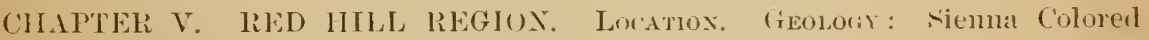
('lay, Gruvel Berl, Buhrstone, Siliceous Rock. Sons: Analyses. C'unc.te. Growtr. FTATITISS ..pp. 1111-111i.

('HAPTER VI. SANED HILL REgION. Pusition and Area: Elevation, Contour. Diagram, Streams, Lakelets, Blowing Wells. GsolociY: Granite, Sandstone, Loose sand, Kaolin Clay. Sols: Analyses. Grown and Productions. Chin ristes. ..1)?. 117-1:\%. 


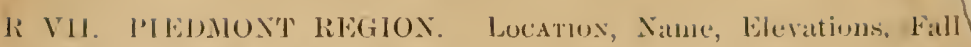
'atersluels, Rivers, Jable, Navigation. Nisology: 'Triple Ocenrrence reiss, Hornblende, Ilica slate, Ores and Minerals, Talc slate, bianond:

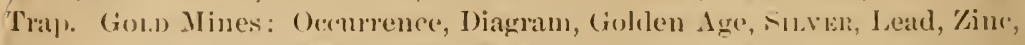
ismuth, Iron, liarytes, Manganese, (iraphite, lielspar. Asluestos, soajutone, urmaline, cormudum, Kireons. Sons: I)isintegration of locks. fonss: (iraly nalysu, Rerl Loams, Analyser, IIormblendic, Analysus, Mical Silate, Clay Slate, ; Trappean, Inalyses, Button lands. CLimate: Temperature, Rainfall, Malarial Line. Cirowti : Cane, l’ines, Chestnut. Provroruss: Cattle, Hemp,

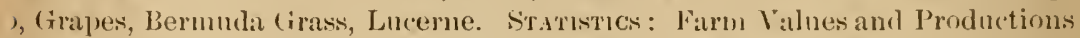
tion to System of Agriculture, Table, Deductions Land IJoldings, Provisions, nces, Banks. LAmor, Wages, Value of Lauds, Rents. Tudacik: Rotation, FallowJld Fields, Manuring. Cotton ('ulture, Enenies Crab Grass. Cirsixi, śmppixq, of l'roluction. Asstrict of Township Corres]ondence..................pl'. 126-182.

AAPTER VII. ALPINE RELION. Locoton: Features, Great Fault, Waters, Mountain Knobs, Elevations, Aspect. Geouons: Rocks, Ores, Minerals. Sorts. istus. Labor. Milatif. Cotton Culture. Cisxixg. Alustract of Township Correslence .pp. $183-19 \overline{\text { s. }}$.

HAPTER IX. WATER POIVERS. Sonres of Information. ThueE Regions, y'sical Conditions, Climate, Rainfall. IVater Courses, Table, Power Litilized, Table. athon of Estimating Water Power. Sumary of Powers, Notes. Afrucexti of the vamnah, Agrgegate of Power, Employment of Water Power, Cost...........pp. 19i-20s.

CHAPTER X. LIST OF VERTEPRATI: ANIMALS OF SOUTH CAPOLIXA. M.ımals, Birdi, Reptum, Fishes, Bibliography. [1). 209-264.

CHAPTER XI. LIST OF THE INVERTEBRATE FAUNA OF SOUTH CAROLINA. INTrontetory: Ixsecrs, Biblioglaplyy, SpIDers, Huxdren-lecis, Crabs. Worus,

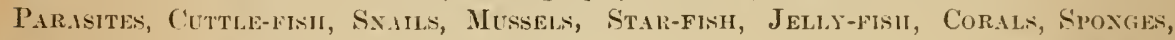
INitsorı, Bibliograply...

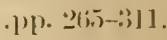

CHAPTER NII. LAST OF TIE PLANTS OF SOUTH CAROLINA. FLUWEX: Plants, with two seed leaves, witl one seed leat. Flowenisess Plants, Horsetails, Ferns, Club-mosses, Water-forns. Mosses. Lichens. Seaweed. Mushrooms. Summary. Biblingraplly p). $312-;: ; ! !$ !

\section{THBLES.}

1Abik 1. Meteorological Recurds from 1752 to 1880 .

TABLF II. Statisti('s of the Agrienltural Regions of South (arolina, 1sio.

TABLL III. Statisties of the Agrieultural Regions of Sonth Carolina, 18 io.

TAPIJ] IV. General Statisties of Agriculture in South Carolina, and in the United states, from 18.00 to 18 sio.

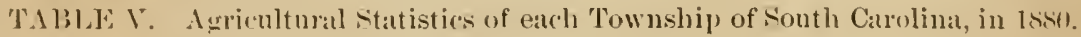

N. B. The data of 'lables II., 1II., and V. may be localized by reference to the Maj' aceompanying this Volmute. 


\section{PART II.}

CHAPTER I. POPULATION. INmans, Origin, Numbers, Nynopsis of Nations and Tribes, Survirors. Negroes, Introduction of, Numbers of Importerl, Rate of Increase from 1714 to 1790, from 1790 to 1865, Increase of Free Negroes, Increase in Sonth Carnlina, 1810 to 1880, Compared with Other Populations, Intermixture, Females, C'entres of Population, Divergence of African and European. Distrustriox of Yegro, Foreign, and Aggregate Population according to Elevation, to Mean Annual Temperature, to Snmmer Temperature, to Winter Temperature, to Highest'Temperature, to Lowest Temperature, to Rainfall. Distribution within the State, Chronologically. Difresiox. Euroreaxs, Chronology 1497 to 1783 , Nimbers, 1790 to 1880, Increase, 1790 to 1880, Tables, Diagram, No Antagonism of Races, Prospect. Mor enext of Population, Population Maps, 1790 to 1SS0, Tables. Formigners. Sexes. Ages, Aggregate Years Lived, Ratio of Different Ages, Tables, Military Age, Citizenship Age, Table, Dwellings and Families, Tables. P. 36 ? $3-399$.

CHAPTER II. VITAL STATISTICS. Mortuary Records, Comparison of Deaths in South Carolina and in the United States, Diagram, Death Rate of Foreigners. Marriuges: Table, Season. BirTiss: Number, Table, Season, Plurality Births, Still Births. Deatus: Table, 185;)-59, Months, Ages, Longerity, Causes of Death. M.ırakia DisEASEs: Census of 18so, Mortality in the Different Regions of the State, Age, Sex, Principal Diseases......................................................

CIIAPTER III. INATITUTIONS. Government and Laws of Sontl Carolina. Oratix of the name Carolina. Ciraracter and Nationalities of the colonists, Government under the Lords Proprietors. Locke's Constitution, the Royal (iovernors, Constitutions of 17 - 6 and 1790, Progress between the Revolutionary War and secession. Leantrg Prin ciples of the Constitution, Declaration of Rights and Form of (overnment, Legislative Department, Executive Department, Judicial Department; The Suffrage, Taxation, Education; The Militia, Marriage and Divorce, Amendments and Rerision of the Constitution. Tine StatuTe Law, Crimes and Punishments, Anrrler, Rape and Arson,

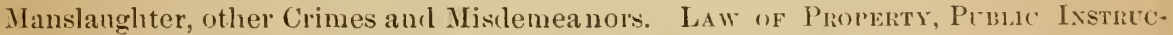

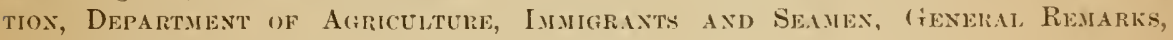
Altionities consulted. ..pl. t.1-14t.

SHAPTER IV. A SKEYCH OF EDTCATION IN NOUTH CAROLINA.

P1. 44.5-5.5!).

CHAPTER V. CHURCHEs. Church of England, other Clunrches, Negro Churdies, Tables

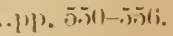

CHAPTER VI. OCCUPATIONS. Population Acconnterl for, Percentage of Worlyers, Increase. Sex, and Nativity, Changes of Occupation, Agriculture, Professional and Personal Services, Trade and Transportation, Mannfactures and Mining. The Lssive: Idiots, Blind, Deaf Mutes, Patupers, Prisoners............................

CHAPTER VII. MANUFACTIRES. Compared with Agriculture, lictrospect,

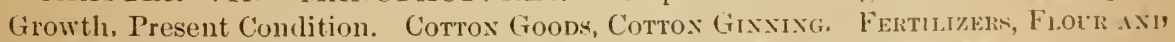
Grist Mills, Sawing Lumber, Turpextixe, and other Manfatures. Misisi: Phosphates, Kaolin, Granite, Fisheries. pp. $573-1910$.

CHAPTER VIII. THE HISTORY AND PRESENT CONITTION OF TRANSPORTATION IN SOUTH CAROLINA ..................................p., (i11-(it). 
CHAPTER IX, DEBT AND TAXITION. Fiscal History, Bank of the thate.

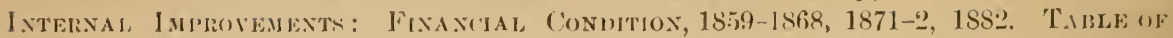

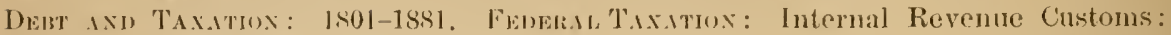

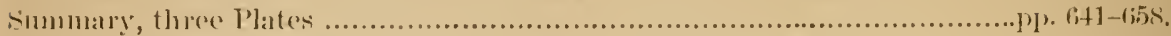

CIIAPTER X. TOWNS OF SOITH GAROLINA. Retrospect, Table of Towns aml Trading Points; Bank statement, 1849 to 3851. ('o.s Reciox: Port Royal, Beanfort, Momt l'leasent, Charleston, Georgetown. Low Fis Pise Bent : llampton, Colleton, Berkeley, Williamshurg, Clarendon, Ilorry. TPres PIxe Belt: Barmwell, Orange-

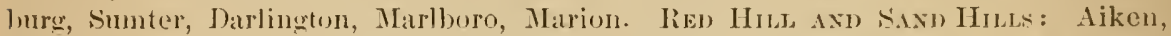
Lexington, Richland, Columbia, Kershaw, C'lesterfield. L'unnoxt Regiox: Abbeville, Anderson, Chester, Fairfield, Cireenville, Jancaster, Lamens, Newberry, Spartanburg, Inion, York. Alpine Reaiox: Oconee, Pickens................................pp. 6iti-i1li.

\section{ERRATA.}

10)th pitge, last line, for $1 \times(60$ read 1sint). 11 th page, 5 th line, for 1550 read 1 istot. 12th page, 4tlı line, for State reat United States. 1.5th page, 36th line, for erosive read erodect. "2od page, itth line, for being read was.

82d page, th line, for 11.4 read 1.14 .

$111 \mathrm{ch}$ page, $37 \mathrm{th}$ line, for hy read but.

112th page, th line, for literal read littoral.

115th page, 19th line, for included real uncultivated.

llath page, soth line, for in reacl it.

122d page, 30th line, for saill read sand.

12-4th page 18th line, for Piedmont rearl Alpine. 1.2th page, 20th line, for truly read to rely. I2Ith page, 3ith line, for herd reat head.

$1 \times 2$ d page, 19th line, omit "and their gradual slopes on their northeastern lace.

'-(kith page, 5th line, for lsti read 1800 .

2l th page. Ith line, for uctivagans read noelivagans.

12:3stl page, listh line, for spring real spiny.

fist page, 2ath line, after Prof. Goole insert annu:illy.

fith page, 13th line, for Pelaris read Eolaris.

flath page, listh line, for ratarins read aratrarius. 219th page, 27 th line, for Bollosoma reat boleosolma.

2ilst page, Bh line, for Blaluari read Blephario. silst page, linth line, for eolsos lead c'olias.

2-j3d page, ath line, for hasis lead bases.

2isd page, soth line, for Jlimrhamphus rear Hemirhamplus.
$251 t h$ yage, 14th line, for of fishes reat of other fishes.

25ith page, w2d line, for eyloid read eycloid.

"sith page, 2th line, for kell read well.

25th page 24 th line, for vertebrate read vertebrae.

250th page, 12th line, for Sepidosteus read Lepiclosteus.

318th page, 2llh line, for copillina read eopallina. 325. h page, 13th line, for masculata read maculata.

isith page, :36il line, for Hooke's read Hooker's, 36ith jage, ith line, for natives real nations. 3sith page, 20lth line, for comnties read states. 381 st page, listh line, for $: 77$ read $40^{*}$.

3x!lth pange, fith line, for eighty read seveutyeight.

3asth page, 26th line, fol Belquiver rearl Belgium, fo6th page, lstlu line, for 128 read 417. tobth page, 24 h line, for 277 read 26 . fwith page, ?th line, for ? read 9 .

113th page, 20th line, after mortality read from this ertuse.

ifisth page, 3ith line, for $\mathrm{B}$ real $\mathrm{F}$.

5ith page, 2Ist lime, for possesses read possessed.

5isth page, $17 \mathrm{lh}$ line, for renumcration read reenmmeration.

(ii)lst page, lith line, for changes read eharges. bistl page, lst line, real "year's subsenuently. was, in the hands," sc. 


\section{PART I.}

AN ACCOUNT OF THE COUNTRY. 



\section{CHAPTER I.}

\section{N T R O D U C T O R Y.}

\section{LOCATION.}

The State of South Carolina lies between North latitude $32^{\circ} 4^{\prime} 30^{\prime \prime}$ and $35^{\circ} 12^{\prime}$ and longitude West from Washington $1^{\circ} 30^{\prime}$ and $6^{\circ} 54^{\prime}$.

\section{AREA.}

William Gerald De Brahm gave to the public, in 1757, the first Map of South Carolina, estimating the area of the State at 33,760 square miles. James Cook, in 1771, and Henry Mouzon, in 1775, published in London excellent maps of the State, from which Drayton and Ramsay make the area 24,080 square miles. Between 1816 and $1 S 20$ the State expended $\$ 52,760$ on a map of the State, under the direction of John Wilson; this map was published in $1 S 22$. The State spent $\$ 12,000$ more for this purpose in 1S25, and obtained Robert Mills' large Atlas of Soutl Carolina, probably the most accurate map of the State even to this day. Mills estimates the area of the State at 30,213 square miles, The United States Census of $1 S 70$ places it at 34,000 square miles, while the census of $1 S S 0$ makes it 30,170 . Thus, although geography may be held as one of the exact sciences, it seems that these geographers, with no material changes in the boundaries, vary in their estimates from twenty-six to thirtyseven per cent.

\section{BOUNDARIES.}

The State approaches in shape the form of an isosceles-triangle. The equal sides being on the North, the boundary line of North Carolina, and on the South and West, the Savannah river separating it from Creorgia. The apex of the triangle rests upon the summits of the Blue Rictge mountains. The base sweeping with a gentle s shaped curve from the southwest to the northeast, forms part of the Atlantic shore line of North America. This line is parallel, or nearly so, with about one-half the 
contst lines of the continents of the carth, as witness the northwest eoast lines of America, Europe and $A$ frica, and the southeast const lines of South $A$ merica, $\lambda$ frica and $A$ sia.

\section{GENERAL FEATLRES.}

P'arallel also with this eoast line trend the divisions between the various geological formations of the State. First, extending not more than ten miles inland, we have the strata of the post pleiocene resting on the formations of the eocene. These, with here and there a patch of the meioene and cretaceous formations, stretch back into the interior about one hundred miles, until they reach the crystalline rocks, whose woll marked line has, during the entire past history of the State, divided it socially, politically and industrially, as well as physically, into what has always been known as the up-country and the low-country of Carolina. This division of the State into up-country and low-country by the line bounding the southern margin of the crystalline rocks, and trending northeast and southwest across its central portion, is strongly marked in everything, in the hills and highlands of the up-country, with their heary red clay soils, and in the gentle slopes or wide flats of lighter colored sandy loam of the lowcountry, in the rapid, turbid water courses of the one, and the slow, elear currents of the other; in the regetable growth, the chestnut, the deciduous oaks and the short leaf pine, occupying the up-country, and the long leaf pine, the magnolia and the evergreen oaks, with the long gray moss, marking the low-country; and lastly, in the manners, character, ancestry, and even in the very tones of roice of the inhabitants. Passing beyond the lower margin of the crystalline rocks and proceeding towards the mountains, we find in all the various strata-in the order of their superposition-one above the other, the limestones, the itacolumite, the clay tale and mica slates, the gneiss and the granite-that the same parallelism is maintainerl throughout, the prevailing strike in all being $\mathrm{N}$. $20^{\circ}$ to $30)^{\circ} \mathrm{E}$. If we regard the movements of the atmosphere, we find here also that the predominating currents of the air move in a northeasterly and southwesterly direction.

\section{RIVERS.}

Perpendicular to this direction-that is to say, in a southeasterly course- the four great rivers, with their numerous tributaries that drain and irrigate South Carolina, make their way from the mountains to the sea. Before leaving the crystalline rocks-the point that marks their lower falls and the head of steam navigation-the rivers have received the rapid currents of nearly all their afiluents. Thereafter their stately 
flow proceeds more slowly, passing the great inland swamps of the low country, as if the waters still remembered when they found issuances through these ancient deltas. In the great freshet of 1796 , the watcrs of the Santee river broke through at Hell-Hole swamp, and made their way to the sea through Cooper river. During the same freshet, the Sarannah river made its way through the swamps of Hampton county, and emptied its waters through Broad river into the sea at Port Royal. As cach river leaves the region of rocks to enter the bordcrs of the lowcountry, it makes a sudden and well-marked detour eustward, except the Savamah, which seems to have had its bed shifted westward at this line of demareation. 'Thus, hat the grooves cut through the ancient strata of the crystalline rocks by these streams been prolonged among the sands and clays of the low-country, their estuaries would have been quite different from what they are at present. Harl the line of the Surannah, as it chamneled its way ages ago through the mica, slate and gneiss rock of Oconee, Anderson and Abbeville counties, not been thrown westward by the granites of Horse creck and the high sand and clay hills of Aiken county, it would have continued its course to Broad river, at present that magnificent arm of the sea forming the head of Port Royal harbor. Here it would have been joinerl, too, by the waters of the North and South Edisto, had they not been deflected eastward by the granite rocks and sand hills of Aiken and Orangeburg counties. Here, also, the waters of the Santee, containing those of the Wateree and Congaree, would have joined them, had they followed the line of the ancient channel of the Catawba, their most easterly affluent, as it grooved its way through talc slates and granites of Laneaster, York and Chester counties. It would seem more appropriate that some great Father of Waters, having these proportions, should have built up such a grand deltii as the islands, rivers, sounds and bays of Beaufort present, rather than it were the sole and undisputed estuary of such insignificant claimants as the rivers Tillifinny, Pocotaligo and Coosawhatchie, preserving in their long names alone the memory of the noble river that once must have found its way to the ocein here. Noting the remarkable parallelism in this eastward deflection of nearly all the water courses of Carolina, it would seem that one and the same cause must have produced these changes. Such a cause would have been an uphearing force-or forces, rather-operating from the southwest to the northeast, in the line of the eruptive rocks that cross the State from Edgefield to York counties. We may readily imagine how these successive elevations running from the southwest, after turning the Savannah into its present delta, pushed the other streams eastrard, dropping the different affluents as it passed along, leaving the Combahce 
and Eslisto at St. Helena sound, as the Tillifinny, Pocotaligo and Coosawhatchie were left at Port Royal to mark the delta there, and losing the Ashley and Cooper rivers at Charleston harbor, while the Santee, moved further westward, still marks out its chamel to the sea near Winyaw bay.

Again, on the near approach of the rivers to the sea, some of them show a deflection westward. But the previously noticed parallelism does not obtain in this ease. In some, as in the Pee Dee, the westward bend is well marked. In other's, as in the Edisto, the river is merely turned from an eastward to a south course, while the Santee seems scarcely at all diverted from its eastwardly course. It would not seem, therefore, that this change had resulted from the action of any single cause, but, rather, that it was the resultant of opposing forces, operating with varying intensities. Such forces would be found in the southeasterly currents of the streams themselves, opposed by that southwesterly ocean current-a recurrent of the Gulf Stream-that sweeps along the Carolina coast. Where the river currents were strong, and loaded with a wealth of detritus from the drainage of an extensive back country, it would hold its own against the ocean current, dam it out and establish for itself the direction of its outlet. Hence the Santee piles up its banks and carries the shore line out beyond Cape St. Romain, and all the coast southwest of it, the site of ancient and actual deltas, is lined with islands. Short or sluggish streams, however, supported by the detritus of no great water-shed-as the Waccamaw river-would yield readily to the action of the ocean currents, conform to their direction, establish no nests of islands at their deltas, but leave the sea to make a smooth, bare sand beach. Such we find the curving shore from Georgetown entrance to the North Carolina line to be, where, for twenty miles on a stretch, a carriage may roll along the beach at low water, leaving in the hard sands not the slightest impress of its wheels.

Crossing the crystalline rocks nearly at right angles, the waters, in their course through the up-country, encounter a series of natural dams, which, while it renders them easily available as water-powers, seriously obstructs navigation. The passage of boats, say of two hundred tons burthen, as a rule, reaches inland but very little farther than the remarkable belt of high and healthy sand hills which lie along the lower borders of these rocks.

The tortuous course into which the streams have been forced by the causes already stated, after entering the low country, while it has increased the navigable waters of the State, giving, "apart from creeks and inlets of the sea, an inland navigation of twenty-four hundred miles," has seriously impeded the drainage of the low country, creating there 
some fifty-five hundred square miles of swamp lands, which, though naturally, when reclaimed, of almost inexhaustible fertility, remain to this day for the most part waste, the prolific source of the miasms so deleterious to the health of this region. Numerous suggestions to remedy this evil have been made, but as yet nothing has been attempted on a scale commensurate with the importance of the undertaking. The Legislature even refused, in 1846, to grant a charter to a company proposing to prolong the channel of the Edisto in a direct line through Wassamassaw swamp to the Ashley river; and a suggestion of a similar character, for straightening the Santee through to the Cooper river, and draining, thereby, Biggin, Fair Forest, Walleye, and the numerous adjacent swamps, made by Governor Seabrook, in 1S48, met with no response. Such works would have reclaimed for the plow large bodies of soil, consisting of fine mud and decomposing vegetable matter, resting, at a depth of five to ten feet, on marl or gravel; restored the adjoining uplauds to remunerative culture; and would have established on a secure foundation the healthfulness of the entire region.

\section{PHYSICAL AND AGRICULTLRAL REGIONS.}

In addition to the two grand divisions of South Carolina already dwelt upon into the "up-country" and "low-country," it will facilitate the consideration of the agricultural characteristics of the State to treat of them under certain minor natural and parallel sub-divisions, which are quite well marked. These are as follows:

I. The Coast Region. It coincides very nearly with the post pleiocene formation, rarely extending inland more than ten miles from the shore line. It consists-

1st. Of the Sea Islands lying south of Santee river, and containing about eight hundred square miles.

$2 \mathrm{~d}$. The salt marshes, uncovered at low tide, bordering and intercalating with the Sea Islands, capable of being reclaimed, and embracing six hundred square miles.

$3 \mathrm{~d}$. The continuous shore line.north of Santee river and Georgetown entrance, three hundred square miles in extent.

II. The Lower Pine Belt or Saramnah Region, lying inland and parallel with the Coast Region. It has a width of about fifty miles, attains a maximum elevation above the sea of one hundred and thirty feet. It may be divided,

1st. Into the region below the influence of the tirles, the rice fieldis of South Carolina. 
2a. The region above tide water, notable for its turpentine farms and its cattle ranges.

III. The Upper Pine Belt or the Central Cottom Belt, having a wilth of turenty to forty miles. It is covered with a groneth of long leaf pime, mixed with oal: and hicliory. The soil eonsists of a light sandy loam underlaid by renl and yellow clays. It las an elevation above the sea of from one humdred and thirty to two hundred and fifty feet. Large inland swamps, bays and river bottoms of unsurpassed fertility, covering five thousand five hundred square miles, are interspersed among the two regions last named.

IV. The Red IIIlls are immediately north of the last region. They have an elevation of three humbled to six hundred feet above the sai. The soil is red clay and sand, and there is a heary growth of oak and lickory. 'They embrace the range of.hills extending from Aiken county' through Orangeburg to Sumter, where they are known as the High Hills of Santee, and also the ridge lands of Ergefield, famons for their fertility.

V. The Sand Hill Region. A remarkable chain of sand hills, attaining an elevation above the sea of six hundred to seven hundred feet, and extending across the State from Aiken to Chesterfield comnties.

V'I. The Piedmont Region includes that portion of the State known as the upper country. It has a mean elevation above the sea level of four hundred to eight hundred feet. Its soils are-

1st. The cold gray lands overlying for the most part the elay slates.

2d. The gray sandy soils from the decomposition of granite and gueiss.

3d. The red hornblende lands.

4th. The trappean soils, known as flat woods meadow or black-jack lands in various sections.

VII. The Alpine Region is the extreme northwestern extension of the rocks and soils of the region just mentioned, differing from the former ly its more broken and mountainous character, and by its greater elevation. ranging from nine hundred feet to three thousand four hundred and thirty feet at Mount Pimacle, near Pickens C. H., the highest point in the State.

\section{AGRICULTURAL RETROSPEC'T.}

The first permanent settlers established themselves on the sea-coast of South Carolina in 1(i70. Bringing with then the traditions of a husbandry that must have been very rude at a period so long ante-dating the 
Tullian era of culture, and adapted solely to the requirements of colder katitudes, they met with such poor success in the cultivation of European cereals that they soon found it would be more profitable to employ themselves in collecting and exporting the products of the great forrsts that surrounded them. In return for the necessaries of life, they exported to the mother country and her cólonies, oranges, tar, turpentine, rosin, masts, potashes, cedar, eypress and pine lumber, walnut timber, staves, shingles, eanes, deer and bearer skins, ete. It is interesting to remark in the accompanying diagram, that after being more or less in abeyance during a period of two hundred years, amid the fluctuations of other great staple crops, these forest industries seemed, in 1870, about to assume their aneient supremacy once more. With the settlement of the ur-country the culture of small grain became more suceessful ; and when Joseph Kershaw established his large flouring mills near Canden, in 1760, flour of excellent quality was produced in such abundance as to become an article of export of considerable consequence. In 1802, flouring mills hatd proven so profitable that quite a number were established in the counties of Laurens, Greenville and elsewhere. About that time, however, the attractions of the cotton crop became so great as to divert attention from every other, and the cereals lost ground, until the low prices of cotton prevailing between 1840 and 1850 prepared the way for a greater diversity of agrieultural industries, and the small grain crop of 1850 exceeded four million bushels. Since then cereal crops have declined, and seem likely to do so, unless the promise held out by the recent introduetion of the red rust proof oat should be fulfilled and restore them to prominence.

In 1693, Landgrave Thomas Smith-of whosedescendants more than five hundred were living in the State in 1808 (a number doubtless largely in(creased since), moved perehance by a prophetic sense of the fitness that the father of such a numerous progeny should provide for the support of an extensive population-introduced the culture of rice into South Carolina. The seed eame from the island of Madagasear, in a ressel that put into Charleston harbor in distress. This proved a great success, and as early as 1754 , the colony, besides supplying an abundance of rice for its own use, exported one hundred and four thousand six hundred and eighty two barrels. Great improvements were made in the grain by a careful selection of the seed. Water culture was introduced in 1784 , by Giideon Dupont and General Pinckney, rendering its produetion less dependent on the labor of man or beast than any cultivated crop. In 1778 , Mr. Lucas established on the Santee river the first water power mill ever adapted to eleaning and preparing rice for market-the model to which all subsequent improvements were due--diminishing the cost of this pro- 
cess to a degree incalculable without some standard of reference as to the value of human labor, on which the drudgery of this toil had rested for ages. In 1828, one hundred and seventy-five thousand and nineteen tierces were exported, and the crop of 1850 exceeded two hundred and fifty thousand tierces, that of 1860 was something less, and in 1870 the product tumbled headlong to fifty-four thousand tierces.

\section{INDIGO.}

In 1742, George Lucas, governor of Antigua, sent the first seeds of the indigo plant to Carolina, to his daughter, Miss Eliza Lucas (afterwards the mother of Charles Cotesworth Pinckney). With much persererance, after several disappointments, she succeeded in growing the plant and extracting the indigo from it. Parliament shortly after placed a bounty on the production of indigo in British possessions and this crop attained a rapid development in Carolina. In 175t, two hundred and sixteen thousand nine hundred and twenty-four pounds and in 1775, one million one hundred and seven thousand six hundred and sixty pounds were produced. But the war with the mother country, the competition of indigo culture in the East Indies, the unpleasant odor emitted and the swarms of flies attracted by the fermentation of the weeds in the rats, but above all the absorbing interest in the cotton crop, caused the rapid decline of its culture, and in the early part of this century it had ceased to be a staple product, although it was eultivated in remote places as late as $18+8$.

\section{- INDIAN CORN.}

Indian corn, the grain which, "next to rice, supplies food to the largest number of the human race, * * the most valuable gift of the new world to the old," as a plant unknown to European culture, and in ill repute as the food of the ever hostile red man, received little attention from the early settlers. Nevertheless, with the steadiness that marks true merit, it worked its way to the front rank among the crops grown in the State. As early as 1739 it had become an important article of export ancl continned such until after 1792 , in which year ninety-nine thonsand nine hundred and eighty-five bushels were exported. About this time, in consequence of the absorption by cotton of all surplus energy, it fell from the list of exports and shortly after entered that of imports, on which to-day-taken in all its forms-it stands the largest. But its culture was by no means abandoned; on the contrary, the erop grew in size with the increase of the population. In $18 f 0$, morethan sixteen millions 
of bushels were produced. In 1857, Dr. Parker made, near Columbia, the largest crop per acre ever obtained anywhere; from two acres he gathered three hundred and fifty-nine bushels, and one acre gave two hundred bushels and twelve quarts. In consequence of the higher prices of cotton the corn crop was reduced in 1860 by one million of bushels; in 1870 it had gone down one half, having fallen to seven and a half million bushels.

\section{COTTON.}

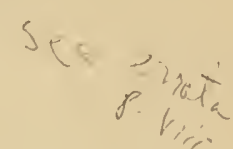

Cotton is mentioned in the records of the colony as early as 1604 , and in 1747 , seven bags appear on the list of exports from Charleston. In 1787, Samuel Maverick, and one Jeffrey, shipped three bags of one hundred pounds each of seed cotton from Charleston to England as an experiment, and were informed for their pains by the consignee, that it was not worth producing, as it could not be separated from the seed. In 1790 a manufactory of cotton homespuns was established by some Irish, in Williamsburg county, the lint used being picked from the seed by hand. a task of four pounds of lint per week being required of the field laborers in addition to their ordinary work. All this speedily changed with the invention of the saw gin by Eli Whitney, in 1794. The first gin moved by water power was erected on Mill Creek, near Monticello, in Fairfield, by Capt. James Kincaid, in 1795. Gen. Warle Hampton erected another near Columbia, in 1797, and the following year gathered from six hundred acres, six hundred bales of cotton, and cotton planting became soon after the leading industry in nearly every county in the State. The crop steadily increased in size until 1860, when the three hundred and fifty thousand bales produced in the State were worth something over fourteen millions of dollars. From this date to 1870 there was a great decline, the crop of that year being more than one-third less than the crop of ten years previous, and reaching only two hundred and twenty-four thousand five hundred bales.

\section{TABLE,}

Showing the Production of Cotton in South Carolina from 1830 to 1880:

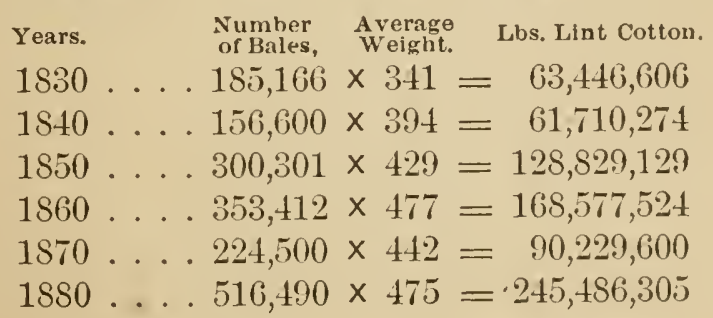




\section{SEA ISLAND COTTON.}

The first crop of sea island cotton was raised on Hilton Head, in 1790, by William Elliott. This crop reached its year of maximum production in 1827 , when $15,140,798$ pounds of long staple cotton was exported from the State; in 1841 it had fallen to $6,400,000$ pounds. Since 1856 this crop has fluctuated from a minimum in 1867 of 4,577 bales to a maximum in 1872 of 13,150 bales.

Even in so brief a summary as this, the attention of the reader must be called to the remarkable influence exerted on the three great erops of corn, cotton and rice, by their culture on the South Carolina coast.

The finest, as food for man, of all the known varieties of corn is the white flint corn, peculiar to the sea islands.

The finest cotton ever produced is the long staple cotton of Edisto island, which has sold for $\$ 2$ per pound, when other eottons were bringing only nine cents.

Carolina rice heads the list in the quotations of that article in all the markets of the world. Not only has its yield and culture been brought to the highest perfection here, but mankind are indebted to the planters of this coast for the mechanical inventions by which the preparation of this great food stuff, instead of being the most eostly and laborious, is made one of the easiest and eheapest. 
Showing the relative importance and fluctuations of the staple crops cultivated 1670 in South Curolina from 1670 to 1850 . The money value $1670>1$ of each crop is estimated for the year of its maximum pro1680 I duction anterion to 1880 , and a point assigned it above the line A B. From this point the distance of the line of each crop above the line $A^{*} B$ is determined by the amount produced without regard to prices.

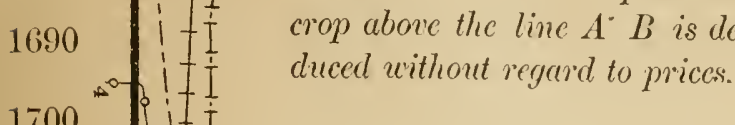

1710

1720

1730

1740

1

1760

1770

1780
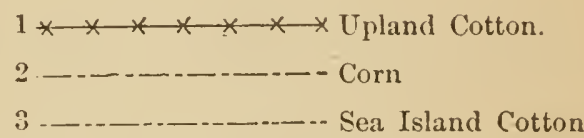

to 00000000 Rice

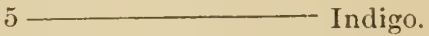

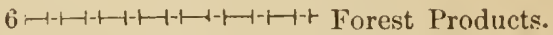

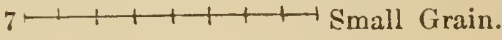




\section{CHAPTER II.}

\section{THE COAST REGION.}

\section{LOCATION AND AREA.}

The coast of Carolina, from the mouth of the Savannah river to that of Little river, on the North Carolina line, is about one hundred and ninety miles in length. East of the outlet of the rivers, that is northeast of Winyaw Bay, the coast line curves inland, there are no islands, and the smooth hard beach (noted for its delightful seaside residences during the sunmer months) that forms the continuous shore line, is of little interest agriculturally. South of Winyaw Bay, whence issue the waters of Black and Lynch's rivers, and of the Great and Little Pee Dee, with the Waccamaw, the Santee river, with its great watershed in North and South Carolina, draining an extensive region stretehing to the highest elevations of the Apalachian range, dikes its delta out into the ocean, and the shore line swelling seaward beeomes lined with numerous islands. From this point to Charleston Harbor the islands, though numerous, are small and low, and in this distance of more than fifty miles not more than seven hundred acres are planted in cotton, yielding about two hundred and seventy-five bales of long staple. South of Charleston Harbor the islands inerease rapidly in size and number to the waters of Port Royal, where they line the shore in tiers three and four deep. They attain their maximum development around Broad river, and diminish again in size and number more rapidly even than they had increased, as they approach the Georgia line at the mouth of Savannah river. The Sea Islands are separated from the mainland by numerous salt water rivers, ereeks and inlets of the sea.

\section{GEOLOGY.}

The eoast region corresponds almost exactly with the post-pleiocene for'mation. Its strata of sand, elay and mud, have an estimated thickness of about sixty feet, stretehing inland some ten miles and thimning out at a slight elevation above tide water. They rest in Horry and Georgetown on the pleiocene, and for the remainder of the coast, on the eocene, in which occur the phosphate deposits of the Ashley, the Cooper and the Coosaw rivers. 
The origin and formation of the sea islands may be aceounted for by one of four possible suppositions.

1st. By a subsidence of the coast resulting in the submergence of the lower lands. This explanation was offered by Sir Charles Lyell, and recently by Professor G. H. Cook, who believes that the whole Atlantic: seaboard is sinking.

2d. By the elevation of the sea bottom. This theory has not been maintained by any one and need not be considered.

3d. By the erosive action of the tides and currents of the sea, cutting into the shore line and detaching, as it were, portions of the mainland. I theory of Professor Shaler.

4th. By an outgrowth of the land into the sea, resulting from the deposition at the mouths of the rivers of the detritus brought down by their currents from the interior.

Mr. Tuomey shows in detail that the instances of the submergence of oak, pine and cypress trees, and other landmarks, ardluced as evidence of subsidence of the coast, oecur in localities of restricted area. That the lands immediately adjacent show no signs of participation in this movement, which they would do if the cause were so general a one as the subsidence of the coast. That encroachments of the sea of a purely local character after storms explain the phenomena. And lastly, that if it were admitted that the submerged live oak and pine stumps near Little River, or the dead cedars and eypress of the "Chureh Flats," on Wadmalaw island, were evidence of a subsidence of the coast, the rate at which it is progressing, aceording to this data, is so rapid that on this low lying shore, sca water would long since have been admitted to the rice plantations, totally destroying them, and that St. Michael's Church, the ornament of Charleston, would now be a geological monument of the greatest interest, with its tall spire only protruding above the waves.

If the sea islands resulted from the erosive action of ocean currents, we should expect to find them most numerous in localities where the erosire action is most manifest. Such a locality is the recess of Long bay, hollowed out by the action of the sea, between Winyaw bay, the outlet of the great rivers of South Carolina and the outlet of the rivers of North Carolina at Cape Fear. So far is this from being the case, howerer, that there is not a single island on this incurving line of erosive coast. On the contrary, it is only when the land bellies ont into the sea near where the great rivers deliver their detritus to its waves that the sea islands make their appearance.

At this point, namely, at Georgetown entrance, we look in vain for evidence of crosion. The records all point the other way, to a gradual encroachment of the land upon the sea. Thus, in the year 1700 , the 
"Rising Sun," a large vessel, with three hundred and forty-six passengers, that could not cross the Charleston bar, made its way without a pilot to the present site of Georgetown, a thing utterly impossible during the last one hundred years. Moreover, a comparison of the soundings on Chart No. 428 , of U. S. Coast Survey of 1877 , with a Chart of the same locality, published in Drayton's View of South Carolina, in 1802, shows that, instead of any scouring out or erosion, there has been a great filling up in the interval. Seaward from Georgetown Light House, Drayton gives depths of 9 feet to 30 feet, where Captain Boutelle only found $6 \frac{1}{2}$ feet to 19 feet of water. Inside the entrance, where the water once was 30 to 36 feet, the mean level of low tide now only gives a depth of 9 to 31 feet. Ten soundings taken off South Island average now $7 \frac{1}{2}$ feet, while ten soundings in the same locality on Drayton's Chart average 18 feet.

It would seem, then, according to the fourth and remaining hypothesis, that the Sea Islands were an outgrowth of the mainland into the sea. And that this is but a continuation of the process by which the tertiary plain, stretehing back to the feet of the ancient and lofty Apalachim chain, was itself formed. The broadest portion of this plain lies under the lofticst and broadest vestiges of this mountain chain, whose denudation furnished the most abundant material. Northward, under lesser elevations, which could only furnish less material, the tertiary plain gradually wedges out and the sea approaches the mountains. The slow uniformity of this long process of growth is further shown by the gentle and uniform slope with which this plain approaches the sea. Nor docs it end abruptly there. For one hundred miles or more the sea scarcely exceeds one hundred fathoms, until it suddenly deepens to two thousand fathoms under the gulf stream. The sea islands are not isolated phenomena peculiar to this period. In the interior the intricate network of swamps and bays corresponding with the present inlets, creeks and rivers of the coast, represent the old channels and deltas through which tho waters flowed, when the pine flats and ridges, still resting in the meshes of this network, were themselves reritable sea islands.

Prof. Toumey refers to Murphys island, south of South Santee inlet, as furnishing a typical illustration of the mamer in which this accurs. A bar is formed at the mouth of the river by the action of the ocean. "Breakers make their appearance seaward, and gradually push forward the sand as they approach the shore. When the sand rises above the surface, the water becomes too shallow to produce breakers; they disappear, and commence again off the shore, and further south. An eddy is formed between the sandbar and the shore, in which the river deposits its sediment. From an eddy it is changed, first into a lagoon, and then into a mudflat, which increases until the level of high water is reached. 
It then becomes a marsh and is taken possession of by the marsh reed, to be succeeded, when the debris collected by their growth has raisert the locality above high water, by tufts of rushes. Meanwhile seaward, the sands, first pushed up against the outflowing current of the river by the ocean, are dried by the sun, and then blown forward and heaped into hills and ridges, forming a protection against the encroachments of the waters whence they came. Every breeze blowing landward carries along with it particles of fine sand, till they meet with a log or bush, or other obstacle, when they begin to accumulate in pronortion to the velocity of the wind, sometimes with extraordinary rapidity-piling up and rumning over the top, rising in ridges and hills to the height of thirty or even of forty feet. The prevailing winds of this region, the southwest and northcast, are indicated by valleys rumning in this direction through these hills."

In the manner thus described, the salt water of the ocean being excluded, the surgent island is prepared for the growth of fresh water plants, such as the cypress and other swamp trees, while pines and palmettoes, the advance guard of the regetable kingdom, establish outposts wherever a few inches of intervening sand renders them safe from immediate contact with sea water.

This theory will also account for certain topographical features observed on these islands and in their vicinity. The highest land is usually found on the margin of the island. A fact which, viewed in connection with the general observation that the banks of streams are higher than the adjacent alluvial lands, strongly sustains the view of their deposition from river currents. The prevailing shape of the islands is triangular. The apex is directed southwest, often terminating in marshes, while the higher and dryer base faces northeast. From Mr. Tuomey's observations, it appears that it is the sandbar on the northeast that first rises above the waves, remaining the most elevated, while the growth proceeds in a southwesterly direction. This southwardly growth results from a deflection of the river current that is transporting the material of which the island is to be formed. Whether this deflection toward the right (or the southwest) be due, as Prof. Kerr thinks, to a force arising from the earth's rotation, which deflects all moving bodies to the right in the northern hemisphere, or to the prevailing southwestwardly current along these shores, or to both, it is certain that such a deflection clearly exists. Seaward it may be clearly noted in the charts of the coast survey in the depositions now taking place at the mouths of the rivers. The ship channels are always found to the south of the harbors. Inland, the south and southwest bend of the rivers has been already mentioned; and coupled with it is the observation made long since by Mr. Ruffin, that the bluff's are on the west 
and the swamps are on the east banks of these streams, or as it would be stated from observations on the sea islands, the short slopes face north and east, and the long slopes south and west. The contours of the slopes throughout the tertiary plain conform generally to this rule, and may be accounted for in this way.

\section{PIYSICAL FEATURES.}

In approaching the coast from the sea about the time the white caps of the first breakers are seen, a long, low line of smooth, hard, sandy beach, for the most part of a snowy whiteness, makes its appearance. Immediately inland from the beach swell the undulating ridges of blowing sand, ripple-marked by the action of the wind, in striking similarity to the ware marks of water.

Here the palmetto meets you, standing often solitary and alone, a conspicuous landmark in the picture. Beyond rise the dark green turrets of the pine, beneath which a tangled growth of myrtles and vines is found. Sometimes more than one ridge of sand hills, with an average elevation of ten or fifteen feet, must be traversed before the borders of the salt marsh are reached. The salt marshes, their stiff, green reeds rising out of the black ooze visible at low tide, and at the flow apparently floating on the water, with here and there a stray palmetto or a group of under-sized live oaks, their limbs covered with the long, gray moss, form the scarcely varying framework of all landscapes among the sea islands. Everywhere these marshes are penetrated by salt rivers and creeks of greater or less width and deptl, and surround islands varying from a few acres to many square miles in area. These islands attain a height of ten to fifteen feet-rarely of twenty-five or thirty-above high tide. The mean rise and fall of the tides is $6.9 \mathrm{ft}$. at the mouth of the Sarannah river; $6.7 \mathrm{ft}$. at Port Royal; $5.1 \mathrm{ft}$. at Charleston harbor, and $3.5 \mathrm{ft}$. at Georgetown entrance, showing a marked diminution as you adrance northeast along the coast. The influence of the tide extends to a distance of thirty miles in a direct line from the sea, up the Sarannals river, and about fifteen miles up the Santee. Salt water, however, usually ascends the Santee river only about two miles, and even when the current of the river is diminished in seasons of great drought, not more than four miles. Up Georgetown bay it reaches farther, and is sometimes injurious to the crops at a distance of fourteen miles. What has been said of the Santee in regard to fresh and salt water, is true to nearly the same extent of the Savannah river.

\section{SOIL}

The soil of the sea island consists, for the most part, of a fine, sandy loam. This soil rests on a subsoil of yellow sand or yellow clay, of fine 
texture and deepening in color, sometimes to red. These clays give a yollow hue to the otherwise gray surface, which is noticed by Mr. siabrook as indieating lands peculiarly adapted for the prorluction of the silky fibre of long staple cotton. Besides these soils there are numerous flats, or fresh water swamps, known as bays; here and there a few of these have been reclaimed by drainage; the soil is a black regetable monld of great fertility, resting on fine blue clay and marl. To a very limited cxtent the salt marsh has also been reclaimed, but as yet agriculture has arailed itscelf so little of the rast possibilities in this line, that the chief value of the salt marsh attaches to its use in furnishing forage and litter for stock and inexhaustible material for the compost heap. Low as these lancls lie, they are susceptible of drainage. The following analyses will indicate more in detail the character of the soils :

(1)

Insoluble matter . . . . . . . . . 89.868

Soluble silica. . . . . . . . . 2.062

Potash . . . . . . . . . . 0.131

Soda . . . . . . . . . . 0.077

Lime . . . . . . . . . . . 0.077

Magnesia . . . . . . . . . . 0.038

Br. ox. manganese . . . . . . . 0.15t

Per oxide iron . . . . . . . . . 0.59s

Alumina. . . . . . . . . . . . 3.051

Phosphoric acid. . . . . . . . . . 0.163

Sulphuric acid . . . . . . . . . 0.15t

Water and organic matter . . . . . 4.759

Carbonic acid.

\subsection{0}

0.425

0.200

0.892

trace

2.490

0.095

0.070

2.928

$0 .+20$
(:3)

5. 5.110

(0.3) 2

0.190

1.476

0.420

0.517

1.560

1.131

0.062

0.422

$4+865$

$0.8+0$

(1) Is soil from northeast end of James island, furnished by Elias Rivers, Esq., for analysis, to Dr. Eugene A. Smith, of Tuscaloosa, Ala., and may be taken as a specimen of the less sandy soils of the sea islands. Such land will yield three hundred pounds of long staple lint one year with another.

(2) Is by Prof. C. U. Shepard, of Charleston, of soil from Mr. J. J. Mikell's place on Edisto island, famous for having long and profitably produced the finest grade of sea island cotton, and may be considered as a representative soil.

(3) Is also by Prof. C. U. Shepard, being an analysis of an air-dry specimèn of salt marsh.

These analyses will serve to correct serious errors in statements as to the poverty of sea islands, made by J. B. Lyman and J. R. Sypher, in a 
work on cotton eulture, pullished by Orange Judd \& C'o., New York. It is stated there (page 129) that a chemical analysis disclowes the fact that the soil on an acre of scal island cotton land, taken to the depth of one foot, contains only fifteen pounds of plosphoric acid and twenty pounds of potash. By the alove analyes, however, we find an average of more than one-tenth of one per" cent. of phosphoric acid, and one-sixtcenth of one per cent. of potash. Allowing a culje foot of earth to weigh one hundred pounds, we would have on an acre to the depth of one foot four million, three hundred and fifty-six thousand pounds, of which one-tenth of one per ecnt. would be four thousand, three hundred and fifty-six pounds, showing nearly two long tons of phosphoric acid instead of fifteen pounds to the acre. The potash, by the same calculation, would amount to five thousand and fifty pounds instead of twenty pounds to the acre. Thus, in the place of being barren for lack of these ingredients, cach acre of the sea islands possess an ancunt which, if rendered arailable to plant growth, would suffice for the production of over eight million, six hundred and eighty thousand pounds of lint cotton, as they do not, by Jackson's and Shepard's analyses, constitute the one-twentieth of one per cent. of cotton fibre. Besides, the salt marsh materials for maintaining and developing the fertility of the soil abound throughout the coast region. There are numerous deposits of post pleiocene marl on the islands, as at Daton's swamp, Johnson's island, Stono creek, Edisto island, James Seabrook's island, Distant island, near Beaufort, and elsewhere. The banks of "raccoon oyster" shells, peculiar to this latitude, are found in abundance on this coast and furnish excellent and easily accessible stores of lime. These shells are also used for concrete for walls, known as tabby work. The walls of forts several centuries old attesting its durability. Roads and streets are also made smooth and hard by their use. Here, also, in the Stono, Edisto, Coosaw, Bull, Morgan, Johnson's, Beaufort and Broad rivers, and in other creeks and marshes, is found, and largely exported as a fertilizer to foreign lands, the phosphate rock. Experiments have also demonstrated that the fish, so numerous in these waters, may be caught and used for manures.

\section{CLIMATE.}

Notwithstanding their proximity to the mainland, the sea islands enjoy in a high degree the equable climate peculiar to islands generally. The extremes of temperature are, as might be expected, greatest in the direction of low temperature, and the cold, which is sometimes injurious to the orange and olive trees, destroys, also, the germs of many insects, as of the cotton caterpillar, inimical to regetation; and of more importance 
still, it destroys the germs of disease, as of yellow fever and of numerous skin diseases that flourish in similar regions elsewhere, preventing them from becoming indigenons, and keeping them exotics forever, reguiring yearly renewal from without.

Table I, at the end of Part I, presents the leading features of the coast climate, as preserved in the records of meteorological observations made at Charleston, S. C.

Notwithstanding the amount of rainfall and proximity to the sea, the climate is not excessively moist, as might be inferred. This is owing to the large number of clear days, areraging about two hundred and thirtyfive during the year, against an average of eighty-six days in which rain fell, and forty-four cloudy and rainless days. Fogs are of very infrequent occurrence. Tegetation is usually checked by cold for not more than six weeks in the year, from the middle of December to the first of February. Nature, that does not allow the inhabitants of higher latitudes to become purely agricultural in their pursuits, foreing them, during the snows and ice of winter, to seek occupation in other arts and industries, here bares her bosom the year round to furnish food and work for man, and seed time and harvest occur in every month.

\section{HEALTH.}

By the U. S. Census for 1870 , it appears that the minimum number of deaths in South Carolina oceur during the month of October. After that month the number stcadily increases during winter and spring, until the month of May, when the maximum number of deaths take place. From this date the mortality diminishes, more rapidly than it lias increased, until the minimum in October is reached. By the same authority it is also shown that the groups of diseases most fatal during the month of May are such as hydrocephalous, apoplexy, accirlents and injuries, none which can in any way be considered as due to chmatic or local influences. From this it follows that death, and, consequently, ill health, in south Carolina camnot be attributed to the preponderance of any climatic or local causes, but supervene from such causes as may and must exist everywhere. The correctness of this negative conclusion may be safely accepted as descriptive of the sanitary condition of the State at large. There has been, however, and not without some foundation, an idea prevalent regarding the unhcalthfulness of the coast region from malarial causes, which requires mention, especially as occurrences of recent date have greatly modified it. While the sand ridges between the rivcrs have always been esteemed healthy; while the well-kept vital statistics of the city of Charleston show that its health record will compare farorably 
with that of other cities; and while numerous localities along the coast, as Mount Pleasant, Sullivan's island, and Beaufort, and many other places were much frequented as health recorts during the summer months, even by people from the up-country, it was confidently predicted, at the commencement of the late war, that no picket line along the coast between the armies could be maintained during the summer months. To the surprise of nearly every one, however, such dis not prove to be the ease. Climatic influences interfered in no way with the vigorous prosecution of hostilities. And it was demonstratcd that large bodies of white men, under proper hygienie regulations, with the use of quinine as a preventive, might be safely counted on to endure unusual exprosure and toil on these shores during the heat of summer. Since the war numerous white families, who formerly rmoved to the North or to the up-country during summer, have remained upon their farms the fear round in the enjoyment of thcir usual hoalth. By the ccnsus enumeration of June, 1880, the death rate among the rural population of the entire sca island district was fourteen per one thousand for the preceding year. Of the twenty-three. white men who were enumerators of the tcuth ccnsus on the sea islands, during the months of June and July, 1850, there was no day lost from work on account of sickness, though many of them were unaccustomed to the exposures which the work necessitated. Doubtless the prophylactic use of quinine has had something to do with the apparently increased healthfulness of this section, but it is also true that the clanger to health was formerly greatly orerestimated. With thorough drainage and careful attention to the rules of health, and especially to sceuring pure drinking water, there is no question that ferers might be expelled here as completely as they were from the fens of (ambridgeshire, in England, where they once prevailed, but have since yielded to the above methods. During the excessively hot and dry summer of 1728, "yellow fever" made its first appearance in Charleston. At greater or less intervals of time it has since visited the city during the summer months. After 1748 it did not make its appearance during a period of forty-four years. John Drayton writes, in 1s01, "to the natives and long inhabitants of the eity it has not yet been injurions." The germs of this disease have never been naturalized on this coast, and require a fresh importation every year. An cpidemic occurring in Charleston during the war being elearly traced to a vessel from Havana, that had run the blockade, and, as Mr. Drayton describes it, this disease still remains restricted to certain localities, within a few miles of which perfect immunity from it may be enjoyed. This was clearly shown in the rery fatal epidemic imported into Port Royal in 1877, causing a number of deaths there, while no ease originated in the town of Beaufort, four miles distant, to 
which place, howerer, patients suffering from the disease in Port Royal were carried for treatment.

The following table is from the reports of the Boarl of Health, and. shows the number of deaths occurring in each one thousand of the population of the city of Charleston:

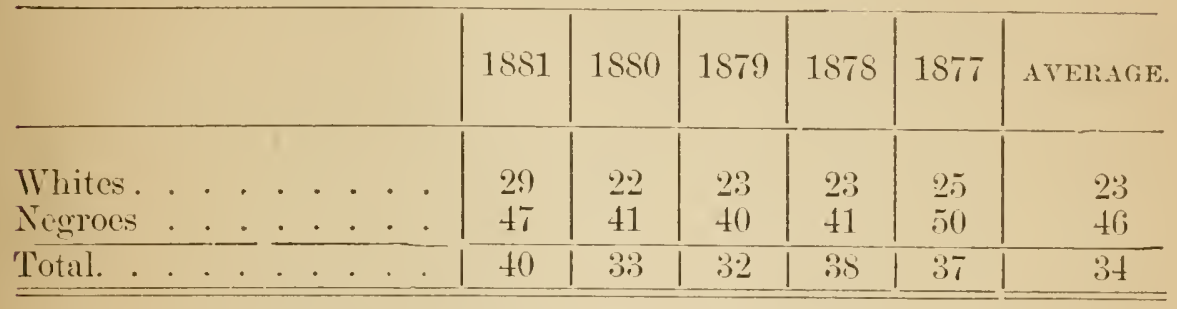

The figures for $18 S 0$ show fifty per cent. more deaths than were reported by the enumerators of the tenth U.S. Census. Of 1,621 deaths in 1881 , 61 , or nearly 4 per cent. were of persons over 80 years of age.

\section{S'TATISTIC'S.}

The population of the coast region, exclusive of the towns of Beaufort, Charleston and Georgetown, is 67,132 . Of this number, 83 per cent. are colored, being the largest percentage in any region of the State, the proportion of the colored to the white population decreasing in each successive region as you go inland, until it is only 27 per cent. in the mountain region. This percentage has decreased on the coast since 1870 , appearing in the census of that year as 90 per cent., a difference of 7 per cont. The population per square mile is 39.4, which, in spite of the large amount of marsh land, is the largest of any region in the State, the ratio varying elsewhere from 11.7 in the sand hills, to 37.8 in the upper country or region of the metamorphic rocks.

The farms are 5,847 in number, and arerage 3.4 per square mile, which is the largest average of any of the regions of the state execpt that of the upper country, which is 3.7 per square mile; hut cxcluding the six hundred square miles of mąrsh on the coast, no similar tract of waste land being found in the upper country, the ratio of farms to area is much greater on the coast than clsewhere. This is not the case with the ratio of farms to population, which here rcaches a minimum of eight-hundredths of a farm per capita, or twelve and one-half people to the farm, while in the sand hills it reaches fourteen-hundredths of a farm per capita, or seren people to the farm. 'This shows that here the population is in excess even of the small farms; and there being no other occupation, except, 
perhaps, phosphate mining, in which they may he employed, it follows that a large number must earn a living as farm laborers or live without employment, both of which conclusions are correct.

The work stock numbers 7,692 aninals, being eleven-hundresths of an animal per capita, which is more than the ratio in the lower pine belt, but less than that of the other regions. The work stock per square mile is 4.5 , being greater than in any other region, except in the upper pine belt and Piedmont regions.

The product of grain, including corn, small grain and rice, is 793,669 bushels, being 11 bushels per cupita, the minimum found in any region of the State. Per square mile, the average is 466 bushels, which compares favorably with an average of 501 bushels for the whole State, especially when the salt marshes are allowed for. This is an increase on the erop of 1870 , which was only stated at 389,720 bushels, or 229 bushels per square mile, and 18 bushels per capita, the latter figure being much diminished by the larger population returns of 1880 .

The total of all stock, including work stock, is 43,946 , averaging 25.8 per square mile against an average of 57.1 for the whole State, and 0.65 per capita, being a little less than half the average of the whole state, which is 1.27 . This is an increase since 1870 , the average then being 9.4 per square mile, and 0.70 per capita.

The acreage of improved land is 106,772 , being 62 acres per square mile, not quite one-tenth of the total area, and 1.5 acres per capita, as against an arerage of 3.8 acres per capita for the whole State. The bulk of this land is planted in $\cdot$ corn, cotton, small grain and rice, there being only 9,552 acres in other crops and fallow; a large part of the latter lueing, doubtless, the cotton lands left fallow by the best planters each alternate year.

\section{PRODUCTIONS.}

The olive and orange tree bring their fruit to full perfection on the South Carolina coast. Once only during a period of sixteen years previous to 1880 were the orange trees injured by frost, when the tops of about one-fourth were killed, while the roots put out fresh shoots; the fruit from single trees in the neighborhood of Beanfort has for a series of years sold for $\$ 150$ to $\$ 250$. The oranges of this region bring a higher price in the market and are thought superior to those grown further south. Even the banana, with a not expensive winter protection, has been marle to ripen its fruit. Fig trees of every variety, with little or no attention, grow everywhere and produce several abundant crops yearly; so that could some process similar to the Alden process for drying fruit 
be adapted to them, they might become an important staple of export. Every rariety of garden produce does well, as witness the extensive truck gardens on Charleston Neck, which furnish large supllies of fruits and regetables of the finest quality to distant markets. The wild grapes, which attracted the notice of the first French colonists in 1562, still abound, and perhaps the largest grape vine in the world is one eighteen inches in diameter, near Sheldon Chureh, Beaufort County. Hay made of Bermuda grasses, ranking in the market with the best imported hay, has been profitably grown. Five acres at the Atlantic farm have, for a series of years, yielded nine thousand pounds per acre yearly, and on the Stono farm two tons one year, and four and a half another, has been made to the acre. Winter vetches grow wild, and the vine of the cow pea furnishes an abundant forage, besides increasing the fertility of the soil. The red rust proof oat, recently introduced, is peculiarly arlapted to the mild winters of this region, yielding readily, and with great certainty, thirty to fifty bushels per acre. Should an increase of the population call for a larger food supply, the sweet potato would furnish it to an extent practically unlimited. Indigo, rice, hemp, beans, peanuts, the castor oil bean, the sugar cane, and many other sub-tropical fruits and regetables, too numerous to catalogue here, have been successfully cultivated as field crops. Indian corn, of the white flint variety, yields in the coast counties a little more per acre than the average yicld of the same crop throughout the State. Nevertheless, only a very limited attention is bestowed on the culture of any of these articles, the leading crop, to the exclusion or dwarfing of all others, being

\section{LONG STAPLE COTTON.}

In every handful of ordinary cotton seed, three varieties, presenting well marked differences, may be recognized at a glance. The largest of these is covered with a green down; another, smaller and much more numerous seed, is covered with a white or gravish down; the third variety is naked, smooth and black. Whether these three sorts of seed correspond to three classes under which the numerous varieties of cotton are arranged, that is, the green seed with gossypium hirsutum or shrub cotton, attaining a height of ten or twelve feet, a native of Mexico, and varying as an annual, biennial or perennial, according to the climate in which it is grown; the white seed, with gossypium herbaceum, or herbaceous cotton, an annual, attaining a height of two feet, native of the Coromandel coast and the Nilgeherries; the black secd, with gossypium arboreum, or tree cotton, a native of the Indian Peninsular, but attaining a height of one hundred feet on the Guinea coast, and producing a silky 
cotton, it may not be possible to say. The black seed, however, is not distingrisher from the seel of the long staple or sea island cotton. If selecter from among the other varieties of upland cotton seed, it will in a series of years produce a fincr, silkier and stronger fibre than ordinary uplands. If the best and purest sea island cotton seet be planted in the neighborhood of the mpland or short staple cotton they will readily hybridize. Among the numerous varieties of hybrids thus produced, there will prominently appear a vigorous plant, with a very large green seed. The staple of these green seed plants varies greatly, in some instances being very short and coarse, in others longer and finer even than the best sea island. The most marked characteristic, however, of these hybrids will be the size and vigor of the plants, the size of the seed and the very small amomt of lint they yicld. A noticeable feature, too, is the large number of vigorous, growing, but unfruitful, plants that these green seed hybrids produce, their large, glossy leaves showing above the other plants, but bearing the season through neither bud or blossom. Possibly such plants merely resume the biennial character of the tree or the shrub cotton and would be fruitful the second season.

Were it in place here to offer a theory, these characteristics of this green seed hybrid might be adduced as evidence of a reversion to the original type of the allied species which Darwin refers to, as a frequent occurrence among hybrids produced between remoter and more dissimilar varieties.

\section{ORIGIN OF LONG STAPLE COTTON.}

It would be a matter of much interest to determine the origin and history of the varieties of cotton now in cultivation. The difficulties of rloing this are much increased by the rery wide geographical range occupied by the plant. The earliest explorers, Columbus, Magellan, Drake, Capt. cook, and others, seem to have found it almost everywhere in the broad belt extending from the equator to $30^{\circ} \mathrm{S}$. and to $40^{\circ}$ and $45^{\circ} \mathrm{N}$. latiturle, where it now grows. Although it is not found among those oldest of restments, the wrappings of Egyptian mumnies, its use was known to man in Europe, Asia, Africa, America, and the outlying islands of the sea, in the remote past, far beyond the historic age. Its very name itself bears evidence to this, occurring as it does in many, and in the most ancient languages. Thus through the Dutch ketoen, Italian cotone, Spanish algorlon, we pass to the Greek kiton, turned wrong side out in the Latin tunic, to the Arabic katan, the Syriac kethene, the Samaritan kitana, the Sansecrit katan, the Hebrew kuttoneth (Gen. xxxii: 2:3, 31), the Ethiopic kethan, the Chaldee kethan; and Gesenius conducts us to a most ancient and obsolete Semetic root, kathan, signifying to cover. Nevertheless nothing 
can show more clearly the importance of tracing and understanding the histeny of plants under fultivation than the variations and improvements in black seed cotton since its introduction on the Carolina coast. It is known that the first bale of long staple cotton exported from America, in 1788, was grown on St. Simon's island, Georgia. That this bale was grown by a Mr. Bissell, from seed that came from either the Bahama or the Barbadoes islands. Singularly enough the authorities leave this matter in doubt-the Hon. W Wm. Elliott saying it came from Anguilla, one of the Bahamas, and Signor Filippo Partatori (Florence, 1S66) saving it came from Cat island, one of the Barbadoes. But as Anguilla is one of the Barbadoes, and Cat island one of the Bahamas, it would seem difficult to decide to which group of islands we are indebted for these seed. However, as Mr. Thomas Spalding, of Sapelo island, says in a letter to Goremor Seabrook, in 1844, that three parcels of long staple cotton seed were brought to a gentleman in Georgia, from the Bahamas, in 1785 and 1786 , it would seem that the seed reached our coast from those islands. In the Bahamas it was ealled gossypium barbarlense, in consequence doubtless of being brought from Barbadoes. In the latter island it was known as Persian cotton (Edward's West Indies, vol. iv., p. 363) and was thought to have come from that country where it was originally derived from the gossypyum arboreum of India. Be this as it may, Mrs. Kinsey Burden, of Burden's island, Colleton county, S. C., obtained some of these seeds from Georgia and planted them. This crop failed to mature, and the first successful crop of long staple cotton grown in South Carolina was planted in 1790, by William Elliott, on the northwest corner of Hilton Head, on the exact spot where Jean Ribault landed the first colonists and erected a column of stone, claiming the territory for France a century before the Enclish settled on the coast. Mr. Elliott's crop sold for $10 \frac{1}{2} \mathrm{~d}$. per pound. Other planters made use of this seed, but it was not until Kinsey Burden, Sr., of Colleton county, began his selections of seed, about the year 1805 , that attention was strongly called to the long staple. Mr. Burden sold his erop of that year for twenty-five cents per pound more than did any of his neighbors. He continued to make selections of seed and to improre his staple, and in 1825 he sold a crop of sixty bales at $\$ 1.16$ per pound. The year subsequent his crop sold for $\$ 1.25$, and in 1828 , he sold two bales of extra fine cotton at $\$ 2.00$ per pound, a price not often exceeded since. The legislature was on the point of offering Mr. Burden $\$ 200,000$ for his method of improving the staple of cotton, and Mr. W' $\mathrm{m}$. Seabrook, of Edisto, was prepared to pay him $\$ 50,000$ for his secret, when it was discorered that the fine cotton was due wholly to improvements made in the seed by careful and skillful selections. Since then the greatest eare has been bestowed upon the selection of the seed, and to such perfection 
Was the staple brought by this means, that the crops of some planters weresold, not hy sample, but by the brand on the bale, as the finest wines are. 1)uring the war the cultivation of the finest varieties being alsandoned on the islands, the seed removed to the interior greatly deteriorated in quality. So scarce, on this account, was good seed directly after the war, that J. T. Dill, a cotton merchant in Charleston, at one time had in an ordinary letter envelope the seed from which all the better qualities of long.staple cultivated now was derived. Nor lave the improvements made by careful selection of the seed ceased in later years. The staple has kept fully up to the best grades of former days, and the proportion of lint to seed cotton has been increased. Formerly one pound of lint cotton from five pounds of seed cotton of the fine raricties was considered satisfactory. 'Thanks to the efforts of Mr. E. M. Clark, a fine variety of cotton has been recently found, which yields one pound of lint to three and one-half pounds of seed cotton, preserving at the same time the strength, length and evenness of fibre characteristic of the best varieties.

\section{APPEARANCE OF THE PLANT.}

The sea island cotton plant is a larger and more rigorous grower than the upland plant. It withstands the vicissitudes of the heat and cold better, and it is less subject to discasc ; blight and rust do not affect it as readily as they do the upland cotton, nor does it shed its forms and bolls to anything like the same extent. These remarks as to rust apply also to those varieties of uplands in which the length of the staple has been improved by selection of the seed, and rows of this are often seen healthy and rigorous, while the short staple uplands around are withered with the rust. The early growth of the sea island is so vigorous, that it maintains itself in fields infested with Bermurla and nut grass, as the uplands could not do. The leaves are larger, smoother, and of a brighter green than uplands, and the flowers are larger, hand:omer, and of a more golden yellow. But the bolls are smaller, and instead of being fire-lobed are only three-lobed-these lobes being so sharp pointed as to prick the fingers, to the serious inconvenience of pickers not accustomed to gather it. Of course the small size of the bolls requiring so many to make a pound, adds much to the tediousness and expense of harvesting the crop. 'The fibre of the lint is much finer, stronger, smoother and silkier than uplands; and while the latter is only $\frac{1}{2}$ to $\frac{3}{4}$ inches in length, the sea island will measure $1 \frac{1}{2}$ to 212 inches; the color, too, has a cast of creamy yellowness not observed in uplands. 


\section{LABOR AND SYSTEAI OF PLANTING.}

On the sea islands of Carolina, field labor is performed almost exclusively by negroes. Nearly all of them are engaged in farming on their own account; a large number own farms; a still larger number rent lands for cultivation, and even the laborers are paid most generally by granting them the use of so many acres of land for certain stipulater services. The total number of farms on the islands is stated to be fifty-four hundred and fifty-three, but the number probably exceeds six thousand, the enumerators having had the lands and crops cultivated by renters retumed by the landowner, and consolidating them as being in some sort under one management, when they were, in reality, entirely independent-an error ever likely to occur, and sometimes quite difficult to aroid, and which has no doubt caused the number of farms to be underestimated and their size orerestimated in many sections of the South. The largest number of acres of sea island cotton planted under one management nowhere exceeds one hundred acres. The white planters do not probably arerage more than thirty acres, and this necessitates that they should be landlords of considerable estate. For as the laborers are frequently given five to seven acres for two days' work in the week, and as this two days' work per week does not suffice for the eultivation of more than four acres, to cultirate thirty acres of cotton under this system requires seventy-five acres of land; add to this the amount usually planted in corn and other crops, and we will have one hundred and twenty acres. As under the best system the land lies fallow every other year, the planter of thirty acres of cotton will require two hundred and forty acres of open land; and as scarcely one-fiftl of the land is under cultivation, such a planter will probably own some twelve hundred acres. Thus there is no proportion between the size of the farm actually cultivated and the land holdings-the first being quite small and the last large. This state of things is owing to absence of eapital and the low price of land and labor. Lands which were worth $\$ 50$ to $\$ 60$ an acre more than half a century ago (Mill's Statistics S. C., pp. 372 and 472), and which had increased in ralue down to 1560 , being until recently either wholly unsaleable or selling at $\$ 10$ per acre or less.

\section{WAGES.}

On James island, which at this time is perhaps under a more progressive system of culture than the other sea islands, laborers are paid eash for their work, at the rate of fifty cents per diem and $\$ 10$ per month, with 
board-the latter being a ration of threc pounds of bacon and one peck of engist a week, with shelter and fuel. The soil and the condition of the laborers is reported as improving, and cash wages are considered preferable to the sliare, or the lanel system of payment. Arable land rents here at $\$ 2$ an acre per annum. The price of land is from $\$ 15$ to $\$ 30$ an acre. I few laborers own their houses, but very few own any farming land.

On John's island, cash wages are from $\$ \$$ to $\$ 10$ a month, with board. Most of the laborer's, however, are engaged for two days' work a week by allowing them a house, fuel, and six to seven acres of laml free of rent. The report is that the system is not satisfactory. The lands worked by the landlords are improving; that worked by the laborers on their own account is deteriorating rapidly. The labor is not so easily controlled as when cash wages are paid. The lands vary greatly in price-prices ranging from $\$ 2.50$ to $\$ 20$ per acre, with some lands valued recently still higher. Rient is higher than on James' Island, in consequence of a system that increases the demand by multiplying small farmers, and it is sabout \$3 per acre per annum.

On Elisto island, the two dạs' system prevails. The laborer gives the landlord two days' work in every week during ten months of the year, and receives in return a house, fuel, and six acres of arable land, which, together with such other land as he mar rent, he cultivates on his own account during the remainder of the wegk. When extra work is required on the farm, these laboring tenants are employed at fifty cents by the day. The system is reported as being quite mastisfactory, these two days hands not cultivating more than two acres as an average for the proprictor, and burkening his estate with the support of a much larger population than necessary to its cultivation. By means of this, however, a large amount of resiclent labor is securer on the place, which is of prime importance during the cotton-picking season. The laborers themselves prefer this system, having four days out of the week for themselves, they are more independent, and can make any day they choose a holiday. As a rule, they are comfortably off', and about seven per cent. are reported as owning homes of their own and some land. The land for which they pay rent service generally deteriorates in value. The lands worked by the proprietors are among the very best on the sea-coast, and are improving. The average yield of cotton on the whole island is a bale to 2.6 acres; for the six largest planters it is a bale to 1.7 acres. Considering the quality of the staple produced, it may be safely said that the larger farms yielded between two and three times as much as the small ones. Lands here are worth from $\$ 10$ to $\$ 25$ per acre-formerly they were worth from $\$ 50$ to $\$ 70$ per acre. Small tracts rent for about $\$ t$ per acre 
per annum, larger tracts for less. And there is a state of things which tends to reduce the saleable value of lands, while it increases the rental value of it.

West of St. Helena sound, land is almost without exception in the hands of small negro farmers, either as tenants or proprictors. Much of this land, valued formerly at $\$ 40$ to $\$ 60$ an acre, was confiscated, as a war measure, by the U. S. government. $A$ good deal of it was purchased by negroes at the government sales, at $\$ 1.25$ an acre, on credit, and is still owned by them. The size of the land-holdings is from one to twenty acres, and nowhere is more than fifteen acres of cotton cultivated under one management. Much of the land is uncultivated, and the remainder, in small patches, varying from one-eighth of an acre and less to three acres in size, is planted in corn, cotton and swcet potatoes, curionsly intermingled. Nowhere in the State, not even among the gardens on Charleston Neck; is the system of small culture so strikingly illustrated. The farmers usually own a cow, a mule or horse, and the work stock is sufficiently numcrous, though of a very inferior quality. Farm fixtures are of the simplest and cheapest description. There is seldom any shelter for the stock, the cabin of the proprietor being generally the only house on the premises. The stock is fed on marsh grass, with a little corn, and is, in a large measure, subsisted by being picketed out, when not at work, to graze on such weeds as the fallow spontaneously furnishes. Plows are numerous enough, but the chief reliance is upon the hoe, which, for several generations, was the only implement known to agriculturists on this coast. These small negro farmers have enjoyed many advantages. They bought their lands on easy terms, at one-thirticth to one-fiftieth of their value. They had the benefit of the famine prices of cotton during the war for their staple product. Since the war, the industries connected with the working of the phosphate rock in the rivers, and on the main lands adjacent to them, have furnished the men with employment at higher wages than could be obtained elsewhere in the State. The opening of the railway to Port Royal harbor has, also, made a demand for labor in loading and unloading vessels, at a better per dien than was elsewhere obtainable. Graded schools were early established here, and have been maintained on a large scale, uninterruptedly, for many years. Fish, oysters and game abound, and poultry, as chickens, ducks and turkeys, do particularly well. This adds largely to the ease with which these people subsist. They live comfortably, happily and peacefully. All the larger houses and buildings abont the old farmsteads have rotted down or been burned down, and have been replaced by small cabins and a few country stores, where the traders, invariably white men, who take no part in the cultivation of the soil, collect and dispose of the crop and supply 
the community with such articles of food and dress as are required. Most of the men are engagerl at the phosphate works, or on the wharves at Port Royal, and the heft of the farm work is performed by the women and children. Land is worth $\$ 10$ to $\$ 15$ an acre. (See opposite table, showing relation of size of farms, number of work stock and production.)

\section{CREDITS $A N D$ ADVANCES.}

Purchasing supplies on a credit prevails to a considerable extent, especially among the small farmers. The exact rate at which these advances are made camnot be given, as it is not charged as interest, but is included in an increased price asked for supplies purchased on credit. It varies from twenty to one hundred per cent. above the market value of the goods, according to the amount of competition among the store-keepers, who here, as elsewhere in the State, are by far the most prosperous class of the community, in proportion to the skill and capital employed. 'The better class of farmers do not approve of this credit system. It furnishes facilities to small farmers, and encourages them to undertake operations they camnot make remunerative to themselves; it reduces the number of laborers, and precludes high culture. The rental value of land is thus increased, and land which could not be sold for $\$ 10$ may be rented for $\$ 5$. The thriftless culture resulting from the small farms, unduly multiplied by this unhealthy stimulus of credit, causes many acres to be thrown yearly out of cultivation. Thus the increasing demand to rent land, in consequence of the increasing facilities for credit to small farmers, and the constantly diminishing area of arable land, resulting from the very imperfect system of culture their lack of means. forces them to adopt, create high rents, injurious to the small farmer, and impoverishes the landlord by deteriorating the quality of his land, as well as by abstracting the labor he could employ in remunerative culture.

\section{TILLAGE AND IMPROVEMENT.}

The sea islands have, since 1866 , enjoyed a law special to them, requiring the owners of live stock to enclose them. Owing to this and to the numerous creeks and marshes that intersect these islands, and which serve as natural divisions, when required, between the different fields, fences are not a burden on the agriculture of the coast lands, and there is comparatively little fencing.

Drainage, although said by Gov. Seabrook to be so little attended to on the sea islands as to be searcely worthy of being considered a regular agricultural operation, has of necessity always been practised to some extent. 


$$
\begin{aligned}
& ||^{111} \mid \\
& \text { HAH } \\
& \text { 害㐫 }
\end{aligned}
$$

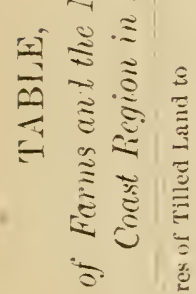

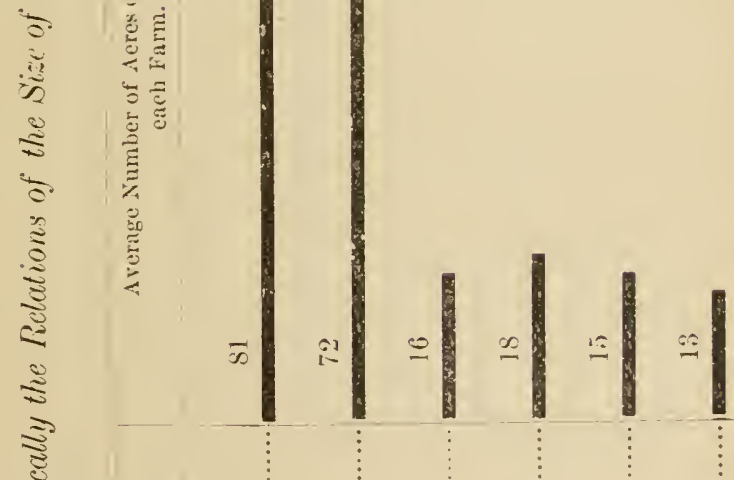

$$
\begin{aligned}
& 11111
\end{aligned}
$$



The remarkably high beds on which cotton is planted here, being from eighteen inches to two feet high, subserves this purpose. The best planters have long had open drains through their fields. These were generally made by ruming two furrows with a plow, and afterwards hanling out the loose dirt with a hoe, thus leaving an open ditch, if it may be so termed, a foot or more in deptl. In recent years the enterprising farmers on James' island have made deeper ditches and placed plank drains in them. Seeing the great benefit resulting from this, they subsequently replaced the plank with regular drainage tile. In this way they have reclaimed a good deal of land, besides adding largely to the value of that already under cultivation. The outlets open to the sea at low-water mark and the pressure of the water in the pipes preserves a constant outflow even at high tide. So that land only a foot or two above high-water mark, is susceptible of thorough drainage to the depth of four or even five feet. The borders of these islands being usually their highest parts, and the interior often quite low, a wide field for improvement is offered in this direction.

In the early part of the century, when agriculture had so far developed the value of these lands as to make $\$ 60$ an acre for planting land not an unusual price, the use of the plow was entirely unknown here, and all the operations of tillage were performed by hand with the hoe alone. This continued to be the usual practice until the war. Since then plows have come more and more into use, until their employment is now quite general.

Fallowing is practiced to the extent that land planted in cotton one year is pastured by cattle and sheep, not hogs. It is claimed that great benefit is derived by having the loose soil of the islands trodden by stock during the year they lie fallow. The rapid growth of bushes, briars and weeds is kept down by the stock, and the dried stems of the cotton stalks of the previous year are broken up and trampled down. If care be taken "that the grass is not eaten so close as to expose the soil on the tops of the beds to the summer sun," it is found when the stock are turned off in November, to range through the fields, that the pasture "is in exactly the right condition for the coming season's cotton fields, with no cotton stalks, or troublesome growth to be got off, or under the land and make it too husky."

About one-half of the land formerly cultivated is reported as "turned out" on John's island, and the same or a larger proportion on Wadmalaw. On the other islands less land has passed out of cultivation, but nowhere has the acreage under cultivation inereased. 


\section{CULTIVATION.}

$A$ mule ean do the plowing required in the cultivation of thirty acres in sea island cotton, and can, in addition, cultivate a sufficiency of land to supply corn for its own feed, perhaps something over. The first step in the preparation of the land is to hoe off the weeds ("hurricane"), cut up the cotton stalks, and pile and burn this litter. This costs forty cents per acre. Bushes are grubled up at a cost of seven cents per acre. The land is not broken up broadeast with the plow, but early in February two furrows of a single-horse turning plow are run in the old alleys, making a trench seven or eight inches deep. In this furrow a subsoil plow may or may not be run, according to the character of the subsoil. Wherever under drainage is practised, as on Janes island, the furrow is generally used. Before plows came into use this trench was never made, and even now it is omitted by some of the most successful planters. Into this trench, or into the middle of the alley, where there is no trench, the manure is placed. This consists usually of about twenty eart loads of marsh mud and one thousand to one thousand four hundred pounds of cotton seed. Stable and lot manure, together with composts of marsh mud and rushes, are also applied in the furrow at the rate of forty cart loads per acre on such a portion of the land as the limited number of stock enables the farmer to treat in this method. On the lines of manure thus laid down, a certain quantity of commercial fertilizer is drilled. This practice, wholly unknown formerly, is very common now, even the smallest negro farmers often going heavily in debt to obtain these fertilizers from the store-keepers. They are handy, obviate the labor and care of stock and the forethought and toil of collecting and manipulating composts. On James island and John's island a mixture eonsisting of two hundred and fifty pounds acid phosphate, two hundred pounds kainit (German potash salt) and two hundred pounds calcined marl is applied per acre. On Edisto island they use two hundred pounds fish scrap) (half dry in barrels), two hundred pounds kainit and two hundred pounds acid phosphate per aere. On St. Ifelena island little fertilizer is userl. Cotton seed is worth $\$ 15$ to $\$ 20$ per ton, and the commercial fertilizer's from $\$ 15$ to $\$ 30$, which would make $\$ 15$ an acre the cost of the manure anong the best farmers.

The land is now ready for listing, which is done by hauling on to the manure with a hoe the soil from the tops and sides of the old bed. A more recent practice is to lap in with two furrows of a turning plow on the manure. 'This costs only serenteen and one-half cents per acre, 
while the listing with the hoe costs eighty cents, although the latter has the great advantage of bringing all the vegetable mould and humus directly to the spot where the roots of the plant are to grow. Over the mass of dirt, weeds, manure, etc., thus collected in the old alley, a double roller, five feet from centre to ecutre, and weighing about eight hundred pounds, is passed to press together and compact the whole, completing two rows at a time. All this should be completed by the first to the middle of March, and the bed is then built up by lapping in two more furrows on a side, with a single or double horse turning plow.

The land is now rearly for planting, which may begin any time after the 20th of March; but the 1st to the 10th of $A$ pril is the time preferred. Cotton planters are not used. Three hands do this work; the one ahead chops a hole with a hoe on the top of the bed at intervals of twelve to eighteen inches; another hand drops eight or ten seed in each hole, and the third follows and covers carefully with the hoe. Three to four pecks of seed are nsed to the acre. The seed makes its appearance above ground in eight to twelve days after being planted, and the stand is perfected from the second week in April to the first week in May. Hoeing begins about the first of May. The second hoeing takes place the last of May. The plows then break out the middles (the spaces between the new beds where the old beds stood). The hoe hands follow, and pull up the loose dirt left by the plow to the foot of the cotton. This is called hauling; by it the new bed is completel, the cotton is kept from "flagging" (falling down), and the grass is kept under. It costs eighty cents per acre. At the second hoeing some stalks are thinned from the bunch in which the seed breaks the ground, and at each succeeding hoeing and hauling other stalks are removed, until in July only one stalk of each bunch is left. There are four hoeings and four haulings by the last week in July, one or more furrows with a sweep plow being run through the middles previous to each hauling. By the last of July the culture is completed, except to run a furrow with the sweep between the rows in August, to destroy grass and keep the cotton growing.

The first blossoms appear about the middle of June, when the cotton is fifteen inches high, and the bolls open towards the end of August, when the plants have attained a growth of four to five feet. Cotton picking commences from the last week in August to the second week in September. For the first picking, while the cotton is thin, one and a half cents per pound seed cotton is paid. Subsequently the price is one cent per pound, never less, until the last of November, when it rises again to one and a half to two cents. By the 15th December the crop is gathered.

Mr. W. E. Fripp, a progressive planter on John's island, remarks in concluding his report: "No improved implements are used or needed 
in sea island cotton culture." "Any one hand, with ordinary implements and management, can make four times as much cotton as he can gather." Naturally this suggests the reflection, what is to be dlone, in a region devoted almost exclusively to cotton culture, with the three hands not needed during the cultivation of the crop, but of paramount importance during the picking season. What industries can be introduced to give them employment? It would seem, whaterer they are, they must be of such a character as is suited not only to cheap labor, but to cheapen labor. Already the cotton picker pockets one-sixth of the gross value of the crop, and is a heavy burden on the producer. At $\$ 7.50$ per bale, which is below the actual cost of picking, it requires an expenditure of $\$ 40,000,000$ to $\$ 45,000,000$ to gather the crops now made. This large sum is paid out in the space of two months for work in which the most unskilled and least robust laborers excel. Just here there is a gorge in the industry of the cotton belt, piling up a vast reserve of stagnant energies to surmount the obstacle of cotton picking. Should it ever be removed, and machinery be invented to reduce the cost of this work, improvements in culture would follow so rapidly, and the product of cotton could be so greatly increased, that, besides being used for clothing, it might become one of the cheapest materials for building purposes. Everywhere, in the production of this staple, improvements are possible to an indefinite extent; but when cotton picking is reached, there, as in gold digging, the only resource is a human being, an unskilled drudge, at low wages. This absolute dependence of cotton production on purely human labor has not been without its humanizing influences, and king cotton has been more powerful to preserve friendly relations between the stronger and the weaker race than military governors and reconstruction acts. The comparatively small amount of manual labor necessary for crops of grain or hay might, had such crops replaced the culture of cotton, have left the negro with as little support on American soil as the Chinaman, and their hegira to the West, or to Africa, might have been possible; as it is, the home of the cotton pickers has been made too soft and easy a place to them to render any such occurrence at all probable.

\section{DISEASES AND ENEMIES.}

As has been already stated, the long staple cotton is a more vigorous grower and less subject to diseases than upland cotton. Neither sore shin, blight, rust, or the shedding of fruit in unfarorable seasons, seems to affect it to the same extent. Its enemies are in the regetable kingdom, weeds and grass, especially the nut grass and the Bermuda, and against these the constant and skillful use of the hoe and plow are the only safe- 
guards. The most dreaded enemy of the crop is the cotton caterpillar, which makes its appearance in warm wet spells in the latter part of summer, and speedily consumes the foliage. At one time so great and constant were the depredations of these worms, that it was feared that they would, as they did for some years, put a stop to the profitable culture of this crop. Now, however, by the use of paris green the planter counts securely on contending successfully with them, and no crop has been lost in late years where it has been used in season. A mixture of one pound of paris green, one of rosin, and forty pounds of flour, is dusted by hand orer the leaves on the first appearance of the worm, and this inexpensive process secures exemption from their ravages, even when they come in such numbers and work with such rapidity, that the portion of a field not treated to the mixture in consequence of the intervention of Sunday, is consumed beyond remedy.

\section{PREPARATION OF THE COTTON FOR MARKET.}

When the cotton has been picked, weighed and housed, it is next spread out in the sun, on what is called "an arbor." This is a platform, usually made of inch boards, raised a few feet above the ground and some twenty-five feet or more square. Here the sun and air dries the cotton, preventing it from heating, which it is liable to do when stored in bulk, and it is also thought to cause the lint to absorb some of the oil in the seed, which adds to the silky lustre of the fibre. After being thus dried, it may be either stored or passed at once to the "whipper," a machine that knocks out the dust and sand, and leaves the cotton whiter and more open. Formerly, when the price was higher than it is at present, it was all assorted. A hand was given one hundred and fifty pounds of seed cotton as a day's task, which he thoroughly overhauled, picked out all specks, stained cotton, fragments of leaf, etc. At present, however, this is usually done by two hands, who examine the cotton as it passes into the gin, and two others behind the gin, who piek out eracked seed, motes, etc., as the lint issues from the gin. The roller gin in some form has always been used for detaching the lint from black seed cotton. Nearchus, the admiral of Alexander the Great, reports its use among the Hindoos in his time. The first roller gin used in this country was one constructed in 178S, by Mr. Bissell, of Georgia, the gentleman already mentioned as having introduced this variety of cotton. It consisted of two short wooden rollers moving in opposite directions, each turned by a boy or girl, and giving, as the result of a day's work, five pounds of lint cotton. To this succeded the foot or treadle gin, imported from the West Indies, where they had been in use, having reached 
there with this varieiy of cotton seed, desecuclants, doubtless, of the Hindoo gins, mentioned by Nearchus. In 1790, I)r. Joseph Eve, a distinguished physician and poet, then of the Bahama iskands, but subsequently a resident in (icorgia, near Augusta, made great improvements in this gin, and aldapted it to be rum by horse or water power. It was claimed that his gin would detach the seed from short staple cotton; but it appears not to have suceeeded in doing this. Other improvements took place in the roller gin, from time to time; and about 1840, F. Mcrarthy, of Alabama, devised a machine which bears his name, and has been in use ever since on the sea islands. Shortly after this, small steam engines were used with the McCarthy gin, and now oxen and horses have been discarded and all the gins on the sea islands are run by steam power. A two horse power is required for each gin, which turns out on an average a bale weighing three humdred and fifty pounds as a day's work. There is a recent English improvement of the Mc.Cartly gin, known on the sea islands as the double McCarthy. This gin gives two bales in a day's work; but as it requires greater sill to attend it, they are not in general use; two, however, are in successful operation in the large ginhouse of Mr. John G. Nichols, on St. Helena island.

The great subdivision of the land into small farms under independent management, renders it impracticable for each cotton planter, as formerly, to have a gin and ginhouse of his own. To meet this state of things, "toll" gins have been established. They are usually in the hands of store-keepers at the various boat landings. 'The largest establishment of this sort is the one above mentioned on St. Helena island. Here ten gins under one shelter are run by one steam engine. Bagging is kept on hand for the convenience of customers, and the cotton is either purchased by the proprietor of the gin, or shipped by him directly from the ginhouse to any American or European port the planter may prefer. There being a large store on the premises, where the wants of the planters are supplied throughout the year, and a skilled machinist being in constant attendance on the gins, to keep everything rumning in the best order, it is much patronized. Almost the entire crop is prepared and marketed here, and planters, even as remote as Edisto island, bring their cotton to be gimned and disposed of at this gin, saving thereby, as they say, the heavy charges of wharfage, storage, insurance and commission, which are incurred when sent to city factors to be sold. This establishment is worked, in connection with others of a similar character along the coast of Georgia, and in Florida, which together handle and dispose of eight thousand or nine thousand bales of long staple cotton annually.

The usual charge at these gins is three and a half to four cents per nound, lint, and they are said to pay well. The cotton is packed in 
Dundee bagging, in round bales. No press is used, as it is thought it would injure the fibre. The work is done by hand, the cotton being beaten into the bag with a pestle. At the large ginhouse on St. Helena, however, even this work is accomplished by machinery. The bag is conveniently suspended from an iron hoop, and a disc of two inch plank, exactly fitting the bag, and moved by steam, pushes the cotton in, securing greater dispatch and accuracy in the packing.

The seed is used for manure, and when sold for this purpose, brings twenty-five to thirty-five cents per bushel of forty pounds. In 1880 , only about fifty tons were exported from Charleston, chiefly to Egypt, to be used as planting seed. In this connection an incident related by Gorernor Seabrook illustrates the difficulties attending the handling of newly introduced products. In 1796, on Mr. Brisbane's White Point plantation, in St. Paul's Parish, the disposition to be made of the cotton seed, which "the gins began to furnish freely, became a perplexing question. Being carelessly thrown on the ground, the hogs ate it and they died. It was then put into pens, but the pigs found their way between the interstices of the rails and shared the fate of their elders. As a last resort, and with a view to be rid of the nuisance, it was deposited in a small creek contiguous to the Mansion House. There, at low tide, it soon generated a miasmatic odor, which, when the wind was farorable, was so offensive as to create a strong feeling against the future culture of the erop."

What has been written refer's distinctly to the sea islands. A considerable quantity of long staple cotton in addition is grown on the mainlands and is known as Santees and as mains. The general economy of the culture is the same as on the sea islands. The seed is obtained annually or biemnially from the islands, as it is thought to deteriorate very rapidly on the mainland. In the absence of determinate experiments for a series of years it is not easy to say what the cause of this deterioration is, or even if it is due to causes of a permanent character. That the seed does deteriorate is a fact beyond question. But whether it would do so if not exposed to hybridization with uplands, and if the selections were made with the same skill and patience that is shown by the sea island planters, cannot be said to have been demonstrated. To be perfeetly secure from the influence of uplands it should be planted at least three miles distant from it, that being determined as the range of the bee whose search for honey and pollen is the fruitful source of this miseegenation. New factors too might have to be taken into consideration in the selection of the seed on new soils and in a new climate. Crops of sea island cotton have been made as high up as Orangeburg and Aiken counties. The yield was as good as on the coast, and the staple, while ranking well in the market, did not command the higher prices. Were a serious effort made for a 
number of years, it is not improbable that the eulture of this high-priced cotton might be much extended.

It is difficult to find a satisfactory answer to the question why is long staple cotton planted exclusively on the coast. Uplands have been tried there, and it has been found that they yield no more than long staple, which of course caused their abandonment as less profitable. The only explanation offered is to refer this case to that general law of cultivated plants, that their eulture is most profitable at the northern limit at which they can be grown, inasmuch as their yield at that point is greater, their cultivation cheaper, the period of growth being shorter, and their product of better quality. This certainly is true to a large extent of cotton. Latitude is the only reason that cambe given why the Carolina long staples are superior to those of Florida and Georgia. Cotton samplers say that thesame is true of uplands, and the staple grown near the mountains are finer, stronger, and more eren than the crops raised south of them. The rapid adrance that cotton culture is making in the Piedmont country would seem to show that its culture there was being found more profitable than further south.

\section{THE COST OF COTTON PRODUCTION.}

The eest of production may be considered from two points of view. First, the actral cost to certain producers, of whom inquiry has been made. Second, what may be termed the rational cost, that is, the labor, material and capital necessarily expended in production, directly or indirectly, by the producer himself, or by some one else. The first is real, but by no means expresses everything involved. For instance, on umsaleable land, a landholder, with little or no expenditure of capital, may prodnce a certain amount of cotton with labor given in return for debts that could not be otherwise collected. Such cotton would cost almost nothing to the producer. Between this and the opposite extreme, where the land had been bought above its real value, and a large expenditure made in the culture, theje is every variation of indivilual experiencefrom one of immense profits, to one ending direetly in bankruptey. The rational cost, on the other hand, is purely theoretical; in estimating the cost of each item of expenditure, it must be generalized and reduced to an average that does not, perhaps, conform exactly to the experience of any individual. It summarizes these items, and leaves them recorded for consideration. Both methods are given. Messis. Hinson \& Rivers, on James' island, say $\$ 80$ a bale of 400 pounds, or 20 cents per pound. Dr. A. B. Rose, of Charleston, puts the cost at $\$ 70$ per acre, which should yield a bale of 350 pounds, which gives, likewise, 20 cents per pound. One of 
the most, if not the most, successful among sea island planters, Mr. J. J Mikell, of Edisto, say's the cost is 15 eents per pound there.

Before considering the rational cost, a word should be said as to the amount of production. The highest yield on record to one acre is if6if pounds of lint, on a single acre on Mr. Schaffer's place, on Warmalaw island. A planter on John's island made an average of 290 pounds of lint per acre, on a tract of 20 acres, while small-farmers in the same locality produced only 50 pounds to 75 pounds lint per acre. The members of the Farmers' Club on James' island recorded, for 1870, an average yield on their fields of 280 pounds of lint. On Edisto island, there is a tract of 100 acres, producing, in that year, 210 pounds of lint per acre, and conservative farmers there consider 200 pounds of lint an average on the larger farms, year in and year out, a fair yield of fine staple. In Mills' Statistics of South Carolina, published in 1825, it is stated that a farmer on Edisto island produced, on an extensive seale, an average of 270 pounds of clean cotton to the acre. He also states that there were lots of land that had produced 435 pounds of lint to the acre. From which it would appear that the soil, elimate, and old methods of culture had a capacity not very far inferior to that with which the invention of fertilizers, and of improved implements and methods, at the present time, endows this locality.

The following table presents the rational cost, giving an itemized account of all expenditures, as reported by intelligent sea island planters. The first three columns are from Edisto, the yield being placed at 200 pounds of lint cotton to the acre. Number four is from James' island, the yield taken at 280 pounds of lint per acre. Number five represents the average expenditures of the better class of small farmers on John's island: 
Cost of each Item of Labor and Material expended in the Culture of an Acre of Cotton.

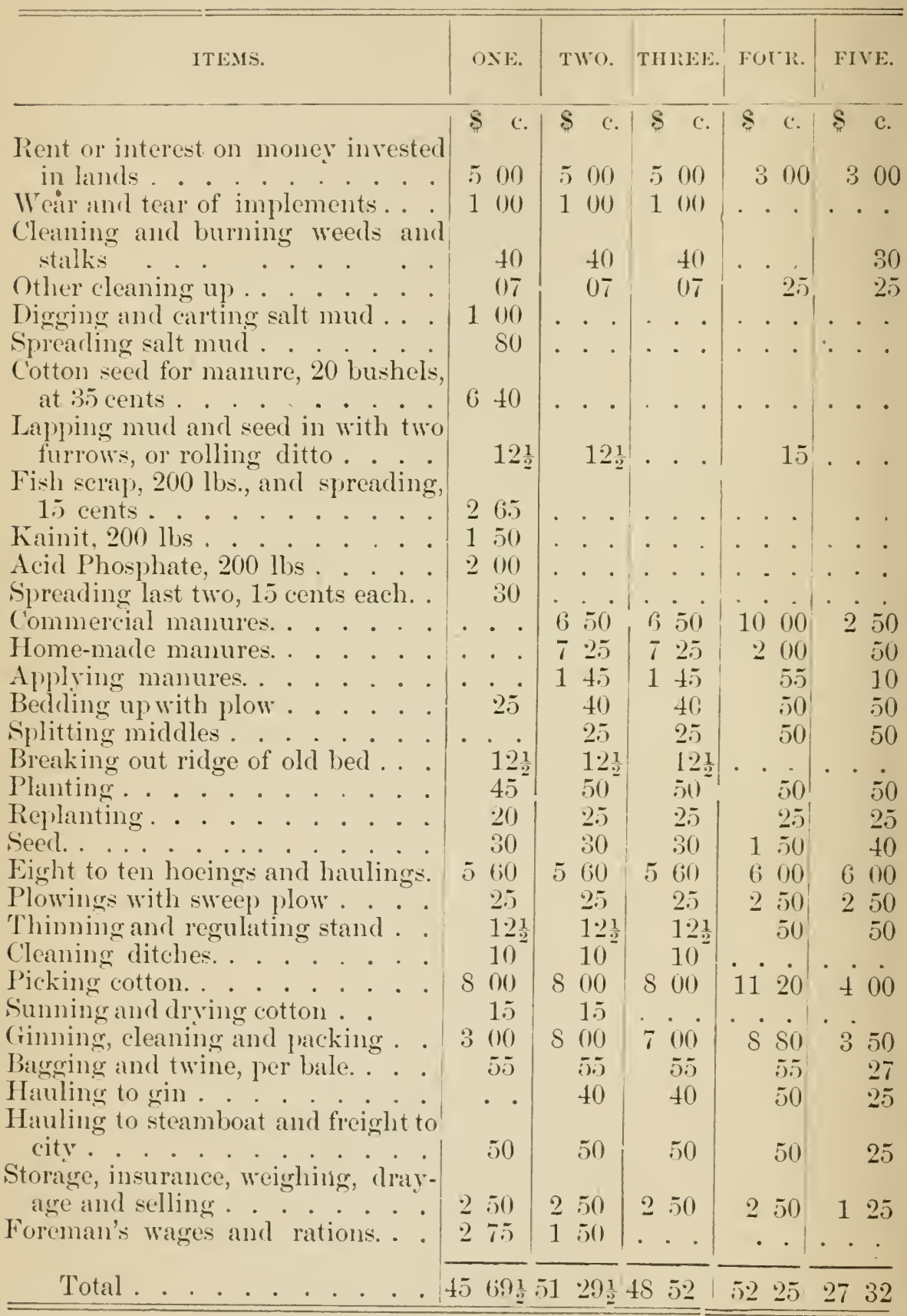


It would be a still more diffienlt problem to arrive at a satisfactory estimate of the profit per acre to the farmer. This would vary, in the first place, according to the grade of eotton produced, the prices fluctuating, with the fineness of the staple, from 30 cents all the way up to $\$ 1.10$ per lb. The value of the cotton, too, would depend greatly on the handling of the crop, whether it was picked in time, properly stored, sumnerl, dried, ginned, and moted-in all of which operations the skill, care, and forethought of the farmer would count for a great deal. But if we place the price of the cotton at 40 cents per pound, we may offer the following estimates as eoming somewhere near the eorrect decluctions to be made from the data furnished by the foregoing figures.

Cost of Cotton Per Pound, and Profit Per Acre.

\begin{tabular}{|c|c|c|c|c|c|}
\hline & ONE. & Two. & THREE. & Fouk. & FIVE. \\
\hline Cost per pound & $2 \cdot 2-10 \mathrm{c}$. & $25 \frac{1}{2} \mathrm{c}$ & $24 \frac{1}{4} \mathrm{c}$ & 18 3-5c. & $273-10 \mathrm{c}$ \\
\hline $\left.\begin{array}{c}\text { Do. plus value of seed } \\
\text { produced and less in- } \\
\text { terest on investment, }\end{array}\right\}$ & $17.9-10 \mathrm{c}$. & $207-10 \mathrm{c}$. & $193-10 \mathrm{c}$ & $151-10 \mathrm{c}$. & $21 \frac{3}{4} \mathrm{c}$ \\
\hline Profit per cultirated aere & $\$ 4520$ & $\$ 38 \quad 20$ & $\$ 4140$ & $\$ 6972$ & $\$ 7825$ \\
\hline
\end{tabular}

These figures can, of course, only be approximately correct, but the wide difference that prevails between large farms and high culture, and the small farms and insufficient culture, is a hopeful indication that the efforts at improvement have met with success, a success that would be much enhanced if we estimate the improved value of soil itself, where high culture has been practiced. 


\section{CHAPTER III.}

\section{THE LOWER PINE BELT, OR SAVANNA REGION.}

\section{LOCATION AND BOUNDARIES.}

Contiguous to and immediately inland from the coast region lies the Lower Pine Belt, or Savanna region, of South Carolina. Northward it may be bounded by a line dividing Hampton county nearly in half, leaving the Savamnah river in Lawton township, running east across the county and through Broxton and Warren townships, in the northwest corner of Colleton county, to Orangeburg county, including the townships of Branchville and Cow Castle. Thence along the northern boundary of Charleston county to the Santee river. Leaving the Santee river about Wright's Bluff, this line traverses Clarendon county to its northeast corner, crosses Lynches river, descends that river to a point opposite where Catfish creek empties into the Great Pee Dee ; follows that stream to Barker's creek, passes up it to Reerly creek; down it to the Little Pee Dee, and up that river to the North Carolina line. 'The section thus bounded includes the half of Hampton county, nearly all of Colleton, two townships in Orangeburg, all but the northwest corner of Clarendon, the southwest portion of Marion, the whole of Williamsburg, and all Charleston, Georgetown and Horry counties not lying on the coast, and comprises nearly one-third of the entire State.

\section{THE PHYSICAL FEATURES}

of the Lower Pine Belt bear a striking analogy to those of the coast region. The uplands, the so-called "pine barrens," represent the sea islands. Numerous large fresh water rivers replace the great salt water rivers and arms of the sea along the coast, and the interminable net-work 
of extensive swamps and bays recall the salt marshes of the coast. Eight large rivers receiving all the water that falls in South Carolina, and a large proportion from the watershed of North Carolina, besides several smaller rivers and innumerable lesser streams, traverse this region and furnish more than 1,000 miles of navigable waters. The general appearance of the country is low and flat. The uniform level of the surface is scarcely broken anywhere, except here and there on the banks of the streams by the oceurrence of slightly rolling lands. Lime sinks are found and there is a notable ehain of them south of Eutawille, between the great bend of the Santee river and the head waters of Cooper river. In a depression of the sturface a miniature lake, never exceeding fifty vards in length by a dozen in width, and sometimes only a few feet in diameter, is found. The water is of crystalline clearuess, with a visible depth of twelve to fifteen feet, and is contained in a fumel-shaped hollow of the blue limestone rock, that underlies the soil at the depth of a few inches. These lakelets or springs have no outlet, but at their bottom fissures in the limestone rock, leading to unknown depths, are observed. Through these fissures numbers of all the rarieties of fresh water fish common to this locality, including eels and alewives, some of them of consirlerable size are seen to pass. So numerous are these fish that if all these open basins were put together into one, it would not afford food or breeding space for one-hundredth part of the fish found in any one of them. The inference seems warranted that there is here, in the caverns of the limestone rock, a subterranean stream or lake many miles in extent. The maximum elevation of this region above tide-water is reached at the village of Branchville on the South Carolina railway, and is 134 feet. From the data furnished by the survers of the railroads traversing this region, the Port Royal, South Carolina and Wilmington roads (the Charleston and Savannah road runs near to and parallel with the coast, and the surveys of the Northeastern road have been destroyed), it appears that the average slope is about $3 \frac{1}{2}$ feet per mile. This slope, however, seems to be much more rapid in the western and narrower part than it is in the eastern and broader portion of the belt. Altmans, on the Port Royal railroad, is 105 feet above mean high tide at the head of Broad river, 18 miles distant in a direct line, giving a fall of $5.8 \mathrm{ft}$. per mile. Branchville is $134 \mathrm{ft}$. above the sea, which at North Edisto inlet, near Jehossee island, is 48 miles distant, making the fall 2.8 feet per mile. In the east the railroad bridge of the Great Pee Dee is 52 miles from the sea and has an elevation above it of only about 59 feet, or but little more than oue foot to the mile. This fall would, with skillful engineering, be sufficient for thorough drainage. Left as it is, however, wholly to the operations of nature, this desirable object is far from being accomplished, 
and the broal but slow currents of the tortuous streams never free the swamps and lowlands of their superfluoms water. So level is the country amd so abumclant the supjly of water, that the engineering skill and outlay repuirer to perfect its irainage would, at compratively small additional outlay, reurler the larger part of the surface susceptible to cultivation by irrigation. In connection with drainage and the embankment of the rivers, the assertion is frequently made, that such works are less practicable now than formerly, when they were attempted in consequence of the increased size and frequency of freshets, resulting from cutting down the forests, the chief obstructions to the rapid passage of rain water into the streams. In the absence of records giving exact data on this point, this assertion rests more on the apparent nature of the case than on ascertained facts. On the contrary, nothing can be more certain than that no subsequent freshet has attained the height and extent of the great floor of 1796, known as the Yazoo freshet, and that none has exceeded the May freshet of $1 S 40$.

\section{GEOLOGICAL FEATURES.}

Out-crops of the cretaceous rocks of the secondary formation oceur east of the Santee river, in numerous localities in the Lower Pine Belt of South Carolina. Commencing at Little river, in the southeastern corner of Horry county, Prof. Tuomey followed these rocks to Mars Bluff on the Creat Pee Dee and to points as far north as Darlington C. H. They make their appearance on Lynches river in about the same latitude, and were traced by Mr. Ruftin as far west as Kingstree, the county seat of Williamsburg. They consist of a soft marl of a dark gray color, containing (as at Mars Bluff) the remains of belemnites in great number. 'This marl arerages about 34 per cent. of carbonate of lime, and rests on a stratum of hard lime or marl stone, which yields 75 per cent. of carbonate of lime. The marl stone in turn rests on a black shale of laminated clay, which rests on berls of sand. The buhr-stone reaches down into the Lower Pine Belt in several localities along its northwestern edge. Prof. Tuomey thought he had traced it as far as the Ashepoo river in Colleton and to Huspa creek in Beaufort county. But as the rocks he referred to are now recognized as belonging to the phosphate rock formation, the buhr-stone does not extend so far south as he supposerl.

The body of the Lower Pine Belt is underlaid by marl belonging to that portion of the eocene formation of the tertiary, designated by $\mathrm{Mr}$. Ruflin the Great Carolina Bed. 'These marl berls are divided into two well-marked groups, known as the Santee marls and as the Ashley and Conper river marls. The Santee marls are the older, lower and more ex- 
tensive formation. Reaching from Mayck's ferry on the Santee in Charleston county to Vance's ferry on that river in Orangelurg county, and underlying nearly the whole of Clarendon county, they have been traced along Potato ereek as far north as Sumter county. Westward they extend through Colleton, Orangehurg, Hampton and Barnwell counties, to the Savamnah river; reaching as high up on that stream as Shell bluff, a noted locality in Burke county, Ga. Their northem margin rests on the buhr-stone, and to the west and south they pass under the Ashley and Cooper marls. The Santee marls form the lowest member of the calcareous struta of the Charleston basin, and was designated by Prof. Tuomey the Coralline bed of the Charleston basin, being composed of the remains of corals and gigantic oyster shells. It eonsists of strata of soft marl, marl-stone and green sand, and is very rich in earbonate of lime, averaging 90 per cent. of that valuable ingredient of the soil.

Resting on the Sintee marls, and passing out with them beneath the pleiocene and post-pleiocene of the coast under the sea to a great depth, are the Ashley and Cooper marls. Unlike the Santee marls, they contain neither corals or oyster shells, but are composed of minute many chambered shells (Polythalamia and Foraminfera). These marls are of a dark gray color and granular texture, sometimes so compact as to render the material suitable for building purposes. Prof. Tuomey mentions a ruined house, erected long ago, by Sir John Colleton, of this material, which reminded him of Portland stone. The marks of the tools upon the walls exposed to the weather were as well defined as if they had been impressed yesterday, and the angles of a tasteful mantelpiece, handsomely moulded and decorated, were as sharp, despite its long neglect, as when first exeeuterl. These marls are not so rich as the Santee marls and arerage only about 60 per cent. of earbonate of lime. They have long been known, however, to contain a notable quantity of phosphate of lime, and a great interest attaches to them, as it is the fragments broken from their irregular surface, and rounded by the waves, which have been converted into the nodules rich in phosphate of lime and known as

\section{PHOSPHATE ROCK.}

The deposits of phosphate rock oceur over a wide range of country, reaching from North Carolina to Florida, and extending in some instances as much as 60 miles inland. Vertically, so far as their oceurrence in quantities of value economically is concerned, their distribution is confined within narrow limits. They are found at the bottom of rivers, 20 to 30 feet in depth, and on land they oceur at an elevation but slightly above mean high tide, so that the tides of the existing sea, supplemented 
in a few instances perhaps by the action of storms, is sufficient to account for any movements that these water-wom nodules have undergone. The rock of commerce occurs always above the marl, and is known as the land or water rock, according as it is found in the one element or the other. The water rock is ratker in color and harder than the land rock, and is frequently found in a layer or sheet of cementer or tightly compacted norbules, overlying the marl at the bottom of the rivers and creeks, where it either forms the bottom itself or is overlais by a deposit of mud of greater or less depth. It has been seldom dredged for at a depth exceeding 20 feet. The land rock is found at a depth of 2 feet to 10 feet (and more under elevations) below the surface of the soil, but is not mined at a depth excechling 5 to 7 feet. It is found in masses or nodules, varying from the size of a potato to several feet in diameter. These nodules are rounded, rough, indented, and frequently perforated with irregular carities. They vary in color from olive or bluish black to a yellowish or grarish white. Their specific gravity is 2.2 to 2.5 . Their hardness from 3.5 to 4 ." The fragments of a nodule give off a peculiar fotid odor on friction. By analysis it is found to contain phosphate of lime 55 to 61 per cent., carbonate of lime 5 to 10 and organic matter and water 2 to 10 per cent., with small quantities of fluorine, iron, magnesia, alumina and sulphuric acid, besides sand. The land rock is found in a loose layer, varying from a few inches to $30 \mathrm{in}$ deptl, averaging about 8 inches. It occurs in sand, mul, clay or peat, and is often intermingled with numerous remains of land and marine animals. Among the former are the remains of the mastodon, elephant, tapir, decr, and of our domestic animals, the horse, the cow and the hog. Thus showing that these very animals which were imported by the first white settlers had once inliabited this region, from which they had disappeared, so fur as tradition informs us, before the advent of man, furnishing Prof. Agassiz with one of his strongest arguments in faror of "independent centres of creation." The remains of these lind animals are found intermingled with, but never imbedded in, the phosphate rocks, giving no evidence that there was any community of origin between them. So abundant are the remains of marine animals that Mr. Toumey named this formation the "Ashley Fish Bed." Most striking among these remains are the beautifully preserved teeth of sharks, from 2 inclies to 4 inches in length; if the proportions between the teeth and the body found among existing sharks obtained with these monsters, they must have been 60 feet to 80 feet in length. The sharks teeth, on the other hand, found in the Santee marls do not differ much as regards size from those of the slarks now living on the coast, and artesian wells in the phosphate region yicld, at a depth of 700 feet below, these colossil teeth-teeth similar in size to the ancient 
fossil teeth found far inland, imbedded in the Santee marls, and to those of the fish now living in the vicinity. As to the origin of the phosphate rock, the identity of the fossil shells it contains with those of the underlying marl make this much certain, that it consists of fragments broken from the irregular surface of the marl, and that its rounded and nodular form was imparted to it by the action of the waves and currents to which it was subsequently subjected. The important question of how a marl containing originally 60 per cent. of carbonate of lime and 2 to 4 per cent. of pliospliate of lime has been changed into one containing 50 to 60 per cent. of phosphate of lime and 5 to 10 per cent. of carbonate of lime remains for consideration. 'It is a noteworthy eireumstance, that, while the great body of the eocene marls in South Carolina have preserved their constitution almost unchanged, a remarkable change is manifest at the begimning and at the close of the series; in the buhr-stone on the northern border, and in the widely removed phosphate rock on the southern; in the buhr-stone the original carbonate of lime composing the shells has been replaced by silica, renclering great masses of rock, that once might have imparted raluable properties to the soils, valueless agrieulturally; in the plosphate region masses of carbonate of lime have been converted into the phosphate, rendering them still more valuable to the tiller of the soil. Two theories have been offered to account for this substitution of the phospliate for the carbonate of lime.

One theory assumes that the fragments of marl were charged with the sweepings from guano beds formed above them by the congregation there, at some indefinite time in the past, of vast flocks of birds; in this case, bones of the birds should be among the fossils preserved in these beds. No such remains having been found, but instead the remains of numerous animals, such as the mastodon and elephant above mentioned, and it was thought that immense herds of these animals had collected at one time about the shallow salt lakes in which the nodules were left upon the recession of the sea, just as animals now do about the salt licks of Kentucky, and that the phosphoric acid derived from their exerements and remains wrought the change in the marl. To this it is objected that the spots where the most of these bones are found are not the richest in phosphates; and while it is by no means probable that the nodules were in all, or even in most instances, formed where they are at present found, it is difficult to suppose that agencies of such local and restricted character as salt licks could account for the conversion of so great a mass of material, over an area so extensive, as that presented by the phosphate formation.

The other explanation of the formation of these rocks is, that certain mollusks possess the power of separating the phosphate of lime from sea water, and that through their instrumentality the marl, and especially 
the upper strata, lecame charerei with a certain amomut of phosphate of lime. That the propertion of the phosphatr of lime thas obtained to the whole borly of thesuperficial layer's of the marl was afterwards increased; 1.st, by the removal of a comsiclerable anomut of the carlonate of lime, renelered solublely the perealation through it of rain water containing "arbonic aciel, deriyed from the decomposing vegetable matters in the soil overlaying the marl. 2d, by a well known proneness of phosphoric acid, when diffusely distributed, to concentrate and to give rise to concretionary processes similar to those olserved in the flint nodules and pebbles of the English chalk. This theory angees with the diffused oceurrence of phosphate of lime in the superficial layers of the marl, as well as with the fact that the upper layers of the deposits and the ontside of the nodules are the richest in phosphate. It substitutes for a local canse a general one, commensurate at once with the wille area oceupied hy the phosphate rocks and by the phosphatic marls of the south Atlantic seaboarcl. Such a cause also might have been in operation ages ago, when the layers of phosphate rock, found at a depth of 300 feet in arterian borings, were forming; and it may be in operation now, as the dred ring work of the Enited States Coast Surver shows that the marls accumulating at the depth of 200 fathoms on the floor of the Gulf Stream, between Florida and (uba, contain a considerable percentage of plosphate of lime.

No systematic survey, determining the extent of these deposits, has get been attempted. The only information on this bead comes from propectors, secking casily accessible rock in localitics convenient for shipment. Widely rarying estimates as to the yuantity of the rock have been rentured. Some have placed it as high as five hundred millions of tons, and others as low as five millions. The latter is the estimate of Prof. Shepard, who has prepared a map of the region. He traced the deposit over 240,000 acres, and roughly estimates the accessible rock as covering only about 10,000 acres. Even this estimated area at 800 tons per acre, which lie gives as an average, should vield $\$, 000,000$ tons. But if we examine a single mining region, as that for instance oceupied by the cro-aw company, we must eonchurle that he has very greatly underestimated the amount. This company has the exchusive right to a territory of about 6,000 acres in ('oosaw river, besides the adjacent marshes, ret mexplored. Everywhere the river botton is covered with rock, which) for the most part forms a soliel sheet, varying from $\&$ inches to $1 \frac{1}{2}$ feet in thickness. Taking the lesser thickness, we have, with a spreific grarity of 2.n, after subtracting 25 per cent. for loss in washing and drying, something over 1,700 tons to the acre, which would give for the river territory alone belonging to this one company something more than 
ten millions of tons. And in effect this company (which is the only thoroughly equipped rives mining company now at work, 1881) consider, in spite of their large plant, consisting of extensive drying sheds and wharves, three heary dredges, four larye steam tugs, sixty large flats and a numerous fleet of smaller ones, besides washers, workshops, \&c.., by which they daily raise and prepare for market hundreds of tons of rock, that their supply of material is practically unlinited. From the works of this comprany fleets of dredging boats belonging to other parties may be seen at work, and in the neighborhood there are several well known localities where rock as rich, as abundant, and, with suitable machinery as accossible, is found, but which remain unworked. It seems remarkable that while coal mining at great depths is found profitable, when the produet sells at $\$ 3.00$ per ton, that capital has not more eagerly sought employment in these superficial deposit;, worth never less than $\$ .0 .00$, and now $\$ 9.00$ per ton.

There are ten (1S81) companies engaged in land mining. The land either belongs to them or is leased by them for a term of years. Parallel ditches, two yards wide, are sunk through the soft soil to a depth of 4 feet to 7 feet, to the stratum of sand or mud in which the loose layer of phosphate nodules is found. The rock is shoveled out, thrown into heaps and transported by rail to the washers situated on the wharves, whence it is shipped. A common laborer will raise a ton a day, for which he is paic $\$ 1.75$. The product of the land rock is about 100,000 tons a rear, and the most of it is ground and manufactured into acid phosphates and other fertilizers, liy the eight manufacturing companies within the State.

The river miners work under charters from the State, which grant them a general right to work a specified territory with any other comers, or under an excluwive right to such territory. In either case they pay a royalty to the state of $\$ 1.00$ for every ton of rock raised. The river works yield about 100,000 tons of rock per annum; being harder, and therefore more difficult to grind, it has been mostly shipped to foreign or northern ports to be manufactured. Labor receires good wages at this work. Divers raising the rock from a depth of 10 feet or 12 feet, paid lyy the amount raised, working $1 \frac{1}{2}$ hours on the ebb and $1 \frac{1}{2}$ en the flood tide, earn as much as $\$ 18$ a week. This work is neither dangerous or unhealthy, and those engaged in it seem to enjoy their aquatic exercise. It is thonght that large quantities of rock underlie the salt marshes between the high and low water mark, which would be the property of the State. So far very little work, and no extensive exploration, has been made in this direction. In fact, rast quantities of the best rock ret unworked cover the buttom of many of these rivers.

The total amount of phosphate rock mined from the 1st of June, 1Sit, 
to the 31 st of January, 1882 , is estimated at $1,505,550$ tons; of this about 44 per cent. was shipped to foreign ports. The royalty of $\$ 1.00$ per ton paicl to the State for rock raised from navigable waters amounted, in 18s1, to $\$ 124,541$; a single company, the Coosaw, paying $\$ 99,135$. In this year 71,316 tons of river rock were shipped to foreign, and 52,225 tons to domestic ports. The State can safely count on a much larger revenue from this source for years to come, for at this rate of production the Coosaw comprany itself would not exhaust the rock in sight, without further exploration in its own territory, in 120 years, and the demands of agriculturists for this valuable material, while they can scarcely be less than at present, are likely to increase very much.

\section{SOIL.}

The 7,000 square miles. of uplands in the Lower Pine Belt comprises three leacling varieties of soil: 1st. A sandy loam, with a white sandy subsoil. 2d. A sandy loan, with a yellow subsoil. 3d. A sandy loam, with a clay subsoil; the clay is generally yellow, but sometimes it is red. The surface soil is lighter or darker, in proportion to the varying quantities of regetable matter it contains, and where the clay subsoil occurs, it assumes, on cultivation, a mulatto color. These soils bear a strong resemblance to the sea island soil, having this advantage, however, over them that are very generally underlaid by easily accessible beds of marl, richer in lime than those of sea islands. In drainage, however, they compare unfavorably with the sea islands. For the scouring effect of the rise and fall of the tide, which keeps the water ways around the islands open, is not only not experienced in this belt, but, on the contrary, the luxuriant water growth that flourishes here has filled up the channels, converting then into swamps, through which scarcely any current passes. This, in comnection with the level character of the country, renders the body of these lands wet. But for this, the good mechanical constitution of the soil, being light and easily tilled, and at the same time (except in the case of white sandy subsoil) sufficiently compact to be retentive of manures and moisture, together with the abundance of marl and of peat and muck at hand as amendments to the rirgin soil, would have made them most desirable lands for tillage. As it is, not more than one acre in 22 is under cultivation, and the prices of lands are from $\$ 5.00$ down to 50 cents.

The following analyses by C. U. Shepard, Sr., from Toumey's report, give an idea of the constitution of some of the poorer soils of this region, classed as pine barren. 1. Loose sandy soil. 2. Dark gray soil. 3. Very light sandy soil. 4. Loose yellow sandy soil: 


\begin{tabular}{|c|c|c|c|c|}
\hline & 1 & 2 & 3 & 4 \\
\hline Silica & 92.57 & 91.64 & 94.00 & 93.00 \\
\hline Alumina Peroxide iron and carbouate and phosohate & 1.70 & 1.70 & .94 & .81 \\
\hline $\begin{array}{l}\text { Peroxide iron, and carbonate and phosphate } \\
\text { lime }\end{array}$ & $0-1$ & O & $0-0$ & \\
\hline Water of absorption and organic matter. . & 5.03 & 6.16 & 4.56 & 4.99 \\
\hline & 00.1 & 0000 & 0000 & 0.00 \\
\hline
\end{tabular}

Dr. J. L. Smith furnishes, in the report cited, the following analyses of cotton lands in this section. 'In 1,000 parts of surface soil :

\begin{tabular}{|c|c|c|c|c|}
\hline * & 2 & 3 & 4 & \\
\hline ni & 900 & 800 & GS & SO \\
\hline & 62 & 165 & 21 & 170 \\
\hline & 8 & 1 & & 10 \\
\hline le matter & 30 & 22 & 3 & \\
\hline
\end{tabular}

Portions of these soils, soluble in warm muriatic acid, were found to contain phosphoric acid.

The 4,500 square miles of overflowed lands in the saramna region present quite a variety of swamp lands. The most elevated of these are cypress ponds-shallow flats, with an impervious elay bottom, thickly grown with small eypress. Some of them contain a thick deposit of regetable matter, and, when drained, have proved very productive. Next in order come the almost impenetrable bays, thickly set with a growth of bay, gum and tulip trees, and a dense undergrowth of vines and bushes. The soil is peat or muck, resting on blue mud, and underlaid by marl and sand. Then come the open savannas and the river bottoms, a rich, tough, loamy soil, having at times a depth of sixty feet, derived from the denudation of the upper country, whose "riehest possessions are found in well-sifted purity in these vast swamps." These are the rice lands of Carolina. Taken all in all, whether we consider the physical character of the soil, the amount of organic matter it contains, the variety of its mineral constituents, or the subtropical climate of the locality, with the facilities for irrigation, either for culture or to renew the surface fertility, they are, perhaps, excelled in productiveness by no lands in the world.

\section{GROWTH.}

The characteristic growth of the uplands is the long-leaved pine, extending in open pine woods over the wide plain, with scarcely any undergrowth except here and there the scrub oak and grasses of the 


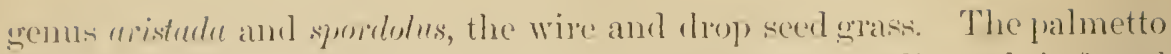
reacher only a few miles inland from salt water, but the live oak is found as much as sixty miles from the shore line. The magnolia, tulip tree, swect ambl blak geum, the white amb leed bars, the white oak, the black walnut, the elun, hickory ame eypess are amomg the largest and most conspicuous trees of the swampis; the undergrowth, commeneing with at fringe of gall berry (primos gluber) on the matrin of the swamps, and consisting of a great rariety of grape, briar and other vines, myrtles, de., is rely rense.

\section{CLIMATE.}

In the absence of weather records, it is difficult tgexpress the difference between the climate of lower pine bett and that of sea coast, alleady described, more definitely than to say that it is such difference as is to be found between the conditions finvorable for the growth of the cabluage palmetto, which barely touches the southern border of the belt, and of the live oak, that just extends to its northern or inland margin. A low, flat country, intersected by numerous swamps, might naturally be thought very sickly. This region, howerer, has one adrantage. Almost everywhere there are found small tracts, islands, as it were, of dry, sandy soil, heavily timbered with the long leaf pine, which is a barrier to the invasion of malaria. These retreats furnish places of residence as healthy ats are to be found anywhere; such a place is the village of summerville, on the s. (. R. R., a health resort that divides with sullivan sisland the fatronage of the citizens of charleston during the warm weather: McPhersonville, in IIampton, and Pineville, in Creorgetown, alre villages of the same character, and there is scarcely a neighborhood that has not some such healthy spot as a place of rexilence during summer. The dread of malaria is much less than it was when the opinion that the colored race was exempt from such influences was alluced as an alrgument to show the providential mature of their location here to develop these fertile lands. The reverses of fortune, sustained as a result of the War, have fored many white fimilies to resirle the summer long where it Wias once thought fatal to ilo so, and the experiment hals been sucessful, thus explenting the irlea that white people could not enjoy health here during the summer months. Replies from twenty-three townships state without exception, that the inhabitants enjoy good health, and that a considerable portion of the field work is performed by whites-a great (hamge since the war. The census returms give fifteen deatls per one thousand population in the portions of ('harleston and colleton counties lying in this region, for the year 1850. 


\section{STATISTICS.}

The lower pine belt con tains 10,226 square miles, of which 4,500 are alluvial or swamp lands, either covered with water or subject to orerflow. 'The tilled land is 358,5393 acres, by the ecnsus returns of 1880 , which is 30 per cent., or 171,306 acres, less than the mmber giren by the census of 1 s. $^{\prime} 0$. 'There are 1.6 farms and 35 acres of tilled land per square mile, or 20 acres of tilled and 400 acres of untilled land to the farm. Fomething less than 1 per cent. of the total area, or 6.4 acres per square mile, is planted in eotton; there is in grain of all kinds 15.8 acres, and in other crops and fallow, 13 acres per square mile, with 1.5 hearl of work stork and 2: head of all live stock. These figures represent the ninimum (the area in other (rops and fallow alone excepted) to be found anywhere in the State. Notwithstanding the small proportion of stock to the area, the people here are the staunchest alherents of the fence law, and claim entire frectom of range for their eattle. This, too, while the entire number of stock of all worts is only 1.15 per eapita of the population, being less than in any part of this state, except upon the coast.

The population numbers 203.745 (including 49,999 in the city of (harleston), or 18.9 per square mile, which is less than in any part of the State, the sand hills excepted, where the number is 11.7. The ratio of colored to white is greater than elsewhere except upon the coast, and is sixty-nime per cent., the same that it was given at in 1870.

The tilled land is 1.7 acres per capita; .2 aces more than on the coast. This is not quite one-half the average for the whole State, and is uwing. 1st, to the large area of unreclaimed swamps; $2 n d$, to the number of the population engager in the turpentine and lumber business. The large borlies of land held solely for the forest prolucts they yield, as turpentine. lumber, shingles, staves, \&c., accounts for the fact that while the number of farms to the square mile is few, the number in proportion to the population is as great, even as among the small farms on the coast, being one to every twelve and a half of the population. Nerertheless the amount of land tilled per capita has lecreased thirty-eight per cent. since 1570. showing that the forest industries are gaining on agriculture.

In point of production we have 2.7 bales of cotton per spuare mile against 1.9 in 1870 , an increase of forty-one per cent., but still less than half the minimum produced elsewhere, except on the coast. P'er calpita the yield is only sixty-eight ponnds of lint, but per acre planted in cotton it is 219 pounds, showing that in this little cultivated region the yidel of the land planted is not only above the average of the State, but is absolutely the maximum any where reached. So, too, of the grain crop, while 
it was only seven bushels in 1870 , and in 1880 only cleven bushels per capita, and only $2: 36$ bushels to the square mile, it averages over fifteen bushels to every acre planted, which is nearly fifty per cent. above the average of the State. The increase in the amount of grain produced has been eighty-two per cent. on the erop of 1870 . The work stock during the same period have increased fifty per cent, and the live stock seventysix per eent.

The explanation of these seemingly paradoxical facts is found in the consideration, that this fertile but thinly peopled region is searecly reclaimed at all from the dominion of the waters for man's uses. That there being neither capital or organized labor commensurate with this undertaking, what of either of these forces is to be found, employs itself in cul-. tivating the poorer, but more easily tilled land, or in the more tempting oceupation still of gathering the products of the forest, which nature with lavish hand offers in abundance.

\section{PRODUCTIONS.}

The most characteristic, if not the most important, crop of this region is the rice erop. The various methods of its culture fall under two classes, the dry and the wet culture.

The dry enlture is pursued on uplands and on low grounds not susceptible of irrigation. It is enltivated very much like cotton, planted in drills two and a third to three and a half feet, and in hills eighteen to twenty-four inches apart, twenty to thirty seed being dropped in the hills. The ground is afterwards kept elean and stirred ly the use of the plow and hqe, with one hand picking of the grass in the hills, when the rice is about six inches high. The yield varies with the soil and eulture, from fiften bushels to fifty bushels to the acre. This rice sometimes fetches a fancy price, as seed rice, being free from the seed of the red rice that springs up as a volunteer in the fields under water culture.

The water culture of rice is conducted on three sorts of low grounds. 1st. Flats, which may be irrigated from ponds or water "reserves" lying at a higher level. 2nd. River swamps, into which water may bo conducted by canals running from the river above, and returned to it anain at a lower level; such lands may be found anywhere in the State. sirt. The tide water lands, which are only found near the coast. These lands lie in such a prosition on the lower course of the rivers, that while they are subject to a sufficient "pitch of the tide" to irrigate them on the flood and to drain them on the ebb, they may be dammed against the invasion of salt water below and from the freshets above. By taking in the fresh water from the rivers above and letting it out below at low tide, these lands have been 
reclaimed as low down as the salt marshes. They are of limited quantity and of inexhaustible fertility, the waste of cultivation being constantly restored by the rich deposits from the turbid streams that irrigate them. Formerly their value was estimated in hundreds of dollars per acre. Since the war the difficulty of obtaining labor has changed this, many of the finest plantations remain uncultivated, or are only partially eultivated, and lands once worth from $\$ 200$ to $\$ 300$ per acre may now be bought at from $\$ 20$ to $\$ 30$, or less. There are more than two million of acres of land, consisting of inland and river swamps, and of fresh water and of salt marshes, admirably adapted to rice culture, now lying unused, in this section of the State, most of it in its original wilderness. There are numerous methods employed in the water culture of rice, from that known as dry culture, when water is sparingly used, to that known as the "all water culture," where the crop is only dried cnce or twice during the season for the purpose of weeding it. Usually it is flowed four times. Known as the "sprout flow," to perfect germination, the "point flow," to stretch up the young plant, the "long flow," when the plant is six to eight inches high, after" the first and second hoeings, and the "lay by flow," after the third hoeing and until harvest. The fine mud and decomposed vegetable matter that compose this soil is so soft that a horse will readily bog in it, and therefore horse power has been little used in their cultivation, an objection that, with the solid cross dams at short distances, would not apply to the plow moved by steam power. Horse power has, however, been used so far as to show that seed drills for planting and the mowing machine for harvesting may be successfully employed in rice culture. Under these eircumstances, taking into consideration the amount and certainty of the yield, from forty to eighty bushels per acre, and the improverl machinery for threshing and hulling, there is perhaps no food crop so entirely under the control of mechanical inventions, and so little subject either to the vicissitudes of season, or the uncertainties of human labor as the rice crop. The straw is much superior as forage to that of any of the small grains, and except the hulls of the grain, there is no waste in the crop, the very dust from the pounding, known as rice flour, being most nutritious food for stock.

Although eighty bushels per acre is generally given as a large field crop, the possibilitios of the product are much greater, and Mr. Kinsey Burden reports a yield from selected seed at the rate of 1,486 bushels per acre. The rice crop for the whole State averages 20 bushels to the acre. This means 600 pounds of merchantable rice, worth say $\$ 30 ; 400$ pounds of straw, worth $\$ 2.80$; and 100 pounds of flour, $\$ 1.50$-in all, $\$ 35.30$. Cotton gives an average of 182 pounds per acre, which, at ten cents, would be only $\$ 18.20$, or a little over half the gross yield of rice. Why 
is it, thron, that rice culture is in so deplessed a condition, and cotton cultureso flondishing". It may be brefly stated as that condition of industry which tavors small enterpreises, and discontages aceumulation of (ap)ital in large investments and the oreanization of labor into lange masses, which the enbankment, drainage and irrigation of a rice field requiles.

It has also been asserted that the protective duty of $2 \frac{3}{1}$ cents per pound on rice operates adversely to its culture. This culture repuires a large outlay of rested eapital in rams, lithes and waterwas. But as an act of congress may any day remove the protective tariff, and thus lower the matket value of the product by onc-thirel or more, captital is unvilling to encounter such a risk, refuses to enter into permanent investments in improving and restoring these lands, or in mortenges given for this purpose, and prefers to restrict itsclf to haind to mouth arlvances on the growing crop at exorlsitant rates. Thus throwing larely into the hank of mere speculators what was once the most solid and certain industry of the state. One thing is certain: while the cotton (rol) has largely increased, even while burdened with a tax of two ecnts per pound on it, the rice erop, with the protection of a duty of two cents per pound, has not recuperated, and amomnts to scarcely one-thind of the production it attained formerly without protection.

The allurement of the ready money realized by collecting the products of the forest, and by rice and cotton culture, has diverterl attention from other (rops in this section. The culture of eorn as a market crop' would be profitable. The red rust pronf oat is admirably adapted to this climate, and is one of the nost certain cols, vielding readily thirty bushels to fifty bushels to the ace. Although New England, and even European, hay has for many years been purehased to subsist, in part the work stock in this section, Mr. Ruffin, who eame from the cluver fields of Tirginia, says in his official report on the agriculture of the lower and miclille parts of South Carolina : "Few countries possess greater natural facilities, or which are more improvable by industry, for proulucing in abundance, grasses, hay and live stock, and their products of meat, butter and milk, all of which are now so deplorably deficient."

\section{O'TOTON.}

Athough the lower pine belt comprises nearly one-third of the state, it produces only a faction orel fire pere cent. of the cotton crop. The fer centane of the total area planted in cotten is less than one-tenth of one pere e'nt. in the southeastern thirel of charleston county, in the whole of Cieorgetown connty, and in the greater portion of llorry county. 
From one-tenth to one per cent. of the area is planted in cotton in the lower half of Mampton county, in Colleton county, in the northeastern portion of Charleston county, in the southem thirel of IVilliamshmra, and in portions of Horry. From one to five per cent. of the area is planted in cotton in the northeastern corner of colleton, in the northeastern part of Charleston, in the upper two-thires of Williamsburg, in the lower onefourth of Marion, and in Clarendon county.

\section{LABOR AND SYSTEM OF FARMING.}

In Colleton county, the farms on which cotton is planted vary in size from fifty to two humelred acres, and are in some instances as much as four hundred acres. A system of mixed farming is pursued; fool supplies mostly, and in an increasing legree, are raised at home. Bacon, however, for the laborers is mstally bought in ('harleston. There are a few white laborers, and the labor is chiefly performed by negrocs. Wages vary from $\$(i$ a month to $\$ 120$ and to $\$ 150$ a year. Tery few farms are worked on shares; when it is done, the landholder msually furnishes all supplics, and takes one-third of the cotton and one-lualf of the provision erop. The share system is not entirely satisfactory; the quality of the staple is not affected by it, but the fuantity produced is small, and the land deteriorates. Money wages are preferred, because it places the management under intelligent control, enables the laborer to meet his current expenses and preserves his independence from debt. The condition of the laborer is good, and about two per cent. of the negro laborers own some land, or the houses in which they live. The market value of land is two to five dollars. The rent is from one dollar and fifty cents to three dollars an acre. The system of receivingadvances on the growing cotton crop is diminishing.

In Williamsburg county, the farms on which cotton is planted vary from one huntred to six huneled acres in size. Nixed faming is practicel; the family supplies of the lamblord being usually raised at home, those of the laborer purchased in ('harleston; the tendenc'y to raise supplies is increasing. There are some white laborers, but generally negroes are cmployed; wages averaging eight dollars a month, are paid monthly or oftener. A few rotton farms are worked on shares-the terms being one-quarter of all crops for the landlord, he for the most part advancing all supplies, for which he is repaid. Land deteriorates under the share; and improves under the wages system, which latter is better for the laborer, his energies being more intelligibly directed his labor is more productive and worth more, besides it induces conomy, enables him to understand fully his financial conclition, and he is more satisfied at the 
end of the year, than when there is a settlement of accounts, the run of which he camnot keep. There is little demand for land; the price ranges from two to fifteen dollars an acre. It rents for one to two dollars an acre; more generally for one-quarter or one-third of the crop. The system of credits and advances on the growing cotton crop prevails largely from one-half to three-quarters of the farmers, both black and white, receiving such assistance.

In Clarendon, the usual size of a cotton farm is cighty acres. Mixed furming is practiced, but much of the supplies consumed is purchased in Charleston, though the tendency to raise them at home is increasing. The field labor is performed by native whites and negroes. Laborers are usually contracted with by the year, and the settlement takes place at its close. One-third of the crop to the landlord is the usual rate, where cotton farms are worked on shares, he advancing all supplies, for which he is repairl. The share system is preferred to wages. The condition of the laborers is good, and about five per cent. of them own houses and lands. Land is worth from three to five dollars an acre, and rents for one dollar per acre. The lions for advances on the growing crops, recorded in the Clerk of Court's office for the year 1S50, numbered 2,716, or one to every farm save nine, and aggregate $\$ 283,317.18$.

In Horry, the farms average fifty acres, and run from ten acres to two hundred acres in size. All supplies are made at home. The laborers are largely white natives, but there are some negroes. Wages five to sixteen dollars by the month, fifty dollars to $\$ 125$ by the year. No cotton farms are worked on shares. The soil improves under culture. Wages system preferred. The condition of the laborers is good, and about twelve per cent. of the negroes own houses and land. Unimproved land sells for one to two dollars an acre; very few advances on the crop, and those wholly for fertilizers. The liens on the growing crop recorded in the Clerk's office, 1850 , numbered twenty-seven, and aggregate $\$ 1,179.80$.

\section{TILIAGE AND IMPROVENENT.}

In Colleton county, one-quarter to one-half of the swamp lands are reported as thrown out of cultivation, but none of the lighter uplands. In Williamslurg, ten to thirty per cent. of the cultivated lands lave been abandoned. In Clarendon, at least one-third of the cultivated lands have been turned out since the war; in IIorry, very little. 'These lands all produce as well as virgin soil when reclaimed and again brought under cultivation. The depth of plowing is usually four inches with a single horse plow; sometimes a double horse plow is used, and a depth of six to seven inches attained. Subsoiling is little practiced; fall plowing is es- 
pecially adapted to these light soils that are not run together and packed by winter rains, but it is not generally practiced, because the weak force on the farms are scarcely ever sufficiently up, with the work to afford the time. Fallowing is only practiced to the extent of letting fields lie idle during summer, which it is found greatly benefits them. A rotation of erops is attempted so far as the exigencies of the cotton crop allow; by following cotton with corn, and that in the same year with oats, sowing peas on the stubble, and following with cotton again next spring. Home made manures are used, so far ás they go, with excellent results. Composts of muck and stable manures are coming more into use, and the field pea, either turned under green or allowed to wither on the surface, adds largely to the fertility; by these means almost any of the uplands are made to produce a bale of cotton to the acre. The limited means at the disposal of the farmers in these regards, in a section where little attention is paid to corn and eattle, is largely supplemented by the purchase of commercial fertilizers, especially the Charleston phosphates. In Clarendon, these are used almost exclusively, but in Colleton they are coming somewhat into disfavor, and the preference is given to the potash salts. Cotton seed, which were once thought to be only valuable as a manure for corn, are now applied with great benefit to cotton, and with the exception of a very small amount fed to stock, it is all employed in this manner; selling at from ten to fifteen cents a bushel.

\section{PLANTING AND CULTIVATION.}

Under the best system the land is broken up broadcast, with single or double plows, in the winter or early spring, but the prevailing practice is simply to turn the old beds into the alleys by running the bar of a singlehorse plow to them, making two to four furrows to the bed, the usual wilth of the rows being three and a half feet. This leaves an open furrow in the centre of the old bed, in which the manure is deposited as early as practicable in February and March. The furrows are then re-covered, and the dirt thrown on the manure, the bed built up again, and the land is ready for planting. The seed used belongs to the more prolific and improved varieties of short staple, and passes under the names of Dickson's or Herlong's improved, select, or cluster cotton. From one to three bushels are sown to the acre. Cotton-planters are much used, a cheap machine, drawn by a mule, rolling on a wheel similar to that of a wheelbarrow, by the rotation of which motion is imparted to fingers that keep the seed moving in a hopper containing them, and from which they fall into the furrow; a plow in front of the hopper opens a trench to receive the seed, and a board follows and covers. There is an arrangement to 
recrulate the amomnt of seed sown, and a grood hand and mule will easily plant six acres a day and do it in the lest mamner. The enlyoljection to the use of the machine is the difliculty of obtaining a careful hand to work it ; simple and ascy as it is, practically it is fommd they allow the

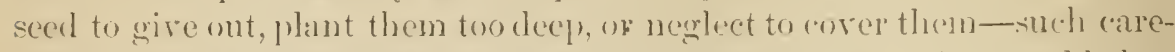
leseness, which nay escape notice at the time. rexulting as irreparable loss in injury to the stand. On this aceount much seed is sown in a trench opened on the top of the berl, made with a plow or some implement devised for the purpose, or in holes rhopped at proper intervals with a hoe. The latter methol has the arvantage of spaleing the plants more aceurately than can be done after they come up, by chopling them ont with a hoc. Planting takes place about the 10th of . Ipril. The sad alpear alove ground in five to ten days, although when late planted, in dry time, they may remain in the ground for four weeks, and when the rain comes. still give a good stand. The work of chopling out the plants in the drill, to a stand twehe to fifteen inches apart, is commenced as som as they are firmly set, that is when they have a height of five inches, and the third, or first true leaf makes its appourance. It is desirable to complete the thimning early in Jume, in order that the plants may spread when the forms or squares are making their appearance. The after cultivation consists usually of four hoeings and four plowings, to keep the plant free from grass and the surface soil light and porous. These are completer from the last of July to the 1st of August. The plant attains a height of ten to fifteen inches before blooming, and the first blooms make their appearance from the 1st to 20th of Jume. The first open bolls are seen from the last of July to the middle of August. Picking commences from the middle of August to the 1st of September. By the 10th of Norember the cotton is generally all picked. Black frost occurs sometimes as early as the 20th of October, hut is not comnted on mutil the middle of Torember, and it is sometimes deferred as late as the midrlle or end of December.

Cotton attains a height of two to four fect, and is most productive at three fect. Fresh upland, ummanured, vields from 300 to 1,000 pounds of soced cotton, the arerage being safely set at 600 pommls. Emeler good cultivation, even without manure, five erops may be taken without diminishing the vield; 1,200 poumels of secel cotton is thomght, on an averace, to yictl a bale of 400 pounds of lint, and the estintates of the amount recpuired for this purjose range from 1,000 to 1,300 pounds. It jis thought by some that the staple on old is shorter than on fresh land, but so nice a point is difficult to decide, and there is no general opinion upion the subject. 


\section{PREPARATION OF THE CROP FOR MARKET.}

The cotton is housed or earried to the gin as fast as picked, and the object is to prepare it for market with the greatest dispatch. The grimuing season closes about the ('hristmas holidars. A variety of saw gins-the Henry, the Brown, and the Winship-are amployed. Mr. (irace, of Colleton, uses the needle gin. They vary in size, from forty to fifty sims, require, when lumby horse-power, one mule to fifteen saw. About half tire gins are run by steam engines of from six to ten hor-e-power; the balance by horses. The arerage of lint turned out per lour is 217 pounds, but it varies from 120 pounds per hour on a forty-saw Winship gin, run by horse-power, to 400 pounds on the nealle gin, run by steam. There $i x$, also, a variety of presses. The old-fashioned screw is gradually being replacel by lever presses of cheap construction. Man and horse power alone are used, four men and one to two lorses packing from six to cight bales a day. liope las been entirely replaced by iron ties for baling. and the arrow tie is generally used. Crunny bagging is used, the object being to get the heaviest in the market. Much of it is furmished from a bagging factory established in Charleston, which produces annually abont the amount consumed in the State. The bales range from 450 to 550 pounds, and the arepage is 500 pounds. The erop is shipped by sailing vessel direct to New York from Horry county, at a cost of \$1.75 per biale, and all charges, including insurance, commission, \&c. \&e, amount to $\$ 3$ to $\$ 3.50$ per bale. Elsewhere, the erop is mostly shipped to Charleston-if ly river, the Santee and Pee 1)ee, at a cost of \$1 per bale: if by rail, on the Northcastern or Charleston and Sarannah railway, at \$1.2) per bale The total cost of marketing, including freight and all charoes, when sent to Charleston, is reported at from \$: to \$.) per bale.

The total cost of production is stated at seven cents per pound, at six cents to seven eents, at five cents to ten cents, varying with the season, and at cight cents.

From the following table, taken from the statements of planters as to the cost of the labor and material expended in eultivating an acre of cotton, it would appear that this averages $\$ 31.32$ in the lower pine leelt. Such cultiration should produce a 500 pound bale, but allowing for the ricissitudes of season, and taking 4.50 pounds of lint as a fair yield under this plan of operations, putting this at ten cents at the gin house, we have a net profit of $\$ 13.68$ per acre, making the cost of lint cotton per pound, (6 1-10 cents, or a little less than the above estimates. This profit per acre $i$ s not eredited with the value of the 1,000 pounds of cotton seed produced, amounting to about $\$ 10$ more. 
Cost of cach Item of Labor and Material expended in the Cultivation of an Acre of Cotton:

Rent

Fencing, Repairs and Interest . . . . . .

Knocking stalks . . . . . . . . .

Pulling and burning stalks

Other clearing up

Listing .

Berlding with hoes

Breaking up .

Harrowing

Barring old beds .

Splitting middles.

Reversing .

Laving off.

Commercial manures

Home-made manures

Applying manures .

Bedding up

Splitting middles.

Knocking off beds

Planting-opening dropping.

Replanting covering.

Seed

Thinning

Plowing

Hoeing

Picking .

Hauling to gin.

Gimning.

Nanagement.

Wear of implements.

Bagging and ties

Total

\section{$\$ 200 \$ 300 \$ 200$}

$300 \quad 100 \quad 100$

20

$25 \ldots$

25

25

50

100

50

$25 \quad 40$

$\begin{array}{rrrrr}16 & 50 & 25 & 20 \\ 4 & 00 & 0 & 2 & 50\end{array}$

$400 \quad 800 \quad 125$

$\begin{array}{lll}65 & 50 & 25\end{array}$

$30 \quad 50 \quad 30$

$\begin{array}{lll}30 & 25 & 32\end{array}$

$15 \ldots 10$

$25 \quad 40$

$\begin{array}{lll}20 & 25 & 20\end{array}$

25) 10

$20 \quad 25 \quad 10$

$40 \quad 40 \quad 45$

$\begin{array}{lll}10 & 50 & 10\end{array}$

$\begin{array}{llllll}1 & 75 & 2 & 25 & 1 & 00\end{array}$

$\begin{array}{llllllll}2 & 00 & 2 & 00 & 3 & 00\end{array}$

$560 \quad 560 \quad 700$

10 $10 \quad 100$

$\begin{array}{lllll}3 & 00 & 37 & 1 & 50\end{array}$

$100 \ldots 100$ $40 \ldots . .$.

1 () $100 \quad 100$ |\$31 $\$ 5|\$ 3597| \$ 2615$

\section{DISEASES, INSECTS, ENEMIES, \&C.}

It may be safely said that more injury is done to cotton in this section by grass than by anything else, and the only remedy that can be devised against this is hoeing and plowing. Crab grass is the chief intruder. In 
warm and wet seasons the cotton sometimes grows too much to weed, when heavily manured. Topping is tried as a remedy, but it is thought that under-drainage would be more effective. "Sore shin" is supposed to result from bruising the plant from careless hoeing, and is not a trouble of much consequence here. Shedding occurs in extremes of heat and cold. Rust and blight make their appearance late in July and August; they are attributed to the exhaustion of some elements of the soil, and potash is very popular as a remedy; they are likely to occur on coarse, sandy, ill-drained soil. Caterpillar is seldom hurtful, and Paris green has been used successfully for its destruction.

\section{ABSTRACT OF 'THE REPOR'TS OF TOWNSHIP CORRESPOND- ENTS IN THE LOWER PINE BELT.}

\section{HAMPTON COUNTY.}

Coosawhatchic Township: Pine uplands-light, porous, gray, sandy loam, with yellow sand, sometimes with yellow and red clay subsoil. Swamp lands-vegetable mould or fine alluvial deposits, resting on blue mud. About one per cent. under cultivation. Land for sale at from two to ten dollars per acre; improved land rents at from one dollar to three dollars per acre. Phosphate rocks found, but not developed. Clay of good quality for brick making. Summer pasturage of native grasses good; fine growth of cane in swamps for winter pasturage. Little attention paid to stock. Very little white labor in the lower, but a good deal in the upper portion of the township.-H. D. Burnett, Grahamville, S. C.

Pecples Tounship: Uplands-light, sandy loam, with clay in some sections; subsoil generally a coarse, yellow sand, under which is found red clay, with strata of coarse, white gravel and quicksand. Price of land, one dollar to five dollars. Rents, one dollar per acre. Wages of labor, fifty cents to one dollar per day. One-half of field labor performed by whites.-J. H. Steimage, Jr., Early Branch, S. C.

\section{COLLETON COUNTY.}

Adam's Run: Level, light, sandy loam, on dark sandy subsoil. Depth to water in wells, five to ten feet. Price of land, three dollars to five dollars per acre. Wages of day labor, seventy-five cents for men, fifty cents for women. One twentieth of field work is done by whites. Marl in abundance. 
Carn: Lands level, flat, mostly clay loam, sometimes sandy, yellow clay subsoil. Corn yields ten to thirty bushels per acre; rice, ten to forty bushels per acre. Much land is rented, little for sale, price two dollars to four dollars per acre. Much ash, poplar and cypress timber in Four-Hole swamp. Little attention paid to stock. Day wages, forty cents.

George's: Lands level; two-thirds fine sandy loam, light gray color, four to six inches to sandy subsoil, resting on clay. Corn yields ten bushels, riee fifteen bushels, and sugar cane 300 gallons syrup per acre. One-third in swamps and bays mreclaimed. Price of land $\$ 2$ to $\$ 5$ per acre. Clay for brick. Three water-powers, one working, the other two abandoned. Wages forty to fifty cents a day. One-third of field work done by whites.

Glover: Fifteen per cent. pine uplands, barely rolling enough for good drainage. Soil coarse sandy loam, resting on red clay, with a white eoarse sand below it. Ten per eent. abandoned rice folds. Soil, regetable mould two to four feet deep, resting on stiff blue clay; easily reelaimable by cleaning out the old eanals and ditches, which, while serving to drain and irrigate the land, would also give water transportation for the produce. Seventy-five per cent. swamps and hammocks unreclaimed, but very fertile, yielding, when fresh, fifty bushels corn per acre, and yielding now twenty-five bushels to thirty bushels corn, after being worked every year without manure since 1852. Nearly all the land owned by non-residents, and for sale; rents when improved for two dollars per acre. Sells for cash at from fifty eents to two dollars per aere. Lower portion underlaid by phosphate roek, but not developed. Stoek do well, but little attention is paid to it. Wages fifty cents a day. One-tenth of the farms worked by white men.-H. C. Glover, Walterboro, S. C.

\section{CHARLESTON COUNTY.}

St. Thomas and St. Denis: Once one of the wealthiest and most populous parishes of the Colony and State, now scarcely one per cent. of the land under cultivation. Uplands level, light, sandy loam, resting on clay. Natural growtl-pine, live oak, palmetto. Swamp lands unreclaimed, except the rice plantations on Cooper river. Industries-three brick-yards, five turpentine stills, and wood for fuel boated to Charleston. Phosphate rock abounds in W'ando river and the adjacent swamps, not developed.

St. John's Berkeley: Much of the land unreclaimed swamp; there is a belt of open prairie near the Santee, running from Orangeburg to the St. Stephen's line. Soil, light, fine sandy loam, resting on yellow clay; at six inches to twelve inches depth bolow chalk and marl are found. Lime rock crops out on Santee river, that hardens on exposure and might be 
utilized for building material; water, near the river, limestone; inland, free stone. Price of land, $\$ 1$ to $\$ 5$ an acre. One place sold for $\$ 8$. Very little field work by whites; negroes hire at from twenty cents to forty cents per day, or $\$ 50$ to $\$ 75$ by the year, or work two days in the week for a house and as much land as they can cultivate, or on shares, the landowner furnishing all except manures, and taking half. Timber abundant for lumber, staves, shingles, hoops, \&c.

St. Stephen's: Lands along the river rolling, for the rest level and swampy; soil, a sandy loam, resting, at depth of six inches to twenty inches, on subsoil of stiff red clay. Much unreclaimed swamp, composed of alluvial deposits and rich vegetable mould. Some marl stone found on the river, with some green sand. Price of land, $\$ 1$ to $\$ 5 ;$; per diem wages, average forty cents; the long staple cotton, known as Santees, formerly grown here, neglected now; woods grass, swamp cane and marsh furnish a good range for stock, to which little attention is paid.

St. Andrew's: Fine, dark, gray, sandy loam, resting, at six to ten inches depth, on blue clay, underlaid by phosphate rock and marl. No land for sale; rents at from $\$ 1$ to $\$ 3$ per acre; eighty per cent. not under cultivation; cane, woods grass, and swamp marsh furnish a good range for stock.

\section{CLARENDON COUNTY.}

Mott's Tounship : Three-fourths level, fine, gray, sandy loam, six inches to twelve inches to yellow sand (sometimes clay) subsoil, elay found one to two feet beneath surface; one-fourth white, sandy soil, and stiff clay land, or black flat land. Yields 700 pounds of seed cotton, five to twentyfive bushels of corn, ten to twenty-five bushels of rice. Land sells from $\$ 2$ to $\$ 10$ an acre, and rents for from $\$ 1$ to $\$ 5$; unimproved water-powers on Lynch's river and Douglass swamp. Two-thirds of field work done by whites; wages average sixty-two and a half cents by the day.

St. Paul's: 1st. Light sandy soil ; near the river swamp, not subject to overflow; contains lime, and is very productive. $2 d$. Inland from last, a belt of stiff clay land, called "bay land," produces a bale of cotton to the acre, without manure. 3il. The highlands, comprising the body of the township, known under the name of "clay lands," low and somewhat rolling, a sandy loam with small gravel in it, subsoil, yellow clay. Marl is found four to eight feet below low water mark; yields 700 pounds of seed cotton, ten to twenty bushels corn, and the same of rice. Sugar-cane two to three hundred gallons of syrup per acre; potatoes two to four hundred bushels. Half the landholders reside outside the township; land mostly rented to negro farmers for four hundred pounds of lint for one mule farm; two hundred pounds for one ox farm. White farmers do their 
own field work; labor only to be had by the job or by the day, at forty eents to one dollar. Land sells cheap for cash ; on time at from $\$ 1$ to $\$ 6$ per acre.

Manning: Surface level ; two-thirds uplands, fine dark sandy loam, resting on subsoil of yellow sand with yellow clay at one to twelve feet, beneath which a blue elay is found; alluvial bottoms. Virgin upland soil yields fifteen bushels corn, or six hundred pounds seed eotton, or two hundred and fifty bushels potatoes per acre. Price of land, one dollar to twenty dollars per acre. Besides elays, kaolin, ete., there are peats of good quality, marl and lime rock. Wages of day labor, fifty cents to one dollar. One-third of farm work done by whites.

Summy Swamp: 1st. Light, dark gray, sandy loam. 2d. Reddish clay and sand loam, with clay subsoil. 3d. Low, flat, sandy loam, with a gray elay subsoil ; wet, but produces well when drained. No. 2, the most productive, yielding, with manure, two thousand pounds of seed cotton. Price of land, one dollar to ten dollars per acre. Day wages, forty cents to one dollar; one-half the field labor performed by whites. Marl, as a shell rock, underlays this township at a depth of five feet.

\section{WILLIAMSBURG COUNTY.}

H>ps Township: Lands low, flat, level ; upland; fine, dark gray, sandy loam, with yellow sand subsoil ; clay found at a depth of eighteen inches; swamp lands unreclaimed; yield of cotton, two hundred to four hundred pounds per acre; corn, eight bushels; rice, fifteen bushels; rent for one dollar and fifty cents per acre; can be bought for cash at three dollars to four dollars per acre; two water-powers unimproved; amount of white labor increasing; day wages fifty cents; abundance of yellow pine, oak, cypress, ete., for lumber, staves and shingles.

Scranton: Low, level lands, with fine, gray, sandy soil; subsoil of yellow sand, beneath which is fine, stiff clay, overlying quicksand; four per cent. under cultivation; yield-corn ten bushels; rice, twenty bushels; potatoes, one to four hundred bushels; cotton, eight hundred to twelve hundred pounds in the seed; price, from one dollar and fifty cents to three dollars per acre; rents for one dollar, or one-fourth of the crop. Strata of marl occur; some valuable water-powers; turpentine, shingles and staves are gotten; abundant timber, including black walnut; wages, a day, fifty cents for men, thirty cents for women; five-sixths of the work done by whites.

Cump Ridge: Lands low, level; large swanps unreelaimed; upland fine, sandy loam, gray and dark, with yellow sand subsoil, under which oceurs clay and sometimes strata of marl; about one per cent. eultivated. 
Forests yield staves, shingles, yellow pine lumber and turpentine. Yield of corn, two to twenty-five bushels; rice, five to fifty bushels ; seed cotton, two hundred to eighteen hundred pounds. Land sells from one dollar and fifty cents to three dollars per acre; improved land rents from one dollar to three dollars per acre; lands rented mostly to negro tenants, a house and six to twelve acres given for two days' work in the week for ten months of the year; day wages, from twenty cents to seventy-five cents; half of the field work done by whites.

Suttin's: Near the river, lands rolling, fine, dark sand; six inches to clay subsoil; wells twenty-five to fifty feet deep. Further off, low, flat, light sandy soil, one foot to clay subsoil; wells, four to ten feet deep; strata of marl rock occur; white oak staves, shingles, ton timber, \&c., abound in the forests, besides turpentine. Yicld, without fertilizers, six to twenty bushels corn, one-half to one bale cotton. Turpentine lands sell for one dollar and fifty cents to two dollars per acre; other lands, three dollars to ten dollars per acre. Day wages, fifty cents to one dollar; nine-tenths of the field labor white, though the negroes are one and one-half to one of the whites.

Mingo: The uplands level, fine sandy loam, gray to darkish and black, with clay subsoil. Swamps yield fifty to eighty bushels corn per acre; rice, twenty to fifty bushels; uplands, ten bushels corn, one-half bale cotton, without manure; sweet potatoes, one hundred to three hundred bushels per acre. Naval stores, white oak staves, cypress shingles, and other forest products abound. Day wages, fifty cents on farms, one dollar in turpentine business; land rents from one dollar to two dollars per acre, sells for two dollars to three dollars. Three-fourths of field work by whites. Yellow calcareous sands and marl occur.

\section{MARION COUNTY.}

Britton's Neck: Most of the land river swamps or inland swamps, known as bays or back swamps; not reclaimed, but might be. The uplands are pine ridges and flats, a gray, sandy loam; four to twelve inches to subsoil of yellow clay; produce well. Cypress timber and other swamp woods in abundance; cattle raising much followed formerly. Day wages, fifty cents; much, if not most, of the field work done by white men.

\section{HORRY COUNTY.}

Gallivant's Ferry: Three-fourths of the land is a fine, dark gray, sandy loam, six inches to twelve inches to subsoil of red, less frequently of yellow clay, below which pipe clays of various colors occur. One-fourth 
swamp land of great fertility, but unimproved. Yield, three hundred to fifteen liundred pounds seed cotton per acre, five to thirty bushels corn, fifteen to thirty bushels rice. Nine-tenths of the labor performed by whites, and directed principally to collecting forest products, timber, staves, shingles, naval stores, de.

\section{GEORGETOWN COUNTY.}

Plantersille. Large inland swamps, not eleared; pine upland, white to gray colored sandy soil, with a subsoil of sand, sometimes of red clay; tide water rice lands, alluvial deposits, four to fifty feet thick. Price of uplands, one dollar to fifteen dollars per acre; of rice lands, three dollars to fifty dollars per acre. Wages fifty cents per day. 


\section{CHAPTEE IV.}

\section{THE UPPER PINE BELT.}

\section{LOCATION, PHYSICAL FEATURES AND GEOLOGY.}

The upper pine belt of South Carolina is sometimes called the middle country, as distinguished from the upper eountry and the low country, between which it lies. It has also been known as the central eotton region of Carolina, having formerly led, as it still does, in some regards, in the eulture of that staple. It may be defined as that portion of the State lying between an elevation above the sea of 130 and 250 feet. It crosses the state, in a northeasterly direction, from the Savannah river to the North Carolina line. To the south it is bounded by the lower pine belt, where the flat, open piney woods, with an undergrowth of eoarse grasses, gradually gives place to the higher and more rolling pine lands, with an undergrowth of oak and hickory. To the north, the upper pine belt sweeps round the feet of the interrupted range of high red hills traversing the State, or rises, in the intervals of this range, to the still more elevated sand hills. It comprises, generally, the counties of Barnwell, Orangeburg, Sumter, Darlington, Marlboro and Marion. The northern half of Hampton and the northwest corner of Colleton are included in it. Along the rivers, it penetrates north ward beyond the limits of the eounties named. As uplands, on the first level above the swamps, it extends, in Aiken county, as high up the Savannah as Old Fort Moore, at Sand Bar ferry; in Riehland, it reaches along the Congaree nearly to Cohumbia, embraeing the wide, level area of Lower Township, lying between that river and the sand hills; along the Wateree, between the swamps and the High Hills of Santee, it passes into Kershaw county, and along the Great Pee Dee it passes up among the sand hills of Chesterfield. 


\section{PHYSICAL FEATCRES.}

The land is level, without being flat, and is sufficiently rolling to insure good drainage for the most part. While the general slope follows the southeasterly course of the rivers, the land rises more rapidly in the west, which gives the region a marked easterly slope in addition to its southeasterly inclination. Thus, in the west, Appleton, on the Port Royal railroad, 46 miles distant from tide water, has an elevation of 259 feet, while Orangeburg, on the South Carolina railway, 65 miles from tide water, has only the same clevation, and Wedgefield, on the Manchester and Wilmington road, 74 mils srom tide water, has an elevation of only 236 feet; these being the highest points on the respective roads. The

\section{WATER COURSES}

rising in this region, or in the sand hill region above, are clear and rapid, while the larger rivers passing throngh it, that come from the mountains, are turbid. The latter furnish this region with valuable facilities for the transportation of produce. On the western side, the Savannah is navigable to Angusta for steamboats of two hundred to three hundred tons burden. The Salkehatchie river, rising in Barnwell county, might be rendered navigable to the county seat, by renoving logs. The two Edistos might be rendered navigable for small steamboats, and if the contemplated canal, connecting these streams with the Ashley river, were opened, it would become an important arenue for the cheap transportation of produce. Steamboats carrying eight hundred to one thousand bales of cotton have passed up the Santee and its confluents, the Congaree and Wateree, as far as Granby (two miles below Columbia), and to Camden. In the east, the Great Pee Dee is narigated to Cheraw, one hundred and twenty miles in an air line from the sea, by steamers; for smaller craft, Lynch's river (the Kaddipah) and Black Creek were navigable, the one eighty, and the other thirty miles from where they join the Great Pee Dee. The Little Pee Dee is also narigable for ressels of considerable burden. Besides the large streams mentioned, there are numerous smaller ones in this region, flowing with a rapid current, through healthy localities heavily timbered with pine, and capable of furnishing water-powers sufficient for the largest factories. Such are the Three Runs creeks and the Little Salkehatchie river, in Barnwell, with many smaller mill creeks; in Orangeburg, such are Four Hole, Caw Caw, Ialfway, Bull, and Dean swamps, with many lesser mill streams (on the ridge between the North and South Edisto, springs of fine drinking water 
furnish a water-power sufficient for grinding and ginning, a few hundred feet from the spot where they issue from the earth). In Sumter, such are Black river, Scape, and Big and Little Rafting ereeks; in Darlington, Cedar (where a cotton factory was erected in 1812 by General Williams), Sparrow, High Hill, Swift, Dake, Jeffry's, Middle, and Brickhold creeks, with others; in Marlboro, Crooked, Beaver Dam, Three Runs, Naked, Muddy, White's, Phill's, Ilusband's, and Hick's ereeks; in Marion, Catfish, Ashpole, Buck, Sweet, Big, Smith, and Pope ereeks. There are numerous small lakes, eliefly in the swamps, but sometimes on the uplands; in Barnwell, there is one, a beantiful sheet of elear water, two miles in cireumference, with a beach-like shore, affording a fine clrive, and surrounded on all sides by high and healthy pine uplands. The sweep wells, the bucket being attached to a pole, fastened to a long lever balanced near its middle, are characteristic of this region; generally they are from ten to twenty feet in depth, with only a short wooden eurb on top, for the rest uncurbed, being dug through a fine, compact, yellow or red clay, to a stratum of quicksand, in which an abundant supply of pure and cool water is found.

\section{GEOLOGICAL FEATURES.}

West of the Black river, in Sumter comnty, the line where the buhr-stone formation passes under the Santee marls, traverses the centre of the upper pine belt. North of it oceur the silicified shells of the buhr-stone; south of it, the coralline marls, both belonging to the eocene. East of the stream named, and in the direetion of Darlington courthouse, oceur numerous outcroppings of the miocene marls, in Sumter and Darlington counties. Lower down, in Darlington and Marion counties, on the waters of Lyneh's river and of the Great and Little Pee Dee, extensive beds of marl of the eretaceous formation of the secondary make their appearance.

Commencing on the Savannah river, a few miles above the mouth of the lower Three Runs, Mr. Tuomey traces the upper limit of the Sintee marls to Tinker's ereek, the dividing line of Aiken and Barnwell counties; thence, southeasterly, to Bimnaker's bridge, on the South Edisto river; thence to Caw Caw swamp, north of Orangeburg, and aeross to Halfway swamp, where, below the site of Stuart's old mill, the most satisfactory locality is found for observing the passage of the buhr-stone formation under the green sand, overlaid by thick strata of Santee marls; thence to the Santee river, and aeross that stream into Clarendon and Sumter counties. As an average, the Santee marls are found to contain $S S_{1}^{5}$ per cent. of carbonate of lime, and were formerly in considerable use as an 
amendment to the soil. Quantities of excellent lime were also obtained from them by burning, especially by Dr. Jamison, on Caw Caw swamp. The green sand marls intercalated with them contain 30 per cent. of carbonate of lime, and 22 per cent. of green sand.

The marls of Sumter and Darlington, examined by Mr. Tuomey, were found to contain 60 to 70 per cent. of earbonate of lime, with traces of phosphate of lime. Larger quantities of the latter are said to have been found here since attention has been directed to the value of phosphates.

\section{SOILS.}

The upper pine belt contains something over 6,000 square miles, about one-sixth of which is swamp and the remainder uplands.

The uplands consist of a fine, light, gray, sandy loam, resting on a subsoil of red or yellow clay. In the east, in Marlboro and Marion, it is usually found at only three inches to four inches. In the west it is often deeper, and a subsoil of yellow or red sand intervenes between it and the surface soil; even here the depth to clay is seldom as much as two feet.

The following are the analyses of these soils, made by Eugene A. Smith, of Alabama, for the Tenth United States Census:

(1)

Insoluble matter . . . 93.695

Soluble Silica . . . . 1.483

Potash . . . . . . 0.076

Soda . . . . . 0.060

Lime . . . . . 0.114

Magnesia . . . . . 0.202

Bn. Oxide of Manganese • $\quad 0.020$

Peroxide of Iron . . . 0.737

Alumina ...... 1.846

Phosphoric acid . . . . 0.036

Sulphuric acid . . . 0.106

Water and organic matter 1.771
(2)

91.230

2.489

0.092

0.046

0.092

0.046

0.105

0.760

2.389

0.125

0.160

3.091
(3)

96.000

0.950

0.040

0.027

0.052

0.062

0.023

0.564

0.456

0.049

0.063

1.561

99.843
(4)

S4.754

4.435

0.192

0.069

0.068

0.294

0.036

1.997

4.854

0.022

0.236

3.312

Total . . . . 100.146

Hydroscopic moisture@

$$
75^{\circ} \mathrm{F} \text {..... } 2.512
$$

100.625

2.245

1.441

100.269

No. 1 is from the Johnson field, on the Cathwood plantation of P. F. Hammond, in Aiken county, near the Savannah river, the soil being taken uniformly, as all the samples were, to the depth of twelve inches. The 
original growth was long leaf pine, with undergrowth of post oak and black jack runners. The land was cleared in 1835 and has been planted continuously in cotton for the last thirteen years, yielding from 1,000 to 1,200 pounds seed cotton average on two hundred acres last year. The cotton being a long staple variety of uplands, selling for two to five cents a pound above ordinary uplands and not very prolific.

No. 2, from Gov. Hagood's plantation, near Barnwell C. H.; mulatto soil; original growth, long leaf pine; oak and hickory undergrowth; yield 764 pounds seed cotton, average for ten years on one hundred and forty acres.

No. 3, field of Hon. C. S. McCall, near Bennettsville; original growth long leaf pine, with undergrowth of oak and dogwood; has been planted for two or three generations; yield for several years past, one bale per acre.

No. 4, virgin forest soil, from red clay ridge, near Marion and Marlboro line, on Donohoe, plantation of W. D. Johnson; growth, large hickory, oak and pine; similar land under present culture averages for large fields a bale of cotton to the acre one year with another, when planted for a succession of years in the same crop.

The following analyses are by Prof. Shepard, and were published in Tuomey's Agricultural Survey of South Carolina, in the year 1S48. No. 1 is from the cotton lands below Columbia, in Richland county; and No. 2 is from near Bennettsville, Marlboro county:

Organic matter......... 9.00

Silica ........... . 7650

Alumina . . . . . . . . . 660

Oxide of iron . . . . . . . . 240

Lime ............ . . . 1.00

Magnesia . . . . . . . . . 0.50

Potash and soda ........ t. trace

Phosphates . . . . . . . . . 0.00

Water and loss........ . . 4.00

100.00

100.00

The Pee Dee lands were little esteemed formerly, and seventy-five years ago many of them were considered so impoverished by cultivation as to have been abandoned by their owners for the fresh lands of Alabama. Under the present system of culture they are the most productive and certain in the State. As the above analyses show no superiority of the 
chemical constituents of these soils, it must be stated that their greater productiveness can only be attributed mainly to their excellent and judicious management, by which lands, naturally yielding only three to four lundred pounds of seed cotton, are made to give a bale of cotton one year with another. A good, though not a thorough, drainage, by open ditches, has lowered the water level in those lands at least four feet. The physical properties of the soil lend themselves readily to improvement. The sandy surface soil, although thin, is very fine, and the clay is of so fine a texture as to be usually described as floury. It is noteworthy, also, that fresh land of a grayish color, or where the plow turns up the subsoil of a yellowish or reddish east, blackens on exposure, and becomes darker year by year as they are cultirated. The exemption from drought, which these lands in large measure enjoy, while greatly due to their drainage and good tilth, may depend somewhat on the body of live water in the quicksand which underlies them at a depth of fifteen to twenty-five feet, whose inhaustion, in hot dry seasons, through the fine texture of the intervening clays, is not unlikely. At any rate this locality rarely suffers from drought.

The swamps, covering 1,000 square miles of this region, are of two descriptions :

1st. The river swamps. The soil is of a mulatto or mahogany color, and is a heavy alluvial loam, rendered lighter sometimes by an admixture of fine sand and mica, whence they are called isinglass lands. Such swamps are found on the banks of the Sarannah, the Santee, the Congaree, Wateree and Pee Dee rivers, varying from narrow strips to broad bottoms six and eight miles in breadth. The following is an analysis made for the patent office, by C. T. Jackson, M. D., of Boston, in 1S57, of the allurial soil of the Savannah river :

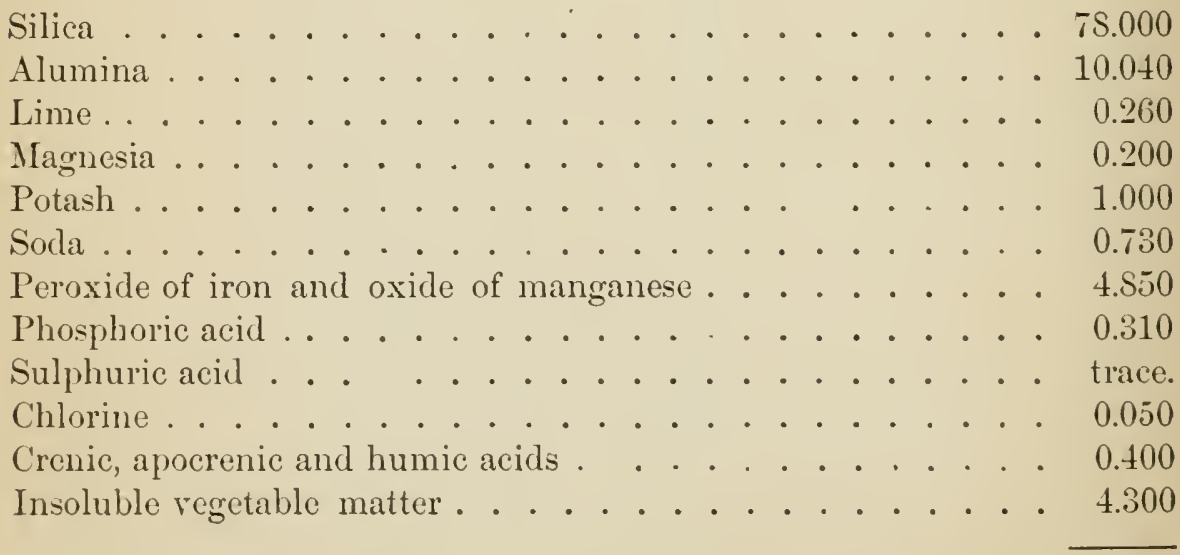


The body of these swamps lie below the point where the above sample was obtained, and are of course more fertile. Such soil, well cultivated, yields, without manure, 1,200 to 1,500 pounds of seed cotton, and from forty to seventy-five bushels of corm. These lands were being rapidly eleared and cultivated anterior to the war. Since then they have been to a great extent abandoned for the highor and more easily tilled uplands. The freshet of 1865 broke the dams on the Great Pee Dee, which excluded the freshets, and they have never been repaired. These lands are subject to overflow, and the ereetion of levees for protection has been only practiced here and there by large planters. In the absence of records showing the risk from freshets to these lands, the following extract from a plantation record, kept by James H. Hammond, is taken. The island field is at Silver Bluff, on Savannah river, and lies rather lower than the average of the Savannah river swamps. It received no manure, and being small and of little moment in the larger operations of the plantation, it had hardly average care bestowed upon it. It was planted continuously in corn and pumpkins (no record kept of the latter crop, which was always abundant). The years not entered are due to the absence of the proprietor, the land being planted as usual:

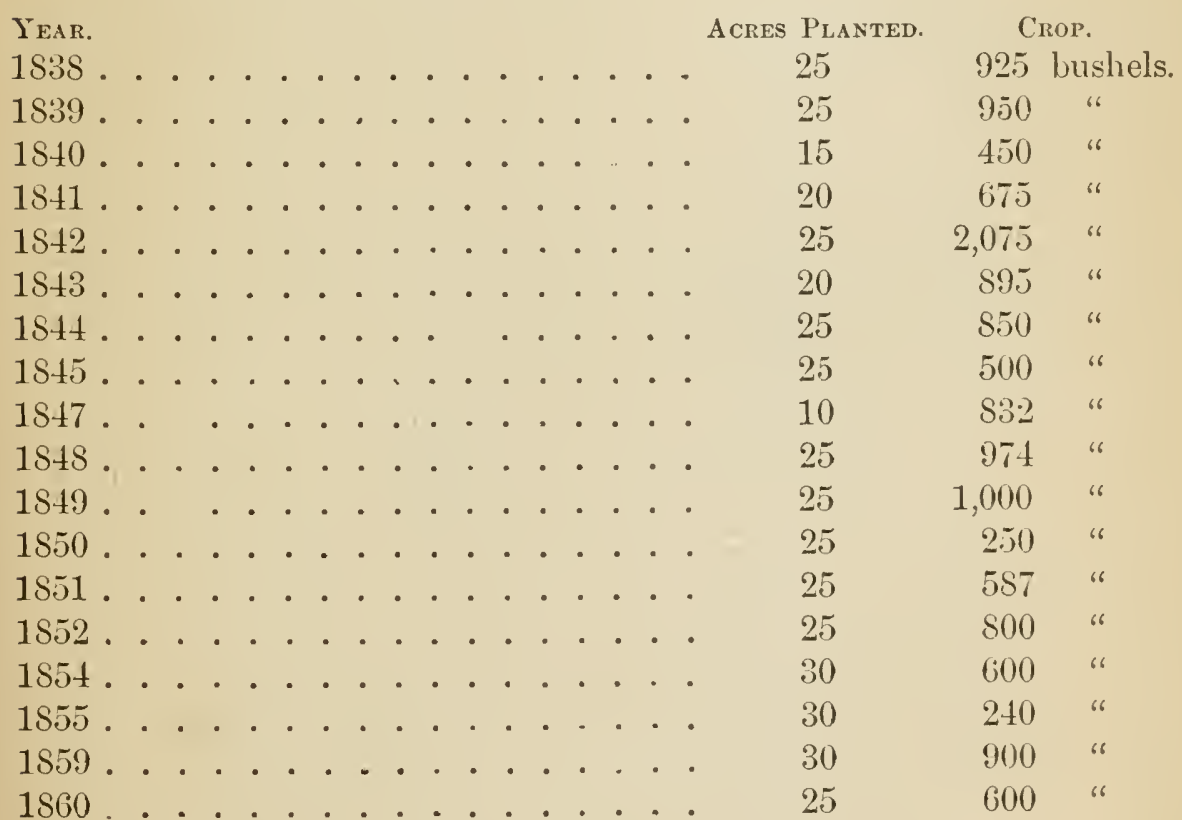

Giving an average yield of thirty-five bushels corn per acre. During these twenty-two years only one crop was seriously damaged by freshets. 
The great August freshet of 1852 injured one-third of the erop so that it could only be fed to hogs. The fluctuations of yield from eight to eightyfive was due to the seasons to a very small extent, and resulted chiefly from negleet of this field for larger interests.

2d. The other descriptions of swamps are known as bays, or upland swamps, and creck bottoms. They occur on the smaller streams, and rarely exceed two miles in width. They are also found in bodies of several thousand acres in the pine lands, on the second levels from the riversprobably ancient lakes, choked up with water-growth: The soil is black, consisting largely of decomposed vegetable matter, with a depth of three to fifteen feet, resting usually on white sand. The following analysis was marle by Professor Shepard, of a sample taken from the swamp of South Edisto river :

Organic matter. . . . . . . . . . . . 28.00

Silica . . . . . . . . . . . . . 6000

Alumina .................. . . . 4.00

Oxide of iron . . . . . . . . . . . . . . . . . 3.40

Lime . . . . . . . . . . . . . . 0.50

Potash and soda................ t trace

Water and loss ................ . . 5.10

100.00

From 1845 to 1860 , a good deal in the way of elearing these lands was done. Since then they have been much negleeterl, of necessity, and are relapsing into their original state. They are not suitable for cotton, but produce large erops of corn. The Cowden plantation gave for twelve years, without manure of any sort, an average yicld of thirty-five bushels of corn per acre, on 600 to 900 acres in one field. One year 600 acres gave an average of sixty-two and one-third bushels of corn per acre. Now it does not produce even enough to feed the stock of the negro renters, who are cultivating patehes of cotton on its margin, owing to the abandonment of all drainage.

Under the system of agriculture, at present pursued, the chief attention is paid to the more easily tilled, but less fertile uplands. Nevertheless, there is in the upper pine belt a body of 600,000 acres of productive com land, now almost wholly negleeted, but once cultivated with great profit, when eorn was worth only fifty to sixty eents a bushel, capable now of yielding fifty per cent. more than the present entire corn crop of the State. 
The latest \& the earliest Fros by James $t$

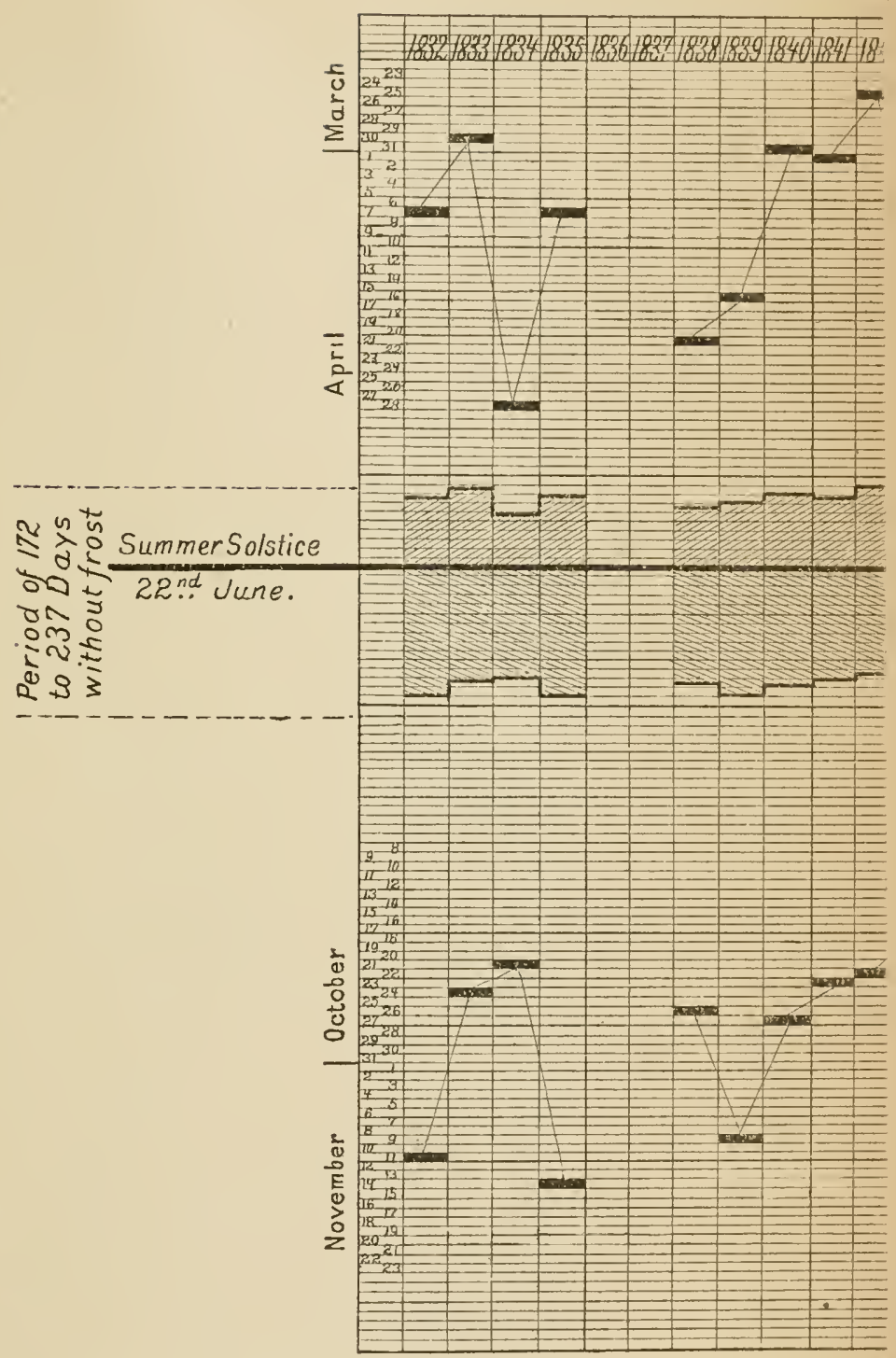

Explanation of Table.-Take the 1st column, the Year 1832, an there was frust on Narch 7 th, and lower down, in same column, on No first on November 11th, and so on through each year. 
The latest \& the earliest Frost in each year from a plantation book of record kept by James H.Hammond near Silver Bluff S.C.

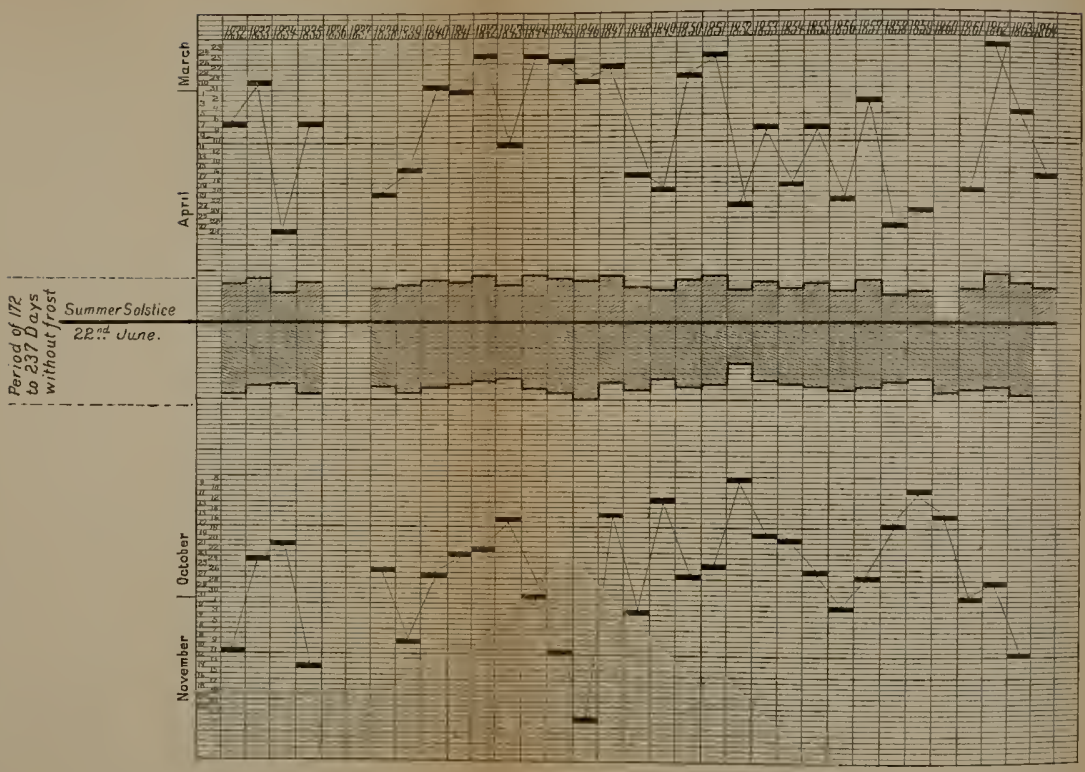

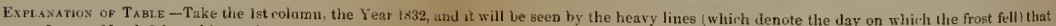

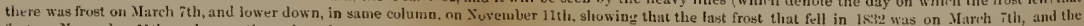

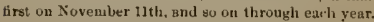




\section{CLIMATE.}

The upper pine belt is a peculiarly healthy region, and throughout its extent Mills and Simms, in their statistics, have enumerated a remarkable number of instances of longevity. There are no prevailing diseases unless it be a mild type of malarial fever during autumn, along the river swamps. The upland swamps not being subject to overflow, and resting on sand, are not troubled with these complaints when drained and cultivated. The seasons most farorable for cotton are those in which there is a dry, eold winter to facilitate the preparation of the land. Light showers in April to insure germination. A dry and warm May and June, not only to render the destruction of the grass easy, but, as the cottonplanters term it, to "eook the cotton plant"; hot weather, and even drought, at this stage of growth, increasing its productiveness. In July and August, hot weather, and seasonable showers, to keep up the strength of the plant and promote fruetification. A dry fall for picking. The length of time between the latest frost in the spring and the earliest frost in autumn has an important bearing on the crop, and, in the absence of other records, the preceding table is given.

Although the cotton planting during these years was sometimes completed as early as the 30th of March, irreparable injury to the stand was only inflicted once, in 1849, when snow fell on the 15th of April, and was succeeded by cold weather. Nor do the autumn frosts always destroy the plant completely ; blossoms at Christmas and New Year are not unfrequently seen, and there are occasionally winters of such mildness that the old cotton roots throw out fresh shoots in the spring, and there are rare instances where fields lying out have thus borne a crop the second year, that was worth gathering.

\section{GROWTH.}

The early settleis in this region were stock raisers. They kept up the Indian practice of burning off the woods during the winter. The destruction of the undergrowth by this means favored the growth of grasses, and numerous herds of almost wild cattle and horses found abundant pasturage, chiefly upon what was known as the wild oat, and the wild pea-vine. The eattle were sometimes slaughtered for their hides and tallow. The names of many townships and neighborhoods still testify to this primitive industry, as Steer Pen, Steerpoint, Horse Pen, and Pen Corner. The uplands were covered, as they still are, with a large growth of yellow pine, but a deer might then have been seen, in the vistas made by their smooth stems, a distance of half a mile, where now, since the discontinuance of the spring and autumn fires, it could not be seen fifteen 
paces for the thick growth of oak and hickory that has taken the land. Among the many varieties of oaks, the live oak does not appear, except ats a planted tree; the water oak, however, attains perfection, covering with its evergreen foliage, not unfrequently, an area of half an acre, and measuring eight to ten feet through at the root. This is the northern limit of the magnolia in its wild state, and of the gray moss. The swamp woods are cypress, white oak, gum, ash, hickory, beech, elm, and black wainut. Besides the pine, there is on the upland, dogwood, hickory and eight or ten varieties of oak, among which are the forked leaf blackjack, indicative here of a dry and thirsty soil; and the round leaf blackjack, showing a moister and more fruitful soil. The olive, the Italian chestnut, and pine, varieties of mulberry, the fig, peaches, apples, pears, pomegranites, plums, pecan nuts, English walnuts, grapes, \&e., are successfully grown.

\section{PRODUCTIONS.}

The staple crops are eotton, corn, oats, rye (the southern variety), and wheat, to a limited extent; peanuts, yielding an average of forty bushels per acre, sweet potatoes and rice. The culture of indigo and tobacco has been abandoned, though once found profitable. Considerable attention is paid in some localities to forest products-turpentine, pine timber, cypress shingles, and white oak staves. Little attention is paid to stock raising. Ninety to ninety-five per cent. of the work stock, oxen excepted, are imported. Cattle, hogs and sheep depend almost entirely for their support upon such food as the range furnishes, with as little (or less) looking after as the first settlers bestowed on their wild herds. Mills gives the stock in Orangeburg county, in 1525, as foilows: cattle, 25,000; sheep, 10,000; swine, 50,000. In the census of 1850 it stands: cattle, 16,573; sheep, 5,766 ; swine, 37,742 - a decline in the total of 20,000 , notwithstanding the population has increased from 15,563 , at that time, to 40,995 in 1850 , agriculture remaining still their chief pursuit. Besides clay for bricks and marl (except a deposit of iron ore near High Iill creek, Orangeburg), no minerals of value have been discovered in this region. The Pee Dee is the last river to the south where herring is caught in large numbers. Shad in the spring, and sturgeon.and rockfish in the summer and autumn, ascend all the rivers in this region, except that shad never enter the water:s of the Little Pee Dee, notwithstanding they are clear and deep like those of the Edisto.

\section{STATISTICS.}

The upper pine belt covers about 6,230 square miles, and has a population of 221,409 , or 35.5 to the square mile, bearing in this regard about the same proportion to the other regions of the State that it did in the 
enumeration of 1870 . The percentage of colored population is sixty against sixty-three in 1870 .

The area of tilled lend is 948,521 acres, being 152 acres to the square mile, or nearly one-fourth of the entire surface. It is 4.2 acres per capita, and twenty-one acres to the head of work stock. These lands being of easy tillage, not unfrequently forty-five acres, exclusive of small grain, is well cultivated to the mule. This is an increase of 167,497 acres over the enumeration of 1870 , by no means proportionate to the increase in the population since that date. More than one-third, or 358,505 acres, is in cotton, which is nine and a third per cent. of the entire surface, and twenty-six per cent. of the cotton acreage of the State. It is ten acres to the work animal, and one and a half acres per capita of the population; 418,417 acres are in grain crops of all kinds, including corn, small grain and rice; 169,796 acres are in fallow and in other crops; as fallow is not regularly practiced in the husbandry here pursued, and as the other crops include only sugar cane, potatoes, orchards and gardens; almost exclusively for local use, and consequently small, this figure inchudes some of the corn lands whose culture has been so largely abandoned, but which are not ret entirely grown up.

The farms number 19,649, areraging nearly fifty acres of tilled land to the farm, which is the largest average in the State. Their relation, however, to the population remains about the same as in the regions south of this, viz: one farm to twclve and a half of the population; north of this the number of farms in proportion to the population increases.

The crops are:

Cotton, 148,050 bales, against 83,210 in 1870 , an increase of seventy per cent. It is twenty-eight per cent. of the crop of the State. The yield is 327 pounds lint per capita, the largest, except in the comparativoly small Red Hill region, where it is 348 pounds of lint. The average yield per acre is 202 pounds of lint, which is also larger than elsewhere, except for the small erop of the lower pine belt. In Marlboro county, the yield per acre arerages 267 pounds of lint, and the yield per capita, 536 pounds of lint. This is the maximum product in the State, and entitles the region to its designation as the central cotton belt of Carolina.

The grain crop is $3,631,302$ bushels, an increase of one and a half millions of bushels on the returns of 1870 . This includes corn, small grain and rice, and constitutes twenty-one per cent. of the grain crop of the State. It is sixtcen bushels per capita of the population, and 8.6 bushels per acre. Allowing eighty bushols a year to the head of work stock, the 35,469 head in this region would leave less than 600,000 bushels for the population, two and three-quarter bushels per capita, with nothing for the other live stock. The maximum average product is attained in Marlboro, 
ten and a quarter bushels per acre, twenty and a half bushels per capita of polulation.

The live stock number 313,811 , which is one to every thirteen acres; sixteen to each farm; 11.4 head to each one of the population; two to the bale of cotton, and one to every eleven bushels grain produced.

\section{STSTEM OF FARMING AND LABOR.}

A mixed system of farming is pursued in the upper pine belt, and the attempt is made to raise at least a portion of the necessary farm supplies. They are not raised, however, to the extent they were formerly, and although the reports all state that the tendency to raise them is increasing, the deficiency still remains very great, as the number of liens given for provisions and recorded against the growing crop show. In Barnwell there were 2,026 liens, averaging one hundred and twenty-five dollars, being eight dollars and eighty cents per bale of cotton produced; in Orangeburg there were 2.470 liens, averaging ninety dollars, being nine dollars and eightr-seren cents per bale; in Darlington there were 3,92.5 liens, areraging one hundred dollars, being sixteen dollars and forty cents per bale; in Marlboro there were 1,183 liens, averaging one hundred and ten dollars, being five dollars and forty cents per bale; in Marion there were twelve hundred liens, areraging one hundred dollars, being five dollars and a half per bale. The number of liens for 1850 show an increase on those given above for 1879 . This does not indieate a diminution in the amount of supplies raised by farmers, but only shows an increase in the number of laborers who are seeking a credit, to enable them to do business on their own account as tenant farmers. It is by this class chiefly that the liens are given, mostly for provisions, next for fertilizers, and to some extent for mules and farm implements. It is the general experience that these small tenant farmers, mostly negroes, meet their obligations to the best of their ability; nevertheless, a mortgage given in January or February, on a crop not to be planted until April, is not taken as a first-class commercial security, and consequently the charges on the advances are heavy; for instance, when the cash price of corn is seventy five cents, the credit price is not unfrequently one dollar and twenty cents and up, ward.

West of the Santee and Wateree rivers in this region, the average acreage in cotton to the farm is fourteen acres; on only one farm is there over four hundred acres in cotton; in seventeen townships the maximum acreage is under one hundred acres; in twenty it is one hundred to two hundred; in five it is two hundred to three hundred; in two it is three hundred to four hundred. 
East of the rivers named there are farms having over six hundred acres in cotton, the average aereage in cotton to the farm is sixteen acres. Here forty-six per cent. of the farms are rented, and fifty-four per cent. worked by the owners. Of the rented farms, thirteen per cent. are over fifty acres, while of those worked by the owners eighty per cent. are above that figure.

The laborers are chiefly negroes, but the number of whites engaged in field labor is largely increasing, in some localities, especially east of the Pee Dee, where one-third to one-half the field labor is performed by whites. The general price of day labor is fifty cents and food, though it fluctuates from forty cents to seventy-five cents. The class of day laborers is also largely increasing, being recruited from the increasing class of tenant farmers, who supplement their earnings by hiring out when not busy with their own crops, or when pressed for ready cash. Contract laborers are becoming much fewer; the general wages is ten dollars a month and rations, but in some localities it is as low as six dollars to eight dollars, and in others as high as twelve dollars to fifteen dollars, the higher prices prevailing in the northeast, the lower to the sonthwest, being less where the percentage of negroes is greatest, and vice versa. Hands hired by the year receive from ninety dollars to one hundred and twenty dollars, with rations, shelter firewood and truek patehes. Hands, however, have always preferred, when contracting for a year's work, to have some interest in the erop, and this desire has steadily increased so as to have become by far the most general practice. This has been arranged in so many, and in such complieated ways, as to preelude any general description. For instance, a widely adopted system is one proposed as early as 1866 , by a negro laborer in Silverton township. The laborer works five days in the week for the land owner and has a house, rations, three acres of land, and a mule and plow every other Saturday to work it when necessary, with sixteen dollars in money at the end of the year. Had he worked four days and a half per week for the land owner, and one and a half days for himself, this would have been equivalent to one-fourth of the crop and his food. The sixteen dollars was intended to cover the fiftytwo half day's more than this, which he worked.* This system proved

* This freedman was impressed with the belief that the share of the laboler shonld be his fool and shelter, and one-fourth of the produce. While he was sure that his proportion covered this, he could neither state the rationale as above given, or apparently understand it, when stated. It may serve as an itlustration of the instinctive processes by which these people seemed to grasp intuitively the most complicated problems, and the most advanced doctrines in the great questions as to the remuneration of labor. Only just emancipated, they at once take ground, to which the laborers of the old world seem to have been struggling up through all the centuries since the abolition of serfdom. 
very successful, and the second year a number of labolers proposed to work only four days, feed themselves and take rlouble the land and mule work, without the noney. The third year three-day hands came in, furnishing in part their own work stock; and as some hands paid the rent for a house and an acre of land by giving two days work a week, there were found various classes of hands on the sane places, working from two to six days in the week. The share system is practicer more largely in Barnwell than in Hampton, and still more in 1)arlington and Marlboro. The terms are generally the same, the employer furnishing land, teams and implements, the laborer feeding himself and getting one-third to onehalf, after paying for his pro rata of bagging, ties, and fertilizers. Chancellor Johnson says (Marlboro county): "I liave a good many tenants, white and black. I furnish the stock, food for it, pay one-half the blacksmith, fertilizer, bagging and ties account, and furnish ginning facilities; the tenant (has his garden and potato patch free) does all the work, from repairing fences and ditches to preparing the crop for market, my advances are repaid and the crop is equally divided. The tenants gencrally get at the rate of eight to ten bales for each mule they work, grain for their family supplies and enough to make their meat. I get the same amount of cotton and more than grain enough for the next year's crop. I have had some tenants over ten years." He prefers hired labor where the plantation is not too large, that is about eight plows. The advantage of either system depends upon the character of the individnal, good tenants being sometimes poor laborers, and vice versa. Each locality reports favorably of the system pursued there.

In Hampton, the wages system is preferred, the laborers run no risks, the soil is improving, the condition of the laborers good, very few of them own house or land. Lands sell from one dollar to twenty-five dollars per acre, and rent for one dollar to three dollars in small patches; little land is rented.

In Barnwell, the laborer decides under which system he will work. Share hands and renters pick cleaner cotton than wage hands. The wages system is preferred, by the planters, the laborer runs no risks, his pay is net money, he spends it and lives and works better, and land improves. The condition of the laborer is good and improving, quite a number own houses and lands. The market value of land is three dollar's to ten dollars an acre, including improved and unimproved. The rent is from one dollar to three dollar's in money; in kind it is seventyfive pounds of lint cotton per acre, or one thousand pounds of lint for a forty acre farm, or a five hundred pound bale for fitteen to twenty acres.

In the lower part of Orangeburg, year hands receive monthly six dol- 
lars; the share system is also practiced here; no preference expressed between the two. The eondition of the laborers is reported as good. The market value of land is from two dollars to ten dollars; and a good deal is rented from two to four dollars.

In Darlington, wages by the year are one hundred and twenty dollars for men, ninety dollars for women, with house, rations, fuel and truck patches. The share system and tenant system are largely practiced; the laborers do not work so well, nor do they realize so much, but they prefer less and to be independent of control; their condition is good, two per cent. own houses and land. The market value of land is ten dollars, and the rental yields about seven per cent. on the investment.

In Marlboro and Marion, a considerable part of the field labor is performed by whites; dar wages are from thirty to sixty cents, by the month six dollars to twelve dollars, and the same when engaged for the year, in all cases with board. The share and tenant system are largely practiced (see above for terms, \&e.). Condition of the laborers good, they are contented and happy; three to five per cent. of the negroes own land or a house. The market value of land is ten dollars to fifty dollars per acre, and rents are from three dollars to fifteen dollars per acre. (For further particulars see abstract of reports of township correspondents.)

From the southwest of Aiken county it is reported that the tendency to raise supplies fluetuates with the price of cotton, being increased by low and diminished by high prices. The share system is largely practiced, the laborer having one-third where he feeds himself, one-fourth where he is fed, the land owner adrances everything, and the laborer's proportion of the expenses is taken out of the crop. The share system is not generally satisfactory; it is difficult to get cotton cleanly handled; land worked under the supervision of the proprietor generally improves; when rented, especially to negro tenants, it rapidly deteriorates; five per cent. of the negro laborers own land or their house; those who work steadily are prosperous, the proportion that do this is not, however, large. The market value of land is four dollars to fifteen dollars per acre, including wood land; tilled land rents for from one dollar to five dollars per acre.

The following comparison in some of the regards above treated of between Darlington and Narlboro counties is offered, because in 1870 Darlington led all the counties in the State in the production of cotton, nearly doubling the crop of the next highest; now it stands eighth in total production, and Marlboro stands highest in the yield per capita and per acre; the counties lie side by side: 


\begin{tabular}{|c|c|c|c|c|c|c|c|c|c|}
\hline \multirow{3}{*}{ COUNTIES. } & \multicolumn{2}{|c|}{$\begin{array}{l}\text { Yield in } \\
\text { lbs. lint } \\
\text { Cotton. }\end{array}$} & \multirow{3}{*}{$\begin{array}{c}\text { Amount } \\
\text { of licns } \\
\text { for each } \\
\text { Bale of } \\
\text { Cotton } \\
\text { produced } \\
\text { in } \\
1879 .\end{array}$} & \multicolumn{6}{|c|}{ FARMS. } \\
\hline & \multirow{2}{*}{ 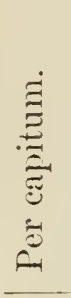 } & \multirow[b]{2}{*}{ 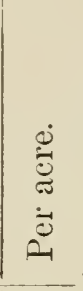 } & & \multicolumn{2}{|c|}{ Percentage. } & \multicolumn{2}{|c|}{$\begin{array}{c}\text { Pereentage } \\
\text { worked by } \\
\text { owners. }\end{array}$} & \multicolumn{2}{|c|}{$\begin{array}{l}\text { Percentage } \\
\text { worked by } \\
\text { renters. }\end{array}$} \\
\hline & & & & 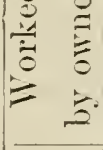 & 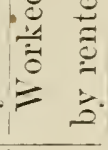 & $\begin{array}{l}\text { Under } \\
\text { fifty } \\
\text { Aeres. }\end{array}$ & \begin{tabular}{|} 
Orer \\
fifty \\
Acres.
\end{tabular} & $\begin{array}{l}\text { Under } \\
\text { fifty } \\
\text { Acres. }\end{array}$ & $\begin{array}{l}\text { Over } \\
\text { fifty } \\
\text { Acres }\end{array}$ \\
\hline Darlington.. & 339 & 197 & $\$ 16.40$ & 43 & 57 & 17 & 83 & 85 & 15 \\
\hline Marlboro....... & 536 & 267 & $\$ 5.40$ & 55 & 45 & 12 & SS & so & 20 \\
\hline
\end{tabular}

\section{TILLAGE AND IMPROVEMENT.}

Enclosures, under the colonial laws, that have not been changed, are required to be cattle proof. The fences are built of pine rails ten feet in length, running about one hundred to the cord, worth usually fifty cents a cord, and are split for fifty cents per hundred, making the cost one dollar per hundred in the woods. Fourteen rails make eight feet in length of worm fence, or 9,240 rails per mile, lasting, on an average, five years. A recent act of the legislature allows each township to determine by vote, whether the crops or the stock shall be enclosed, if the latter, the township to tax itself for the fences necessary to protect it from the stock of the adjoining townships. To this date few townships in this belt have availed themselves of this law.*

Drainage is little practiced in this region; the culture of the swamps being generally abandoned, and the uplands being thought not to require it. In Marlboro and Marion, however, great benefit results from a system of open ditehes very generally adopted (see above soils). Little or nothing is required in the way of hillside ditches on these comparatively level lands, where little injury is experienced from washing.

The former practice of allowing fields to lie fallow, for the benefit of the growth of weeds, which increased the vegetable matter in the soil, and

\footnotetext{
* Since the above was written the State legislature has passed a ceneral law for the whole State, making it incumbent on the owners of lire stock to see that they do not trespass on others. The tiller of the soil is no longer compelled to build fences to protect the fruits of his labor from the in roads of his neighbors' cattle, thus saving all cost in building and repairing fences, estimated in 1879 at $\$ 917,000$ by the 10 th U. S. Census.
} 
which killed by their shade the grasses that were especially troublesome on cultivated lands, has been almost wholly abandonerl. Nor is there any regular or general system of rotation of erops. Cotton lands especially are planted year after year in the same crop, and if properly manured, are thought to improve. Rotation, when practiced, is two years cotton, one year corn; small grain is planted in the fall, after the corn is gathered, and the next summer a crop of corn or cow-peas is grown on the stubble, to be followed the next spring by cotton. In Marlboro county, land planted in cotton for fourteen suceessive years, without additional manure, except the increased eotton seed from the larger crops, produce double what they did at first.

The fall plowing of cotton and corn lands, once much practiced, has been very generally abandoned; some still think it pays to break the land eight or ten inches deep in the fall about every fourth year, otherwise it is only done to turn under weeds on land that has been resting.

The depth of tillage varies from two and a half to six inches, measured on the land side of the furrow, and it is very rare to see more than one animal used in plowing. It is only the larger farmers, who are becoming scarcer, who use two-horse plows occasionally.

The amount of land once cultivated, that has been abandoned, is stated as very little in Hampton county; at from ten to twenty per cent. in Barnwell; at ten to fifteen per cent. in Orangeburg; at twenty-five per cent.in Darlington, and, excluding swamps, at nothing in Marion and Marlboro. When the uplands are turned out in this region, they grow up first in broomsedge, which is succeeded by short leaf pine, beneath which in time all grass and undergrowth disappears. When again taken in, they yield well with manuring, but without good treatment they deteriorate more rapidly than virgin soil. It is a question-on which there is a diversity of opinion-whether the second growth of pines is a benefit or an injury to land; in the lower country it is thought to be injurious, supporting the view that narrow leaved growths do not improve the soil. In the upper country the opinion is, however, decided that the soil improves under the old-field pine. With some other growths there is no question, in this regard; for instance the persimmon always improves lands, and seems to exert no bad influence even on the growing erops in cultivated ficlds, it being often remarked that the tallest cotton is found under such trees, where it is dwarfed by the proximity of a pine or a post-oak. Certain other forest trees seem to favor particular growths here, as the sugarberry, under which verdant patches of blue grass are often seen, when found no where else. There seem to be friendly and unfriendly relations among plants. Bermuda grass will not grow under pines or cedars, but thrives most under the Euonymus. Polk is said to give the rust to cotton, and Jamestown weed will, it is believed, eradicate nut grass. 
Green manuring, especially with the cow-pea, is regarded favorably, although it is not practiced as a system. Sown broadcast, manured with the "Ash element" (a cheap fertilizer composed chiefly of lime and potash) and turned under after the rines are wilted by frost, remarkable results have heen attained. Col. Thomas Taylor says that lands subject to rust, and never yielding more than seven bushels of wheat, have given twentysix bushels under this treatment. After the cotton is laid by a furrow is sometimes run in the alley, and cow-peas drilled in, forming the basis on which the next year's cotton bed is to be constructed. Peas grown among corn are esteemed highly for the beneficial influence they exert on the soil, as well as for the crop they yield.

The limited amount of stable and lot manure, furnished chiefly by the work stock, other cattle being rarely fed or penned systematically, is much ralued. Cotton seed is wholly used for manure, and its use has much increased, either alone, or composted with woods mould and litter, or the superphosphates. These means of maintaining the fertility of the land are largely supplemented by the use of guanos and other fertilizers. In Narlboro county the general rule is, to return to the land all the cotton seed produced on it, and in addition one sack of Guanape guano, or half a sack of it, with one hundred pounds of superphosphates, and if rust is apprehended, one hundred pounds of kainit. Lands so treated are counted on with much certainty to give a bale of cotton to the acre one year with another. This may be taken as the best established and most successful practice regarding manures. There are wide variations from it. A very few, but not the least successful farmers, purchase no commercial fertilizers and rely wholly on cotton seed, composts of woods moulds and leaves, and stable manure. The use of fertilizer is very generally deprecated as unthrifty and extraragant, but the facility with which they may be obtained and used, makes their employment the general practice.

The first step in preparation for planting cotton is to dispose of the old stalks. If small, they are not attended to. Ordinarily they are knocked to pieces by hand with a club. Machines have been devised for this purpase, but have not proved successful, thus leaving a field open to inventors. When the stalks are very large, say four to five feet high, they have to be prulled up, and sometimes to be burned. Some planters pull up the stalks and lay them in the furrow on which the bed is to be made; it is objected to this practice that the plow in cultivation strikes the buried stalks and destroys the young cotton.

The furrow for the bed is either run in the alley between the rows, or the old bed is barred off and the furrow run through its centre. The first practice altemates the cotton rows every year, the second plants on 
the same spot. The rows are rarely unler three feet three inches, they average three and a half, and are sometimes four feet, and even fire feet, on land making a large growth. The manure is placed in the furrow, and the hed is built up in February and Narch, the object being to get cotton seed in and covered as early as possible to prevent its sprouting and heating after planting, which is injurious to the stand. In Marlboro the fertilizers are not applied with the cotton seed, but a furrow is run through the bed just before planting and the fertilizer put into it then. The wal practice has been to put the manure in as decply as possible; a practical difficulty in accomplishing this arises from the settling of the fincly pulverized and lightly thrown up beds; and finer and specifically heavier particles of the soil pass through and under the coarser and lighter cotton seed, compost, or stable manure. So that even after the greatest care to cover them deeply has been taken, they disappoint the planter by ajpearing at or near the surface during planting or the subsequent* cultivation of the crop. A very successful practice in Aiken and Barnwell countics has been to put the manure in a shallow furrow. but to finish the bed by splitting the middle out with a double horse shovel plongh ruming to the depth of fourteen inches. This leaves the sides of the beds and the alley light and loose, and it is kept so by after cultivation. The sweep runs shallow in the harder soil near the plants, and deeper in the looser soil of the alley, and can thus skim the surface and destroy weeds near the plant without cutting the roots; the drainage of the bed is increased, and loose earth is provided, where it alone can be maintained during cultivation, in the alley, to absorb atmospheric moisture, and to dirt the plant or manure.

Planting oceurs during the month of April, from the 1st to the 30th. Early planting runs the risk of frost, late planting runs the risk of a dry spell, which not unfrequently prevents cotton planted the last of April from coming up before the first of June. These risks are nearly equal, and the early planting has the additional advantage of a longer season for its growth and maturity. Bancroft's or Dicksons's improved cluster cotton seed are generally used; a prolific cotton, making a good yield of lint, being sought after, without regard to the quality of the staple. Improved staples have been produced, and are profitably cultivated by the larger planters who ship it themselves to the North, or Europe. Smaller

*It appears that particles of the solid earth are not at rest, but are continually in movement, caving in and settling after rains, fo. So that here the law of suecific gravities also operates, and in the lapse of time, the diverse components are assorted, finding their true level as certainly as a cork rises or lead sinks in water. In illustration of this law, large quantities of bones, buried two feet deep, in land formerly prepared for vineyards in this region, have, in the course of ten years, worked their way to the surface. 
farmers, confined to the home markets, camnot sell such staple to advantage, and therefore neglect it. The quantity of seed used depends on the method of planting; in drilling by hand, the most common practice, three bushels is required; with the planter, which is coming more into use, one to one and a half bushels answers; with the dibble, a two-wheeled implement, drawn by a horse, the wheels running on the beds and riaking holes for the seed by blocks fastened on to the tire, a half-bushel will do. The seed comes up according to the greater or less favorableness of the season, in from four to ten days after planting. The young plants are thimned out to hills eight inches to twelve inches apart, sometimes to eighteen inches; usually only one stalk is left, some prefer to have two. Thinning oceurs four to six weeks after planting, from the time the third to the sixth leaf makes its appearanee, and is completed early in June. Blossoms first appear when the plant is six inches to twelve inches high, from the 10th to the 20th of June. Bolls open forty-two to forty-five days after the blossom in the latter part of July and first of August. In favorable seasons, picking has commenced before the 12 th of August; ordinarily not until the 20th. The cotton is picked and ginned as fast as it opens, and the work can be done, the best planters estimating the loss of leaving it in the field, even during good weather, for a few weeks, as very heavy. All the crop is picked by the 1st to the 15th of December, and by far the most of it in the market before Christmas. The after cultivation of the crop consists of four to five ploughings with the sweep and three to four hand hoeings, and is completed from the first of July to the last of August.

\section{GINNING, BALING AND SHIPPING.}

No decided preference for any of the numerous gins used in this region can be ascertained those most commonly in use are the Brown, Winnship, Gullett, Carver, Findley and Massey, Elliott, Winn, Taylor and Excelsior. Thirteen correspondents report that four employ steam engines, seven employ horse power, and two employ water power in ginning. The steam gins turn out two hundred and twenty-five to four hundred pounds - lint per hour, the horse-powers one hundred pounds to two hundred pounds in the same time, the water-powers two hundred and fifty to four hundred. The estimate of seed cotton required to make four hundred pounds of lint, varies from 1,200 to 1,400 pounds, and averages 1,225 pounds. On this point a correspondent says: "The proportion of lint varies largely with the season, with the variety of cotton, with the stage at which the cotton is picked, and even with different bolls of the same variety picked at the same stage. I plant a large part of my erop with a fancy long staple upland variety. I have known it to require 1,S00 
pounds seed cotton average through the season to make a bale of five hundred pounds, while the past season the entire crop gave at the rate of a five hundred pound bale to 1,540 pounds of seed cotton. A few years ago my crop of Rio Grande, a very short staple variety, gave a five hundred pound bale to 1,365 pounds of seed cotton. Cotton picked damp, and that suffered to remain sometime without picking, gives the smallest proportion of lint, while that picked as soon after opening as the bolls dry off gives the best. I once picked a large number of bolls from a patch, itself grown from selected seed, weighed them separately on a druggist's seales and separated the lint from the seed by hand. The poorest boll gave nineteen per cent. of lint, the best thirty-six per cent. The weight of the heaviest boll, seed and lint, was one hundred and thirty-six gross, and of the lightest, forty-two gross. Even such wide variations as these could not have been detected by the eye or without the use of the scales."

Owing to the musatisfactory character of the mechanical arrangements for using horse power, the use of horses for ginning is being superseded by steam engines. It was thought that traction engines would supply this want, and, like steam grain threshers, would move from farm to farm and gin the cotton. They were tried to a considerable extent, but it was found that the exigencies of the farmer did not allow him to keep his cotton, as he might his grain, until the gin came to him, and that it did not pay to move the gin once or twice a day, to gin the crops, bale at a time as it was gathered, so that they have been mostly abandoned.

There is a similar diversity as to the press in use. In twelve gin houses there were six hand presses, the Brooks, Schofield, McBride, Finley, Boardman, and Smith, packing about eight bales with four hands per day. There was one water press, and one run by steam, four old wooden-pin screw presses run by mules. Four hands on the Smith or the Bosrdman press will average a bale every fifty minutes: eight men and three mules on the old screw will average a bale every thirty minutes; by pushing, more can be done. The delay and cost in packing occurs in treading the light, loose cotton into the box, at which only one, or at most two men can work, the other hands being meanwhile idle. Formerly the lintrooms were built very large, and twenty or thirty bales were ginned before any was packed. Now with smaller lint-rooms, and with condensers coming into use as a preventive of fire, the cotton is packed as fast as it is ginned. Feeders to gins have been tried, but owing to the difficulty of keeping them in order, they are not much used.

Rope for baling has been entirely replaced by the iron "Arrow" tie and the heaviest gunny bagging is used. The bales vary in weight, from four hundred and fifty pounds to five hundred and fifty pounds, and 
average four hundred and eighty-nine pounds. Shipments to market are made during the fall months, from September to January. By steamboat there are no extra charges for extra weight; the charge is seventyfive cents per bale on the Savamah river to Savamnah, and one dollar on the Pee Dee to Charleston. On the Port Royal raihoad to ('harleston or Savamulh the charge is two dollars per bale of four hundred and fifty pounds or less, and twenty cents for each hundred pounds over that weight. On the South Carolina railway the charge from Augusta is one dollar for way stations on this route, one dollar and fifty cents and thirty-five cents per hundred weight over five hundred pounds. From Darlington to Charlesten by rail the charge is one dollar and twenty-five cents. From Marlboro and Marion it is three dollars and twenty-five cents to New York, and one dollar and fifty cents to Charleston or Wilmington by rail; in the latter there is an extra charge (amount not stated) for bales weighing over four hundred and fifty pounds.

\section{DISEASES, ENEMIES, \&C.}

There are few crops grown anywhere more certain than the cotton crop in the upper pine belt. A complete failure nerer occurs, and a reduction of twenty per cent. in the rield is an unusual occurrence. The greatest variations have been in an increase of product under better cultivation, and it is believed that a wide field for development lies in this direction. The prineipal obstruction to the growth of the plant is the crab grass,* necessitating constant labor and vigilance, or resulting in fatal injury to the crop. Usually the task is one acre in hoeing, which is completed by dimner time; but most frequently it is far from being thoroughly done. In Marlboro, where the work is well done, and perhaps on this account, two acres is the task and it is completed by + P. M., usually.

Drought is very seldom injurious, except during the fruiting season in July and August. Sore shin, except as resulting from bad hoeing, is not known.

Lice, a minute aphid, appears on the underside of the leaves in May and later, and gives them a curled, but at the same time a deeper green appearance. Dry weather is favorable to them, and in good seasons they are not thought to injure the plant. Some say they promote fruitfulness. In bad seasons, i. e., excessive drought, during fruiting, rust appears earliest and is most injurious where these aphids have been most numerous.

Rust and blight affect the crop, especially during the fruiting setson; it is most injurious to the prolifie short-limbed cluster cotton. Under fa-

\footnotetext{
*Corruption for crop grass, being found only on cultivated lands, and often furnished excellent crops.
} 
vorable conditions the plant will take on a heavy crop of fruit in four to six weeks, any time from the middle of June to the milldle of September. At such a period it will cease to grow, the leaves will pale and turu red, all the energies of the plant being devoted to reprorluctive efforts. Commercial fertilizers promote this crisis, by contributing more to the fruitfulness than to the growth of the plant. Any vicissitude of the weather, heat or cold, wet or drought, will seriously enfeeble or even kill the plant in this its term of labor, especially on poor, sandy, or ill-clrained soils. A crop will have been made, the utmost that the soil, the variety of seed, and the seasons admit of, but the future growth and fruitfulness of the plant is checked or destroyed. This is what is usually termed rust or blight. The remedies are, varieties of the plant that are more vigorous growers, those of longer limb, and less given to excessive finiting; stable manure in the place of fertilizers; the potash salts are used with marked benefit; and thorough drainage.

Cotton sheds by far the largest portion of the forms which come on it, and the closest obscrvers state that in the great mass of our cotton lands, the cotton plant will not, in the best of seasons, mature into open bolls one in five of the blossoms that appear, generally not one in ten. Remedies for this are being sought in the selection of seed, and in various methods of culture, but nothing decided has been thus far obtained.

When the early season is wet and warm, the plant may run too much to weed. Some attribute this in part to late thimning and deep cultivation; others think it may be checked by running a deep, narrow furrow, closing after the plow, close to the cotton. Short-limbed varieties of cotton, cotton seed and phosphates as fertilizers, are recommended as remedies.

Although the cotton caterpillar moth is frequently met with, even during the severest winters, the worm rarely makes its appearance before September, and hardly ever does any damage.

\section{CHARGES ON SELLING.}

In addition to freight, these consist of the following items, at the rates stated: commissions on sales, two and a half per cent.; storage, twenty-five to fifty cents per bale per month ; drayage, wharfage, mending, forty cents ; insurance, twenty-five cents. These charges vary slightly, and with freight, amount to from three-quarters to one cent per pound of lint, or a little over seven per cent. on the net sales.

\section{COST OF PRODUCTION.}

Eight correspondents state the cost of production at six to eight cents per pound lint; one at eight and a half cents; one at twelre and a half 
cents; one at four cents. Paul F. Hammond, of Beech island, furnishes the following: "The cost of production varies greatly with the character of the land cultivated, and the skill of the planter. The complement of hands and mules is two of the former and one of the latter. The items of expense are, wages of hands, meat for hands, cost per annum of mule, exclusive of feed; extra picking, guano, gear, implements, bagging and ties. One mule and two hands will eultivate, on an average, twenty acres in cotton, fourteen acres in corn and four acres in oats, making grain enough to furnish bread to the laands, and feed for the mule. I am inclined to think that 4,000 pounds of lint, including weight of bagging and ties, to the mule, is rather above than below the average. In some instances planters may reach a production of 8,000 or eren 10,000 pounds of lint to the mule, while more frequently those who fall below 2,000 pounds may be met with. In the following estimates no allowance for taxes, rents, interest on capital invested, nor for the services of the proprietor or manager, nor for transportation or charges for selling, is made.

Twelvebales Eight bales Four bales to the mule. to the mule. to the mule.

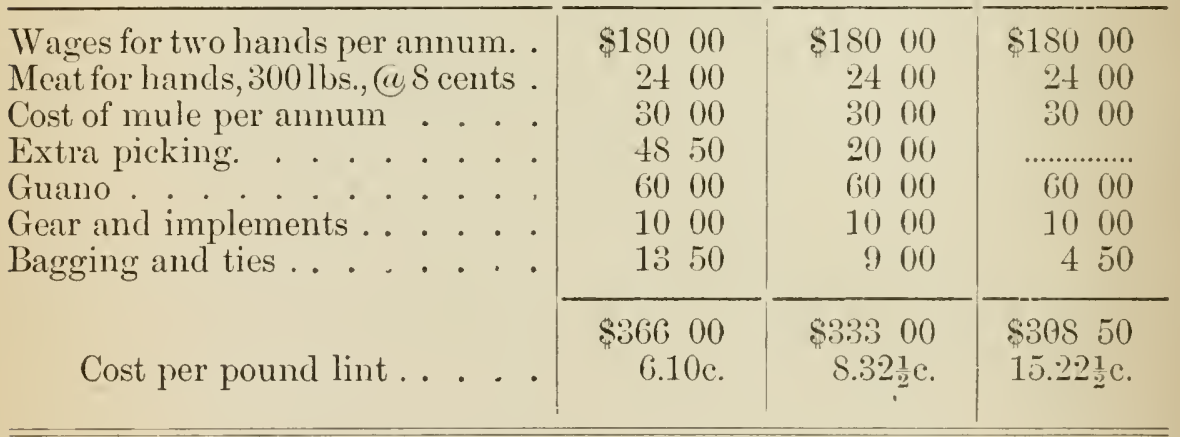


Table showing the cost of each item of Labor and Material expended in the cultivation of an aere of Cotton in the Upper Pine Belt Region of South Carolina:

\begin{tabular}{|c|c|c|c|c|c|c|c|c|c|c|c|}
\hline & 1. & 2. & 3. & 4. & 5. & 6. & 7. & 8. & 9. & 10. & 11. \\
\hline IIL... & $\$ 200$ & $\$ 200 \$$ & $\$ 300 \$$ & $\$ 250 \$$ & $\$ 250 \$$ & $\$ 2511 \$$ & $\$ 400$ & $\$+00$ & $\$ 360$ & $\$ 300$ & 3375 \\
\hline encing, repairs and in terest on & 100 & 40 & 50 & 60 & 25 & 51 & 25 & 50 & 100 & 75 & 100 \\
\hline Knor & 20 & 12 & 10 & 15 & 17 & 10 & 30 & 25 & 10 & 10 & 15 \\
\hline . & {$\left[\begin{array}{ll}\cdot & \ldots . .\end{array}\right.$} & $\cdots \cdot$ & ...... & ...... & ...... & ...... & ...... & ...... & 20 & ....... & ...... \\
\hline Othe & ....... & 05 & 05 & ...... & 05 & 10 & ...... & ....... & $\cdots \cdot$ & 25 & 10 \\
\hline 130 & 50 & ..... & 50 & ...... & ..... & ....... & ...... & ...... & ...... & ...... & $\ldots .$. \\
\hline Bedd & ...... & ....... & ...... & ...... & ...... & ...... & ...... & ....... & ...... & ...... & ...... \\
\hline Bre & 150 & 150 & -..... & $\cdots \cdots$ & ...... & 100 & 125 & ...... & 50 & $\cdots \cdots$ & 75 \\
\hline ar & ...... & ....... & $\ldots$. & ...... & ...... & ...... & ....... & ...... & ....... & …... & ...... \\
\hline Bar & .... & 37 & ...... & 38 & 33 & ...... & ...... & ...... & ....... & ..... & $\ldots . .$. \\
\hline l & 50 & 18 & ....... & .25 & 17 & ...... & ..... & ..... & .... & …... & ....... \\
\hline Reve & ...... & $3 \bar{i}$ & ...... & ...... & 33 & ...... & 125 & ...... & ....... & ....... & ...... \\
\hline Laying & 25 & * & 15 & ...... & 25 & 10 & ..... & 13 & 25 & ...... & 18 \\
\hline $\mathrm{Ma}$ & 300 & 350 & 200 & 350 & 300 & +50 & 450 & $\begin{array}{lll}6 & 25\end{array}$ & fi 00 & $\begin{array}{lll}6 & 000\end{array}$ & 450 \\
\hline Manures, home & 200 & 400 & 300 & 225 & +25 & 300 & 300 & 560 & 250 & ...... & 500 \\
\hline ( & 25 & $38 !$ & 15 & 08 & 57 & 100 & 250 & 35 & 50 & 12 & 75 \\
\hline B & 50 & 37 & ...... & 50 & 33 & 75 & 100 & 50 & 25 & 150 & 150 \\
\hline 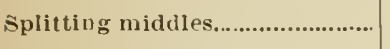 & ....... & 18 & ....... & 25. & 20 & ....... & 50 & 25 & 10 & ....... & $\ldots . .$. \\
\hline ....................... & .... & 15 & ..... & $25^{5}$ & $\cdots$ & ....... & 20 & ...... & 10 & 10 & ...... \\
\hline 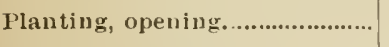 & 20 & 20 & 35 & 25 & 31 & 16 & 30 & 13 & 25 & 20 & 25 \\
\hline Pla & 25 & 20 & ....... & ....... & ....... & ...... & ....... & 17 & 25 & 15 & ....... \\
\hline $\mathrm{PI}$ & 20 & 10 & $\ldots .$. & 25 & ...... & ....... & ...... & 13 & 20 & 20 & ....... \\
\hline $\mathbf{R}$ & 50 & 28 & 10 & 05 & 10 & 10 & 10 & ....... & ....... & ....... & ....... \\
\hline$\cdots$ & 30 & 50 & 35 & 50 & 30 & 30 & 30 & 60 & 50 & 30 & 25 \\
\hline ....... & 25 & 28 & 50 & 15 & 30 & 20 & | & $\cdots \cdots$ & 40 & 50 & 50 \\
\hline nd 6 & 185 & 200 & -165 & 225 & 133 & 250 & 300 & 225 & 25 & 200 & 200 \\
\hline , $1,1,1, \ldots$ & 80 & 100 & 50 & 140 & $\begin{array}{lll}1 & 00\end{array}$ & 175 & 200 & 200 & 200 & 150 & 200 \\
\hline Picki & 675 & 600 & 500 & $\begin{array}{lll}4 & 70\end{array}$ & 600 & 550 & 500 & 600 & 500 & 500 & 600 \\
\hline $\mathbf{H a}$ & 15 & 50 & ...... & 60 & 25 & 50 & 100 & 50 & .... & 100 & 75 \\
\hline Gin & 225 & 200 & 300 & 260 & 208 & 165 & 200 & 250 & 200 & 120 & 200 \\
\hline$\cdots$ & 500 & 100 & 500 & 250 & ....... & 200 & 200 & ....... & 300 & 200 & $\ldots .$. \\
\hline S... & ....... & ...... & ...... & .... & ..... & ....... & : & ....... & .... & ...... & 425 \\
\hline Bagg1 & 135 & 135 & 110 & 120 & 115 & 110 & $\begin{array}{ll}1 & 30 \\
\end{array}$ & 135 & 108 & 110 & 110 \\
\hline To & $\$ 3155$ & $\$ 2 \times 9 \times$ & $\$ 2690$ & 82718 & 52512 & 5235 & $\$ 3575$ & E32 56 & $\$ 3143$ & $\$ 267$ & $\$ 678$ \\
\hline Cost pe & 07 & 07 & $08 \quad 1-6$ & $069-10$ & $067-10$ & 08 & 107-10 & $082-10$ & $\overline{094-10}$ & 08 & $091-5$ \\
\hline per & $\$ 2345$ & $\$ 11102$ & $\$ 640$ & $\$ 1192$ & $\$ 1188$ & $\$ 625$ & $\$ 245$ & $\$ 7 \quad 14$ & $\$ 157$ & $\$ 653$ & $\$ 322$ \\
\hline rofit & $\$$ & & $\$$ & 692 & $\$ 1430$ & $\$ 1075$ & $\$ 35$ & \$11 14 & 8787 & $\$ 1153$ & $\$ 1122$ \\
\hline
\end{tabular}


1. E. 11. Peeples, Lawton Township, Hampton counfy: Makes a bale of 4.j0 pounds lint cotton per acre under this eulture-seed eotton $1,3,50$ pounds, cotton seed thirty busliels.

2. Homer H. l'eeples, Peeples' Township, Humpton county : A verage l,200 pounds seed cotton, 400 poumals $11 n t$, twenty-seven bushels seed.

3. G. Val'n, Esq., Folk's store, Colleton county : Crop 1,000 pounds seed eotton, lint 333 pounds, seed twenty-two bushels.

4. W. 13. Rice, l3amberg, Barnwell county : Crop 850 to 1,500 pounds per acre, say $1,17.5$ seed cotton, average 391 pouncls lint, twenty-six bushels seed, at twelve and a hall cents.

5. Join S. Stoney, Allendale, Barnwell comnty: Yield 1,200 pounds seed cotton, 376 pounds lint, seed twenty-two bushels

6. O. N. Bowman, Rowesville. Orangeburg county : 1,100 pounds seel cotton, 370 pounds lint, twenty-six bushels seed.

7. H. T. Stack house, Little Rock, Marion eounty: Hesnys, "I worked last year twenty aeres in eotton on contract with Esau Page, which actually cost as follows: All work repairing fencing. pieking, ginning, \&c., \$34.00; Commereial manures, $\$ 114.00$; feed and rent of inule, $\$ 10 \% .60$; wear and ten to machinery, $\$ 35.00$; hauling straw, \&e., to stable, \$13.00; bagging and ties $10 \mathrm{r}$ twentynme bales, $\$ 16.00$; for iny direction, $\$ 50.00$. 'Total, $\$ 702,00$, or $\$ 35.00$ per acre. Crop. 13,27 pounds lint cotton. Contract satisfactory; has run for several years. Rents 230 of the 290 acres of his home farm for forty-four pounds lint cotton. Renters engage to make all repairs and keep up fertility ot land. Estimate on 1,000 pounds seed cotton, 3is pounds lint, twenty-three bushts seed."

8. W. D. Johnson, Marion C. H: Yield 1,200 pounds, 400 pounds lint, thirty bushels seed. In a good year 1,400 to 1,500 pounds seed cotton. N. 13. The rent and home made manure, $i$. $e_{\text {, eotton }}$ seed, constitute one-half or more of profits.

9. C. S. McCall, Benmettsville, Marlboro county: Average yield 1,000 pounds, 333 pounds lint, twenty-three bushels seed.

10. Edward E. Evans, Soejety Hill, Darlington county: Yield 1,000 pounds, 333pounds lint, twentyeight bushels seel.

11. Henry P. Duvall, Cheraw, Chesterfield county: Yield 1,200 pounds, 400 pounds lint, thirty busheis seed.

The meat of the above estimates makes the cost of cotton $83-10$ cents; not ealculating the im. provement of the land by culiure or any of the numerons perquisites attending such emplorment. The average profit per acre is $\$ 7.80$, deducting eharges for rent and managenent it is $\$ 15.75$. Thrift and management will asso reduce and even wipe out many of the items charged as expenses, Home-macle manures, consisting largely of eotton seed which is reproduced each suecessive year in constantly inereasing quantity, is such an item.

It is interesting to compare these estimates of the cost of producing cotton with those made in former times. A writer in the Carolinian, in 1848 , dechares that five cents a pound for cotton will not pay a profit, and gives this statement as the experience on a plantation with twenty field hands, total investment, $\$ 20,000$.

Expenses for 1848.

Wages of overseer . . . . . . . . \$ $\$ 30000$

Blacksmith and medical accounts . . . . . . . 6500

Clothing . . . . . . . . . . . . Ss 00

Bagging and rope for 120 bales cotton . . . . . . 15000

Taxes .......................... 3000

Salt $\$ 12$, nails $\$ 5.00$, hoes $\$ 4.50 \ldots . . . . . . .2150$

IIospital supplies . . . . . . . . . . . . . 750

Wear and tear of land . . . . . . . . . . . 33000

Wear and tear of mules, wagons, \&c. . . . . . . . 20000

Transporting cotton to market at seventy-five cents per bale . . 9000 
Crop 120 bales of 350 pounds, 42,500 pounds lint, cost three cents per pound, not counting interest on investment. 'That, at seven per cent., would have made the cost six and a third cents, omitting to eredit the account with all perquisites to the planter, as a home and home supplies, with increase of negro property, \&e.

Mr. Solon Robinson, of New York, in an extensive tour through the South, gave, in 1S48, the following carefully prepared statement regarding the plantation of Col. Williams, of Society Hill, Darlington county, South Carolina:

\section{CAPITAI, INVESTED.}

4,200 acres land $(2,700$ cultivated $)$ at $\$ 15$ per acre . . . . $\$ 63,00000$ 254 slaves at $\$ 350$ average, old and young . . . . . $\$ 9,90000$ 60 mules and mares, one jack, one stud . . . . . 3, 3,2000 2,000 head of cattle . . . . . . . . . . 2,00000 23 carts, six wagons. . . . . . . . . . 52000 500 head of hogs . . . . . . . . . . 1,000 00 60 bull-tongue plows, 60 shaving plows, 25 turning plows, 18 drill plows, 15 harrows . . . . . . . . . . 26200 All other plantation tools, estimated . . . . . . 1,000 00

Total investment ............ . $\$ 161,40200$

EXPENSES.

Seven per cent. interest on first five items. . . . . . . \$11,10300

3,980 yards Dundee bagging at 16 cents . . . . . . 53680 3,184 pounds rope at six cents . . . . . . . . . 19104

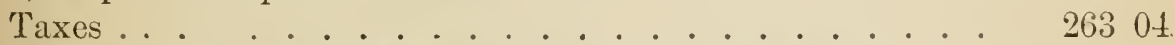
Three overseers, wages $\$ 900$, medical attendance $\$ 317.50 \ldots \quad$. 1,21750 Iron and tools purchased . . . . . . . . . 20000 Clothing account . . . . . . . . . 1,57950 Fifty sacks of salt $\$ \$ 0.00$, lime and plaster $\$ 194.00$. . . . 27400 Carpenters and blacksmith work extra . . . . . . 10000 Outlay for gin belts, \&e.......... . . $\$ 000$ Molasses, tobacco and flour . . . . . . . 17000 Three-eighths cent per pound freight and charges for marketing cotton ............... 2,06900 


\section{CROP.}

13,509 pounds bacon for lome place and factory . . . . . $\$ 67500$

Beef and butter for ditto and sales. . . . . . . 50000

1,100 bushels corn for ditto and sales . . . . . . . . . 55000

Eighty cords of tan bark for tan yard . . . . . . . . 48000

Charges to others for blacksmith work . . . . . . . 10000

Mutton and wool for home use and sales ....... 12500

$\$ 2,430 \quad 00$

This sum, that is products other than cotton, deducted from

expenses above stated leaves then . . . . . . \$1弓,46400

This was the cost of a cotton crop of 351,000 pounds lint cotton, making the cost per pound $47-10$ cents. The cotton was sold at seven cents per pound. Omitting charges for interest and taking no account of the increasing value of the property, this gives $116-10$ per cent. profits on the total investment. Mr. J. J. Lucas, also from Society Hill, Darlington county, reports, for 1879 , that the cost of making cotton is twelve and a half cents per pound, that the value of land is ten dollars and not fifteen dollars per acre, as Mr. Williams states it, and that rents pay seven per cent. on the investment in place of the above.

It will be noticed that the cost of transportation to market and charges for selling, \&c., were about one-half in 1848 what they are now.

Abstract of the replies of Township correspondents, arranged according to the Counties, Supervisor's Districts (Sup. Dist.) and Enumeration Districts (E. D.) of the 10th United States Census, in which they resided :

\section{Hamptox Countr, (2d Sup. Dist. 10th United States Census.)}

Lawton Township, (E. D. 118 and 119): Northern part rolling, remainder level. Swamps on the Sarannah river and other water courses, for the most part unreclaimed; one-third, a stiff mulatto upland, with clay subsoil borders the swamp; two-thirds, upland, a dark gray sandy loam, underlaid by clay at the depth of eighteen to twenty inches. Crops under good cultivation yield four hundred pounds lint cotton, twelve to twenty bushels corn, thirty bushels oats, fifteen to fifty bushels rice; peanuts, twenty-five to fifty bushels; sugar cane syrup, two hundred gallons per acre. Timber, best yellow pine, cypress, white oak, ash and poplar. Stock raising has been profitable, and might be greatly enlarged, there being abundance of Bermuda grass, cane and swamp mast. Wages of field laher, forty to fifty cents a day; one-tenth performed by whites. A large portion of the laborers rent lands, obtain supplies by giving a lien 
on the growing crops to the country merchants, and work most of the time on their own account. Land sells from two dollars to ten dollars per acre; rents for one-fourth of the crop, or one dollar to two dollars in money. Health good, except mild type of malarial fever in low places.

Pceples' Township, (E. D. 120): One-fourth of the land in swamps. The uplands slightly rolling; soil coarse and fine sandy loam, gray to brown and black in color. Subsoil yellowish red, blue and brown clay, containing brown pebbles, underlaid by gravel and quieksand at twelve to twenty feet, in which water is found. Considerable business in collecting turpentine, getting timber and shingles and sawing lunber. Little attention paid to stock. Wages for field work, eight dollars per month; one-half field labor performed by whites. At Pondtown there is a large number of white farmers owning small tracts of lands, doing all their own work and working out for wages, who are prosperous and excellent laborers, free from debt. Land rents for two dollars an acre. Malarial fever in the swamps, otherwise healthy.

\section{Barxwell County, (2d Sup. Dist. 10th United States Census.)}

Bull Pond, (E. D. 29): Gray pine lands, generally level, a fine sandy loam with clay subsoil. Growth, pine, oak and hickory. Little attention paid to stock. Wages, forty cents per day. Five per cent. of field labor performed by whites. No land in the market; one-half is rented for eighty pounds of seed cotton per acre. Yield, about one bale to the three acres, rented land badly cultivated, reduces the general arerage.

Allendale, (E. D. 25): "Light clay lands," rather elevated and rolling. Soil, a light elay loam, gray and yellow in color, underlaid by clays of various hue, from red to purple, also sandy subsoil. Growth, pine, oak, hickory, dogwood, maple, poplar, ash, black wahnut, eypress. Marl oecur's and is available. Two streams, twenty and forty feet wide, respectively, with velocity of three to four miles an hour, furnish water powers. Little attention paid to stock. It might be profitably raised. Wages, forty to fifty cents a day. One-tenth of field labor performed by whites. No lands in the market. No fevers except in the river bottoms.

Bemett Springs, (E. D. 26): Land level. Soil, sandy subsoil, sometimes red clay and sometimes red sand. Growth, pine, oak and hickory on the uplanis; usual growth of the Sarannah river swamps on that stream. Crops, seven hundred and fifty pounds of seed cotton, ten bushels corn, twenty-five bushels rice, seventy-five bushels peanuts per acre. Some business done in shingles, staves and turpentine. Stock raising might be made profitable. Six gins and grist mills driven by water power, not more than one-fifth of which is utilized. No prevailing discases. No 
field work performed by whites. Much of the land is rented for five hundred pounds lint cotton for twenty-five acres.

Hillistom, (E. I). 37): The level lands are a sandy loam, with clay subsoil within two feet. The rolling lands are a clay soil. Clay extends beneath the soil and subsoil to depth of twenty to sixty fiet, as shown in wells. Cirowth, yellow pine, oak, hickory. Crops, ten to twelve bushels corn, eight hundred to one thousand pounds seed cotton; oats, twentyfive to thirty bushels per acre. Littlo attention paid to stock. Edisto. river is a clear stream, one hundred feet wide, six feet deep, velocity, two to three mires an hour. Two mill streams empty into the Edisto. Wages of field labor, six dollars to ten dollars, and rations, per month. Onethird of field work performed by whites. Very little improved land for sale. It rents from two dollars to three dollars per acre, supplies and rents secured by a lien on the crop.

\section{Orangeburg Countr, (2d Sup. Dist.)}

Hebron, (E. D. 143): Some valuable swamp lands on the North Edisto river and its tributaries. Uplands rolling sometimes, but generally level, without being flat. Soil, mostly a fine sandy loam, subsoil sandy, in some places clay. Growth, pine, with large red oak in places. Crops, ten to thirty bushels corn per acre, four hundred and fifty pounds lint cotton to two acres, thirty to thirty-five bushels rice per acre. Some business in turpentine, shingles, staves and timber is done. Stock is not, but might be raised profitably. Wages of field labor, forty to fifty cents a day. Onefourth of it performed by whites. North Edisto affords a large waterpower, and there are two flour and four saw mills on its tributaries. Land rents for two dollars an acre, or one-fourth of the crop. There are some tracts for sale at five dollars an acre.

Liberty, (E. D. 144): Large bodies of swamp lands on the North Edisto, consisting of deep, black vegetal,le mould, resting on clay. Little of it improved. The uplands are elevated, fine, dark, gray, sandy loam, six to eight inches to subsoil of yellow clay, underlaid by chalk and clay. Growth on uplands, pine, oak, hickory and dogwood. As much as 2,000 pounds of seed cotton, thirty bushels corn, and sixty bushels oats per acre has been made on these lands, but the usual average is much less. Wages of farm labor, forty cents a day. One-half to two-thirds of it performed by whites. Very little land for sale; prices, three dollars to ten dollars an acre. The poorer lands are rented at from one dollar to two dollars an acre. The locality is very healthy.

Willow, (E. D. 154): Some very fertile, but mostly unreclaimed, swamps on the South Edisto and its tributaries. Uplands level, fine, gray, sandy 
loam, six to eighteen inches to subsoil of sticky clay, beneath which sands, gravel and chalk are found. Marl oecurs on South Edisto river. Growth, pine, oak and hickory. Crops, fifteen bushels corn, one-half bale cotton, twenty bushels oats per acre. There is a large turpentine factory. The tributaries of the Edisto furnish water powers for ginning and grinding. Stock does well, and might be profitably raised. Wages for field work, fifty . cents a day. One-third of the field work performed by whites. Land for sale at four dollars to ten dollars an acre; rents from two dollars to three dollars. Generally healthy; mild form of chills and ferer sometimes.

Union, (E. D. 153): Land level. Soil, fine, gray, sandy loam, three inches to yellow sand subsoil, and eighteen to twenty inches to yellow elay, containing sometimes numerous brown pebbles, which become mixed with surface soil and give it a darker color. Growth of uplands, pine, ash, hickory and dogwood; of the swamps, elm, poplar, ash, white oak, gum. Crops, six hundred pounds seed cotton, ten bushels corn, fifteen bushels rice, one hundred and fifty bushels sweet potatoes, three hundred gallons syrup per acre. Besides the South Edisto river, there are Cooper creek, ten feet wide, two feet deep, relocity two miles an hour; Snake creek, fifteen feet wide, four feet deep, velocity two miles an hour. Some industry in shingles, hoops and turpentine. No attention paid to stock; it might be profitably raised. Wages for work, forty cents per day. Onefourth of field work performed by whites. Mild form of chills and ferer in swamps, otherwise healthy. Lands sell at five dollars to six dollars an acre, and rents for two dollars and fifty cents.

Goodloye's, (E. D. 141) : Lands level. Soil, light sandy loam, with oceasionally a stiff strip. Subsoil, at six inches depth, light yellow elay. Growth, pine, oak, hickory. One-third of the field labor performed by whites. Lands sell from one dollar to five dollars, and rents from one dollar to two dollars an acre. Some chills and ferer.

Vunces, (E. D. 155): Lands level, except along Santee river, where they are rolling. Soil, fine sandy loam, beneath which is a yellow sand subsoil resting on red clay, that extends to a depth of twenty to thirty feet on the river, and twelve to fourteen feet elsewhere, to the depth of the wells in both instances. Growth, pitch pine. Crops, five to twenty-five bushels corn, five hundred to fifteen hundred pounds seed cotton, ten to forty bushels oats per acre. Marl occur's in abundance. Little attention given to stock; it might be profably raised. Some lands for s.le at eight dollars to ten dollars an acre. Some chills and fever.

Sumter County, (3d Sup. Dist. 10th United States Census.)

Prinateer, (E. D. 120): Lands level; light gray sandy loam, with sub- 
soil of yellow sand and clay. Growth, pine, oak and hickory. Crops, five humdred pounds seed cotton, ten bushels corn per acre. A black rock found that is used for building to some extent. Forest products are turpentine and shingles. Several mill sites. Wages for field work, fifty cents a day. All kinds of stock do well. Land sells at from three dollars to twelve dollars; rents from one dollar to five dollars per acre.

Concord, (E. D. 114): Lands low and level, much of it swamp; uplands dark gray calcareous sands, with clay subsoil at depth of eight inches to ten inches that extends to the depth of the wells, fifteen feet to twenty feet. Marl oceurs. Wages, fifty cents a day for field labor, one-fourth of which is performed by whites. Little land for sale; rents for one dollar and fifty cents to two dollars per acre. Some chills and ferer.

IIt. Clio, (E. D. 119): Lands level; dark sandy loam, four inches to six inches to subsoil of red clay, beneath which layers of white clay and fine sand are found to the depth wells are dug, fifteen to thirty feet. Growtl, pine, with occasional ridges of oak and hickory. Average crop, four hundred pounds seed cotton. Marl oceurs. Scape creek affords fine water power. Wages for farm work, forty cents to fifty cents a day; one-eighth of field work performed by whites. Lands sell from five dollars to ten dollars, and rent from one dollar to three dollars an acre.

Slitoh, (E. D. 123): Land level. Soil, light, loose saridy loaim, four inches to six inches to subsoil of yellow clays underlaid by stiffer clays, containing gravel to the depth of the wells, sixteen feet to twenty feet. Growth, pine, oak and hickory. Crops average eight hundred pounds seed cotton, eight bushels corn; as high as one and a half bales of cotton per acre has been made. Marl is found under all the swamp lands. Stock raising might be made profitable. Farm labor receives fifty cents a day; in some portions nearly all the work is done by whites. Land sells from five dollars to eight dollars an acre, rents for onefourth to one-third of the erop. Sometimes chills and ferer, otherwise healthy.

Bishopville, (E. D. 112): Western or upper part sand hills, the middle undulating, known as "ridge lands;" the lower part level. Soil, light sandy loam, six inches to two feet to red elay subsoil, extending to the depth of the wells, ten to twenty feet, Growth, pine, with occasional spots covered by large red oaks and hickory. Crops, eight hundred pounds seed cotton, ten bushels corn, but the tenant system has so diminisherl the yield that an average ean not be stated. Wages, fifty eents for field labor, more than one-half of which is performed by whites. Land 
sells at eight dollars to ten dollars, and rents at from two dollars to four dollars an acre.

Darlington Countr, (3d Sup. Dist. Souti Carolina.)

Fan's Bay, (E. D. 4S): Lands low, level, interspersed with bays that are very productive when reclaimed; uplands, a fine light sandy loam of a dark gray color. Subsoil, light sandy clay, underlaid by white clay. Heavily timbered with pine and oak; swamp growth, oak, poplar, walnut and cypress. Crops, cotton, five hundred pounds to fifteen hundred pounds seed cotton, eight bushels to fifteen bushels corn, fifteen bushels to thirty bushels rice. Little attention paid to stock. Much of the land uncleared. No demand to purchase land; rents for from one dollar and fifty cents to two dollars per acre. No prevailing disease; fifteen deaths in 1880 no three from same cause. Farm labor, thirty to fifty cents a day. Nearly all the whites do field work.

IIrtsville, (E. D. 36) : One-half lands elevated, level. Soil, coarse gray sandy loam. One foot to subsoil of yellow clay, underlaid by alternating strata of sand and clay. The other half hilly, broken and sandy; not very productive. Growth, pine, oak and hickory. Crops, six to eight hundred pounds seed cotton, ten bushels corn, five to forty bushels small grain per acre. Large beds of chalk occur. Black creek affords good water power. Wages, fifty cents. One-half the field work done by whites. Land sells for six dollar's to twenty dollars an acre; rents for two dollars to four dollars. Very healthy.

Timmonsville, (E. D. 49): Soil, a stiff mixture of sand and clay, with a red clay or pipe clay subsoil at four inches to six inches depth, underlaid by very stiff clay and gravel to the depth of the wells, ten fect to twenty feet. Growth, pine, oak and dogwood. Crops, cight hundrerl to two thousand pounds seed cotton, ten bushels corn, ten to one hundred bushels oats, ten to fifty bushels rice per acre. Grapes do especially well and a good deal of wine is made. Geese are raised in great number's. Lake Swamp creek, twenty feet wide, four feet deep, velocity three to four miles an hour. One-half of the field work done by whites. No land for sale price ten dollars to fifty dollars; rents for three dollars to six dollars an acre. Tery healthy.

Florence, (E. D. 35): Lands level, flat. Soil, dark sandy loam, four inches to five inches to subsoil of red clay. Growth, pine and small oaks. Crops, seven hundred pounds seed cotton, ten bushels corn, twenty bushels to thirty bushels oats per acre. Wages, fifty cents a day. No field work done by whites. Improved lands sell at from ten dollars to twelve dollars an acre. About half the lands are rented at two dollars and fifty cents per acre. 
High Hill, (E. D. 37): Land flat. Soil, a dark clay loam, with clay subsoil to the depth of the wells, fifteen feet to twenty-five feet, when a yellow sand is found. Growth, pine, oak and hickory. Improved lands sell at eight dollars to twelve dollars, and unimproved at three dollars to six dollars an acre. One-fourth field work performed by whites.

Antioch, (E. D. 29) : Lands level. Soil, mostly sandy, though clay lands cover a considerable portion of the township; subsoil, red clay and red sand, the latter is best adapted to corn, the former to cotton. Growth, pitch and yellow pine, oak, hickory and dogwood. Much fine shingle and stave timber, and a considerable amount of turpentine produced. Little attention is paid to stock. Several water powers. Farm labor, forty cents to fifty cents; one-half or more performed by whites. Lands rent at from five hundred pounds to one thousand pounds lint cotton for a one-horse farm (thirty acres). Very healthy. Much uncertainty in securing laborers.

Society Hill, (E. D. 45): There are clay lands, mostly swamp along the Pee Dee river. The central portion is rolling; the soil is a fine sandy loam, four inches to subsoil of a yellowish color, turning white on exposure; underlying this is red elay, in the west the gum flats, consisting of fine black sand, have a similar subsoil. Growth of uplands, pine, oak, and dogwood; of the swamps, white oak, ash, and poplar. Crops, average three hundred pounds seed cotton, eight bushels corn, thirty bushels oats per acre; under good culture 1,500 pounds to 2,000 pounds seed cotton, and twenty bushels to twenty-five bushels eorn per aere is made. A sand stone is used for building chimneys. Cedar creek is twenty feet wide, three feet deep, velocity three miles an hour. Wages, fifty cents a day. Locality very healthy. Improved lands sell at ten dollars to twelve dollars an acre, mimproved at three dollars to five dollars.

Pelmetto, (E. D. 43): Lands rather rolling. Soil, of coarse and of fine sand, mixed with clay; subsoil, red clay; growth, pine and oak. Crops, five hundred pounds seed cotton, eight bushels corn, twenty bushels oats per acre. High Hill creek is twenty feet wide, with good fall; Black creek is forty feet wide, eight feet deep, velocity four to five miles an hour. Wages, fifty eents a day. No land offered for sale; rents for about two dollars an acre.

\section{Mariox Countr, (3d Sup. Dist., 10th United States Census.)}

Cain, (E. D. 87): Lands level; soil, fine dark gray sandy loam, six inches to eighteen inches to clay subsoil, beneath which occur strata of marl and clay. Growth, pine, oak, dogwood, eypress, \&c. Crops, seven hundred pounds seed cotton, ten bushels corn per acre. Wages of field 
labor, twenty-five cents to fifty eents a day; one-third field work done by whites; land sells from three dollars to ten dollars an acre.

Rowell, (E. D. 101): Lands level; soils, on the bottoms, heavy; on the uplands, a light "fluffy" sandy loam, on a red clay subsoil. Growth, pine, oak, poplar, dogwood, lickory, cypress, \&c. Some business done in shingles, hoops, staves and turpentine. Fine pasturage for stock. Wages for field work, forty cents to fifty cents a day for men, and thirty cents to forty cents for women. The locality has been very healthy for fifty years. Land sells for ten dollars, and rents for two dollar's an acre.

Jeffires, (E. D. 91): Prevailing soil a sandy loam, mixed with clay, varying in eolor from yellowish to dark gray, and resting on subsoil of red and yellow sand, containing a good deal of clay. The higher lands have more clay, the bottoms are more sandy. Much very fertile land unreclaimed on the Great Pee Dee and other water courses. Nost of the land needs drainage. Growth of lowlands, oak, lickory and dogwood; on ridge lands, pitch and yellow pine, with oak, \&c. Grapes are unfailing, and grow with little eare. Stock raising has been profitable. Wages for field work, thirty cents to forty cents a day; one-third of it performed by whites. Some fever in the swamps, otherwise healthy. Some lands for sale at five dollars to ten dollars an acre.

Marion, (E. D. 95): Lands level or slightly rolling, one-half known as "fluffy soil," is a dark gray clay loam, four inches to twelve inches to a subsoil of red or yellow elay. The other half is fine dark sandy loam, with subsoil of yellow sand; below the subsoil oceur clays of various colors, which extend to the depth of the wells, ten feet to twenty-five feet, where excellent water is found in a stratum of quicksand and gravel. Very fertile bodies of unreclaimed swamps may be purchased at fifty cents to one dollar an acre, admitting of thorough drainage and easy tillage. Growth, pine, oak, hickory on uplands, with the usual swamp growth. Crops, eight hundred pounds seed cotton, fiftcen bushels corn, twenty bushels rice, two hundred bushels sweet potatoes, under good culture much more is made. Much attention is paid to fruits, which do well; the finer varieties of grapes suceed admirably; the scuppernong is native to the locality. Timber for shingles, staves and hoops abundant, and some turpentine. Marl occurs. Field work, paid forty cents to fifty cents a day; one-half of it performed by whites. A little land for sale at five dollars to eight dollars an acre, more for rent at two dollars to six dollars an acre, or one-fourth or one-third the crop, rent for a portion of the erop preferred. No malarial disease; very healthy.

Kirby,(E. D. 72): Land level. To the north, coarse, sandy soil, three feet to ten feet to light colored elay, mixed with gravel. In the centre, 
the land is darker and finer. To the south, there is a gray loamy soil, resting at one foot to three feet on bright red clay. The ridges on what is known as the "slashes," is a mulatto soil on dark red clay, beneath the clay, white sand, mixed with gravel, is found. Crowth, long and short leaf pine, with the usual swamp growths on the water courses. Crops, eight hundred pounds seed cotton, ten bushels corn, twenty bushels oats, twenty bushels rice per acre. The sandy lands were formerly considered worthless, a bale to three acres was unusual; now with manures and judicious culture, an arerage of 1,500 pounds to 2,000 pounds seed cotton is not uncommon. Farmers now who do not make their supplie.s and a bale to the acre are not considered as doing well, e. g., a farm of three hundred and thirty acres in cotton made, last year, three hundred and forty-six bales; on smaller fields more has been made; last year a farm of twenty acres made 44,600 pounds seed cotton. Besides thorough tillage, twenty or thirty loads of straw or litter, one hundred pounds to two hundred pounds Kainit, with one hundred and fifty pounds or two humdred pounds of superphosphate or of Peruvian guano, is applied to the acre. The "Thomas grape," a fine variety scuppernong, was first cultivated here, and is still found wild. Farm wages, for men, fifty cents a day; for women, thirty cents; one-eighth of the field work is performed by whites; some fever near the river, otherwise remarkably healthy. Improved lands rent for five dollars an acre, unimproved for a four hundred pound bale for a one-horse erop. Lands sell from three dollars to one hundred dollars an acre.

Legett's, (E. D. 93): Rolling elay lands, sometimes flat and low. The sandy soils are level and dry. The subsoil mostly al yellow clay, some of red, or yellow sand. Sand is found again four feet to ten feet beneath the clay, and in some places marl occurs. Wages of field labor, forty cents to fifty cents a day, four dollars to eight dollars a month. Onehalf of the field work done by whites. Knows of no land for sale, may be bought for four dollars to ten dollars an acre. Rents for one-third or one-fourth of the erop, or worked on shares for one-half to two-thirds of the cotton, and two-thirds of the corn; rents often yield five dollars to ten dollars an acre.

Hillsboro. (E. D. 90): Soil a darkish gray clay loam, six inches to eight inches to a yellow clay subsoil, overlying a very compact red elay that reaches twelve feet to twenty-five feet, the depth of wells, where water is found in quicksand. In the eastern part thousands of acres of most fertile swamp lands might be reclaimed by drainage. There are also some sandy soils, with yellow sand subsoil. Crops, ten bushels to twentyfive bushels corn, five hundred pounds to fifteen hundred pounds seed cotton, one hundred bushels to two hundred and fifty bushels sweet po- 
tatoes per acre. Field work paid thirty cents to forty cents a day; onethird done by whites. IIealth good.

Carmichad, (E. D. SS): Lands elevated and level. Soil, a fine sand or red clay loam, containing much vegetable mould, underlaid at two feet or more by a very dark clay. Growth, pine, oak, hickory and dogwood, with juniper and cypress in the swamps. Average crops, one thousand pounds seed cotton, twelve bushels to fifteen bushels corn, fifteen bushels wheat, thirty-five bushels oats, twenty-five bushels rice per acre. Grapes do unusually well. Field labor paid, thirty-five cents to fifty cents a day; onethird of it done by whites, a sturdy wide awake population of Scoteh descent. Locality very healthy. Some land for sale at two dollars to thirty-five dollars an acre. Most of it rented to laborers at two dollars to eight dollars an acre, or for one-third of the crop.

Harllesville, (E. D. 89) : Most of the land is elevated and level, some of it, however, is low enough to require drainage. Three-fourths of the soils are fine clay, with little vegetable matter, except in the bottoms; one-fourth are sandy soils, with a subsoil of yellow clay, mixed with sand; it is the bestoadapted to corn and small grain ; beneath the subsoils clay is found to the depth of the wells, fifteen feet to twenty feet, where water is found in quicksand. Growth, on uplands, pine and oak; in the swamps, poplar and cypress; much timber is rafted down the Little Pee Dec. Provision crops are neglected for cotton, and high prices for the advancement of suplpies are paid. No fever, the locality is very healthy. Price of lands, six dollars to forty dollars an acre. Farm labor paid, thirty cents to fifty cents a day; one-half the field work done by whites.

\section{Marlboro Couvtr, (3d Sup. Dist., 10th United States Census.)}

Red Hill, (E. D. 110): Lands generally level or slightly rolling; rarely hilly or broken. The cultivation of large bodies of rich river lands on the Cireat Pee Dee has been abandoned, or they are rented to negro oxfarmers. Some bay lands have been reclaimed. To the north, the uplands are a sandy loam, resting on dark clay. Growth, oak and hickory. Crops, six to twelve hundred pounds seed cotton, ten to fifteen bushels corn, eight to forty bushels oats, fifteen to twenty-five bushels wheat. Fruit very fine. Wages of farm labor, fifty cents to seventy-five cents a day. One-eighth of field labor done by whites. The best land will command twenty-five dollars to thirty dollars; average lands fifteen dollars, and river bottoms two dollars and fifty cents per acre. Ordinary land rents for one hundred pounds seed cotton an acre, or two four hundred pound bales for a one-horse farm. Some fever on the river, elsewhere remarkably healthy. 
Bennettsille, (E. D. 105) : Large borlies of bottom land on the Pee Dee; once very productive, are now abandoned. Culture is chiefly confined to the uplands, which are level or gently undulating. Soil, a fine sandy loam, resting at four inches on red clay underlaid by a chalky clay. Growth, pine, oak and dogwood, with the usual swamp growths. Crops, one thousand pounds to fifteen hundred pounds seed cotton, ten bushels to thirty bushels corn, twenty bushels to sixty bushels oats, fifteen bushels wheat per acre. Grapos, fruits and regetables do well. Wages for farm work, fifty cents to seventy-five cents a day; onc-third of it done by whites. Two large mill creeks traverse the township. Little land for sale, price ten dollars to twenty-five dollars. Rent, three dollars to five dollars per acre. Very healthy.

Hebron, (E. D. 10S): Level to flat lands. Soil, a sandy loam, mixed with clay on clay subsoil. Growth, pine, oak and dogwood. Crops, eight hundred pounds seed cotton, ten bushels to thirty bushels corn, ten bushels to forty bushels oats, five bushels to thirty bushels wheat per acre. All fiuits do well. Wages, fifty cents to seventy-five cents a day ; onefourth of field work done by whites. No prevailing disease. Land sells from ten dollars to fifty dollars an acre; rents for three dollars to five dollars an acre.

Brightsville, (E. D. 106): Lands elevated. Two-thirds of the soils fine gray sandy loam, with yellow sand subsoil resting on red clay; the other one-third the same, without the clay. Growth, pine, oak and dogwood. Crops, eight hundred pounds seed cotton, eight bushels corn per acre. Wages, fifty cents a day; two-thirds of the labor performed by whites. No prevailing disease. No land offered for sale or to rent.

Adamsville, (E. D. 104): Lands level or a little broken. Soil of fine and coarse whitish or yellowish sand, ten inches to fifteen inches to subsoil of red clay, under which a chalky clay occurs. Growth, pine, oak, hickory and dogwood. Crops, one thousand pounds seed cotton, fifteen bushels corn, seventy-five bushels oats, twenty bushels wheat per acre. Crooked creek is twenty fect wide, eight feet deep, fall eight feet per mile. Wages, fifty cents a day. One-half of field work done by whites. Very little sickness of any sort. No land offered for sale; price would be twenty-five dollars an acre; it rents for one hundred and twenty-five pounds seed cotton, or two bales of five hundred pounds for one-horse farm (twenty-five acres).

Red Bluff, (E. D. 109): Prevailing soil a gray or brown sandy loam, with subsoil the same, less the vegetable matter, resting at one foot to two feet on clay that extends eighteen feet to the botton of the wells, where excellent and abundant water is found in quicksand. Growth, pine, oak, hickory, dogwood and gum. Great resources in timber, hoops, shingles, 
turpentine, \&c., untouched, except a little rafted down the Little Pee Dee. There is a mill at Red Bluff, on the Little Pee Dee; the river here has a width of fifty-five feet, a depth of six feet, and a current of three miles an hour. Crops, one thousand pounds seed cotton (many farms yield a bale per acre), and fifteen bushels corn. Farm wages, forty cents to sixty cents a day; one-half of the field work done by whites. Little land offered for sale; prices range from five dollars to forty dollars an acre. Rent, in money, is six dollars an acre, or one-third of the crop. 


\section{CHAPTER V.}

\section{TH E RED H I L L REGION.}

\section{LOCATION.}

The very gradual slope of the upper pine belt having attained an elevation of two hundred to two hundred and fifty feet above the sea level, an irregular and somewhat interrupted line of high hills is encountered. These hills rise two to three hundred feet above the plane of the upper pine belt in the distance of a few miles, and not unfrequently this elevation is attained in traversing a few hundred yards. To the south and east extensive views over the gentle and irregular slope of the lower country are exposed from the summit of these declivities. To the north and west a sort of table land stretches back and gradually merges into the higher and more extensive sand hill region of the state.

The general trend of these hills correspond pretty nearly with that of the other regions of the State. Starting on the Savamnah river near Hamburg, they extend across the southern and western portion of Aiken and the northern townships of Barnwell counties. Following the northern boundary of Orangeburg, they asquire their greatest width in that county around Fort Motte, near the eonfluence of the Congaree and the Wateree rivers. West of the Santee river their course is more to the north, and they constitute that remarkable line of hills traversing Sumter county, long known as the "High IFills of Santee." Ineluded in this region is also a body of lands in Edgefield county, known as the "Ridge," which lie along the Augusta and Charlotte railroad. Although the latter are above the ontcrop of the granite rocks, being continuous with the red hills, and resembling them elosely in physical features and soil, they are described with them.

While these red hills form a well marked belt aeross the State below the sand hills, from the southwestern part of Aiken county to the north- 
eastern corner of Sumter, they are not continuous, but are interrupted at greater or less intervals by the protrusion of the sand hills. Mills' description of them east of the Santee river will give an idea of how this oceurs. He says, "they take their rise about nine miles north of Nelson's ferry on the Santee, and form that fine body of brick mould land (3d Sup. Dist., E. D. 14 and 15) in the Richardson settlement. After continuing eight miles, they become suddenly sand hills a little above Manchester. At the end of eleven miles they again become red land, which continues to Buck creek, nine miles above Statesburg. These hills up to this point appear to hang over the Wateree swamps, but now they diverge and turn to the northeast, with one ridge in the middle forming a backbone; breaking off into hills towards the Wateree, and sloping off gradually towards Black river. At Buck ereek the hills again become sandy, which gradually increases for fifteen or sixteen miles, to Bradford Springs; a little above this place they join the sand hills of the middle country." If these altermations were carefully traced it is probable they would be found to be due to removal by denudation of the red clay loam from the slopes of sand and gravel that rise in the sand hills. For the siennacolored clay loam, characteristic of this region, seldom has a depth greater than twenty feet, and is underlaid by beds of sand and gravel.

\section{GEOLOGICAL FEATURES.}

The red hill region belongs to the buhn-stone formation of the eocene. It presents a series of four quite dissimilar and well marked strata. Commencing with the superior, or more recent, these are:

1st. Beds of red sienna-colored siliceous clay, having a thickness of fifteen to thirty feet, and containing fragments of buhr-stone. It was the observation by Mr. Tuomey of the passage of these clays under the marl and green sand formations of the Charleston basin, at the Belle Broughton place, on Halfway swamp, in Orangeburg county (E. D. 150), which satisfied him that Mr. Lyell had erred in supposing that the bulnr-stone overlaid the calcareous beds in South Carolina. This observation settles a point of considerable practical importance. For as the buhr-stone underlies and forms the floor of the lime formations of the eocene, no marl beds need be looked for above the line of its occurrence.

2d. Berls of coarse red and yellow sands, haring i thickness of thirty to sixty feet. In these beds are sometimes found, at a deptlo of fifty feet, erystals of rutile, either lying loose among the sands or imbedded in rounded masses of quartz or felspar, water-worm by still quite perfect pyramidal crystals of quartz an inch in length, are also found among these sands. 
3d. Masses of buhr-stone, composed of silicified shells and other organic remains of the eocene. Among the shells gasteroporla predominate, which, together with the presence of land shells, and shells of mollusks which live in marshes (Auriculae), indicate the literal character of the formation. The leaves of oak, beech and willow trees, silicified or converted into lignite, were found here by Mr. Toumey. On Cerlar creek, in Aiken county, there are beds of huhr-stone thirty "cet in thickness, and at several points between this locality and the Savannah river on the west, and the Santee and Congaree on the east, there are extensive outcrops of this mate rial, from which mill-stones of excellent quality, equal to the best French buhr, have been quarried. In the southwestern corner of Aiken county, on Hollow creek (E. D. 16), beds of lignite occur, underlaid by clay that was used by the ordinance department during the late war for the manufacture of fire-proof crucibles, and pronounced equal to the best Stourbridge clay for that purpose. Similar beds of lignite are found in Chesterfield county, on Whortleberry branch, and at Mr. Croghan, underlaid by clay of the same character.

4th. Beds of a white siliceous rock, varying from a laminated silieeous clay to a hard rock, having a jointed structure, breaking with a conchoidal fracture, and resembling menilite. This eurious rock has been traced from near Aiken C. I. to the northern part of Clarendon county. In the latter county there is a remarkable occurrence of it on the public roarl just north of Gov. Manning's residence (3d Sup. Dist. E. D. 15). On the head waters of Congaree creek this rock is sawed into blocks, fashioned with an axe, and used for building chimneys. It resists disintegration well, and its extreme lightness facilitates its carriage and handling.

Below the series of strata thus described are the great beds of loose sand, intermingled with kaolin and rarionsly colored elays, which rise into the extensive sand hill region, lying north of the red hills.

\section{SOLLS.}

The reddish loam of this region presents an appearance somewhat similar to that of the soils derived from the hormblende rocks in the upper country, but it is not so tenacious and waxy. Although when not cultivated it becomes very hard in dry weather, in wet weather, owing to the large amount of sand it contains, the intervals when it can not be worked are short. Vegetable matter rots rapidly in it, and for this reason long manures (as composts) are better adaptech to it than commercial fertilizers. The former are rapidly incorporated and well retained, and there is no soil that responds so well or is so capable of great improvement under treatment with stable and lot manures as these. Worked without manure they rapidly consume themselves and become unproductive. 
The following analyses of typical soils in this region were made by Dr. Eugene A. Smith, of Tuscaloosa, Alabama, for the 10th United States Census:

1.

Insoluble matter . . . . . . . . . 88.960

Soluble silica . . . . . . . . . . 3.055

Potash . . . . . . . . . . . . . . . . .

Soda . . . . . . . . . . . . . . . . . .

Lime . . . . . . . . . . . . 062

Magnesia . . . . . . . . . . . . . . . . .

Br. oxide of Manganese . . . . . . . . . .095

Peroxide of Iron . . . . . . . . 1.250

Alumina ............ 4.000

Phosphoric aeid . . . . . . . . . . . 075

Sulphuric acid . . . . . . . . . . . . . . . . . . . .

Water and organic matter . . . . . . . 2.621

Total ............ $\overline{100.351}$

Hygoscopie moisture absorbed at $\mathrm{S}^{\circ}$ Fah. . . 1.982

These samples were taken uniformly to the depth of twelve inches on the table land in Amelia township, Orangeburg county, about three miles below the junction of the Wateree and Congaree rivers, from the place of J. Peterkin, Esq. The three hundred and seventy-five acres in cotton on this place made, in 1879, two hundred and fifty bales of cotton. No. 1 is from woodlands never eleared; the growth, large red oak and hickory, with a sprinkling of very large short leaf pine. No. 2 is from a field that has been planted for more than one hundred years; having on it a crop of about twelve hundred pounds of seed cotton to the acre when the sample was taken. The field had received only cotton seed and commercial fertilizers as manures for a number of years. Prof. Toumey, in his survey of South Carolina, published in 1848, gives the following analyses of these soils:

\begin{tabular}{|c|c|c|c|c|c|c|c|c|c|}
\hline Organic matter. & .. & & & & & & $\begin{array}{r}\text { No. } 1 . \\
5.60\end{array}$ & $\begin{array}{r}\text { No. } 2 . \\
7.00\end{array}$ & $\begin{array}{r}\text { No. } 3 . \\
4.40\end{array}$ \\
\hline Silica... . . & . & . & . & . & . & 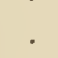 & . 66.90 & 71.00 & S0.30 \\
\hline Alumina & . & 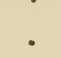 & • & & & & 9.60 & 8.50 & 6.60 \\
\hline Oxide of Iron .. & . & . & . & & & & 6.00 & 4.00 & 3.70 \\
\hline Lime... . . & $\therefore$ & $\therefore$ & . & & & . & 2.00 & 1.56 & 0.90 \\
\hline Magnesia ... . & 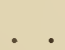 & & 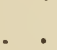 & & & . & .50 & 1.00 & trace. \\
\hline Potash and soda & . & . & . & & & . & trace. & .50 & . \\
\hline Water and loss . & 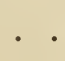 & . & & & & & 9.40 & 6.44 & 4.10 \\
\hline S & & & & & & & $\overline{100.00}$ & $\overline{100.00}$ & 100.0 \\
\hline
\end{tabular}


No. 1 was from near Orangeburg village, the southern limit of the region under consinleration, and near the line where the buln-stone passes under the Santce marls.

No. 2 was from Lang Srne, the same plantation from which the samples analyzed by Dr. Smith, were taken.

No. 3 was from the "High Hills of Sintee," near Statesburg, in Sumter county.

\section{CLIMATE.}

Having an elevation of four hundred to five hundred feet and upwards above the sea level, the red hills enjoy a dryer and more bracing atmosphere than the regions to the south. While it is a notable fact that they are not so subject to the severer influences of storm winds as the lower lying lands, the ordinary movements of the air are more perceptible there than in the lower grounds. Thus, during the extremest heats of summer, there is rarely a night when the refresling influence of a gentle south wind is not felt, blowing with a uniformity as though it had directly traversed the seventy miles intervening between these slopes and the ocean. Owing to this movement of the air and to its greater dryness, late spring frosts are of less frequent occurrence here than they are further south. Nor is vegetation destroyed by cold so early in the fall. In ascending these hills in the autumn and early winter at a certain elevation a stratum of warm air is encountered, which seems to cling about the hill-tops, while a much chillier night air fills the bottoms. These adrantages at one time made this region famous for its fruits. During the sererest winter of the last half eentury the banana and the sago palm in the open ground, protected only by a few handsful of cotton seed on their roots, though cut by the frost, retained sufficient vitality to throw up vigorous shoots the ensuing spring. This greater length of growing season has also made attempts at growing sea island cotton and sugar cane more successful here than lower down. The whole region is remarkably healthy, no taint of malaria approaches it and it is in an unusual degree free from epirlemics of every description. For these reasons many. localities here, especially the "High Hills of Santee," were formerly much frequented as summer and health resorts by planters from all parts of the State, as well as from other southern States.

\section{GROWTH.}

The long leaf pine thins out on these hills and is sometimes replaced by short leaf pine of large growth. Their southern aspect is the upper limit of the long gray moss. The characteristic growth, however, is oak 
and hickory of large size. All the oaks common to the section attain here an munsual size, including eren the blackjack and the post oak, not conspicuous elsewhere for their growth; the red oak, lowever, surpasses them all in size, measuring sometimes as much as seren feet in diameter, while trees four feet and fire feet through are not uncommon. The live oak when planted does well, the chinquapin is found wild in the woods; the Roman chestnut, the pecan nut, the English walnut, and the almond, bear abundant erops. So that the region is to a large extent suitable for the growth of plants natural to higher and to lower latitudes.

\section{STATISTICS.}

The red hill region contains about 1,620 square miles, and has a population of 44,566 , being 27.6 to the square mile. Fifty-six per cent. are colored.

The area of tilled land is 234,682 acres; being 144 acres per square mile, or 22 per cent. of the entire surface; and five acres per capita of the population.

The number of farms is 4,568 , being 2.8 per square mile, or a farm to nearly every ten persons; areraging for the whole, $22 S$ acres to the farm, of which fifty is under culture; the remaining 178 being included and for the most part yielding no return whaterer.

The crops are cotton, in which $\$ 4,939$ acres are planted, yielding 34,249 bales of cotton in 1S79. Averaging a yield per acre of 183 pounds of lint, or $34 S$ pounds per capita for the whole population; which is the largest yield per capita of any region of the State, This is a little more than six per cent. of the area planted in cotton in the whole State, and yields six and six-tenths per cent. of the entire erop of the State. In grain of all sorts 114,425 acres are planted, yielding $\$ 04,4+3$ bushels, a little over seven bushels to the acre, and seventeen bushels per capita of the population, a yield wholly disproportionate to the capabilities of the soil, which is particularly adapted to small grain. This area is a little over six per cent. of the total area planted in grain in the State, and the yield is four and seven-tenths per cent. of the total crop of the State. Of course very little rice is planted here, which in part accounts for the falling off, that being the most productive grain crop in the State; but lands which in 1525 made an average of eight to twelve bushels (see Mills, p. 660 ), and when well manured, thirty-four bushels of wheat per acre, and from ten to twenty-five bushels of rice to the acre, and still more when planted in rye and oats, are far below their normal production when rielding as above indicated. In fallow and other crops there is 35,315 acres, nearly fifteen per cent. of the land once under cultiration. The 
eulture of much of this land is abandoned as a eonsequenee of the disasters that have overtaken the rich planters, who formerly lived here, ineident to the results of the war.

The work stock numbers 7,663 , not quite five to the square mile, one to every thirty aeres of tilled land, and to every six of the population.

The live stock is 61,569 , chiefly logs; thirty-eight to the square mile, and nearly one to every four acres of cultivated land.

At Wedgefield, on the Columbia and Wilmington Railroad, these lands are well cultirated and sell as high as twenty-five dollars an aere. At Fort Motte, on the Columbia and Charleston railroad, the prices are fifteen dollars to twenty dollars an aere, and in Millbrook, Aiken, by the South Carolina railroad, they sell for fifteen dollars to twenty dollars, and in Beech island, in the same eounty, near Augusta, Georgia, they have recently brought over forty dollars an aere. The great body of these lands, however, lying off the railroads, are to be had at much lower prices. Large tracts, by no means inferior to those already mentioned, except as regards accessibility, are offered at from three dollars to ten dollars an aere. It is remarkable that mere accessibility should affect prices to this degree. For, while the lands themselves produce every variety of crop, they are well adapted to eotton, of which a two-horse wagon ean transport as mueh as two hundred dollars worth at one load; the roads are exeellent and there is scarcely a point that is a day's journey removed from a market. That not one-fourth of these lands, capable of supporting, in health and abundanee, as large a population as land anywhere, are under cultivation, illustrates how mueh is wanting in capital and population to develope the resourees of this section. 


\section{CHAPTER VI.}

\section{THE SAND HILL REGION.}

The sand hill region of South Carolina stretches across the State from the Savammah river, opposite to Augusta, to the intersection of the North Carolina line by the Great Pee Dee river. The arerage distance of its lower border, among the Red Hills, from the sea, is about ninety-five miles. Its length is one hundred and fifty-five miles. Its width is variable; the maximum, which is reached in Lexington county, is about thirty miles, and the average width will hardly reach twenty miles. It occupies the larger portion of five counties, viz: Aiken, Lexington, Richland, Kershaw and Chesterfield. The upper pine belt, ascending the eastern bank of the Congaree river, in Richland county, until it touches the granite rocks of the Piedmont region at Columbia, divides the sand hill region into two portions, an eastern and a western portion.

\section{THE PHYSICAL FEATURES. .}

The physical features of this region are of a monotony aptly characterized by the term "pine barren," applied to it. The hills slope up from the Savannah river to a plateau, having an elevation at Aiken C. H. of about six hundred feet above the sea level. Beyond the North Edisto river the gradual ascent is resumed, until an elevation exceeding seven hundred feet is reached in Platt Springs township, in eastern Lexington, whence there is a rapid descent of more than five hundred feet in a short distance to the Congaree river. East of this stream the rise is again gradual, and the maximum elevation is reached on the northeast border of Richland county, where the hills again descend abruptly to the Wateree river. Beyond this river there is no data as to levels, except that on the water shed of the Great Pee Dee there is evidence as to extensive denudation of the surface to a depth of at least one hundred and fifty feet. The eridence is furnished by a conical hill rising in central Chesterfield one hundred and fifty feet above the surrounding country, and known as Sugar Loaf 
mountain. This hill consists of horizontal layers of sand and kaolin clays, similar to the prevailing formations of the sand hills, and has been preserved from denudation by blocks of ferruginous sandstone covering its top and sides, identical in character with the same sandstone, known as ironstone, found on the summit of these hills in many other localities. The following diagram presents a view of the relative elevations of this region :

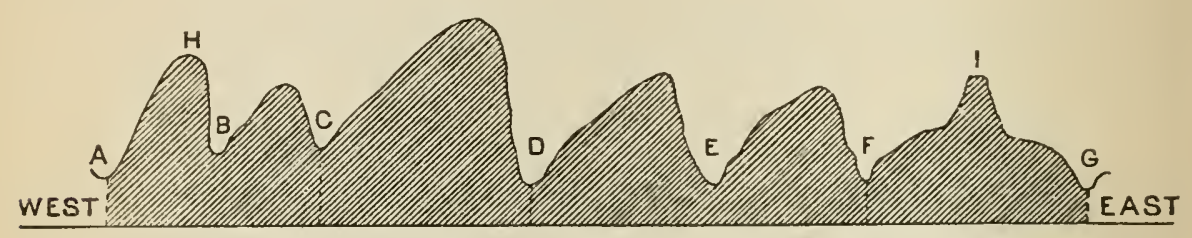

SFA LEVEL. AIKEY.

LEXINGTON,

RICILAND.

KeIshaw. Chesterfield. ŚEa Levet.

$A$ Savannah River; $B$ South Edisto River; $C$ North Edisto River; $D$ Congaree River; $E$ wateree River; $F$ lynch's River; $G$ Pee Dee River; $H$ Aiken Court House ; $I$ Sugar Loaf Mountain.

SCALE-35 miles per inch. Elevation 100 feet per $\frac{1}{10}$ inch.

This longitudinal section of the sand hills illustrates once more the law already noticed as prevailing elsewhere-that the long slopes face west and south, and the short slopes face east and north; and, also, that the western portion of the State is more elevated than the eastern. It will also be noticed that, notwithstanding their just reputation for great dryness, these pine barrens are well watered. They are crossed by seren rivers of considerable size, having an aggregate length among these hills of more than two hundred miles. Of creeks, not counting lesser streams and branches, there is an aggregate length in this region of eleven hundred and seventy miles, capable of furnishing a large amount of water power. For instance, one average creek out of the serenty-eight found here, Horse ereek furnishes in the single township of Gregg, in Aiken county, power for a large paper mill and three cotton mills, being 1300 horse power utilized, and estimating the power not employed, the stream can furnish 2500 horse power. Showing that the streams of medium size in this region have a capacity for work, now scarcely utilized, greater than that of all the work stock of the State. On the margins of these streams there are more than 100,000 acres of bottom lands, for the most part uncleared, but capable of being rendered, by drainage and irrigation, in the highest degree productive. The water of these streams, which are little sulject to freshet, but maintain a flow of great uniformity throughout all the seasons of the year, is as clear as that of the purest springs. Spring branches, and even streams of considerable size, sink sometimes into the loose sands of this region and disappear, to appear at distant points as "boiling" springs, that is, springs bubbling 
up with some force, and throwing out considerable quantities of fine, white sand. The action of these underground streams in removing and transporting these fine sands, accounts for a number of circular depressions not very different in appearance from lime-sinks, found scattered here over the elevated flats and plateaus, and when, by an accumulation of vegetable growth or a caving in of the earth, the chamels of these streams are obstructed, rains sometimes till these depressions, giving rise to clear sheets of water or lakelets. Another phenomenon occurring here, and not well understood, are blowing wells, of which there are several. For example, on a high sand hill in Hammond township, Aiken county, a number of unsuccessful attempts were made during many years to dig a well. At length an auger, eight inch diameter, penetrating the loose, coarse, white sand, and nothing else, to a depth of one hundred and twenty feet, encomtered a bold stream of excellent water. When the well was curbed and completer, it was found that a current of air issued from it all the time, which, in threatening and stormy weather, acquired such force as to make itself heard at some distance, and to blow several feet into the air a hat or cloth laid over the orifice.

\section{GEOLOGICAL FEATURES.}

These hills form a dividing rilge between the more recent formations of the low country and the very ancient formations of the upper country. Their southern aspect overlooks the tertiary plane descending to the sea shore of the Atlantic. On the north they reach the clay slates (dipping north) of Edgefield, Lexington, Richland and Chesterfield counties, and the granite and gneiss rocks of Kershaw county. Outcrops of these most ancient rocks occur among the sand hills themselves, as follows:

In Aiken county, granite occurs on Horse creek, and granite overlaid by gneiss rock and homblende slate on the South Edisto, where the Columbia road erosses in.

In Lexington county, granite is found at Quattlebaum's mill, on Lightwood creek.

In Kershaw county, masses of steatite oceur on Spears, Twenty-five Nile, and Pine Tree creeks, and at Liberty Hill and at other places rounded blocks of coarse granite are scen, "as though they were pushed up through the sand."

Next to the granite is found a stratum of sandstone, consisting of the ruins of the granite consolidated into a pretty hard rock. It occurs on Horse creek, on the ridges at the head of Lightwood creek, on Congaree creek, where Mr. Tuomey observed in it comminuted fossils of the eocene type; at the Rock House, in Lexington county, where it has been quarried for architectural purposes, and on Second creck, in the same neighbor- 
hood, where silicified shells and fragments of lime were found embedded in the stone.

Lying on this sandstone are extensive beds of loose white sand, intermingled with strata of clay of varions colors, the whole having an estimated rertical thickness of one hundred and fifty to two hundred feet. Large beds of kaolin clay, free from grit or other impurity, and of great whiteness, are found intercalated among these sands. Several quarries to the west of Aiken C. I. having been worked with much profit, the material being used as porcelain clay, and also by paper manufacturers. Some of the clays of Lexington county, beautifully mottled with various colors, harden, on exposure, to such a degree that it is thought they might be utilized for ornamental building purposes.

The last member of this series of strata is the "ironstone," already alluded to as covering the summit of Sugar Loaf mountain. Next in order comes the porous, siliceous rock, resembling menilite, and the buhrstone series.

\section{SOILS.}

The characteristic of the soils of this region is the loose rounded sands which form their chief constituent. The organic matter which it contains consists largely of charcoal, resulting from burning off the woods, principally the pine straw (leaves of the pine). Occasionally there are rounded hills of very fine sand of a dazzling whiteness, of such purity that they seem just to have emerged from the waters, or to have been blown together by the winds on the seashore. There are, however, many elevated flats, which, under good culture and manuring, give excellent crops, and in the vales, the soil is often very productive; it is cultivated with care, and continues to produce so long as there is an atom left of anything that can sustain a plant.

The following analyses of the sand hill soils were made by Prof. C. U. Shepard, Sr., in $18+6$ :

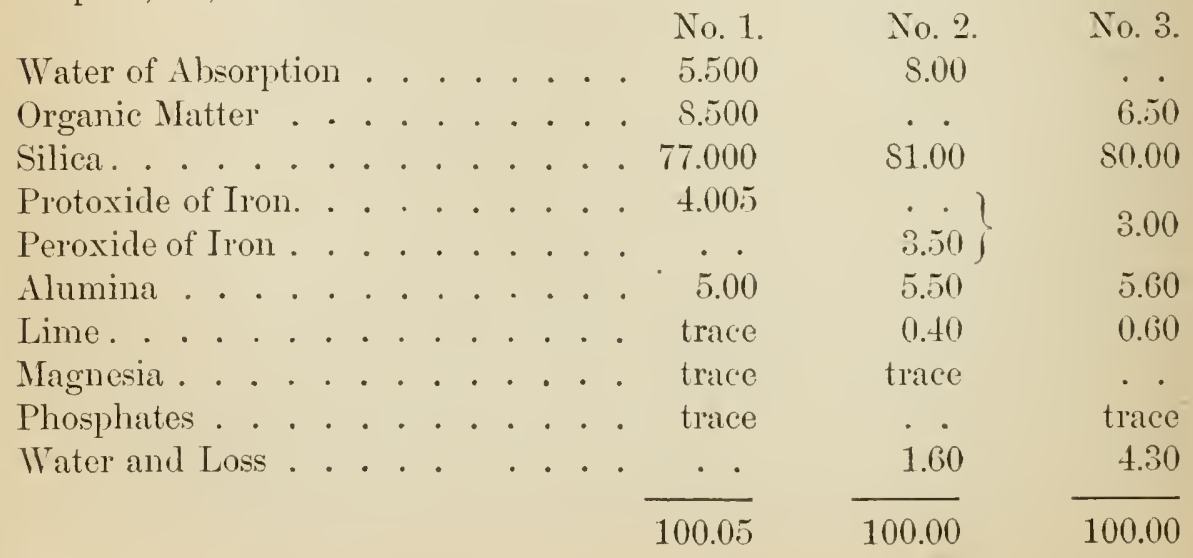


No. 1 is surface soil near Aiken; No. 2 is subsoil of the same; No. 3 is from Platt Springs, Lexington.

In recent years, under high culture, "on a lot in Aiken, adjacent to the one where the above analysis was made, the product was forty bushels of corn, and thirty bushels of wheat per acre." Since the introduction of fertilizers, level lands in the neighborhood of the South Carolina railway, which sold in 1860 for three dollars an acre, have sold for thirty dollars and even as high as forty dollars an acre. Throughout this region thousands of acres, equal and superior to these, though not immediately upon a railroad, are for sale at one dollar to five dollars an acre.

\section{GROWTH AND PRODUCTIONS.}

The growth is almost exclusively long leaf pine, and on the more barren rillges, even this tree becomes stunted, and sometimes, on the higher and finer sand crests, yields its place to the Now Jersey tea plant, which alone covers the dazzling whiteness of the sands. Usually, however, there is a heary growth of long leat pine, and this tree here-almost on its northern limit in the State-attains its highest perfection, not only as regards size, trees of three feet and four feet in cliameter being not uncommon, but also as to the quality of its wood, which has more heart and is more resinous than elsewhere, a fact duly recorded in the names of localities, as Lightwood creek, and Lightwood Knot springs, the inhabitants of even this mild climate being not unmindful of the light and warmth furnished by this excellent fuel. There is often an undergrowth of the forked leaf blackjack, and where there is a suspicion of moisture in the soil, this is replaced by the round leaf blackjack, a sure indication here of better soil. On the hillsides, there are not unfrequently outcroppings of kaolin, and here a growth of kalmia adds a pleasing variety to the monotony of the pine forest.

Besides the staple products of cotton, corn, the small grains, peas and potatocs, common to this latitude, these soils have been thought specially adapted to certain other crops. One locality has been known for more than one hundred years as "Pinder Town," from the number of pea-nuts formerly produced there. Many years ago the lands of Lexington and Kershaw were thought especially adapted to the growth of Palma Christi, and even with the rude appliances for its extraction in those early days, a yicld of one hundred and fifty gallons of excellent oil per acre was obtained. These sandy soils produce sorghum, which, while it is of smaller growth than that on more fertile lands, yields more abundantly a syrup that is much superior in quality. No where are watemelons produced with such ease and certainty, in so great quantities, of so large a size, and 
so fine a flavor as on the poorest of these lands. There was no finer vegetable or flower garden in the State than that of the late William Gregg, situated on a high and sandy hill between Aiken and Graniterille; one scuppernong vine covered the fourth of an acre with its luxuriant and productive growth. On the apparently barren hills of this vicinity there also flourisher formerly a most remunerative culture of the peach. The late James Purvis cultivated, with three hands, sixty acres in this fruit, and in six vears he made five crops, realizing on each from $\$ 5,000$ to $\$ 10,000$. Neighboring orchardists engaged in this culture have more than once made five hundred dollars to the acre. The

\section{CLIMLATE}

of the sand hills is dry, tonic, sumny and stimulating, and entirely free from malarial influences. They have long been a resort during winter for consumptives from northern latitudes, and during the summer months for persons from the lower country of the State. The inhabitants themselves enjoy an unusual degree of health. C'ases of great longerity are common, and the death rate is unusually low. For example, in Platt Springs township, Lexington, in a population of eight hundred and fiftythree by actual count, there were only two deaths in 1579, and only four deaths in 1850. Of the latter three were of persons over eighty years of age; nor can this be considered an exceptional case.

The period without frost has an average duration of two hundred to two hundred and twenty-five days, nor are they of rery frequent occurrence, even during midwinter.

The mean annual temperature is $62^{\circ}, 50^{\prime}$ Fah. The winter mean is $48^{\circ}, 53^{\prime}$ Fah. The spring mean is $55^{\circ} \mathrm{Fah}$. The summer mean is $75^{\circ}$ Fah., and the autumn mean is $71^{\circ}$. Excluding August, the warmest month of the year, the mean for autumn, $i$. e., September and October, would be $65^{\circ}$ Fah. The average diurnal range of temperatures is $12^{\circ}, 65^{\prime}$, a fraction less than at the important health resort of Santa Barbara, California. The elevation and the porous subsoil of said, in which water is found only at a depth of eighty feet to one hundred and twenty-five feet, make this a remarkably dry climate. Steel instruments may be exposed for months without rusting; matches left open never miss fire; moth and mould are rarely seen, and the cryptogameous plants are feebly represented. Obserrations at Aiken show that the relative humidity of the air is 64.04 , being less than at any of the famous health resorts of Europe, except Camnes and Hreres, which are somewhat less, due, perhaps, to the prevalence of the mistral. Heavy dues never occur. Fogs are also rare. The number of rainy days varies from twenty-nine to forty-five, and of the 
remainder, two hundred and sixteen to two hundred and thirty-nine are clear, leaving only eighty-four to one hundred and seven clourly days. During sixteen years the rain fall at Aiken varied from 33.57 inches to 56.49 inches, with an average of 46.70. During five years six falls of snow were recorded, but as a rule there were only a few flakes, which melted as soon as they reached the ground. Sleet is more frequent than snow, but disappears on a few hours exposure to the sun. The prevailing winds are from the south and southwest. The water of wells and springs is of a superior character, being transparently clear, with a temperature varying from $62^{\circ}$ to $64^{\circ}$ Fah. (Climate and topography of Aiken, by E. S. Gaillard, M. D., Richmond, Va.; Aiken as a Health Station, by WV. H. Geddings, M. D.). It must be remembered that this deseription applies to no restricted locality, but refer's to an area of more than 2,000 square miles, where the sanitary conditions above alluded to are present with the terebinthinate and healing odors of a great pine forest.

\section{AGRICULTURAL S'TATISTICS.}

The area of the sand hill region is estimated at 2,441 square miles. The population is 28,612 ; being 11.7 per square mile, nearly one-third less than the average of the State, and less than in any other region. Fifty-nine per cent. of the population is colored.

The area of tilled land is 151,359 acres, which is sixty-two acres to the square mile, or a fraction under one-tenth of the entire surface. This is twelve acres below the average of the State, and less than in any other region except the lower pine belt, where it is thirty-five acres per square mile. It is five and a third acres per capita of the population, the largest proportion in the State, and is due to the few towns and railroads in the region, leaving the rural population more exclusively to agricultural pursuits.

The tilled land is divided among 4,238 farms; giving thirty-five acres of tilled land to the farm; five acres less than the average for the State. The number of farms in proportion to the population is greater than anywhere else, being one farm to every seven of the population. More farms are worked by their owners, and fewer by renters than elsewhere. Thus in Kershaw and Chesterfield counties, sixty per cent, of the farms in the sand hills are worked by the owners, and forty by renters; in the portion of the same districts embraced in the upper pine belt, the Red Hill and the Piedmont regions, fifty-six per cent. of the farms are rented. This independent small proprietary has exereised its influence on the agricultural policy of the State, and the long opposition to a change of the fence law is largely due to them. They have also, in times past, been a 
third party, as it were, stretching across the middle country of the State, between the larger farmers of the upper country on the one hand, and the planters of the lower country on the other. This, together with the sparsely settled country, where heavy sand hills were not favorable to transportation, before the days of railroads, has mate this section in some sort a barrier between these two sections, socially and industrially, as it is geologically.

The crops are: cotton, 35,433 acres, two per cent. of the entire surface; yield, $15,05.5$ bales, 6.1 bales per square mile, or about one hundred and ninety-three pounds of lint cotton per acre, a little above the average of the State, owing doubtless to the large area from which the small number of acres planted is selected. The yield per capita is only two hundred and thirty-nine pounds, less than in any portion of the State north of the lower pine belt and south of the Piedmont country.

Corn and other grain, 93,283 acres, vielding 920,444 bushels, a fraction less than ten bushels per acre, but thirty-two bushels per capita of the population, nearly double the average for the state, and twelve bushels per capita more than the next highest (the Piedmont) region. Another result of an independent small proprietary and of a rural population removed from the thoroughfares of travel and of trade, and forced truly on their own resources for subsistence.

In all other crops and fallow there is 22,643 acres, most of which is in orchards and gardens.

The work stock numbers 8,518 , being 3.8 per square mile, which is less than in any region of the State, except among the extensive unimproved forests of the lower pine belt, where the proportion is only a little more than half the above. The ratio of work stock to population is 29-100 to one, being nearly double the average of the State. This is owing to the larger proportion of rural population, and consequently of farmers employing stock; to the small independent farm-holdings, separated by wide tracts of unimproved land; the small proportion of crops worked by hand, such as cotton and rice and the larger proportion of land in grain, tilled chiefly by horse power; and to the great facility and cheapness of keeping stock on home-raised supplies, in place of doing so with corn and haly brought from the north and west. These same reasons will account for there being only seventeen acres of tilled land to the head of work stock, seven acres less than the average of the State, although the lands are light and of easy culture.

There is 70,901 herd of all kinds, being only twenty-nine to the square mile, which is eight less than the average for the State, and less than any where in the State, except upon the sea coast, and in the lower pine belt. This statement will cloubtless scem very strange to the farmers in these 
regions, affording the widest ranges of forest pasturage for stock, and who consider stock-raising as one of their most important concerns. This opinion among the sand hills arises from the fact, that there is 2.47 head of stock to each one of population, nearly double the average for the State, which confirms the importance of their stock to them, while it fails to show that lands in woods-pasture, with freedom of range for stock, give as much return in stock as lands under cultivation. On the contrary, tables here appended, show that the amount of live stock per square mile increases, with the increase in the number of acres of tilled land per square mile. Whence it follows that stock raising in this State has passed out of that early condition of things, when wild stock roaming at large yielded the largest return. 


\section{CHAPTER VII.}

\section{THE PIEDMONT REGION.}

\section{LOCATION, PHYSICAL FEATURES.}

The Piedmont region of South Carolina coincides very nearly with what is known as the upper country of the State. It includes the whole of eight counties, to wit: Abbeville, Anderson, Newberry, Laurens, Union, Fairfield, Chester and Lancaster. It also embraces the northern portion of Edgefield and Lexington, and the northwestern portions of Richland, Kershaw and Chesterfield. The southern parts of Oconee and Pickens, and the southern and larger portions of Greenville,Spartanburg and York are within its limits. A line drawn from a point on the Savammah river three miles above Hamburg to Columbia, and rumning thence northeast to where the Great Pee Dee river crosses from North into South Carolina, defines, in a general way, its southern border. Its northern boundary follows, in the main, the direction of the Atlanta and Charlotte Air Line railroad, which lies on the edge of the Alpine region, just north of the one under consideration.

\section{PHYSICAL FEATURES.}

The physical features of this portion of the State entitle it to the name of the Piedmont Region. Its rocks are so similar to those of the Blue Ridge mountains that, though they have been broken down, levelled off, and worn away by exposure, during the countless ages, to the vicissitudes of the seasons, they are, and always have been, the foot hills of the Apalachian range, while the broken and mountainous region to the north, usually spoken of as the Piedmont country, might be better called the Alpine or Sub-Alpine region of the State. 
The elevation of thirty-one points in the Piedmont region, varying from a minimum of 179.5 feet on the granite rocks at the Congaree bridge, below Columbia, to a maximum of SSO feet at Belton, on the Greenville railroad, give a mean elevation above the sea of 590 feet. The mean elevation of the Columbia and Augusta railroad, where it passes along the southern border of the region, is 575 feet. That of the Air Line railroad in South Carolina, lying to the north of it and almost wholly within the Alpine region, is 910 feet. Between these two lines, therefore, a distance of some ninety miles, there is a general rise of the surface of three hundred and thirty-five feet, or less than four feet to the mile. This is a gentler slope than that of the tertiary plain or low comntry. The distance from the sea to its northern border being about one hundred miles, and the difference in elevation something more than five hundred feet, or orer five feet to the mile.

The face of the country presents a gently undulating plain, which becomes more rolling as it approaches the rivers and larger streams, and is finally hilly and broken above the bottoms and narrow, low grounds, through which the numerous water courses find their passage.

While the general rise in the surface is less than that in the low country, the rise in the beds of the streams, owing to the resistance of the underlying rocks, which prevent the water from deepening their channels, is much greater. Thus, the elevation above the sea of the lower falls of these rivers is, for the Sarannah, 133 feet; for the Congaree, 135.3 feet; for the Wateree, 133 feet; but where they enter this region from the north, the surface of the water has an elevation above the sea level of 403 feet for the Saramnah, of 552 feet for the Broad river, and of $5+4$ feet for the Catawba. This gives an average difference of 360 feet in about S3 miles, or a fall per mile in the Piedmont region of $4 \frac{1}{2}$ feet, against an average fall in the lower course of these rivers of about 1.2 feet per mile. While this renders the navigation of the upper portions of these rivers difficult, it adds largely to their availability as water powers for moving stationary machinery.

The Savannah river, on the western boundary of the State, passes through the metamorphic rocks for more than one hundred miles, and although it receives many affluents, and some of them quite large, on its eastern bank, they join at such an acute angle as to make its eastern water shed very narrow - scarcely anywhere exceeding twenty miles in width. To the east, Lyneh's river passes through this region for about twelve miles, its western water shed not exceeding five miles. Between these two narrow water sheds in the east and west there is an interval of about one hundred miles. The numerous streams traversing this interval belong to one river system, and unite shortly after fntering the ter- 
tiary plain to form the Santee river, which has been called the river of South Carolina. The swift Catawba, with a fall of nearly six feet to the mile, merges into the Wateree and forms the eastern and main channel of this river system. Its larger afluents all reach it from the west, those from the east being, in comparison, small. The Salucla, on the other hand, the most westerly river of the group, receives all its larger aflluents from the east; a high ridge on its western water shed, for the most part barely five miles wide, separates its waters from those flowing into the Savannah. The triangular space enclosed between these two streams and washed by their numerous tributaries, viz: Reedy, Little, Bush, Broad, Ennoree, Tyger, Pacolet and Fair Forest rivers, besides many large creeks and branches, bears ample evidence to the erosion it has suffered. The softer rocks, such as talc and mica slates, found beyond these streams on the eastern and western ridges of the triangle, are wanting within, it having been washed away, leaving behind them only the hard gneiss or the still harder granite to dispute the passage of the waters.

\section{RIVERS.}

The following gives the leading characteristies of some of these streams so far as they have been ascertained, numerically : 
TABLE.

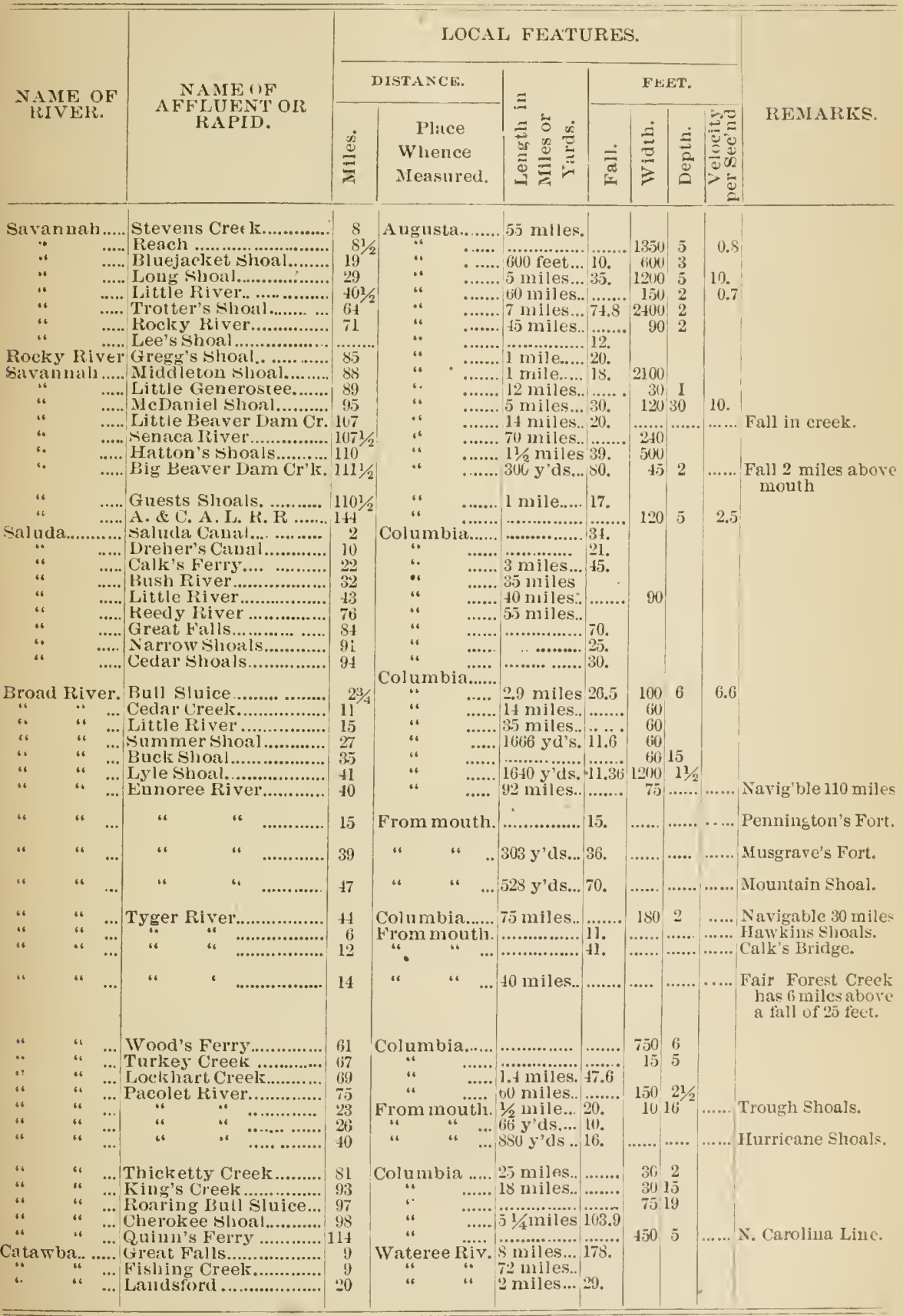


The Savannah river is now navigable for pole boats carrying fifty bales of cotton for one hundred and and fifty-four miles above Augusta. The report of the Chief Engineer U. S. A., 1879, states that, for an outlay of $\$ 1 S 8,000$, a permanent channel, three feet deep and sixty feet wide, of safe and easy navigation for such boats, could be made. For $\$ 97,000$, in addition to the above, one hundred and fourteen miles could be made into a steamboat channel, ninety feet wide and three feet deep.

The Saluda river is navigable for eighty-four miles above Columbia, where it unites with the Broad to form the Congaree river, for the same kind of boat.

The Broad river is navigable for one humdred and thirteen miles in South Carolina, above Columbia, and for twenty-eight miles more in North Carolina, for this class of boats. It has a total length of one hundred and seventy-five miles.

The Catawba river has a fall of three hundred and twenty-five feet in the fifty-five miles of its course in South Carolina. Its banks are three hundred to three thousand feet apart, and from ten to one hundred feet high. Above Rocky Mount, in Chester, there is a fall at one point of fifty feet in four hundred yards. It has a total length of two hundred and seventytwo miles, and its source is two thousand five hundred feet above the level of the sea.

The data above given were obtained by surveys made in the dryest season of a very dry year, and, therefore, represents these streams at extreme low water. This low stage of the water prevails during October and November. At other seasons, the volume of water would be, on the average, two or three times as great. The rivers are subject to freshets, rising twenty to thirty feet above low water mark, this rise being greatest where they issue from the Piedmont region. No local falls under ten feet have been entered in the table, although such falls not unfrequently afford the most available powers. Together, these.streams furnish a navigable highway of four hundred and five miles, which might be greatly and permanently improved and much increased for a moiety of what the same length of railroad would cost.

\section{GEOLOGICAL FEATURES.}

The rocks of the upper country of South Carolina are a continuation of and similar to the rocks of middle North Carolina, identified by the Geologist of that State, Prof. W. C. Kerr, as belonging to the Laurentian and Huronian formations. They are held to be the most ancient of rocks, and antedate the unnumbered ages during which the varied forms of plant and animall life have succeeded each other on this planct. Disclos- 
ing themselves no evidence free from question that any living things existed at the period when they were formed, it is upon their flanks, and largely from material furnished by their disintegration, that the whole series of formations composing the surface of the earth and marking the different geological eras of its history has been built up. In South Carolina these oldest rocks appear among the sands of the tertiary-the most recent geological age. The records of the intervening ages have disappeared, and the stone pages upon which the introductory and concluding chapters of the earth's history are written, here lie side by side. Among the oldest of these rocks are the

\section{GRANITES,}

which have their outcrops in Carolina along three nearly parallel lines, as follows:

1st. On the most southern of these lines the granite shows itself among the sand hills at Graniteville, on Horse creek, Aiken county, and thence at various points in a iorortheasterly direction to Columbia. Notable quarries for building materials are worked at Graniteville and at Granby, below Columbia.

2l. The second line of outerop extends from the neighborhood of Horn's creek, Edgefield county, across Newberry, Fairfield and Kershaw counties, to the northwestern corner of Chesterfield. In Edgefield, Newberry and Fairfield, the granite is associated with beds of hornblende rock and forms the substratum of a heavy, dark, red clay loam, which is one of the best and strongest soils in the State. Here, also, quarries of excellent granite, fine-grained and easily splitting, have been found, especially in Newberry and Fairfield counties, where inexhaustible quantities of the best building granite are found. There is a beautiful flesh-colored porphyritic granite found in Kershaw. In Edgefield and Lancaster it becomes coarser and syenitic in character.

3d. The third line of outerop stretches through Laurens, Union and York counties. In the vicinity of Union C. H., the granite is of exceedingly fine grain, and well adapted for architectural purposes, but the most of it on this line is characterized by a coarse porphyried structure, and it shows itself in an undecomposed state at only a few points.

\section{GNEISS,}

or laminated granite, forms by far the larger portion of the rock underlying this region. No strict line of demareation between it and the granite has been established. In mineral constituents, color and grain, they 
are alike and seem to shade off insensibly into each other. This explains why, in nearly every township, the occurrence of rock, well adapted for building, and called granite, is reported in greater or less quantitics. The most marked difference is, that where the stratiform character of the gneiss is most marked the hornblende beds, associated with the granite, and of such high value as a soil yielder, disappear. Although traversed by numerous veins, this rock has so far furnished nothing of importance to the miner in this State. Its general dip is slight and to the southeast. On its southern border, however, the gneiss rock is found with a rertical dip, as at Edgefield C. H. South of the Saluda river, in Lexington, it is found between the granite and the clay siates, dipping N. E. $80^{\circ}$. In Nerrberry, near the thirty mile post on the Columbia road, a coarse feldspathic gneiss, alternating with hornblende slate, forms an anticlinal ridge, dipping southeast on its southern, and northwest on its northern slope.

Immediately overlying the gneiss, belts of hornblende slate, of no great breadth, and having nowhere an ascertained thickness exceeding twentyfive feet, are exposed.

\section{MICA SLA'TE.}

These belts of homblende generally surround isolated areas of mica slate, which overlie them. They are found chiefly towards the north, along the base of the triangle formed by the aftuents of the Santee, or to the west of this river system in Abbeville, Ander'son, Greenville and Pickens. They occupy the summit of ridges, as of King 's Mountain, in York. On the water courses they give place, first to the hornblende slate, and then to the gneiss, which forms almost everywhere the beds of the streams. They have an ascertained thickness, exceeding in no single locality one hundred feet. Mines sunk in them hare, in sereral instances penetrated to the underlying gneiss. Mica slate thus occurs as large islands, the remnants, perhaps, of what may once have been a succession of ware-like parallel folds, dipping gently with the Atlantic slope to the sontheast and covering the entire surface, but disappearing long ago under the crosire action of the present river system of the State. Numerous gold mines and reins bearing copper, lead and silver, have been found in these rocks, and, to a limited extent, worked. The iron furnaces of Cowpens and Hurricane Shoals are also located in this formation. Mica of excellent quality has been mined in Dark Corner township, Anderson, and in Abberille. In the former locality beryl and copper are also found; corundum and zireons are found in Hall township, Abberille, and in other localities. Asbestos occur's near Glenn Springs, Spartanburg, a noted health resort, the curative virtues of whose waters, with those of many 
other similar springs in this region, is due to the minerals dissolved from these miea slates during their passage through them.

\section{TALC SLATES.}

Next in the order of superposition above the miea slates oceur extensive areas of tale slate. These rocks seem to have yielded more completely to the erosive action of the rirers even than the mica slates. They scarcely appear at all in the angle enclosed between the Catawba and the Saluda. Their largest outcrops are east of the Catawba, in Lancaster and Chesterfield, and separated from these by the whole wilth of the rirer system of the State, eighty miles, to the sonthwest they occur on the further side of the Saluda, in Edgefield and Abbeville. These two localities are the great gold-bearing regions of the State.

\section{ITACOLUMITE.}

On Broad river, near the northern boundary of the State, where Union, York and Spartanburg corner, an interesting series of rocks occur, the most peculiar of which is a flexible sandstone, the itacolumite or diamond bearing rock, which gives its name to the group under the designation of the itacolumitic series. Thus far only one diamond has been found in South Carolina, though several have been obtained from the continuation of these rocks, both in Georgia and in North Carolina.

\section{CLAY SLATE.}

South of the rocks abore mentioned, and extending along the edge of the tertiary from Ergefield to Chesterfild, a broad belt of clay slates occur. On their southern border, among the sands of Lexington and Chesterfield, or just north of the granite in Kershaw, Richland and Edgefield, these clay slates dip north west $14^{\circ}$ to $18^{\circ}$. This angle increases further north, until the slates stand vertically; still further on the dip is reversed to the southeast. In Erlgefield and Lexington, where they occupy the widest areas, these rocks seem to have had their positions much disturbed, and while the elges of the strata preserve their northeasterly strike, their faces are turned alternately northwest and southeast-now towards the mountains, and again towards the sea. These elay slates are contiguous to the jurassic strata of North Carolina. Mr. Tuomey found in Chesterfield fossils which he credited to the new red sandstone, and intimated that these slates themselves might possibly be identified with the paleozoie series. It scems at least certain that they orerlic, and are, there- 
fore, younger than the other rocks of this region, excepting, possibly, the itacolumitic series alone.

TRAP.

The Trappean rocks remain to be mentioned. They are found chiefly on two lines. The principal one is the most southerly and extends from Edgefield across to where the Catawba enters the State. Their trend is a little more to the nortl of east than that of the other strata, which they therefore cross at an angle. Their greatest development is in Chester and York, where they form the substratum of a large body of very peculiar lands, known as the blackjack lands. These Trappean rocks show themselves along another line parallel with this one and to the north of it, stretching from Calhoun's Mills, in Abbeville, to the Lockhart shoals on Broad river, in Union. Here they also give rise to a peculiar and interesting body of lands known as the "flat woods" of Abbeville, and the "meadow lands" of Union. In Chester and York the prevailing dykes are of melaphyre and of aphanitic and dioritic porphyry; in Abbeville of felsitic and dioritic porphyries.

This brief sketch of the geological features of the region requires a reference to the ores and minerals found there:

\section{GOLD.}

"Gold," writes Gorernor Drayton, in 1802, "is said to have been found in suffieient quantity to be made into a ring, but this is only a report of what is said to have taken place many years ago." In 18:26, the oceurrence of gold in Abbeville and Spartanburg is merely mentioned by Mills in his "Statisties of South Carolina." The United States Census of 1840 states, that "fifty-one hands were engaged (chiefly in iron mines) in mining in South Carolina." In 1848, Mr. Thomey found over two hundred hands at work in the Brewer gold mine in Chesterfield, from which more than $\$ 1,000,000$ in gold has since been taken. In 1859, Lieber writes on a line on the map of the State crossing it at the lower border of the metamorphic rocks: "Above this line most streams contain some gold in their sands." At that date twenty-one gold mines had been opened in the talc slates of Chesterfield and Lancaster, and ten in the same slates in Abbeville and Edgefield; among the latter, the Dom mine, that has yielded $\$ 1,100,000$ and upwards in gold. In Spartanburg, in Union and York there were nineteen gold mines, mostly in the mica slates, and in Greenville and Pickens, eight others, chiefly gravel deposits-in all fiftyseven. Work has been abandoned since the war in all or in nearly 
all of these mines. With rare exceptions, if any, it was never systematically conducted, as may be inferred from Mr. Tuomey's description of the Brewer mine, which was leased to twenty or thirty independent companies, numbering three to six persons each, and having each a portion equal to about twelve feet square of the surface.

From the returns of the 10 th U. S. Census it appears that besides minor minerals, to the value of $\$ 27,709$, South Carolina produced in 1879 of gold $\$ 13,040$; ranking in the order of production of this metal fifteenth among all the States, and third among the States east of Dakota

Gold occurs in Sonth Carolina:

I. In numerous gravel deposits. Of these, one class occur in beds of rounded and water-worn pebbles and gravel, showing that the material has been transported from a distance. Other deposits are found among angular fragments of rocks, and these, in some instances, liave been traced back to the neighboring rocks, from which they were derived.

II. In silicious veins of three leading types, viz. :

1st. The "Carolina group" of crystaline quartz veins. The upper part of the vein abounds with iron pyrites. The gold is in coarser grains and more abundant above. In descending, the vein contracts and the gold lessens in quantity. At the same time copper makes its appearance and increases steadily in quantity so far as followed, and with the copper is frequently associated ores of manganese, lead and silver. These reins extend from the itacolumite above, down through the clay, talc and mica slates into the underlying gneiss. They are most productive of gold in traversing the talc slates. Of this type was the neighboring Reid mine, of North Carolina, famous for having yielded a nugget of twenty-eight pounds, and another of eighty pounds, and of which Lieber writes; "I question if any one spot in California or Australia ever produced as much gold."

2 d. The saccharoid veins of a fine granular quartz, resembling powdered sugar. Only traces of these veins are found in the itacolumitic rocks, and none in the clay slate. They have their greatest productiveness in the talc slates, becoming less so as they descend through the mica slates to the underlying gneiss.

3d. The hornstene lenticular veins, irregular, wedge-shaped, detached quartz veins, having sometimes very rich pockets. They are found only in the talc slates.

III. In gold-bearing beds of the slate rock itself. These auriferous beds are found only in the talc slate, save in one instance in the overlying clay slate. The following diagram, after Lieber, showing the relative 
position of the different rocks and the degree of development of the gold veins of the various types in each by the size of the dark blocks opposite its name, may make this clearer:

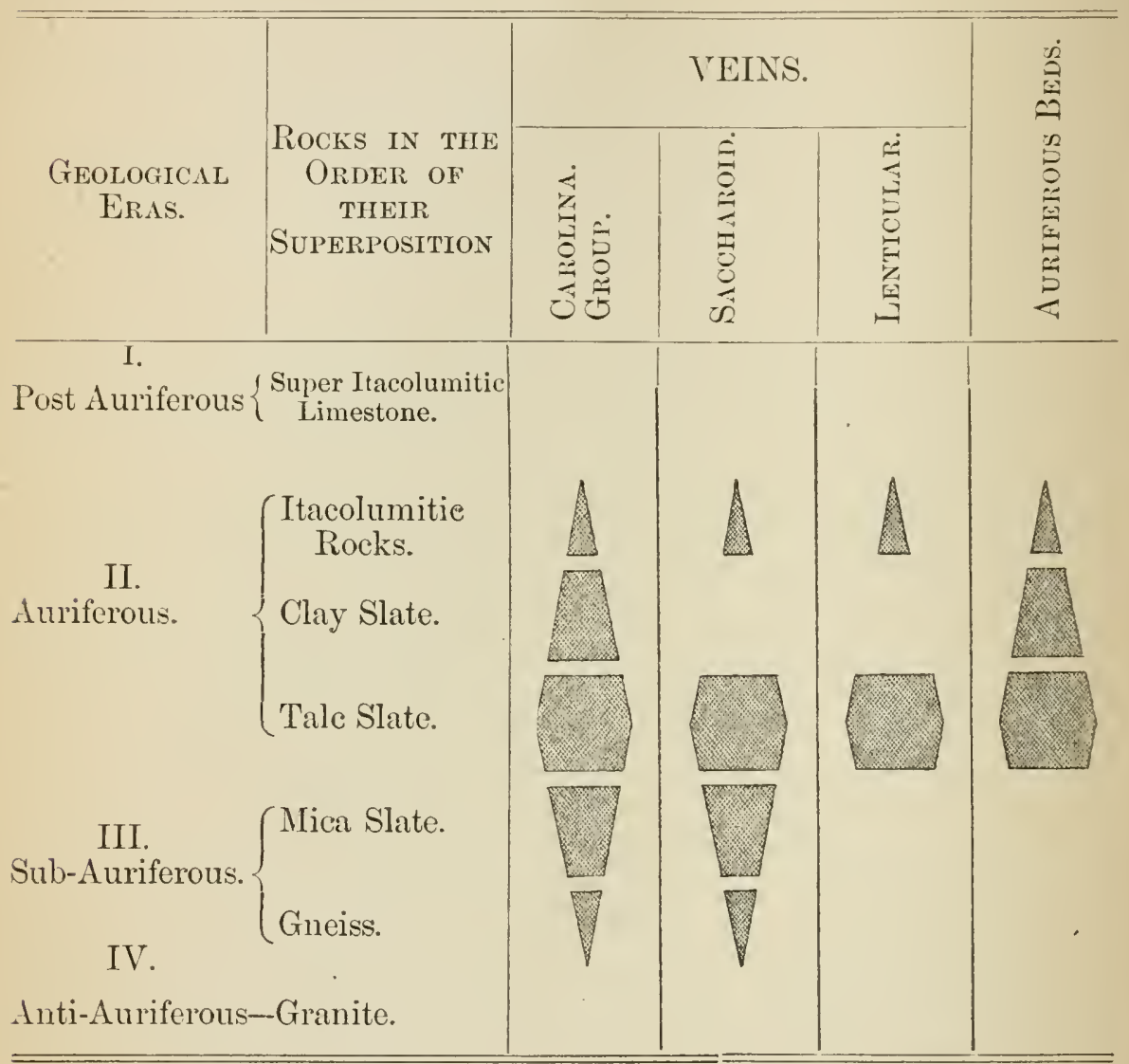

These facts support the views of Sir Roderick Murchison and Lieber, that there has been a golden age among the geological periods. Here it seems clearly marked as the period when the talc slates were forming. As to whether the gold came up from the bowels of the earth, through the agency of eruptive forces peculiar to that or a subsequent period, or had a meteoric origin, falling upon what was then the surface, from the interplanetary spaces, just as iron dust is now falling on the perpetual snows of the east coast of Greenland, may be matter for discussion. Gold certainly gives out at certain depths; whether it exists at all at still lower depths is unknown. That it exists outside of the earth the metalic vapors of the sun and stars revealed by the spectroseope renders probable. 


\section{ORES AND MINERALS.}

Silver in argentiferous galena is found in Spartanburg and Laurens, and more recently in Edgefield and Abbeville. Across the Savamah river, from the last named localities, the mining of this ore for silver, as well as for lead and the zine blende associated with it, is attracting much attention at this time.

Copper is found everywhere in the gold yeins of the "Carolina group." As it increases regularly with the depth to which the reins have been worked, experts have been satisfied that it will be found in remunerative quantities. With this view, work was being rigorously pushed in the Mary and in the Wilson mines, in York, just previous to the war. Since then attention has not been directed to the matter.

Bismuth, in quantity, was found by Mr. Tuomey at the Brewer gold mine in Chesterfield.

Iron in magnetic and specular ores is found in inexhaustible quantities on the western slope of King's mountain, in York, Spartanburg and Union, one also in Chester and Abbeville. Brown hematite occurs in the miea slates of Pickens and Spartanburg, and has been used at the Pacolet and Cowpens Iron Works. Bog iron ore occurs in nearly every county of the State.

Limestone appears in York, Spartanburg, Laurens and Pickens.

Barytes, in great quantities, occurs near the Air-Line railroad in York.

Manganese, in great purity and abundance, is found at the Dorn mine in Edgefield, and also in Abbeville, York, Laurens and Anderson.

Graphite, in considerable quantities, is found in Williamston township, and elsewhere in Anderson, also in Spartanburg, Greenville and Laurens.

Feldspar; of excellent quality, in extensive veins, occurs in Easley township, Piekens; in Lowndesville, Abbeville, and also in Anderson and Laurens.

Asbestos oceurs in Spartanburg, Laurens, York, Anderson and Pickens.

Steatite or soapstone is found in Chester, Spartanburg, Union, Pickens, Oconee, Anderson, Abbeville, Kershaw, Fairfield and Richland; whetstones and flagging stones are found in Edgefield, Abbeville, Chester, Lexington, Fairfield, and the Pee Dee country.

Spinel rubies, in Pickens; tourmaline, in York, Edgefield, Lanrens, Anderson and Oconee; beryl, in Edgefield and Laurens; corundum, in Laurens, Anderson and Oconee; zircons, in Abbeville and Anderson.

\section{SOILS.}

The area of land in the Piedmont region whose eulture is impeded by the rocks prevalent there, is comparatively insignificant. This is due to 
the rather remarkable extent and depth of the disintegration of these rocks. It is not an uncommon occurrence that wells sunk through granite to a depth of thirty or forty feet, require for their excavation no other implement than a spade. Frequently so thorough is the decomposition, that the sides of railroad cuts and of mines might be mistaken for a heap of transplanted materials, did not the existence of seams and quartz veins, which may be always traced on the fresh surfaces, make it certain that the rock had rotted where it stood. The chief impediments to culture are the masses of quartz rock, once forming these reins, but now scattered broadcast over the surface, in consequence of the rotting and denudation of the strata that contained them. 'This is especially the case among the clay slates, and often the first indication which a traveller has that he has entered the Piedmont region is the sight of fields and woods covered with angular fragments of these white quartz rock. The inclination of the rocks of this region allows drainage along their edges, and even where the rock is near the surface, water seldom collects above them to an injurious extent.

Owing to the transportation and intermixture (often by the wind) of the debris from the different rocks, the areas of the soils derived from each can be characterized with much less distinctness than the areas occupied by the underlying rocks themselves. Nevertheless three leading varieties of soil may be traced, with much clearness, viz.: the granitic, the clay slate and the Trappean soils.

I. The granitic soils occupy by far the largest area, as under this head is comprised the soils whose substratum is granite and gneiss, and also those resting on the hornblende, tale and mica slates. These soils are characterized by two distinct names: 1 st. the gray sandy soils; $2 d$. the red clay soils.

1st. The gray sandy soils occupy the ridges and levels, and have been formed by the gradual separation of the silicious and argillaceous materials found in the debris of the decomposing rocks that underlie them. This has been efiected by a process of lixiviation, during which the rain water not rumning off, owing to the level nature of the land, sank directly into the earth, carrying down with it the heavier and finer particles of the clay through the interstices of the lighter and larger particles of sand. This gives a light, loose, warm sandy loam, varying in depth from three to eighteen inches, and fine or coarse, according to the grain of the rock, from which they are derived. The subsoil is red or yellow clay. Such soils are of easy culture, respond readily to the use of commercial fertilizers, and are well adapted for cotton. For these reasons they are much more highly esteemed now than formerly. The following analsses of them are taken from Tuomey's report: 
THE PIEDMONT REGION.

(1)

Organic matter . . . . 3.62

Silica . . . . . $\$ 4.30$

Alumina . . . . . 5.80

Iron oxide . . . . . 2.00

Lime . . . . . . 0.50

Magnesia. . . . . . 0.40

Potash and soda. . . 0.50

Water and loss .... . 2.Ss
(2)

2.60

90.00

7.40

3.00

0.00

1.00

0.60

5.40
(3)

1.20

S3.00

5.40

2.00

(4)

3.00

0.00

80.00

S0.00

7.00

9.80

2.00

0.30

0.60

4.00

0.40

0.75

0.02

0.00

0.50

0.70

6.80

7.05

5.48

\subsection{0}

$\overline{100.00}$

100.00

100.00

100.00

No. 1 is from Pinckney township, Union; No. 2 is from Waterloo township, Laurens; No. 3 is from Donaldsville township, Abbeville; No. 4 is from Sullivan township, Laurens; No. 5 is from Central township, Pickens.

2 d. The red clay loams are the prevailing soils of the hilly and broken country. Occupying slopes of greater or less declivity, the loose sand has been washed away as fast as it has been released from the tenacious clay, by the process of lixiviation, or settling, above alluded to. The washing of these hills is not so destruetive of their fertility as it would have been if the soil were not formed from rocks rotting in situ, and thus including at every depth, all the numerous and varied elements of the parent rocks. Thus it happens here that the earth from the bottom of deep wells, usually barren elsewhere, has been found, when spread over the surface, to increase notably the fertility of fields. Galled spots, deprived of all humus and every trace of organic matter, are, of course, barren for a time, but even their nakedness is soon covered by the oldfield pine, and their thriftiness restored. As might be expected, with the clearing of the lands, and the washing down of the ridges, the amount of gray lands is diminishing, and the amount of red lands is increasing.

Mr. Tuomey gives the following analyses of these soils:

Organic matter . . . . . . . . 2.18

Silica ............ . . 74.00 
The following analyses of soil of the same character, from near Spartanburg, collected by Prof. W. C. Kerr, of North Carolina, was made by Dr. Eugene A. Smith, of Tuscaloosa, Alabama, for the 10th Uniterl States Census. No. 9 is a yellowish red soil, taken to the depth of three inches; No. 10 is its red subsoil, taken to the depth of twenty inches:

Insoluble matter. . . . . . . . 77.860

Soluble Silica. . . . . . . . 1.790 43.740

Potash . . . . . . . . . . . . 0.092

Sola. . . . . . . . . . 0.011

Lime . . . . . . . . . . . 0.036

Magnesia . . . . . . . . . . . 0.070

Br. Oxide of Manganese . . . . . . . . 0.056 0.003 0.212

Peroxide of Iron . . . . . . . . 5.646

Alumina . . . . . . . . 7.557

Phosphoric acid . . . . . . . . . . 0.063

Sulphuric acid. . . . . . . . . . 0.0.5s

Water and organie matter . . . . . . 6.167 11.660

Total

$\overline{99.436}$

Hydroscopic moisture . . . . . . . 4.685

99.675

11.210

Absorbed at ......... . $23^{\circ} \mathrm{C}$.

$22^{\circ} \mathrm{C}$.

The hornblendic soils are a variety of these red clay soils, derived from granite and gneiss rock, traversed by seams of homblende. They are dark in color, and of a more brilliant red. They occur in Edgefield, about Horn's creek, and most extensively in Newberry, especially between the Court House and Asheford's ferry, extending thence into Fairfield. They form excellent cotton lands, and are well suited to the culture of all the grains. The following analyses of them are from Tuomey :

Organic matter . . . . . . . . . 6.20

Silica . . . . . . . . . 7930

Alumina . . . . . . . . . . . 5.20

Oxide of iron . . . . . . . . . . 1.75

6.30

Lime . . . . . . . . . . . . . 0.04

Magnesia . . . . . . . . . . . 0.00

Soda and potash . . . . . . . . . . 0.00

Phosphoric acid . . . . . . . . 0.00

0.30

Water and loss......... . . 7.40 trace

2.70

100.00

100.00

No. 11 is from Newberry; and No. 12 is from Monticello, Fairfield. 
Where the mica slates are underlaid by or alternate with gneiss, as in Abbeville, they give rise to good soils. In most places, however, the slate contains lenticuler quartz grains, coated with mica, which, being indestructible, occupy the surface as the rock disintegrates and gives rise to poor soils. The sand of the talcose slate is exceedingly fine, and pack very closely. Says Leiber, in speaking of clearing out a spring: "At a depth of six inches below the bed of the stream, the sand was as dry as ashes, showing that the water had never penetrated to that depth." This affords an explanation of the serious effects produced by droughts on such soils.

II. The clay slates underlie a soil that is characterized as a cold gray soil. In color they vary from gray to yellow and brown. The subsoil is for the most part, of yellow clay; but, sometimes it is reddish. These soils are better adapted for small grain, and especially for oats, than for cotton. They cover an extensive area in Edgefield, and reach along the northem border of the tertiary, thence to Chesterfield. The clay slate soils in the last named county contain less silica than those of Edgefield. Instead of being gray, they are reddish, and are altogether better soils.

The following analyses are given by Tuomey:

\section{(13)}

Organic matter . . . . . 2.40

Silical . . . . . . S S0.72

Alumina. . . . . . . 12.00

Oxirle of iron . . . . . . 1.60

Lime . . . . . . . . trace.

Magnesia . . . . . . 0.50

Potash and soda . . . . . trace.

Irater and loss . . . . . 3.33

100.00
76.30

10.40

2.00

1.00

0.50

0.40

2.70 trace.

100.00

No. 13 is from Stevens creek, Elgefield; No. 14 from Richland; No. 15 from Lexington.

III. The Trappean soils overlie the extensive dykes of melaphyre and aphanitic porphyry, traversing York and Chester counties in a northcasterly direction, coinciding very nearly with that of the Charlotte and Columbia railroad. They give rise to a distinetly marked body of lands, known as the "rolling blackjack lands" and as "blackjack flats." The latter are the most extensive, and better defined in their characters. The lands are level, the streams slow and tortuous, with low banks, notwithstanding that the general eleration is little less than that of the surround- 
ing country. The soil is of a rich, dark brown chocolate color. Sometimes jet black. The subsoil is a yellow, waxy clay, execedingly tenacious, and, where the rocks are not thoroughly decomposed, it assumes an olive green color. Beneath it the decomposed, and lower down the undecomposed, rock is found, called here "iron rock" or "negro head." The level configuration of the surface, and the impervious nature of the subsoil, interfere naturally with drainage; an interference, however, not at all beyond the remedy of art, as the fall for properly conducted drains and outlets is ample. But because they require drainage, these lands, which, from their general appearance, and from their chemical analysis, should be ranked as among the very best in the State, have received little attention. Corn and cotton planted on them turns yellow, "frenches," as it is termed. When, however, thorough drainage has been effected, and stable manure used, they have proved very productive and enduring. Such treatment is exceedingly circumscribed, the demand of the present system of agriculture being for light lands of easy tillage, whose defects of constitution may be at once supplied by the purchase of chemical fertilizers for the exigencies of the growing crop, and with no view to permanent improvement. The "rolling blackjack lands," as might be inferred from their name, have a better natural drainage, and have long been highly prized for their productiveness, The following analyses of these soils were made by Dr. Eugene A. Smith, of Tuscaloosa, Alabama, for the 10th United States Census:

Insoluble matter . . . . . . . . . 80.340

Soluble Silica . . . . . . . . . 9.114

Potash ....... . . . . . . 0.135

83.145

3.585

Soda . . . . . . . . . . . 0.070

0.126

Lime . . . . . . . . . . . . . . 0.329

0.060

Magnesia . . . . . . . . . . . 0.329

0.389

Peroxide Manganese . . . . . . . . . . . 0.210

0.251

Peroxide of Iron . . . . . . . . . 1.895

0.155

Alumina . . . . . . . . 4.701

Phosphoric acid . . . . . . . . . 0.060

4.051

Sulphuric acid . . . . . . . . . 0.150

Carbonic acid ............. . .

Water and organic matter . . . . . 2.06s

$\frac{2008}{99.401}$

Hydroscopic moisture . . . . . . . . 3.967

100.021

Absorbed at .......... . $S 2^{\circ} \mathrm{F}$. 
No. 16 is from an uncleared blackjack flat, a slort distance east of Chester Court House, considered worthless. No. 17 is from a field of J. B. Stokes, southeast of Chester Court House; the land roHing blackjack, having on it a crop of about 1,200 pounds of seed cotton to the acre. The soil and subsoil taken uniformly to the depth of twelve inches in both instances. The dioritic and felsitic porphyries of Abberille, produce a soil known there as the "flat woods." They are found in Calhoun's Mills, Magnolia, Abbeville, Smithville, and Ninety-Six townships, of Abbeville county. Formerly, when more capital and skill was employed in agriculture, these lands were very highly esteemed. Since a cheap and easy, not to say thriftless, culture has superseded other husbandry, they are neglected. (For more particular description see Calhoun's Mills township, Abstract of Correspondents.) Mr. Tuomey gives the following analyses of these soils.

Organic matter ...... 9.20

Silica . . . . . . . . 52.00

Alumina . . . . . . . 22.10

Oxide of Iron . . . . . . 9.00

Lime . . . . . . . . 2.50

Magnesia . . . . . . . . trace.

Potash and soda . . . . . . . 0.40

Phosphate of lime . . . . . 0.00

Water and loss....... 4.80
10.05

48.30

19.36

S.40

4.00

0.00

0.90

0.10

S.S9
0.50

trace.

0.00

7.90

\subsection{0}

$\overline{100.00}$

100.00

No. 18 is from a well cultivated place north of Calhoun's Mills; No. 19, ditto, near Ninety-Six; No. 20 is from abandoned lands in the meadow woods of Union.

These analyses are indicative of the chemical changes that affect the productiveness of these soils. The abandoned field in Lnion showing a great falling off in organic matter, lime and potash, due to insufficient drainage and a thriftless culture, at the same time there is a large increase of iron, arising doubtless from the absence of those acids resulting from the decomposition of organic matter, whose office it is to dissolve and carry off the injurious excess of the salts of this metal. The large amount of lime in all these Trappean soils will be noted, it has induced some writers to classify them as calcareous soils, and adapts them peculiarly for the growth of pea-rines and clover, which thrive almost spontaneously upon them. 
In addition to the soils above mentioned, there is a large amount of bottom lands seattered along the numerous rivers, creeks and branches that everywhere traverse this well-watered region. Though rarely of any great width, they are for the most part of great fertility, and are highly valued. In some sections these lands have brought as high as one hundred dollars an acre; the adjacent ridge lands being thrown in at a nominal price, just as the pine barrens are, in the sales of the low country rice lands.

\section{CLIMATE.}

The shorter seasons and lower temperatures of the Piedmont region, as compared with those lying immediately south of it, are but slightly attributable to differences of elevation or of latitude, these differences being themselves slight. In so far as it obtains, it results, perhaps, from greater nearness to the mountains, and, as affecting agriculture, still more to the heavier clay soils and subsoils, more retentive of moisture, and, therefore, colder and later in spring than the lighter sandy loams of the lower country. Cotton planting is about ten days later than in the upper pine belt. Cotton blooms are also later, but by a lesser period, and the same is true of the opening and picking season of the plant; showing that, with a later start, it grows faster, passing more rapidly through its various stages to maturity. This region, howerer, does not seem to be much affected by that variableness of temperature common to localities in proximity to mountain ridges. This is shown by the singular exemption of certain localities here from the injurious effects of late spring frosts. Thus, on Rich Hill, in Pacolet township, Spartanburg, a ridge six miles broad, between the Pacolet and Fair Forest rivers, fruit has been injured by late frosts but once in forty years. Localities in Lnion also enjoy this immunity in nearly the same degree. In the absence of other records, some idea of the temperature may be formed by observations on the temperatures of springs, assuming that this temperature approximates the annual mean. Lieber states, as the result of a number of obserrations, that the springs of the Alpine region have a temperature of $55^{\circ}$ to $55^{\circ}$ Fahrenheit; those on a line passing through the centre of the Piedmont region, one of $55^{\circ}$ to $61.5^{\circ}$ Fahr., and below this line, one of $61.5^{\circ}$ to $66^{\circ}$ Fahr. The only accessible records of rainfall are those published by the Smithsonian Institution, May, $18 S 1$. They give an average annual rainfall in this region of 52.34 inches, varying from 44.05 inches to 60.12 inches. This gives a greater annual rainfall for this region than for those south of it, and places it, in this regard, next to the areas of greatest annual precipitation in the United States. The spring rains vary from 
twelve inches to fifteen inches, and in this regard it holds the same relations as in the former to the regions south of it and to the United States. The summer rains are ten inches to fourteen inches less than in the regions sonth of it, and third or midway between the areas of greatest and of least summer precipitation in the United States. The autumn rains are eight inches to ten inches, and in the counties east of Broar river, they are ten inches to twelve inches, being about the same as in the region to the south, and midway between the areas of greatest and least autumn precipitation in the United States. The winter rains are ten inches to fourteen inches, something more than in the lower country, and a little above midway between the areas of greatest and of least winter precipitation in the United States. In the whole year, and in each season of the year, the rainfall is less than in the Alpine region north of it. As suggesting a possible connection between meteorological conditions and the interior of the earth's crust, it may be mentioned that it las been thought that the synclinal axis running northeast, near Allston, on the Greenville railroarl, has been, during some years past, a line of demarkation between areas suffering from drought to the south of it, and areas having seasonable rains to the north of it. The first occupying surface under which the rocks dip northwest, and the latter one under which they they dip southeast. Along this same line, during the months of drought, tremors were observed and ascribed to slight shocks of earthquake.

In point of healthfulness, this region leaves little to be desired. When first settled, the country was entirely free from all malarial influences. Subsequently, during the period when the first clearing of the forest was in active progress, the hitherto clean-bordered channels of the streams became obstructed, in part with fallen timber and brush from the clearings, and in part by the washings of the hill sides, under the injudicious use of the plow. These washings occurred to such an extent as to alter the original level of the surface, and to pile the dirt up around the trees in the bottoms until they were killed. Such operations were attended with the prevalence of malarial fever's. Later, the aplands having been cleared and partly exhausted, attention was directed to the drainage and reclaiming of the low grounds for agricultural purposes, and the healthfulness of the locality was restored. It has thus happened that, with the extension of the settlements, a belt of malarial influences has moved forward with them, vanishing below and advancing above, until it reached the wooded slopes of the mountains before disappearing. 


\section{GROWTH.}

Remarkable changes have occurred in the growth of the upper country since its settlement, during the middle and earlier part of the 18th century. The "long-drawn, beautiful valleys and glorious highlands," spoken of by Lord Cornwallis, were then interspersed with "forests, prairis, and vast brakes of cane, the latter often stretching in unbroken lines of evergreen for hundreds of miles" (Logan). On the highlands, the oak, hickory and chestnut were of large growth, standing so wide apart that a buffalo or a deer conld be seen by the pioneer hunters for a long distance. There was no underbrush, and the woodlands were carpeted with grass and the wild pea vine, the latter growing as high as a horse's back. The cane growth was the standard by which the early settlers estimated the value of the land. If it grew only to the height of a man's head, the land was esteemed ordinary; but a growth of twenty or thirty feet indicated the highest fertility. This cane growth not only filled the bottoms, but extended up the slopes to the tops of the highest hills. Thus it was designed to place the first house built on the present site of the town of Abberille, on the summit of the hill; but afterwards, when the tall cane that covered the whole place was cleared away, an error of more than fifty yards was discovered. The Trappean soils around Ninety-Six, the "flat woods" of Abberille, the "meadow woods," Union, and the blackjack lands of York and Chester were prairies, with no growth of trees, but covered, for the most part, with maiden cane. Upper Carolina was then not inferior to any portion of the great West as a grazing country. Buffalo and deer in great numbers roamed through these luxuriant pastures. Henry Foster, a pioneer settler on the Saluda, in Edgefield, counted one hundred buffalo grazing at one time on a single acre of ground in Abbeville. The original forest has disappeared almost altogether, and has been replaced by younger oaks of small growth, by underbrush, and by the loblolly pines of the abandoned fields. The cane has gone likewise. The wild pea vine is no longer known, though since the stock has been pemned, under the new fence law, a plant supposed to be it has appeared in the open woodlands, with several other grasses not observed before. The prairies have become covered with a growth of heavy bodied post oak and blackjack; the latter, in turn, has now given place to the cedar in Chester. The chestnut has been dying out for fifty years. In some localities where it once flourished, it has entirely gone, and in others, the large dead stems and stumps are the only vestige of this valuable and stately tree. The chinquapin is also sickening and dying, and the chestnut oak likewise. During some years past, somewhat 
similar symptoms of disease have appeared in the red and black oak, and fears on this account have been entertained. The distinctive growth of the region is the short leaf pine, with a large variety of oaks and hickorics. On the water courses, willow, beech, birch, black walnut, ash, poplar and gum abound. In sections of Laurens the long leaf, formerly unknown in this section, has, within the last ten years, appeared among the ofd field pines. The sycamore sometimes attains a great size, one in York being twenty-eight feet in girth. The tulip tree, also, is often very large. The sugar maple is found, and another maple of larger growth and yielding a superior sugar, both as to quantity and quality, is known in Laneaster, under the name of the sugar tree (Mills).

\section{PRODLCTIONS.}

The skins and furs of wild animals were the earliest products which the upper country gave to commerce. About the middle of the 1Sth century "the cowpen keepers" and the "cow drivers," led thither by the representations of the trappers, hunters and Indian traders, built their cabins among these pastures, and made large enclosures, into which their numerous herds were driven for marking, handling, \&c. The business was a large one, and numbers of neat cattle were driven annually to the markets of Charleston, Philadelphia and New York. Horse raising, also, was largely engaged in, and so highly were the qualities of the Carolina horse of that early day esteemed, that a statute of the provincial Legislatures forbids the introduction of the inferior horses of Virginia and other northern plantations. Around the "cowpens" of the stock drivers the agricultural settlers appeared. Their crops of wheat and Indian corn formed, for many years, a considerable item of export from the province. Hemp, particularly between the Broad and Saluda rivers, was largely cultivated, and Dr. Brahm says it was the finest and most durable grown anywhere in the world for the cordage of vessels. The cultivation of tobacco was engaged in, but was restricted by the difficulty of bringing so bulky an article to market in the then condition of the country roads. It was packed in casks, trumnions fastened to each head, shafts attached, and drawn by a horse several days journey to market, as a large roller. Silk was grown, and the vine successfully cultivated by the early settlers of New Bordeaux, in Abbeville. It is noteworthy that, within the last few years, sinee the French vineyards have suffered from the phyloxera, besides the seuppernong roots, hundreds of thousands of cuttings of the Warren grape, natives here, have been ordered from France, and being planted there they have yielded a wine of excellent quality. In 1801, Col. Hill, of York, made forty-eight tons of red clover on eighteen 
acres of land, although Governor Drayton says the season was a very dry one. For several years past Governor Hagood has obtained two cuttings a year of excellent hay from fifty acres, and more, that he set out in Bermuda grass, on the Saluda river bottoms. The yield is two to four tons per acre. Mr. Doty, a Kentuckian, who owns a blue-grass farm in that State, but who is now living at Winnshoro, says, that taking the value of the land into account, he makes his forage cheaper on the worn out hills of Fairfield than he does on the famous blue-grass lands of his native State. His crops are oats and German millet. The latter he estimates that he houses at a cost of six dollars per ton. Lucerne has long been established in this town, and there are stools of this valuable forage plant, still vigorous, known.to be fifty years old. In the same town, Col. James H. Rion sowed, in 1S74, a half acre of red land, a worn out old field, infested with nut grass, in lucerne. In 1875 he got one cutting, and from that date to 1850 , from four to ten cuttings each year. The ten cuttings were obtained in 1878 . The lucerne averaged two and a half feet in height at every cutting, making a total growth for the season, of twentyfive feet. By actual weighing, each cutting averaged 4,189 pounds from this half acre, which was also carefully measured, giving a total of twenty and a half tons, or at the rate of forty-one tons per acre. The mention of such facts are not out of place, inasmuch as since the invention of the cotton-gin the culture of cotton has so superserled all other agricultural pursuits, that it might well be thought that nothing else conld be grown here. Cotton planting has become so easy and simple, it requires so little individual thought and effort, the money returns are so certain and direct, or the crop may be so cheaply stored and preserved from injury for such an indefinite time, every business, trade and industry accessory to the work of the farmers, from bankers and railroads to implement and fertilizer manufacturers, have become so thoroughly systematized and organized in unison with this pursuit, that any change is difficult, and as a consequence, the manifold resources of the country are neglected and undeveloped.

\section{STATISTICS.}

The metamorphic region embraces about 10,425 square miles, or nearly one-third of the entire State. The population numbers 395,043, the increase since the census of 1870 being thirty per cent. The density of population per square mile varies from twenty-six to twenty-seven in Laurens and Lancaster, to forty.six and forty-eight in Newberry and Greenville; the average being 37.8 per square mile, which makes it the most thickly peopled portion of the State, except the sea islands, which have 39.4 to the square mile. The pereentage of colored population 
raries greatly in the different counties, being as high as seventy in Fairfield, and as low as thirty-four in Spartanburg. The average is fifty-eight.

Of the $6,672,000$ acres of land in this region fifty per eent. is in woor lands; twenty-two per cent. is in old fields, and twenty-eight per cent. is tilled. There are 38,591 farms. This is an increase of at least eighty per cent. since 1870 , and of one hundred and eighty per cent. since 1860 , while the increase in the decade preceding that, a time of much prosperity, did not much exceed one per cent.; fifty-six per cent. of the farms are worked by renters, and forty-four per cent. by owners. This is nearly six per cent. more of farms rented than in the State at large, or ten per cent. more than in the other parts of the State. The maximum of the farms rented is sixty-seven per cent. in Fairfield, and the minimum is forty-two per cent. in Laurens; forty-five per cent. of the farms are under fifty acres, but seventy-one per cent. of the rented farms are under fifty acres, while only thirteen per cent. of those worked by owners are under fifty acres. The farms under fifty acres worked by owners constitute only six per cent. of the total number of farms in this region; thus, notwithstanding the great subdivision of farm holding that has been, and still is taking place, it camnot be said that land is here, as it is on some of the sea islands, in the hands of a small proprietary.

The tilled land is 1,861,922 acres, an increase of fifty-six per cent. since 1870 . This gives an average of 4.7 acres per capita. or nearly one acre above the average for the State, and one-half more than in 1870. Of it forty-eight per cent. is in grain of all kinds, forty per cent. is in cotton, and twelve per cent. is in gardens, orchards, fallows and all other crojs. The proportion in cotton varies from a maximum of forty-six per cent. in Laurens and Union, to a minimum of twenty per cent. in Lancaster.

The crops are cotton, 274,318 bales, against 94,494 in 1870 ; an increase of one hundred and seventy-two per cent., or nearly six times as great as that of the population within the same period. It constitutes fifty-three per cent. of the crop of the State, on less than one-third of its area. The average number of bales per square mile is twenty-six, and raries from twenty and one-third bales, in Lancaster, to thirty-six and three-cuarters bales in Newberry. In many of the townships the number of bales grown per square mile is much greater. In Fairfield, township No. 3 (E. D., 69) produces forty-six bales per square mile; in Newberry, Floyds township (E. D., 114) produces forty-seven; in Chester, Chester township (E. D., 36) produces fifty-nine; in York, Fort Mill township) (E. D., 169) produces eighty-four. These facts indicate that the establishment of enlarged and improved gin-houses for the better preparation of the staple is practicable in many places now, as they show that the main obstacle in the way of such establishment, viz.: the distance over which a suffieient 
quantity of seed cotton would have to be hauled is greatly lessened. The yield of lint cotton per acre varies from one hundred and eighty-eight pounds, in Newberry and Lancaster, to one hundred and forty-four in Abbeville. The average for the region being one hundred and sixty-six pounds of lint per acre, which gives it rank as fifth in the State in point of production per acre. The yield of lint cotton per capita of population varies from four hundred and three pounds, in Fairfield, to two hundred and three pounds in Greenville; the average is three hundred and sixteen pounds, being less than in the red hill region, but more than it is elsewhere in the State. The grain crop is 7,731,528 bushels, an increase of one hundred and thirty-nine per cent. on the crop of 1870 . The average vield for the whole region is nine bushels per acre, and it varies from a maximum average of eighteen bushels per acre in York, to a mininum of eight bushels in Laurens; these variations depending more on the amount of attention bestowed on this class of crops than on differences in the productive capacity of the soil. Per capita of the population the yield is nineteen bushels, which is four bushels more than in 1870 . If this were all corn, or its equivalent, and were fed to the population at a rate of ten bushels per capita yearly, and the work stock at the rate of seventy bushels a head, it would leave, counting nothing for the supply of other live stock, a deficiency of 1,091,000 bushels, or about fourteen per cent. Estimated in the same mamer, this deficiency was thirty-one per cent. in 1870. Compared with the other regions of the State the yield per capita is below that of the sand hills, which is thirty-two bushels, and that of the Alpine region, which is twenty bushels, but above the four others.

The work stock is one to every twenty-seven acres of tilled land, the average for the whole State being one to eighteen. More land is tilled here to the head of work stock than anywhere in the State, except in the red hill region. As the lands themselves are not lighter or of easier tillage, this is chiefly due to a more economical use of this power.

The live stock number 473,180 . This gives forty-five to the square mile, against an average for the State of thirty-seven. Although this region ranks third in its proportion of live stock to area, it was here that the first movements in favor of the law requiring the enclosing of stock took place. It is also noteworthy that the counties here, in which the enclosure of stock has been enforced by law, for some years support fifty head of live stock to the square mile, while the four counties in which the stock have enjoyed the freedom of ranging wherever they could, support only thirty-six head to the square mile. 


\section{FARM YALUES AND PRODUCTIONS.}

The total of values invested in farms in this region, obtained as the sum of the values entered in the 10th United States Census for lands and improrments, for farm implements and machinery, and for live stock, amounts to thirty-nine millions of dollars, which does not differ very widely from the valuation of the same property on the tax returns of these counties. The value of farm productions annually, is nineteen and a quarter millions of dollars, or forty-nine per cent. on the above investment. This percentage varies in the different counties from thirty-nine per cent. in Greenville to seventy-one per cent. in Laurens. It may not be possible to ascertain, even approximately, how the profits of this production is distributed; how much of it rests with the farmer and laborer, or how much goes to merchants, bankers, and railroads. Nevertheless, whoever gets the net profits, it is safe to assume that the value represents in a general way the productiveness of agriculture in this region. Here are twelve adjacent counties, between whose soil, climate, population, social, political and industrial system, there is very great similarity. On the other hand, there are very wide rariations, among these same counties, on four points, frequently and earnestly discussed as affecting fundamentally, southern agriculture. These are:

1st. The ratio between the area planted in cotton and that planted in other crops.

$2 d$. The ratio of large and small farm holdings.

Brd. The proportion of farms rented to those worked by their owners.

4th. The proportion of the white to the colored population. 
The following table will show the relations of these counties in these four respects to the percentage of farm production on farm values in each.

TABLE.

\begin{tabular}{|c|c|c|c|c|c|}
\hline $\begin{array}{l}\text { Nanes of } \\
\text { Counties. }\end{array}$ & $\begin{array}{l}\text { Percentage } \\
\text { of } \\
\text { tilled land } \\
\text { in } \\
\text { Cotton. }\end{array}$ & $\begin{array}{c}\text { Pereentage } \\
\text { of } \\
\text { Farms } \\
\text { over fifty } \\
\text { Aeres. }\end{array}$ & $\begin{array}{c}\text { Percentage } \\
\text { of } \\
\text { Farms } \\
\text { rented. }\end{array}$ & $\begin{array}{c}\text { Percentage } \\
\text { of } \\
\text { Colored } \\
\text { Populationi. }\end{array}$ & $\begin{array}{c}\text { Percentage } \\
\text { of value } \\
\text { of } \\
\text { Farm pro- } \\
\text { ductions on } \\
\text { farm values }\end{array}$ \\
\hline Newberry . . & 45 & 57 & 56 & 68 & 49 \\
\hline Lancaster .. & 20 & 49 & 56 & 52 & 60 \\
\hline York .. . & 34 & 66 & 45 & 54 & 46 \\
\hline Laurens... & 46 & $\$ 2$ & 42 & 60 & 71 \\
\hline Spartanburg. & 38 & 54 & 52 & 34 & 41 \\
\hline Edgefield . . & 3s & 47 & 57 & 64 & 51 \\
\hline Chester. . . & 43 & 57 & 60 & 64 & 54 \\
\hline Greenville. . & 34 & 48 & 53 & 38 & $39^{\circ}$ \\
\hline Union . . . & 46 & 47 & 66 & 56 & 50 \\
\hline Fairfield . . & 39 & 45 & 67 & 70 & 60 \\
\hline Anderson. . & 38 & 60 & 57 & 43 & 46 \\
\hline Abbeville. . & 39 & 52 & 60 & 66 & 41 \\
\hline
\end{tabular}

Considered wholly within the limits of the above data, and bearing in mind that they ean give only an approximation to the truth, Prof. B. Sloan, of the University of South Carolina, states the arithmetieal conclusions to be obtained from this table as follows:

An increase of ten per eent. of the proportion of tilled land in cotton inereases the values produced by seven and a half per cent. 
An inerease of ten per cent. of the proportion of farms over fity aeres increases the values produced by five per cent.

An increase of ten per cent. of the proportion of farms rented increases the values produced by one-half per cent.

An increase of the proportion of colored population increases the values produced three and one-third per cent.

Such conclusions are liable to material modifications, when riewed in relation with the numerous conditions that complicate such a problem. For instance, the increase in the colored population does not necessarily show that the proportion of colored farm labor is increased in the same ratio; a fact which will be observed by reference to the reports of township correspondents. Nevertheless, if these facts only show in which direction the answer lies, it follows that these answers are opposed to the generally received teachings and theories on these questions, and at the same time that these answers are in accord with the persistent and prevailing practice of those whose decision is paramount in the matter-the land owners and the laborers.

\section{SYSTEM OF FARMING AND LABOR.}

The larger portion of the lands are held in tracts of from two hundred to five hundred acres. On three-fourths of the farms mixed husbandry is practiced, and on the remaining fourth attention is bestowed almost exclusively on cotton.

The attempt to raise farm supplies is, therefore, pretty general, and is reported as increasing, except in Laurens, where it remains the same, and in Abbeville, where it is decreasing. Usually this attempt is in so far successful as to provide a considerable portion of the subsistence for farm hands and stock. Bacon is largely imported from the North and West, and sometimes, hay and corn also, for farm use. In two instances these supplies are reported as brought from North Carolina. The amount of provisions raised for sale is everywhere inconsiderable. The facilities offered by railroads have largely contributed to this. For instance, in Chester the country mills, which were formerly numerous and flourishing, have been to a large extent abandoned, since it has been found easier to get meal by rail each week as required, from the Merchant Mills in Augusta, Georgia; and there is an increasing tendency, under the low rates of through fares to supersede the Augusta mills by the product of the northwestern mills.

The system of eredits and advances prevails to a large extent, consuming from one-third to three-fifths of the erop before it is harvested. The statement is general that this is on the decrease, and is correct in so 
far that a larger amount of supplies is being produced at home, and a larger number of purchases for cash are being made by farmers since 1576. On the other hand, the number of farms having largely increased in the same period, the number working on advanees, especially among the smaller farmers, has largely inereased also. The records of the courts show that the number of liens on the growing crop is greatly on the increase; the rate of increase being twenty-three per cent. per annum for the last two years. The number of such liens on record in eleven of the counties under consideration is (there being no return from Union) 30,205 ; a number nearly equal to the number of farms, but as two or more liens are not unfrequently recorded against the same crop, probably not more than one-half of the growing crops are under lien. The aggregate value of these liens is $\$ 2,334,956$; an average to the lien of seventy-seven dollars. It appears that the five counties lowest in the ratio of farm productions to farm values have a larger amount in liens, by thirteen per cent., than the five counties standing highest in this ratio. In the former the recorded indebtedness is four dollars and twenty-eight eents for each acre in cotton, on which crop alone liens are taken; in the latter it is two dollars and eighty-four cents per acre in cotton. As may be inferred from the number and average amount of these liens, they are mostly taken from the smaller farms, usually renters, for advances made by the landlord, or more frequently by the store keeper. There has grown up in this region a system of banks at the county seats, for the accommodation of farmers. The National Bank of Newberry was the first to be established; under the excellent and judicious management of its president, Robert L. MeCaughrin, the operations of this bank have added largely to the prosperity and independence of this comnty; which, besides leading in cotton production in proportion to its area, is, in many other regards, the most thriving in the region. The capital of this bank, $\$ 150,000$, was subscribed by the citizens of the county, except $\$ 12,000$, and ninety-fire per cent. of the stoek, which is at thirty per cent. premium, and not for sale, is now held within the county. It has six hundred and fifty-four accounts, three-fourths of which are with farmers. These accounts vary in amount, from forty dollars upwards; only sixty-five of them, however, reach or exceed $\$ 1,000$. Since 1872 , the rate of discount has been from twelve to seven per cent., or from one-half to one-third of the average rates prevailing elsewhere in the State. The loans during the crop season aggregate $\$ 324,000$, and the doubtful debts for the operations of the last ten years do not reach in all $\$ 6,000$. Loans are made purely on personal security or on collaterals, liens and mortgages are not asked for or given. If there is a question as to the ability of the party seeking accommodation to meet his payments promptly, he is required to obtain 
the endorsement of one or more of his neighbors. In this way it frequently happens that three neighbors endorse each others notes, so that if ill-luck befall one during a crop season, the others help him through, and it is found that such assistance is equalized in a series of seasons. Besides the direct assistance this bank affords, its indirect influence is highly beneficial, not only does it encourage personal trustworthiness and integrity, but by the circulation of its capital during the active season of the year, it gives a healthy cash tone to business; where a large proportion of the sales are for ready money, the purchases by merchants are more carefully and economically made, and even advances on liens are less exorbitant than elsewhere.

Field labor is performed exclusively by natives, and chiefly by colorerl laborers. In Spartanburg, two-thirds of the field labor is performed by whites, even where the colored population largely preponderates. The reader will find by reference to the township reports, that a considerable amount of it is done by whites; not unfrequently a much larger proportion than one would infer from the ratio between the races. The laborers are healthy, easily managed, work moderately and live easily. Their condition is reported as good in eight localities; as improving in two; and as poor, but contented and happy, in one. Very few negro laborers own land or houses in Newberry, York and Abbeville; sixteen per cent. own a house or land in Greenville; and five per cent. in Spartanburg, Fairfield, Chester and Laurens.

The prevailing wages of field labor is eight dollars by the month, or one hundred dollars by the year. In Greenville it is seven dollars, and in Laurens it is eight dollars to twelve dollars by the month. In portions of Edgefield it is seventy-five dollars per the year. In all cases the laborer is furnished with shelter, rations and firewood, and almost invariably with a garden and the privilege of raising poultry and some stocka cow or a hog. The farm work is light, and the extreme care formerly given to preserving the health of the slaves, has bequeathed regulations regarding labor not customary elsewhere. Work commences at sunrise, and is over with at sunset; no night work of any sort being required; the time allowed for meals varies; for dinner it is from one to three hours, according to the length of the days. All exposure to rain or bad weather, even in pressing exigencies, is scrupulously avoided, and during exceptionally chilly weather little work is obtained or expected of negro laborers.

A large proportion of the land is worked on shares. When the landlord furnishes the tools, stock, and stock-feed, he takes one-half the crop in Laurens, Chester, Abbeville, and York, and in portions of Fairfield and Spartanburg. In Greenville, and in portions of the counties last 
named, the laborer takes one-third, and the landlord two-thirds, under the above conditions. In Greenville also, the laborer takes two-thirds, if he furnishes tools, stock and feer for it. The portion paid for land alone varies from one-third to one-fourth of the crop-the latter rate being the most general one.

In Laurens, Newberry and Spartanburg, and portions of Fairficld and Chester, wages are preferred, the laborer running no risk of the seasons, faring better and working better in consequence. In Abberille and York the share system is preferred, and is the prevailing practice; the demands "on the care and attention of the landlord is less, and the independence of control and freedom from steady work it affords the laborer is highly prized by him. In Greenville, laborers using stock, tools and provisions, find the share system most profitable, otherwise they prefer wages.

Tolerable satisfaction with the system prevailing in each locality is expressed, but the feeling is general that the relations of labor and eapital are in a transition stage, and, either that those now existing need perfecting, or that better ones would be preferred.

Eight out of nine correspondents report that under the present system the lands are not improving, but deteriorating, especially those rented and worked on shares; the ninth only qualifies the general statement by the expression, "with care it improves." Though there may be much sad reality in these statements, they are to be considered in connection with the facts above given, which show that within the last decade the two leading crops in this region have increased, one by one hundred and seventy-two, and the other by one hundred and thirty-nine per cent.

Statements regarding the average market value of land vary with every locality. They are for Greenville and Laurens, six dollars to ten dollars an acre; for York, six dollars; for Abbeville and Spartanburg, ten dollars; for Newberry, six dollars to twenty-five dollars; for Fairfield, three dollars to fifteen dollars; for Chester, seven dollars to eighteen dollars. There will be found a fuller detail in the Abstract of Township Correspondents, "and attention is directed to their frequently recurring expression, that "there is little land for sale, but nearly all of it to rent." Only three out of eleven correspondents state the rental of land in money; it is put in York and Chester at two dollars, and in Laurens at three dollars to four dollars. Three state that no land is rented for money. In these cases one-fourth to one-third of the crop-estimated in Fairfield at an average of five dollars an aere-is given, or a larger proportion where stock and other supplies are furnished. In Abbeville, the average rent is given as three bales of cotton for as much land as one plow can eultivate; in Fairfield it is nine hundred pounds, and in Chester as much as twelve hundred pounds of lint. Or, in other words, something over one thousand 
pounds of lint cotton, worth one hundred dollars, for the rent of thirty acres of land. This would be three dollars and thirty-three cents rental per acre, which is the interest at seven per cent. on a capital of forty-seven dollars and fifty cents. Taking seven per cent. as the standard rate of interest, this may be taken as the intrinsic value at present of the arable lands of this region. As, however, only twenty-eight per cent. of the lands are under the plow, this amounts only to an average minimum valuation of all the land tilled and mntilled at thirteen dollars and thirty cents per acre. As stated in the returns of the 10th United States Census, which may be considered as fairly up to the actual average market values, the lands with all farm improvements are put at an average of four dollars and eighty-seven cents an acre. At this valuation, placed upon them by their owners, these lands are paying dividends not less than twentyeight per cent. per annum, not taking into account that more than twothirds of these values are wholly unemployed, and that the remaining one-third are operated mainly by the poorest and most ignorant class of the community, where want of means alone would prevent them from obtaining such returns as good culture would give. If the artificial absurdities, inherited from the dark ages and feudalism, which enslave land even under this free government, and burden its transmission from one owner to another, could be abolished, if titles to this species of property could be made commercial paper, and as convertible as the titles to property in railroads and factories are through the medium of bonds and stocks, such paradoxes as the above would be impossible, and that fundamental value, held to be the source of all others, land would be free to furnish its full quota towards supplying human wants and assisting in human progress.

\section{TILLAGE AND IMPROVEMENT.}

The usual depth of tillage is four inches on the land side of the furrow. In Abbeville, Spartanburg, and portions of Chester, it is generally only three inches. In parts of Fairfield it is only two inches, but in some parts of Chester it is six inches to eight inches.

The draft employed is almost always one horse; in a very few instances two horses are used.

Subsoiling has only been practiced on a small scale, chiefly as an experiment, generally with excellent results.

Fall plowing is very little practiced ; it is opposed to what is known ats the "David Dickson method of culture," which is the prevalent one, the opinion being, that lands broken up in the fall become tightly packed by the winter rains, an evil not counterbalanced by the disintegrating in- 
fluence of frosts in this mild climate. The additional expense is also a consideration. To the limited extent to which it is done, five reports wive the results as good, and in York and in portions of Chester, it is reported as greatly on the increase; five other reports state that it is of doubtful advantage or none.

Rotation of crops is nowhere reduced to a system. With a moderate use of manures, and careful culture, the same lands are planted for years in cotton, it is thought not only without deterioration, but with actual improvement. The ratio which the price of cotton bears to that of meat and corn affects the succession of crops more than anything else. Nevertheless, there is but one opinion as to the beneficial influence of a rotation of crops as a cheap means of preserving the thriftiness of the soil. The succession of crops, as elsewhere in the State, is cotton, corn and small grain. The clean culture of cotton leaves the land in good order for any erop, and the small grain is planted in the same year, after the corn is gathered. Usually, the land is kept in cotton from three to five years, and after one crop of corn and small grain is taken from it, the culture of cotton is resumed.

\section{FALLOWING.}

Fallowing forms no part of the system of culture, and it is thought that the exposure of the soil, by tillage, to the summer sun is injurious. The fallows consist ehiefly of the lands lying out after the small grain crops are gathered, in May and June, and even these are generally used as pastures for stock. The

\section{OLD FIELDS}

are preferred, in many instances, to wood lands, and they are being cleared of the short leaf pine that covers them, and replanted. They produce well with fertilizers, and, under careful treatment, are thought equal to any of the land. One of the principal reasons for abandoning these lands in the first instance was the washes and gullies produced by the unskillful use of the plow. Efforts to remedy this by horizontal culture and hillside ditches, where intelligently made-especially where the plumb or the level has been used to lay off the rows and ditches-have been very successful. Unskillfully made ditches, however, often do more harm than good. Filling the gullies with brush is a safer and a very effective practice, but no attempt at under drainage, to remedy washing, has been made. The damage to the soil is mainly to the hillsides, and it is seldom the bottoms are injured by the detritus they receive. 


\section{MANURING}

has for its basis cotton seed. About one thousand pounds of cotton seed are obtained from each bale of cotton, which makes 137,000 tons the supply of this region. Of this, 25,000 tons, at two bushels per acre, is used for planting; a small anount is fed to stock. None is carried to the oil mills, and very little is sold, the price being ten to fifteen cents per bushel; the balance, about 100,000 tons, is returned to the soil as manure. For small grain, it is sown broadcast, and plowed in with the seed in the fall. For corn, it is killed by heating, and applied in the hill. For cotton, it is becoming the practice to compost it with acid phosplhates and stable manure, sometimes with the addition of other litter and lime. It is applied in the drill, at the rate of a ton to two to four acres. This leares a large portion of tilled land to be supplied with manure from other sources. Corn rarely receives any manure, and the deficiency for the cotton lands, when cotton seed and stable manures are exhausted, is supplied by the purchase of commercial fertilizers. The amount purchased in this region reaches an aggregate cost of nearly one-half million of dollars, or \$1.98 for each acre planted in cotton. It varies, from a maximum in Spartanburg of $\$ 3.33$ per acre in catton, to a minimum of .92 cents in Abbeville. It is used most extensively in Spartanburg, Greenville, Tork and Anderson, to stimulate the growth and maturity of the cotton plant in these counties, which, being more elevated and nearer the mountains, have a shorter growing season. In Newberry, the county most productive in cotton of the region, the average is $\$ 1.02$ per acre in cotton. Green nanuring has been practiced only as an experiment. Such experiments with pea rines have had a very promising success, but it has been found better to allow the vines to wither before turning them under.

\section{CULTIVATION.}

Fallow lands or lands that have been in other crops, and sometimes the heary red lands, are broken up broadeast during the winter and spring. The great body of the lands, however, being planted year after year in cotton, the usual method is to lay off in the alley with a shovel plow, drill in the manure, and bed to it with a turning plow. Three to fire furrows complete the berl, and the land is ready for planting. On the thinnest lands, the rows are two and one-half feet apart-generally they are three feet to three and one-half feet-and on the strongest lands they are four feet. Planting commences on and after 10 th April, and is completed on or before the 10tll of May. The seed used is the short limbed 
cluster variety of cotton, known under the name of Dickson's improved, or Boyd's prolific. It is rather a delicate plant, a prolific bearer, of early maturity, and a short staple. Carcfully sown, one bushel of seed will plant an acre, though as much as three and sometimes five bushels are used. With a planter, two bushels answer, and two to two and onehalf may be taken as the arerage. Nost of the seed is sown by hand, in a furrow opened by a small plow, and eovered by various devices of boards, propelled by hand or by a horse. On the smooth, well-prepared land, planters, especially the Dowlow, are much used and well thought of. The seed eomes up in four to ten days in farorable seasons; late plantings in dry seasons are longer in appearing, and may not come up in a month, and then give a good stand. This occurrence is always a misfortune, as it not only retards the crop, but allows the grass a chance to overtake it. As soon as the stand is perfeeted, thinning commences, and the cotton is ehopped out with a hoe to spaces varying from six inches on thin lands to eighteen inches on the strongest, usually to nine inches and twelve inches.

The after cultivation consists in keeping the ground light and loose by the use of the plow, and in keeping the grass out of the row with the hoe. A great rariety of plows are used for this purpose-twisters, turn-plows, shovels and harrows; the later workings, when the plant is fruiting, are usually given by passing twiee through the row with a sweep, which skims the surface. Generally there are four plowings, and four hueings; sometimes three answer.

When the plant is ten inches to fifteen inches high-usually about the 1st of July-it begins to bloom, though blooms are sometimes noticed as early as the 15th of June. Open bolls appear about the middle of August; in favorable seasons they are sometimes seen the last of July, and at other times not until the 1st of September. Although in some instances the plant grows as high as four feet to five feet, the height at which it is thought to be most productive here is from two feet to three feet. Picking may commence about the 25th of August, but it is not in full blast until the 1st to 20th of September. The crop is gone over three to four times, and it is all out of the field by Christmas; sometimes as early as the 20th of November.

\section{DISEASE AND ENEMIES.}

In its early growth, unless in exeeptionally windy and cold seasons, or through bad hoeing, cotton does not suffer here at all from "sore -hin." Nor does it often run to weed; in unusually warm and wet seasons, or on strong fresh land this may oceur; cultivation and manuring are thought 
to check excessive growth, and to promote fruiting. Worms are rarely seen in this region, and are not at all feared. Shedding and rust are often injurious. The first is likely to oceur during altermations of dry and wet weather. Black rust is confined to ill-drained soils, especially to those of the trap rocks. Wet weather is more likely than dry and hot weather to affect the cotton plant injuriously here. No erop grown anywhere over so extensive an area is more certain than is the cotton crop in this region. Drainage and stable manure, with fairly good culture, are unfailing remedies for such diseases as have as yet affected it. The enemy most dreaded and most certain to require the best efforts of the farmer to hold it in check, is grass; and, with one consent, the species is known as "crab-grass," "a corruption," John Drayton says, "of cropgrass, as it was unknown until the land was cultivated." BeBrahm, writing of Carolina in 1752, says: "Because new land produces scarce any grass, and once hoeing will do for the season, but the grass comes and increases in such a manner that sometimes three hoeings are scarce sufficient in one season, and when this comes to be the ease, the planters relinquish these fields for pastures and clear new ground of its wood." This grass makes an excellent hay, attaining a height of two feet to three feet, and yielding from one to four tons to the acre, according to the land and the season. Next to cotton picking, however, it is the chief source of trouble and expense in the culture of this crop.

\section{GINNING.}

The ginning and picking season open and close together. The gin's in general use are Brown, Winnslops, Taylor and Hall gins. The most generally used power is horse-power-four mules and the old wooden cog-wheel gearing. Such power is used for gins of forty to forty-five saws, and the out-turn is about two and a half pounds of lint an hour to the saw, or an average of about eleven hundred pounds of lint as a day's work for a gin. With steam and water power the same number of saws are made to do double this work, but it is questionable if it is so well done. The cotton on the average does not quite third itself, and as estimated, 1,231 pounds of seed cotton are required to make four hundred pounds of lint. This gives seventy-one bushels of seed as the daily product, per gin, in the estimate above stated. For baling, six out of eleven reporters used and.preferred the old wooden serew, run by horse power; two used the Scofield press, and the remainder the Finley and other hand-presses. It appears with these presses, if three to four hands and one to two mules are employed, the out-turn for ten hours work is about four thousand pounds of lint in eight or nine bales. The iron arrow tie 
has entirely superseded rope for baling. Jute bagging, the heaviest Dundee, or the domestic Ludlow is used. The weight aimerl at in the bale varies from four hundred pounds to five hundred pounds; the arerage is four hundred and fifty-two pounds.

\section{SHIPPING AND SELLING.}

As soon as the cotton is packed it is moved to market, commeneing about the 1st of September; by the end of the year almost the whole crop has passed out of the farmers' hands. The farmer usually sells to the merchant at the nearest railroad station, and has only a charge against him of ten cents a bale for weighing. In some localities the transportation, hauling from Laurens county to Greenville, is stated to cost two dollars a bale. Cotton shipped by railroad to New York costs three dollars and fifty cents a bale. To Charleston it costs, from Fairfield, two dollars to two dollars and twenty-five cents; from Spartanburg, two dollars and fifty cents; from Abbeville, two dollars and seventy-five cents. From Chester the charge is, to Charleston, forty-eight cents per humared weight; to New York it is sixty-three cents per hundred weight. Cotton shipped from Fairfield to Charleston, and sold by the farmer, costs, everything included, four dollars and fifty-seven eents for a bale weighing four hundred and sixty-five pounds, and it is usually estimated at about one cent per pound.

\section{COST OF PRODUCTION.}

This is estimated in four reports at seven cents; in one report at eight cents, and in one at nine eents per pounds of lint. The following table exhibits the detailed statements on this head. 
Cost of each Item of Labor and Material expended in the Cultivation of an Acre of Cotton.

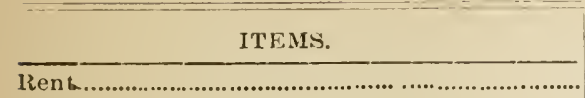

\begin{tabular}{|c|c|c|c|c|c|c|c|}
\hline I. & II. & III. & IV. & V. & VI. & ViI. & Average \\
\hline & $\$$ & 33 & $\$ 260$ & 3400 & $\$ 3$ & $\$ 300$ & $\$ 561$ \\
\hline
\end{tabular}

Fencing, repairs interest on

Kinocking stalks..

Pulling and burning stalks.

Other cleaning np.

Listing

Beddin

Breaking $\mathrm{up}$

Harrowing.

Barring old beds..

Splitting middles

Reversing

Laying off

Commercial Manures

Home-made Manures.

25

Applying manures.

Beduing up.

splitting middles.

Knocking off beds

Planting, opening.

Planting, dropling.

Planting, covering..

Replanting.........

Steu

Thinuing.

Tluree plowings.

Three hoein 2 s.

Picking

Hauling to gin.

Ginning

Management.

Wear and tear of tools.

Bagging and ties

Total

Cost per pound, dedacting cotlon seed at 12 cents per bushel.

Profit per acre, cotton $10 \mathrm{cts}$. per pound, seed 12 cts. per bnshel, $\overline{2919} \overline{25 \times 5} \overline{3566} \overline{2085} \overline{2255} \overline{1189} \overline{1797} \overline{2378}$

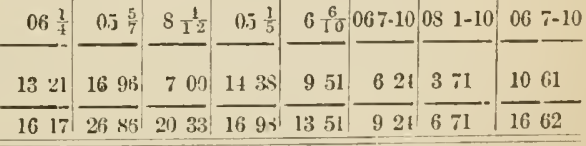

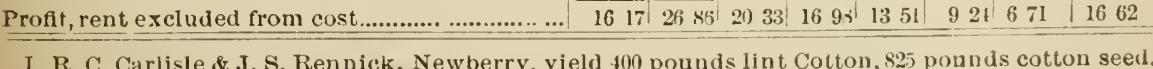

I. R. C. Carlisle \& J. S. Rennick, Newberry, yield 400 pounds lint Cotton, 825 ponnds coth II IV. L. Donaldson, Greenville, yield t00 ponnds lin t Cot ton, 800 ponnds cot ton seed. IV. G. H. McIaster. Fail'field, yield 330 pounds lin t Cotton, 670 pounds cotton seed. V. Jumes Pagan, Winnsboro, yield 300 pounds lint Cotton, 620 pounds cotton seed. Vi. W. R. Bradley, Abbeville, yield 19 i pounds lin t Cotton 400 pounds cotton seed. VII. Jno. A. Summer. Lexington, yield $20^{\circ}$ pounds lint Co ton, 420 pounds cotton seed. Average, 318 pounds lint Cotton, 6 is ponnds cotton seed. 
Abstract of reports of township correspondents in the Piedmont Region of South Carolina :

\section{Abreville County.}

Colieslury Township (E. D. 12): Lands hilly and broken, light, gray; gravelly and sandy soils, six inches to eight inches to subsoil of yellow, sometimes of dark red clay. Streaks of red clay and mulatto soils traverse these sandy soils. Underlying the subsoil is rotten sandstones, soapstone, tough clay, and rotten mica slate. Growth, oak, hickory and pine, generally small. Lands occasionally change hands at seven dollars to ten dollars an acre. Field labor is paid fifty cents a day, one-fourth to onethird of it performed by whites.

Donaldsville Tounship (E. D. 11): Lands level, soils fine, light, gray, sandy loam, with some clay loam; subsoil red and yellow clay, underlaid by solid clay. Growth, oak, hickory, walnut, poplar and pine. Crops, corn, ten bushels; wheat, eight bushels; oats, fifteen bushels; barley; fifteen bushels; potatoes, thirty bushels; seed cotton, six hundred pounds to one thousand pounds per acre. Lands sell for three dollars to ten dollars an acre. Uplands rent for one-fourth, bottoms for one-third of the crops. A good deal is rented for four hundred pounds to eight hundred pounds of lint cotton for a one-horse farm. Quarries of building rock are worked. Traces of gold occur. Lime rock is said to be found. Large waterpowers on Saluda river. No attention is paid to stock, which might be made profitable. No prevailing diseases. Field labor is paid forty to fifty cents a day, with board; nearly one-half of it is performed by whites.

Greenwood Township, (E. D. 13): Surface level and rolling. Soils, fine gray, sandy loam and rich clay loam; subsoil, red clay. Growth, oak, hickory and pine. Some land for sale at three dollars to ten dollars an acre. Average crop, six hundred pounds to seven hundred pounds seed cotton per acre. Lucerne, clover and millet do well. Summer pasturage abundant. Sheep kept during the winter on cotton seed and turnips, at a cost of thirty cents a head. Attention is being much directed to stock raising since the abolition of the fence law. Field labor paid fifty cents to seventy-five cents a day; one-fourth is performed by whites.

Smithrille Township (E. D. 16): Lands elevated and rolling. Soil, a fine, gray, sandy loam, and a red clay loam, with subsoil of clay resting on clay or a fine white earth, resembling chalk. Growth, oak, hickory and pine, with wild clover and various grasses. Crops, six hundred pounds seed cotton; ten bushels corn on uplands and twenty-five to thirty bushels on bottoms. Lands sell from three dollars to ten dollars per acre. Wages of farm labor, fifty cents a day to one dollar and fifty cents and two dollars during harvest; one-fourth performed by whites. 
Whitehall Township (E. D. 15): Level and undulating lands. The postoak and hickory land is a coarse, gray, sandy soil, resting on red clay, the red bottom lands are on the creeks and branches. Growth, oak, lickory and pine. Wild clover and native grasses abound. Crops, the best fresh land will make a bale of cotton, without manure; a bale to two aeres is a good average; ten bushels to sixty bushels of eorn; ten bushels of wheat; twenty bushels to one hundred and twelve bushels of oats an acre. Particles of gold found in all the small streams. Traces of manganese oceur. Most of the lands are rented for eight hundred pounds to one thousand pounds of lint cotton for twenty-five acres. Price of land from eight dollars to ten dollars per acre, and advancing. Very little ficld work done by whites. No climatic disease; locality very healthy.

Bordeaux Township (E. D. 5): Ridge lands elevated and rolling. Soil, a sandy loam, with spots of gravel and rock, with a subsoil of yellow clay, mixed with sand, underlaid by a stiff red clay. Growth, oak, hickory, gum and pine, with some chestnut. There are extensive river bottoms, also creek and branch bottoms, which are very fertile. Crops, five hundred pounds to one thousand pounds seed cotton; ten bushels to forty bushels corn ; twenty bushels oats per acre. Land can be bought at five dollars an acre; rents for two bales of four hundred pounds of cotton for a one mule farm, or one-fourth of all crops. Nore than a million dollars in gold has been taken from the Dorn mine; and several new mines have been recently diseovered. The Savamah river, Reedy river and Longeane afford numerous water powers. One-fifth of the farm work performed by whites.

Ninety-Six Township (E. D. 14): Lands undulating, very little hilly. Soil, a gray sandy loam, and a deep red soil, subsoil generally clay, underlaid by clay. Soft roek and white chalk. Growth, oak and hickory, with some pine. Crops, half a bale of cotton; fifteen bushels of corn; twenty bushels of oats per acre. Very little land for sale; most of it worked on shares; little worked by hired labor.

Cedar Springs Township (E. D. 3): High rolling ridges, broken and hilly on the streams. Soils, a gray sandy loam, and mulatto and red clay loams. Sandy soils coarser than in the low country; these are considered, since the introduction of fertilizers, as the most paying lands. Subsoils clay, underlaid at eighteen feet to twenty feet, by granite slates and an ash colored earth that has some fertilizing qualities. Growth, oaks of all kinds, short leaf pine, walnut, hickory, sugar-maple, cueumbèr tree and white gum. Crops, six hundred pounds seed cotton; ten bushels of corn; twenty-five bushels to seventy-five bushels of oats; ten bushels to fifty bushels wheat. A little land for sale at three dollars to ten dollars an acre for some; but not the best. Rent from three dollars 
to ten dollars an acre, or on shares. Building granite and soapstone occur. Gold, silver, lead, copper, zine and iron are found. Longcane creek furnishes several good water powers. Lucerne, clover, blue, orehard and timothy grass are found to do well. No local diseases. One-half the field work performed by whites.

Culhoun Mills Township (E.D.6): The flatwoods are low, flat land. Soil, a black loam, resting on a tenacious yellow clay, containing masses of carbonate of iron, which, when broken off by the plow and mixed with soil, give rise to the appellation, "Buckshot" lands; underlaid by decomposed felsitic and dioritic porphyry, that becomes hard in descending. Growth, heavily-bodied post oak and sealy bark hickory. Old fields grow up in persimmon and sassafras, later, in old-field pine. Lands wet, require draining; make good corn erops. Clover, peas and the grasses do well; but cotton rusts. Surrounding the flatwoods, like the rim of a cup, are the rolling, hilly, red lands. Growth, oak, pine and hickory. Some of these lands, under cultivation since the Revolution, with little manure, will produce good crops still; although they have been poorly farmed, and are much washed. I have made thirty bushels of corn, forty bushels oats, fifteen hundred pounds of seed cotton to the acre; but this is above the average. Excellent bottom lands are found on Little and Savannah rivers, and the small streams. Spring-water and shallow wells, impregnated with iron and sulphur. Farms may be bought at from two dollars to ten dollars an acre; if well improved will sell higher. Traces of gold, copper and antimony have been found. Eurite furnishes blocks of excellent building material, a very fine granite, hammondite occurs, and soapstone. Farm wages, ten dollars a month, with rations, garden, the privilege of a cow and of poultry raising.

\section{Anderson Countr.}

Anderson Court House (E. D. 18): Level in the north and east; rolling to the south. Soil: 1st. A stiff, sticky, red clay, with deep red subsoil. 2d. Red, loamy soil, mixed with fine sand, and having a red subsoil. $3 \mathrm{~d}$. Gray sandy soil, with yellowish subsoil. Growth, oaks of all kinds, hickory and pine. Crops, cotton, a bale to three acres; corn, ten bushels; oats, ten bushels to fifteen bushels an acre. Some land for sale, at ten dollars to fifteen dollars an acre. Rents for one five hundred pound bale of cotton for every ten acres. Farm labor paid fifty cents a day; onehalf of it performed by whites. Has forty acres set in clover, orchard grass and red top, which does well.

Garrin Tounship (E. D. 27): Land elevated and rolling, with some flats. Soil: 1st. A gray or brown sandy loam, on red or yellow clay. 2d. Red 
loam; depth of soils two inches to eight inches; the soils on bottoms have a depth of from two inches to six inches, or more. Beneath the subsoil is a fine, gray, soapy, sandy earth, mixed with mica. It has been used successfully as manure. Growth, red, white, black, post, Spanish and chestnut oaks, chestnut and hickory. Very little land for sale; price from eight dollars to ten dollars an acre. A good deal to rent for onefourth the cotton, two-thirds of the other crops. Croppers furnishing labor and paying for guano, get one-third, two-fifths or one-half of the crop. The worn out old fields, grown up in pines, are, when cleared again, more productive than virgin forest, yielding with one hundred and fifty pounds of guano one thousand pounds of cotton the first year. Clover and other grasses do well. Wages of farm labor six dollars to ten dollars a month; about one-half performed by whites.

Holland's Store Township (E. D. 23): The ridges are flat topped, and are a fine gray sandy loam, on clay subsoil ; not having washed under cultivation, they have steadily risen in value. Near the rivers and creeks the land is hilly and broken, the soil a red clay, and soft micaceous rocks are found. Growth, oaks, hickory, sourwood, dogwood and old-field pine. Since the abolition of the fence law has restricted the range of cattle, many grasses and forest plants, thought to be extinct, have re-appeared, among them the wild pea and vetches. Wild oats are getting so abundant that large tracts of wood lands look like oat fields. Crops, one-third of a bale of cotton, ten bushels to twenty-five bushels corn, on upland; and twenty bushels to fifty bushels on bottom land, six bushels wheat, ten bushels to twenty bushels oats per acre. Traces of gold are found. A bed of brown hammotite covers a square mile or more, and near it is a knob of soapstone, much used for hearthistones. Generostee creek furnishes six mill sites of twenty to fifty horse power, and at McDaniel's shoals, on the Savannah river, there is a fall of twenty-five feet to forty feet in two miles. Wages of farm labor, fifty cents a day; for ditching and harvesting, one dollar and sixty cents; more than one-half performed by whites.

Equality Township (E. D. 28): The ridges are flat or rolling, of a light gray, gravelly and sandy porous soil, suited to cotton, but requiring fertilizers to preserve their fertility. Towards the streams the land is more hilly and broken. Soil, a stiff red clay on a red clay subsoil ; there are lands under cultivation, yielding good crops, that were cleared one hundred years ago, and have been worked for the last twenty-three years without manure. Subsoil underlaid by rotten gneiss, mica, slate and hornblende, about one-sixteenth dark brown loamy creek bottoms. Growth, black, white, post and turkey oak, hickory, pine and chestnut. Crops, eight hundred pounds seed cotton, fourteen bushels to forty bushel corn on uplands, thirty bushels to seventy on bottoms, eight bushels to thirty bushels 
wheat, twenty-five bushels to one hundred bushels oats per acre. Peavines and red clover make good forage crops. Traces of gold are found, but no regular mining. Field labor paid fifty cents a day and board, and is largely performed by whites.

Irilliamston Tounship (E. D. 29): Land rolling. Soil, light brown or reddish sandy loam, five inches to six inches to subsoil of red clay, mixed with sand. Beneath the subsoil rotten gneiss rock is found. Growth, oak and pine, with some hickory and ash. Cotton yields a little less than three-fourths of a bale fer acre. Provisicns not much raised. Price of land, ten dollars to thirty dollars per acre. Graphite of good quality is found in lumps over a considerable arca, also red hermatite. The Piedmont and Pelzer factories are two large cotton mills on the Saluda. At the first it is estimated that a twenty-foot dam will give over eight hundred horse power; at the latter an eight-foot dam will give three to four hundred horse power. The Allen shoals, between the two, is about equal to the Piedmont falls. Below the Pelzer factory, the Clement shoals furnish a fall of fourteen feet, with abundant rock and an excellent site for building. Native grasses and cane afford forage. Little attention is paid to stock. Day labor, fifty cents to one dollar and twenty-five cents. Nearly one-half the field work is performed by whites. Williamston is a health resort, with a chalybeate spring, containing iron, magnesia, potash, sulphur, iodine and an excess of carbonic acid; and it has a large male academy and female college, with one hundred and twenty-five pupils.

Varennes Tounship (E. D. 20): Land elevated and rolling; sometimes hilly and broken. Soils are: 1st. Fine and warm sandy loam, three inches to four inches to a yellowish sandy or dark drab-colored subsoil. 2d. Clay loam, four inches to eight inches to a red or brown subsoil, which is generally stiff clay, underlaid for ten feet by stiff red clay, that there becomes mixed with roek, mica, sand and rotten looking clay of all colors. Growth, red, post, black, white and water oak, hickory, elm, pine, blackjack and blackgum. Crops, four hundred pounds seed cotton, fifteen bushels corn, eight bushels wheat, twelve bushels oats an aere. Lands sell at eight dollars to twenty dollars an acre; rents for one-third of the erops. Building granite abounds. The McDonald mine yields gold, some silver and rubies. Corundum of inferior quality is found at various places; also zireons and beryl. High shoals on Rocky river has a fall of thirty-one feet in three hundred yards, estimated as furnishing one hundred horse power.

\section{Chester Countr.}

Baton Rouge Tounship (E. D. 37): Rolling lands. Soils, gray, sandy, gravelly, six inches to red clay subsoil and red clay loam. Cirowth, oak, 
ash, walnut, pine, hickory. Lands rent for two bales cotton per one-horse farm. There is a gold mine, not worked now, however. The Lockhart shoals furnish a great water power. The river is one-fifth of a mile wide, eight feet deep, and has a fall of forty-seven feet in one-half a mile. Field labor paid fifty cents per day; one-half performed by whites.

Rossille Tounship (E. D. 43): Northeastern corner, blackjack land and level; the balance hilly and broken. Soils, gray, sandy loam, red and mulatto clay loam. Subsoil, mostly red clay and grayish pipe clay. Growth, a variety of oaks, hickory, blackjack and old field pines. Crops, ten bushels to twelve bushels corn, four bushels to five bushels wheat, fifteen bushels to twenty bushels oats, and three hundred pounds to four hundred pounds cotton an acre. Sixty bushels of corn have been made on my place. Lands for sale at ten dollars to twelve dollars an acre; rent for three bales of cotton of four hundred pounds to the mule, and less. Much land could be rented for clearing it up. Most of it having been thrown out is grown up in old field pines. Good building granite is found. An immense water power furnished by the old State canal on Catawba river. Farm wages, fifty cents a day; one-fourth performed by whites.

Lewisville Township (E. D. 42): Broken into hills and ridges, about one hundred and fifty feet higher than the valleys of the numerous streams crossing it. soils, a gray sandy loam, and a red clay loam, resting on red clay. In the northwest the blackjack lands have a grayish or whitish pipe clay subsoil. Growth, many varieties of oaks, pine, chestnut, walnut, and chinquapin. Cedar is taking the place of the old field pine. Little land for sale. Most of it is forest. Abundant water powers. A large cotton factory is being built on Fishing creek.

Chester Tounship (E. D. 36): Northwestern portion a light, sandy soil. Growth thirty years ago was chestnut and chinquapin. They have died out, and been replaced by oak and hickory. Once considered worthless, these lands, with fertilizers, now produce heavy crops of cotton, and sell for from ten dollars to fifteen dollars an acre. The middle portion is the blackjack lands, level and flat, requiring ditching. The blackjack is disappearing, and being replaced by oaks. These lands are adapted to corn and clover and the grasses. With ditching, stable manure, kainit, to prevent rust, they make good cotton crops. Spring water is limestone. They may be bought for from two dollars to five dollars an acre. The southern portion is mulatto or red land. It is broken and hilly; hard to cultivate; rents to negroes for seventy-five cents to one dollar an acre. Farm wages, from forty cents to fifty cents a day ; one-fourth performed by whites. 


\section{Edgeifeld County.}

Wise Tounship (E. D. 65): Lands elevated and lilly and broken, with narrow bottoms on the creeks. White sandy and red clay loam the prevailing soil. Subsoil heavy, red, clay, gravelly Growth, short leaf pine, white oak, red oak, walnut, hickory and maple. Arerage yield, four hundred pounds seed cotton, eight bushels corn, fifteen bushels oats per acre. Most of the land rented by the year for one-fourth of the crop; may be purehased on easy terms. Good building granite and soapstone are found, with clay, used for making earthenware. Several mill sites; very healthy; only about one-tenth of the field work performed by whites.

Ryan Township (E. D. 60): Lands elevated and slightly rolling. Soil, a fine, gray, sandy loam, with a yellow clay subsoil, and a coarse mulatto loam, with red clay subsoil. The subsoil is closé and compact, and is underlaid by slates, soapstone and granite. Growth, short leaf pine, cedar and a variety of oaks, hickory, walnut, dogwood, ash and elm. Crops, six hundred pounds of seed cotton, fifteen bushels corn, fifteen bushels wheat, thirty-five bushels oats, twenty-five bushels peas, one hundred and fifty bushels potatoes per acre. Lands sell at from three dollars to ten dollars an acre, and rent at fifty dollars for a one-horse farm. Gold, manganese, silver and copper ores are found, but are only slightly dereloped. Wild clover, cane and several native grasses afford pasturage. Stock raising is profitable, and could be made more so. Farm wages, fifty cents per day; one-tenth of it performed by whites.

Washington Township (E. D. 63): Elevated, hilly and broken in the upper portions. The level soils are gray, sandy and gray clay loam. Subsoil, grayish, light eolored elay, underlaid by red elay, flint and slate rock. Growth, white, red and post oak, hickory and pine. Crops, onefourth to three-fourths of a bale of cotton, twenty bushels to forty-five bushels oats, ten bushels to twenty-five bushels corn, five bushels to twelve bushels wheat per acre. Very little land for sale, prices ten dollars to twenty dollars an acre; rents from three dollars to five dollars per acre. Good water powers on Stephen's creek. Very little field work done by whites.

Rehobeth Tounship (E. D. 62): Hilly, some level places and a few flats. Soil, a dark or light gray loam, with subsoil of red clay, underlaid by clay slate. Growth, oak, hickory, pine, ash and cedar. Crops, one-fourth to one bale of cotton, ten bushels to twenty bushels corn, ten bushels to twenty bushels wheat, ten bushels to thirty-five bushels oats an acre. Know of none for sale, plenty to rent, for two bales to the plow. Prices of land would average from two dollars and fifty cents to eleven dollars 
an acre. Traces of gold. Large water powers on Stevens and Turkey creeks. Wages of fleld labor, thirty cents to seventy-five cents a day; one-twentieth of it performed by whites. Tery healthy.

Duntonsville Township (E. D. 45): Rolling lands. Soils, clay loam, mixed with small particles of clay slate, or with grit or a stiff waxy clay. Subsoils of the first two varieties composed of shatters of rotten clay slate; of the last, yellow and deep red clay, underlying the subsoil is red clay, clay slate, granite and chalk. Growth, oak, hickory, pine and ash. Crops, one-third of a bale of cotton, fifteen bushels to fifty bushels oats, fire bushels to ten bushels wheat, seven bushels to ten bushels corn an acre. Land for sale at four dollars to five dollars an acre; rents for fifty dollars for what one horse can cultivate; house, firewood and pasture included. There are three slate quarries, and traces of gold. Cirasses do well on flat places. Very healthy. Farm wages, fifty cents a day, and board; one-third performed by whites.

Grey Township (E. D. 51): Level, undulating and hilly, not broken. Soil, mostly a gray clay loam, underlaid by gray slate rock. Growth, red, black, post, white and other oaks, with hickory, pine and dogwood. Crops, six hundred pounds to eighteen hundred pounds (with acid phosphate) seed cotton, ten bushels on upland to thirty bushels on bottoms of corn, five bushels to ten bushels of wheat, ten bushels to forty bushels oats per acre. Unimproved lands sell for from three dollars to five dollars an acre. Little improved land for sale; it rents for eight liundred pounds to one thousand pounds seed cotton for forty acres. Arable land, farmed on shares, everything furnished but labor and rations, and the crop clivided. Traces of gold are found, and there are quarries of soapstone and whetstones, but not much developed. Good chalk and clay for manufacture of earthenware abound. Farm wages, fifty cents a day; cradlers, one dollar and twenty-five cents to one dollar and fifty cents. No prevailing disease. One-fourth of the labor is performed by whites.

Mobley Township (E. D. 56): Generally level. Soils, gray clay loam, underlaid by hard and soft slate rock. Growth, mostly pine. Crops, three hundred pounds to eight hundred pounds seed cotton, five bushels to twenty bushels corn, five bushels to twenty bushels oats per acre. Some land for sale at from five dollars to ten dollars per acre. A goorl deal to rent for four hundred pounds lint cotton for ten to fifteen acres. Hibbler's Township (E. D. 53): Generally level, in some parts hilly. Soils, a black clay loam, with red clay subsoil; and a gray clay loam, with white and yellow clay subsoil. The subsoil is underlaid by slate rock and some granite. Growth, white oak, red oak, ash, pine and poplar. Crops, eight hundred pounds seed cotton, ten bushels corn, thirty bushels oats, twenty bushels wheat per acre. Land sells for four dollars per acre; 
and rents for four hundred pounds lint cotton for twelve acres; some slate and soaptones are found; also veins of gold. Clover and grasses do well. One-half of the field work performed by whites.

Huit's Township (E. D. 54): Elevated and rolling. Soils, gray and red clay loam, two and one-half inches, the subsoil of yellow or red clay. Growth, oak, hickory and pine. Crops, six hundred pounds seed cotton, ten bushels to fifteen bushels corn, fifteen bushels to thirty-five bushels oats, eight bushels to twenty bushels wheat per acre. Lands sell for five dollars to ten dollars an acre, and rent for two dollars to three dollars an acre. Fine water power on Saluda river. Very healthy. One-half of the field work is performed by whites.

Cooper Township (E. D. 49) : Lands rolling. The prevailing soil a stiff, red clay. The subsoil is the same, with absence of vegetable mould. There are also flat lands, known as "buckshot" or "black gravel soils," very dark. Cotton rusts, and corn "frenehes" on them; but oats do well. Flint and black rock (trap) occur under the subsoil. Growth, white, red and post oak, hickory and pine. Crops, five hundred pounds cotton (seed) to one bale, ten bushels corn on the hills, twenty-five bushels to forty bushels on the bottoms; ten bushels to forty bushels wheat, twenty-five bushels to seventy-five bushels oats per acre. Blue grass is making its appearance. Red and yellow elover do well. Stock raising has been made profitable by a few persons on the streams, where native grasses and clover, growing wild, furnish good pasture. Farm.wages, from twenty-five cents to fifty cents a day; sixty dollars to seventy-five dollars by the year with board.

\section{Fairfield Countr.}

Fairfield Township (E. D. 79) : Lands level, rolling, sometimes hilly and broken. Soil, light gray sandy loam, with yellow elay subsoil and red mulatto loam, with red clay, subsoil underlaid by red clay, granite and decomposing rocks. Growth, short leaf pine, oak, elm, walnut. Fine building granite. Little attention paid to stock. Wages of field labor, men, fifty cents to seventy-five cents; women, thirty cents to fifty cents a day. The negro not a success as a tenant. The land for sale at six dollars to eight dollars an acré, and one-half to rent for one-fourth of the erop. Varieties of granite, iron rock and soapstone oceur. Gold and iron have been mined. Bermuda grass and clover do well; also crabgrass and swamp grasses. Stock raising is found profitable. One-twentieth of the field work performed by whites.

Fairfield, No. 10 Township (E. D. 76): Hilly, rolling or broken. Soil, a fine sandy loam, with yellow clay. Subsoil, a heary clay loam, and a 
shallow, gravelly soil, with red subsoil of red elay, mixed with gravel; under the subsoil strata of red clay and sand of variegated colors, with gravel, are found. Growth, red and white oak, hickory, ash, walnut and short leaf pine. Crops, one-third of a bale of cotton, cight bushels corn, five bushels wheat, ten bushels to thirty bushels oats per aere. Know of no lands for sale; rents are one-fourth the crops. Farm labor, from twenty-five cents to fifty cents a day.

No. 2. Tounship (E. D. 6S) : Elevated, broken and hilly. Soil, fine sandy loam, with red clay subsoil, underlaid by soft rock. Growth, oak, hickory and gum. Crops, one hundred pounds lint cotton, six bushels corn, five bushels wheat, fifteen bushels oats per acre. No land for sale, but much rented for three dollars to four dollars an acre. Very little field work done by whites.

No 1. Tounship (E. D. 67) : Elevated and mostly hilly, with some tableland, considerable bottoms on Broad river and its tributaries. Soil, of a gray, chinquapin, sandy loam, and red clay loam. Subsoil, red or mulatto clay. Growth, oak and hickory, and old field pine, the latter assisting greatly the recuperation of worn out soil. Crops, three hundrerl pounds to fifteen hundred pounds seed cotton, six bushels to twenty-five bushels corn, fifteen bushels to fifty bushels oats, eight bushels to fifteen bushels wheat per acre. Little land for sale, most of it rented for onefourth of the crop, or for from one to six bales of cotton for a one-horse farm. Good water power at Lyles's ford, on Broad river. The Egyptian or Means grass grows luxuriantly on the red lands. Wages of field labor, fifty cents a day; one-fifth of it performed by whites.

No. 1. Tounship (E. D. 67): Hilly; three-quarters of the soil coarse and sandy; one-fourth stiff red clay. Subsoil, red or mulatto colored clay. Growth, oak, hickory, pine and blackjack. Some land for sale at eight dollars to ten dollars an acre. Wages, forty cents a day, except in harrest time, then one dollar and fifty cents. One-fifteenth of the labor is white.

No. 5. Tounship (E. D. 71): Lands elevated and rolling. The soil is a sandy loam. Subsoil, stiff red clay, underlaid by rotten granite. Growth, red, white and blackjack oaks, and old-field pine. Cash price of lands, in large tracts, three dollars; in smaller tracts, six dollars to seven dollars an acre. Most of it is rented; field stock and implements furnished for one-half the crop, or for from two to four bales of four hundred and fifty pounds of cotton for one-horse farm. Traces of gold found, but not mined. One-fifth of the field labor performed by whites.

No. 4. Township (E. D. 70) : Elevated and broken. Soil, gray and yellow, gravelly, and sandy loam, and red clay loam. Subsoil, red clay. Growth, oak and hickory. Crops, four hundred pounds seed cotton, ten bushels corn, ten bushels wheat, twenty bushels oats per acre. Some 
lands for sale at six dollars to seven dollars an acre; rent for about one dollar and fifty cents.

\section{Greenville County.}

Greenille Township (E. D. 82): Land rolling. Soil, gray sandy loam, four inches to subsoil of fine red clay, underlaid by soft gray rock. Growth, red, white, black and chestnut oaks, hickory, ash, walnut, dogwood and pine. Crops, about eight hundred pounds seed cotton, and twenty bushels of the various grains per acre. Lands sell for ten dollars to forty dollars an acre. There is good brick clay and abundant water power on Reedy and Saluda rivers. About one-fourth of the field work is performed by whites.

Gant Township (E. D. S3): From level to rolling; more or less hilly and broken on the streams Soils, a gray sandy loam and a red clay loam, six inches to sixteen inches to subsoil of red or brown clay, underlaid by sound and rotten granite, sometimes coarse and fine gravel. Growth, as in last, with the addition of long leaf pine. Crop, one-half bale of cotton per acre. Clover and the grasses do well, when attended to. Attention is being directed to fruit culture, especially apples. Price of land from ten dollars to fifteen dollars an acre. A large proportion rented for onethird the crop, or where stock, tools, seed, provisions and feed are advanced, for one-half the crop. Cost of fertilizer divided by renter and owner. Iron ores occur. Abundant water powers on Reedy and Saluda rivers. No climatic disease. One-twelfth or more of the farm work performed by white men, women and children.

Bates Tounship (E. D. 96): Land rolling. Soil, coarse, dark, sandy loam, six inches to eight inches to subsoil of deep red, sometimes of dark, mulatto clay, underlaid by clay and dark gravelly sand. Growth, oak, hickory and chestnut. Crops, six hundred pounds to seven hundred pounds seed cotton, twelve bushels to forty bushels corn, cight bushels wheat, fifteen bushels oats per acre. Lands sell from six dollars to ten dollars an acre; improved bottoms at forty dollars to fifty dollars; rent; from two dollars and fifty cents to five dollars per acre, or for one-third the grain and one-fourth the cotton crop. Granite and red soapstone, with other good building materials found. Gold found in the branches. Wild clover, grasses and cane furnish forage. Three-fourths of the labor performed by whites.

Dunllin's Tounship (E.D.S5): Mostly rolling, some parts level and some flat. Soil, a gray sandy loam, and a red clay loam, both with red clay subsoil, underlaid by coarse gray gravel ; sometimes by gray rock mixed with flint. Growth, oak, hickory and pine. Crops, one-half to one and 
one-half bales of cotton, fifteen bushels corn, seven bushels to twenty bushels wheat, fifteen bushels to fifty bushels oats. The mud bottoms on Reedy river will produce fifty bushels of corn to the acre, and the corn crop would be largely increased, if this stream, now much obstructed by logs, was cleared out. Clover, lucerne and the grasses do well, when attended to. Lands sell for ten dollars an acre; about one-half is rented annually. Shoals on the Saluda river unimproved, afford abundant water power. Good building granite is found. Farm wages, from eight dollars to ten dollars a month. One-half the field work performed by whites.

Paris Mountain Township (E. D. 90 and 97): Level, broken and hilly. Soils, sandy, chocolate and clay loam. Subsoil, red clay, underlaid by a white gravelly earth, containing mica. Growth, oak, hickory and pine. A little land for sale from five dollars to twenty dollars an acre. Building granite and soapstone are found. Farr's mills and Mackelheny's shoals on Saluda river furnish water powers. Farm wages, fifty cents a day; one-half performed by whites.

\section{Lancaster County.}

Waxhaw's Tounship (E.D. S4): Land rolling. Soil of southern portion red loam, ten inches to red clay. Subsoil, granite, crossed by porphyritic dykes. Northern portion, coarse, light colored sand, four inches to white clay, rocks, talcere slate; underlying subsoil a light colored dirt, showing mica. Growth, oak, hickory, short leaf pine and holly. Crops, eight hundred pounds seed cotton, and twelve bushels com per acre. No land for sale. Plenty to rent for eight hundred pounds to fifteen hundred pounds lint cotton to the work animal. Splendid water power near Land's ford, on the Catawba. Field labor paid fifty cents a day, without rations; comparatively none performed by whites.

Pleasant Hill Township (E. D. 42): Generally level. Soil, coarse sand, three inches to eight inches to red clay subsoil. Growth, pine, oak, and hickory; on the bottoms, black gum and poplar. Crops, six hundred pounds cotton (seed), ten bushels com, eight bushels wheat, ten bushels or twelve bushels oats per acre. Not much land for sale. Unimproved land is selling for three dollars, improved land for five to ten dollars an acre; rents for one-fourth of the crop. There is a gold mine, and kaolin is found. Long and short leaf pine in abundance. Little attention paid to stock; might be profitably raised. Have practiced medicine here for twenty-three years, and know of no place freer of disease. More than one-half the field labor is performed by whites. Wages, fifty cents a day and fed. 
Cedar Creck Tounship (E.D.1S): Elevated, hilly, and broken. Soil, coarse sand and sandy loam; subsoil, yellow clay, underlaid by red, gravelly clay. Growth, short leaf pine, oak, and hickory ; abandoned ficlds grow up in loblolly pines in three to six years, which, in turn, give place to cedar. Crops, seven hundred pounds of seed cotton, eight bushels corn per acre. Land sells at from three dollars to ten dollars per acre. Unlimited water power on the Catawba river, which is one hundred and fifty yards wide, three feet deep, and flows nearly with the velocity of a cataract. Little attention paid to stock. It might be made profitable. Good building granite. Very healthy. Wages of field labor thirty to fifty cents a day.

Flat Creek Township (E. D. 79): Some level land, but mostly hilly and rocky. Soils, coarse and fine, white, sandy loam and red clay loam; subsoil, a red clay. Growth, long leaf pine, oak and hickory. Crops, one-half bale of cotton, ten bushels corn, ten bushels wheat, ten bushels oats per acre. Price of land, from two dollars to ten dollar's. There are several gold mines. Valuable mill sites on Lynch's River.

Cane Creek Tounship: Elevated, rolling, in some places nearly level. Soil, a fine, sandy loam, changing to clay loam near the streams; subsoil, red clay, underlaid with yellowish clay and gravel. Growth, oak and hickory, also short leaf pine. Crops, eight hundred pounds seed cotton, ten bushels corn, fifteen bushels oats per acre; an average, on twenty acres, of eighteen hundred pounds seed cotton has been made. Know of no land for sale. At Land's ford, the Catawba river is three-quarters of a mile wide, one foot to three feet deep, with a fall of thirty feet to the mile. Lucerne, red and white clover, orchard, meadow, red top and blue grass, all do well. These lands sold for fifteen dollars to twenty-five dollars before the war, and have been under cultivation for nearly two hundred years.

\section{Laureas County.}

Jacks Township (E. D. 103): Elevated and rolling. Soils, red or mulatto clay loam, with red clay subsoil, and gray, sandy lands, with a lightcolored clay subsoil. Growth, red, white, post, and water oaks, hickory and walnut, some sugar maple. Hundreds of acres of abandoned land are grown up in short leaf pine; in the last decade, many long leaf pines have appeared among them, and are rapid growers. - Crops, five hundred pounds seed cotton, eight bushels corn, twenty bushels oats, eight bushels to ten bushels wheat, are about the average; on the bottoms, fifty bushels corn per acre is made. Know of no lands for sale. There are thousands of acres, owned by non-residents, rented to freedmen for a portion of the 
crop, and miserably farmed. There is an immense amount of fine granite. No prevailing sickness. Amount of field work performed by whites increasing. Wages, fifty cents a day and rations.

Waterloo Tounship (E. D. 106): Hilly, washes when not properly ditched. Soils sandy, gravelly, and clay loam ; color mulatto, sometimes a deep red ; depth, two inches to three inches to a pale red clay subsoil, underlaid by elay, and in some places, by a dusky or bluish sandy earth. A very hard, bluish granite rock found in some wells. Growth, red, white, and post oak. Lands thrown out of eultivation grow up in pine, and are more productive than the original forest. Crops, six hundred pounds to twelve hundred pounds seed cotton, ten bushels corn on uplands, and fifty on bottoms, fifteen bushels oats, eight bushels wheat per aere; erab grass, after small grain, yields, sometimes, hay to the value of twenty dollars an acre. Lands for sale at from five dollars to twenty dollars per acre. Indications of gold are found in many places, but no mines are worked. Reedy river and Saluda river furnish valuable water powers. These streams are much obstructed by logs. Farm labor paid ten dollars a month, generally employed for a share of the crop; one-fourth of it is performed by whites.

Sullivan's Township (E. D. 105): Elevated ridges and level land between the streams. Soils, a fine sandy loam, gray and chocolate in color, and a red clay loam, resting on red clay subsoil. Growth, oak, hickory, ash, dogwood, poplar, walnut and elm, with abundance of cedar along the Saluda river. Crops, five hundred to twelve hundred pounds seed cotton, ten bushels to thirty bushels corn, twenty bushels to thirty bushels barley, fifteen bushels to sixty bushels oats, and eight bushels to twenty-five bushels wheat to the acre. Land ean be bought at five dollars to ten dollars an acre; rents for one-fourth of the crop, or eight hundred pounds lint cotton to the plow; sometimes the laborer boards limself and pays one-half to the land owner, who furnishes everything else. Gray and blue granite, the latter used as mill rocks, are found. Gold, copper and lead are found, but not mined. Lime rock crops out on Reedy river, and below Garlington falls, on Reedy river, it is quarried for monuments and for lime burning; soapstone of fine quality also occurs. The great falls on Saluda river, at the head of navigation, are seventy feet in two miles. Abundant water powers are also furnished by other falls on the river, by five falls on Reedy river, by falls on Rabnor creck. Very healthy. Onehalf the field work performed by whites.

Scuffletown Township-(E. D. 104): Undulating. Soil, gray, gravelly, sandy loam; subsoil, elay. Growth, oak, hickory, maple, pine, cedar and walnut. Crops, six hundred pounds to twelve hundred pounds seed 
cotton, five bushels to thirty bushels corn per acre, Know of no land for sale; rents for one-fourth of the crop.

\section{Newherry County.}

Cromer Tounship (E. D. 112): Level and flat, rolling on the rivers. On the levels; fine, gray, sandy loam, six inches to eight inches to subsoil of red clay. The rolling lands have a clay soil and subsoil; sand and gravel underlies the subsoil. Growth, oak, hickory, walnut, cedar and pine. Crops, one-half bale of cotton, ten bushels corn, twenty bushels oats, eighty bushels barley, nine bushels wheat, seven bushels rye per acre. About one-tenth of the land for sale for six dollars to eight dollars an acre, and one-half to rent for one-fourth of the crop. Varieties of granite, iron rock and soapstone occur. Gold and iron have been mined. Bermuda grass and clover do well, also crab grass and swamp grasses. Stock raising is found profitable. Field labor is paid fifty cents a day; one-twentieth of it performed by whites.

HellerTounship (E. D. 119): Lands elevated, level, along the streams, hilly. Soils, fine sandy loan, gray or whitish, eight inches to twelve inches to subsoil of fine, compact, red clay, free from grit. Growth, oak, hickory, short leaf pine, walnut, mulberry, ash and maple. Japan clover and Bermuda grass cover the land when left uncultivated, and the Egyptian or Means grass grows luxuriantly along the borders of streams, and on sandy bottoms. Land for sale in small tracts at eight dollars to ten dollars an acre; three-fourths of it for rent; if stock, stock feed, and implements are furnished, the rent is one-half the crop ; for the land alone, it is four hundred pounds lint cotton for every twelve or fifteen acres, or one-third of all crops. Granite of the finest quality for building abounds. Splendid water powers on Broad river and Hellers creek. Little attention paid to stock raising. Wages, seventy-five dollars to eighty-five dollars per annum, or fifty cents a day, with board. One-fifth to one-seventh of the field labor performed by whites.

Jalapa Tounship (E. D. 113): Lands hilly and broken. Soil, red clay loam, eight inches to red clay subsoil, underlaid by red clay. Growth, oak and hickory. Three mill sites. Wages', fifty cents a day with board. Very little white labor; negro labor very unreliable, only willing to work about one-third of the time.

Saluda Old Toun Tounship (E. D. 115): Lands level or gently undulating, broken into abrupt slopes near the rivers-and creeks. Soil, on the uplands, red clay loam and gray, sandy loam, subsoil of red-rarely of yellow-clay; a very fine and nearly white granite underlies the clay at the depth of ten to twenty feet. The Saluda river bottom averages a 
mile in width, and is a very rich, alluvial soil. Growth, short leaf pine, oak, ash, hickory, walnut, poplar; a considerable variety of native grasses afford good summer pastures, both on the uplands and in the bottoms, and canc for winter pasturage is abundant. Crops from onc-third to one bale cotton, seven bushels to fifteen bushels corn on uplands, and twenty bushels to sixty bushels on bottoms, twenty bushels to fifty bushels oats, eight bushels to twenty-five bushels wheat per acre. One-fourth of the land for sale at six dollars to twelve dollars an acre; one-half for rent for two to two and one-half bales of cotton for a one-horse farm of thirty acres or more. There is a mill-dam across Saluda river. Little attention is paid to stock. Field labor is paid fifty cents a day; about one-sixth of it is performerl by whites. Locality healthy. Traces of gold are found. - May'inton Township (E. D. 111): Bottoms level, uplands rolling, hilly and broken near the water courses. Soil, red clay and gray, sandy loam, underlaid by red and snuff-colored clay; depth of soil, three inches to five inches; below the subsoil, granite, gneiss, hornblende and traprocks occur. Growth, hickory, several varieties of oaks, short leaf pine, cedar, walnut, dogwood, ash, poplar; cane abundant in the bottoms. Crops, from four hundred pounds to twenty-nine hundred pounds seed cotton, from five bushels to one hundred bushels corn, from six bushels to forty bushels wheat, from twenty bushels to one hundred bushels oats an acre; clover has given four tons per acre. All for rent for from one hundred pounds to three hundred pounds seed cotton per acre; not much land for sale; price seven dollars to fifteen dollars per acre. There is excellent granite for building. Broad river is six hundred yards wide; depth, in shoals, four feet; velocity, in shoals, estimated at thirty miles an hour; fall, at Lyles ford, eighteen feet in a mile. Ennoree river eighty yards wide, six feet deep; velocity, six miles in an hour. Wages of field labor fifty cents a day; one-fourth performed by whites. Very healthy.

\section{Spartanburg County.}

Cowpens Township (E. D. 145): Rolling. Soil, coarse, gray, sandy loam, with subsoil of red clay, underlaid by mica slate. Growth, white and post oak, hickory and pine. Bottom lands very fortile. Gold is found, and there are several fine water powers on Pacolet river, notably at Clifton cotton factory. One-half of the labor is performed by whites.

Glenn Springs Township (E. D. 143): Elevated, level. A dark gray, sandy soil, eight inches to ten inches to subsoil of red clay. Growth, oak, hickory, pinc. Crops, six hundred pounds seed cotton, eight bushels to ten bushels corn, eight bushels to ten bushels wheat, twenty bushels to forty bushels oats per acre. Land sells from five dollars to twenty dollars 
per acre, and rents for one-third of the crop. There are several gold mines and an asbestos mine. Glenn Springs has long been a health resort for those using mineral waters. One-third of the labor is white.

Cherokee Tounship (E. D. 140): Elevated, rolling, with steep hills on the large streams. Soil, a gray, sandy loam, with yellowish sandy subsoil, and a red clay loam, with stiff, red clay subsoil, underlaid by a yellowish isinglass earth that crumbles on exposure, and enriches the soil when strewn on the surface. Growth, oak, hickory, and pine. Crops, seven hundred and fifty pounds seed cotton, ten bushels corn, eight bushels wheat, fifteen bushels oats per acre, a yield that is more than doubled by manuring and good culture. Lands sell for eight dollars to ten dollars an acre; rent for one-fourth of the crop, or, with stock and tools, for one-half. Bottom lands are very fertile. Gold is found, and iron mines were formerly worked. There are several mineral springs. The north fork of the Pacolet furnishes great water power. All the cultivated grasses may be grown. Farm wages, fifty cents a day; threefourths performed by whites.

Fairforest Township (E. D. 142): Rolling; on the water courses, hilly and broken. A gray, sandy loam, underlaid by a yellowish or dark red clay, is the prevailing soil; there is some clay loam; ten to fifteen feet below the clay subsoil, rotten, and sometimes decomposed, granite and gneiss are found. Growth, oak and hickory, occasionally chestnut and walnut. Crops, four hundred pounds to eight hundred pounds seed cotton, ten bushels to fifteen bushels corn, five bushels to ten bushels wheat per acre, without fertilizers. Traces of gold. Valuable water powers on Tyger river. The ridge between Tyger and Fairforest rivers is well adapted for fruit growing, being seldom affected by frosts. Lands are advancing in price, selling from eight dollars to fifteen dollars an acre. A bout one-half the farm labor performed by whites.

Pacolet Tounship (E. D. 145): High, table land. Soil, a fine sand, twelve to fourteen inches to a light red clay subsoil, deepening in color as you descend; at twenty to twenty-eight feet, solid or disintegrated granite is met; in the northwest, lands are red clay. Lands sell from ten dollars to fifteen dollars an acre, and rent for one-third of the crop. There is a quarry of fine granite. Shoals on the Pacolet have a fall of twenty-two and one-half feet in one hundred yards, and a mile below, there is another fall of thirty-three feet. All garden vegetables, melons and grapes do well. Rich Hill, a high plateau, six miles in extent, between the Pacolet and Fairforest rivers, is unequalled for the production of fruits of all kinds. Frosts have injured it but once in forty years. Farm wages, from eight dollars to ten dollars a month. Twothirds of the field work done by whites. 


\section{Union County.}

Union Township (E. D. 150): Lands broken, hilly. A light, gravelly soil, resting on red clay subsoil, underlaid by granite rocks. Water of the shallower wells impregnated with magnesia; of deeper wells penetrating the granite freestone. Growth, short leaf pine, oak, dogwood, sassafras, walnut, beech, poplar. Price of lands much advanced since passage of stock law; sell for ten dollars to twenty dollars an acre. A fine-grained, hard, durable, and easily split granite abundant. Water powers, a fall of twenty feet on Fairforest river, over granite rocks, and another of five and one-half feet; several falls on Tyger river. Stock raising not considered profitable. No attention paid to anything but cotton. No prevailing disease. Very healthy.

Gowdeysville Township (E. D. 156): Hilly, and a good deal broken. Prevailing soil red clay, with a red clay subsoil; some sandy soil, with white clay subsoil. Underlying subsoil is granite, and some rotten rock, or white clay. Growth, short leaf pine, oak and hickory. Bermuda and Means grass thrive. Clover grows finely. Creek bottoms, rich, sandy and vegetable loam. Crops, seven hundred pounds seed cotton, corn, upland, twelve bushels to twenty-five bushels, and fifty bushels on bottoms per acre. Lands sell from five dollars to fifteen dollars an acre; rent for one-third of the crop. Several mill sites on creeks, and unlimited water power on Broad river. Stock might be profitably raised, but no attention is paid to it. Field labor, ten dollars a month, and fifty cents a day. No local disease. Three-fifths of the field work performed by whites. Several gold and iron mines.

Santee Township (E. D. 149): Lands generally level towards centre of township. Prevailing soil is a fine white sandy loam; along Broad and Tyger rivers, red elay hills; depth to subsoil of pipe clay six inches to twelve inches. Sand underlies the pipe clay. Growth, short leaf pine, oak and hickory. Average crops, six hundred pounds seed cotton, ten bushels corn, and fifteen bushels oats per acre. Price of lands increased from two dollars and fifty cents to ten dollars per acre, since passage of stock law. Sandy lands considered the poorest before the use of commercial fertilizers, now bring the highest prices. A neighbor made last year forty bales of cotton, a sufficiency of corn, and sold seed oats, on a twohorse farm. Not an isolated case. Know of no lands for sale. Most of it to rent for three four hundred and fifty pound bales of cotton for a one horse farm, which usually contains forty aeres in cultivation and sixty acresin old field pastures and woodlands. Almost impossible to hire a hand for wages. Laborers prefer to work on shares or to rent. A mill site on Broad and also on Tyger rivers. No attention paid to stock. Day labor 
on farm, fifty cents a day, with rations; seventy-five cents without. Very healthy. Don't know a doctor who lives by his profession in the county. One-fifth of the field labor performed by whites.

Goshen Township (E. D. 155): Hilly and rolling. Soil, fine, dark gray, light sandy loam, two inches to four inches to subsoil of stiff red elay, or pipe clay, with rocks underlaid by whitish sand, hard and soft rocks, with some isinglass. Growth, different oaks, poplar, ash, walnut and pine. Crops, one-half bale of cotton, eight bushels to fifteen bushels corn, on uplands; twenty bushels to fifty bushels, on bottons; ten bushels to eighty bushels oats, four bushels to ten bushels wheat per acre. Clover and the grasses do well, where attended to. Lands sell from five dollars to ten dollars an acre; rent for three bales of cotton for a one-horse farm. Farm hands paid eight dollars a month. No attention paid to stock raising, except some fine horses. A very small proportion of the labor is white.

\section{YORK COUnTY.}

King's Mountain Township (E. D. 170): Lands rolling or level, in places mountainous, elsewhere hilly. Soils, sandy, rocky gravelly or clay loam, with red or yellow clay subsoil. Growth, oak; where cut down it is succeeded by broom sedge and pine. Crops, twelve bushels corn, upland; thirty bushels creek bottom; wheat, ten bushels to twenty bushels; oats, ten bushels per acre. The poorest soils yield cotton well, with aid of guano. Fine monumental granite, iron ores and barytes are found. Lands sell for from two dollars and fifty cęnts to ten dollars an acre. Healthy; negroes suffer from consumption. Wages of field labor, fifty cents a day, or ten dollars a month, with board; one-half of it performed by native whites.

Bethesda Township (E. D. 162): The hilly and rolling lands are red clay or sandy soils, with yellow clay subsoil. These are the best cotton lands. The level or flat lands are the blackjack lands. Black, rocky soils, with pipe clay subsoil, underlaid by a hard, whitish, gravelly substance, produce the small grains well, but cotton rusts and continues yellow or frenches after a few years cultivation, unless stable manure is applied. Lands sell from two dollars to twenty-five dollars an acre, and rent for eight hundred pounds of lint cotton for a one-horse farm of twenty-five or thirty acres. 


\section{CHAP CER VIII.}

\section{THE A L PIN E REGION.}

\section{LUCATION.}

The Alpine Region of South Carolina occupies the extreme northwestern border of the State. Commencing at King's mountain, in York county, it extends westward through Spartanburg, Greenville, Pickens and Oconee counties, widening in the three last named, until it embraces a tier of the most northern townships, two or three deep. This wedgeshaped area has a length of one hundred and fourteen miles, and a width varying from eight to twenty-one miles.

\section{THE PHYSICAL FEATURES}

of this region present a rolling table-land, broken and hilly on the margin of the streams, but scarcely anywhere inaccessible to the plow. It has a general elevation above the sea level of 1,000 to 1,500 feet. The gently undulating surface extends to the mountains, whose rock-bound walls often rise suddenly to their greatest height. The southeastern face of King's mountain rises perpendicularly five hundred feet above the plain, and its northwestem slope descends gently towards the Blue Ridge mountains. Table Rock also rises eight hundred feet vertically, or a little overhanging above the southeastern terrace at its base, formed of the loose fragments that in the course of ages have fallen from above. The steep ascent of these mountains from their South Carolina or southeastern face, and their gradual slope on their northeastern face, and their gradual slope to the northwest, where the mountains of North Carolina rise apparently from a level country, is the reverse of the prevailing rule on the Atlantic slope, which is, that the short, steep sides face northwest, and the long, gentle slopes face southeast. Lieber thinks that these 
mountain cliffs indicate the occurrence here, in the remote past, of a great fissure or crevasse in the earth's crust, a gigantic fault when the southern slopes fell down hundreds of feet and exposed the preeipitous rock walls that now face the southeast.

The boundary line of South Carolina reaches the most ensterly chain of the Appalachian mountains, known here as the Saluda mountains, near the corner of Greenville and Spartanburg counties, and follows the summits of the ridge for fifty miles (thirty miles in an air line) until it intersects the old Cherokee Indian boundary line. From this point the mountain chain, here called the Blue Ridge, curving lightly to the north, passes out of the State, and the boundary line pursues a more southerly and a straight course to where the east branch of the Chatuga river intersects the thirty-fifth degree of north latitude. The Chatuga, flowing westward to its junction with the Tugaloo river, which in turn becomes the Savamah river, flowing to the southeast, are the northwestern and western boundaries of the State. The mountain chain divides the waters of the State flowing to the Atlantic Ocean from those flowing northward, which eventually find issuance to the southwest through the Tennessee and Mississippi rivers into the Gulf of Mexico. Considering the water-shed of South Carolina alone, the culminating point whence the rivers of this section flow, is to be found in the horse-shoe curve of the mountain chain north of the straight boundary line referred to as uniting the Chatuga and the Blue Ridge. Hence the numerous sources of the Keowee river, White Water, Toxaway, Jocassee and other creeks take their rise and flow nearly due south. The main stream of the Saluda sweeps away to the east, and the Chatuga hurries westward.

It was from a noted summit of this range (Whiteside) that Mr. James E. Calhoun observed, as early as 1525 , that the eharacter of the mountains change from an unbroken chain to isolated masses towards the south. Such isolated masses form a striking feature of the mountains of South Carolina, and they make their appearance over a wide area of the State, extending west and east from Stump House mountain, near Walhalla, in Oconee eounty, past Paris mountain, in Greenville, Gilke's mountain, in Union, to King's mountain and Henry's Knob, in York. Southward they reach to Bird's mountain, in Laurens, Parson's mountain in Abbeville, and Ruft's mountain on the Newberry and Lexington line. The narrow mountain ridge that divides the river system of the Mississippi from that of the Atlantic slope, and the interdigitation, as it were, of the sources of the Hiwassee and Tennessee with those of the Savannah, have long suggested to engineers the possibility of establishing an interflow between these waters. A canal, Mr. Calhoun says, across Rabun Gap would pour thirty-five miles of smooth water from the Little Temnessee 
into the Tugaloo river, while the Chatuga, the Hiwassee, the Toxoway, and innumerable mountain streams of this well-watered region would serve as feeders to maintain the water supply in any desired quantity. In 1873 water was drawn from Black ereek, an afluent of the Tennessee, across the Gap, to Izell's mills, on Chicken creek, an affluent of the Savannah.

The elevation above the mean level of the sea of the following points in western South Carolina were determined by the United States Coast Geodetic Survey: King's Mountain, 1,692 feet; Paris Mountain (near Greenville), 2,054 feet; Casar's Head, 3,118 feet; Mt. Pinnacle (near Pickens, the highest point in South Carolina), 3,436 feet.

The bracing and healthy elimate of this region, its beautiful scenery, the bold mountain outlines, the rich luxuriance of every growth, no stunted plant on mountain side or summit, every part, even the crevasses of the rocks, covered with trees and shrubs of some kind, all full of life and vigor; the clear, swift streams that everywhere leap in a succession of cascades from crag and cliff, and sparkle in their course along the narrow but fertile valleys, have made it for generations a health and pleasure resort during summer.

\section{THE GEOLOGICAL FEATURES}

of this region are very similar to those of the one lying immediately south of it. The prevailing rock is gneiss, sometimes changing into granite, of good building qualities, and sometimes slaty, furnishing superior flagging stones, a remarkable locality of which oceurs eight miles south of Pickens Court House, on the Greenville road. For the most part, the rock is found at a depth of thirty to fifty fect beneath the surface in a state of greater or less decomposition. Above the gneiss, whose out crops are much confined to the beds of streams, islands of mica slate, occupying the more elevated lands, are found. The largest of these isolated bodies extends for a considerable width along the ridges above the Chatuga river.

The proportion of mica slate is greater here than elsewhere in the State. Between the mica slate and the gneiss, and cropping out almost everywhere around the edges of the first named rock, are extensive seams of hornblende rock, and its decomposition adds largely to the fertility, especially of the ereek and river bottoms, of this region. Above the mica slate, on the large body of that rock on the Chatuga, some tale slate is found. The last named slate underlies a considerable area of itacolumitie sandstone that, in turn, support several bodies of limestone rock. A number of limekilns have been in operation here. 
Of the useful ores and minerals of this section, it may be further stated :

There are numerous gold deposits, at some of which washings have been carried on with much profit. Vein mining, in spite of many promising indications, has not been regularly undertaken.

Indian and Revolutionary traditions tell of lead mines, which in former times furnished belligerents with an ample supply of this necessary metal. Unfortunately, these traditions have not preserved the disclosure of their locality. At the Cheohee gold deposit mine, on the headwaters of Little river, in Oconee county, Lieber examined a very promising vein of argentiferous galena, which he thought might be profitably developed.

Traces of copper were observed by Lieber on Tyger river, in Spartanburg county, near the Galena mine above mentioned, and in some mill races in southern Pickens and Greenville.

Graphite is found on Paris mountain, and also in Oconee county.

Manganese and iron occur, but have not been explored.

Valuable soapstone quarries have been worked to a limited extent in Pickens. Large sheets of transparent mica have been found near Walhalla, and asbestos of good quality is reported as occurring near Seneca City.

\section{THE SOILS.}

The soils are similar to those found elsewhere in the State, which are produced by the decomposition of gneiss rock in situ. On the more level uplands, a gray, sandy loam, with a red, and sometimes on the mica slates, with a yellowish white, clay, predominates. On the hillsides, a stiff, red clay soil prevails. In the bottoms, a still darker loam, more thoroughly saturated with lime and potash from the decomposed hornblende and mica slates, is found. Those bottom lands have long been highly esteemed as yielding abundant crops of corn, the small grains, and the grasses. Little thought or attention was bestowed on the uplands previous to the attempt so successfully made within the last few years to introduce upon them the culture of cotton.

\section{CLIMATE.}

According to the physical charts of the ninth United States census, and the rain charts of the Smithsonian Institute, $2 \mathrm{~d}$ Ed., 1877, this region has a mean annual temperature corresponding with that of Kansas or New Jersey. The more mountainous portions have, however, a mean annual temperature that corresponds with that of Montana, or the lower 
region of the great lakes. The mean of the hottest week of 1872 , taken at $4 \mathrm{~h} .35 \mathrm{~m}$. P. M., was $90^{\circ} \mathrm{F}$. The mean of the eoldest week of $1872-3$, taken at $7 \mathrm{~h} .35 \mathrm{~m}$. A. M., was $25^{\circ} \mathrm{F}$.

The prevailing winds are from the southeast, and the mean velocity of the movement of the atmosphere is much below the average for the United States at large, In the frequency with which the region is traversed by storm areas of say fifty miles in diameter, it ranks with the lowest in the United States. With the more extensive region south of it, it is peculiarly exempt from destructive storms.

Blessed with an unusual number of clear days and a large amount of sunshine, the fig tree thrives here without protection, at an elevation of fifteen hundred feet above the sea. "The climate is less subject to sudden changes than in the plain below. Vegetation is late, but when once fairly begun, is seldom destroyed by subsequent frosts. Neither are there any marks of trees being struck by lightning,* or blown up by storms." (David Ramsay, Hist. of S. C.)

The annual fall of water is over sixty inches, and this is, therefore, among the regions of heaviest precipitation in the United States. For spring, it is over eighteen inches, and for autumn, it is twelve inches, which are also the maximum in the United States. In winter, it is sixteen inches, which is less than the maximum, and in summer, it is fourteen inches, which places it third in a series of five, or just medium. Dewless nights rarely occur, and the luxuriant vegetation of this region does not in consequence suffer from the rigor of extreme droughts so frequent elsewhere.

The following observations on the temperature of springs in this region were made by Lieber:

\begin{tabular}{|c|c|c|c|}
\hline \multirow{2}{*}{ LOCALITY. } & \multirow{2}{*}{$\begin{array}{c}\text { TIne of } \\
\text { Observation. }\end{array}$} & \multicolumn{2}{|c|}{ Temperature. } \\
\hline & & ATMOSPHERE. & WATER. \\
\hline $\begin{array}{c}\text { Poinsett Spring, in Greenville, } \\
\text { near N. Carolina line. }\end{array}$ & 7th June, $7 \frac{1}{2}$ A. M. & $72.050^{\circ}$ & $56.86^{\circ}$ \\
\hline $\begin{array}{c}\text { Spring on Jones' Gap Road, } \\
\text { near Turnpike gate. . . }\end{array}$ & 16th June, 2 P. M. & $75.74^{\circ}$ & $57.56^{\circ}$ \\
\hline Cold Spring, or Cæsar's Head. & 29th June, $9 \frac{1}{2}$ A. M. & $80.60^{\circ}$ & $55.40^{\circ}$ \\
\hline House Spring, Cresar's Head & 29th June, $10 \frac{1}{2}$ A. M. & $78.80^{\circ}$ & $57.56^{\circ}$ \\
\hline
\end{tabular}

*It is a saying in this region that "to pick the teeth with a splinter from a tree struck by lightning. will cure the toothache;" the meaning being that such a splinter is not to be had. 


\section{GROW'TH.}

The prevailing growth is oak, chestnut, and short leaf pine. Proceeding toward the mountains, the following trees mark the ascent in the order here named: Rock chestnut, osk (quercus primus monticola), cucumber tree (magnolia accuminatar), mountain laurel (rhododendron maximum), white pine (pinus strobus), hemlock or spruce pine (abies canadensis). The forest products are shingles, tan bark, and dogwood, with other hard woods, besides abundant timber for building purposes. The Indians once gained their chief livelihood here by gathering and disposing of medicinal herbs, such as spigelia marylandica, ginseng and snake root, which are to be found in great abundance.

\section{S'TATISTICS.}

The Alpine region of South Carolina embraces an area of 1,250 square miles, and is, therefore, the smallest division of the State here treated of. The population numbers 34,496 , an increase since the census of 1870 of sixty-six per cent. This gives the density of the population as twentyseven to the square mile which is below the average of the State, and less than in other regions-the sand hills and lower pine belt alone excepted. Twenty-six per cent. of the population is colored.

Eighty per cent. of the land is wood land and forest, sixteen per cent. is tilled, and four per cent. is in old fields. The area of tilled land has more than doubled since 1870 , being now 132,791 acres, and then, only 64,802 acres. This is $3 . S$ acres per capita of population, against 3.1 acres in 1870 , showing that improvement has more than kept pace with the increase of the population,

The number of farms is $4,6+6$, which gives an average of twenty-eight acres of improved land to the farm. Of this number, forty-three per cent. is under fifty acres, and may be considered as in the hands of small farmers. Nevertheless, there are some large landholders in this region. For instance: Mr. James E. Calhoun owns a body of 100,000 acres* of

\footnotetext{
*On the margin of his plat of these lanis, Mr. Culhoun remarks: "Well timbered. soil good, scenery superb. It is so healthy that no physician ever lived in that part of the country. There are mineral springs. Cultivation is exclusively by white labor. It is a platean within the 'thermal belt.' where fruit is never affected by' frost Gold, iron, lime, lygdraulic cement and kaolin are known to be abundant. Report adds silver, copper, lead and corundum. The Blue Ridge railroad runs twelve miles through it. In its length of twenty-two miles and width of fifteen miles, it would be difincult to find a single spot two miles distant from water powers, of which there are more than eighty miles in direct line, and which, if rlereloped, would be exempt from
} 
land along the Chatuga river, in Oconee county. Of the farms forty-five per cent. are rented, and of the rented farms seventy-four per cent. are under fifty acres-showing that the renters are farmers on a small scalc. Of the fifty-five per cent. worked by their owner's only fifteen per cent. are under fifty acres. Of bona fide small proprietors, if landholders of under fifty acres, who till their own land, may be termed such, the number is small, being only seven per cent. of the total number of farmholders. By far the larger number of farms are rented for a portion of the crop, very few being rented at a fixed money rental. For instance: in five adjacent townships in Greenville, where there are six hundred and thirty-one farms rented, only one is reported as rented at a fixed money rental.

Of the tilled land, $\$ 8,766$ acres, or sixty-five per cent, is in grain of all kinds; 25,740 acres, or twenty per cent., is in cotton; and 18,285 acres, or fifteen per cent., in fallow, and all other crops, including gardens, orchards and vineyards, and a small area in tobacco.

The average yield of grain is only a little over eight bushels to the acre, and does not express the capability of this section for the production of this article. Fields of corn on bottom lands averaging forty to sixty bushels an acre are not uncommon, and the minimum calculation of the crop for uplands without manure is ten to twelve bushels per acre, while twenty to thirty bushels are obtained by good culture. Rice has grown here, without any manure, over one hundred bushels to the acre, though very little of it is planted. The yield of grain per capita is twenty bushels, and is greater than elsewhere in the State, except in the Sand Hill region.

The average yield of cotton to the square mile is 6.3 bales, an increase of over six hundred per cent. since 1870. This is more than upon the coast; in the lower pine belt, and in the sand hill region, but much less than elsewhere in the State. The average yield of lint per acre planted in cotton is one hundred and forty-one pounds, which is sixty per cent. more than the yield on the coast, but less than elsewhere in the State. The yield per capita is one hundred and five pounds of lint against fourteen pounds in 1870. This is one hundred per cent. more than the yield on the coast, and seventy per cent. more than the extensive lower

taxation for ten years. Immigrants are exempt for five years. The northwesteru States onght to be most urgent for an outlet to the ocean through the Tennessee, IIwassee, Tugaloo and Savannah rivers. Besides being the shortest and safest, and always available, it would bring them directly in front of the marts of the world ; whereas, by descending the Mississippi, they are thrown willely away, and, moreover, are made to encounter deadly malarial diseases every season, and yellww fever at short intervals. The eastern eities should also advocate this outlet, since it would place the vast productions of the Northwest within easy grasp of their coast shipping." 
pine belt. Still it is not one-third of the yield in the remainder of the State.

The work stock number 5,798, against 4,096 in 1870 . This is 4.1 to the square mile, the average for the State being 4.4. The ratio of work stock to the population is less than elsewhere in the upper country, but more than in the regions below the red hills. There are twenty-two acres of tillert land to the head of work stock, which is more than elsewhere in the State, except in the red hills and the metamorphic region.

Other live stock numbers 66.035 , being more per square mile than elsewhere in the State, and more per capita of the population except only among the sand hills.

\section{LABOR AND SYSTEM OF FARMING.}

The farms are very rarely larger than can be worked by four horses. The landholdings average from one hundred and fifty to three hundred acres, including woodlands. The larger portion of the farm supplies are raised at home, but near the towns, and along the Air-Line railroad supplies from the west are largely purchased, the system of eredits and advances to the smaller farmers prevails, absorbing with rents, not unfrequently, seven-eighths of the entire crop. Most of the land is rented or worked on shares. The cash rental varies from two dollars and fifty cents to four dollars an acre; the usual terms are one-fourth the cotton and one-third of the grain; where stock and implements are furnished by the landlord, he gets one-half the crop. The average market value of lands is stated at five dollars an acre; improved lands sell at from six dollars to ten dollars an acre. About one-half the field laborers are negroes, and since attention has been given to cotton culture they are on the increase. Wages are fifty cents a day; six dollars to eight dollars a month, with board; seventy-five dollars a year, with board. The condition of industrious laborers is good. The number of negro laborers owning houses and land varies from one to five per cent. according to the locality.

\section{TILLAGE AND IMPROVEMENT.}

One-horse plows are generally used, very rarely two horses. The depth of the furrow on the land side varies from three to four inches. Subsoiling is not practiced. Occasionally lands lie fallow, and the result is beneficial if stock are not allowed to destroy the crop of grass and weeds. Cultivated fallows are unknown. There is no system in the ro- 
tation of crops. After land has been planted two or three years in cotton it is planted one or two years in wheat, corn or oats; the results of such a change are excellent, if stock is kept off the stubble. Fall plowing is little practiced; it has been found of advantage where stubble, grass or weeds cover the land to turn them under at this time. The amount of land in old fields is not great. Such fields, after lying out eight or ten years, have been found to produce as well as ever, and most of them have been brought into eultivation again. The washing of hillsides does not amount to a serious evil, and it is reported as easily prevented and effectually checked by hillside ditching when necessary. The use of commercial fertilizers has largely inereased with the facility of obtaining them by railroad, and the practical demonstration of their value in the culture of cotton. Cotton seed is worth ten to fifteen cents a bushel; little of it is sold. It is applied green and broad-cast as a manure for wheat, and composted with stable manure as a fertilizer for cotton. A portion of it is fed to stock.

\section{COTTON CUL'TURE}

was a leading industry in the upper counties of South Carolina previous to 1826 . The erop raised was from one hundred and twenty pounds to two hundred pounds lint per acre in the four most northerly counties, and areraged one hundred and forty-five pounds. At that date, howercr, and for long afterwards, probably not an acre of cotton was planted in the region now under consideration. The opening of the Air-Line railroarl having reduced the cost of fertilizers, attention was drawn to the large bodies of gray sandy lands hitherto little considered, and experiments in cotton growing by their aid proved so successful that the cultare was largely increased. It has extended over the table lands and even up the mountain slopes, and is now grown in every township of the region except one, Chatuga township, in Oconee county, already referred to as the culminating point of the river system. It has been found that while the season is shorter, the stimulation of the growth by the use of fertilizers compensates for this. The same tillage as is given further south expended here in a shorter period of time has a like effect in pushing the plant to maturity. With slave labor this was inconvenient, if not impracticable. With free labor it is, if anything, easier and cheaper to accomplish thirty days work in three days than to do it in ten. It has been further found that the growth of the plant is steadier here; it does not suffer from those checks during long dewless intervals, which retard its progress in the hotter and dryer sections. The claim is also made, that better cotton is grown here than further south. Experienced cotton buyers have long given 
preference to staples of both long and short cottons grown towards the northern limits respectively of their culture. It is said that the fibres are stronger and of more equal and uniform length, admirable qualities, which might naturally be expected from a short, steady and continuous growth. For all these reasons, together with the improvements in the selection of seed, by which the period of growth is lessened and an earlier and more simultaneous ripening of the fruit is obtained, it is expected that what has been already done is only the commencement of 'a much wider extension towards the mountains of the growth of the cotton plant.

No peculiarities of cotton culture are to be noted in this region. Little or no previous preparation is given to the soil until it is thrown into ridges thirty inches to four feet apart, according to the strength of the land, just before planting. The seed is planted from the 10 th to the 20 th of April, eommencing on the same date as in the region below, but concluding earlier by ten to twenty days. About two bushels of seed are used to the acre, and it is, for the most part, sown by hand, the outlay of twelve dollars for a planter being generally considered too great for the advantage gained, especially by small renters, who hold their farms only for the crop season. The seed comes up in six to fifteen days. The variety preferred is some one of the cluster cottons, prolific bearers, of early maturity. In two weeks after planting, the cotton is chopped out with a hoe to about twolve inches apart, sometimes to only six inches, and on very strong land, intervals of eighteen inches between the plants may be left. If the soil be well stirred with the plow, and kept clean in the drill with the hoe, the cotton will have obtained a height of eight inches to eighteen inches by the 1st to the 10th July, when blossoms will appear. The first blooms are now looked for the latter part of June, but until the last year or two, they were never expected before the 4 th of July, and even that was thought early. Open bolls are seen from the 25th of August to the 1st of September. Pieking commences from the 10 th to the 15 th September. The growing season ends with the first black frost, which oecurs about the 15 th October to the 1st November. The erop is gathered by the 15th to the 31 st December. The plant is considered most productive when it attains the height of two feet. Fresh lands yield scven hundred pounds to twelve hundred pounds of seed cotton. The same lands, after two to ten years culture without manure, yield six hundred pounds to four hundred pounds seed cotton; with moderate manuring and fairly good culture, they improve. It is estimated that it requires here an average of twelve hundred and twenty-five pounds of seed cotton to prorluce a bale of four hundred pounds. 


\section{DISEASES AND ENEMIES}

are restricted here almost exclusively to one-frost. Caterpillar is unknown. A little rust and shedding occur on ill-drained soils, but there is no general complaint regarding them. The vegetable enemies of the plant are crab grass, with now and then complaints of rag weed and Maypop vine.

\section{GINNING}

here differs in no regard from the accounts already given of it in the other regions. The weight aimed at for the bale is four hundred and fifty pounds to five hundred pounds, and the average obtained, from the statements made, is four hundred and eighty-three pounds.

Farmers sell their cotton to the merchants at the nearest railroad station, without charges of any kind, and make no estimate as to the cost of shipping and selling.

The cost of production is estimated at eight cents to ten cents per pound. No itemized statement of the cost of culture could be obtained from this region, and it probably differs in no wise from that in other regions.

Abstract of the reports of township correspondents for the Piedinont Region:

\section{Oconee County.}

Wagner Township (E. D. 120): Lands hilly and rolling, embracing Stump House mountain, the slopes of which are very fertile; below the mountain there is much table or level land. The soils are, 1st, a gray, sandy soil, underlaid by stiff clay, with partially decomposed slates at a depth of fifty feet; this soil is well adapted to cotton: $2 d$, a mulatto soil, producing tobacco well, the culture of which is found very remunerative and is yearly increasing : $3 \mathrm{~d}$, black, loamy soils of creek and branch bottoms, very productive in corn, oats and the grains. The growth is pine, oak, hickory, very large chestnut, and dogwood; the lastnamed wood is being sawn into blocks for shuttles, and shipped north by the carload. One-half mile from Walhalla there is an inexhaustible quarry of very fine building granite; very large plates of mica are also found here. Numerous swift, clear streams afford abundant water porers not developed. Land is cheap, but is not priced by the acre. Stock 
raising might be made profitable. Field labor is paid fifty cents a day, two-thirds of it performed by whites. There are no prevailing diseases.

Keouce Township (E. D. 123): Southern portion nearly level, western portion hilly; Smeltzer's mountain in northeast corner. Soils chiefly gray, sandy soils; the bottoms of the Keowee river, averaging two hundred yards in width, and extending eighteen miles through the township, are very fertile; the subsoil is red, sometimes white clay. Growth, pine, oak, ash, hickory, chestnut, beech, blackjack, dogwood. Crops, corn, thirty bushels per acre in bottoms, twelve bushels on uplands; sweet and Irish potatoes, one hundred bushels per acre; tobacco does well, is grown only for home use; cotton was not planted before 1879 ; the average yield is six hundred pounds seed cotton per acre. Improved lands, with river or creek bottoms, would sell for ten dollars an acre; improved uplands at three dollars to five dollars an acre; forest lands at two dollars; a large pine forest recently sold at less than one dollar per acre. Not more than one-tenth of the lands under cultivation; about one-third of the farming lands for rent, at from one-third to one-fourth the crops, or where stock and tools are furnished, at one-half. There are fourteen fine water powers in the township. There are four tanyards. Most of the farm lands, hitherto neglected, are well suited for cotton culture, under the present method, with the use of fertilizers.

Pulaski Township (E. D. 121): The Stump House mountain belt crosses the southern portion; on the north, along the Chatuga river, and on the west along Tugaloo river, the river hills and eliffs make it mountainous; through the centre a belt three to four miles wide of well-watered rolling land is found. The numerous erreeks and branches erossing it have bottoms, fifty yards to two hundred yards in width, of great fertility, yielding, witl good culture, twenty-five bushels to eighty bushels of corn, and abundant grass crops. Fruits do well; apples, from the early June to the late winter produce well, grapes grow well also. The soil is mostly a sandy loam, with red, sometimes with yellow elay subsoil. Limestone is found and there is a lime-kiln in operation. Soapstone of excellent quality oceurs. Not more than one-twelfth to one-fifteenth of the land is under cultivation. There are numerous water-powers, there being on four streams twelve falls, varying from thirty feet to one hundred feet fall perpendicular. There are indieations of gold, silver and copper ores, but no regular mining is done. Lands sell for fifty cents to ten dollars an acre. Parties clearing have the use of it free of charge for two to four years. Rent is one-third of the crop, or one-half if stock and tools are furnished. Fine stock ranges are found among the mountains, the large droves of sheep, however, destroy the grass for the cattle. 


\section{Pickens County.}

Hurricane Township (E. D. 131): Country for the most part broken and hilly. Soil, a light yellowish brown loam, three inches to fire inches to a stiff red clay, lying on sandstone and gray rock. Crowth, pine, oak, and hickory. The uplands yield ten to twenty bushels com per acre. Within a few years the people have found out that they can raise cotton, the lands producing five hundred pounds to one thousand pounds seed cotton to the acre. Lands for sale from two dollars to ten dollars an aere. There is considerable goor bottom land on the streams. Four ereeks afford good water-powers. There are no prevailing diseases. Nine-tenths of the field labor is performed by whites. 


\section{CHAPTER IX.}

\section{WATER-POWERS OF SOUTH CAROLINA.}

Between the years 1816 and $1826, \$ 1,712,626$ were expended by the State of South Carolina in internal improvements. A large portion of this amount was appropriated to building nine canals around the rapids of the Wateree, the Catawba, the Congaree, the Broad and the Saluda rivers, with a view to the improvement of their narigation. From time to time surveys of these streams, especially by engineer officers of the United States army, have been made with the same object in view. In the absence of anything like a general or detailed account of the waterpower of the State, it was upon reports regarding these works that persons interested in the matter chiefly relied for information. Quite recently, however, Gen. Francis A. Walker, Superintendent of the 10th United States Census, as a part of the census work, has had a surrey of the water-power of the Southern Atlantic water-shed made by Mr. George F. Swain, S. B., Instructor in Civil Engineering in the Massachusetts Institute of 'Technology, Boston, Mass. Mr. Swain's report, just published by the census office, contains a large amount of new'and very valuable information; so far as South Carolina is concerned, it is the first attempt to give a systematic account of its water-power. In the endeavor here made to condense a statement of the points of chief interest in this report relating to this State, the reader is informed that Mr. Swain's report is so closely written and so full of facts that it is not susceptible of such treatment satisfactorily, and those interested in the subject are referred to the report itself.

Mr. Swain divides the Southern Atlantic water-shed into three belts, ruming in a northeasterly direction, parallel for the most part with each other, and also with the sea coast on the southeast, and with the general trend of the Appalachian mountain chain on the northwest. These are:

I. The eastern belt, reaching inland from the coast one hundred to one hundred and forty miles, and formed by the slowly descending slope of 
the tertiary plain. In South Carolina the average elevation of the streams at the upper edge of this belt above tide level is about seventy feet in an average distance, following the winlings of the streams of about two hundred and fifteen miles; this gives something like 0.3 foot fall per mile, and of course renders the streams of this section, as a rule, unavailable as motor powers, although the smaller streams sometimes have such fall as to allow of their use for cotton gins, grist, and even for saw mills. Formerly along the coast of Carolina tidal water-power was utilized for rice mills, but this motor has been here superseded by stean.

II. The middle belt comprises what has been described as the "Red Hill," "Sand Hill " and "Piedmont" regions of South Carolina, with a portion of the upper pine belt, in all about 18,000 square miles. It has a general elevation above the sea level of about six hundred feet, and the average fall of the streams passing through it varies from two feet to seven feet per mile. This is the region of the great water-powers, and to it Mr. Swain has deroted his chief attention.

III. The western belt is among the mountains. In South Carolina it is described as the Alpine region, and embraces about twelve hundred square miles. The streams here are numerous, and their fall is very great, but they are much inferior in volume to those of the middle belt, and consequently rank below it, as affording water-power of the largest capacity.

The ardrantages offered by the water-power of South Carolina are much enhanced by topographical and climatic conditions prevailing here.

The undulating plateau of the Piedmont region has a pervious soil to an average depth of fifty feet or more, formed by the unusually deep disintegration of the metamorphic rocks, and presenting a mixture of sand and clay, well adapted for the absortion of rain water. This perrious soil rests at the depth indicated on the impervious strata of rock, granite, and gneiss, or the various slates, which impede the deeper percolation of water. The streams have cut their ehannels down to these unclerlying beds of rock, and it is along their surface that constant supplies of water held in reserve by the permeable soils of their water-sheds are received, thus actding largely to the amount and the regularity of their flow. A similar condition obtains among the sand hills, where the porous sands, through the interstices of which the rain disappears almost as readily and rapidly as it does through the air, rest at a depth of one hundred feet to one hundred and fifty feet on impervious beds of kaolin clay. . As a consequence the streams of the sand hill region lose little of the rainfall through surface evaporation and maintain a flow hardly affected perceptibly by unusual seasons of rain or drought, and Mr. Swain more than once expresses his astonishment at the horse-power furnished by streams 
having so small a drainage area. This result is likewise promoted by the extensive woodlands of the middle and western belt, which occupy, according to the census of 1580 , something more than seventy-five per cent. of the surface. The larger streams of the Piedmont region, in addition to their drainage area within the State, receive the rains from 3,058 square miles of water-shed in North Carolina. The rocky beds of these streams afford everywhere good sites and permanent foundations for mill dams, while the high angle at which they cross the ledges of rock increases the perpendicularity of the fall, and presents a clean smooth edge, adding to the facility with which the water-power is made arailable. Thus, at TanPatton's shoals, on the Enoree river, so very even is the edge of the rock that a single plank bolted to it, forms a sufficient dam by which 1,550 horse-power may be utilized. "The facilities for storing water are on the whole good."--Swain. Besides the resources of the neighboringpine forests, building material is furnished everywhere in the excellent clay for brick-making that is found. In addition to these, the metamorphic rocks laid bare on the banks of the streams furnish material for dams and buildings of the best quality. Besides soapstone, gneiss, talc and mica slates, there are few localities where a fine-grained and easily splitting granite is not to be had. The last named rock extends even into the sand hill region, forming the shoals and rapids in the streams there, and las been utilized in the structure of the large cotton mill at Graniterille on Horse creek.

Speaking of the elimate, Mr. James E. Calhoun writes: "Blessed with sunshine and showers throughout the year, there is just winter enough to keep the insects in check, while the pomegranate and the fig do not require to be sheltered. Destructive storms of wind, rain or hail never occur here. Living immediatel on they banks of a river half a mile wide (Trotters's shoals, on the Savannah), I am never troubled with mosquitoes. Nowhere can there be found a larger percentage of the population of seventy years and upwards. I am an octogenarian, with the fresh vitality of twenty-five." Low water from snow-fall or freezing, and freshets from ice gorges are unknown here. It has been argued that in more bracing climates, as in Maine, the operatives in factories can accomplish ten per cent. more work than in these wamer latitudes. It is possible that unacclimated Northern operatives might experience some such degree of languor here. Nevertheless there are few better workers than the Southern factory hand. The climate does disincline the Southern white to out-ofdoor employment, and, surrendering, in a large measure, farm labor to the colored race, they eagerly seek employment in factories. 'Thus it happens that factory hands are much more abundant than would be anticipated from the density of the population. Northern mill owners have 
not been slow to express their high estimate of Southern help. Contrast with the negro element of the population cultivates a pride of race which inspires a ligher tone and renders the white working class more reliable than it is usually found elsewhere. Labor unions and leagues are unknown, and there are those who maintain that this freedom from labor troubles, and the permanency and certainty they enjoy in their help more than compensates for some remoteness from railroad transportation. The expense saved in the item of heating adds largely to the econony of factories, and by rendering the conditions of life easier and healthier, it promotes the increase of an already very prolific population, which, if prevented from migrating and fostered by such capital as woukl open up employment in manufactures, would respond readily to almost any demand marle upon it.

The average annual rainfall is stated at fifty-two inches, and it probably exceeds rather than falls below this figure. This is from four inches to six inches more than in the same region in Virginia, North Carolina and Georgia. The following statement shows how it compares with the rainfall of the New Englanl an 1 Millle States, the man of observations mude at twenty-six station; on the principal river's in those states being given :

\begin{tabular}{|c|c|c|c|c|c|}
\hline & 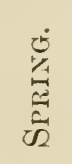 & 窇 & 曾 & 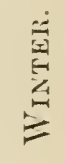 & 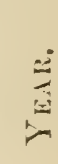 \\
\hline & In. & In. & In. & In. & In. \\
\hline Piedmont region of South Carolina.. & 12 & 14 & 10 & 16 & 52 \\
\hline New England and Middle States......... & 11 & 12 & 10 & 9 & 42 \\
\hline
\end{tabular}

There are four chief river systems in South Carolina-the Pee Dee, the Santee, the Edisto and the Savamnah. The numerous salt water rivers, important as they are for purposes of communication along the coast, and even for a considerable distance into the interior, are omitted, as tidal water-power is not to be considered. Such streams as flow through the level country, although they are sometimes of considerable length, with large drainage areas, and affording some water-power, as the Big and Little Saltkehatchie and others, are likewise omitted. The following table exhibits the leading features of these rivers. The number of mills and the horse-power utilized are from the enumerator's returns for the 10th United States Census; the estimate of drainage area, length and fall, are by Mr. Swain : 
Tuble, giving Names of 'Streams, Number of Mills, Horse-Power Utilized and estimated Drainage Area, Length and Fall of the Rivers of South Carolina.

\section{NAME OF STREAM.}

\begin{tabular}{|c|c|c|c|c|}
\hline 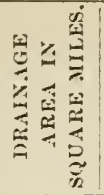 & 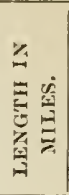 & 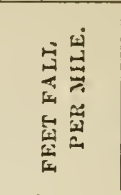 & 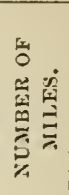 & 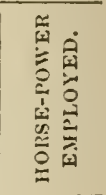 \\
\hline 17,000 & 159 & 0.44 & 62 & J \\
\hline 1,200 & 65 & & 2 & $2 \cdot 2$ \\
\hline 2,000 & 50 & & 21 & 4. \\
\hline 1500 & & & $1: 3$ & -32 \\
\hline 1,350 & 240 & & 26 & $38:$ \\
\hline & & & 124 & 1.76 \\
\hline 14,725 & 184 & & & \\
\hline 5,225 & 116 & 1 to $4 \frac{1}{2}$ & 28 & 37 \\
\hline 4375 & 76 & 5.24 & 40 & 8: \\
\hline 7,965 & 50 & 1. & 27 & 38 \\
\hline 4,950 & 105 & 3.9 & 38 & 640 \\
\hline 730 & 711 & ....... & 36 & $01=$ \\
\hline $7 \div 0$ & 30 & 4 to 7 & 52 & $0-$ \\
\hline 475 & 50 & 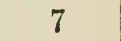 & 37 & 805 \\
\hline 2350 & 110 & 3 to 6 & $10: 3$ & 2,267 \\
\hline & 60 & & 66 & 1,33 \\
\hline & & & $4 \div 7$ & 7,83 \\
\hline 1,535 & 60 & 2 to 4 & 95 & 1,12 \\
\hline, 000 & 355 & 04 to $2 \frac{1}{2}$ & 78 & $1.45:$ \\
\hline 143 & 20 & 20 & 8 & 1.807 \\
\hline & 45 & & ii) & 253 \\
\hline & 411 & & $\tau$ & 12 \\
\hline & 60 & $\tau$ to $8_{4}^{3}$ & 75 & 88 \\
\hline 0 & 49 & $6 \frac{1}{2}$ & $\because 8$ & ذ1 \\
\hline & 30 & & $\ldots$ & ....... \\
\hline & & & 206 & 4800 \\
\hline & & & 124 & 1.760 \\
\hline & & & 407 & 7,830 \\
\hline & & & 95 & \\
\hline & & $\begin{array}{lll}\cdots & . .\end{array}$ & 206 & 4,806 \\
\hline & & & $?$ & \\
\hline
\end{tabular}

Santee River

\section{PeE DeE System.}

Great Pee Dee and lesser tributaries $(9,700 \mathrm{sq}$ miles in North Carolina $). . . . . . . . . . . . . . . . .$.

Waccamaw.

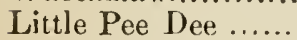

Black River.

Lynch's River

Total ...

Santee System.

Vateree and tributaries.

Catawba and tributaries $(1,725$ \&q. m. dr. area in North Carolina.

Congaree and tributaries..........................

Broad and tributaries $\left(1,400 \mathrm{sq} . \mathrm{m} . \mathrm{dr}\right.$. area $\mathrm{in}_{\mathrm{n}}$ North Carolina...............................

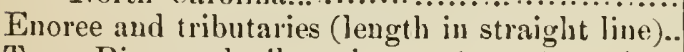
Tyger River and tributaries " " " " Pacolet and tributaries

Saludla aud tributaries.

Reedy River (fall greater than Saluda or Enoree)

\section{Total.}

\section{EDisto System.}

North and South Forks and tributaris.

Savanah River Systei.

Savannaly River and lesser tributaries $(5,000$ sq. $m$ dr. area in Georgia) ............ ....

Horse Creek

Stevens Creek

Little River.

Rocky River.

Seneea River and affluents.

Tugaloo River.

Chatauga River

T'otal.

Recapitulation.

Pee Dee system.

Santee system.

Edisto system.

Savamul system

Tosal 
The kind of milis and the amount of power employed by each may be summarized thus:

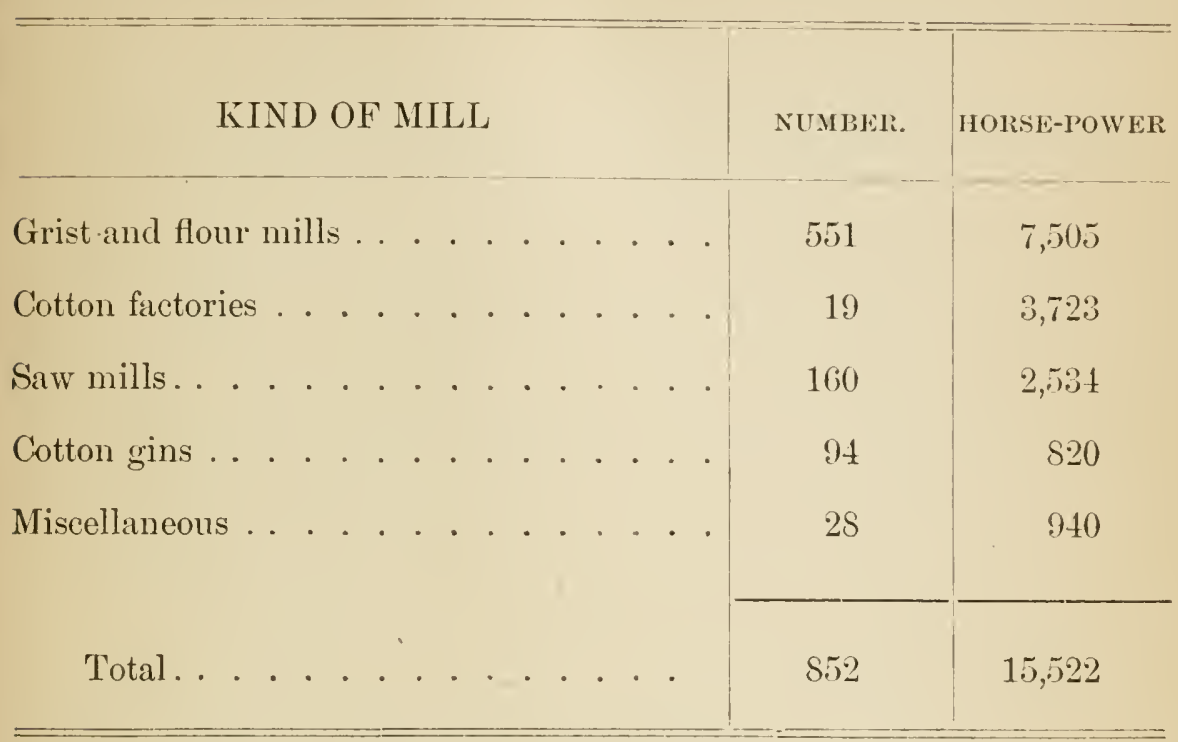

The water-power that a stream will furnish is determined by its fall and its volume of water. The amount of fall is accurately determined by a carefully made line of levels. The time allowed Mr. Swain to survey the large field allotted to him enabled him to visit in person only a few of the most important water-powers, and even in these instances the only instrument of measurement he eould use was a Locke pocket level, with which he says he was in some eases "enabled to arrive at quite close approximation of the fall, while in others the results obtained are liable to large errors." To determine the volume of water in a stream is a much more difficult, tedious and delicate matter. Accurate gaugings of the stream are to be made, and these are to be continued through the different seasons of the year, and for a series of years, before the average amount of flow to be relied on ean be stated. "In the absence of such a series of gaugings," Mr. Swain was forced, in order to arrive at any approximate estimate of power, to adopt an entirely different method. He proints out the uncertainty of this method, and is scrupulously careful that his errors, whatever they may be, shall always be on the safe side-that is, below the mark, but never above it. His method consists, first, in determining the drainage area of the different streams by geometrical measurement on the best maps accessible to him, and here he naturally remarks on the inaccuraey and lack of agreement among the maps; the next was the determination of the arerage annual rainfall and the spring, summer, 
autumn and winter rainfall on each drainare basin. Jere, again, the number of years during which observations have been recorded, at least so far a south Carolina is eoncerned, leave much to be desired, esp cially in the regions remote from the sea coast. Then comes the consideration of the very complex factors affecting the disposition of this rainfall, the proportion dissipated by evaporation under the various and varying influences of temperature, the humidity of the atmosphere, the prevalence of winds, the permeability of the soil, and its protection by forests, and, lastly, the residue remaining to ba discharged by the streams. Now, it would seem that in these regards, the item of temperature only excepted, the discharge of streams in the Sonth shonld be greater than those of the Nort'.. The foree of the wind is les.s. No large lakes present broad surfaces for evaporation. There is no loss by evaporation from snow and ice during months of the year. The soil is deeper and more permeable, and its protection by forests must be as great or greater. For the streams of the sand hill region Mr. Swain seems to allow some force to such considerations in placing the minimum flow at one-thirl to one cubic foot per second for each square mile of drainage area. For the other streams of South Carolina he allows a less discharge, placing the minimum flow at 0.13 to 0.23 cubic feet per square mile of drainage area, notwithstanding that the average minimum flow in ten New England rivers which he gives, is 0.26 cubic feet. Whenever Mr. Swain's estimates of fall or flow differ from those made by others, it will be found that Mr. Swain's is much below theirs. As an instance of how much such under-estimates may amount to, Mr. Swain himself points out that while his estimate of the minimum flow on the Portman shoal, of Seneca river, is one hundred and eighty-nine cubic feet per second, "it must be specially mentioned here that Maj. Lee, who is an engineer of eminence, long experience and well acquainted with the country, writes that 'one thousand cubic feet of water per second all the year round-two-thirds of the year double this flow-is to be had.'" But, however far short of the aggregate Mr. Swain's estimates of the waterpower may be, there can be no question that, under the circumstances, he has accomplished a great deal, and, as a preliminary reconnoisance, his treatise is invaluable.

Mr. Swain makes four estimates of the horse-power at each locality he mentions :

I. The minimum, being the minimum flow during a period not exceeding a few days at intervals of several years.

II. The minimum low seasons. This oceurs for a period of three to six weeks, when the stream is at its lowest. In most year's the average flow during the season of least flow will exceed this amount, and a small 
storage of water will render it available at all times. 'This flow is ascertained by taking twenty-eight per cent. of the rainfall as the amount discharged by the streams. This would be something like fourteen and a half inches for the middle and western water-power regions of South Carolina, but Mr. Swain limits it not to execed ten inches to thirteen inches.

III. Naximum with storage. This is the same as the last, assuming that by storage (ponds and dams) a discharge of two inches to four inches on the water-shed ean be arded thereto, less for the larger and more for the smaller areas.

IV. Low season flow dry years. Without storage this flow may be depended on. In ordinary years a quarter more may be calculated on.

The following summary of the water-power of South Carolina, so far as investigated by Mr. Swain, through correspondence or by personal examination, will not be liable to any charge of being an over-estimate. 
Summary of Powers on Rivers in South Carolina, Examined by G. F. Suain S. B., Special Agent Tenth U. S. Census.

\begin{tabular}{|c|c|c|c|c|c|c|c|c|c|}
\hline \multirow[b]{2}{*}{ STREA IN AN IOCALITY. } & \multirow{2}{*}{ 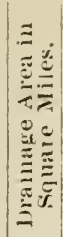 } & \multicolumn{2}{|c|}{ FALI. } & \multicolumn{2}{|c|}{$\begin{array}{c}\text { FLOW } \\
\text { PEK } \\
\text { SECOND. }\end{array}$} & \multicolumn{4}{|c|}{$\begin{array}{l}\text { HORSF-POWER } \\
\text { AVAILAILK. }\end{array}$} \\
\hline & & 产 & 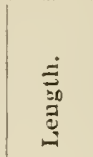 & $\underset{\Xi}{\Xi}$ & 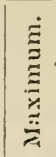 & $\underset{\Xi}{\stackrel{\Xi}{\Xi}}$ & 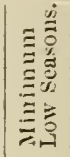 & 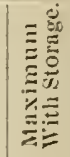 & 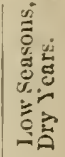 \\
\hline & & & & & & & & & \\
\hline ributaries: ligh pine l'ree Creek & 5 & & ................. & 28 & 5,5 & 3.2 & 41 & & \\
\hline atawba Kiver, freat Falls (c) ..... & $3,6(2)$ & & $8 \mathrm{~m}$. & 793 & 2.900 & 1500 & $21(100)$ & & \\
\hline …..... & 3,425 & & & & & 3,401 & $+(6,51)$ & 33.0130 & 527 \\
\hline ularies of Catawbat liiver: Rocky Cree & $1 \times 5$ & & & is & 160 & & & & \\
\hline & 223 & & ......... & & 200 & & & 22.8 & \\
\hline Gitree River at & $-3 \times 0$ & & ….......... & $51)$ & $3: 30$ & $51 ?$ & & & \\
\hline gatree latver at & 7,300 & $22, \mathbb{E}$ & & & & $4,201)$ & & & 6,40 \\
\hline tarie & 115 & & & & & 66 & & 13,2 & \\
\hline River, Bu & & 12 & & $\cdots$ & ........ & ........... & 41) & & \\
\hline Islat & 1,761 & 17.2 & $23 / 4 \mathrm{~m}$ & ......... & …..... & 2.150 & 2800 & 7.9 .36 & 3,3 \\
\hline ........... & 4,023 & 6.4 & & ........ & (....... & $7(01)$ & 925 & 26011 & 107 \\
\hline ….... & $\begin{array}{l}1,+60 \\
3,190\end{array}$ & & $0.94 \mathrm{~m}$. & $\ldots .$. & $\ldots . . .$. & $\begin{array}{l}1.3 .20 \\
1.1 .51\end{array}$ & 1,775 & $5,0,10$ & \\
\hline & 2590 & & & ........ & & $(6,3)$ & 8.5: & $2,5,51 \mid$ & 1,60 \\
\hline & 2.469 & $47.1 \mathrm{i}$ & m. & ........ & ...... & 2000 & 3900 & 11,1000 & \\
\hline & 1.357 & 5i & $3.20 \mathrm{~m}$. & ......... & & 1800 & 23,0 & 69061 & 2.70 \\
\hline & $1: 357$ & 50.2 & $2 \mathrm{~m}$. & ........ & ....... & 1,800 & 2,$35 ;$ & $6 .(n) 0$ & 2.7 \\
\hline ........ & 1,142 & & $1.75 \mathrm{~m}$. & ..... & ....... & 1,000 & 12,0 & 1,0100 & $1,4 i$ \\
\hline er Yiu & 1,$1 ;: ; 2$ & 10 & $1 \mathrm{in}$. & & & 2819 & 36 & $1.15^{\prime \prime}$ & 400 \\
\hline er, Y:i & 375 & 36 & ; .............. & 62 & 400 & 11:2 & 144 & 725 & \\
\hline (............. & $2 \times 0$ & 80 & …........ & +2 & 301 & $3: 30$ & 4.11) & 2.100 & 50 \\
\hline ….... & 234 & 12 & 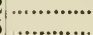 & $\begin{array}{l}3.5 \\
3.5\end{array}$ & 250 & 25 & $\stackrel{i}{i}$ & 310 & 7 \\
\hline$n y .$. & 91 & $\begin{array}{l}3.1 \\
30\end{array}$ & & io & 100 & $\begin{array}{c}230 \\
3\end{array}$ & $\begin{array}{r}-311 \\
42\end{array}$ & $\begin{array}{l}1,310 \\
3111\end{array}$ & 51 \\
\hline & 91 & in & & I0 & 100 & 20 & 25 & 200 & 3 \\
\hline & 94 & 23 & 8. $80 \mathrm{ft}$. & 10 & 100 & 55 & 32 & (26) & 3 \\
\hline Tyger River, Hi & 3115 & 4) & $3 / 4 \mathrm{~m}$. & 45 & 330 & 204 & 272 & $150 ;)$ & 32 \\
\hline 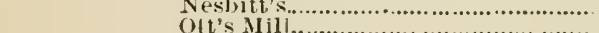 & 274 & & ;in....... & ..... & ....... & 71) & $1 \times 0$ & 27 & \\
\hline & 112 & & & $\mid \cdots .$. & ….... & 72 & $\begin{array}{c}90 \\
\ldots . .\end{array}$ & 288 & 20 \\
\hline & 50 & ii) & & ........ & $\ldots . . .$. & ............. & .......... & ............. & \\
\hline ... & & 14 & & ..... & ....... & ......... & .. & & \\
\hline$\cdots \cdots$ & 50 & 3.5 & $1 / 4 \mathrm{~m}$. & & & & 1 & 140 & $t$ \\
\hline 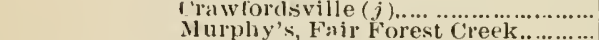 & isii & $171 / 2$ & & & 210 & & 108 & & 35 \\
\hline colet River, 'T & 3,01 & 60 & & 62 & 420 & 12i) & 600 & 2,860 & 70 \\
\hline Hi & $\times 2$ & 15 & & & & & & & .00 \\
\hline .......... & & & & & & & $1+9$ & 210 & $20 \% 1$ \\
\hline luda River, Si & $2,3,31]$ & 16 & & 62 & 2,110 & 1.010 & $1,7,75$ & 3.011 & 1510 \\
\hline & 23,301 & 31 & $\mathrm{~m}$. & ..... & .......... & 2100 & 2,700 & & \\
\hline & 2.310 & 20 & & ....... & ........ & 1,1 ind & 1.5. & 4.400 & $1 .(0)$ \\
\hline & $(j 3.5$ & 5.3 & $1 \frac{1}{4} \mathrm{~m}$. & ..... & ..... & 800 & $1.00 n$ & 4.001 & $1.20 \%$ \\
\hline & $6 ; 00$ & 5 & & ....... & & 60 & 75 & ; $3(10)$ ? & \\
\hline & 53 & 11) & & ........ & ...... & 120 & $15^{\prime \prime}$ & 600 & \\
\hline$y(s)$. & (4101) & 21 & & & & & & & \\
\hline$t \ldots . .$. & $3 \leqslant 0$ & 20 & & 70 & 425 & 160 & 210 & 970 & 25 \\
\hline & & 10 & ft. & 62 & & $\begin{array}{r}7 \\
34\end{array}$ & 9.4 & 454 & 11 \\
\hline & & 20 & & & $\ldots . .$. & $\begin{array}{l}31 \\
40\end{array}$ & & & \\
\hline & 87 & 2. & & …... & $\cdots .$. & 25 & 32 & 260 & s. \\
\hline & ...... & 61 & $500 y$ & ..... & $\cdots \cdots$ & $\ldots$ & & 710 & \\
\hline & & $\hat{i}$ & & … & & & & & 12 \\
\hline. & Pat & 75 & $7 \mathrm{~m}$. & 670 & 2,50 & $5.6,00$ & 8.100 & & (i) 165 \\
\hline & 220 & $!$ & & ....... & & 560 & 801 & 2.1110 & 910 \\
\hline & 2.100 & 11 & $i$ & ….... & $\ldots$ & $82 ;$ & 1154 & 3.20110 & 1,25 \\
\hline & $2,07$. & is & & ...... & ..... & 1.1460 & $1.5 m$ & 4.0000 & $1.7(k)$ \\
\hline . . ........ & $3,90) !$ & 31 & 51 & & $\ldots .$. & 1,600 & 2275 & $t, 1(1)$ & 2,400 \\
\hline ries $s$ & 531 & & & $7 i$ & 450 & & 12 & & 14 \\
\hline & is & & & 22 & $15 \mathrm{~N}$ & 25 & $3.2 !$ & & \\
\hline , 1 & 845 & 39 & $11 / 2 \mathrm{~m}$. & 20 & $9 \div 5$ & 9346 & $1.1: 1$ & $1.01 \%$ & 1,247 \\
\hline & 775 & 17 & & & & 375 & 450 & $1+i=0$ & 520 \\
\hline eneea River, Pr & 710 & (6) & & 199 & 82 & 1,201 & 1.700 & 5.62014 & 1950 \\
\hline & $11 \mathrm{~s}$ & 60 & & 1) & 13 & 102 & 141 & $12+$ & $16 i^{\circ}-(x)$ \\
\hline l,itlle I & 140 & & & 20 & 110 & 23 & 34 & 19.11 & \\
\hline
\end{tabular}


(a) A eanal here built by the State, 1818-25, is five miles long and has fifty-two feet fall, with six locks. +ud would be avalable in utilizing the entire power.

(b) Streams in sund hills of Kershaw county. The horse power given pel font fill. That given here may be doubled by storing the water at night. Other tributaries to the Wateree furnish good powers, concerning which no detalled information could be obtuined.

(c) Three State canals here: 1st, Lower canal, one mile long, with three locks. The total amount of water could be utilized through it. 21. Middle canal, three miles long, having three flights of locks, viz., four locks thirty-two feet lift, foul locks thirty-six feet lift, tliree locky twenty-seven feet lift, another lock abrive, nine feet lift, and guard lock, in all, thirteen locks, one hundied and fom feet lit. At any and all the three flights, the facilities for using a large power are very great; building room ample.

The upper catual is the property of Mrs. S. A. Boylston, of Winushoro, S. C. It is one and three-fourths miles long, on the west side of Catawba river, and enters Fishing creek at a point about five niles from Fort Lawn, on the Chester and Cheraw railroad. The total fall is fifty-one feet. There are two flights of locks; the lower one has four locks, thlrty-three feet lift; the unper has two locks, fifteen feet lift. These works are well built of eut stone laid in cement are in gond preservation, and were constructed by thestate at a cost of about $\$ 100,000$. There atre four factory sites, with ample building room. The first site has a fall of twenty-fom' and twenty-oneone-hundredths feet; the second, of thirty feet; the third, of thirty-eight feet; the fourth, of thirty-three feet. Granite of the best quality is at hand: The avalable power is estinuted at fifteen thousind horse-power.

(d) State cumal here, two miles long, dam, guardlnck, and four other locks of thirty-five feet lift; abundant building room, no liability to overflow.

(e) Sand hill streams of Lexington. 'Those of Richland not examined.

( $f$ ) The State of South Carolina is now enraged in developing the power in Broad river, from Bull sluiee shoal, by bulling a dam at that point, with a canal two and seven-eighths miles long, extending to Gervais street in the city of Columbia. The works are being buil first-class in every respeet, with dimensions sufficient to give four hundred and fifty-three horse powers of water for ench loot fall. 'The total power devel opel will be, on the averare f.ll, about 10,090 horse powers of water.

'The Saluck and Broad rivers unite opposite the elty of Columbia. These streams, near their confluence, have, in ordinary low water, a flow with suffieient fall to yield 49,000 horse-powers of water if properly developed. They take their rise in the Blue Ridge mountains, fluwing through, in their upper eourse, al wooded country, giving them a very uniform flow of water, and suffering but little from high water, and that but of short duration. This magnificent power has surroundings adapting it to manufacturing purposes equal to any locality in the South; a liealthy elimate, an abundance of the raw material, railroad faeilities in every direction, with gool sites for buildings, and other desirable features. (Maj. Thos. B. Lee, Engineer (olumbia eanal.)

(g) State canal here, 7,869 feet long with guard lock and six other locks of first-class cut stone masonry, eost $\$ 130,000$. Estimate of eost to put gates, locks and masonry in good order, $\$ 3,79$. Used in $155 \%$.

(h) Above is site of abandoned works of Magnetie Iron Ore Company. T'hree hundred horse power obtained, with surplus of water all the lime from fall of ten teet. A fall of sixteen feet is available; banks very fatvorable for building.

(i) Above Mountain Shoal are Kilgore's, Yurborough's, Flemmlng's and Wofford's shoals, having available falls.

$(j)$ South Tyger river, drainage area one hundred and eight square miles; furnishes two to seven horse-power per foot fall, and has several available falls.

(k) Abuve are Brown's mill, fourteen feet fall; Hammett's mill, ter feet fall ; Crocker's, Thompsisn's fords, shoals and other rapids.

( $l$ ) Above is Lindner shoal, eight feet fall; North and South Paeolet forks, with eighty square miles drainace area; each have numeruus fulls of twelve feet to thirty-four feet.

(n) Beiow (ilendale, on Sampson's fork, is a falt of fifteen feet-ninety horse-power; above are several gooi shoals. Thicketty ereek, one hundreal square miles drainage area; Bullock's and Kıng's creeks, seventy-two square miles drinage area, and Buffalo creek, one hundred and seventy-two square miles drainage area, empty into Broad river. Buffulo creek has considerable fall, with five and one-halt to fifteen horse-power per foot fall.

(o) There is here a state canal two and one-half miles long. five loeks, thirty-four feet litt; inight be repaired, and would render available double the present fall.

$(p)$ state eanal here, two and one-half inites long, with four locks, twenty-nne feet lift. Between this point and the Newberry and Loxington line are sevell falls, viz.: Wise's ferry, seventeen reet; Hunter's ferry, six feet; snellgrove's isla.nd, nine feet; M.mning island. fifteen feet; Simm's furry, fifteen teet. Above, in Newherry and Edgetield, are McNary's mull, eleven feet; Perkin's tord, ten feet; souknight's mill, six feet.

(q) Mills gives this lidl as seventy-six feet.

(r) Above are Harper's shoals, eight feet: Kay's and Gambrell's shoals, Poor's and Cox's mills, 
eight feet; Hamilton's shoal, ten feet; Irlland's shoal. flfteen feet i three hundred yards, one and one-quarter miles from ruilroal: Blackhurn's island shoul, ten feet; Tripl's shoal, sixteen feet.

(s) Above, Allen's showl, fourtcen feet f.ll in two humlred and fifty yards; may be increased to 18 feet.

(t) Ahove are Blassingame's, Harrison's, l'arris's and other shoals, all about six miles from Greenville.

(w) Above is cedar fills, twenty-nne feet.

(x) Above are Harrison's and Hoff's mills, ten feet fall each; Log shoal, fourteen feet fall; Ashmore's mill, ten feet fall, and Liuderman's sluoal.

(y) Jones's paper mill, eleven and one-half teet fall, fifty horse-power; Parkin's mill, eleven feet fall; Green's shoal; sawmill shoal.nine feet fall.

(z) Tributary to Reedy river are Laurel creek and Rearburn creek, with a good full of $t$ wentysix feet at Goodgion's mill, and another of fourteen feet at Fuller's factory.

(*) Twelve II lle ereek, tributary of the salura, in Lexington eounty, has a drainage area of ninety-three square miles, and five horse-power per foot fall at low water. Several falls on it are from seven feet to twelve feet. and minht be inereased to twenty feet or thirty feet. Other trihutaries are, Little Saluda river, drahing two hundred and ninety-seven square miles in Edgefita; Bush river, one hundred aud five squate miles in Newberry; Little river, two hundred aid iwenty square miles.

(†) Nisth Fork silutia, draining fifty-six squire miles, his a perpendiealar fall of two to three huthdred feet over a gneiss ledge, and another not yuite so high. Nlillie fork dritis fifty-six square miles. South Fork drains seventy-eight square miles; on it liork shoul has aine feet, and an mused shoul, twelve feet fall. A mill sixteen miles from Greenville has eighteen feet fit!. All the head water's abound in cataracts, some several hundred feet, almort vertie 1 .

The tributaries and affluents of the Savannah river not enumerated above are in the sand hill region-the Upper and Lower Three Runs, Hollow creek and Horse creek, all considerable streams. On Horse creek 1,S07 horse-power have been utilized, and there is a large amount, say one-third, still unemployed. The streams named should furnish at least as much as this one, which would give about 10,000 additional horse-power available in this section alone. Above the fall line Big Stevens creek is a large stream, and so are Big and Little Generostee creeks. Tugaloo river has for its tributaries Big Beaver Dam, Choestoe and Chauga creeks. The Chatanga river has Brasstown, Whetstone and other considerable tributaries, scarcely any spot in its drainage basin heing two miles from a water-power. Seneca river has Deep, EighteenMile, Twenty-three Mile, Twenty-six Mile and Conner's creeks, all large streams, with abundant fall. The Keowee river has Toxaway, Big Estatoe and Whitewater creeks, the latter with one fall of six hundred feet in three hundred yards. This whole region abounds in streams of clear water flowing over rock, having numerous cataracts and fed by an annual rainfall of more than sixty inches.

In the above statement the available water-power examined is estimated at something over 300,000 horse-power. Of this amount about 4,000 horse-power only are employed by all kinds of mills, which is only a little more than one per cent. The returns of the census enumerators, however, above given, show that altogether more than 15,000 horse-power are actually employed by mills in this region. Now, it is more likely that Mr. Swain would pass over without examination such water-powers 
as were not utilized than such as were, and the total may be safely increased in the proportion in which he has done this, which would be to multiply the above total by four. So that, without further allowance for his low estimates or for the improvement that art might effect by dams and canals, there ean be no question that from the lower line of liill country northward in Sonth Carolina there is more than a million of horse-power in water-powers, varying in size from thirty to thirty thousand horse-power, easily and cheaply available under condition peculiarly aulvantageous, not comnting the presence of the large amount of raw material in the shape of cotton to be manufactures.

A million of horse-power is about eighty per cent. of all the waterpowers now in use in manufacturing throughout the United States. It is about seven times the amount of water-power now employed in the Uniter States in the manufacture of cotton goods, and nearly four times the stcam and water-power together so employed. It is sufficient to more all the cotton factories, grist and flour mills and saw mills now worked by water throughout the entire country. If such a power were used in manufucturing cotton goods it would call for 600,000 operatives; in grinding flour and grist, 75,000; in sawing lumber, over 200,000. It appears, therefore, that the supply, for some time to come, must be in excess of any demand likely to be made on it. If, however, the present rate of increase in the employment of water-power in South Carolina should continue, the time when all this power might be utilized is not so indefinitely remote as might at first sight be thought. The amount of water-power employed in manufacturing in South Carolina was thirtythres per cent. greater in 1850 than it was in 1870. At this rate about two hundred and twenty years would elapse before all this power would be required. Just at the present time, however, the rate of increase is much greater than this. By the census of 1880 , only $2,398, \mathrm{H}$. P. water-power was employed in the manufacture of cotton goods. By an enumeration, however, made by the State Department of Agriculture, in Norember, 18s2, it was ascertained that $4,113, \mathrm{H}$. P. water-power were thus employed, an increase of seventy-one per cent. in a little over two years, or ten times greater than the rate of increase shown between the 9th and 10th Unitel States Census. Up to this date this rate of increase is maintained, and may be said to be accelerated, rather than diminished. How long it will continue, and what will limit it, can not now, with any certainty, be estimated. The increase in the employment of steam-power in South Carolina, as given in the 9th and 10 th Census, is much greater than that of water-power, and amounts to one hundred and sixty-four per cent. Of the total power used in manufacturing in South Carolina, in 1870, 69.62 per cent. was water, the balance being steam, but in 1580 this ratio is much 
reduced, and water gives only 53.63 per cent. of the total power employed. This tendency of supplanting the use of water by steam prevails throughout the United States, with the exception of five only of the newer and remoter States and territories. For the whole country the pereentage of stexm in the total power used has risen, since 1876, from fifty-one to sixtyfour per cent.

Under the United States tariff protecting manufactures, no pressing necessity has been felt for attention to economy in the matter of motive powers. The present attitude of the public mind seems to indicate that this state of things will not obtain much longer, and the cost of motive powers of different kinds and in different localities must become a question of much consequence. The following statement exhibits the cost of water and steam powers at several well-known manufacturing points:

Annual Rent or Estimated Cost of One Horse-Power.

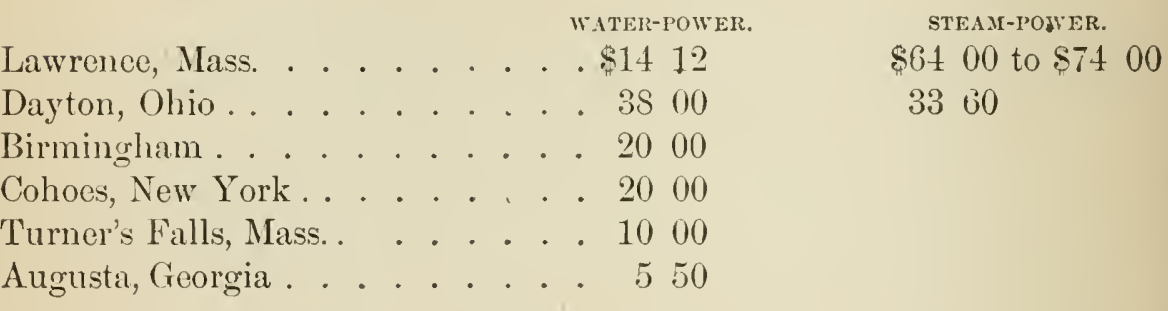

It is estimated that if the State rents the water it is now developing at Columbia at five dollars per annum for one horse-power, that it will obtain a handsome revenue from the labor and material expended.

At seven per cent. on the cost of dans and canals for the water-power utilized and available in South Carolina, the following is a statement of the cost of a horse-power per annum at several factories in this State:

Langley .. . . . . . . . . . . . . . . \$2 10

Graniteville . . . . . . . . . . 581

Vaucluse . . . . . . . . . . . . 700

No. 1, Camperdown . . . . . . . . . . . 043

Glendale. . . . . . . . . . . . . . . 039

Saluda Factory .............. . . 022

Average for the whole, one dollar and seventy cents per annum per horse-power. 


\title{
OHAPTEE $X$
}

\section{A LIST OF THE VERTEBRATE ANIMALS OE SOUTH CAROLINA.*}

\author{
BY FREDERICK W. TRUE, \\ CURATOR IN THE U. S. NATIONAL MUSEUM.
}

SUB-KINGDON VERTEBRATA. THE VERTEBRATES.

CLASS MAMMALIA. MLMMALS.

A class of hair-clad vertebrates, possessing a four-celled he:art, discharging warm, red blood, which contains both white and red corpuscles. Skull with two condyles. Limbs never less than a single pair, never more than two pairs. Symmetry of the two sides of the body complete. Young from a minute egg, brought forth alive, and nourished by a secretion (milk), from modified glands of the skin.

*This list is based, in part, upon data furnished by Dr. G. E. Nanigault, of the Charleston Museum. The literature relating to the vertebrate fauna of the Southern States has likewise been carefully examined. That the list may not be a merely nominal one, the mark of interrogation has been placed before the names of those species whose range is supposed to extend over South Carolina, but whose occurrence in the State has not been recorded. An exception is made, however, in the ease of species known to occur in both North Carolina and Georgia. These are included withont question. A comparison with the list published by Prof. Gibbes, in 1S47, is almost impracticable on account of the many changes which have occurred in the nomenclature and determination of species, resulting from the progress of the study of vertebrate zoology since that time. F. W. True. 
A group of anmals representing the highest phases of the development of life. To man, the highest exponent of the class, the les; perfected species stand in the most important relations, both as being, in a sonse, his progenitors, and as furnishing him with those things which are quite indispensable to his sustenance and advancement. A number of species have exister in a state of domestication from time immemorial.

Compared with lower groups, the class is a small one, although having no inconsiderable number of species. Ahout three hundred species inhabit North America.

\section{SLB-CLASS MONODELPHIA.}

Nammals, whose young are of considerable size and almost perfect development at birth. The anterior portion of the brain, or cerebrum, much overlaps the posterior portion, or cerebellum (super-order Edu(abilia), or leaves the latter considerably exposerl (supcr-order Inedu(abiliat).

\section{SUPER-ORDER EDLCABILIA.}

\section{ORDER CARAIYORA. CARATYOROCS MAMMALS.}

Flesh-eating mammals, having both fore and hind feet well developed; in one sub-order, Pinnipediu or Seals, for aquatic progression; in others, for terrestrial progression. The thumb or pollex of the fore limb is never opposabie to the fingers, as in man. 'Teeth of three sorts, molars, canines and incisors.

It is somewhat difficult to define this order in a manner intelligible to all, since the distinctions are mostly of an anatomical nature. Two of its representatives, however, the house rat, Felis domestica, and the dog, Canis fromilictits, are familias to every one. The ('annirores furnish but little food supply for man, bat their thick fur's enible him to withstand the rigors of winter. In the tropics, where one branch of the order, that of the cats, reaches its highest derelopment, they are decidedly more harmful than useful to man. 


\section{FELII).F.}

WILD ('AT. Lynx rufus (Cinldenstidit), Rafinesque. PLiMA or PANTHER.* Felis concolor, Limné.

\section{(}

WHITE-AND-GRAY WOLF. Canis lupus. Linn: griseo-albus. RED FOX. Vulpes fulvus, Desmarest.

GRAY FOX. Urocyon virginianus, (schreler: tiray.

\section{M(N'TELII).E.}

BROWY IINK. Putorius vison, shreber Galp.

ERIIINE: STOAT. Putorius erminea, (Linné liriftit.

AMERICAN OTTER. Lutra canadensis, (Turon, F, curier.

COMMON SKIXK. Mephitis mephitica, Shaw Bairu.

LITTLE STRIPEL SKI'NK. Mephitis putorius, I:nné: Cones.t

\section{PROC'YONII) E.}

RACCOON. Procyòn lotor, (Linné) Storr.

\section{[PISI] E.}

BLACK BEAR Ursus americanus. Pallas.

\section{PHOCIDE.}

\section{COMMON SFAt L. Phoca vitulina, Limné.}

* Probably extinct in South Carolina.

t Included upen the athority of Cateshy as interpreted hy coues.

¥A seal was caught in the harbor of Charleston in 15 . The specinen i. now in the museum of the College of Charleston.-(i. E. Al. 


\section{ORDER UNGULATA. HOOFED MAMMALS.}

Herbivorous, terrestrial mammals, possessing three sorts of teeth, the permanent series of which is preceded by a set of milk teeth. Fingers and toes encased in horny eoverings or hoofs, and never prehensile. One sub-group with horns or antlers, and more or less complex stomachs (Artiodactyli)—deer, antelope, swine, \&e.; another with neither (Perissodactyli)-horses, tapirs, \&c.

The most useful of mammalian orders, ineluding the majority of domesticated animals, and furnishing the greatest proportion of the most valuable animal products employed in the arts and for consumption.

The order is not abundantly represented in North America, the number of recognized species being about fifteen.

\section{CERVID E.}

TIRGINIA DEER. Cariacus virginianus (Boddaert), Gray. WAPITI; ELK. Cervus canadensis, Erxleben. (Extinct.) BISON; BUFFA LO. Bison american's, (Gmelin) Smith. (Extinct.)*

\section{ORDER CETE. WHALES.}

An order of aquatic mammals, devoid of hind limbs, but possessing fore limbs, modified into paddles, the fingers being furnished with an unusual number of bones, and enveloped in a common integument. Skin without hair; teeth, when present (porpoises, sperm whales, \&c.), conieal and not preceded by milk teeth; absent in some species (baleen whales), which are furnished, instead, with horny plates.

The whales are, perhaps, the least known of mammals. The number of species is still unsettled, and the habits and migrations of some are yet. entirely unknown.

* Ir. Vincent killed the last elk known of in South Carolina, in Fairfield cointy. The following statement regarding the last baffalo known on the Atlantic slope is by Col. Chas. C. Jones, Jr., of Augusta, Ga. :

"I have seen the skull of a buffalo, with the horns still attached, in good state of preservation, which was plonghed $n \mathrm{p}$ in a field in Brooks county, Georgia; and the father of Mr. James Hamilton Couper, of St. Simon's island, shot a wild buffalo early in the present century, near the head waters of Turtle river, not very far from Brunswick, Georgi:. The swamp is known to this day as Buffalo swamp. 
The majority of toothed whales subsist upon fish and cuttlefish, while the whalebone whales devour immense quantities of small organisms, principally crustaceans, which they strain out from the water taken into the mouth, by means of their baleen plates.

The whale fishery, once a most extensive industry, has shrunken to comparatively small proportions, principally on aceount of the disuse of whale oil as a burning fluid.

BALANID E.

RIGH'T WHALE.* Eubalæna cisarctica, Cope.

ZIPHIIDE.

BOTTLE-NOSED WHALE.* Hyperoodon semijunctus, Cope.

DELPHINIDE.

PORPOISE. ?Phocæna brachycion, Cope.

\section{SUPER-ORDER INEDUCABILIA.}

\section{ORDER CHEIROPTERA. BATS.}

An order of mammals at once distinguishable from all others $b y$ the great modification of the anterior limbs for purposes of flight. The fingers are much elongated, devoid of nails except in one family, and comnected with each other and the body by an extremely thin skin. Thumb abortive, and furnished with a strong hook or nail. Teeth of three sorts, encased in enamel. Young suckled by pectoral mammae.

The bats form a group of moderate size, and are distributed througlyout the globe. They are eminently fitter for ærial progression, but walk very a wkwardly and with much difficulty. They are active only during the dark hours, remaining, during the day, in secluded places, suspended

\footnotetext{
* Specimens of both these Cetaceans have been caught in Charleston harbor, and their skeletons are in the museum of the College of Charleston.-G. E. M,
} 
by the hind feet, which are furnished with strong, acutely-pointed claws. The majority eat insects and worms, but a few are fruit eaters. They are most abumlant in tropical comntries. North Anerican species, about twenty-fice.

\section{NOCTIJIONID E.}

I.ARGL-NOSEL BAT. Nyctinomus brasiliensis, Geofroy.

\section{IESPERTILIONIDE.}

TWILI( $H$ H'T IAT. Nycticejus crepuscularis, LeConte. RED B.IT. Atalapha noveboracensis, (Erxleben) Peters. HOARI PAT. Atalapha cinerea. (Beauvois) Peters. CAROLINA B.tT. Vesperugo serotinus, (Schreber) Keys. and Blas.; fuscus. (AEORGIAN BAT. Vesperugo georgianus, (F. Cuvier) Dobson. IITTIE BROWY BAT, Vespertilio subulatus, Say. SILVER Y-HAIREI) BAT. Scotophilus uoctivagans, LeConte. BLTYT-XOSEI BAT. Vespertilio lucifugus, LeC'onte* BIG-lidRlin BAT. Plecotus macrotus, LeConte.

\section{ORDER,INSECTIVORA. INSECT EATERS.}

A group of small mammals, possessing many of the characteristics of the bats, but having both fore and hind limbs adapted for walking. The two bones of the fore-arm are separate. The mammae are inguinal.

This order. of which the common mole forms a well-known example, is composed mostly of burrowing animals, which feed upon insects and live a secluded life. Few or none are of economical value, and the moles, at least, prove obnoxious to the farmer by injuring his pasture land.

\section{SORICIDE}

MASKED SHREW: Sorex personatus, Geoffroy.

CAROLINA SHREW. Blarina brevicaudata, (Say), Baird.

* Tespertilio virginiunus, Aurlubon and Bachman, a species of uncertain identity, is included by Gibbes in the South Carolina famm. " $T$. nigrescens, Bachman," also given by (iibbes, I have been unable to find a description of. 


\section{TALPID.E.}

COMMON MOLE. Scalops aquaticus, (Linné) Fischer. STAR-YOSED IIOLE. Condylura cristata, (Linn') Desmarest.

\section{ORDER CILIRES. RODENTS.}

A large order of manmals, at once distinguishable from all other placental mammals by the form of incisor teeth, which are bent into an arc of greater or less magnitude, possess a chisel or gouge-like edge, and grow perpetually from a soft pulp. Canine teeth are wanting; the feet are suited for walking and leaping.

The species of rodents are more numerous than those of all other orders of mammals combined. They are distributed throughout the world. Some, as the squirrels and chipmunks, are adapted for arboreal life, while others, as the marmots, live in the open prairies. The common rat has been introduced everywhere where commerce has penetrated.

The rodents are of comparatively little commercial valne, although some families, as the beavers, furnish beantiful furs, and others, as the squirrels and hares, may supply some considerable amount of palatable food. On the other hand, many members of the family Muridx, or rats, are injurious to grain and other products of husbandry.*

\section{SCIURIDE。}

? EASTERN CHICKADEE. Scuirus hudsonius, Pallas; hudsonius. SOUTHERN FOX SQUIRREL. Sciurus niger, Limné; niger.

? NORTHERI GRAY SQUIRREL. Sciurus carolinensis, Gmelin; leucotis. SOUTHFRN GRAY SQUIRREL. Sciurus carolinensis, Gmelin; carolinensis. FLYING SQUIRREL. Sciuropterus volucella, (Pallas) Geoff.; volucella. CHIPMUNK; STRIPED SQUIRREL. Tamias striatus, (Linné) Baird. WOODCHUCK ; GROUND HOG. Arctomys monax, (Linné) Schreber.

*The Jumping Mouse, Zapus hudsonius, (Zimm.) Coues, representing the family Zapodidx, is included by Gibbes in the fauna of south Carolina, but apparently without reason. 


\section{MIURID E.}

BROWy RAT. Mus decumanus, Pallas. (Introduced.)

BLACK lidT. Mus rattus, Linné. (Introduced.)

COMIMON MOUSE. Mus musculus, Linné. (Introduced.)

MUSK RAT. Fiber zibethicus. (Linné) Cuvier.

PINE MOUSE. Arvicola pinetorum, (LeConte) A. and B.

COMHON MEADOW MOUSE. Arvicola riparius, Ord.

HARVEST MOUSE. Ochetodon humilis, (Aud. and Bach.) Wag.

RED MOUSE. Hesperomys aureolus, (Aud. and Bach.) Wag.

COTTON MOUSE. Hesperomys gossypinus, LeConte.

GRA Y-BELLIED MOUSE. Hesperomys leucopus. Wagner.

RICE-FIELD MOUSE. Hesperomys palustris, (Harlan) Wagner.

FLORIDA OR WOOD RAT. Neotoma floridana, Say and Ord.

COTTON RAT. Sigmodon hispidus, Say and Ord.

\section{CASTORID E.}

AMERICAN BEAVER. Castor fiber, Linné. (Extinct.)

\section{LEPORID E.}

GRAY RABBIT. Lepus sylvaticus, Bachman; sylvaticus.

MARSH HARE. Lepus palustris, Bachman.

\section{SUB-CLASS DIDELPHIA.}

A sub-class of mammals distinguished from the preceding by the fact that the young are born in an incompletely dereloped condition, and are protected in a pouch on the abdomen of the mother, where they are retained for several months, being nourished by the milk secreted by the mammae therein contained. The sub-class contains but a single order, the MIarsupalia.

The marsupials vary rery much in size, and are mostly confined to Australasia. A single family, the Didelphida, or opossums, inhabits America, and is peculiar to our continent.

DIDELPHID E.

OPOSACM. Didelphys virginiana, Shaw. 


\section{CLASS AVES. BIRDS.}

A class of oviparous, warm-blooded, air-breathing vertebrates, having the anterior limbs greatly modified for flight. Hind limbs always present. Exoskeleton in the form of feathers. Teeth in existing species absent. In certain extinet forms, Odontorniths, teeth are present.

The birds form a remarkably compact class of animals. They have attracted moreattention on account of their beauty and prevailing harmlessness than, perhaps, any group of animals, and vie with the mammals in the degree of their usefulness to man.

No corner of the globe is without representatives of this group. About nine hundred and twenty-four species and sub-species are North American. Many orders, such as the ostriches, are not represented in our country.

\section{ORDER PASSERES. PASSERINE BIRDS.}

Birds having four toes fitted for perching, but never versatile, $i$. c., capable of being turned laterally from one position to another. Hind toe on a level with the others, and always with a claw as long or longer than that of the middle toe. Tail-feathers twelve, primaries (the stiff feathers inserted from the bend of the wing to the tip, and usually ten in number), nine or ten. Sternum uniform in pattern in the various species.

This group of birds is the most numerous of all in species. The musical capabilities are developed in a high degree, and throughout their structure they display "the highest grade of development and the most complex organization of the class."-(Coues). Their relations to the success of agriculture are varied, some families being granivorous, and doing much damage to corn and grain, others being insectivorous, and hence of importance in reducing the abundance of noxious insects. Recognized North American species, about three hundred and forty.

\section{TURDID E.}

WOOD THRUSH. Hylocichla mustelina, (Gmel.) Baird.

WILSON'S THRUSH. Hylocichla fuscescens, (Steph.) Baird.

? GREY-CHEEKED THRUSH. Hylocichla aliciæ, Baird.

OLIVE-BACKED THRUSH. Hylocichla ustulata swainsoni, (Calan.) Ridgw. 
HERMIT TIIRUSH. Hylocichla unalascæ pallasi, (Cabanis) Ridgway.

AIERICAN ROBIX. Merula migratoria, (Linné) Sw. and Rich.

JOCKING BIRI). Mimus polyglottus, (I Linnć) Boie.

CAT-BIRI). Galeoscoptes carolinensis, (Linné) Caban.

BROWX THRLSH OR THRASHER. Harporhynchus rufus, (Linné) Caban.

\section{SAXICOLIDE.}

BLUE-BIRD. Sialia sialis. (Linné) Haldeman.

\section{SYLVIIDE.}

BLUE-GRAY GNATCATCHER, OR FLYCATCHER. Polioptila cærulea, (Linné) Sclater.

RUBY-CROWNED KINGLET, OR WREN. Regulus calendula, (Linné) Lichtenstein.

GOLDEN-CRESTED KINGLET. Regulus satrapa, Licht.

\section{PARIDE.}

TLFTED TITHOUSE. Lophophanes bicolor, (Linne) Bonaparte.

BLACK-CAPPED CHICKEDEE, OR TITMOUKE. Parus atricapillus, Linné.

(AROLINA TITMOLSE, OR CHICKADEE. Parus carolinensis, Audubon.

\section{SITTIDE.}

WHITE-BELL1ED NUTHATCH. Sitta carolinensis, Gmelin.

? RED-BELLIED NLTHATCH. Sitta canadensis, Linné.

BROWN-HEADED NUTHATCH. Sitta pusilla, Latham.

\section{CERTHIID E.}

BROWN CREEPER. Certhia familiaris mexicana, (Gloger) Ridgway.

TROGLOD YTID E.

CAROLINA WREN. Thryothorus ludovicianus, (Gm.) Bonaparte. BEWICK'S WREX. Thryomanes bewicki, (Aud.) Baird.

HOUSE WREN. Troglodytes aedon, Vieillot. 
LONG-BILLED MIARSI WREN. Telmatodytes palustris, (Wilson) Baird. SHURT-BILLED MARSH IVREN. Cistothorus stellaris, (Light.) A (cb. WINTER WREN. Anorthura troglodytes hyemalis, (Vieillot) Coues.

\section{MOTACILLIDA.}

AMERICAN TITLARK. Anthus ludovicianus, (Gm.) Lichtenstein.

\section{MNIOTILTID E.}

BLACK-AND-WHITE CREEPER. Mniotilta varia, (Linné) Vieillot. PROTHONOTARY WARBLER. Protonotaria citrea, (Bodd.) Baird. SWAINSON'S WARBLER. Helonæa swainsoni: Audubon.

WORM-EATING WARBLER. Helminthotherus vermivorus, (Gm.) Salvin \& Godman.

BACHMAN'S WARBLER. Helminthophaga bachmani, (Aui.) ('abanis. BLUE-TINGED YELLOW WARBLER. Helminthophaga pinus, Linné) Baikł GOLDEN-WIXGED WARBLER. Helminthophaga chrysoptera, (Liné) Bairl. NASHYILLE WARBLER. Helminthophaga ruficapilla, (Wils.) Baird. ?ORANGE-CROWNED WARBLER. Helminthophaga celata, (Say) B:tird TENNESSEE WARBLER. Helminthophaga peregrina, (Wilson) Raird.

BLUE YELLOW-BACKED WARBLER. Parula americana, (Liné) Bonajarte. CAPE MAY WARBLER. Perissoglossa tigrina, (Gmelin) Baird.

SUMAKR YELLOW BIRD; YELLOW WARBLER. Dendrœea æstiva, (Gm.) Baird.

BLACK-THROATED BLUE WARBLER. Dendrœca cærulescens, (Linné) Baird. YELLOIV-RUMP WARBLER. Dendrœca coronata, (Limné) Gray.

BLACK-AND-YELLOW WARBLER. Dendrœca maculosa, (Gmelin) Baird. BLUE WARBLER; CERULEAN WARBLER. Dendrœca cærulea, (Wils.) Rair(. CHESTXUT-SIDED WARBLER. Dendrœca pennsylvanica, (Linné) Bairi. BAY-BREASTED WARBLER. Dendrœca castanea, (Wilson) Baird. BLACK-POLL WARBLER. Dendrœca striata, (Forst.) Baird.

BLACKBURNIAN WARBLER. Dendrœca blackburniae, (Gu.) Baird. YELLOW-THROATED WAPBLER. Dendrœca dominica, (Linné) Bairl. BLACK-THROATED GREEN WARBLER. Dendrœea virens, (Gmelin) Baird. PINE-CREEPING WARBLER. Dendrœea pinus, (Wilson) Baird.

YELLOW RED-POLL WARBLER. Dendrœca palmarum hypochrysea, Rirlgway.

PRAIRIE WARBLER. Dendrœca discolor, (Vieillot) Baird. WATER THPUAH. Siurus nævius, (Bodd.) Comes. GOLDEN-CROWNED THRUSH. Siurus auricapillus, (Linné) Swains. LARGE-BIJLED WATER THRUSII. Siurus motacilla, (Vieillot) Coues. 
CONNECTICLT WARBLER. Oporornis agilis, (Wilson) Baird. KENTUCKY WARBLER. Oporornis formosa, (Wilson) Baird. MOLRNING WARBLER. Geothlypis philadelphia, (Wilson) Baird. MARYLAND YELLOW-THROAT. Geothlypis trichas, (Linné) Cabanis. YELLOW-BREASTED CHAT. Icteria virens, (Limné) Baird. HCODED WARBLER. Myiodioctes mitrata, (Gmel.) Audubon. BLACK CAPPED YELLOW WARBLER. Myiodioctes pusillus, (Wils.) Bp. ? SIIALL-HEADED FLY.CATCHER Myiodioctes minuta, (Wils.) Baird.

CANADIAN FLY-CATCHING.WARBLER ; CANADA FLY-CATCHER. Myiodioctes canadensis, (Limné) Audubon.

A.MERICAN REDSTART. Setophaga ruticilla, (Linné) Smainson.

\section{VIREONIDE.}

RED-EYED VIREO; RED EYED FLY-CATCHER. Vireosylvia olivacea, ? PHILADELPHIA V'IREO. Vireosylvia philadelphica, Cassin.

WARBLIxG VIREO. Vireosylvia gilva, (Vieill.) Cassin.

(Linné) Bon.

YELLOW-THROATED VIREO; YELLOW-THROATED FLY-CATCHER. Lanivireo flavifrons, (Vieillot) Baird.

BLUE-HEADED VIREO OR FLY-CATCHER; SOLITARY VIREO. Lanivireo solitarius, (Vieillot) Baird.

WHITE-EYED VIREO. Vireo noveboracensis, (Gm.) Bonaparte.

\section{LANIIDE.}

LOGGERHEAD SHRIKE. Lanius ludovicianus, Linné. ? GREAT NORTHERN SHRIKE. Lanius borealis, Vieillot.

\section{AMPELID E.}

CEDAR WAX-IVING; CEDAR BIRD. Ampelis cedrorum, (Vieillot) Baird.

\section{HIRUNDINIDE.}

PLRPLE MARTEx. Progne subis, (Linné) Baird.

?CLIFF SWALLOW. Petrochelidon lunifrons, (Say) Lawrence.

BARN SWALLOW. Hirundo erythrogastra, Boddaert.

WHITE-BELLIED SWALI.OW. Tachycineta bicolor, (Vieill.) Cabanis

BANK SWALLOW. Cotile riparia, (Liuné) Boie.

ROCGH-WINGED SWALLOW. Stelgidopteryx serripinnis, (Aud.) Baird. 


\section{TANAGRIDE.}

SCARLET TANAGER. Pyranga rubra, (Linné) Vieillot.

SUMMER REDBIRD. Pyranga æstiva, (Linné) Vieillot.

\section{FRINGILLID E.}

PURPLE FINCH. Carpodacus purpureus, (Gm.) Baird.

AMERICAN GOLDFINCH; YELLOWBIRD. Astragalinus tristis, (Linné) Cabanis.

PINE GOLDFINCH ; PINE FINCH. Chrysomitris pinus, (Wils.) Bonaparte.

?SNOW BUNTING. Plectrophanes nivalis, (Linné) Meyer.

SAVANNAH SPARROW. Passerculus sandwichensis savanna, (Wils) Ridgway.

GR.ISS FINCH. Poceetes gramineus, (Gm.) Baird.

YELLOW-IVINGED SPARROW. Coturniculus passerinus, (Wils.) Bonaparte.

HENLOW'S SPARROW OR BUNTING. Coterniculus henslowi, (And.) Bonaparte.

? SHARP-TAILE FINCH. Ammodromus caudacutus, (Gm.) Swainson.

?SEA-SIDE FINCH. Ammodromus maritimus, (Wils.). Swainson.

WHITE-CROWNED SPARROW. Zonotrichia leucophrys, (Forster) Swainson.

WHITE-THROATED SPARROW. Zonotrichia albicollis, (Gm.) Bonaparte.

TREE-SPARROW. Spizella montana, (Forst.) Ridgway.

CHIPPING SPARROW. Spizella domestica, (Bartram) Cones.

FIELD SPARROW. Spizella pusilla, (Wils.) Bonaparte.

BLACK SNOW BIRD; SNOW BIRD. Junco hyemalis, (Linné) Sclater.

BACHMAN'S FINCH. Peucæa æstivalis, (Licht.) Cabanis.

SONG SPARROW. Melospiza fasciata, (Forster) Scott.

SIVAMIP SPARROW. Melospiza palustris, (Wils.) Baird.

? LINCOLN'S FINCH, Melospiza lincolni, (Aud.) Baird.

FOX-COLORED SPARROW. Passerella iliaca, (Merrem) Sw.

CHEWINK; TOWHEE GROUND-ROBIN. Pipilo erythrophthalmus, (Linné)

vieillot.

CARDINAL GROSBEAK; REDBIRD OR CARDINAL REDBIRD. Cardinalis

virginianus, (Brisson) Bonaparte.

ROSE-BREASTED GROŞBAK. Zamelodia ludoviciana, (Linné) Cones.

BI,UE GROSBEAK. Guiraca cærulea, (Limné) swainson.

INDIGO BUNTING. Passerina cyanea, (Linné) Gray.

? PAINTED BUNTING; NONPAREIL. Passerina ceris, (Linné) Gray.

BLACK-THROATED BUNTING. Spiza americana, (Gm.) Bonaparte. 


\section{IC'TERID E.}

BOBOIINK; MAY-BIRD; REED BIRD; RICF-BIRD. Dolichonyx oryzivorus,

(Linné) Swainson

(OWBIRD. Molothrus ater, (Bodd.) Gray.

RED-AND-BCFF-SHOCLIERED BLACKBIRD. Agelæus phœniceus, (Linné) Vieil.

MEADOW LARK. Sturnella magna, (Linné) Swainson. ()RCHARD ORIOLE. Icterus spurius, (Linné) Bonaparte. BALTIIORE ORIOLE. Icterus galbula, (Linné) Cones.

BULLOCK's ORIOLE. Icterus bullocki, (Swainson) Bonaparte

RUSTY BLACKBIRD OI: GRACKLE. Scolecophagus ferrugineus, Gmelin Swainson.

BOAT-TAILED GRACKLE OR JACKDA IV. Quiscalus major, Vieillot. PURPLF GRACKLE, Quiscalus purpureus, (Bartr.) Licht.

\section{CORVIDA.}

COMIION CROW. Corvus frugivorus, Bartr.

?AMRICAX RAVEX, Corvus corax carmivorus, (Bartr.) Ridlgway.

liSH CROW. Corvus ossifragus, Wilson.

liLUE JAY. Cyanocitta cristata, (Linné) Strick.

\section{ALAUDIDE.}

SIIORE IARK. Eremophila alpestris, (Forst.) Boie.

\section{TYRANNIDE.}

KINGBIRD; BEE MARTIX. Tyrannus carolinensis, (Iinné) Temminck. GRIAT-CRESTED FIT'CATCHER. Myiarchus crinitus, (Linné) Cabanis. JIHCEE BIRD) PEWTE. Sayornis fuscus, ( $\mathrm{sm}$.) Baird.

?OLIVE-SIDED FLY-CATCHER. Contopus borealis, (Nwains.) Bp.

WOOT PEWEE. Contopus virens, (Timé) ('alanis.

TRAILA'S FLY-CATCHER. Empidonax pusillus trailli, (Aurubon) Bairi. YELLOW-BELLLEI) FIY゙-(AT IJER. Empidonax flaviqentris, Bairl.

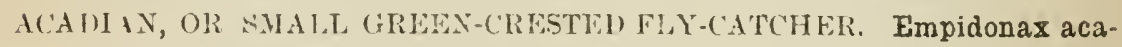
dicns, ((imelin) Bairl.

LEAST FIS-(ATCHKiF, Empidonax minimus, Baird.

YEILOW-BELLIED FLY-CATCIER. Empidonax flaviventris, Baird. 


\section{ORDER PICARIE. PICARIAN BIRDS.}

Birds with four toes, the hinder small, sometimes absent, with a claw shorter than that of the middle toe. Third and fourth toes sometimes with fewer than the normal number of joints: second and fourth sometimes versatile. Tail feather's eight to twelve, but usually ten : primaries. telı.

A much varied group of peculiar birds, with imperfect musical powers. Includes the humming birds, in some respects the most bcautiful of birds. Mostly insectivorous or carnivorous, and, with a few exceptions, of great uscfulness to the farmer. Widely distributed orer the glohe, except the humming birds, which are strictly American.

\section{TROCHILID E.}

liUBY-THROATED HUMMIX BIRD. Trochilus colubris, Linné.

CYPSELID A.

CHIDNEY SHIFT OR "sWALLOW:" Chætura pelasgica. (Linné) Bairl.

\section{CAPRIIULGIDE.}

CHUCK-WILL'S-WIDOW. Antrostomus carolinensis, ( (mm.) Gold.

WHIP-POOR-WILL. Caprimulgus vociferus, (Wils.) Bp.

NIıHTHAWK. Chordeiles popetue, (Vieillot) Baird.

\section{PICTD,E.}

IVORY-BIJLED WOODPECKER. Campephilus principalis, (Linné) Gray.

IIARY WOODPECKER. Picus villosus, Linné.

DOWXY WOODPECKER. Picus pubescens, Linné.

RLI)-COCKADED WOODPECKER. Picus querulus, Wilson.

YLLLOW-HELLIED WOODPECKER. Sphyrapicus varius (Linné), Bairi.

PILFATED WOODPECKKL OR BLACK WOODCOCK. Hylotomus pileatus.

(Limné) Baird.

REI)-PELLAED WOODPECKRR. Centurus carolinus, (Linné) Bp.

IRU.IHLADED WOODPECKKR. Melanerpes erythrocephalus, (Linné) sir.

YELLOW-SHAFTED FLICKKR. Colaptes auratus, (Jinné) Sw. 


\title{
ALCEDINID A.
}

BELTED KINGFisher. Ceryle alcyon, (Linné) Boie.

\author{
CUCULID A.
}

YELLOW-BILLED CUCKOO. Coccyzus americanus, (Linné) Bonaparte BL.ACK-BILLED CLCKOO. Coccyzus erythrophthalmus, (Wils.) Baird

\section{ORDER PSITTACI. PARROTS.}

Brilliantly colored birds, with extremely thick bills, strongly hooked tongues short and fleshy (Jordan). The outer toe of the foot reversed, so that two toes are opposed to two (zygodactyle).

Well-known birds, much admired for their gorgeous plumage, and for the quaint efforts at speech which some can be trained to put forth. Inhabitants of tropical countries. Not well represented in North America, but abundant in South America.

\section{PSITTACIDA.}

CAROLINA PARAKEET.* Conurus carolinensis, (Linné) Küuhl.

\section{ORDER RAPTORES. BIRDS OF PREY.}

Large and powerful carnivorous birds, with strong beaks and sharp claws. Four toes, the fourth sometimes versatile. Legs frequently feathered to the ankle. Tail feathers, twelve; primaries, ten.

Found in every part of the world. The order includes some of the strongest flying birds. Many are obnoxious to the poultry keeper (hawks), while others (buzzards) are of great service in removing carrion.

\section{STRIGID E.}

? B.ARN OWL. Aluco flammeus americanus, (Aud.) Ridgway. LONG-EAREI OWL, A sio americanus, (Steph.) Sharpe. SHORT-EARED OWL Asio accipitrinus, (Pallas) Newton.

*Extinct in South Carolina -G. E. M. 
BARIED OWL. Strix nebulosa, Forster.

LITTLE SCREECH OWL. Scops asio, (Linné) Bonaparte.

(GREAT-IIORNED OWL. Bubo virginianus. (Gm.) Bonaparte.

SA W-WHET OWL. Nyctale acadica, (Gmel.) $\mathrm{B}_{\mathrm{p}}$.

SNOWY OWL. Nyctea scandiaca, Linné.

\section{FALCONID E.}

PEREGRINE FALCON DUCK IIAWK. Falco peregrinus nævius, (Gm.) Ridgway.

PIGEON HAWK. Æ̇salon columbarius (Linné), Kanup.

SI'ARROW HAWK, Tinnunculus sparverius (Linné), V'ieillot.

AMERICAN OSPREY; FISH HATK. Pandion haliaetus carolinensis, (Gm.

Ridgway.

SWALLOW-TAILED KITE Elanoides forficatus, (Linné) Ridłway.

NISSISSIPPI KITE. Ictinia subcærulea, (Bartram) Coues.

MARSH HAWK; IIARRIER. Cirius hudsonius, (Linné) Vieillot.

COOPER'S HAWK. Accipiter cooperi, Bonaparte.

SHARP-SHINNED HAWK. Accipiter fuscus, (Gmelin) Bonaparte.

IRED-TAILED HAWK. Buteo borealis, (Gm.) Vieillot.

RED-SHOULDERED IIAK. Buteo lineatus, (Gm.) Jardine.

WIITE-TAILED HAWK. Euteo albicaudatus, Vieillot.

? BROAD-WINGED HAWK. Buteo pennsylvanicus. (Wils.) Bonaparte.

?ROUGH-LEGGED HAWK. Archibuteo lagopus sancti-johannis, (im.) Rilyway.

? GOLDEN EAGLE. Aquila chrysaetus canadensis, (Limné) Riilgway.

B.ALD EAGLE; GRAY EAGLE, Haliæëtus leucocephalus, (Linné) Savin.

\section{CATHARTIDAE.}

TURKEY BUZZARD. Cathartes aura, (Linné) Illiger.

BIACK VULTURE; CARRIOA CROW. Catharista atrata, (Wils.) Lesson.

\section{ORDER COLUMBE. DOVES.}

Birds, typified in the common dove, having small heads ami straight beaks, horny at the tip, which is separated from the softer portion by a constriction. The hinder toe on a level with the rest. 
Birds of downy plumage and gentle mamner. Monogamous. Many species domesticated. Abundant in most regions, but especially so in the East Indies. The Columba livia of that part of the globe is supposed to be the aneestor of all the domesticated breeds of pigeons.

\section{COLUMBIDA.}

MESSEYGER; WILD PIGEON. Ectopistes migratoria, (Linné) Sw. MOURNING DOVE; TURTLE DOVE. Zenaidura carolinensis, (Linné) Bp. GROUND DOVE. Chamæpelia passerina, (L.) Swainson.

\section{ORDER GALLINA. GALLINACEOUS BIRDS.}

Mostly thick-set birds, having short and stout wings, legs and bills, the latter convex and horny and not constricted. Hind toe elevated, shorter than the rest, sometimes wanting.

A large order of the most useful birds, including some of the domestic fowls and the principal game birds. Too well known to require comment.

\section{MELEAGRID E.}

WILD TURKEY. Meleagris gallopavo americana, (Bartram) Coues.

\section{TETRAONID E.}

? RUFFED GROU.sE. Bonasa umbellus, (Linné) Steph.

\section{PERDICID R.}

PARTRIDGE; BOB WHITE; AMERICAN QUAIL. Ortyx virginiana, (L.) Bonaparte. 


\section{ORDER LIMICOLA. SHORE BIRDS.}

Birds usually of small size, with rounded heads, long legs and necks, and long, soft bills, suited for probing in the mud. Hind toe elevated.

Largely aquatic and widely distributed. Abundant in America. The order includes many much valued game birds.

\section{PLATALEID E.}

? ROSEATE SPOONBILL. Ajaja rosea, (Brisson) Ridgway.

$$
\text { HEMATOPODIDE. }
$$

AMERICAN OYSTERCATCHER. Hæmatopus palliatus, Temminek.

$$
\text { STREPSILID E. }
$$

TUR.NSTONE. Strepsilas interpres, (Linné) Illiger.

\section{CHARADRIIDE.}

BLACK-Beilied PLover. Squatarola helvetica, (Linné) Cuvier.

GOLDEN PLOVER. Charadrius pluvialis, Linné.

KILLDEER; KILLDEER PLOVER. Oxyechus vociferus, (Linné) Reich.

SEMIPALMATED PLOVER. Fgialites semipalmata, (Bonap.) Cabanis.

PIPING PLOVER. Ægialites meloda, (Ori) Bp.

IVILSON'S PLOVER. Ochthodromus wilsonius, (Ord) Reich.

\section{SCOLOPACID E.}

AMERICAN WOODCOCK. Philohela minor, (Gmel.) Gray.

ENGLISH SNIPE. Gallinago media, Leach.

IVILSON'S SNIPE. Gallinago media wilsoni, (Temm.) Ridyway.

RED-BREASTED SNIPE; GRAI SNIPE. Macrorhamphus griseus, Gmel.) Leach.

?RED-BELLIED SNIPE; GRE.ITER GRAY-BACK. Macrorhæmphus griseus scolopaceus, (Say) Cones.

STILT SANDPIPER. Micropalama himantopus, (Bonap.) Baird.

KNOT. Tringa canutus, linné. 
PLRPLE SANIPIPEL. Arquatella maritima, (Brunn) Bairc. (iIASS SNII'E. Actodromus maculata, (Vieillot) Coues. BUNAPARTE'S SANDPIPER. Actodromas fuscicollis, (Vieill.) Ridgway. LEAST SAYDPIPER. Actodromas minutilla (Vieill.) Bl). RED-BACKED SANDPIPER. Pelidna alpena americana, C'assin

?CLRLEW SANDPIPER. Pelidna subarquata, (Gulb.) Cuvier. SEMIPALMATED SANDPIPER. Ereunetes pusillus, (Linné) Cassin. SANDERLING. Calidris arenaria, (Linné) Illiger. IIARBLED GODWIT. Limosa fedoa, (Linné) Ord. HLDSONIAN GODWIT, Limosa hæmastica, (Linné) Coues. TELL-TALE; GREATER YELLOW-LEGS. Totanus melanoleucus, (Gmel.) Vieillot.

YELLOW LEGS; LESSEI YELLOT SHANKS. Totanus flavipes, (Gmel.) Vieillot.

SOLITART SANDPIPER. Rhyacophilus solitarius, (Wils.) Cassin. WILLET; STONE CURLEW. Symphemia semipalmata, (Gmel.) Hartlaub. FIELD PLOVER; BARTRAM'S SANDPIPER. Bartramia longicauda, (Bechstein) $\mathrm{B}_{\mathrm{P}}$.

BUFF-PREASTED S.INDPIPER. Tryngites fuscescens, (Vieill.) Calanis. SPOTTED SAXDPIPER. Tringoides macularius, (Linné) Gray. LONG-BILLED CIRLEW. Numenius longirostris, Wils. HUDSOXIAX C'TRLEW. Numenius hudsonicus, Latham. ESIIIO ('LPLEW. Numenius borealis, (Forst.) Latham.

\section{PHALAROPODIDE.}

?RED PHALAROPE. Phalaropus fulicarius, (Linné) Bp.

? NORTHERT PHALAROPE. Lobipes hyperboreus, (Linné) Cur.

? WILSOXS PHALAROPE. Steganopus wilsoni, (Sab.) Coues.

\section{RECLRTIROSTRID E.}

? AMERICAY AVOSET. Recurvirostra americana, Gimelin.

? BLACK-NECKED STILT. Himantopus mexicanus, Vüllgord.

\section{ORDER HERODIONES. STORKS AND HERONS.}

Birds of peculiar appearance, with long legs and S-shaped necks. and witl broad wings and short tails. Hind toe long, and usually not elevated. Bill long, hard and pointed, with sharp, cutting surfaces. 
Readily recognizable birds of odd form. Of no considerable value commercially. Certain species are or have been renerated by different nations, c.g., the European stork and the sacred ibis of Egypt.

\section{ARDEID E.}

GREAT BLUE HERON. Ardea herodias. Linné.

AMERICAN EGRET; WHITE HERON. Herodias alba egretta, (Gmel.) Ridyway.

SNOWY HERON. Garzetta candidissima, (Gmelin) Bp.

LOUISIANA HERON. Hydranassa tricolor ludovicianuas, (Wils.) Ridgway.

LITTLE BLUE HERoN. Florida cærulea, (Limné) Baird.

GREEN HERON. Butorides virescens, (Limné) Bp.

NighT HERON. Nyctiardea grisea nævia, (Bodd.) Allen.

WHITE-CROWNED NIGHT HERON. Nyctherodius violaceus, (Linné) Rich. AMERICAN BITTERN. Botaurus lentiginosus, (Montague) Steph.

LEAST BITTER.Y. Ardetta exilis, (Gm.) Gray.

\section{CIRCONIID E.}

WOOD IBIS. Tantalus loculator, Linné.

\section{IBIDID E.}

WHITE IBIs. Eudocimus albus, (Linné) Wagler. GLOSSY IBIS. Plegadis falcinellus, (Linné) Kaum.

\section{ORDER ALECTORIDES. RAIILS AND CRANES.}

Birds somewhat resembling the herons. The hind toe small and elevated. "Body more or less compressed. Wings short, rounded, concave. Tail short and small; size various."-(Jordan).

A comparatively small order of tall birds, chicfly ralued as gamebirds. 
RALLIDA.

RED-BREASTED RAIL; MARSH IHEN. Rallus elegans, Audubon.

CLAPPER RAIL. Rallus longirostris crepitans, (Gmel.) Ridgway.

VIRGINIA RAIL. Rallus virginianus, Linné.

SORA RAIL; CAROIINA RAIL. Porzaua carolina, (Linné) Baird.

LITTLE TELLOW RAIL. Porzana novoboracensis, (Gmel.) Balrd.

LITTLE BLACK RAlL. Porzana jamaicensis, (Gmel.) Baird.

PURPLE GALLINULE. Ionornis martinica, (Linné) Reich.

FLORIDA GALLINULE. Gallinula galeata, (Licht.) Bp.

AMERICAN COOT. Fulica americana, Gmel.

? WHOOPING CRANE. Grus americana, (Linné) Temm.

\section{ORDER LAMELLIROSTRES. ANSERINE BIRDS.}

Birds with flattened bills, raised on the edges into a series of toothlike ridges. A high, compressed head, with small eyes. Usually with short legs (excepting the flamingoes, in which they are remarkably long), giving a "squatty" appearance. All swimming-birds to a greater or less extent.

In economic importance this group compares favorably with the gallinaceous birds. "An important and familiar order, comprising nearly all the 'water-fowl' which are valued in domestication or as game-birds."

The order is comparatively small, and includes but two families, the ducks and the flamingoes.

\section{PHENICOPTERIDA.}

?AMERICAN FLAMINGO. Phœnicopterus ruber, Linné.

\section{ANATIDE.}

WHISTLING SWAN. Olor americanus, (Sharpless) Bp. SNOW GOOSE. Chen hyperboreus, (l’allas) Boie.

AMERICAN WHITE-FRONTED GOOSE, Anser albifrons gambeli, (Hartlaub) Cones.

CANADA GOOSE. Bernicla canadensis, (Linné) Boie. 
BRANT GOOSE. Bernicla brenta, (Pallas) Steph.

MALLARD. Anas boscas, Linné.

BLACK DUCK. Anas obscura, Gmelin.

GADWALI. Chaulelasmus streperus, (Linné) Gray.

PIN-TAIL DUCK; SPRIG-TAIL DUCK. Dafila acuta, (Linné) Bonap.

BALDPATE. Mareca americana, (Gmel.) Steph.

SHOVELLER; SHOVELLER DUCK. Spatula clypeata, (Linné) Boie.

BLUE-WINGED TEAL. Querquedula discors, (Linné) Steph.

GREEN-WINGED TEג L. Nettion carolinensis, (Gmel.) Baird.

WOOD DUCK ; sUMIMER DUCK. Aix sponsa, (Linné) Boie.

SCAUP DUCK; BIG BLACK-HEAD. Fulix marila, (Linné) Baird.

LITTLE BLACK-HEAD. Fulix affinis, (Eyt.) Baird.

RING-BILLED BLACKHEAD : RING-NECKED DUCK. Fulix collaris, (Donov.) Baird.

CANVAS-BACK. Æythyia vallisneria, (Wils.) Boie.

REDHEAD. Æythyia americana, (Eyt.) Bp.

AMERICAN GOLDEN-EYE. Clangula glaucium americana, (Bp.) Ridgway.

BUTTERHEA ; BUFFLEHEAD. Clangula alveola, (Linné) Steph.

? LONG-TAILED DUCK; OLD SQUAW. Harelda glacialis, (Linné) Leach.

? AMERICAN SCOTER. EJemia americana, Sw. and Rich.

?AMERICAN TELVET SCOTER. Melanetta velvetina, (Cassin) Baird.

?SURF DUCK. Pelionetta perspicillata, (Linné) Kaup.

AMERICAN SHELDRAKE. Mergus merganser americanus, (Cassin) Ridgway.

RED-BREASTED SHELDRAKE. Mergus serrator, Linné.

HOODED SHELDRAKE. Lophodytes cucullatus, (Linné) Reich.

ORDER STEGANOPODES. TOTIPALMATE BIRDS.

Toes entirely webbed; the hinder one lengthened. Bill horny, but never lamellate. A prominent gular pouch.

A tolerably large group of medium sized or large birds, aquatic and largely marine. Fish-eating. Well distributed over the globe.

\section{TACHYPETIDE.}

FRIGATE PELICAN; MAN-OF-WAR BIRD. Tachypetes aquila, (Linné) Vieil. 


\section{PELECANID_E.}

IMIRICAN WHITE PELICAN. Pelecanus erythrorhynchus, Gmelin. BROWY PELICAN. Pelecanus fuscus, Linné.

PHALACROCORACID E.

FLORIDA CORMORANT. Phalacrocorax dilophus floridanus, (Aud.) Ridgway. PLOTID E.

SNAKE BIRD; AMERIUAN ANHINGA. Plotus anhinga, Linné.

$$
\text { SULARIDE. }
$$

COMMON GANNET. Sula bassana, (Linné) Brisson. BOOBY GANNET. Sula leucogastra, (Boddert) Salvin.

\section{ORDER LONGIPENNES. LONG-WINGED SWIMMERS.}

Birds with peculiarly long and pointed wings, and possessing remarkable powers of flight. Feet webbed; hind toe small (sometimes wanting) and elevated.

This order includes only two families, the gulls and the petrels. Both are largely marine, subsisting on fish. Being excellent flyers they are often found many hundred miles from land.

\section{RHYNCHOPSIDE.}

BL.ACK SKIMMER. Rhynchops nigra, Lınné.

\section{LARID E.}

GREAT BLACK-BACKED GULL. Larus marinus, limné. HERRING GULI. Larus argentatus, Brünn.

RING-BILLED GLLL. Larus delawarensis, Ord.

IAUGHING GULL. Larus atricilla, Linné. 
BONAPARTE'S GULL. Larus philadelphiæ, (Ord) Gray.

BULL-BILLED TERN ; MARSH TERN. Sterna anglica, Montag.

COMMON TERN. Sterna fluviatilis, Naumann.

FOSTER'S 'TERN. Sterna forsteri, Nuttall.

CABOT'S TERN. Stema cantiaca acuflavida, (Cabot) Ridgway.

ROYAL TERN. Sterna regia, Gambel.

ROSEATE TERN. Sterna dougalli, Montague.

LEAST TERN. Sterna antillarum, (Lesson) Coues.

BLACK TERN. Hydrochelidon lariformis surinamensis, (Gmeliu) Ridyway.

\section{PROCELLARIID E.}

GREATER SHEARWATER. Puffinus major, Faber. DUSK Y SHEARWATER. Puffinus audubonii, Finsch.

? BLACK-CAPPED PETREL. Estrelata hæsitata, (Temm.) Cones.

? MOTHER CARY'S CHICKEN; STORMY PETREL. Procellaria pelagica, Linné.

WILSON'S PETREL. Oceanites oceanica, (Kuhl) Coues. ·

\section{ORDER PYGOPODES. DITING BIRDS.}

Birds with very short wings and palmate or lobate feet. External portion of the body legs very short, causing awkwardness in terrestrial progression. Bill horny, variously serrate or lamellate.

Strictly American birds. Noted for their powers in diving and lack of proficiency in flight. About twenty-one species are recognized. One member of this group, the Great Auk, Alca impennis, has been exterminated within a century. Purely marine and mostly aretic birds.

\section{PODICIPITID E.}

AMERICAN RED-NECKED GREBE. Podiceps holbölli, Reinhardt.

HORNED GREBE. Dytes auritus, (Limné) Ridgway.

THICK-BILLED GREBE; DABCHICK. Podilymbus podiceps, (Linné) Lawrence.

\section{COLYMBIDE.}

LOON. Colymbus torquatus, Brunn.

RED-THROA'TED DIVER. Colymbus septentrionalis, Linné.

BLACK-THROATED DIVER. Colymbus arcticus, Linné. 


\section{ALCID R.}

?(OMION PUFFIN. Fratercula arctica, (linné) Steph.

\section{CLASS REPTILIA. REPTILES.}

Air-breathing vertebrates with cold, red blood. Exoskeleton dereloped as scales (serpents and lizards), or horny or bony plates (tortoises). Limbs absent (serpents), or present and adapted for walking and swimming. Eggs hatehed externally (oviparous reptiles), or in the bodty of the parent (ovoviviparous reptiles).

A large class of useful (tortoises) and baneful animals, remarkable for their varied modifications of structure. Many species which are perfectly harmless, and possess great interest for the unbiased observer, are commonly regarded with an aversion kept alive by the fables of folk-lore. About two hundred and sixty species are North American. Five orders are usually recognized.

\section{ORDER OPHIDIA. SERPENTS.}

Reptiles of an extremely attenuated form, devoid of limbs (rarely possessing rudiments of hind limbs), and with the two halves of the lower jaw united by ligament. Right and left lungs unequally developed. Exoskeleton in the form of scales. Oriparous.

This order includes some of the most venomous of all animals. Only two poisonous families, however, are represented in the United States, namely, the rattlesnakes (Crotalidix), and the harlequin snakes (Elapidx). All other North American snakes, except five species, belong to the great family Colubride, and are perfectly harmless. About one humdred and thirty-two species of this order inhabit North America. 


\section{CROTALID A.}

BANDED RATTLESNAKE** Crotalus horridus, Linné.

WATER RATTLESNAKE. Crotalus adamantens, Beaurois.

GROUND RAT'TLESNAKE. Caudisona miliaria, (Linné) Baird and Girard.

BLACK RATTLESNAKE; PRAIRIE RATTLESNAKE; MASSASAUGA. Caudi-

sona tergemina, Say.

WATER MOCCASIN. Ancistrodon piscivorus, (Lacépède) Cope.

COPPERHEAD. Ancistrodon contortrix, (Limné) B. and G.

\section{ELAPID E.}

IBEAD SNAKE. Elaps fulvius, (Limné) Cope.

\section{COLUBRID E.}

GROUND SNAKE; WORM SNAKE. Carphophiops amœnus, Say.

TALERIA'S SNAKE. Virginia valeriæ, Baird and Girard.

BROWN SNAKE. Haldea striatula, (Linné) B. and G.

CROWNED TANTILLA. Tantilla coronata, Baird and Girard.

RED-LINED SNAKE. Abastor erythrogrammmus, (Daudin) Gray.

RED-BELLIED HORN SNAKE. Farancia abacura, (Holbrook) B, and G.

YELLOW-BANDED SCARLET SNAKE, Cemophora coccinea, (Blumenbach)

Cope.

SCARLET SNAKE. Osceola elapsoidea, (Holbrook) B. and G.

SCARLET KING SNAKE. Ophibolus doliatus doliatus, (Linné) Cope.

RED KING SNAKE. Ophibolus doliatus coccineus, (Linné) Cope.

HOUSE SNAKE; MILK SNAKE; CHICKEN SNAKE; THUNDER AND

LIGHTNING SNAKE. Ophibolus doliatus triangulus, (Linné) Cope.

THUNDER SNAKE; KING SNAKE; CHAIN SNAKE. Ophibolus getulus

getulus, (Linné) Cope.

BLOTCHED KING SNAKE. Ophibolus rhombomaculatus, Holbrook.

RING-NECKED SNAKE. Diadophis punctatus punctatus, (Linné) Cope.

* This and the succeeling species of venomous snakes, except the harlequin, can be readily distinguished from the immocent ones, on close examination, by the presence of a pit in the cheek, between the eye and the nostril. No infallible remely seems to have been discovered for the cure of bites of these serpents. The immerliate cauterization of the wound and the application of large quantities of stimulants, alcohol, whisky, and the like, internally, constitute the treatment most generally successful. Delay in this matter is dangerous. 
? RING-YECKED SNAKE. Diadophis punctatus amabilis, (Linné) Cope.

XANTU', SXAKE. Hypsiglena ochrorhyncha, Cope.

GREEX SXAKE. Cyclophis æstivus, (linné) Günther.

CHICKEN SXAKE. Coluber quadrivittatus, (Holbrook) B. and G.

IIOUNTAIN BLACK SNAKE. Coluber obsoletus obsoletus, (Say) Cope.

RED-HEADED COLUBER. Co!uber obsoletus confinis, (B. and G.) Cope.

CORY SNAKE. Coluber guttatus, (Linné) B. and G.

? COUPER'S SIAKE. Spilotes couperi, Holbrook.

? GEORGIA SNAKE; INDIGO SNAKE. Spilotes erebennus, Cope.

? PINE SNAKE; BULL S.AKE. Pityophis melanoleucus, (Dandin) Holbrook. BLACK STAKE. Bascanium constrictor, (Linné) B. and G.

COACH-WHIP SNAKE. Bascanium flagellum, (Shaw) True.

RIBAND SNAKE; SWIFT GARTER SNAKE. Eutænia saurita, (Linné) B. and $\mathrm{G}$.

?LONG'S GARTER SNAKE. Eutænia proxima, Say.

STRIPED SNAKE; GARTER SNAKE. Eutænia sirtalis sirtalis, (Linné) Cope

?CHURCHILL'S GARTER SNAKE. Eutænia sirtalis dorsalis, (Linné) Cope.

GRASS SNAKE. Eutænia sirtalis ordinata, (Linné) Cope.

STORER'S SNAKE. Storeria occipitomaculata, Storer.

?DE KAY'S SNAKE. Storeria dekayi, Holbrook.

BROWN QUEEN SNAKE. Tropidonotus leberis, Linné.

GREEN QUEEN SNAKE. Tropidonotus rigidus, Say.

BELTED WATER SFAKE. Tropidonotus fasciatus, (Iinné) Holbrook.

WATER SNAKE; WATER IIOCCASIN. Tropidonotus sipedon sipedon, (Linné)

Cope.

COPPER BELLY. Tropidonotus sipedon erythrogaster, (Linné) Cope.

DARK-SPOTTED WATER SNAKE. Tropidonotus taxispilotus, Holbronk.

BLOWING VIPER; HOG-NOSED SNAKE. Heterodon platyrhinus, Latreille. BLACK HOG-NOSED SNAKE. Heterodon platyrhinus atmodes, (Latreille) Cope. BLACK VIPER. Heterodon platyrhinus niger, (Latreille) Yarrow.

HOG-YOOSED SXAKE. Heterodon simus simus, (Linné) Cope.

\section{ORDER LACERTILIA. LIZARDS.}

A very compact order of reptiles, presenting close affinities with the serpents. From these they are distinguished, however, by the presence of external ears, the osseous union of the two halves of the lower jaw, and the occurrence, in the majority of cases, of visible limbs.*

* The "glass snake," Ophiosaurus centralis, although de void of external limbs, presents the remaining and fundamental characteristies of the lizards, and is not to be regarded as a serpent. 
The lizards, as a class, revel in sunshine and all warmth, and abound most in countries where these things are most plenty. In the United States, they live principally in the southern States, though one or two species make their way as far north as Pennsylvania and Washington Territory. Nany species will bite when provoked, but few are venomous. The order will repay a far greater amount of attention than has yet been bestowed upon it.

\section{SCINCIDE.}

(RROUND LIZARD, Oligosoma laterale, (Say) Girard.

SCORPION; RED-HEADED LIZARD; BLUE-TAILED LIZARD, Eumeces fasciatus, (Linné) Cope.

\section{TEID E.}

SIX-STRIPED LIZARD. Cnemidophorus sexlineatus, (Limné) Dumeril and Bibron.

$$
\text { ANGLIDE. }
$$

GLASS SNAKE. Ophiosaurus ventralis, Daudin.

$$
\text { IGUANID E. }
$$

BROWN LIZARD. Sceloporus undulatus undulatus, (Harlan) Cope.

$$
\text { ANOLID F. }
$$

GREEN LIZARD. Anolis principalis, (Linné) Cope.

\section{ORDER TESTUDINATA. TORTOISES.}

An order of reptiles characterized by the absence of teeth, and the modification and expansion of the ribs and vertebrae to form a more or less bony chamber, which covers and protects the soft part of the body. Exoskcleton usually in the form of horny scales. Oviparous. 
This order is, perhaps, the most useful of the class, at least from an economical point of view. The flesh and eggs of the sea turtles furnish palatable and nutritious food, while the scales of some species, the hawkbill turtles, afford the beautiful " tortoise-shell " of commerce. The terrapins and soft-shelled turtles are the delight of the epieure. The "gopher" is the bon bouche of the Southeru negro. Many species of tortoises now unused might be employed for food were it not for prejudice.

The toptoises have a very peculiar distribution, being most largely represented in the eastern parts of America and Asia. About seventeen genera and forty-two species inhabit the United States.

\section{SPHARGIDID E.*}

LEATHER TURTLE. Iermatochelys coriacea, (Vandelli) Strauch.

\section{CHELONIID E.*}

LOGGERHEAD. Thalassochelys caretta, (Linné) True.

GREEN TURTLE. Chelonia midas, (Linné) Schweigger.

\section{TRIONYCHID E.}

SOUTHERx SOFT-SHELLED TORTOISE. Aspidonectes ferox, (Schw.) Wagler. SPRING SOFT-SHELLED TORTOISE. Aspidonectes spinifer, (Les.) Agassiz.

\section{CHELYDRIDE.}

SNAPPING TURTLE, Chelydra serpentina, (Linné) Schw.

\section{CINOSTERNID AE.}

MUSK TORTOISE; STINK POT. Aromochelys odorata, (Latreille) Gray. MUD TORTOISES. Cinosternum pennsylvanicum, (Bosc) Gray.

\section{EMYDID E.}

FLORIDA TERRAPIN. Pseudemys concinna, (LeConte) Gray.

YELLOW-BELLIED TERRAPIN. Pseudemys scabra, (Linné) Cope.

SAIT WATER TERRAPIN. Malacoclemmys palustris, (Gmelin) Agassiz.

*These marine turtles occur along the greater part of the Atlantic coast of the United States, and although likely at any time to be found on the shores of South Carolina, cannot properly be said to be included in its fauna--F. W. T. 
CHEQUERED TERR.IPIN. Chrysemys picta, (Hermann) Grya. CHICKEN TERRAPIN. Chrysemys reticulata, (Bosc) Cope. SPECKLED TORTOISE. Chelopus guttatus, (Schw.) Cope. COMMON BOX TORTOIsE. Cistudo carolina, (I.inné) Giray.

\section{TESTUDINID E.}

GOPHER. Xerobates polyphemus, (Dandin) Cooper.

\section{ORDER CROCODILIA. CROCODILES.}

An order of lizard-like reptiles, with four legs, fitted for walking or swimming, the feet being webbed. Skin hard and raised into scales, beneath which there are often bony plates. Tail with a series of scales, each crested on the back. Teeth conical, rootless. Heart with two ventricies.

The Crocodilia, of which the prominent North American species, the alligator, is well known, form a compact group, better represented in past time than at present. They live in sluggish rivers and ponds, and subsist largely on animal food.

Species of this order are abundant in South America. In North America there are but two recognized species, the alligator and the Florida crocodile (Crocodilus acutus, Cuvier).

\section{ALLIGATORID E.}

\section{ALLIGATOR. Alligator mississippiensis, Daudin.*}

\section{CLASS AMPHIBIA. AMPHIBIANS.}

A class of cold-blooded rertebrates, closely allied to the fishes. They breathe when young, or throughout life, by external gills. Limbs, when present, present bony elements homologous to those in the limbs of rep-

*The question has been raised whether there are two species or varieties of alligators in North America, differing in color and other characters. Observations on this point would be of great value.-F. W. T. 
tiles. Skin usually without seales. Eggs without hard shell, strongly resembling those of fishes.

$A$ class of animals mostly of no economic value. The frogs, however. furni-h excellent food, and the toads are invaluable to the agriculturist a.s insect-eaters. Many absurd notions exist regarding these animals, which have no foundation of truth, but are progeny of ignorance and prejudice. The majority of amphibians are entirely harmless.

\section{ORDER ANURA. TAILLESS AMPHIBIANS.}

Amphibians without tails in the adult state. Body broad and short; legs large, usually adapted for jumping. Young (tadpoles) with tail and gills, but without teeth.

A comparatively small group of closely allied animals, found throughout the world. Some are almost exclusively terrestrial (Bufonidie and Hyflatx), while others are almost totally aquatic. This and the remaining orders of amphibians are, in certain respects, the least known of the vertebrates.

\section{RANIDE.}

B(iLL-FROG. Rana catesbiana, Sliaw.

GREEN FROG; SPRING FROG. Rana clamitans, Merrem.

SIIAD FROG. Rana halecina halecina, (Kalm) Cope.

IIRSH FROG. Rana palustris, LeCcnte.

WOOD FROG. Rana temporaria silvatica, (Linné) Cope.

? FLORIDA FROG. Rana areolata capito, (Baird and Girard) Cope.

\section{SCAPHIOPID_E.}

SOLITARY SPADE-FOOT. Scaphiop:as holbrookii. (Harlan) Baird.

\section{HYLID F.}

GREEN TREE-TOAD. Hyla carolinensis, Pennant.

DALDIX'S TREE-TOAD. Hyla femoralis, Daudin.

(O)MMON TREE-TO.AD. Fyla squirella, Dautin.

? FLORIDA II YLA. Hyla gratiosa, LeConte.

CHA.IFLION H LA. Hyla carolinensis semifasciata, (Pennant) Cope. 
ANDERSON'S HYLA. Hyla andersoni, Baird.

DARK-GREEN TREE-FROG. Chorophilus nigritus, (Leconte) Cope.

BLACK-SPOTTED BROWN TREE-FROG. Chorophilus ornatus, (Holbr) Cope.

? TREE FROG. Chorophilus ocularis, Daudin.

CRICKET FROG. Acris gryllus gryllus, (Leconte) Cope.

WESTERN CRICKET. Acris gryllus crepitans, (LeConte) Cope.

ENGYSTOMIDE.

CAROLINA TREE FROG. Engystoma carolinense, Holbrook.

BUFONID E.

LATREILLE'S TOAD. Bufo lentiginosus lentiginosus, (Shaw) Cope.

AMERICAN TOAD. Bufo lentiginosus americanus, (Shaw) Cope.

OAK FROG. Bufo quercicus, Holbrook.

ORDER URODELA. SALAMANDERS.

Amphibians, possessing elongated bodies, covered with smootl, naked skin. Four limbs present. No external gills in the adult. Tail long, round or flattened.

A large group of peculiar and, usually, small animals.

\section{PLEURODELID E.}

EASTERN IVATER LIZARD. Diemyctylus miniatus miniatus, (Raf.) Cope. GREEN TRITON. Diemyctylus miniatus viridescens, (Raf.) Cope.

\section{DESMOGNATHID E.}

BLACK TRITON; BLACK SALAMANDER. Desmognathus nigra, (Green) Baird.

BROFN TRITON. Desmognathus fusca fusca, (Raf.) Cope.

EARED TRITON Desmognathus fusca ariculata, (Riaf.) Cope. 


\section{PLETHODONTIDAE.}

TWO-STRIPED SALAMANI)ER. Spelerpes bilineatus, (Green) Baird. YELLOW-BACKED SALAMANDER. Spelerpes guttolineatus, (Holbrook) Cope.

RED SALAMANDER; RED TIITON. Spelerpes ruber ruber, (Daudin) Cope. MOUNTAIN TRITON. Spelerpes ruber montanus, (Daulin) Cope. SALIION TRITON. Gyrinophilus porphyriticus, Green. LEAST SALAMANDER. Manculus quadridigitatus, (Iolbr.) Cope. VISCID SALAMANDER. Plethodon glutinosus, (Green) Baird. RED-BACKED SALAMANDER. Plethodon erythronotus, (Green) Baird.

\section{AMBLTSTOMID AE.}

BURROWING SALAMANDER. Amblystoma talpoideum, (Holbrook) Gray. OPAQUE SALAMANDER. Amblystoma opacum, (Gravenhorst) Baird. SPOTTED SALAMANDER. Amblystoma punctatum, Linné. TIGER SALAMANDER. Amblystoma trigrinum, Green.

\section{MENOPOMID.E.}

HELLBENDER. Menopoma alleghiense, Harlan. TENNESSEE HELLBENDER. Menopoma fuscum, Holbrook.

$$
\text { AMPHIUMID TE. }
$$

c ONGO EEL. Amphiuma means, Linné.

\section{ORDER PROTEIDA. PROTEATS.}

Tailed amphibians, with large external gills persistent throughout life. The lungs, however, retain a more or less functional capacity.

Peculiar animals, closely resembling fishes, for which they are frequently mistaken by the unleamed. Some species inhabit cares and are blind. 


\section{PROTEID E.}

GIBBES' PROTEUS. Necturus punctatus, Gibbes. LAKE SIREN ; PROTEUS. Necturus lateralis, Sar.

SIRENID E.

STRIATED SIREN. Pseudobranchus striatus, LeConte. SIREN. Siren lacertina, Jinné.

\section{CLASS PISCES. FISHES.}

Cold-blooded, aquatic vertebrates, with fore and hind limbs, the pectoral and ventral fins, adapted for swimming. A more or less bony skull. A relatively small brain. The single or unpaired fins, namely, those on the median line of the back (dorsal fins), and that behind the vent (anal fin), do not represent limbs, but are special derelopments from the skin. A distinct lower jaw. A heart with two cells and an arterial bulb. Breathing carried on by means of gills (branchiæ). Skin covered with seales or bony plates; rarely naked.

The foregoing definition is intended to include the true fishes and the ganoid fishes, such as the sturgeons and gar-pikes.

The fishes constitute a very large group, whose representatives vary greatly in size, form and morle of life. They are distributed everywhere over the globe, occurring in all bodies of water, whether large or small, as well in arctic as tropical regions. A few lakes, such as the Dead sea. are uminhabited by fishes. Other bodies of water of quite as unusual it character, such as hot springs and saline springs, often contain representatives of this class.

Fishes form the object of the most completely organized, extensive, and important industry anywhere carried on in comnection with animals in the wild state. The fisheries of the world, according to Prof. Goode, furnish products at the present time valued at not less than $\$ 235,000,000$. Not only do fishes furnish an abundant food-supply, but, also, great quantities of other valuable products, such as oils and fertilizers.

About thirteen thousand species of fishes are known, of which some thirteen hundred are North American. 
SLB-CLASS PHYSOCLISTI. CLOSED-BLADDER FISHES.

\title{
ORDER PLECTOGNATHI.
}

Fishes which have the intermaxillary bone (that in front of the upper jaw bone) immorably united with the jaw bone. Ventral fins absent. skin hard, rough, or corered with plates. Marine fishes.

\section{ORTHAGORISCIDE.}

SUN-FISH. Mola rotunda, Cuvier.

\section{TETRODONTIDE.}

PIN-CUSHION; RABBIT FISH. Chilomycterus geometricus, (Bl. and Schn.) Kaup.

SIIOOTH PUFFER; TAMBOR. Lagocephalus lævigatus, (Linné) Gill. ROUGH PCFFER ; BLOWER; SWELLFISH. Tetrodon turgidus, (Mitch.) Gill. ? SPENGLER'S PUFFER. Tetrodon spengleri, Bloch.

\section{BALISTID AE.}

LONG-TAILED FILE FISH. Alutera schœpfi, (Walb.) Goode. CHECKERED FILE FISH. Alutera scripta, (O-beck) Bleeker. HOG FISH ; FILE FISH Ceratacanthus aurantiacus, (Mitch.) Gill. STORER'S FILE FISH ; FOOL FISH. Monacanthus broccus, (Mitch.) Dek. ELROPEAN FILE FISH ; OLD-WIFR; LEATHER-JACKET. Balistes capriscus, Gmelin.

\author{
OSTRACIID E.
}

COW-FISH ; CUCKOLD. Ostracium quadricorne, L.

\section{ORDER PEDICULATI.}

Fishes, prominently represented by the goose-fish (Lophius piscatorius), which are peculiar in having the wrist-bones elongated so as to form a sort of arm, at the juncture of which with the body the gills open. Marine fishes. 
MALTHEID E.

?.BAT FISH ; NOSE FISH. Malthe vespertilio,(Linné) Cuvier.

?SPOTTED SEA-BAT. Malthe vespertilio nasuta, (Cur. and Val.) J. and G.

\section{LOPHIID E.}

? FISHING-FROG; MONK-FISH ; GOOSE-FISH ; ALL-MOUTH ; BELLOUSFISH ; ANGLER. Lophius piscatorius, Linné.

\section{ORDER HETEROSOMATA. FLAT-FISHES.}

Fishes which are peculiar in that the anterior portion of the skull is so twisted that the sockets of both eyes are brought to the same side, one being vertical, the other lateral. The posterior portion of the skull is normal.-(Cope):

The Flat-fishes form a compact group, all the species being included in a single family. They are almost exclusively marine, and are widely distributed. About four hundred species are recognized.

\section{PLEURONECTIDA.}

TONGUE-FISH; LONG SOLE. Aphoristia plagiusa, (Linné) J. and G. SPOTTED SOLE : HOG CHOKER. Achiras lineatus, (Linné) Cuvier. GRAY FLOUNDER. Etropus crossotus, J. and G. NEW YORK FLOUNDER. Paralichthys ommatus, Jor. and Gilb. FLOUNDER. Paralichthys squamilentus, J. and G. ? PALE-SPO'TTED FLOUNDER. Paralichthys albigutta, J. and G. SOUTHERN FLOUNDER. Paralichthys dentatus, (Linné) J. and G. FLOUNDER. Paralichthys ocellaris, (Dek.) J. and G. FLOUNDER Citharichthys spilopterus, Günther.

ORDER ACANTHOPTERI. SPINY-RAYED FISHES.

This is the great order of typical modern fishes. The skull is symmetrical. The gills and their covers (the opercular apparatus) are normal and 
complete. 'The former open anterior to the pectoral fins. The anterior' rays of the dorsal and anal fins exist as spines.

The fishes of this order are of wide distribution, and among them are found both marine and fresh-water forms. The majority of the marine firod-fishes belong here. About six hundred species are found in the waters of and about North America.

\section{G.IDIDE.}

H.ADDOCK. Gadus æglifinus, L.

EARLL'S HAKE. Phycis earlli, Bean.

\section{OPHIDIID A.}

? BROWN SNAKE-FISH. Ophidium marginatum, DeKay.

\section{LYCODID.E.}

Lycodalepis pclaris, (Sabine) J. and G.

\section{BLENNIIDE.}

? Clinus nuchipinnis, Quoy and Gaimard.

CAROLIXA BLENYY. Blennius carolinus, (C. and V.) J. and G.

? BLENNY. Hypleurochilus geminatus, (Wood) J. and G.

SPOTTED BLENNY. Isesthes punctatus, (Wood) J. and G.

HENTZ, BLENNY. Isesthes hentzii, (Les.) J. and (i.

OLIVE-GREEN BLENNY. Isesthes scutator, J. and G.

BOSC'S SHANYY. Chasmodes boscianus, (Lac.) Cur. and Val.

\section{BATRACHIDE.}

TOAD FISH ; OYSTER FISH. Batrachus tau, (Linné) Cur. and Val. IIDSHIPIIAN. Porichthys plectrodon, J. and G.

GOBIESOCID E.

Gobiesox strumosus, Cope. 


\section{TRIGLIDE.}

FLYIAG ROBIs. Cephalacanthus spinarella, (Linné) Lac.

LINED SEA-ROBIN ; FLYING FISH. Prionotus evolans; (Linné) Gill.

WED-FINGERED SEA-ROBIN; CAROLINA IOOBIN. Prionotus palmipes, (Mitch.) Storer.

SEA-ROBIN. Prionotus tribulus, Cur. and Tal.

SPOTTED SEA-ROPIN. Prionotus scitulus, J. and G.

\section{SCORP ENID E.}

SCORPION. Scorpæna steamsii, Goode and Bean.

\section{GOBIIDE.}

? SCALELESS GOBY. Gobiosoma bosci, (Lac.) $\$. and $G$.

BLACK GOBY. Gobius carolinensis, Gill.

OLIVE GOBY. Gobius encæomus, J. and $G$.

STRIPED SILEPER. Dormitator lineatus, Gill.

OLIVE CULIUS. Culius amblyopsis, Cope.

Lepidogobius thalassinus, $J$. and $G$.

Gobionellus oceanicus, (Pall.) J. and G.

\section{URANOSCOPIDE.}

? NAKED STAR-GAZER. Astroscopus anoplus, (Cuv. and Val.) Brevoort. Astroscopus y-græcum, (C. and V.) Gill.

\section{CHATODONTIDE.}

?ANGEL-FISH ; IsABELITA. Pomacanthus ciliaris, (Linn.) J. and G.

? BANDED BRISTLE-TOOTH. Chætodon maculocinctus, (Gill) J. and G.

\section{EPHIPPIIDE.}

ANGEL FISH ; MOON FISH. Chætodipterus faber, (Bronss.) J. and G. 


\section{JABRID E.}

IBLACK-FISII ; TAUTOG. Tautoga onitis, (Linné) Günther.

Caliodon ustus, Cuv and Val.

R.IZOR-FISH. Xyrichthys lineatus, Cuv, and Val.

BLUE-FISH ; DONCELLA. Platyglossus radiatus, (L.) J. and G.

\section{GERRID A.}

? BROWN GERROID. Gerres homonymus, (Goode and Bean) J. and G SILVER GERROID. Gerres gulo, C. and $Y$.

\section{SCIANID E.}

SPOTTED SEA TROUT; SALION TROUT. Cynoscion maculatum, (Mitchell). Gill.

SALT-IVATER TROUT; WEAK FISH. Cynoscion regalis, (Bloch) Gill.

SALT-IVATER TROUT. Cynoscion thalassinus, (Holb.) Gill.

WHITE TROUT : SALT-WATER TROUT. Cynoscion nothus, (Holb.) Gill.

DRUM. Pogonias chromis, (Linné) C. and $\mathrm{V}$.

YELLOW TAIL. Liostomus xanthurus, Lacépìde.

CHUB. Sciæna stellifera, (Block) J. and G.

SILVER PERCH. Sciæna chrysura, (Lac.) J. and G.

SEA-BASS ; SPOTTED-BASS. Sclæna ocellata, (Linné) Güıther.

CAROLINA WHITING. Menticirrus alburnus, (Linné) Gill.

SHORE WHITING. Menticirrus littoralis, (Holl)r.) Gill.

(ROAKER. Micropogon undulatus, (Linné) Cur. and Val.

CROAKER. Larimus fasciatus, Ilolbrook.

\section{SPARID E.}

BREAM. Pimelepterus boscii, Lacépède. SPOT-TAILED PIN-FISH. Diplodus caudimacula, (Poey) J. and G. BREAM. Liplodus holbrooki, (Bean) J. and $\mathrm{G}$.

BREAM. Lagodon rhomboides, (Linné) Holbrook.

SIIEEPSHEAD. Archosargus probatocephalus, (Walbaum) Gill.

PORGY. Stenotomus argyrops, (Linné) (Yill.

(ilLT IIEAD. Sparus aculeatus, (C'ur. and Val.) Gill.

FLASHER. Lobotes surinamensis, (Bloch) Cuvier.

? WHITE GRUNT. Diabasis trivittatus, (Bloch and Sckn.) J. and G. 
STRAIGIT-BACKED GRUNT. Diabasis chrysopterus, (Linn.) J. and G.

BLACK GRUNT. Diabasis formosus, (I., J. and G.

? VIRGINIA HOG-FISH. Pomadasys virginicus, (Linné) J.and G.

SAILOR'S CHOICE; HOG-FISII. Pomadasys fulvomaculatus, (Mitchell) J. and $\mathrm{G}$.

MANGROVE SNAPPER; BASTARD SXAPPER. Lutjanus aurorubens, (Cu: and Val.) Vaillant.

YELTING ; GLASS-EYED SNAPPER. Lutjanus caxis, (Bl., Schn.) Gill.

\section{SERRANID E.}

SOAP-FISH. Rypticusmaculatus, Holbr.

RED GROUPER. Epinephelus morio, (Cuvier) Gill.

BLACK GROUPER. Epinephelus nigritus, (Hollor.) Gill.

SQUIRREI، FISH; SERRANO. Serranus fascicularis, Cuv. and Val.

GRAY SERRANO. Serranus trifurcus, (Linn.) J. and G.

BLACK FISH. Serranus ratarius, (Linné) J. and G.

ROCK-FISH ; STRIPED BASS. Roccus lineatus, (Bl., Schn.) Gill.

WHITE PERCH. Roccus americana. (Gmelin) J. and G.

\section{PERCID压.}

YELLOW PERCH; AMERICAN PERCH ; RINGED PERCH. Perca americana, Schranck.

BARRATT'S DARTER. Pœcilicthys barratti, (Holbr.) J. and G.

? Nothonotus vulneratus, (Cope) Jor.

? Nothonotus rufilineatus, (Cope) Jor.

CRA WL-A-BOTTOM. Hadropterus nigrofasciatus, Agassiz,

Alvordius crassus, Jordan and Brayton.

? Alvordius neviensis, (Cope) Jor.

? Bollosoma effulgens, (Grd.) Cope.

?Boleosoma olmstedi, (Storer) Agassiz.

? Ioa vitrea, (Cope) J. and B.

\section{CENTRARCHID E.}

SMALL-IOUTHED BLACK BASS. Micropterus dolomieu, Lac.

Lepomis holbrooki, (Cuv. and V'ai.) McKay.

BLUE SUNFISH ; COPPER-NOSED BREAM ; DOLLARDEE. Lepomis pallidus,

(Mitch.) Gill and Jor.

LONG-EARED SUNFISH. Lepomis megalotis solis, (Cur. and Val.) McKay. 
? LONG EARED SLNFISH. Lepomis auritus, (I.) Raf.

Lepomis elongatus, (Hollor) Gill and Jor.

BLACK-B.INDED SUNFISH. Mesogonistius chætodon, (Baird) Gill.

Enneacanthus simulans, (Cope) NcKay.

? Enneacanthus gloriosus, (Holbr.) Jor.

? Enneacanthus obesus, (Baird) Gill.

MUD SUNFIsH. Acantharchus pomotis, (Baird) (iill.

Centrarchus macropterus, (Lac.) Jor.

\section{APHREDODERID E.}

? PIRATE PERCH. Aphredoderus sayanus, (Gilliams) DeKay.

BRAMID症.

Pteraclis carolinus, Valenciennes.

CORYPHENIDE.

Coryphæna sueuri, Cuv. and Val.

STROMATIDE.

HARVEST FISH. Stromateus peru, Linné.

POMATOMID.E.

BLUEFISH ; SKIP-JACK. Pomatomus salatrix,.(Linné) Gill.

\section{CARANGID E.}

HORSE FISH. Selene setipinnis, (Mitch.) Lütken.

SILVER MOON-FISII. Selene vomer, (Linné) Lütken. DOTTED SCAD. Decapterus punctatus, (A gassiz) Gill.

YACKEREL SCAD. Decapterus macarellus, (Cuv. and Val.) Gill

? BIG-EYED SCAD. Caranx crumenophthalmus, (Bloch) Lac. YELLOW CREVALLÉ. Caranx pisquetus, Cur. and Val. HORSE CREVALLÉ. Caranx hippos, (Limné) Günther.

HORSE CREVALLÉ. Caranx fallax, Cuv, and Yal. 
GREEN ClETALLÉ. Caranx falcatus, Holbr.

? BEA N'S CREVALLÉ. Caranx beani, Jordan.

THREAD FISH. Blethari crinitus, (Akerly) DeKay.

THREAD FISH. Chloroscombrus chrysurus, (Linné) Gill.

SHORT PAMPANO. Trachynotus ovatus, (Linné) Gïntlıer.

GLAUCOUS PAMPANO. Trachynotus glaucus, Cuv, and Val.

CREVALLÉ; CAVALLI.

POMPYNOSE Trachynotus carolinus, (Jinné) Glll.

POMPYNOSE. Seriola fasciata, (Bloch) C. and V.

RUDDER FISH; BONITO. Seriola zonata, (Mitch.) C. and V.

RUDDER FISH. Seriola carolinensis, IIolb.

? YELLOW-TAIL. Seriola lalandi, Cuv, and Tal.

? PILOT-FISH. Naucrates ductor, (Linn.) Raf.

\section{SCOMBRID AE.}

MACKEREL. Scomber colsos, Gmelin.

MACKEREL (occasional). Scomber scombrus, Linné.

BONITO SKIP-JACK. Sarda mediterranea, (Bl. and Sch.) J. and G.

IIORSE MACKEREL. Orcynus thynnus, (Limné) Poey

SPANISH MACKEREL. Scomberomorus maculatus, (Mitch.) J. and (r.

BLACK-SPOTTED SPANISH MACKEREL. Scomberomorus regalis, (Bloch) J. and $\mathrm{G}$.

SIERRA. Scomberomorus cabaila, (Cuv. and Val.) J. and G.

\section{TRICHIURID $\mathrm{E}$.}

HAIR-TAIL. Trichiurus lepturus, Linné.

\section{XIPIIID E.}

?BILL-FISH ; SPEAR-FISH ; AGUJA BLANCA. Tetrapturus albidus, Poey. ? COMIION SWORD-FISH. Xiphias gladius, L.

$$
\text { ELACATID王. }
$$

CRAB-EATER; COBIA. Elacate canada, (Linné) Gill.

\section{ECHENEID A.}

REIIORA, Echeneis remora, L.

LONG-JAIVE REMORA. Phthirichthys lineatus, (Menzies) Gill.

PEGADOR. Echeneis naucrates, L. 
POLYNEMID A.

Polynemus octofilis, (Gill) J. and G.

SPYRENIDE.

PICUDA; BARRACUDA PIKE. Spyræna picuda, Blech and Schn.

? BARRACUDA. Sphyræna guaguancho, Cur. and Val.

\section{ATHERINID E.}

?SILVERSIDES. Menidia notata, (Mitch.) J. and G.

WANDERING SILVERSIDES. Menidia vagrans, (Goode and Bean) J. and G. BOSC"S S1LVERSIDES. Menidia vagrans laciniata, Swain.

CAROLINA SILVERSIDES. Atherina carolina, Cuv. and Tal.

\section{MUGILID E.}

MULLET. Mugil albula, Linné.

WHITE MULLET; LIZA. Mugil brasiliensis, Agassiz.

\section{ORDER HEMIBRANCHII. HEMIBRANCHS.}

A small order of fishes, allied to the Acanthopteri, but having the mouth bounded above by the premaxillary bones only, and the bones of the throat reduced in number. The rentral fins are abdominal.

The North American species are but eleven in number. All the representatives of the order are of small size and economically unimportant.

\section{GASTEROSTEIDE.}

STICKLEBACK. Apeles quadracus, (Mitch.) Breroort.

COMIION STICKLEBACK; BURNSTICKLE. Gasterosteus aculeatus, L. 


\section{ORDER LOPHOBRANCHII.}

Fishes with tufted gills and small toothless mouths, bounded above by the premaxillary bones and carried at the end of a long snout. The basis of the pectoral fins are clevated, and the skin is covered with bony plates.

Small fishes of peculiar form and curious and interesting habits. Six species representing two families occur in North American waters. Fishes of the sea and brackish waters.

HIPPOCAMPID E.

FLORIDA SEA-HORSE. Hippocampus stylifer, J. and G. SEA-HORSE. Hippocampus heptagonus, Raf.

SYNGNATHIDE.

LOUISIANA PIPE-FISH. Siphostoma louisianæ، (Günther) J. and G.

\section{ORDER SYNENTOGNATHI. SYNENTOGNATHOUS FISHES.}

Fishes in which the shoulder-blade is comnected with the skull by means of a post-temporal bone. The parietal bone of the skull is very small. The ventral fins are abdominal, and, as in the case of the others, are without spines.

This order includes but a single family, the Scombcrcscidx, or Flyingfishes and Gar-fishes. They have peculiar elongated mouths, and are carnivorous. The family is represented in North America by seventeen species. Marine fishes. The flying-fishes have attracted much attention on account of their curious aërial performances. They are able to sustain themselves in the air for about a minute at a time, during which period they vibrate their "wings" or pectoral fins, and move with great rapidity. At such times they are fleeing from their aquatic enemies.

\section{SCOMBERESOCID E.}

FLYTNG FISH. Exocœtus novaboracensis, Mitchill.

FLIING FISH. Exocœtus hillianus, Gosse.

H.ALF-BEAK. Himrhamphus unifasciatus, Ranzani. 
SHORT-NOSED SKIPPER. Scomberesox brevirostris, Peters.

?SAURY; SKIPPER; BILL-FISI. Scomberesox saurus, (Walb.) Fleming.

SILVER G.AR; HILL-FISH. Tylosurus marinus, (Bl. and Schn.) J. and G.

? NEEDLE-FISH. Tylosurus hians, (C. and V.) J. and G.

\section{SUB-CLASS PHYSOSTOMI. SOFT-RAYED FISHES.}

\section{ORDER APODES. EELS.}

An order of fishes well known from its representative, the common Eel. The maxillary bones and gill-covers are frequently wanting, as are in all cases the ventral fins. The vertebre are unusually numerous. No spines in the dorsal and anal fins, which are not distinct from the tail. The body is serpentine and usually entirely without scales.

There has been much doubt relative to the manner in which eels spawn, but it has at length been proved that the mode is not unlike that of fishes. The male is smaller than the female.

\section{ANGUILLIDE.}

? CONGER EEL. Conger niger, (Risso) J. and G. COMnION EEL. Anguilla rostrata, (Le Sueur) DeKay. GOLDEN SNAKE-FISH. Ophichthys chrysops, Poey.

\section{ORDER HAPLOMI. HAPLOMOUS FISHES.}

In the fishes of this order the mouth and gill-corers are normal, and the former is furnished with teeth. The rentral fins are present (except in a few instances), and are abdominal in position. The vertebre are normal. The scales of the head and body are eycloid.

A large group of fishes of varying size, of which the family of Pikes are kell known. The majority inhabit fresh waters. The Cyprinodonts swarm in erery brook. 


\title{
ESOCIDE.
}

COMIION EASTERN PICKEREL; GIREN PIKE. Esox reticulatus, Lesueur.

BANDED PICKEREL. Esox americanus, Gmelin.

\section{CYPRINODONTIDE.}

\author{
Girardinus formosus, Grrl. \\ Gambbusia patruelis, (B. and G.) Girard. \\ Zygonectes cingulatus,, (C. and V.) Jor. \\ MINNOWS. $\{$ Zygonectes zonatus, (Nitch,) Jor. \\ Zygonectes chrysotus, (Günther) Jor. \\ ?Zygonectes melanops, (Cope) Jor. \\ ?Zygonectes atrilatus, Jordan and Brayton.
}

COMIION KILLIFISI ; MUMMICHOG ; SALT-WATER MINNOW. Fundulus

heteroclitus, (L.) Günther.

? Fundulus nigrofasciatus, (Le S.) $C$ and $T$.

Fundulus similis, (Baird and Girard) Gthr.

KILLIFISH ; MAYFISH; ROCKFISH. Fundulus majalis, (Walb.) Gthr.

Fundulus swampius, (Lac.) Gthr.

? Cyprinodon variegatus, Lacépècle.

\section{AMBI YOPSID E.}

BLIND-FISH. Chologaster cornutus, Agassiz.

\section{ORDER ISOSPONDYLI. ISOSPONDYLOUS FISHES.}

$A$ very large order, of which many representatives are well known, but which it is dificult to define on account of the lack of positive characters. The vertebrate, mouth and gills are normal. The latter are four in number, and behind the last is a slit. In sereral families, notably in the Salmonidx, an adipose, rayless fin is found on the back. The order has nearly a hundred representatives in North America, including the Salmons, Herrings, and other very important food-fishes.

\section{SALMONID 玉.}

BROOK TROUT; SPECKLED TROCT. Salvelinus fontinalis, (Mitch.) Gill and Jor. 
SCOPELID E.

SAND PIKE; LIZARD FISH. Sinodus fotens, (L.) Gill.

\section{ENGRAULIDID E.}

ANCHOVY. Stolephorus brownii, (Gmelin) J. and G.

MITCHILL'S ANCHOVY. Stolephorus mitchillii, (C and V.) J. and G.

\section{DOROSOMATID正.}

GIZZARD SH.ID; HICKORY SHAD. Dorosoma cepedianum, (Le S.) Gill.

\section{CLUPEID NE.}

MENHADEN ; BUG FISH. Brevoortia menhaden, (Mitclı.) Gill.

SHAD. Clupea sapidissima, Wilson.

THREAD HERRING; IIENHADEN. "Opisthonema thrissa, (Osbeck) Gill. BRANCH HERRING. Clupea vernalis, Mitch.

HICKORY SHAD; FALL SHAD. Clupea mediocris, Mitchill. GLUT HERRING; BLUE-BACK. Clupea æestivalis, Mitchill. ? COMIION HERRING; "WHITEBAIT" (Young.) Clupea harengus, L. ? ROUND HERRING. Etrumeus teres, (Dekay) Günther.

\section{ELOPID E.}

TARPUI; JEW-FISH. Megalops thrisoides, (Bloch and Schneider) Günther. BIG-EYED HERRING. Elops saurus, L.

\section{ALBULID E.}

? LADY-FISH ; BONE-FISH. Albula vulpes, (L.) Goode.

\section{ORDER PLECTOSPONDYLI. PLECTOSPONDYLOUS FISHES.}

A large group of fishes, with normal mouths and gills, but with the first four vertebræ much modified. They are mainly inhabitant of fresh water, and abound alike in large rivers and tiny brooks. They rary 
much in size, some species being the smallest of all fishes, while others, such as the Buffalo fish, are conspicuously large. Nore than three hundred species are recognized as inhabiting North America.

\section{('IPRINIDE.}

CARP. Cyprinus carpio, L. (Introduced).

SOUTHERI BREAII. Notemigonus americanus, (L.) Jor

BREAM. Notemigonus gardoneus, (C. and V.) Jor.

Squalius vandoisulus, (Vat.) Jor. and Gilb.

? CHUB ; HORNED DACE. Semotiius corporalis, (Mitch.) Putn.

DACE. $\left\{\begin{array}{l}\text { Ceratichthys zanemus, Jordan and Brayton. } \\ \text { ? Ceratichthy: labrosus, Cope. } \\ \text { Ceratichthys hypsinotus, Cope. }\end{array}\right.$

Minnilus scepticus, Jordan and Gilb.

? Minnilus matutinus, (Cope) Jor.

FALL-FISH. $\{$ ? Minnilus altipinnis, (Cope) Jor.

Minnilus chiliticus, (Cope) J. and (r.

Minnilus chlorocephalus, (Cope) Jor. and Gil.

? RED FALI,-FISH. Minnilus rubricroceus, (Cope) J. and G.

RED-CHEEKED SHINER. Minnilus coccogenis, (Cope) Jorlan.

SHINERS. $\left\{\begin{array}{l}\text { Cliola pyrrhomelas, (Cope) J. and G. } \\ \text { Cliola chloristia, Jordan and Braytun. } \\ \text { Cliola nivea, (Cope) J. and G. }\end{array}\right.$

MILKY-TAILED SHINER. Cliola galactura, (Cope) J. and G.

SHIxERS. $\left\{\begin{array}{l}\text { Cliola euryopa, (Bean) J. and G. } \\ \text { Cliola storeriana, (Kirt.) J. and G. } \\ \text { Cliola saludana, Jor. and Brayt. } \\ \text { ? Cliola spectruncula, (Cope) J. and G. }\end{array}\right.$

\section{CATOSHID.E.}

JUMPING MULLET; JUMP-ROCKS. Moxostoma cervinum, (Cope) Jordan.

JUMPIXG $\left\{\begin{array}{l}\text { ? Moxostoma conus, (Cope) Jordan. } \\ \text { ? Moxostoma crassilabre, (Cope) Jordan. } \\ \text { ? Moxostoma thalassinnm, (Cope) Jordan. } \\ \text { ? Moxostoma pidiense, (Cope) Jordan. } \\ \text { ? Moxostoma velatum, (Cope) Jordan. } \\ \text { Moxostoma papillosum, (Cope) Jordan. }\end{array}\right.$

? WHITE MLLLET. Moxostom album, (Cope) Jorlan.

BLUE MULLET. Moxostoma coregonus, (Cope) Jordan. 
SPOTTED MULLET; STRIPLD SUCKER Minytrema melanops, (Raf.) Jordan. ? (REEK FISH; CIIUB SU(KER. Erimyzon sucetta, (Lac.) Jordan,

?HOG SUCKER; STONE ROLLER; TOTER; CRAWL-A-BOTTOM ; HAMMERHEAD); STONE JUGGER; HOG MOLLY, Catostomus nigricans, I.e Suenr.

?COMMON SUCKER; WHITE SUCKLR; BROOK SUCKLR; FINE-SCALED SUCKER. Catostomus commersoni, (Lacépède) Jordan.

\section{ORDER NEMATOGNATHI. CAT FISHES.}

This order is principally typified in the well-known cat-fishes (Siluridx). The lower jaw is rudimentary, and prolonged into the base of the longest. of the barbels which adorn the chin. There are no real scales, but sometimes bony plates in the skin.

These are mostly fresh-water fishes, and are particularly abundant in South America.

\section{SILCRIDE.}

FORK-TAILED CATFISH. Elurichthys marinus, (Miteh.) Baird and Girard.

SEA CATFISII. Arius felis, (L.) J. and G.

CHANNEL CAT ; WHITE CAT. Ictalurus punctatus, (Raf.) Jordan.

MLD CA'T. Aniurus platycephalus. (Grel.) Gill.

GREFN MLD CAT. Amiurus brunneus, Jordan.

Noturus insignis, (Rich.) Gill and Jorlan.

? Noturus eleutherus, Jordan.

\section{SLBCLASS HOLOSTEI. BONY GANOIDS.}

\section{ORDER HALECONIORPHI. AMIAS.}

Ganoid fishes with partially heterocercal tails, vertebrae concare at both ends, and peculiarly modified pectoral fins. The intestine with a rudimentary spiral valve. But one species is known. It inhabits the fresh waters of the United States. 


\section{AMIID E.}

ILUD FISII; DOG-FISH ; BOW-FIN ; GRIXDLE; "JOIIN A. GRINDLE;" LAWYER. Amia calva, L.

\section{ORDER GINGLYMODI. GAR-IJKES.}

The Crar-Pikes resemble the Amias, and with them form the sub-class Holostei or Bony Cranoids. The tail is heterocercal; the vertebrae are concave only in front. The jaws are elongate, the upper being the longer. The body is corered with rhombic plates.

\section{LEPIDOSTEID E.}

LONG-NOSED GIR ; BILL-FISIY; COMION GAR PIKE. Lepidosteus osseus, (L.) Agassiz.

SHORT-YOSED GAR. Sepidosteus platystomus, Raf.

\section{SUB-CLASS CHRONDROSTEI.}

\section{ORDER GLANIOSTOMI. STURGEONS.}

An order of ganoid fishes possessing an eìngated body covered with five rows of bony scales or shields. There are four barbels under the mouth, which is toothless and opens directly downwart. The tail is heterocercal.

A small order of peculiar and readily recognizable fishes, usually of large size, and mostly inhabiting fresh waters northward. A few species are marine. The eggs of these animals furnish the well-known caviare, a food product more extensively eaten in Europe than in America.

\section{ACIPENSERID E.}




\section{CLASS ELASMOBRA TCHII. SHARKS ATD RAYS.}

Having a cartilaginous skeleton, no swim-bladker and a naked skin, or one covered with plates. 'The skull is cartilaginous. The pectoral fins are large. 'Teeth are invariably present. The eggs are few, large, often laid within a leathery, tendrilled case, secreted by a large gland in the oviduct.

The class contains two sub-classes, the Chimaras, Holocephali, which have sub-terminal mouths, large fins, very long tails, and naked skins; and Sharks and Rays, Plagiostomi, which have inferior mouths, shorter tails, and skin covered with large, placoid scales. The sub-class of the Clumaras is undivided, but in the sub-class Ilagistomi, two orders are recognized, the Sharks, Squali, and the Rays. Price. All are marine.

'This class' was more fully represented in the past than at present. The American species are not well known. The members of the group have but little commercial value in America, except among the Chinese of the West coast. In Europe, howerer, skates are quite extensively caten. Sharks, especially those species known as dogfish, furnish considerable quantities of oil.

ORDER RAIE. RAYS.

CEPHALOPTERID $\mathrm{E}$.

DEVIL-FISH. Manta birostris, (Walbaum) J. and G.

MYLIOBATIDE.

CLAM-CRACKER; BISHOP RAI. Ætobatis narinari, (Euphrasen) Mül'er and Henle.

? COW-NOSED RAY. Rhinoptera quadriloba, (Les.) Cuvier.

?SHARP-NOSED RAY. Mylobatis fremenvillei, LeSueur.

TRYGONIDE.

BUTTERFLI RAY. Pteroplatea maclura, (LeSueur) Müller and Henle.

STING RAY. Dasyatis sabina, 'Lesueur) Goode and Bean.

? STING RAY; STINGAREE. Dasyatis centrurus, (Mitch.) J. and G.

?SAY'S RAY. Dasyatis sayi, (LeSueur) Goode and Bean. 


\section{RAIID E}

? CLEAR-YOSED RAY. Raia eglanteria. (Lac.) JeSneur.

?SUMMER SKATE. Raia erinaceus, Mitchill.

?WINTER SKATE. Raia laevis, Mitchill.

Raia ornata, Garman.

Raia plutonia, Garman.

TORPEDINID E.

TORPEDO; CRAMP FISH. Torpedo occidentalis, Storer.

RHINOBATIDE.

SPECKLED LONG-YOSED RAY. Rhinobatus lentiginosus, Carman.

PRISTID庇.

SAW FISH. Pristis pectinatus, Latham.

ORDER SQUALI. SHARKS.

SQUATINIDE.

?ANGEL-FISH; SHARK RAY. Squatina angelus, Dumeril.

\section{LAMINID E.}

MACKEREL SHARK. Isurus glaucus, (M. and II.) J. and G.

$$
\text { CARCHARIID E. }
$$

SAND SH.ARK; SHOYEL-YOSE. Carcharias americanus, (Mitch.) Jordan and Gilbert. 
SPHYRIIDA.

HAMLER-HEADED SHARK. Sphyrna zygæna, (Linné) II. and H. SIIOVEL-HEAD SIIARK; BONNET-IIEAI). Reniceps tiburo, (Linné) Gill

\section{(G.ALEORHINII).E.}

SHARP-XOSED SIIARK. Scoliodon terræ-novæ, (Lich.) Gill. SHORT-NOSED SAW-TOOTH. Hypoprion brevirostris, Poey. SMOOTI HOUND; DOG-FISH. Mustelus hinnulus, (Blainv.) J. and G.

\section{GINGLYMOSTOMATIDE.}

NURSE SHARK. Ginglymostoma cirratum, (Gmel.) M. and H.

\section{CLASS LEPTOCARDII. LEPTOCARDIANS.}

A class of aquatic vertebrate animals in which the skull is undeveloped, being represented by a continuation of the cartilaginous back-bone (notochord). The brain and the heart are not developed.

A very limited group of rather rare animals, the lowest of the vertebrates, connected with the fishes, in a systematic arrangement, through the class Marsipo branchiates, or lamprey, eels and hog-fishes. All are marine. The following species belong to the order Cirrostomi:

\section{BRANCHIOSTOMIDE.}

L.ANCELET. Branchiostoma lanceolatum, (Pallas) Gray. 


\section{BIBLIOGRAPHY.}

1. GENERAL WORKS ON BIOLOGY. Jevons-The Principles of Science. Vols. I. and II. London: Macmillan \& Co., 1874 .

Slexcer-The Principles of Biology. Vols. I. and II. American, edition. New York: D. Appleton \& Co., 1881.

DARTrx-On the Origin of Species. Ameri(an elition. New York: D. Appleton \& Co., 1880.

\section{GENERAL WORKS ON ZOOLOGY:}

Semper-Animal Lífe. New York: D. Appleton \& C'o., $18 S 1$.

Gegexdbaur - Elements of Comparative Anatomy. English Translation. Lon don: Macmillan \& Co.; 187 S.

BALFour - A Treatise on Comparative Embryology. Vols. I. and II. London: Macmillan \& Co., 1880.

IuxLer-An Introdnction to the Classification of Animals. New edition. London, 1ss?.

\section{WORKS RELATING TO NORTH AMERICAY MAMMALS.}

BaIRD--Mammals of North America. Philadelphia: J. B. Lippincott \& Co., 1859.

Glu-Arrangement of the Families of Mammals. Smithsonian Institution, Washington.

Cours-Mustelida, or Fur-Bearing Animals. Tnited States Geological Survey. Washington, 1877.

ALLEN-History of North American Pinneperls. Uniter States Geological surrey. Waslington, ] 880 .
Coles Axt Allex-Momographs of Sorth American Rodentia. Enited States Geological survey. Waslington, 1sit.

Allex, H. - Monograph of the liats of North America. Smithsonian Institute, Washington, IStit.

JordAN-Manual of the Vertebrates of the Northern United States. Second edition. Chicago: Jansen, Ilclury \& $\mathrm{Cu}, 18 \mathrm{~s}$.

4. WORKS RELATING TO NORTH AMERICAN BIRDS

RIDGWAY-Nomenclature of North American Birls. United States National Museum, Washington, 1881.

BAIRD-Review of American Birds. Smithsonian Institution. Washington, 1864.

Batro, Brewer axp Ridgwy-A History of North American Birds. Land Birds. Boston: Little, Brown \& Co., 1574.

Cores-Birds of the Northwest. Tniter States Geological Survey. Washington, 1874 .

Cooper-Oruithology of California, Vol. I. Land Birds. Baird, Editur. Cambridge: 1870.

5. WORKS RELATING TO NORTH AMERICAN REPTILES AND BATRACHIANS.

Cope-Check-List of North Imerican Reptilia and Batrachia. Smithsonian Institution, Washington, ISTJ.

Agassiz - Contributions to the Natural History of the United States, Vols. I. and II. Boston: Little, Brown \& Co., 15., 7 .

HoLmRook - North American Herpetology, Vols. I. $-\mathrm{V}$. Philarlelphia, 18t2. 
BaIrd AXD Girard-Catalogue of the Serpents of North America. Smithsonian Institution, Washington, 155?.

Bollaxger-A Catalogue of the Specimens of Batrachia Salientia and Ecuudata in the British Museum, Second edition. London, 1882.

6. WORKS RELATING TO NORTH A.MERICAN FISHES.

GOODE-Fishery Report, United States 10th Census, Vol. I, Part 33. Fishes, Washington, [In Press].

Gürner-An Introduction to the Study of Fishes. London, 1981.
Grit-List of the Families of Fishes. Smithsonian Institution, Washington, 1872.

Güxtner-Catalngue of the Fishes in the British Museum, Vols. I.-VIII. London, 1864.

Jordax-Contributions to North American Ichthyology, Nos. 1 to :3. United States National Museum, Washington, 15:1578 .

Jordax AND Gilbert.-Synopsis of the Fishes of North America. Bull. 16, U.S. National Museum, iFashington. 1583. 


\title{
CH A РТË XI.
}

\section{A LIST OF THE INVERTEBRATE FAUNA OH SOUTH CAROLINA.}

\author{
BY L. O. HOWARD,
}

U. S. AGRICULTURAL DEPARTMENT, WASHINGTON, D. C.

\section{INTRODUCTORY REMARKS.}

As an appendix to the report of Professor Tuomey, on the Geology of South Carolina (Columbia, 1845), appeared a list of the fauna of the State, prepared by Prof. Lewis R. Gibbes. To the portion of that list upon the invertebrata, the present paper may be considered as a supplement, so far as the elasses Insecta, Arachnida, and Myriaporla are concerned, and as a revision of the remainder of the list, including many speeies since described, and others which have since been found to form part of the fauna of the State. For the portion of the list relating to the Insecta, I am myself responsible. With regard to the order Araneina (spiders), I have been enabled, through the kindness of Mr. George Marx, of Washington, to present not only a list of the described species, but to add to it a large number of undescribed species, indicated by Mr. Marx's manuscript names. The list of Myriapoda I have compiled from Prof. H. C. Wood's monograph of this group. For the remainder of the list, beginning with the Crustacea, Mr. Henry W. Turner, of the U. S. Geological Survey, is responsible. He has carefully compared Prof. Gibbes' list with the more recent publications, and the list is as accurate as the limited time and material will allow. 
It will be noticed that where a species is reended from an adjoining State, rendering it highly probable that it also occurs in South Carolina, the State is entered after the specific name in parenthesis. The species is recorded without remark (1), when it has been collected within the confines of the State; (2), when, as is frequently the case, it has becu collected at Sarannah, just across the border line; and (3), where it has been recoreded both from North Carolina and Georgia, or from Virginia and Cieorgia, as, in such case, it is almost certain to be also found in South Carolina.

With the Class Insecta, a complete list would swell this work far beyond its practical requirements. I shall, therefore, confine myself to the enumeration of the principal species which are injurious to regetation, or which are beneficial through their direct products, or from the fact that they prey upon or are parasites upon injurious species. This enumeration is supplemented, however, by a list of such works as the student will find useful in filling out gaps. In this list no works are mentioned which do not bear upon the geographical distribution of the species.

LELAND O. HOWARD.

Washington, October 22, 1SS2.

\section{SUB-KINGDONI ANNULOSA.}

\section{CLASS INSEC'TA.}

[Air breathing articulates, with three regions (head, thorax and abdomen), six legs, and usually wings.]

\section{LIST OF WORKS.}

Boisderal axd LeCoste-Histoire Général et Iconographie des Lepidoptères et des Chenilles de l'Amerique Septentrionale, Paris, 1833.

Comstock, J. H.-Report on Scale Insects. An. Rept. U. S. Dept. Agric., 1880.

Cusson, E. T.-Catalogue of the described species of sereral families of Hymenoptera inlabiting North America. Proc. lintomological Society Philadelphia, 186i]-6is.
Cressox, E. T.-Notes on the Species belonging to the sub family Ichneumonides found in A merica, north of Mexico. Trans. Am. Entomological Soc, 1877.

EDWaris, W. H.-The Butterflies of North America. Boston, 1879.

Glover, T.-Manuscript Notes from my Journal - Iemiptera Waslington, 1876. Only a few copies printed from stone for private distribution.) 
HAgen, Dr. IT. A.-Synopsis of the Neurop- PAckarn, A. S., Jro-A Monograph of the tera of North America. Washington, Smithsonian Institute, 1861.

LeConte, J. L.-All of Dr. LeConte's general papers in the Proceedings Acarl. Sciences, Philata., and Proc. American Philosoph. Soc.

LeCoxte ani Horn-The Rynchophora of America north of Mexico-Proc. Am. Phil. Soc, 1876.

MIorkis, Dr. J. G.--Synopsis of the described Lepidoptera of the United States, Washington, Smithsonian Inst., 1860.

Norton, Edw.-Catalogne of the described Tentluredinide of North Anerica Trans. Am. Entom. Soc., 1867-68.

Ostex-SACKen, C. R-Catalogue of the lescribed Diptera of North America. Washington, Smithsonian Inst. 1878. Geometris Aloths, or Phalenides of the United States. Vol. X. Resports of the U. S. Geological Survey of the Territories. Washington, 1876 .

de SAusstre, Hexri-Synopsis of American Wasps. Washington, Smithsonian $\mathbf{n -}$ stitnte, 185.

Surtir and A ввотt-The Natural IIistory of the rarer Lepidopteruls In-ects of Georgia. Lonlon, 17y7.

Thomas, Crrus-Synopsis of the Acridiclax of North America. U. S. Gelogical Survey of the Territories, Vol. V. Washington. $15 \%$ ?

Zinuermanx, C.-Synopsis of the Scolytide of America, north of Mexico, with Notes and an Appendix by Dr. Lecente Trans. Am. Entom. Soc., 1868.

\section{ORDER HYMENOPTERA.}

[Four membranous wings with comparatively few reins; the posterior wings smaller than the anterior; mouth parts formed for sucking and biting; metamorphosis complete.]

Of the families Uroceridx (Horn-tails), Cynipidx (Gall-flies), Evaniide, Proctotrupidx, Chrysididx, Formicidex(Ants), Mutillidx, Scoliadx, Pompilidx, Sphegide, Larridre, Bembecidre, Nyssonidre, Crabronidx, Tespidx (true Wasps) Andrenidre, and Apidx (Bees), we shall omit detailed lists.

\section{FAMILY ICHNEUMONIDE. ICHNEUMON FLIES.}

As all Ichneumon Flies are of prime importance, in that they are parasites upon other insects, we give as complete a list as possible of the principal sub-family. 


\section{SUB-FAMILY ICHNEUMONINA,}

fchneumon saucius Cress. maturus Cress. viola Cress. cincticornis Cre-s. galenus Cress., ( Va.) centrator say. cæruleus Cress. merus (ress, ( $\mathrm{V}$ ia.) subcyaneus Cress vittifrons Cress. sublatus Cress., (Va.) azotus Cress., (Va.) unifasciatorius Say. bronteus Cress. wilsoni Cress., (Viı.) versibilis Cress., (Va.) comes Cress., (Va.) laetus Brullé, (Va.) zebratus Cress., (Ga.) parvus Cress., ( $\mathrm{Va}$.) flavizonatus Cress., (Va.)

Ifoplismenus morulus (Say), (Va.)

Amblyteles montanus (Cress.), (Va.) illaetabilis Cress., (Ga.) indistinctus (Prov.), (Ga.) fraternus (Cress.), ( $\mathrm{Ta}$.)

Trogus exesorius Brullé.

ob-idianator Brullé.

brulléi Cress.
Ichneumon paratus Say, (Va.) vinulus Cress., (Va.) honestus Cress., (IV. Va., Ga.) leviculus Cress., (Va.) grandis Brullé, (Via.) rufiventris Brullé, (Va.) devinctor Say. insolens Cress. lewisii Cress. trogiformis Cress. instabilis Cress. funestus Cress., (Va.) maius Cress. duplicatus Say. annulipes Cress., (Va.) scitulus Cress., ( $\mathrm{V}$ a.) seminiger Cress., ( $\mathrm{V}_{\mathrm{a} a .}$ ) volens Cress. mucronatus Prov., (Va.) nanus Cress. rutilus Cress., (Va.)

Amblyteles nubivagus Cress., ( $\mathrm{T}$ a.) subrufus (Cress.) (Va.) suturalis (Say), (Va.) concinnus (Say.)

Trogus apicalis Cress. (Ga.) austrinus Cress., (Ga.) nubilipennis Hald.

\section{FAMILY CHALCIDIDE. CHALCIS FLIES.}

The species of this family, also parasitic upon other insects, have been very little studied in this country, hence the list subjoined, on account of the present state of knowledge, can hardly be considered as even indicative of the genera:

Leucospis affinis Say.

Smicr: torrina Cress, ( $\mathrm{Ta}$ )

nortonii Cress., ( $\mathrm{Ta}$.)

bracata Sanborn, (Va.)
Smicra mariae (Riley.)

nigrifex Walk., (Ga.)

mirabilis Cress, (Ga) 
Chalcis ovata Sily,

(laalcis minuta Fabr, (Ga.)

Phasqumophora sulcata, Westw., (Ga.)

Perilampus alexinus Walk., (Ga.) lepr.os Walk., (Ga.)

Perilampus cyaneus Brullé.

Isosoma hordei (Harr.) (The joint worm-fly.)

Spalangia politus (Say) (Va.)

Epistenia coerulata Westw., (Ga.)

Eupelmus mirabilis (Walsh.)

Metapelma spectabilis Westw., (Gia.)

Comys bicolor Howarl, ( Ta.)

Chilonemus albicomis Howard, (Va.)

Aphyeus eruptor Howard, (Va.)

Blastothrix longipennis Howard, (Va.)

Aphelinus mali (IIahl.)

mytilaspidis LeBaron.

Aphelinus fuscipennis Howard, (Va.)

pulchellus IIoward, (Va.)

abnormis Howard, (Va.)

Coccophagns lecanii Fiteh.

Cocephagus varicornis Howard, (Va.)

fraternus Howard, ( $\mathrm{V}$ a.)

Enplectrus comstockii Howard, (Ga )

Cirrospilus esurus, Riley, (Ga.)

Trichogramma pretiosa Riley.

\section{FAMILY TENTHREDINID E. SAIT FLIES.}

The larvae of all the saw flies, sometimes called "false caterpillars," are injurious to vegetation. The following list is taken mainly from Norton's Catalogue of the deseribed Tenthredinidie:

Cimbex americana Leach.

Schizocerus plumigera (Kilug.) (Ga.)

Atomacera ruficollis Norton, ( $V_{i}$. $)$

Ilylotoma macleayi Leach.

analis Leach, (Ga.)

virescens Kklug, (Ga.)

Hyłotoma abdominalis, Leach, (Ga.)

humeralis, Beauv.

coccinea Fabr.

Pristiphora tibialis Norton, (Va.)

Pristophora grossulariae Walsh., (?) (Native currant worm).

Emphytus inornatus Say, (Va.) apertus Harr., (Ta.)

Emphytus varianus Norton, (Va.) testaceus Norton, ( $\mathrm{V}$ ia.) 
Dolerus arvensis Say.

Selandria vitis Llarris, (The vine saw fly.) obtusa (Klug.) (Ga.)

Selandria labiata (Klug.) (Ga.)

Marroplyya pulchella (Klug.) (Ga.) flavicoxae Norton, (Va.)

Macrophya tibiator Norton, (Va.) formosus (Klng.)

Taxonus albido-pictus Nortm, (Va.)

Strongyloraster multicinctus Norton, (Va.)

Teuthredo 14-punctatus Norton, (Va.)

Lophyrus fabricii Leach, (Gia.)

compar Leach, (Ga.)

Lophyrus abbottii Leach, (Ga.) (Pine saw fly.)

americanus Leach, (Ga )

Lyda semicincta Norton, ( Va.)

cireumeincta Klug., (Ga.)

Lyda amplecta Fabr.

\section{ORDER LEPIDOPTERA. BUTTERFLIES AND MOTHS.}

[Wings, four, membranous; covered with imbricated scales. Mouth parts formed for sucking: Met:morphosis complete.]

\section{FAMILY PAPILIONIDE. BUTTERFLIES.}

There are about seventy-five species of diurnal Lepidoptera or Butterflies in South Carolina. We will mention, however, only three species, distinguished by their particularly injurious larrae:

Pieris rapae L. (The Rape Butterfly, parent of the "Imported Cabbage-Worm.")

protodice Bd. (The Soathern Cabbage Butterfly).

Goniloba proteus L. (The Roller-Worm Butterfly).

\section{FAMILY SPHINGID E. IHAWK-MOTHS.}

Splinx carolina L. (The tobacco-worm of the Sontly).

Philampelus pandorus Hb. (Injurious to the vine).

achemon Dr. (Injurious to the vine).

Darapsa myron $\mathrm{Cr}$ (Injurious to the vine).

Thyreus abbotti Swains. (Injurious to the vine). 


\section{FAMILY AEGERIDE. (LEAR-ITINGED MOTHS.}

Aegeria exitiosa Say. (Peach tree brrer).

tipuliformis L. (Currant borer).

\section{FAMILY BOMBYCIDAE. SPINAERS.}

Although this family contains many leaf-eating caterpillars, none are sufficiently noted to be mentioned here. We give, howerer, several of the larger spinners, the silk of which has been or could be used.

Actias luna (L.)

Attacus (ynthia Dru.

Antheria polyphemus (L.)

Callosamia promethea (Dru.)

Samia cecropia, (L.)

\section{FAMILY NOCTUIDE. OWLET MOTHS.}

This family comprises many of the most injurious insects of the State, which we shall give somewhat in detail. Every species not otherwise designated in the list is a cut-worm in its larra state: .

Agrotis baja S. V.

normaniana $\mathrm{Gr}$.

c-nigrum Iinn.

bicarnea Guen.

subgothica Ilaw.

tricrsa Lintner.

herilis Gr.

plecta Linn.

cupida Gr.

Manestra legitima Gr.

subjuncta $G$. and R.

Hadena arctica Boisd.

Hypa xylinoides Guen.

Prodenir commelinae Guen.

Trigonophora periculosa Guen.
Agrotis clandestina Harr. incivis Guen. lubricans Guen. velleripennis $\mathrm{Gr}$. messoria Harr. annexa Treitsch, (one of the cotton cut-worms).

malefida Gnen. ypsilon Rott. sancia Hübn.

Mamestra laudabilis Gnen.

Hadena miselioides Guen.

Prodenia flavimedia Harr. r-brumeum Gr. 
Enplexia lucipara (I.)

Nephelodes violans Guen.

IIydroecia nictitans Bonk.

Laphygrna frugiperda (Sm, and Abb.) (Grass-worm).

Leucania pallens $\mathrm{L}$.

Le'scania unipuncta, (Haw.) (Army worn of the North.)

phragmitidicola Gr. psendargyria Guen.

Aletia xylina (Say). (Cutton worm).

Plusia brassicae Riley. (Cabbage loope:).

Heliothis armigera If übr. (B $l l-W o r m$ or Corn E.ır Worm).

\section{FAMILI GEOMETRIDE.}

The larvae of the Geometridae are familiarly known as "measuringworms," or "loopers." Dr. Packard, in his Monograph, referred to before, enumerates 154 species found in the limits of the Alleghanian and Carolinian faunae, and the great majority of these are doubtless to be found in South Carolina. A common example is the "Crooseberry Span-worm " (Euftehia riberia, Fitch). The larva of Engonia sulsignaria (Hübn.) has recently done much damage to fruit trees in Fannin County, Georgia, and is rery common in South Carolina.

\section{FAMILY PYRALIDE.}

This is a poorly defined and very miscellaneous family. It has recently been split up into several smaller families, but it answers our purpose to consider it as a whole. The habits of the larve are extremely raried, and many of them are very injurious. The most injurious South Carolina species are subjoined:

Asopia costalis (Fabr.) (The Clorer Hay Worm).

Pempelia lignosella Zell, (The sualler Corn-stalk Borer).

Distraea sacchari (Fabr.) (The large Corn-Stalk and Sugar-C'une Borer).

Chilo oryzaeellus Riley. (The Rice-Stalk Borer).

\section{FAMILY TORTRICIDE. LEAF ROLLERS.}

This is a large family of small moths, the larvae of which roll the leaves of different trees and plants. Although injurious to a certain degree, they rarely occur in sufficiently great numbers to become mark- 
elly so. A familiar example in Carolina is the "Cotton leaf-roller" (Loxotania rosaceana, Harr. ?)

\section{FAMILY TINEIDE. LEAF MINERS.}

The larvae of this family are mainly leaf-miners, twig borers or case bearers. About eight hundred species have been described in the United States. The most injurious South Carolina species is murloubtedly the Angoumois grain moth (Eelechia cerculla, Oliv.). The clothes moth (Tinea flarifrontella, Linn.) is also a familiar example.

ORDER DIPTERA. FLIES, GNATS, ETC.

[Wings, two; the posterior pair replaced by a pair of knobbed threads ("poisers" or "balancers"): Miouth parts formed for sucking: Metamorphosis complete.]

The collected North Amsrican Diptera number about 5,000 species of sixty families. We shall montion here the eight families which possess the greatest economic interest.

\section{FAMILY CECIDOMYIDA. GALL FLIES.}

This family contains several very injurious insects, two of which are found in South Carolina, as will be seen in the following list:

Cecidomyia chrysopsidis Loow, (D. C.) Cevidomyia hirtipes O. S., (D. C.) destructor Say. (The Hesserrulatae O. S., (D. C.) sian $f y)$.

Diplosis caryae O. S., (D. C.) maceus Loew, (D. C.)

Diplosis robiniae (Hald.) (I. (.) tritici (Kirby). (The Wheat Midge.)

\section{FAMILY CULICIDE. NOSQUITOES.}

Culex boscii R. Desvoidy. rubidus $\mathrm{R}$. Desvoidy.
Culex taeniatus Wied., (Ga.)

taeniorhynchus Wied. (Atlantic. 


\section{FAMILY ASILIDE. ASILUS FLIES.}

The Asilus, or "Robber-flies" are of much interest, as they destroy other insects, both injurious and beneficial:

Leptogaster carolinensis Schiner.

Diogmites discolor Lew. (Kills cotton vorms.)

Atomosia puella Wied.

Dasyllis saffrana Fabr.

Laphria carolinensis Schiner.

flavescens Macq.

Laphria melanogaster Wied.

bicolor, Wied. (So. States.)

Andrenosoma pyrrhacra Wied.

Mallophora bomboides Wied, (Ga.) Mallophora orcina Wied. clausicella Macq., (Va)

Promarhus quadratus Wied, (Ga.)

Promachus rufipes Wied, (Ga.)

Erax apicalis 11 iel. (Kills cotton worms.) Erax fem ratus Macq. bastardi Macq., (N. A.)

Prortacanthus heros Wied.

Proctacanthus longus Wied, (Ga.)

Neomoctherns gracilis Wied.

Tolmerus annulipes Macq.

Tolmerus notatus Wied.

\section{FAMILY OESTRIDAE. BOT-FLIES.}

Gastrophilus equi Fabr. (Horse bot-fly.) Gastrophilus nasalis L., (X. A.)

haemorrhoidalis L., (N. A.)

Hypoderma bovis DeG. (Cattle bot-fly) Hypoderma lineata Villiers, (N. A., Ky.)

Oestrus ovis L. (Sheep bot-fly.)

Cephenemyia phobifer Clark.

Cuterebra buccata Fabr.

Cuterebra horripilum Clark.

cunieuli Clark (Rabbit bot-jly.)

\section{FAMILY TACHINIDE. TACHINA FLIES.}

The Tachina flies much resemble common house flies. They are parasitic upon other insects:

Trichopoda ciliata Fabr.

cilipes Wied.

flavicornis R. Desvoidy.

formosa Wicd. (lia.)
Trichopoda hirtipes Fabr.

lanipes Fabr. (Gai)

plumijes Fabr. 
(xymnosoma íuliginosa R. Desvoidy.

(Cistogaster immaculata Macq.

Ocyptera epytus Walk., (Ga.)

Ervia triquetra Oliv.

Jurinia amethystina Macq., (Ga.)

georgica Macq., (Ga.)

O.yptera lituarta Olir.

Micropalpus piceus Macq.

Gonia auriceps Meigen, (Ga)

Nemoraea leucaniae (Kirk.). (Preys on the Army-morm.)

trixoides, Walk., (Ga.)

Tachina atra Walk., (Ga.)

Tathina interrupta Walk., (cia)

Clytia atra R. Dewoidy.

FAMILY HIPPOBSCID A. FOREST FLIES AND SIHEEP TICK'.

Olfersia americana (Leach), ithe owl tick).

arrexe Macq., (X. A.)

brunneal Oliv.

Ornithomya avicularia L. (N. A.) (birt tick).

nebulosa Say, (N. A.)

pallida Say, (X. A.)

Melophagus ovinus L., (N. A.), (sheep tick).

Hippobosca equina I., (X.A.), horse tick).

\section{ORDER COLEOPTERA. BEETLES.}

[Wings four; anterior pair (elytra) meeting, usually, in a strairhth line duwn the hack. Elytra much thickened, forming a case, uncler which the posterior wings ane folded: Posterior wings membranous: MIouth parts formed for liting. Metamorphosis complete.]

This is the best known order of Insects. Some eight thonsind fire hunIred species have been describer in the United States and ('anada, and, at an e-timate, some four thousand species will probably be found, by diligent collecting, in South Carolina. An extensive collection of the Colcopterib of the State was made by Dr. C. Zinmermann, who revided for some time at Columbia. This collection is now in the jowision of the Museum of Comparative Zoology, at Cambridge, Mass, and Dr. Zinnermann's MS. notes are in the good care of Ir. LeConte. of Philadelphial 
The number of known species of South Carolina Coleoptera is so great that, in order to keep our list to its proper proportions, we have introduced simply an authoritative list of the genera of the more importarit families. For this list we are indebted to Mr. E. A. Schwarz, a wellknown Coleopterist. Each of these genera i: represented in South Carolina, those in italics being essentially Southern genera.

\section{FAMILY CICINDELID E. TIGER BEETLES.}

The beetles of this family are all predaceous.

Tetracha West.

Cicindela Linn.

\section{FAMILY CARABIDE. GROCND BEETLES.}

The ground beetles are mostly carnivorous; some of the species have, however, been found to be vegetable feeder:

\begin{tabular}{|c|c|c|c|}
\hline Omophron Iatr. & Panagreus Latr. & Casnonial Latr. & Calathus Bon. \\
\hline Calosoma Web. & Morio Laltr. & Leptotrachelus Latr. & Platynus Bon. \\
\hline Carabus Linn. & Melnomorpha Lat. & Eucrerus LeC. & Loxandrus LeC. \\
\hline Nomaretus LeC. & Galerita Fabr. & Lebia Latr. & Euarthrus LeC \\
\hline Cychrus Fabr. & Pterostichus Bon. & Nemotursis LeC. & Agonoderus Iej. \\
\hline Pasimachus & Amara Bon & Tetragonod erus Dej. & Anisodactylus Dej. \\
\hline Scarites Fabr. & Barlister Clairs. & Apristus Cliamel. & Anisotarsus Chr. \\
\hline Dyschirius Bon & Dijlochila Brullé. & Blechrus Motsch. & Gynandropus Dej. \\
\hline Ardistomis I'ntz. & Dicelus Bon. & Apenes LeC. & Bradycellus Er. \\
\hline Aspidoglossa Putz. & Anomoglossus Cha. & Cymindis Latr. & Selenophorus Dej. \\
\hline Clivina Latr. & Chlænius Bon. & Phløexena Chend. & Híarpalus Latr. \\
\hline Schizogenius Putz. & Ondes Ban. & Callicla Dej. & Stenolophus Dej. \\
\hline Brachynus Web. & Cratacanthus Dej. & Coptoulera Dej. & Bembidium Latr. \\
\hline
\end{tabular}

\section{FAMILI COCCINELLIDA. LADT-BIRDS.}

The familiar larly-birds are, in the main, beneficial by destroying injurious insects. Certain species have, howerer, been found to be regetarian.

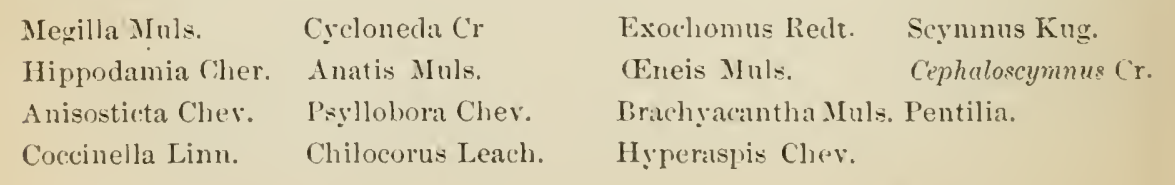




\section{FAMILY SCARABEIDT.}

Many of the Scarabeids are vegetable feeders; others feed upon dung and decaying animal and regetable material. These last are here omitted.

Serica McLeay. Diplotaxis Kirby. Polyphylla. Strigoderma Burm.

Macrodactylus Latr. Lachuosterna Hope. Anomala Koeppe, Pelidnota MICLay.

Cycloceplaala Latr. Polymrechus LeC. Phileurus Latr. Osmorlerma Iep.

thalepus MeLeay. Ayloryetes Hope. Allorhina Burm. Gnorimus Lep.

Ligyrus Burm. Strategus Hope. Euphoria. Trichius Fabr.

Aplonus LeC. Dynastes Kirby. Cremastochilus Kn. Vulnus Seriba.

\section{FAMILY BUPRESTIDA.}

The larva of the Buprestida are wood-borers.

$\begin{array}{llll}\text { Calcophora Sol. } & \text { Cinyra Lap. } & \text { Actenodes Lac. } & \text { Agrilus Sol. } \\ \text { Dicerca Esch. } & \text { Melanophila Esch. Acmæodera Esch. } & \text { Taphrocerus Sol. } \\ \text { Poeilonota Esch. } & \text { Anthaxia Esch. } & \text { Mastogenius Sol. } & \text { Brachys Sol. } \\ \text { Buprestis Linn. } & \text { Chrysobothris Esch. Rhæboscelis Cher. } & \text { Brachyscelus Sol. }\end{array}$

\section{FAMILY ELATERIDE. CLICK-BEETLES.}

The larve of the "Click-beetles" are the familiar "wire-worms."

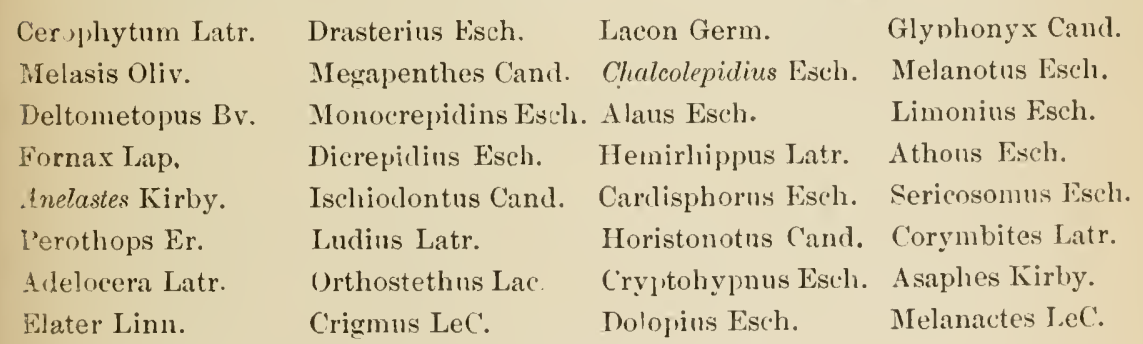

Cebris Fabr.

\section{FAMILY TELEPHORIDA. SOLDIER BEETLES.}

The larvæ of the Soldier beetles often destroy injurious larve: Thus, Chanliognathus marginatus destroys the Cotton worm.

$\begin{array}{clll}\text { Chanliognathus } & \text { Telephorus Schiffer. Ditemnus IeC. } & \text { Malthinus Latr. } \\ \text { Hentz. } & \text { Polemins LeC. } & \text { Trypherus LeC. } & \text { Malthodes Kiesenw. } \\ \text { Podabrus Westw. } & \text { Silis Charp. } & \text { Loberus Kiesenw. } & \end{array}$




\section{FAMILY CERAMBY('II)E. LONG-HORNS.}

The larve of the Long-horns are almost all wood-borers.

\begin{tabular}{|c|c|c|c|}
\hline $\begin{array}{l}\text { Maliorion Ferv. } \\
\text { Urthos sma Sers }\end{array}$ & $\begin{array}{l}\text { Clytus Laich. } \\
\text { Xylotrechus chev. }\end{array}$ & $\begin{array}{l}\text { Phymatodes Muls. } \\
\text { IEme Newin. }\end{array}$ & $\begin{array}{l}\text { Liopus Serv. } \\
\text { Lepturges Bates. }\end{array}$ \\
\hline rionus Geofl. & Seoelytus Thoms. & Ehion Newm. & Hyperplatys IIald. \\
\hline henostethus Hald. & Clytanthus Thoms. & Elouria Serv. & Graplisurus Kirlyy. \\
\hline Asemum Esch. & Microclytus LeC. & Elaphidion Serv. & Acanthocinus Stepin, \\
\hline Criocephalus Muls. & (yrtophorus Ied: & Tylonotus Hald. & Dectes IeC: \\
\hline smodicum LeC: & Tillomorpha Blaneh. & Heterachthes Newm. & Ecyrus LeC. \\
\hline Dularius Thoms. & Euderces LeC. & Curius Newm. & Eupogonius LeC. \\
\hline Pliyton Newm. & Atimis Halrl. & I.eptura Sers. & Oncideres Serv. \\
\hline allymoxys Kinatz. & aia serr. & Cyrtinus LeC. & ia Hald. \\
\hline Iolorchus Fabr: & Necydalis Lim. & P'senocerus LeC. & Hippopsis Serv. \\
\hline Rhopralapnora Serv. & Rhagium. & Yonohammus Serv. & Saperda Fabr. \\
\hline atyle Thoms. & Centrodera leeC. & Porehaschema LeC. & Mecas LeC. \\
\hline Stenosphenus Halk. & Toxotus Serv. & Hetcemis Hald. & ea Muls. \\
\hline Cyllene Sewm. & Galurotes LeC. & Gioes LeC & Tetraopes Serv. \\
\hline opalus Serv. & Strangalia Serv. & Acanthoderes Serr. & aTlıon \\
\hline & & & \\
\hline
\end{tabular}

\section{F.MILY ('HRYSOMELID)E. LEAF BEETLES.}

This family includes many of the most injurious beetles, including the Colorado Potato-beetle, the Sweet Potato-beetle, the Grape-rine Fleabectle, and many others.

Donacia Fab:.

Macroplea Sam.

Orsolachual Latr.

Leina Fabr.

Anomere Lace.

Babia Cliev.

Strxinis Lac:

Coscinoptera Jac.

Chlamys Finoch.

Exema Lac.

Monachus Chey

Cryptocephalus Geoff. Gastrophysa Cher.

Triachus LeC.

Diachus LeC

Gribnrius Hald.

Fidia Baly.

Xanthonia Paly.

Heteraspis Cher.

Glyptos:elis Ler.

Myochrous Cher.

Typophorus ('her.

Paria LeC.

Metachroma Cliev.

Colaspis Fabr,

Chrysomela Linn.

Melasoma.

Cerotoma Cher.
Pachybrachys Chev. PhyllecthrusLec.

C'luelimorpha C'her.

Physonota Boh.
Limperus Geoff.

Diabrotica Chev.

Arlimonia Laich.

Gilerucra Geuff.

Trirhabda LeC.

Cher Ceratialtica Cr.

II ypolampis Clk.

Edionychis Latr.

Disonycha Chev.

Giraptodera Cher.

Longitarsus LeC.

Batophila Fond.

Phyllotreta Fond.

Aphthoma Cher.

I libulia C'lev.
Systena Cher.

Orthaltiea Cr.

Lyperaltica Cr.

Crepidodera Chev.

Epitrix Foud.

Mantura Steph.

Chaetocmema Sterh.

Psylliodes Latr.

Blepharida Cher.

Oclontota Cher.

Charistena Baly.

Microrluopala Cliev.

Cassida Linn.

Coptocyla Cher. 


\section{FAMILY MELOIDA. BLISTER-BEETLES.}

The Blister-beetles are vegetable feeders, but their larve are usually parasitic.

Meloë Linn.

Macrobasis LeC
Epicauta Rerlt. Pomphopea LeC. Tetraonyx Latr. Pyrota LeC. Cantharis L. Zonitis Fabr.

Nemognatha Ill.

\section{COLEOPTERA RHYNCOPHORA.}

[Several of theolit family, including the weevils and the Staphylinids, are now united in this group, which may be called a sub-order. Nearly all the species are injurious.]

\section{FAMILY RHINOMACERID正.}

Rhinomacer Fabr.

\section{FAMILY RYNCHITID E.}
Auletes Sch. Eugnamptiis Sch.
Rynchites Hust.
Pterocolus Sch.

\section{FAMILY ATTELABID E.}

Attelabus L.

\section{FAMILY OTIORHYNCHID E.}

Epicrerus Sch. Phyxelis Sch. Agraphus Sch.

Sitones Sch. Listronotus Jekel. Macrops Kirby. Pachylobus LeC.
Neoptochus Horn.

Pachnaus Sch.

Tanymecus Sch.
Pandeletejus Sch.

Brachystylus sch. Aramigus Horn.
Aphrastus Sch. Eudiagogus Sch.

\section{FAMILY CURCULIONID A.}

Anchodemus LeC. Conotrachelus Sch. Coliodes Sch.

Lissorhoptrus LeC. Rhyssematus Sch. Centorhynchus Germ. Bagous Germ. Chalcodermus Sch. Otirlocephalus Chev. Zaglyptus LeC.
P'elenomus Thoms.

Coelogaster Sch. 
IIylobins sch. r'issodes (ierm.

Lixus Fabr.

Dorytumus sch. Desmoris LeC.

Pachytychius Jekel. 'thy Smicrunyx Sch. Phyllotrox Sch. Endalus Lap. Brachy bamus Germ. Centrinus Sch. Onychylis LeC. Or.hestes III. Miarus Sch. Zygobaris LeC.

\section{Magdalis Germ.} Aramptus LeC. Anthonomus Germ. Acalles Srh. Prionomerus Sch. Piazorhinus Sch. Tyloderma Say. Phyrdenus LeC. Cryptorhynchus III. 'lyysanocnemis LeC. Piazurus Sch. Gymnetron Sch. Laemosaceus Sch.
Copturus Sch. A coptus LeC.

Tachygonus sch. Mononychus Germ. Craponius LeC: Balaninus Germ.
Rhinonchus Sch. Trirhobaris Lel: Aulobaris LeC. Baris Germ.

Onychobaris Lec: P'seuclobaris LeC. Ampeloglypter LeC. Madarus S.h. Stethobaris Ler: Barilepton LeC. Plocamus LeC.

\section{FAMILY BRENTHIDE.}

Eupsalis Lac.

\section{FAMILY CALANDRIDE.}

Rhyicophorus.

Sphenophorus Sch.

Calandra Chaur.
Dryopthorus Sch.

Cossomus Clairv.

Stenomimus Woll.
Phloephagus.

Wollastonia.
Amaurorhinus.

Stenoscelis.

\section{FAMILY SCOLYTIDA.}

Platypus Hbst.

Corthylus Er.

Xyleborus Eich.

Cryphalus Er.

Nonarthrum Kirsch. Xylocleptes.

Pityopthorus Eich. Tomicus Latr.

Hypothenemus West.Micracis LeC.

\author{
Scolytus Oliv. \\ Chramesus LeC. \\ Phloeotribus Latr. \\ Cnesinus Lec.
} Hỵlesinus Fabr.
Phloeosinus Eich. Carphoborus Eich. Dendroctomus Er. Hỵlastes Er.

\section{ORDER HEMIPTERA.}

[Wings, fonr; anterior portion either of same thickness throughout, and, ustually, sloping at sides, or thickened at base with thinner extremities which overlap: Mouth parts formed for sucking: Metamorphosis incomplete.] 


\section{SUB-ORDER IIOMOPTERA.}

[Hemiptera having the anterior wings of the same thickness throughout. and usually sl poing at the sides: Mouth parts inserted at the posterior and inferior portion of tìe head.]

\section{FAMILY COCCIDAE. BARKLICE, OR SCALE FNSECTS.}

This is one of the most injurious families of insects. The species liave been very little studied, so that their geographical distribution is not well known. A number of species have been deseribed by Prof. Comstock, from the District of Columbia, and, as the majority of these will probably be found in South Carolina, they are included in the following list: Aspidiotus ancylus Putnam, (D. C., on Ma- Aspidiotus pini Comst., (Ga., on pines). ple, Peach, Hackberry.)

obscurus, Comst., (D. C., on tenebricosus Comst.(D. C., on Willow and Oak.) red Maple.)

Diaspis carneli Targ., Tozz.-(I). C., on Diaspis rosae (Sandberg). (On Rose, BlackJuniper aud Arbor Vitae.) Chionaspis euonymi Const., (V'al, on Euon- Chinaspris nyssae Comst. (On Black Gum.) y'mus.

furfurus (Fitch). (D. C., on Apple.) pinifoliae (Fitch). (On Pines.) Mytilaspis pomorum (Bouché). (On Apple.) Lecanium hesperidum (L.) (On Iry ani Orange.) Kermes gallaeformis Riley. (On Oak.) Dactylopins destructor Comst. (Nealy but.) longifilis Comst. (D. C.)

\section{FAMILY APHIDIDA. PLANT LICE.}

About 170 species of Plant lice have been describer in the United States. They are very injurious insects, and are familiar to all gardeners and florists. During the past year the grain louse (Siphonophora acenae, Fabr.) has done much damage to wheat in North and South Carolina. We mention some of the most prominent South Carolina species:

Siphomophora arenae (Fabr.) (The grain Siphonophora rosae Beaur. (On Rose.) louse.)

Myzus cerasi (Fabr.) (On Cherry.)

Iplis mali Fabr. (On Apple.) maidis Fiteh. On Corn.)

Schizoneura lanigera Hausm. (The Woolly Schizoneura americana Riley. (On Elm.)

Penphigus alnifolii Riley. (On Maple.)

$$
\text { Apple Louse.) }
$$

Plyylloxera vastatrix Planchon. (The Grape Phylloxera.)

\section{Myzus persicae (Selzer). (On Peach.)}

A phis brassicae Linn. (On Cabbage.) 


\section{FAMHLY CICADELLIDA. LEAF HOI'PERS.}

This is a family of large extent, and is not well worked up. The common "Girape vine thrips" (Erythroneura vitis Fitch) is a good example. The Cicarlula exitiose of Uhler did much damage to winter grain in York, Abbeville, Union, and Laurens comnties, South Carolina, in the spring of 1879, and another member of this family, Diedrocephala fluvireps. Riley, was concerned in the same work.

\section{FAMLY CIC.ADID压. "LOCUSTS."}

The Seventeen Year Locust (Cicada septendecim Linn.) is the best known representative of this family.

\section{SUB-ORIER HETEROPTERA.}

[Hemiptera having the anterior wings thickened at base, with thinner extremitics, which overlap on the back: Mouth narts inserted at the anterior and inferior portion of the head.]

This sub-order is one of great extent and includes many of our most injurious insect enemies, as well as many of the most beneficial predatory species. The North American species have been carefully monographed by Mr. P. R. Uhler, of Baltimore, and this monograph will probably be published before long as one of the Smithsonian contributions.

\section{FAMILY REDUVIIDA.}

The insects of this family prey upon other insects and may be classed as very beneficial to man.

Nabis ferus Latr. (Destroys plant lice.)

Prionotus cristatus L. (The "Wheel-bug," or "Devils' Conch Itorse ;" destroys a variety of injurious trsects.)

Sinea multispinosu Say. (Destroys the Cotton-uorm). 


\section{FAMILY CORISIDE.}

The members of this family (we use it for convenience in its oild signification) have varied habits, some being regetable feelers and very injurious, while others are carnivorous; others still combine the two habits:

Acantliocephala femorata Filbr. (Desiroys cotton und army roums.)

Anasi tristis DeG. (Feeds on garden regetubles.)

armigera say.

Anthocorus insidions Say. ("Fulse Chinch bug.")

Corimelaena pulicaria Germ. (Punctures strawber'y and rusp'serry plunts.)

Euschistis tristigma Say. (Carnixorous.)

I eptoglossus phyllopus L. (Destroys Cabbage-lug.)

Lygaeus bicrucis Say.

lineolaris Beanv. (Punctures plunts.)

Micropus leucopterus Say. (Chinch bug.)

Nezara hilaris Say. (Destroys Cotton-worms.)

Oebalus typheus (Fabr) (Carnirorous.)

Pirates biguttatus Say. (Feeds on Bed-bugs.)

Podisus cynicus Say. (Tegetuble feeder; also carnivorous.)

spinosus Dallas. (Destroys Colton-uorms.)

Strachia histrionica Halnn. (The II.trlequin Cabbage bug.)

\section{FAMILY MEABRACIDE.}

Mention is made of this family on account of its containing, among its members the common bed-bug (Acruthia lectuleria, L.)

\section{FAMILY PEDICULIDAE. BODY LICE.}

\section{ORDER ORTHOPTERA. CRICKETS, GRASSHOPPERS, ETC.}

[Wings four; anterior pair thickened and usually overlapping; posterior pair thinner and folded in plates longitulinally: Mouth parts formed for biting: Metamorphosis incomplete.]

This order includes many injurious insects. We shall make special mention of four of the seven families, omitting the Plasmidx (Walkingsticks), Blattide (Cockroaches), and Forficulidic (Earrigs). 


\section{FAMILY GRYLLIDE. CRICKETS.}

This family is not well worked up for America. Among the South Carolina species we mention only the following:

Gryllus luctnosus Serv.

Gryllus abbreviatus Serr.

Gryllotalpa longipennis sudud. (Mole cricket.)

Oecunthus niveus Harr. (showy tree-cricket.)

\section{FAMILY LOCUSTIDE. LONG-HORN GRASSIOPPERS.}

Microcentrus retinervis Scudl. ("Katy-did.")

Orchelinum glaberrium Burm. (?)

Orchelinum agile DeG.

Xiphidium fasciatum DeG.

Conocephalus crepitans Scudd.

Phanerotptera curvicanda Harr.

\section{FAMILY ACRIDIDAE. GRASSHOPPERS OR TRUE LOCLSTS.}

The members of this family are all so injurious that we shall give ats complete a list as possible.

Tryxalis brevipenis Charp.

Opomala punctipennis Serv. bivittata Serv.

Pyrgomorpha punctipennis Thos.

Opomala varipes Serv. marginicollis Serv.

Stenobothrus admirabilis Uh1.(D.C.S. Ill.) Stenobothrus.Maculipennis Scudd. occidentalis Sauss.

Tragocephala infuscata Harr.

Tomonotus sulphureus Sauss.

CEdipoda sordida Burm

(arolina Linn.

fenestralis Serr.

rugosa scudd.

Pezotettix longicornis Sauss. edax Sauss.

Jaloptenus femur-rubrum De Geer. differentialis Thos.

Ch.romachris colorata (Serv.)

Acridium rubiginosum Harr. alutaceum Harr americanum (Trury.)
Tragocephala viridifaseiata Harr.

Tomonotus xanthopterus (Burm.)

Edipoda discoidia Serv. phenicoptera. sincerata Harr.

Pezotettix scudderi Uhl (Md.)

Caloptenus bivittatus (Say.)

Oxya claviger (Serv.)

Acridium ambigum Thos. (Tenn.) obscurum (Fabr. obtusum Burm. 
Rhomalea centurio (Drury.)

Tettix ornata (Say.)

femorata Scudd (Md.)

Tettigidea lateralis (Harr.)
Rihomalea marci Serv.

Tetlix oxycephala Burm.

Tettigidea polyuorpha (Burm) (Ala.)

\section{FAMILY MANTIDE.}

The insects of this family are raptatorial, and prey upon other insects. The common South Carolina species is Mantis curolina Linn., commonly known as the "Rear-horse." It is eommon all through the South, but was originally described from Carolina.

\section{ORDER NEUROP'TERA.}

[Wings four, membranous, net-reined, generally lapre and of nearly equal size: Mouth-parts formed for biting: Metamorphosis complete or incomplete: Abdomen of female with no sting or piercer.]

This is a very heterogeneous Order, and none of its members are of sufficient importance economically to merit special mention here Dr. Hagen, in his synopsis (1S61), mentions eight hundred and twelve North American, of which twenty-nine only are from Carolina, while one hundred and four are from Georgia. This, however, camot be taken as an index to the true number of species in the State

\section{CLASS ARACHNOIDEA.}

[Borly of two regions (ceplalo-thorax and abdomen): thorax with eight legs: al)domen with six spinarets: head without antennx: No metamorphosis.]

\section{ORDER ARANEINA. SPIDERS.}

[Jalls used exclusively for biting: abdomen spherical, sac-shaped, not diridec] into segments, and attached to the cephalo-thorax by a slender pedicel.] 


\section{FAMILY EPEIROIDA. ORB-WEATERS.}

Gasteracantha cancer (Hentz.)

A(rosoma spinea (Hentz.)

rugosa (Hentz.)

$\Lambda$ rgiope riparia (IIentz)

Eveira insularis IIentz.

septima IIentz.

domiciliorum Hentz.

Mịiranda bombycinaria (Hentz.)

displicata (Hentz.)

A(ranthepeira stellata (Hentz.)

verrueosa (Hentz.

O(repeira ectypa (W:ilk.)

(yrtophora tuberculata Marx MS.

Cyrtarachne cornigera (IIentz.)

Singa foliata (Hentz.)

pratensis (Hentz.)

rubella (Iientz.)

Ziila globosa (Keyserling.)

labyrinthea (Hentz.)

placida (Hentz.)

gibberosa (Hentz.)

Epieira jrompta Heutz. albida Marx MS.

I hyllira mameata Hentz.

Iypriotes cavatus (Hentz.)

Nephilla plumipes Koch.
Acrosoma initrata (Hentz.)

Argiope fasciata (Hentz.)

Epeira vulgaris İentz.

strix Ilentz.

thaddeus Hentz.

Mirandla nigrostriata Marx MIS.

heptagon (IIentz.)

Acanthepeira spinosa Marx MS

Singa tetragnathoides Marx MS. nigrifrons Marx MS.

Zilla maculata Keỵs. hortorum (Hentz.) scutulata (Hentz.) caudata (Hentz.)

Epeira fera Marx MS. textrix Marx MS.

Phyliira riparia Hentz.

\section{FAMILY THERIDIOIDA. SNARE-ITEATERS}

Episenus truncatus Walk.

Erigone coccinea (Hentz.)

indirecta Cambr.

neoplita (Heutz.)

Linyphia commis Hentz.

marmorata IIentz.

scripta Hentz.

Mimethus interfecta Hentz.

Erigone anglica (Hentz.)

oscitabundum ( $\mathrm{Hz}$.)

rosirla (Hentz.)

Linyphia conferta Hentz.

costata Hentz.

Ilimethus tuberosus Hentz.

Thalamia parietalis Hentz. 
Theridium vulgare Hentz. serpentinum IIentz. jnarmoratum Hentz. boreale Hentz. studiosum Hentz. frondeum Hentz. rruciatum Hentr. funebre Hentz. cancellatum Hentz.
Theridim intentum llent\%. blandum flentz. lyra Hentz. sphaerula IIentz. trigonum Hent\%. tectum Hentz. jictum fientz.

fuliaceum Hent\%.

Lathrodectus verecundus (Hentz.)

sipinthrus flavidus Hentz.

\title{
FAMILY PHOLCOID E.
}

Pholeus atlanticus Hentz.

Pholcus puliulus (Hentz.)

Spermaphora meridionalis Hentz.

\section{FAMILY SCYTODOIDE.}

Sicytodes camerarlus Hentz.

Loxosceles longipes Marx MS.

\section{FAMILY AGALENOIDE. FUNNEL SPINNERS.}

\author{
Dictynat sublata (IIentz.) \\ rolupis Keys. \\ Amaurobius atrox Marx MS. \\ Corlotes comunis Marx MS. \\ Tegrenaria medicinalis Hentz. \\ Hahnia pulchella Marx MS. \\ Agalena navia flentz.
}

Dictyna moderata Mrarx MS.

\section{FAMILY DRASSOIDE. ASSASSIN SPIDERS.}

Trachelas inermis Marx MS.

Liocranum zonarium (Heatz.)

crocatum (Hentz)

Micaria nitens Marx MS.

Herpyllus ecclesiasticus Hentz.

bicolor Hentz.
Liocranum variegatum Marx MS.

Herprllus vulgaris Marx Мঙ. 
Anyphæna fallens (IIentz.) albens (Hentz.)

Phonolithus nitens Marx IIS. Gnaphosia variegata (Hentz)

Clubiona pallens IIentz.

obesa Ilentz.

piscatoria Hentz.

tranguilla Hentz.

celer Hent $z$.

saxatiles Kouch.

Cheiracanthium abicum Marx MS. saltabunclun (Hentz.)

Drassus aureolis Marx MIS.

longipalpus Marx MS.

Phrurolithus nitens Marx MSs.
Alyph:ena gracilis (Hentz.)

Phonolithus fisciatus Marx MS. Guaphosa columbiana Marx MS. Ciubinna amarıntha Walk. akottii Koch. excepta Koch. cortic'slis Walk. riparia Koch.

Clieiraranthium atrox Marx MS. ripariun Marx MS.

Drassus tristis Marx MS. pavidus Marx MS.

Phrurolithus fasciatus Marx MS.

FAMILY DYSDEROID A.

I'ylarus bicolor Hentz.

\section{FAMILY FILISTATOID E.}

Filistata hibernalis Hentz.

\section{FAMILY THERAPIOSOID.E. MINING SPIDERS.}

Atypus niger Hentz.

Pachylomerus solsticialis (Hentz.) Pachylomerus carolinensis (Ientz.)

Eurypelma bicolor (Hentz.) Euryl elna gracilis (Hentz.)

11 ygale truncata Hen!z.

\section{FAMILY THOMOSOID AE. CRAB SPIDERS.}

Xysticus trignttatus Keys. pulgerimus Keys. lenis Keys. punctatus Keys. elegans Keys.

Oxyptilla georgiana Kieys. Coriarachne versicolor Keys. Synema parvula Keys.
Xysticus limbatus Keys. emertonii Keys. variabilis Keys. gulosus kieys.

Synema nigromaculata Keys. 
Misumena spinosa Keys. rosea Keys. americana Keys.

Diaea lepida Thorell.

Runcinia brenclelli Keys.

Tmarus candatus Keys.

'Tibellus luttoni Keys.

Thanatus rhomboloidus Marx MS.

Philodromus aureolus Kieys

laticeps Keys.

vulgaris Hentz.
Misumena georgiana Key's. ratia Walk.

Thanatus rubicundus Keys.

Philodromus infuscatus Keys. imbecillus Keys. molitor Marx MIs.

\section{FAMILY LYCOSOIDE. WOLF SPIDERS.}

Lycosa scutulata Hentz. punctulata Hentz.

Tarentula sagitata (Hentz). ocreata (Hentz). ruricola (Hentz). lenta (Hentz). carolinensis (Hentz). georgiana (Marx MIS). fatifera (Hentz).

Trochosa furiosa Marx ms.

Dolomedes tenebrosus Hentz. tenax Hentz. albineus Hentz. urinator Hentz.

Ctenus literalis Marx MS.

Ocyale carolinensis (Hentz).
Lycosa funerea Hentz.

Tarentula saltatrix (I Ientz). erratica (Hentz). litoralis (Hentz). maritima (Hentz). aspersa (Hentz). ripararia (Hentz).

Dolomedes sexpunctatus Hents. marginatus Marx MS audax Marx MS.

Ocyale variegata Marx MS.

\section{FAMILY OXYOPOIDE. LYNX SPIDERS.}

Oxyopes viridans Hentz. scalaris Hentz.
Oxyopes salticus Hentz. astutus Hentz.

\section{FAMILY ATTOIDE. JUMPING SPIDERS.}

Attus insolens Hentz. cardinalis Hentz. capitatus Hentz. militaris Hentz. 19
Attus parrus Hentz. rarus Hentz. niger Hentz. gracilis Hentz. 
inulticolor fientz.

sexpunctatus Hentz.

falcarius Hentz.

hebes Hentz.

rastaneus Hentz.

taenifolia Hentz.

elegans Hentz.

familiaris Hentz.

tripunctatus Hentz.

Lystaceus Hentz.

atiosus Hentz.

fasciolatus Hentz.

rufus Hentz.

podagrosus Hentz.

rupicola Hentz.

nubilis Hentz.

parvus Hentz. leopardus Hentz.

puerperus Hentz.

vittatus Hentz.

coronatus Hentz.

coceatus Hentz.

pulex Hentz.

anratus Hentz.

riridipes Hentz.

multivagus Hentz.

cristatus Hentz.

mitratus Hentz.

sylvanus Hentz.

supereiliosus Hentz.

morigerus Hentz.

cyaneus Hentz.

octarus Hentz.

Epiblemum faustum Hentz.

Hentzia palmarum (Hentz).

Synemosna formica Hentz seorpionia Hentz.

Synemosyna ephippiata Hentz. picata Hentz.

\section{ORDER PEDIPALPI.}

[Maxillary palpi greatly enlarged, ending in a forceps ; abdomen jointed.]

\section{FAMILT PIALANGIDE. HARVEST MIEN, "DADDY-LONG- \\ LEGS."}

Phalangium dorsatum Say (?) (Va.)

vittatum Say.

calcar Wood.

formosum Wood.
Phalangium maculosum Wood. ventricos:um Wood. grande siay. nigram saly.

\section{FAMILY GONILEPTIDE.}

Gonyleptes ornatum Say. (?) 


\section{ORDER ACARINA. MITES.}

[Cephalo-thorax merged with the non-jointed abdomen: Mouth parts aclapted for biting or sucking.]

The Mites of this country have not been well studied, and we shall omit them from our list.

\section{CLASS MYRIAPODA.}

[Body cylindrical ; composed of from ten to two humdred joints.]

\section{ORDER CHILOPODA. CENTIPEDES.}

[Each body-joint simple, and bearing a single pair of legs: Head composed of two regions; one before and one behind the mouth.]

\section{FAMILY CERMATIIDE.}

Cermatia forceps Rafinesque.

\section{FAMILY LITHOBIID E.}

Lithobinus americanus Newport.

Botin ropolys multidentatus Newport.

\section{FAMILY SCOLOPENDRIDÆ.}

Scolopendra heros var., castaniceps Wool, Scolopendra viridis Say ; (mountains of

polymorpha IVood.

Cryptops hyalina Say (Ga.)

Opisthemega postica Wood.

Scolopocryptops sexspinosa (Say). 


\section{FAMILY GEOPHILID E.}

Mecistocephalus melanotus Wood (Ga.)

Geophilus lacris Wood (Ga.)

Strigamia laevipes Wood (Ga.)

Strigamia taeniopsis Wood (Ga.)

\section{ORDER DIPLOPODA. MILLIPEDES.}

[Body divided into numerous joints, each furnished with two pairs of short legs.]

$$
\text { FAMILY LISIOPETALIDE. }
$$

Spirostrephon lactarius (Say).

$$
\text { FAMILY JULIDE. }
$$

Julus minutus Brandt.

Spirobolus marginatus (Say).

Spirobolus spinigerus Wood.

\section{FAMILY POLYDESMIDE.}

Paradesmus erythropygus Brandt.

Fontaria virginiensis (Drury).

FAMILY POLTXENID E:

Polyxenus fasciculatus (Say).

\section{FAMILY POLYZONIDE.}

Octoglena bivirgata Wood (?) Ga.

$$
\text { FAMILY SIPHONOPHORID E. }
$$

Brachycybe LeContii Wood (?) Ga. 


\section{CLASS CRUSTACEA.}

[Articulate animals with two pairs of antennae or feelers, with jointed appendages to some of the abdominal segments, with gills or vesicles for breathing air in water, and a hard chitinous or subcalcareous covering to the body.]

\section{ORDER DECAPODA. TEN-FOOTED CRUSTACEANS.}

Achelous gibbesii Stm. (N. C.)

depressifrons Stm. (N. C.)

Alpheus heterochelis Say (N. C.)

Araneus cribrarius Dana (N. C.)

Calappa marmorata Fabr.

Callianassa stimpsonii Smith (Atlantic coast).

Callichirus major Stm.

Callinectes hastatus Ordway (Sea-crab).

Cancer irroratus Say (Rock-crab).

Cambarus (Cray-fishes Fresh water.) advena.

acutus.

blandingii Harlan.

carolinus Erichson.
Achelous spinimana DeHaan (N. C.)

Alpheus minus Say.
Cancer borealis Stm. (Atlantic coast).

Cambarus immunis Hagen ( $\mathrm{X} . \mathrm{C}$.)

latimanus LeConte.

lecontei Hagen (N. C.)

pencillatus LeConte.

Carinus moenas Leach (Atlantic coast).

Clibanarius vittatuș Stm. (N. C.)

${ }^{*}$ Crangon vulgaris Fabr.

Euceramus praelongus Stm. (N. C.)

Eurytium Jimossum Say.

Eupagurus (Hermit-crabs, living in abandoned slells of periwinkles, and other mollusks; the following three species are found):

E. annulipes Stm.

longicarpus Stm.

pollicaris Stm.

Gebia affinis Say.

Gelasimus. (Fiddler-crabs. Very abundant on the muldy banks of salt-marsh, streams, and hiding in holes in the ground).

G. $\operatorname{minax}$ LeConte (N. C.)

pugnax Smith.

pugillator (N. C.)

* This is the common shrimp. It may be distiuguished from its congener, the conmon praten. by the character of the rostrum or beak that projects trom the head end of the back. Tuis beak in the shrimp is short, with a single spine behind it. In the prawn it is long. upturned, and tonthed, having eight or nine teeth on the upper edge, and three or four on the lower. The name of the common prawn is Palcemoneles vulgaris. 
Hepatus ilecorus Gibbes. (Spotted crab.)

IIeterocrypta granulatil Gibbes.

llippa talpoida say.

Hippolysmata wurdemanni (Gibbes) Stm. Hippolysmata paludosa.

Homarus americanus M. Euw. (Lobster.)

[The common Lobster has been found at Ft. Macon, North Carolina, but it does not appear to have been recorded from Sonth Carolina.]

Lepiclops scutella Desm. (X. C.)

Libinia caniliculata Say (Spider crab). Libinia dubia (M. Edw)

Lithadia cariosa Stm. (X. C.)

Menippe mercenaria Say (Stone crab).

Metoporhanis calcarata Say.

Neptunus sayi Stm. (Atlantic coast).

Ocyopoda arenaria Say (Land crab).

Palaemonetes carolinus Stm.

Panopeus herbstii II. Edw.

Palaemonetes vulgaris Say (Comimon praun). Panopeus harrisii Gould (Atlantic coast).

Panopeus depressus Smith (Atlantic coast.) Panopeus sayi Smith (Atlantic coast.)

Peneus braziliensis Latreille.

Peneus setiferus M. Edw.

constrictus Stimpson.

Pelia mutica Gibbes.

Persephone punctata Browne.

Pilumnus aculeatus M. Edw.

Pinnixa chretopterana Stimpson (N. C.) Pinnixa sayana Stimpson (I. C.)

cylindrica Say ( $\mathbf{N}$. C.)

Pinnotheres maculatus Say

Pinnotlieres ostreum Say (Oyster Crab.)

Playusia.

Platyonichus ocellatus Herbst (Sund Crab.)

Pontonia domestica.

Porcellana ocellata Gibbes.

Porcellana sociata Say.

Ranilia muricata Edw. (Atlantic coast.)

Sesarma cinerea Bosc.

Sesarma reticulata Say.

Tozeuma carolinensis Kingsley (N. C.)

Urocaris longicaudata Stimpson.

Virbius pleuracanthus Stimpson (N. C.)

\section{ORDER STOMAPODA.}

[Seven or eight pairs of legs. Eyes pedunculated. Gills generally attached to the false fat of the abdomen.]

śquilla dubia M. Edg.

empusa Siy.

? Squilla neglecta Gibbes.

mantis.

scabricauda Sas. 


\section{ORDER AMPHIPODA}

[Seven pairs of legs. Eyes sessile. Membraneous vesicles for breathing or rans. Body frequently compressed.]

Amphithce dentata Say.

Gammarus mucronatus Say. Gammarus fasciatus Say.

Talorchestia longicornis Smith (commonly known as Beach-flea, and Sand-hopper.)

\section{ORDER ISOPODA.}

[Seven pairs of legs. Eyes sessile. Gills for breathing or rans. Body usually depressed.]

Armadillidium pilularis Say (Pill-bug.)

Asellus communis Say.

Asellus lineatus Say.

Conilera concharum Hargr.

Idotrea creca Say.

Livoneea ovalis Say (Fish-louse.)

Lygia gaudichan dij M. Edw. (Wharf-louse)

Nesrea caudata Say.

Nerocilla variabilis Gibbes.

Porcellio (probably several species; on land only; commonly known as sow bugs and pill bugs.)

Sphæroma quadridentata Say.

\section{ORDER LEMODIPODA.}

[Posterior segments of body provided with legs. Eyes sessile. Breathing by vesicles. All marine.]

Caprella equilibra Say.

Caprella geometrica Say.

\section{EATOMOSTRACA.}

[This group inclndes several orders of crustaceans, which have mostly a horny or chitinous shell. Most species are minute, and many live in fresh water.]

Cyclops naviculus Say.

Cypris sp. 
Cythere bifasciata Say.

Daphnia angulata Say.

Limulus polyphemus Linn. (This species has a long, pointed, spine-like tail. It attains a length of more than a foot. It is commonly known as the Horse-shoe (rab, also King Crab.)

\section{CIRRIPEDIA. BARNACLES.}

[Six pairs of forked, cileated limbs. Permanently attached in the adult state ]

Acasta spongites.

Balanus balanoides Stm. (Acorn barnacles.)

eburneus Gould.

galeatus Darwin.

Lepas (Goose barnacles.)

anatifera Linn.

anserifera Linn.

pectinata Svengler.

\section{CLASS ANNELIDA. TRUE WORMS.}

[Mostly with red blood; body with external segmentation. No jointed appendages. Aquatic respiration by meaus of the general surface of the body, by involntions of the skin, or by gills.]

\section{ORDER POLYCHETA.}

A rabella opalina Verrili (N. C.)

Anthostoma robustum Verrill (N. C.)

Cistenides goulhii Verrill.

Diopatra cuprea Claparède.

Hydroides dianthus Verrill (X. C.)

Sephthys picta Ehlers.

Nereis limbata Ehlers.

Rhynchobolus americanus Verrill (N. C.) 
Sabellaria vulgaris Verrill (N. C.)

Sabella micropthalma Verrill (N. C.)

Serpula fascicularis Lam.

Spio caudatus.

Spirorbis sp.

Terebe'la conchifera Pall.

Terebella ventricosa Bosc.

\section{ORDER OLIGOCH ETA.}

Lumbricus terrestris Linn. (This is the common earth or angle worm.)

\section{ORDER HIRUDINEA. IEECHES.}

Clepsine swampina Diesing. (Upon frogs and toads.)

\section{CLASS SCOLECIDA.}

[Mostly parasitic; possessing a water-vascular system.]

\section{ORDER TURBELLARIA. NON-PARASITIC.}

Balanoglossus aurantiacus Verrill.

Cerebratulus ingens Verrill (N. (..)

Meckelia ingens Leidy.

\section{ORDER GORDIACEA. HAIR WORNS.}

[In one state parasitic in grasshoppers, etc. They are the so-called Hair-snakes when in water.] 


\section{ORDER NEMATODA. ROCND WORMS.}

The two following doubtless occur:

Trichina spiralis. (The pork parasite.)

Anguillula aceti. (Vinegar eel.)

\section{ORDER TENIADA. TAPE WORMS.}

Trenia echinococcus is found in the dog, and Trenia merliocanellata and solium in man. (For further information, see Verrill's work on Parasites.)

\section{II $0 \mathrm{LLUSCA}$.}

\section{CLASS CEPHALOPODA.}

[Mollusks with a distinct head; around the mouth are eight or more tentacles; body enclosed ir a mantle; two or four plume-like gills.]

Loligo brevis Blainville. (Squid.)

Octopus granulatus Lam. (Cuttle-fish.)

Ommastrephes bartramii Lesueur (N. C.)

\section{CLASS GASTEROPODA.}

[Shell univalre; locomotion effected by a ventral foot or fin-like organ : head distinct.]

\section{TERRESTRIAL OR LAND SNAILS.}

Glandina truncata Gmelin.

Hyalina cernioidea Anthony (N. C.)

arborea Say (Eastern U. S.)

indentata Say (East. U. S.)

intertexta Binney (Ga.)

(Helicodiscus) lineata Say (E. U. S.)
Hyalina ligera Say (Ga.)

demissa Binney (Ga.)

fulva Draparnaud (U. S.)

interna Say (Ga.) 
Macrocylis concava Say (Ga.

Helix alternata (East U.S.)

perspectiva Say (East. U. S.)

posteliana Bland (Ga.)

espicola Ravenel.

hazardi Bland (Ga.)

pustula Fer.

pustuloides Bland (Ga.)

leporma Gould (Ga.)

spinosa Lea (Ga.)

barbigera Redfield (Ga.)

stenotrema Fer (Southern States.)

maxillata Gould (Ga.)

monodon Rackett (East. U. S.)

palliata Say (Ga.)

obstricta Say.

appressa Say.

inflecta Say (Ga.)
Helix rugila shuttleworth (N. C.)

tridentata Say.

fallax Sily.

introferens Bland (N. N.)

hopetonensis Shuttleworth.

major Binney.

albolabris Say.

elevata Say (Ga.)

clarkii Lea ( $\mathrm{X}$. C.)

christyi Bland (N. C.)

exoleta Binney (Ga.)

wheatleyi Bland (N. C.)

thyroides Say.

bucculenta Gould (N. C.)

jejuna Say (Ga.)

pulchella Mueller.

aspera Mueller (European. Intro-

duced.)

Bulimulus dealbatus Say (X. C.)

Stenogyra decolata Linn. (Introduced from Europe at Charleston, S. C.)

Pupa pentodon Say.

fallax Say.

Vertigo milium.

Succinea avara Say (East U. S.)

obliqua Say (Ga.)

Sonites kopnodes Binney (Ga.)

lævigata Pfeiffer (E. U. S.)

inornata Say (N. C.)

Tebennophorsus carolinensis Bose

Limax flavus Linn.
Pupa contracta Say (East. U. S.)

costicaria Say.

Vertigo orata Say.

Succinea campestris.

Sonites sculptilis Bland (N. C.)

elliotii Redfield (N. C.)

suppressa Say (East. U. S.)

\section{MOSTLY FRESH WATER.}

Carychium exigunm Say.

Melampus bidentatus Say.

Limnæa coluniella Say

Physa gyrina Say.

Planorbis lentus Say.

glabratus Say.

trivoluis Say (U. S.)

Pomus depressa Say (Ga.)

Viripara intertexta Say (Ga.)

contectoides Buiney (Ga.)

Melantha decisa Say.
Melampus obliquns Say (On beach N. C.)

Limnæa humilis Say.

Physa heterostropha Say (Ga.)

Planorbis bicarinatus Say (E. U. S.)

parrus Say.

Viripara georgiana Lea.

Melantha coarctata Lea. 
Lioplax eyclostomatiformis Lea (Ga.)

Bythinella tenuipes Coupr. (Ga.)

Pomatiopsis lapiclaria Say (Ga.)

(Uncler stones in wet places).

Helicina articulata (Ga.)

\section{MOSTLY MARINE.}

Utriculus canaliculatus Say.

Bulla solitaria Say.

Chiton apiculatus Say.

Entalis pliocena T. and H. (N. C.)

Crepidula formicata Linn.

Crepidula unguiformis Say (N. C.)

formicata var. intorta Say (N.C.) aculeata Gmelin.

conveya Say.

Fissurella alternata Say.

Zizyphinus sp. (N. C.)

Turbo crenulatus Gm. ?

Littorina irrorata Say.

Scalaria humphreysii Keiner (N. C.) angulata Say.

Littorina dilatata d'Orbrgny. (N. C.)

Scalaria lineata Say. turbinata Conrad (N. C.)

Solarium granulatum Lam. (N. C.)

Vermetus radicula Stimpson (N. C.)

Cerithium sp. (N. C.)

Bittium nigrum Tott.

greenii C. B. Ad. (N. C.)

Bittium sp. (N. C.)

Triforis nigrocinetus C. B. Atl. (N. C.)

Chemnitza spirata Ktz. and Stm.

Odostomia seminuda C. B. Ad.

Odostomia impressa Say.

Turbonilla interrupta Tott. (N, C.)

Obeliscus crenulatus Holmes. (N. C.)

Rissoa pupoidea Ktz. and Stm.

Eulima oleacea Ktz. and Stm.

Eulima conoidea Ktz. and Stm.

Sigaretus perspectivus Say.

Natica pusilla Say.

Porcellana (Cypraea) exanthema Linn. (N. C.)

Pleurotoma cerina Ktz. and Stm.

Pleutotoma plicata C. B. Ad. (N. C.)

Marginella apicina Menke. (N. C.)

Marginella roseida Redfield (N. C.)

guttata Dillwyn.

Oliva literita Lam 
Olivella mutica Say.

Columbella avara Say.

lunata Say,

Columbella mercatoria Linn. (N. C.)

ormata Ravenel ? (N. C.)

Dolium galea Linn.

Semicassis granulosa Lamarck (N. C.)

Cassis cameo Stm. (N. C.)

Purpura floridana Conr. (N. C.)

Ilyonassa obsoleta Say.

Tassa vibex Say.

Cerithiopsis terebralis C. B. Adams.

Acus concavus Say.

Anachis similis Verrill. (N. C.)

Rapana (Fusus) cimerea Say.

Busycon pyrum Dillw.

canaliculatum Linn.

Nassa trivittata Say.

Acus dislocatus Say.

Busycon carica Linn.

perversum Linn.

Cancellaria reticulata Linn.

Fasciolaris tulipa Linn.

distans Lam.

Ranella caudata Say.

Murex spinicostata Val. (X. C.)

Strombus pugilis Gm. (N. C.)

Mitra granulosa Lamarck.

Strombus alatus Gm.

\section{CLASS PTEROPODA.}

Free; swimming by means of two wing-like appendages (epiporlia).

Styliola acicula Lesueur (N. C.)

\section{CLASS LAMELLIBRANCHIATA.}

Gills in the form of lamellae; shell bivalve. 


\section{FAMILY LNIONIDE. FRESH-WATER CLAMS OR MILSSELS.}

Unio abberillensis Lea.

aberans Lea (X. C.)

angustatus Lea (Cooper Rirer.)

barrattii Lea (Abbeville.)

beaverensis Lea (N. C.)

bisselianus Lea (N. C.)

buxens Lea (Abberil'e.)

('astus Lea.

catawbensis Lea ( $\mathrm{N} . \mathrm{C.}$ )

charlottensis Lea (X. C.)

chathamensis Lea (N. C.)

cistellaeformis Lea.

complanatus Sol.

concarus Lea (Abueville.)

confertus Lea (Santee ranal.)

congaraeus Lea (Congaree River.)

contiguus Lea (X. C.)

contractus Lea (X. C.)

curatus Lea (N. C.)

clatus Lea (N. C.)

decoratus Lea (Abbeville Dist.)

dorsatus Lea (N. C.)

emmonsii Lea (N. C.)

exactus Lea (N. C.)

fulvus Lea.

gastonensis Lea (N. C)

geddingsranus Lea (Congaree River.)

gracilentus Lea (N. C.)

griffithianus Lea.

hepaticus Lea (Salkahatchie River.)

humerosus Lea ( $\mathrm{N} . \mathrm{C}$.)

indefinitus Lea (X. C.)

ineptus Lea (Abbeville Dist)

insulus Lea ( $\mathrm{X} . \mathrm{C}$ )

jejunus Lea.

lanceolatus Lea ( $\mathrm{N}$. C.)

lazarus Lea (Abberille Dist.)

liringstonensis Lea ( $\mathrm{N}$. C.)

Jucidus Lea ( $\mathrm{x}$. C.)

mecklenbergensis Lea ( $\mathrm{N}$. C.)

mediocris Lea (N. C.)
Unio merus Lea (Abbeville Dist.)

micans Lea (N. C.)

modioliformis Lea (Santee canal.)

nasutulus Lea ( $\mathrm{X} . \mathrm{C}$.$) .$

neusensis Lea (N. C.)

nubilis Lea ( $\mathrm{N}$. C.)

obesus Lea.

oblatus Lea (N. C.)

palliatus Lea (N. C)

pawensis Lea (N. C.)

percoarctatus Lea ( $\mathrm{N}$. C.)

perlatus Lea ( $\mathrm{X} . \mathrm{C}$.)

perlucens Lea ( $\mathrm{N} . \mathrm{C}$.)

pernodosus Lea ( $\mathrm{X} . \mathrm{C}$.)

perstriatus lea (Abbeville Dist.)

pertennis Lea ( $\mathrm{X}$. C.)

planilaterus Con. ( $\mathrm{X}$. C.)

protensus Lea ( $\mathrm{N}$. C.)

pullus Con (Wateree River.)

pumilus Lea (N. C.)

purus Lea ( $\mathrm{N}$. C.)

pygmaeus Lea (Abberille.)

quadrilaterus Lea.

raleighensis Lea ( .. C.)

ravelianus Lea ( $\mathbf{N}$. C.)

roanokensis Lea (N. C.)

rostrum Lea (N. C.)

rufusculus Lea (Abbeville Dist.)

sordidus Lea (Abberille Dist.)

spadiceus Lea (N. C.)

squalidus Lea (X. C.)

squamens Lea ( $\mathrm{X} . \mathrm{C}$.

striatulus Lea (N. C.)

tenerus Rav.

tuomeyi Lea (Abberille Dist.)

utriculus Lea (X. C.) ·

vaughanianus Lea (Camden.)

viridulus Lea (N. C.)

watereensis Lea (Wateree canal.)

waccamawensis Lea (N. C.)

weldonensis Lea ( $\mathrm{N} . \mathrm{C}$.) 
Margaritana marginata Say. raveneliana Lea ( $\mathrm{X} . \mathrm{C}$.)

Anodonta doliaris Lea (N. C.) dunlapiana Lea.
Margaritana triangulata Lea.

Anodonta virgulata Lea (X. C.)

\section{MARINE SPECTES.}

Teredo megotara IIanley.

Pholas truncata Say.

Zirpluea crispata Morch.

Saxicava distorta Say.

Paudora trilineata Say (Ni. C.)

Lyonisia hyalina Cour (N. C.)

Cochlodesma leanum Conr. (N. C.)

Gastrochema sp. (N. C.)

Panopea americana Conr. (N. C.) Myalina subovata Conr. (N. C.)

Corbula contracta Say.

Mya arenaria Linn (long Clam.) (This is also called the soft-sinelled (lam.)

Solemya relum Say (N. C.)

Siliquaria bidens Chemn (N. C)

Solen ensis Linn. (Kazor shell.)

Strigilla sp (N.C.)

Tellina alternata Say.

tenera Say.

tenta Say.

Abra requalis Say.

Amphidesma constricta? Phill. (N. C.)

Semele orbiculata Say

Cumingia tellinoides Cour.

Donax variabilis Say.

Mactra lateralis Say. solidissima C'hem.

Ræta lineata Say.

Petricola pholadiformis Lam.

Venus mercenaria Linn. (Quahog) (This is the common round clam.)

Lucinopsis sp. (N. C.)

Dorsinia discus Reeve.

Cytherea gigantea Chemn. (X̃. S.)

Cytherea convexa Say (Ň. C.)
Siliquaria gibba Spengle.

Stricilla flexuosa Say.

Tellina iris Say. polita Say.
Mactra raveneli Cour. (N. C.)

Rreta canaliculata Say.

Petricola dactylus Sow.

Teredo dilatata Stm.

Pholas costata Linn.

Tottenia manhattensis Verrill (X. C.)

Chione grata Say (N. C.)

Gemina totteni Stm. (N. C.)

Panopea bitruncata Cour. (fossil?) (X. C.) 
Mercenaria mortoni Conr. (N. C.)

Mercenaria violacea var. notata (X. C.)

violacea Schum. (X. C.)

Cardita tridentata Say.

Astarte lunulata Conr.

Diplodonta? punctata Say (N. C.)

Lucina chrysostoma (N. C.)

Lucina strigilla Stm.

Liocardinm mortoni Conr. (N. C.)

Laocardium levigatum Lam. (N. C.)

Cardium isocardia Linn

Cardium magnum Born. (N. C.)

muricatum Linn.

Chama macrophylla Chemn. (Ṇ. C.)

Chama arcinella Linn.

(Sea Mussels)

Mytilus carolinensis (N. C.)

Mytilus cubitus Say.

edulis Linn. (N. C)

Argina pexata Gray (Bloody clam.)

Modiola americana Leach (N. C.)

castanea Say?

Iodiola plicatula Iam.

lamatus Verrill (N. C.)

Modiolaria lateralis Say.

A vicula atlantica Lam.

Pinna muricata Linn.

Leda acuta Conr. (N. C.)

Yoldia limatula Say.

Nucula proxima Say.

Arca americana Gray.

holmesii Kurtz.

lienosa Say.

nor Linn.

occidentalis.

Pinna seminuda Lam.

Arca transversa Say.

limula Conr.

ponderosa Say.

incongrua Say.

Pectunculus charlestonensis? Holmes.

Pectell nodosus Lam.

concentricus Say.

Lima scabra Born.

Plicatula depressa Lam.

(Oysters)

Ostrea virginiana Latr.

Ostrea fundata Say.

equestris Say.

Anomia glabra Verrill (fossil ?).

Pecten dislocatus Say.

TUNICATA.

[Body protected by a leathery, elastic integument. Mouth opening into the bottom of a respiratory sack.]

Molgula pellucida Verrill (A. C)

Cynthia partita Stm. (N. C.)

A maroecium stellatum Verrill (N. C.) 


\section{BRACHIOPODA.}

[One nerve ganglion; shell bivalve; month with two long cirriferous arms. Mostly fossil.]

Lingula pyramidata Stm. (N. C.)

\section{BRYOZOA OR POLYZOA.}

[Body consisting of a double-walled sack; mouth surrounded by a circle or crescent. of hollow, ciliated tentacles. Animals always in composite colonies.]

Crisią eburnea Lamx. (N. C.)

Amathia alternata Lamx. (N. C.)

Vesicularia armata Verrill (N. C.)

Aetea anguina Lamx. ? (N. C.)

Bugula turrita Verrill (N. C.)

Acamarchis neritina Lamx. (N. C.)

Membranifora lineata Busk. (N. C.)

Biflustra denticulata Smitt (N. C.)

Hippothoa hyalina Smitt (N. C.)

Membranifora catenularia Smitt (N. C.)

biaperta Smitt (N. C.)

Cellepora avicularis Hisscks (N C.)

Lepralia americana Verrill (N. C.)

Discopora nitida (N. C.)

Hippothoa (Aescharella) variabilis Verrill.

\section{CLASS ECHINODERMATA.}

[Radiate animals, with a calcareous shell, or with calcareous spicules in the skin. They possess an ambulacral system.]

\section{ORDER HOLOTHUROIDEA. SEA CUCUMBERS.}

[Echnioderms covered with a coriaceous skin, in which are calcareous granules or spicules. Shape of body, elongated, slug like.]

Thyone briareus Selenka (N. C.)

Pentamera pulcherrima Ayres.

Thyonella gemmata Verrill.

Anaperus carotinus Frosch. 


\section{ORDER ECHNOIDEA. SEA URCHINS.}

[Echinoderms with a shell usually globose in shape, and made up of calcareous plates, having a definite arrangement. Teeth present, forming a complicated mechanism, known as Aristotle's lantern, Pedicellaria present in some ]

Arbacia punctulata Gray (N. C.)

(Commonly known as the purple sea-urchin).

Cislaris tribuloides Bl.

Clypeaster subdepressus Ag.

Echinunthus rosaceus Gray.

Echinometra subangularis Desml.

Echinocardium flayescens A. Ag. Echinocardium cordatum Gray.

Encope emarginata $\mathrm{Ag}$.

Mellita pentapora Lütken \} Sand cakes.

sexforis A. Ag. $\quad \int \quad$ Shape flattened.

Moira atropos A. Ag.

Strongylocentrotus droebachiensis A. Ag.

(Commonly known as the green sea-urchin).

Toxopneustes variegatus A. Ag. (N. C.)

\section{ORDER ASTROIDEA. STAR-FISHES.}

[The viscera extending into each of the five arms. Pedicellaria present. No teeth.]

Asterias forbesii Verrill ( $\mathrm{X}$. C.)

Astropecten articulatus (Say) Luetken.

Luidia clathatra (Say) Luctken.
Asterias spinosus Link.

\section{ORDER OPHIUROIDEA. BRITTLE SEA-STARS.}

[Body discoidal; the five arms do not contain prolongations of the alimentary canal. No pedicellaria. A masticatory apparatus.]

Ophiura brevispina Say.

Ophiophragmus wurdemanni Lyman (N. C.)

Ophiotrix angulata Ayres.

Ophiura elongata Say. 


\section{CLASS ACALEPHÆ. JELLY-FISHES.}

[Radiate jelly-like animals, with a central cavity hollowed out of the mass of the bouly, which is usually made up of four (or some multiple of four) parts.]

Bolena littoralis McCready.

Mnemiopsis gardenir Agassiz.

Mnemiopsis leidyi A. Agassiz.

Beroe punctata Esch.

Ilyiopsis clarkii Ag.

Stomolophus meleagris Ag.

Dactylometra quinquecirra $\mathrm{Ag}$ (N. C.)

Cyanea versicolor $A \mathrm{~g}$.

Foveola octonaria A. Ag.

Cunina discoides Fewkes (N. C.)

Cheiropsalamus quadrumanus F, Mueller (N. C.)

Tamoya haplonema F. Mueller (N. C.)

Persa incolorata McCready.

Liriope scutigera McCready.

Oceania folliata Ag.

Encheilota ventricularis McCready.

Dipleuron parvum Brooks (N. C.

Clytia bicophora Ag.

Platypyxis cylindrica Ag.

Campanularia carolinensis Verrill (N. C.) Campanularia noliformis $\mathrm{ICCr}$. (N. C.)

Eucope divaricata A. Ag.

Eucope obliqua Brooks (T. C.)

Eutima mira $\mathrm{McCr}$.

cuculata Brooks (N. C.)

Aglaophenia tricuspis Ag.

trifida.

Eutima emarginata Brooks (N. C.) variabilis McCr.

Aglaophenia rigida? Allman (X. C.)

Nematophorus sp. Brooks (N. C.)

Plumularia quadridens $\mathrm{McCr}$.

Dynamena cornicina $\mathrm{M} \mathrm{LCC}$.

Plumularia (catharina-like) MícCr.

Dynamena bilateralis Brooks ( $\mathrm{Y}$. C.)

Diphasia (nigra-like) Ag.

Margelis carolinensis $\mathrm{Ag}$.

Nemopsis bachei Ag. (Charleston).

Endendrium ramosum $\mathrm{McC}$.

Enclendrium tenue? A. Ag. (N. C.)

Turritopsis nutricula McCr. (Charleston).

Stomatoca apicata MeCr. (Charleston).

Willia ornata McCr.

Dipurina cervicata $\mathrm{McCr}$.

Dipurina strangulata $\mathrm{M} \cdot \mathrm{Cr}$.

Corynetis agassizii $\mathrm{McCr}$.

Gemmaria gemmosa $\mathrm{McCr}$.

Pennaria tiamella $\mathrm{M} \mathrm{cCr}$.

Pennaria inornata Brooks (N. C.) 
Ectopleura turricula $\mathrm{Ag}$.

Parypha cristata $\mathrm{Ag}$.

Streenstrupia gracilis Brooks (N. C.)

Hydractinia polyclina Ag.

Eudoxia alata $\mathrm{MeCr}$.

Diphyes pusilla MeCr.

Physalia arethusa Til.

Velella mutica Bosc.

Porpita linniana Less.

Nanomia cara A. Ag.

Obelia commissuralis McCr. (Charleston).

Lafoea calcarata A. Ag. (Charleston).

Sertularia cornicina Verrill (Charleston). Sertularia carolinensis Verrill (N. C.)

(Desmoscyphus) achilleas Ver-

$$
\text { rill (N. C.) }
$$

Pelagia cyanella Peron and Lesueur (N. C.)

Diphasia sp. (N. C.)
Ectopleura ochracea A. Ag (N. C.)

\section{CLASS POLYPI OR ANTHOZOA.}

[Radiate animals, with a tubular or sack-like body, in the centre of the summit of which is an opening called the mouth, which is surrounded by one or more rows of tentacles.]

\section{ORDER ALCYONARIA. CORAL ANIMALS.}

[Body built on the plan of four; eight pinnately fringed tentacles. They are called the Asteroid Polypes. The red coral of commerce belongs here.]

Renilla renifornis Cuvier (N. C.)

Leptogorgia carolinensis Verrill (N. C.) Leptogorgia virgulata M. Edw. (N. C.)

setacea Verrill (N. C.)

Antlopodium rubens Verrill (N. C.)

Titanideum suberosum Verrill (N. C.)

Telesto fructiculosa Dana (N. C.) 


\section{ORDER ACTINARIA. SEA ANEMONES \&C.}

Sagartia leucolena Verrill (N. C.)

Paractis rapiformis $\mathrm{M}$. Edw. (N. C.)

Halocampa producta (Stm.) Verrill (N. C.)

Calliactis sol Terrill (N. C.)

Anlactinia capitata Verrill (N. C.)

Cladactis cavernata Verrill (N. C.)

Cerianthus americanus Verrill (N. C.)

Ilyanthus chloropsis (Ag.) Verrill (N. C.)

Paranthea pallida Verrill (N. C.)

\section{ORDER MADREPORARIA.}

[The polypes of this order have tentacles, mostly six or some multiple of six in number. Most corals are formed by animals of this group. They abound in tropical waters ]

Astrangia danæ Ag. (Star coral.)

Oculina arbuscula Verrill (N. C.)

Oculina implicata Verrill (N. C.)

\section{PROTOZOA.}

[Animals generally of minute size, composed of a nearly structureles.3, jelly-like substance, having no definite body cavity, presenting no trace of a nerrous system, and whose alimentary apparatus, if at all differentiated, is very rudimentary.

\section{SPONGIDA. SPONGES.}

Microciona prolifera Verrill (N. C.)

Chalina arbuscula Verrill (N. C.)

Cliona sulphurea Verrill (N. C.)

Hircina campana Nardo (N. C.)

Spongia vermiculata var. Hyatt (N. C.)

Spongelia spinosa Hyatt (N. C.)

Spongelia dubia var. foraminosa Hyatt (I.C.)

Dysidea fragilis Johnston? (N. C.)

Doubtless, if the fresh water ponds are examined, other sponges will be found growing in quiet spots on submerged branches, stones, \&e. The student is referred to an article by II. J. Carter, in the Anm. and 
Mag. Nat. Hist., Febr., 1S81, on the known species of Spongilla; also, to Mr. E. Potts, Acad. Nat. Sci., Phila., Pa., who is making a special study of Fresh Water Sponges.

\section{MICROSCOPIC PROTOZOANS.}

[Most of the following Rhizopods and infusorians were originally described by Ehrenberg.]

Amceba proteus

Amblyophis riridis.

Amphileptas anser.

A rcella dentata.

Arcella vulgaris.

Difflugia proteiformis.

Difflugia spiralis Bailey.

Dinobryon sertularia.

Epistylis anastatica.

Euglena plenronectes.

Euglena viridis.

Hydatina senta.

Lepadella ovalis.

Megalotroeha albofiavicans

Monostyla lunaris.

Ophrydium versatile.

Peridinimm carolinianum Bailey:

Peridinium cinctum Ehrenberg.

Pterodina patina.

Scardidium longicaudum.

Squamella oblonga.

Vorticella clorostigma.

The following Protozoans belonging to the Rhizopoda, as defined by Leidy, are so wide sprear in the fresh waters of the United States: that they probably all occur in Sonth Carolina. They are to be looked for in the ooze of ponds, among Sphagnum in swamps, \&e.

Amoba verrucosa Ehrenberg.

Pelomyxa villosa.

I)iffugia pyriformis Perty. urceolata Carter. cratera Leidy. acuminata Ehrenberg.

Nebela collaris Ehren

Arcella discoides Ehren.
Amweba radiosa.

Difflugia lobostoma Leidy. corona Wailich. constricta Ehren.

Arcella mitrata Leidy. 
Centropyxis aculeata Elren.

Cochliopoclium bilimbosum Auerbach.

Cochliopodium vestitum Archer.

Pamplhagus mutabilis Bailey. Pampliagus hyalinis Ehren.

Pseudodifflugia gracilis Schlumberger.

Cyphoderia ampulla Ehren.

Campascus cornutus Leidy.

Euglypha al veolata Dujardin.

Sphenoderia lenta Schlumberger.

Actinophrys sol Miüller.

Actinosphærium eichornii Ehren.

Acanthocystis chætophora Schrank.

Most of the above species marked (N. C.) are given on the authority of Drs. Cones and Yarrow, whose papers on the fauna of Ft. Macon, N. C., in the Proc. Phila. Acad. Sci., 1871 and 1876, will be found of value to the student. We suggest that those interested endeavor to verify and add to this list.

The following works, most of which have been used in the revision, will be useful to the student of South Carolina Invertebrata :

Invertebrates of Tineyard Sound; by A. E. Verrill in the Rep. U. S. Fish Commission, $1571-72$.

Land and Fresil itater Shells of N. A.; by W. G. Binney. Smithsonian Miscellaneous Collections.

A Sinopsis of the Fanily Unionid.e: by Isaac Lea. 4to, Phila., 1870.

Monograpit of N. A. Astacid.e; by Hermann Hagen, Museum of Comp. Zoology, Cambridge, Mass.

Tie External and Ixternal Parasites of Max and Donestic Animals; by A. E. Verrill in the Report Connecticut Board of Agriculture, 1870.
Illustrated Catalogue of N. A. Acalepils or Jelly Fishes; by $A$. A gassiz, 入Iuseum Comparative Zoology, Cambridge, 1865 .

History of the Infesors; Pritchard. Published in London.

Microscopic Opservations made ix s. C., G...AxD FLג.; by J. W. Bailey, and published in the Smithsonian Contributions to Knowledge, Vol II., 1851.

Fresir Water Pinzopoda of N. A.; by by Jos. Leidy. U. S. Geol. Survey, 1879. 4to, with 48 plates.

(The last three works treat wholly of microscopic animals.) 


\title{
CHAPTER XII.
}

\author{
A LIST OF THE MORE COMMION
}

\section{NATIVE AND NATURALIZED PLANTS OF SOUTH CAROLINA.}

BY H. W. RAVENEL, AIKEN, S. C., MARCH, 1882.

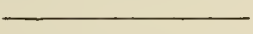

\section{SERIES I.}

Flowering plants, with roots, stems, leares, fruit and seeds. Phaenogams.

\section{CLASS I.}

Plants with two seed leares (cotyledons), as cotton, peas, \&c., having stems with bark and pith, and a woody layer between then : growth by annual layers between the wood and bark; veins of the leaves forming a network. Dicotyledons or Exogens.

\section{DIVISION I.}

Having two sets of floral leaves, one green, the other colored; the colored leares more or less numerous; separate. Polypetalous. 


\section{ORDER I. CROWFOOT FAMILY. RANUNCULACEAE.}

Herbs or climbing shrubs, with watery, acrid juice: leaves generally divided, with Ieaf stalk dilated at base; ovaries distinct, nmmerous; fruit dry.

1. CRISPED CLEIATIS; BLUE JESSAMINE.

2. TRA YELER'S JOY ; LEATHER FLOWER.

Clematis crispa.

3. VIRGIN'S BOWER.

Clematis viorna.

4. DIVARF CLEHATIS.

Clematis Virginica.

5. WOOD ANEMONE

Clematis ochroleuca.

6. CAROLINA ANEMONE.

Anemone nemorosa.

7. LIVER LEAF.

8. EARLY MEADOW RUE.

Anemone Caroliniana.

Hepatica triloba.

Thalictrum dioicum.

9. IIEADOIV RUE

Thalictrum cornuti.

10. RUE ANEIIONE.

11. ORANGE ROOT; YELLOW ROOT; GOLDEN SEAL.

Thalictrum anemonoides.

12. MARSH MARYGOLD; COLT'S FOOT; GROUND IVY.

Hydrastis Canadensis.

13. CELERY-LEA YED CROIVFOOT ; BITIYG CROWFOOT.

14. CREEPING CROWFOOT.

15. ROUGH CROWFOOT,

16. SHINING CROWFOOT.

17. SIIOOTH CROWFOOT.

18. DWARF CRO WFOOT.

19. COLUMBINE.

20. BLUE LARKSPUR.

21. TALL LARKSPUR.

22. DWARF LARKSPUR.

Caltha palustris.

Ranunculus sceleratus.

23. GARDEN LARKSPUR.

R. repens.

R. recurvatus.

R. nitidus.

R. abortivus.

R. pusillus.

Aquilegia Canadensis.

Delphinium azureum.

D. exaltatum.

D tricorne.

D. consolida.

24. MONKSHOOD; WOLFSBANE.

Aconitum uncinatum.

25. YELLOW ROOT.

Zanthorhiza apiifolia.

26. RATTLE-TOP; BLACK SNAKE ROOT; COHOSH.

Cimicifuga racemosa.

27. BANEBERRY; WHITE COHOSH.

Actæa alba.

\section{ORDER II. MAGNOLIA FAMILY. MAGNOLLACEE.}

Aromatic trees or shrubs, with alternate, leathery leaves, and large, showy flowers.
1. MAGNOLIA; BIG LAUREL.
Magnolia grandiflora.
2. SWEET BAY; WHITE BAY.
M. glauca.
3. LONG-LEA VED CUCUMBER TREE.
M. Frazeri. 
4. HEART-LEAVED CUCUMIBER TREE.

M. cordata.

5. CUCUMBER TREE.

M. acuminata.

6. UMBRELLA TREE.

M. umbrella.

7. TULIP TREE; POPL.IR.

Liriodendron tulipifera.

ORDER III. CUSTARD APPLE FAMILY. ANONACEE. 1. PAPAW; CUSTARD A PPLE.

Asimina triloba.

ORDER IV. MOONSEED FAMILY. MENISPERMACEA Climbing, shrubby vines.

1. RED-BERRIED MOONSEED.

Cocculus Carolinus.

2. MOONSEED.

Menispermum Canadense.

ORDER V. BARBERRY FAMILY. BERBERIDACEA.

1. BARBERRY.

Berberis Canadense.

2. BLUE COHOSH ; PAPOOSE ROOT; SQUAW ROOT.

Caulophyllum thalictroides.

3. UMBRELLA LEAF. Diphylleia cymosa.

4. WILD JALAP; MAY-APPLE; MANDRAKE. Podophyllum peltatum.

ORDER VI. POND-NUT FAMILY. NELUMBIACEE. Aquatic herbs, with large, circular, floating leaves. Fruit, a nut.

1. WATER CHINQUEPIN; POND NUT. Nelumbium luteum.

ORDER VII. WATER SHIELD FAMILY. CABOMBACEE. Aquatic herbs with floating leaves.

1. WATER SHIELD.

Brasenia peltata.

2. NARROW-LEAVED WATER SHIELD.

Cabomba Caroliniana.

ORDER VIII. WATER LILY FAMILY. NYMPHEACEE.

Water plants, with round or heart-shaped leaves. Fruit, berry-like.

1. WATER LILY; POND LILY; BONNETS. Nymphæa odorata.

2. YELLOW WATER LILY.

Nuphar advena.

3. ARROW-SHAPED WATER LILY.

N. sagittifolia. 


\title{
ORDER IX. PITCHER PLANT FAMILY. SARRACENIACEA.
}

Perennial marsh herbs, with hollow, pitcher or trumpet-shaped leaves, and nodling flowers.

1. HUNTSMAN'S CUP; PITCHER PLANT.

2. RED-FLOWERED TRUMPET LEAF.

Sarracenia purpurea.

3. SIDE-SADDLE FLOWER; TRUMPETS;

\author{
FLY-TR AP. \\ S. flava.
}

S. rubra.

4. SPOTTEDTRUMPET LEAF; FLY-CATCHER. S. variolaris.

ORDER X. POPPY FAMILY. PAPAVERACE.E.

1. MEXICAN POPPY; THORN APPLE; PRICKLY POPPY.

Argemone Mexicana.

2. PUCCOON ; BLOOD ROOT.

Sanguinaria Canadensis.

ORDER XI. FUMITORY FAMILY. FUMARIACEA.

These are mostly mountain plants.

ORDER XII. MUSTARD FAMILY. CRUCIFERA.

Herbs with pungent juice; the four petals of the flower forming a cross.

1. WATER CRESS.

2. MARSH CRESS.

3. WALTER'S CRESS.

4. SPRING CRESS.

5. PEPPER ROOT.

6. SICKLE POD.

7. TANSY MUSTARD.

8 HEDGE MUSTARD.

9. WHITLOW GRASS.

16. WART CRESS; SIVINE CRESS.

11. PEPPER GRASS.

12. SHEPHERD'S PURSE.

13. SEA KALE.
Nasturtium officinale.

Nasturtium palustre.

$\mathrm{N}$. tanacetifolium.

Cardamine rhomboidea.

Dentaria diphylla.

Arabis Canadensis.

Sisymbrium canescens.

S. officinale.

Draba verna.

Senebiera pinnatifida.

Lepidium Virginicum.

Capsella bursa-pastoris.

Cakile maritima.

ORDER XIII. VIOLET FAMILY. VIOLACEA.

1. BLUE VIOLET.

2. HAND-LEAF VIOLET.

3. WILD PANSY ; HEARTSEASE.
Viola cucullata.

V. palmata.

V. tricolor, va. arvensis. 

4. HAIRY VIOLET.
5. ARROW-LEAF TIOLET.
6. BIRD-FOOT VIOLET.
7. PRIIROSE-LEAF VIOLET.
8. LANCE-LEAF VIOLET.
๑. PALE VIOLET.
V. villosa.
V. sagittata.
V. pedata.
V. primulæfolia.
V. lanceolata.
V. striata.

ORDER XIY. ROCK ROSE FAMIIY. CISTACEE.

1. FROST WEED.

2. ROCK ROSE.

3. SMALL PIN-WEED.

4. LARGE PIN-IVEED.
Helianthemum Canadense.

H. Carolinianum.

Lechea minor.

L. major.

ORDER XV. SUN DEW FAMILY. DROSERACEE.
1. THREAD-LEAVED SUN DEW.
Drosera filiformis.
2. LONG-LEAYED SUN DEW.
D. longifolia.
3. ROUND-LEAVED SUN DEW.
D. rotundifolia.
4. SHORT-LEATED SUN DEW.
D. brevifolia.

5. YENUS' FLY-TRAP.

Dionæa muscipula.

ORDER XY'I. PARNASSIA FAMILY. PARNASSIACEE.

.1 GRASS OF PARNASSUS.

Parnassia Caroliniana.

ORDER XVII. ST. JOHN'S-IVORT FAMILY. HYPERICACEE.

1. ROCK ROSE.

2. ST. JOHN'S-WORT.

3. GROUND PINE; ORANGE GRASS.

4. ST. PETER'S-WORT.

5. MARSH JOHN'S-WORT.
Hypericum prolificum.

H. perforatum.

H. sarothra.

Ascyrum crux-Andreæ.

Elodea Virginica.

\section{ORDER XVIII. PURSLANE FAMILY. PORTULACCACEE.}

1. PURSLANE.

2. GARDEN PORTULACCA.

3. SPRING BEAUTY.

4. SEA PURSLANE.
Portulacca oleracea.

P. pilosa.

Claytonia Virginica.

Sesuvium pentandrum. 
ORDER XIX. PINK FAMILY. CARYOPHYLLACEA.

1. SAND SPURRY.

2. PINE CHEAT; SAND SPURRY.

3. INDIAN CHICK WEED.

4. SAND-WORT.

5. S.ND-WORT.

6. CHICKWEED.

7. STAR CHICKWEED.

8. ONE-FLOWERED CHICK WEED.

9. MOUSE-EAR CHICKWEED.

10. STAR CHAMPION.

11. INDIAN PINK.

12. CATCH-FLY.

13. SOAP-IYORT

14. COCKLE.
Spergularia rubra.

Spergularia arvensis.

Molugo verticilata.

Alsine squarrosa.

Arenaria serpyllifolia.

Stellaria media.

S. pubera.

S. uniflora.

Cerastium vulgatum.

Silene stellata.

S. Virginica.

S. antirrhina.

Saponaria officinalis.

Agrostemma Githago.

ORDER XX. MALLOW FAMILY. MALVACEA.

1. MALLOW.

2. SPRING MALLOW.

3. VELVET LEAF. INDIAN MLALLOW.

4. MARSH MALLOW.
Malva rotundifolia.

Sida spinosa.

Abutilon Avicennae.

Hibiscus Moscheutos.

[In this order are also the Garden Okra, Hibiscus esculentus, and the Cotton-plant, Gossipyum herbaceum, and the Althea.]

ORDER XXI. THE LINDEN FAMILY. TILIACEAE.

1. SOUTHERN LINN.

2. WHITE LINN.
Tilia pubescens.

T. heterophylla.

\section{ORDER XXII. CAMELLIA FAMILY. CAMELLIACEAE.}

\section{LOBLOLLY BAY.}

2. STUARTIA.
Gordonia Lasianthus.

Stuartia Virginica.

[Under the Order Aurantaceae, Orange Family, may be mentioned the Orange, both sweet and sour, the Lemon, and the Shaddock, which are cultivated in the southern portion of the State, extending up as far north as Charleston.] 
ORDER XXIII. PRIDE OF INDIA FAMILY. MELIACEAE.

1. IRIDE OF INDIA. CHINA BERRY.

Melia azadarach.

Now well naturalized.

ORDER XXIY. FLAX FAMILY. LINACEAE.

1. WILD FLAX.

Linum Virginicum.

ORDER XXY. WOOD SORREL FAMILY. OXALIDACEAE.

1. PURPLE WOOD SORREL.

Oxalis violacea.

2. WHITE WOOD SORREL.

0 . acetocella.

3 YELLOW WOOD SORREL.

0 . stricta.

ORDER XXVI. GERANIUM FAMILY. GERANIACEAE.

1. CRANESBILL, ALUM ROOT.

Geranium maculatum.

2. CAROLINA CRANESBILL.

G. Carolinianum.

ORDER XXVII. BALSAM FAMILY. BALSAMINACEE.

1. PAIE TOUCH-ME-NOT.

Impatiens pallida.

2. JEWEL WEED-SPOTTED TOUCH-ME-NOT. I. fulva.

ORDER XXVIII. RUE FAMILY. RUTACEÆ.

1. PRICKLY ASH; TOOTH ACHE TREE.

Zanthoxylum Carolinianum.

2. HOP TREE. Ptelea trifoliata.

ORDER XXIX. CASHEIV OR SUMACH FAMILY. ANACARDIACEE.

1. STAG-HORN SUMACH.

2. SMOOTH SUMACH.

3. COMMON SUMACH.

4. DWARF SUMACH.
Rhus typhina.

R. glabra.

R. copillina.

R. pumila. 
5. POISEN SUMIACH ; POISEN ELDER.

R. venenata.

6. POISEN OAK.

R. toxicodendron.

7. PUISEN VINE.

R. radicans.

\section{ORDER XXX. VINE FAMILY. VTTACEA.}

1. FOX GRAPE.

2. SUMMER GRAPE.

3. FROST GRAPE; WINTER GRAPE.

4. BULLACE; SCUPERNONG.

э. VIRGINIA CREEPER; AMERICAN IVY.
Vitis Labrusca.

V. æstivalis.

V. cordifolia.

V. vulpina.

Ampelopsis quinquefolia.

ORDER XXXI. BUCKTHORN FAMILY. RHAMNACE.

1. SUPPLE JACK.

2. TI-TI:

3. CAROLINA BUCKTHORN.

4. JERSEY TEA; RED ROOT.
Berchemia volubilis.

Sageretia Michauxii.

Frangula Caroliniana.

Ceanothus Americanus.

ORDER XXYII. STAFF TREE FAMILY. CELASTRACEA.

1. STRAWBERRY BUSH; BURSTING HEART. Euonymus Americanus.

2. BURNING BUSII.

E. atropurpureus.

3. WAX-WORK; BITTER-SWEET.

Celastrus scandens.

ORDER XXXIII. BLADDER-NUT'FAMILY. STAPHYLEACEE.

1. BLADDER-NUT.

Staphylea trifolia.

ORDER XXXIT. SOAP BERRY FAMILY. SAPINDACE.E.

1 SOAP BERRY.

2. BUCK-EYE; HORSE-CHESTNUT.

3. YELLOW BUCK-EYE.

4. SIIALI, FLOWERED BUCK-EIE.
Sapindus marginatus.

Æsculus Pavia.

Æ. flava.

Æ. parvifiora.

ORDER MXYY. MAPLE FAMILY. ACERACEE.

1. ASH-LEAVED MAPLE; BOX-ELDER.

2. RED MAPLE.

3. SIIVVER MAPLE.

4. SUGAR MAPLE.

5. STRIPED MAPLE.
Negundo aceroides.

Acer rubrum.

A. dasycarpum.

A. saccharinum.

A. Pennsylvaricum. 
ORDER XXXVI. MILKWORT FAMILY. POLYGALACEF.

1. BACHELOR'S BUTTON.

2. SENECA SNAKE-ROOT.

3. BLOOD-RED POLYGALA.
Polygala lutea.

P. senega.

P. sanguinea. And many other species.

\section{ORDER XXXVII. PULSE FAMILY. LEGUMENOSE.}

Herbs, shrubs and trees with compound alternate leaves, fruit a legume or pod. A large and very important family of plants-well represented in our State.

1. RATTLE BOX.

2. PARTRIDGE PEA.

3. LUPINE.

4. HAIRY LUPINE.

5. BLUE LUPINE.

6. RED CLOVER.

7. WHITE CLOVER.

8. CAROLINA CLOVER.

9. BUFFALO CLOVER.

10. RABBIT-FOOT CLOVER.

11. YELLOW CLOVER.

12. HOP MEDICK, LUCERNE.

13. YELLOW MELLILOT.

14. WHITE NELLILOT.

15. BUCK ROOT.

16. INDIGO BUSH.

17. LOCUST ; FALSE ACACIA.

18. CLAMMY LOCUST.

19. ROSE LOCUST.

20. VIRGIN'S BOWER; AMERICAN WISTARIA. Wistaria frutescens.

21. RABBIT-PEA; GOAT'S RUE.

22. CAROLINA INDIGO.

23. INDIGO.

24. IILK VETCH.

25. VETCH; TARE.

26. WILD VETCH.
Crotallaria sagittalis.

C. ovalis.

Lupinus perennis.

L. villosus.

L. diffusus.

Trifolium pratense.

T. repens.

T. Caroliniana.

T. reflexum.

$\mathrm{T}$. arvense.

T. procumbens.

Medicago lupulina.

Melilotus officinalis.

-M. alba.

Psoralia canescens.

Amorpha fruticosa. And one other species.

Robinia pseudo-Acacia.

R. viscosa. Only in the mountains.

R. hispida.

Tephrosia Virginica. And two other species.

Indigofera Caroliniana.

I. Anil. Introduced and formerly cultivated.

Astragalus glaber.

Vicia sativa.

V. Caroliniana. And two other species. 
27. PENCIL FLOIVER.

28. JAPAN CLOVER.
Stylosanthes elatior.

Lespedeza striata. A native of

Japan-now matualized and spreading everywhere-also three or four more native speries.

29. BEGGAR'S TICKS.

Desmodium. This is a larre fitmily of plants, of whith there are sixteen species growing in the state. The term "Beggar's Ticks" is indiscriminately applied to all of them, from the peculiar formation of the Lerume, or seed-porl, composed of jointed parts, easily separated, and clothed with hooked hairs, eausing them to alhere to clothes of any one brushing them.

30. DOLLAR PLANT.

31. WILD GROUND-NUT.

32. WILD BEAN.

33. NATIVE ERYTHRINA.

34. WILD PEA VINE.

35. MILK PE.L.

36. WILD INDIGO.

37. JUDAS TREE; RED BUD

38. WILD SENNA.

39. FLORIDA COFFEE; STYPIIC IVEED.

40. PARTRIDGE PEA; GOLDEN CASSLA.

41. HONEY LOCUST.

42. ONE-SEEDED LOJUST.

43. SENSITIVE PLANT.
Rhynchosia monophylla. And two other sprecies.

Apios tuberosa.

Phaseolus perennis. And two

Erythrina herbacea.

other sprecies.

Amphicarpa monoica.

Galactia pilosa And four other species.

Baptisia tinctoria. And seven other species.

Cercis Canadonsis.

Cassia Marylandica.

C. occidentalis.

C. chamzorista. And two other spereies.

Gladitschia triasanthos.

G. monosperma.

Schrankia angustata.

[Under this Order are many of our cultivated plants-Garden Peas, Cow Peas, Beans, Ground-Nut, or Pindar, or Pea-Nut-and many oihers.]

ORDER XXXVIII. ROSE FAMILY. ROSACEA.

1. CHICKASAW PLUM.

2. RED PLUM ; AUGUST PLUM.

3 SOUR PLUM.

4. WILD CHERRY.

5. WILD ORANGE; MOCK ORANGE.

6. INDIAN PHYSIC.
Prunus Chicasa.

P. Americana.

P. umbellata.

P. serotina.

P. Caroliniana. ( 1 tine evergreen.)

Gillenia trifoliata. 


\section{AMERICAY IPECAC.}

8. AGRIMONY ; FEVEREEW.

9. WHLD BULYYT.

10. AVENA.

11. CINQUIFOLI; FIVE-FIXGER; WILD STRAWBERRY.

12. WILD STRA WBERRY.

13. COMMON STRAWBERRY.

14. HIGH.BUSI BLACKBERRY; DEW BERRY

15. JUYE BERRY.

16. LOW-BUSH BLACKBERRT; TRAILING BLACKBERRY.

17. FLOWERING RASPBERIT.

1S. PURPLE RASPBERRY.

19. STAMP LOSE.

20. WILD OR DWARF ROSE.

21. EGLANTINE; SWEET BRIAR.

21. CHEROKEE ROSE.

23. NARROW-IEA VED THORX.

24. SUMMER HAW; RED HAW.

25. IIAIRT THORN.

20. DWARF THORN.

27. SCARLET HAW.

28. SUMMER HAW ; PONI) HAW.

291. PARSLEY-LEAYED HAW.

30. COCKSPUR HAWTHORN.

31. TREE HAW.

32. CRAB APPLE.

33. NARROW-LEAVED CRAB.

34. CHOKE BERRY.

35. WILD CRANBERRY.

3i. SERVECE TREE.
G. stipulacea

Agrimonia eupatoria.

Sanguisorba Canadensis.

Geum album.

\section{Potentilla Canadensis.}

Fragaria Virginiana.

F. vesca. (This species strays from gardens and has become naturalized.)

Rubus villosus.

R. cuneifolius.

R. trivialis.

R. odoratus. (In the mountains.)

R. occidentalis. (In the moun-

Rosa Carolina. tains.)

R. lucida.

R. rubiginosa.

R. lævigata.

Cratægus spathulata.

C. flava.

C. glandulosa.

C. parvifolia

C. coccinea.

C. æstivalis.

C. apiifolia.

C. Crus-galli.

C. arborescens.

Pyrus coronaria.

$P$. angustifolia.

P. arbutifolia.

P. erythrocarpa.

Amelanchier Canadensis.

[The cultivated representatives of this large and important order are, the dpple, Pear, Quince, Plum, Peach, Apricot, Amond, Cherry, Ruses, Spireas, ete.]

\section{ORDER XXXIX. CAROLINA ALLSPICE FAMILY.}

\section{CALICANTHACEN.}


ORDER XL. DEER-GRASS FAMILY, MELASTROMACEA.

1. DEER GRASS.

Rhexia glabella, and five otler species.

ORDER XLI. LOOSE-STRIPE FAMILY. LYTHRACEAE.

1. LOOSE STRIFE.

2. SWAMIP LOOSE STRIFE.

3. BLUE WAX WEED.
Lythrum alatum.

Nesea verticillata.

Cuphea viscosissima.

[The Crape Myrtle (Lagerstrœmia Indica), so common in cultivation as a flowering tree, from Eastern Asia, belongs to this order.]

ORDER XLII. ETENING PRIMROSE FAMILY. ONAORAC'E.E.

1. EVENING PRIMROSE.

2. SUN DROPS,

3. SEED BOX.

4. WATER PURSLANE.

5. ENCHANTER'S NIGHTSHADE.

6. MERMAID WEED.

¡. WATER MILFOIL
Oenothera biennis.

0. fruticosa, and two or three other species

Ludwigia alternifolia.

L. palustre, and ten other species.

Circæa Lutetiana. (In the mountains.)

Proserpinaca palustris, and one other species.

Myriophyllum verticillatum.

ORDER XLIII. CACTUS FAMILY. CACTACEE.

1. PRICKLY PEAR.

2. CROIFFOOT PRICKLY PEAR.
Opuntia vulgaris.

o. Pes-Corvi.

ORDER XLIT. CURRANT FAMLY. GROSSULACEA.

1. SMOOTH GOOSEBERRY.

Ribes rotundifolium. (In the mountains.)

ORDER XLT. PASSION-FLOWER FAMILY. PASSIFLORACEF.

1. MAY POP ; PASSION FLOWER.

2. YELLOW PASSIFLORA.
Passiflora incarnata, P. lutea. 


\section{ORDER XLVI. GOURD FAMILY. CUCURBITACEA.}

1. COMMON GOURD; CALABASH.

?. ONE-SEEDED CUCUMBER.
Lagenaria vulgaris.

Sicyos angulatus.

[In this order are the Squash, Pumpkin, Watermelon, Muskmelon, Cantaloupe, (ucumber and Gherkin of the gardens.]

ORDER NLVII. ORPINE FAMILY. CRASSLLACEA.

1. WILD ORPINE.

2. THREE-LEA VED STONE CROP.

3. MOUNTAIN MIOSS.

4. DITCH STONE CROP.
Sedum telephoides. (In the mountains.)

S. ternatum.

S. pulchellum. (In the mountains.) Penthorum sedoides.

ORDER XLTIII. SAXIFRAGE FAMILY. SAXIFRAG.ACEA.

1. LETTUCE SAXIFRAGE.

2. EARLY SAXIFRAGE.

3. ALUM ROOT.

4. FA LSE MIITRE-WORT.

J. MITRE-IVORT.

6. GOLDHN SAXIFRAGE.

7. WILD HYDRANGEA

8. SNOWY HYDRA NGEA.

9. CLIMBING DECUMARIA.

10. ITEA.

11. SYRINGA.

12. ROUGH SYRINGA.

13. SCENTLESS SYRINGA.
Saxifraga erosa. (In the mountains.)

S. Virginiensis. (In the mountains.)

Heuchera Americana.

Tiarella cordifolia.

Mitella diphylla.

Chrysosplenium Americanum. Hydrangea arborescens.

H. radiata.

Decumaria barbara.

Itea Virginica.

Philadelphus grandiflorus. (In

the mountains.)

P. hirsutus. (In the mountains.)

P. inodorus.

ORDER XLIX. WITCH HAZEL FAMILY. HAMAMELACEE.

1. WITCH HAZEL.

2. DIVARF ALIJER.

3. SIVEET GUM.
Hamamelis Virginica.

Fothergilla alnifolia.

Liquidambar styraciflua. 
ORDER L. PARSLEY FAMLLY. UMBELLIFERE.

1. PENNY-WORT.

2. WATER GRASS.

3. SANICLE; BLACK SNAKE ROOT.

4. BUTTON SIAKE ROJГ.

5. DIVARF CARROT.

6. COMMON CARROT.

7. WATER HEMLOCK.

S. BISHOP IVEED.

9. WATER PARSNIP.

10. MEADOW PARSNIP.

11. A NGELICA.

12. ARCHANGELICA.

13. WATER DROP-WORT.

14. COW-BANE; PIG POTATOE.

14. CHERVIL.
Hydrocotyle Americana.

H. umbellata, and two or three other species.

Sanicula Marylandica, and one other species.

Eryngium Virginianum. (IV have five species of Lryngium, and most of them are known as Button Snake Root.)

Daucus pusillus.

D. carota. (Some what n ituralized. Cicuta masculata.

Discopleura capillacea.

Sium lineare.

Thaspium aureum, and two other species.

Ligusticun actæifolium.

Archangelica hirsuta.

Tiedmannia teretifolia.

Archemora rigida, and one other species.

Chærophyllum procumbens.

\section{ORDER LI. GINSENG FAMILY. ARALIACEA.}

1. SPIKENARD.

2. WILD SARSAPARILLA.

3. PRICKLY ASH; HERCULES CLUB.

4. GINSENG; SANG.

5. DWARF GINSENG.
Aralia racemosa.

A. nudicaulis.

A. spinosa.

Panax quinquefolium. (In the mountains

P. trifolium. (In the mountains.)

\section{ORDER LII. DOGIVOOD FAMILY. CORNACE.}

\section{DOGWOOD.}

2. STAMIP DOGWOOD.

3. SOUR GUM; BLACK GUM ; PEPPERIDGE.

4. TUPELO ; POND TUPELO.

5. SWAMP TUPELO; COTTON GUM.

6. OGEECHEE LIME; SOUR TUPELO.
Cornus Florida.

C. sericea, and three other species. Nyssa multiflora.

N. aquatica.

N. uniflora.

N. capitata. 
DIVISION II. Floral envelopes double, consisting of both calyx and corolla, the latter mostly united into one petal. Monopetalous.

ORDER LII. HONEYSUCKLE FAMILY. CAPRIFOLIACEA.

1. CORAI BERRY.

2. BUSH HONEYSUCKLE.

3. WOODBINE; HONEYSUCKLE.

4 YELLOW WOODBINE.

5. HORSE GENTIAX.

6. ELDER.

7. RED-BERRIED ELDER.

8. BLACK HAIV.

9. SHEEP BERRY.

10. POSSUM HAW ; SHAWNEE HAW.

11. ARROW-WOOD.
Symphoricarpus vulgaris.

Diervilla trifida. (In the mountains.)

Lonicera sempervirens.

L. flava.

Triosteum perfoliatum.

Sambucus Canadensis. All over the State.

S. pubens. In the mountains. Viburnum prunifolium.

V. Lentago.

V. nudum.

V. dentatum.

ORDER LIV. MADDER FAMILY. RUBIACEE.

1. SMALL BEDSTRAW.

2. BUTTON WEED.

3. BUTTON BUSH.

4. PARTRIDGE BERRY; RUNNING BOX.

5. GEORGIA BARK.

6. BLUETS; DAISEY.

7. PINK ROO'T.

s. MIITRE WORT.

9. YELLOW JESSAMINE.
Galium trifidum. And three other species.

Diodia Virginiana.

Cephalanthus occidentalis.

Mitchella repens.

Pinckneya pubens.

Houstonia cœrulea. And several other speries.

Spigelia Marylandica.

Mitreola petiolata.

Gelsemium sempervirens.

ORDER LV. VALERIAN FAMILY. TALERIANACEE.

1. LAМB LETTUCE.

ORDER LVI. COMPOSITE FAMILY. COMPOSITA.

1. IRON WEED.

2. ELEPHANT'S FOOT.
Fedia radiata.

Vernonia Novæboracensis. And two other species.

Elephantopus Carolinanus. 
3. BLAZING STAR.

4. BUT'TON SNAKE-ROOT.

5. VANILLA PLANT.

6. THOROUGH-WORT; BONE-SET.

7. TRUMPET WEED.

8. UPLAND BONE-SET.

9. RICH WEED.

10. WILD HOREHOUND.

11. DOG FENNEI.

12. DOG FENNEL.

13 CLIIBING HEMP-WEED.

14. MIST FLOWER.

15. WIITE-TOPPED ASTER.

16. ASTER; STARWORT.
Liatris squarrosa.

I. spicata.

L. odoratissima. And six or seren other species.

Eupatorium perfoliatum.

E. purpurem.

E. sessilifolium.

E. ageratoides.

E. aromaticum.

E. fœniculaceum.

E. coronopifolium. And eleven other species.

Mikania scandens.

Conoclinum coelestinum.

Sericocarpus conyzoides.

Aster corymbosus. This is a very

large genus, comprising about thirty-five species found in the state, but they have received 10 common names.

17. DAISEY FLEL-BANE.

18. HOG-WEED; HORSE-WEED.

Erigeron strigosum.

E. Canadense.

E. Philadelphicum.

E. bellidifolium.

20. ROBBIN'S PIANTAIN.

21. GOLDEN ROD; ANISE-SEED GOLDEN ROD. Solidago odora.

[This is another large genus, comprising over thirty species in this State. MIost of them are called indiscriminately Gollen Rod, but that name more properly applies to the species noted above.]

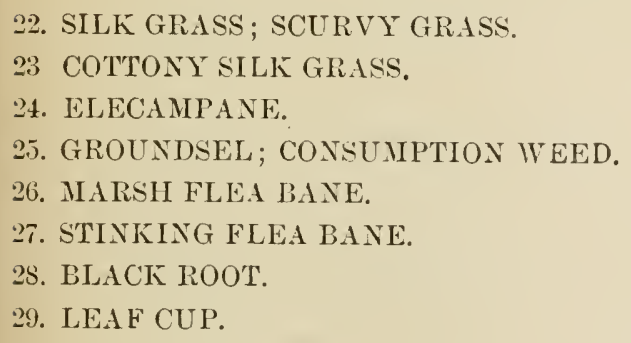

A. artimesiaefolia. 
35. COCKLE BUR; SHEEP BUR.

36. THORNY COCKLE BUR.

37. BRAZILIAN COCKLE BUR.
Xanthium strumarium.

$\mathrm{X}$. spinosum.

Acathospermum xanthioides.

This Exotic is a recent introduction of about twenty years ago. Spreading from the woollen mills of Augusta, Ga., it has extended along the railroads in all directions, anıl may be found at nearly every station.

\section{SEA OX-EYE. \\ 39. ZINNIA; OLD MAID.}

40. OX-EYE.

41. PURPLE CONE FLOWER.

42. CONE-FLOWER.

NARROW-LEAVED SUN-FLOWER.

Borrichia frutescens.

Zinuia multiflora. Stray from the

Heliopsis lævis. gardens.

Echinacea purpurea.

Rudbeckia hirta.

Helianthus angustifolius. We have several other species in the State. The common cultivated SunFlower, Helianthus annuus, and the Jerusalem or Ground Artichoke, Helianthus tuberosus, are partially naturalized.

43. TI'K-SEED.

44. TICK-SEED SUN-FLOWER.

45. TAII COREOPSIS.

46. BUR MARYGOLD.

47. BEGGAR'S LICE.

48. BEGGAR'S LJCE; SPANISH NEEDLES.

49. STICK WEED; CROWN BEARD.

50. SYEEZE WVEED.

51. MAY WEED; FALSE CHAMOMILE.

52. MILFOIL; YARROI?.

58. OX-EYE DAISY ; WHITE DAISY; WHITE WEED.

24 TANSY.

ว.). WTLD WORMWOOD.

56. EVERLASTING.

57. CUD WEED.

is EVERLASTING.

59. FYRE-IVEED.

60. INDTAN PLANTAXY.

61. RAG WORT.

62. THISTLE.

63. SWAMP THISTLE.

64. YELI.OW THISTLE.
Coreopsis discoidea.

C. trichosperma.

C. tripteris.

Bidens chrysanthemoides.

B. frondosa.

B. bipinnata.

Verbesina Siegesbeckia.

Helenium autumnale.

Maruta Cotula.

Achillea millefolia.

Leucanthemum vulgare.

Tanacetum vulgare. Sparingly naturalized.

Artemesia caudata.

Gnaphalium polycephaluu.

G. purpureum.

Antennaria margaritacea.

Erechthites hieracifolia.

Cacalia atriplicifolia.

Senecio aureus.

Cirsium lanceolatum. Introduced and naturalized.

C. muticum.

C. horridulum. 
6.j BURDOCK.

66. HAWK-WEED.

67. RATTLE-SNAKE WEED.

68. WHITE LETTUCE.

69. GALL OF THE EARTH.

70. DANDELION.

71. FALSE DANDELION.

72. WILD LETTUCE.

73. BLUE LETTUCE.

74. SOW THISTLE.
Lappa major.

Hieracium scabrum.

H. venosum.

Nabalus albus.

N. Fraseri.

Taraxacum Dens-Leonis.

Pyrrhopappus Carolinianus.

Lactuca elongata.

Mulgidium acuminatum.

Sonchus oieraceus.

ORDER LVII. LOBELIA FAMILY. LOBELIACEE.

1. CARDINAL FLOWER.

2. GREAT LOBELIA.

3. BLUE LOBELIA.

4. INDIAN TOBACCO; LOBELIA.
Lobelia cardinalis.

L. syphilitica.

L. puberula.

L. inflata. And three or four other species.

\section{ORDER LVIII. CAMPANULA FAMILY. CAMPANULACEE.}

1. BELL, FLOWER.

2. MARSH BFLL FLOWER.

3. HARE BELL.

4. VENUS' LOOKING-GLASS.
Campanula Americana.

C. aparinoides.

C. divaricata.

Specularia perfoliata.

ORDER LIX. HEATH FAMILY. ERICACEA.

1. BLUE HUCKLEBERRY.

2. DIVARF HUCKLFBERRY.

3. BLACK HUCKLEBERRY.

4. BEAN BERRY.

5. SWAMP HUCKLEBERRY.

6. DEER BERRY; GUOSEBERRY.

7. CREEPING HUCKLEBERRY.

8. SPARKLE BERRY.

9. GROUND IVY; MAY FLOWER; TRAILING ARBUTUS.

10. MOUNTAIN TEA; WINTER GREEN.

11. DOG LAUREL.

12. TI-TI.
Gay-Lussacia frondosa.

G. dumosa.

G. resinosa.

G. ursina. In the mountains. Vaccinium corymbosum.

V. stamineum.

V. crassifolium.

V. arboreum.

\section{Epigæa repens.}

Gaultheria procumbens.

Leucothœ Catesbaei.

I. acuminata. 
13. FLTTER BUSH.

14. STAGGER BUSII.

15. PEPPER BUSIT.

16. SOUR WOOD; SORRELL TREE

17. WHITE ELDER; SWEEF PEPPER BUSH.

18. CALICO BUSH ; KALAII.

19. WICK $\mathrm{Y}^{\prime}$; SHEEP LATREL.

20. PURPLE HONEY-SUCKLE.

21. BLAZING HONEY-SUCKLE.

22. CLAMMY HONEY-SUCKLE.

23. SHOOTH HONEY-SUCKLE.

24. LAUREL; ROSE BAY.

25. O.AK-LEAVED LAUREL.

26. DIVARF LAUREL.

27. SAND MYRTLE.

2S. FALSE WINTER GREEN.

29) PIPSISSEWA ; PRINCES PINE.

30. SPOTTED IVINTER GREEN.

31. DUTCHMAN'S PIPE; EYE-BRIGLT.

:. PINE SAP.
Andromeda nitida.

A. Mariana.

A. Ligustrina.

Ozydendrum arboreum.

Clethra alnifolia.

Kalmia latifolia.

$\mathrm{K}$. angustifolia.

Azalia nudiflora.

A. calendulacea.

A. viscosa.

A. arborescens.

Rhododendron maximum. In the mountains.

R. Catawbiense. In the mountains.

R. punctatum. In the mountains.

Loiophyllum buxifolium. In the muuntains.

Pyrola rotundifolia.

Chimaphila umbellata.

C. maculata.

M) aьะopa uniflora.

II. Hypopitys.

ORDER LX. GALAX FAMLY. GALACINE.

1. COLT'S FOO'T.

Galax aphylla.

ORDER LXI. HOLLY FAMILY. AQUHFOLACEE.

1. COMMON HOLLY.

2. DAHOON HOLLY.

3. YAUPON.

4. GALL BERRY : INK BERRY.

5. TALL GALL BERRY.
Ilex opaca.

I. Dahoon.

I Cassine.

Prinos glaber.

P. coriacea.

ORDER LXII. STYRAX FAMILY. STYRLCEE.

1. MIOCK ORANGE.

2. SNOIV-DROP TREE.

3. SWEET LEAF; YELLOW WOOD.
Styrax grandifolia.

Halesia tetraptera.

Symplocos tinctoria. 
ORDER LXIII. CYRILLA FAMILY. CYRILLACEE. 1. BUIN-WOOD BARK; HE IUUCKLEDERRY. Cyrilla racemiflora.

ORDER LXIV. EBONY FAMILY. EBENACEA.

1. PERSIMION.

Diospyros Virginiana.

ORDER LXY, SAPODILLA FAMILY. SAPOTACEA.

1. BUCK THORN.

2 TOUGH BUCK THORN.
Bumelia lyciodes.

B. tenax. And two other species.

ORDER LATI. PLANTAIN FAMILY. PLANTAGINACEA.

1. PLANTAIN.

2. NARROW-LEAVED PLANTAIN.
Plantago major.

P. lanceolata. Ind three other species.

ORDER LXVII. LEAD-IVORT FAMILY. PLUMBAGINACEA.

1. MARSH ROSEMARY.

Statice Caroliniana.

ORDER LXVIII. PRIMROSE FAMILY. PRIMULACEA.

1. FEATHERFOIL.

¿. LOOSE STRIFE.

2. FIVE SISTERS.

3. A.MERICAN COWSLIP.

4. PIMPERNEL.

j. CHAFF IVEED.

6. BROOK IVEED.
Huttonia inflata.

Lysimachia stricta.

I. quadrifolia. And three or four other species.

Dodecatheon Media.

Anagallis arvensis.

Centunculus minimus.

Samolus floribundus.

ORDER LIX. BLADDER-ROOT FAMILY. LENTIBULACEA.

1. BLADDER WORT.

Utricularia inflata. And seren other species ; mostly in bogrgy grounds, or floating in still waters.

2. BUTTER WORT.

Pinguicula lutea. 
ORDER LXX. BIGNONIA FAMILY. BIGNONIACEA.

1. CROSS VINE.

2. TRUMPET FLOWER.

3. CATALPA.

4. UNICORN PLANT.
Bignonia capreoleta.

Tecoma radicans.

Catalpa Bignonioides.

Martynia proboscidea.

ORDER LXXI. BROOM-RAPE FAMILY. OROBANCHACEE.

1. BEECH DROPS.

2. SQUAIV ROOT.

3. CANCER ROOT.
Epiphegus Virginiana.

Conopholis Americana.

Aphyllon uniflorum.

ORDER LXXII. FIG-WORT FAMILY. SCROPHULARIACE.E.

1. MULLEIN.

2. MOTH MULLEIN.

3. FIG WORT.

4. SNAKE-MOUTH.

5. BEARD-TONGUE.

6. TOAD FLAX.

7. MONKEY FLOWER.

8. HEDGE HYSSOP.

9. FALSE PIMPERNEL.

10. CULVER'S PIIYSIC.

11. PAUL'S BETONY.

12. PURSLANE SPEEDWELL.

13. CORN SPEEDWELJ.

14. FICKEL SPEEDIVELL.

15. BLUE HEARTS.

16 FALSE FOX-GLOVE.

17. FLAX-LEA VED GERARDIA.

1S. PURPLE GERARDIA.

19. CHAFF SEED.

20. LOUSE WORT.

21. COW WHEAT.
Verbascum Thapsus.

V. Blattaria.

Scrophularia nodosa

Chelone glabra.

Penstemon pubescens.

Linaria Canadensis

Mimulus ringens.

Gratiola Virginiana. And two or three other species.

Ilysanthes gratioloides.

Veronica Virginica.

V. serpyllifolia.

$\mathrm{V}$. peregrina.

V. arvensis.

V. agrestis.

Buchnera Americana.

Dasystoma pubescens. And three

Gerardia linifolia.

other species.

G. purpurea. And three other species.

Schwalbea Americana.

Pedicularis Canadensis.

Melampyrum Americanum. 


\section{ORDER LXXII. ACANTHUS FAIILY. ACANTIACEE.}

1. RUELLIA.

2. WATER WILLOW.
Diptercanthus strepens And two

other spreries.

Dianthera Americana.

ORDER LXXIV. VERYAIN FAMLY. TERBENACE.E.

1. WHITE VERVAIT.

2. BLUE VERVAIS.

3. TERVAIN.

4. FROG FRUIT.

5. AIERICAN MULBERRY; WILD MULBERRY.

6. LOP SEED:
Verbena urticifolia.

V. hastata.

V. officinalis. And two other species.

Lippia nodiflora.

Callicarpa Americana.

Phryma leptostachya.

ORDER LXXY. MINT FAMILY. LABIAT君.

1. SPEAR MINT.

2. PEPPER IIINT.

3 ROUND-LEAF MINT.

4. BUGLE WEED.

5. DITTANY.

6. MOUNTAIN MINT.

7. HORSE BALMT.

8. PENNY ROYAL.

9. BASIL THIYIE.

10. BALII.

11. WILD SAGE,
Mentha viridis.

M. piperata.

M. rotundifolia. All our Mints are introduced.

Lycopus Virginicus.

Cunila mariana. In the mountains.

Pycnanthemum incanum. And a few other species.

Collinsonia Canadensis.

Hedeoma pulegioides

Calamintha Nepeta.

Melissa officinalis.

Salvia urticifolia. S. officinatis

is the common garden sage. S. Coccinea, is partly naturalized.

12. HORSE MINT; RIGNUM.

13. HORSE MINT.

14. GIANT HYSSOP.

15. CATNIP.

16. HEAL-ALL.

17. SCULL-CAP.
Monarda punctata.

Blephilia ciliata.

Lophanthus nepetoides.

Nepeta Cataria.

Brunella vulgaris.

Scutellaria versicolor. Five or six other species. 
19. M.ICIBRIDA.

19. DIRAGON IIEAD.

20. DEAD NETTLE; HEX-BIT.

21. HOREIIOLIJ).

2.). MOTHER WORT.

23. HFDGF YETTLE

24. FALSE PENYY ROYAL.

25. BLTE CLRLS.

26. WOOD SAGE.
Macbridea pulchra.

Physostegia Virginiana.

Lamium amplexicaule.

Marrubium vulgare.

Leonurus Cardiaca.

Stachys aspera.

Isanthus coeruleus.

Trichostema dichotomum.

Teucrium Canadense.

ORDER LAXYI. BORAGE FAMILY. BOR.LGIAACEE.

1. HELIOTROPE.

2. INDIAN HELIOTROPE; TURNSOLE.

3. GROMIIELL

4. HAIRY PUCCOON; GROMWELL.

5. ROANOKE BELL; I'IRGINIA COWSLIP.

6. HOLND'S TONGUE.

7. WILD COMFREY.

s. BEGGAR LICE.

9. FORGET-IJE-NOT
Heliotropium Curassavicum. Heliophitum Indicum. Onosmodium Carolinianum. Litnospermum hirtum. Mertensis Virginica.

Cynoglossum officinale.

C. Virginicum.

C. Morisoni.

Myosotis laxa.

ORDER LXYYII. WATER-LEAF FAMILY.

HYDROPHYLLACEE.

1. WITER LEAF.

Hydrophyllum Virginicum. (In

the mountains.)

\section{ORDER LXXTIII. POLEMONIUY FAMILY. POLEMONIACE.E.}

1. PHLOX.

2. WILD PINK ; RUYYING PILOX.

3. HAIRI PILOX.

4. GREEK YALERIAN.

5. FLOWERING MOSS.
Phlox paniculata.

P. subulata.

P. pilosa, and tluree or four other species; the Texan Phlox, Plilox Drummondii, of the garlens, is partially naturalized.

Polemonium reptans.

Pyxidanthera barbulata. 
ORDER LXXIX. CONVOLVULUS FAMILY. CONVOLYULACEA.

1. CYPRESS VINE.

2. MORNING GLORY.

3. WILD POTATOE.

4. SIIEET POTATOE.
Quamoclit vulgaris.

\section{Pharbitis Nil.}

Ipomea pandurata, and three other species.

Batatas edulis. (This can scarcely be said to be naturalized, the frosts of winter killing the tubers, and the plant not maturing seel. Wo have a native species growing on the sands of the coast, B. Littoraïis.)

5. BIND WEED.

6. LOW BIND WEED.

7. SILKEN BIND WEED.

8. DWARF GROUND CONVOLYULUS.

9. DODDER; JOYE VINE.

10. LCI'E VINE.
Calystegia sepium.

C. spithamea.

Evolvulus sericeus.

Stylisma humistrata.

Cuscuta arvensis.

C. Gronovii.

ORDER LXXX. NIGHTSHADE FAMILY. SOLANACEE.

1. NIGHTSHADE.

2. HORSE NETTLE.

3. SODOM APPLE.

\section{Solanum nigrum}

S. Carolinense.

S. aculeatissimum. (Among the cultivated representatives of this order are the Jerusalem Cherry, (S. Pseudo-capsicum), Tomato (S. Lycopersicum), the Irish Potatoe (S. tuberosum), and the Egg Plint or Guinea Squash (S. Melongena).

4. GROUND CHERRT.

Physalis viscosa.

5. JAMESTOWN WEED; THORN APPLE; STRAMONIUM.

Datura stramonium.

ORDER LXXXI. GENTIAN FAMILY. GENTIANACER.

1. CENTENARY.

․ FIYE-FLOWERED GENTIAX.

3. FRLNGED GENTIAN.

t. S.LMPSON SNAKE ROOT.

5. SAMPSON SNAKE ROOT.

6. SAMPSON SNAKR ROOT.

7. NARROW-LEAVED GENTIAN.

8. COLUMBO.

9. FLOATING HEART.
Sabbatia angularis, and six other species.

Gentiana quinqueflora.

G. crinita.

G. ochroleuca.

G. Elliottii.

G. saponaria.

G. angustifolia.

Frasera Carolinensis.

Limnanthemum lacunosum. 
ORDER LXXXII. DOGBANE FAMILY. APOCTNACEE.

1. INDIAN HEMP.

2. DOGBANE.

3. PERIVINKLE.
Apocynum canabinum.

A. androsæmifolium.

Vinca rosea. (Naturalized.)

ORDER LXXXIII. MILKWEED FAMILY. ASCLEPIADACEA.

1. POKE MILK WEED; SQUAW ROOT.

2. PLEURISI ROOT ; BUTTERFLY IVEED.

3. PURPLE MILK IVEED.

4. SWAMP MILKWEED.

5. RABBIT'S MILK.

6. GREEN MILKWEED.

7. RUNNING MILKWEED.
Asslepias phytolaccoides.

A. tuberosa.

A. purpurascens.

A. incarnata.

A. amplexicaulis, and eight other species.

Acerates viridiflora

Gonolobus hirsutus.

ORDER LXXXIV. OLIVE FAMILY. OLEACEA.

1. DEVIL WOOD; AMERICAN OLIVE.

2. PRIVET.

3. FRINGE TREE; OLD MAN'S BEARD.

4. WHITE ASH.

5. WATER ASH.

6. RED ASH.

7. GREEN ASH.
Olea Americana.

Lisustrum vilgare. (Partly naturalized.)

Chionanthus Virginica.

Fraxinus Americana.

F. platycarpa.

F. pubescens.

F. viridis.

DIVISION III. Floral envelopes single, consisting of a calyx only, or altogether wanting. Apetalous.

ORDER LXXXV. BIRTHIVORT FAMILY. ARISTOLOCHLACEA.

1. IIEART LEAF.

2. HEART LEAF.

3. WILD GINGER.

4. VIRGINIA SNAKE ROOT; SMALL SNAKE ROOT.

5. BIG SARSAPARILLA; WILD GINGER.
Asarum Virginicum.
A, arifolium.
A. canadense.

Aristolochia serpentaria.

A. sipho. 
ORDER LXXXVI. POKEWEED FAMILY. PHYLOLAECACEA.

1. POKE WEED.

Phytolacca decandra.

ORDER LXXYYI. GOOSE-FOOT FAMIIY. CHENOPODIACEA.

1 LAMB'S QUARTERS.

2. WORM SEED : JERUS.ILEM OAK.

3. ORACHE.

4. SAND ORACHE.

5. SEA GOOSE-FOOT.

6. SAMPHIRE.

7. SALT-IVORT.
Chenopodium album.

C. anthelminticum.

Atriplex hastata. (Sea shore.)

Obione arenaria. (Sea shore.)

Chenopodina maritima. (Salt marsh.)

Salicornia herbacea. (Salt marsh.)

Salsola kali. (Sea shore.)

ORDER LXXXVII. AMARANTH FAMILY. AMARANTACEE.

1. AMARANTH.

2. GREEN AMARANTH.

3. THORNY AMARANTH.

4. DIVARF AMARANTH.

5. WATER HEMP.

6. FORTY KNOT; REBEL PLANT.
Amarantus albus.

A. hybridus.

A. spinosus.

Euoxolus pumilus.

Acnida canabina.

Alternanthera achyrantha.

\section{ORDER LXXXIX. BUCKWHEAT FAMILY. POLYGONACEA.}

1. SOUR DOCE.

2. SWAIP DOCK.

3. BLOODY DOCK.

4. BITTER DOCK.

5. GOLDEI DOCK.

6. SORREL.

7. SORREL.

S. BUCKWHEAT.

9. PRITCE'S FEATHER.

10. LADY'S THUUB.

11. SIIART WEED.

12. WATER PEPPER.

13. KNOT GRASS.

22
Rumex crispus.

$R$ verticillatus.

R. sanguineus.

R. obtusifolius.

R. maritimus.

R. acetosella.

R. hastatulus.

Fagopyrum esculentum. (Partially naturailized.)

Polygonum orientale.

P. persicaria.

P. acre.

P. hydropiperoides.

P. aviculare. 
14. SCRATCH GRASS.

15. TEAR THUMB.

16. FALSE BUCKWHEAT.

17. ERIOGONUM.
P. arifolium.

P. sagitatum

P. dumetorum.

Eriogonum tomentosum. (In the Sand Hills.)

ORDER XC. LAUREL FAMILY. LAURACEA.

1. RED BAY.

$\therefore$ SASSAFRAS.

3. SPICE BUSH.

4. IOXD BUSH.
Persea Carolinensis.

Sassafras officinale.

Benzoin odoriferum.

Tetranthera geniculata.

ORDER XCI. MEZEREUM FAMILY. THYMELEACEE.

Dirca palustris.

ORDER XCI. SANDAL WOOD FAMILY. SANTALACEA.

1. TOAD FLAX.

2 OIL NUT; BUFFALO NUT.
Comandra umbellata. Pyrularia oleifera.

ORDER XCIII. MISTLETOE FAMILY. LORANTHACEÆ.

1. MIISTLETOE.

Phoradendron flavescens.

ORDER XCIV. LIZARD-TAIL FAMILY. SAURURACEE.

Saururus cernuus.

ORDER XCT. HORN-WORT FAMILY. CERATOPHYLLACEA. 1. HORN-WORT.

Ceratophyllum demersum. (In still water.

ORDER XCYI. WATER STAR-WORT FAMILY. CALLITRICHACE E.

1. WATER STAR-WORT.

Callitriche verna. 
ORDER XCVII. RIVER IVEED FAMILY. PODOSTEMACEA.

1. RIVER WEED.

Podostemon ceratophyllum.

ORDER XCVIII. SPURGE FAMILY. EUPHORBIACEE.

1. FLOWERING SPURGE.

2. WARTED SPURGE.

3. WILD IPECAC.

4. SPOTTED SPURGE.

5. SHORE SPURGE.

6. VARIEGATED SPURGE.

7. QUEEN'S DELIGHT.

8 CANDLE TREE; WAX TREE.

9. THREE-SEEDED MERCURY.

10. NETTLE.

11. TREAD SOFTLY ; HORSE NETTLE.

12. CASTOR OIL PLANT.
Euphorbia corollata.

E. obtusata.

E. Ipicacuanhae.

E. maculata.

E. polygonifolia.

E. marginata. Naturalized.

Stillingia sylvatica.

S. sebifera. (Naturalized.)

Acalypha Virinica.

Tragia urens.

Cridoscolus stimulosus.

Ricinus communis.

ORDER TCIX. CROWBERRY FAMILT. EMPETRACEAS.

1. HEATI CERATIOLE.

Ceratiola ericoides. (In the Sand

Hills.

ORDER C. NETTLE FAMILY. URTICACEF.

1. TALL NETTLE.

2. STINGING NETTLE.

3. WOOD NETTLE.

4. CLEAR WEED.

5. PELLITORY.

6. FALSE NETTLE.
Urtica gracilis.

U. urens.

Laportea Canadensis.

Pilea pumila.

Parietaria Pennsylvanica.

Boemeria cylindrica.

ORDER CI. MULBERRY FAMULY. MORACEA.

1. MULBERRY.

Morus rubra.

2. FRENCH MULBERRY; PAPER MULBERRY. Broussonetia papyrifera.

[The edible fig (Ficus carica) belongs to this order.] 
ORDER CII. ELM FAMILY. ULMACEE.

1. WHITE ELII; COMMON ELII.

2. SLIPPERY ELM.

:. WAHOO; WINGED ELM.

4. PLANER TREE.

5. SUGAR-BERRY TREE; HACKBERRY.
Ulmus Americana.

U. fulva.

U. alata.

Planera aquatica.

Celtis occidentalis.

ORDER CIII. PLANE TREE FAMILY. PLATANACEE.

ORDER CIV. WALNUT FAMILY. JUGLANDACEE.

1. BLACK WALNU'T.

2. WHITE WALNUT; BUTTERNUT.

3. SHELL-BARK HICKORY.

4. THICK SIIELL-BARK HICKORY.

5. PECAN NUT.

6. WHITE IIICKORY.

7. PIG-NUT IIICKORY.

3. SHALL NUT HICKORY.

9. NUTMEG HICKORY.

10. BITTER-NUT HICKORY.

11. WATER BITTER NUT.
Juglans nigra.

J. cinerea.

Carya alba.

C. sulcata.

C. olivæformis. (Naturalized.)

C. tomentosa

C. glabra.

C. microcarpa .

C. myristicæformis.

C. amara.

C. aquatica.

ORDER CV. OAK FAMILY. CUPULIFERE.

1. WILLOW OAK:

2. LAUREL OAK.

3. MYRTLE OAK.

4. SHINGLEOAK.

5. TURLEY OAK; HIGH GROUND WHLLOW

$$
\text { OAK. }
$$

6. DWARF OAK.

7. LIVE OAK.

8. DWARF LIVE OAK.

9. WATER OAK.

10. BLACK JACK.

11. SCRUB OAK.
Quercus Phellos.

Q. laurifolia.

Q. myrtifolia. (Coast.)

Q. imbricaria. (MIountains.)

Q. cinerea.

Q. pumila.

Q. virens.

Q. maritima. (Coast.)

Q. aquatica.

Q. nigra.

Q. Catesbæi. 
12. BLACK OAK.

13. SCARLET OAK.

14. RED OAK.

15. SPANISH OAK; RED OAK.

16. BEAP OAK.

17. POST OAK.

18. IVHITE OAK

18. OVER-CUP OAK.

19. MOSSY-CUP OAK.

20. SIVAMP CHESTNU OAK.

2I. ROCK OAK.

22. CHESTNUT OAK.

23. CHINQUAPIN OAK.

24. CHESTNUT

25. CHINQUAPIN.

26. BEECH.

27. H.AZL NUT.

28. BEAKED HAZEL NUT.

29. HORN BEAMI; IRON IVOOD.

30. HOP HORN BEAM.
Q. tinctoria.

Q. coccinea.

Q. rubra.

Q. falcata.

Q. ilicifolia. (Mountains.)

Q. obtusiloba.

Q. alba.

Q. lyrata.

Q. macrocarpa. (Mountains.)

Q. prinus.

Q. monticola. (Mountains.)

Q. castanea.

Q. prinoides.

Castanea vesca.

C. pumila.

Fagus feruginea.

Corylus Americana.

C. rostrata.

Carpinus Caroliniana.

Ostrya Virginica.

ORDER CVI. WAX-MYRTLE FAMILY. MYRICACEA.

1. WAX MYRTLE; BAYBERRY.

2. DWARF MYYRTLE.

3. SIVEET FERN.
Myrica cerifera.

M. pumila.

Comptonia asplenifolia.

ORDER CVII. BIRCH FAMILY. BETULACEE.

1. RED BIRCH.

2. BLACK BIRCII.

3. ALDER.
Betuia nigra.

B. lenta. (Iountains.)

Alnus serrulata.

ORDER CVIII. WILLOW FAMILY. SALICACE.E.

1. SWAMP WILLOW.

2. GRAY IVILLOW.

3. WEEPING WILLOW.

4. CAROLINA POPLAR.

5. COT'TON TREE.

6. LARGE-TOOTHED ASPEN.

7. LOMBARDY POPLAR.
Salix nigra.

S. tristis. (Mountains.)

S. Babylonica. (Naturalized.)

Populus angulata.

P. herterophylla.

P. grandidentata.

P. dilatata. (Naturalized.) 


\section{ORDER CIX. PINE FAMIIY. CONIFERA.}

1. TABLE MOUNTAIN PINE.

2. JERSEY OR SCRLB PIXE.

3. SPRUCE PINE; WALTER'S PINE

4. SHOR'T-LEAF PINE; OLD FIELD PINE.

5. PITCII PIXE.

1). POND PINE.

7. LOBLOLLY PINE; OLD-FIELD PINE.

๑. LONG-LEAF PINE; YELLOW PINE.

9. ELLIOTT'S PINE.

10. WHITE PINE.

11. BALSAII EIR.

12. BLACK SPIUC'E.

13. WHITE SPRCCE.

14. HEMLOCK SPRUCE.

15. RED CEDAR.

16. WHITE CEDAR.

17. CYPRESS ; BALD CY PRESS.

18. ARBOR VITA.
Pinus pungens. (Mountains.) P. inops.

P. glabra.

P. mitis.

P. rigida.

P. serotina.

P. Taeda.

P. australis.

P. Elliottii.

P. strobus. (Mountains.)

Abies Fraseri. (Muntains.)

A. nigra. (Mountains.)

A. alba. (Mountains.

A. Canadensis. (Mountains). Juniperus Virginiana.

Cypressus thyoides.

Taxodium distichum.

Thuja occidentalis.

\section{CLASS II.}

Plants with one seed leaf (cotyledon), as the Grasses, Sedges, Palms, \&e., having stems eomposed of cellular tissue, and seattered bundles of woody fibre and ressels, without proper pith; bark in concentric layers, and inreasing in diameter by the deposition of new fibrous bundles. Leares mostly alternate, entire, and parallel-reined; commonly sheathing at the base, not falling off by an articulation. Monocolytedons or Exogens.

\section{ORDER CA. PALM FAMILY. PALME.}

1. PALMETTO; CABBAGE PALAetTo.

2. SAW PALMETTO.

3. DWARF PALMETTO.

4 BLUE PALMETTO.
Sabal Palmetto.

S. serrulata.

S. Adansoni.

Chamærops hystrix.

ORDER CXI. ARUM FAMILY. ARACEE.

1. INDIAN TURNIP.

2. DRAGON ROOT.

\%. ARROW ARUM.
Arisæma triphyllum.

A. Dracontium.

Peltandra Virginica, 
NATIVE AND NATURALIZED PLANTS OF SOUTH CAROLINA. 343

4. SPOON FLOWER.

5. GOLDEN CLUB; WATER DOCK.

6. CALAMIUS.
Xanthosoma sagittifolium.

Orontium aquaticum.

Acorus Calamus.

ORDER CXII. DUCK-WVED FAMILY. LEMNACEA.

1. DUCK-IVEED.

Lemna minor, and two other spe('ies. Very small aquatic plants floating in still water.

ORDER CXIII. CAT-TAIL FAMILY. TYPHACEE.

1. CAT-TAIL.

2. BUR REED.
Typha latifolia.

Sparganium ramosum.

ORDER CXIV. POND WEED FAMILY. NAIADACEE.

1. EEL GRASS ; SEA WR ICK.

2. DITCH GRASS.

3. POND WEED.
Zostera marina.

Ruppia maritima.

Potamogeton pectinatus, and four other species.

ORDER CXV. WATER PLANTAIN FAMILY. ALISMACEA.

1. WATER PLANTAIN.

2. ARROW GRASS.

3. ARROIV LEAF.
Alisma Plantago. Triglochin triandrum.

Sagittaria variabillis, and four other species.

ORDER CXVI. FROGSBIT FAMILY. HYDROCHARIDACEE.

1. IVATER WEED.

2. TAPE GRASS.

3. FROG BIT.
Anacharis Canadensis.

Valisneria spiralis.

Limnobium Spongia.

ORDER XCVII. ORCHIS FAMILY. ORCHIDACE.E.

1. ADDER'S MOUTH.

2. TWINING $\dot{B} \mathrm{BL}+\mathrm{DE}$.

3. CORAL ROOT.

4. PUTTY ROOT.
Microstylis ophioglossoides.

Liparis liliifolia.

Corallorhiza odontorhiza.

Aplectum hiemale. 

5. BEARDED PINK.
6. CRLNE-FLY ORCIIS.
7. TREE ORCHIS.
8. POGONIA.
1. SIIOWY ORCHIS.
10. YELLOW ORCHIS.
11. GREEN ORCHIS.
12. YELLOW FRINGED ORCHIs.
13. WHITE FRINGED ORCHIS.
14. CRESTED ORCHIS.
15. RAGGED ORCHIS.
16. TWISTED ORCHIS; LADY'S TRESSES.
17. RATTLESNAKE PLANTAIN.
18. TURVYBLADE.
19. YELLOW LADY'S SLIPPERS.
20. PURPLE LADY'S SLIPPERS.

Calopogon pulchellus.

Tipularia discolor.

Epidendrum conopseum.

Pogonia ophioglossoides, and three other species.

Orchis spectabilis.

Platanthera flava.

P. bracteata.

P. ciliaris.

P. blephariglottis.

P. cristata.

P. lacera.

Spiranthes cernua.

Goodyera pubescens.

Listera australis.

Cypripedium pubescens.

C. acaule.

ORDER CXVIII. CANNA FAMILY. CANNACEE.

1. INDIAN SHOT.

2. CANNA.
Canna flaccida.

C. Indica. Partly naturalized.

ORDER CXIX. AMARYLLIS FAMLY. AMARYLLIDACEA.

1. ATAMASCO LILY.

2. SPIDER LILY.

3. RATTLESNAKE'S MASTER-PIECE : FALSE ALOE.

4. AMERICAN ALOE.

5. YELIOIV STAR GRASS.
Amaryllis Atamasco.

Pancratium rotatum. And three other species.

Agave Virginica.

A. Americana. (In cultiration) Hypoxis erecta.

ORDER CXX. BLOOD-WVORT FAMILY. HEMODORACEA.

1. RED ROOT

2. WHITE STAR GRASS; COLIC-ROOT.

:. GOLDEN STAR GRASS.
Lachnanthes tinctoria. Aletris farinosa.

A. aurea.

ORDER CXXI. PINEAPPLE FAMILY. BROMELIACEA.

1. LONG MOSS.

2. BARTRAM'S MOSS.
Tilandsia usneoides.

T. Bartramii. 
ORDER CXXII. IRIS FAMILY. IRIDACEE.

1. BLUE FLAG.

2. THREE-PETALLED FLAG.

3. CRESTED IRIS.

4. DWARF IRIS.

5. BLUE-EYED GRASS; PEPPER GRASS.
Iris versicolor.

I. tripetala.

I. cristata.

I. verna.

Sisyrinchiun Bermudianum.

ORDER CXXIII. YAM FAMILY. DIOSCOREACEF.

1. WILD YAM.

ORDER CXXIT. SMILAX FAMILY. SMILACEA.

1. EVERGREEN SMILAX; CHINA ROOT.

2. SARSAPARILLA.

3. RED-BERRIED BAMBOO.

4. LAUREL-LEA VED SMILAX.

5. CARRION FLOWER.

6. WAKE ROBIN.

7. WILD FEPPER.

S. CUCUMBER ROOT.
Dioscorea villosa.

Smilax Pseudo-China.

S. glauca.

S. Walteri.

S. laurifolia.

Coprosmanthus herbaceus.

Trillium sessile.

T. erythrocarpum. (In the mountains.)

Medeola Virginica.

ORDER CXXY. LILY FAMILY. LILIACEE.
1. TURK'S CAP LILY.
2. CAROLINA IILY.
3. YELLOW LILY.
4. ORANGE LILY.
5. CATESBY'S LILY ; SOUTHERI LIIY.
6. SPANISH BAYONET.
7. BEAR GRASS.

s. DOG'S TOOTH VIOLET; YELLOW ADDER'S TONGUE.

9. SOLOMION'S SEAL.

10. FALSE SPILENARD.

11. LILY OF THE VALLEY.

12. WILD ONION.
Lilium superbum. (mountains.)

L. Carolinianum. (Low Conntry.)

L. Canadensis. (Mountains.)

I. Philadelphicum.

L. Catesbæi. (Flat woods in low ('ountry.)

Yucca aloifolia.

Y. filamentosa, and two other species.

Erythronium Americanum.

Polygonatum bifloruin.

Smilacina racemosa.

Convalaria majalis.

Allium mutabile, and two or three other species. 
ORDER CXXYI. COLCHICUM FAMILY. MELANTHACEA.

1. BELL-WORT.

2. BUNCH FLOW'ER.

3. BIG HELLEBORE; BEAR CORN.

4. FLY POISON; CROW POISON.

5. BLAZING STAR; DEVIL'S BIT.

6. FALSE ASPHODEL.
Uvularia perfoliata, and three other species.

Melanthium Virginicum.

Veratrum viride. (Mountains.)

Amianthium muscætoxicum.

Chamælirium luteum.

Tofieldia glabra.

ORDER CXXVII. RUSH FAMLLY. JUNCAOEE.

1. BIG RUSH.

Juncus efussus, and twelve other species.

ORDER CXXYII. PICKEREL-IVEED FAMILY.

PONTEDERACEN.

1. PICK EREL IVEED.

Pontederia cordata. (Swamp.)

ORDER CXXIX. SPIDER-IVURT FAMILY. COMMELYNACEE.

1. DAY FLOWER.

2. SPIDER-WORT.

3. ROSE SPIDER-IVORT.
Commelyna communis, and two other species.

Tradescantia Virginica.

T. rosea.

ORDER CXXX. YELLOW-EYED GRASS FAMILY. XYRIDACE E.

1. YELLOW-EYED GRASS.

Xyris brevifolia, and seven other species.

ORDER CXXXI. PIPE-WORT FAMILY. ERIOCAULONACEE.

1. PIPE-WORT FAMILY.

2. YELLOW PIPE-WORT.

3. HAIRY PIPE-WORT.
Eriocaulon decangularie, and two other species.

Pæpalanthus flavidus.

Lachnocaulon Michauxii. 


\section{ORDER CXXXII. SEDGE FAMILY. CYPERACEA.}

1. STRIGOSE CYPERUS; BRISTLE-SPIKED

\section{GALINGALE.}

2. JOINTED CYPERUS.

3. COMPACT-HEADED CYPERT'S.

4. SHARP GRASS

5. YELLOW CYPERUS.

6. SLENDER CYYPERUS.

7. NLT GRASS.

S. GRASS NUT.

9. SHEATHED DUIICHIU.M.

10. DWARE KYLLINGIA.

11. UMBRELLA GRASS.

12. SPIKE RUSH.

13. SWORD GRASS.

14. WEAK-STALK SCIRPUS.

15. LARGE MARSH SCIRPUS.

16. MARITIME SCIRPUS.

17. COTTON GRASS.

18. TICK-SEED GRASS; BEAK RUSH.

19. HORNED RUSH.

20. BALD RUSH.

21. SAIV GRASS.

22. TWIG RUSH.

23. NUT RUSH.

4. TUSSOCK SEDGE.

\section{Cyperus strigosus.}

C. articulatus.

C. vegetus.

C. virens.

C. flavescens.

C. gracilis.

C. rotundus.

C. repens, and fifteen other species.

Dulichium spathaceum.

Fyllingia pumila.

Fuirena squarrosa.

Eleocharis equisetoides, and sixteen other species.

Scirpus pungeñ.

S. debilis.

S. lacustris.

S. maritimus, and four or five other species.

Eriophorum Virginicum.

Rhynchospora plumosa, and twenty other species.

Ceratoschœnus machrostachyus. Psylocarya rhynchosporoides. Cladium effusum.

C. mariscoides.

Scleria triglomerata, and four other species.

Carex stricta. (This very liırge genus of sedges, Carex, containing about serenty-five species in the Southern States, is well represented in South Carolina, but there are few that hare attracted attention enough to have acquired common names. There are some fifty or sixty species within the limits of our State.)

\section{ORDER CXXXII. GRASS FAMILY. GRAMINE.}

1. RICE ĞRASS; FALSE GRASS.

2. CULTIVATED RICE.
Leerzia oryzoides, and two other species.

Oryza sativa. (The common rice in cultivation.) 
3. WIID RICE; INDIAN RICE.

4. WILD OATS.

5. FLOATING WILD RICE.

6. FLOATING FOX-TAIL.

7. MEADOW FOX-TAIL.

S. TIMOTIIY; CAT'S-TAIL GRASS; HERD'S GRASS.

9. BEARD GRASS.

10. WIRE GRASS; DROP-SEED GRASS.

11. BLACK SEED GR.ASS.

12. RUSH GRASS.

13. TIII GRASS.

14. HAIR GRASS.

14. BENT GRASS ; HERD'S GRASS.

15. DELICATE HAIR GRASS.

16. WOOD REED GRASS

17. NIMIBLE WILL; DROP-SEED GRASS.

18. HAIR GRASS.

19. REED BENT GRASS,

20. FEATHER GRASS.

21. WIRE GRASS.

2.). POVERTY GRASS.

23. THREE-ARMED GRASS.

24. MARSII GRASS.

25. MARSH GRASS.

26. MARSH GRASS.

27. FL.AT GRASS

28. BERIITDA GRASS; JOINT GRASS.

29. LEMON GRASS.

30. CROW-FOOT GRASS; EGYPTIAN GRASS.

31. GOOSE-FOOT GRASS.

32. SAND GRASS.

33. MELIC GRASS.

3. CANE; LARGE REED.

35. REED; DWARF CANE.

36. SPIKE GRASS.

37. MAY GRASS ; SPEAR GRASS.

37. BLUE GRASS; MEADOW GRASS.

39. BLUE GRASS.

39. ORCIIARD GRASS.

40. ERAGRostis.
Zizania aquatica.

Z. miliacea.

Hydrocholoa Carolinensis.

Alopecurus geniculatus.

A. pratensis.

Phleum pratense.

Polypogon maritimus. (Sea coast.) Sporobolus junceus.

S. Indicus. (Common about lawns.) Vilfa aspera.

Agrostis perennans.

A. scabra.

A. alba.

A. arachnoides.

Cinna arundinacea.

Muhlenbergia diffusa.

M. capilaris.

Calamagrostis coarctata.

Stipa avenacea.

Aristida stricta.

A. dichotoma.

A. purpurescens, and five other species, all of which are known as "Wire Grass."

Spartina juncea. ) In the salt

S. polystachya. $\quad$ marshes of

S. glabra. the coast.

Eustachys petræa. On the coast. Cynodon dactylon.

Ctenium Americanum.

Dactyloctenium Æggytiacum.

Eleusine Indica.

Triplasis Americana.

Melica mutica.

Arundinaria gigantea.

A. tecta.

Brizopyrum spicatum.

Poa annua.

P. pratensis. † Both species are

P. compressa. $\int$ called Blue Grass.

Dactylis glomerata.

Eragrostis. Nine speries of this 
41. FESCLE GRAS:

42. TALL FESCUE; MEADOW FESCUE.

43. CHEA'T: CHESS.

44. RESCLE GRASS.

45. BEACH GRASS

46. REEI) GRASS.

47. LIME GRASS; RYE GRASS.

47. BOTTLE BRUSH.

4S. DARNEL; RAY GRASS.

49. HAIR GRASS.

50. WILD OAT GRASS.
Festuca Myurus.

F. elatior. And four other species. Bromus secalinus. And one other species.

Ceratochloa breviaristata. Nil:uralizerl.

Uniola paniculata. And two other spevies.

Phragmites communis.

Elymus Virginicus. And one otlier species.

Gymnostichium Hytrix.

Lolium Temulentum.

Aira flexuosa.

Danthonia spicata.

[Triticum vulgare, Wheat; Secale cereale, Rye; Hordeum vulgare, Barley; Avena sativa, Oats, are in common cultivation.]

51. TALL OAT GRASS.

52. SWEET-SCENTED GRASS.

53. SOUTHERI CANARY GRASS.

it VELTET GRASS.

55. FLOATING PASPALUM

56. SHEATHED PASPALUM.

57. TWIN SPIKED PASPALUM.

58. JOINT GRASS; RICE-FIELD JOINT GRASS. P. distichum. This grass is sometimes confouncied with Bermuda Grass, or highland joint grass, Cynodon, Dactylon.

59. EARLY PASPALUM.

60. SMIOOTH I'ASPALUM.

61. PURPLE PASPALUM.

62. HAIRT-LEAVED PASPALUM.

6.3 FLORIDA PASPALUM.

64. CRAB-GRASS.

65. ERECT PAXICUII.

66. GUINEA GRAsS.

67. TEXAN MILLET.

68. PURPLE PANICUM.

69. GAPING PANICUM.

70. COMPRESSED PATICUMI.

71. SEA-SHORE PANICUM.
Arrhenatherum avenaceum.

Anthoxanthum odoratum.

Phalaris intermedia.

Holcus lanatus.

Paspalum fluitans.

P. Walteri.

P. Digitaria.

P. distichum. This grass is some-
, or highland joint grass, Cynodon,

P. præcox.

P. læve.

P. undulatum.

P. ciliatifolum

P. Floridanum.

Panicum sanguinale

P. filiforme.

P. jumentorum. Introduced asd partly naturalized.

P. Texana. Partly naturalized.

P. gibbum.

P. hians.

F. anceps.

P. virgatum. 
72. BITTER PANICLII.

7\%. LARGE WATER PAXICTM.

74. HAIRY-STALKED PANICUM.

75. NARROW-LEATED PANICUM.

76. BROAD-LEA VED PAXICUM.

77. LARGE-SEEDED PANICUM.

78. FEW-FLOWERED PANICLM.

79. VISCID PANICUM.

80. ROUGH-STEM PANICLY.

S1. MANY-BRANCHED PANICUM.

S2. COCK'S-FOOT GRASS.

83. SOFT PANICUN.

S4. CREEPING PANICUM.
P. amarum.

P. geniculatum.

P. capillare.

P. angaustifolium.

P. latifolium.

P. scoparium.

P. pauciflorum.

P. viscidum.

P. scabriusculum.

P. dichotomum.

P. Crus-Galli.

P. molle.

P. hirtellum. This is the iargest genus among the Grasses. There are some omitted from this list, as they have not received common names. IIost of the common names above (of Paspalum and Panicum) have been taken from Elliott's Sketches.

S5. FOX-TAIL.

S6. ITALIAN IIILLET.

87. SAND SPUR.

SS. COCK'S SPUR.

89. GAMA GRASS.

90. BROOM GRASS.
Setaria glauca.

S. Italica. Along the const natıralized.

Cenchrus tribuloides.

C. echinatus.

Tripsacum dactyloides.

Andropogon scoparius. And five or six other species, nearly all of which are callerl "Broom Grass"

Erianthus alopecuroides. And one other species.

92. INDIAN GRASS.

Sorghum avenaceum.

93. WOOD GRASS.

S. nutans.

94. MEANS' GRASS ; JOHNSTON'S GRASS ;

CUBA GRASS; COCO GRASS.

S. Halapense. Naturalized.

[Of the Sorghum in cultiration there are the Durrah Corn (S. Vulgare), the Broom Corn and Sweet Sorghum (S. saccharatum) and the Guinea Corn (S. cernuum).

\section{SERIES II. CRYPTOGAMS, OR FLOWERLESS PLANTS.}

Vegetables destitute of proper flowers, and producing, in place of seeds, minute homogenous bodies (spores) containing no embryo. 
CLASS III. ACROGENS.

Plants with a distinct stem, growing from the apex only, containing woody fibre and ressels.

ORDER CXXXIT. HORSE-TAIL FAMILY. EQUISETACEA.

1. SCOURING RUSH; HORSE-TAIL.

Equisetum lævigatum.

\section{ORDER CXXNT. FERNS. FILICES.}

1. POLYPOD.

2. HOARY POLYTOD.

3. BRAKE.

4. DWARF BRAKE

5. LIP FERN.

6. MAIDEN HAIR; HAIR FERY.

7. WOODWARDIA.

8. WALKING LEAF.

9. SPLEEN WORT.

10. EBONY SPLEEN WORT.

11. BLADDER FERN.

12. WOOD FERN.

13. SHIELD FERN.

34. SENSITIVE FERN.

15. CLIMBING FERN.

16. FOWERING FERY.

17. MOON WORT.

18. ADDER'S TONGUE
Polypodium vulgare.

P.incanum, and one other species. Pteris aquilina.

P. Cretica.

Cheilanthes vestita.

Adiantum pedatum.

Two species.

Camptosorus rhizophyllus. In the mountains.

Asplennium pinnatifidum. In the mountains.

A. ebeneum. And two or three other species.

Cystopteris fragilis.

Aspidium Thelypteris.

A. Novæboracense. And two other species.

Onoclea sensibilis.

Lygodium palmatum.

Osmunda regalis. And two other

species.

Botrychium Virginicum. And one other species.

Ophioglossum vulgatum.

\section{ORDER CXXXYI. CLUB-MOSS FAMILY. LYCOPIACEE.}

1. CLUB-MOSS.

2. GAROLINA CLUB-MOSS.

3. GROUND PINE.
Lycopodium clavatum.

L. Caroliannum.

L. dendrodeum. 

4. CRLEPING CLUB-MOSS.
5. SELAGINELLA.
6. PSILOTUM TRIQUETRUM.

I. alopecuroides.

Two species.

\section{ORDER CXXXYII. WATER-FERN FAMLYY. HYDROPLERIDES.}

1. FLOATING AZOLLA.

Azolla Caroliniana. In still water.

\section{CLASS IV. ANOPHITES, OR ACROGENS.}

Cryptogamous acrogenous plants, growing upwards by an axis or stem, and usually furnished with distinct leaves (sometimes the stem and foliage confluent into a frond) composed of cellular tissue alone.

\section{ORDER CXYXVIII. MOSSES. MUSCI.}

These small and inconspicuons plants have attracted so little of general attention that scarce!y any of them have received common or popular names. It is only of late years that they have claimed the attention and study of Botanists in our country. The elher American botanists confined themselves mostly to the larger and more conspicuous flowering plants; and thus it is that there are many new species continually being discovered.

The same may be said of all the other lower Cryptogams, the Hepatics, the Lichens, the Fungi, and the Algr.

$A$ mere list of scientific names of species of all these Cryptogams, besides occupying more space than can be spared, would be of little interest, except to botanists I will, therefore, give an enmeration only, -and say that in my own herbarium there are about 127 species of Insci colleited within the limits of the State.

\section{ORDER CXXXIX. LIVER WORTS. HEPATICE.}

Of this order I have in my herbarium sixty-five species collected in this State.

\section{CLASS T. THALLOPHITES, OR THALLOGENS.}

Flowerless plants of the lowest grade, entirely composed of cellular tissue, with no distinction of stem, root, and leaves; not growing by buds, nor furnished with reproductive organs analagous to flowers; some 
of the lowest forms remarkable for the spontaneous movements they exhibit.

\section{ORDER CXL. LICHENS. LICHENES.}

Perennial plants spreading in the form of a lobed-thallus over trees, or upon rocks, or on the ground. Some of them contain nutritious qualities, and are used in the arts and in medicine. The Iceland Moss of the druggists shops (Cetraria Islandica) contains eighty per cent. of gelatinous nutritious substance. The Tripe de Roche (Rock Tripe) is a species of Umbilicaria, and the Rein-deer Moss is a Cladonia. Some of them yield important coloring matters, and are employed in the arts.

I have in my herbarium 258 species, collected in this State.

\section{ORDER CXLI. SEA WEEDS. ALGE.}

Leaffess plants with no distinct axis, growing in water (fresh or salt water) and rarely on trees, consisting either of simple vescicles or of articulated filaments, or of lobed fronds. Many of the marine sea weeds have useful properties. The "Irish Moss" (Chondrus crispus) of the shops is used for its gelatine in making blancinange. Many other species have similar qualities, and the famous edible "Swallow's-nests" of the Chinese is composed of a species of Alga.

Of the Algæ found in our State, Prof. Harvey, in his "Nereis Boreali-Americana," gives twenty-eight marine species found in Charleston harbor. These alded to my own collection, amounting to 140 species (composed altogether of those inhabiting fresh water, trees, \&c.), will give a total for the State of 168 species.

\section{ORDER CXLII. THE MUSHROOM FAMILY. FUNGI.}

Plants growing on dead or dying matter,--sometimes on living plants,--often on the ground, deriving nutriment mostly from the substance on which they grow. Fruit various in external character. Spores either naked or contained in utricles (Asci) ancl then called Sporidia,-mostly producing a mass of threads or cells (Mycelium) from which the plant grows.

This is an immense Order, counting by the thousands; but a sunall proportion of which have attracted popular attention-and we cannot pretend to do more than merely to indicate a few of the more prominent and conspicuous forms which affect us, either for their benefits or for the evil they entail.

They comprise a great variety of external form and size, from the larger Mushrooms which we see on the ground and on trees, to the minute species which infest the leaves of plants, and are scarcely visible to the naked eye.

If the annual loss on our cultivated crops by insect depredation is estimated at millions of dollars, no less do the minute fungi do their part to the same effect, in the form of rust, smut, mildew, and mould. Most growing plants-crop plants-are more or less infested by these microscopic organisms, which injure them to some extent, and frequently destroy vitality. It is only of late years that much attention has been drawn to them. In fact, it is only through the superior microscopes, so much improved of late, that we can form any idea of their structure and organization.-and thus proceed in a proper manner towards their treatment. Their structure, habits and mode 
of propagation must be investigated and understood, before any legitimate mode of treatment can be devised. But in order to do this, we have first to collect, elassify and arrange them in some intelligible order, and to give them names, so they may be known, and so that scientists, in describing them, may know what they are talking about. The first pioneer work therefore is to make collections, and then classify and arrange them by some definite method for future use. To thoughtless persons it may seem useless to devote attention to such small objects, and eren frivolous to occupy oneself with such matter's, but the day for such comnents is passing away. As we learn more and more of the works of the Creator, we see that "small and great" are only terms of our own. They have no place in the vocabulary of nature. In fact it is loy the examination and study of these simplest forms of life, that we are enabled to learn more of the higher and more complete forms. They assail us directly at all points. Their minute and invisible spores are everywhere present-in the air we breathe and in the water we drink. Diseases, injurious to animal as well as regetable life, owe their origin to them and their destructive agency,-and demand our attention. It is to these simplest forms of the animal and vegetable kingdom, as easiest of comprehension, that the most profound philosophers of our day are turning their inquiries and studies in their search after the origin of life.

Every one is familial with the ordinary Mushrooms which we see springing up about the woods, or on the roadways, and in fields and gardens-how numerous they areand how they vary in color, and size. These are the Agaries. They constitute a very large genus of fungi, and to them belongs the famous edible Iushroom, and many others which are not only wholesome food, but even sought after as delicacies. They are the most highly organized group of the order. There are doubtless many un. wholesome, and some very poisonous, members of this genus, but probably the much largest portion are either innocuous or wholesome. The late Dr. Curtis, of North Carolina, who paid special attention to this branch of botany, proved by personal experiment, the wholesome properties of over one hundred different species. In Europe, where population is more dense, large quantities are consumed. In our newer country, where the means of living is easier, we hear less of them, because other food is more abundant.

I will now proceed to note a few of the most prominent and well known species (in accorlance with the arrangement in the previous part of this paper) and then give an enumeration of the whole number of fungi found in our State.

\section{IMPERIAL MUSHROOM.}

2. FLI-AGARIC.

3. HALLIMASCHE.

4. CLUSTERED AGARIC.

5. PARASOL MUSHROON.

6. LONG-ROOTED MUSHROOM.

7. OYSTER MUSHROOM.
Agaricus Cæsareus. Edible; in woods.

A. muscarius. Poisonous; in woods.

A. melleus. Edible; in clusters on rotten stumps.

A. cæspitosus. Very similar to the last.

A. procerus. In lawns and woods; edible.

A. radicatus. Elible; in woods.

A. ostreatus. Edible; on dead

trunks. 
8. COMMON MUSHROOM.

famous eatable mushroom of Eirone, and cultivated for market in larre quantities.

9. PEACH-SCENTED MUSHROOM.

10. FIELD MUSHROOM.

[The Agaries constitute one of the largest genera among fungi. We have collected and noted albout — different species growing in this State, of which a large portiun are edible.

11. LA CHANTARELLE.

12. DRY-ROT

13. FAIRY-RING MUSHROOM.

14. BEEF-STEAK MUSHROOM.

15. MEDUSA-HEAD MUSHROOM.

16. CLAVARIA.

17. JEWS-EAR.

18. STINK-HORN; DEVIL'S BREATH.

19 PUFF BALL; EGG MUSHROUM.

20. EARTH:STAR.

21. HYDROMETER.

2. CUSTARD MUSHROOM.

23. LITTLE-NEST.

24. RUST.

25. CEDAR BALLS

26. RED RUST.

27. SMUT.

28. CORN SMUT.

29. CLUSTER CUPS.
Cantharellus cibarius. Edible; in woods.

Merulius lacrymans. In cellars and damp wood.

Marasmius oreades. In woods; edible.

Fistulina hepatica. Edilsle; on trees.

Hydnum Caput-Medusæ. On trimks. Nost of the Clavarias are edible.

Herniola auricula-Judæ. On logrs. Phallus rubicundus. In fields and roaclside.

Lycoperdon Bovista. Very gocd.

There are also several other smaller species equally good.

Geaster fornicatus.

G. hygrometricus.

Æthalium septicum. On $\operatorname{logs}$; not eatable.

Nidularia pulvinata.

Puccinia graminis. Common on grasses.

Podisoma macropus. On Cedar trees.

Uredo rubigo. Common on grasses and cereals.

Ustilago Segetum. On oats, d.c.

U. Zeæ. On Indian eorn, destroying the ear. Æcidium. There are large numbers of species, growing on various plants. 
30. HORNED CLUSTER CUP.

31. BLACK-SELD GRASS SIUT.

32. MORELLE.

3:3. EARTH TONGUE.

34. PLUM DISEASE.

26. TUC'KAHOE; INDIAN POTATOE.

36. NOULDS. Various species of Mucor, Pennicilium, \&c.
Rœstelia. Many species of this also, mostly on the Apple family.

Helminthosporium Ravenelii.

Very common on Black-seed grass (Sporobolus Indicus), and destroys the seed.

Morchella esculenta. Good, edible. Geoglossum hirsutum. In woods. near rotten logs.

Sphæria morbosa. Attacking the living branches.

Pachyma cocos.

[Note.-In the above" List of the more Common Native and Naturalized Plants of South Carolina," I have only noted :

1st. Such Phrengamous plants as were most common and well known, and had received popular names. To have given the botanical names of all others would have exceeded the limits to which this paper is restricted. In the recapitulation, at the end, I will state the whole number found within the limits of our State, including those above-mentioned.

2d. Of Cryptogamous plants, there are but very few that have received popular names, and to these few I have alluded; and for the same reason as stated above, I have omitted the others, but I will also give, in the recapitulation, the whole number found thus far in our State. I am not aware that any other botanists have ever marle any collections of the lower Cryptogams within our State, except the late Dr. Curtis (who resided a few years at Society Hill) and myself, nor have any catalogues ever been published. 'Not having access to Dr. Curtis' collections to ascertain his species, I am compelled to consult only my own Herbarium. In stating the number, therefore, it must be borne in mind that these are only what I have myself collected in this State.] 


\section{SUMMARY.}

FLOWERING PLANTS-Exogens, about...........................1,310 Species.

Endogens, about

1,810

FIOWERLESS PLANTS-Filices, about 500

Equisetacer................................... 1

Lycopodiacere .................................... 9

Hydropterides ................................ 1

Characeæ ......................................... 3

Musci, abont ..................................... 127

Hepaticæ, about................................. 65

Lichenes, about .................................. 258

Algæ, about .................................... 168

Fungi, about..................................1,920

Total species found in the State..................... 4,392 


\section{LIST OF BOOKS, PAMPHLETS, CATALOGUES AND}

\section{CONTRIBUTIONS TO SCIENTIFIC MAGAZINES.}

\section{RELATING TO THE BOTANY OF THIS STATE.}

Flora Caroliniana, Thomas Walter; 1 Vol. London, 1787,

Flora Carolineexsis, J. L. E. Shecut; 1 Vol. Charleston, 1806.

Carolina Florist, by John Drayton; 1 Vol., 1807. MSSS. in library of State University, Columbia, S. C.

Sketch of the Botaxy of South Carolina Axd Georgia. Stephen Elliott; 2 Vols. Charleston, 1817-182t.

Catalogue of Pifenoganous Plants and Feris, Native or Naturalized, Found GROWING IN THE ViciNity OF CharLesTov, John Bachman. 1834.

Catalogue of the Plants of Columbia ANd its Vicinity, Lewis R. Gibbes. 1835.

A Medico-Botanical Catalogue of tile Plants and Ferns of St. John's BerkeLEY, F. Peyre Porcher. $18+7$.

Catalogue of the Natural Orders of Plants in the Vicintty of the Santee Canal, as Represented by Genera Axd Species, H. W. Ravenel; Proc. Am. Ass. Adv. Science, Vol. III. 1850.

Flora of the Lower Country of South Carolina, Wm. Wragg Smith; Proc. Ell. Soc. 1859.

Notice of Sone New and Rare Plants Found in this State, H. W. Ravenel; Proc. Ell. Soc. 1856.
Description of a New Species of Baptisia (with plate), H. W. Ravenel; Proc. Ell. Soc. 1856.

Some Rare Southeri Plants, H. W. Rarenel; Bulletin Torrey Bot. Club, New York, 1876.

Description of Species of Fungi folvd sear Charlestox, S. C., M. Bosc. French Consul, in Berlin Magazine, 1811.

Contributions to the Cryptoganic Botany of Soutin Carolixa, H. W. Ravenel; Southern Medical Journal.

Fuxgi Caroliniaxi Exsiccati, H. W. Ravenel ; Charleston, 5 Vols. 1852-1860.

Fuxgi Americani, H. IV. Ravenel; London, 8 Vols. 1S78-1882.

Enumeration and Description of Sotth Carolixa Fuxgi, M. C. Cooke-Grevillea. London, 1878.

Tintry New Species of Ayericax Fixgi, Baron de Thuemen. Vienna, 1878.

Species of Auerical Hrphomycetes, Baron de Thuemen. Vienna, 1879.

Notes on tile Marine Alg.æ of S. C. and Florida, J. Cosmo Melvil, in Trimens' Journal of Botany, Vol. IV. London. 


\section{PUBLICATIONS OF A MORE GENERAL, CHARACTER, IN WHICH THE BOTANY OF THE STATE IS ILLUSTRATED.}

Flora Boreali-Americaxa, Andre Mi-|North Americax Fuxgr, M. J. Berkley. chaux. 1796.

Flora of Norti Anerica, Frederick Pursh. Tine Erisiphei of tire United States, C. 1814 .

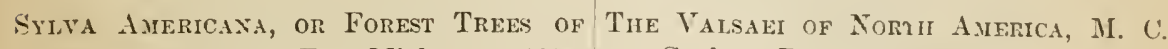
North Auerica, F. A. Michaux. 1504.

Nortu Americin Flori, Torrey and Gray. The Hyponycetors Fungi of the Unitei) $1 S 3 S-1840$.

Soutnerd Botaxy, Darby. 1 Vol

Fiora of Southern United States, A. W. Chapman. 1860. 1 Vol.

Rfsoctres of the Sortinerx Fiflns AND Forfsts, F. Pevre Porcher. 1869. 1 Vol.

Nereis Boreali Ayericayi, W. H. Harvey. 3 Vols. Smithsonian Institution. 1857.

Prodroyus of a Study of North Auerican Fresi Water Alg.e, H. C. Wood. 1869.

Coxtributioxs to tile History of tile Fresir Water Alg.e of Nortil A merica, If. C. Wood. Smithsonian Institution, 1S73. 1 Tol.

Species of Fresh Water Alg.e, Francis Wolle. Bull. Tor. Bot. Club. New York.

Syxopsis Fungorum Carolixe, L. de Schweinitz. Leipsick, 1822. 1 Vol.

Syxopsis Fuxgortir in Boreali-Anerica, L. de Schweinitz. Philadelphia, 1831. $1 \mathrm{Vol}$.

Ixtroduction to Cryptoganic Botany, M. J. Berkley. London, 1857. 1 Vol.

Contriettions to the Mrcology of North A Merica, Berkley \& Curtis. Silliman's Journal, 1848.

Contribetions to the Mycology of Nonti Aserica, Berkley \& Curtis. Hooke's London Journal of Botany.

Mrcogra piri, sed Icones Fungorum, M. C. Cooke. 1875-1879. Six Parts.

Sryopsis of the Disconycetous Fuxgi of the Uxited States, M. C. Cooke. Bull. Buffalo Soc. Nat. Science, $18 \overline{\text { ioj. }}$

The Mrxomycetes of the Uxited States, II. C. Cooke. Annals of Lyceum of Nat. Hist., New York.

Species of Lycoperdox in United States. Cl. H. Peck. Albany Institute, 15iy.

MI'sct Boreali-Ayericavi, Sullivant d Lesquereux. 1856.

The Mosses and Hepatics of U. S., East of the Mississippi, W. S. Sullivant. 1850.

Icones Mrsconta, W. S. Sullirant. 1864. 1 Vol., with plates.

Mfesci Appalacimani, C. F. Austin. 1870.

Hepatice Boreali-Americaxe, C. F. Austin. 1573.

Description of Mosses and Hepatics, C. F. Austin. Bull. Tor. Bot. Club.

Genera Lichenum, or ax Arrangejext of the North Americax Lichess, Ed. Tuckerman. 1 Vol. 1872 .

A List of Nortil American Lichexs, H. Willey. 1573.

Oreervatroxs ox Norti A mericax Lichexs. Ed. Tuckerman.

Symopsis of Norti AMericay Lichens, Ed. Tuckerman. Part I. 1852.

Botary of Nortil CaroliNa (in connection with the Geological Surrey of the State), M. A. Curtis. 1867. 

TABLE I.-Abstract of Meteorological Observations in South Carolina, Recorded b

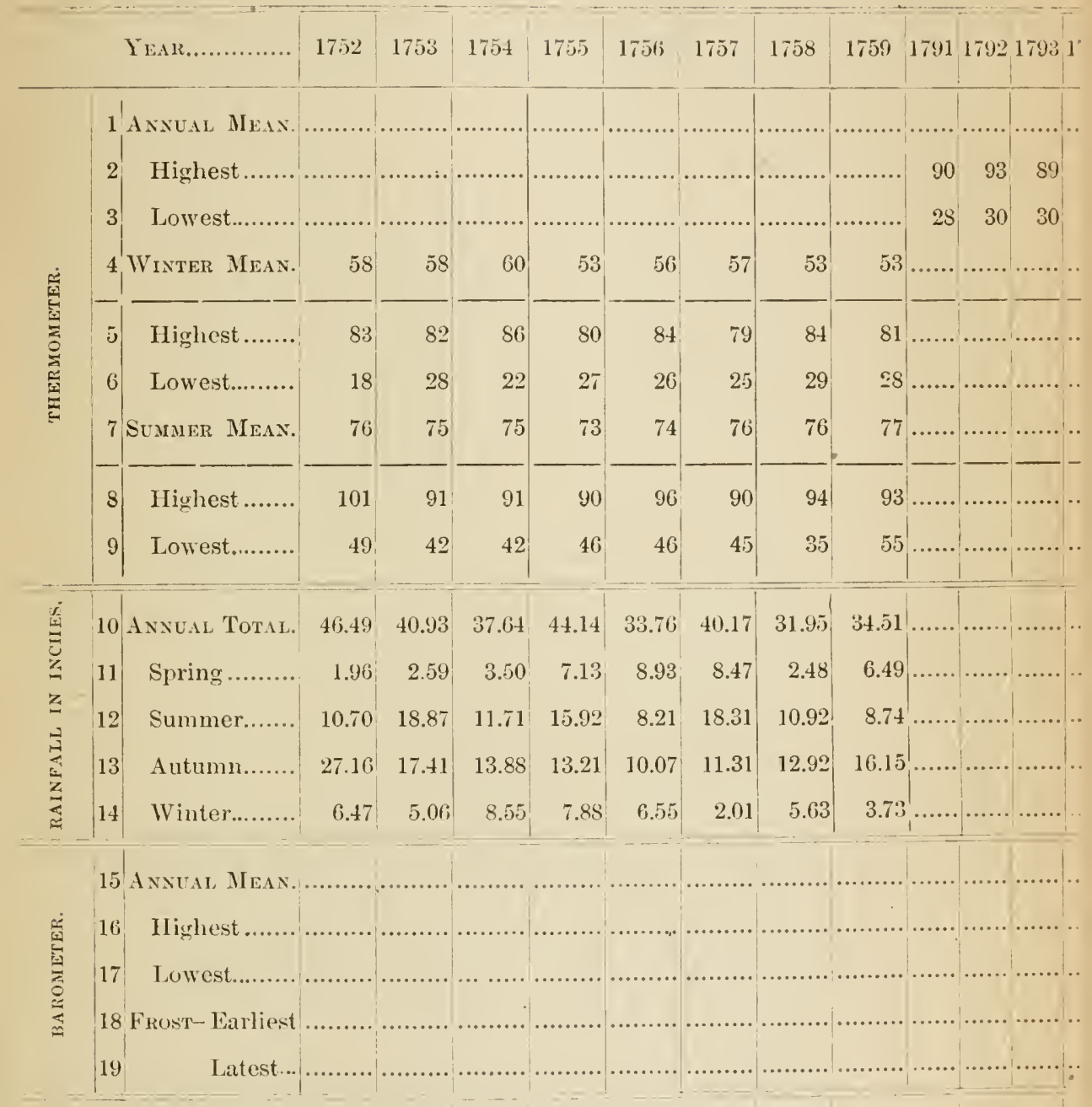

Prevailing Wind.

No. of Days rain fell. 


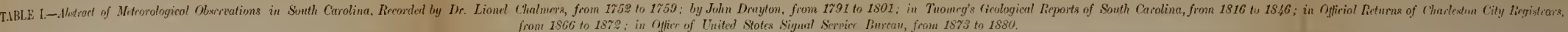

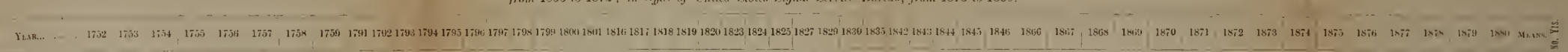

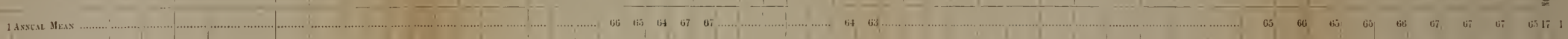

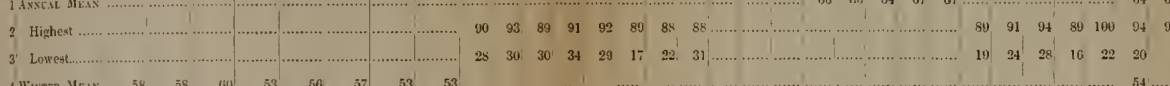

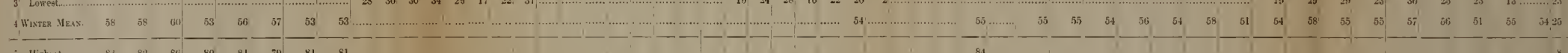

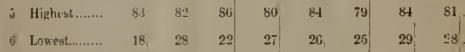

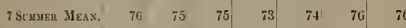

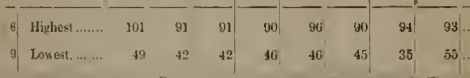

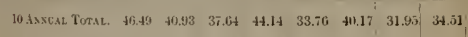

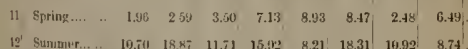

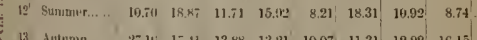

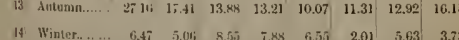

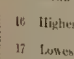

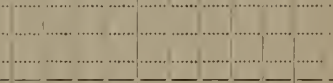

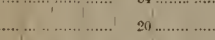

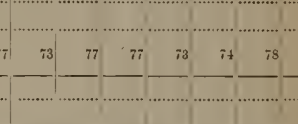

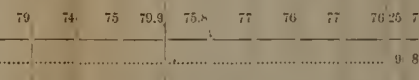

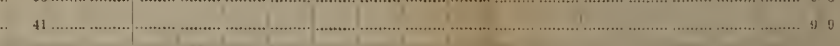

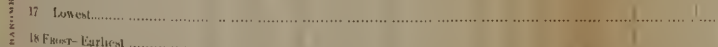

14 talket $\ldots$

Prevoilin Wive

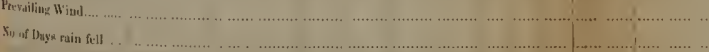

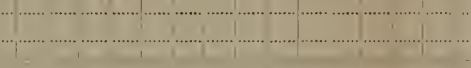

Jor 
TABLE II.-Table compiled from Census Returns of 1880, showing the At each Agri

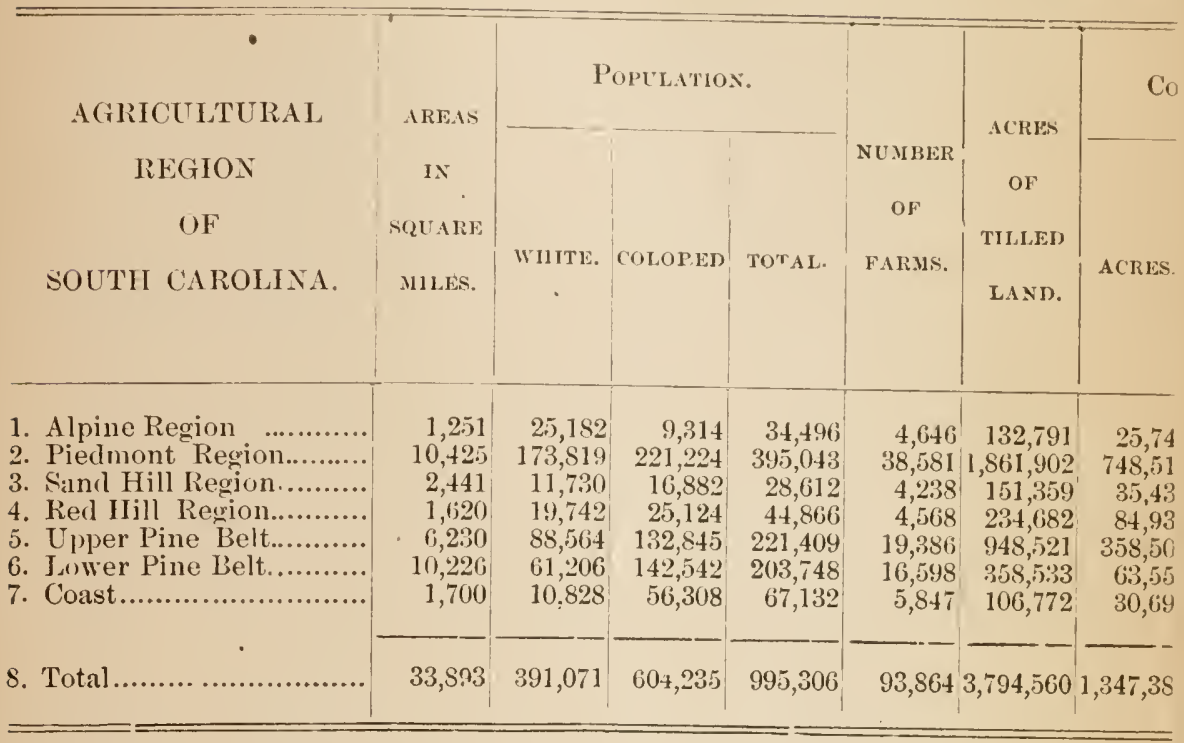

TABLE III.-Table compiled from Census Returns of 1870, showing the I Agricul

\begin{tabular}{|c|c|c|c|c|c|c|}
\hline \multirow{2}{*}{$\begin{array}{c}\text { AGRICULTURAL } \\
\text { REGION } \\
\text { OF } \\
\text { SOUTH CAROLINA. }\end{array}$} & \multirow[b]{2}{*}{$\begin{array}{l}\text { AREA } \\
\text { IN } \\
\text { SQUARE } \\
\text { MILLS. }\end{array}$} & \multicolumn{3}{|c|}{ Population. } & \multirow[b]{2}{*}{$\begin{array}{c}\text { ACRES } \\
\text { OF } \\
\text { IMPROVED } \\
\text { LAND. }\end{array}$} & \multirow[b]{2}{*}{$\begin{array}{r}\text { BAL } \\
\text { OF } \\
\text { COTT }\end{array}$} \\
\hline & & WIIITE. & COLORED. & TOTAL. & & \\
\hline $\begin{array}{l}\text { 1. Alpine Region........... } \\
\text { 2. Piedmont Region........ } \\
\text { 3. Sand and Red Hills" “" } \\
\text { 4. Upper Pine Belt.......... } \\
\text { 5. Lower Pine Belt. ........ } \\
\text { 6. Coast......................... }\end{array}$ & $\begin{array}{r}1,251 \\
10,425 \\
4,061 \\
6,230 \\
10,226 \\
1,700\end{array}$ & $\begin{array}{r}16,020 \\
138,392 \\
29,665 \\
44,238 \\
58,342 \\
2,135\end{array}$ & $\begin{array}{r}4,785 \\
135,478 \\
46,758 \\
85,230 \\
124,511 \\
19,052\end{array}$ & $\begin{array}{r}20,805 \\
273,870 \\
76,423 \\
129,468 \\
183,853 \\
21.187\end{array}$ & $\begin{array}{r}64,802 \\
1,214,679 \\
333,540 \\
780,024 \\
729,839 \\
87,655\end{array}$ & $\begin{array}{r}1 \\
9.3 \\
24 \\
83 \\
20 \\
1\end{array}$ \\
\hline 7. Total..................... & 33,893 & 289,792 & 415,814 & 705,606 & $3,010,539$ & 224 \\
\hline
\end{tabular}




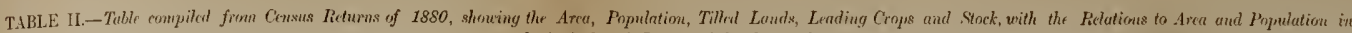
cach Agricultural Region of Sunth Carolina

\begin{tabular}{|c|c|c|c|c|c|c|c|c|c|c|c|c|c|c|c|c|c|c|c|c|c|c|c|c|}
\hline \multirow{2}{*}{ 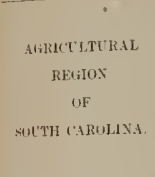 } & \multirow{2}{*}{$\begin{array}{l}\text { ARE.AS } \\
\text { IN } \\
\text { SQP TRE } \\
\text { MHLES. }\end{array}$} & \multicolumn{3}{|c|}{ Pupelation. } & \multirow{2}{*}{$\begin{array}{c}\text { NEVBER } \\
\text { OF } \\
\text { FARMS. }\end{array}$} & \multirow{2}{*}{$\left|\begin{array}{c}\text { ACHES } \\
\text { of } \\
\text { THLLEO } \\
\text { LAND. }\end{array}\right|$} & \multicolumn{3}{|c|}{ Curros. } & \multirow[b]{2}{*}{$\begin{array}{l}\text { woRk } \\
\text { stock. }\end{array}$} & \multirow[b]{2}{*}{$\begin{array}{l}\text { OTHER } \\
\text { LSVE } \\
\text { STOCK. }\end{array}$} & \multicolumn{8}{|c|}{ PER SquARe Mrye } & \multicolumn{3}{|c|}{ Per Captita of Poftlatiox } & \multirow{2}{*}{ 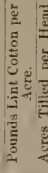 } & \multirow{2}{*}{ 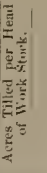 } \\
\hline & & "WT:. & $\cos$ & ToтAL. & & & $A C R E B$ & BALES. & $\begin{array}{c}\text { of } \\
\text { GRAIX. }\end{array}$ & & & 产 & 总 & 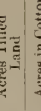 & 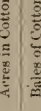 & $\begin{array}{ll}0 \\
0 \\
0\end{array}$ & 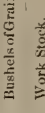 & 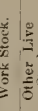 & हैं & 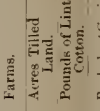 & 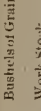 & 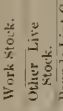 & & \\
\hline 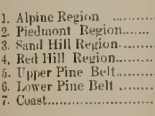 & $\begin{array}{r}1,251 \\
10,423 \\
2,441 \\
1,692 \\
6,230 \\
10,226 \\
1,700\end{array}$ & $\begin{array}{r}25,183 \\
173,819 \\
11,730 \\
19,742 \\
88,54,414 \\
61,206 \\
10,828\end{array}$ & $\begin{array}{r}9,314 \\
221,224 \\
16,882 \\
25,124 \\
132,845 \\
142,542 \\
56,318\end{array}$ & $\begin{array}{r}34,496 \\
395,043 \\
28,612 \\
44,866 \\
221,409 \\
203,748 \\
67,132\end{array}$ & $\begin{array}{r}4,646 \\
38,581 \\
4,238 \\
4,568 \\
19,386 \\
16,598 \\
5,847\end{array}$ & $\begin{array}{r}132,791 \\
1,861,902 \\
161,354 \\
234,682 \\
948,521 \\
858,533 \\
106,772\end{array}$ & $\begin{array}{r}25,740 \\
748,510 \\
35,423 \\
84,434 \\
358,451 \\
63,558 \\
30,6946 \\
4,640\end{array}$ & $\begin{array}{r}7,970 \\
27,318 \\
15,065 \\
34,249 \\
148,050 \\
28,300 \\
8,548\end{array}$ & $\begin{array}{r}712,031 \\
7,731,525 \\
920,444 \\
804,443 \\
3,131,3112 \\
2,417,176 \\
793,669\end{array}$ & $\begin{array}{r}5,798 \\
69,603 \\
\times, 518 \\
7,663 \\
35,469 \\
18,453 \\
7,692\end{array}$ & $\begin{array}{r}66,035 \\
473,180 \\
70,461 \\
611,46,4 \\
313,411 \\
235,524 \\
43,424 \\
43,445\end{array}$ & $\begin{array}{l}27.5 \\
37.8 \\
11.7 \\
27.6 \\
35.5 \\
18.9 \\
39+\end{array}$ & $\begin{array}{l}3.7 \\
3.7 \\
1.1 \\
2.8 \\
3.1 \\
1.6 \\
3.4\end{array}$ & $\begin{array}{r}106 \\
178 \\
62 \\
144 \\
152 \\
35 \\
62 \\
62\end{array}$ & $\begin{array}{cc}20 & 6 \\
71 & 26 \\
14 & 6 \\
52 & 21 \\
57 & 23 \\
6 & 2 \\
38 & 5\end{array}$ & $\begin{array}{ll}6.3 & 5 \\
26.3 & 7 \\
6.1 & 3 \\
22.1 & 4 \\
23.7 & 5 \\
2.7 & 2 \\
5 & 4\end{array}$ & $\begin{array}{ll}5699 & 4 \\
741 & 6 \\
377 & 3 \\
496 & 4 \\
582 & 5 \\
286 & 1 \\
466 & 4\end{array}$ & $\begin{array}{l}4.1 \\
6.6 \\
3.8 \\
4.7 \\
5,6 \\
1.8 \\
4.5\end{array}$ & $\begin{array}{l}52 \\
45 \\
29 \\
38 \\
50 \\
23 \\
25\end{array}$ & $\begin{array}{lll}13 & 3.8 & 105 \\
.09 & 4.7 & 311 \\
.14 & 5.2 & 239 \\
.10 & 5.2 & 248 \\
.05 & 4.2 & 322 \\
.08 & 1.7 & 18 \\
.08 & 1.5 & 42\end{array}$ & $\begin{array}{l}20 \\
19 \\
32 \\
17 \\
16 \\
11 \\
11\end{array}$ & $\begin{array}{ll}.16 & 1.3 \\
.17 & 1.1 \\
.29 & 2.4 \\
.17 & 1.3 \\
.16 & 1.4 \\
.941 .1 & 1.1 \\
.11 & .6\end{array}$ & $\begin{array}{l}141 \\
161 \\
193 \\
1 \times 3 \\
1 \times 3 \\
0 y 2 \\
219 \\
92 \\
92\end{array}$ & $\begin{array}{l}27 \\
17 \\
36 \\
21 \\
12 \\
11\end{array}$ \\
\hline . & 33,893 & $391,0 \pi 1$ & 607,230 & 995,306 & 93,864 & $3,794,5601$ & $1,34 \overline{7}, 381$ & 510,400 & $17,010,593$ & $153,1466]$ & $1,265,166$ & 29.3 & $2 . \bar{i}$ & 111 & 3915 & 15.15 & \begin{tabular}{l|l}
501 & 4
\end{tabular} & 4.4 & 37. & $.093 .8 \quad 245$ & 17. & 1.27 & 183 & \\
\hline
\end{tabular}

TABLE III--Table compiled from Census Returns of 18ro, showing the Populotion, Improved Land, Leading Crops, sic., with their Relations to Area and Population in each Agricultural Region of South Carolina.

\begin{tabular}{|c|c|c|c|c|c|c|c|c|c|c|c|c|c|c|c|c|c|c|c|c|}
\hline \multirow[b]{2}{*}{$\begin{array}{l}\text { AGRICULTURAL } \\
\text { REGIOS } \\
\text { OF } \\
\text { SOUTII CAROLINA. }\end{array}$} & \multirow[b]{2}{*}{$\begin{array}{l}\text { AEEA } \\
\text { TX } \\
\text { BQt ARE } \\
\text { SILLS. }\end{array}$} & \multicolumn{3}{|c|}{ Pofulatios. } & \multirow[b]{2}{*}{$\mid \begin{array}{c}\text { ACRES } \\
\text { OF } \\
\text { IMPROVED } \\
\text { LAND. }\end{array}$} & \multirow{2}{*}{$\begin{array}{c}\cdot \\
\text { BALEs } \\
\text { of } \\
\text { cotrox. }\end{array}$} & \multirow[b]{2}{*}{$\begin{array}{c}\text { BL'SHELS } \\
\text { or } \\
\text { GRAJN. }\end{array}$} & \multirow[b]{2}{*}{$\begin{array}{l}\text { wonk } \\
\text { stoek. }\end{array}$} & \multirow[b]{2}{*}{$\begin{array}{l}\text { OTUER } \\
\text { stock. }\end{array}$} & \multicolumn{6}{|c|}{ Per sotart Mile. } & \multicolumn{5}{|c|}{ Per Capta of Porelateos. } \\
\hline & & WHTTE. & COLORED. & тотAL. & & & & & & 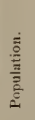 & $\int_{0}^{\frac{J}{0}}$ & 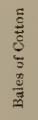 & 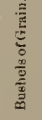 & 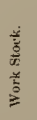 & 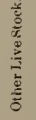 & 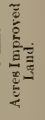 & 营 & 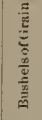 & 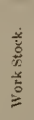 & 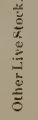 \\
\hline 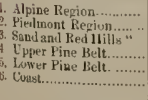 & $\begin{array}{r}1,251 \\
10,425 \\
4,061 \\
6,230 \\
10,226 \\
1,710\end{array}$ & $\begin{array}{r}16,020 \\
13,4,392 \\
29,665 \\
44,238 \\
58,342 \\
2,135\end{array}$ & $\begin{array}{r}4,785 \\
185,478 \\
46,758 \\
85,230 \\
124,511 \\
19,052\end{array}$ & $\begin{array}{r}20,805 \\
273,870 \\
76,423 \\
129,468 \\
183,853 \\
21.187\end{array}$ & $\begin{array}{r}64,802 \\
1,214,679 \\
333,540 \\
780,024 \\
724,4339 \\
87,635\end{array}$ & $\begin{array}{r}1,299 \\
93,494 \\
24,222, \\
83,210 \\
20,403 \\
1,4 \div 3\end{array}$ & $\begin{array}{r}400,449 \\
4,407,365 \\
487,343 \\
2,133,237 \\
1,327,316 \\
389,720\end{array}$ & $\begin{array}{r}4,096 \\
47,779 \\
12,544 \\
20,214 \\
13,465 \\
2,115\end{array}$ & $\begin{array}{r}32,865 \\
299,7,78 \\
92,653 \\
149,448 \\
133,740 \\
16,134\end{array}$ & $\begin{array}{l}16 \\
27 \\
15 \\
20 \\
15 \\
12\end{array}$ & $\begin{array}{c}51 \\
110 \\
310 \\
125 \\
51 \\
51\end{array}$ & $\begin{array}{r}1.9 \\
8.9 \\
5.9 \\
11.7 \\
1.9 \\
1.1\end{array}$ & $\begin{array}{l}320 \\
428 \\
243 \\
347 \\
129 \\
229\end{array}$ & $\begin{array}{l}3.2 \\
4.5 \\
3 . \\
8.5 \\
1.2 \\
1.2\end{array}$ & $\begin{array}{r}25 \\
24 \\
22 \\
24 \\
13 \\
9\end{array}$ & $\begin{array}{l}3.1 \\
4.2 \\
4 . \\
6 . \\
2.8 \\
4.1\end{array}$ & $\begin{array}{c}14 \\
131 \\
139 \\
195 \\
44 \\
29\end{array}$ & $\begin{array}{l}19 . \\
16 . \\
12 \\
17 . \\
7 . \\
18 .\end{array}$ & $\begin{array}{l}19 \\
.16 \\
.16 \\
.17 \\
.07 \\
10\end{array}$ & $\begin{array}{l}15 \\
11 \\
11 \\
11 \\
07 \\
07\end{array}$ \\
\hline ; Total... & 33,893 & 289,792 & 415,814 & 7115,600 & $3,014,539$ & $224,5 \cup 0$ & บ.735,469 & 100,715 & $721,11 \mathrm{x}$ & 20 & 88 & 6. & 287 & 2.9 & 21 & 4.2 & $14 i$ & $13 . \tau$ & .14 & 1.2 \\
\hline
\end{tabular}


TABLE IV.-Goneral Statistics of Agriculture for the United States and for South Carolina, according to the Lnited States Consus, with the Percentage of Increase and Decrase in cach Particular, since 1850.

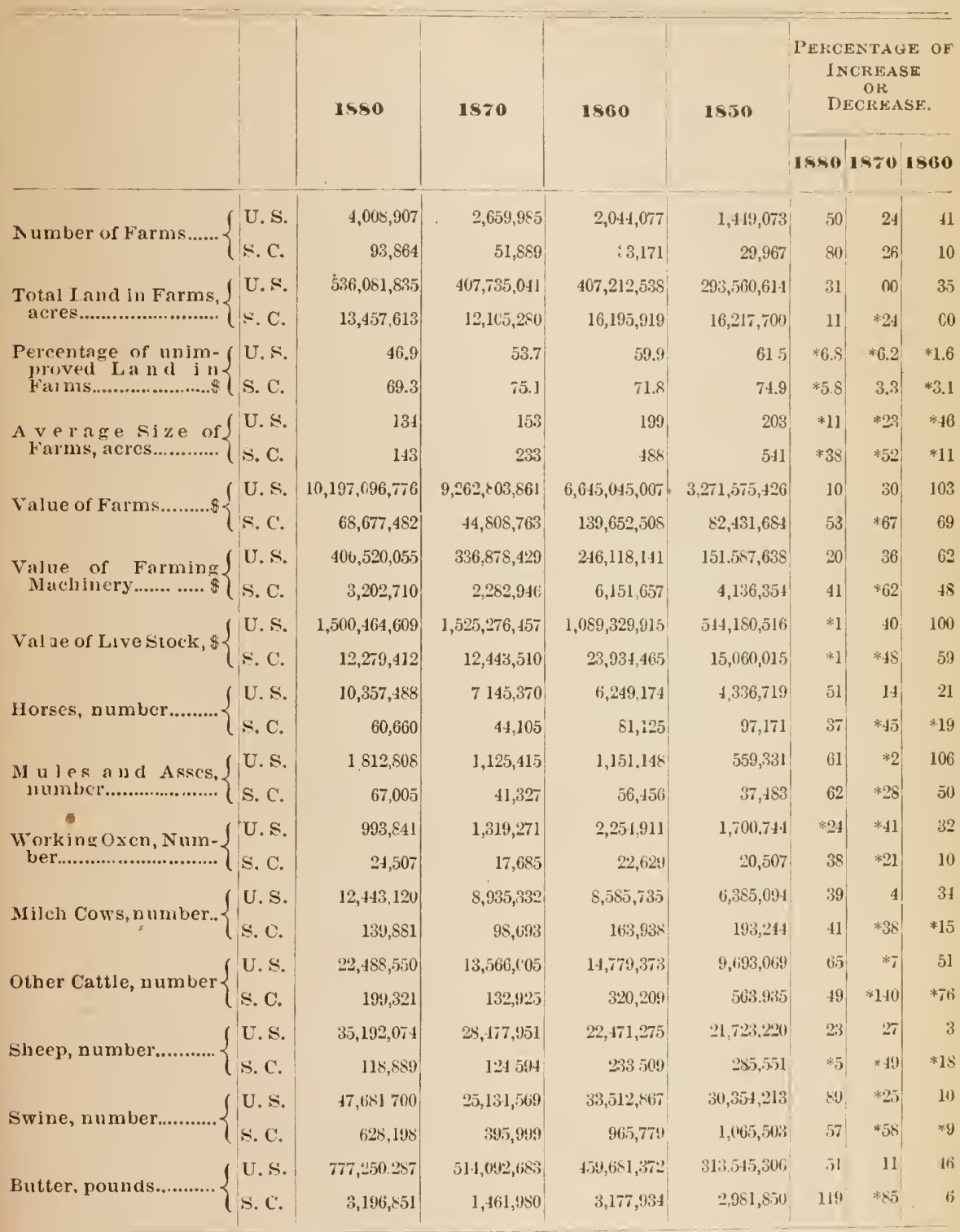

Note.-In the three colmmns showing percentage of increase and declease, decrease is indicated by *. In comparing the values of $18 \%$ with 1870 , it is to be remembered that the averag prers jum of gold tor the latter was 25.3 per cent, 
TABLE IV.-(ConcLuned.) - General Statisties of Agriculture for the United States and for South Carolina, according to the Unitcd Statcs C'cnsus, with the I'ercentage of Increase and Decrease in each Particular, since 1850.

\begin{tabular}{|c|c|c|c|c|c|c|c|c|}
\hline . & & \multirow{2}{*}{1850} & \multirow{2}{*}{1870.} & \multirow{2}{*}{1560} & \multirow{2}{*}{1550} & \multicolumn{3}{|c|}{$\begin{array}{c}\text { PEKCENTAGE OF } \\
\text { IXCREASE } \\
\text { OR } \\
\text { DECREASE. }\end{array}$} \\
\hline & & & & & & ISSO & 1580 & 1860 \\
\hline \multirow{2}{*}{ Wool, pounds. ............ } & U.S. & $155,681,751$ & $100,102,387$ & $60,264,913$ & $52,516,959$ & 55 & 6.5 & 11 \\
\hline & S. C. & 272,758 & 156,314 & 127,102 & $487,23: 3$ & 74 & $* 61$ & $* 10$ \\
\hline \multirow{2}{*}{ Cotton, bales.............. } & U.S. & $5,755,359$ & $§, 011,996$ & $5,387,052$ & $2,169,093$ & 91 & $*-18$ & 117 \\
\hline & S. C. & 522,518 & 224500 & 353,412 & 300,901 & 132 & $* 36$ & 17 \\
\hline \multirow{2}{*}{ Corn, bushels.............. } & U. S. & $1,754,591,676$ & $760,944,519$ & $838,792,712$ & $592,071,104$ & 130 & $* 9$ & 41 \\
\hline & S. C. & $11,767,099$ & $7,614,207$ & $15,065,606$ & $16,271,454$ & 51 & *95 & $* 7$ \\
\hline \multirow{2}{*}{ Rice, pounds............... } & U.S. & $110,181,373$ & $73,635,021$ & $187,16 \pi, 032$ & 215313,497 & 49 & $\approx 60$ & $* 13$ \\
\hline & S. C. & $52,077,515$ & $32,304,8 \div 5$ & $119,100,528$ & $159,930,613$ & 61 & $* 72$ & $* 25$ \\
\hline \multirow{2}{*}{ Wheat, bushels.......... } & U.S. & $459,483,137$ & $287,745,626$ & $173,104,924$ & $100,485,944$ & 59 & 66 & 73 \\
\hline & S. C. & 962,358 & 783,610 & $1,2 \varsigma 5,631$ & $1,066,277$ & 22 & $* 39$ & 20 \\
\hline \multirow{2}{*}{ Oats, bushels. ............. } & U.S. & $407,858,999$ & $282,107,157$ & $172,613,185$ & $146,584,179$ & 41 & $* 63$ & 17 \\
\hline & S. C. & $2,715,505$ & 613,593 & 936,974 & $2.322,155$ & 312 & $* 36$ & *59 \\
\hline \multirow{2}{*}{ Barley, bushels.......... } & U.S. & $43,997,495$ & $29,761,305$ & $15,825,80 \varepsilon$ & $5,167,015$ & 47 & 88 & 206 \\
\hline & S. C. & 16,257 & 4,752 & 11,490 & 4,583 & 212 & $* 58$ & 150 \\
\hline \multirow{2}{*}{ Rye, bushels.............. } & U.S. & $19,831,595$ & $16,918,795$ & $21,101,380$ & $14,188,813$ & 17 & $* 19$ & 32 \\
\hline & S. C. & . $\quad 27,049$ & 36,165 & 89,091 & 43,790 & $* 25$ & $* 59$ & 103 \\
\hline \multirow{2}{*}{$\begin{array}{l}\text { I } \mathrm{rish} \text { Potatoes } \\
\text { bushels......................... }\end{array}$} & U.S. & $169,458,539$ & $143,337,473$ & $111,148,867$ & $65,797,896$ & 18 & $2 s$ & 68 \\
\hline & s. C. & 144,942 & 83,252 & 226,725 & $136,49 t$ & 71 & $* 83$ & 67 \\
\hline \multirow{2}{*}{$\begin{array}{l}\text { S w e et Pot a toes }, \\
\text { bushels..................... }\end{array}$} & U.S. & $33,378,693$ & 21,709824 & $42,095,026$ & $38,268,148$ & 53 & $* 18$ & 10 \\
\hline & S. C. & $2,189,622$ & $1,342,165$ & $4,115,688$ & $4,337,469$ & 63 & $* 6 \pi$ & $* 5$ \\
\hline
\end{tabular}


TABLE V.-Agricultural Statistics of South Carolina, for the year 1880, by Tounships.

\section{FIRST SERIES.}

\begin{tabular}{|c|c|c|c|c|c|c|c|c|c|c|c|c|c|c|c|c|c|c|c|c|c|}
\hline \multirow[b]{2}{*}{$\begin{array}{l}\dot{y} \\
\vdots \\
0 \\
0 \\
0\end{array}$} & \multirow{2}{*}{$\begin{array}{l}2 \\
3 \\
0 \\
0 \\
0 \\
0 \\
0 \\
0 \\
0 \\
0 \\
0\end{array}$} & \multicolumn{5}{|c|}{ POPULATION. } & \multirow{2}{*}{ 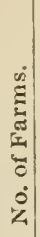 } & \multirow{2}{*}{ 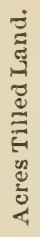 } & \multicolumn{2}{|c|}{ CotToN } & \multicolumn{7}{|c|}{ SтосK. } & \multicolumn{4}{|c|}{ GRAIN. } \\
\hline & & $\frac{\mathscr{2}}{\frac{\pi}{2}}$ & $\frac{\tilde{d}}{\mathbb{E}}$ & $\frac{\dot{0}}{2}$ & $\frac{\mathfrak{d}}{0}$ & हु & & & 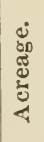 & $\frac{\mathscr{d}}{\mathscr{Q}}$ & 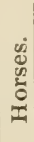 & 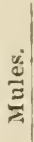 & $\begin{array}{l}E \\
0 \\
0 \\
0 \\
\frac{1}{2} \\
0 \\
2\end{array}$ & $\begin{array}{l}5 \dot{0} \\
ٍ \\
=0\end{array}$ & 总芯 & $\frac{\dot{d}}{\stackrel{D}{D}}$ & $\underset{\Xi}{\Xi}$ & 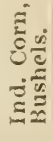 & $\underset{\sigma \infty}{\frac{\dot{s}}{\omega}}$ & 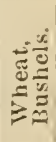 & 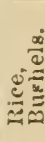 \\
\hline
\end{tabular}

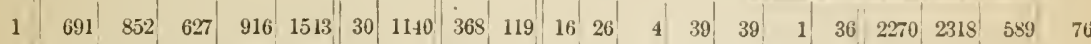

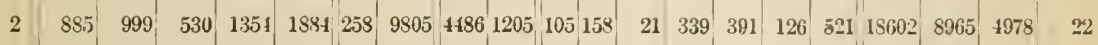

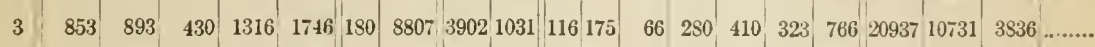

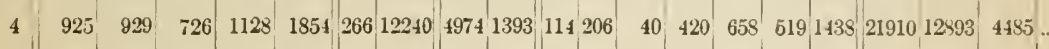

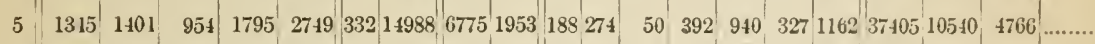

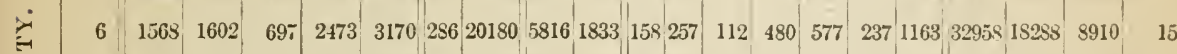

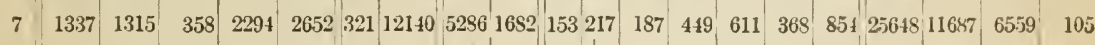

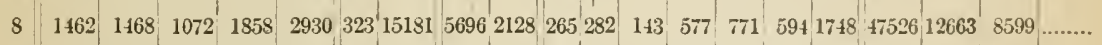

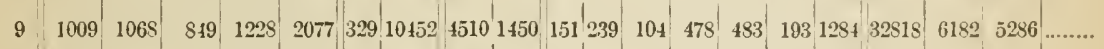

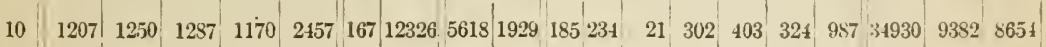

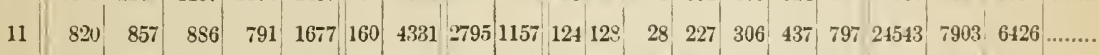

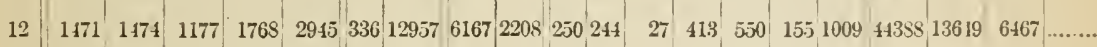

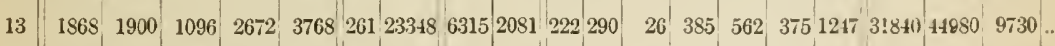

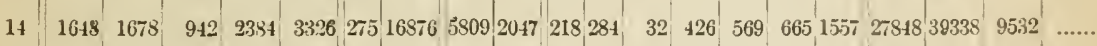

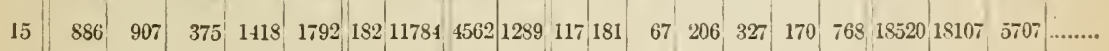

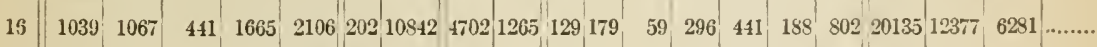

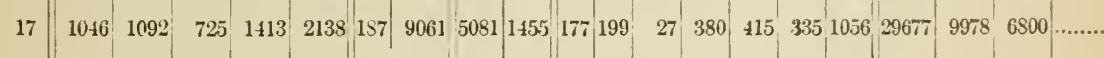

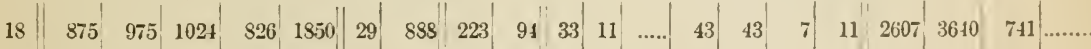

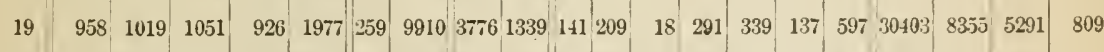

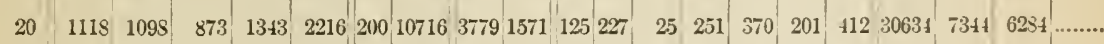

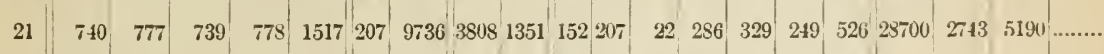

\begin{tabular}{l|lllll|l|l|l|l|l|l|l|l|l|l|l|l|l|l|l}
22 & 704 & 732 & 926 & 511 & 1437 & 229 & 8292 & 2678 & 968 & 157 & 123 & 50 & 321 & 350 & 15 & 774 & 25077 & 1711 & 4936 & 4
\end{tabular}

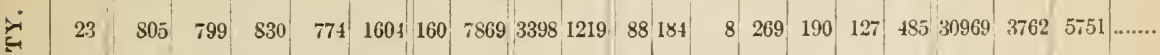

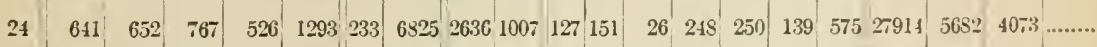

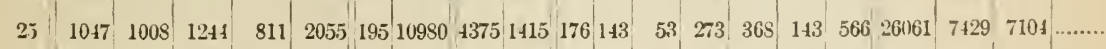

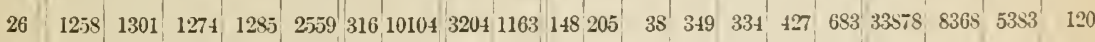

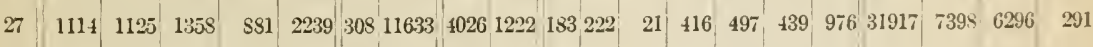

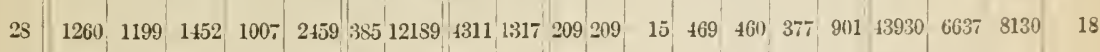

\begin{tabular}{l|llllllllllllllllllllll}
29 & 1176 & 1370 & 1679 & 867 & 2516 & 239 & 9205 & 4216 & 1376 & 181 & 195 & 19 & 310 & 325 & 194 & 394 & 21295 & 7214 & 6818 & $\ldots \ldots \ldots$
\end{tabular}

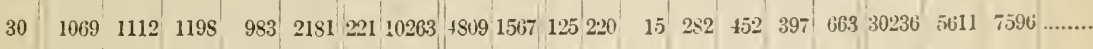

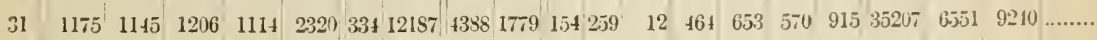

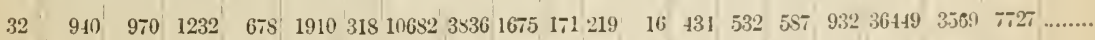

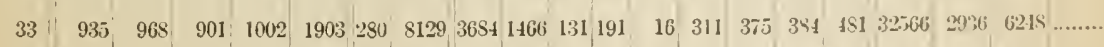

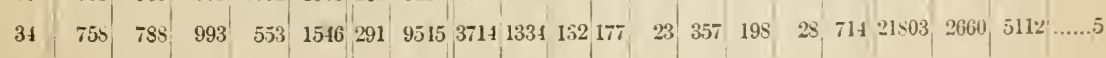


TABLE T.-Agricultural Statistics of South Carolina, for the year 1880, by Townships.

FILST SERIES.-(ContINUED.)

\begin{tabular}{|c|c|c|c|c|c|c|c|c|c|c|c|c|c|c|c|c|c|c|c|c|c|}
\hline \multirow[b]{2}{*}{ 点 } & \multirow{2}{*}{ 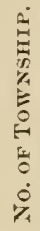 } & \multicolumn{5}{|c|}{ POPULATION. } & \multirow{2}{*}{ 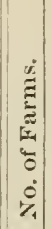 } & \multirow{2}{*}{ 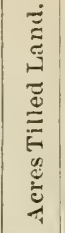 } & \multicolumn{2}{|c|}{ Cotron. } & \multicolumn{7}{|c|}{ STock. } & \multicolumn{4}{|c|}{ GRAIN. } \\
\hline & & $\stackrel{\dot{y}}{\stackrel{\dot{v}}{\tilde{z}}}$ & $\frac{\dot{d j}}{\stackrel{\Xi}{\Xi}}$ & $\frac{\stackrel{D}{\Xi}}{2}$ & $\frac{0}{0}$ & $\underset{\dot{E}}{\stackrel{\vec{J}}{0}}$ & & & 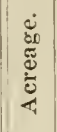 & 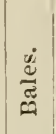 & 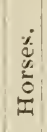 & $\frac{\dot{q}}{3}$ & 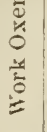 & 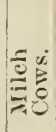 & 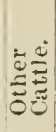 & $\underset{\frac{\dot{q}}{\pi}}{\frac{c}{\pi}}$ & 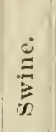 & 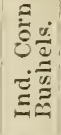 & 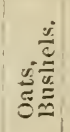 & 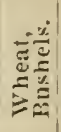 & 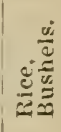 \\
\hline \multirow{9}{*}{$\begin{array}{l}5 \\
\vdots \\
0 \\
0\end{array}$} & $3 \overline{5}$ & .885 & 1014 & 978 & 921 & 1899 & 33 & 10178 & 480 & 223 & 38 & 22 & ...... & 26 & 14 & ....... & 26 & 2361 & 2159 & 697 & \\
\hline & 36 & 1999 & 2066 & 778 & 3287 & 406.5 & 357 & 22274 & 9512 & 35836 & 282 & 5 5i) & 21 & 467 & 267 & 413 & 1208 & 61535 & $12: 64$ & 4091 & \\
\hline & 37 & 1757 & 1802 & 1314 & 2215 & 3559 & 329 & 20565 & 8513 & 25.8 & 271 & 463 & 18 & 599 & 669 & 229 & 1416 & 52293 & 6473 & 4831 & \\
\hline & 38 & 1140 & 1205 & 816 & 1529 & 2345 & 213 & 11601 & 5065 & 1910 & 151 & 295 & 9 & 1. 250 & 236 & 69 & 993 & 37645 & 9765 & 4045 & \\
\hline & 39 & 665 & 720 & 329 & 1059 & 1388 & 121 & 6597 & 3170 & 1377 & 83 & 19.5 & & 240 & 203 & 85 & 566 & 32204 & 6418 & 875 & \\
\hline & 40 & 1296 & 1358 & 814 & 1540 & .2654 & 252 & 13657 & 6534 & 2453 & 198 & 330 & 25 & 386 & 505 & 478 & 1028 & 39510 & 123.59 & 4413 & \\
\hline & 41 & 1321 & 1321 & 904 & 1741 & 2615 & 198 & 13563 & 6630 & 2290 & 288 & 285 & 26 & 639 & 323 & 351 & 748 & 31414 & 11314 & 5323 & \\
\hline & 42 & 1832 & 1844 & 1148 & 2528 & 3676 & 281 & 20102 & 736.5 & 2839 & 322 & 380 & 23 & 529 & 704 & 693 & 1727 & 53715 & 20759 & 8613 & \\
\hline & 43 & 952 & 970 & 551 & 1368 & 1922 & 241 & 10623 & 4715 & 1857 & 129 & 247 & 15 & 269 & 169 & 195 & 1066 & $\$ 3628$ & 5873 & 2277 & \\
\hline \multirow{22}{*}{ 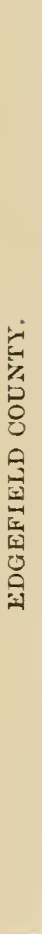 } & 44 & 194.5 & 1994 & 1062 & $25 \pi$ & 3989 & 238 & 11921 & 5.513 & 2391 & 220 & $22 \tau$ & 72 & 2351 & $66 \pi$ & 64: & 1396 & 30462 & 24737 & 4006 & \\
\hline & 45 & 631 & 650 & 473 & 808 & 1281 & 111 & 10730 & 2218 & 819 & 183 & 119 & 34 & 1 281 & 436 & 34 & 992 & 20800 & 5134 & 2532 & \\
\hline & 46 & 577 & 589 & 545 & $62 \mathrm{i}$ & 1166 & 169 & 6828 & 2656 & ; 857 & 79 & 122 & 30 & 236 & 417 & 87 & 1034 & 12007 & 10608 & 2472 & \\
\hline & 47 & 1022 & 1064 & 354 & 1732 & 2086 & 210 & 7726 & 1641 & 1593 & 97 & 197 & 45 & $5 \quad 219$ & 919 & 156 & 769 & 19102 & 6669 & 510 & \\
\hline & 48 & 1211 & 1220 & 1056 & 1375 & $246 !$ & 313 & 135.59 & 5644 & 2305 & 292 & 262 & 39 & $54 \pi$ & 505 & & 2121 & 13631 & 25801 & 480 & \\
\hline & 49 & 1296 & 1236 & 852 & 1680 & 2532 & 345 & 11895 & 2617 & 1038 & 223 & 393 & 38 & 436 & 492 & & 2081 & 47582 & 40166 & 665 & \\
\hline & 50 & 672 & 710 & 1075 & 307 & 1382 & 180 & 7568 & 2119 & 875 & 211 & 103 & 41 & 407 & 458 & 1062 & $18 \% 0$ & 19208 & 17439 & 4747 & \\
\hline & 51 & 1061 & 1121 & 1010 & 1175 & 2185 & 248 & 16262 & 3556 & $14 S 6$ & 123 & 245 & 30 & 422 & 483 & 49 & 1584 & 31653 & 36117 & $42 \pi$ & \\
\hline & 52 & 31 & 31 & 26 & 36 & 62 & 10 & 588 & 260 & 116 & 10 & & 4 & 24 & 24 & .... & 131 & 1677 & 260 & 11 & \\
\hline & 53 & 905 & 878 & 787 & 996 & 1783 & 195 & 9265 & 3200 & 903 & 210 & 130 & 80 & 375 & 615 & 537 & 1626 & 15095 & 21811 & 4190 & \\
\hline & 54 & 1215 & 1161 & $11 \pi$ & 1199 & 2376 & 243 & 14133 & 3917 & 1753 & 302 & $2: 2$ & $4 \overline{7}$ & 497 & 675 & 736 & 2631 & 41852 & 35753 & $5 \overline{5} 5$ & \\
\hline & 55 & 1866 & 1779 & 775 & 2570 & 3015 & 319 & 17717 & 9221 & 3389 & 189 & 385 & 17 & 438 & $5 \pi 2$ & 101 & 1786 & 32158 & $235 \pi 1$ & $165 \mathrm{~s}$ & \\
\hline & 56 & 1443 & 1452 & 1398 & 1498 & 2396 & 320 & 16283 & 5909 & 2339 & 326 & 240 & 95 & 563 & 806 & 812 & 2695 & 36252 & 33760 & 4192 & \\
\hline & 57 & 735 & 745 & $33 T$ & 1143 & 1480 & 186 & 6800 & 2880 & $82 \AA$ & 143 & 102 & 89 & 344 & 472 & 186 & 110? & 14279 & 14041 & 2305 & \\
\hline & 58 & 1476 & 1482 & $106:$ & 1896 & 29.58 & 132 & 15.555 & 7512 & 3227 & 225 & 245 & 39 & 304 & 354 & 165 & 1814 & 34480 & 16782 & 425 & $2 i$ \\
\hline & 59 & 1329 & 1329 & 1174 & 1482 & 2656 & 371 & 17196 & 4579 & 18.58 & 365 & 212 & 65 & 604 & 1159 & 20 & 2907 & 45630 & 37541 & 39.1 & \\
\hline & 60 & 5 & $5 \tilde{5}$ & 315 & 802 & 1117 & 121 & 4108 & 1600 & 471 & $85^{\prime}$ & 93 & 55 & 219 & $4 \pi 7$ & 355 & 640 & 12378 & 7524 & 2218 & \\
\hline & 61 & 812 & 747 & 508 & 1051 & 1559 & 150 & 7418 & 1081 & 1750 & 81 & 142 & 19 & 170 & 320 & 78 & 1092 & 14734 & 4475 & 1722 & \\
\hline & 62 & 618 & 640 & 262 & 996 & 1258 & $15 \overline{7}$ & 7125 & 2875 & 754 & 84 & 130 & 50 & 285 & 363 & 505 & 619 & 11039 & 13884 & 2135 & \\
\hline & 63 & 912 & 762 & 310 & 1361 & 1674 & 200 & 8048 & 4550 & 1471 & 87 & 218 & 47 & 300 & 440 & $23 \overline{7}$ & 993 & 20067 & 10265 & 2207 & \\
\hline & 61 & 1231 & 1281 & 9.51 & 1567 & 2518 & 263 & 9435 & 4718 & 1850 & 137 & 178 & 39 & 299 & 365 & 54 & 1419 & 27919 & 4711 & 1340 & \\
\hline & 65 & 1420 & 1410 & 479 & 2351 & 2830 & 318 & 13677 & 7027 & 2831 & 171 & 234 & 39 & 322 & 431 & 121 & 1245 & 23748 & 11191 & 1442 & \\
\hline
\end{tabular}


TABLE V.-Agricultural Statistics of Sonth Carolina, for the year 18s0, by Townstips.

FIRST SERIES.-(CONTINIED.)

\begin{tabular}{|c|c|c|c|c|c|c|c|c|c|c|c|c|c|c|c|c|c|c|c|c|c|}
\hline \multirow[b]{2}{*}{$\begin{array}{l}\dot{y} \\
\vdots \\
0 \\
0 \\
0\end{array}$} & \multirow{2}{*}{ 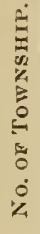 } & \multicolumn{5}{|c|}{ POPULATION. } & \multirow{2}{*}{ 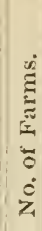 } & \multirow{2}{*}{ 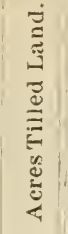 } & \multicolumn{2}{|c|}{ COTTON. } & \multicolumn{7}{|c|}{ STOCK. } & \multicolumn{4}{|c|}{ GRAIN. } \\
\hline & & 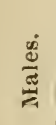 & 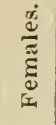 & 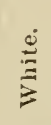 & $\frac{J}{0}$ & $\stackrel{\vec{I}}{\circ}$ & & & 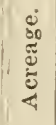 & $\frac{\dot{e}}{\stackrel{\dot{E}}{\tilde{I}}}$ & 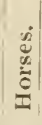 & 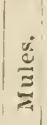 & 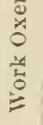 & 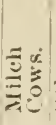 & 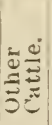 & 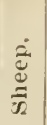 & $\stackrel{\Xi}{\Xi}$ & 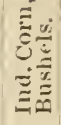 & 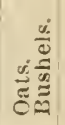 & 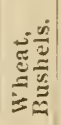 & 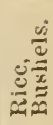 \\
\hline & 66 & 1003 & 1147 & 685 & 1465 & 2150 & S5 & 3535 & 2506 & 996 & 30 & 105 & 2 & 67 & 42 & 33 & 56 & 8199 & 4361 & 1409 & \\
\hline & 67 & 1209 & 1213 & 705 & 1717 & 2422 & 20 is & 19312 & 5241 & 2136 & 130 & 310 & 6 & 199 & 151 & 133 & 816 & 38260 & 12750 & 2542 & \\
\hline & 68 & 1394 & 1473 & 527 & 2310 & 2567 & 186 & 12268 & $S 7$ & 2710 & 115 & 335 & 4 & 248 & 374 & 294 & 1133 & 43720 & 6451 & 3611 & \\
\hline & 69 & 1200 & 1236 & 489 & 1947 & 2136 & 355 & 17359 & 7665 & 3181 & 135 & 361 & 12 & 253 & 351 & 231 & 1017 & 53525 & 6511 & 2694 & \\
\hline \multirow{10}{*}{ 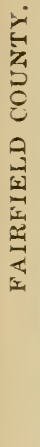 } & 70 & 796 & 726 & 207 & 1315 & 1522 & 204 & 7492 & 4559 & 1566 & 44 & 231 & 6 & 218 & 237 & 37 & $42 \pi$ & 20725 & 1229 & 598 & \\
\hline & 71 & 782 & 737 & 217 & 1302 & 1519 & 234 & 12365 & 4307 & 1542 & 62 & 151 & 53 & 190 & 267 & $\ldots$. & 329 & 19750 & $35 \pi 5$ & $42 t i$ & ….. \\
\hline & 72 & 763 & 793 & 605 & 951 & 1556 & 183 & 5748 & 2879 & 950 & 88 & 126 & $76^{\circ}$ & 175 & 229 & 70 & 835 & 15938 & 3741 & 645 & 12 \\
\hline & 73 & 437 & 462 & 180 & 719 & 899 & 97 & 6106 & 2956 & 898 & 33 & $11 \mathrm{I}$ & 16 & 115 & 90 & 84 & 246 & 12630 & 3962 & $58 \mathrm{C}$ & $3 \bar{j}$ \\
\hline & 74 & 1260 & 1298 & 1131 & 1427 & 25.58 & 219 & 7737 & 4149 & 1433 & 122 & 188 & 62 & 305 & 428 & 408 & 1184 & 21144 & 7474 & 1562 & 25 \\
\hline & 75 & 1014 & 1074 & 576 & 1512 & 2088 & 196 & 10457 & 5941 & 1788 & $2 \pi 4$ & 195 & 53 & 535 & 410 & $25 \mathrm{~s}$ & 775 & 18088 & 11390 & 1723 & 48 \\
\hline & 76 & 631 & 661 & 387 & 905 & 1292 & 130 & 6517 & 3511 & 1146 & 60 & 149 & 30 & 157 & 326 & 327 & 561 & 14210 & 5966 & 1356 & ..... \\
\hline & 77 & 823 & $\$ 21$ & 262 & 1385 & $16 \pm 7$ & 210 & $67+1$ & 3135 & 1147 & $\pi$ & 176 & 26 & 193 & 308 & 87 & 055 & 17920 & 4300 & 819 & If \\
\hline & is & 922 & 918 & 303 & 1537 & 1810 & 224 & 12799 & 6920 & 2753 & 83 & 334 & 4 & 248 & 185 & 206 & 800 & $42 \div 36$ & 5480 & 3805 & ...... \\
\hline & 79 & 1180 & $14 \$ 9$ & 611 & 2358 & 2969 & 328 & 14836 & 8493 & 2955 & 125 & 369 & 43 & 306 & 493 & 179 & 995 & 41035 & 9357 & 2732 & \\
\hline
\end{tabular}

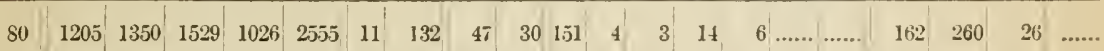

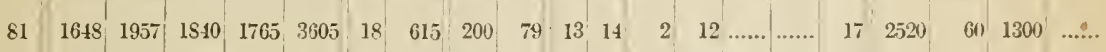

$\begin{array}{lllllllllllllllllllllll}82 & 1086 & 1066 & 637 & 1515 & 2152 & 239 & 6109 & 2505 & 1156 & 127 & 159 & 21 & 235 & 231 & 123 & 390 & 23151 & 4059 & 3061 & 20\end{array}$

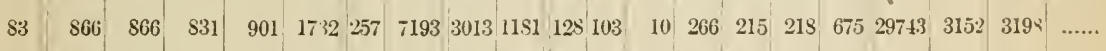

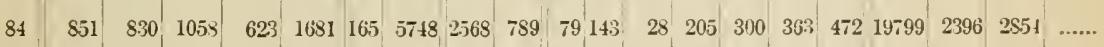

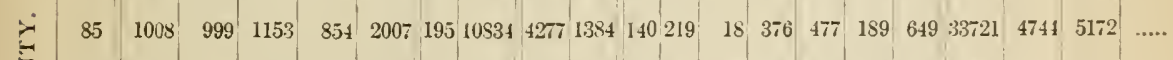

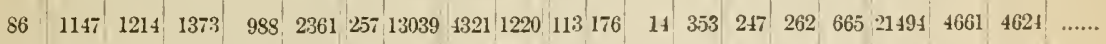

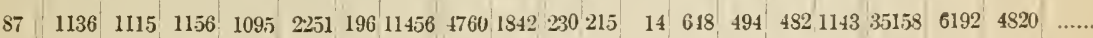

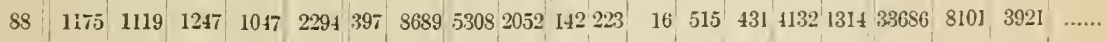

$\begin{array}{lllllllllllllllllllllll}89 & 1172 & 1220 & 1306 & 10 \$ 6 & 2392 & 179 & 10655 & 3923 & 1557 & 158 & 182 & 16 & 317 & 239 & 2 \pi & 759 & 26394 & 4624 & 2212 & \ldots \ldots\end{array}$

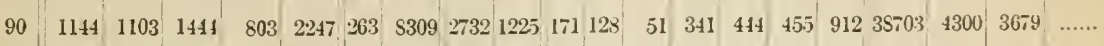

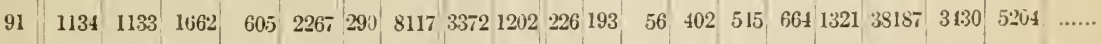

\begin{tabular}{l|lllllll|l|l|l|llllllllll}
92 & 893 & 913 & 1477 & 359 & 1836 & 236 & 7599 & 2131 & 896 & 204 & 157 & 12 & 305 & 271 & 562 & 1276 & 44693 & 2151 & 6021 & $\ldots$
\end{tabular}

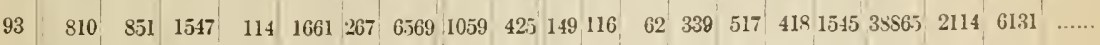

\begin{tabular}{l|l|l|l|l|l|l|l|l|l|l|l|l|l|l|l|l|l|l|l|l}
91 & 912 & 997 & 1590 & 349 & 1939 & 321 & 6291 & 802 & 310 & 124 & 146 & 117 & 333 & 380 & 502 & 2052 & 75065 & 2300 & 2921 & 7
\end{tabular}

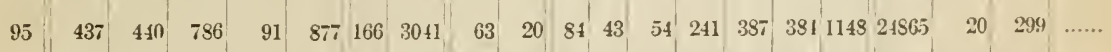

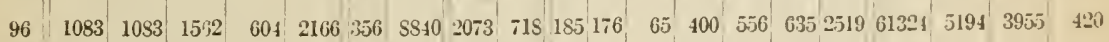

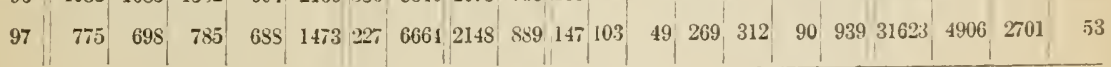


TABLE V.-Agricultural Statistics of South Carolina, for the year 1880, by Townships.

FIRST SERIES.-(CoNTINUED.)

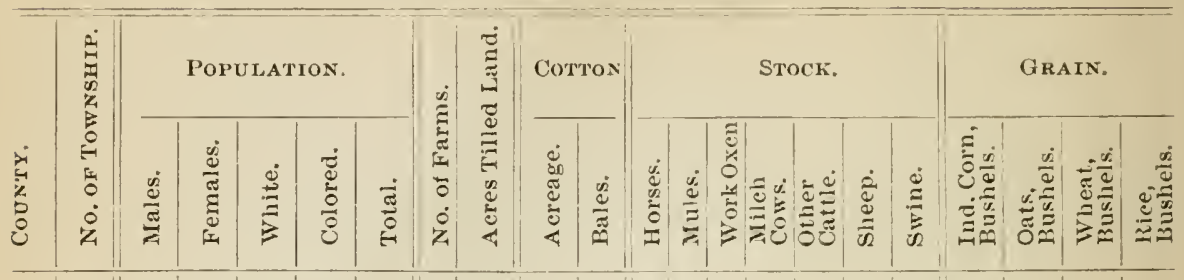

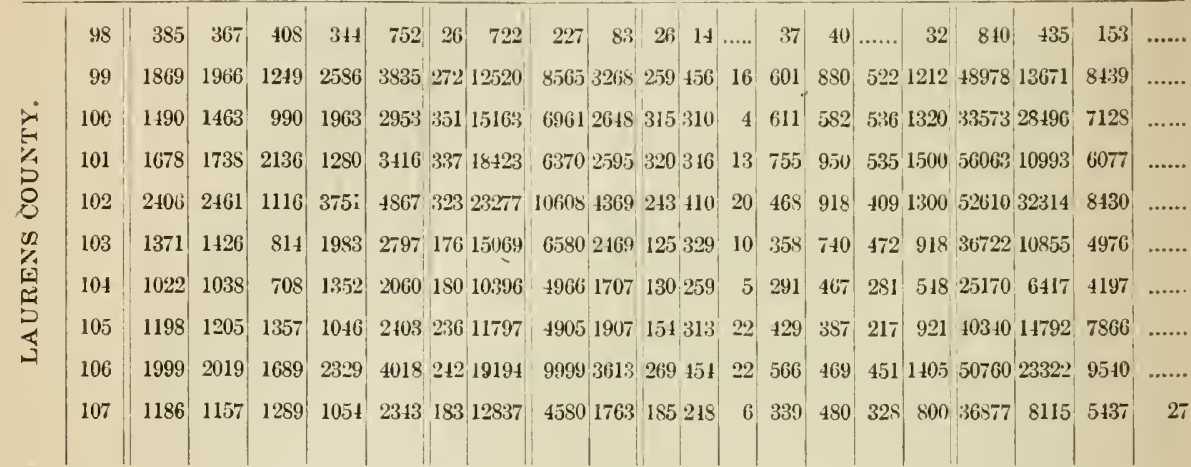

$\begin{array}{llllllllllll}108 & 1083 & 1259 & 1012 & 1330 & 2 ; 42 & 25 & 1029 & 603 & 258 & 35 & 12\end{array}$

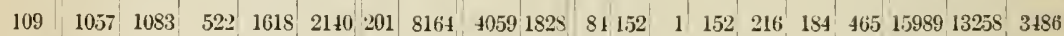

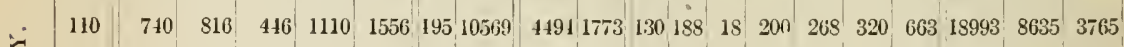

弪

8

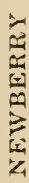

告

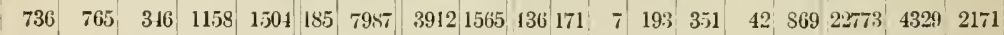

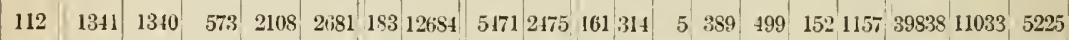

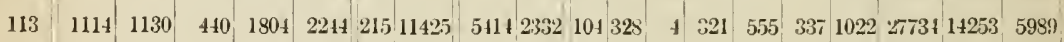

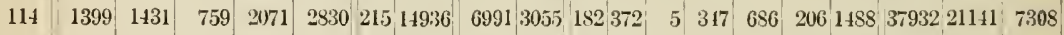

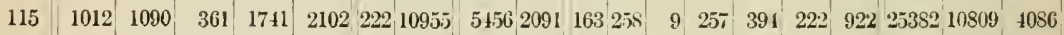

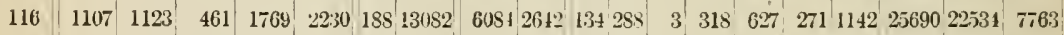

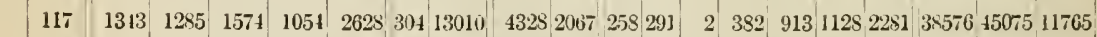

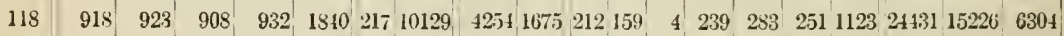

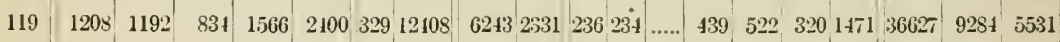

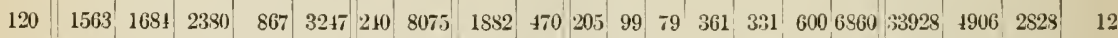

\begin{tabular}{|c|c|c|c|c|c|c|c|c|c|c|c|c|c|c|c|c|c|c|c|c|}
\hline 121 & 1497 & 1588 & 2092 & 993 & 3085 & 325 & 13660 & 4505 & 1143 & 293 & 210 & 98 & $4 S^{\circ}$ & 781 & 721 & 1213 & 47680 & 13376 & $96 \mathrm{~S} 2$ & \\
\hline 122 & 311 & 401 & 678 & 41) & 718 & 112 & 2925 & & ;... & 66 & 51 & 54 & 197 & 350 & 1066 & 827 & 20431 & 806 & & \\
\hline 123 & $\$ 91$ & $95 \overline{7}$ & 1521 & 327 & 1848 & 298 & 6622 & 1727 & 505 & 192 & 1111 & 132 & 371 & 603 & 1111 & 216 & 12655 & 3268 & $15 i$ & \\
\hline 124 & 351 & 90 & 715 & 26 & 741 & 121 & 2669 & 42 & 12 & 46 & 35 & 118 & 150 & 244 & 744 & 1069 & 15164 & $35 \pi$ & & \\
\hline 125 & 1793 & $18: 0$ & 2133 & $14 S 0$ & 3613 & 244 & ز189. & 3980 & $1250^{\prime}$ & 218 & 201 & 78 & 427 & 533 & 475 & 1727 & $5 s 188$ & 11115 & 10 & \\
\hline 126 & 1090 & 1144 & 1688 & 516 & 2334 & 15i) & 7113 & 1469 & 410 & 161 & 97 & 97 & 281 & 210 & 695 & 1300 & $32: 345$ & 5147 & 3530 & \\
\hline $1:$ & 380 & 390 & 71 & 2 & 770 & 87 & 2515 & 51 & 13 & 70 & 19 & 4 & 169 & 227 & 73 & 1013 & 18505 & 117 & & \\
\hline
\end{tabular}


TABLE V.-Agricultural Statistics of South Carolina, for the year 1880, by Townships.

FIRST SERIES.-(Continuen.)

\begin{tabular}{|c|c|c|c|c|c|c|c|c|c|c|c|c|c|c|c|c|c|c|c|c|}
\hline \multirow[b]{2}{*}{$\begin{array}{l}\text { तै } \\
0 \\
0 \\
0\end{array}$} & \multirow{2}{*}{ 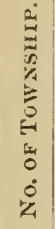 } & \multicolumn{5}{|c|}{ POPULATION. } & \multirow{2}{*}{ 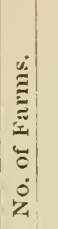 } & \multirow{2}{*}{ 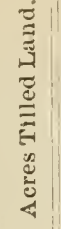 } & \multicolumn{2}{|c|}{ COTTON } & \multicolumn{6}{|c|}{ Sтоск. } & \multicolumn{4}{|c|}{ GRAIN. } \\
\hline & & 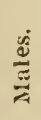 & 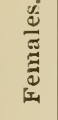 & 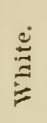 & 苛 & Е & & & 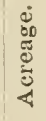 & 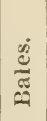 & 䓵 & $\frac{\dot{d}}{\frac{d}{\Xi}}$ & 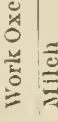 & 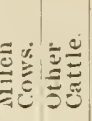 & 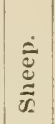 & $\overbrace{\tilde{J}}^{\circ}$ & 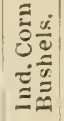 & 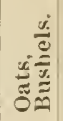 & 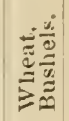 & $\overbrace{}^{\frac{\infty}{\infty}}$ \\
\hline
\end{tabular}

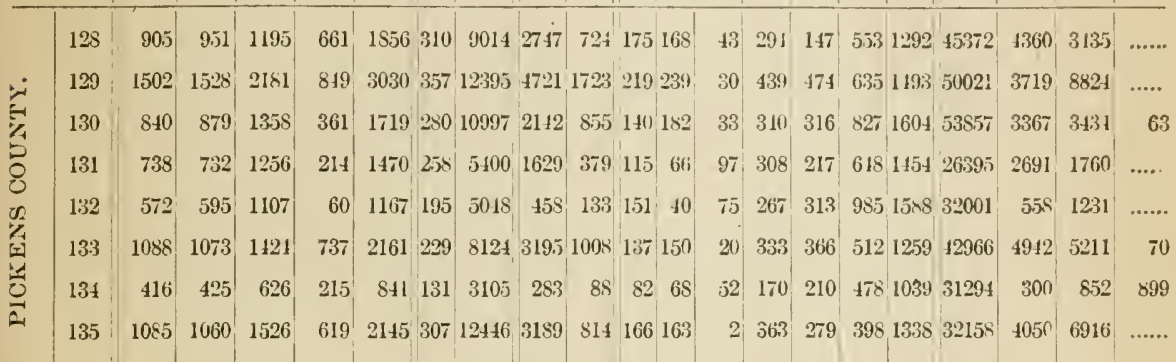

\begin{tabular}{|l|l|l|l|l|l|l|lll|l|}
136 & 970 & 1099 & 1019 & 1020 & 2069 & 8 & 196 & 67 & 26 & 13
\end{tabular}

\begin{tabular}{l|l|l|l|l|l|l|l|l|l|l|l|l|l|}
137 & 588 & 596 & 682 & 502 & 1181 & 18 & 218 & 113 & 41 & 18 & 2
\end{tabular}

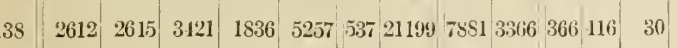

\begin{tabular}{l|l|l|l|l|l|l|}
8 & 11 & $\ldots .$. & 10 & 405 & $\ldots \ldots$ & 130
\end{tabular}

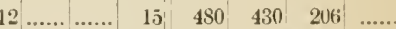

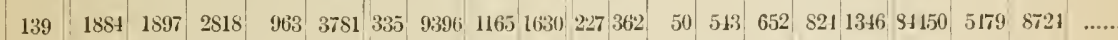

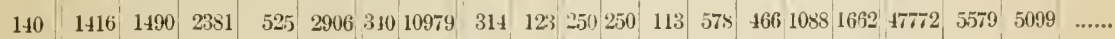

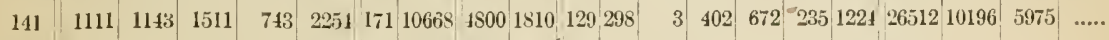

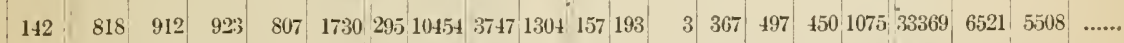

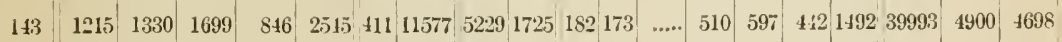

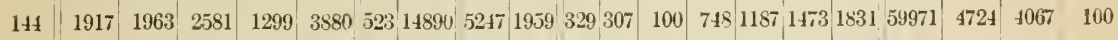

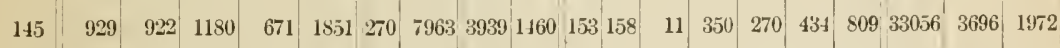

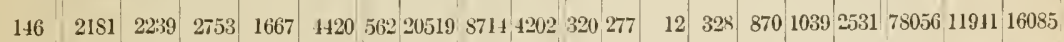

\begin{tabular}{lllllllllllll|lllllll}
147 & 1148 & 1189 & 1509 & 828 & 2337 & 211 & 7771 & 4098 & 1353 & 176 & 168 & 16 & 313 & $28 \%$ & 312 & 788 & 35980 & 2140 & 2542
\end{tabular}

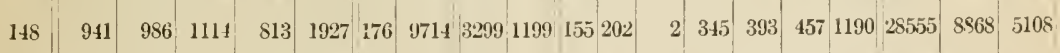

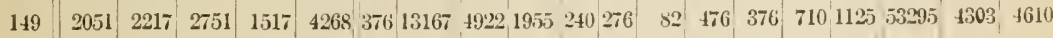

150

151 $\begin{array}{llllllllllll}1775 & 1562 & 1566 & 2071 & 3637 & 159 & 9076 & 1728 & 1656 & 147 & 205\end{array}$

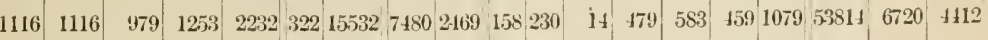
\begin{tabular}{l|llllllllll}
729 & 766 & 825 & 670 & 1495 & 216 & 8096 & 3586 & 1397 & 114 & 171
\end{tabular} \begin{tabular}{l|l|l|l|l|l|l|l|l|l|l|l}
1064 & 1123 & 1208 & 979 & 2187 & 301 & $S 849$ & 1379 & 1555 & 172 & 239
\end{tabular}

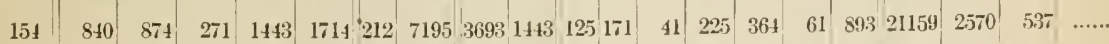

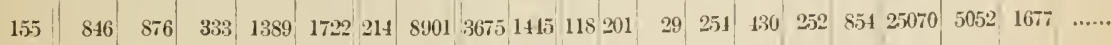

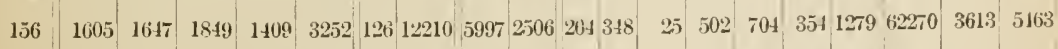

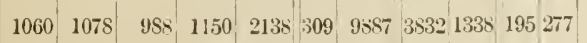

\begin{tabular}{l|llll|l|l|l|l|l|l}
1550 & 1572 & 1660 & 1.167 & 3127 & 397 & 15931 & 7269 & 2537 & 250 & 369
\end{tabular}

\begin{tabular}{l|l|l|llllllll}
1280 & 1296 & 837 & 1739 & 2567 & 265 & 12895 & 6272 & 2165 & 160319
\end{tabular}
$11473 \quad 425 \quad 286 \quad 1326,34161 \quad 2755,4556 \quad \ldots$.

$\begin{array}{lllllllll}7 & 561 & 778 & 502 & 1957 & 52766 & 5566 & 6735 & \ldots \ldots .\end{array}$

$\begin{array}{llllllllll}29 & 591 & 59 ! & 396 & 1314 & 36072 & 3122 & 2014\end{array}$ 
TABLE V.-Agricultural Statistics of South Carolina, for the year 1880, by Townships.

FIRST SERIES.-(C'ONCruDED.)

\begin{tabular}{|c|c|c|c|c|c|c|c|c|c|c|c|c|c|c|c|c|c|c|c|c|c|}
\hline \multirow[b]{2}{*}{$\begin{array}{l}0 \\
0 \\
0 \\
0 \\
0\end{array}$} & \multirow{2}{*}{ 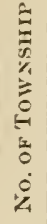 } & \multicolumn{5}{|c|}{ POPULATION. } & \multirow{2}{*}{ 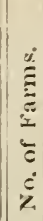 } & \multirow{2}{*}{ 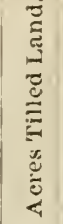 } & \multicolumn{2}{|c|}{ COTTON } & \multicolumn{7}{|c|}{ STOCK. } & \multicolumn{4}{|c|}{ GRAIN. } \\
\hline & & $\frac{\stackrel{d}{2}}{\frac{\pi}{a}}$ & 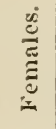 & $\stackrel{\stackrel{\Xi}{\Xi}}{\Xi}$ & $\frac{\tilde{U}}{\frac{0}{0}}$ & $\stackrel{\Xi}{\tilde{E}}$ & & & 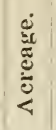 & $\stackrel{\stackrel{\mathscr{B}}{\mathscr{E}}}{\stackrel{\approx}{\approx}}$ & 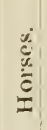 & $\stackrel{\stackrel{d}{c}}{\Xi}$ & 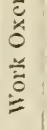 & $\begin{array}{l}\bar{y} \\
\vdots \\
0\end{array}$ & 婄 & 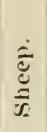 & $\frac{\stackrel{8}{\Xi}}{3}$ & 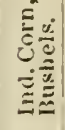 & 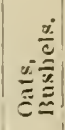 & 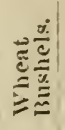 & $\underset{\approx}{\stackrel{0}{\frac{\dot{w}}{3}}}$ \\
\hline \multirow{11}{*}{ 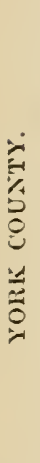 } & 160 & 2080 & 2168 & $206:$ & 2155 & 4248 & 264 & 13887 & 5596 & 2332 & 198 & 353 & 15 & 421 & 411 & 549 & 923 & 62924 & 86.55 & 8253 & \\
\hline & 161 & 1230 & 1342 & 1232 & 1810 & $25 \pi^{2}$ & 225 & 18636 & 4959 & 2133 & 222 & 376 & 3 & $3 \pi$ & 496 & 705 & 1234 & 66037 & 10305 & 8464 & \\
\hline & 162 & 1836 & 1845 & 1299 & 2382 & $56 \mathrm{sl}$ & 306 & 19664 & 7905 & $329 y$ & 348 & 400 & 14 & 522 & 500 & 70 & 1486 & 865 & 19082 & 9116 & 25 \\
\hline & 163 & 1106 & 1140 & 1055 & 1191 & 2216 & 190 & [131] & 3556 & 1317 & 171 & 304 & 31 & 411 & 705 & 725 & 184 & 62966 & $5+31$ & 5013 & \\
\hline & 164 & 1675 & 1671 & 1315 & 2031 & 3346 & 229 & 16556 & 6167 & 2446 & 138 & 393 & 33 & 453 & 575 & 427 & 1163 & 68365 & 7172 & 5922 & \\
\hline & 165 & 1180 & 1269 & 992 & 1457 & 2449 & 179 & 8117 & 1020 & 1558 & 131 & 177 & 14 & 236 & 270 & 20 & 632 & 22404 & 10216 & 2546 & \\
\hline & 166 & $99: 3$ & 1001 & 670 & 1324 & 1994 & 289 & 13591 & 5719 & 2261 & 123 & $27 x$ & 35 & 290 & 175 & I6I & 579 & 33456 & $10 \pi 27$ & 3856 & \\
\hline & 167 & $1: 10$ & 1231 & 1667 & 774 & 2411 & 227 & 7070 & 2212 & $\$ 20$ & 166 & 228 & 25 & 338 & 518 & 992 & 1177 & 58084 & 4000 & 7071 & \\
\hline & 168 & 1168 & 1060 & 683 & 1545 & $22: 28$ & 263 & 24127 & $75: 7$ & 3226 & 162 & 182 & 8 & 298 & 170 & 106 & 711 & 66127 & 1667 & 8021 & $\cdots$ \\
\hline & 169 & 1407 & 1427 & 1392 & 1442 & $2 \$ 31$ & 311 & 14817 & 7314 & 2798 & 155 & 309 & 7 & 338 & 325 & 232 & 1107 & 55312 & 21928 & $7 \mathrm{H} 0 \mathrm{~S}$ & ....... \\
\hline & 170 & 1345 & 2315 & 166 & 1009 & 267.1 & 315 & 11765 & 151 & 61 & 215 & 360 & 39 & 436 & 371 & 1215 & 1715 & 62665 & 5662 & 9463 & w.... \\
\hline
\end{tabular}


TABLE V.-Agricultural Statistics of South Carolina, for the year 1880, by Townships.

\section{SECOND SERIES.}

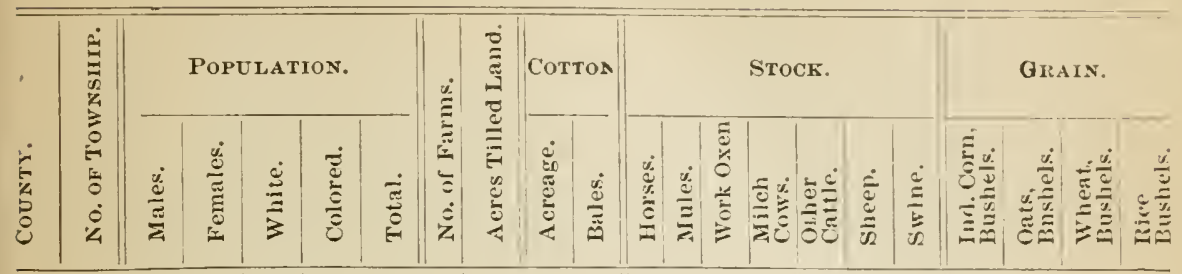

\begin{tabular}{|c|c|c|c|c|c|c|c|c|c|c|c|c|c|c|c|c|c|c|c|c|c|}
\hline & 1 & 592 & 608 & 479 & 721 & 1200 & 200 & 6162 & 1781 & 678 & 95 & 78 & 59 & 221 & 382 & & 1173 & 16197 & 7376 & 1059 & 12 \\
\hline & 2 & 818 & 999 & 701 & 1116 & 1817 & 11 & 86 & 173 & 116 & 20 & 13 & $\cdots .$. & 23 & 19 & .... & ....... & 128. & 835 & ... & ..... \\
\hline & 3 & 445 & 400 & 450 & 395 & 845 & 120 & 4992 & 1151 & 392 & 90 & 64 & 89 & 254 & 374 & 80 & 1190 & 11770 & 1054 & 1882 & 61 \\
\hline & 1 & 1183 & 144 & 2157 & 470 & 2627 & 26 & 1075 & 212 & 63 & 18 & 8 & 10 & 54 & 54 & & 232 & & 61 & 52 & 100 \\
\hline & 5 & 129 & 1262 & 1404 & $98 \bar{\imath}$ & 2391 & 109 & 4636 & 1381 & 613 & 56 & 98 & 58 & 221 & 426 & 726 & 1482 & 19218 & $2 \pi 19$ & 269 & 220 \\
\hline & 6 & 881 & 905 & 419 & 1370 & 1789 & 221 & 6982 & 2968 & 1246 & 86 & 167 & 21 & 241 & 160 & & 1416 & 23106 & 2355 & 391 & 350 \\
\hline & 7 & 923 & 877 & $3 \times s$ & 1412 & 1800 & 360 & 9693 & 4161 & 1909 & 114 & 285 & 24 & 170 & 362 & 188 & 2232 & 55135 & 9185 & $51 \overline{1}$ & 1830 \\
\hline & 8 & 175 & 200 & 302 & 73 & 375 & 54 & 1369 & 388 & 111 & $43^{\prime}$ & 17 & 37 & 135 & 244 & ....... & 626 & 7050 & 588 & 1217 & ..... \\
\hline$=$ & 9 & 251 & 255 & 329 & 180 & 509 & 82 & 2797 & 506 & 160 & 54 & 37 & 90 & 169 & 320 & 126 & 980 & $1040 \mathrm{~s}$ & 451 & 1480 & $3 ! n$ \\
\hline & 10 & 260 & 227 & $31 \overline{7}$ & 170 & 487 & 94 & 3003 & 837 & 316 & 56 & 45 & 36 & 122 & 133 & 27 & 771 & $\$ 020$ & 1901 & 1001 & $\cdots$ \\
\hline & 11 & 32 & 321 & 412 & 2 & 650 & 119 & 3708 & 602 & 191 & 83 & 49 & 61 & 218 & 401 & ...... & 1439 & 11484 & 1081 & 1527 & 55 \\
\hline & 12 & 1005 & 23 & 1028 & $90 \mathrm{v}$ & .928 & 236 & 10601 & 9000 & 1242 & 173 & 163 & 78 & 414 & 767 & 145 & 52317 & 27618 & 6429 & 2762 & 80 \\
\hline & 13 & 260 & 261 & 389 & 132 & 521 & $9 \dot{3}$ & 3123 & 679 & 244 & 52 & 45 & 94 & 166 & 381 & 285 & 1194 & 12075 & 485 & $182 ?$ & 73 \\
\hline & 1 & 443 & $45 s$ & 491 & 410 & 901 & 72 & 4258 & 1269 & 500 & 86 & 7 & 61 & 162 & 380 & 1 & 1108 & $194 \pi$ & 2977 & 1725 & ....... \\
\hline & 15 & 1192 & 1250 & 490 & 1952 & 2442 & 137 & 9187 & 3493 & 1321 & 83 & 169 & $\overline{7}$ & 287 & 425 & 109 & $9119 \bar{~}$ & 18621 & 8035 & 72 & 12 \\
\hline & 16 & 1018 & 1018 & 404 & $163:$ & 2136 & 198 & $1110^{\circ}$ & 352 & 1283 & 115 & 206 & 34 & $2 \pi 1$ & 501 & & 5250 & 35970 & 970 & 10 & $1 \div 209$ \\
\hline & 17 & -9 & 591 & 429 & 711 & 1170 & 158 & $697 \overline{7}$ & 2458 & 1134 & 78 & 133 & 68 & 226 & 350 & & 1103 & 16472 & 3088 & 1110 & 11 \\
\hline & 18 & 980 & 951 & 788 & 1143 & 1931 & 193 & 13308 & 4501 & 1521 & 105 & 233 & 39 & 624 & 715 & & 21429 & 35570 & 2189 & 53 & 1310 \\
\hline & 19 & 30 & 453 & 524 & 403 & $9:-1$ & 124 & $5 \pi+0$ & 1747 & 609 & 93 & 92 & 45 & 208 & 300 & & 1133 & 12323 & 665 & 1171 & 80 \\
\hline & 20 & 583 & 548 & 736 & 395 & 1131 & 140 & 5588 & 1165 & 345 & 107 & 72 & 112 & 283 & 278 & $20 s$ & 51803 & 19583 & 1322 & 1699 & 243 \\
\hline & 21 & 328 & 307 & 299 & 33 & 635 & 74 & 4043 & 783 & 293 & 64 & 53 & 54 & 190 & 423 & 151 & 1,875 & 13540 & $5 \pi 0$ & 1932 & 199 \\
\hline
\end{tabular}


TABLE V.-Agricultural Statistics of South Carolina, for the year 1880 , by Tounships.

SECOND SERIES--(CONTINTED.)

\begin{tabular}{|c|c|c|c|c|c|c|c|c|c|c|c|c|c|c|c|c|c|c|c|}
\hline \multirow[b]{2}{*}{ है } & \multirow{2}{*}{ 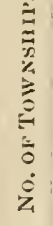 } & \multicolumn{5}{|c|}{ POPCLATION. } & & \multirow{2}{*}{ 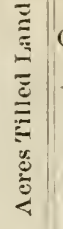 } & \multicolumn{2}{|c|}{ Cotron } & \multicolumn{6}{|c|}{ Sтоск. } & \multicolumn{3}{|c|}{ GRAIN. } \\
\hline & & 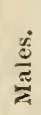 & 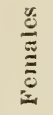 & $\stackrel{\stackrel{S}{\Xi}}{\geqq}$ & $\frac{0}{0}$ & $\stackrel{5}{5}$ & & & 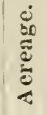 & $\frac{\dot{c}}{\tilde{E}}$ & 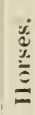 & $\frac{d}{\grave{\Xi}}$ & 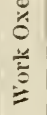 & 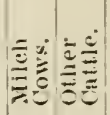 & 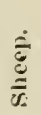 & $\stackrel{0}{\Xi}$ & 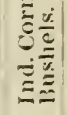 & 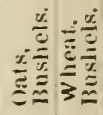 & 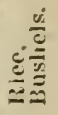 \\
\hline
\end{tabular}

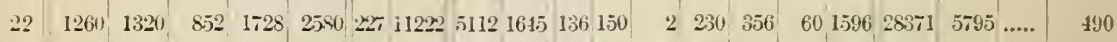

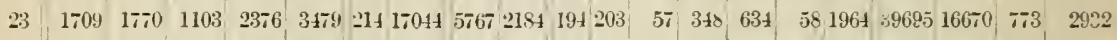

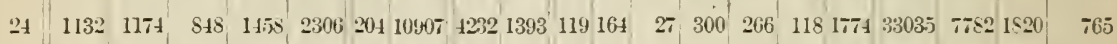

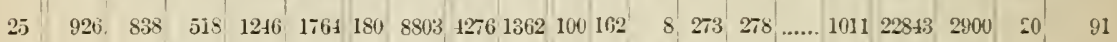

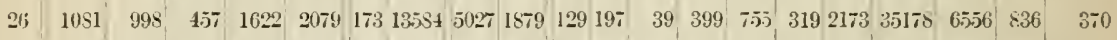

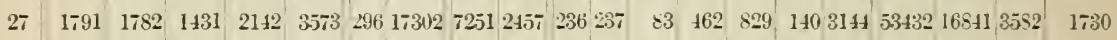

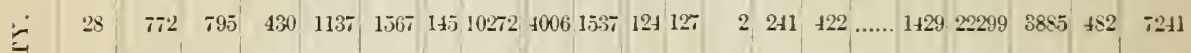

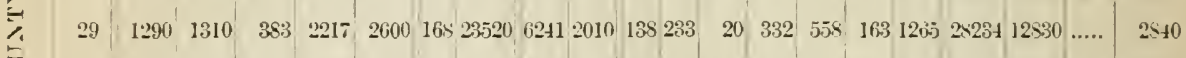

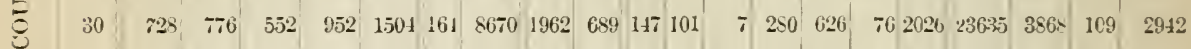

\begin{tabular}{ll|lllllllllllllllllllll}
\hline & 31 & 960 & 1012 & 378 & 1594 & 1972 & 169 & 13165 & 1579 & 1856 & 101 & 240 & 36 & 331 & 471 & 140 & 2359 & 3925 & 2650 & 343 & 754
\end{tabular}

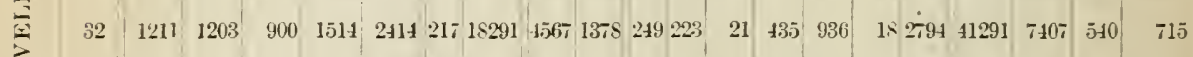

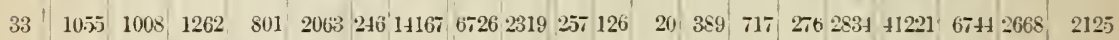

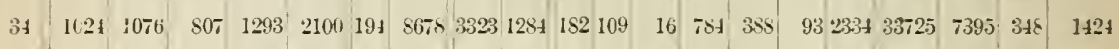

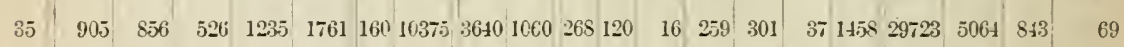

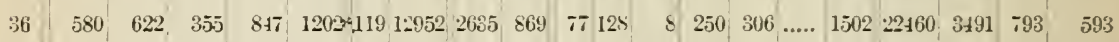

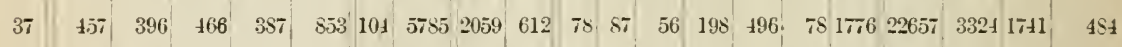

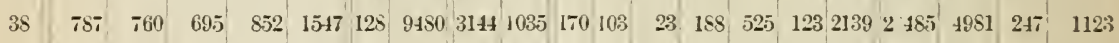

$\begin{array}{lllllllllllllllllllll}39 & 953 & 891 & 786 & 1038 & 1824 & 170 & 9608 & 5715 & 1360 & 197 & 152 & 2 & 278 & 623 & 286 & 2292 & -7695 & 9263 & 95 . & 2285\end{array}$

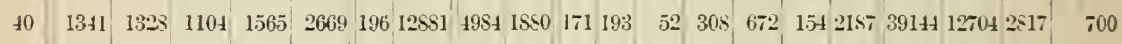

\begin{tabular}{ll|lll|l} 
& 1117 & 1432 & 616 & 1933 & 2549
\end{tabular}

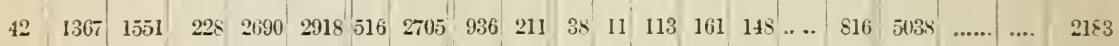

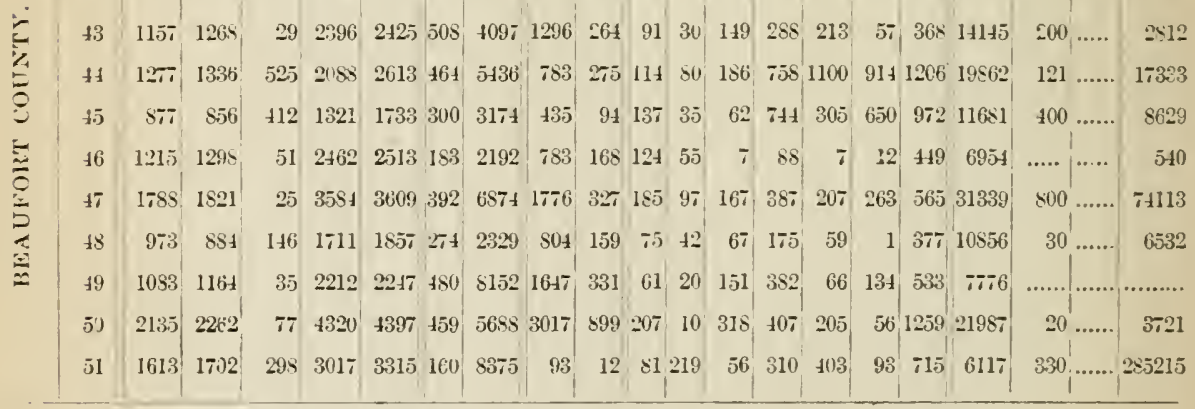


T.ABLE V.-Agricultural Statistics of South Carolina, for the year 18SO, ly Townships.

SECOND SERIES.-(Contineted.)

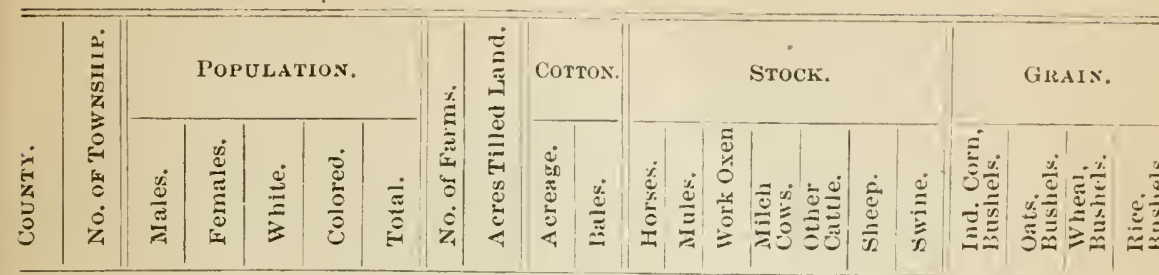

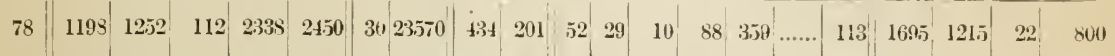

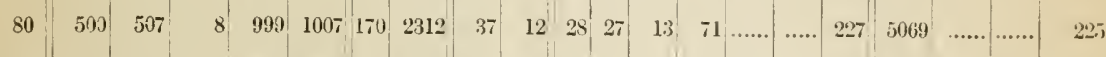

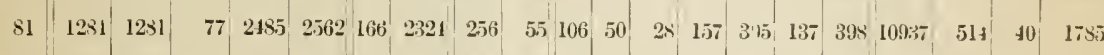

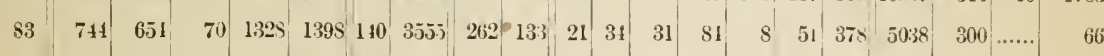

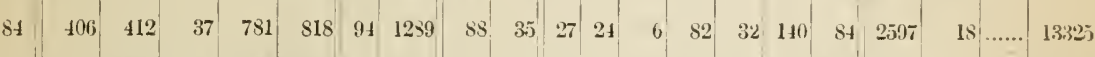

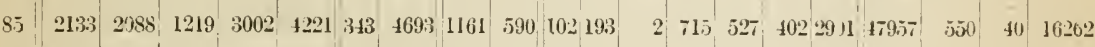

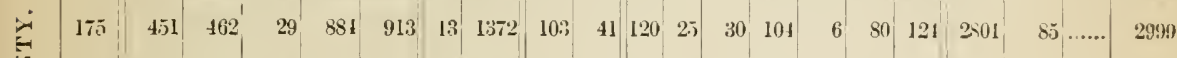

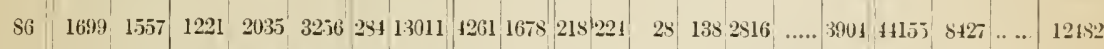

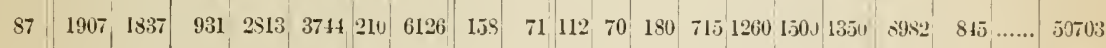

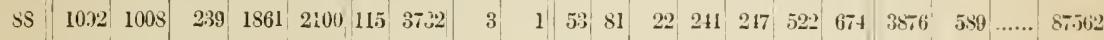

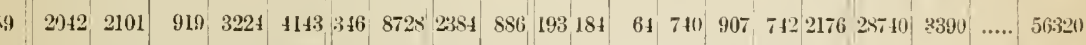

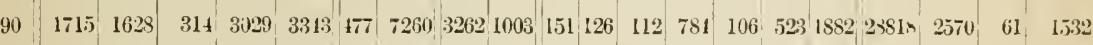

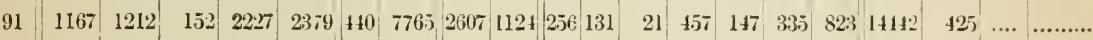

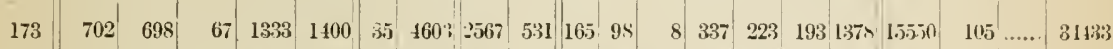
\begin{tabular}{l|l|l|l|l|l|l|l|l|l|l|l|l|l|l|l|l|l|l|l|l}
92 & 1145 & 1226 & 189 & 2182 & 2371 & 360 & 8515 & 1651 & 511 & 146 & 44 & 1 & 225 & 59 & 93 & 364 & 1040 & 160 & $\ldots \ldots$. & 87
\end{tabular}

\begin{tabular}{l|l|l|l|l|l|l|l|l|l|l|l|l|l|l|l|l|l|l|l|l}
93 & 2077 & 2161 & 151 & 4087 & 1238 & 470 & 7190 & 2998 & 913 & 275 & 111 & 38 & 576 & 212 & 130 & 585 & 16301 & 130 & $\ldots$. & 1.5
\end{tabular} \begin{tabular}{l|lllllll|l|l|l|l|l|l|l|l|l|l|l|l|l}
95 & 939 & 985 & 784 & 1198 & 1977 & 140 & 3981 & 481 & 137 & 87 & 55 & 49 & 637 & 889 & 599 & 2044 & 9674 & 923 & 20 & 2011
\end{tabular}

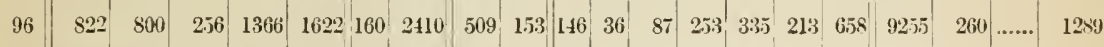
\begin{tabular}{l|l|l|l|l|l|l|l|l|l|l|l|l|l|l|l|l|l|l|l|l}
97 & 1238 & 1104 & 252 & 2090 & 2342 & 60 & 3419 & 177 & 53 & 48 & 61 & 58 & 303 & 388 & 48 & 751 & 4766 & 700 & $\ldots \ldots$ & 45105
\end{tabular}

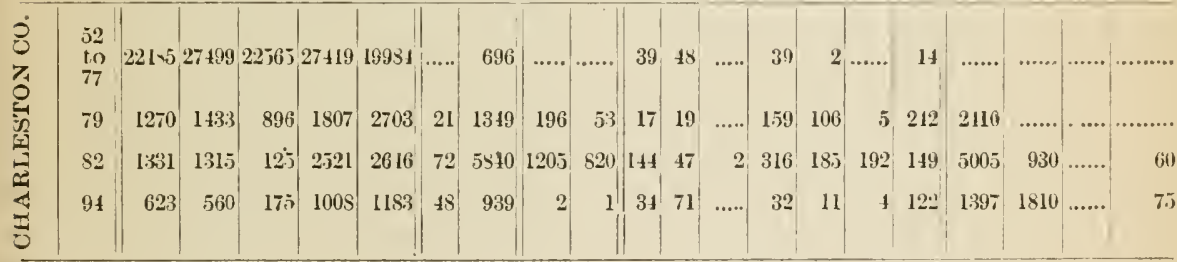


TABLE V.-Agricultural Statistics of South Carolina, for the year 1880, by Townships.

SECOND SERIES.-(ContineEd.)

\begin{tabular}{|c|c|c|c|c|c|c|c|c|c|c|c|c|c|c|c|c|c|}
\hline \multirow[b]{2}{*}{ 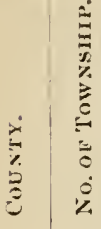 } & \multicolumn{5}{|c|}{ POPUlation. } & \multirow{2}{*}{\multicolumn{2}{|c|}{ 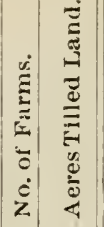 }} & \multicolumn{2}{|c|}{ Соттол. } & \multicolumn{5}{|c|}{ STOck. } & \multicolumn{3}{|c|}{ GRAIN: } \\
\hline & 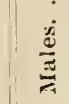 & 胥 & $\stackrel{\Xi}{\Xi}$ & $\frac{\dot{d}}{\tilde{0}}$ & 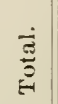 & & & 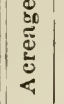 & $\frac{d}{\tilde{z}}$ & 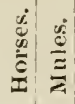 & 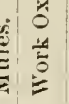 & 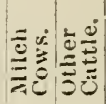 & $\frac{\dot{\bar{\Xi}}}{\stackrel{\tilde{\Xi}}{\pi}}$ & 崽 & 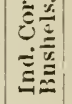 & 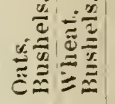 & $\stackrel{\frac{m}{\tilde{m}}}{\frac{\tilde{m}}{\tilde{w}}}$ \\
\hline
\end{tabular}

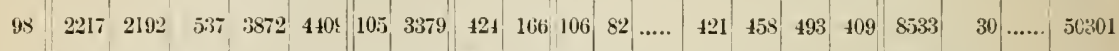

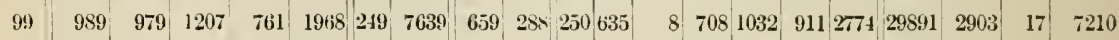

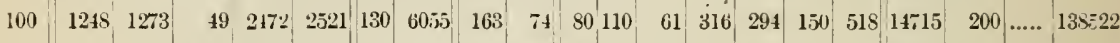

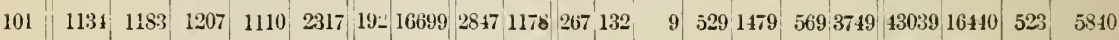
\begin{tabular}{l|l|l|l|l|l|l|l|l|l|l|l|l|l|l|l|l|l|l|l|l}
102 & 1064 & 926 & 760 & 1230 & 1990 & 200 & 3237 & 357 & 187 & 197 & 43 & 19 & 611 & 510 & 189 & 2818 & 21137 & 376.5 & $\ldots \ldots$. & 3521
\end{tabular}

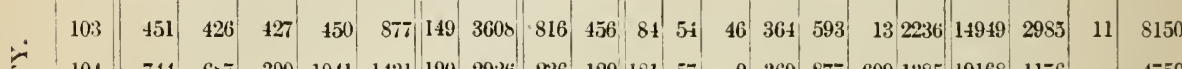
\begin{tabular}{ll|l|l|l|l|l|l|l|l|l|l|l|l|l|l|l|l|l|l|l|l}
\hline & 101 & 744 & $6 \times \overline{7}$ & 390 & 1041 & 1431 & 190 & 2926 & 236 & 129 & 181 & 57 & 9 & 360 & 877 & 609 & 1385 & 19168 & 1176 & $\ldots \ldots$ & 4750
\end{tabular} \begin{tabular}{lll|lllllllllllllllll|l|l|l|l}
5 & 105 & 1319 & 1334 & 971 & $168 \overline{7}$ & 2658 & 212 & 3733 & 551 & 253 & 132 & 65 & 34 & 433 & 379 & 311 & 1331 & 22581 & 350 & $\ldots .$. & 6910
\end{tabular} \begin{tabular}{l|l|l|l|l|l|l|l|l|l|l|l|l|l|l|l|l|l|l|l|l|l}
8 & 106 & 817 & 861 & 160 & 1548 & 1708 & 122 & 3257 & 357 & 119 & 7 & 50 & 21 & 198 & 299 & 96 & 120 & 7273 & 358 & $\ldots .$. & 56221 \\
\hline 7 & & & &
\end{tabular}

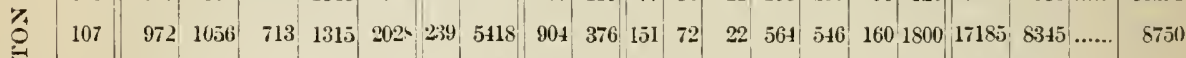

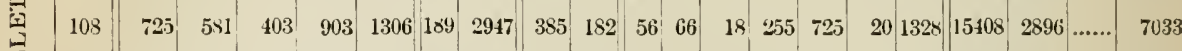

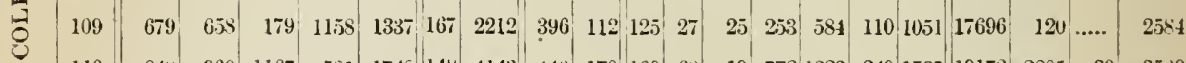

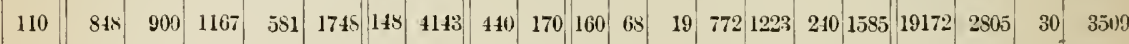

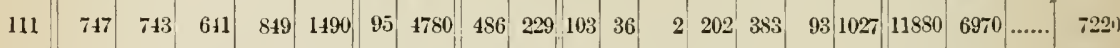

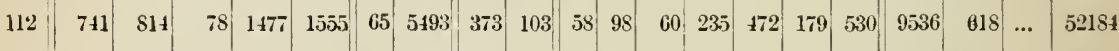

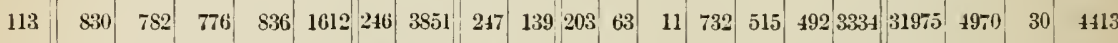

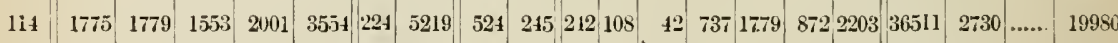
\begin{tabular}{l|l|l|l|l|l|l|l|l|l|l|l|l|l|l|l|l|l|l|l|l}
115 & 932 & 945 & 966 & 911 & 1877 & 269 & 9811 & 1192 & 440 & 243 & 83 & 25 & 967 & 1153 & 584 & 2979 & 35880 & 8136 & 194 & 9560
\end{tabular}

\begin{tabular}{|c|c|c|c|c|c|c|c|c|c|c|c|c|c|c|c|c|c|c|c|c|c|}
\hline \multirow{9}{*}{ 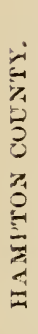 } & & & & & & & & & & & & & & & & & & & & & \\
\hline & 116 & 931 & 832 & 705 & 1058 & 1763 & 304 & 6943 & 782 & 245 & 145 & 75 & 113 & 689 & 1215 & 519 & 1374 & 22709 & 1430 & $\ldots$ & 25253 \\
\hline & 117 & 1486 & 1591 & 1090 & 1985 & $307 \pi$ & 390 & 15714 & 5490 & $16 \pi$ & 313 & 191 & 94 & 798 & 1740 & 766 & $45 \pi$ & 17550 & 14807 & 64 & 5850 \\
\hline & 118 & $12 \times 3$ & 1309 & 535 & $20: 37$ & 2592 & 204 & 12818 & $\$ 411$ & 1726 & 138 & 216 & 39 & 685 & 1035 & 50 & 2861 & 41171 & 15219 & $\ldots$ & 950 \\
\hline & 119 & 980 & 1033 & 338 & 1675 & 2013 & 132 & 7473 & 3803 & 1414 & 76 & 134 & 19 & 189 & 419 & 362 & 926 & 19228 & $7+93$ & & 275 \\
\hline & 120 & 2415 & 2290 & $22: 36$ & 2199 & 4755 & $30 \%$ & 16416 & 4698 & 1874 & 318 & 248 & 32 & 931 & 682 & 494 & 1572 & 68602 & 15266 & 83 & 8750 \\
\hline & 121 & 964 & 9.58 & $75 \bar{z}$ & 1155 & 1822 & 142 & 5311 & 697 & 230 & 133 & 58 & $3 t$ & 469 & 400 & 152 & 1240 & 14505 & 1990 & $\cdots$ & 7523 \\
\hline & 122 & 899 & 801 & 311 & 1449 & 1760 & 63 & 254 & 1328 & 442 & 58 & 61 & 11 & 230 & 364 & 35 & 951 & 11190 & 1805 & $\ldots$. & SE51 \\
\hline & 174 & $410^{\circ}$ & 433 & 284 & 59.5 & 879 & $\tau 6$ & 1126 & 202 & $4 \pi$ & 35 & 14 & $2 \pi$ & 320 & 825 & 161 & 445 & 2629 & 495 & 9 & 1371 \\
\hline
\end{tabular}


TABLE V.-Agricultural Statistics of South Carolina, for the year 1880, by Tounships.

SECOND SERIES.--(CoNTINUED.)

\begin{tabular}{|c|c|c|c|c|c|c|c|c|c|c|c|c|c|c|c|c|c|c|c|c|}
\hline \multirow[b]{2}{*}{ 岁 } & \multirow{2}{*}{ 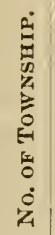 } & \multicolumn{5}{|c|}{ Population. } & \multirow{2}{*}{ 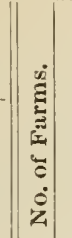 } & \multirow{2}{*}{ 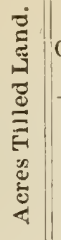 } & \multicolumn{2}{|c|}{ Cotton } & \multicolumn{6}{|c|}{ Sтоск. } & \multicolumn{4}{|c|}{ GRAIN. } \\
\hline & & $\frac{\dot{\alpha}}{\frac{\hat{\sigma}}{\pi}}$ & 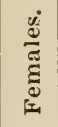 & 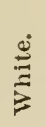 & 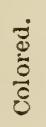 & हूँ & & & 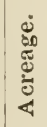 & $\mid$ & 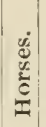 & $\frac{d}{3}$ & 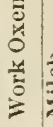 & 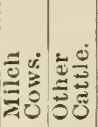 & $\frac{\dot{\Xi}}{\grave{\Xi}}$ & $\stackrel{\stackrel{\oplus}{\Xi}}{\bar{\Xi}}$ & 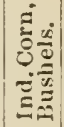 & 竎 & 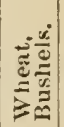 & 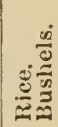 \\
\hline
\end{tabular}

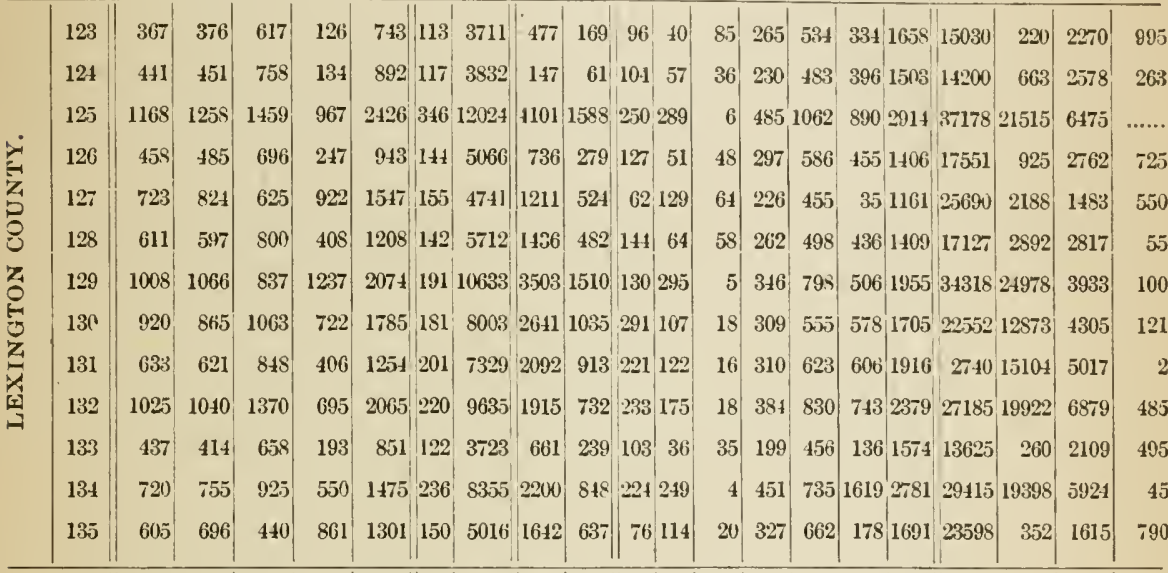

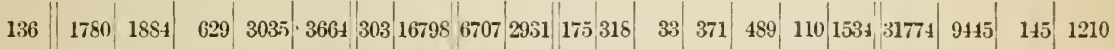

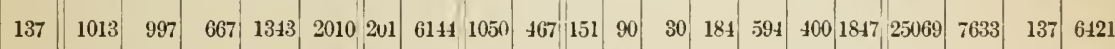

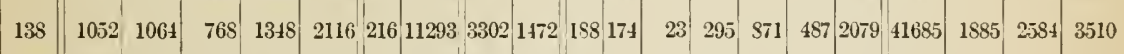

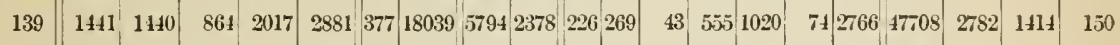

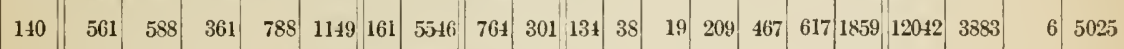

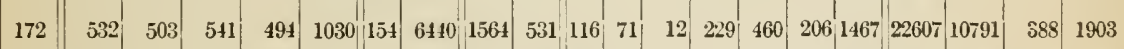

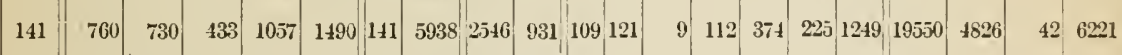

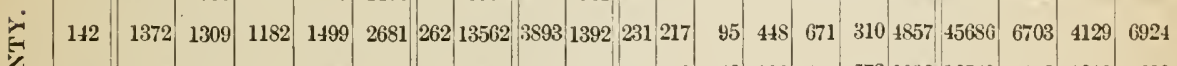

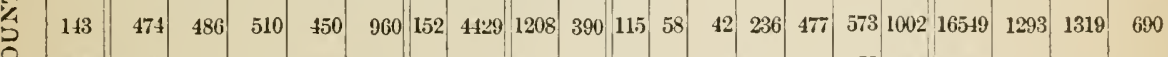

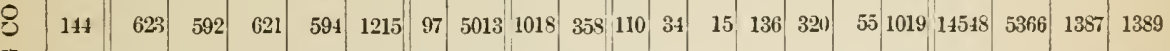

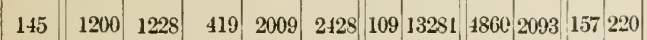

\begin{tabular}{llllll|l|l|l}
3 & 152 & 466 & 110 & 1380 & 24109 & 5294 & 128 & 2293
\end{tabular}

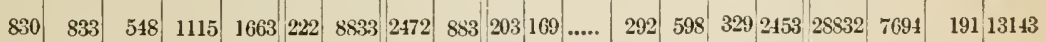

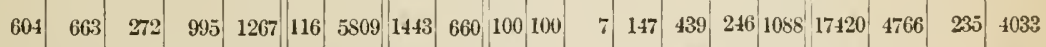
\begin{tabular}{l|l|l|l|l|l|l|l|l|l|l|l|l|l|l|l|l|l|l|l}
1054 & 1086 & 927 & 1213 & 2140 & 36 & 1298 & 295 & 183 & 38 & 21 & $\ldots . .$. & 55 & 96 & 24 & 169 & 4800 & 1385 & $\ldots . .$. & 1340
\end{tabular}

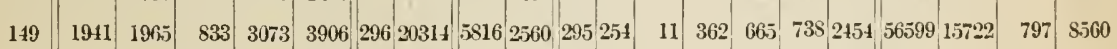

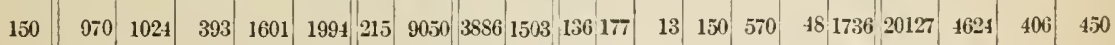

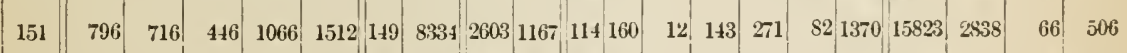

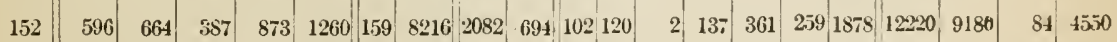

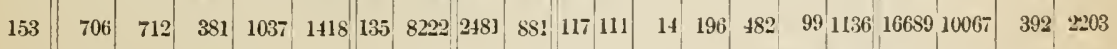

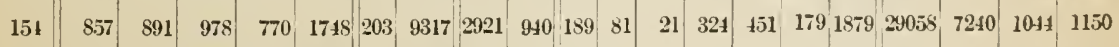

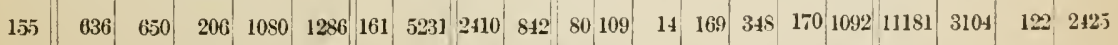

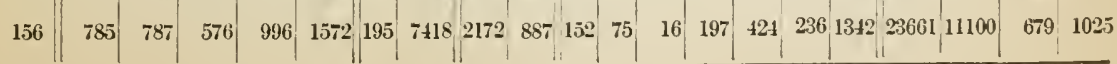


TABLE V.-Agricultural Statistics of South Carolina, for the year 1880, by Tounships.

SECOND SERIES-(Concr.uded.)

\begin{tabular}{|c|c|c|c|c|c|c|c|c|c|c|c|c|c|c|c|c|c|c|c|c|c|c|}
\hline \multirow[b]{2}{*}{$\begin{array}{l}3 \\
3 \\
0 \\
0\end{array}$} & \multirow{2}{*}{$\begin{array}{l}3 \\
3 \\
0 \\
0 \\
0 \\
0 \\
0 \\
0 \\
0 \\
0\end{array}$} & \multicolumn{5}{|c|}{ PoPUlation. } & \multirow{2}{*}{\multicolumn{2}{|c|}{ 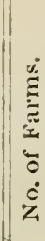 }} & & \multicolumn{2}{|c|}{ CоттоN } & \multicolumn{7}{|c|}{ STOCK. } & \multicolumn{4}{|c|}{ GRAIN. } \\
\hline & & 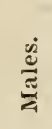 & 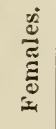 & $\stackrel{\stackrel{0}{\Xi}}{\Xi}$ & $\frac{3}{0}$ & हु & & & & 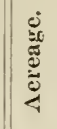 & $\frac{\dot{\omega}}{\tilde{\omega}}$ & 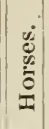 & $\mid \frac{\dot{\Phi}}{\frac{\dot{d}}{\Xi}}$ & 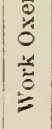 & 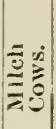 & 雚 & 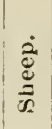 & $\frac{\stackrel{0}{\Xi}}{3}$ & 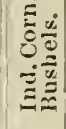 & $\stackrel{\frac{u}{0}}{\frac{u}{\partial}}$ & $\left\{\begin{array}{l}\frac{u}{0} \\
=\end{array}\right.$ & 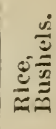 \\
\hline \multirow{9}{*}{ 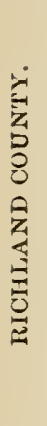 } & 157 & 789 & 799 & 1140 & 448 & 158 & 2 & & 3731 & 765 & 225 & 58 & 88 & 145 & 388 & 240 & 155 & 1211 & 10921 & 560 & ... & \\
\hline & $15 \mathrm{~s}$ & $116 \mathrm{~s}$ & 1118 & 1024 & 1262 & 228 & & & 6365 & 2504 & 917 & 101 & 97 & 89 & 336 & 437 & 592 & 1402 & 17652 & $4(1) 3$ & 551 & 290 \\
\hline & 159 & 481 & 529 & 423 & 587 & 101 & & 5 & 2512 & 553 & $25 t$ & 65 & 50 & 9 & 100 & 72 & $\ldots$. & 141 & 5324 & 5110 & $\tilde{5} \omega 0$ & 150 \\
\hline & 160 & 945 & 1092 & 374 & 166 & $200^{\circ}$ & 1 & & 5655 & 2251 & 1163 & 95 & 168 & 40 & 190 & 161 & 44 & 519 & 23414 & 5199 & 785 & 2510 \\
\hline & $\begin{array}{c}161 \\
\text { to } \\
167\end{array}$ & 4639 & 5397 & 4338 & 5698 & 100 & & 9 & 194 & 91 & 59 & 6 & 10 & ..... & 12 & 12 & 10 & 12 & 490 & 190 & ....... & \\
\hline & 168 & 1604 & 1556 & 244 & 2910 & 316 & & 61 & 18193 & 6618 & 2635 & 80 & 282 & 197 & 220 & 289 & 200 & 886 & 39592 & 705 & 147 & 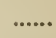 \\
\hline & 169 & 1121 & 1093 & $15 t$ & 2060 & 221 & & & 9989 & 5233 & 1926 & 88 & 19.5 & 95 & 195 & 258 & 161 & 1017 & 19173 & 1592 & 9 & 350 \\
\hline & 170 & 1739 & 1768 & 519 & 2988 & 350 & & & 12292 & 7150 & 2696 & 145 & 259 & 180 & 3.53 & 351 & 302 & 968 & 31567 & 6351 & 52 & ...... \\
\hline & 171 & 1359 & 1376 & 969 & 1766 & $2 \pi$ & & & 9936 & (1) 3196 & 1098 & 184 & & 85 & 405 & $6 S^{\circ}$ & $32 \tau$ & 1509 & 22607 & 10791 & 1572 & \\
\hline
\end{tabular}


TABLE V.-Agricultural Statistics of South Carolina, for the year 1880, by Townships.

THIRD SERIES.

\begin{tabular}{|c|c|c|c|c|c|c|c|c|c|c|c|c|c|c|c|c|c|c|c|c|}
\hline \multirow[b]{2}{*}{ 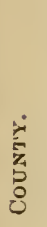 } & \multirow{2}{*}{ 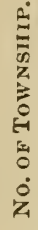 } & \multicolumn{5}{|c|}{ POPULATION. } & \multirow{2}{*}{ 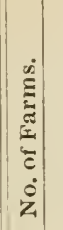 } & \multirow{2}{*}{ 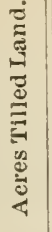 } & \multicolumn{2}{|c|}{ Cotton } & \multicolumn{6}{|c|}{ STоск. } & \multicolumn{4}{|c|}{ GraIs. } \\
\hline & & 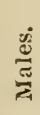 & 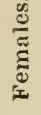 & $\stackrel{\stackrel{\Xi}{\Xi}}{3}$ & $\frac{3}{0}$ & हुँ & & & 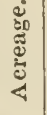 & 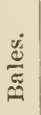 & 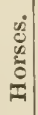 & 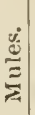 & $\begin{array}{l}0 \\
0 \\
0 \\
0\end{array}$ & 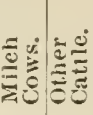 & 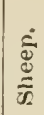 & $\stackrel{8}{\Xi}$ & 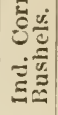 & 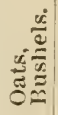 & 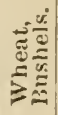 & 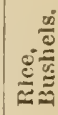 \\
\hline
\end{tabular}

\begin{tabular}{l|l|l|l|l|l|l|l|l|l|l|l|l|l|l|l|l|l|l|l|l|l}
$\therefore-1$ & 1 & 639 & 586 & 891 & 334 & 1225 & 146 & 3790 & 930 & 325 & 93 & 47 & 100 & 276 & 392 & 444 & 1545 & 19651 & 540 & 416 & $\ldots \ldots$
\end{tabular}

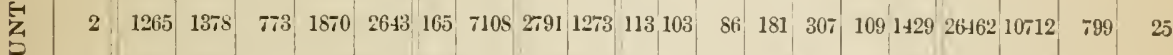

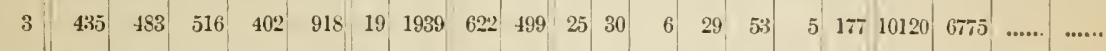

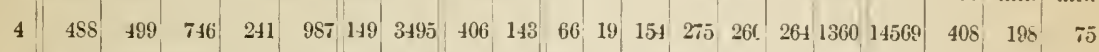

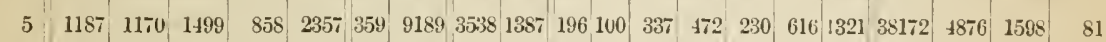
\begin{tabular}{l|lllllll|lllllllllllll}
6 & 882 & 879 & 1273 & 488 & 1761 & 232 & 7937 & 2820 & 1832 & 129 & 154 & 114 & 427 & 859 & 830 & 1865 & 32493 & 2770 & 1378 & $\ldots . .$.
\end{tabular}

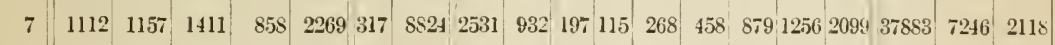

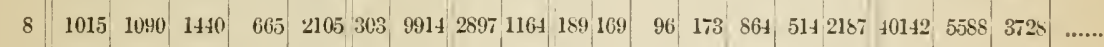
\begin{tabular}{l|lllll|llllllllllllllll}
9 & 983 & 1097 & 949 & 1131 & 2080 & 247 & 8606 & 1905 & 778 & 119 & 114 & 172 & 362 & 759 & 329 & 1736 & 27938 & 2731 & 85 & 10
\end{tabular}

\begin{tabular}{|c|c|c|c|c|c|c|c|c|c|c|c|c|c|c|c|c|c|c|c|c|}
\hline 10 & 253 & 255 & 259 & 249 & 508 & 80 & 3453 & 321 & 95 & 38 & 21 & 31 & 111 & 140 & 80 & 678 & 3913 & 790 & ..... & 252 \\
\hline 11 & $80 i$ & 832 & 455 & 1181 & 1636 & 171 & 9166 & 3126 & $998^{\prime}$ & 110 & 113 & 35 & 181 & 401 & 78 & 931 & 17582 & 2299 & 12 & 810 \\
\hline 12 & $4 \leqslant 0$ & 484 & 295 & 669 & $96 t$ & 118 & 5016 & 1526 & 516 & 47 & 61 & $2 \pi$ & 147 & $25 \pi$ & 5 & 782 & 12605 & 1495 & 12 & 1182 \\
\hline 13 & 348 & 343 & 516 & 175 & 691 & 114 & $240 \overline{7}$ & 526 & 135 & 53 & 40 & 40 & 117 & $16 i$ & 218 & 1102 & 9195 & 880 & 59 & 1530 \\
\hline 14 & 928 & 932 & 317 & 1543 & 1860 & 242 & 9150 & $3 \times 35$ & 1353 & $119]$ & 137 & 31 & $32 \mathrm{~s}$ & 271 & $\ldots$ & 1355 & 16976 & 8341 & 27 & 955 \\
\hline 15 & 580 & 575 & 122 & 1033 & 1155 & 168 & 3711 & $17 \notin 3$ & 512 & 72 & $\varepsilon 2$ & 18 & 134 & $3 \approx$ & 46 & $98 \bar{i}$ & 8809 & $102 \%$ & 48 & 190 \\
\hline 16 & $36 \pi$ & $35 \mathrm{t}$ & 170 & 551 & 721 & 85 & 2917 & $85 \tilde{5}$ & 256 & 40 & 34 & 37 & 139 & 336 & $14^{-}$ & 741 & 8118 & 535 & 24 & 990 \\
\hline 17 & 712 & 728 & 692 & 748 & 1440 & 107 & 3201 & 1032 & $3 x \bar{z}$ & 55 & 58 & 30 & 201 & 396 & 40 & 1450 & 13920 & 3197 & 34 & $16 \varsigma 5$ \\
\hline 18 & 512 & 52 & 332 & $70 \overline{7}$ & 1039 & 164 & 5125 & 1152 & 398 & 51 & 79 & 63 & 197 & $40 \overline{7}$ & 190 & 1907 & 15976 & 1003 & 6 & 1925 \\
\hline 19 & 481 & 116 & 754 & 173 & $92 \pi$ & 120 & 4075 & 971 & 321 & 94 & 46 & 51 & 190 & 243 & 228 & 1544 & 14822 & 1404 & 182 & 6999 \\
\hline 20 & 275 & 294 & $28 \pi$ & 287 & 574 & 100 & 1928 & 524 & 172 & 27 & 22 & 31 & 153 & 216 & 172 & 851 & 7295 & 275 & 54 & $\pi 5$ \\
\hline 21 & $40 \pi$ & 388 & 224 & 571 & $79 \tilde{~}$ & 141 & 3288 & 1061 & 303 & 45 & 64 & 56 & 151 & 229 & 50 & 1039 & 8505 & 1140 & .... & 1784 \\
\hline 22 & 457 & 498 & 326 & 629 & $9 \overline{5}$ & 165 & 3909 & 1406 & 4 ติ & 49 & 60 & 38 & 198 & 265 & 101 & 1068 & 11321 & 2112 & ...... & 610 \\
\hline 23 & 496 & 533 & 422 & 607 & 1029 & 170 & 4483 & 1521 & 451 & 55 & 74 & 60 & 170 & 250 & 47 & 968 & 12908 & 1350 & 121 & 1350 \\
\hline 24 & 212 & 190 & 248 & 154 & 402 & 61 & 1617 & $4 i 1$ & 141 & 36 & 15 & 33 & 71 & 134 & 61 & 699 & 6190 & $\ldots$ & ....... & 1202 \\
\hline 25 & 899 & $85 \%$ & 323 & 1428 & 1751 & 213 & 7082 & 2498 & 788 & 84 & 113 & 79 & 282 & 531 & 10 & 1752 & 20781 & 150 & 10 & 2925 \\
\hline 26 & 496 & 45 & 172 & 779 & 951 & 191 & 1138 & 1817 & 630 & 56 & 91 & 76 & $21 i$ & 326 & 14 & 95 & 14626 & 1158 & $\cdots$ & $6: 29$ \\
\hline 27 & 357 & 352 & 275 & $43 t$ & 709 & 112. & 2197 & 729 & 214 & 48 & 22 & 43 & 170 & 165 & $\ldots$ & 836 & 85538 & 418 & 5 & 1317 \\
\hline 28 & $5: 36$ & 547 & 93 & 990 & 108 & 200 & 5403 & 1555 & 514 & 61 & 52 & 56 & 189 & $2 \pi$ & 102 & 989 & $\mid 10241$ & 903 & ..... & $15 \pi 0$ \\
\hline
\end{tabular}


TABLE V.-Agricultural Statistics of South Carolina, for the year 18s0, by Townships.

THIRD SERIES.-(CoNTINUED.)

\begin{tabular}{|c|c|c|c|c|c|c|c|c|c|c|c|c|c|c|c|c|c|c|c|c|}
\hline \multirow[b]{2}{*}{ 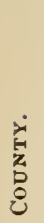 } & \multirow{2}{*}{ 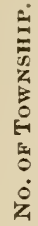 } & \multicolumn{5}{|c|}{ Population. } & \multirow{2}{*}{$\begin{array}{l}0 \\
\\
z \\
z\end{array}$} & \multirow{2}{*}{ 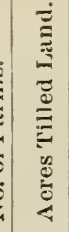 } & \multicolumn{2}{|c|}{ Cotton } & \multicolumn{6}{|c|}{ STock. } & \multicolumn{4}{|c|}{ GRAIN, } \\
\hline & & $\frac{\dot{e}}{\frac{\tilde{\sigma}}{\sigma}}$ & 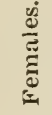 & $\stackrel{\stackrel{0}{\Xi}}{\Xi}$ & $\frac{\bar{d}}{0}$ & ${ }_{0}^{\bar{J}}$ & & & 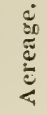 & 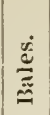 & $\frac{u}{\underline{a}}$ & $\frac{\dot{Q}}{\underline{\underline{a}}}$ & 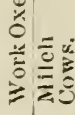 & لَّة & $\stackrel{\dot{\hat{\Xi}}}{\frac{\dot{\theta}}{\tilde{w}}}$ & $\stackrel{0}{\Xi}$ & 这脑 & 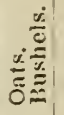 & 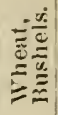 & 咲 \\
\hline
\end{tabular}

\begin{tabular}{|c|c|c|c|c|c|c|c|c|c|c|c|c|c|c|c|c|c|c|}
\hline & & 576 & 563 & 91 & & 112 & $462 \pi$ & 180 & 701 & 90 & 4954 & 5 & 126 & $4:$ & 317 & $10 \overline{7}$ & 512 & \\
\hline & & 77 & 0 & 1417 & & & 9386 & 821 & 1769 & 1061 & 157105 & 225 & 202 & 4111 & & 326 & 55 & \\
\hline & & 713 & 722 & 91 & 2 & 175 & 6879 & 26691 & 1129 & 164 & $\begin{array}{ll}68 & 53\end{array}$ & 178 & 326 & 6114 & 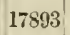 & 100 & 1281 & \\
\hline & & & 774 & 2042 & & & 7245 & 32381 & 1192 & & & & & & 47 & 359 & $25 \pi$ & \\
\hline & & 60 & 287 & 1031 & $18^{\prime}$ & 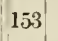 & 9028 & 31221 & 1102 & 90 & \begin{tabular}{l|l|}
74 & 81
\end{tabular} & 120 & 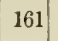 & 17 & 13 & 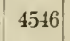 & 274 & \\
\hline 34 & & 582 & 651 & 509 & 1160 & 161 & 4953 & 1113 & 413 & ( & $\begin{array}{lll}78 & 71\end{array}$ & 187 & $3+1$ & 8015 & 1 & 721 & 240 & \\
\hline & & $156 \overline{7}$ & 972 & 2110 & 3082 & 57 & 5358 & 1437 & 668 & 70 & \begin{tabular}{|l|l|}
37 & 37 \\
\end{tabular} & .81 & 48 & $16 \mathrm{~s}$ & & & & \\
\hline & & 766 & 901 & 636 & 1537 & 164 & 6730 & 27551 & 12151 & 1351 & 11261 & 204 & 215 & 1791526 & 50 & 4565 & 874 & \\
\hline 37 & & 81 & 529 & 1125 & 54 & 159 & 7178 & 33501 & 1351 & 152 & \begin{tabular}{l|l}
92 & 65
\end{tabular} & 180 & 168 & 191 & 24186 & 3323 & 524 & \\
\hline & & 3. & 432 & 239 & $6 \overline{1} 1$ & 93 & 3000 & 834 & 287 & 54 & $\begin{array}{ll}40 & 30\end{array}$ & 145 & 286 & 116 & & 859 & 31 & \\
\hline & & 7 & 542 & 1022 & 1561 & 157 & 8999 & 3426 & 1332 & 1351 & 11758 & 163 & 221 & 2281 & 21835 & 6485 & 74 & \\
\hline & 62 & 1063 & 1186 & 1039 & 2 & 1 & 10019 & 3781 & $1480:$ & 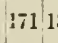 & 109 & 317 & 330 & 62 & 8 & 4629 & 245 & \\
\hline & 766 & 777 & 835 & 708 & 1542 & 192 & 702 & 31771 & 12301 & 156 & $\begin{array}{ll}97 & 50\end{array}$ & 165 & 236 & is 1 & $2644 \overline{7}$ & 3032 & 132 & \\
\hline & 761 & 748 & 205 & $130 \overline{7}$ & 1512 & 238 & 7935 & 34171 & 12371 & 1071 & 135126 & 162 & 309 & 1791 & 17078 & 1030 & .... & \\
\hline & & 75 & 364 & 1274 & 8 & 171 & 8630 & 6411 & 1942 & 1371 & 14470 & 136 & 185 & 433 & & $72 \pi$ & 49 & \\
\hline & & & 710 & 599 & 1309 & 202 & 6522 & 2751 & 964 & 144 & $\begin{array}{ll}86 & \mathbf{7 4}\end{array}$ & 178 & 280 & 50 & 21 & 3ิ 181 & 900 & \\
\hline & 007 & 1357 & 450 & 2214 & 2661 & 236 & 9713 & 4 & , & 15 & 44 & 165 & 202 & 57 & 33336 & 1298 & 139 & \\
\hline & & & 859 & 441 & 0 & 219 & דiה & 3200 & 1 & 152 & \begin{tabular}{l|l}
95 & 29
\end{tabular} & $19 \overline{7}$ & 473 & 1491524 & 19070 & 6133 & 16 & \\
\hline & & 880 & 757 & 949 & 1706 & 157 & 7841 & 30701 & 1266 & 136 & \begin{tabular}{l|l}
99 & 59
\end{tabular} & 150 & 155 & 251406 & 2787 & 5967 & 17 & \\
\hline & 505 & 586 & 305 & 786 & 18 & 168 & 3923 & 1732 & 631 & 47 & $56: 106$ & 150 & 228 & 13927 & 15096 & 290 & .... & \\
\hline & & & 71 & 826 & $15+1$ & 116 & 3955 & 1103 & , & 100 & & 1 & $34^{\prime}$ & $102 \pi$ & 15923 & 3.503 & 58 & \\
\hline & & 1 & ror & & & ...... & & & & & & $\cdots$ & & & $\cdots$ & $\cdots$ & & \\
\hline & $4 x$ & 3 & 167 & 1756 & 1923 & 66 & 5398 & 2 & 1 & 17 & 87111 & 323 & 3281 & 1450152 & 7825 & 1584 & & \\
\hline & 644 & & 5 & & 1329 & 140 & 2413 & 78 & 22 & 71 & & 1 & 661 & & 12051 & 50 & & \\
\hline 5 & 5 & 5. & 231 & 826 & 10 & 49 & 1237 & 44 & 22 & 33 & 46 & 90 & 199 & $42 \quad 330$ & 032 & ? & & \\
\hline 5 & 4 & 2082 & 466 & 3591 & 4057 & 120 & 5234 & 36 & 17 & 63 & 83105 & 331 & 534 & 5311189 & 6320 & 227 & $\ldots$ & \\
\hline & 9 & 9117 & 155 & 2031 & 2196 & 44 & 2846 & 17 & 11 & . & & 113 & 195 & $280 \quad 378$ & 2160 & 100 & & \\
\hline & & 8 & 11 & 13 & 15 & 2. & 1223 & & & 22 & & 34 & 51 & 25104 & $8 \pi$ & 80 & & \\
\hline & 1661 & 1650 & 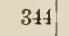 & 2997 & 3341 & 69 & 2219 & 20 & 8 & 14 & & 98 & 59 & $\begin{array}{ll}118 & 35\end{array}$ & 3611 & 400 & $\ldots$ & \\
\hline & 8 & & $75 \%$ & 876 & 163 & 17 & 1554 & 166 & 71 & 1 & & 35 & 366 & 5011393 & 8191 & & & \\
\hline
\end{tabular}


TABLE V.-Agricultural Statistics of South Carolina, for the year 1880, by Toumships.

THIRD SERIES.-(CONTINUED.)

\begin{tabular}{|c|c|c|c|c|c|c|c|c|c|c|c|c|c|c|c|c|}
\hline च & & Popt & ULAT & ION. & & & & Сотто & & & & Sтоск. & & & & GRAIN. \\
\hline 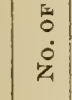 & $\frac{\dot{q u}}{\tilde{z}}$ & 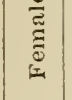 & $\frac{\stackrel{\rho}{E}}{E}$ & 离 & 焉 & $\begin{array}{ll} & \\
\vdots & \\
\dot{0} \\
z\end{array}$ & | & $\mid$ & & 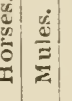 & $\stackrel{\circ}{=}$ & 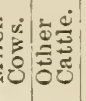 & $\mid \begin{array}{c}\tilde{\Phi} \\
\stackrel{\tilde{s}}{\infty}\end{array}$ & 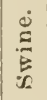 & 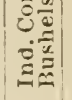 & 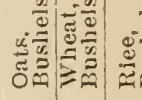 \\
\hline
\end{tabular}

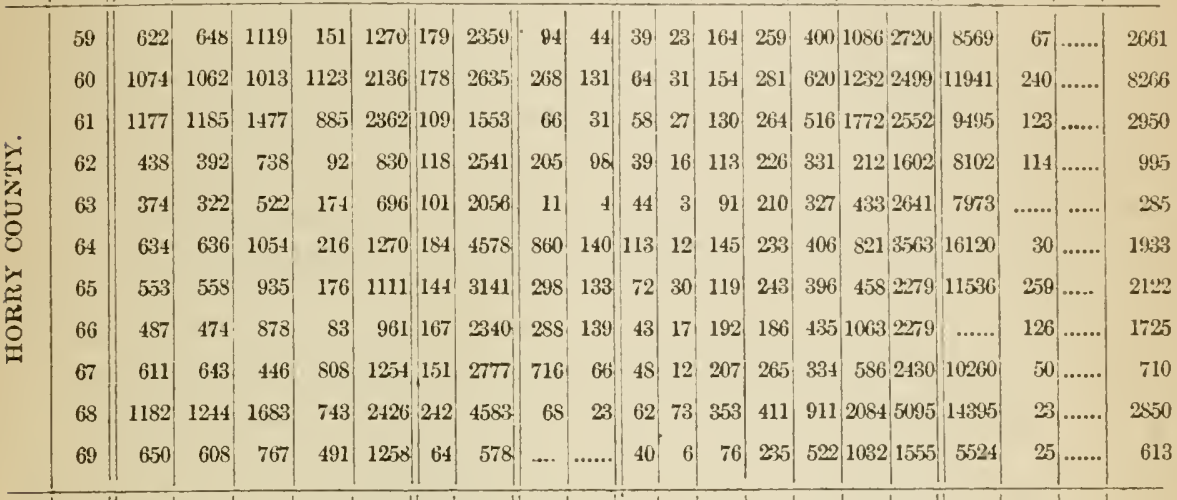

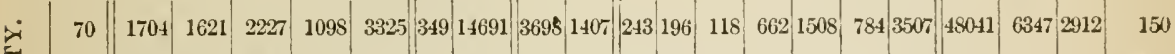

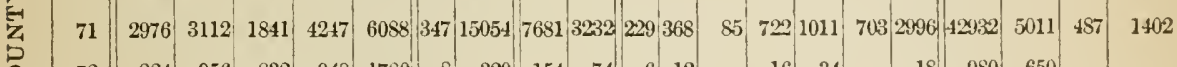

\begin{tabular}{l|l|l|l|l|l|l|l|l|l|l|l|l|l|l|l|l|l|l|l|l}
\hline 8 & 72 & 824 & 956 & 832 & 948 & 1780 & 8 & 320 & 154 & 74 & 6 & 12 & $\ldots \ldots$ & 16 & 34 & $\ldots \ldots$ & 18 & 980 & 650 & $\ldots . .$.
\end{tabular}

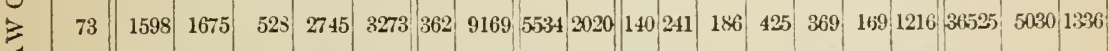

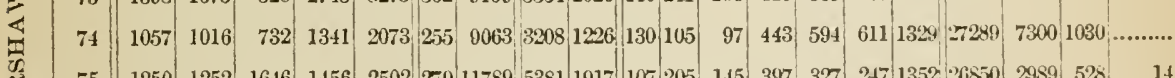

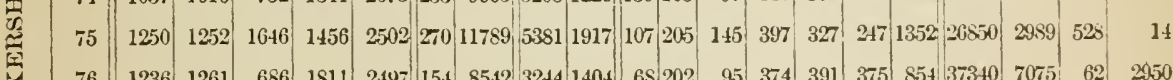

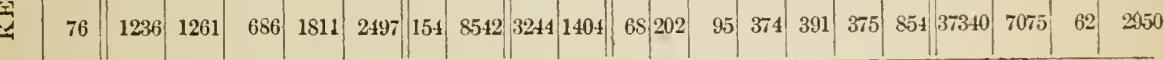



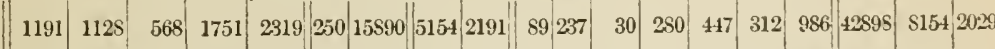

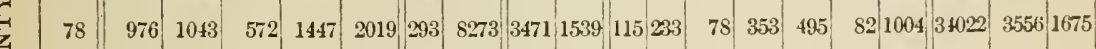

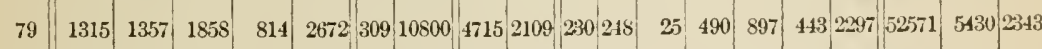

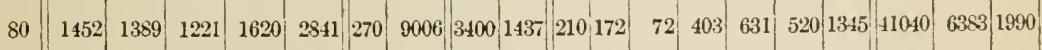

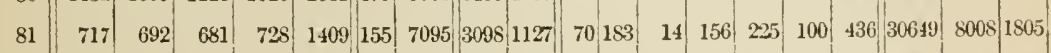

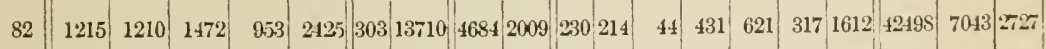

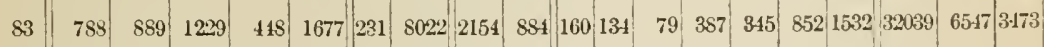

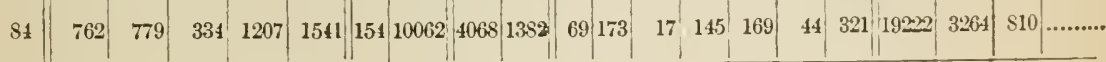


TABLE V.-Agricultural Statistics of South Carolina, for the year 1850, by Tounships.

THIRD SERIES.-(Contrined.)

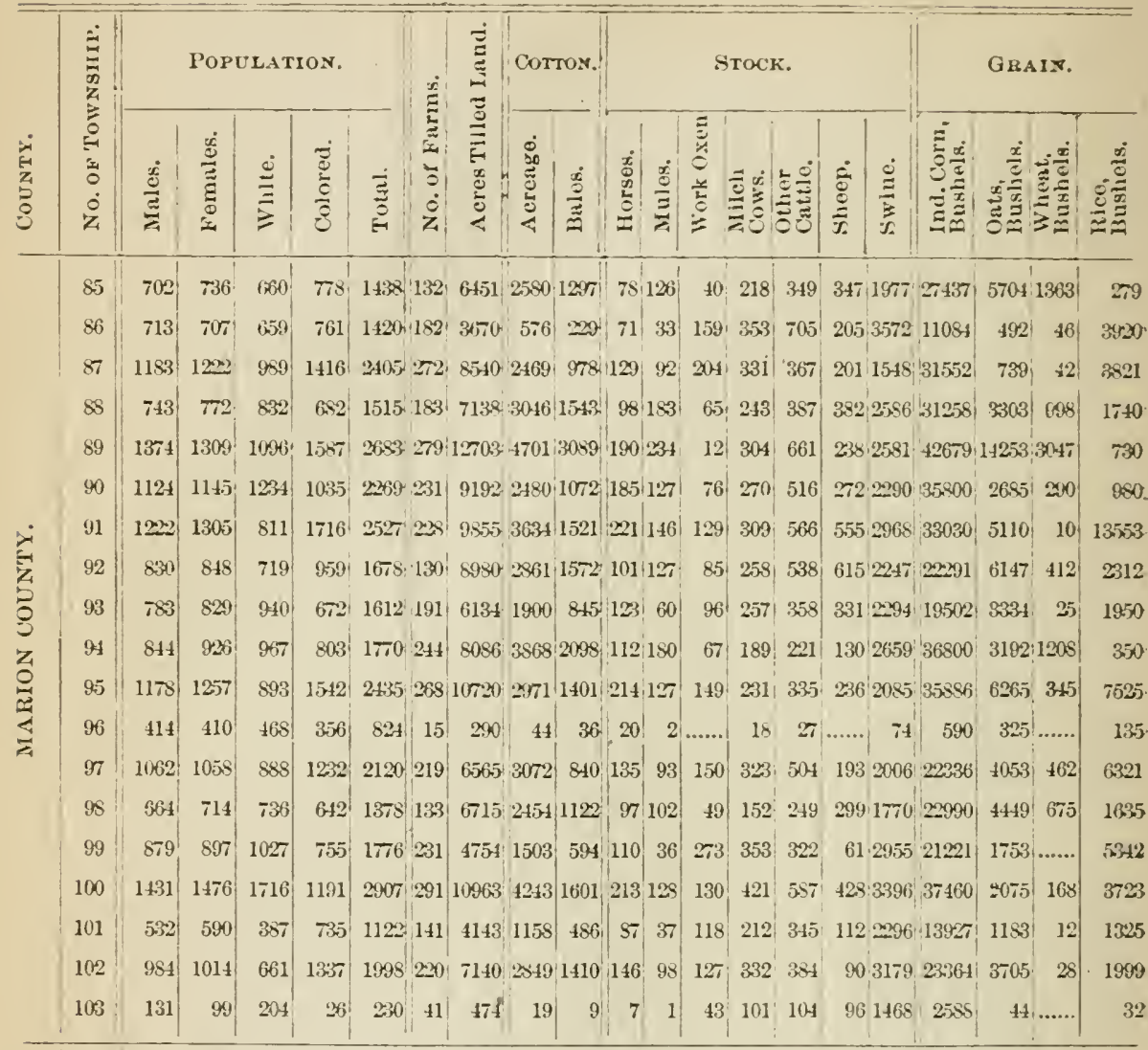

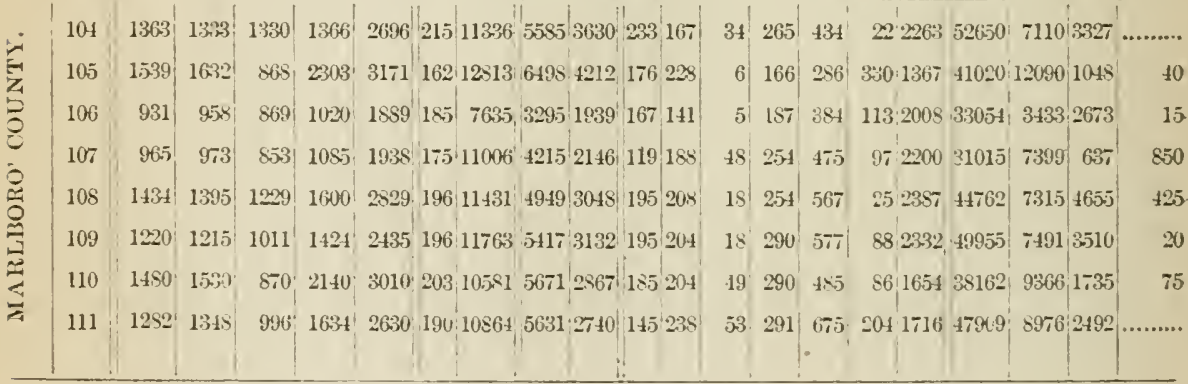


TABLE V.-Agricultural Statistics of South Carolina, for the year 1880, by Tounships.

THIRD SERIES.-(CoNCLUDED.)

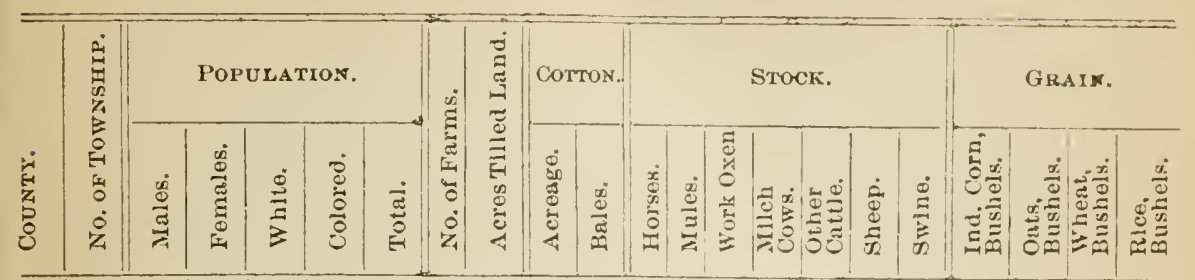

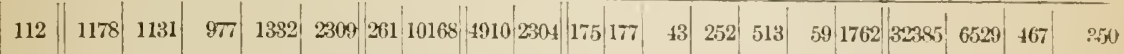

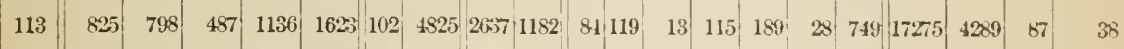

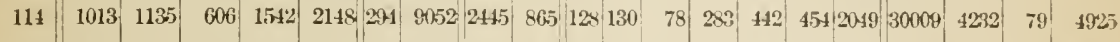

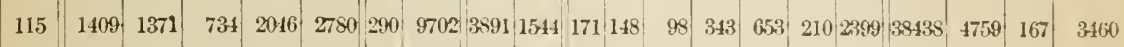

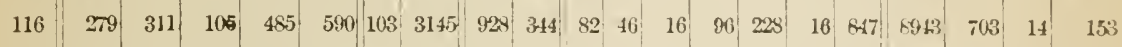

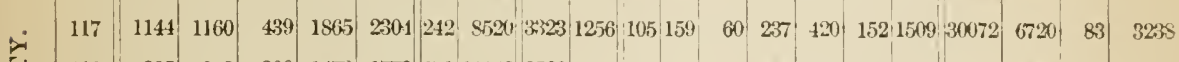

\begin{tabular}{l|l|l|l|l|l|l|l|l|l|l|l|l|l|l|l|l|l|l|l|l|l|}
\hline & 118 & 885 & 888 & 300 & 1473 & 1773 & 171 & 11142 & 2566 & 1190 & 111 & 146 & 55 & 240 & 257 & 210 & 1450 & 24405 & 5397 & 161 & 391
\end{tabular}

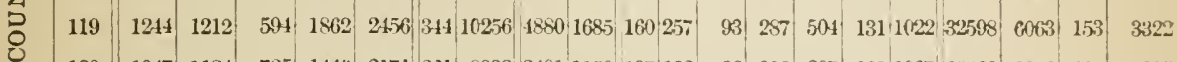

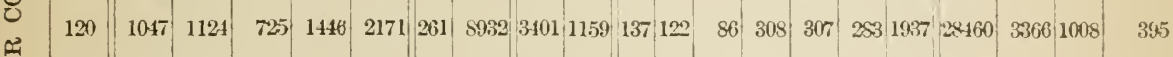

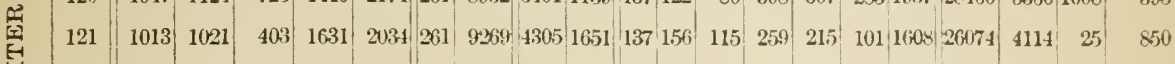

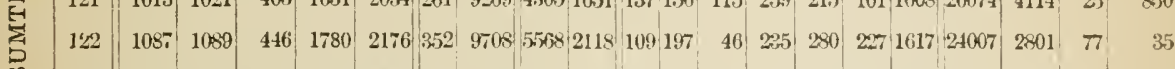

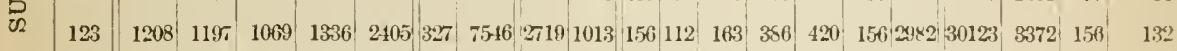

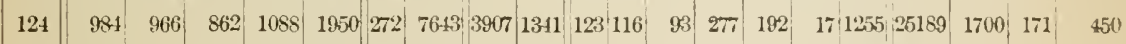

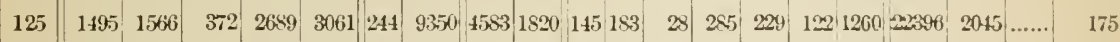

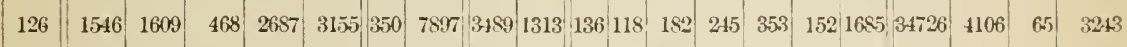

\begin{tabular}{l|l|l|l|l|l|l|l|l|l|l|l|l|l|l|l|l|l|l|l|l}
127 & 888 & 1123 & 1035 & 976 & 2011 & 20 & 382 & 96 & 47 & 27 & 4 & $\ldots \ldots$ & 28 & 18 & $\ldots \ldots$ & 34 & 1378 & 1455 & $\ldots \ldots$ & 250
\end{tabular}

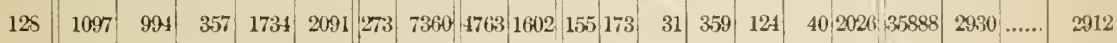

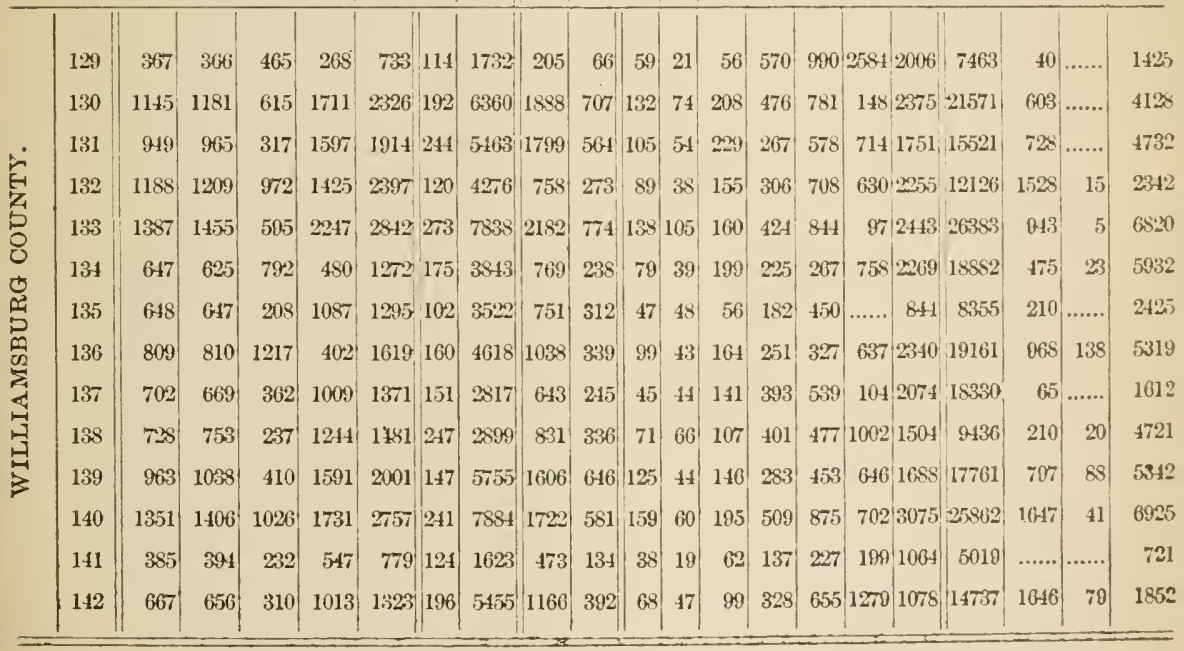





\section{PART II.}

AN ACCOUNT OF THE PEOPLE. 



\section{CH APTER I.}

\section{P O P U L A T I O N.}

\section{INDIANS.}

The three fundamental races of mankind, the yellow, the white and the black-the American, the European, and the African-are occupants of the soil of South Carolina. Within her borders, as elsewhere on many wider fields throughout human history, the still unsettled problems of the eonflict and intermingling of races present themselves for solution. Although four centuries barely separate us from the discovery of America, it would be quite as difficult to give an aceurate statement of the nations and tribes of the Indians and of their numbers, as encountered by the first European explorers, as it would be to turn back forty centuries and to disentangle the Egyptian, Ethiopian, Libyan, Chaldean, Nubian and Berber races, united under the sixth dymasty of the Pharaohs in the eonstruetion of the pyramids. The history of the.Indians is almost a blank. Their earth mounds, stone implements and weapons, and other relics, throw only a very uncertain glimmer of light over their past. 'Their vague traditions are known in some instances not to retain any count of many memorable erents for eren one century. Their origin is a subject open to the widest enjecture. Adair entertains the fanciful notion that they are descended from the lost tribes of Israel, and the proximity of Northwest America to Asia, has suggested their migration by way of Behring Straits to this continent. The most recent researches, noting on the other hand a general westward migration of the Indian tribes from the $\Lambda$ tlantic to the interior, and tracing a resemblance between their languages and that of the Basque people of Europe, hold that they are emigrants from that country. That they were driven thence by the intrusion of the Aryan hordes from 
the East, themselves contemplative and submissive races, whose character and language was modified by the high spirited, liberty-loving aborigines of Central and Western Europe, whom they absorbed or dispersed. A remarkable fact in the economy of the Indians is, that they alone, of all the peoples of the world, possessed and cultivated Indian corn, and that it was their only cereal. That the most valuable of all the grains should have been the exclusive possession of one people is sufficiently strange, but becomes much more so, when it is considered that this people were the least advanced of all in the arts of peace, that they were the poorest and most thriftless of laborers, in fact, in no sense laborers at all; and yet that they depended entirely for their bread on this grain, requiring more skill, care, and labor in its enlture than any other.

Great discrepancies exist as to the estimates of the condition and numbers of the Indians between the accounts of travelers in the 16th and in the 18 th centuries. 'The latter, in explanation of the small number of fragmentary tribes they found, where great and powerful nations were reputed to have dwelt, give the traditions of great wars, famines and epidemics, that were said to have occurred. The prevailing opinion now is that these were not exceptional occurrences among the aborigines, but that they had always been subject to such disasters, which had kept in check their population and their civilization. Bancroft and Draper think that, by the highest estimates that can be placed upon their numbers, all the Indlians east of the Mississippi, from the Gulf of Mexico to the St. Lawrence, did not, 200 years ago, exceed 180,000. As the great plains of the W'est were not habitable for man before the introduction of guns and horses by the Europeans, the estimate of these distinguished authorities may be considered as applying, with inconsiderable additions, to the whole area of the United States having its drainage towards the Atlantic. This area contains now (Rep. Secretary of Interior, 1851) 203,608 Indians, and the number of Indians in the United States, exclusive of Alaska, is 255,938.

Governor Drayton hazards the opinion that the Indians of South Carolina may have numbered originally 30,000 or 40,000 souls, but gives no data upon which it is founded. Adair says, that old traders stated that about 1700 , the Cherokees had 6,000 warriors. In 1752 , he found only some 2,300 warriors among them, and says, "so great a diminution, that after a like revolution of time there will be few of them alive." A prediction regarding the destructibility of a race, that, like many similar ones, has fallen far wide of verification. Mr. Bancroft says that the "Cherokees are more numerons now than ever."

The oldest reports from Georgia claim that there were only a few Indians within 400 miles of Savannah. John Lawson estimates very succinctly the Indian population of North Carolina as 4,780, men, women, 
and children, including 1612 fighting men, in the year 1700 . Judging from his journal of a thousand miles travel among the Indians, from South to North Carolina, they conld not have been more numerous in this State at that date.

The following is a synopsis of the natives and tribes of Indians mentioned as residing in South Carolina :

I NATIONS.

\begin{tabular}{lc} 
Nations. & \multicolumn{1}{c}{ Tribes. } \\
Cherokee & Echotee, Nequasse
\end{tabular} 4
Chatusee, Noyowce,
7
8 Estatoe, Tussee, Cussatee, $10 \quad 112$ Tugoola, Keowee, Echay, Aconee, Toxaway, Seneka, Tewraw, Tukwashwaw, 18, Th 19 Chickerohe, Naguchie, Totero, burg, which would make the Quacoratchie, Chota, Enoc, Stickoey, Esaw, Sapona, Wisack.

II

Catawba. 29
The Cherokees were a mountain race, oceupring extensive territory in Alabama, Tennessee, Georgia, Nortly and South Carolina and Kentucky. Less than $1-10^{\circ}$ of this territory is in the present boundaries of South Carolina, comprising the counties of Oconee, Pickens, Anderson, Greenville and Spartannumber of warriors in this State by Adair's computation, to have been 230 , or a total population not exeeding 1000. They were expelled in 1777 , for siding with the British, and are now the most advanced in civilization of the Indians.

The Catawbas were a C'anadian tribe, driven thence, in 1650 , by the more powerful Connewangas. Part of their number amalgamated with the Chickasaws and Choctaws. The remmant reached South Carolina in 1660 , fought a great Jatthe with the Cherokees on Broat river, and made that stream the dividing line between the two nations. They occupied York, Chester and Lancaster countics. Their warriors were estimated by Gorernor Grenn at 400, giving a population of about 1600 . 
III.

Uchees.
IV.

Creek or ${ }^{30}{ }^{31} \quad{ }^{32}$
II ${ }^{32}$ Kogee Savanna, Sernna, Cusoboe.
About 1-S of the territory of the Uehees extended across the Savannah river into Aiken, Edgefield and Barnwell counties. There is no estimate of their numbers. Their Princess of Cutifachiqui (Silver Bluff') entertained DeSoto with great splendor, a ceording to the narrittive of the gentleman of Elvas (1540). They were absorbed by the Creeks, and lave left no trace except in the name of a small stream in Silverton township, Aiken county, and of a neighboring steanıboat landing on the Savannah, Talemeco, after their great temple, which it is said stood there in DeSoto's time.

Fragmentary tribes on the Salvamnah river, south of the Uehees, in Barnwell county.

The Yamassees numbered about 100 men, women and ehildren, near Pocotaligo, in 1715 , and were driven across the Savamnah, by Governor Craven. Twenty men of the tribe were left at Saint Augustine, Florida, in 1743, and they were absorbed by the Seminoles.

The Yamassee, or Jamassi, were one of a small number of isolated tribes, of dark complexion, found widely scattered among the inhabitants of North and South America. Supposed to have been immigrants from Africa prior to the European discovery of America (see Hu- 
POPULATION.

man Species, Ly A. De Quat:efages). If this be su, it explains why D'Alyou persisted in slave liunting about Beaufort (152l), these negroes being valuable as laborers, while the Indians were worthless. It were strunge, too, if negroes first oceupied this seetion where they now predominate.

Salutah.

37

Congaree.

Santee.

$39 \quad 40$

Westoes and Stonoes.

Wateree and Chickasee.

43

Waxsaws.

Wenee.

Winyaw.

46
Sewee.
Located near Saluda old town, Newberry county, removed to Comnestoga, in Pennsylrania.

On the river of that name. Jno. Lawson visited them in 1700 , and found a town of 12 huts, one man at home and the women gambling.

Near Nelson's Ferry, in Clarendon. Jno. Lawson found a few of their huts, in 1700 .

Between Edisto and Ashley rivers, in Colleton and Charleston counties, amalgamated with the Catawbas.

On Pine Tree Creek, Kershaw county, Lawson says they were more populous than the Congarees.

Lawson makes a day's march from the last.

Indian, old township, Williamsburg county.

On the inlet of that name.

On Sewee bay. Lawson says the larger part of them were lost at sea, or rescued and sold as slaves by the English, in an at- 
$\stackrel{47}{43}$ Saraw or Cheraw.

49

Kadapaw.

tempt they made to open direct communication with England, by a fleet of canoes, in which they put to sea in the direction whence they hat observed the English ressels arrive.

Chesterfield and Marlboro counties, absorbed by the Catawbas.

Lyneh's creek, joined the Catawbas.

The Pee Dees are not mentioned, as it is thought the name is of European origin, probably from P. D., the initials of Patrick Daly, a white man, carved upon a tree by an early settler. The nineteen tribes, claimed under the Creek nation, occupying at least one-half of the State, appear: to have been very insignificant in numbers, according to the earliest authentic accounts of them. Governor Glenn sums them all up in one sentence. "There are among our settlements several small tribes of Indians, consisting only of some few families each." Lawson says of them : "Although their tribes or nations border upon one another, yet you may often discern as great an alteration in their features and disposition (he was much impressed by the comeliness of the Congaree women) as you can in their speech, which generally proves quite different from each other, thou gh their nations be not above ten or twenty miles in distance."

Admitting, however, that these seattered and fragmentary tribes equaled in numbers the Cherokees and the Catawbas, there is no datil for supposing that the total Indian population within the present boundaries of South Carolina could have much exceeded 3000 at the date of the early white settlements.

Accepting Lawson's enumeration (above given) of the Indians of North Carolina, and assuming an equal density for them in the two States, there would have been 2870 Indians in South Carolina.

Adopting the maximum estimate of Bancroft and Draper, it would give a population of one Indian to five square miles, or 6116 for Sonth Carolina. In 1750 there were in South Carolina 64,000 whites and negroes, so that eren at this early date immigrants from across the Atlantic exceeded the aborigines by more than ten to one.

By the census of 1851 , the number of Indians, chiefly Catawbas, in South Carolina, is 131 . This statement would seem to confirm the very general notion as to the rapid process of decay and extinction among the 
Indians. Such â conclusion is, however, by no means warranted, if account is taken of the number of Indians removed from the State and residing on reservations west of the Mississippi. The Cherokees are there more populous and prosperous than ever, and with them are Santees, Senekas, and the other small tribes absorbed by them. Furthermore, there is scarcely a township in the State in which one or more families (chiefly negroes) are not found, showing the distinct traces of the Indian descent which they claim. If such half-breeds numbered $6-10$ of one per cent. of the present population, there would be as much Indian hlood in South Carolina to-day as at the date of its settlement by the Europeans. The intermixture of the Indians witl the whites and negroes was facilitated by the total absence of all moral restraint among their women-there was no word for continence in their languages - as well as by the remarkable lack of sexual initiative on the part of the men, as observed by Lawson and others. In 1758, Anthony Park found a solitary Scotchman among the Indians west of the Alleghanies, who had liverl there forty years and was the father of some serenty children in the nation. One hundred such Scotchmen would have transmitted to another generation as much Indian blood as was found in Carolina by the first settlers.

The conclusion from such facts can only be that an inferior race, in a condition of absolute savagery, brought into contact with superior races, enjoying all the advantages of the highest civilization, has not only not dwindled away and perished, but has fully held its own and perpetuated itself. So indestructible is a race of men.

\section{NEGROES}

were brought to America as early as the year 1503. In 1511 they were pronounced by the Spaniards to be more robust and hardy, more capable of enduring fatigue, and more patient under servitude than the aborigines. The labor of one negro was computed as equal to that of four Indians. Charles V., in 1516, granted a privilege that was transferred to the Genoese merehants, of introducing four thousand Africans to the Spanish colonies; and Queen Elizabeth, through her agent, Sir John Hawkins, engaged, about 1567 , in a lucrative African slave trade with these colonies. A Dutch ressel, in 161s, sold part of her cargo of Africans to the English colonists on James river, Tirginia. The first negroebrought to South Carolina were brought by Sir John Yeamans, from the Barbadoes, in 1671. The year following, white slaves from England were sold in Virginia at $£ 10$ apiece, while negro slaves brought there, at the same date, from $£ 20$ to $£ 25$. In 1727 , the citizens of Sonth Carolina loudly complained of the importation of Africans, both because they 
were Africans, and because they could only be slaves. The mother country, however, persisted in forcing them upon the colony, maintaining, as late as 1745 , that "the African slave trade was the great pillar and support of the British plantation trade."

The negroes were brought from the whole western coast of $\Lambda$ frica, between the Sahara and Caffre land. There is no record of their lineage. A single ship would bring emigrants of different nations, and from places a thousand miles apart in Africa. They came as strangers to each other; they brought no common language, no abiding usages, no worship, no nationality. The admixture of diverse people thus inaugurated, was further greatly increased by the numerous and widely remote settlements in America among which the negro emigrants were distributed. Never in the same space of time was any race so rudely mixed, shaken together and sifted out.

Raynal and Hume compute that, outside of the United States, nine millions of Africans were forcibly imported into the various European settlements. The present treatise is not concerned with their fate, still it may be mentioned, that, of the total import into the British West Indies of two millions of Africans, there remained to enjoy the advantages of emancipation, in 1834, only six hundred and sixty thousand.

Nor was this fearful mortality due to climatic causes; for among the British troops in the West Indies, the average annual death rate for the whites was 8.81 per cent., and for the negroes, 3.91 per cent.

The importations of negroes into the United States never approached these figures. In Macpherson's Annals of Commerce(Tol.VI.,p. 150, et seq.), such statements as these are to be found. During the eight months ending 12th July, 1753, five hundred and eleven negroes were imported into Charleston; fourteen hundred and eighty-two Africans were imported into Georgia in the years 1765 and 1766 ; from 1783 to 1787 none were brought directly from Africa to the United States, but it was estimated that three hundred came annually from the West Indies. The slave trade was abolished by Act of Congress in 1776, but was reopened for the port of Charleston for four year's-1804 to 1807 . During this period the following numbers of African slaves were imported in two hundred and two vessels into Charleston, by citizens of foreign nations and the United States, as here given : 
By English merchants . . . . . . . . . 19,649

" merchants of Rhode Island . . . . . . . 8,238

" " " of other foreign nations . . . . . 5,177

" " " and planters of Charleston and vicinity 2,006

" " of other Northern States . . . . . 1,400

" " " of France . . . . . . . . 1,078

" " of other Southern States . . . . 6887

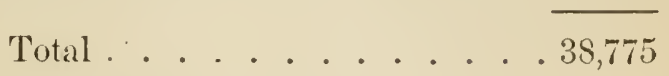

In 1714, there were in all the English colonies, from New Imampshire to South Carolina, fifty-eight thousand eight hundred anct fifty Africans, of whom it was thought that about one-half had been imported. H. C. Carey, in his work on the slave trade, domestic and foreign, gives the following estimate of the numbers of Africans imported subsequent to that date:

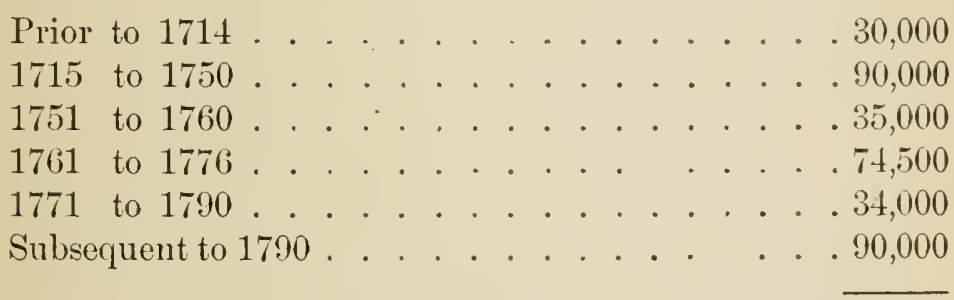

Total . . . . . . . . 353,500

By the United States census of 1790 , there were 757,208 negroes, which would make 464,858 , the number of the natural increase. This would be for the whole period of seventy-six years, from 1714 to 1790 , a natural increase upon those already in the country, and imported during that time, of something over one hundred and fifty-eight per cent., or more than two per cent. per annum.

At the date of the emancipation of the negro slaves, which practically took place in 1865 , they numbered about 4,600,000. Subtracting the number imported during this period, viz: 90,000 (a very large estimate), and not counting those who emigrated, this gives an increase of $3,752,792$, or the enormous natural increase in seventy-five years of four hundred and forty-two per cent. If there be something repulsive to the delicateminded in this rapid propagation of the human species under slavery, perhaps it may be admitted that it were better, as in this case, that twelve should be emancipated where one was enslaved, than as in the ease of the 
British West Indies, where the philanthropists only found one to be emancipated where four had been enslared.

But this rapid increase is by no means due to slavery. The free negroes increased during slavery even more rapidly, and while their numbers were angmented by manumitted slaves, the faet that their increase was somewhat the same in the slave, as in the free States, shows that it was dependent in a large degree on the birth rate. The numbers are for the

FREE NEGROES.

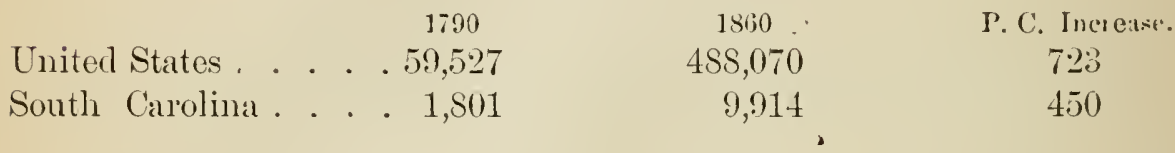

The census of 1880 shows that there are $6,580,793$ negroes in the United States, an increase of $1,980,793$, or a natural increase of forty-three per cent. during the fifteen years which have elapsed since emaneipation.

Practically, there has been no importation of negroes from foreign countries into South Carolina since 1810. By the U. S. Cersus of that year, there were 200,919 negroes in the State. The census of 1880 shows that the number has increased to 604,332 . But these figures do not show the full rate of increase. For in 1850, of negroes born in South Carolina there were 93,498 residing in other States, ehiefly in Georgia, Mississippi, Alabama and Florida, in the order here named. On the other hand, there were only 15,513 negroes residing in South Carolina, who were born ontside of the limits of the State. Showing a nett loss of 77,985 by emigrition in the negro population. Nor is this loss so great as the one in the preeeding decade on the same account. By the census of 1870 , it appears that 97,479 negroes born in South Carolina were living in other States, while the negro population of the State was only increased by 7,219 , born beyond its limits, showing a nett loss of 90,260 in a smaller population than that of 1880 .

The extraordinary rate of inerease among the negro population is one of the most interesting and important questions presented by the race problem in America. J. Stahl Patterson, who has made a special study of this subject, estimates this rate of increase for the negro raee thronghout the United States has been $33 \frac{1}{3}$ per cent. for the last decade, while that of the native whites at the North was less than 15.7 per cent. Should these respective rates of increase continue without interruption, for the next century, the negro would outnumber the native Northern whites by 12,000,000 , notwithstanding that at the present time the negroes stand six and one-half millions to twenty-four and one-half millions of Northern 
whites. Majorities may not always govern, even under universal suffrage, but they have their importance, and it is interesting to note that the competitors in point of increase with the negroes are the Southern whites, whose rate of increase is 30.4 per decade, and immigrants from Europe, whose rate of increase here is as great, or greater.

No effort adequate to even an approximate determination statistically of the intermixture of the negro and white race, has, as yet, been undertaken. The enumeration of mulattos, attempted by the census of 1860 and of 1870 , was entirely unsatisfactory, and, in the census of 1880 , none was attempterl. Mr. Patterson, who has given attention to the subject, says: "Even now they are no longer negroes. One-third has a large infusion of white bloord, another third has less, but still some, and of the other third it would be difficult to find an assured specimen of pure African blood." This is a startling statement, but in the absence of statistics, who puts it to the test among his negro acquaintance, will be surprised at the degree in which it conforms to the facts. If the lineage of those negroes whose coior and features seem most unmistakably to mark them as of purely African descent, be traced, indubitable evidence may often be obtained of white parentage, more or less remote. In such eases it will be noticed that external characteristies are by no means invariably associated with internal ones, and that such blacks are often more intelligent, and bear morally a closer resemblance to the white race than do many bright-colored mulattos. Here, as elsewhere, "in the crossings between unequal human races, the father" almost invariably belongs to the superior race. In every ease, and especially in transient amours, woman refuses to lower herself ; man is less delicate." (Quaticfages).

Thus, whatever adrance a race makes, it is the female who preserves and perpetuates it. The intermixture of the races being dependent on negro mothers will be most rapid and complete where the negro females are in excess to the males, and vice versa. In this connection it may be remarked that the number of negro females, in proportion to males, scems to have been steadily on the decline in South Carolina since 1850. The number of negro females to 100,000 males of that race, as given at the following dates, being:

$\begin{array}{cccc}1850 & 1860 & 1870 & 1830 \\ 105,290 & 104,192 & 104,232 & 102,938\end{array}$

The last figure is less than the ratio of white females to males, which, in 1880 , is 103,125 to 100,000 males. The proportion of females to males, among the negro population, is much greater in some of the Northern 
States. Thus, in Massachusetts, Comecticut, Rhode Island, New York, New Jersey and Pemnsylvania, there were, in 1850, 108,100 females to 100,000 males in the negro population of these States; and in 1SS0, the number is 108,419 females to each 100,000 negro males,

The centre of the negro population of the United States lies near the 84 meridian, between the 32 and 33 parallel north latitude, a few miles to southeast of Macon, Georgia. On the same meridian, but some 600 miles to the north, lies the centre of the foreign born population of the United States, between the cities of Toledo and Detroit. The foreign born exceeds the negro population by only about 100,000 , each being in the neighborhood of $6 \frac{1}{2}$ millions. On the same meridian again, and between the two centres named, is found at a point in Kentucky, a short distance southwest of Cincinnati, the centre of the aggregate population of the United States; since 1790 this centre has moved westward from the city of Baltimore along the 39 parallel of latiturle, a distance of 457 miles. The wide divergence of these two well marked and nearly equal streams of population, the European and the African, while making the same progress westward during so considerable a period of time, might naturally be taken to indicate that it was a result of latural and insurmountable climatic and geographical conditions. Between these poles the greater proximity by 200 miles of the aggregate population to the northem one, in consequence of the sympathy of Christendom with the European immigrants, and race prejudice against the African, have confirmed this plausible but superficial riew, and given rise to many wide spread and erroneous impressions, regarding the unsuitableness of the Southern section of the United States as a home for the Cancasian race. It has come to be regarded as a low, wet, marshy, malarial region, fitted for the negro and cotton culture, and owing to these, as it were accidental features, its chief importance. It should be remembered, however, that before the advent of negroes, and long before any importance attached to cotton, wealthy Englishmen, with the whole country open to them, well informed as to its climate and resources, after two centuries of explorations, made choice of South. Carolina as the locality best adapted for the material development of an English colony. The Northem and Afiddle States were colonized by political and religious refugees, or by persons of peculiar social views. The South was chosen as a land of promise for those who sought to increase their fortunes, and establish a people under conditions most favorable for their development. This is not the place to discuss the adventitious circumstances which have favored the mis-impressions here referred to; such, for instance, as the changes in the art of navigation, which opened the most direct and speedy communication between the nearest points of Europe and Ameriea, in 
spite of ocean winds and currents, whereas the sailing vessels of a hundred years ago found their easiest route from Europe even to New York, to be by Charleston. But the relation of the population to climatic and topographical conditions, as given by the 10th United States Census, will show that these are not real hinderances to the peopling of the South with greater numbers of the Caueasian race. For while it appears that the African race does not thrive outside of certain climatic limits, these limits include nothing injurious to the Caucasian race It will be noted that the pereentage of negroes diminishes in low temperatures and that it also diminishes in high temperatures, and that in both cases where the negroes decrease in numbers the percentage of foreign born Caueasians increase. It would seem that the more temperate and genial climate and the most fertile soils, haring been first occupied by Afrieans, European immigrants, influenced by prejudice against the institution of slavery, which has passed away, and by prejudice against a race which, as has been shown, has greatly changed, and is in process of still greater changes, have settled on less favored soils, under greater extremes of climate.

The following table shows the distribution of the population in elevation above the sea level, according to the 10 th Census.

PERCENTAGE OF

Foreign. Aggregrate. Negro.

\begin{tabular}{|c|c|c|}
\hline Below $100 \mathrm{ft}$ & 28.31 & 15.25 \\
\hline Between 100 and $1000 \mathrm{ft}$ & 40.07 & 59.41 \\
\hline Above $1000 \mathrm{ft}$. . . & 31.62 & 22.34 \\
\hline
\end{tabular}

Here the negro population occupies the medium elevations, while a larger percentage of foreigners occupy low lands or greater elevations. The largest percentage of the aggregate population is also found at the same elevations with the negro population. And in each instance, except as to extreme elevations, the distribution of the negroes more closely approaches that of the aggregate than the foreign does.

In South Carolina 27 per cent. of the negro population is below $100 \mathrm{ft}$. and of this number one-third is immediately on the coast, and not excecding $40 \mathrm{ft}$. above the sea level. The remaining two-thirds who live below 100 ( $\mathrm{ft}$. are thinly scattered over a wide region. It appears that each population falls off between an elevation 100 and 500 feet. Owing doubtless to the fact that these elevations, more than others, need drainage to render 
them suitable for human habitation. Between 500 and $1000 \mathrm{ft} .43$ per cent. of the negro population of South Carolina is found just where the largest percentage of the foreign and the aggregate population are located in the country at large.

The mean annual temperature of South Carolina varies from $50^{\circ}$ in the mountains to $64^{\circ}$ on the seaboard. Within this range of temperature is found fifty-four per cent. of the aggregate population of the United States.

The following table shows the distribution of the foreign, aggregate and colored populations in accordance with the mean annual temperature:

\begin{tabular}{|c|c|c|c|c|}
\hline & \multicolumn{3}{|c|}{ PERCENTAGES OF } & VEGETABLE PRODUCTS \\
\hline & $\begin{array}{l}\text { Foreign. } \\
.1 .30\end{array}$ & $\begin{array}{c}\text { Aggregate. } \\
1 .\end{array}$ & $\begin{array}{c}\text { Negro. } \\
0.03\end{array}$ & $\begin{array}{l}\text { of THE REgIONs. } \\
\text { Wheat. }\end{array}$ \\
\hline $40^{\circ}$ to $50^{\circ}$ & 53.66 & 37. & 3.67 & Corn. \\
\hline $50^{\circ}$ to $60^{\circ}$ & 40.03 & 44. & 36.52 & Tobacco. \\
\hline $60^{\circ}$ to $70^{\circ}$ & .4 .10 & 17. & 57.42 & Cotton, Rice, Sugar \\
\hline Above $70^{\circ}$ & . 91 & 1. & 2.36 & Tropical Fruits. \\
\hline & 100.00 & 100.00 & 0.00 & \\
\hline
\end{tabular}

Both the foreign and the aggregate population are distributed over a wider range of mean amual temperatures than the negro. The lower temperatures are doubtless not favorable to the latter, if indeed they are to any, but they occupy a temperate climate, and one that yields to the agriculturist the largest variety of the most profitable crops, with a mean anmual temperature similar to the region reported to have been the birth-place and cradle of the human race.

The distribution of the population according to the midsummer temperature, or the mean of July as the hottest month, is:

PERCENT.IGES OF

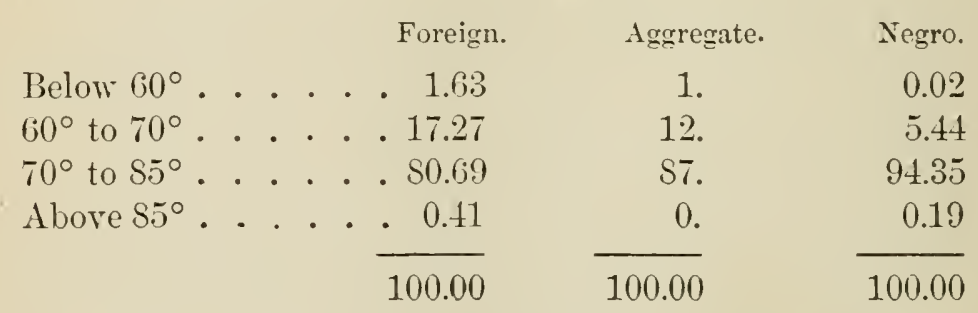

Here again the bulk of the population forms the mean between the negro and the foreign, and the latter has a wider distribution, especially as to the extremes of high and low temperatures. 
The distribution of the population according to winter temperature, or the mean temperature of January, taken as the coldest month, is as follows:

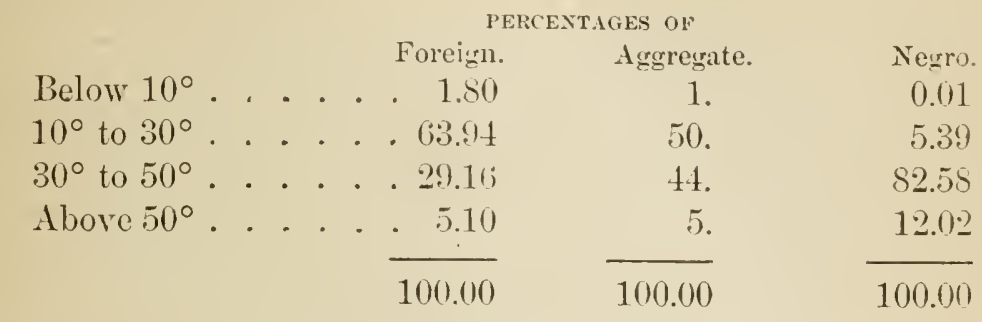

Here again the negro has a more restricted distribution in the more temperate regions than the foreigner, whose percentages exceed those of the aggregate in the extremes of both heat and cold.

The distribution of the population according to the greatest observed heat is as follows:

\begin{tabular}{|c|c|c|c|c|c|c|}
\hline & & & & PEF & $G E s \quad O F$ & \\
\hline Below $90^{\circ}$ & . & . & . & $\begin{array}{c}\text { Foreign. } \\
\text {. } 3.59\end{array}$ & $\begin{array}{c}\text { Aggregate. } \\
0 .\end{array}$ & $\begin{array}{c}\text { Negro. } \\
0.07\end{array}$ \\
\hline $90^{\circ}$ to $105^{\circ}$ & & . & . & .91 .87 & 94. & 96.53 \\
\hline Above $105^{\circ}$ & . & . & • & 4.54 & 6. & 3.40 \\
\hline & & & & 100.00 & 100.00 & 100.00 \\
\hline
\end{tabular}

-The extreme high temperatures here referred to are much more frequent at the North than at the South, and the result is shown by the numerous deaths from sunstroke at the North every summer. Such heat does occur at rare intervals at the South, and it is equally as fatal here, as witness the deaths in Charleston in June, 1876, when the hottest day in more than a century occurred.

The distribution under the extremes of cold observed is:

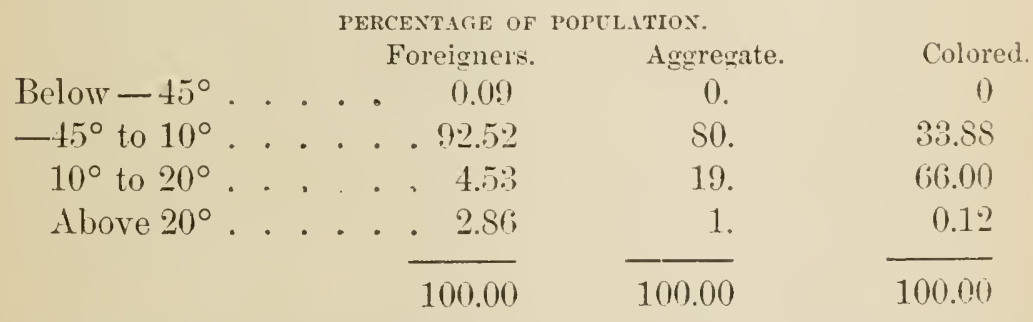

The remarks made regarding other climatic conditions apply here also ; the negroes occupy the medium and temperate regions, the aggregate population comes next, and on the outside, in the extremes, are the foreign born. 
Distribution of population in conformity to the annual rainfall, Table 1, and to the summer rainfall, Table 2 .

\begin{tabular}{|c|c|c|c|}
\hline \multicolumn{4}{|c|}{ TABLE 1st-P'ercextage of } \\
\hline Below $30 \mathrm{in.}$. & $\begin{array}{c}\text { Foreign } \\
.12 .89\end{array}$ & $\begin{array}{c}\text { Agrregate. } \\
0.08\end{array}$ & $\begin{array}{r}\text { Negro } \\
0.38\end{array}$ \\
\hline $30 \mathrm{in.} \mathrm{to} 45 \mathrm{in.}$. & .54 .5 .5 & $\therefore 2.57$ & 17.14 \\
\hline $45 \mathrm{in}$ to $60 \mathrm{in.}$ & $.81 .5 t$ & 89.65 & $76 . S S$ \\
\hline \multirow[t]{3}{*}{ Above $60 \mathrm{in.}}$. & .1 .02 & 1.70 & 5.60 \\
\hline & 1.00 .00 & 100.00 & 100.00 \\
\hline & \multicolumn{3}{|c|}{ TABLE 2D-PERCENTAGE OF } \\
\hline Below $13^{\circ}$ & $\begin{array}{l}\text { Foreign. } \\
5.86\end{array}$ & $\begin{array}{c}\text { Aggregate. } \\
2.89\end{array}$ & $\begin{array}{r}\text { Tegro } \\
0.20\end{array}$ \\
\hline $15^{\circ}$ to $25^{\circ}$ & .87 .8 .3 & 76.18 & 38.47 \\
\hline $25^{\circ}$ to $35^{\circ}$ & . 6.29 & 20.77 & 60.76 \\
\hline Above $35^{\circ}$. & .0 .02 & 0.16 & 0.57 \\
\hline & 100.00 & 100.00 & 100.00 \\
\hline
\end{tabular}

It is to be borne in mind that where the annual rainfall is less than twenty-five inches, or the summer rainfall, that is the rainfall during the crop season, does not reach fifteen inches, agriculture camnot be conducted profitably except by irrigation. And of course the irrigation afforded by streams traversing such regions must be so limited that a large agricultural population can take no foothold there. In these arid regions the bulk of the population is foreign, and engage little in agricultural pursuits. With regard to rainfall, as with the other factors of climate, the percentage of negroes is greatest where the conditions are most favorable for the support of the human race; the aggregate population have the next choice, and the foreigners again fall upon less farored regions. While the negroes oecupy regions of abundant rainfall, this rainfall is nowhere excessive, nor does it produce an atmosphere saturated with moisture. The porous eharacter of the soils of South Carolina, through which the water, not necessary for vegetation, readily disappears, and the large number of cloudless days make mist and fog, mildew and rust, a rare occurrence, so that even in areas of the heaviest rainfall the relative humidity of the atmosphere is similar to, but even less than that of the most noted health resorts of the world. (See Sand Hill Region Climate.)

Within the State of South Carolina the distribution of the negro population does not appear to have been determinately influenced by climatic or topographical conditions. They still preponderate most largely along the southern and south-western border's of the State, where they were first 
colonized. Hence they have spread over irregular areas, maintaining in them their preponderance even to the northern boundaries of the State. The areas thus suecessively occupied by them are those where cotton culture has been the leading pursuit. They are characterized by a light soil, of easy culture, yielding a crop readily and directly convertible into cash. requiring $n o$ fore-cast as to drainage and fallows, and no complex combinations of the areas to be directed to tillage and pasturage, to grain and cattle. Their minimum pereentage to the other population is found in Horry county, upon the southeastern seaboard of the State and diagonally across the State from this locality, among the mountains in the northwest. While three or four lines, where the white population predominates, eross the entire State in a north and south direction.

The rate of increase of the negro population from 1790 to 1860 was much slower in those counties in which they were originally the most numerous-in Beaufort, Charleston, Georgetown and Colleton. Here their numbers were barely doubled during this period, while they were being quadrupled in the State at large. They seemed to have reached their maximum then, and were on the decline. This was most marked in the case of Charleston county. Here, in 1790 , they numbered 34,546 , in 1830 they were 65,534 , and then steadily declined to 40,822 in 1860 .

Since 1860 the increase has been pretty uniform. Charleston has regained her losses, and reached and passed her maximum of 1830, numbering now 71,808 , but the other counties which were earliest most thickly peopled with this race still lag behind, and Beaufort, Colleton and Georgetown continue to show considerable losses, while the increase of the upper country has been large. This is the more notable, as this region where these losses have accrued is the very one thought best adapted to the African, being low, wet and warm.

The geographical indefiniteness of the eensus of 1870 does not allow the movements of the colored population during the last decade to be traced with precision. The following table gives the nearest approximation that could be obtained to the facts in this regard.

PERCENTAGE OF COLORED IN TOTAL POPULATION.

1870. 1880 Increase Decrease.

Alpine Region . . . . . 23

Piedmont Region. . . . . 49

Sand and Red Hills. . . . . 61

Upper Pine Belt . . . . . 665

Lower Pine Belt . . . . . 67

Coast Region..... . .90

$\begin{array}{lll}27 & 3 & * \\ 56 & 7 & * \\ 56 & * & 5 \\ 59 & * & 7 \\ 70 & 3 & * \\ 84 & * & 6\end{array}$


These figures show no tendency of the colored population to separate from the aggregate population and to become localized. On the contrary, the coast region, where they lave preponderated for generations, where they own more property than elsewhere, where they have retained undisputed control in political affairs, and where, in fine, every condition seems most favorable to promote, develope and maintain colored predominance, exhibits a marked decrease in their percentage of the propulation. At the same time in the Alpine and Piermont regions, where their numbers have always been smaller, an increase appears which more than compensates for the decrease on the coast. Such fluctuations seem rather to indicate that the colored race has a tendency to mix with the white population in certain limited proportions. This opinion gathers force by considering their ratio in the towns as compared with what it is in the rural districts in the different sections of the State. Thus, while the negroes form 86 per cent. of the rural population of Charleston (old), Beaufort and Georgetown counties, they only form 56 per cent. of the population of the towns themselves. And in the Piedmont region, while they are only 35 per cent. of the rural population of Greenville and Spartanburg counties, they form 45 per cent of the population of the towns. Of the 739 towns of the united counties having a population of 4,000 and upwards, only eight are without a colored population. Only three, however, in all this number, viz: Newbern and Wilmington, N. C., and Danville, I'a, have a colored population that reaches sixty per cent., a percentage quite common among the rural population.

The rapidly angmenting and more mobile populations of the towns may thus indicate what is to be the general tendency in the proportions of the races that where negroes are in excess of 56 per cent. they will diminish, and where they are less than 45 per cent. they will increase in presence of the white race. It is at least more probable that the final result will be determined by some law like this, and not by any wholesale movement on the part of either race. For the exodus of negroes to the northwest appears, in the light of the late census, to have amounted to nothing, just as their much talked of return to Africa from Charleston a few years since did. Mississippi, Louisiana and North Carolina, whence the emigrations took place, show large gains in their colored population; while Kansas and Iowa, whither these emigrants went, have actually lost in the relative proportion of the black to the white population. But while a movement in mass of the negro population has not and may never take place, the indications that their general diffusion is progressing rapidly are well marked. They are now present in greater or less number in every State and Territory, and are increasing most rapidly where formerly they were fewest. The northern and western non-slave- 
holding States had less than six per cent. of the negro population of 1860 , but they have nearly ten per cent. of the much larger negro population of 1880 ; and while the increase during this period was only forty-eight per cent. for the whole country, it was one hundred and twenty-five per cent. for this region.

Contrary, then, to the many theories on this subject, the facts, up to this date, point decidedly to a general dissemination of the negro race. To say that they are not adapted to these northem and western latitudes, and that they will only go there to be destroyed by the severity of the climate, is, to use an argument that has no general application to the great movements of mankind. Even now, the foreigners who go to those same regions, suffer fearfully from the severity of the climate, as shown by their death rate (see page 377 ); nevertheless, they continue to go.

The negro in South Carolina is performing a fair share of physical labor, but left to himself he is without initiative and is well content to do little work and to reap small profits. They are of temperate habits, and drunkenness and gluttony are rare among them. Without the more robust virtues or vices of the white race, they are cheerful, pleasant tempered and inoffensive. If they suffered grievous wrongs during slavery, as has been so widely asserted, with every opportunity and incitement from outsiders to do so, they have shown no disposition to take revenge upon their former masters. The personal relations between the two races continue most friendly, and perhaps no where in the world and at no time in its history, has such easy, considerate, kind and respectful intercourse subsisted between employer and employee, as between the Southern white man and the negro.

\section{EUROPEANS}

1497 derived their first knowledge of South Carolina from Sebastian Cabot, an English subject, who visited these coasts shortly after the discovery of the new world.

1520 D'Ayllon, in quest of gold and slaves, landed on St. Helena island, gave it its name, and claimed the country for Spain.

1562 Admiral Coligny sends a colony of French Huguenots, in two small vessels, to Port Royal; a settlement of twenty-six persons is made there; but the following year they build a vessel and return to France, leaving to the country only its name, Caroline, after their king, Charles IX., and a suall fort.

1629 The country is granted to Sir Robert Heath by Charles I. of England, under the name of Carolina. 
1663 Charles II. of England grants the country to certain English noblemen, styled the Absolute Lords and Proprietors of Carolina.

1670 The proprietors, at an expenditure of $£ 12,000$, send out two small vessels, under Capt. Wm.'Sayle, to Beaufort. This colony removes the next year to Ashley river, and a few years later occupy the present site of Charleston, and form the first permanent white settlement in South Carolina.

The proprietors offer to all immigrants lands at $£ 20$ per one thousand acres; where cash could not be paid, an annual rent of one penny per acre was required. For the first five years every freeman was offered one hundred acres, and every servant fifty acres, at an annual rent not exceeding half penny per acre.

1671 The proprietors grant land to a colony from the Barbadoes, under Sir Joln Yeamans.

1674 The proprietors furnish two small vessels to remove a Dutch colony from Nova Belgia (New York) to John's island, whence they spread into the surrounding country.

1679 Charles II. provides at his own expense two small vessels to transport foreign Protestants, chiefly French Huguenots, to Charleston.

1696 Members of a Congregational ehurch, with Mr. Joseph Lord, their pastor, remove in a body from Dorchester, Massachusetts, to the neighborhood of Charleston.

1701 According to Dr. Hewitt, the population of South Carolina is seven thousand. It consists of a medley from many countries, and of different faiths. There are Cavaliers and Puritans from England, Dissenters from Scotland, Dutchmen from New York, French Huguenots, and Africans.

1712 The Assembly of South Carolina offer $£ 14$ to the "owners and importers" of each healthy male British servant, between the ages of twelve and thirty years, "not a criminal."

1715 Five hundred Irish immigrate at their own expense to occupy the lands from which Yemassee the Indians have been driven, but finding them laid ont in baronies for the Lords Proprietors, most of them remore to the North.

$171 \mathrm{~S}$ The Lords Proprictors, having advanced $£ 1 \$, 000$ to the settlers, refuse to furnish additional supplies, and when asked for cattle, reply that "they wished not to encourage graziers, but planters."

1719 The proprietors sell their right and interest in the soil and government of Carolina to the king, for $£ 17,500$, and an additional $£ 5,000$ for the quit rents, over due by the colonists.

1724 Aeeording to Dr. Hewitt, the population is thirty-two thousand. 
1730 The colonial govermment marks out eleven townships of twenty thousand acres each, and offer fifty aeres, rent free for ten years, to every man, woman and child who would como over to oceupy them. After that period a rental of four shillings per one hundred acres was to be paid annually.

1731 The government offers Peter Pury $£ 400$ for every one hundred effective men brought over from Switzcrland. Three hundred and seventy arrive, and are granted forty thousand acres on the lower Savannah river, at Purysburg. (Full fare across the ocean at this time is $£ 5$ for immigrants.)

1733 The Scoteh-Irish descendants of the Scotch Covenanters, from Downe county, Ireland, settle Williamsburg county, named after King William III.

1735 A colony of Germans settle in Orangeburg county, which is named after the Prince of Orange.

1736 The Assembly grants a large tract of land on the Pee Dee to Welsh settlers from Pennsylvania.

1739 The council appropriate $£ 6,000$ as a bounty to the first two hundred immigrants (above twelve years of age, two under to count as one over that age) from Wales, settling upon the Welsh tract on the Pee Dee. They offered in addition to cach head above twelve years, twelve bushels corn, one barrel of beef, fifty pounds pork. one hundred pounds rice, one bushel salt, and to each male one axe, one broad hoe, one cow and calf, and one young sow.

1746 After the battle of Culloden many of the Scotch rebels were removed to South Carolina.

1750 Saxe Gotha township (Lexington eounty) was laid off and oceupied by settlers from Saxe Gotha, Germany. In the same year a colony of Quakers from Ireland settle Camden (Kershaw county).

1755 Governor Glenn opens the upper-country for settlement by a treaty he makes with the Cherokee Indians, obtaining from them the cession of a large tract of territory, and by erecting in the Northwest (Pickens county) Fort Prince George.

1760 After Braddock's defeat, numbers of Pennsylyanians and Virginians, feeling insecure on account of the Indians, move overland to the upper-country of South Carolina.

1764 King George furnishes $£ 300$, tents, one hundred and fifty stand of arms and two small vessels, to a colony of Germans, who receive, on reaching Charleston, $£ 500$ from the Assembly, and are assigned lands in Londonderry township (Edgefield county).

1764 Two hundred and twelve French Protestants reach Charleston, and are furnished transportation to Long Cane, Abberille county, where they settle New Bordeaux township. 
176.5 Population accorrling to Itewit: white, 38,000; colored, 85,000; total, 12:,000.

1753 'The war of independence being achieved, "multitudes from Europe and the Eastern and Viddle States of America mored into South Carolina."

Such, in brief, were the various and numerous peoples who contributed to the early colonization of South Carolina. The first permanent settlement had for its motive the ambition of certain wealthy English noblemen. In the hope of increasing their power and wealth, they offered lands, transportation, and bounties to all adventurers; offers not unacceptable to the crowded populations of Europe, who had fallen heirs to religious, social and political oppressions as their sole legacy. Afterwards colonization was promoted by direct trade with England, by European wars and persecutions, by military disasters in the Northern States, by largesses offered to settlers by the local government, and last, but above all, by the successful issue of the war of independence, which opened this country to the oppressed of all nations.

The following table shows the population of South Carolina and of the United States for each census, from 1790 to 1550 :

\begin{tabular}{|c|c|c|c|c|c|c|c|c|c|}
\hline \multicolumn{4}{|c|}{ UNited States. } & \multicolumn{6}{|c|}{ Solth Carolixa. } \\
\hline $\begin{array}{l}\text { CENSLS } \\
\text { YEAR. }\end{array}$ & 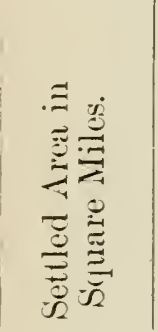 & $\underset{\Xi}{\stackrel{\Xi}{\Xi}} \underset{\Xi}{\Xi}$ & 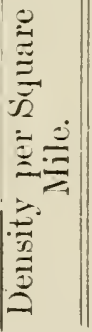 & 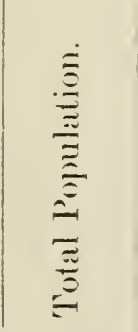 & $\stackrel{\doteq}{\Xi}$ & $\frac{\dot{0}}{0}$ & 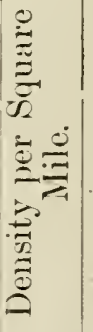 & 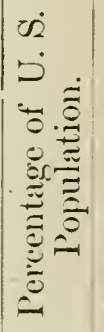 & 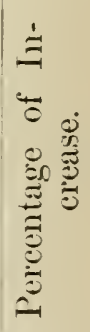 \\
\hline 1790. & 239,935 & $3,929,214$ & $|16.4|$ & 249 & $140,17 \mathrm{~S}$ & $10 S, 805$ & S. 2 & 06 & \\
\hline $1 S 00$. & 305,708 & $5,308,483$ & 17.4 & 34 & 196,255 & 149,336 & 11.5 & .06 & $3 S .7$ \\
\hline 1810 . & 407,945 & $7,239,8 S 1$ & 17.7 & 415,115 & $214,196^{\prime}$ & 200,919 & 13.S & .05 & 20.1 \\
\hline $1 S: 0$ & $50 S, 717$ & $9,633,822$ & 18.9 & $502,7+1$ & $237,4+0$ & 265,301 & 16.7 & .05 & 21.1 \\
\hline 1830 . & 632,717 & $12,866,020$ & 20.3 & $\overline{5} \$ 1,18.5$ & $257,863:$ & 323,322 & 19.3 & .04 & 15.6 \\
\hline $1 S 40$. & $S 07,292$ & $17,069,453$ & 21.1 & 594,395 & $259,084:$ & 335,314 & 19.7 & .03 & 2.2 \\
\hline 1850 . & 979,249 & $23,191,876$ & 25.7 & 665,507 & $274,563:$ & 393,944 & 22.2 & .03 & 12.4 \\
\hline $1 S 60$. & $1,194,754$ & $31,443,321$ & 26.3 & $703,70 S$ & 291,300 & 412,320 & 23.3 & .02 & 5.2 \\
\hline 1870. & 1,2 & $3 S, 558,371$ & 30.3 & $70.5,706$ & 259,667 & $+15,814$ & 25.3 & $.01_{10}^{\frac{8}{10}}$ & 0.2 \\
\hline 1880. & 570 & $50,155,78$ & 32. & דיד,5.5 & 391,1051 & 604,332 & $32.9 \mid$ & $.01_{10}^{9}$ & 41. \\
\hline
\end{tabular}


PERCENTAGE OF THE INCREASE

At Each Census, from 1790 to 1880, of the Population of Solth

Carolina, represented Graphically.

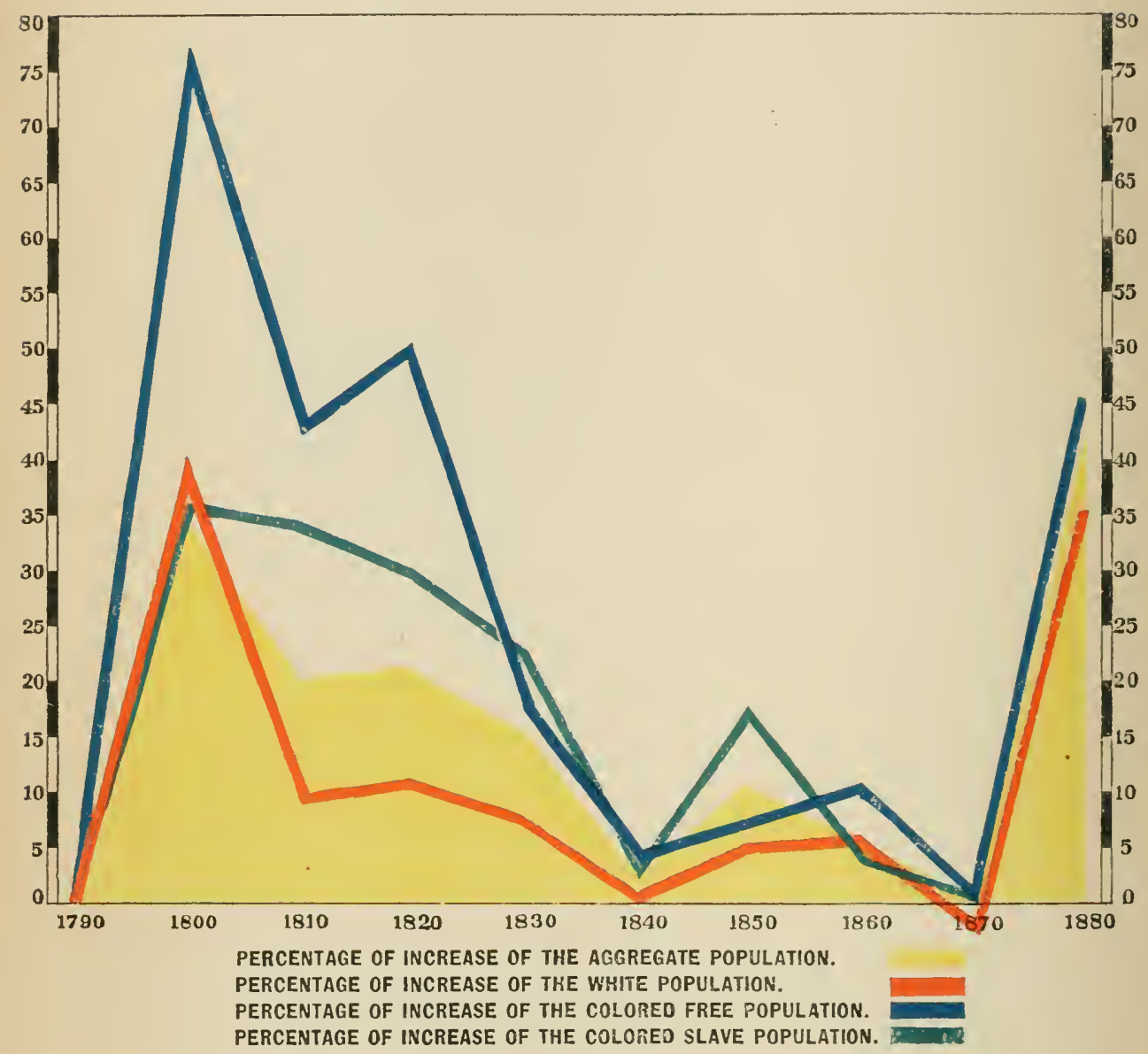


Percentage of Increase of the Population of South Carolina from 1790 to 1850.

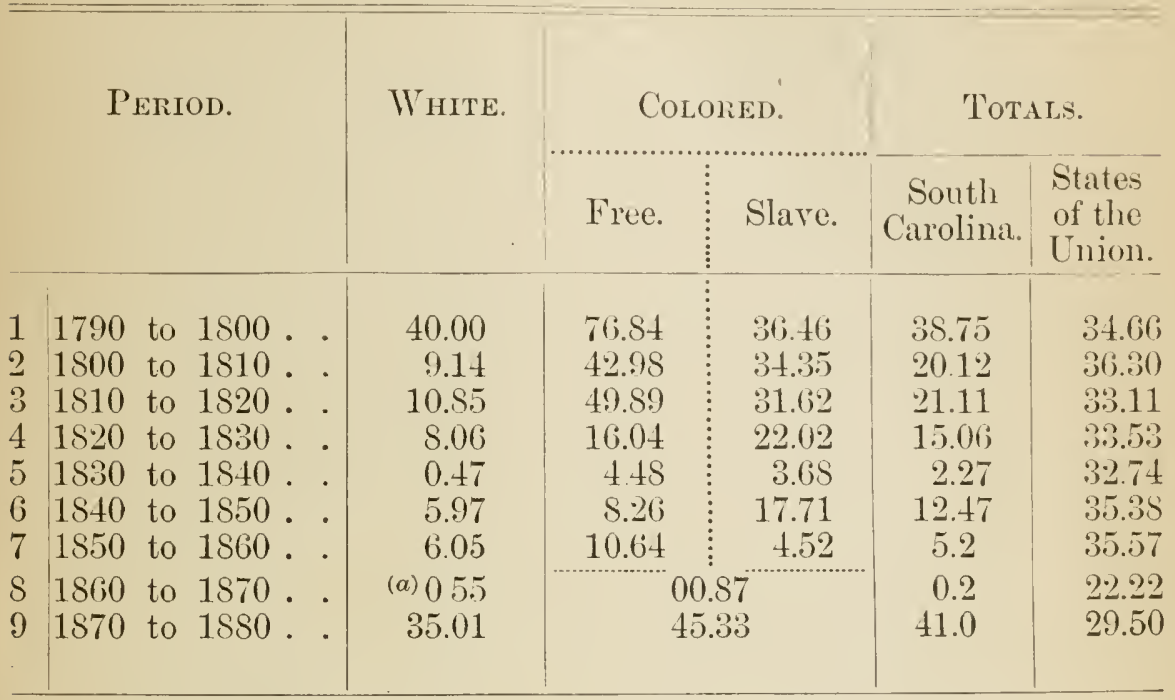

(a) Decrease.

\section{THE INCREASE OF THE POPULATION}

of South Carolina from 1790 to 1800 was greater that it has been at any subsequent period prior to the census of 1850 . The increase for that decade was much greater than for the country at large, and there were only five out of all the States, at that date, that were making a more rapid growth than South Carolina. The second decade-the one during which the slave trade was temporarily reopened at Charleston-showed a large diminution in the rate of increase; it went down sixteen per cent. below that of the country at large, and from fifth, the State fell to eleventh in the order of inerease. The third decade showed a slight improvement, and South Carolina stood thirteenth among the twenty-four States of that date in order of increase. In the fourth decade the decrease continued: twenty States had a larger growth, and South Carolina was increasing at a rate less than half of that at which the country at large was growing in population. The fifth decade was marked in South Carolina by the nullification agitation; the rate of increase fell enormously. While the country at large maintained nearly the same rate as at the outset, the rate here was only one-seventeenth of what, it had been in 1800, and South Carolina stood last of all the States, at this date, except one-Delaware. There was a marked improvement between $1840-50$, the rate of increase being nearly six times as great as in the preceding decade. 
Nerertheless, South Carolina was again lowest, except the States of Termont and New Hampshire, and the very erroneous opinion was entertained in some quarters that, like those States, she had about reached the limit of the population that her soil would sustain. The next decarle opened with the first secession agitation; there was a still lower rate of increase, and South Carolina still stood behind all the States except Vermont and New Hampshire. Then came the sixth decade, of war and reconstruction; the political and social doctrines at variance with the public opinion of all Christendom came to an open rupture, and were submitted to the arbitrament of the sword. The increase of the population was less than one per cent.; among the whites there was an actual decrease of one-half of one per cent., and South Carolina was behind all the States but Maine. The dust has scarcely lightened from the ruin wrought by this great overthrow than a new South Carolina appear's, more vigorous than ever. The census of 1850 shows that, from next to last, she has advanced above twenty-nine of her sister States, and stands eighth in the order of increase of the population. For the ninth decade her increase is forty-one per cent.-higher than it ever was-and more than one-third more than that of the country at large. One of the most remarkable features of this increase is, that it is not due, to any very large extent, to immigration, but chiefly to the large degree in which the migration of her natives to other States has ceased.

The obvious parallelism between the changes of the aggregate population and those of each of its constituent elements, indicates most clearly that here there has been no distinctive antagonism of the races and conditions of men. Slave insurrections and the dread of them have been much dwelt on. In reality, they have amounted to nothing. Only two are recorded in a period of more than two hundred years. In 1740, a mob of drunken negroes, supposed to have been incited thereto by hostile Spaniards, marched a distance of fifteen miles, murdering two clerks in a warehouse and Mr. Godfrey and his family. They were attacked by the congregation of a small country church at Willtown, who at once dispersed them without suffering any loss. In 1821, some negroes (34) were hanged in Charleston on what was held to be evidence of a conspiracy to excite a slave insurrection. The Hamburg and Ellenton riots, in 1876 , resulted in seventeen homicides, with, possibly, an equal number for all the election conflicts during reconstruction; and were all the casualties resulting from the contests of the whites and negroes in Sonth Carolina during the whole history of the State counted, the number would not equal that of the agrarian outrages reported in a single year in Ireland. For ninety years the increase of the white and colored population of the State las moved on parallel lines, with only two ex- 
ceptions. The variable element in each of these exceptions has been the slave population, which, in 1820 and in 1860, diminished, while the white and free colored were angmenting their rate of increase.

The variations are not great, and were, probably, due to the movement of slaves in larger numbers, at these dates, to the fresh lands of the Southwest. No such variations appear between the rate of increase of the whites and the free colored. With the facts as they presented themselves in 1860 , it is remarkable that, in view of the uniformly greater rate of increase of the free eolored population, that the Superintendent of the seventh census should have ventured to predict the disappearance of the negro race as the probable consequence of emancipation. It is noteworthy, regarding these predictions of the census office, made during the war, that, while the white population of 1880 in the United States falls fifteen per cent. short of the figure it was thought it would reach, the colored population reaches within one-half of one per cent. of the number it was estimated at. This prediction was based on the estimate that the colored race would increase at the rate of 22.07 per cent. in each decade, a rate of inerease that is less that the least recorded at any date for the aggregate population of the United States. In as much as the increase of the colored race has fallen short, in the last two decades, of even this moderate figure, the fears that have been expressed by certain scientific writers, that their numbers would attain proportions threatening the supremacy of the white race, are evidently without foundation in fact.

The wonderful recuperation in the rate of increase of the population of South Carolina within the last decade, after seventy years of steady decline in that rate, and so immediately after the final and overwhelming catastrophe of the decade of 1860 to 1870 , makes it plain that the limit of the natural resources of the State for sustaining a large population has not only not been reached, but that these resourees may be said to be almost untouched. If the drainage basin of the Santee river, the river of Carolina, were peopled as thickly as the basin of the Hudson or the Delaware, instead of a population of three hundred thousand, it would hold one of more than two and one-half millions. In natural advantages, whether the amount of navigable highway be considered, or the power its waters could furnish for stationary machinery, and the facility with which it might be utilized, or the healthfulness of the climate, or the fertility of the soil and the diversified crops it ean produce -in any and all these regards the river of Carolina will compare favorably with the others named. If the State were as thickly settled as Rhode Islar. $I$ and Massachusetts, it would eontain a population of seren to eight millions, a number equal to the population of the entire United 
States in 1810, more than double that of Scotland, and more than twice the population of Australia, now paying annually ninety millions of dollar's interest to England on loans of English capital invested there. Meanwhile, ten thousand square miles of the most fertile region of Carolina does not to-day average as many inhabitants to the square mile as are to be found in each house of the old town of Edinburg. Practically, therefore, in these regards, the natural advantages and capacities of South Carolina may be said to be unlimited. Whatever her future increase may be, it will suffer no let or hindrance on these accounts, but will depend upon the degree in which she can succeed in establishing and maintaining cordial relations with the other States and nations of Christendom. Freed finally and forever from all that in the past has so hcarily shackled their intercourse with outsiders, the polity of her people has taken a new and vigorous departure; they have thrown their gates wide open to all comers; aid and welcome is extended to immigrants; manufacturers are encouraged by relieving the capital invested in them from taxation, and their traditional doctrines of free trade would admit all people to their commerce.

\section{MOVEMENT OF THE POPULATION.}

The first settlements took place along the seacoast, thence, slowly moving inland, they followed the rivers. There were settlers in the upper-country as early as 1736 , but no great progress was made there until the middle of the eighteenth century. Meanwhile there remained, as there is now and has been during all the movements of population in the State, a vacant or thinly-settled belt between the upper and the lower country. The State is this day traversed by two such belts of thinlysettled country, the sand hill region and the flat lands of the lower pine belt. The first is comparatively narrow, and is due to the dry and sandy soil which unfits it, in large measure, for the present methods of agriculture. The other is due to the want of drainage, which, with the accession of wealth, will be remedied, and an cxtensive and fertile region will be opened to settlers.

The Indians were, perhaps the most mobile of all the populations that have inhabited South Carolina. Nevertheless, there is everywhere and always a continual morement of the population in progress. Even in England and Scotland, where the population might be considered "to the manor born," it has been found that only a little over seventy-five per cent. were living in the counties where they were born. If for counties, States are substituted, about the same percentage obtains for the United States, a little more than seventy-six per cent. of the native popu- 

lation being found in the States in which they were born, according to the census of 1880 . This percentage, however, varies widely in the different States. In Vermont, only fifty-eight per cent. of those born there were found remaining in their native State. In Texas, on the other hand, this percentage was ninety-five, as given, in both instances, by the census of 18S0. For South Carolina it is eighty per cent., and only fourtecn out of thirty-eight States retain more of their native population. than she does. The fluctuations that have oecurred in this regrard will be seen by reference to the following data, taken from the returns of the United States census for the years specified :

Movement of the Population of South Carolina in the United States, and from other Countries.

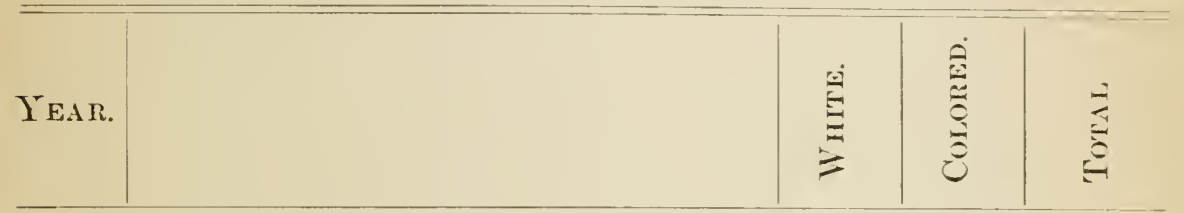

Persons born in S. C. living in the U. S. 470,257

Persons born in S. C. living in S. C. . . 276,868

1860 Loss by movement within the U.S. . . 193,389

Population of S. C. . . . 291,300 $412,40 S$ 703,70s,

Gain by immigration from all quarters. 14,432

Balance of emigration over immigration. 178,957

Persons born in S. C. living in the U. S. 418,575,505,899

Persons born in S. C. living in S. C. . . $270,301408,407$

1870 Loss by morement within the U.S. . . 145,57t 97, 492

Population of S. C. . . . . 290,067415,935

Gain by immigration from all quarters . 19,766 17,531

Balance of emigration over immigration. $128,509 \quad 79,961$

924,774

$67,70 \mathrm{~s}$

246,066

706,005

37,297

208,770

Persons born in S. C. living in the U. S. 500,9946S2,\$17 1,1S3,311

Persons born in S. C. living in S. C. . . 363, $\pi 6558,519 \quad 952,395$

$1 S S O$

Loss by movement within the U. S. . . 137,418 93,498

Population of S. C. . . . . . . 391,105601,472

$\begin{array}{llll}\text { Gain by immigration from all quarters. } & 27,529 & 15,653\end{array}$

Balance of emigration over immigration. $109,599 \quad 77,845 \quad 187,734$ 
Percentage of the Population at cach Decade.

\begin{tabular}{|c|c|c|c|c|}
\hline YeAr. & & 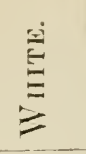 & 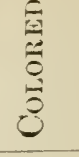 & : \\
\hline 1860 & $\begin{array}{l}\text { Born in S. C. and residing in other States. } \\
\text { Coming into S. C. from all quarters } \\
\text { Balance of emigration over immigration. }\end{array}$ & $\begin{array}{l}.66 \\
.04 \\
.61\end{array}$ & & \\
\hline 1870 & $\begin{array}{l}\text { Born in S. C. and residing in other States. } \\
\text { Coming into S. C. from all quarters . } \\
\text { Balance of emigration over immigration. }\end{array}$ & $\begin{array}{l}.51 \\
.06 \\
.44\end{array}$ & $\begin{array}{l}.23 \\
.04 \\
.19\end{array}$ & $\begin{array}{l}.34 \\
.0 .5 \\
.28\end{array}$ \\
\hline 1880 & $\begin{array}{l}\text { Born in S. C. and residing in other States. } \\
\text { Coming into S. C. from all quarters } \\
\text { Balance of emigration over immigration. }\end{array}$ & $\begin{array}{l}.35 \\
.07 \\
.28\end{array}$ & $\begin{array}{l}.15 \\
.02 \\
.13\end{array}$ & $\begin{array}{l}.23 \\
.04 \\
.17\end{array}$ \\
\hline
\end{tabular}

There can be no doubt as to the significance of these figures. The immense losses the State has hitherto sustained in the migration of her matives to other States, is rapidly lessening, especially as regards the white population. Natives of South Carolina are found in erery State and Territory of the Union, not excepting Alaska. They are met with in the largest number in the following States, varying in the order here named, from 50,000 to 11,000: Georgia, Alabama, Nississippi, Texas, Florida, North Carolina, Arkansas and Temnessee. Natives of each State and Territory of the Union, except Alaska and Washington Territory, are found in South Carolina; the largest number are from North Carolina, 17,297; Georgia, $7,6+1$; Virginia, 4,15s; New York, 1,070. There are, also, among the citizens of South Carolina, natives of each of the following countries: Africa, Asia, Australia, Anstria, Belgium, Bohemia, Canada, New Brunswick, Nora Scotia, Newfoundland, British Ameriea, Central America, China, Cuba, Denmark, France, Baden, Bavaria, Brunswick, Hamburg, Hanover, Hessen, Mecklenburg, Nassau, Oldenburg, Prussia, Saxony, Wurtemberg, England, Ireland, Seotland, Wales, Greece, Greenland, Holland, Hungary, India, Italy, Malta, Mexico, Norway, the Pacific Islands, Poland, Portugal, Russia, Sandwieh Island; South America, Spain, Sweden, Switzcrland, Turkey, and the West Indies, 
besides thirty-two born on the high seas. The total number of foreign born is 7,686 , which is 2,300 less than in 1860 , showing that the State has not yet resumed relations, as they existed previous to the war, with foreign countries, despite the efforts being made to encourage immigration. That the conditions of life in South Carolina are unusually favorable to foreigners is shown by the fact of the much larger proportion of persons descended from foreign born parents in South Carolina than in the country at large. Thus, the number of persons in this State having one or both parents foreign born. is 21,666 , or something over 2.8 for each resident foreigner, while for the country at large it is only 2.2 for each resident foreigner. That persons of foreign descent in South Carolina should number 182 per cent. of the foreign born population of the State, and only 128 per cent. of that of the whole country, is due to the lower rate of mortality and to the higher rate of natural increase promoted by a more temperate and healthful climate in Carolina, and also doubtless to moral causes. These are, that owing to the large colored population of the State, the more skillful and intelligent foreigners are able to command more remumerative positions in the higher occupations here than elsewhere. And when their descendants, having more time for observiation, ascertain this state of things, they are not slow to migrate hither, from places where, from the facilities offered by transportation, their parents may have first landed and settled. Thus 12 per cent, of the foreign population of the whole country is engaged in agriculture, but only 6 per cent. of that population in South Carolina is so engaged; 14 per cent of the foreign population of the country is engaged in personal and professional service against $10 \mathrm{per}$ cent. in South Carolina; and of this 14 per cent. 11 per cent., or 777,382 foreigners belong to the lowest of drudgeries, that is to the class of common laborers and domestic servants. In the higher and more remunerative occupations of trade and transportation only 7 per cent. of the foreign population of the country at large find occupation, while 19 per cent. of that of South Carolina is thus engaged. Again, in manufactures and mining, 18 per cent. of foreigners in the country at large find work, against 11 per cent. of that population in South Carolina; and of this 18 per cent. there are 126,325 miners; 74,961 cotton factory operatives, and 167,971 operatives and laborers in other manufacturing establishments; making in all 5 per eent. of the entire foreign-born population in this class of laborious and comparatively poorly paid occupations. Now that slavery is abolished and labor is free here, foreign workmen and artisans will not be slow to perceive the better chance offered by the condition of affair's in Carolina. 


\section{SEXES.}

There are fourteen thousand scren hundred and sixty-one more females than males in South Carolina, or something over three per cent., indicating a peaceful and settled mode of life, and the prevalence of such oceupations as furnish employment to females. In the ratio of females to males South Carolina ranks sixth among the States of the Union, the District of Columbia standing first. The Western and newer States, where the conditions of life are harder and the occupations require more robust natures, rank lowest, and in some of them the number of females are only half the number of males. Within the State the males are slightly in excess in Horry and Clarendon counties, and in portions of Colleton, Hampton, Barnwell, and Edgefield. Elsewhere females predominate.

\section{AGES.}

Multiplying the number of individuals enumerated at each age and adding the products together, the aggregate number of years lived by the population is ascertained. This aggregate for the population of the entire United States, accorching to the late Census of 1850 is $1,211,565,528$ years. If divided by the number of individuals it will give an average of $247-10$ years for each. For South Carolina the arerage number of years for each individual ascertained in the same way is $2127-100$ years. At first view it might be inferred that the population of South Carolina, having lived fewer years, was the shorter lived. The real explanation is however, quite different. Foreigners constitute about 12 per cent. of the population of the United States and only $7-10$ of 1 per cent. of that of South Carolina. The maximum number at any one age among the foreign-born population is found between the ages of 40 and 50 , while among the native population this maximum varies from the age of one year for colored females in the United States to six years for the same class in South Carolina. Thus it happens that the number of years lived by the population, including the larger percentage of adult foreigners is swelled by the number of years these immigrants have lived in other countries, while the year's lived by the native population is diminished by the deaths common everywhere in the early periods of life. This observation has especial force in South Carolina, owing to the greater number of ehildren there. It will be found also that the aggregate of years lived by those attaining old age in South Carolina gives an average of $772-10$ years for each person over 70 , while this average for the country at large, despite the ad vantage given by the foreign element, is only 
76 years. Which indicates that the chances for longevity of persons advanced in life is greater in Carolina than elsewhere. If instear of the above estimate, the number of individuals enumerated at each age be multiplied by the mean future expectation of life from that age, as given in life assurance tables, it will be found the results for South Carolina and for the United States agree very nearly, being about 33 years each.

From an economical point of view, the ages of the population may be considered in regard to the proportions between the number of persons belonging to the dependent ard the number belonging to the self-sustaining and contributing ages. The following table shows the number of persons in each 1,000 of the male and femaie, white and colored native population of South Carolina and of the United States at the early dependent or formative age, 1 year to 15 years; at the self-sustaining and contributing ages, 15 years to 70 years; and at the later dependent age, 70 years and over, according to the United States C'ensus of 1850 :

\begin{tabular}{|c|c|c|c|c|c|c|c|c|}
\hline \multirow{3}{*}{ AGES. } & \multicolumn{4}{|c|}{ White. } & \multicolumn{4}{|c|}{ Colored. } \\
\hline & \multicolumn{2}{|c|}{ Male. } & \multicolumn{2}{|c|}{ Female. } & \multicolumn{2}{|c|}{ Male. } & \multicolumn{2}{|c|}{ Female. } \\
\hline & U.S. & S. C. & U.S. & S. C. & U.S. & S. C. & U.S. & S. C: \\
\hline 1 to 15 years. & 445 & 459 & 443 & 422 & 464 & 508 & 460 & 483 \\
\hline 15 to 70 years. & 535 & 523 & 539 & $5.5 \%$ & 521 & 473 & 521 & 497 \\
\hline 70 y'rs \& over. & 17 & 18 & 18 & 21 & 15 & 19 & 19 & 20 \\
\hline Total.. & 1000 & 1000 & 1000 & 1000 & 1000 & 1000 & 1000 & 1000 \\
\hline
\end{tabular}


The following table gives the same data for the aggregate population, and for the male and female foreign born population of South Carolina and of the United States, and the average of seven European States:

\begin{tabular}{|c|c|c|c|c|c|c|c|}
\hline \multirow{3}{*}{ AGEs. } & \multicolumn{2}{|c|}{ AgGregate. } & \multicolumn{4}{|c|}{ Foreigis Bors. } & $\Xi$ \\
\hline & \multirow[b]{2}{*}{ U.S. } & \multirow[b]{2}{*}{ S. C. } & \multicolumn{2}{|c|}{ Male. } & \multicolumn{2}{|c|}{ Female. } & \\
\hline & & & U.S. & S. C. & U.S. & S. C. & $\frac{12}{1}$ \\
\hline 1 to 15 years. & 399 & 470 & 70 & 29 & 79 & 45 & 336 \\
\hline 15 to 70 years. & 582 & 511 & 899 & 921 & $\$ 86$ & 894 & 632 \\
\hline 70 years and orer. & 19 & 19 & 31 & 50 & 35 & 61 & 32 \\
\hline Total. & 1000 & 1000 & 1000 & 1000 & 1000 & 1000 & 1000 \\
\hline
\end{tabular}

The most notable feature in these tables is the greater number of young persons in South Carolina than in the country at large and the still greater number than in foreign countries. While this necessarily adds to the burden of the working population, it forms the hope of the future, and life is so much easier in South Carolina than it is in more densely peopled countries, that the promise to multiply and increase and replenish the earth is still regarded here as a promise of blessing, and surprise is felt that it should anywhere be a burden. There are only two exceptions to this preponderance, namely, among the foreign-born and white females. The foreign-born however do not seem to find the conditions unfarorable to them, the proportion that pass on through the working period of life to full old age being much greater in this state than it is either in the United States at large, or in their native countries. The somewhat smaller proportion of white females, if not accidental, is otherwise unexplained, unless it results from a diminution of female births, which might also account for the diminution of females to males, which has oceurred within the last decade.

It will be observed that in the particular above referred to, the ages of the population of the country at large resemble those of the European populations more than the ages of the population of South Carolina do. 
In Europe the natural increase of the population is much restrained, the closer struggle for existence there tells against the young, adults are required to endure its hardships, and hence their preponderance. And it is at once sad and curious to reeall that in this, these highly civilized Christian nations resemble savage tribes, among whom the pronortion of children to adults is always small. The population of South Curolina, as represented by the numbers at the different ages, is one growing rapidly by natural increase, and under favorable conditions; these farorable conditions being exhibited by the relatively large numbers passing over from the working period of life to old age. Such a state of things is highly promising, provided that the numbers in the early formative age realize by their labors on reaching the self-sustaining and contributing age what has been expended in rearing them.

It is a popular estimate that one-fifth of the population are fighting men. If this is intended to designate the natural militia, that is the male population over eighteen and under forty-five years of age, it will almost always be an over estimate except in a population receiving large accessions of adult immigrants or among savage tribes. It is true that during the war of secession South Carolina is estimaterl to have put 60,000 men in the field from a white population, from eighteen to fortyfive years, not exceeding 55,0 0 . This was during a period of four year's however, and the number actually in service at one time probably never exceeded 44,000. During the war of the Revolution, 1775-S3, South Carolina furnished more than eight per cent. of the entire American forces.-(Rep. Secretary of War, Nay 10th, 1790,) although her white population was only four per cent. of that of the old Thirteen States. During the war with Mexico, 1S46-4S, the voluntecr troops from South Carolina sustained one-seventh of all the casualties in the voluntecr forces of the whole country. South Carolina's losses in the Confederate service, 1861-65, is estimated at 12,000 men. Thile in times of war South Carolina thus "stiffened her sinews and bent up every spirit to its full height," in times of profound peace, as at present, she feels there i. "nothing more becomes her than quiet, stillness and humility." IIer" military service is purely voluntary. The whole number of troops enrolled is about 4,000 , of whom only about 2,500 parade at inspections. The Legislature appropriates $\$ 5,500$, or $\$ 1.35$ a man, in aid of those connected with the military organizations of the State. The following table shows, according to the United States Census for the year's specified, the numbers of the natural militia in the white (native and foreign), the colored and in the aggregate population of South Carolina and of the United States, and also the percentage of this elass in each of the above named constituent elements of the population and in the total population: 
MALES FRONI 18 TO 45 YEARS OF AGE.

\begin{tabular}{|c|c|c|c|c|c|c|c|c|}
\hline \multirow[b]{2}{*}{ YeAR. } & \multicolumn{4}{|c|}{ White. } & \multirow[b]{2}{*}{ Colored. } & \multirow[b]{2}{*}{ 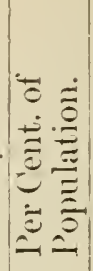 } & \multirow[b]{2}{*}{ Тота.L. } & \multirow{2}{*}{ 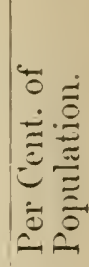 } \\
\hline & Native. & 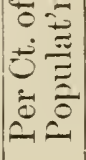 & Foreign. & 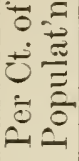 & & & & \\
\hline 1860, U.S & . . . . & . . & . . . & . . & . . . & . & $5,624,065$ & 20 \\
\hline 1860, S. C & 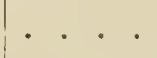 & . & . & . & . . & . & 55,016 & 18 \\
\hline 1870 , U.S. & $4,782,409$ & 17 & $1,873,402$ & 34 & $S 61,164$ & 18 & $7,570,457$ & 19 \\
\hline $1 S 70$, S. C. & 49,721 & 17 & 2,606 & 32 & 70,407 & 16 & 120,154 & 17 \\
\hline $18 S 0$, U. S. & $7,02 S, 134$ & 18 & $1,960,751$ & 29 & $1,242,354$ & $1 S$ & $10,231,239$ & 20 \\
\hline 1Ss0, S. C. & 70,616 & 18 & 2,021 & 26 & $9 S, 2 S 5$ & 16 & 170,922 & 17 \\
\hline
\end{tabular}

It will be noted how much the foreign element adds to this class in the country at large, being more than double the colored race, although the two populations differ in numbers only about one-tenth of one per cent. It will also be obscrved that this class is on the increase in the white population of South Carolina, while there is a marked decrease among the negroes, owing, doubtless, to the emigration to other States of adult negros. 
Similar data from the same sources, in regard to the number of males at the age of citizenship, are exhibited in the following table:

\section{MALES 21 YEARS OF AGE AND UPIVARDS.}

\begin{tabular}{|c|c|c|c|c|c|c|c|c|}
\hline \multirow{2}{*}{ YEAR. } & \multicolumn{4}{|c|}{ White. } & \multirow[b]{2}{*}{ Colored. } & \multirow{2}{*}{ 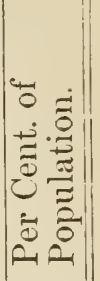 } & \multirow[b]{2}{*}{ Total. } & \multirow{2}{*}{ 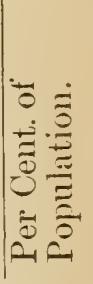 } \\
\hline & Native. & 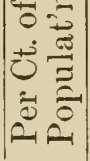 & Foreign. & 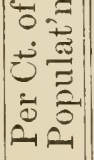 & & & & \\
\hline $1860, \mathrm{U} . \mathrm{S}$. & . . . . & $\cdot \cdot$ & . . . & . & . & . . & $6,690,620$ & 24 \\
\hline 1860, S. C. & . . & . . & ... & . & 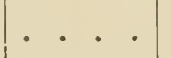 & . . & 64,956 & 21 \\
\hline 1870, U.S. & $5,811,136$ & 20 & $2,542,475$ & 45 & $1,032,475$ & 21 & $8,425,941$ & 23 \\
\hline 1870, S. C. & 58,269 & 20 & 4,278 & 53 & 85,475 & 20 & 146,614 & 20 \\
\hline 1880, U.S. & $8,270,518$ & 23 & $3.072,487$ & 46 & $1,487,344$ & 22 & $12,830,349$ & 25 \\
\hline 18s0, S. C. & 82,910 & 21 & 3,990 & 51 & 118,889 & 19 & 205,789 & 20 \\
\hline
\end{tabular}

Here a more remarkable increase is shown in the ratio of voters in the native white population, and it is quite sufficient to dispel any apprehension than any but native whites will preponderate in this country. This increase occurs in South Carolina, but is less marked than in the country at large, the population of the State not having yet, in this regard, recovered fully from the losses iucurred during the war. Were the races arrayed politically against each other, as was practically the case prior to 1876 , it would have required a change of thirteen per cent. of the colored voters to the whites in 1880 to give the latter a majority, and, in 1770 it would have required a change of more than fourteen per cent. Local and restricted political issues between the races may occur hereafter, but the plea, that if the whites obtained representation the liberties of the colored race would be lost, with which alien white men organized a solicl black vote in the State, has forever lost its force. The experience of seven years has assured the colored race in South Carolina that they have nothing to fear, as a race, from the native whites of the State. 


\section{DWELLINGS AND FAMILIES.}

While the climate of South Carolina, like that of Greece, Rome and Palestine, renders life out of doors pleasant and preferable for the larger portion of the time, and while it never necessitates the protection of costly houses, the materials for building are abundant and cheap. In the upper third of the State the crystalline rocks furnish a great variety of building stones; the granite itself being of the very finest quality; in the low country the great lime beds are being utilized in the manufacture of concrete blocks for building. and the lime rock, though not developed, has long since been tested, and found durable (see Lower Pine Belt). Clay suitable for brick is found in nearly every neighborhood, they are burned at a cost of about $\$ 3.00$ per thousand, and sell at from five to ten dollars per thousand, according to the facilities of transportation and the demand. The best yellow-pine lumber may be had forseren to twelve dollars per thousand. Crpress, for roofing, is cheap and aluundant, and there are many varieties of hard woods. The cheapest houses are $\log$ cabins. Such a house, twenty feet square, with a good wooden floor raised a foot or more above the ground, ten feet between joints, plastered outside with clay and ceiled inside with split pine boards, with a good chimney and board roof, furnishes complete protection against the vicissitudes of the seasons, and is estimated to cost, work and material, from thirty to fifty dollars, according to locality. The population of South Carolina has always enjoyed ample house room, as will appear from the following comparison with the country at large, not to speak of the populations of Europe, where, with the exception of France, Wappeaus makes the average number of occupants to a dwelling from 5.86 in Saxony to 5.42 in Belquiver. The following table gives the facts relating to dwellings and the number of persons to a family in South Carolina, with such general data as serves to exhibit the status here in comparison with the country at large: 


\begin{tabular}{|c|c|c|c|c|}
\hline & \multicolumn{2}{|r|}{ Dwelinas. } & \multicolumn{2}{|r|}{ FAMILIES. } \\
\hline & 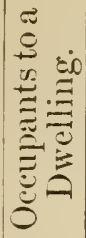 & $\begin{array}{l}\text { Maxima and Minima } \\
\text { for the } \\
\text { United States, and } \\
\text { Number of States having } \\
\text { less than So. Carolina. }\end{array}$ & 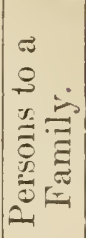 & $\begin{array}{l}\text { Maxima and Minima } \\
\text { for the } \\
\text { United States, and } \\
\text { Number of States having } \\
\text { less than So. Carolina. }\end{array}$ \\
\hline
\end{tabular}

1850 , S. C. . 5.392 States having fewer. $\quad 5.36$ \& States have fewer.

U. S. . 5.95 R. I., 6.59; Cal., 3.90. 5.56 Missouri, 5.89; Cal., 3.77.

1860 , S. C. . 5.187 States having fewer. $\quad 5.1410$ States had fewer.

U.S. . 5.54R. I., 6.43; Kansas, 2.96. 5.2s La., 5.93 ; Nevarla, 3.35.

1870, S. C. 4.927 States have fewer. $\quad 4.67$ + States had fewer.

U.S, . 5.49 N. Y., 6.37 ; Nevada, 3.27. 5.09 Ken., 5.67; Cal., 4.35.

1880, S. C. 5.1911 States having fewer. $\quad 4.9320$ States have fewer.

U.S. 5.60 R. I. 6.68 ; Idaho, 4.24. 5.04 W. Va., 5.54; Montana, 3.24. 


\section{CHAPTER II.}

\section{VITAL STATISTICS.}

It is conceded that the numbers of all the living in the United States are, with inconsiderable exceptions, included in the returns of the 8th and the 9th Census. Most strenuous efforts were made at these dates to obtain a complete enumeration of those who died during the census year's of 1860 and 1870. On an inspection of the returns, however, it was admitted that in no case did this enumeration approach the actual facts nearer than by forty or forty-one per cent. Nor is it expected that much greater accuracy will be attained by the results of the 10th Census. For instance, the attention of the very intelligent enumerators in the city of Charleston, in 1880, being called to the difficulty of obtaining aceuracy in the mortality returns no pains were spared to accomplish all that was possible in this regard. The result of the enumeration made the death rate 2.01 per cent. The actual death rate obtained from the rery accurate city registration being 3.25 per cent. A difference of about thirty-eight per cent. Even here it might be questioned, whether the enumeration or the registration was the more correct. So rapidly does that universal solvent, death, obliterate the traces of the things which pass from life, that all memory and record of their existence vanishes with unexpected, not to say indecent, haste. The known and numbered graves are as one grain to the sands of the sea-shore in comparison with the rast multitudes of the unrecorded dead. The intelligence and power of mankind have been so actively engaged through all ages of human progress in devising and perfecting means for the destruction of human life, that little of either has been left free to find employment in the preservation of this obstacle to progress, and still less for collecting and preserving facts concerning the entrances and the exits on the stage of life, and of the ills and accidents which beset the living. Without such data any opinion as to the comparative healthfulness of populations and localities must be of the raguest and most uncertain 
character; unfortunately this circumstance in no wise diminishes the facility with which such opinions are formed, their prevalence, or the tenacity with which they are entertained.

The United States Census returns for 1850 , ' 60 , '70 make the average annual death rate 1.25 per cent of the aggregate population. The same returns make the death rate for South Carolina 1.21 per cent. There being no reason to suppose that these returns were more defective in the one case than in the other, it may be assumed that the ratio of these percentages to each other expresses with tolerable accuracy the comparative mortality of the two populations.

The following statement touching the same matter is derived from the census returns of 1860 . It shows the order in which South Carolina stands among the other States of the Union in regard to the greatest mortality resulting from certain principal classes of disease.

Percentage of total deaths caused by the following diseases:
Position of South Carolna among other States in the order of the greatest mortality from these diseases:

24.7 Diseases of the respiratory organs. . . . . 32d.

11.3 Diseases of the nervous system . . . . . 29th.

5.9 Diseases of the digestive organs . . . . 13th.

5.0 Violence . . . . . . . . . 13th.

4.3 Fevers . . . . . . . . 9th.

It will be observed that this State, ranking then as 18 th in population, ranked as $32 \mathrm{~d}$ in the number of deaths from those diseases which destroy about one-fourth of mankind ; and 29th for diseases destroying more than one-tenth. For the less fatal diseases, where the variations are necessarily less between different communities, her position was higher.

The comparison may perhaps be more accurately made by another method. If a people were perfectly healthy, and free from all the accidents of life, death would only result from old age, and the population would form an unbroken column from the cradle to the grave, except that if it were increasing, the base of the column, representing those under one year of age, would be larger than the other diameters, and if it were diminishing the base would be smaller. Of course no such condition of perfect healthfulness is ever found, and the numbers of the living at different ages so far from being represented by a parallelogram actually assume the form of a pyramid, with a very broad base for the early periods of life, rapidly diminishing as years advance, and terminating towards old age in a very slender and attenuated apex. Nevertheless, that population would be most healthful which showed the greatest 
similarity between the numbers living at each age. To institute a comparison between South Carolina and the country at large, in this regard, the diagram on the opposite page las been prepared. The number of living persons at the five ages specified were obtained from the 7 th, Sth and 9th United States Census, and their percentage of the aggregate population of the United States and of South Carolina was caleulated. A perpendicular line, A B, was marked off in lengths corresponding with the number of years in each period of life from one to one hundred. The seale used was too small to show the relative height for those under one year of age, and this class are represented higher than it should be. The percentage of the population found in each period was divided by the number of years included in the period, and the quotient gave the breadth of the block representing the living of that period.

It will be remarked that while the number under one year old is greater in the country at large than in South Carolina, the decrease and consequent mortality from one to fifteen years is much more marked for the whole country than for South Carolina. In the working period of life, from fifteen to sixty, the numbers for the country at large considerably exeed those in South Carolina. This, however, is unfortunately not due to greater healthfulness, but to the large accession of foreign immigrants, persons mostly between those ages, very few of whom come to South Carolina. In fact, South Carolina lost heavily by emigration, the emigrants being largely of the working age, (see Chapter on Population). Naturally it would be expected that the greater numbers between these ages would give the United States a marked superiority over South Carolina during the sueceeding period of life, from sixty to one hundred. It is observed, however, that such is not the case. The explanation is found in the exceptionally large death rate of foreigners exposed to the vicissitudes and rigors of the northern climate, where the large majority seek homes. This death rate is estimated in the census of 1860 as 4.261 per cent. for the males who preponderate, while the death rate for the whole country is put at 1.75 per cent., and for the white population of the eleven largest cities at 2.75 pèr cent.

It appears that the black spaces, which represent the dead, are less in South Carolina than in the country at large. Still they are of appalling magnitude, and if the health of a people be a matter of the first consequence it would seem that government, alone able to effect it, is ealled on to collect and preserve vital statisties to the end that some light at least might be thrown on this great darkness, so pregnant with human woe.

I.-The proportion of white and colored in the aggregate population of South Carolina is summarized in the following table, taken from the records of the United States Census; 


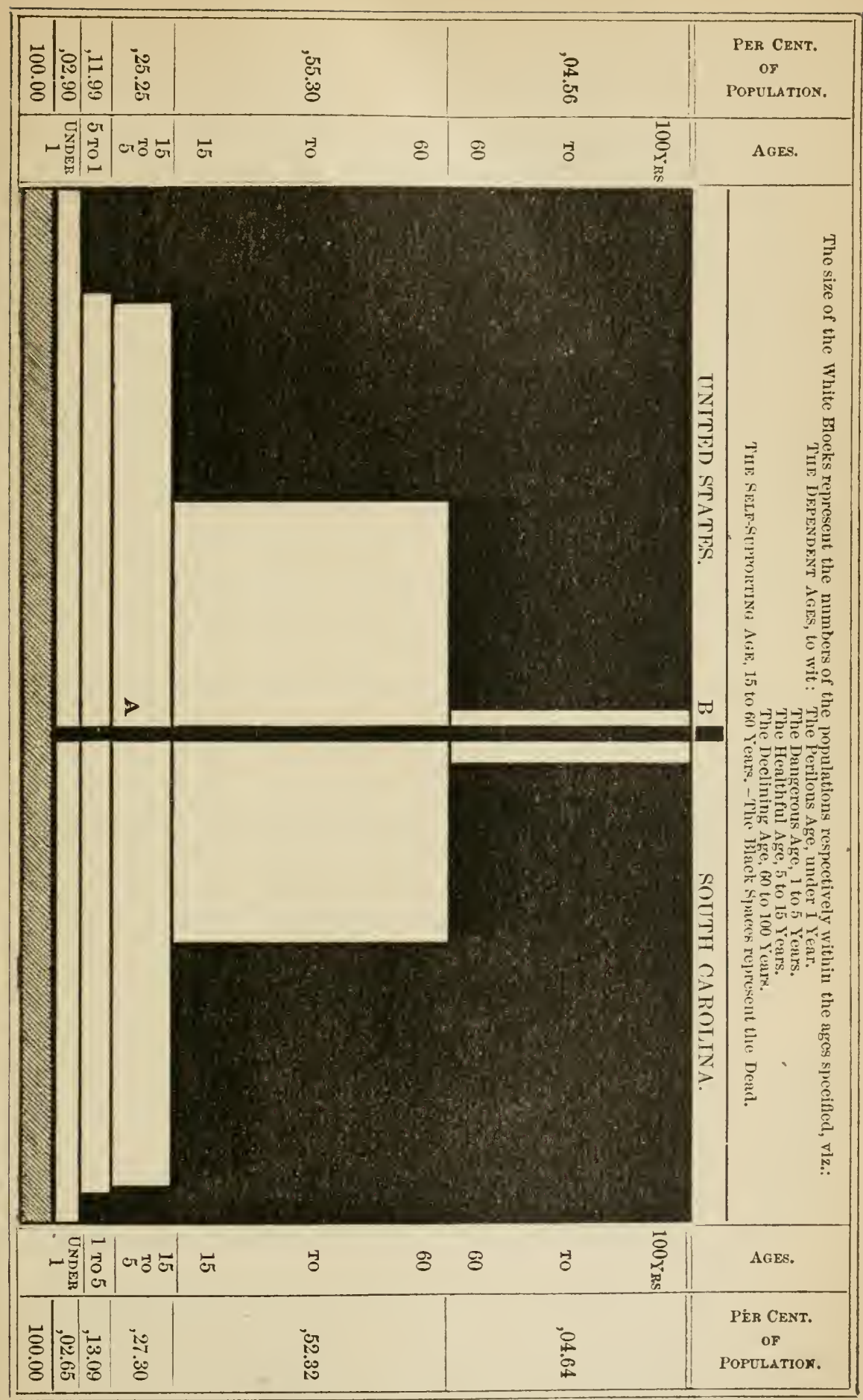



Proportion to Popllation.

YEAR.

$1790 . . \ldots \ldots$

$1800 \ldots \ldots \ldots$

$1810 \ldots \ldots \ldots$

$1820 \ldots . . . . .$.

$1830 \ldots . . . . .$.

$1840 \ldots \cdot \cdots \cdot \cdot \cdot \cdot$

$1860 \ldots \ldots$

$1870 \ldots \ldots \ldots$

1880.
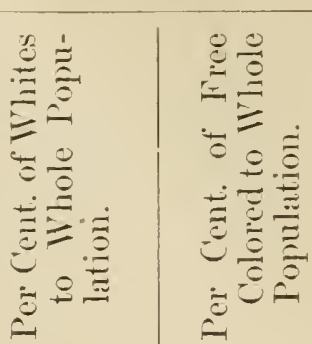

这

$\div \frac{0}{0}$

$\stackrel{\Xi}{\approx}=$

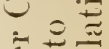

(2)

II.-Marriages.-In the 4 years, $1856-9$, there were registered 6,537 marriages anong the white population, estimated at 287,000 , or an average of 5.71 annually to each 1,000 of the population.

The following table gives the ages at which each sex was married during the same period:

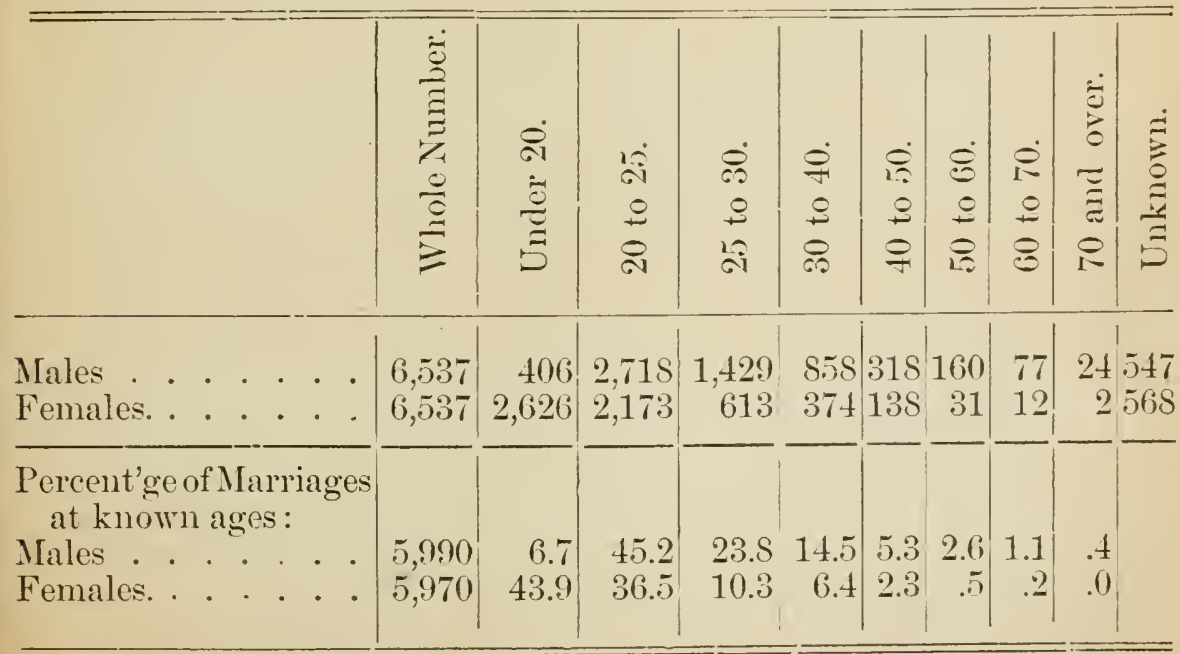


For the year 1859 the social condition of those marrying is stated as follows: 1,213 bachelors, 281 widowers, and 169 unknown. Of the widowers more than half married again before they reached 40 years, and 20 of them were married beyond the age of 65 . Of the women, 1,340 were maids, 105 widows, and 168 unknown. One-third of the widows were married under 25 years, and 2 between the ages of 60 and 70 .

'The number of marriages oceurring during each month of the year, for two years, is given as follows:

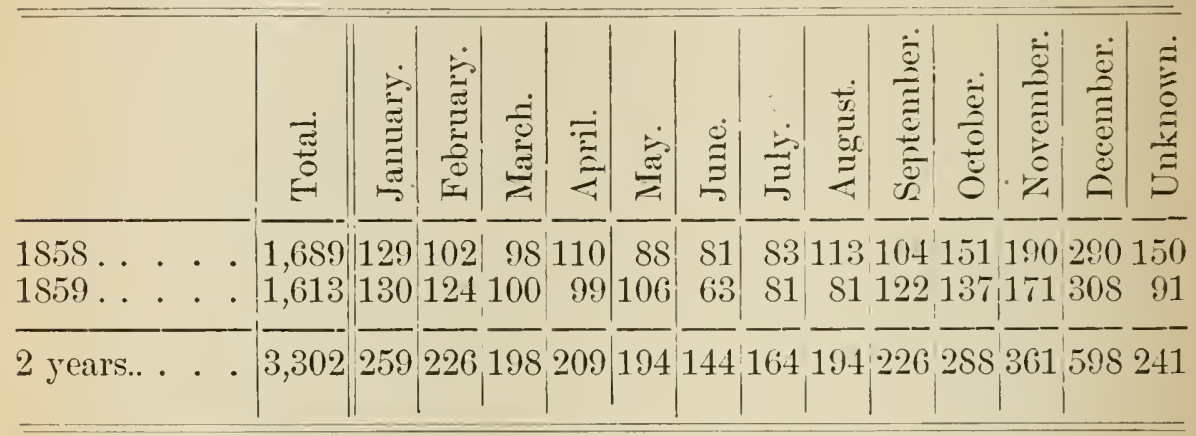

We have here a striking coincidence in the result of the two years. December both times furnishes the largest number of marriages, Norember stands second, Oetober third, and January fourth, while we always find June lowest and July next.

III.-Binths.-The number of births, with distinetion of race and sex, is given as follows:

\begin{tabular}{|c|c|c|c|c|c|c|c|c|c|c|}
\hline \multicolumn{6}{|c|}{ White Birthe. } & \multicolumn{5}{|c|}{ Negro Birthe. } \\
\hline YEAR. & 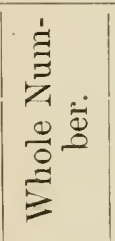 & $\frac{\frac{\dot{D}}{\tilde{D}}}{\bar{z}}$ & 离 & 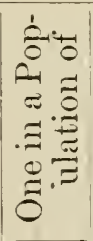 & 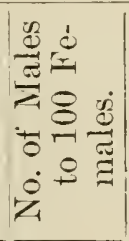 & 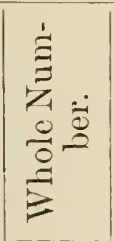 & 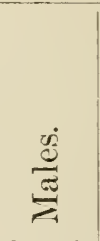 & 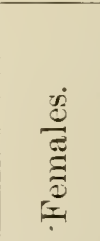 & 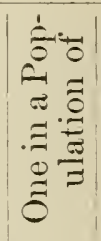 & 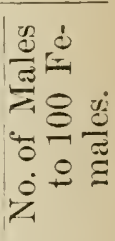 \\
\hline 1853 & 2,011 & 1,049 & 962 & $\$ 1.31$ & 109.04 & 5,957 & 3,061 & 2,890 & 32.47 & 105.69 \\
\hline 1854 & 1,765 & 914 & $\$ 51$ & 79.31 & 107.52 & 5,734 & 2,939 & 2,795 & 30.98 & 105.15 \\
\hline 1856 & 4,381 & 2,294 & 2,087 & 64.71 & 109.91 & 14,492 & 7,492 & 6,980 & 26.55 & 107.33 \\
\hline 1857. & 4,628 & 2,410 & 2,218 & 61.26 & 108.65 & 14,292 & 7,332 & 6,960 & 26.93 & 105.31 \\
\hline$-\pi$ & 4,816 & 2,479 & 2,337 & 60.24 & 106.07 & 14,226 & 7,110 & 7,116 & 27.06 & 99.91 \\
\hline $185 \tilde{9}$ & 5,677 & 2,950 & 2,727 & 48.27 & 108.14 & 14,377 & 7,287 & 7,090 & 26.05 & 102.77 \\
\hline Total. & 23,278 & 12,096 & 11,182 & 73.09 & 108.17 & 69,078 & 35,221 & 33,837 & 33.43 & 104.08 \\
\hline
\end{tabular}


Comparing the births and marriages during the period $1856-9$, for which the record of each is given, it appears that while the average amnual number of marriages was 5.71 to 1,000 of the population, the births stood 13.6 to the 1,000 . These figures apply to the white population. The rate of increase among the negroes was much greater. The above table makes the average annual number of their births 29.9 per thousand. For both races the birth rate was 23 per 1,000 . The number of births during each month for the four years 1856-9 is given with the distinction of sex as follows:

Births for Four Jears.

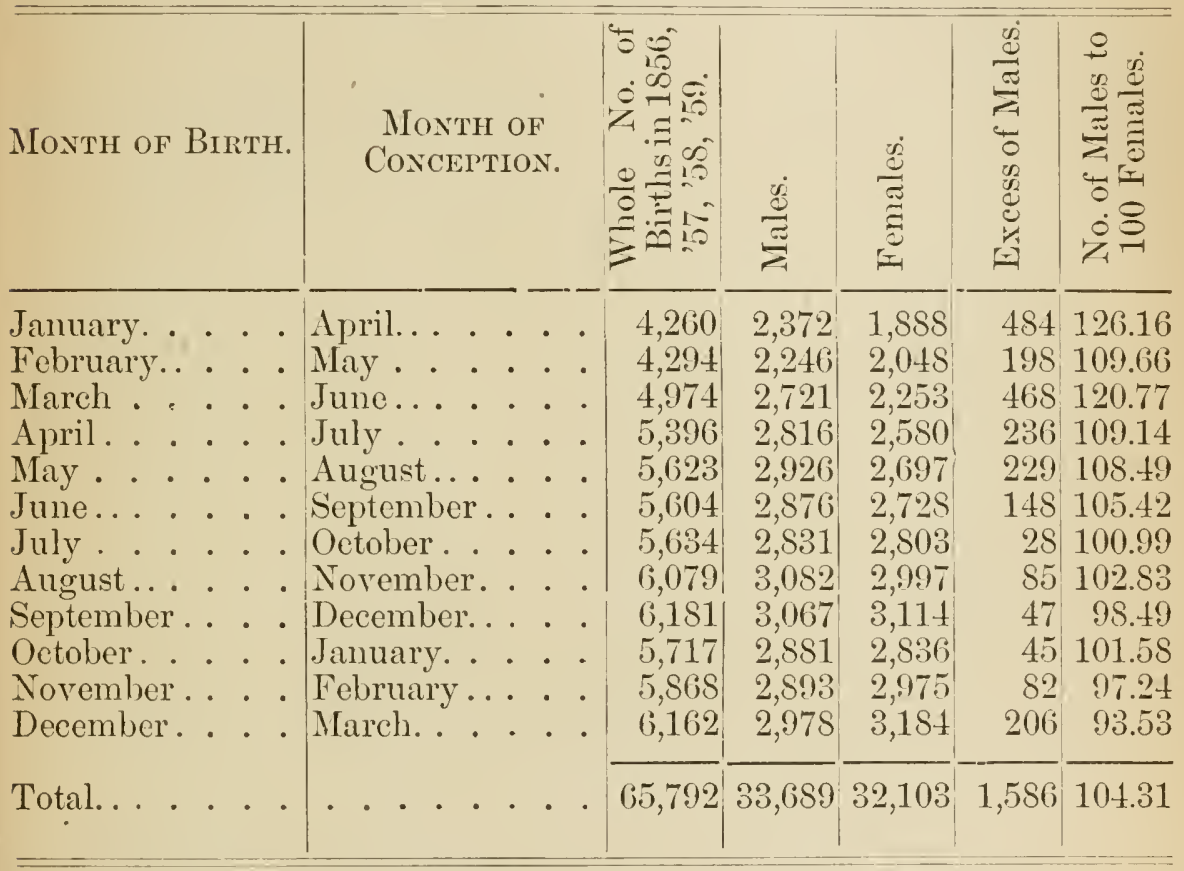

This being the whole number of births of known dates, registered in South Carolina during this period. From the foregoing tables may be deduced the following one, showing the order of relative fecundity of each month.

\begin{tabular}{|c|c|c|c|c|c|c|c|c|c|c|c|c|}
\hline Retur & Sept. & Dec. & Aug. & Oct. & June & July & Nov. & May & Apr. & March & Jan. & Fel \\
\hline etı & Sept. & Aug. & July & Nay & June & Nov & Dec. & Oct. & Apr. & March & Feb. & 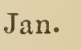 \\
\hline Retr & Sept & Dec. & No & Oct. & Aug. & May & Apr. & June & July & March & Fe & \\
\hline Returns of 18 & Dec. & Aug. & No & Jun & May & Sept. & July & Apr. & Oct. & March & $\mathrm{Fe}$ & \\
\hline
\end{tabular}


It is remarkable that either January or February always gives the lowest number of births, while Mareh uniformly comes next.

The first quarter gives the least number of births, and the third quarter the greatest. If we examine the following table we find that in four year's the births of known dates registered, stood thus:

$\begin{array}{cccc}\text { 1st quarter, } & 2 \mathrm{~d} \text { quarter, } & 3 \mathrm{~d} \text { quarter, } & \text { th quarter, } \\ 13,528 . & 16,623 . & 17,894 . & 17,7+7 .\end{array}$

If the year be separated into summer and winter months, the former embracing the $2 d$ and $3 d$ quarters, and the latter the 1st and 4 th, it will be observed that there were 34,517 births in the warmer, and only 31,278 in the colder season.

It was noticed in the returns of 18.58 and 1859 that January, which gare the fewest births, gave much the largest male excess; while September, November and December, showing the most births, produced the smallest proportion of males. December, January and February appear to be the months most farorable to conception.

Plurality Birtis.-In the returns of twin and triplet birth the races are not giren separately until the year 18.59. In that year 4 ?2S children were born twins or triplets; which was 2.1 per cent. for all the children born. There being 212 cases of such births, they were over 1 per cent. of the total number of births. Among the whites there was it cases of plurality births, and 148 children, the cases being 1.3 per cent. of the births, and the children 2.6 per cent. of those born. Among the negroes the cases were 138 , and the children $27 \%$, the former being 9 per cent. of the births, and the latter 1.9 per cent. of the children.

The following table gives the number of plurality births in each month for four years :

Plurality Births for Four Iears.

\begin{tabular}{|c|c|c|c|c|c|c|c|c|c|c|c|c|}
\hline & & & & 总 & 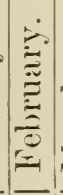 & ن & $\dot{E}$ & $\stackrel{\dot{D}}{\Xi}$ & & 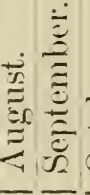 & 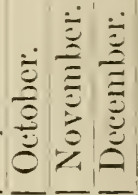 & Еं \\
\hline 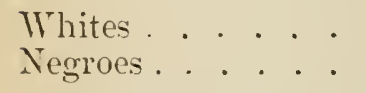 & $\begin{array}{l}\cdot \dot{ } \\
\cdot\end{array}$ & $\begin{array}{l}\cdot \cdot \cdot \\
\cdot \cdot\end{array}$ & $\dot{.}$. & 14 & 14 & $\begin{array}{l}1 S 12 \\
2424\end{array}$ & $\begin{array}{l}212 \\
432\end{array}$ & $\begin{array}{r}S \\
35\end{array}$ & $\begin{array}{l}5101 \\
202\end{array}$ & $\begin{array}{l}1416 \\
2522\end{array}$ & $\begin{array}{ll}12 & S, 10 \\
1 S & 18,25\end{array}$ & $\begin{array}{l}148 \\
269\end{array}$ \\
\hline 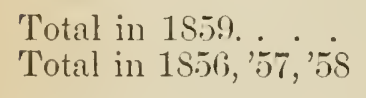 & $\begin{array}{l}\cdot \dot{ } \\
\cdot\end{array}$ & $\begin{array}{l}\cdot . \\
\cdot \cdot\end{array}$ & $\begin{array}{l}\cdot . \\
\cdot .\end{array}$ & $\mid \begin{array}{l}24 \\
29\end{array}$ & $\begin{array}{l}30 \\
48\end{array}$ & $\begin{array}{l}4230 \\
41.58\end{array}$ & $\begin{array}{l}641 \\
840\end{array}$ & $\begin{array}{l}43 \\
63\end{array}$ & 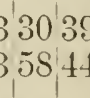 & $\begin{array}{l}3938 \\
4448\end{array}$ & $\begin{array}{l}302635 \\
355051\end{array}$ & $5+417$ \\
\hline otal in four years. & 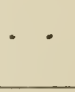 & . & . & 53 & $T S$ & 8394 & 484 & 106 & SS $8:$ & 5386 & 657686 & 982 \\
\hline
\end{tabular}


June is foremost in plurality births, and January stands lowest of all. Of 982 , the total number, 512 were males, and 470 females, or 108.93 of the former to 100 of the latter.

Still-Births.-The races in these tables are given separately only for the year 1859. In this year there were 403 children registered as born dead. Of these 139 were whites, or one child was lost out of every 40.80 births; and of negroes there were 264 , or one out of 54.46 , whilst in the whole number of births in the total population, one was still-born in every 49.76. This would give 2.4 per cent. of the white births, and 1.8 of the negro births still-births:

Still-Born for Four Years.

\begin{tabular}{|c|c|c|c|c|c|c|c|c|c|c|}
\hline & 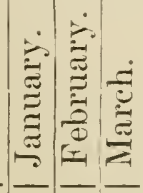 & : & & & & & & & & $=$ \\
\hline $\begin{array}{l}\text { Whites.. . . . . } \\
\text { Negroes. . . . }\end{array}$ & \begin{tabular}{|l|l|l}
13 & 11 & 8 \\
15 & 24 & 13 \\
\end{tabular} & $\begin{array}{r}915 \\
2617\end{array}$ & $\begin{array}{l}515 \\
16\end{array}$ & 27 & 19 & & $\begin{array}{c}8 \\
20\end{array}$ & & & $\begin{array}{l}139 \\
264\end{array}$ \\
\hline 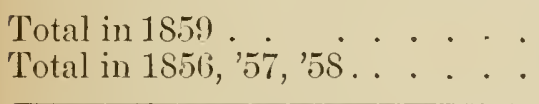 & $\begin{array}{lll}29 & 35 & 21 \\
29 & 48 & 41\end{array}$ & & 63 & $\begin{array}{l}37 \\
58\end{array}$ & 41 & & 28 & & & $\begin{array}{l}403 \\
565\end{array}$ \\
\hline. & $58 \$ 362$ & 9372 & $294^{\prime}$ & & & & & & & 968 \\
\hline
\end{tabular}

For a series of years, Jamuary gave almost uniformly the fewest stillborn as well as plurality and also total births. July, June, December and April produced each nearly the same number of still-births, and a good many more than the months next highest to them. There are more still-born negroes in December and fewer in Narch, while among the whites there were most in August and least in November.

*There is a remarkable preponderance of males in the still-births. This preponderance is greater in the white than in the negro race. In the former the still-born were 162.33 males to 100 females. In the latter there were only 118.1 s males to 100 females. For the two races during the whole 4 years the still-born were 121.54 males to 100 females.

*Note. - It is supposed the sex is determined by the preponderance of the sexual impulse in the sexes at genesis. If the female impulse is strongest for the male, males are produced; if the male impulse for the female is strongest, females are produced; and the number of males preponderating among the still-born is another among the many natural checks to a strong sexual impulse among females, 
IV.-Dentus.-The following table presents an abstract of all the deaths registered in South Carolina during six years, viz:

\begin{tabular}{|c|c|c|c|c|c|c|c|c|c|c|}
\hline \multicolumn{6}{|c|}{ DEATHS OF Whites. } & \multicolumn{5}{|c|}{ Deathis of Negroes. } \\
\hline YEAR. & 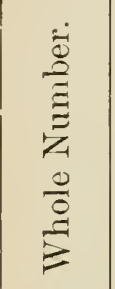 & $\frac{\dot{\mathscr{E}}}{\frac{E}{ت}}$ & 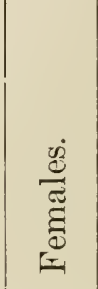 & 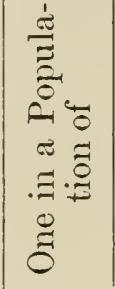 & 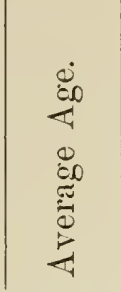 & 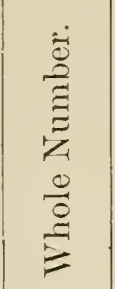 & $\underset{ت}{\stackrel{\dot{E}}{ت}}$ & 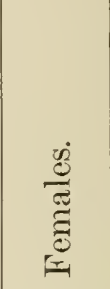 & 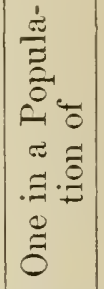 & $\begin{array}{l}0 \\
00 \\
-0 \\
0 \\
00 \\
\frac{0}{0} \\
\frac{1}{4}\end{array}$ \\
\hline $1853 .$. & 942 & 485 & 457 & 173.60 & Unknown. & 2,746 & 1,398 & 1,348 & 70.44 & Unknown. \\
\hline $1854 \ldots$ & 1,117 & 582 & 525 & 127.45 & 6 & 2,771 & 1,414 & 1,357 & 64.11 & $" 6$ \\
\hline 1856. & 2,183 & 1,101 & 1,082 & 129.52 & " & 7,627 & $3,7 \mathrm{~S} 1$ & $3, S 46$ & 54.76 & $"$ \\
\hline $1857 \ldots$ & 2,917 & 1,436 & 1,481 & 97.19 & 28.03 & 8,770 & 4,404 & 5,366 & 43.89 & 21.13 \\
\hline $1858 \ldots$ & 2,423 & 1,265 & $1,15 \mathrm{~s}$ & 117.01 & 25.36 & 7,277 & 3,608 & 3,669 & $\tilde{5} 2.91$ & 15.29 \\
\hline 1859. & 2,003 & 1,033 & 970 & 136.82 & 28.42 & 6,318 & 3,129 & 3,189 & 50.20 & 14.87 \\
\hline Total. & 11,585 & 5,902 & 5,673 & 146.90 & 27.27 & 35,509 & 17,734 & 17,775 & 65.05 & 17.09 \\
\hline
\end{tabular}

The annual average of registered deaths to the population was 11.7 per 1,000. Among the whites it was 7 deaths to the 1,000, and among the negroes 15.3, a disproportion not due altogether to the greater mortality of negroes, but owing to the fact that the return of deaths among this class of the population was more accurate, inasmuch as every case was reported by a master, who had sustained thereby a severe pecuniary loss, and was on this account less likely to overlook or forget the event.

As regards the sexes, the proportion of deaths in both races together was 100.8 males to 100 females. Among the whites it was 104.03 males to 100 females; among the negroes it was 99.76 males, a difference due in part to the preponderance of males among the whites and females among the negroes.

Deducting the deaths from the births, we have an average annual rate of increase for both races of 11.3 per 1,000. For the whites it is 6.6 per 1,000 . For the negroes it is 14.6 per 1,000 . 
The following table exhibits the number of deaths oceurring in each month for four years:

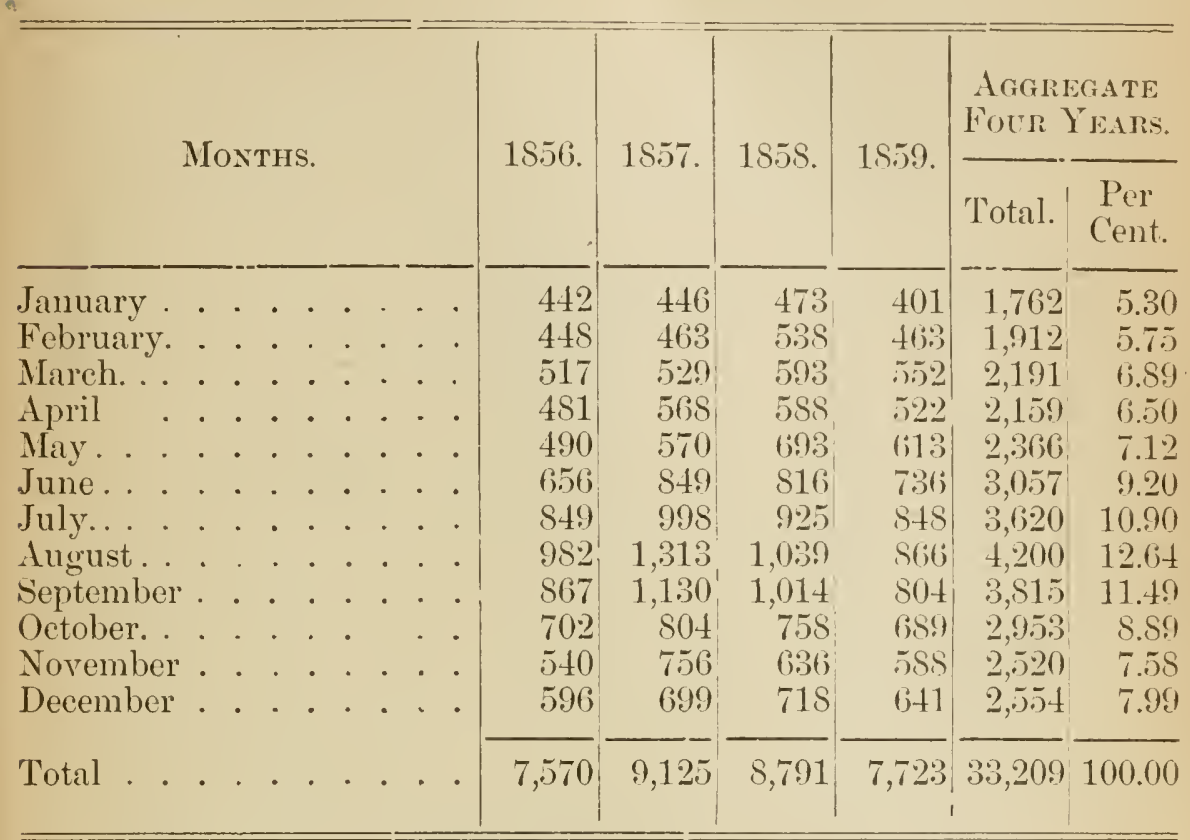

It will be observed that only 40.64 per cent. of the deaths oceur during: the first six months of the year, while 59.36 per cent. occur during the last six months.

The following table shows the order of mortality among the months, commencing with the most fatal:

\begin{tabular}{|c|c|c|c|c|c|c|c|c|c|c|c|}
\hline $1856 \ldots \ldots$ & Aug. & Sept. July & Oct. & June & Dec. & Nov. & March & May. & April. & Fel & Jan. \\
\hline $1857 \ldots$ & Aug. & Sept. July & June & Oct. & Nov & Dec. & May. & April. & March & Feb & Jan. \\
\hline 1855. & Ang. & Sept. July & June & Oct. & Dec. & May & Nov. & March & April. & Feb. & Jan. \\
\hline $1859 \ldots \ldots \ldots$ & Aug. & July Sept. & June & Oct. & Dec. & May & Nov. & March & April. & Fel. & Jan. \\
\hline
\end{tabular}

The months showing the least mortality correspond very nearly with those most favorable to conception. 
The following table eontains the returns of death at different ages, and also expresses the aggregate number of each sex dying at proximate ages, and their proportions to each other:

\begin{tabular}{|c|c|c|c|c|c|c|c|c|c|}
\hline \multirow[b]{2}{*}{ AGES. } & \multirow[b]{2}{*}{$1 S 56$} & \multirow[b]{2}{*}{$15.5 \%$} & \multirow[b]{2}{*}{$1 S 5 S}$. & \multirow[b]{2}{*}{1559.} & \multicolumn{5}{|c|}{ Aggregate for Four Years. } \\
\hline & & & & & 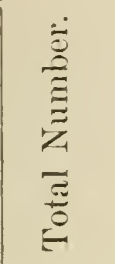 & $\begin{array}{l}\underset{\Xi}{E} \\
0 \\
0 \\
0\end{array}$ & 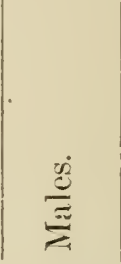 & 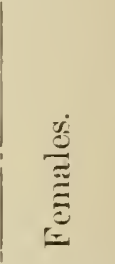 & 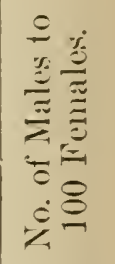 \\
\hline Lnder 1 year. & $1,6 \pm 9$ & $1, \$ 21$ & 2,122 & 1,973 & 7,565 & 23.31 & 3,592 & 3,673 & 105.96 \\
\hline 1 to 5 vears. & 1,636 & 2,151 & 1,981 & 1,560 & 7,328 & 22.58 & $3,8+1$ & 3,487 & 110.15 \\
\hline 5 to 10 years. & 481 & 629 & 677 & 486 & 2,276 & 7.01 & 1,166 & 1,110 & 105.04 \\
\hline 10 to 15 years. & 272 & 416 & 405 & 328 & 1,421 & 4.37 & 683 & 738 & 92.54 \\
\hline 15 to 20 years. & 236 & 461 & 423 & 363 & 1,583 & 4.57 & 728 & S.50 & S5.14 \\
\hline 20 to 30 years. & . 578 & 755 & 755 & 555 & 2,643 & S.1t & 1,272 & 1,371 & 92.85 \\
\hline 30 to 40 years. & 439 & 613 & 554 & 505 & 2,111 & 6.50 & 919 & 1,192 & 7.09 \\
\hline 10 to 50 years. & 362 & 479 & 472 & 406 & 1,719 & 5.29 & 795 & 924 & S6.03 \\
\hline 50 to 60 years. & - 356 & 459 & 396 & 332 & 1,543 & 4.75 & 778 & 769 & 101.69 \\
\hline 60 to 70 years. & . 373 & 511 & 452 & 401 & 1,737 & 5.35 & 875 & 862 & 101.50 \\
\hline 70 to $S 0$ years. & . $\quad 313$ & 407 & 345 & 322 & 1,357 & 4.27 & 700 & 687 & 101.89 \\
\hline Orer 80 years & $=263$ & 326 & 283 & 263 & 1,135 & 3.49 & $5+2$ & 593 & 91.39 \\
\hline Total.. & 7,061 & 9,028 & $S, 865$ & 7,494 & $32,44 \mathrm{~S}$ & 100.00 & 16,191 & 16,257 & 99.59 \\
\hline
\end{tabular}

As respects the proportional mortality of the sexes at the same age, it will be seen that the male deaths are much in excess up to the age of 10 years, after which period, as far as 50 years, more females die. Males then predominate until 80 years, after which females again are remored in greater proportion. Hence, it appears, that "from the approach of puberty to the end of the period of reprorluetion, the female is more liable to disease and death."

Deaths ix Extreme Old Age-There were twenty-two deaths registered at the age of 100 years and over, of which only four were whites, viz: one male and three females, the remaining eighteen (nine of each sex) being negroes. The oldest were a black man and a black woman, both of whom died in St. Bartholomew's Parish, the former aged 120 years, and the latter 110 years. A list of them is here given: 
VITAL STATISTICS.

Deaths at Adranced Ages.

\begin{tabular}{|c|c|c|c|c|c|c|c|c|}
\hline Districts. & & & RACE. & Sex. & Montir. & & GE. & CAUSE. \\
\hline 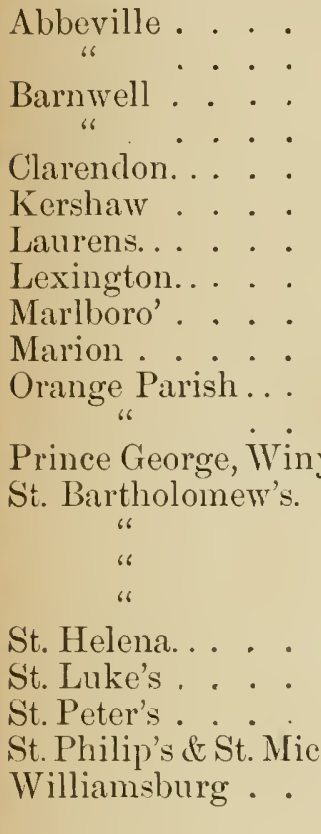 & $\begin{array}{ll} & \cdot \\
\cdot & \cdot \\
\cdot & \cdot \\
\cdot & \cdot \\
\cdot & \cdot \\
\cdot & \cdot \\
& \cdot \\
\cdot & \cdot \\
\cdot & \cdot \\
\cdot & \cdot \\
\cdot & \cdot \\
\cdot & \cdot \\
\text { yaw } \\
\cdot & \cdot \\
\cdot & \cdot \\
\cdot & \cdot \\
\cdot & \cdot \\
. & \cdot\end{array}$ & $\begin{array}{l}\cdot \\
\cdot \\
\cdot \\
\cdot\end{array}$ & $\begin{array}{c}\text { Col'd } \\
\text { " } \\
\text { " } \\
\text { " } \\
\text { White. } \\
\text { " } \\
\text { Col'd } \\
\text { "' } \\
\text { White. } \\
\text { Col'd } \\
\text { " } \\
\text { "، } \\
\text { " } \\
\text { " } \\
\text { " } \\
\text { " } \\
\text { White. } \\
\text { Col'd }\end{array}$ & $\begin{array}{l}\text { F. } \\
\text { M. } \\
\text { F. } \\
\text { M. } \\
\text { M. } \\
\text { M. } \\
\text { F. } \\
\text { M. } \\
\text { F. } \\
\text { F. } \\
\text { F. } \\
\text { F. } \\
M . \\
\text { M. } \\
\text { M. } \\
\text { F. } \\
\text { F. } \\
\text { M. } \\
\text { F. } \\
\text { F. } \\
\text { F. }\end{array}$ & $\begin{array}{l}\text { November. } \\
\text { June. } \\
\text { Unknown. } \\
\text { June. } \\
\text { April. } \\
\text { June. } \\
\text { July. } \\
\text { August. } \\
\text { December. } \\
\text { November. } \\
\text { April. } \\
\text { February. } \\
\text { September. } \\
\text { November. } \\
\text { December. } \\
\text { Septenber. } \\
\text { February. } \\
\text { December. } \\
\text { February. } \\
\text { August. } \\
\text { March. } \\
\text { November. }\end{array}$ & $\begin{array}{l}100 \\
100 \\
100 \\
100 \\
100 \\
100 \\
102 \\
102 \\
100 \\
100 \\
104 \\
100 \\
100 \\
100 \\
100 \\
120 \\
110 \\
100 \\
100 \\
100 \\
100 \\
100\end{array}$ & 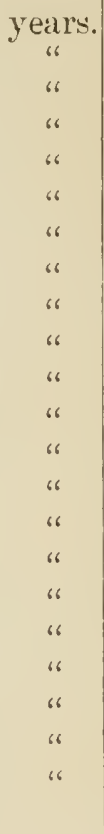 & 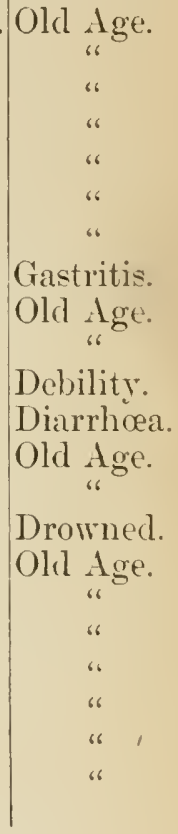 \\
\hline
\end{tabular}

This list might be largely added to. One compiled from the records of the Sextons of the Cameteries of the City of Charleston enumerates, between 1808 and 1850, twanty-seven deaths in that city occurring between the ages of 100 and 12S. During 1880, forty-five deaths oceurred of people over 80 years of age-twenty-one whites and twenty-four negroes. Robert Mills enumerates among a large number of aged persons, 41 (specifying their names and residences) who exceeded 100 years, between 1800 and 1820, in South Carolina, giving in addition cases like the following: Mrs. Morgan, of Darlington County, died in 1805, aged 90, leaving 244 descendants; Mrs. Easeley, of Pickens County, was the mother of 34 live-born children, having twins only once; Mr. and Mrs. Neighbors, of Laurens county, enjoyed 80 years of married life together; Mr, and Mrs. Nettles, of Sumter County, who had been married 72 years, had 134 descendants in 1803. In 1882 there died in Orangeburg County, Mr. and Mrs. Smoak, over ninety years of age, leaving within a rarlius of 9 miles from the spot where they had lived so long together more than 300 of their descendants. 
The following abstract exhibits the relative mortality from each clase of diseases in the total population during the six registration years:

\begin{tabular}{|c|c|c|c|c|c|c|c|}
\hline & $1 S 53$. & 18.54 & 15.56. & 1857. & $18 . j \mathrm{s.}$ & $185 \%$. & $\begin{array}{l}\text { AVERAGE } \\
\text { FOR } \\
\text { SIX IFARS. }\end{array}$ \\
\hline I. Zymotic Discases. . . & 42.99 & 46.15 & 36.81 & $36.6 \mathrm{~S}$ & 34.65 & 28.84 & 37.68 \\
\hline II. Encertain Seat... . & $6.5 \mathrm{~S}$ & 6.95 & 8.75 & 11.26 & $10.9+$ & $11.6 \% 2$ & 9.35 \\
\hline III. Nervous Organs. & 5.97 & 6.95 & 7.79 & 7.25 & 9.15 & 10.03 & 7.55 \\
\hline IV $^{\top}$. Respiratory Organs. & 18.23 & 17.77 & 17.69 & 19.40 & 19.49 & 21.97 & 19.09 \\
\hline I. Circulatory Organs. & .90 & .96 & .95 &.$S t$ & .64 & 1.30 & .93 \\
\hline VI. Digestive Organs. . & $9.6 \mathrm{~S}$ & 6.64 & 9.31 & 12.00 & 10.87 & 10.94 & 9.90 \\
\hline VII. Urinary Organs. & .01 & .08 & 29 & .21 & .40 & 46 & .24 \\
\hline VIII. Generative Organs. & 2.34 & 1.80 & 2.46 & 1.85 & 2.32 & 2.33 & $2.1 \mathrm{~S}$ \\
\hline IX. Locomotive Organs. . & $.5 S$ & .35 & .65 & .45 & .42 & .42 & .48 \\
\hline X. Integumentary Ory's. & .00 & .00 & .06 & .08 & .19 & .05 & .05 \\
\hline XI. Old Age. . . . . & 4.37 & 4.7 .9 & 4.71 & j.11 & 4.22 & 4.41 & 4.60 \\
\hline XII. Tiolence . . . . . & 5.26 & 7.52 & 8.00 & 5.91 & 6.50 & 7.54 & 6.79 \\
\hline
\end{tabular}

In the 1-t Class, Merasles, Influenza and IIhooping Cough are most fital to negroes, and also "fever," which, however, is too vague a term to mean any disease in particular. Of Diplitheria, a zrmotic which has been rery prevalent in the Northern States, we have but three deaths recorded in 18.59, all in negroes, two being.under 10 ycars, and the other one of unknown age.

The second class in order of mortality, is always Class IT., comprising the diseases of the Respiratory Organs, at the head of which stands Pncumomia, giring 10.41 per cent. of all deathe from known causes. In negroes the percentage is 1026 , but in whites only 7.86 , The greater number occurred in February, nearly half being under 10 years of age, and there being $4: 36$ males to 304 females.

Consumption connes next, killing 6.8 .5 per cent. in whites, and 3.94 per cent. in negroes, the month of July, and the period between 30 and 40 year's of age showing the highest mortality, there being a considcrable excess of females in both races. Cioup destroyed 150 children and 1 negro woman, the latter between 30 and 40 years of age. It is almost twice as fatal to whites as to negroes. The largest number of deaths were in the month of Norember, all but fifteen of the whole being under five years, and only fourteen between five and ten years of age.

In Class VI., which is the fourth in fatality, the principal causes are Tentling, Worms, and indefinite "diseases of the bowels," all of which claim the most rictims in young negroes. Whites die in larger numbers 
from Colic, Dyspepsia, Enteritis, Gastritis, Hepatitis, Jaundice, Disereses of the Liver, Peritoncum, Spleen and Stomach, \&e. There were two deaths among negroes from Dirt Eating, both females, one of whom was between ten and fifteen years, and the other of unknown age.

Diseases of the Nervous System, comprising (lass III., are the next in order, giving a mortality of 10.03 per cent, which is considerably higher in 1859 than in any one of the five preceding years. This class has been found more fatal to whites in each one of the past years, although more deaths of negroes are ascribed always to the indefinite "Convulsions," the most fatal of all causes under this hearl, as well as to Trismus Nascentium. Apoplexy, Delirium Tremens, Hydrocephalus, Neuralgiu, Puralysis and Disease of the Spine, were all more severe with whites.

The 12th Clas., external causes or violence, produced, in 1859, 7.54 per cent. of all the deaths, which is a little more than the average for six year's. As might be expected, it is more than doubly fatal to slaves than to whites, the principal figures being from Burns, Accidents and Suffocation, (infants smothered, choked or overlairl.) V'ery few slaves died of Homicide, Intcmperance, Neglect, Poison and Suicide.

Old Age, which forms the 11th Class, furnished 4.41 per cent., which is a little below the average for six years. In slaves, the mortality in 18.59 was 4.97 , and in whites only 2.75 per cent. A very similar difference in the two races is observed every year. As to sex, the females were in the majority in both races. 
Table showing the P'ercrntage of the Total Dortality Due to the Principal Diseases in cach Race, and for the Whole I'opulation dering Three I'cars.

\begin{tabular}{|c|c|c|c|c|c|c|c|c|c|c|}
\hline \multirow{2}{*}{\multicolumn{2}{|c|}{ Principal Diseanes. }} & \multicolumn{3}{|c|}{$\begin{array}{c}\text { RetuRss of } \\
185 \overline{7} .\end{array}$} & \multicolumn{3}{|c|}{$\begin{array}{c}\text { RETURNS OF } \\
1858 .\end{array}$} & \multicolumn{3}{|c|}{$\begin{array}{c}\text { Returess of } \\
1859 .\end{array}$} \\
\hline & & $\stackrel{g}{\Xi}$ & 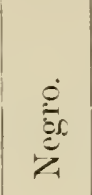 & 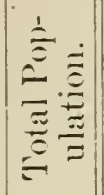 & $\stackrel{\stackrel{\Xi}{\Xi}}{=}$ & 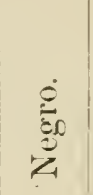 & 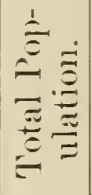 & 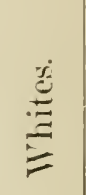 & 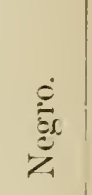 & 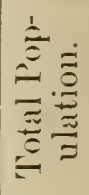 \\
\hline & & 10.20 & 12.55 & $11.90^{\circ}$ & 6.16 & .12 & 9.84 & 7.86 & 11.26 & 10.4 \\
\hline yphoid Fever. & & 9.83 & 7.29 & 7.99 & 10.76 & .87 & 9.27 & 8.76 & 9.36 & 9.2 \\
\hline ropsy. . . & & 5.79 & 7.43 & 6.98 & 3.84 & 6.50 & 5.81 & 3.42 & 5.83 & 5.2 \\
\hline ysentery & & 5.71 & 5.66 & 5.68 & 4.07 & 3.01 & 3.41 & 3.57 & 1.65 & 2.2 \\
\hline iarrhoea & & 11.51 & 2.83 & 5.23 & & 1.68 & 1.98 & 2.64 & 1.76 & $1 . ?$ \\
\hline Age. . & & 3.79 & & & & & & 2.75 & 4.97 & 4.4 \\
\hline leasles. . & & 2.57 & 5.32 & 4.55 & 3.55 & 3.54 & 3.55 & .44 & .76 & \\
\hline Teething . . & & 1.83 & 4.57 & 3.93 & 1.32 & 4.19 & 3.45 & 2.13 & 4.18 & 3.6 \\
\hline mption. & & 3.83 & 3.06 & 3.28 & 5.31 & 2.92 & 3.53 & 6.85 & 3.94 & 4.6 \\
\hline Fev & & 2.04 & 3.31 & 2.96 & 1.66 & 2.6 .5 & 2.40 & 1.34 & 3.36 & 2.8 \\
\hline , disease of & . & 14 & 3. & & 1.80 & & & 1.51 & 1.72 & .6 \\
\hline . . . . & & .53 & 3.37 & 2.59 & .52 & 3.72 & 2.90 & .50 & 2.60 & 2.0 \\
\hline disease of. & . & 3.83 & 1.64 & 2.25 & 3.46 & 1.53 & 2.03 & .34 & 1.55 & .0 \\
\hline & & 2.77 & 1.84 & 2.14 & 7.21 & 2.60 & 3.79 & 5.61 & 1.14 & 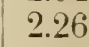 \\
\hline g Cough & & & 2.47 & 1.99 & 1.13 & 3.25 & 2. & 1.62 & 4.69 & 3.9 \\
\hline IS . . & 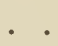 & .89 & 2. & & .94 & & & 1.85 & & 2.4 \\
\hline ... . & & 1.34 & 1.92 & 1.76 & 1.28 & 1.35 & 1.33 & .39 & 2.17 & 1.7 \\
\hline and Scalds & & .44 & 2.08 & 1.29 & .71 & 2.22 & 1.83 & .95 & 2.32 & 1.9 \\
\hline & & 1.51 & 1.53 & 1.52 & 2.27 & 1.79 & 1.92 & 3.20 & 1.76 & 2.1 \\
\hline d. & & .08 & 2.06 & 1.51 & .18 & 2.35 & 1.80 & .33 & 3.11 & 2.4 \\
\hline Fever & & 1.67 & 1.18 & 1.32 & 1.66 & 1.25 & 1.23 & 1.96 & 1.33 & 1.4 \\
\hline nt Fever & & 2.36 & .81 & 1.24 & 1.80 & 1.08 & 1.27 & 1.51 & 1.12 & 1.2 \\
\hline & & 1.30 & 1.25 & 1.26 & 1.51 & 1.43 & 1.45 & .78 & 1.61 & 1.4 \\
\hline infantum & . & 1.10 & 1.01 & 1.04 & 1.23 & .95 & 1.02 & 1.57 & 1.08 & 1.2 \\
\hline & & 1.10 & .90 & .96 & 2.08 & 1.25 & 1.47 & 1.79 & .90 & 1.1 \\
\hline Child-binth . . & & 1.10 & .87 & .94 & 1.28 & .87 & .97 & .95 & .93 & .9 \\
\hline Quinsy . . . & & $1.3 \pm$ & .72 & .89 & .71 & .11 & .26 & .28 & .11 & .1 \\
\hline Paralýsis .. . & & 1.75 & .42 & .79 & 1.85 & .41 & .78 & 2.19 & .80 & 1.1 \\
\hline Yellow Fever. & & & & & 9,15 & .26 & 2.55 & & & \\
\hline
\end{tabular}

Pneumonia was much more fatal among negroes than among whites, especially in the months of January and February, and under 5 years of age, as well as between 20 and 40 years. July produced the largest num- 
ber of deaths from Typhoid Fever, which was most fatal between the ages of 15 and 30 , and more so by a fraction in negroes than in whites.

The tables and statements above given are taken, almost exclusively, from the six annual report's to the Legislature, made by Robert IV. Gibbes, M. D., Registrar, and published with Acts of the General Assembly.

The opinion has prevailed widely that certain regions of South Carolina were peculiarly liable to malarial fevers of a deadly type. Those regions were the Coast and the Lower Pine Belt, eomprising together about 10,000 square miles. The remainder of the State it has never been doubted was as free from this seourge as any portions of America. It was also maintained that the negro race was less liable to these malarial fevers than the whites. It is, therefore, of interest to consult these reports of the Registrar regarding the causes of death in the different climatie regions of the State, and as to the two races, to obtain, as far as possible, some numerical expression as to the conclusions.

The following table shows the percentage of total mortality from specified causes, resulting from fever, including under the headings Fever and Congestive Bilious, Remittent, Intermittent and Yellow Fever, as reeorded in the Registrar's Reports, arranged with reference to the different regions, and compared with the percentage of death caused by Typhoid Fever :

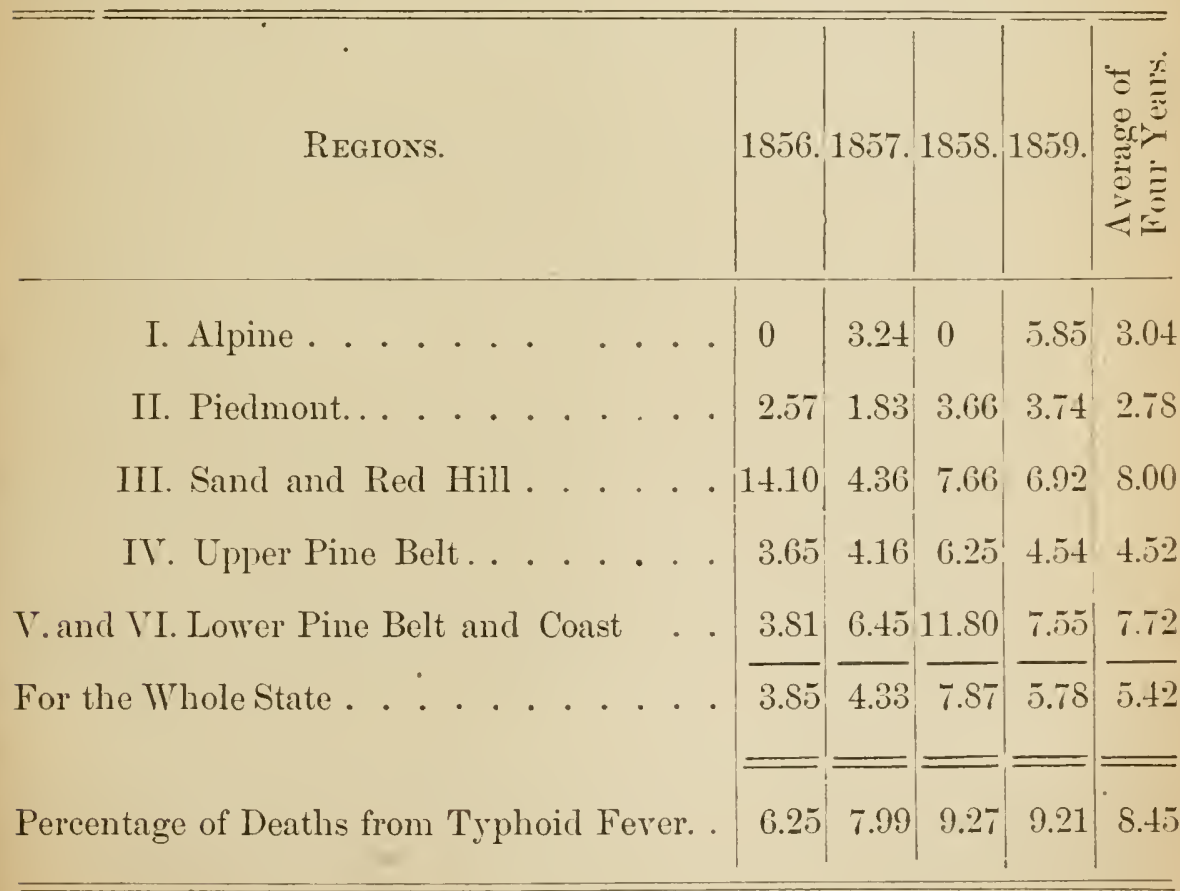


It is to be noted, first, that the unusual mortality in the Sand Hill Region, in 1856 , was confined to Kershaw County. Seventy-five negroes lied there from fever, while in the other three Counties of the region there were only four deaths from this cause. It was, therefore, dependent not on any general influence, but probably on some local and aceidental cause, as a new settlement and clearing on some stream, or the breaking of a milldam in summer. 2d. The next largest percentage of deaths was on the Coast, in 1858, and was due to Yellow Fever, from which cause there were 178 deaths in the City of Charleston, where the disease was imported, and 21 deaths in Christ Church, across the harbor, a health resort, to which cases contracted in Charleston were doubtless taken for treatment, these 209 deaths in one locality being all that oceurred in the State. There were also 13 deaths on the Coast from Yellow Fever in 1857, the disease being again imported, but not sprearling. 3d. In this table is included all the deaths that could have oceurred from malarial or climatic causes, and it is probable many that were not due to these causes, for the general term fever may well cover many other sorts of fever than those in question.

But taking the figures as they stand it appears:

1st. That the number of deaths from Typhoid and Premmonia much exceed those from malarial causes in South Carolina, even crediting the imported disease, Yellow Fever, to the latter.

2d. That if there is an excess of deaths from malaria in the lowel' country, it does not amount to more than 2.30 per cent., which would make the malarial influences of that region rank as tenth among the cainses of death, or less than the number of infants overlaid and suffocated by their mothers.

Of Yellow Fever it is to be remarked that the epidemics of this disease are much less fatal in Charleston than in cities further North, as Norfolk: Philadelphịa, Brooklyn, and, above all, Boston, where the largest proportion of deaths to eases occur. Nor is its recurrence anything like as frequent or its diffusion so great as in New Orleans and along the Mississippi River. Intervals of over 40 years have occurred between its risitations to the Carolina Coast, and it is almost invariably confined to the immediate locality into which it is imported.

The following table shows the percentage of total mortality from specified causes in each race, resulting from causes that might in any wise be termed malarial: 


Rices.

This table would seem to confirm the general impression that negroes are less injuriously subject to malarial influences than whites. But this impression requires important modification when it is stated that deaths from Yellow Fever is included in the table. It being a question here of a large section of country, it is not proper to include a disease that nerer occurs except in one or two restricted localities of that region, and which is far more fatal in these localities to foreigners than to natives or residents of either race. If, therefore, deaths from Yellow Fever be excluded from the table, it will stand thus:

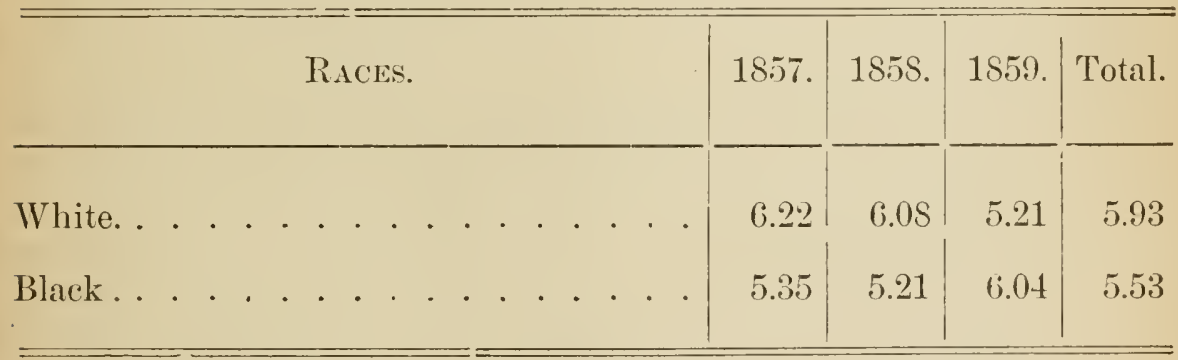

Thus in 23,770 deaths from specified causes, the white race in Souti Carolina seems to have suffered from malarial influences more than the black race by four-tenths of one per cent., a difference which amounts literally to nothing.

It is noteworthy that in the ratio of deaths from specified causes to total deaths reported in 1860 , under the head of ferers, South Carolina stands ninth, while Kansas stands first.

According to the mortuary statisties of Kentucky for eight years, South Carolina for four years, New Orleans for two years, fever, including congestive, remittent and intermittent fevers, caused 4.85 per cent. of the deaths among whites, and 7.82 per cent. of the deaths among negroes. 
Furthermore, the death rate among negroes appears to be much greater in localities considered most subject to malarial influences than in those less so. Thus, up to 1860 , the returns of the eleven largest cities of the United States show an arerage annual death rate among negroes of 3.47 per cent. In malarial districts, as New Orleans, it was 5.82 ; in Memphis it was 5.74; while in Charleston it only reached 2.66 per cent.

Since this chapter has been in press the compendium of the 10th United States Census has been published, giving a portion of the Vital Statistics collected by the enumeration of 1850 . The general results are exhibited in the following table:

Table A.-Percentage of Deaths in the Population of the Lnited States' and South Carolina, and in the Population of the Upper, Middle, and Lower Country of the latter.

Total. Male. Female.

\begin{tabular}{|c|c|c|c|}
\hline 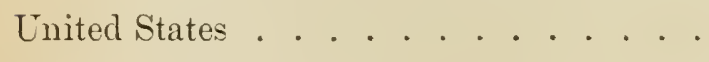 & 1.51 & 1.53 & 1.48 \\
\hline South Carolina. & 1.57 & 1.55 & 1.60 \\
\hline Upper Alpine Region. & 1.09 & . & \\
\hline $\left.\begin{array}{l}\text { Middle Country, or Piedmont, Sand and } \\
\text { Red Hill, and Lpper Pine Belt Regions. }\end{array}\right\}$ & 1.33 & & \\
\hline $\left.\begin{array}{l}\text { Lower Coụntry, or Lower } \\
\text { Pine Belt and Coast Regions }\end{array}\right\}$. . . & 2.08 & & \\
\hline
\end{tabular}

It is estimated the number of deaths not reported do not exceed thirty per cent. of those reported. The average mortality for the whole country is given, when thus corrected, at 18.2 per thousand, as against 20.5 per thousand in England, and 21.5 per thousand in Scotland. The slightly higher death-rate above given for South Carolina, may be due to a more accurate enumeration, or it may be accounted for by the preponderance of the colored race, whose death-rate is always higher than that of the whites. In this census these respective rates, as given by the enumeration, are 17.28 per thousand for the colored population against 14.74 per thousand for the white population. This difference is chiefly due to the difference in infant mortality. Both reasons above mentioned co-operate to produce the heary death-rate in the Lower Pine Belt and Coast region, 
one-fourth of this population is in the City of Charleston, where an accurate system of the registration of deaths makes the mortality returns more complete than they are anywhere else, except in twenty-two of the large cities, where the same measures are in force. The colored race also forms seventy-three per cent. of the population in these regions, against sixty per cent. for the State at large.

Table B.-Pcrcentage of Total Deaths occurring under 1 Iear, under 5 Years, and under all Ages among the Male arid Frmale I'opulation of the United States and of South Carolina, and in the Liper, Middle, and Lower Country of the latter.

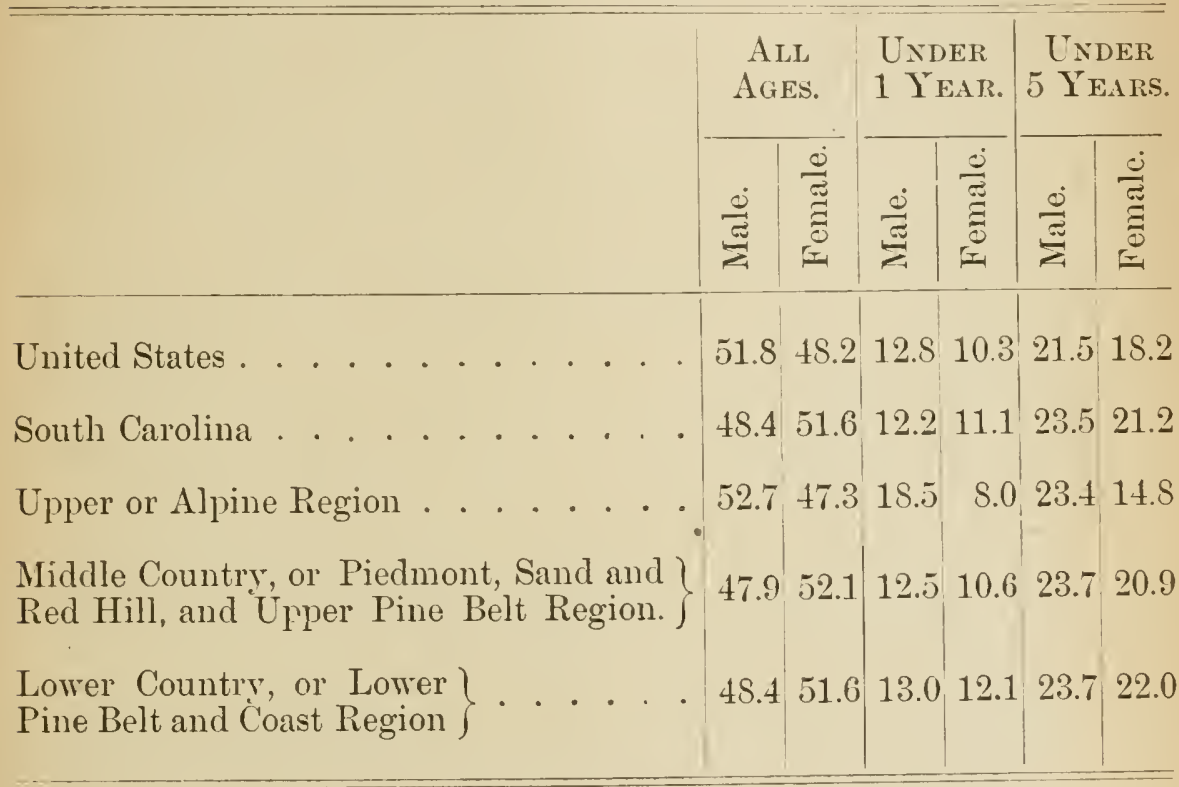

The number of deaths under five years of age amount to sixty-three per cent. of all deaths in the country at large, and to nearly seventy per cent. in South Carolina, due to the excess of infant mortality in the colored population. The excess of female orer male deaths is due in part at least to the preponderance of females in South Carolina. 
T.nine C.-Percontages of Deaths in the United States and in South Carolina, and in the Upper, Middle, and Lower Country of the latter, resulting from ten principal Diseases.

\begin{tabular}{|c|c|c|c|c|c|c|c|c|c|c|}
\hline & 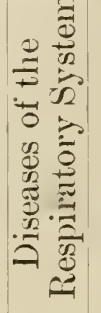 & 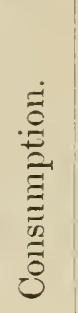 & 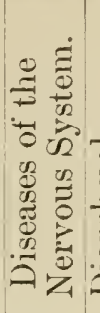 & 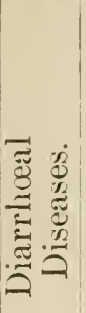 & 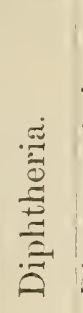 & 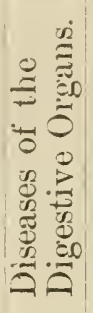 & 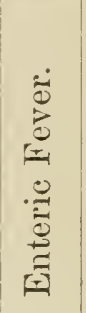 & 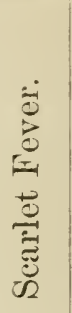 & 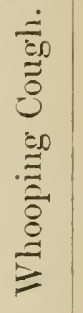 & $\frac{\frac{\dot{g}}{\vec{J}}}{\frac{\vec{J}}{\tilde{J}}}$ \\
\hline United States . . . & 14.2 & 12.0 & 11.0 & 8.6 & 5.0 & 4.5 & 3.0 & 2.0 & 1.2 & 1.1 \\
\hline South Carolina . . . & 12.3 & 10.4 & 9.2 & 8.0 & 3.5 & 6.2 & 3.7 & 0.1 & 2.2 & 1.9 \\
\hline Alpine Region . . . & $1 \tilde{5.7}$ & 7.7 & 6.5 & 7.7 & 1.8 & 4.6 & 11.1 & 0.2 & 1.2 & \\
\hline $\left.\begin{array}{l}\text { Piedmont, Sand and } \\
\text { Red Hill, Upper } \\
\text { Pine Belt Regions. }\end{array}\right\}$ & 13.1 & 9.8 & 8.6 & 9.0 & 3.1 & 6.7 & 4.0 &. & 2.4 & 3.0 \\
\hline $\left.\begin{array}{l}\text { Lower Pine Belt and } \\
\text { Coast Regions. }\end{array}\right\}$ & 10.7 & 9.7 & 10.4 & 6.2 & 4.1 & 5.7 & 2.4 & $\cdot$ & 3.9 & 1.1 \\
\hline
\end{tabular}

Table "C" exhibits the eauses of death, and shows that the most fatal diseases are less potent in South Carolina than elsewhere. The data, as regards malarial diseases, are not giren. But deaths from this eause are only 2.7 per cent. of the total deaths for the country at large, and 6.5 per thousand in the grand group, where it is most prevalent, being in New Orleans itself only 4.4 per cent., are less than the deaths in the country at large from diseases of the digestive organs. The pereentage from consumption in Carolina is doubtless much larger than it should be, the numbers being increased by the deaths of transient visitors, having this disease, to health resorts in this State, as well as by the permanent settlement here of many persons bringing the disease with them, in the hope that they may find relief in the mildness of this climate. 


\section{CHAPTER III.}

\section{A SKETCH}

OF THE

\section{INSTITUTIONS, GOVERNMENT AND LAWS}

\section{OF SOUTII CAROLINA.}

PREPARED FOR THE STATE DEPARTMENT OF AGRICLLTURE,

BY G. H. SASS, EsQ OF THE CHARLESTON BAR.

The first permanent European settlement in South Carolina was made by a colony of Englishmen, who landed at Port Royal in 1670. There had been several previous attempts at colonization by, French and Spanish expeditions, but they had all failed, and had left no trace behind them except in the name bestowed upon the Province, which was called Carolina, in honor of King Charles IX. of France.* 'The advantages of

* The question of the derivation of the name of Carolina is a somewhat obscure one. Some historians derive it from Charles II. of England. Rivers seems to give the preference to Charles I. of England, because, in the grant by that king to Sir Robert Heath, in 1630, the country is called Carolina, or Carolana. This fact is certainly fatal to the daim of Charles II., but it cloes not dispose of the prior claim of Charles IX. Some of the early annalists (such, for example, as Drs. Melligan and Hewett) say distinctly, that the name was giren in honor of Charles IX.; and it is reasonable to suppose that the name given by Ribault and Laudonnière to the comntry surrounding Charles Fort (arx Citrolina), in honor of the French King, survired the 
Port Royal, with its magnificent harbor, had also been pointed out by the French expedition under Ribault, and this led to its selection as a landing place by the English colony mentioned above. In 1663, Charles II. of England granted a charter to certain English noblemen, known in the history of the Province as "The Lords Proprietors," conveying to them all the lands lying between the thirty-first and thirty-sixth degrees of north latitude, comprising all of the present States of North Carolina, South Carolina and Georgia. This grant was enlarged two years later so as to include all between twenty-nine degrees and thirty-six degrees and forty seconds, north latitude, and from these two points on the Atlantic coast westward to the Pacific ocean. The Bahama islands were subsequently added to the grant. The colony which landed at Port Royal in 1670 was sent out by the Lords Proprietors, and. was commanded by Col. Wm. Sayle. Port Royal proved to be too near to the Spanish settlements in Florida, and to the Indian tribes allied with the Spaniards, for the peace or safety of the colony, and within a year Col. Sayle determined to remove further up the coast. Leaving between themselves and their enemies the several rivers, bays and estuaries which indent the coast of Carolina between Port Royal and Charleston, the colonists selected a spot on the west bank of the Ashley river, about three miles above the present city, and called it, in honor of the King, Charles Town. This situation, however, was soon found to be inconvenient for shipping; and by degrees, the inhabitants of Charles Town began to move lower down the river, and to establish themselves nearer the sea. The point formed by the confluence of the Ashley and Cooper rivers, and known as Oyster Point, was low and marshy, and cut up by numerous creeks; but there was sufficient high ground on the Cooper river side to afford room for a settlement, and by 1677 there were enough houses built upon it to need some designation, and the new settlement was called Oyster Point Town. In 1680, so large a majority of the people had removed to this spot, that the seat of gorermment was formally transferred to it, and its name was changed to New Charles Town. Two years later, the old settlement was virtually abandoned, and the new one became the only Charles Town. It was at that time declared a port of entry, and in $168 \overline{5}$ a collector was appointer. It was not, however, until 17S3 that the city

destruction of the French colony, and was adopted by the English settlers. This is the view held by Simms, in his "History of South Cirolina." speaking of the fort which Laudonnière called "La Caroline," in honor of the reigning monirch, he says (page 28): "The name thus conferred extended wer the whole country a full century before it was occupied by the English. It remained unchanged, and was adopted by them, as it really served to distinguish their obligations to Charles II. of England, under whose anspices and charter the first permanent Enropean colony was settled in Carolina." 
was incorporated by the State Legislature under its present name of Charleston.

The colony of Carolina, very early in its history, began to attract to itself emigrants from all parts of Europe. Though the Chureh of England was the established church, freedom of religious worship was guaranteed to all, and settlers of all social classes and all religious denominations began to swell the population. Emigrants were offered land at an easy quit-rent, and clothes and provisions were distributed by the Proprietors to those who could not provide for themselves. The Proprietors, being of the caralier class, aided or induced many of their friends or dependents to emigrate to Carolina; while the English Puritans, whom the restoration of the monarchy in England had deprived of many of their religious rights, were attracted to the colony by the greater religious freedom there enjoyed. Two vessels also arrived from New York with emigrants, and in 1671, the Grand Council of the colony laid out for them a town on a creek to the south of Stono, to be called James Town, lots in which were granted to every person in each family. These colonists were Dutch, and they were followed by others of their countrymen from Holland. The settlement at James Town was abandoned after a few years, and the settlers spread themselves over the country. In 1679, Charles II. provided, at his own expense, two small vessels to transport to Carolina a few foreign Protestants, who might there clomesticate the productions of the South of Europe. In 1683, a colony of Irish were attracted to the Province by the fame of its fertility, which was spread abroad, and they were received with so hearty a welcome that they were soon merged in the other colonists; and about the same time, the remnants of a Scotch settlement at Port Royal, who were driven thence by the Spaniards, found a refuge in (harles Town and its vicinity. In 1685-6, a very important accession to the colony was made by the arrival of a large number of French Protestant refugees, whom the revocation of the Edict of Nantes drove out of France. In 1696, a colony of Congregationalists, from Dorchester, in Massachusetts, settled near the head of the Ashley river, about twenty-five miles from Charles Town.

Such were the components of the colony over which the Lords Proprietor's exercised their original jurisdiction, and for the government of which they proceeded to frame a system of laws under the powers committed to them in the eharter of Charles II. Their first organized attempt at such a system embodied itself in the famous Fundamental Constitutions, generally attributed to the English philosopher, John Locke, but probably inspired to a considerable extent by Lord Shaftesbury. It is unnecessary here to state in detail the provisions of Locke's Constitution. Its principal feature was the establishment of an oligarchy of rank 
and power. The eldest of the eight Proprictors was always to be Palatine, and at his decease was to be succeeded by the eldest of the seven survivors. The Palatine's court was to sit in place of the King, to review all laws made by the Colonial Legislature, and to appoint a Governor, who was the King's representative in the colony. Three orders of nobility were created, called Barons, Cassiques, and Landgraves, the first to possess 12,000 , the second 24,000 , and the third $t S, 000$ acres of land, and their possessions were to be inalienable. An upper and a lower House of Assembly were to be established, which, with the Governor, constituted the Parliament. A sort of feudal military system was provided, and all the inhabitants from sixteen to sixty years of age were subject to the call of the Governor and Council. Three terms of religious communion were fixed. 1st. Belief in a God. 2d. That He is to be worshipped. 3d. That it is lawful and the duty of every man, when called upon by those in authority, to bear witness to the truth. Without acknowledging these tests no man was permitted to be a freeman or to have any estate or habitation in Carolina. But religious toleration within these limits was ensured, and all persecution for religious differences was expressly forbidden. Supreme Courts were established, but it was declared to be a base and vile thing to plead the cause of another for money or reward.

It is not surprising that such a system of government should have been distasteful to the colonists. The introduction of Locke's Constitution was strenuously resisted by the people, and its practical working was soon found to be so unsatisfactory that, in 1693, the Proprietors, upon public petition, abolished the Constitution, and for a considerable time the colony was regulated by certain temporary rules and instructions prescribed by the Proprietors. The government was of the form which Englishmen naturally adopt. The executive power was represented by the Proprietors, who appointed the Governor and other officers; the Legislature, by a Council or Upper House, also appointed by the Proprietors, and a Commons House of Assembly chosen by the freemen. The first popular election in South Carolina of which there is any record, was held in April, 1672, under a proclamation of the Grand Council, requirnng all the freeholders to elect a new Parliament. From this body five. Councillors were chosen, who, with the Governor and the Deputies of the Lords Proprietors, formed the Grand Council.

Such a condition of things could not last. The rule of the Proprictors, exercised, as it was, from a distance, and with little regard to the local necessities of the colony, som became intolerable to the free spirit of the people, and in 1719 the colonists at last made up their minds to get rid of the Lords Proprietors altogether. The history of the Revolution. 
which ensued, need not be given in detail. It was bloodless but decisive. The colonists organized a convention, appointed a new governor, and announced their intention of casting off "the confuserl, helpless, and negligent government of the Lords Proprietors," and putting themselves directly under that of the British crown. In 1721 the goremment of George I. decided in their favor, and in 1729, in the reign of George II., the Province was purchased by the crown from the Lords Proprietors, and was divided into North and South Carolina. The form of government conferred on the colony was modeled upon the English Constitution. It consisted of a Governor, Council and an Assembly. To them the power of making laws was committed. The King appointed the (ioremor and Council; the Assembly was elected by the people.

During the next half century the population of South Carolina steadily increased. Many inducements were offered to emigrants. Bounties were given, free lands assigned, and the door was thrown open to settlers of every description. Parties of emigrants arrived constantly from Great Britain and the various countries of Europe. Between the ycars 1730 and 1750 a large number of settlers from Great Britain and Ireland, Germany and the Palatinate, Switzerland and Holland, found homes in South Carolina. The Germans established themselves chiefly in that portion of the country around Orangeburg and along the Congaree and Wateree Rivers; the Scotch-Irish settled in Williamsburg; the Welsh along the Pee Dee River, in what are now the counties of Marlboro and Marion, and the Swiss along the banks of the Savannah River. After the Scotch rebellions of 1715 and 1745 many of the expatriated Highlanders came to Carolina. The population, which had hitherto been confined to a radius of about eighty miles from the coast, now began to spread into the interior of the State. A large territory was acquired from the Indians, embracing the present counties of Edgefield. Abbeville, Laurens, Newberry, Union, Spartanburg, York, Chester, Fairfield and Richland, and settlements were soon made all through those fertile portions of the country. Fifteen hundred French arrived from Nora scotia, and in 1764 a French Protestant colony settled in Abbeville District, and gave the names of Bourdeaux and New Rochelle to their settlements. The cultivation of wheat, hemp, flax and tobacco was introduced by colonists who came from Virginia, Maryland and Pemsylyania, and that of the vine and of silk by emigrants from the Palatinate. Indigo, also, was for some years profitably cultivated. When the War of Independence began, the population of South Carolina amounted to forty thousind sonls. It is needless to dwell upon the part played by South Carolina in the Revolutionary War. It belongs to the history of the whole country, and cannot be treated of here. During the war, of course, the growth 
of the population was cheeked, hut this was amply compensated by the progress made by the State after the peace of 1783. Nultitudes from Enrope and the more Northern parts of Ameriea poured into Sonth Carolina; and Greenville and Pendleton Districts, which were obtained in 1777 , by treaty founded on eonquests, from the Cherokee Indians, filled so rapidly with settlers that in the year 1800 those two Districts alone are estimated to have contained upwards of 30,000 inhabitants. The last group of settler's which the State received from foreign countries consisted of several hundred French, chiefly from St. Domingo, who settled for the most part in the ricinity of Charleston.

Peference has been made to the Constitution of John Locke and to the forms of govermment which superseded it under the Lords Proprietors, and, later, under the royal administration of the Prorince. For the first ninety-nine years Charleston was the seat of justice for Provincial Carolina. In 1712, a Court of Chancery was established in the persons of the Governor and his Council, and, later, in 1769, an Aet was passed by which new District Courts were established at Beaufort, Georgetown, Cheraw, Camden, Orangeburg and Ninety-Six. The Penal Code of Great Britain, when introduced into this Province, underwent considerable revision. An Act was passed in 1712 making certain English Statutes of force in the Province, and by that Act the English Common Law was declared to be of full force in Carolina, except in a few comparatively unimportant particulars. The aneient tenures were abolished, and free and common soceage was declared to be the tenure of all lands in the Province. The Habcas Corpus Aet of Charles II. was also adopted and enacted. The Chureh of England enjoyed a nominal supremaey, but liberty of conscience was fully guaranteed to all persons; and all religious denominations worked together in the dissemination of moral and religious training. The Presbyterians were among the first settlers, and were always numerous in South Carolina. The Independents, or Congregationalists, in conjunction, with the Presbyterians, were formed into a church in Charleston as early as 1682; and the Baptists formed a church there in 1685. The Methodists established themselves in 1785. The French Protestants formed a church in Charleston in 1700. The Jews have had a synagogue in Charleston since the year 1756 ; and about the same period the German Protestants formed themselves into a eongregation. The Roman Catholics were not organized into a ehureh in South Carolina until 1791. The Quaker's were rery early in the field, and one of the most distinguished Governors of the Province, Joln Archdale, after whom one of the streets in Charleston is still ealled, was a Quaker. The impulse towards freedom, which had driven the emigrants who settled Carolina from their homes in the Old World, kept alive in their 
breasts the spirit of religious liberty and toleration, and all through the history of the State the same spirit has manifosted itself in shaping legislation and administering government. Such persecution for opinion's sake as defaced the annals of some of the other American colonics luas no place in the history of South Carolina.

When the State threw off the royal authority, it adopted (in 1776) a provisional Constitution, and, so far as the civil power could be exercised, this Constitution was in operation during the Revolutionary War. After peace was declared, it became necessary to devise a more permanent form of government, and, in 1790, a convention was called, which, after mature deliberation, established a Constitution, which, with but few mojications, continued to be the law of the State until the end of the great civil war. As that Constitution has been superseded by the one now in operation, and which was adapted to the new conditions and relations of society growing out of the results of the civil'war, it will not be necessary here to detail its special provisions. The judgment of a learned and eloquent writer may, however, be fitly quoted upon its general scope and character. "Though the form of government in South Carulina," says Ramsay, "has been materially altered six or seren times, yet each change has been for the better. In the eighteenth century, while experiment and the reasoning powers of man were improving the arts and sciences, the art of government was by no means stationary. South Carolina, as one of the United States, and acting her part in the American Revolution, has practically enforeed the following improvements in the art of government: 1. That all power is derived from the people, and ought to be exercised for their benefit; that they have a right to resist the tyranny and oppression of their rulers, and to change their government, whenever it is found not to afford that protection to life, liberty and property for the protection of which it was instituter. 2. 'That it is the true policy of States to aftord equal protection to the civil rights of all individuals and of all sects of religionists, without discrimination or preference, and without interference, on the part of the State, in all matters that relate only to the intercourse between man his Maker. 3. That the ultimate end and object of all laws and government is the happiness of the people, and that, therefore, no law's should be passed, or taxes or other burdens imposed on them, for the benefit of a part of the community, but only such as operate equally and justly on all for the general good. 4. That war shall only be declared, or entered upon, by the solemn act of the people, whose blood and treasure is to be expended in its prosecution. $* * * * *$ A government founded on reason and the rights of man, and exclusively directer to its proper object, the advancement of human happiness, was first established by common 
consent in the eiglnteenth eentury, and in the woods of America. Its foundation in South Carolina rests on the following principles: No power is exercised orer the people but what had been granted by them with the express view of its being used for the general good. No laws bind them, nor are any taxes imposed on them, but with the consent of themselves, or representatives freely and fairly chosen every second year by a majority of rotes. There are no privilegerl orders. All are equally subject to the laws, and the rote of any one elector goes as far as that of any other. No freeman can be taken, or imprisoned, or disseized of his freehold, liberties or privileges, or ontlawed, or exiled, or in any manner destroyed or deprived of his life, liberty, or property, but by the judgment of his peers, or by the law of the land. Religion is so perfectly free that all sects have equal rights and privileges, and each individual may join with any or with none, as he pleases, without subjecting himself to any civil inconvenience. These and similar principles of liberty and equality pervade the Constitution and laws of the State. The first is the work of the people in their sovereign capacity, and preseribes limits to all the departments of govermment. These departments are threelegislative, executive, and judicial ; for it is necessary in regular gorernment that laws be enacted, expounded and applied, and finally executed. * * * * The duties required and the burdens imposed by the laws are equally binding on the law makers as on the people. They who are legislators cease to be so in the Senate at the end of four years, and in the House of Representatives at the end of two, and all power reverts to the people till, by a new election, they invest the men of their choice with authority to act for them. Every precaution is taken to identify the interests of the people and their lulers. If the electors are not wanting to themselves, the laws thus cautiously made, impartially expounded, and liberally executed by the men of their choice, must be the collected will and wistom of the people deliberately pursuing their own happiness as far as is practicable in the imperfect state of human mature. Such, after two revolutions in one century, and three attempts to form an efficient Constitution, is the result of the efforts of the people of South C'arolina for the preservation and adrancement of their political interests." [Ramsay's History of South Caroliua, Vol. 2, p. 139, ct seq.]

The period which elapsed between the two great wars was one of constant growth and prospcrity. Under the operation of the constitutional government described by Ramsay, the progress of South Carolina was marked and steady. The various nationalities which have been shown to have contributed to her population beeame gradually welred together into a homogenous whole, and the upper districts of the State soon besame the homes of thriring and industrious settlers. County seats were 
established in the different Districts, and various Judicial Circuits were formed, the Judges and Chancellors alternating with each other in the different Circuits, while appeals were heard in Charleston and Columbia by a full Appellate Bench. The pursuits of the people were almost entirely agricultural, the chief staples of the State, cotton and rice, being mainly worked by the aid of African slave labor. The political differences between the Northern and Southern States which culminated in the eivil war, though always existing, did not interfere with the internal prosperity of the State. In 1860 the white population had increased to 291,300. In the United States Census of 1860 the white population is rated at 391,105 and the colored at 604,332 . In the civil war South Carolina put more than 50,000 soldiers into the field, and when the war was over, in 1865 , more than 12,000 of her male population had laid down their lives in the struggle for independence. The result of the war left the State in a prostrate and exhausted condition. An immense amount of public and private property had been destroyed. Columbia, the capital, had been burned by the Federal armies, and the whole machinery of govermment was subverted and overthrown. Under the authority of the United States Congress a convention was called in 1865 to frame a new Constitution. The present Constitution of South Carolina was framed by that convention, and was submitted to the registered voters of the State at an election held on the 14 th, 15 th and 16th days of April, 1S68, and was adopted and ratified by them.

\section{LEADING PRINCIPLES OF THE CONSTITUTION.}

The leading principles of the Constitution may be briefly summarized as follows:

All men are born free and equal, endowed with certain inalienable rights, among which are the rights of enjoying and defending their lives and liberties, of acquiring, possessing and protecting property, and of seeking and obtaining their safety and happiness. Slavery is prolibited, as well as involuntary servitude, except in the shape of confinement with labor, inflicted as a punishment for crime, of which the party shall have been duly convicted. All political power is declared to be derived from and vested in the people alone, and they have the right at all times to modify their form of govermment as the public good may demand. Every citizen owes paramount allegiance to the Constitution and govermment of the United States, and no law of this State passed in contravention thereof can have any binding force. The American Union is declared to be indissoluble, and the State shall ever remain a member thereof, and shall resist any effort to dissolve it. The right of the people peaceably to 
assemble to consult for the common good and to petition the govermment or any department thereof shall never be abridged. All persons may freely speak, write and publish their sentiments on any subject, being responsible for the ahuse of that right, and no laws shall be enacted to restrain or abridge liberty of speech or the press. In prosecutions for libel upon public officers, the truth of the matter may be given in evidence to justify the publication, and the jury in such cases are the judges of the law and the facts. Absolute freedom of conscience shall be secured to all, with only the prorision that such freedom shall not justify practices inconsistent with the peace and moral safety of society. There shall be no established church nor form of religion, but every denomination shall be protected by law in the peaceable enjoyment of its own mode of worship. The right of trial by jury shall remain inviolate. Every individnal shall have the same personal rights; that is, no class of persons shall have any adrantages before the law over any other class, and there shall be no discrimination between classes or individuals with regard to rights, restraints or responsibilities. No person shall be held to answer for any crime or offence until the same is fully and clearly explained to him; and he shall not be compelled to accuse himself or furnish evidence against himself, but shall have the right to produce all his proofs in his defence; to be confronted with the witnesses against him and to crossexamine them; to have a speedy and public trial by an impartial jury, and to be fully heard in his own behalf, either personally or by his counsel, as he may elect.

No person shall be arrested, imprisoned, deprived of his property or privileges, put out of the protection of the law, exiled or deprived of his life, liberty or estate, except by the judgment of his equals or the law of the land. No law shall be passed by the General Assembly subjecting any one to punishment without trial by jury, nor shall any law hare a retrospectire effect, but shall apply only to offerices committed after its passage.

All Courts shall be public, and every person aggrieved shall have full access to them and remedy by due course of law, and there shall be no umnecessary delay in the administration of justice. All persons shall be bailable, before conviction, by sufficient sureties, except for capital offences where the proof is evident or the presumption great, and excessive hail shall not be required. Whipping and corporal punishment of any sort are prohibited. The privilege of the writ of habeas corpus shall not be suspended except in cases of insurrection, rebellion or invasion, when required by the public safety.

To person shall be tried again for the same offence after having been once acquitted by a jury. Small offences, under the rank of felonies, and 
in which the punishment does not exceed a fine of one hundred dollars or imprisonment for thirty days, shall be tried summarily before a Justice of the Peace, on information under oath, without the intervention of a grand jury, but the defendant shall have the right of appeal to a higher Court. No person shall be held to answer for any higher crime or offence unless on presentment of a grand jury, except in cases arising in the land and naval service of the United States, or in the mititia in actual service in time of war or public danger. Imprisonment for debt is abolished, except in eases of fraud : and a certain amount of property shall be set aside as a family homestead [as more particularly stated hereafter], which shall be exempt from seizure or sale for any debts or liabilities, except for debts due the State. No bill of attainder, $e x$ post facto law, nor any law impairing the obligation of contracts, shall ever be passed, and no conviction shall work corruption of blood or forfeiture of estate. All persons have the right to be exempt from unreasonable searches or seizures of their persons, houses, papers or possessions. Such searches or seizures can only be made by special warrants formally issued by proper officers and supported by affidavits, and containing a particular designation of the persons or objects of search, arrest or seizure. Private property cannot be taken for public use, or for the use of corporations, or for private use, without the consent of the owner, or a just compensation being made.

The Legislature alone has the power to declare martial law. The legislative, executive and judicial departments of the government shall be forever separate and distinct, and it is declared that the Legislature ought frequently to assemble for the redress of grievances and the making of new laws. The right of the people to keep and bear arms for the common defence is recognized and established. Standing armies are prohibited, and the military power is declared to be always in subordination to the civil. In time of peace no soldier shall be quartered in any house without the consent of the owner, and in time of war only in such manner as shall be prescribed by law.

No person who conscientiously scruples to bear arms shall be compelled to do so, but shall be allowed to pay an equivalent for personal service. All elections shall be free and open, and all electors shall have the same rights to elect officers and be elected. There shall be no property qualification for holding office, and no office can be held for a longer time than during good behavior. Fighting a duel, or sending, bearing or accepting a challenge for that purpose, is prohibited, and shall disqualify a person for holding office. Representation shall be apportioned according to population, and the right of suffrage shall be sceured to all citizens, and, once obtained, shall not be forfeited by temporary absence from 
the State. Property shall be taxed in proportion to its ralue, and no taxation or impost of any kind shall be established except by Act of the Legislature. No title of nobility or hereditary emolument shall ever be granted. All citizens, without distinction, shall enjoy equality of public, legal and political rights. All navigable waters are public lighways, free to all the citizens of the State.

I lagishative Departmext.-The legislative department consists of two distinct branches, styled respectively the Senate and the House of Representatives, and both together the General Assembly of the State of South Carolina. The Honse of Representatives is composed of members chosen by ballot every second year by the qualified electors of the State. Each C'ounty of the State constitutes one election district. The General Assembly has the power to organize new Counties by changing the boundaries of the old, but no new County can be formed of less extent than 62.5 square miles, nor can any old County be reduced to less area than 625 square miles. The House of Representatives consists of 124 members, apportioned among the several Counties, according to the population. A census every ten years is provided for to regulate this appointment. The Senate is composed of one member from each County, except Charleston County, which has two Senators, to be elected for four years by the qualified voters of the State. But upon the first election after the adoption of the Constitution, the Senators were dirided by lot into two classes as nearly equal as possible, the members of the first class holding their seats for two years, and those of the second for four years, so that onehalf of the Senators may be chosen every second year. No person is eligible to a seat in the Senate or House who, at the time of his election, is not a citizen of the United States, nor any one who has not been for one year next preceding his election a resident of the County whence he is chosen, nor any one who has been convicted of an infamous crime, nor any one holding any office of profit or trust under this State, the United States, or any other State of the Union or foreign power, except officers of the militia, Magistrates or Justices of Inferior Courts receiving no salary. Senators must be at least 25 and Representatives at least 21 years of age. All bills for raising revenue must originate in the Honse, but may be altered, amended or rejected by the Senate. All other bills mar originate in either body. No bill has the force of law until it has been read three times, on three several days, in each house, has had the Great Seal of the State affixed to it and has been signed in the Senate House by the President of the Senate and the Speaker of the House. No money can be drawn from the treasury except in pursuance of an appropriation made by law, and a regular statement of receipts and expenditures of all public moneys must be published annually. The members of both 
houses receive a fixed per diem and mileage settled by the General Assembly. In all elections by the General Assembly, or either House, the members rote vive roce, and their rotes are entered in the Journal. Both houses sit with open doors unless a seeret session be ordered, in their discretion.

Executive Departuext. The supreme executive authority of the State is vested in a Chief Magistrate, who is styled the Gorernor of the State of South Caroliua; he is elected by the qualified electors of the State, holds his office for two years and until his successor shall be chosen and qualified, and is re-eligible. No person is eligible for the oftice of Governor who denies the existence of the Supreme Being, or who, when elected, is not thirty years of age, or who has not been a citizen of the United States and a citizen and resident of this State for two years next preceding the day of election. 'The Lieutenant Governor is chosen in the same manner and at the same time as the Governor, must possess the same qualifications, and is ex officio President of the Senate. The Governor is Commanderin-Chief of the militia of the State; he has the power of reprieve and pardon, but must report his actions in that regard to the General Assembly; he must sign all bills passed by the General Assembly before they become laws, and if he refuses his assent to any bill, it can only be passed over his veto by a two-thirds vote. The other executive officers of the State are the Comptroller General, Treasurer, and Secretary of State. They are elected by the qualified voters of the State, and hold their offices for the term of two years.

Judicial Departanest. The judicial power of the State is rested in a Supreme Court, consisting of a Chief Justice and two Associate Justices, two Circuit Courts, namely, a Court of Common Pleas, having civil jurisdiction, and a Court of General Sessions, having criminal jurisdiction ; Probate Courts, having jurisdiction in matters testamentary and in business relating to minors, and of dower, idiocy and lunacy ; Courts of Trial Justices, having cognizance of minor offences and ciril matters of a trifling sort. The Trial Justices also act as examining courts in criminal matter's, and discharge, commit or bind over to the Sessions Court persons charged with offences. They may bail all persons except those charged with capital crimes. The Supreme and Circuit Court Judges are elected by the General Assembly, the Probate Judges by the electors of the several counties, and the Trial Justices are appointed by the Governor. The term of office of the Justices of the Supreme Court is six years, but it was directed that, immediately after their first election under this Constitution, the General Assembly should determine by lot which of the two Associate Justices should hold office for two years, and which for four years, so that there should be an election for Chief Justice or one Associate 
Justice cvery two years. The Circuit Judges hold office for four years; the Probate Jurlges and Trial Justices for two years. The Judges receive a fixed compensation, and are allowed no fees nor percuisites of office. The Supreme Court has appellate jurisdiction only in cases of chancery, and constitutes a court for the correction of errors at law. It has a general supervisory control over all other courts in the State. Two of the judges of the Supreme Court must concur to make a decision. The Circuit Judges interchange circuits. The C'ircuit Court has the usual civil jurisdiction exercised by Courts of Common Pleas, and the distinction between law and equity is abolished. The Court of Common Pleas must sit at least twice a year in each judicial district, and the Court of General Sessions at least three times a year. Three persons are elected every two years by the qualified electors of each county as a board of County Commissioners, who have jurisdiction over roads, highways, ferries, bridges, and in all matters relating to taxes, disbursement of money for county purposes, and the internal affairs and local concerns of the respective counties. Appeals lie to the State courts from their decisions. Judges are forbidden to charge juries in respect to niatters of fact; they may state the testimony and declare the law. The Attomey General of the State is elected for two years, and a Solicitor for each circuit for four years. The electors of each county elect a Sheriff and Coroner for the term of four years, who must reside in their respective counties during their continuance in office, and who shall be disqualified for re-election if in default of moneys collected by virtue of their offices.

The Suffrage. In all elections by the people, the electors vote by ballot. Every male citizen of the United States, of the age of twenty-one years and upwards, not laboring under the disabilities named in the Constitution, without distinction of race, color or previous condition, who was a resident of the State at the time of the adoption of the Constitution, or who, after that period, shall have resided in the State for one year, and in the county in which he offers to rote sixty days next preceding any election, is entitled to vote in any election by the people. But no person disqualified by the Constitution of the United States, nor any person while kept in any alms house or asylum, or of unsound mind, or while confined in any prison, can vote or hold office. Absence, while employed in the service of the United States, or while engaged upon the waters of the State or of the United States, or on the high seas, or tem. porary absence from the State, does not forfeit residence for the purpose of voting. On the other hand, the mere sojourning within the borders of the State of any person there stationed as a soldier, mariner or seaman, in the army or navy of the United States, does not confer residence for the purpose of voting. The right to vote involves and implies the right 
to hold office, except as otherwise limited by the Constitution. No law curtailing the right of suffrage can be passerl by the Cieneral Assembly, except for treason, murder, robbery or duelling, whe reof the person shall have been tried and convicted. The Presidential Electors who cast the vote of the State for President and Vice-President of the United States, are elected by the people. In all elections by the people, the candidates receiving the highest number of votes shall be declared clected. The State is divided into thirty-four judicial districts, called counties. Each county is a body politic and corporate. [By a recent Act of the Legislature, following a provision of the Constitution, all electors must be registered in the election precinct in which they reside before they are entitled to vote.]

TAxatiox.-Taxation must be uniform and equal, and no tax shall be levied except in pursuance of a law, which shall distinctly state the object of the same, to which object such tax shall be applied. Nll State taxes are levied by the General Assembly. A poll tax of one ilollar on each poll is provided, to be applied exclusively to the public school fund. The buildings and premises actually occupied by public schools, colleges and institutions of learning, all charitable institutions in the nature of asylums for the infirm, deaf, dumb and blind, idiotic and indigent persons, all public libraries, churches and burying grounds, are exempt from taxation. A new assessment of property must be made every five years. The State may contract public debts for the purpose of defraying extraordinary expenditures, but it must do so by special act, specifying some single object, and levying a special tax sufficient to pay the annual interest on such debt; and such Act must be passed by the vote of two-thirds of the members of each branch of the General Assembly recorded by yeas and nays on the journal. Municipal taxes are levied by the corporate authorities of counties, townships, school districts, cities, towns and villages, under the authority of the Legislature. Such taxes must be uniform in respect to persons and property.

Enucation. The supervision of public instruction is vested in a State Superintendent of Education, who is elected by the qualified electors of the State, in the same mamner as the other State officers. One School Commissioner for each county is also elected biennially, and the Commissioners so elected form a State Board of Education, of which the State Superintendent is ex officio Chairman. It is made the duty of the General Assembly to provide for a liberal and unifom system of free public schools throughout the State and to provide for their support by taxation. These schools must be unsectarian. [See infra "Statute Law ; Public Instruction."]

The Militia. [See infra under "Statute Law."] 
Malriage axid Divorce. [See imfra under "Statute Law."]

Amexpmexe and Revision of the Constitution. The Constitution may be amended in the following manner: The proposed amendment may be moved in either house. If two-thirds of the members elected to each house agree to it, such amendment shall be entered on the journals, and the yeas and nays recorded. It is then submitted to the qualified electors of the State at the next general election thereafter for representatives, and if a majority of the roters rote in favor of it, and two-thirds of each branch of the next General Assembly ratify such amendment, after reading the same three separate times on three several days in each house, it shall become a part of the Constitution. A convention to revise the Constitution can only be called by a rote of two-thirds of the members elected to each branch of the General Assembly, which action of the General Assembly shall be submitted to the electors at the next election for Representatives, and such electors shall vote for or against a convention. If a majority of all the electors voting at said election shall vote for a convention, the next General Assembly shall provide by law for calling the same, and such convention must consist of at least as many member's as compose the largest branch of the General Assembly.

[Under these provisions several amendments to the Constitution of 1 S6is have been made. The first prohibits the creation of any debt by the State without the consent of the people, signified by a majority vote of two-thirds of the qualified electors; the second changes the time of holding elections from October to November. Both these amendments were adopted in the regular manner in the years $1870-73$. The third amendment, ratified March 5, 1875, changes the terms of office of the Comptroller-General, Secretary of State, Treasurer, Attorney-General, Adjutant and Inspector-General, Superintendent of Education, from four to two years. The fourth amendment, ratified January 26th, 1S7S, provides for a county school tax to be levied in each county by the Boards of County Commissioners, for the support of the public schools. The fifth amendment, ratified December 13, 1S80, relates to the homestead exemption, and settles the law upon that point, as more particularly stated hereafter. Two amendments are now pending, one of which adds to the list of erimes disqualifying any citizen for the suffrage, " burglary, lareeny, perjury, forgery, or any other infamous crime," and the other relates to the mode of creating new counties. These last two amendments have not yet been voted upon.] 


\section{THE STATUTE LAW'}

The Statute Law of the State, which has been recently consolidated intc a Code and is embodied in a rolume called The General Statutes, is a devilopment of the organic law as laid down in the Constitution, and proceeds along the lines there indicated. It will only be necessary here to note some of the more important provisions.

Crines axp Puxisminists. Every person arrested under process, or taken into custody by an officer, has a right to know from the officer who arrests him, the true ground on which the arrest is made, and if the officer refuses to inform him, or informs him falsely, or declines to produce his warrant, such officer shall be punished as for a misdemeanor. Any person may arrest a felon upon view or certain information of the commission of the felony, and take him to a jurlge or trial justice to be dealt with according to law; and any eitizen secking to arrest a person who has broken into a house, or has stolen property in his possession, or where the circumstances raise a just suspicion of his design to commit a felony, may use any means to enforce the arrest, even to the extcnt of taking the life of the offender. The punishment of death by hanging is attached in South Carolina to the following crimes, viz.:

Murder, Rape, axd Arsox. In addition to the common law definition of murder, it is provided that where the death of any person results from any obstruction placed upon a railroad, the person convicter of placing or causing to be placed such obstruction shall be adjudged guilty of murder. Any person wounding another in a ducl is guilty of murder if death ensue from the wound within six months. Rape is punishable with death, but the jury may find a special verdict recommending the party to mercy, in which case the punishment shall be reduced to imprisonment for life in the penitentiary at hard labor. Arson is the wilful and malicious setting fire to or burning by day or nigist of (1) any house of any kind whaterer within two hundred yards of and appurtenant to a dwelling; (2) any court house or public building, whether owned by the State or a corporation or individuals; (3) any barn or stable, coachhouse, gin-house, store-house, ware-house, grist or saw-mill, railroad depot, coach or cotton factory, or other house used for manufacturing purposes, or any building habitually used for public worship. Any person convicted of arson as principal, aider, abettor or accessory before the fact, shall suffer death by hanging, with the same proviso for a spccial verdict as stated above in the case of rape.

Mavscaugnter, or the unlawful killing of another withont malice, express or implied, is punishable by imprisonment in the penitentiary, 
at hard labor, for not less than two nor more than thirty years. Attempt to administer poison is punishable by imprisonment in the penitentiary for not less than two nor more than ten years. Any one sending or accepting a challenge to fight a duel, shall be deprived of the right of suffrenge and disqualified from holding any office of honor or trust, and imprisoned in the penitentiary not exceeding two years. Any person carrying a challenge shall be disqualified from holding office, and imprisoned in the penitentiary not exceeding two years, and finerl not less than $\$ 500$, nor more than $\$ 1,000$. The principal or second in a dnel may be compelled to give testimony against any person indicted without criminating himself. The carrying of a deadly weapon concealed about the person is a misdemeanor, punishable by fine and imprisonment, and an assault with such concealed weapon is an aggravated offence. Killnapping sailors or minors, ill treatment of apprentices, children, servants, \&c.. and enticing away a laborer under contract with another, or employing a laborer known to be under such contract, are misdemeanors, punishable by fine and imprisonment. Burglary at common law is punishable by imprisonment in the penitentiary for life at hard labor. Breaking into a house in the day time is a felony, punishable by imprisonment for not more than one year. Burning stacks of corn, \&c., and burning or cutting frames of timber, are punishable by imprisonment. Firing turpentine farms is a felony, punishable by fine or imprisonment. Stealing grain or cotton from the field is a felony, punishable by fine or imprisonment. Larceny of live stock is punishable by fine and imprisonment in the penitentiary for not less than one nor more than ten years. Among the misdemeanors to which special punishments are attached are: Setting fire to grass; malicious wounding of live stock: malicious injury or defacement of houses, trees, \&c.; marking or branding of the animals of others; obtaining property under filse pretences: obstructing rivers and creeks and fish sluices, ditches and drains; selling property on which a lien exists; fraudulent removal of property levied on by sheriff; false packing of cotton; selling seed cotton between sundown and sunrise; failure of factors to account for produce placesd in their hands; and cruelty to animals. Bigany is punishable by imprisonment in the penitentiary not less than six months nor more than five years, and by fine not less than $\$ 500$. Adultery and fornication are punishable by fine and imprisonment, or both. Practicing medicine or dentistry without the proper qualifications is punishable by finc, and all practicing physicians are required to register themselves in the office of the Clcrk of the Court of Common Pleas for their respective counties. Lotteries are prohibited, and penalties are attached to setting up or allvertising the same, or selling lottery tickets. Where any person is reported to the 
coroner to have come to a violent or untimely death within his jurisdiction, he shall hold an inquest upon the body with the aid of a jury of fourteen men of the county, and all persons sulject to jury duty in the Cireuit Court are liable to serve on a coroner's jury. The coroner can arrest and bind over for trial any person appearing to be concerned in such death, and also material witnesses to the faets. As already stated, the punishment of whipping is not permitted by the laws of South Carolina.

Law of Property. There are, of course, many details of property law which can only be learned by consulting a lawyer, but a few general prineiples and important provisions may be noted here. Any man or woman of legal age, owning real estate in fee simple, may freely dispose of it by will, or sell and convey the same by deed, executed in the presence of two or more witnesses, and duly recorded. If the deed be by a married man, the wife must renounce her dower in a formal mamner, provided by statute. A married woman may hold property separately from her husband and may dispose of the same as if she were unmarried. All deeds of converance or mortgage, trust deeds, marriage settlements, \&e., leases between landlord and tenant for a longer period than twelve months, liens on crops and mechanies' liens, and liens on ships and vessels, must be recorded in the office of the Register of Mesne Conveyances for the comnty where the property is situated, in the case of real estate, and in the case of personal property, for the county where the owner resides, within forty days from the time of execution or delivery, in order to affect the rights of subsequent ereditors or purchasers without notice. No person having a lawful wife or children can give to any illegitimate children or concubine, by conveyance, gift or legacy, a greater proportion of the value of his estate than one-fourth thereof. Every conveyance for the purpose of defrauding creditors is void. So, also, are conveyances to deceive purchasers. Upon the payment of a debt secured by mortgage, the mortgagor may compel the mortgagee to enter satisfaction on the mortgage. No parol lease is valid for more than one year, and every written lease shall terminate at the period therein stated, without its being obligatory on either party to give notice. The landlord may distrain for rent in arrear. Tenants in common and joint tenants are compellable to make partition. Liens on real estate are of no forec after the lapse of twenty years, unless kept alive by some payment or acknowledgment of indebtedness, except in the cases of judgments provided for in the Code of Procedure. Wills in South Carolina must be signed and acknowledged by the testator in the presence of three witnesses, who must sign in the presence of the testator and of each other. Aliens can hold and dispose of real and personal property in the same way as 
citizens, and so far, therefore, as the rights of property are concerned, naturalization is not neccssary. So, also, aliens can lend money upon sccurity, and can have the same remedies for suing for and recovering. the same as if they were citizens, whether the forcign State, of which the alien is a subject, be at war with the United States or not; and if a citizen leave an alien widow, such widow's rights in his estate shall be exactly the same as if she were naturalized. In case of intestacy, the property of the intestate is distributed by law among his nearest kin, according to certain rules specifically laid down by statute. Where he leaves a widow and children, the widow takes one-third and the children two-thirds. The Probate Court has power to grant administration of the personal estate. The property of a felon is not escheated, but descends to his representatives. A liomestead in lands, whether held in fee or any lesser estate, not to exceed in value one thousand dollars, with the yearly products thereof, is exempt to the head of every family residing in South Carolina from levy or sale for debt upon any judgment recorered against him ; and it is the duty of the sheriff before selling the real estate of any head of a family to have such homestead set off by appraisers in the manner prescribed by law. If the property cannot be set off, the sheriff must sell and pay one thousand dollars of the purchase money into Court, to be applied to the purchase of a homestead. If the husband be dead, the widow is entitled to the homestead; and if both parents be dead, the right is secured to the children, and no waiver of the homestead is valid, except in cases of conveyance or mortgage. Personal property to the value of five hundred dollars is exempt from attachment, levy or sale. Where a married woman has separate property she is entitled to the homestead when the husband's property is not sufficient. The Statute of Frauds is in force in South Carolina, and all agreements for the sale of lands, leases for more than one year, promises to answer for another's debt or default, contracts for the sale of goods above the value of fifty dollars, dc., must be in writing and signed by the party to be charged, or his duly authorized agent. Assignments of the property of an insolvent debtor for the benefit of creditor's which give to any creditor preference over any other, are utterly void. The legal rate of interest is seven per cent.; but by written contract a rate of interest not exceeling ten per cent. may be charged. If more than ten per cent. be charged, all the interest is forfeited, and only the principal sum can be recorered. And if any greater amount than ten per cent. shall be received, the person or corporation receiring it shall forfeit double such amount.

Pumlic Ixstectiox. The duties of the State Superintendent of Education have been already touched upon. ITe has general supervision over all the free public schools of the State, and is required to visit every 
County in the State to inspect the same and to make an annual report to the Cieneral Assembly. He is trustee for all property granted or devised for the purposes of elucation. The State Board of Examiners consists of the State Superintendent of Education and four persons appointed by the (rovernor, with the consent of the Senate. They meet from time to time and constitute an Advisory Board for the Superintendent of Elucation. They have a general power in all matters relating to the sehools and espevially to teachers. They examine persons who apply for appointment as teachers, and issue certificates of their qualifications. In each County a Sthool Commissioner is elected at the general election, whose duty it is to superintend all the shools in his county, to report their condition to the State Superintendent and to apportion the school fund for his eounty. It is the duty of the County Boards of Examiners and of the Boards of Trustees to see that in every school under their care shall be taught, as far as practicable, orthography, reading, writing, arithmetic, geography, English grammar, History of the United States and of this State, the principles of the Constitution and laws of the United States and of this State, morals and good behavior. In each county there is a County Board of Examiners, eomposed of the County School Commissioners and two other persons appointed by the state Board. They constitute the Advisory Board of the County School Commissioner's. They appoint in each School District in their county three School Trustees, who take the management of the local erlucation of tho Sehool District, subject to the supervision of the County Board of Examiners. The poll tax is applied to school purposes and the County Treasurer is required to account for it to the School Commissioners.

The Departinest of Agriculture is administered by a Board of five persons-the Governor, Chairman c.x officio, the Master of the State Grange of Patrons of IIusbandry, the President of the State Agricultural and Mechanical Society, and two citizens chosen by joint vote of the General Assembly for two year's. The Commissioner of Agriculture must be an agriculturist, chosen by joint vote of the General Assembly for two years. The Board prescribe the duties of the Commissioner; they regulate the returns of County Agrieultural Societies ehartered by the State; issue blanks to County Auditors for collection of agricultural statistics; investigate all matters relating to agricultural interests, diseases of stock, fish, ite., and to commercial fertilizers, and have eontrol over the phosphate interests of the State. The Commissioner of Agriculture is required to keep a book in which lands for sale may be registered, and also books in which shall be entered the names of persons desiring employment as laborers, a fee of $\$ 1$ being eharged for such registry, and the books shall be open for inspection free of eharge. He shall collect specimens of ag- 
licultural products, minerals, \&c. The Department of Agriculture regulates the matter of immigration to the State. An ammul report of all its proceedings is made to the General Assembly.

Immigants axd Seamen. To person is permitted to keep an immigrants' or sailor's hotel or boarding house in the city of C'harleston without a license from the City ('ouncil, and hotels not so licensed cannot solicit boarders. The City Council must issue barlges and the agents or owners of boarding houses must wear such badges when engaged in soliciting boarders. Harboring deserting seamen or enticing them to desert is punishable by fine and imprisomment. Impressing seamen is a misdemeanor punishable by fine and imprisonment.

Tre Militia. All able-bodied male citizens of the State between the ages of 18 and 45 years, except such as are exempt by law, are liable to service in the militia, but there is no compulsory military service except in certain cases of emergency. The Governor has power to call out the militia to execute the laws, repel invasion, repress insurrection and preserve the public peace.

Marriage AND Divorce. Complete freedom of marriage is allowed, except within certain elose degrees of consanguinity, and except that intermarriage between the white and colored races is forbidden. The real and personal property of a woman held at the time of her marriage, or that which she may thereafter aequire either by gift, grant, inheritance, devise, or otherwise, does not pass to her husband by her marriage, nor become in any way subject to his debts, but remains her separate property, and she ean deal with it as she chooses during her life and dispose of it by will as if she were ummarried. It is provided by the Constitution that divorces from the bonds of matrimony shall not be allowed but by the judgment of a court as shall be prescribed by law. For some years after the adoption of the Constitution an Act was in force providing for and regulating such dirorees by the courts, but that Act has been repealed, and there is, therefore, now no tribunal in South Carolina by which dirorees can be granted. The Court of Common Pleas has, however, power to hear and determine any issue affecting the validity of contracts of marriage, and to declare such contracts void for want of consent of either of the contrating parties, or from any other cause going to show that at the time the supposed contract was marle, it was not, in fact, a contract-provided that such contract has not been consummated by colabitation of the parties.

Gexerat Remarks. Except as it may have been modified by special enactment, the common law of England is in force in South Carolina. The general tendency of the legislation under the new Constitution has been towards the simplification of the tenure and disposition of property, 
of process and pleading in the Courts, and of the collection of debts, and towards the increased seeurity of person and estate. Short and easy remedies are provided for the recovery of debts. The agricultural interests of the citizens are protected by the laws already mentioned with relation to the maiming and stealing of stock, Sc.. and by a recent Act entitled "An Act to provide a general stock law and regulate the operations of the same," which prohibits persons from allowing their live stock to run at large beyond the limits of their own land. The counties of Georgetown, Horry and Williamshurg are excepterl from the operation of the law, but are required to have fences and gates creeted on their boundary lines. Owners of stock trespassing are liable for damage done and expenses of seizure, dc. Stock trespassing may be seized by the owner of the land. It is made a misdemeanor to break or leave down gates or fences, and also to resene stock impounderl. Persons making advances either in money or supplies to those engaged in planting have a lien on the crop to the extent of the advances so marle in preference to all otlier liens, provided an agreement in, writing be entered into. Landlords have such a lien to the extent of one-third of the crop without reeording or filing. Laborers employed in making a crop have a lien thereon for their wages. Persons furnishing labor or materials for erection, alteration or repair of buildings, have a lien upon the building and upon the interest of the owner in the land on which it stands for their debt.

Every encouragement is given to the employment of capital in manufacturing industries. By a special Act of the Asembly, it is provided that eapital invested in the manufacture of cotton. woolen and paper fabries, iron, lime, and agricultural implements, shall be exempted from all State, County and municipal taxation for a period of ten years from the time of the commencement of the enterprise, excepting only the two mill tax for school purposes. But this exemption does not apply to the land upon which factories are erected. Tessels of one hundred tons measurement, and upwards, built and owned within this State, are entitled to the benefit of this Act. Those desiring to arail themselves of the Act must file with the Comptroller-General proof of the investment. For the purpose of encouraging immigration, real estate purehased by immigrants, and eapital invested in improvements thereon, up to $\$ 1,500$, is exempted for five years from all State, County or municipal taxation, except the two mill sehool tax. The department is authorized to use a fund under its control to encourage and aid the introduction of immigrants. 


\section{PRINCIPAI AUTHORITIES CONSULTED.}

History of South Carolina, 1670-1S0S. D. Ramsay. Charleston, 1809. An Historical Account of the Rise and Progress of the Colonies of South Carolina and Georgia. Hewit. London, 1779.

History of South Carolina. IV. G. Simms. Charleston, 1860.

History of the United States, George Bancroft. Boston, 1841-1874. Statistics of South Carolina. Robert Mills. Charleston, 1826.

"Dual State Governments." Address by Joseph W. Barnwell, Esq., before the South Carolina Historical Society, May 1Sth, 18s0. Charleston, 1880 .

Guide to Charleston. Charleston, 1875.

Charleston Year Books, 1881 and 1882.

Appleton's American Cyclopedia, title "South Carolina." New York, $1873-1876$.

Constitution of South Carolina. 1868.

General Statutes of South Carolina. 1851.

Acts and Joint Resolutions of the General Assembly of South Carolina. 


\section{CHAPTER IV.}

\section{A SKETCH OF EDUCATION IN SOUTH CAROLINA.}

BY R. MEANS DATIS,

PROFESSOR OF HISTORY AND POLITICAL SCIENCE IN SOUTH CAROLINA COLLEGE.

1882.

CONTENTS OF SKETCH.

I. Historical Sketcil.

II. Public School Sisted.

III. Schools ix Ciharlestor.

IV. Schools in Columbia.

T. Charitable and Edichtonal Associations.

vi. Private Scironls.

VII. Higher Enccation for Males.
VIII. Military Training and Instrlection FOR MALES.

ix. Higher Euecation for Females.

I. Professional axd Special IxstrucTION.

Xi. Edecation of Colored Race.

XiI. Perionfchl Litherature.

Aiti. Illiteracy.

XIV. Arpexdr.
School Officers, 1851-2.

HEGH S. THONPSON,

State Suplintexdext of Edcation.

State Bohrd of Exhminers. HENRY P. AFCHER.

REV. JAMES DUNLOP.

IREV. J. SCOTT MURRAY. CIIARLES PETTY.
Scinol Officers, $1882-3$.

ASBLRY (OWARD,

State Superintexinest of Encation.

State Bonis of Fixhmisers.

HENRY P. ARCHEI.

REY.J. SCOTT MURRAY.

*R. IV. BOYD.

*R. MEANS DAVTS.

* Vice Rev. James Dunlop and Charles Petty, resigued. 


\section{HISTOPICAL SKETCH.}

The people of South Carolina, from the earliest period, fostered education. The first permanent settlement was made about the year 1671, and at the close of the seventeenth century the population scarcely reached five thousand, yet among the first recorded acts of the Colonial Asscmbly was the enactment of laws for the observance of the Sabbath, the prevention of idleness and drunkenness, and for "securing the Provincial Library in Charleston." In these early times

\section{RELIGION AND EDUCATION WENT HAND IN HAND.}

Contemporaneously with the establishment of these Colonies, was the organization in England of a "Society for the Propagation of the Gospel in Foreign Parts," by which missionaries were sent out, not only to preach, but "to encourage the setting up of schools for the teaching of children."

Through the liberality of Dr. Bray, the Bishop of London's Commissary for Maryland, aided by the public spirit of the Lords Proprietors and settlers, the nucleus of a public library had already been formed in

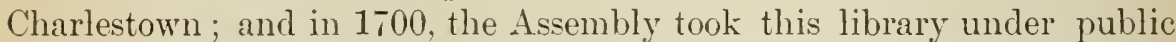
control, appointed the minister of the Church of England ex officio librarian, and created an advisory board of nine commissioners to aid him in the discharge of his duties. Other libraries were established in the Province by the combined action of the people, the Assembly, and the Society for the Propagation of the Gospel.

From Carroll's History we learn that "the missionaries represented frequently to the Society the great want of schools in the Province for the instruction of the children in the principles of religion, and teaching convenient learning. Dr. Le Jau, of Goose Creek, did very earnestly press the Society to allow a salary for a schoolmaster in his parish, and they appointed Mr. Dennis schoolmaster in 1710. He had a good number of scholars for several years, till the Indian war broke out, which dispersed the people and all his scholars." About this time, the Rev. Mr. Guy was appointed schoolmaster and assistant curate at Charleston.

FREE SCHOOLS.

Free schools date their origin as far back as 1710 . In that year, the Assembly passed "An Act for the founding and erecting of a Free School" in Charlestown. The preamble recites that "It is necessary that a free school be erected for the instruction of the youth of this Province in 
grammar and other arts and sciences and useful learning, and also in the principles of the Christian religion," and that "several well disposed Christians, by their last wills, have given several sums of money for the founding a free school." The Act constitutes a body corporate, consisting of the Governor and fifteen others, with power to prescribe rules, and to elect a master, who shall be of the Church of England, and shall teach the Latin and Greek languages, and, also, the useful parts of the mathematics. An amendatory and more general Act passed in 1712, appointing John Douglass master, at a salary of $£ 100$ and a house, allowing him an usher, and a writing master to teach writing, arithmetic and merchants' accounts, and the arts of navigation and surveying. 'Twelve beneficiaries were provided for, and free scholarships for five years were granted to any citizens on payment of $£ 20$ each. An additional provision was that " any

SCHOOLMASTER SETTLED IN A COUNTRY PARISH,

and appointed by the vestry, should receive $£ 10$ per annum from the public treasury ;" while each parish was allowed $£ 12$ towards erecting a school-house.

This Act deserves mention, not so much from the actual results achieved, but as a proof of the enlightened and liberal spirit of the people in the presence of most unpropitions circumstances. It must be remembered that the early settlers of Carolina were continually harassed by foes from without and dissensions at home. "They raised their scanty crops, not only with the sweat of their brows, but at the risk of their lives." Cavaliers and Puritans brought with them the memories of old feuds, and were united only in oppressing the Huguenots. Locke's model constitution was an exasperating failure. Proprietors and people held diverse interests, and Governors were often at dagger's' points with the governed. Over issues of money had destroyed public confidence and depleted the treasury. A disastrous expedition against the Spaniards, in 1702, and the necessity of repelling a counter invasion, rendered the situation still more distressing. At the rery time that the free school was founderl, the Province was torn by the claims of two conflicting Governors, and the dispute was scarce settled before a severe contest arose against hostile Indians. The four years from 1715 to 1719 marked constant strife between the people and the Proprietor's, and tranquility was not secured until the appointment, in the latter year, of a royal Governor.

THE FIRST ROYAL GOVERYOR.

The first appointee of the Crown, General Francis Nicholson, combined boldness, activity and firmness with liberality, wisdom and integrity. 
Iis great zeal in behalf of education is thus chronicled by Hewitt: "As no public school had yet been instituted for the instruction of youth in the principles of virtue and religion, the Governor urged, also, the usefuhness and necessity of such provincial establishments. It was alleged that the want of eary instruction was one of the chice sonrees of impiety and immorality; and if they continued any longer to neglect the rising generation, piety and Christianity would insensibly decay, and they would soon have a race of white people in the country equally ignorant as the brown Indian. Animated by the example, and assisted by the generosity of the Governor, the colonists, therefore, in good eamest enganged in providing seminaries for the religious education of youth."

\section{PRIVATE IBENEFACTIONS.}

Particular legacies swelled the educational fund. Mr. Whitmarsh left $£ 500$ to St. Paul's Parish; Mr. Ludlam, 22,000 to Goose Creek; and Richard Beresford, $£ 6,500$ to St. Thomas; James Childs bequeathed $\$ 600$, and other parishioners added $£ 2,200$ more to an institution in St. John's Parish, established in 1733; Francis Williams donated $£ 200$ for the instruction of the poor.

In 1734, a free school was opened in Dorchester, a town that had been settled in 1696 by a colony of Congregationalists from Massachusetts, under the Rer. Joseph Lord. The preamble of the act of incorporation mentions that the school at Charlestown is insufficient to meet the wants of the people. The teacher was required to give instruction in the learned languages and the principles of the Christian religion.

After this time, as we are informed by Ramsay, the youth of the Province were always able to secure instruction in the classics and in elements of mathematics.

With increasing wealth came increasing love of learning. Opulent planters maintained private tutors, or sent their sons abroad. "None of the British Provinces, in proportion to their numbers, sent so many of their sons to Europe for education as South Carolina."

\section{EDUCATIONAL ANI) CHARITABLE ASSOCIATIONS}

continued to be formed during colonial times. The South Carolina Society, organized in 1737 , and incorporated about fifteen years later, employed teacher's and taught and clothed poor children; besides extending bounty to indigent members and their sons and daughters. The Winyah Indigo Society of Georgetown was incorporated in 1757, and the Fellowship, Socicty of Charleston in 1739, for a similar purpose. In this last 
named year an attempt was made to found a provincial college, but it failed, owing, it is said by some, to the opposition of those who believed that, by facilitating the acquisition of knowledge, existing distinctions of rank would be destroyed; or, as other's say, because the rich and influential members, who controlled legislation, were able to send their children abroad, and felt no need for higher education at home.

\section{THE REVOLTTIONARY PERIOI).}

During the trying times of the revolution, learning did not languish. In 177\%, were incorporated Mount Zion Society, Wimnsboro', and Catholic Society, Camden; in 177s, Salem Society, Camden, and St. Darid's Society, Cheraw. Immediately after the declaration of peace a fresh impetus was given to education, three colleges being incorporated in 1785 on the same day; the first, the College of Charleston, which still exists; the seconrl, Mount 'Zion College, in Winnsboro', which subsequently became an academy of great merit, and a third, which was to be established at Cambridge, but never went into operation. In 1795, a college was founded in Beaufort, but the funds were subsequently transferred to a seminary of high grade. The Beaufort Society had already been incorporated in 1786 , and the St. Helena Society in the same year. In 1757 was incorporated the Camden Orphan Society; in 1759, the Claremont Society, at Stateburg; in 1791, the Beaufort District Society; in 1798, St. Andrew's Society, in Charleston ; in 1799, Upper Long Cane Society, in Abbeville; in 1500, the John's Island Society, and in 1809, the Mount Pleasant Academy. All these, as far as known, were endowed either by private donations, or by the proceeds of escheated and confiscated lands, or both. Besides these, the Fair Forest Academy in Union, the Nount Bethel Academy of Newberry, the Minerva Academy in Richland, and one of the same name in Spartanburg, are mentioned by Rimmsay as filling positions of great usefulness.

In 1797 , the Legislature went so far as to incorporate a fifth college, located in Pinckney District, and styled "The College of Alexandria." The district and its college alike live only in the memories of the past.

Besides these chartered academies were sereral flourishing private schools, chief among them,

TIIE WILLINGTON ACADEMY,

in Abberille, conducted by Dr. Moses Waddell. Hore gathered students from all parts of this and adjoining States, and the wild woods of the Saramalh resounded with the echoes of Homer and Virgil, and Cicero 
and Horace, as the "winged words" issued from the lips of this renerable preceptor, or his ardent disciples. Generations have passed away, but the impress of Dr. Waddell's genius and influence is still seen in the social and political condition of the State.

By 1801 the State had become convinced of a want of wisdom in dissipating its resources; and upon the strong recommendation of Governor John Drayton, the Legislature that year passed an act incorporating

TIE SOUTH CAROLINA COLLEGE.

A sketch of this celebrated institution will be given elsewhere. Since then, at different times, private colleges of great usefulness have been established, to which further reference will also be made.

In 1798, trustees were appointed to establish free schools in Orangeburg. With this exception, it would appear that, after the efforts of the early colonial governments, no further special attention was paid to free instruction until the year 1811.

FREE SCHOOL SYSTEM.

On the 26th of November of that year, Governor Henry Middleton urged, in his annual message, the establishment of free schools. On the following day Senator Strother presented petitions for free schools, signed by citizens of Fairfield, Chester, Williamsburg, Darlington, Edgefield, Barnwell, York, St. Stephen's, St. James' Santee, St. John's Colleton, and St. Peter's. A joint committee was appointed, with the Hon. Stephen Elliott as chairman. A bill drawn by Mr. Elliott was reported by the committee; passed the Senate without the roll call, and was adopted in the House by a vote of seventy-two to fifteen.

This Act established in each district and parish free schools equal in number to the representatives in the lower house. Elementary instruction was to be imparted to all pupils free of charge, preference being given to poor orphans and the children of indigent parents. Three hundred dollars per annum were voted to each school. Commissioners, varying in number from three to eleven in each district and parish, serving without pay and without penalty, were entrusted with their management. Until a sufficient number of schools should be established, the commissioners were permitted to move the schools annually, but no school should be established until the neighborhood had built a school house. The funds of the free schools might be united with the funds of the public schools. The aggregate appropriation was about $\$ 37,000$ a year. The system having been thus auspiciously inaugurated, vigorous efforts 
followed to put it into successful operation. Legislative eommittees made annual reports, showing greater or less progress. Leading men interested themselves in free education.

GOVERNORS, IN THEIR ANYLAL MESSAGES,

evinced an earnest desire for a more general diffusion of knowledge. Among these were Governor Middleton, in 1812; Governor Williams, in 1815 and 1816; Governor Pickens, in 1817; Governor Bennett, in 1822; Governor Wilson, in 1823; Governor Manning, in 1826; Governor Miller, in 1829; Governor Hamilton, in 1831 and 1832; Govemor Hayne, in 1S33; Governor NcDuffie, in 1835 and 1836; Governor Butler, in 1837 and 1838; Governor Noble, in 1S39, and Governor Henegan in the following year. Governor Hammond, in both his messages (1St2 and 1843), urged the endowment of an academy in each district. Other govemors have touehed upon the subject with more or less earnestness.

An amendatory Aet, introdueed by Judge Frost, and passed in 1835, provided penalties for non-performanee of duty by the commissioners, but gave no pay; and failed to designate any one whose business it should be to enforce the law. While such thiekly inhabited localities as Charleston had derived benefits from these schools, sparsely settled eommunities had aecomplished little, and the general result was unsatisfaetory. Instead, however, of abandoning the attempt,

\section{INCREASED EFFORTS WERE MADE}

to ensure suecess. A committee, eonsisting of Rev. Stephen Elliott and Rev. James H. Thornwell, was appointed in 1838 , to eonfer with the various school commissioners, and suggest improvements. Their report, presented in 1839, is full of interest; containing, among other eontributions, a most elaborate paper by the Hon. Edmund Bellinger, of Barnwell, which showed that in twenty-seven years, the average attendance for the State was 6,01S pupils, and the average annual expenditure, $\$ 35,000$, that during the whole time regular reports were made in only five years, that the expenditure for each year bore no proportion to the seholars, that sereral parishes and distriets reeeived no regular sum, that the expenditure for each distriet bore no proportion to the seholars edueated or to the population, that out of the attendanee not more than onesixth was believed to be eomposed of necessitous pupils. The greatest number of scholars in any one year was 10,718, in 1833; and the largest expenditure was $\$ 45,951$, in 1819 , during which year the attendance was but 3,002 . Sinee 1815 the annual appropriation had been $\$ 37,000$. 
There was an almost unanimous concurrence in the recommendation of some sort of general superrision, either in the person of one official, or of several, with liberal salaries. This same measure had been insisted upon by leading statesmen and educators time and again; but it was never allopted.

\section{NO DEFINITE RESLLTS}

came from the presentation of this report. In 1546 , at the request of the State Agricultural Society, Hon. R. F. W. Allston prepared an elaborate report, in which he dwelt upon the necessity of supplementing the State appropriation by local taxation of an: equal amount. Though thoroughly imbued with a desire for better schools, Governor Allston, suhsequently, when President of the Senate, opposed al larger State appropriation, on the ground that, without local taxation, it would accomplish nothing. Mr. Henry Summer made a report to the Legislature in $1 S 47$, insisting upon better free schools, as supplementary to the college, urging the establishment of a normal school, and a more equitable apportionment of the public funds.

In 1852, the Legislature, by a close vote, passed an det doubling the appropriation for free schools; and after that time $\$ 7 t, 400$ were annually set apart for their maintenance. Attendance in 18.33 was over 17,000 , and in 1554 , over 16,000, exclusive of Charleston. While in some districts free schools were established, in other's contracts for tuition of indigent jupils were made with teachers of private schools. The report for 1830 shows an aggregate of 1,270 schools, and $18,91.5$ pupils. The appropriation was $\$ 74,400$, the expenditures $\$ 127,33)$.41 , an excess of $\$ 62,367 . \$ 0$, of which $\$ 19,344.39$ were in Charleston City, and were prob.bly met by a city tax. Excess in the other districts and parishes may be explained partly by overdrafts and partly by unexpended balanees of former years.

In 1863, there were 828 schools, 845 teachers, and 10,811 pupils.

It may reasonably be asked why this system of instruetion

\section{BORE SO LITTLE FHUIT,}

in the face of so much interest and so many admirable attempts to cultivilte it. Dr. Curry attributes the cause to the existence of slavery. "Slavery sparsified our population, created a kind of aristocracy, among whom, as Burke said, 'Froodom was to them not only all cenjoyment, but a kind of rank and privilege.' slare owners hehl borrowed estates, were surrounded by a host of menial dependents, lived huxuriously, dispensed a cordial and magnificent hospitality, 'combined with the spirit of freedom the haughtiness of domination,' ank free schools breame un- 
necessary or impossible." Although these schools were made free to all by the Act of 1811, they soon came to be regarded in many localities as pauper schools. As far back as 1839, Rev. Mr. Thrummell, of All Saints', reports, as the radical defect of the system, that "it is a bounty, intended for the poor. The rich will not avail themselves of it, since they do not need it, while the poor will rather keep their children home altogether, than, by sending them to the free school, attach to them, as they think and feel, the stigma of being poor, and of receiving edncation as paupers." In his view, the imposition of a local tax, by compelling all to contribute to the school would induce all to send to it, thus removing the existing reproach. Instances are eited in which parents refuse to send children to these "pauper institutions," yet willingly accept the offer of a rich neighbor to pay their bills at a private academy.

- Another cause of failure was the want of proper superrision, and the consequent incompetency of many teachers. Another defect was the establishment of schools in proportion to representation in the Legislature, instead of causing them to be based upon the number of children. Under the ante bellum Constitution, wealth was an equal factor with population, in determining representation. So that the richer the district, the greater the number of free schools.

But the controlling cause of the failure of the free schnol system was, that its need was not felt by the people. Private institutions lad sprung up on every hand; and, through individual beneficence or the generosity of teachers, the rudiments of instruction, if nothing more, were in reach of all who desired to secure them. In this way have some of the brightest intellects of the State been trained to shed lustre upon the pages of her history.

THE CENSL'S OF 1850

shows that the expenditures for education within the limits of the State during that year, amounted to $\$ 510,879$, of which $\$+10,430$ were raised by tuition fees, $\$ \mathbf{7 9 , 0 9 9}$ by taxation and public funds, and $\$ 21,350$ by endowment, fepresenting endowment funds aggregating $\$ 305,000$, on a basis of seven per cent.

THE SUCCEEDING DECADE

was in every respect a period of unexampled progress. By the census estimates, the true value of property had risen from $\$ 28 \$, 257,694$ in 1850 , to $\$ 5 \pm S, 138,75 \pm$ in 1860 . The sums expended for education had increased to $\$ 690,412$, of which $\$ 420,944$ came from tuition fees, \&c., $\$ 135, \$ 13$ from taxation and public funds, and $\$ 133,755$ from endowment, representing, at seven per cent., endowment funds of $\$ 1,910,78 \$$. This last 
feature is worthy of special note, as evincing a determination to assure the permanence of elucational institutions. This absolute increase is remarkable, being six fold in ten years. Its comparative increase is noteworthy, as being from a fraction over two per cent. of the aggregate endowments in the whole Union, in 18.50, to something more than six per cent. in 1560 . In that year South Carolina was fifth on the list in the amount of College endowments, and sixth also in the income of her Colleges; as will be seen by reference to the eensus.

At this time were in most successful operation the South Carolina College, the State Militury Academy, the Charleston College, Erskine College, Wofford College, Furman University, Newberry College, the Medical College in Charleston, and three Theological Seminarics, all for males. Female Colleges of high repute flourished in different portions of the State. Classical or Military Academies were located in almost every town, and in many country places, selected for their salubrious climate or other natural adrantages. All these were patronized alike by parents who had received a liberal education, and by those who, feeling the want themselves, desired it for their sons and daughters. Nor was patronage confined to schools and colleges at home. Large sums of money flowed into the coffer's of renowned educational institutions in other States and beyond the seas, so that it is safe to estimate the annual expenditure at not much less than a million dollars for education.

\section{AS TIIE CLOUDS OF WAI}

thickened, these institutions closed one by one, and teachers and pupils alike passed from classic sharles to the tented field. Some school edifices were destroyed, some converted into hospitals for the sick and wounded, and others afforded shelter to refugees from the derastated districts. The last call for troops, in February, 1865, swept into the field every white male from sixteen to sixty.

The year 1865 was most disastrous to every interest. The pangs of defeat were intensified by the pangs of hunger, and the desire for knowledge gave place to cravings for bread. The following year, howerer, marked

\section{A GENERAL REOPENIYG OF SCHOOLS}

One of the first acts of the new legislature that succeeded military rule was the rehabiliment of the South Carolina College, and its enlargement into a University, with a full academic esurso and complete schools of law and medicine. Private colleges set themselves brarely to the task of (ollecting scattered students and replenishing bankrupt treasurics. 
Schools and academies again opened their doors to the rising generation, and it was fondly hoped that progress would be rapid. This hope was short lived.

An organic revolution soon oceurred which convulsed society to its very foundations, and wrought changes more violent even than those that first followed the surrender. A new constitution was adopted, the old forms of government, the courts and many existing institutions were changed. New law-makers, sup orted by a new constitueney, brought in new ideas and new methods.

The old system of private institutions was henceforth gradually to be supplanted by a general system of State instruction for rich and poor alike. Hereafter we will find public schools occupying a much more prominent place in the public mind and in public legislation.

\section{PUBLIC SCHOOL SYSTEI.}

The adoption of the amendments to the Federal Constitution caused a thorough reconstruction of the State government, and elevated an entirely new element to the control of public affairs. A new State Constitution was adopted in 1868. It incorporated a system of public instruction into the organic law of the land, and provided for the election of a State Superintendent of Education, and for subordinate officers in the different counties for the management of schools and the improvement of teachers. Provision was made for raising necessary school funds, and a compulsory attendance was ordered so soon as the school session should reach six months in each year. The sourees of revenue were threefold-first, a general legislative appropriation ; second, a polltax of one dollar on all able-bodied male citizens (with a few exceptions) within certain specified ages; and third, a voluntary local taxation.

The system, perfected as it had been in other States as the result of careful study and long experience, was

\section{GOOD ENOUGII IN THEORY;}

but in practice proved a failure, owing partly to its norelty, but chiefly to the ignorance and dishonesty of many parties connected with its management.

State Superintendent Jillson (1868-1S76) makes repeated complaints of the diversion of school funds to other purposes, and, in his report for 1876 , shows an aggregate deficiency of $\$ 324,058.40$. Besides this, in 
almost every county existed school claims in excess of estimated appropriations, thus swelling the debt to still greater proportions.

Notwithstanding the disconragement and even exasperation of friends of education in consequence of these gross frauls against the system, the number of schools and pupils all along increased, an evidence of what might be expected under better management.

In 1577

\section{A CHANGE OF GOVERNMENT}

occurred, since which time the charges of dishonesty have totally ceased, and complaints of incompetency are steadily decreasing. Much of this progress is due to the zeal and ability of the Hon. Hugh S. Thompson, for six years State Superintendent. As parents, children, and officials become better acquainted with their respective duties and responsibilities, the system improves in a constantly inereasing ratio.

SCHOOL REVENUES.

A constitutional amendment, adopted by all parties in 1876 , provides for an annual levy of not less than two mills on the dollar for public schools, to be expended in the county in which it is raised, thus insuring stability to the system. The poll-tax is devoted to educational purposes, and in some localities the option of local taxation rests with the property holders.

TERRITORIAL DIVISIONS AND GOVERNAENT.

Each county is divided into school districts, varying in number in difierent counties, managed by local boards of trustees, and being for the most part co-terminus with the townships. Every such school district is a body politic, capable of suing and being sued, of contracting, and of holding property for school purposes.

STATE AND COUNTY OFFICIALS.

The State Superintendent of Education is a constitutional officer, elected biennially by the people, giving a bond for $\$ 5,000$, and receiving a salary of $\$ 2,100$. He exercises general supervision over all the public schools of the State, and is required to visit every county for the purpose of inspecting the schools, and awakening an interest in cducation. He is required to secure, with the ald and advice of the State Board of Examiners, uniformity of text-books and the exclusion of secular or partisan books and instruction, and to perform such other duties as may ioe 
prescribed, or become necessary. An annual report of his visits, and of the condition and requirements of the public schools, must be made by him through the Governor to the Legislature.

The State Board of Examiners consists of the Superintendent of Education and four persons, appointed biennially by the fovernor. 'This board meets twice a year, or oftener, if deemerl advisable, and is constituted an advisory body, which the Superintentent shall consult when in doubt as to his official duty. It renders final decisions upon all questions of appeal from the County Boards. It has power to adopt rules not inconsistent with the general law for the government of the schools, to prescribe standards of efficiency for teachers, to examine teachers, and grant State certificates; and also to prescribe text-books for a period of not less than five years.

At each general election a School Commissioner is chosen by the voters of each county giving bond for $\$ 1,000$, and receiving a per diem allowance not exceeding $\$ 600$ a year, except in the County of Charleston.

He acts as the organ of communication between the State Superintendent and the local authorities. It is his duty to apportion the school fund among the several districts in his county according to the average attendance of pupils during the preceding year, to visit the schools and acquaint himself with their character and condition, and to make suggestions that, in his opinion, are conducive to the welfare of the system. An amual report is sent by him to the State Superintendent.

The County Board of Examiners is composed of the County School Commissioner and two persons appointed by the State Board of Examiners, to serve two years without pay. It conducts county examinations for teachers upon questions prescribed by the State Board, arranges the school districts, appoints school trustees, and acts as a tribunal in all disputes arising between trustees and teachers or patrons.

Three School 'Trustees for each district are appointed biennially by the County Board of Examiners. They serve two years without compensation, and are entrusted with the general management of affairs, such as the erection and location of school-houses, the employment and parment. of teachers, the suspension or dismission of pupils, the calling of district meetings, and the visiting and supervision of schools.

TEACHEIS.

Every teacher in the public schools of South Carolina must be of good moral character, and must hold a certificate of qualification issued by the State Board, the County Board, the City Board of Charleston, or the Faculty of the State Normal Institute. To school commissioner or trustee shall teach in the public schools. Three grades of excellence are 
recognized in the issuance of certificates. The first may be renewed for three years without re-examination; the second for two years; third grade certificates are valid for but one year. 'Three Normal Institute certificates entitle the holder to a life diploma. Teachers are required to file monthly reports of enrollment and attendance, with the branches tanght, upon which pay certificates are granted by the trustees, approved by the school commissioners and paid by the county treasurer.

\section{CURRICULUY.}

In every school shall be taught, as far as practicable, orthography, rcaling, writing, arithmetic, geography and English grammar, History of the United States and of the State, the principles of the Constitution, and laws of the United States and of this State, morals and good behavior. In some schools higher instruction is also imparted.

\section{SCHOOL, AGE.}

The school age is not absolutely fixed, but the school census taken in former years embraces all children between the ages of six and sixteen years.

\section{SCHOOL DISTRICTS AND SCHOOLS.}

There were 481 school districts, and 3,05t schools in 1SS1, distributed as follows:

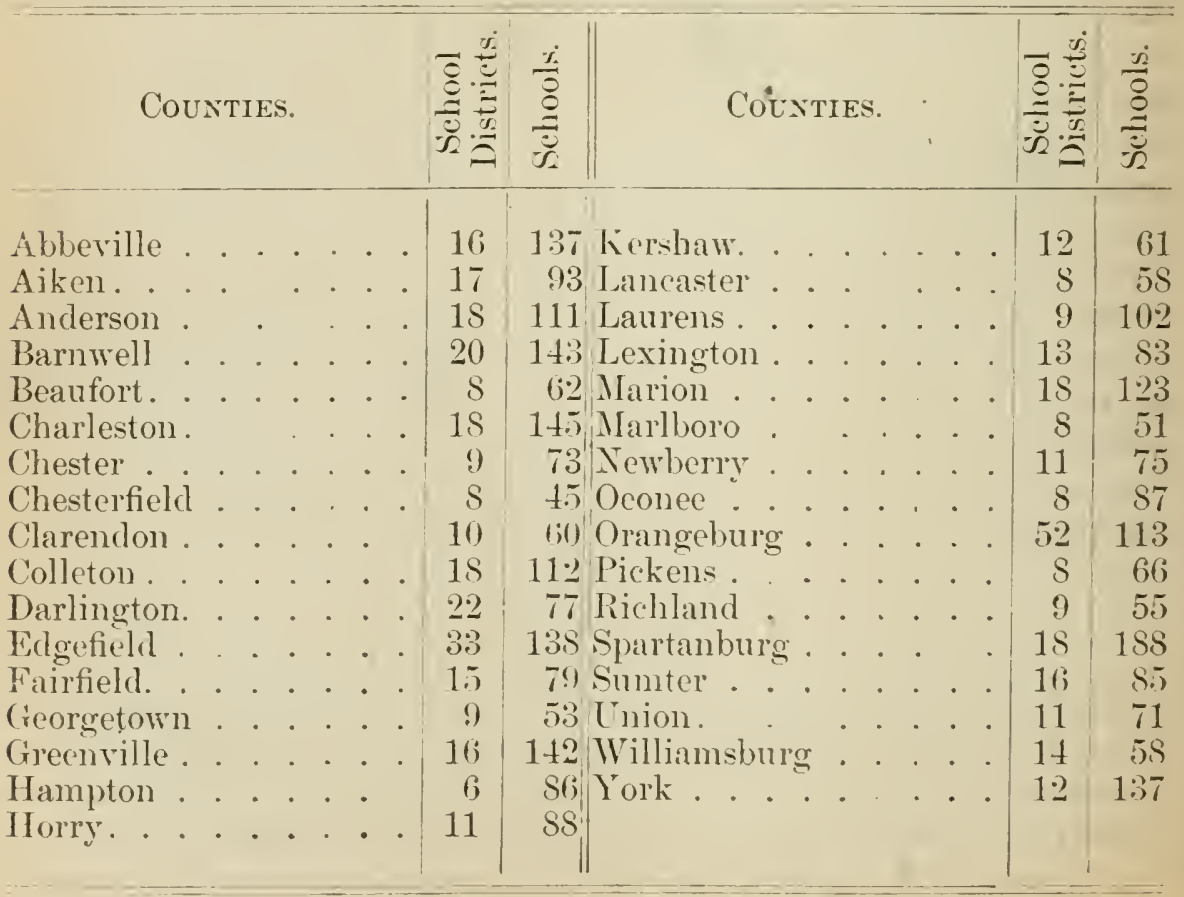


SCHOOL BUILDINGS.

Reports in 1SS1, from all but four counties, give the number of school buildings as 2,989 , with a valuation of $\$ 435,289$. In adrlition to these, 163 buildings were rented for school purposes during the year, at a cost of $\$ 2,552.0 \mathrm{~S}$. Of all these, 695 were owned by school districts, and the remainder by other parties. There were 1,649 reporterl as in goorl condition, $\$ 13$ in fair condition, and 477 in bad condition.

GRADED SCHOOLS AND LOCAI TAXATION.

The public schools of Charleston City have always been supported in part by a city tax. The system of local taxation, which exister throughont the State between the years $186 S$ and $1 S 76$, and which was abrogated in 1877 , has been renewed in sereral localities in more recent years under restrictions which protect the property-holders from oppression by providing that they alone shall exercise the right to rote in the district tax mectings. Under the operation of the amended law graded schools for white and colored pupils were established in Winnsboro in 1578 . Chester established similar schools the year following. 'The success of these attempts to secure more ample instruction has induced other towns to follow their example, and it is believed that in a few year's graded schools, based on local taxation as supplementing the public fund. will be found in many, if not all, the towns of South Carolina. The pririlege of local taxation now exists in Charleston, Columbia, Winnsboro, Chester, Canden, Union, Johnston, Tarnsville, Monticello and Feasterville. It had not, up to 1S82, been put into operation in Columbia, Union and Feasterville. An excellent graded school is conducted in Graniteville, by Mr. IV. N. Marchant; a large portion of the funds for its support being furnished by the Graniteville Manufacturing Company. Other manufacturing companies, with equal liberality, have established good schools for the instruction of the children of the operatives. Abberille has had a graded school for some rears, under the charge of Mr. D. B. Johnson. The school is supported by tuition fees for seven months, and during the last three is a public school, free to all. Sumter has a similar school.

STATE NORMAL INSTITLTES.

The late State Superintendent of Education, Hon. Hugh S. Thompson, whose great zeal in the cause was cqualled by the ability with which he discharged the duties of his office, at an early day urged upon the Legislature the necessity of providing for some special instruction of teachers, 
in order that they might become still more efficient in their profession. For this purpose he recommended the establishment of a Normal School. Failing in this, he resolved to establish a summer teacher's institute. Through the liberality of the Peabody trustees, who furnished him a thousand dollars, he organized the first

\section{STATE YORMAL INSTITUTE,}

in the City of Spartanburg, during the month of August, 1SS0. The authorities of Wofford College tendered the use of their building and apparatus, free of charge, and the Faculty of the College and the citizens generally vied in their efforts to make the institute a success.

Professor F. Louis Soldan, of St. Louis, an eminent educator, was made. principal of the institute, assisted by Prof. E. S. Joynes, of the University of Tennessee, and several teachers of the State. The institute lasted four weeks, and proved a most gratifying success. Lectures were delivered by most of the college presidents of the State, and by other distinguished gentlemen. The enrolled attendance was nearly two hundred, from all parts of South Carolina, and on special oceasions the attendance was estimated at between five and six hundred.

\section{SO GREAT WAS THE SUCCESS OF THIS}

Institute, that in the following August, a second institute was held in Greenville, in the buildings of Furman University, which were generously tendered for the purpose. Prof. Soldan again presided, assisted by the former faculty and by other teachers. The enrolled attendance was three hundred. Lectures were delivered by General Eaton, United States Commissioner; Prof. W. T. Harris, of Concord, Mass. ; Rer. J. L. M. Curry, and others.

\section{In 1883}

\section{A THIRD INSTITUTE}

was held in the buildings of the South Carolina College, in Columbia. To the great regret of all his friends, Prof. Soldan was prevented by business from again taking part; but his place was ably filled by Dr. M. A. Newell, the State Superintendent of Maryland.

The Legislature had in the meantime passed an Act conferring authority upon the Faculty of the Normal Institute to issue certificates and diplomas, which are of the highest grade in the State. At the close of the Institute in 1882 several teachers passed sucessful examinations and received certificates. 
Thene institutes are growing in furor and in usefulness, and promise to become permanent features in the public school system of South Carolina, though the benefits secured are free to all teachers and other persons desirous of obtaining knowledge. These institutes have already given a great impetus to education by introducing new methods and the best ideas of leading teachers.

\section{A COLORED INSTITUTE}

was held in Columbia during the month of July, 18s1, under charge of Prof. Montgomery, a leading colored teacher of Washington, assisted by an able faculty. The attendance was rery encouraging, in point of numbers and earnestness.

\section{A SECOND COLORED INSTITUTE}

was held in Columbia, during July, 1852 ; Prof. Montgomery again presiderl. The work was thorough and most interesting, and proved of great advantage to the colored teachers of South Carolina. Institutes for colored teachers will continue to be held.

During the month of October, 1880, a colored county institute was held in Cliarleston for one week, under the auspices of Bishop P. F. Stevens, School Commissioner of Charleston County.

COUNTY INSTITUTES.

A very successful county teachers' institute was conducted in the town of Johnston, Edgefield County, for four weeks, during the summer of 1892, under Prof. B. Neely, of Augusta. About fifty pupils were present. and the interest was maintained throughout.

Besides these, county conventions and teachers' institutes have been held in a number of counties in the State; notably in Spartanburg.

\section{SCHOOLS IN CHARLESTON.}

When the Free School system of the State was establisherl in 1810, the sum of $\$ .5,100$ was assigned to Charleston for the pay of three male and two female teachers, the former at a salary of $\$ 1,200$, the latter of $\$ 750$ each. Out of this each teacher was required to provicle a school house, 
and often, to supply text-books to indigent pupils. The attendance generally averaged from eighty to a hundred for each teacher.

Notwithstanding the existence of numerous admirable private schools, it was resolved, in 1854, to make such improvements in the free school system as were demander by the progress of the city, and the growing needs of the people. The first step was the erection of the Bennett, the Memminger, the Friend Street, and the Morris Street School buildings. Trained teachers were secured who soon raised the schools to a high degree of excellence. Four thousand white pupils attended during the year 1860 .

At the close of the war, the school authorities recognizing the altered condition of affairs, set apart the Morris Street building, the largest of all, for the instruction of the colored children. This action, and the previous destruction of the Friend Street school, by fire, in 1861, has left somewhat restricted accommodations for white pupils.

THE FIVE TEACHERS

of 1811 had grown, in 1881 , to 91 , six males and eighty-five females. The white pupils numbered 2,009, and the colored 2,005, a total of 4,014.

The schools were as follows:

Bennett School, Mr. H. P. Archer; boys, 745, girls, 379. Total, 1,124.

Memminger School, Miss Simonton, girls, 597.

Meeting Street School, Mr. F. W. Clements; boys, 108, girls, 180 . Total, $28 S$.

Morris Street School (colored), Mr. A. Doty; boys, 547 , girls, 714 . To- . tal, 1,261 .

Shaw Memorial Sehool (colored), Mr. Edward Carroll; boys, 330, girls, 414. Total 744 .

The School Session embraces a period of ten months, vacations occurring in August and September, with two weeks in April and one in December. Daily sessions from 9 A. M., to 2 P. M.

SCHOOL LAW.

At every general municipal election, one School Commissioner is elected for each ward. These Commissioners constitute the School Board and elect officers, and perform all such duties as devolve upon the Boards of Trustees of other School Districts.

A City Superintendent is elected by the Board. Mr. William Simons is the present incumbent. 
REVENUES.

In 1850 the taxation for Public Schools in the City of Charleston was $3 \frac{1}{2}$ mills, made up of 2 mills State tax, $1 \frac{1}{4}$ mills special tax, and $\frac{1}{4}$ mill for the rebuilding of the Friend Street School. 'The total revenue reached $\$ 61,500$, exclusive of appropriations to institutions of higher learning. During the past decade Charleston has expended about three quarters of a million dollars for public schools, of which $\$ 347,602.12$ was from the special tax. This largely exceeds the rate of taxation, even in the most progressive of the larger cities of the North.

For the year 1881, the income was $\$ 61,072.12$, and the expenditure $\$ 59,320.07$, a per capita expenditure of $\$ 14.78$, for the year.

The Friend Street School was rebuilt in 1881-82, and named in honor of the late William Crafts, an ardent friend of free schools more than seventy years ago. It was reopened this Autumn, under the charge of Mr. F. W. Clements.

THE HIGH SCHOOL,

designed as a training school for business or college, was established in 1839 , and has had an honorable career. In the past two years, it has been reorganized and perfected. The King mansion and grounds have been purchased and converted into a commodious school building, while an admirably equipped gymuasium, in charge of competent teachers, furnishes facilities for instruction in athletic exercises and sports. The standard of scholarship has been raised, the study of Latin made imperative, and Greek, or French and German as alternatives, required. This institution is in charge of $\mathrm{Mr}$. Virgil C. Dibble, with a competent corps of assistants. The revenues are derived partly from tuition fees, and partly from an appropriation by Council, which reduces the rates of tuition one-half. The average attendance is about one hundred and fiftyall males. The receipts for 1881 were $\$ 6,391.04$.

SEMI - PUBLIC INSTITUTIONS.

Several educational establishments in the city, though supported by private means, may be considered almost as public schools.

THE CENTRAL SCHOOL,

founded by Bishop England; of the Roman Catholic Church, in 1820 , has been constantly growing in usefulness. Loeated on George street, it employs six teachers and has. an attendance of between three and four 
hundred pupils, at an average annual expense of about $\$ 3,600$. A female school in Society street, established in 1873, has fire teachers and an average attendance of 230 pupils.

A PAROCHIAL SCHOOL, FOR COLORED CHILDREX,

attached to St. Peter's Chureh, numbers two teachers and 130 pupils.

\section{HOLY COMMUNION CHLRCH INSTITLTE.}

In the year 1867 , the Rer. A. Toomer Porter, D. D., of the Protestant Episcopal Chureh, conceiver the idea of establishing a classical school for children of parents in straitened circumstances, the pupils to pay such sums for tuition and board as they might be able, while many were taught gratuitously. Its excellence has commended it to general patronage. The alumni of the school already number orer two thousand. Expenses have averaged $\$ 1 \$, 000$ a year, a total of nearly $\$ 300,000$ during its existence. Its revenues are derired partly from tuition fees, and partly from subscriptions raised at home and abroad.

Parties in New York had contributed up to 1S\$1, $\$ 13,000$, Baltimore and Washington $\$ 24,000$, Hartford $\$ 15,000$, Boston $\$ 12,000$, while other localities had swelled the total from abroad to $\$ 108,000$. Friends in England contributed $\$ 32,000$ more.

In 18s1, the further sums of $\$ 12,400$ were given by Northern friends, and $\$ 4,300$ by English philanthropists. The school clused the year free of all debt. Mr. John Gadsden is principal, with nine male and five female assistants. Attendance in 1881 was 206, of which number $4 t$ boarder's, and 37 clay scholars were beneficiaries.

\section{CONFEDERATE HOME AND SCHOOL.}

The first practical step for the organization of the Confederate Home ant School in Charleston was taken August 12, 1867. On that day, the present and only President which the institution has ever had-Mrs. M. A. Snowden-in company with her pastor, securerl the present premises, at the rent of $\$ 1,800$ per year. To meet this rent there was but one clollar in hand, the gift of an inmate of a charitable institution in Baltimore.

Immerliately after securing the building, which has been ever since nsed, a meeting of larlies was called, a constitution adopted, and an organization effected. The following officers were elected: President, Mrs. M. A. Snowrlen; Vice-Presiłent, Miss Susann Matilda Mildleton; Secre- 
tary and Treasurer, Miss Mary B. Camplell ; Corresponding Secretary, Mrs. Wm. E. Mikell ; Managers : Mrs. P. C. Gaillard, Mrs. Daniel Elliott Huger, Mrs. Geo. Robertson, Mrs. W'm. Ravenel, Mrs. Henry Ravenel, Mrs. Isabel S. Snowden, Mrs. C. S. Tedkler, Mrs. John S. Palmer, Mrs. M. P. Matheson, Miss Anna Simpson, Miss Eliza E. Palmer.

The institution was immediately opened, and twenty-five ladies were furnished with rooms. A school was organized for the children of the inmates, numbering twenty-five pupils. These were gratuitously taught by young ladies of the eity.

\section{THE FIRST SEMI-ANNUAL REPORT}

showed that the institution was giving shelter to seventy inmates, and that the school numbered fifty scholars. As there was still room in the spacious premises for more oceupants, the plan was then devised to make the educational feature of the "IIome" more prominent, and to take a limited number of young ladies, who should be provided with all the conveniences of home, and attend upon some of the best schools in the eity. This plan was earried out, and proved so valuable and successful that it was still further improved upon. Some disadrantages arose from having the young ladies at different schools, however excellent, and there were considerations of expense which compelled attention. The importance of having the pupils under the immediate supervision of the Board of Control-who were responsible for their welfare-and excited to generous emulation by pursuing the same studies under the same teachers, led to the organization of

\section{A FEMALE SEMINARY WITHIN THE IIOME.}

This is the plan under which the institution has now worked for twelve years. Competent teachers, a portion of them residing in the institution, have charge of the school. All the branches of a thorough education are taught, beginning with the rudiments, and inclucling French, German, Latin and Music. The young ladies are provided with board, lodging, fuel and washing, and provision is made, in extreme cases, to aid in the purchase of books and uniform. The number of pupils each year has averaged about fifty, who have been resident in the Home for the annual term of nine months. Day scholars are received also from the city.

The institution is under the charge of a Board of Control, consisting of fifteen ladies, who meet each alternate Tuesday. Daily oversight of 
its management is given by the President, Mrs M. A. Suowden, and by a matron and housekeper, and by resident teachers.

THE HOME IIAS LITTLE SOLRCE OF INCOME

but voluntary contributions. The Confederate Home Association numbers one hundred and fifty, who pay annual dues of one dollar, and a "Gentlemen's Auxiliary Association," the yearly membership of which is ten dollars. The donations of friends have heen liberal and frequent, so that the Home Association not only owns the premises which were at first rented, but has added to them a very large building adjoining, and fronting upon another street. At the request of some of the donors, their gifts have been used to purchase scholarships of $\$ 500$ each, bearing an annual interest of $\$ 35$ for beneficiaries of the Institution.

By far the greater portion of the pupils are wholly or in part beneficiary. When, however, there is ability upon the part of the parents or friends to pay anything, it is strictly required. The sum of two hundred dollar's yearly will provide board, lodging, fuel, lights, books and uniform; yet but one pupil last year and but one pupil this year has been able to meet this requirement. All others have been wholly gratuitous, or the amount paid merely nominal.

The number of pupils, including resident and day scholars, averages sixty. In addition to the pupils of the school, the Confederate Home has provided, for fourteen years, and still provides rooms for an average of forty permanent inmates-mothers, widows or daughters of Southern soldiers, with every possible help to their maintenance.

THE SHAW MEMORIAL SCHOOL.

After the close of the war, the relatives of Col. R. G. Shaw, of Massachusetts, who was killed in command of a regiment of colored troops before Battery Wagner; endowed the "Shaw Memorial School" for colored children. For several years it was supporter by Northern funds, but in 1874 , the property was conveyed to the city, which undertook its maintenance, at an annual expenditure of between six and seven thousand dollars. This school has been mentioned among the public schools.

THE AVERY NORMAL INSTITUTE,

for colored students, was organized in 1865. A building was erected at a cost of $\$ 25,000$, in 1868 , by the American Missionary Association, and named for the Rev. Mr. Avery, a philanthropist of Pittsburg, who 
gave $\$ 150,000$ to the Society for educational purposes. Superintendent W. L. Gordon has eight assistants. The attendance for 1881 reached 439 , and the expenditures, $\$ 5,199$, of which $\$ 2,674$ were drawn from tuition, and the rest supplied by the A. M. Association.

\section{WAILINGFORD ACADEMY,}

established for colored pupils in 1865 , occupies a building erected at a cost of $\$ 13,500$, of which $\$ 7,800$ was given by the Freedmen's Bureau. It is conducted by Principal L. A. Grover and six assistants, with an enrollment, in 18s1, of 618 pupils, an expenditure of about $\$ 2,900$. The school takes its name from a lady in Pittsburg, who paid off the indebtedness on the building.

\section{PRIVATE SCHOOLS.}

Besides the public and charitable institutions, the city contains a number of private academies and schools for youth of both sexes. These are of the highest order of excellence, and not only supply additional facilities for the young people of Charleston, but attract a number of pupils from abroad.

Some of the principal private schools are as follows:

\section{Charleston Classical School, B. R. Stuart, Principal.}

English Classical and Mathematical School, Jos. T. Caldwell, Principal. English and Classical Suhool, Messr's. Coleman and Kent, Principals. German Academy, C. H. Bergmann, Principal.

Confederate Home School (Female), Mrs. G. W. Alexander.

Charleston Female Seminary, Miss E. A. Kelly.

Schools for Girls and Kindergarten, Mrs. Isabel A. Smith.

Miss Murden's School, for girls and boys.

Miss S. D. Pinckney's Sahool, for girls and boys.

Miss Dasulussure's School, for girls and boys.

Miss C. M. Smith's School, for girls and boys.

The Misses Scott's School, for' girls and boys.

Mrs. Toomer's School, for girls and boys.

Miss A. T. Quigley's School, for girls and boys.

Mrs. F. A. Porcher's School, for girls and boys.

Madam Feugas' School, for girls and boys.

Miss Beckmann's School, for girls and boys. 


\section{CITY OF COLUMBIA.}

\section{PUBLIC SCHOOLS.}

The Legislature, in 1SS0, passed an Act providing for a special system of public instruetion for the City of Columbia. Four School Commissioners are elected by the, voters of the city, who have authority over the schools.

The law provides for an annual vote by the resident tax-payers of Columbia upon the question of levying a local tax. Meetings were held in 1851 and 1SS2, at each of which the proposition to lery a tax was defeated. By the year 1SS3, the quota of the school fund arising from the two-mill tax had become so small, in consequence of small attendance at the public schools, that these were open only for sixty days. Out of nearly $\$ 7,500$ paid into the school fund, the eity received back only about $\$ 1,700$. It a meeting held January 31st. 1SS3, however, a levy of one mill was made, which will realize nearly four thousand dollars, and will do much towards creating a system, which as yet cannot be said really to exist. The Park School, for whites, is in charge of Mrs. Stein. The Howard School, for colored children, is conducted by Prof. IV. MI. Dart.*

\section{PRIVATE SCHOOLS.}

The Columbia Male Aeademy and the Columbia Female Academy, under the control of a board of trustees, have long been in successful operation. Their early history has been lost; but it is known that land was given to them by Colonel Thomas Taylor, and that under the old charter of McGowan's Ferry across the Congaree, half the tolls were given to the academy. This provision is not continued in the new eharter of Guignard's Ferry.

THE MALE ACADEMY

is now eonducted by Mr. Charles H. Barnwell. He has several assistants, and more than sixty pupils, some of adranced standing.

\section{THE FEMALE ACADEMY}

i. in charge of the Misses Elmore, who have a large number of pupils.

MIr. R. H. Clarkson established a classical school a few years since, which is growing rapidly in faror.

\footnotetext{
* Since the above was written, the rity Board of Columbia lave fully oranizer a system hy the election of D. B. Johnson, Esq., as Superintendent, and a full coops of instructors. The male and female acalemies have been leased for the use of the public schoo's.
} 
The Misses Martin lave a private school of great exeellence and long established reputation.

The female school of the Misses Reynolds has sent into life many young ladies thoroughly and carefully trained.

A female boarding sehool of high grade has reeently been opened by Mrs. Mary Preston Darby, chiefly for the accommodation of visitors from abroad, who seek the climate of Columbia for health or pleasure.

The Palmetto Academy was established by the Odd Fellows. It has been in existence a number of years, and has done much good.

Other private schools are in existence in the city.

\section{CHARITABLE, EDUCATIONAL, AND LITERARY INSTITUTIONS.}

1751. South Carolina Society, Charleston.

1757. Winyah Indigo Society, Georgetown.

1769. Fellowship Society, Charleston.

1777. Mount Zion Society, Winnsboro.

1777. Catholic Society, Camden.

177S. Salem Society, Camden.

1778. St. David's Society, Cheraw.

17S3. Beaufort Society, Beaufort.

17S6. St. Helena Society, St. Helena.

1787. Camden Orphan Society, Camden.

1789. Claremont Society, Stateburg.

1791. B anfort District Society.

179S. St. Andrew's Society, Charleston.

179\%. Upper Long Cane Society, Abberille.

1800. John's Island Society.

1809. MIt. Pleasant Academy, Christ Church.

1811. Free Schools established.

The reader camnot but be struck with the number of these societies organized between 1751 and 1809, which are a proof that though little was done for public schools, attention was directed to private institutions.

Mr. B. f. Ramage, of this State, in an essay read at Johns Hopkins' University, attributes this fact to the tendency existing in South (arolina towards local self-govermment, it being believed that each neighborhood could judge better of the educational needs than the State at large. The 
sparseness of population of the State was also a bar to any general public system.

These societics flourished with more or less vigor, and some of them exist to the present day. A few of these will receive special mention.

THE WINYAH INDIGO SOCIETY.

According to tradition, "The planters of Georgetown District, about the year 1740 , formed a convivial club, which met in the town of Georgetown on the first Friday in each month, to talk over the latest news from London (never less than a month old), to hold high discourse over the growth and prosperity of the Indigo plant (then, and for a long time after, spelled in the inroices to London, Intico), and to refresh the inner man, and so keep up to a proper pitch the endearing ties of social life by imbibing freely of the ineritable bowl of punch." The members were genial gentlemen and liberal benefactors; so that when the treasury, in 1753, had bccome plethoric with gold, it was moved by the president and unanimously resolved, amid the elinking of glasses, "that the surplus funds in the treasury be deroted to the establishment of an independent charity school for the poor."

To Thomas Lynch, president, and his associates, was granted, in 1757, a charter, by King George. A school was established that "has been the school for all the country lying between Charleston and the North Carolina line for more than a hundred years. In its infancy it supplied the place of primary, grammar and high-school, and collegiate institute. Rich and poor alike have drunk from this fountain of knowledge, and to many it has been the only source."

By private benefactions, added to fees and the proceeds of escheated lands, the endowment had reached $\$ 11,000$ in 1846 , despite a loss of $\$ 7,000$ by the United States Bank, and the income was for years sufficient to warrant gratuitous tuition to all scholars.

The entire endowment was lost by the war. The academy building was oecupied as a Federal garrison. Soldiers defaced the walls, injurerl the premises, and carried off many valuable books, among them Audubon': Collection of Birds. Fifteen years ago the school was re-opened.

The handsome and commodious two-story brick building has been repaired and fitted with furniture of the most approverl pattern.

Fifteen or twenty pupils still receive gratuitous instruction; but the society is compelled to exact fees from the rest in attendance. Since the re-opening the instructors have been Mr. Comnor, Prof. D. A. DuPré, and Mr. A. NeP. Hambr.

The society claims a large membership); and, true to its traditions, cn- 
joys an annual oration and an annual banquet; the two combinerl bearing no small part in awakening the members to "renewed efforts to make the society again a potent agent for good in the educational interests of the State."

The largest bequests to the society were $\$ 1,453.50$, by Jonah Horry; $\$ 500$ by George T. Lathrop; and $\$ 5,000$ by Francis Wither's.

THE MOUNT ZION SOCIETY.

This society was established at Charlestown, January 29th, 17-7, and incorporated on the 13th of February following, for the purpose of "founding, endowing and supporting a public school in the distriet of Camden." It was empowered to hold property not exceeding three thousand dollars per annum. The membership was about equally divided between the low-country and the up-country. C. C. Pinckney, Wm. Bull, Elias Horry, John Vanderhorst, Wade Hampton, Richard Wimn, and Thomas Taylor were among the number. Of thirteen directors seven were to be from the country and six from the "eity." John W"inn was first president.

In 17S5, Mt. Zion College was incorporated, located in Winnsboro. Its faculty were Rer. T. H. McCaule, president; tutors, S. W. Yongue, W'm. Dary, and Humphrey. In 1793, Rev. Wm. Nixon became president, and, in 1794, Rev. Samuel Yongue. The college for a time gave regular diplomas, at least one of which is in existence.

The most distinguished principal was the late James IV. Hudson, who taught from 1834 to $185 \mathrm{~S}$. He drew students from all the Southern States, and the attendance reached into the hundreds. At the time of his death, twenty members of his first class were admitted into the South Carolina College. A handsome marble monument was ereeted to his memory over his grave on the college green.

During the latter part of the war the college buildings were oceupied as a hospital.

In 1866 exereises were resumed under Mr. T. J. Wells. Sinee then the principals have been G. A. Woodward, M. M. Farrow, R. H. Clarkson, W. M. Dwight, R. Means Daris, and D. C. Webb.

In May, 1867, the large three-story building, valued at orer $\$ 20,000$, was destroyed by fire. In 1873 , a smaller building, costing about $\$ 3,500$, was erected. In 1878, a public graded school was established in Winnsboro, in connection with the MIt. Zion Society. It has been very suceesful. The present principal has three assistants, and the $\mathrm{u}$ upils number between 125 and 150 .

Endoument. Shout $\$ 800$ were received in $17 \varepsilon 5$, from a fund left by a Mr. Prew, of Charleston, "to be equally divided among the first schools or 
colleges that should be incorporated for the purpose of education." (reneral Wim gave abont one hundred acres of land, and tradition says that Colonel John Vanderhorst gave $\$ 10,000$. About twenty acres more of land were given by other parties. The endownent was about $\$ 8,000$ at the beginning of the war, and $\$ 2,000$ at its close. Lands were sold to aid in the erection of the new building. The property is now valued at about $\$ 5,000$, in buildings and lots. There are two $\$ 300$ scholarships, one belonging to Colonel J. H. Rion, the other to Messrs. Mellaster \& Brice.

No exact estimate can be marle of beneficiary instruction, but a large number of pupils have been taught without pay, or have been sent to school by public spirited citizens. Since the establishment of the graded school all the common school curriculum is tanght free of charge. The society is still in active existence, and promises to continue its great influence for good.

THE CAMDEN ORPHAN SOCIETY

was incorporated in 1787. Although its records prior to 1822 were destroyed by Sherman's army, reliable information is that the school was first established in the lower part of Camden, in Colonel Kershaw's residence, known as "Cornwallis's Headquarters." The first teacher, Dr. Flynn, was succeeded in turn by Mr. Judah Lee and Dr. Reed. At this time the school was moved to the "Yellow House," on the west side of the town, and was placed under Dr. Whitaker, and his son, Mr. D. K. Whitaker, who was at one time editor of the Southem Quecterly Revieu', in Charleston, and is now living in New Orleans. The existing handsome buildings in DeKalb street were creeted in 1822. The following principals were elected in succession: Dr. MeEwin, Mr. E. P. Miles, in 1S28; Mr. H. P. Hatfield, in 1830, and Dr. Moses Holbrook, in 1836.

The public features of the institution were now abandoned, and the property was let to private teachers on condition of admitting a certain number of beneficiaries. Thus the institution flourished many years.

In 1820, the fine library of Judge Desaussure, consisting mostly of standard English works, was purchased by the society. It had become much injured and depleted by 1856 , and was sold at that time.

After the war the society languished, but in $187 t$ the three or four surviving members resuscitated it, and admitted many new ones. The buildings were repaired and used, one as a school-house, the other as the teacher's residence. Captain J. WV. Jamison was elected principal, and served till 1850, when ill health impielled his resignation.

A graded public school was established in Camden in 1851, in charge 
of Prof. Schoenberg. It is located in the society buildings, and fulfils to al large extent, by its public features, the original aims of the benerolent founders of the society.

ST. DAVID'S SOCIETY, CHERAW.

St. David's Society was incorpurated in 1778 , but nothing was done until 1787, when it was reorganized, and maintained a flourishing school until 1836 or 1838 . The society then closed an actire existence, and the buildings were transferred to private teachers. About 1820, the ladies of the community established a female school of very high grade, which lasted for ten years. The two societies then exchanged buildings, and the St. David's Academy was "transferred to the Baptist C'hurch for use as a lecture-room. After the war, it was sold to the Freedmen's Bureau, and it is now used as a school for colored children. In early days, the school was patronized by most of the Pee Dee country. Col. IV. II. Evans, of Society Hill, says: "In my boyhood, we had scholars from ('heraw to Ceorgetown. The rod, the dungeon and the fool's cap reigned supreme. I have seen them all in full operation." The dungeon remained until the transfer of the property to the Baptist Church. Dr. Park and Mr. Handford, both afterwards professors in the South Carolina College, taught here, as dirl also Judge Wilds. Further information about the society can be obtained in "Gregg's History of the old Cheraws."

\section{TIIE CIIERAW LICEUM}

was organized Sth January, 18.56, with a president, rice-president, a book committee of three, an executive committee of three, and a secretary and treasurer. Nonthly meetings are held, at which an original essay is rearl and some subject discussed. A course of public lectures has been delivered ever since the beginning, and an amniversary oration is pronouncel on the Sth of January. An original poem is sometimes read. The Lyceum has a well selected library. During the twenty-six years of its existence it has exercised much influence in furthering the enlightenment of the people.

\section{THF DE LA IIOWE FCHOOL.}

Dr. John De la Howe, of Abbeville district, by a will daterl Tth September, 1796 , devised the bulk of his property to the Agricultural Society of South Carolina, in trust "for the purpose of establishing and maintaining forever, at his former residence in that district, an agricul- 
tural school for twelve poor hoys and twelve poor girls, to be boarded and clothed, as well as edneated and taught to work." This is said to have been

TIIE FIRST MANUAL LABOH SCIIOOL,

in the United States. The desire of the testator was, that scientific agriculture and, especially, the science of chemistry should be taught.

The Agricultural Society resigned the trust to the State in 180. Since that time the fund has been in charge of trustees elected by the Legislature, with directions to make annual reports. For many years, and until quite recently, a school was conducted at Lethe, the home of the testator. The report of 1848 shows that the full number of boys and girls were in attendance; the capital was $\$ 13, \$ 2 \bar{\gamma}$, and expenditures, $\$ 2,476.33$. By 1859 , the fund had increased to $\$ 47,000$. The report states that the pupils were engaged in manual labor half their time, the boys on the farm, the girls in housework and domestic occupations. By law, the trustees were authorized to apprentice the boys at twelve years of age for five years, and the girls at ten years for a similar period. Teachers were elected ammally by the trustees. By the fortunes of war, much of the endowment was swept away. The fund now amounts to about ten thousand dollars. 'The school is at present suspended for want of sufficient means to carry it on. William Henry Parker, Esq., of Abbeville, is treasurer of the fund.

THE LULLAM FUND.

The Rev. Richard Ludlam, Rector of St. James' Goosecreek, dring in 1728 , bequeathed all his estate, real and personal, to the society, in trust for ereeting and maintaining a selhool for the instruction of the poor children in this parish. His estate was valued at about $£ 2,000$. The fund thus accruing was placed at interest for accunulation. In 17.4t, certain parishioner's added $£ 675$, and, subsequently, about $£ 1,400$ or more were subscribed to the fund. The school-house was erected about the year 1765 , and the purposes of Mr. Ludlam began to be realized. The fund, in 1778 , amounted to $£ 15,272$.

For nearly a century, four schools were maintained with the procects of this bounty. A report made in 1818 to the Legislature, showed an investment of $\$ 9,850$ in State, city and bank stock, and a note for $\$ 3,379$ additional. Thirty-seren pupils were receiving instruction in two'schools.

The find realized an income of $\$ 8 S t$ in 1860 , expended in the maintenance of three schools. A "leagne and labor" of land in Texal haul been mortgaged as security for the note above mentioned. 
The report of the vestry in 1863 shows a capital of $\$ 14,531$, besides the mortgage on the land in Texas. These schools were still in existence, with fifty-six pupils. Part of the fund was invested in Conferlerate bonds. The Attorney General was ordered by the Legislature to take steps to recover this land, but the close of the war put an end to the effort. After the war, the land was identified. Efforts were made to realize something from the land, the other part of the fund having been swept away: About four thousand acres lie in Coryell county, Texas, which, at last. accounts, had been sold to parties for taxes. It is to be hoped that this historic fund will not lapse.

\section{THE DOWNER INSTITLTE.}

Alexander Downer, an Englishman by birth, who, when a lat, had enjoyed the benefits of an orphan sehool in Richmond county, Georgia. and had subsequently acquired a handsome estate near Beech island, then in Edgefield district, left the bulk of his estate, by a will marle in 181S, for the founding of an institute at Beesh island for the maintenance and education of orphan children. Nothing was done until $18+3$, the estate having in the meantime suffered some diminution. In that year an institute was erected on an eligible spot. Exercises were begun on the 17th May, 1848, and continued without interruption until the close of the war, excepting a temporary suspension from April, 1858 , to January, 1859. Fifty orphans had received benefits during that time. The deranged condition of the funds has prevented reopening since 1865 . The fund, in 1851 , amounted to $\$ 15,621$, and in 1859 , to $\$ 20,500$. The institute and grounds were valued at $\$ 8,000$ additional. In $18-9$ the Legislature appointed a referee, Mr. E. S. Itummond, to investigate the fund. The next year he was appointed treasurer of the fund. Three commissioners were also appointed. It is believed that the fund will amount to about $\$ 6.500$ by 1885 . Tears will be required for it to accumulate so as to earry ont the beneficent purposes of Mr. Downer. By a provision of the will, Richmond county, Creorgia, is entitled to one-fourth of the benefits of the fund, and "Elgefield distriet" to the remainder.

THE WADSWORTH FUND.

Dr. Thomas Wadsworth, of Charleston, in the year 1808 , devised it considerable quantity of land - some lying in Laurens district, and some in the adjoining districts - to trustees to be elected by the "freemen residing in Laurens district, in the lower battalion of the 9th Regiment, and second Brigade of the upper Dirision of the State, 
to be hokken by them, or their suecessors in trust, for the purpose of raising a fund for the annual support of a free school." The Legislature, abont 1810, authorized these trustess, by speeial Act, to sell these lands for the purpose of establi-hing a school. Shortly afterwards, sales were made of at least a portion of the land for a period of ninety-nine ycars, and the proceeds applied, partly to the erection of a school-house, and partly to the support of a teacher. The school was loeated ncar a place called Belfast, the home of Col. John Simpson. It was carried on successfully until the war, doing much good. Poor children were taught free, others supplemented the fund. The endowment was lost during the war. The lands leased will revert in about twenty years, and will then be, doubtless, of considerable value. Some years before the war, Messer. C. P. Sullivan and IV. D. Simpson were employed by the trustees to seeure posession of certain lands on which the present town of Anderson is situated. The artificial marks were all lost, but by a certain spring, and other natural marks, the land was located. The plat, by survey, was found to eorner in one of the streets, and on digging down below the surface, a lightwood knot was found as called for. Oring to lapse of time, the Court presumed a grant from the trustees, and deeided against the plaintiffs.

Mr. Edward Pasly, of Laurens county, is the sole surviring trustee, and has for years been treasurer of the fund. In view of the prospect of a renewal of the fund after the expiration of the leases, this board should be filled at once, especially as leases may have been granted for a shorter term than ninety-nine years.

THE BERESFORD BOUNTY.

In 1721, Richard Beresford, Esq., of St. Thomas' Parish, derised to Colonel 'Thomas Broughton in trust, eertain property to be devoted, partly to the support of a school-teacher, and partly to the maintenance and edueation of the poor of the parish. The fund, after some years, amounted to $£ 6,500$, Carolina money, of which $£ 1,200$ were expended for a plantation, and the rest inrested as a fund. The foundation was known as the "Beresford Bountr." Five hundred pounds were added by Mr. Richard Harris in 1731. In 1763. Rev. Mr. Garden reports that eight children were elothed, boarded and educated from that bounty: In 1777 , the fund amounted to $£ 16,013$, but a reduction soon oceurred from shrinkage in securities.

Records from 1796 up to the war are lost. The fund, in 1861 , reached nearly $\$ 70,000$. It now amounts to at least $\$ 15,000$. The restry of St. Thomas has, in accordance with the original plan, combined the office of rector and teacher, and in this way, keeps open both the church and 
the school at Cainhoy. Rev. R. F. Clute, the rector, has now twelve pupils in the school. He has been requested by the vestry to endeavor to supply the missing records. The fund is in careful hands, and is increasing.

The Beresford Bounty is specially noteworthy, first, from its great antiquity, and second, from its being the only colonial endowment still in healthy existence.

THE COKESBURY SCHOOL.

The first school of high grade in that section of the country was established at "Old Tabernacle Church," about two miles from Cokesbury. The first teacher, 1821-1824, was Mr. Stephon Olin, of Vermont, who subsequently entered the Methodist ministry, and became professor in the University of Georgia, President of Randolph Macon College, and President of the Wesleyan University at Middletown. His school was moved to "MIt. Aricl," its present site, for hygienic reasons, and was presicled over by the Rev. Joseph Travis. In 1836, it was turned over to the Conference, which converted it into a

\section{MANUAL LABOR SCHOOL,}

the students working five hours a day, and receiving a discount on board and tuition. This feature was soon abandoned. About the year 1844, Mr. Holloway, then living near old Cambridge, endowed the school with $\$ 20,000$, the interest being applied to the board and tuition of the sons of Methodist ministers in the Conference. Only $\$ 2,000$ remained after the war, the interest of which is still used in the same way. The school is a three-story building, fifty by sixty feet. It is now in charge of Mr. Reid, a competent teacher. The attendance numbers about fifty, and is mostly local.

THE SOUTH CAROLINA SOCIETY,

of Charleston, was the oldest and richest of these associations. It existed as a semi-educational corporation for nearly a hundred years. In 1846 , its capital amounted to $\$ 116,455.17$, notwithstanding a loss of $\$ 17,000$ through the United States Bank. About that time it supported fifty widows or families, and was educating twelve children. A little later it gave instruction to seventy-two pupils. Upon the rise of public schools in Charleston, the Society put an end to the educational feature, and de- 
voted its fund to the maintenance of families of members. The Society still has a good endowment, and owns substantial buildings.

THE FILLOWSHIP SOCIETY.

This Society for many years maintained both male and female schools, and elected teachers annmally. After 1858 , these schools were abandoned, and the Society entered into an arrangement with the Normal and High schools, by which, and on payment of $\$ 10,000$, it was agreed that the pupils of the Society" shall never be debarred the right of admission to these schools in case of crowding. This contract is still in force. The endowment of the Society was $\$ 100,000$ at the beginning of the war. It is now about twelve or fifteen thousand.

The membership now numbers fifty-four. Weekly meetings are held for the promotion of goodfellowship. The charitable feature is still maintained.

\section{THE GERMAN FRIENDLY SOCIETY.}

A number of sons of the Fatherland had alrearly settled in South Carolina by the year 1766 , and at that time they conceived the charitable design of organizing a society for mutual benefit, and for the aid of fellow-countrymen in the colony. By the year 1772 , the funds had so increased as to warrant the establishment of a permanent charity, and in 1777 a loan was made to the State of $£ 1,300$.

The membership and the fund constantly increased, until in 1800 the income was $\$ 1, \$ 00$. A commodious hall was erected. Two years later a sehool was opened, for children of members, and for others. In twentysix years the school lost but $\$ 37.50$ in tuition fees.

The report for 1828 shows an endowment of $\$+0,000$.

In $184 \overline{7}$, according to the report, "It was found that it was believed that our schools were charity schools (although it was a very erroneons opinion) and it had the effect of injuring the usefulness of the schools, and they were abolished."

This society suffered, like the rest, by the war, losing much of the endowment, and also its hall. Still it celebrated its centemnial in 1866, and by strenuous efforts it has erceted a new hall, and is aceumulating a fund which already reaches a considerable amount.

\section{ST. ANDREW'S SOCIETY}

was founded in 1795, with features similar to those of its sister associations. For years it maintained a school, which was abandoned when the necessity for it was remored. It was in st. Andrew's Iall that the 
ORDINANCE OF SECESSION

was passed, December 20th, 1861. The great conflagration swept the thall away. The society still exists, with reduced endowment.

THE CHARLESTON IIBFARY SOCIETY.

In 1748 , seventeen young gentlemen of Charleston united in sending ten pounds sterling to London for the purchase of pamphlets and magazines. Some months later they organized a library society, and elected officers. By 1750 the society had increased to 160 members. After two unsuceessful efforts, owing to the hostility of Governor Glemn, a charter was secured in 1754, and ratified by the crown the following year. After this the society rapidly inereased in numbers, and its library reeeived constant additions. The governor of the Province was regularly elected president; and membership was regarded as a mark of social distinction.

For many years it was desired to establish a high school or college in connection with the library; but estimates made in 1762 , showing that an immerliate outlay of $\$ 15,000$, and increased annual revenue of $\$ 2,0,00$ would be required, caused a reluctant abandonment of the scheme.

A disastrous conflagration, in 1778 , swept away almost the entire library of five thousand volumes; only one hundred and eighty-five escaping the flames. Many eurious pamphlets were irreparably lost.

The Legislature, in 1790, refunded eleven thousand dollars that had been placed in the treasury at the beginning of the Revolution. Six thousand four hundred dollars were deposited in bank as a permanent fund, and the rest used to purchase books. in 1792 .

In $180 S$ the catalogue showed 4,500 volumes; in 1S11, 7,000; in 1826 , nearly 12,000 ; in $1876,15,500$, and in $1852,17,130$. During that year over seven thousand volumes were taken out by subscriber's, The library has been carefully selected, and many of the books are of great merit.

The soeiety owns a substantial building. The receipts for 1852 were $\$ 2,102.54$, of which $\$ 925$ were derived from membership fees.

The annual membership fee is four dollars, A number of members, who paid $\$ 100$ each in 1835 , for the purchase of the building, are absolved from dues.

In 1770, Benjamin Smith left a legacy of six hundred dollars. ExGovernor Aiken has presented the society with about $\$ 3,000$ in securities, and the late William Lebby bequeathed a legacy of $\$ 1,000$. General W. G. DeSaussure is president; Colonel C. H. Simonton, viee-president, and Réné R. Jervey, Esq., librarian, of the society.

The Apprentices' Library, formed in 1S24, for the benefit of apjren- 
tices and minors, gradually increased in prosperity until 1861, when its hall was burned. In 1870, it placed its books on the shelves of the ('harleston Library, and in 1874 the new society was fully merged into the elder.

A handsome catalogue (1876) gives full information regarding the library.

THE SOUTH CAROLINA HISTORICAL SOCIETY

was organized at Charleston in 1856 , "with the design of tracing ont those minor points in the history of our State which have escaped the notice or eluded the grasp of our historians, and more particularly to record the history of local events which, however, strikingly illustrative of social life, are generally considered unworthy of notice. It proposes to collect information respecting every portion of the State, to preserve it, and when deemed advisable to publish it." In that year and for three years thereafter the Legislature appropriated five hundred dollars annually to aid the society in its publications. Three rolumes of publications were issued up to 1860 , but of the last volume only a few scattering numbers survived the war, the greater part not having been distributed.

Some years after the war the society was reorganized. It now numbers about one hundred members, of whom one-third reside in the interior of the State. The publications and manuscripts of the society are deposited in the Charleston Library. Sufficient material is now on hand for a fourth volume, which will be published when the society is able to meet the expense. Its revenues are about $\$ 200$ per annum. The present officers are Prof. F. A. Porcher, president; Rer. C. C. Pinckney and S. P. Ravenel, vice-presidents, and Messrs. Yates Snowden and C. A. McHugh, secretaries.

THE THORNWELL ORPHANAGE.

Bordering on the thriving village of Clinton, in Laurens County, is a farm of a hundred and twenty-five acres, the property and site of the Thornwell Orphanage. On the 1st of Oetober, 1872, a number of gentlemen met and diseussed the plan of an orphanage conducted under Presbyterian auspices. To-day that plan is in suceessful operation. Two handsome concrete buildings, and other woorlen struetures, accommodate the officers of the institution and the thirty-two orphans under their charge. Another building, the Orphans' Seminary, is now in course of construction, on the completion of which there will be accommodations for a hundred children. Besides the literary instruction, the boys are practised in farming, printing, carpenter work, houso-painting and shoemaking. The girls are trained in domestic duties. This orphanage has 
gathered about $\$ 20,000$. worth of property, and $\$ 13,000$ have been cxpended in its support. The endowment is already $\$ 5,270$, in paying securities. Aid has come from Sabbath schools and churehes, and from benevolent persons in this and other States, including Illinois and California. Though great good has been accomplished, much remains to be done; and the orphanage is a most worthy olject of benevolence. Although a Presbyterian institution; it supports orphans representing six denominations.

There is an admirable school, a small library, and a printing press, from which a newspaper is issued. The officers are as follows: Rev. IV. P. Jacobs, president; Mrs. Lucy N. Boyd, matron; Miss Pattie Thornwell, Prof. W. S. Lee, and Miss Laura Whaley, instruetors; Mr. T. C. Scott, ngent, and Mr. R. S. Whaley, superintendent of the farm.

\section{O'THER PRIVATE SCHOOLS.}

It is impossible to secure a correct list of the private schools in South Carolina. The State Superintendent and the United States Commissioner of Education have made repeated efforts to do so, without suceess. The following partial list is publisher in the hope that it will stimulate other teachers to report their schools to the State Superintendent of Education in Columbia. The educational work of the State cannot be computer without full statistics from private as well as public schools. Especially is it important to secure itemized returns from those schools that are conducted by joint prirate and public funds:

Partial List of Private Schools, 18S1-2.

\section{IBBEVILLE.}

Lethe (De la Howe School suspended for the present.)

Brewer Institute (colored).

AIKEX.

(Private schools are usually conducted conjointly with publie seloools.) AXDERSON.

TEACUERS. PUPILS.

Anderson Female Seminary, L. M. Arer . . . . . . . . . T 100 Anterson Home School, Mrs. Murray . . . . . . . . . 1 2j 
BARINELI.

(Either public or private schools.)

BESLIOR'T.

Penu Iurlustrial School, Miss L M. Towne...

Marher Industrial School, Mrs. R. C. Marher. . . . . . . 2

Mr's. Bohum's School, Elementary . . . . . . . . . 2 57

CHARLESTON.

(Reported elsewhere.)

C'IIESTEL.

( To private schools.)

('HESTERFIELD.

Ice-Hampton High School, Joseph Blain.

cheraw Academy, A. M. Rankin.

('LARENDON.

Manning High School, R. B. Mahoney . . . . . . . . 2

COLLETON.

(No returns.)

DARLINGTON.

Darlington Male Acadeny, H. S. Thompson . . . . . . . 2

Miss Player, 15; Miss Spain, 10; Miss Davis, 4S; Miss Me-

Carter, 15; Miss Woodward, 9 ; Miss Waring, 12; Miss

Church, 40 ; Mrs. Singletary, 14; Miss Kilpatrick, 37 ;

Miss Murphy, 20; Miss Bilcot, 7; Mrs Elwards, 25;

Miss Dalrymple, 10; Mrs. Doover, 25; Miss Moon, 15.

Florence High School, Mr. Evans. . . . . . . . . . . . 1

Florence IIgh School, Mr. Hooper . . . . . . . . . . . 1

Florence IIigh School, Mr. Seabrook . . . . . . . . . . 1

Kershaw Elementary (colored) . . . . . . . . . . . 1 
EDGEFIELD.

(No report.)

FAIRFIELI).

(All schools public.)

(iEORGETOWN.

Winyah Indigo, A. MeP. Hamby . . . . . . . . . . . . 1

TE.THERS. P'TPIS.

GIEENTILIL.

Patrick's Military School, J. B Patrick . . . . . . . t in

Business College, J. M. Perry . . . . . . . . . . 1 (5.,

Trescot Sichool, Misses Trescot . . . . . . . . . 2

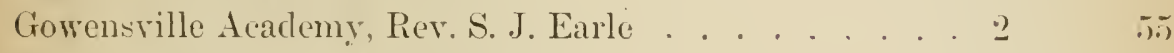

Grier's Acarlemy, J. W. Kennedy . . . . . . . . . 2 2 4.

Grove Military Academy, E. T. Kemp. . . . . . . . 1 f()

Piedmont High School, A. E. Miller . . . . . . . 2 .j)

HAMPTON.

(No returns.)

HORRY.

(No returns.)

KERSHAW.

Leslie McCandless, Mrs. M. C. Thomason, Miss Fretag, Mrs.

Withers.

\section{LAURENS.}

Laurens Female College, J. D. Anderson . . . . . . . t t it

Clinton Male High School, H. E. Lee. . . . . . . $\frac{1}{4} \quad 7$

LEXINGTON.

Lexington Academy,

MARION.

Marion Academy, A. W. Lynch . . . . . . . . 2

Marion Female Seminary, J. R. McLean . . . . . . . 2 4

Marion Primary School, Miss DuBois . . . . . . . . 1 52

Little Rock Acarlemy, H. R. Walker . . . . . . . . . 14

Mullins Academy, Charles Lovejoy . . . . . . . . . 2

Mars' Bluff, F. S. McLean . . . . . . . . . . . 1 20 


\section{MA RLBORO'.}

TE.ICHIRS, PUPIL.

Mincral Spring High School, J. Eleigh . . . . . . . 1 of

Bennettsville School, Miss Sallie Cook . . . . . . . . 1 1.)

Meadow School, Miss Lily Breeden . . . . . . . . . . 1 1:)

Fletcher's Mill, Henry Newton . . . . . . . . . . 1 2.;

NEWBERRY.

('ollege Preparatory,

Prosperity School, J. S. Perrin.

OCONEE.

(No report.)

ORA YGEBURG.

Kiser's School, Rer. J. F. Kiser . . . . . . . . . . . 1

Academy, H. G. Sheridan . . . . . . . . 2 . . . . .

Academy, S. R. Mellichamp . . . . . . . . . . . . 1 5s

Female High School, Miss Albergottie . . . . . . . . . 1 t0

PICKENS.

All schools connected with the public system.

RICHLAND.

Columbia Male Academy, C.. H. Barnwell . . . . . . . . 4

Graded Classical School, R. H. Clarkson.

Columbia Female Academy, Miss Elmore.

Female Academy, Misses Martin.

Female Academy, Misses Rernolds.

Palmetto Academy,

(Full returns not received).

SPARTANBURG.

Wellford High School, W. S. Morrison.

Gaffney City High School.

King's Mountain High School, W. T. R. Bell.

Reidrille Male Academy.

SCMTER.

Female Institute, Mrs. L. A. Brown.

St. Joseph's Academy (Roman Catholic), Misses Hurst, Fleming, Herbert, Nettles, Williams, Hudson.

Boys' Grammar School, 'T. I'. MeQueen.

A numier of schools in the county. 
INION.

(lifford Seminary, Rey. B. G. Clifford. TE.achers. Prerin.

WILLIAMSELRG.

(No report.)

YORK.

Fort Mill Academy, A. R. Banks.

\section{HIGHER EDUCATION FOR MALES.}

While South Carolina has been reproacherl for her failure in the past to provide for the education of the masses, no one can truthfully deny that much attention has been paid to higher education from the earlient times. During the colonial period, the sons of the rich sought instruction in Europe; and when the Revolution came on, South C'arolina'; sons stepped to the front in the formm, as well as on the fielr. In literature and science, as well as in statesmanship, South Carolinians had distinguished themselves from the eartiest days. Dr. Lionel (halners, a native of scotland, practicer medicine in ('arolina from 1737 to 175 , during which time he published several medical works. Liev. Richand Clarke, for some rears rector of St. Philip's, was widely known as a theologian beyond the limits of Ameriea, and when he returred to England, he taught there the sons of ('harlestonians, who had followed him. William Hemry Drayton left a manuscript history of the Annerican Rerolution in three rolumes. Christopher Gardislen understoor Latin. Greck, French, Hebrew, and the Oriental languages. Imprisoned at St. Augustine by the British, "he came out much more learned than he entered." Dr. Alexander Garden moved to Charleston from Scotland, and studied hotany and natural history with such success as to become a vice-preident of the Roral society of England, and to win the admiration of Linneus, who named the "Gardenia" after him. Sir Xathaniel Johnson was a scientific experimenter. He introdueed silk and improved rice culture in South Carolina. The learning of Henry Lanrens is well known. II is son, John Laurens, who, at the age of twenty-five. Was sent to Paris to negotiate with France in 1780, was an adept in "ancient and modern languages, philosophy, geography, history, and the ordinary circle of sciences, and he excelled in drawing, dancing, fencing, riding, and all the graces and refined mamners of a man of fashion." The Rer. 
Thomas Reese amassed great knowledge, and wrote an excellent essaly on the influence of religion in society, for which he was macte a Poctor of Divinity by Princeton. John Rutledge was a man of varied attainments.

I). John Lining was one of the first experimenters in electricity, and ('orresponded on the subject with Franklin. He wrote the first pamphlet on yellow ferer that appeared from America. Willian Bull, the first native of South (anolina that obtained the degree of M. I), defended a thesis before the University of Leylen.

$\Delta \mathrm{fter}$ the Revolution there were a number of learned and scientific men. Dr. Darid Ramsay introduced vaccination into Charleston in 1806 , four years after its discovery by Jemner. (His son, Mfr. Nathaniel Ramsay, who was the first subject, died near (olumbia, in 1852.) Besides this, he wrote a Universal IListory, a History of the Revolution, and a History of South Carolina, from which are taken many facts of this sketch, and of all other sketches of our early history. Stephen Elliott was a thorough botanist. Washington Allston, a painter and poet. Hugh S. Legare, a scholar as well as orator. But it is needless to say more.

This appreciation of higher education led the people of South Carolina first to send their sons abroad and then to endow colleges of their own at lome.

Sketches of these colleges are appended, each written by the president or one of the professors of the college described.

THE SOUTH CAROLINA COLLEGE.

On the 7th day of December, 1723, the Rev. Thomas Morritt made proposals in the Colonial Assembly for the establishment of a college. This is the first time the word oceurs in South Carolina legislation. A manuseript bill, partly in the handwriting of John Rutledge, in the time of Lieutenant-(Fovernor Bull (1769) provides, in addition to public schools, for " a college for the education of the youth of this province." The plan was most liberal, embracing instruction in the natural sciences, medieine and law, as well as in the classics and philosophy.

To Governor Drayton, however, was reserved the hon or of inaugnrating a succesful morement. His messige, Novemler 2:36, 1801, adroeated the erection of a State College. In Aet of Incorporation passed the same year. Fifty thousand dollars were appropriated for buildings, and six thousand annually for salaries.

An organization was effected in February, 1S(2), and buildings were erected by 1S04. A faxulty was chosen in April of that year. Rev. John. athan Maxey wia elected president. Born in .Mat-achusetts in 1768, he 
was chosen presirlent of Brown Lniversity at the age of twenty-four. In 1802 he became presiclent of Union college, and tro years later, came to South Carolina to organize this Institution. There he served faithfully, and with distinguished sucees, until his death, in 15:0. A handsome monment to his memory graces the College Campus.

The College opened on the 10th January, 1S05, its first matriculate being Willian Harper, afterwards Chancellor of the State, and one of the ablest jurists that have adorned the Aninerican bench. Eight other students entered the same day, and by July the number had increased to twenty-nine. From that time the College went on incrasing in honor and in usefulness. Its history is indissolubly connected with that of the State. With reason has it been said that much of the peculiar genius of South Carolina, much of her prominence in the conneils of the Lnion, much of that high sense of honor characterizing her sons in every walk of life, were due to the formative influences of the South Carolina ('ollege:

The youth of the State imbibed political economy from a Cooper, history and government from a Lieber, eloquence from a Preston, logic from a Thornwell, science from an Ellett, or a Le Conte, Greek from a Henry, and other branches from learned masters. Calhoun's I)isquisition on Govermment was, by law, a text-book in the college. All the departments of the State government attended commencement exercises in a body. The college was the gymmasium in which youthful intellects were prepared to grasp the problems of statesmanship equally with those of ordinary business life.

'The succession of presidents up to the war were Rev. Jonathan Maxcy, Thomas Cooper, Robert Henry, pro.tem., Robert IV. Barnwell, William ('. Preston, James II. Thornwell, Charles F. McCay, and A. B. Longstreet.

Among the alumni, now deal, who bore off honols, are James L. Petigru, B. J. Earle, .J. B. O'Neall, George Mcl)uffie, Hugh S. Legaré, 1). L. Wardlaw, F. H. Warllaw, Richard Yeadon, Basil Manly, T. J. Withers, Ednund Bellinger, James H. Thornwell, James Simons, and Robert IV. Barmwell, Jr.

Among the graduates during the first quarter of a century, were Willian Harper, B. F. Whitner, Warren R. Davis, Job Jolnnston, WT. C. Preston, Warlly Thompson, A. P. Butler, T. N. Dawkins, J. H. Hammond, and Stephen Elliott. The dead alone are mentioned; the living speak for themselves.

On several oceasions the College passed through trying ordeals, but the State rallied to her support. Hon. Robert II. Barnwell was especially successful in twice restoring confidence and infusing new life into the Institution. His name is more closely linked with the Collegre than ally wher. 
By the year 1847 additional buildings were necessary, and the roll of students the following session numbered 221. A fire destroyed one building in 1851, ancl, four ycars later, a still more serious loss was incurred in the burning of Rutledge College and the old chapel. These damages were speedily repaired.

$A$ rebellion in 1852 led to a relaxation of the old rule requiring all students to board in commons. After this the Steward's Hall served only as a check upon regularly licensed boarding houses.

The College continued its usefulness until the war. A company was formed within the walls for State service.

In 1862 the exereises were suspended, and the students and professors were called to other duties. Hundreds of matriculates and alumni were near the flashing of the guns, and many of them achiered high reputation.

The college buildings served as a hospital up to the time of the surrender.

THE SOUTH CAROLIXA UNIVERSITY.

In 1866, the college was reopened and converted into a miversity, Hon. Robert W. Barnwell being a second time called from private life to the presidency. He placed the institution on a soun I footing. Schools of law and medicine were attached to the academie department. A number of earnest students attenderl, and the attendance increased to more than a hundred. The reorganization of the Board of Trustees, in 1869, was followed by some resignations in the faculty. In 1873, a radical change was made. The doors were thrown open to all students, regardless of race. The old profestors resigned their places, and a new faculty :1n I a new clas; of stu lonts can s into ozsupancy. In 1877,

\section{THE INSTITUTION WAS CLOSED}

by the Legislature. In 1879 , the Legislature isued State stock to revire the fund, given by the general Government fir an agricultural and mechanical college, and lost by the State anthorities between 1868 and 1876 .

THE UNIVERATTY WAS REOPENED

in 1880 with two branches-the sunth Carolina Agricultural and Mechanical College at Columbia, for the whites, and Claflin University at Orangeburg, for the blacks. Iton. W'm. Porcher Miles Was elected President of the College at Columbia. This nrganization continued two years. In 1881, the Legislature made additional appropriations, and the trustees, 
in May following, elected five additional professors. The college openerl in October with flattering prospects, the attendance reaching one hundred and fifty in a few weeks. Mr. Miles having resigned to accept innportant prirate trusts, the ficulty elected Prof. J. M. AcBryde ('hairman, and he was subsequently elected President.

\section{FACLLTY AND OFFICERS.}

John M. MeBryde, Presilent, and Professor of Agriculture ant Horticulture; James Woodrow, Ph. D., D. D., Professor of Cicology, Mineralogy, Botany, and Zoology; Benjamin Sloan, Professor of Mathenatic- and Natural Philosoplyy; W'm. Burney, Ph. D., Professor of Analytical and Agricultural Chemistry; E. L. Patton, LL. D., Professor of Ancient Languages; E. S. Joynes, .I. A., LL. D., Professor of Modern Language and English; Rev. II. J. Alexander, A. M., Chaplain, and I'rof(r-or of Philosophy; R. Ieans Daris, Professor of History and Political science. Secretary of the Faculty, R. Means Daris; Treasurer, N. B. Barnwell; Librarian, Miss E. W. Bamwell : Marshal, R. S. Morrison.

\section{COLRSES OF STUDY, FOUR YEARS EACH.}

There are three Science courses, conferring the degree of B.S. The first is of general science, the secrond of applied science (mechanics and engineering), and the third of applied seience (agriculture and alplied chemistry).

'There are, also, two Literature courses, conferring the degree of B. A. The first embraces a first course in classics. The second sulu-titutes modern languages for the stuly of Greek.

There are three special courses. Practical Igriculture, Practical surreying, and Practical English.

Tuition is free. A charge of ten dollars is made for reprairs. (te. Board is secured at reasonable rates.

\section{BUILDINGS AND GROUNDS.}

The college buildings are encloser in the college grounds, which contain about sixteen acres. The "campus" contains nearly four acres. Around it are the recitation rooms, the tenements, and the profeseors houses. The dormitory system is adopted. For each pair of stulents there is a suite of three rooms, thus insuring comfort and privacy. The buildings are valued at $\$ 2,50,900$. The library contains about 27,000 
volumes, selected with great care by such scholars as Elliott, Thornwell and Lieber. Many of the books are of rare value.

FUNDS.

The college receives a portion of the procceds of the $\$ 192,000 \mathrm{in}$ agricultural serip. In addition, the Legislature has for two years appropriated $\$ 10,000$ for professors, and $\$ 2,500$ for other purpeses. The trustccs have made an appropriation for the purpose of carrving out the agricultural feature. A handsome conservatory is in course of erection, and an experimental farm will be carried on for the purpose of testing new seeds, fertilizers, \&c. The endeavor will be to make this college practical as well as literary, and to afford a thorough training to the youth of the State.

\section{THE COLLEGE OF CHAlLESTON.}

The College of Charleston was incorporated by Act of the Legislature in 1755. Two other colleges were incorporated on the same day-Mount Zion College, in Winnsboro; and one in Cambridge. The last, it is believed has no further history. The second was, for ycars, a respectable grammar school. Certain funds which were bequeathed by individuals to aid in "the first college which shall be chartered," were thus dividerl among the three which were thus simultaneously created by the Legislature. The college thus chartered in Charleston enjoyed the possession of the Old Barracks, with the lands attached to it, between George, St. Philip's and Green streets, and it is on that land the present college building stands. At the time of the charter the Rev. Willian Smith, afterwards Bishop of the Diocese of South Carolina, kept a large classical school in Charleston, and it was determined to make his school the nuclens of the new college, but it was not until 1794 that the college gave degrees to its graduates. In that year a commencement was held, and the Bacealaureate conferred on six candidates, among whom we find Nathaniel Bowen, afterwards Bishop of the Diocese, and John Daris Gervais.

This was the first and also the last commencement of the college in that century. Its pretensions as a college seem to have been lost sight of, and for many years it held rank only as a classical school, whose reputation depended upon the character of its hear.

In 1524, an effort was made to raise its collegiate character, and three of the principal schools were united under the presidency of Bishop Bowen. It was then a school of a mixed character, in which it was not easy to distinguish the academics from the pupils of the grammar or preparatory school. Having organized the college, Bishop Bowen retired 
from its headship, and was succeeded by Rer. Jasper Arlams. In 1525), the first degree was conferred on Alex. Gadsden, and in 1826 the Rt. Rev. Bishop Wightman took the Baccalaureate. From this time to $183 \pi$ the exercises of the college were continued without interruption, and the list of graduates contains the names of gentlemen who have been farorably known to the community as lawyers, jurists, merehants and divines.

In 1S35, the exercises of the college were suspended in consequence of financial embarrassment. In 1837, by an agreement between the trustees and the City Council, the property of the college was ceded to the Council, which, in return, charged itself with its maintenance.

Under this arrangement the college was re-opened umler the presidency of Rev. W. H. Brantley, D. D., two professors and a tutor. The grammar or preparatory school was dropped, and this arrangement, with the addition of other professors, continues to the present time.

In 1S26, the Old Burracks were taken down, and the centre of the present college building erected. This was enlarged by the addition of the two wings, in 1850 . The first commencement was celebrated in 1840 , and there has been no interuption since that time. In 1S4-, Dr. Brantley died, and was suceeeded by H. Perroneau Finley, Esq., who resigned in 1858. In 1850 the Cabinet of Natural History was added to the college, and occupies the whole of the upper story of the building. The board of instructors was increased to six.

In 1S5S, N. Russell Middleton, Esq., was elected president, and served until the end of $18 S 0$.

During the war the exereises of the college were not suspended, but the greater number of youths of the age to go to college were called into the service, and in 1865 the college was not opened.

The whole number of graluates between 1825 and 1870 is two hundred. and ninety-seven. This, of course, shows small classes, but the college educates few persons outside of the city. Hence the number of students is always, and must always be, small; but among the graduates are found the names of most of those who have led public opinion in the city. In this list are forty-two lawyers, thirty-two physicians, thirty-two merchants, and twenty-tluree clergymen, besides most of those who have made a mark as educators and teachers of youth. The course of studies does not differ materially from that of other colleges in the United States, and it is doubted whether any college excels it in its mathematical course. Of late particular attention has been given to a practical knowledge of English Jiterature, including a critical reading of the carly poets. French and German have been made obligatory portions of the curriculum.

The funds of the college are reported by the Mayor as $\$ 300,000$. This 
has been obtained from various sources. In 1864, Mr. Ephraim Mikell left the college city stock announting to more than $\$ 150,000$. Besides this Mr. Ker Boyce left a fund of more than $\$ 20,000$, the interest of which was to be employed in the support of worthy youths during their college course.

The college opened October, 1882, with the following faculty:

Henry E. Shepherd, President, Professor of English Language and Literature; Lewis R. Cribbes, Professor of Astronony, Physics and Chemistry; Francis W. Capers, Professor of Mathematies and Civil Engineering; A. Sachtleben, Professor of Ancient Languages and Literature; Sylvester Pumer, Professor of Modern Languages and Literature; X. Russell Middleton, Professor Honorary, Lecturer on Moral and Political Philosophy, and Evidences of Christianity; F. A. Porcher, Professor Honorary, Lecturer on Belles Lettres and History; H. M. Bruns, Professor Honorary, Lecturer on Classical Literature.

\section{ERSKINE COLLEGE.}

This Institution is the property of the Associate Reformed Synod, of the South.

It is situated at Due West, in the upper part of Abberille County, four miles west of the Donald's Depot, on the Columbia and Greenville Railroad, and on the line of the Atlantic and French Broad Valley Railroad, now being constructed.

For some years previous to 1836 , the Institution, which afterwards developed into a College, had been open as a Classical School. In the Fall of 1535 , steps were taken to enlarge the course of instruction, which was carried into effect in 1836. The first name of the College, was

CLARK AND ERSKINE SEMINARY.

It was organized as Erskine College, in 1839, and the course of instruction extended so as to comprehend all the studies appropriately belonging to Colleges. The first President was Rer. E. E. Pressly, D. D., with the following corps of Professors: Mr. N. M. Gordon, Rev. J. N. Young and Rer. J. P. Pressly, D. D. As the patronage and means of the College increased, additional Professors were employed until the plans of 1839 were fully met. It has had the following distinguished gentlemen as Presidents: Rev. E. E. Pressly, D. D), Rev. R. C. Grier, D. D., (two terms, 1846 to 1858 , and $18(j .5$ to 1871$)$, Rev. E. L. Patton, LL. D., Rev. II. M. Grier, D. D., son of the furmer Dr. Grier. The following gentlemen have been connected at different times with the College as Profes- 
sors: Rev. D. McCaw, Rev. William McWhorter, Rev. Wr. R. Hemplill, D. D.; Professors J. F. Lee, J. P. Kennedy, Wm. Hood, W. S. Lowry, J. H. Miller, L. P. Kennedy and J. J. McCain. The last five named, together with Dr. Wr. M. Grier, as P'resident, compose the Faculty at this time. These gentlemen represent, as alummi, quite a large number of Colleges and Lniversities. The first Faculties were drawn mostly from Northern Colleges, such as Jefrerson, P’a, and Miami University, Ohio. In later years, they have been taken from graduates of colleges in the South-such as the University of Georgia, south Carolina College, and Erskine College. Several of them have taken courses of special study in Yale, Johns Hopkins' University, Amlerst, tc. All of these gentlemen have been noted for their devotion to education, and have stood high in their respective departments.

The course of instruction is believed to be as thorough and full as the orlinary purposes of an education can require, or as students are able to accomplish in the time usually devoted to a college course.

While it is true that, although like most denominational colleges, Erskine is the child of hard struggles, she has now attained such age and growth as place her future beyond the dangers of ordinary eontingencies.

Endowments. Previous to 1553, the College relied on tuition fees and the interest of a few donations and bequests to defray expenses. In that year, "the plan of endowing the College, by the sale of scholarships was adopted, and a rigorous attempt made to carry out the scheme * * Money was scarce, and crops not abundant, but by making liberal offer's in the way of tuition, more than $\$ 50,000$ was raised towards the endowment of the College." This, in comnection with funds previously receiver from Capt. Blair and others, and nore recently from Christopher Strong. Esq., of Temmessee, and Col. Wm. Wright, of Yorkville, Soutl Carolina, raised the endowment to about $\$ 70,000$.

The results of the late war swept away all of this endowment, excepting about $\$ 13,000$. Having tried some temporary expedients, the Synod, in 1S71, entered on a second effort to secure a permanent endowment. The plan was similar to the one of 15.53 , except that the price of scholarships was raised to $\$ 20$ each, and the term of the College obligation limited to 1895 . Until that time, each sliare or scrip for \$20 entitles the holder to one year's tuition. Thongh the friends of the College were imporerished and discomraged, by the disasters of the war, this effort met a liberal response, and the sale of scholarships, together with a few additional donations and bequests, raised the endowment to about $\$ \$ 0,000$. The largest donation was $\$ 15,000$, by Mrs. Ann Wallace, of Kentucky, and the largest bequest the College has received, was by the will of the 
late Dr. Ilearst, of Ableville, S. C. He left two-thirds of his estate to the Collegre. About $\$ 11,000$ has been realized on it.

Buildings. The first permanent building was erected in 1842 , and is a large fine brick structure of three stories; affording ample rooms for recitations, library and other purposes. A second building was erected in 1850-1. It is also of brick, and has two stories. The first floor is divided into chapel, sehool and reading rooms. The second floor, with a seating capacity of 1,200 to 1,500 , is Commencement Hall, or " Lindsay Hall," named after James Lindsay, Esq., in eonsequence of his liberality as builder. Here all exhibitions and commencements, not only of Erskine College, but also of the Due West Female College, are held.

Attached to this building is an observatory, about one hundred feet high, on which is mounted a large and valuable teleseope under a rerolving cupola.

In subsequent years, two other brick buildings of two stories each were erecter in the campus. These are appropriated to the uses of the two Literary Societies connected with the College. Each contains a general hall for forensic practice, a library and other rooms. They were built by contributions of the mombers, their alumni, and other friends. One was built in 1858 , the other a year or two later.

\section{BENEFICIARY SCIIOLARSIIIPS.}

Provision has always been made in one way or another for aid of deserving students in straitened circumstances, and many young men have been enabled to graduate in this way. Until recently, however, there has been no regular beneficiary fund. In the last year" or two the "Duane Mower Scholarship," has been founded, the annual interest of which is offered by the Faculty to worthy, but indigent young men.

The buildings and other property are valued at about $\$ 10,000$.

The foregroing is a brief sketch of the history and purposes of Erskine College. During the forty odd years of its existence, it has annually (except during the war period) sent out a considerable number of alumni. It has graduated more than four hundred young men, most of whom are now honoring all the learned professions in many States of the Union.

ASSOCIATE REFORMED TIIEOLOGICAL SEMINARY.

Since the origin of Erskine Collexe, a Theologieal Seminary has been conneeted with it, though in no serse a part of it.

Its funds are distinet from the funds of the College. The only connection, is that the two institutions belong to the same body of people, and 
some of the rooms, not needed by the College, ansirer the purposes of the Seminary. No endowment has yet been undertaken for it. It is supported by an annual assessment of the Churehes comprising the Srnod.

The only funds it has received for permanent investment are donations and bequests. The largest of these was by the will of the late Dr. McMillen, of San Francisco, (al. This is not in hand yet, but according to reports of the executors, it is believed it will yield a very handsome sum. This, added to others, similar, the more recent of which is from Mr's. Ann Wallace, of Kentucky, and Mr. Thomas Torbit, of Chester, S. C., raise the amount to about $\$ 20,000$.

At present, the Seminary has three professors, with Rer. James Boyce, D. D., as the President of the Faculty. The course of instruction is two years, of nine months each. Tuition is free.

Intimately connected with the Seminary, and therefore more or less interesting to the friends of the College, is a Board of Foreign Missions, all of whose officers reside in Due West. The Board was organized in 1875 , at which time the first missionary was sent out. As this Board is quite young yet, its funds are also quite small, not amounting to much over $\$ 3,000$.

WOFFORD COLLEGE, SPARTANBURG C. H., S. C.

This Institution was founded by the Rer. Benjamin Wofford, a minister of the Methodist Episcopal Church, South, and is called by his name. For some years before his death, Mr. Wofford had been deeply interested in the sulject of education, and was anxions to aflord the adrantages of the highest literary improvement to the youth of the upcountry of his native state. In his will, he left $\$ 100,000$ " for the purpose of establishing and endowing a college for literary, classical and scientific education, to be located in his native district, Spartanburg, and to be under the control of the Methodist Episcopal Chureh of his native State, South Carolina." The collegre received its charter from the Legislature of South Carolina, Dec. 16, 1851. A board of trustees was appointed, with "authority to confer and award all such distinctions, honors, licenses, and degrees as are usually conferred and awarded in colleges and universities in the United States. The buildings were completed at a cost of $\$ 50,000$, learing the same amount as the nucleus of an endowment. The college luvilding is an imposing and handsome structure of brick, containing a chapel capable of holding about one thousand persons, library, museum and laboratory, and recitation rooms. The other buildings included in the college property consist of a president's house, and houses for four professors. They are all substantial brick buildings 
The first faculty of the college was componerl of the Rev. W. M. Nightman, I). D., P'resident; David Duncan, A. M., P'rofessor of Lancuages: James H. Carlisle, A. M., l'rofesor of Mathematics; Warren 1)ul'ré, A. M., Professor of Natural Science. To there were added, in the following year, Whitefoord Smith, Professor of English Literature. The regular exercises of the college were commenced on the 1st day of August, 185t. During our late war, the cxercises of the institution were never wholly suspended, but a high school was kept up under the superrision of Professors D. Dunean and J. H. Cirlisle.

After the close of the war, the regular collegiate classes were again formed, and the number of students has steadily increased. During the last year, one hundred and forty were in attendance. The standard of scholarkip in this institution has always been very high, and the services of its graduates as teachers have been in great demand. It las given a large number of its graduates to the rork of the ministry, while many others have been ealled to the field of educational labor, others to distinguished positions in civil and politieal life.

It is greatly to the credit of Wofiord College that it has given the advantages of liberal education to many poor young men who otherwise would have been deprived of them; and this is more to its credit when it is known that its endowment funds were nearly all lost in the disastrous effects of the last war.

The college is beautifully located in the northern part of the town of spartanburg, and has a campus embracing about seventy acres, nearly all of which is delightfully shaded with forest trees. This section of the state is noted for the salubrity of its climate, pure water, and general healthfulness. It is known as a good summer resort for those living in the lorrer part of the State. It is almost unequalled for the high moral tone of its society.

The cost of board and tuition is rery reasonable, and the necessary expenses of a student here are small. A group of students formed a mess, list year, at a cost of only seven dollar's a month to each, and their table was as good as is usually found in prirate families.

Sescions begin on the 1st October, and close on the Wednesday after the second Sunday in June.

The present faculty is composed of James H. Carlisle, A. M., LL. D., President, and Professor of Mathematics; Rer. Whitefoord Smith, A. M., D. D., Professor of English Literature; Rer. II. IV. Dunean, A. M., D. D., Professor of Mental and Moral Philosophy: Daniel A. DuPré, A. M., Protessor of Chemistry and Geology; F. C. Woodward. A. M., Profeseor of Latin and French; J. A. Camewell, A. M., Professor in charge of Introductory C'lasses; J. H. Kirkland, A. M., Professor of Greek and German; 
IV. W. Duncan, Financial Secretary and Treasurer; J. A. Gamewell, Secretary of Faculty.

FURMAN UNIVERSITY, GREENTILLE, S. C.

This institution, founded by the Baptists of the State, has been in operation a little more than thirty years. It is situated within the corporate limits of the city of Greenville, upon the western side of Reedy river, a little stream rising near the foot of the mountains and, on its way to the Saluda, intersecting the site of Greenville city. The grounds of the University embrace some forty acres of land, constituting a wooded height of remarkable beauty. Near its centre, and fronting the main street of the western portion of the eity, stands the main pile of the University building. The scene from its tower is one of the finest. The undulations of Laurel creek and Reedy river, the near heights of Lowndes hill, Piney mountain and Paris mountain, the more remote lines of IIngback, Cresar's Head and Table Rock, with yet more distant points of the Blue Ridge, present a view of surpassing beauty. The building itself is wholly devoted to the immediate purposes of instruction; one section containing a chapel, a chemical laboratory, a philosophical apparatus room, and a library room. Another section contains seven recitation rooms, and two society rooms. These two sections are connected by the mathematical room, which is furnished with ample blackboards, and with tiers of desks and seats which enable every student to see distinctly the work upon the blackboards.

There is no provision for boarding within the University. The history of colleges shows that dormitories in college buildings, and boarding in commons, have been the sources of incalculable moral damage. In a correspondence with some leading instructors, instituted by those who projected this institution, facts and opinions were gathered which made them unwilling to embrace the old college system in the plan to be inaugurated in Greenville. The late President Wayland, for instance, gare it as his deliberate opinion, that forty-nine-fiftieths of the trouble in colleges grow out of the dormitory system. Boys, to be safe in college, must divide in families; and the boarding-house which is most like home is the best place for them. More than thirty years' experience in Furman University has confirmed these views. There has never been the slightest sign of any thing litie a rebelliom. There has been searcely any need for discipline beyond the kind, quiet admonition. A few instances, at long intervals, hare occurred, in which it has been necessary to put away a student for unworthy conduct; but in every such instance, the action of the faculty has had the unqualified moral support of the body of students. 
In addition to this, the utmost good feeling has erer been reciprocated between the students and the citizens of the town.

The name of the institution, under which it was incorporated, "Furman Uuincrsity," was adopted because, in its incipiency, it embraced an academic, ar collegiate, and a theological department, with the expectation of adding afterward, a department of law. Arrangements to this effect were on foot when the war rendered them impracticable. The Southern Baptist Theological Seminary, now located at Louisville, Ky., but originally founded in Greenville, S. C., is an outgrowth of Furman University, which gave up its theological department in order that other States besides South Carolina might be brought in as supporters of a common Southern theological institution.

Soon after the war, the university sought to provide free tuition in the collegiate department on the basis of bonds given for the support of the faculty, on condition of free tuition for ten years. Having $n$ provision for the support of a preparatory department, it was not reorganized.

The plan of free tuition for ten year's proved a failure, oring, mainly, to the fact that the bonds matured at the time of the greatest financial stringency known in the State for many years. Out of $\$ 200,000$ in bonds, the amount actually collected enabled the trustees to invest $\$ 20,000$ as a permanent interest-bearing fund, the balance being appropriated to meet current expenses.

An experience of five years convinced the trustees that the plan of free tuition would not be a success. Aecordingly, at a meeting of the Board, August 30th, 1S81, the University was reorganized. It was determined to discontinue free tuition, and appeal directly to the Baptist churches of the State for the means to meet current expenses. For this purpose, the President visited most of the associations neeting in the fall, and such responses were received as gare assurance that the institution would be continued.

The results of the last session, which closed June 1Sth, were such as greatly to encourage the friends of the institution; and as arrangements have been instituted for the satisfactory settlement of the outstanding bonds, a eareer of enlarged prosperity is confidently anticipated.

The present organization includes an academic and a collegiate department. The former is intended to prepare students for the college studies, and is under the immediate direction of a principal, who has already achieved success in this department. The college department embraces seven distinct schools, riz: the Latin Language and Literature; the Greek Language and Literature; Mathematics and Mechanical Philosophy; Natural Philosophy; Chemistry and Natural History; 
Metaphysies; the English Language and Literature. Provision is made for a two years' course in German and Freneh.

The Faculty is as follows: Charles Manly, D. D., President, and Professor of English; Rev. James C. Furman, D. D. Professor of Metaphysies; C. H. Judson, Professor of Mathematics; Harvey T. Cook, Professor of Ancient Languages; George D. Purinton, Professor of Chemistry and Physies; R. E. Gaines, Assistant Instructor; IT. W. Brown, Principal of Academic Department.

For catalogues giving full information, application may be made to the President, Rev. Charles Manly, D. D., or to the Secretary of the Faculty, Prof. H. T. Cook, at Greenville, S. C.

\section{NEWBERRY COLLEGE, NEWBERRT, S. C.}

At a meeting of the Evangelical Lutheran Synod of South Carolina, held in 1856, it was resolved to establish a "Classical and Literary Institution." A board of trustees was elected, a charter obtainerl, and Newberry, S. C., chosen as the location. In 1557 , the corner-stone of a building was laid, and in the following year, a large and attractive college edifice was completed, at a cost of $\$ 20,000$. The faculty was as follows: President, Rev. T. Stork, D. D., and Professors, R. Garlington, O. B. Mayer, M. D., J. Bachman, D. D., LL. D., J. A. Brown, C. A. Stork, A. P. Pifer, J. M. Streckhise, and M. Whittle.

The college was opened in 1558, and during the second session (1859-60) 175 students were enrolled.

A plan of endowment by scholarship was adopted, which was so successful that, in 1860 , the sum of $\$ 50,000.00$ had been secured. A president's house was built at a cost of $\$ 4,000.00$, and cash subscriptions in hand amounted to $\$ 3,000.00$. Thus it appears that, in 1860 , the property of the college in endowment, buildings, etc., exceeded $875,000.00$ in value.

The breaking out of the war between the States, in 1861, cansed the withdrawal of the faculty, and nearly all the students enlisted in the armies of the Confederacy.

In 1S62, Rer. J. P. Smeltzer, D. D., was elected president, who, during this and the following year, obtained subscriptions to funds of nearly $\$ 50,000.00$. From 1861-5, the college was not regularly open for students. In 1865, the Synod recommended to the Board to reopen the college. Professors were elected, and, with a limited number of students, the exercises of the institution were resumed in November of that year. But the finances of the college were in a shattered condition, the endowment had been totally lost by investment in Confederate securities; and the college building, beautiful in its architecture, but defective in' its 
construction, necesarily somewhat uncared for during the troublous times of the war, and much injured by its occupancy by Lnited States soldiers cluring four montlis of the year 1565, was found in 1866 to be unsafe. Steps were taken to effect the necessary repairs, but to the astonishment of the Board and the friends of the college, clains against the Board to the amount of $\$ 18,000.00$ were presented. Such was the poverty of the people that the building could not be reclaimed and these debts paid. The trustees, therefore, made sale of the property and closed the institution.

At this juncture, the citizens of Wallhalla, S. C., macle farorable proposils to have the college located at that place. The offer was accepted, and in November, 1S68, the college was removed to Walhalla. Here the college sojourned for nine years, struggling amid many and heary embarrassments.

In 1877 , the citizens of Newherry, desiring the re-location of the college on its old site, offered to the Synod buildings and grounds worth $\$ 15,000$. The offer was accepted, and in September, 187\%, the exercises of the college were opened at Newberry. By the close of this rear, a suitable and substantial brick building was finished, and the property of the college at this date, $1 \mathrm{SS} 2$, in building, grounds, library, apparatus, \&c., is worth $\$ 25,000$.

Rev. J. P. Smeltzer, D. D., who had been president of the college for sixteen years, upon the removal of the college from Walhalla, retired from the presideney, and Rer. G. Wr. Holland, the present incumbent, was elected his successor.

Up to 18S2, the college has graduated forty-eight young men, twelve of whom are now teaching in this State.

In addition to the first faculty, the following gentlemen have been at rarious times member's of the corps of instructors: Rer. J. P. Smeltzer, D. D.; D. Arrington, Rer. J. McNeill Turner, D. D., Rer. G. WV. Holland, D. B. Busby, E. J. Dreher, Carl Weber, Rer. J. F. Probst, G. D. Haltiwanger, G. B. Cromer, and perhaps others.

The faculty, as at present constituted, is as follows: President, Rer. G. IV. Holland, and Professors O. B. Mayer, M. D., S. S. Rahn, B. WV. Bittle, C. W. Welch, and E. H. Aull.

The arerage number of students for the past four rears has been about one hundred.

A small endowment of $\$ 12,000.00$ has been raised from proceeds of the college in the State, and generous patrons of elucation in Boston have contributed about $\$ 4,000.00$ toward the equipment of the college.

It is believerl that a career of prosperity and usefulness is now opening to the institution, and that its friends will soon add to its endowment 
and other appliances. It is hoped, also, that its patronage will, in the near future, be largely extended.

ADGER COLleGE (PRESBYTEIiAN), WALhalia, S. C.

In 1S68, Newberry College was removed to Walhalla, at which place it flourished for nine years. The Lutheran Synod, in the spring of 1877 , resolved to carry this college back to its original site in Newberry. Thereupon the people of Walhalla, of all denominations, determined to organize a new college in place of the one about to be removed; and as other denominations had eolleges, it was resolved to place this institution under Presbyterian control.

A subscription was begun, and in a few months the sum of ten thousand dollars had been raised. The subscribers formed a joint stock association on the basis of one vote for every twenty-five dollars of subscription. It was resolved, also, that upon securing an endowment fund of ten thousand dollars in addition to the subscriptions, the institution would be placed under the control of the Presbytery of South Carolina. The subscriptions were secured by bonds, payable 1st January, 1890 , and bearing seven per eent. interest, payable seni-annually from the 1st July, 1877.

At the commencement of Newberry College, June, 1877, announcement was marle of the opening of ADGEr Coldege in the ensuing autumn The new institution was called in honor of a family whose unsullied name had long been identified with Presbyterianism. A charter was obtained for a white male college. The local subscriptions reached $\$ 21,000$, in sums ranging from $\$ 2.5$ to $\$ 500$, and before 1879 the endowment of $\$ 10,000$ was also secured. Presbytery accepted control of the college on 2 ith september, 1878.

A temporary organization was effected with Rev. J. R. Riley, D. D., as chairman of the faculty.

Parties subscribing $\$ 500$ each were entitled to free tuition in all departments for all their sons, and every addititional $\$ 500$ entitled the subscriber to designate a person whose sons should also secure free tuition; this designation being subject to approval of the college management.

Thus equipjed, the college began a career of usefulness. In June, 18S2, a permanent organization was effected, by the election of the Rer. F. P. Mullally, D. D., President; Rev. J. R. Riley, D. D., Professor of Languages; Fiev. H. Strong, Professor of Natural Sciences; and WT.S. Moore, A. B., Professor of Mathematics.

Upon this permanent organization a new interest sprang up, and several hundred dollars in cash were added to the endowment fund, with a prospect of a much greater increase. 
The location of the college is all that could be desired-within four miles of a mountain range, its water and air are pure and bracing. The surrounding population is generally of the moral, energetic, industrious class, which is the hope of true progress and prosperity.

In the town of Walhalla there are four churches of whites, viz: Baptist, Methodist, Lutheran and Presbyterian, with an aggregrate membership of between five and six hundred, supplied by able ministers.

Walhalla is the terminus of the Blue Ridge railroad, eight miles above its crossing of the Atlanta and Charlotte Air-Line Railway, and easily accessible from all sections of the country, but adrantageously remored from the bustle and confusion of larger railroad towns.

Students obtain good board and lodging at nine dollars per month, owing to the fact that the cereals are produced in this neighborhood more abundantly than any other erop. The tuition is forty dollars per scholastic year, and, as might be expected, from the financial statement in regard to the population, there is no extravagance among us. Our college, our town, and our country are all free from debt. Whe have in the county about four whites to one colored inhabitant. The average attendance of pupils in the collegiate and sub-collegiate classes of the college during the five years of its tentative existence has been eighty. Now, that it has been put upon a permanent basis, and its suecess no longer doubtful, with all the adrantages of accessibility and of religious, moral and industrious surroundings, and economy in tuition, board and dress, with a population yearning for learning and liberal in its support, we confidently expect to find this infant, already strong in its preparation for good, substantial, literary work, soon in the foremost rank of educational institutions.

\section{INSTITUTIONS FOR SPECIAL INSTRUCTIOA.}

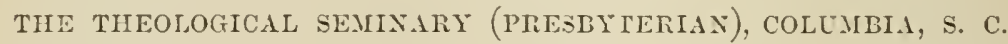

In 1S2S, Hopewell Presbytery, in Creorgia, took the first steps in the establishment of a theological seminary. A theological school was opened in that year, in Lexington, Georgia, under the charge of Rev. Thomas Goulding, D. D. South Carolina Presoytery agitated the matter with such success that, in 1830 , the seminary was removed to Columbia, a commodious private residence with ample grounds having been purchased for the purpose. Dr. Goulding was assisted by the Rev. George Howe. The Synod of South Carolina and Georgia assumed general supervision. After this the seminary prospered, other professors were added, and two 
additional buildings erected. The endowment constantly increased. When the war came on there were five professorships, with an average endowment of about forty thousand each; besides about fifty thousand more for contingent fund and scholarships.

Judge John Perkins, of Columbus, Miss., in 1559-60, erected a "Perkins Professorship of Natural Science in connection with Rerelation," with an endowment of $\$ 40,000$. Exercises continued throughout the war, and were interrupterl only a few months, in 1865.

In 1880 , the institution was compelled to close, in consequence of temporary financial embarrassment. Additional sums were subscribed to the endowment fund, and large amounts again beeame available, so that in September, 1SS2, the seminary reopened with five professors, and an endownent of about $\$ 150,000$; which is still increasing. Its future prospects are full of promise.

The whole number of the alumni is orer five hundred. Of these seventeen are foreign missionaries.

The seminary is open to students of erery denomination.

\section{OFFICERS.}

IIon. James Hemphill, Chairman of the Board of Directors; T. A. MeCreery, Esq., Treasurer.

\section{FACULTY.}

George ITowe, D. D., LL.D., Professor of Biblical Literature; James Woodrow, Ph. D., D. D., Perkins Professor of Natural Science, in connection with Rerelation; J. L. Girardeau, D. D., LL.D., Professor of Didactic and Polemic Theology ; Rev. Charles R. Hemphill, A. M., Associate Professor of Biblical Literature; IV. E. Boggs, D. D., Professor of Eeclesiastical History and Church Polity. The senior professor is chairman of the faculty. Dr. Howe has held this position since 1834 .

Professors formerly comnected with the institution, were Rev. Drs. Thomas Goulding, A. W. Leland, C. C. Jones, A. T. McGill, B. M. Palmer, J. H. Thornwell, J. B. Adger, W. S. Plumer, and Joseph R. Wilson.

Many of the leading divines of the South have been trained in this seminary.

\section{LIBRARY.}

The seminary contains a library of orer 19,000 volumes, chiefly ecclesiastical and theological. They are carefully selected, and are of much value. Few additions have been made since 1860 . 


\section{BUILDINGS AND GROUNDS.}

The seminary oeeupies a square of four aeres, in the heart of Columbia. The buildings are of brick, three stories in height, and substantial. The campus is shaded with trees of native growth.

\section{INSTITUTION FOR TIIE DEAF, DUMB, AND BLIND.}

Prior to the year 1849 , deaf, dumb, and blind children were sent to the American asylum, at Hartford, Connecticut. In that year, seven pupils were in attendance from the "upper division of South Carolina," at a cost of $\$ 121$. At that time a private sehool for mutes was established at Cedar Springs, Spartanburg, by Mr. N. P. Walker. The location was five miles from the courthouse, on a hill, from the foot of which gushed a beautiful, cold spring. Five pupils were in attendance, all from Spartanburg district. Hon. T. N. Dawkins, commissioner of the - leaf, lumb, and blind, was so favorably impressed with the adrantages of this institution that he recommended it specially to the attention of the Legislature, besides paying to it $\$ 250$, and providing for two more beneficiaries. In 1850 , Gov. Seabrook called attention to the fact that out of seventy mutes in the State, only thirteen were receiving instruction. The Legislature resolved to send no more pupils abroad, and appropriated $\$ 3,000$ for instruction, but refused to make the sehool a State institution. The appropriation was increased to $\$ 5,000$, in 1555 , and a school for the blind was added by Prof. Walker. A Board of Commissioners was appointed to negotiate for the purchase of the property by the State, and the transfer was made in 1557. \$10,000 were appropriated for buildings, and $\$ \overline{7}, 000$ for instruction. $\quad \$ 20,000$ more were appropriated, in 1559 , for the completion of the buildings, and in 1560 , they were rearly for occupancy. Sixteen mutes, and seventeen blind pupils were in attendance.

On the 13th November, 1861, Prof. Walker's death elosel his useful libors, and his duties devolved on Mrs. Walker and the faenlty ; Prof. Henderson (blind) being in charge of the school for the blind, while the clepartment for the deaf and dumb was presided over by Prof Hughston, limself one of the late Prof. Walker's first mute pupils. The institution received annually from $\$ 7,000$ up to $\$ 15,000$, in 1863 . Until 1863 , the total appropriation had never been expended.

The school was elosed in the beginning of 1865 , but in the fall of 1566 , the exercises were resumed for a single session. Prof. Hughston had been elected superintendent after the leath of Prof. Walker. In 1S69, the institution was reopened. Prof. Newton F. Walker, son of the found- 
er, was first made assoeiate principal, and then superintendent, Prof. Hughston continuing to preside over the mute department.

In 1873 , this institution was again compelled to suspend, owing to the failure of the Republican Legislature to make appropriations for its maintenance.. It was reopened in 1876 , and has since then been in a prosperous condition.

An instructor in Bell's system of visible speech was added to the faculty, in 18s0, and a number of the mutes are making gratifying progress in the art of conversation.

There are in attendanee fourteen blind, and forty-eight deaf and dumb pupils.

The institution is supported by an annual appropriation of $\$ 10,000$, and is under control of a Board of Commissioners.

In 18S2, an appropriation of $\$ 1000$ was made for a department for colored mutes.

\section{FACULTY.}

N. F. Walker, Superintendent; J. M. Hughston, ${ }^{*}$ and D. S. Rogers,* Instructor's of Deaf and Dumb; L. II. Cromer, $\uparrow$ and Miss Annie Stevens, of the Blind; Miss Eva Ballard, Teacher of Artieulation; H. W. Estes,* Music; Mrs. V. E. Walker, Matron ; R. P. Brown,* Master of Shoe Shop; IL. W. Estes, $\uparrow$ Master of Broom and Brush Shop.

\section{MEDICAL COLLEGE OF THE STATE OF SOUTH CAROLINA.}

The "Medical College of South Carolina," under the eontrol of the Medieal Society of South Carolina, and located in Charleston, received its charter from the State in 1825. In consequence of some difference between the professors and the society, the former resigned, in 1832, and a new faculty was elected, which conducted the college until 1839, at which time it was permanently elosed.

The professors who had resigned from the old Nedical College immediately organized another Me:lical College, which was ehartered under the name of "The Medical College of the State of South Carolina," and which still exists. A full Board of Trustees was elected, with Mr. Nathaniel Heyward as President.

The faculty was organized as follows:

J. Edward Holbrook, M. D. ; Samuel Henry Dickson, M. D.; Thomas G. Prioleau, M. D.; Edmund Rivenel, M. D.; Henry R. Frost, M. D. : and John Wagner, Mí. D.

* Deaf and dumb. † Blind. 33 
The institution was elosed during the war, but reopened immediately. Its list of alumni numbers 2,153 names.

The college owns no property, with the exception of the large and handsome building in which instruction is given, and an expensive and raluable museum of pathological specimens, and anatomical preparations. The college has never been the recipient of any bequest or pecuniary gift, with the exception of one from the State, thirty or forty years ago, in virtue of which the Gorernor has the right of appointing one beneficiary from each congressional district. There are no other beneficiary scholarships.

Edward McCrady, Esq., is President of the Board of Trustees, and E. Horry Frost, Secretary and Treasurer.

\section{FACULTY AND AUXILIARY IXSTRUCTORS.}

Medical Department, J. Ford Prioleau, Dean ; R. A. Kinloch, M. D.. Professor of the Principles and Practice of Surgery and Clinical Surgery; J. P. Chazal, M. D., Professor of Pathology and Practice of Mecticine, and of Clinical sodicine; Middleton Michel, M. D., Piofessor of Physiology; C. U. Shepard, Jr., M. D., Professor of Chemistry; F. L. Parker, M. D., Professor of Anatomy, and Clinical Lecterer of Diseases of the Eye and Ear; J. Ford Prioleau, M. D., Professor of Obstetries and Gymecology; F. Peyre Porcher, M. D., Professor of Materia Medice and Therapeutics; Manning Simons, M. D., Demonstrator of Anatomy; H. D. Geddings, M. D., Assistrut to the Professor of Chemistiy; George G. Kinloch, M. D., Instructor in Microscopy and Prosector to the Professor of Surgery; P. Gourdin DeSaussure, M. D., Piosector to the Professor of Anatomy; John L. Dawson, Jr., II. D., Assistant to the Clinic of the Diseases of the Eye and Ear.

Pharmaceutical Department (established 1S01), C. F. Panknin, Dean.

Faculty : C. U. Shepard, Jr., M. D., Professor of Chemistry ; F. Peyre Porcher, M. D., Professor of Materia Medica, and Lecturer on Medical Botany ; C. F. Panknin, Instructor in Practical Pharmacy, and Professor of Pharmacy; H. D. Geddings, M. D., Assistant in Pharmaceutical and Practical Chemistry.

\section{CLINICAL INSTRECTION.}

For several years past, by arrangement with City Council, the Roper Hospital has been under the medical and surgical direction of the faculty of the college. This hospital contains two hundred beds, and affords excellent opportunities for clinical instruction, daily lectures being giren in the hospital during the session. 


\section{EXPENSES.}

Medical Department.-Matriculation fee, \$5; Laboratory, expenses for first course students, $\$ 5$; Entire course of lectures, including Demonstrator's ticket, and hospital advantages, $\$ 75$; Graduating fee, $\$ 30$.

Pharmaceutical Department.-Matriculation fee, \$5; Tuition fee, $\$ 30$; Practical laboratory work, $\$ 10$ to $\$ 15$; Graduating fee, $\$ 10$.

THE REQUIREMENTS FOR MEDICAL GRADUATION ARE,

1st. The applicant must be twenty-one years of age, and have had a preliminary education satisfactory to the Faculty.

2d. He must file a satisfactory certificate of having studied medicine for at least three ycars under a rogular graduate or licentiate and practitioner of medicine, in good standing.

3d. He must have attended two full courses of lectures at a medical school approved by the Faculty, the last of which has been in this Institution. (No school will be admitted upon the ad eundem list that arranges its course of instruction to graduate students in less than the time prescribed by this College).

4th. His examination on all the branches, attendance upon lectures, habits and general character must be satisfactory to the Faculty.

The Faculty will give a prize to the candidate for medical graduation who passes the best examination.

Professor R. A. Kinloch, for the best report of his Clinical Lectures on Surgery.

Professor F. L. Parker, for the best report of his Clinical Lectures on Disease of the Eye and Ear.

Professor C. U. Shepard, Jr., to the first-class student who passes the best examination upon Practical Chemistry.

The term hegins on the 15th October, and closes during the first week in March. The average attendance is between eighty and a hundred.

The graduating class of $18 S 3$ numbers thirty. Further information may be obtained from Dr. J. Ford Prioleau, Dean of the Faculty.

\section{MILITARY TRAINING AND INSTRUCTION.}

The people of South Carolina in early colonial days and during the revolution became thoroughly enured to the hardships and hazards of war. The exploits of Marion and Sumter, and their companions, were a 
constant theme to succeeding grenerations, and aided in stimulating their martial spirit. At every suceeeding call to arms the sons of Carolina adcled fresh laurels to her chaplet of military glory. With the memories of the past before them, and in the midst of exciting discussions orer political and social complications, which it was evident would terminate in a bloody protracted struggle, it is not surprising that the youth of Carolina were trained to bear arms. Not only the State Military Academy, but private institutions were organized for this purpose.

Since the last war, which lias put an end to all further prospect of strife, military schools are still maintained for the sake of their discipline, to ensure a harmonious development of all the faculties, "the nicns sana in sano corpore."

THE SOUTH CAROLINA MLITARY ACADEHY.

For sone time previous to the year 1841 , this State had two arsenals for storing its arms and munitions of war, one in Charleston and the other in Columbia, each guarded by a company of enlisted soldiers under officers of culture, trained to the profession of arms. The expense of maintaining the two garrisons was $\$ 24,000$. Governor Richardson suggested the propriety of supplying the place of these soldiers with young men, who, in addition to military training, should receive instruction from their officers in the useful and mechanic arts. Accordingly, Col. Phillips introduced in the House a bill to convert the arsenal at Columbia into a military school. It failed of passage, but Gor. Richardson nevertheless placed a number of deserving young men under the instruction of the officers of the guard. In 1S42, Gor. Richardson earnestly urged such legislation as would establish two schools upon a sure foundation. His successor, Gov. Hammond, was equally interested in the measure, and on the 20th December, 1S42, a bill, introduced by Gen. Jamison, was passed, converting both the arsenal and the citadel into military schools.

By the Act, as subsequently amended, authority was invested in a Board of Tisitors, consisting of the Gorernor and the Adjutant and Inspector-General, cx-officio, and fire persons appointed by the Goremor. The first members were Gov. Hammond, Gen. Cantey, and Messrs James Jones, D. F. Jamison, IV. J. Hamma, and John H. Means. They performed the duty of organizing with zeal, fidelity and judgment. Both schools were opened in March, 1St3, provision being made for the entrance of fifty-four beneficiaries and as many pay cadets, the latter paying $\$ 200$ a year, which corered all expenses. At first the academies were independent of each other. In attempt to unite both in Charles- 
ton, in 1St5, failed, and the arsenal was then made auxiliary to the Citadel, providing for the instruction of the entering class.

Thus organized, the academy was in full and successful operation from March, 1St3, to April, 1S65. 'These year's were marked by the lights and shadows of life, and the record of them is crowded with much of joy and of sorrow.

'The course of study resembled as near as possible that pursued at West Point, taking, in some departments even a wider range. "It may justly be claimed that the education there imparted was that of which the State has now the greatest need." The constant purpose of the Board of Tisitors was not to attempt too much, but to do thoroughly what was prescribed. The cadets were taught "how to think," not "what to think." Thus practical education was aimed at and attained. "The course of training was designed to develop the whole man by careful attention to the cultivation of all his powers, physical, mental and molal. From the moment of his matriculation until the time at which he left the academy, the cadet was ever under the eyes of vigilant officers. Thus he was shielded from many of the temptations and allurements of vice which so often beset and mislead the youth when first freed from the restraint. of parental discipline and deprived of the watchful guidance of parental love. But while the authority thus exereised was absolute, it was not arbitrary, and though the diseipline was firm, it was not harsh.

The result of this training is best shown in the career of the graduates. In all associations, whether in the learned professions or in the more active pursuits of life, they have not only done honor to the institution, but have vindicated the wisdom of the statesmen who founded and maintained it, by winning the high prizes always awarded to those possessing what Gov. Richardson styled "the energy and decision of a military character."

During the first period of the academy nearly eighteen hundred roung men of the State were educated partly or wholly within its walls. Though but two hundred and forty passed entirely through the preseribed course of study, the large numbers should not be forgotten who remained long enough in the institution to feel the wholesome effects of its training.

ITS MILTARY RECORD IS BRILLIANT.

Of the 226 graduates living at tine beginning of the war, more than two hundred were officers in the Confederate Army, filling every grade firom lientenant to brigadier-general, and discharging their duties with a zeal intelligence and courage that made them distinguished even in that great army of Southern soldiers. 
Their first military service was performed in drilling the Palmetto Regiment previous to its departure for Mexico. From an unfinished earthwork on the 9th of January, 1S61, a detachment of carlets fired the first shotted gun of the war upon the Star of the West, as she was advancing to the relief of Fort Sumter.

The service of the cadets in many fields from the heginning to tine end of the war are too well known and too higlily eherished to need repetition here.

Upon the evacuation of Charleston the Citadel was seized by Federal forces, and was occupied as a garrison until 1578. On the 13th September, 1S77, the survivors of the graduates met in Cliarleston and organized with Gen. Johnson Hagood as President, and other officers. Immediately thereafter a general meeting was held of all who had been connected with the institution, and steps were taken to secure the reopening of the citadel.

The Federal government claimed the Citadel as conquered property. The State maintained that it was private property, and through Gor. Hampton made application for its restitution. President Hayes declined to act, but suggested an appeal to Congress. A bill was introduced in the Senate of the United States to restore the Citadel to the State on condition that a claim of $\$ 100,000$ for rent and clamages by fire be relinquished. The State refused these terms, and the bill was not passed; but the building was turned over to the State voluntarily, and was taken possession of on 1st April, 1852.

- In 1S81, the legislature passed an Act authorizing the reopening of the academy for the erlucation of $6 S$ beneficiary cadets (two from each county) and as many pay cadets as could be accommodater without expense to the State. Ten thousand $(\$ 10,000)$ dollars were appropriated for the repairs of the building, and five thousand for the expenses of the current year, with the provision that these amounts should be refunded out of the amount which may be received by the State from the general government for rent.

By direction of Gov. Hagood, Senator G. B. Lartigue, of Barnwell, assumed control of the work of reopening, and had the building put in excellent condition. Bathing arrangements, ventilation, and general sanitary measures have been secured under his supervision.

The library will be filled as rapidly as possible, and a reading room is provided with newspapers and magazines for the use of cadets when not on duty. An annual encampment will be held in August and September in different portions of the up-country, for military exercises and practical instruction in surveying, engineering, mineralogy, geology and other subjects. Military discipline will be used as a means to an end- 
the aim being not so much to make soldiers as to make men equal at once to civil and military results.

The Board of Tisitors consists at present of Gex. Johnson Hagioor, Chairman, Barnwell C. H., S. C.; Rev. S. B. Joxes, D. D., Pendleton, S. C.; Col. Edward Croft, Greenville, S. C.: Col. H. A. Galluard, Wimnsboro', S. C. ; Gen. C. I. Walker, Charleston, S. C.; 'The Governor of the State of South Carolina, ex-officio, Columbia, S. C.; The Adjutant and Ixspector-Geveral of the State of South Carolina, ex-officio, Columbia, S. C.

The academy opened on the $2 d$ October, 1882 , with 180 cadets, a number of applications having been dechined for want of accommodations.

The officers and professors are as follows: Col. J. P. Thomas, Superintendent and Professor; Capt. Wy. Cain, Professor; A. Sachtleben, Professor pro tem; Finst Lieut. P. P. Mizyck, Assistant l'rofessor ; First Lieut. H. T. Thompson, Assistant Professor; Dr. F. L. Parker, Surgeon ; Wa. W. White, Bursar.

'ine following is the course of study prescribed at present:

FOURTH CLASS.

First Term. Algebra, Physical Geography, English Grammar and Word Analysis, French, Reading of British Classics.

Second Term. Algebra and Geometry; Elements of Zoology; Anatomy and Physiology ; History of England; French ; Reading of American Classics; Free Hand Drawing; Declamation and Composition, for the Session.

\section{TIIIRD CLASS.}

First Torm. Geometry Completed; Plane Trigonometry ; Spherical Trigonometry completed; Physics; Rhetoric and Study of Synonyms: French; Industrial Drawing; Reading and Analysis of Shakspeare.

Second Tcrm. Surveying-Field Work with Instrument; Descriptive Geometry, Shades, Shadows and Perspective; Physics (continued); Outlines of General History, and Lectures on Philosophy of History; Elements of Mythology; French; Reading and Analysis of Shakspeare; Topographical Drawing; Declamation and Composition for the Session.

\section{SECOND CLASS.}

First Term. Analytical Geometry; Civil Engineering-Descriptive Chemistry-Inorganic; British Literature and Lectures; French Completed; Creman; Projection Drawing; Shaw's Companion Reader, British. 
Sccond Term. Calculus, with Philosophy of Mathematics; Elements of Quaternions; Military Engineering-Descriptive; Chemistry-Organic; Chemistry-Agricultural; United States Literature by Lectures; Mental Philosophy; German; Mechanical and Agricultural Drawing; Elocution and Composition for Session, and Infantry Tactics; Shaw's Companion Reader-American.

\section{FIRST CLASS.}

First Term. Civil Engineering-Stresses in Bridges and Stability of Structures in general; Mechanics; Mineralogy ; Moral Philosoplıy, and Lectures on Ethics; Elements of Logic; German.

Sccond Term. Civil Engineering-Strength of Materials, Retaining Walls, de., and Lectures on Hydraulic and Sanitary Engincering; Astronomy ; Geology ; Science of Wealth, and Lectures; Elements of Constitutional Law, and Lectures; German; Book-keeping; Elocution and Composition for Session, and Artillery Tactics.

During the Military Session, there will be such practical and military (special) instruction as the Board may hereafter prescribe. It is contemplated, further, to give to cadets the advantages of a military system of Gymnastic Exelcises, and a system of Swimming.

\section{KING'S MOUNTAIN MILITARY SCHOOL.}

In 1855, Micah Jenkins and Asbury Coward, who had just graduated with distinction in the State Military Academy, formed a military school at Yorkville. A three story building of brick, with additions for oflicers' houses, was erected, and the session opened with bright promises. As a preparatory school to the Citadel, and an institution for military training it enjoyed great success. At the sound of the tocsin of war the principals entered the army, and served with distinction. The gallant Jenkins fell at the head of his troops in the heat of battle. After the surreider, Col. Coward assumed sole control, and has conducted a school in which the training, intellectual and physical, is of a high orter. In 1852, Col. Coward was elected, without solicitation, State Superintendent of Education. Gen. E. M. Law is now associate principal. Prof. Mnn. Currell is instructor in Aneient Languages and Beiles Lettres, and Licut. John M. Jenkins instructor in Arithmetic and Book-keeping.

There are five classes, the highest of which is required to study Descriptive Geometry, Shades, Shadows and Perspective, Astronomy, Evi- 
dences of Christianity, Whateley's Rhetoric, Steedman's English Composition, Elocution, Drawing.

A full classical course is optional.

This school deserves special mention as the only strictly military school that was established before the war, and is still in successful operation.

GREENVILLE MLITARY ACADEMY.

Another military academy is in successful operation in Greenville, in charge of Capt. J. B. Patrick, formerly an officer and instructor in the South Carolina Military Academy. Capt. Patrick has three assistants and the attendance, according to the report for 1S51, was over fifty. Though comparatively a new institution, it is in a prosperous condition. There are several other academies in the State, in which certain military features exist.

\section{FEMALE EDUCATION.}

The census of 1850 shows that fifty-nine per cent. of illiterate adult whites in South Carolina are females. It is true, also, that the females have a preponderance in the total population; but the excess of population is not in proportion to the excess of illiteracy. This is startling to those especially who believe that intellectual progress depends upon the education of woman. Some consolation may be derived from the fact that South Carolina is no worse off in this respect than her sister States, and that the excess of female illiteracy in this State is decreasing. In 1550 , females constituted sixty-two per cent. of the adult illiterate population of South ('arolina; in 1S60, sixty per cent.; in 1S70, fiftynine per cent.; and in 1S80, fifty-nine per cent. In 1870 and in 1SS0, females constituted fifty-one per cent. of the entire population.

Turning to the census of 1570 , we find that there are more illiterate females than males in all save three States of the Union, California, Nevada and Termont. In these, females show the following proportion: California, in population, 40 per cent., in illiteracy, 44 per cent.; Nevada, in population, 24 per cent., in illiteracy, 20 per cent.; Yermont, in population, 49 per cent., in illiteracy, 48 per cent. In only two States, Nerada and Termont, can fomales claim educational superiority over males.

South Carolina compares favorably with the other States. The percentage of females as to population and illiteracy is respectively as fol- 
lows: Alabama, 51 and 65; Georgia, 51 and 65; Indiana, 47 and 61 ; Kentucky, 49 and 59 ; Massachusetts, 51 and 63 ; New Jersey, 50 and 60 ; New York, 50 and 61; North Carolina, 52 and 65; Pennsylvania, 50 and 65; Rhode Island, 51 and 62; Soutri CAroursa, 51 and 59 ; Tirginia, 51 and 59 .

From the above it will be seen that South Carolina is loing relatively more for her daughters than many of her neighbors. Her people hare long patronized female academies at lome and abroad.

Before the war the schools at Limestone, Barhamville and Orangeburg especially enjoyed high repute; while female colleges in Laurens, Yorkville, Sumter and other places, aided in forming the character and training the minds of hundreds of the women of the State. Female academies and schools also existed, some of which are still in operation, and are noticed elsewhere. The fact, however, remains that the daughters of the State have not as yet received as many advantages as her sons, yet it is hoped that, at no distant day, education will be more nearly propontioned, if indeed the balance do not turu in the opposite direction, under a new order of things, which sends boys into the business walks of life, while girls are kept for a longer period at their studies.

In this connection it is proper to mention the female colleges now in operation in the State.

GREENYILLE FEMAIAE COLLEGE.

"In 1853, the Baptist State Convention of South Carolina appointed-a committee to take into consideration the subject of female education as a denominational interest. At the ensuing meeting of the Convention, held in Greenville in 1854, the committee reported, urging the establishing of ' a Female College of high order,' and, to secure a liberal education for young ladies, recommended that 'the standard of attainment be high." 'The report was adopted, and the enterplise was begun. Greenville was chosen as the location, having been long famed as an intellectual centre, and remarkable for its health and social and religious advantages. A handsome building was erected, and under such educators as Professors Duncan, Sams and Judson, the college entered upon and maintained a highly successful career.

In 1878, Prof. C. H. Judson resigned the presidency, to accept an equally honorable and responsible position in Furman University, and Prof. A. S. Townes, the present incumbent, was chosen to succeed him.

The catalogue of 1851-2 shows a lax rer attendance than at any previous stage of the college's history. The number of pupils in the primary department was 29: in the academic department, 62; students in the collegiate department, S0; irregular students, 9. Total, 180. 
The present accommodations are too small, and handsome additions are expected soon to be in course of crection.

COURSE OF STUDY.

Primary Department. The usual elementary studies, with features of the Kindergarten system.

Academic Department. Studies pursued in grammar schools, particular attention being paid to composition.

Collegiate Deprentment. This department is dividerl into seven schools. Completion of the entire course entitles the student to full graduation, but partial courses are allowed, and diplomas given in each school. The schools are as follows: I English; II. Latin; III. French; IV. Mathematics; T. Physical Science; VI. Mental and Moral Scicnce; TII. History. Extra courses in Greek and German are provided, besides a Post Graduate course, entitling the graduate to the degree of Mistress of Arts. Special attention is paid to Calistrienics, a daily drill being laad during the entire term. The music department is in charge of Prof. M. G. DeCamps, of the Conservatoire of Music of Brussels. Drawing and painting are taught by the lady principal, Miss M. C. Judson. Lessons are also given in ornamental and fancy work.

SOCIETIES, \&C.

The Judson Literary Society meets twice a month, and publishes a monthly periodical, "The College Mirror." The Lula Whilden Missionary Society and a Girls' Temperance Union are in successful operation.

\section{FACULTY.}

A. S. Townes, President, English, Mathematics, Latin, Mental and Moral Science; Miss Mary C. Judsox, Logic, Physical Science, Elocution and Calisthenics; Miss CARoline E. DAwson, French, Mathematics and History; Mrss Ansa M. Gaines, Composition, Latin and English; Prof. J. M. Perry, Writing and Book-keeping; Miss F. G. Bins, Principal of Academic Department; M. G. DeCAsrs, Principal Music Department; Mrs. M. E. DeCanps, Pianoforte; Miss M. C. Judd, Drawing and Painting; Mrss Ida Roberts, Ornamental and Fancy Work; Miss F. G. Birb, Governess; Mrs. J. A. Fitzgerald, Matron.

The term begins in September, and is divided into two terms of twenty weeks each. Terms for twenty weeks, including board, $\$ 57.50$ to $\$ 121.50$; graduation fee, $\$ 5$. 
THE COLUMBIA FEMALE COLLEGE (METHOHIST).

During the prosperous period of the State, between the years 18.00 and 1860 , it was determined by the Methodists of South Carolina to estalılish a first-olass college for their daughters, as they had already secured IT offord for their sons. Liberal subscriptions were made. A lot was secured in Columbia, and a handsome building of brick was erecter, in which exercises were opened during the fall of 15.59. For several years its success was most marked, and its career of usefulness continued until the occupation of the eity by Federal troops, February 17th, 186.5. Owing to the gineral distress which paralyzed intellectual effort, the college was closed, and the building rented as a hotel. By 1973, the effects of the war had partially passel away, and the college was reopened. It has been continually growing since then, and now stands high in attendance and in excellence. Its several presidents have been: Rev. Whitefoord Smith, D. D., Rev. Wm. Martin, Rev. H. M. Mood, Rev. Samuel B. Jones, D. D., J. L. Jones, Esq., and Rev. O. A. Darby, D. D.

The property is owned by the South Carolina Conference, and is controlled by a Board of Trustees appointed by Conference. The attendance is not confined to children of Methodist parents, but all denominations are welcomed. For the year 1SS1-S2, there were SS students in the collegiate department, and 39 preparatory pupils; 45 pupils were taught in music.

\section{FACULTY.}

The faculty consists of Rev. O. A. DARbr, D. D., President, Mental and Moral Science; LAwsor B. HArres, A. M., Mathematies and Natural Science; E. Ton Fingertin, M. A., Ph. L., Modern Languages ; Miss M. E. Bohx, English Literature, Physiology and Botany; Miss A. R. HoLLingsworth, Latin and French; Miss A. H. WARrex, English, History and Elocution; Erisst Brockunas, Instrumental Music; Miss C. J. Laval, Vocal Musie; Miss A. G. Lyxch, Guitar; Miss M. E. Bohs, Painting, Drawing and Calisthenics; Miss Marr B. Wiltberger, Ornamental Work; Miss SAllie F. Reyrolds, Principal of Preparatory Department; Mrs. Kite Darby, Governess; Mrs. Kate Buel, in charge of Domestic Department.

\section{COURSE OF STUDY.}

The Prepiritory Departinext embraces a course of six years, and is divided into a primary and grammar school.

The Comlegiate Departanent is composed of distinct sehools, each constituting a complete course for the subject taught. Of these there are 
thirteen, viz: English Language and Literature; Mathematics; Natural Science; History; Mental and Moral Science; Latin Language and Literature; Greek; French; German; Italian; Commercial School ; School of Art; School of Music.

Three degrees are conferred: Mistress of English Literature; Mistress of Science; and Mistress of Arts.

The session begins in the middle of September. Tuition, including board, lights and fuel, about $\$ 200$ per year, with extra charges for music, \&e.

The students enjoy the benefit of a library, reading room and public lectures. They have two library societies, a missionary society, and a temperance society. Written and oral examinations are required.

The government is firm, but mild.

the dUE west fenale College (associate Reformed preserterian).

This college is located at Due West. Established in 1860, by a company of eitizens, it has been in successful operation erer since. Its first president was the Rev. J. I. Bonner, D. D., who served in this capacity until his death, in the year 18S2. The college has its own buildings, constructed substantially of brick, and supplied with all the modern improrements. Exhibitions are held in the public hall of Erskine College, but the two institutions have no further connection. The grounds cover seren acres, and are laid out in walks and flower beds, affording opportunities for exercise on the part of the pupils. The college has no endowment. It enjoys patronage from a number of States. By the catalogue of 1851, attendance in the collegiate department was 52; in the academic department, 16 ; in the preparatory department, 60. During the present year the attendance has nearly been doubled.

\section{COURSE OF STUDY.}

The course of study is thorough, comprising a Primary Department, an Academic Department, and four Collegiate classes. Especial attention is paid to musie. One hour weekly is devoted to sewing, and the Art Department is conducted in the most thorough manner.

TERMS :

Tuition, per term of three months, Primary, $\$ 5$; Academic, $\$ 7$; Collegiate, $\$ 14$. Extras from $\$ S$ to $\$ 15$ per term each. No charge for Latin or vocal music. Board, including everything, $\$ 3$ per week. 


\section{FACULTY.}

J. P. Kexpeny, A. M., President; Mrs. K. P. Kexpedr, and Mrs. L. M. Bonnel, Vice-Principals; Miss E. McQuerse, Miss J. T. LeGal, Miss S. L. Miluer, Miss A. E. Perty, Miss L. J. Galloway.

Miss E. L. Pressley, Principal Academic Department. Miss M. E. Hoon, Assistant.

The Boarding Department is under the supervision of Mrs. Kennedy and Mrs. Bonner, assisted by Miss Sanders. The students wear a uniform. The term begins on the first Monday in October, and closes in June.

\section{THE WALHALLA FEMALE COLLEGE}

was chartered 4th March, 1872, under the auspices of Dr. Thomas S. Wraring, then its President, and the act of incorporation named sixteen prominent citizens of the town as trustees. It is undenominational. During the first five years after its charter the college was not a success, having no endowment and no suitable buildings in which to conduct it. At the end of this period, Rev. J. P. Smeltzer, D. D., having determined not to remove with Newberry College, was elected President of the Walhalla Female College, and thereupon, with his own means, erected commodious buildings and established a college worthy of his reputation as an educator, which, with the assistance of a competent corps of teachers, he has successfully carried on to the present time.

During the session 1S81-82, the enrolled students, including nineteen in the jurenile department, numbered eighty-seven.

\section{THE COURSE OF STUDY}

is arranged for six classes, three sub-collegiate, and three collegiate, junior, intermediate, and senior. A post-graduate course of study is provided, including Greek, Analytical Trigonometry, and Calculus, English Literature, Mental Philosophy, Geology, and instruction in practical duties of life.

Music and other ornamental branches are optional.

Terus :-Board and washing, $\$ 11.50$ per month; tuition from serentyfive cents to $\$ t$ per month; music, $\$ 3$. Reduction is allowed to ministers' daughters.

\section{FACULTY.}

Rev. J. P. Smeltzer, D. D , President; Miss S. J. Frierson. Latin, English Language and Literature; Miss Lizzie McAxraliy, Music, Piano, Guitar, and Drawing; Miss Lizzie IV. Crapuas, Preparatory Department and Fancy Work; Miss H. J. LeGare, French, Ornamental 
Branches, and Painting; Mrss A. A. Schroder, Wax Works; Miss S. Katie Syeltzer, Organist; Mrs. A. E. Sineltzer, Matron.

\section{WILLIAMSTON FEMALE COLLEGE.}

At the beginning of the year 1S72, Rer. S. Lander, of the Methodist Episcopal Church South, with the co-operation of the citizens of Williamston, in Anderson County, determined to open "a school of high grade for the education of girls." A building formerly used as the Williamston Springs hotel was rented, and on the 12th February, 1872, the school was opened, with forty pupils. So great was its promise that during the fall season a joint stock company was formed, which purchased the building, and organized a permanent institution. In December, 1872 , it was proposed to place the college under control of Conference, but as the Methodist Female College was about to be re-opened, in Columbia, the company deemed it best to preserve this as a non-sectarian institution. A rote of nine-tenths of the stock is now required to place it under the control of any denomination.

Increasing patronage caused the erection of additional accommodations in 1873,1874 and 1875 . The standard has been also raised from time to time, with beneficial results. Attendance has been steadily increasing, the catalogue of 1882 showing a list of 138 students.

\section{PECULIAR FEATURES.}

Several new features have been introduced into the management and curriculum of this college, for which the President claims the sanction, not only of theory, but of practical success. These "imnorations" deserve special mention.

\section{SEMI-ANNUAL SESSIONS.}

The year is divided into two sessions of twenty weeks, each sub-divided into four sections of five weeks, and followed by a racation of six weeks.

New classes are organized each session, instead of only once a rear. This ensures better classification, and allows each pupil to find her level.

\section{TUITIONAL PREMIUMS.}

Instead of offering "prizes" for excellence, the college makes deductions from the regular tuition fees as follows: for an average of from 80 to 85 per cent., a discount of ten per cent.; for an arerage of from Sõ to 
90 , twenty per cent.; from 99 to 94 , thirty per cent.; 94 to 97 , forty per eent.; 97 to 100 , fifty per cent. An additional discount of ten per cent. is offered for an arerage of 95 in spelling. Thus any student may reduce tuition fees from $\$ 20$ down to $\$ S$ per session. Up to June, 18s2, these premiums aggregated $\$ 1,897.25$.

\section{" ONE STUDY PLAN."}

This name is not exactly appropriate, as it eonveys an erroneous idea. The plan is thus described. In most institutions a curriculum is preseribed of several studies in parallel courses, each receiving equal attention during the entire session. In this college there are four departments. 1st, Nathematics; 2d, Natural Science; 3d, Latin ; 4th, Belles Lettres. During the first five weeks, special attention is paid to Mathematies, with Arithmetic as a review study; during the second, the entire school studies Natural Science, with Geography as a review study; during its third, Latin is studied, with a review in English Grammar; and during the fourth, attention is paid to Belles Lettres, with a review in History. A pupil, for instance, in the fourth class, during the first section, has every day three lessons in Geometry, one in Arithmetic, and one in spelling; during the seeond section, three recitations in Science, one in Geography and one in Spelling. During the third section, three daily recitations in Cæsar, one in English Grammar, and one in Spelling, and during the fourth, three recitations in Logic, one in History, and one in Spelling.

Exercises in Reading, Composition, Penmanship, and Tocal Music obviate all danger from monotony.

The adrantages elaimed, are: 1st. Undivided attention to the special subject. 2d. Attention in recitation, the temptation to review stealthily in the class some other study, being remorect. $3 d$. Retention of what is learned ; each lesson forming the introduction to the next. 4th. Enthusiasm arising from rapid progress. 5th. Habits of eoneentration. 6th. Symmetrical development, by preventing the study of a "farorite " branch to the exclusion of others. Tth. Ease of classification, each study being independent. Sth. It is liked by the pupils. 9th. It admits of

\section{GRADUATION EIGIIT TIMES A YEAR.}

That is, a student may graduate at the end of any section of five weeks, as soon as she shall have completed the round of studies.

Another feature is privute graduation. No exhibitions are held, but students are subjected to strict examinations. Completion of the currieulum entitles the student to the degree of Artium Liberalium Baccalaurea. 


\section{FACULTY.}

Rev. Sinuel Lander, 1. M., D. D). ; John (r. Chinkecales, A. B. ; Ret. Jxo. M. Lander, A. B. ; War. T. Lander, A. B.; Mrs. M. L. P'rixcl, Miss Franciade Wagner; Mrs. Margaret J. Langdon; Miś A LGesta M. Hagex; Miss Ada E. Lixeback; Miss Laura MeP. Lander.

Teriss: For trenty weeks, from \$71 to \$136. See catalogue.

COOPER LIMESTONE FEMALE INSTITLTE.

As far back as 1935 , a number of gentlemen, attracted by the fame of the Limestone Springs, in Spartanburg district, resolved to make a famous watering place there, and for that purpose erected a hotel, four stcries in height, with eapacity for accommodating between two hundred and fifty and three hundred boarders.

The want of convenient transportation to and from the Springs defeated the object of the projectors of the enterprise, so that shortly after the attempt. was abandoned, and the proprerty was sold to the State.

In 1846, the Rev. Dr. Thomas Curtis, and his son, William Curtis, of England, purchased the property, and founded a female college. Their administrations are a part of the history of the State. The thorough instruction, the refined home influence, the salubrious climate, offered to pupils, attracted large numbers, and Limestone Springs became almost as fimous as Dr. Warldell's school, at Willington, in former years. The institution continued until the close of the war.

After this, the property changal hands several times. It length it was purchased by the philanthropist, Peter Cooper, of New York, whose intention it was to establish a technical school for women. He subsequently made a donation of the property to the "SinftaxiuRi BAPTist A.sociation," for school purposes.

The present principals, Messrs. H. P. Griffith and R. O. Sams, were elected by the Association, and in October, 1SS1, the exereises of the Institute were regularly begun. About fifty pupils attended during the first year, and the numbers are increasing. The future of the Instiute is full of promise.

Locariox. Limestone is situater in the Piedmont country of South Carolina, one mile from the Air Line Railroad. Its post office is Gaffney City, a flourishing town. The building contains abont one hundred comfortable rooms, and the grounds extend over six acres of blue grass, shaded by elms and oaks. A mineral spring, pouring out sixty gallons a minute, is just outside the enclosmre. 


\section{FACULTY.}

II. P. Grifritir, Ancient Languages, English Literature, Moral Science, History, Rhetoric; R. O. SAys, Mathematics, French, Physical Sciences; Miss E. C. Black, Preparatory Department; Miss H. W. Gale, - Instrumental and Vocal Music, Calisthenics; Miss C. M. Croft, Instrumental Music, Penmanship; Mrss E. C. Besck, Drawing and Painting; Miss M. C. Budn, Matron.

Terus: Board for 20 weeks, $\$ 62.50$; Tuition, Preparatory, $\$ 10$; Academic, $\$ 15$; Collegiate, $\$ 25$. Music, Drawing, dc., extra. Season begins September 28 th.

\section{ANDERSON FEMALE SEMINARY.}

This Seminary was established by the Rev. L. M. Ayer, in 1879. Since that time he has completed the building of a large and elegant boarding house, and an academy building of six commodious school rooms. The school is supplied with furniture and apparatus of the most approved kind.

The school is entirely non-sectarian in character, but a healthy, refined home influence is exercised over all the pupils. The success of the Seminary has been most gratifying. During the session of 1S\$1-\$2, the attendance exceeded a hundred; and the number of pupils will be larger during the present year. The Seminary is situated in the thriving town of Anderson.

\section{FACULTY.}

Rev. Lewis M. A yer, English, Oriental and Classical Literature, Moral and Intellectual Science, and Greek; Mrs. L. M. AYer, Music, Instrumental and Vocal; Miss Safiah Atkixsor, Assistant Instructor of Music; Mrss Bessie F. Bagbr, Latin, Mathematies, Physies, and French, and Calisthenies; Miss Sarair Atrinson, German, French, Mathematics, and Latin; Miss Susar Wrilson, Drawing, Painting, and Intermediate English; Mrs. M. C. Van Wryck, Principal Primary Department; Mrss Maggre G. Simpson, Assistant in Primary Department; Mrs. L. M. Ayer, Matron; Mrss Mary Rowan, Housekceper.

Terms: For twenty weeks, board, \&e., $\$ 70$; Tuition, $\$ 10$ to $\$ 25$; Music, Designing, and Painting, extra.

The pupils enjoy the use of a well selected library of about one thousand volumes. 


\section{X-EDUCATION OF THE COLORED PEOPLE.}

Slavery was introduced into South Carolina almost contemporaneously with the settlement of the colony; by the early part of the eighteenth century the blacks were already the preponderating element of population. These slaves, imported from the coast of Africa, were untutored, unclad savages. The first task of their masters was to civilize them and teach them the English language; and the early labors of the missionaries were largely directed to that end. The first missionary sent to Carolina, the Rev. Samuel Thomas, made a report, in 1705 , to the Society for the Propagation of the Gospel, stating, among other things, that in the parish of Goose Creek, twenty negro slaves came regularly to ehurch, while several others were able to speak and read the English language. He added, that among the thousand negro slaves in the provinee, many of them were well disposed towards Christianity, and were willing to prepare themselves to embrace it by learning to read, the time consumed in which they redeemed from their masters by extra labor.

In the proceedings for 1752 , of the Society for the Propagation of the Gospel, it was stated, "that a flourishing negro school was taught in Charleston by a negro of the society, under the inspection and direction of the worthy rector, Garden, by which means many poor negroes were taught to believe in God, and in his Son, Jesus Christ."

This religious and literary training went on a long time, until the idea began to prevail that knowledge should be reserved for free men, and. could not, with safety, be imparted to slaves. Several insurrections gave strength to this view, and despite the earnest protests of many of the leading men of the State, laws were passed, providing penalties for the teaching of slaves to read and to write. Notwithstanding this prohibition, a number of servants managed to acquire some elementary knowledge, either through their own efforts, or aided by indulgent master's and mistresses, or, more often, by younger children of the family. The daily association of favored servants with their eultured superiors was, in itself, an education of no mean order. Even when literary instruction was denied, religious training was zealously imparted. Scarecly a household was there in the confines of the State in which colored children, and sometimes their parents, were not assembled for either morning or evening prayer, or for catechism and religious services on the Sabbath. In every church was a place set apart for the blacks; they were admitted into church membership, and partook of all the sacraments. On larger plantations chapels of worship were established, in which elergymen of distinguished merit regularly officiated. Preachers of their own color were 
also permitted to minister to their spiritual wants. Catechisms for the special use of the blacks were carefully prepared by such able dirines as Dr. Winkler, of Charleston; Dr. Jones, of (reorgia; and Bishop Capers. It the solicitation of Bishop Capers, two missionaries were sent, in 1825, by Conference to labor on the plantations. In 1855, there were twenty-six Methorlist missionary stations in South Carolina, thirty-two mis-ionarics, 11,546 members, and a revenue of $\$ 25,000$.

The reports of the Presbyterian Synod of South Carolina, for 1559 . aive the colored membership as follows: South Carolina Presbytery, S61 : Bethel, 6ss: Harmony, 1,823; Charleston, 1,637. Total 5,009-five thirteenths of the entire membership. This constituted, of course, but a small jroportion of those who receired religious instruction.

From the parochial reports of the Protestant Episcopal Church, for the year 1860 , the following statistics are taken:

Baptisms, whites, 491 ; colored, 1,156; marriages, whites, 105 ; colored, 209 ; communicants, whites, 3,160 ; colored, 2,960 ; confirmed, whites. 215 ; colored, 173 ; Sunday school scholars, white, 1,563, and colored, 604.

Of fifty-six reports made by rectors, but one contained no mention of services among the colored people; fifty-five rectors report baptisms, burials, and marriages, or at least one of these services for the colored people: twenty report colored communicants in excess of whites; twentyfive report Sunday schools, and twenty-two mention chapels for the use of the blacks. Almost every churcli for whites contained galleries or special seats for colored. Besides this, seren ministers were employed specially as missionaries for the slaves.

Other denominations did equally efficient work, though exact statistics cannot be secured. All these nembers receired more or less instruction, and their mental, as well as material condition, compared favorably with the lower classes in many countries of Europe, at least. The statistics of illiteracy of the colored race in South Carolina, previous to emancipation, are incorrect, since, in those days, an acknowledgment on the part of a slave of an ability to read might have proven, at least, inconvenient. It may be added here that these statistics are not proper criteria by which to judge the standard of culture. The ability to write one's name, or to trace illegible characters representing misspelled words, can be acquired in a few months, at most, and is sufficient to remove from one the stigma of illiteracy. Let, in manners, in morals, in integrity, and even in oral expression, he may be greatly inferior to another, who has learned much of these, and has been forbidden only to write and read. A striking proof of this is afforded by the many instances, just after the war, in which newly enfranchised citizens, though classed as illiterate, made most effective speakers and skillful parliamentarians. 
Very many slaves were apprenticed to the useful trades, and formed a vast proportion of the mechanies and artizans before the war. Amo-t every planter of large means had his own carpenters, masons and blacksmiths. Cabinet-makers, butchers, tailors, porters, hotel waiters, sempstresses and laundresses, and pastry cooks, trained nurses and midwives were taken to a great extent from the colored population. Many of thesc were suffered to hire their own time, and thus accumulate sums of moner. $\Lambda$ few persons of color tiemselves owned slaves. The fireman on the first train that ran from Charleston to Augusta is said to have been a colored man, and his was the longest trip recorded up to that time. From the ranks of the barbers and hotel waiters, who had listened to the conversations of statesmen and public men, were recruited most of the legislator:s and congressmen of the era of reconstruction.

\section{EMANCTPATION WAS FOLLOWED}

by attempts to instruct the freedmen. The efforts of the State were aided by philanthropists from abroad, who founded schools and churches in different portions of the State. The public schools attracted continually increasing numbers, as follows: * In $1870,1,800$; in $1871,33,384$; in 1882. 38,635; in 1873, 46,938; in 1874, 56,249; in $1875,63,415$; in 1876 . 70,802 ; in $1877,55,952$; in $1878,62,121$; in $1879,64,095$; in 1850 , 72 ,853 ; in 1881, 72,119. (It is believed that the report for 1876 is incorrect, as the saliaries of school commissioners depended on the attendance, and there was no fixed rule for estimating the latter.)

ClAFLIN UNIVERSITY, ORANGEBURG, S. C.

Histony. In 1869, the Orangeburg Female College was purchased by friends in the North, prominent among whom was the late Lee Claflin, of Massachusetts, and opened as a school for colored youth. A U'niversity charter was obtained from the succeeding Legislature, perpetuating the name of the most liberal donor.

In 1872, the Act of Congress, appropriating certain lands for maintaining Agricultural Colleges and Mechanical Institutes, was accepted by the Legislature, and an Agricultural College was made a co-ordinate branch of Claflin University.

When the State University was reorganized at Columbia, in 1877 , the Agricultural College was made a branch of that University, but still contimned at Orangeburg, and remains in successful operation under that unions.

*For the inteile ctual progress of the colored people, see the section on Illiteracy. 
Indestrial Departaent. The farm of one hundred and fifty acres of choice lanel, and a carpenter shop connected with the institution, afford an opportunity for manual labor, by which sturents can defray, in part, the expenses of their education.

1st. Literary Departinent. College course of four years, both Classical and Scientific.

The course of study covers about the same range in higher English, Mathematics, Natural Sciences, Ancient and Modem Languages, History, Mental and Moral Science, as is usual in the better class of colleges, North and South.

2D. Normal School Course. The object held in view in this school is the preparation of teachers for the common schools.

The course of study covers a period of three years beyond the ordinary common school studies, and embraces History, Rhetoric, English Composition and Criticism, Higher Arithmetic, Algebra and Plane Geometry, Physiology, Natural Philosophy, and Chemistry.

3D. Grammar Schoor. The object of this school is to prepare students for the higher departments, and will be a necessity till the common schools of the county shall do a higher grade of work.

The course of study covers two years, and does the work of the better class of common schools.

ATTENDANCE THE PAST YEAR.

In College Classes . . . . . . . . . . . . . 24

In Normal and College Preparatory . . . . . . . . . . . . 136

In Grammar School . . . . . . . . . . . . . . . . 184

Total

.344

GRADUATED IN JUNE, 1952.

On College Course . . . . . . . . . . . . . . . . . 2

On Normal School Course. . . . . . . . . . . . . 10

Total .................... . . . . .

A valuable apparatus for the Natural Sciences and higher Nathematics adds to the facilities for instruction in these branches.

The library contains about two thousand volumes and a large collection of pamphlets. Many of the books are very valuable as books of reference.

Faculty: Rev. Edward Cooke, LL.D., President, Professor of Ethics and Lecturer on Agricultural Topies. Rev. W. H. Lawrence, A. M., Pro- 
fossor of Latin, Greek, and German Languages and Literature. William J. De'Treville, Jr., C. E., Professor of Pure and Applied Mathematics. Jas. A. Heyward, A. M., Professor of Natural Science. Miss Saraln G. Bagnall, Preceptress, Professur of Rhetoric, English Literature, and French. Julian A. Salley, Adjunct Professor of Mathematics. William L. Bulkley, A. B., 'Tutor in Classics. Rev. Alonzo G. Townsend, A. B., Master of (riammar School;

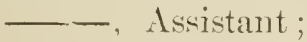

Secomrl

Assistant. Prof. II. H. Lawrence, Librarian.

ALLEN UNIVERSITY (AFRICAN METHODIST EPISCOPAL), COLUMBI, S. C.

Allen University, occupying commodious grounds in the suburbs of the city of Columbia, was organized in April, 1S81, under the control of the Columbia and South Carolina Annual Conferences of the African Methodist Episconal ('hurch, and is sustained by annual contributions from the churches which compose these Conferences. The property already secured aggregates in value about eight thousand dollars. It is in charge of colored educators. The aim of the institution is set forth in a circular written by Right Rev. Wm. F. Dickerson, D. D., of the A. M. E. Church, which concludes as follows:

"To aid in the derelopment of the highest type of Christian manhood, to prove the negro's ability, to inaugurate and manage a large interest, to govern, to control under normal impulses with only the help which is afforded institutions of like grade and similarly situated (for which we entreat our friends); to stimulate and encourage the worthy and aspiring: young womien of a race pressed to the rear by its previous condition; to train them not only for the pulpit, the bar, the sick room and school room, but for intellectual agriculturists, mechanies, and artizans, so that those who are now doing the manual labor in the South shall be fully equipped to perform the mental operations incident thereto as well. 'To educate, in the fullest sense of that comprehensive word, is the work, mission and cause for the establishment of ALLEN UNiversity"

Facurty: Rev. James C. Waters, D. D., President and Professor of Systematic Theology and Hebrew; Rt. Rev. W. M. Dickerson, D. D., President Board of Trustees, and Professor of Moral Philosophy and Church Government; Prof. Joseph Wr. Morris, A. M., LL. B., Mathematics and Ancient Languages, and Instructor in Law; D. A. Straker, LL. B., Dean of Law Department and Instructor in French; Miss B. B. Wolfe, Principal in Department of Music; Mrs. Hamnah A. Jones, Matron. 
Instructols: Rev. J. B. Smith, N. II. Eilwarls, J. D. Edwarde, Jno. II. Byrd, C. C. Dunlap, Mrs. E. A. Pindle. Mrs. II. E. Lee, Misses Sarah F. Perry, Ella Il. Clemens, Julia E. Perrin, and Emma Felder.

COURSE OF STLDY.

The University is divided into the Colleginte Departinent, the Theological Department, the Normal College Depreitment, and the Law Department. A Nedical Departmont will soon, it is hoped, he opened under Dr. George R. Henderson.

Tervs: Board, including fuel, de., $\$ 9.50$ per month. Tuition, 75 cents. Instrumental Music, $\$ 1.50$. Students preparing for the ministry pay no tuition. Tuition in Law Department, 850.

Firm but reasonable rules are adopted for the maintenance of discipline.

Attendance during the session of 1881,1882 , was in excess of three hundred, and the proprietors of the enterprise feel much encouraged.

\section{MISSIONARY AND OTHER SCHOOLS.}

Benedict Instrtute, located in the suburbs of Columbia, was established in 1571, by the American Baptist Home Missionary Society, for the education of ministers of the gospel and of teachers, male and female. It is maintained partly by tuition fees and partly by subseriptions from Northem Baptist ehurehes and individuals. The total receipts for the year ending Mareh 31st, 1S52, were \$7,596.S0; expenditures, \$11,705.24, the difference being contributed by the Society. The value of the property is $\$ 25,000$; endowment $\$ 20,000$. Students of both sexes are taught and boarded under careful regulations. The attendance for the year was more than two hundred. The course of study is Preparatory, Normal. Classical, or Theological. Rer. C. E. Becker, A. M., is Presilent, and he is assisted by Mrs. C. E. Beeker, J. K. Daris, Mr's. A. M. Wood, Miss S. E. Mead and Miss Mary Simms.

Brainerd Ixstitute, Chester, was founded in 157t, by the Northem Presbyterian Chureh, as a Normal school for the colored. It is in charge of Rev. Mr. Loomis and two assistants. It has a small library, and a chemical laboratory. Besides the Numnal dejartment there is a graded school, supported for ten months by state tax and by local taxation. Much good has been accomplished by it.

Fairfield Normal Ixstitute, Wixpsiono, founded in 1869 , by the Northern Presbyterian Church. The church owns a school house, a par- 
sonage, and several outbuildings for the accommodation of boarders. The Rer. I'illard Richardson lus for a number of years labored most acceptably as Principal, assisted by three white ladies. In 1850, of the pupils in attendance one hundred were preparing to teach, and twenty to enter the ministry. Pupils of the school have taken high stands in Howard University and other institutions of learning.

The Schofiemd School, in Aiken, has been supported for a number of years by funds from the North. It has handsome buildings, and is well fitted up. About one hundred thousand dollars, in all, have been expended in its sulport.

\section{PERIODICAL LITERATURE.}

According to Ramsay and others, "Newspapers were first published in South Carolina, in or about 1730, by Lewis Timothy." Prof. Rivers doubts this, as the Legislature, in 1731, passed an Act offering inducements "for the encouragement of a printer to settle here." Mr. King,in his sketch of the news]aper press of Charleston, shows that, in 1730, Mr. King offered to print, at his own charge, the laws of the Province, and argues from this that there was no newspaper in the colony. According to him, the first newspaper, "The South Carolina Gazette, appeared on Saturlay, January Sth, 1731-2," under the management of Thomas Whitmarsh. It was published weekly, at a cost of $£ 3$, and was a quarto, of eleven and a half by seven inches, containing two columns to the page. A copy of the first issue is or was in the Charleston Library. It contains the announcement of the passage of a charter for the establishment of the Colony of Georgia; while the number, bearing date January 20th, 1732, chronicles the arrival of James Oglethorpe and over a hundred colonists.

A press for printing pamphlets was established, by parties now unknown, in 1731. George Webb and Eleazer Phillips, Jr., came over about the same time, and the lattel is believed to have established a paper, called the South Carolina Ireekly. Jommal, but no number of it appears elsewhere than in the notice of the settlement of his estate.

The Gazette, which was the fifth newspaper in America, flomrished for a long time without a rival in Carolina. Whitmarsh died in 1733, of yellow fever, and was succeeded by Lewis Timothy. The Gazctte was conducted in turn by himself, his wife, his son, and other parties, undergoing several changes of name. Indeed, it appears that erery paper in 
the colnny was called a Gazette, with some distinguishing title in arldition. Thus there were The South C'aralina Gazette, The South C'arolina Gazette and Country Journal (1765), The Sonth C'arolina Gazette aned Amorican General Gazette, The Royal Giazette, The South Carolina Ciazette and Gieneral Advertisci, The Charleston Evening Gazctte, \&c. Some of these were different names of the same paper, but they appear to have been distinct from the original Gazctte.

The South Carolina Gazette lived until 1S37, when it was purchased by the Couricr, and continued by that paper as an auxiliary until 1840, when it was discontinued. As is known, the Courier became a part of the Nens and Courier, so that this metropolitan daily can claim an indirect descent from Thomas Whitmarsh.

It is umecessary to notice all the other newspapers that sprang into life and died between 1760 and 1855. A few will be mentioned, owing to their influence on affairs. The State Rights and Free Trade Evening Post was founded in 1S31, under the editorship of John A. Stuart. He sold it to Messrs. Norris \& Gitsinger, but it expired after the excitement of Nullification passed away.

The Inrestigator was founded in 1812 by John Mackey and John Lyde Wilson, and earnestly advocated the war against Great Britain. A mob attacked the paper in September of that year.

Ten years later Mr. Wilson became Grernor of the State. He had great literary attainments; translated into verse and published the episode of "Cupid and Psyche;" codified the laws of the State about 1827, and was the author of the celebrated "Code of Honor."

Governor David R. Williams was also at one time connected with journalism, having been proprietor of the Giaztte for sereral years.

The two leading newspapers of South Carolina up to the time of the war were the Courier and the Mcrcury.

\section{THE CHARLESTON COURIER}

was founded in 1S03, by Loring Andrews and S. S. Carpenter, and printed by A. S. Willington. For many years it was the organ of the opponents of Nullification and Secession. In 1S51, it adrocated co-operation as a choice of evils, and in 1860 reluctantly adrocated withdrawal from the Union, in view of the clection of a sectional President. The chief reputation of the Courier was as a business paper. In matters commercial it was an authority. The proprietor's showed much enterprise. Special couriers, during the Mexican war, outstripped the United States mails, and this undertaking was the precursor of press associations. Surviving the war, the Courier was purchased by the proprietors of the Daily Nexis, and became a part of the Nexws and Courier. 
was founded by Ednund Morford, in 1S22, and purchased by H. L. Pinckney, June 1st, 1823. It became the representative of the "Free Trade and States Right Party of South Carolina." Distinguished by the boldness and the eloquence of its utterances, the Bercury was largely instrumental in bringing about the war between the States. Its material was destroyed in the fire in Columbia in 1565, and, though publication was resumed shortly after, it suspended finally in 1868 .

Other papers in Charleston, Columbia, and different parts of the State, enjoyed greater or less prosperity. The attention of all was chiefly drawn to politics, and they lacked much of what is now considered essential to journalism The editorial department often overshadowed the rest, and they are to be regared more as leaders than as chroniclers of events.

The following is a partial list of the newspapers published at the beginning of the war:

Abbeville Banner, Abbeville Press, Spartanburg Spartan, and Express, Sumter Watchman, Union Times, Yorkville Enquirer, Barnwell Sentinel, Charleston Courier, Charleston 1Lereury, Charleston Eiening Yeus, Southern Christian Adrocate, U. S. Catholic Miscellany, Chester Stundard, Cheraw Gaztte, Clarendon Bamer, Darlington Southcrner, Edgefield Adcertiser, Fairfield Herald, and Register, Winyah Observer, Greenville Mountaincer, and Southern Enterprise, Camden Journal, Lancaster Ledger, Laurens Herald, Lexington Dispateh, Marion Star, Newberry Herald, Orangeburg Clarion, Keowee Courier, Pickens Sentinel, Columbia South Carolinian, Southern Guardian, Southern Baptist, and Southern Presbyterian.

There were also several literary periodicals. The Southern Presbyterion Review, founded in 1S47, which still exists, wielded great influence in the religious world. The Southern Quarterly Review, and Russell's Mayazine, with several literary papers, were the vehicle of thought of the highest order and eloquence not often surpassed.

The census gives the newspaper statistics for 1850,1860 and 1870 . Except as to the number of newspapers, the table is not trustworthy, for no means have ever yet been devised for securing a true report of circulation from all newspapers. 
The following table is an indication :

\begin{tabular}{|c|c|c|c|c|c|c|c|c|}
\hline & 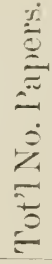 & $\stackrel{\vec{\Xi}}{0}$ & 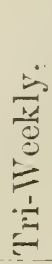 & $\begin{array}{l}\frac{7}{0} \\
= \\
=\end{array}$ & $\frac{\vec{\Xi}}{\stackrel{\Xi}{\Xi}}$ & $\begin{array}{l}\stackrel{\dot{n}}{0} \\
ٍ \\
\Xi\end{array}$ & & 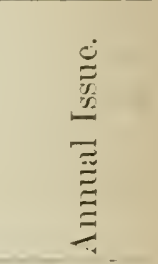 \\
\hline 1850 & 46 & 7 & 5 & 27 & 5 & 4 & $53,7+3$ & $7,145,930$ \\
\hline $1 S 60$ & 45 & 2 & 4 & $3 \tilde{j}$ & 4 & 7 & 53,870 & $3,(5.54,840$ \\
\hline 1870 & 5.5 & 5 & 4 & 42 & 8 & 9 & so,?00 & $8,901,400$ \\
\hline
\end{tabular}

It will be seen that the census of 1560 is utterly wrong. The details give only two daily newspapers, with a circulation of 1,600 against a circulation of 16,000 both in 1850 and 1870 .

Estimating the total issue at $8,000,000$ in 1860 , we find an arerage of eleven issues per year for each inhabitant, against an average of over thirty issues to each inhabitant of the United States. The total issue for that year in Massachusetts reached 102,000,000, and in New York, $320,000,000$. This means that while South Carolina thought and sentiment was expressed $8,000,000$ times, that of Massachusetts was amounced $102,000,000$ times. Is there any cause for surprise at the outeome of the war? The orerwhelming paper broadsides of the North were no less effectual than the guns of a Farragut, in shutting out the South from intercourse with, and assistance from, the rest of the world.

During the war, papers suspended for want of patronage, want of material, and want of compositors. 1865 marks a blank almost in country journalism. The Courier went on, the Mercury was destroyed, and the Columbia papers had gone up in smoke. A new daily was established in Columbia by Julian A. Selby, who brought a bag of type on his back from a neighboring town, and, with the aid of $\mathrm{Wm}$. Gilmore Simms as editor, founded the Phomix. One by one the country papers resumed operations, and in a year or so the number had largely increased. Since that time there has been a steady progress. Old papers have been consolidated, new ones have sprung up, and are being born every day.

\section{THE CHARLESTON DAILY NEWS}

of Charleston was established in August, 1S6.5, by Benjamin Wood, of New York. In 1867 it ehanged hands, Messrs. Riordan \& Dawson becoming the managers. Absorbing the Courier, it is now the only daily in Charleston, and, as 
THE NEWS AND COURIER,

is one of the leading papers in the land. The influence of its enterprise and business management may be seen in the general improvement of the State press.

The Phomix, the Guardian, and the South Carolinian, have lived and died, since the war, in Columbia.

THE REGISTER,

begun several years ago, in Columbia, as a co-operative journal, is now owned by C. A. Calro, Jr., and edited by Col. J. W. R. Pope. It is a sterling journal.

THE PALMETTO YEOMAN

is an ovening daily, prblished also in Columbia by Mr. C. M. MeJunkin. The only other daily in the State is

THE GREENVILLE NEWS,

a live sheet, which discusses all the topies of the day with pungency and rigor. Its editor is A. B. Williams, Esq.

OTIIER PAPERS.

Among the other papers in the State are: The Charleston Zeitung, published in German, which is the only representative of foreign languages in South Carolina. The Abbeville Press and Bamer, and Abbeville Medium, the Saluda Argus, Aiken Recorder, and Journal and Review, Anderson Intclligencer, and Joumal, Barnwell People, and Sentincl, Beaufort Palmetto Post, Berkeley Gazette, Charleston Mercury, and New Era, Chester Reporter, and Bulletin, Cheraw Sun, Clarendon Enterprise, Colleton Piess, Darlington Southron, Florence Times, Edgefield Advertiser, Chronicle, Monitor (Johnston's), Winnsboro' News and Herald, Georgetown Times, and Enquirer, Greenville Nens, and Enterprise and Hounteiner, Hampton Guardian, Conwayboro' Tclephone, Kershaw Gazette, Camden Jompal, Lancaster Lerlyer, and Reriew, Laurensville Herald, Lexington Disputeh, (riibert Hollow News, Marion Star, and Merehant and Farmer, Bennettsville Farmer's Friend, Newberry Herald, News, and Observer, Kenwe Cutricr (Walhalla), Orangeburg Times and Democrat, Pickens Sentinel, Seneea Joumal, Spartanburg Spartan, Spartanburg Herald, Gaffney City Carolinian, Sumter Watchman, Advanee, and Spirit of the Times, Enion Times, Williamsburg Herald (Kingstree), Yorkville Enquirer, Rock Hill Herald. 
REIAGIOUS PAPERS.

Associate Reformed Presbyterian, Due West; Baptist Cóurier, Greenville; Luthman Iisitor, Prosperity; Christian Neighbor, Columbia; Southeru Christian Adrocate (Methodist), Charleston; Southern Piesbyterian, Columbia.

\section{THE SOUTHERN PRESBYTERIAN REVIEW,}

already mentioned, is published quarterly, in Columbia, by the Rer. James Woodrow. It is an able review, being one of the leading exponents of Presbrterianism in the Soutl.

The Departiest of Agriculture issues monthly bulletins, which are full of raluable information to the farmer at home and to the public abroad.

\section{PRINTING ESTABLISHMENTS.}

Messrs. Walker, Evans \& Cogswell, of Charleston, conduct a very large printing and binding establishment, and are the publishers of a series of text books.

The Neus and Courier, the Columbia Register, and the Southem Presbyterian, have large job offices, capable of turning out any kind of work.

Mr. E. R. Stokes, of Columbia, conducts a book bindery. There are a large number of job printing offices in different parts of South Carolina.

\section{CONCLLSION.}

The census of 1580 relating to newspapers has not been published; and the tables of adrertising agencies are not reliable. It can safely be predicted, however, that the statistics will show material progress: while the intellectual and journalistic progress is evident to any careful reader. The power of the press is making itself felt more strongly than ever; and, in consequence, it is calling into service a number of the brightest minds of the State.

\section{ILLITERACI.}

The illiteracy existing in South Carolina is much to be deplored. It is well, howerer, to examine into this abnormal condition, in order to explain it, and deduce hope for the future. A comparison instituted between South Carolina and other States on equal terms, is unfair. Threefifths of her population were, but serenteen years ago, in a state of bond- 
age. With the exception of a few "free people of color" (always free), there is not now, nor will there be for some time, a single colored roter who was not once a slave. Next, with one exception, South Carolina was the heariestsufferer by the war, her assesced property shrinking from $\$ 480,000,000$, in 1860 , to $\$ 183,000,000$, in 1870 , while the true shrinkage was from about $\$ 550,000,000$ to a little over a hundred millions; more than half her territory was ravaged by hostile armies. After the surrender came two years of political chaos, and eight of rapacious robbery. Not until 1876 did South Carolina shake off the leash and enter the race afresh.

What has been done for education lias been shown; the results will now be considered.

In discussing education before the war, it is but proper to exelude the slares from consideration. The subjoined table gives the total white population of several States, with the number of illiterate whites twenty years of age and over twenty. Comparison is made with States justly celebrated for zeal in education. A much more favorable showing might have been made. This and the following tables are compiled from statistics of the U. S. Census.

Comparative White Illiteracy 1850 and 1860.

\begin{tabular}{|c|c|c|c|c|c|c|}
\hline & $\begin{array}{c}\text { Total White } \\
1550 .\end{array}$ & $\begin{array}{c}\text { Population } \\
1560 .\end{array}$ & $\begin{array}{c}\text { Illiterate } \\
20 \text { and } \\
1850 .\end{array}$ & $\begin{array}{c}\text { Whites } \\
\text { over. } \\
1560 .\end{array}$ & $\begin{array}{l}\text { Percen } \\
1850 .\end{array}$ & $\begin{array}{l}1 \text { tage } \\
18 c^{\circ} 0\end{array}$ \\
\hline Connecticut & 363,099 & 451,504 & 4,739 & $S, 4 S S$ & 1.3 & 1.8 \\
\hline Illinois . . . & $8+6,034$ & $1,704,291$ & 40,054 & 58,037 & 4.7 & 3. \\
\hline Indiana . . . & 977,154 & $1,338,710$ & 70,540 & 60,943 & 7.2 & $4 . \tilde{0}$ \\
\hline Maine .. & $581, \$ 13$ & $626,9+7$ & 6,147 & 7,552 & 1.0 & 1.2 \\
\hline Massachusetts & 985,450 & $1,221,432$ & 27,539 & 46,262 & 2.8 & 3.7 \\
\hline Ohio & $1,955,050$ & $2,332,808$ & 61,030 & 58,642 & 3.1 & 2.5 \\
\hline Pemsylrania. & $2,258,160$ & $2,849,259$ & 66,928 & 72,156 & 2.9 & 2.5 \\
\hline Rhode Island. & 143,875 & 170,649 & 3,340 & 5,852 & 2.3 & 3.1 \\
\hline South Carolina & 274,563 & 291,300 & 15,684 & 14,792 & 5.7 & 5.0 \\
\hline Vermont • & 313,402 & 314,369 & 6,189 & S,S69 & 1.9 & 2.8 \\
\hline
\end{tabular}

The percentage decreased in South Carolina. In some others, notably the New England States, possibly owing to immigration, the rate advanced. In 1860 , the rate for South Carolina was 5 per cent.; for Massachusetts, 3.7 per cent; and for Rhorle Island, 3.4 per cent. By 1870, the percentage of illiterates over twenty years had increased to 4.2 in Connecticut; 3.8 in Illinois; 5.6 in Indiana; 2.1 in Maine ; 5.8 in Massachusetts; 4.2 in Ohio; 5.1 in Pennsylvania; 7.5 in Rhode Island; 10.5 in South Carolina; and 4.0 in Vermont. It must be remembered that 
all the other States were prospering, while South Carolina was financially bankrupt.

$$
\text { COLORED ILIITERACY. }
$$

A comparative statement of colored illiteracy in five leading States, before the war, may be of interest.

Colored Illiteracy, 1850 and 1860.

\begin{tabular}{|c|c|c|c|c|c|c|}
\hline & $\begin{array}{c}\text { Total Free Col'd } \\
1850 .\end{array}$ & $\begin{array}{l}\text { Populationi. } \\
1860 .\end{array}$ & $\mid \begin{array}{c}\text { Illitera } \\
\text { Yrs. an } \\
1550\end{array}$ & $\begin{array}{c}\text { ates } 20 \\
\text { ad over. } \\
1860 .\end{array}$ & $\begin{array}{l}\text { Percel } \\
15.50 .\end{array}$ & $\begin{array}{l}\text { ntage. } \\
1860 .\end{array}$ \\
\hline Indiana & 11,262 & 11,428 & 2,170 & 1,773 & 19.2 & $15 . \overline{5}$ \\
\hline Massachusetts & 9,061 & 9,602 & S06 & 6.59 & 8.5 & 6.5 \\
\hline Pennsylrania. & 53,626 & $56,9+9$ & $9,3 t t$ & 9,399 & 17.4 & $16 . t$ \\
\hline Phode Island & 3,670 & 3,952 & 267 & 260 & 7.2 & 6.5 \\
\hline South Carolina . & 8,960 & 0,914 & 880 & 1,416 & 9.8 & $1+.3$ \\
\hline
\end{tabular}

This table shows that prior to the abolition agitation, free persons of color received almost equal advantages in South Carolina and New England, while they were comparatively neglected in I'ennsylvania and Indiana. In consequence of the agitation illiteracy appears to have increased in South Carolina, remained almost stationary in Pennsylvinia, and decreased in the other States. (It may be added that the table does not show any large immigration of colored people North, prior to 1860. Colored artizans fared better in the South than they did elsewhere. "Free persons of color" in the South were not always adrocates of emancipation.)

Reverting to the statistics of South Carolina, it is found that there were

In 1S60, white illiterate males, twenty years and over, 5,811. Total white population, 291,300 .

In 1970, white illiterate males, twenty-one year's and over, 12,940. Total white population, 299,666 .

In 1850 , white illiterate males, twenty-one years and over, 13,924 . Total white population $391,00 \bar{s}$.

This tells the story. Those who were twenty-one years old in 1570, were eleven years old in 1560. The finger of war is evidently here. It is gratifying to see that the increase of adult illiterates during the past decade is small. 
A comparison of illiteracy by ages between the census of 1570 and that of 1880 , is subjoined.

\section{White Illiteracy.}

\begin{tabular}{|c|c|c|c|c|c|}
\hline & $10-1+$ Yrs & $15-21$ I is. & 21 and over. & $\begin{array}{c}\text { Total } \\
\text { Illiterate. }\end{array}$ & $\begin{array}{c}\text { Total } \\
\text { Population. }\end{array}$ \\
\hline 1880 & 15,328 & $10,11 t$ & $34,3.35$ & 5)! 77 & $3 ! 11,1(1,5$ \\
\hline 1570 & $13,67 t$ & 11,102 & 30,391 & $5.5,167$ & 289,$66 ; 7$ \\
\hline Increase & $1,6 \bar{j} 4$ & $9 S S$ & $3,9+4$ & 4,610 & $101, \pm 38$ \\
\hline
\end{tabular}

Total increase of illiterate whites, 4,610 , relative increase, 8.4 per cent.

Total increase of white population, 101,438, relative increase, 35.4 per cent.

The population has increased orer four times as fast as the illiteracy. This is a sign of progress..

\section{Colored Illiteracy.}

\begin{tabular}{|c|c|c|c|c|c|}
\hline & 10-1t Yrs. & $.15-21$ Yrs. & 21 and over. & $\begin{array}{c}\text { Total } \\
\text { Illiteracy. }\end{array}$ & $\begin{array}{c}\text { Total } \\
\text { Population }\end{array}$ \\
\hline 1850 & $57 \overline{072}$ & 52,936 & 200,063 & 3111,071 & $(604,332$ \\
\hline 1870 & $40,80.5$ & 45,605 & 148,754 & $235,16 t$ & $41 \overline{i, 811}$ \\
\hline Iner & 16,267 & 7,331 & 51,309 & $7+, 007$ & 1.5 .515 \\
\hline
\end{tabular}

Total increase in illiterate colored, 74,907 , relative incrcase, 31 per cent.

Total increase in colored population, 158,518 , relative increase, tt per cent.

The population has increased about $1 \frac{1}{3}$ times as rapidly as illiteracy. This, at least, shows that illiteracy is not on the increase.

Again, the census of 1850 , gives the following

Colored persons who could wite, and those who comld not, 1 sso.

\begin{tabular}{|c|c|c|c|}
\hline Ages & 10-1t Yrs. & 15 Yrs. and over, & Total. \\
\hline Colored Population. & $\tau 6,981$ & 317,769 & $89+.70$ \\
\hline Could write... & 19,909 & 64.770 & 54,679 \\
\hline
\end{tabular}

There were, in 1Ss0, therefore, St,679 colored persons of ten years of age, and over, who had some acquaintance with the art of reading and writing. With the exception of a few "free persons of color," these represent the progress of fifteen years, between 1865 and 1850 , or of ten years of free schools, of which fire or six were, in an educational sense, " years 
of famine." It must be remembered, too, that a rery large proportion of the illiterateblacks were too old to avail themselves of school facilities. So that in ascertaining real progress they should be eliminated from the problem. Data for doing this are, unfortunately, not at hand.

The census of 1870 was obviously incorrect, in many respects. Taken carelessly, it was more apt to include prominent than obscure individuals, and, therefore, to lower the percentage of illiteracy. For this reason, greater progress mar be clained for the past decade than a comparison of the statistics would seem to indicate.

Despite the most farorable slowing that can be made, it is ret obrious that some extraordinary measures must be taken to combat ignorance. A State, in which the arerage amount of property per capita is not more than a hundred and twenty dollars, camnot be expected to put one-half its population to school. That it is doing much in proportion to its means is shown by the constitutional tax. The goremment of the United States elevated the slave to citizenship. His political mistakes are to-day apparent in their influence on public affairs. The United States must aid in universal education as supplementary to universal suffrage. One (annot safely exist without the other,

Inr must South Carolina be weary in well doing. Her own people are capable of additional effort. They cannot wait for outside aid.

In these days, knowledge is power. No longer do men sprinkle their chariots with Olympic dust. Never again will Hereutes raise himself to Hearen by dint of muscle, or the fate of Christendom depend on the weight of a Cour de Lion's battle-axe. Physical strength is not the standard of merit.

Man has conquered Nature. She does his work without fatigue, and without complaint. But for him she camnot think. 'Thought is his alone, and he thinks best who thinks most, whose mind is best trained in correct methods. Bismarck, Beaconsfield, Gladstone, Moltke, hare swayed Europe by brain, not by brawn. Indiana's war Goremor and Georgia's Commoner, from their invalid chairs have, at times, shaken our political fabric to its foundations. A single thought of Edison's may be worth millions.

Fertile soil, salubrious climate, rich minerul deposits, unlimited water power, raluable virgin forests--all that nature can bestow-are but nothing compared to the cultured brain. Nore than railroads, more than canals, more than factories, Carolina needs schools. Haring them, the rest will come.

A State that claims such glorious educational traditions, that has manifesterl such lore of knowledge in most untoward circumstances, that eren now is making progress in solving a problem nerer before submitted to 
mankind, may be relied upon to keep abreast with the other members of the great Aryan race, in its peculiar domain, the realm of intellect.

THE PEABODY FUND.

No sketeh on elueation would be complete without some mention of the Peabody fund, that lasting monument to the greatest philanthropist of his age. By the will of George Peabody, several million dollars were given in trust to a Board, for the education of the children of the South. The fund is carefully guarded. The interest annually accruing is devoted, not to helping the destitute, but to building up and improving. schools already in a healthy condition, or to fitting young men and women to become skillful and intelligent teachers. For screral years aid was given directly to the public schools; but recently the greater portion of the revenue is expended upon Normal schools, and Normal Institutes. The report of the U. S. Commissioner of Education, for 1S50, shows that since 1S68, the trustees had expended $\$ 1,191,000$, of which South Carolina, owing to the inefficiency of her sehool system, between 1872 and 1876 , had received but $\$ 3 \$, 200$, while $\$ 223,250$ had been given to Virginia, $\$ 220,150$ to Tennessee, and $\$ 118,000$ to $\mathbb{W}$ est Tirginia.

In $1 S \$ 1$, this State received $\$ 4,050$, and $1852, \$ 5,375$, making in all. $\$ 47,625$.

\section{PEABODY SCHOLARSHIPS -}

for deserving young white and colored persons, of both sexes, desiring to. become teachers, are established, for whites, at Nashville, for the colored, at Hampton, Virginia. Eight students at Nashrille and ten at Hamp-. ton were enjoying this bounty in 1851 . The scholarships are for two years. Applicants are appointed after competitive examination, and these are required, after graduation, to teach at least two years in the public schools of the State. 


\section{APPENDIX.}

Tubular Statements Copied or Compiled from the Tables of the Lnited States Census and the Report of State Superintendent of Education, for 1882.

Table I. A Comparison of White Population, School Expenditures and White Illiteracy in Thirty-three States in 1860.

Tabie II. Scholastic Population of South Carolina in 1880.

TABle III. Population and Illiteracy in South Carolina in $1 S 80$.

T.ible IV. Scholastic Population and School Attendance between the Years 1869 and 1852.

T.ıble T. Record of Public Schools in the State. 1852.

Table TI. Teachers and Salaries, 1882.

Table VII. Course of Study for 1882.

Table VIII. School Fund and Poll-Tax, 1SS0-81.

Table IX. School Houses used by Public Schools, 1852. 
TABLE I.

Showing, in 1860, 1st, the Total White Population of thirty-three States; 2d, the total Expenditures for Education of all linds; $3 d$, the Per Capita Expenditure; 4th, the adult White Illiteracy; 5th, the rute per cent. of 1lliteracy. (Compiled from statistics of the U. S. Census.)

\begin{tabular}{|c|c|c|c|c|c|c|c|}
\hline STATE. & & & $\begin{array}{c}\text { Tot.1L Winte } \\
\text { Populition. }\end{array}$ & ExpexDITURE. & $\left|\begin{array}{c}\text { Per } \\
\text { CaPITA }\end{array}\right|$ & $\mid \begin{array}{c}\text { ADULT } \\
\text { WHITE } \\
\text { ILLITERACY. }\end{array}$ & $\begin{array}{l}\text { Rate } \\
\text { Per Cent. } \\
\text { Illiteraci: }\end{array}$ \\
\hline Alabaina . & . & & 526,271 & $\$ \$ 38,002$ & $\$ 159$ & 37,605 & 7.14 \\
\hline Arkausas . . & . & & 324,143 & 194,344 & 59 & $23,6.52$ & 7.29 \\
\hline California . . & . & & 323,177 & $5,59,849$ & 173 & 18,989 & 5.87 \\
\hline Connecticut . & • & 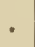 & 451,504 & 748,451 & 16.5 & 8,488 & 1.83 \\
\hline Delaware. . . & . & 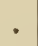 & 90,589 & 124,509 & 137 & 6,661 & 7.36 \\
\hline Florida . . . & . & . & 77,746 & 95,511 & 123 & 5,341 & 6.87 \\
\hline Georgia . . . & . & . & 591,550 & $85 \div, 270$ & 144 & 43,684 & 7.39 \\
\hline Illinois . . & - & . & $1,704,291$ & $2,517,546$ & 147 & 58,037 & 3.40 \\
\hline Indiana . . . & . &. & $1,335,710$ & $\$ S 2,68 S$ & 66 & 60,943 & 4.56 \\
\hline Iowa . . . & & & 673,779 & 701,116 & 104 & 19,752 & 2.83 \\
\hline Kansas . . . & - & . & 106,390 & 50,792 & $4 S$ & 3,004 & 2.82 \\
\hline Kentucky . . & & 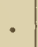 & 919,484 & $1,0 \$ 0, S 00$ & 117 & 67,577 & 7.34 \\
\hline Louisiana . . & . & . & 357,456 & $1,019,726$ & 285 & $17, \mathrm{SOS}$ & 4.98 \\
\hline Maine. . & & . & 626,947 & 554,610 & SS & $7,5,52$ & 1.20 \\
\hline Maryland . . & . & . & $515,91 \mathrm{~S}$ & 510,766 & 99 & 15,825 & 3.06 \\
\hline Massachusetts & & . & $1,221,432$ & $2,230,611$ & 182 & 46,262 & 3.79 \\
\hline Michigan . . & & . & 736,142 & $\$ 16,666$ & 110 & 17,441 & 2.37 \\
\hline Minnesota . . & & & 169,395 & 116,702 & 63 & 4,751 & 2.81 \\
\hline Mississippi . . & & . & 353,899 & 733,621 & 207 & 15,526 & 4.39 \\
\hline Missouri. . . & & . & $1,063,489$ & $1,259,139$ & $11 \mathrm{~S}$ & 59,660 & 5.61 \\
\hline New Hampshir & & . & 325,579 & 369,945 & 113 & 4,693 & 1.43 \\
\hline New Jersey . & . & . & 646,699 & S5̄ & 132 & 19,276 & 2.98 \\
\hline New York. . & . & . & $3,831,590$ & $5,057,971$ & 132 & 115,965 & 3.02 \\
\hline North Carolina & & . & $629,9+2$ & $75 S, 444$ & 120 & $68,12 \mathrm{~s}$ & 10.81 \\
\hline Oliio . . . & - & & $2,332, \mathrm{~S} 0 \mathrm{~S}$ & $3,031,770$ & 130 & $58,6 \pm 2$ & 2.51 \\
\hline Pennsylrania. & . & & $2,8+9,259$ & $3,379,015$ & 118 & 72,156 & $2.5 \%$ \\
\hline Rhode Island & & & 170,649 & 235,827 & 138 & 5,852 & 3.43 \\
\hline South Carolina & . & . & 291,300 & 690,512 & 236 & 14,792 & 5.07 \\
\hline Tennessee . & & . & $\$ 26,722$ & $1,076,571$ & 130 & 70,359 & 8.51 \\
\hline Texas . . & & & 420,891 & 651,374 & 154 & 18,414 & 4.37 \\
\hline Vermont. . & & & 314,369 & 298,595 & $9 \tilde{3}$ & 8,869 & $2.1 \mathrm{~S}$ \\
\hline Virginia. . . & & . & $1,0+7,299$ & $1,289,819$ & 123 & 73,955 & 7.06 \\
\hline Wisconsin . & & & 773,693 & 760,096 & $9 \mathrm{~S}$ & 16,448 & 2.12 \\
\hline $\begin{array}{c}\text { Eighteen Free } \\
\text { States }\end{array}$ & \} & . & $18,595,412$ & $23,170,382$ & 122 & 547,140 & 2.99 \\
\hline $\begin{array}{c}\text { Fifteen Slave } \\
\text { States }\end{array}$ & \} & & $11,244,646$ & $13,991,3+\mathrm{S}$ & 130 & 538,987 & 4.79 \\
\hline
\end{tabular}


TABLE II. SCHOLASTIC POPLLATION.

Showing the number of persons in South Carolina between the ages of 6 and 16 according to the United States Census of 1850.

\begin{tabular}{|c|c|c|c|c|c|c|c|c|c|c|}
\hline \multirow{2}{*}{\multicolumn{3}{|c|}{ AGES. }} & & & \multicolumn{2}{|c|}{ WHITES. } & \multicolumn{2}{|c|}{ Colored. } & \multicolumn{2}{|c|}{ All Classes. } \\
\hline & & & & & Males. & Females. & Males. & Females. & Males. & Females. \\
\hline 6 & Years. & . & . & & 6,131 & 5,893 & 11,156 & 11,449 & 17,287 & 17,342 \\
\hline 7 & Years. & . & . & . & 5,536 & 5,173 & 9,585 & 9,833 & 15,121 & 15,006 \\
\hline$S$ & Tears. & . & . & . & 5,641 & 5,307 & 10,361 & 10,282 & 16,002 & 15,589 \\
\hline 9 & Years. & . & . & & 5,061 & 4,769 & 7,609 & 7,464 & 12,670 & 12,233 \\
\hline 10 & Years. & . & . & . & 5,538 & 5,163 & 10,404 & 9,534 & 15,942 & 14,697 \\
\hline 11 & Iears. & . & . & . & 4,246 & 4,151 & 5,636 & 5,699 & 9,852 & 9,850 \\
\hline 12 & Years. & . & 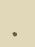 & . & 5,092 & 4,955 & 9,352 & 9,219 & $14,4+4$ & 14,174 \\
\hline 13 & Years. & . & • & & 4,166 & 4,130 & 6.599 & 6.394 & 10,765 & 10,524 \\
\hline 14 & Years. & . & 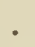 & • & 3,942 & $3, \$ 17$ & $.7,332$ & 6,812 & 11,274 & 10,629 \\
\hline 15 & Years. & . & & . & 2,871 & 2,868 & $6, \overline{7}+5$ & 6,364 & 9,616 & 9,232 \\
\hline 16 & Years. & . & $\cdot$ & . & 3,216 & 3,523 & $6,11 \mathrm{~S}$ & $6,52 S$ & 9,334 & 10,051 \\
\hline & Total & . & . & . & 51,440 & 49,749 & 90,897 & $\$ 9,57 \mathrm{~s}$ & 142,337 & $139,32 \pi$ \\
\hline
\end{tabular}

\section{SUMMARY.}

Males-White . . .51,440 Colored . .90,897 Total . 142,337

Fexules-White . 49,749 Colored . S9,578 Total . 139,327

Totals . . . 101,189

180,475 
A SKETCH OF EDUCATION IN SOUTH CAROLINA.

TABLE III. POPULATION AND ILLITERACY.

According to the Cinited States Census for 1850.

\begin{tabular}{|c|c|c|c|c|c|c|c|}
\hline & \multirow{2}{*}{$\begin{array}{c}\text { Total } \\
\text { Population. }\end{array}$} & \multirow{2}{*}{$\begin{array}{l}\text { Population. } \\
10 \text { Years } \\
\text { AND OVER. }\end{array}$} & \multirow{2}{*}{$\begin{array}{l}\text { C.nxot } \\
\text { Reaio. }\end{array}$} & \multicolumn{4}{|c|}{ Cannot Write. } \\
\hline & & & & $\begin{array}{l}10 \text { to } 14 \\
\text { Years. }\end{array}$ & $\begin{array}{l}15 \text { to } 20 \\
\text { Years. }\end{array}$ & $\begin{array}{l}21 \text { and } \\
\text { Over. }\end{array}$ & Total. \\
\hline $\begin{array}{l}\text { White } \\
\text { Colored }\end{array}$ & $\begin{array}{l}391,105 \\
604,332\end{array}$ & $\begin{array}{l}272,706 \\
394,750\end{array}$ & $\begin{array}{l}\cdot . \\
\cdot \quad \cdot\end{array}$ & $\begin{array}{l}15,328 \\
57,072\end{array}$ & $\begin{array}{l}10,114 \\
52,936\end{array}$ & $\begin{array}{r}3+, 335 \\
200,063\end{array}$ & $\begin{array}{l}59,777 \\
310,071\end{array}$ \\
\hline Total & 995,577 & $667, \pm 56$ & $321,750 *$ & 72,400 & 63,050 & 234,398 & $369,8+8$ \\
\hline
\end{tabular}

*Details not given. 


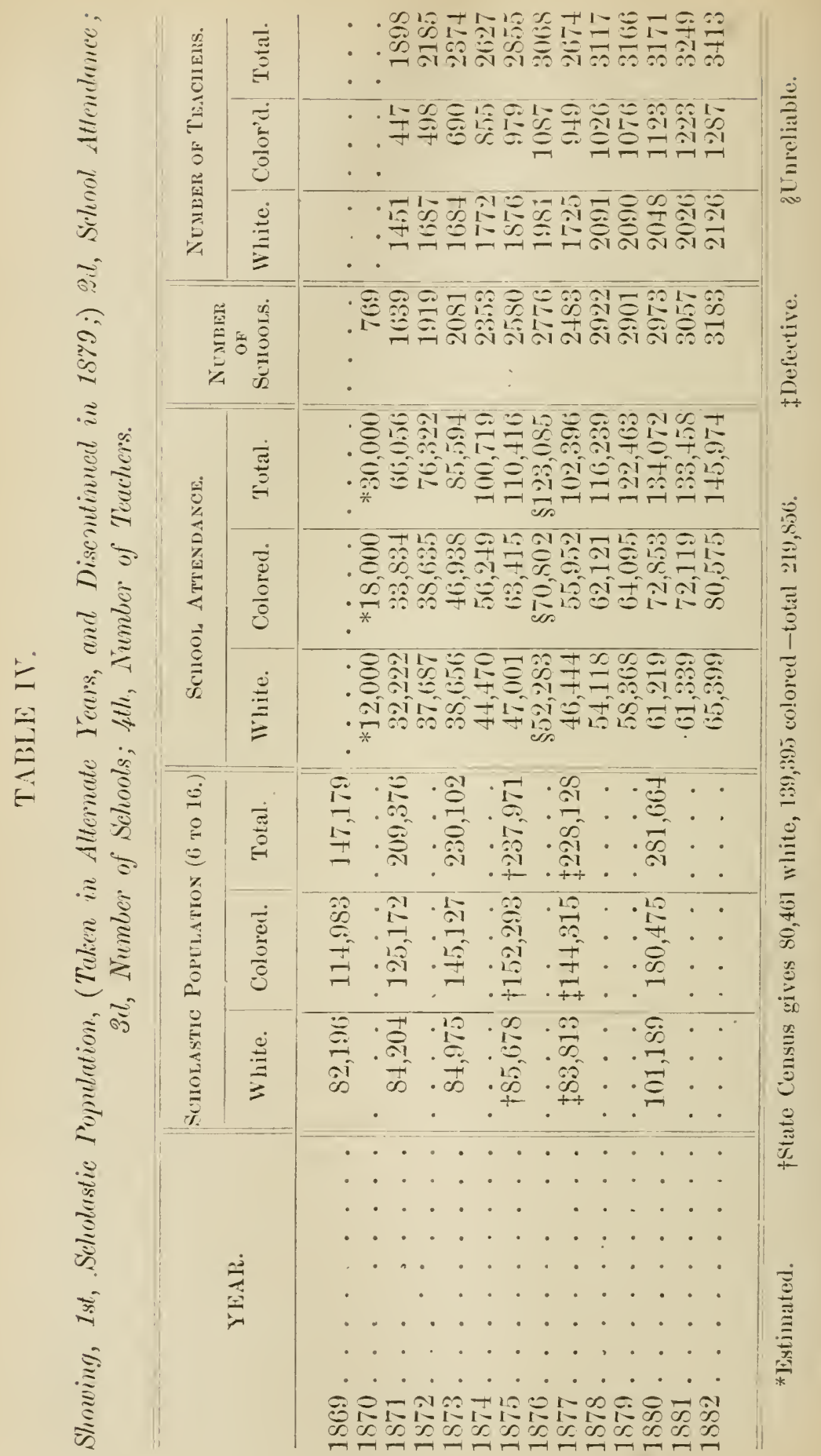


A SEETCI OF EDUCATION IN SOUTH CAROLINA.

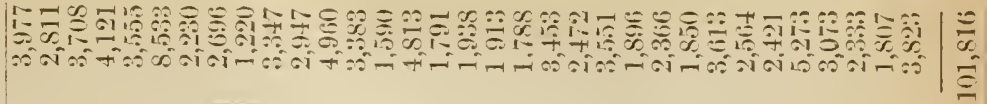

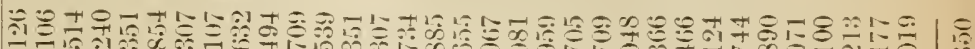

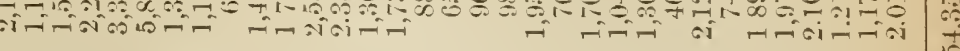

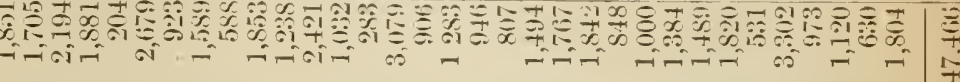

ใ A- R

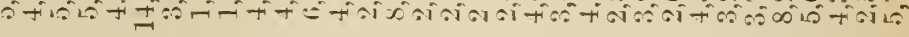

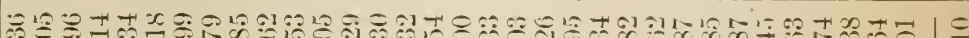

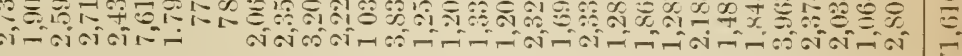

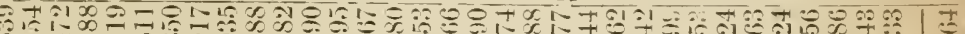

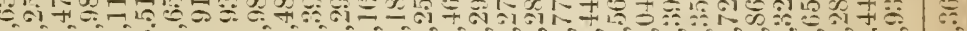

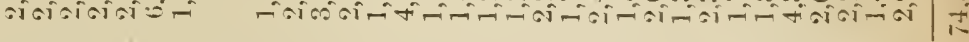

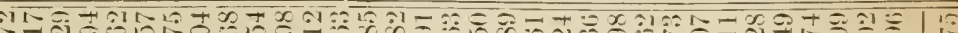

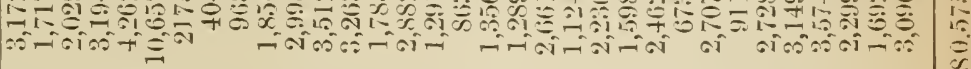

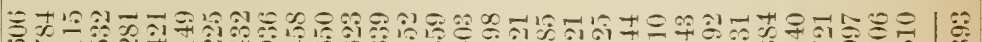

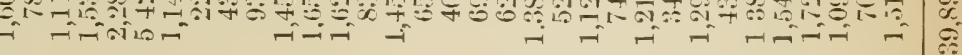

\%

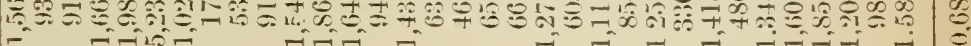

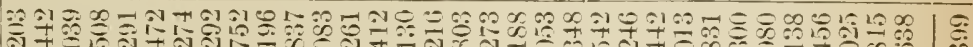
तictoi

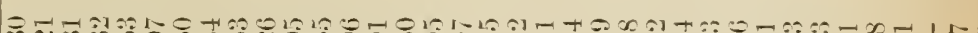
च-A

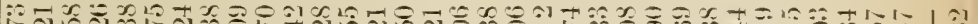

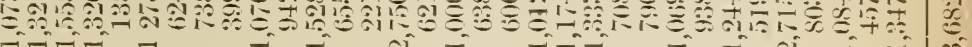
=Stomitos गารภ मо अवधार $\mathrm{N}$

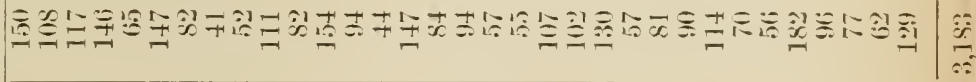
SIILNOIT NI NOISSAS AO HLONaT

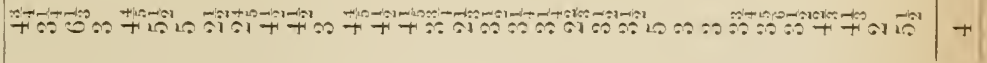

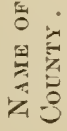

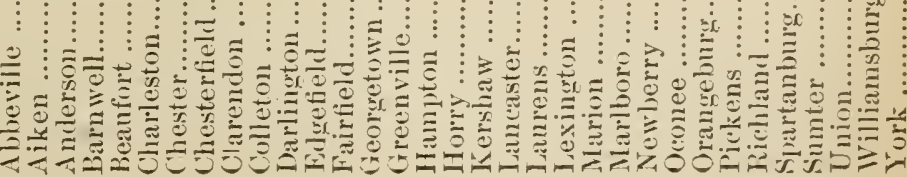




\section{TABLE VI. TEACIERS AND SALARIES.}

Showing the Number of Teachers Employed in 1882, and their Salarios.

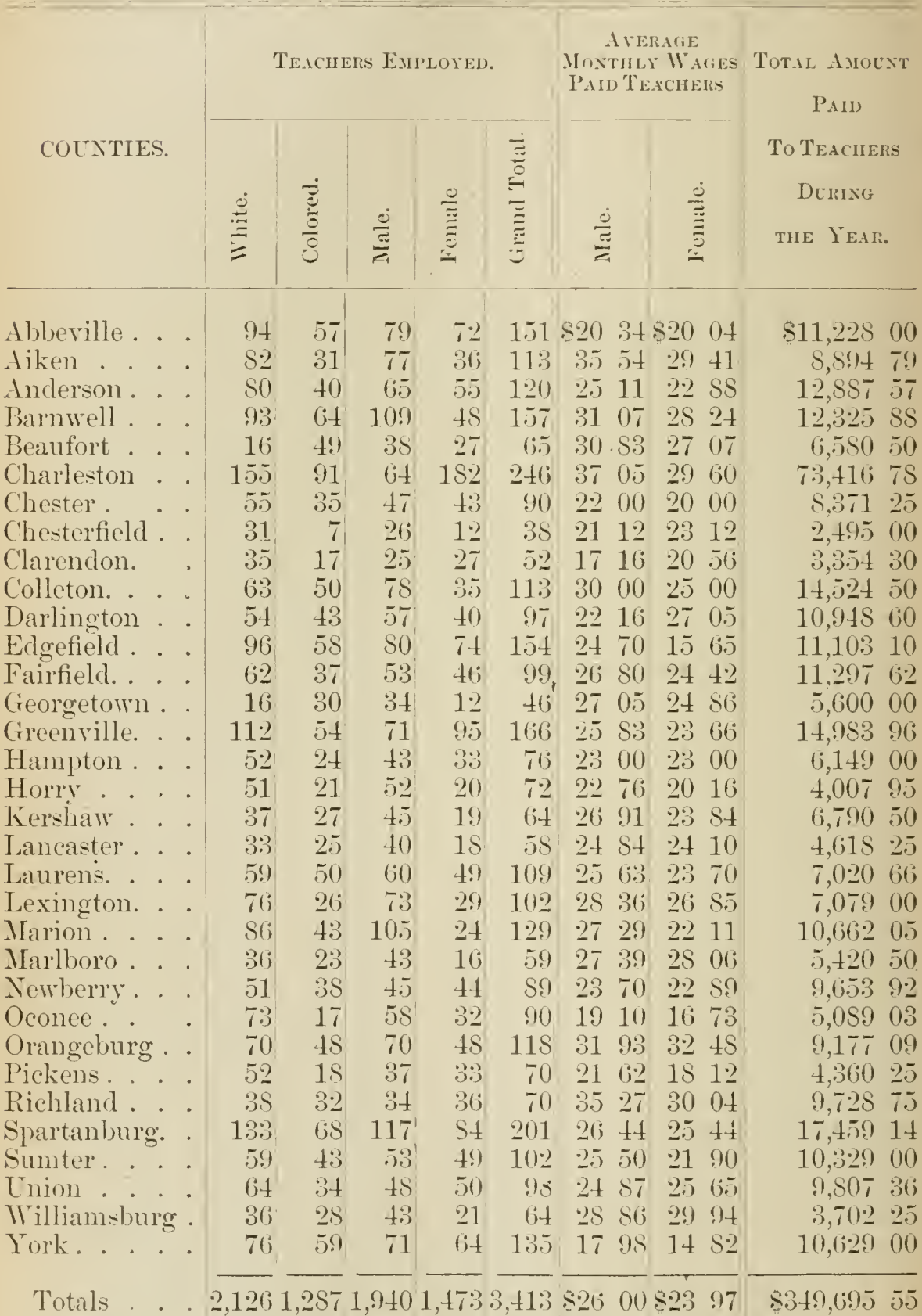


A SKETCH OF EDLCATION IN SOLTH CAROLINA.

TABLE VII. COURSE OF STUDY FOR THE YEARS 1SS1-S2. Number of Pupils Studying euch of the Branches Taught.

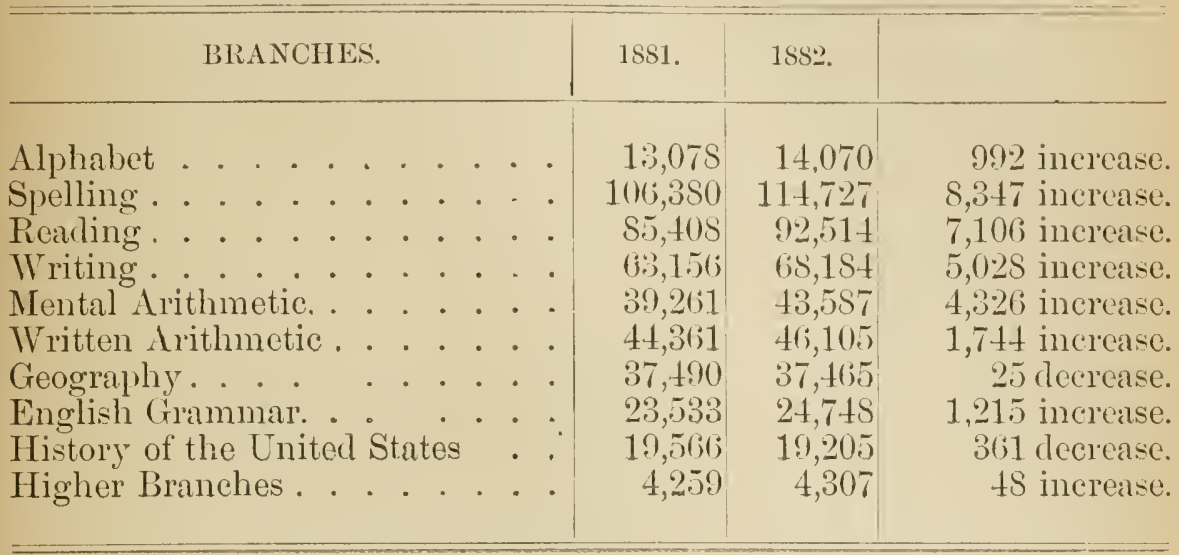




\section{TABLE VIII.}

Showing by Counties the Pullic School Fund for the Fiscal I car 1880-81, as Contained in the Anmual lieport of the Comptroller-General. Also the Net Proceds of the Poll-Tax, (Included in the Available Fund.)

\begin{tabular}{|c|c|c|c|}
\hline COLNTY. & $\begin{array}{l}\text { PaID } \\
\text { ScHoOL ORDERS. }\end{array}$ & CASH ON HAXD. & $\begin{array}{c}\text { Total } \\
\text { drailable Fund. }\end{array}$ \\
\hline
\end{tabular}

Abbeville . . Aiken. . . . Anderson . . Barnwell . . Beaufort. . . Charleston . . Chester .

Chesterfield .

Clarendon.

Colleton...

Darlington. .

Edgefield .

Fairfield. .

Georgetown .

Greenville . .

Hampton . .

Horry. . .

Kershaw. .

Lancaster . .

Laurens. .

Lexington . .

Marion . .

Marlboro. .

Newberry*.

Oconee ..

Orangeburg .

Pickens. .

Richland .

Spartanburg .

Sumter . .

Union. . .

Williamsburg

York . . . .

Totals. . $\$ 373,597952$
$\$ 14,41847 \quad 0$ $10,56493 \quad 0$ 13,851340 16,857 9s 0 10,402 is 0 58,687040 $9,249 \quad 51 \quad 0$ 3,321320 4,481790 $10,458 \quad 450$ $11,781,540$ 13,414630 $14,080 \quad 18 \quad 0$ 5,733850 $13,2918+0$ 6,291760 $2,618 \quad 170$ $7,886 \quad 526$ 4,501710 9,114740 8,499750 $12,8475+0$ 6,159390

5124450 $13,222 \quad 160$ $5,0065+0$ $16,328 \quad 730$ $19,428 \quad 3+0$ 12,568980 7,309880 $\$, 363836$ $17,670 \quad 40 \quad 0$
$\$ 2,022 \quad 704: \$ 16,441 \quad 174$ $\begin{array}{llllll}5,749 & 28 & 5 & 16,314 & 21 & 5\end{array}$ $1,12953715,010577$ $\begin{array}{llllll}3,103 & 07 & 3 & 19,991 & 05 & 3\end{array}$ $\begin{array}{llllll}1,306 & 80 & 0 & 11,708 & 98 & 0\end{array}$ $\begin{array}{llllll}16,423 & 68 & 0 & 75,110 & 72 & 0\end{array}$ $\begin{array}{llllll}1,856 & 71 & 0 & 11,136 & 22 & 0\end{array}$ 6,811 is 5 10,133 10 .5 $2,68420 ? \quad 7,165999$ $2,89+218 \quad 13.352668$ $952144 \quad 12,733$ 68 4 $\begin{array}{lllllll}1,836 & 69 & 1 & 15,916 & 87 & 1\end{array}$ $\begin{array}{lllllll}4.51 & 68 & 0 & 6,185 & 53 & 0\end{array}$ $\begin{array}{llllll}2,390 & 08 & 7 & 15,681 & 92 & 7\end{array}$ $82586 \quad 6,374346$ $\begin{array}{llllll}3,574 & 09 & 0 & 6,192 & 26 & 0\end{array}$ $\begin{array}{lllllll}1,311 & 86 & 0 & 9,198 & 38 & 6\end{array}$

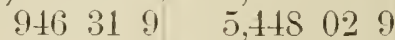
$\begin{array}{llllll}1,818 & 68 & 0 & 10,933 & 42 & 0\end{array}$ $1,880 \quad 3+9$ 3,136 os 0 2,250224 299962 62545 $565 \quad 450$ $1,6430.53$ 787992 5,133 it 0 $1,673 \quad 880$ $4,0.51 \quad 463$ 13,414630 8,499750 14,727 S8 ?

$\$ 5,179000$ 3,233550 4.404470 $5,14532 \quad 5$ $4,028 \quad 4.50$ $\begin{array}{llll}4,567 & 030 & 0\end{array}$ 2,813 600 2,763000 $2,44907 \quad 5$ 5,203430 4,474550 4,461850 4,081700 $2,40800 \quad 0$ 5.075330 2,261204 2,168000 3,158 as 6 2,267000 4,130310 $2.830 \quad 020$ $2,923.940$ $3,916 \quad 700$ 9,296070 $\dot{7} 380676$ 13,522122 5,069085 16,894180 $\begin{array}{llll}21,071 & 39 & 3\end{array}$ $\begin{array}{llll}13,356 & 972\end{array}$ $12,443 \quad 620$ $\begin{array}{llll}10,037 & 71 & 6\end{array}$ $21,221 \quad 86 \quad 3$
$1,850 \quad 20 \quad 5$ 4,918 S2 0 $1,69090 \quad 0$ 2,272000 $4, S S 717 \quad 5$ $4,1 S 1840$ $3,671 \quad 670$ $3,03310 \quad 0$ 3,685675

$\$ 79,36748 \$ \$ 452,965440 \$ 114,439905$

\footnotetext{
*No settlement made as yet. The matter is in course of adjudication.
} 
TABLE IX.

Shouing the Number and Talue of School Houses used by Public Schools in 1SS?.

\begin{tabular}{|c|c|c|c|c|c|c|c|c|c|}
\hline \multirow{3}{*}{$\begin{array}{c}\text { NAME } \\
\text { OF } \\
\text { COUNTY. }\end{array}$} & \multicolumn{7}{|c|}{ SCHOOL HOUSES. } & \multirow{2}{*}{\multicolumn{2}{|c|}{$\begin{array}{l}\text { Sciool Holses } \\
\text { RENTEd } \\
\text { DERING TIIE } \\
\text { Ye.AR. }\end{array}$}} \\
\hline & \multicolumn{3}{|c|}{$\begin{array}{c}\text { Erected } \\
\text { Previously. }\end{array}$} & \multicolumn{2}{|c|}{$\begin{array}{l}\text { Built Diring } \\
\text { thie Year. }\end{array}$} & \multirow{2}{*}{ 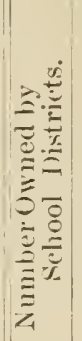 } & \multirow{2}{*}{ 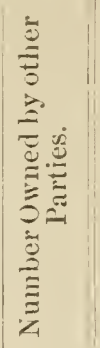 } & & \\
\hline & 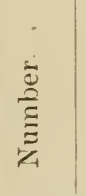 & 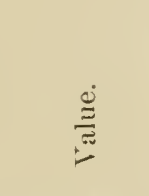 & & 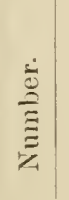 & 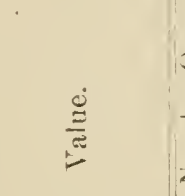 & & & 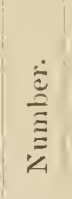 & 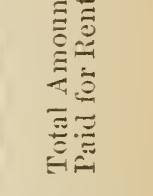 \\
\hline obeville & 121 & $\$ 44,050$ & & & & 40 & 81 & 4 & $\$ 510$ \\
\hline & 62 & & & 2 & $\$+41 \quad 06$ & 24 & 35 & 4 & $9 S 50$ \\
\hline son & 120 & 15,250 & 00 & & & & 120 & & \\
\hline & & 3 & 00 & 3 & 39300 & 43 & 103 & 7 & $4 \mathrm{~S}$ \\
\hline Bea & 69 & 7,025 & 00 & 2 & 36888 & 24 & 45 & 12 & St \\
\hline & 60 & 133,713 & 00 & 12 & $1,842 \quad 05$ & 46. & 14 & 52 & 721 \\
\hline & 61 & & 00 & 2 & 16595 & 21 & 40 & 1 & 200 \\
\hline & 52 & 2,860 & 00 & 2 & 9000 & 2 & 50 & 1 & 15 \\
\hline & 52 & 295 & 00 & 1. & 1500 & 6 & 46 & 1 & 20 \\
\hline Col & 109 & $2, \pi 40$ & 75 & & & 7 & 102 & 1 & 22 \\
\hline Da & 26 & $S, 400$ & 00 & 3 & 18980 & 26 & 56 & 11 & $129 \quad 5$ \\
\hline & 154 & & & 1 & $3 S$ S5 & 6 & 148 & & \\
\hline & 94 & 18,600 & 00 & 2 & $300 \quad 00$ & 4 & 90 & 11 & 8126 \\
\hline & 42 & ) & 00 & (j) & 12500 & 15 & 27 & 6 & 142 \\
\hline 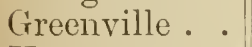 & 137 & & 00 & 10 & 65942 & 22 & 115 & 5 & 3200 \\
\hline Ha & 67 & & 00 & 9 & 48925 & 27 & 40 & 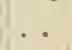 & . . \\
\hline Ho & 96 & & 00 & 3 & 7700 & 43 & 53 & & \\
\hline & $5 \mathrm{~S}$ & 6,8 & 00 & 6 & 323 SS & 9 & 49 & . & \\
\hline & 55 & 3,2 & 00 & 2 & 25000 & 2 & 53 & & \\
\hline & 107 & 8,550 & 00 & 1 & 7500 & 5 & 102 & 1 & 50 \\
\hline$n *$. & & & & & & & & & \\
\hline & 29 & & 00 & 3 & 15650 & 29 & 103 & & \\
\hline & 59 & 8,775 & 00 & 6 & $2,140 \quad 57$ & 33 & 26 & 8 & 59 \\
\hline & 81 & $10,4: 35$ & 00 & 2 & 14675 & 6 & 75 & 1 & $14:$ \\
\hline & 75 & 8,750 & 00 & & & 50 & 25 & & \\
\hline burg. & 110 & & & 4 & 25050 & 29 & 81 & & 103 \\
\hline & 66 & 1,745 & & & . . . & 20 & 46 & & \\
\hline & 55 & $7,5.5 .5$ & 00 & & & 30 & 25 & 7 & 146 \\
\hline arg & 173 & 10,300 & 00 & S & 58820 & 20 & 153 & & \\
\hline & 79 & 7,030 & 00 & 2 & 18000 & 42 & 37 & 2 & 44 \\
\hline & & & 00 & 8 & $670 \quad 00$ & 30 & 42 & 1 & 9 \\
\hline burg. & 62 & 735 & 00 & 2 & 15000 & 32 & 30 & 1 & 15 \\
\hline York. & 127 & 21,250 & 00 & 3 & $550 \quad 00$ & & 127. & 1 & 28 \\
\hline
\end{tabular}

*No report. the public, most of the Public Scbouls being tanght in Churehes. residences and out-buildings, which are owned by other parties, and of which no accurate ref orts can be made. 


\section{CHA P TER V.}

\section{CHURCHES.}

More than a century after the fierce and bloody conflicts of the French Huguenots and the Spanish Catholics along the coast of Carolina, and half a century after the congregation of Pilgrims sought shelter from religious persecution at Plymouth Rock, certain English noblemen, moved by a desire to enlarge the dominions of Charles II., and zeal for the propagation of the Christian faith among savages who had no knowledge of God, planted the first permanent colony in South Carolina. The colonists had no sectarian bias. It was only required that in the terms of communion of every church and profession, these following shall be three:

"1. That there is a God."

"2. That God is publicly to be worshiped."

"3. That it is lawful and the duty of every man, being thereunto called by those that govern, to bear witness to truth."

Most of the Lords Proprietors and the officers of the colony were members of the Church of England, and, in 1698, it excited little attention that a salary was roted to the Episcopal minister in Charleston by the Provincial Assembly. In 1704, when the colony numbered between 5,000 and 6,000 souls, the Episcopalians had one and the Dissenters four churches in the province. Nevertheless, through the instrumentality of the Governor and others, the election of members of the Church of England to a majority of the seats in the Provincial Legislature was obtained in that year. Immediately thereafter, to the surprise and indignation of the people of the province. an Act was passed making conformity to the Church of England a qualification necessary to a seat in the Common House of Assembly, and declaring that church to be the settled and established church of tho province. It became the only chureh having a legal status in Carolina ; its ministers were paid out of the provincial treasury. Each clergyman received $£ 2.5$ upon arrival, and if afterwards elected rectors, their annual legal salary dated from the same period; its parish churches, rectories, and schools were built out of t'l s e om:mon tax fund. 
It first a board of lay commissioners were invested with temporal and ecclesiastical jurisdiction over the affairs of this chureh. In 1726 , the Bishop of London, who had immediate care of these churches, appointed the Rev. Mr. Garden his commissary, and the spiritual and ecclesiastical jurisdiction of the lay commissioners was transferred to hinn. In 1740, the percentages of the different religions denominations in Carolina is given as follows:

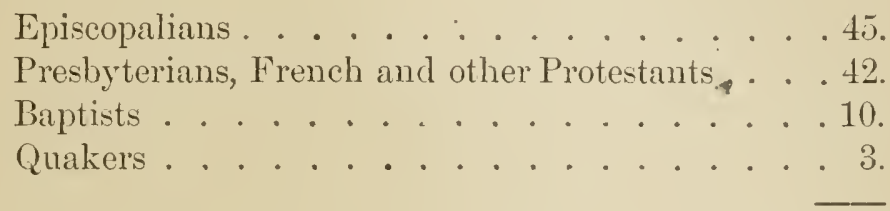

100

Between 1731 and 1775 , as many as one hundred and two Episcopal clergymen arrived from England, the average number officiating at one time for some years prior to the revolution, varying from twelve to twenty ; of the whole there was not a single native of Carolina.

The Church Act encountered violent and continued opposition. It was passed originally by a vote of only one majority in the Lower House. Appeals were made to Parliament, and the English House of Lords petitioned Queen Anne, beseeching her to deliver the province from this oppression. In spite of this, however, and in spite of the steady growth of other religious denominations in numbers and in wealth, the Church of England remained the established church, and sustained its supremacy for serenty years, until the war of the Revolution. Nor was this without advantage to the colony. Through this instrumentality a large number of highly educated and cultivated clergymen were brought into the province. The interest of the Society for the Propagation of the Gospel in Foreign Parts was aroused, and valuable donations, not only of money, but also of books for the parochial libraries, were sent from England. Parishes were laid out, churches, rectories, and schools established, and the poor and the ignorant cared for and taught. The parochial rule was adninistered with moderation and toleration, the watchful opposition of the other denominations operating as a continual check to any undue or arbitrary exercise of authority. Those in authority were persons of culture, liberal in their views, and while their livelihood and position was assured, this never served as a stepping stone to any higher offices. Their very authority was a mere incident to oceupations of more transcendent importance. It was a sort of impersonal rule that taught self government as government of self, and the fierce, and often unworthy, struggles 
of local political bodies were avoided. The parish system, founded in part on the representation of territory and wealth, sprang out of it.

But the spirit of the people was opposed to conformity with prescribed forms of any sort. George Whitficld, a gifted and eloquent divine, declined to be bound to the observance of church forms, and, during thirty years of controversy with the church, preached almost daily to crowded congregations. Besides the growth of other denominations in the low country, the upper country became settled almost exclusively by Presbyterians and Baptists. So that when the entire physical force of the country was called on, in the war against Great Britain, one of the very first acts of the Legislature, with a view to prevent all discord among religious sects, was the repeal of all the privileges granted to the Episcopal Church, and the establishment of all religions on an equal footing. This wise movement fully accomplished its object in uniting all parties in the struggle for independence. Notwithstanding there are those who think that eertain long prevailing differences, and even jealousies, between the upper and the lower sections of the State, owed their origin, in part, to the supremacy during the colonial days of the Episcopal Church. Even after the Revolution it was still known as the Chureh of England, at a time when all things English were not favorably regarded. At this time the Episcopal Church suffered much embarrassment. Deprived of State aid, it was for the first time thrown upon its own resources. While the severance of the tie with the chureh in England was such an obstacle to the Apostolic succession that no ordination of ministers in the State occurred for twelve years previous to 1795 , when all difficulties were removed by a convention of Bishops, in Philadelphia, two American Bishops having been ordained at the Archiepiscopal palace of Lambeth, in England, some years previously, in 1787.

Numerous Scoteh and Irish people among the first settlers of Carolina were Presbyterians. Unaided by the State, they at once established ehurches, and early in the 18 th century the Presbytery of Charlestown was constituted agreeably to the principles and practice of the Church of Scotland.

In 1685, Rev. Mr. Sereven established the first Baptist .Church in Charlestown. Prior to the Revolution this denomination had thirty churches. In $180 t$, there were 130 churches, 100 ministers, and 10,500 communicants of this persuasion.

In 1790 , the Independents, or Congregationalists, established a church in Charleston, the latter forming themselves into a separate congregation in 1730 .

In 1756, a Jewish Synagogue was erected in Charleston.

In 1759, the German Protestants built the first Lutheran Church. 
In 1785 , the Methodists made their first appearance as a religious socicty, and increased with great rapidity. In 1800, camp-meetings were organized, shelters being extemporized out of bagging the planters had for baling their cotton. In 1804 there were 12 circuits, 26 traveling and 93 local mini.ters, preaching in all $17,78 t$ sermons in the year. There were 200 churches and stations erected at a cost of $\$ 27,000$.

In 1791, the Roman Catholic Church was organized, under the care of Bishop Carrol, of Baltimore, the Reverend Doctor Keating officiating in Carolina.

The Christian culture and instruction of the negroes was at first obstructerl by a notion prevalent "from New England to Carolina, that being baptized is inconsistent with a state of slavery." In 1712, the Legislature of South Carolina passed an Act declaring "that it was lawful for any negro to receive and profess the Christian faith, and to be thereunto baptized." The Rev. Mr. Taylor, in 1713, examined a considerable number of negroes in St. Andrew's Parish, who had been instructed in the Christian religion by Mrs. Haige and Mrs. Edwards, fourteen of whom gave him so great satisfaction that he baptized them. In 1742, the Rev. Mr. Garden had a school house for negroes built in Charleston, and for twenty-one years a number of children, varying from thirty to sixty, with sometimes as many as fifteen adults, were instructed there. Other schools were organized and churches erected for the colored population, and their religious instruction became a mattor of the first consideration with all the Christian denominations in the State. The following illustration, one of many that might be cited, will show how wide-spread and groundless the misapprehensions on this point have been. When the Federal Army took possession of Beaufort, they found, in gilt letters over the pulpit of one of the largest churches in the town, PRE.LCH THE GOSPEL TO EVERY CRE.ATURE. Some of them tore down the last word and put in its place, in derision of course, WHITE MAN. Now this church was built by the Rev. Richard A. Fuller, in 1S $\$ 3$, and for many years had about 300 white and about 2,000 colored members. So great were the numbers of the latter that the communion service somatimes oceupied three hours. They were received into the white churches, but in most instances they had separate church organizations, under the eare of white ministers, and not unfrequently under that of preachers of their own race. And it is estimated that not only now, but for several generations past, the percentage of members of Christian churches has been greater among the colored population than among the white. Since emancipation they have withdrawn almost entirely from all connection with the churches of the whites, and have established everywhere numerous organizations of their' own. 'The largest 
numbers are Baptist, and next come the Methodists, but there are also Presbyterian and Episcopal churches among them. They are easily susceptible to profound religious emotions, and each individual seems to realize rividly his immediate personal relations with the Author and Ruler of all things. It is this personal and individual character of their religious sentiments which his prevented the establishment among them on any cxtended scale of a hierarchy or priesthood. Their preachers have great influence with them, but this the more because they are representative men chosen by themselves from among their number, than on account of their priestly character. Their religious services are, for the most part, conducted without a liturgy, but voluntary responses and frequent ejaculations attest that each feels he has, of his own right, a share and interest in them.

This will also explain why separate and independent church organizations as are practicable under the Baptist form of worship, should have yreater attractions for them than the more centralized and elaborately organized systems of the Catholics and Episcopalians. Despite the injunction "judge not," it has been asserted that the morality of the negroes is not in proportion to their religious fervor. A class nnarked as distinctly by their inferior social position as they are by race, invites such charges, which are far more sweeping than just. If morality be the fruit of religion it is notsurprising, wonderful as the progress made by the African in South Carolina has been, that it has not in one century and a half attained that maturity among the colored race which has been the result of nearly nineteen centuries of Christian teachings to the European. Nevertheless, it would be a great mistake to suppose that any people exhibit in a higher degree that instinctive faith in the existence of absolute justice, truth, and goodness, which marks the capacity of human nature alike for religion and for morality, than the colored people of this State (lo. Space does not admit of a delineation here of the attitude of the Christian churches to the colored race in Carolina. It is safe to say, however, that the ecclesiastical polity announced recently at a conference of the Episcopal clergy and laity, of preserving the unity of the church organization, by receiving on equal terms the clerical and lay deputies of the colored race into the Diocesan Conrentions, will meet with encouragement, at least from that portion of the former masters of these people, who are usually stigmatized as Bourbons.

The following table exhibits the general condition of the church in Carolina as compared with those of the United States as far as given by the census records of 1850,1860 , and 1870 . Cunfortunately the figures of the entmeration of 1880, which are essential to complete the picture, are not at this date accessible. 
TABLE A.

\begin{tabular}{l}
\hline \\
\cline { 2 - 8 } \\
\cline { 2 - 7 }
\end{tabular}

TABLE B.-Showing the Condition of the Leating Fieligious Denominations in Sonth Carolina and in the United States in 1850, 1860, 1870, according to Enited sitates Census.

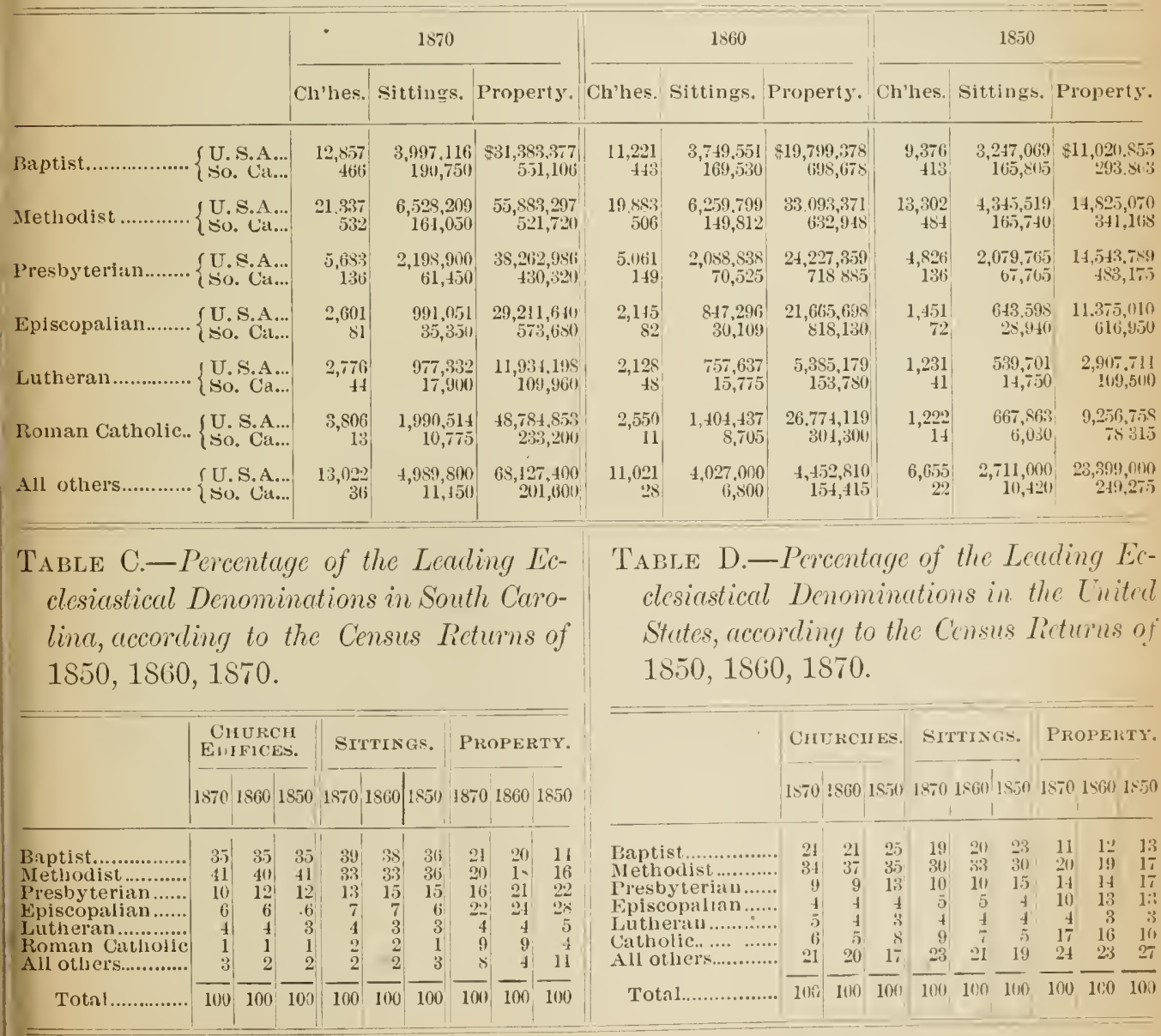


According to table (A) it appears that the growth of the churches in South Carolina duriug the prosperous decalle, from 1550 to 1860 , was not so great as elsewhere. In the succeeding decade of war and reconstruction this slow rate of increase continues, and is to be attributed to the destruction of much chureh property, and even of many of the churches themselves, by the invading army. It is to be observed, however, that even during these periods the proportion of churches and of church accommodations to the population is consiclerably greater in South Carolina than it is in the country at large. It will also be seen that the proportion of church buildings to dwellings is greater here, and that even during the depression of 1870 , a larger percentige of the property of the community was deroted to church purposes.

From the other tables it seems that taking into consideration at one view the number of edifices, the accommodations and the church property, while the preponderance in the country at large was with the Methodists, this preponderance in South Carolina was in some regards divided with the Buptists, the Presbyterians, and the Episcopalians. The pereentage of the latter to all denominations was greater in Carolina than in the Uniter States, while that of the Catholics was greater in the United States than in Carolina. No correct icleas of the general status and tendency of the rarious denominations can be formed, howerer, until the result of the enumerations of $1 S S 0$ are published.

As to the distribution of the various eeclesiastical denominations in the different sections of the State, no data later than of 1870 can now be furnished ; it will be sufficient, therefore, merely to mention here the six counties having the largest proportion of each leading denomination in the order in which they ranked in this regard in 1870 . Showing at the same time the orcler in which they stood as to population.

\begin{tabular}{|c|c|c|c|c|c|c|c|c|}
\hline$\frac{\pi}{c}$ & POPLLATION & $\begin{array}{l}\text { A LL DENOM - } \\
\text { INATIONS. }\end{array}$ & BAPTIST & METIIODIST & $\begin{array}{c}\text { PPES- } \\
\text { BYTERIAA }\end{array}$ & $\begin{array}{l}\text { EPISCO- } \\
\text { PALIAN }\end{array}$ & $\begin{array}{l}\text { LU- } \\
\text { THERAN }\end{array}$ & CATHOLIC \\
\hline 1 & (charleston & Edyefield & Edgefield & Charleston & Fork & Charleston & Edgefield & Charleston \\
\hline 2 & Edgefield & Charleston & Greenville & Ellyefield & Abberille & Beaufort & Lexington & Edgefield \\
\hline 3 & Burnwell & Anterson & Barnwell & Abbeville & Chester & Colleton & Newberry & Barnwell \\
\hline 4 & Beaufort & Abbeville & Anderson & Oranz̧aburg & Charleston & Anderson & Charleston & Sumter. \\
\hline 5 & Abberille & B.aruwell & spartanburg & Anderson & Clarendon & Abbeville & Rielnland & Chester \\
\hline 6 & Darlingtoli & Spartanburg & Banu fort & Ünion & Anderson & Kershaw & Oconee & Beaufort \\
\hline
\end{tabular}




\section{H A P T E VI.}

\section{OCCUPATIONS.}

The population of South Carolina, according to the late census, may be accounted for as follows:

Under the working age, that is under 10 years . . . . . . . 332,121

Over the working age, that is over 80 years . . . . . . . 4,SS7

Children over 10 years attending school . . . . . . . . . 129,975

Defective and Dependent Classes_Idiots . . . . . . . . 1,58s

Defective and Dependent Classes-Insane . . . . . . . . . 1,112

Defective and Dependent Classes-Blind . . . . . 1,101)

Defective and Dependent Classes-Deaf Mutes . . . . . . . jtit

Defective and Dependent Classes_Paupers . . . . . . T20

Delinquents in all the prisons . . . . . . . . . . 6t?

Engaged in all classes of respectable and gainful oceupation . . 392,102

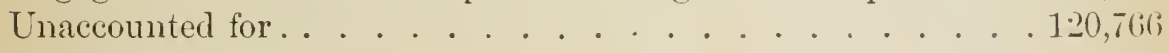

Total . . . . . . . . . . . 995,577

In considering those not accounted for, it must be borne in mind that there are in the State over 185,000 married women. who have their time. more or less, occupied with the care of families and children, especially with the 67,023 of the population, one year or under in age. There are also more than 30,000 unmarried females, between 18 and 25 years of age, most of whom remaining with their parents and assisting their mothers in household duties, are not yet listed in any regular employment. Allowance, too, is to be made for a certain number of young men of the working age engaged in preparation for professional careers, or in acquiring some trade or art. No allowance, howerer, is to be made for those who are unoccupied, simply because their wealth enables them to be so; their numbers are altogether insignificant, the more wealthy class being usually those most fully occupied. After reasonable derluctions on these accounts, the remainder are vagabonds or persons engaged in disreputable occupations. Their numbers cannot be very large, but it must give cause for serious consideration, that not more than thirty-nine per cent. of the population can be classed as bread-wimners.

For the United States at large the percentage of the population engaged in gainful oceupations is still less, being only thirty-four per cent. accord- 
ing to the tenth census. This pereentage varies greatly in the different States and Territories, being fifty-seren in Montana and twenty-eight in $I^{\top}$ est Virginial twelve out of forty-seren having a higher percentage of workers thim South Carolina.

'The status of the State in this regard may be more definitely ascertained by considering the percentage of those of the working age who are listed as workers, and comparing this number with the similar percentage of the population of the whole country orer ten years of age. It will be more satisfactory also to make this comparison for the ante war period as shown by the census of 1860 ; for the period of war and reconstruction as shown by the census of 1570 , and for the periol of peace subsequent to the war and reconstruction, as shown by the census of $18 S 0$. This is lone in the following table:

A.

\begin{tabular}{|c|c|c|c|c|c|c|c|c|c|c|}
\hline \multirow{3}{*}{ 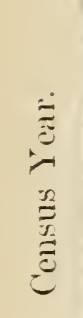 } & \multirow{2}{*}{\multicolumn{2}{|c|}{$\begin{array}{l}\text { Popllation over } \\
\text { TEN Years } \\
\text { OF AGE. }\end{array}$}} & \multirow{2}{*}{\multicolumn{2}{|c|}{$\begin{array}{c}\text { Ditto Exgaged } \\
\text { IN ALL } \\
\text { Occupations. }\end{array}$}} & \multicolumn{6}{|c|}{ Per Cent. of Workers. } \\
\hline & & & & & $\begin{array}{c}\text { On P } \\
\text { tion } \\
10 y\end{array}$ & $\begin{array}{l}\text { opula } \\
\text { over } \\
\text { vears. }\end{array}$ & Incr & rease. & Dec & ease. \\
\hline & U. s. & S. C. & U. S. & S. C. & U. S. & s. C. & U. S. & s. C. & U. S. & S. C. \\
\hline $1 S 60$ & $23,329,997$ & 492,316 & $11,011,64$ & 59,574 &. \pm 7 & .73 & . . & . . & & \\
\hline 1570 & $25,225,945$ & 503,763 & $12,505,923$ & 263,321 & 42 & .50 & & 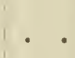 & .06 & .39 \\
\hline $18 S 0$ & $36,761,607$ & 667,456 & $17,392,099$ & 392.102 & .47 &. $\bar{s}$ & .06 & .12 & - & \\
\hline
\end{tabular}

These figures are taken from the census returns of 1870 and $18 S 0$ without change, but although no definite statement to that effect was found, it was inferred that the table of occupations in the census of 1560 referred only to the free population. Of the $\$ 1,631$ persons listed in the occupation tables of 1860 , at least 49,291 were engaged in pursuits not open to slares, such as teachers, merchants, clerks, planters, \&c. There were, however, at that date in South Carolina 278,243 slaves over ten years who all had gainful occupations, and these heary battalions of trained laborers have been added to the $\$ 1,631$ free workers in calculating the table abore given. The table shows that the people of Carolina were workers of old. It shows the immense nett loss the working class sustained by war and the subsequent period of industrial disorganization. And 
above all, it shows the increase in the number of bread-winners for the eountry at large, and for the State, since this period of disguict has passed. A comparison more in detail of the ninth and tenth census as regards the inerease and decrease of persons engaged in gainful occupations will exhibit some of the more general features of the industrial tendencies of the State. The increase and decrease here referred to is estimated as follows: The population of South Carolina over ten years of age in 1870 was 503,763 ; in 1880 , this population was returnerl as 667 ,456 , giving an increase of 163,693 , or thirty-two per eent. In 1570 , the workers numbered 263,321 , and if they inereased in the same ratio as the population, that is by thirty-two per eent, they should have numbered 347,583 , but actually they are numbered in the tenth census at 392,102 , a gain of 44,519 , or a net inerease of workers of twelve per eent. orer and above, and in addition to the natural increase of thirty-two per cent. 'This increase furnishes what may be called the index to the moral, as distinguished from the natural inerease in industrial tendeney. If it is desired to know the gross rate of increase in all oeeupations, or in any leading class of occupations given in the following table $(B$,) the natural rate of inerease of the population orer ten years must be added to the percentage there stated. This is, as above stated, thirty-two for South Carolina, and thirty for the United States.

Table showing the percentage of net increase or decrease- $(m)$ designates the latter-in relation to the increase of the population over ten years, of persons engaged in occupations in South Carolina and the United States, between 1870 and 1580 .

B.

South Carolina.

Total. Male. Female. Total. Male. Female.
Uxited States.

\begin{tabular}{|c|c|c|c|c|c|c|}
\hline All occupations & .127 & .110 & .135 & $\begin{array}{l}.067 \\
(\mathrm{~m})\end{array}$ & $\begin{array}{c}.051 \\
(\mathrm{~m})\end{array}$ & .110 \\
\hline$\ldots$. & .087 & .052 & $.10 \mathrm{~s}$ & .005 & .024 & .161 \\
\hline Transporta- & .410 & .359 & $.4 S t$ & .165 & .275 & .017 \\
\hline Sot & .21 & $.15 s$ & .397 & .167 & .137 & 1.016 \\
\hline $\begin{array}{l}\text { anufacture } \\
\text { ing. . }\end{array}$ & .079 & .079 & .000 & $.0 S S$ & .040 & .353 \\
\hline
\end{tabular}


Here the marked tentency to the increase in female workers is clearly shown. That this should be more apparent in the United States than in South Carolina is doubtless due to the fact, which will presently appear, that the proportion of females among the workers of the United States is considerably less than in South Carolina, and in so far as this is owing to natural conditions the pereentage of inerease in the female workers of the United States above given, shows the force of the moral tendeney in opposition to natural conditions. The rate of increase of the classes engaged in professional and personal services, and in trade and transportation is markedly greater than in the other occupations, and this rate of increase is very much greater for South Carolina than it is for the country at large. By a curious coincidence the increase of the persons engaged in manufactures and mining in South Carolina agrees precisely with the rate of natural increase, that is, thirty-two per cent. A more complete view on these points may be obtained by considering the

\section{SEX AND NATIVITY}

of the working population as given in the census of 1850 , and from data there given is compiled the following:

Table showing the percentage of males and females, native and forcign born engaged in all occupations, and in each leading class of occupations in the United States and in South Carolina.

C.

\begin{tabular}{|c|c|c|c|c|c|c|c|c|}
\hline & \multicolumn{2}{|c|}{ U. S. } & \multicolumn{2}{|c|}{ So. $C_{A}$. } & \multicolumn{2}{|c|}{ U.S. } & \multicolumn{2}{|c|}{ So. Ca. } \\
\hline & M. & F. & M. & $\mathrm{F}$ & 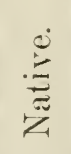 & 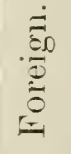 & 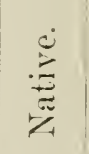 & 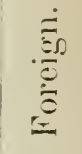 \\
\hline All occupations.. . & .85 & .15 & .69 & .31 & .80 & .20 & .991 & .009 \\
\hline Agriculture... & .92 & .08 & 71 & .29 &.$\$ 9$ & .11 & .995 & .002 \\
\hline Professional it personal services. & .66 & .34 & .54 & .46 & .75 & .25 & $.98 s$ & .012 \\
\hline Trade and Transportation . . . & .97 & .03 & 97 & .03 & .75 & .25 & .924 & .076 \\
\hline Manufucturing and Mining. . & .83 & .17 &.$S 4$ & .16 & .67 & .33 & .986 & .014 \\
\hline
\end{tabular}


Although South Carolina has taken no prominent part in the movement for the emancipation of the female sex, it is notable that here the proportion of women who enjoy the privilege of earning their livelihood in respectable occupations, is more than double that of the country at large. In thus leading in one of the great movements of modern civilization, which sceks more and more to make women bread-winners, the State is largely indebted to fayorable conditions afforded by its climate. For while the percentage of females engaged in the occupations embraced under trade, transportation and manufactures, occupations pursued under shelter, and in a large measure independent of climatic influences, is almost identical in South Carolina and in the United States, the state of the case is altogether different as regards out of doors occupations, such as agriculture. From the above table it appears that in the temperate climate of South Carolina twenty-nine women are capable of performing field work, where under the rigors and vicissitudes of the climate to which the population of the country at large is exposed, only eight women are found able to engage in this employment. The crops cultivated also favor this. Towhere is female labor more remuneratively employed than in picking cotton, and of the four and one-half millions of dollars annually disbursed as wages in the State in this employment, the larger proportion goes to females. The seeding and hand culture of the crop is also light, but nice work, and employs many women. Since the reverses of fortune following the late war, many delicately reared, and once wealthy ladies, have found themselves able to assist in this remunerative labor. This state of things is alone sufficient to explain the greater healthfulness and vigor of Southern women, as indicated by the more rapid increase of the Southern populations. Comparing the white population North and South, in this regard, J. Stahl Patterson, (Pop. sci., Tol. XIX, p. 671,) makes the ratio of increase per decade of the Northern whites to be 15.7 per cent., and for the Southern whites, 30.4, or nearly double.

As regards nativity, it will be observed that while the country at large owes one-fifth of its working population to foreign nations, South Carolina is indebted for only nine-tenths of one per cent. of her worker's to such assistance from abroad. Comparatively few of the foreign born population engage in agriculture, the leading pursuit in South Carolina. They are chiefly miners, traders, and dealers, and domestic scrvants, occupations, hitherto, not largely represented in South Carolina, but which are daily acquiring more importance, and becoming more remunerative here. (See Table E.) 
It is of interest to note the

\section{CHANGES OF OCCUPATION}

which are in progress, and with this view the following table has been compiled from the returus of the Ninth and Tenth U. S. Census, showing the pereentage of persons at different ages and for the sexes engaged in all ocenpations in the United States and Sonth Carolina in 1870 and 1Ss0, and also the per cent. engaged in each of the four great classes of oceupations.

D.

\begin{tabular}{|c|c|c|c|c|c|c|c|c|c|c|c|c|}
\hline & & & $\begin{array}{c}\mathrm{A} \\
10\end{array}$ & $\begin{array}{l}\text { Es } \\
\text { O } 15 .\end{array}$ & ${ }_{15}^{A}$ & o 5. & $\begin{cases}\text { A } & \text { in }\end{cases}$ & ES, & & TOT & ALS. & \\
\hline & & & & & & & $\mathrm{S}_{\mathrm{I}}$ & $x$. & $\mathrm{U}$. & $\mathrm{s}$. & So. & $\mathrm{C}_{\mathbf{A}}$. \\
\hline & & & $\frac{\dot{0}}{\frac{\pi}{\sigma}}$ & 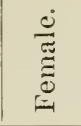 & $\stackrel{\stackrel{0}{3}}{=}$ & $\frac{\dot{O}}{\Xi}$ & $\stackrel{3}{\stackrel{3}{ت}}$ & 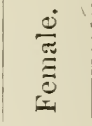 & 1870 & $i 880$ & 1870 & 1880 \\
\hline$\ddot{g}$ & United States & 1870 & .0456 & .0151 & .7584 & 1273 & .0506 & .0080 & .100 & & & \\
\hline 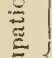 & United States & 1880 & .0475 & .0169 & $.7+67$ & .1312 & .0537 & .0040 & ...... & .100 & ... & \\
\hline छ & South Carolina & 1870 & .0730 & .0446 & .5656 & .2495 & .0567 & .0106 & & & .100 & \\
\hline$\Xi$ & Soutlı Carolina & 1880 & .0810 & .0535 & .5577 & .2413 & .0549 & .0137 & & & ....... & .100 \\
\hline $\begin{array}{l}\text { Son } \\
\text { Agl }\end{array}$ & $\begin{array}{l}\text { It Carolina : } \\
\text { culture }\end{array}$ & 1870 & .0663 & .0361 & .4467 & .1788 & .0480 & .0092 & .48 & & .79 & \\
\hline & & 1880 & .0700 & .0425 & .4156 & .1688 & .0464 & .0088 & & .44 & 10 & .75 \\
\hline Pro & essional and per- & 1870 & .0046 & .0070 & .0507 & .0598 & .0055 & .0047 & .21 & & .13 & \\
\hline & nal services & 1880 & .0094 & .0082 & .0738 & .0638 & $.004: ?$ & .0043 & & .24 & $\cdots \cdots$ & .17 \\
\hline Tra & le and Transpor- & 1870 & .0002 & & .0299 & $.000 \%$ & .0011 & & .10 & & .03 & $\cdots$ \\
\hline & & 1880 & .0004 & ..... & .0320 & .0008 & .0009 & & ..... & .10 & $\cdots \cdots$ & .03 \\
\hline $\mathrm{Ma}$ & ufactures and & 1870 & .0008 & .0006 & .0373 & .0109 & .0030 & .01703 & .21 & & .05 & \\
\hline & illing & 1880 & .0018 & .0007 & |0361 & .0087 & .0032 & .0002 & & .22 & $\cdots \cdots$ & .0 .5 \\
\hline & & & & & & & & & 1.100 & .100 & .100 & .100 \\
\hline
\end{tabular}

The inerease in the percentage of bread-winners among the old and the young is clearly shown in this table, and is even more marked in South Carolina than in the comntry at large. The only exception to the general rule is found among males over sixty years in South Carolina. The decrease in workers of this class is small, and is due, doubtless, to reduction in the number and strength of this class as a consequence of the late war, men now over sixty having been at that date in the prime of life, and especially exposed to the casualties of war. That the same 
reduction is not apparent in the country at large results from the futet, that immigrants, which count for nothing in South Carolina, have elsewhere filled the gap, and, furthermore, that the proportion of soldiers to the population was far greater in Carolina than in the country at large. The explanation of this tendency is that, with the development of civilized life, industrial improvements render labor easier, so that the very young and the very old may, by art, supply the vigor of adult life and become bread-winners. Nature has also assisted here, and in a genial climate like that of South Carolina the young and the old may engage in many kinds of labor, especially in agricultural labor, from which much more robust workers would be precluded by the extremes of severer seasons in more northern latitudes.

Before examining in further detail the changes of occupation taking place, attention is directed to the following table, copied from the eightli, ninth and tenth census, showing the number of persons engaged in each occupation, in which more than fire hundred persons in South Carolina were engaged, according to the census of 1880 . 
E.

\begin{tabular}{|c|c|c|c|c|c|c|}
\hline & \multicolumn{2}{|c|}{$1 S 60}$. & \multicolumn{2}{|c|}{1870.} & \multicolumn{2}{|c|}{1880.} \\
\hline & So. $\mathrm{CA}_{\mathrm{A}}$ & U.S. & So. $\mathrm{C}_{\lambda}$. & U.S. & So. C.1. & U.S. \\
\hline Agricultu & & & $96,6.54$ & $5,922,471$ & 294,002 & $7,6 ; 0,419)$ \\
\hline Agrieu & 6,312 & $79.5,+67 !$ & 163,528 & $2,455,(194 \mathrm{i}$ & 198,147 & $3,892,476$ \\
\hline $\begin{array}{l}\mathrm{Fa} \\
\mathrm{Tu}\end{array}$ & 40,392 & $2,5+7, ; 3 ; 3)$ & $42,5+6$ & $2,981,3201$ & 93,550 & $4,2-25,945$ \\
\hline borers & 160 & $1,30: 3^{\prime \prime}$ & 249 & 2,478 & $2,3.57$ & 7,450 \\
\hline $\begin{array}{l}\text { Professional and personal } \\
\text { services ............................ }\end{array}$ & & & $34,38,3$ & $2,684,793$ & 64,246 & $4,074,238$ \\
\hline Clergyn & -886 & $: 37,5 \div 99$ & 553 & 43 & $1,16 . \mathrm{i}$ & 4,698 \\
\hline & $1,10.3$ & 259, & 24.563 & 975 & 18,463 & $75,6.5$ \\
\hline La & 5,796 & 96 & 16,780 & 1,031 & 32,486 & $1,8.9,2,23$ \\
\hline$r$ and laundress ... & 309 & $38,62: 3$ & $1,5,5$ & 60,106 & 4,793 & 121,942 \\
\hline s and emplovees of & 4.57 & 33,193 & 1,126 & $40,-336$ & 614 & 64,137 \\
\hline Go & $4+5$ & 5 & 475 & 9 & $1,0 \pi$ & 115 \\
\hline Teach $\in \mathrm{r}$ & 1,45 & 118 & 1,111 & 136 & 2,170 & $2: 2,710$ \\
\hline Physician & 1,116 & $55,0.55$ & 789 & $62,28: 3$ & 919 & $856-1$ \\
\hline Trad & & & 8,470 & 1,19 & $13,5,56$ & 1,8 \\
\hline Trader & 3,720 & 268,978 & $-2,798$ & 351,477 & 3,794 & $4 S 1,450$ \\
\hline $\begin{array}{l}\text { Draymen, hackmen, teim- } \\
\text { sters, etc................................. }\end{array}$ & 50.5 & 9 & 661 & 120,756 & 1,309 & 177,586 \\
\hline $\begin{array}{l}\text { Officers and employees of } \\
\text { R. R. companies............ }\end{array}$ & $36 t$ & 36,567 & 1,211 & 163,303 & 2,035 & $250,4.58$ \\
\hline $\begin{array}{l}\text { Sailors, steamboatmels, pi- } \\
\text { lots wattermen ................... }\end{array}$ & 282 & $102,05 i$ & 491 & $98,2.55$ & 691 & 100.902 \\
\hline Mar & & & 13,794 & $2, \pi$ & 19,698 & 3,8 \\
\hline & $(692$ & 11: & $1,1+1$ & & 1,404 & \\
\hline Shoe & 589 & 161,108 & 538 & $171,12 \pi$ & $6+7$ & 194,0 \\
\hline $\begin{array}{r}\text { Briet } \\
\text { st }\end{array}$ & $5(69$ & 10 & 494 & & 735 & 15 \\
\hline Carpe & $1,8+8$ & $2.51,286$, & $2,4.44$ & & 3,17 & 873,142 \\
\hline $\begin{array}{l}\text { Coope } \\
\text { Cottor }\end{array}$ & 176 & 43,624 & $2 ! 4+$ & 50 & 618 & $49,13 \mathrm{~s}$ \\
\hline er & 623 & 87.289 & 1,064 & 21.5 & 2,304 & 310 \\
\hline Millers and sawers........ & 526 & $5: 2,28: 2$ & 678 & 48,512 & $89 ?$ & 120,490 \\
\hline $\begin{array}{l}\text { Tailors, milliners, sea } \\
\text { stresses ........................ }\end{array}$ & 2,898 & 252,958 & 2,528 & 257,317 & 2,544 & $104, ., 79$ \\
\hline All classes of occupations... & $S 1,631$ & $8,287,043$ & 268,301 & 12,$50 ;, 923$ & 392,102 & $17,392,099$ \\
\hline
\end{tabular}

Agriculture remains, as it has always been by a long interval, the predominant pursuit of the people of South Carolina. Nerertheless, there is eridence that this predominance is on the wane. Within the last census recade the number of agricultural workers has only increased twenty-one per cent., which is eleven per cent. less than the natural increase of the working population, and twenty-three per cent. less than the actual increase in workers in that period. The result is that, in com- 
parison with the other leading classes of occupations, agriculture has suffered a decrease of four per cent., and this is the only decrease anywhere to be noted. In the United States at large there is also the same decrease of four per cent. in agriculture, which, relatively to the numbers concerned, is much greater than the decrease in South Carolina. For, while agriculture employs nearly one-half of the aggregate working population of the country at large, and double the number engaged in any other of the leading classes of occupation, still the proportion of agricultural laborers in the United States is not two-thirds of the proportion so employed in South Carolina. In this decrease South Carolina follows the general tendeney throughout the country, and it might be said throughou Christendom. For there seems to have prevailed with increasing power, during the present century, a proneness among the populations everywhere to abandon the open country, and to flock to cities and towns, and laying one side rural pursuits, to adopt urban occupations. England strikingly illustrates this tendency; there, side by side with the development of enormous wealth in commeree and manufactures, has been a decline in agricultural prosperity to such an extent, that, it is said, some of the landholders find it more profitable to lease their lands to sportsmen for hunting and fishing than to cultivate them. There has been in South Carolina, during the decade under consideration, an increase in the number of independent farmer's of 110 per cent., while the increase in the country at large in this regard has only been 40 per cent. Among the classes engaged in

\section{PROFESSIONAL AND PERSONAL SERVICES,}

a marked increase has taken place in Carolina. It amounts to 57 per cent. on those thus engaged in 1570 , while the same increase for the country at large amounted to only 51 per cent. This class of occupations shows in this State a gain of 4 per cent. upon the others, being identical with the loss just remarked regarding agricultural pursuits. Clergymen have increased 110 per cent., or at the same rate as the small farmer's. Lawyers, on the other hand, have decreased 46 per cent., there being less demand for their services since the establishment of peace and good government in 1876. Physicians have increased only 14 per cent., and are still 17 per cent. less than they were in 1860 , notwithstanding the great increase in the population. This enormous falling off is due to the fact, that the colored population are no longer able to pay for the services of physicians, as they were during slavery. Teachers have increased 95 per cent., but this increase amounts to only 49 per cent. on the number of this class in 1860, an increase wholly disproportionate to the great increase of the school population by the introduction of the colored race. 
Domestic servants have decreased one-third, while for the United States at large there has been an increase since 1870 of 11 per cent. in this class, and since 1850 , of 297 per cent. Thus, while domestic servants constitute is per cent. of the whole working population of the country at large, they only form 4 per cent. of that in South Carolina. These facts justify the very shrewd observations of Sir George Camplbell, who points out to the emigrant classes of England and Ireland the excellent opening here for competent servants. The great increase, however, in those engaged in personal services in this State is due to the increase in laborers. For this large and important class it amounts to 98 per cent. since 1870 , and is greater than that which has taken place for the country at large witlin two decades. This augmentation is accounted for in South Carolina only in a very small degree by immigrants, but comes almost exclusively from the large class of idlers and vagabonds created by emancipation, who have been admonished, by the gentle but steady pressure of good government since 1876 , that they must earn their bread in the sweat of their brows. The percentage of all workers engaged in

\section{TRADE AND TRANSPORTATION}

has varied during the last decade less than one per cent. both in South Carolina and in the United States, the increase being but slight in both cases. In spite of the large river and harbor appropriations the actual numbers of sailors, steamboatmen, pilots, watermen, \&c., have decreased more than 1000 in the United States since 1860. In South Carolina this class of workers have increased over forty per cent. in the last decade. There has also been in this State a large increase in the official and employees of railroad companies, amounting to about sixty-eight per cent. on those enumerated in 1870 . As it was formerly a popular argument in this State against railroarls, that they would do away with horses in transportation, to the loss of com and hay raising farmers, and put an end to the occupations of teamsters, stage-drivers, hackmen and draymen, it is curious to note, that side by side with the above statement, the classes here referred to have more than donbled in numbers in the same time. Traders and dealers lave, with the restoration of peace and quiet, increaser over thirty per cent. since 1570 ; they only number, however; serenty-four more than they lid in 1S60. A most insignificant increase in comparison with the increase in the population. None of the colored population engage in trade, saring a few as porters in large stores. In

MANUFACTURES AND MINING

the percentage of increase in the working class of the country at large has been one per cent.; in South Carolina the increment has been 
less. So much for change of occupation. Actually the numbers of persons engaged in these occupations in South Carolina were more numcrous in 1850 than it was in 1870 by nearly forty-three per cent., an increment slightly greater than that of the United States, as a whole, which did not quite reach forty-two per cent. In the major manufacturing industries the numbers engaged have greatly increased in South Carolina. For example, the number of cotton mill operatives increased from 1870 to 1850 one hundred and sixteen per cent., and if account be taken of the additional increase up to the 1 st February, 18s3, as ascertained by a special enumeration, made by the State Department of Agriculture, this increase will be raised to three hundred and fifteen per cent. on those employed in 1870. The same increase has not taken place in the minor manufacturing industries, and this would seem to confirm the impression that South Carolina is lacking as regards the lesser mechanical pursuits, an impression doubtless, in the main, correct. However, by the tenth census, South Carolina is represented in fifty-three out of fifty-scren manufacturing occupations mentioned in the compendium, and has orer and above this seven per cent. of her workers engaged in this class of industries employed in other lesser and miscellaneous pursuits of this character, not mentioned. Rhode Island, Massachusetts, and Connecticut are represented in all the fifty-seven leading manufacturing industries, but in the first two named only six per cent., and in the latter nine per cent. of their artisans are engaged in the smaller and miscellaneous pursuits. So that as far as the mere number of industrial pursuits of this character is concerned, South Carolina would seem to have very nearly as many as these States, notable for the great diversity of their manufactures. More definite information on this point will not be had until the completed census returns of 1850 are published. In the census of 1870 , out of about four hundred specified manufacturing industries, South Carolina is credited with only sixty-three pursued within her bordres. But the deficiency now under consideration may be better accounted for in another way. Take, for example, blacksmiths, masons, and carpenters. The numbers engaged in these occupations form four per cent. of the entire working population of Comnecticut, five per cent. of that of Massachusetts, and six per cent. of that of Rhode Island. In South Carolina only a little over one per cent. of the working population is engaged in these trades. Only 4,442 are enumerated as pertaining to these vecupations. This was far otherwise in 1860 . Then, in addition to the 3 , (i06 free persons, mostly whites, engaged in these occupations, and in arldition to a large number of slaves, who having served their time as apprentices, were hired out at their trades, every large plantation had one or more blacksmiths, one or more carpenters, and not unfrequently a brick- 
layer. The acquisition of such arts by negroes added largely to their vilue, and was being more and more encouraged. The class of plantations here referred to exceeded 2,000 in number, and it would be safe to say that at least 6,000 slares were then engaged in these occupations, which, if added to the number of free artisans, would make the total number at work in these trades 9,000, or more than double the number enumerated in 1S50. The elder of these slave mechanics have almost all passed away in the years which have elapsed since emancipation. The negro apprentices and younger mechanics rery generally abandoned their pursuits when emancipated, each feeling that the brand of servitude attached to the special occupation in which he: had been engaged, and hopeful of a higher calling, threw it aside least it might interfere with his chances. Such callings were to rote, to go to the Legislature, to preach, or to become a land orner. The gap has never been filled. The work-shops, that were filled with negro apprentices in former days, have none now, and very few negroes have learned trades since the war. If to the occupations named, those of tailor, seamstress, shoemaker, and cooper be added, in all of which large numbers of negroes were formerly employed, but among which few are found now, the explanation would be fully given as to the comparatively small numbers engaged in the minor manufacturing industries in South Carolina.

As to the comparative healthfulness of the rarious classes of occupation in South Carolina and elsewhere. The only data at present a vailable are the very meagre ones in the census of $15 \%$. From these it appears that among agriculturists one death occurs in erery one liundred and fourteen so employed in the country at large, and one in every one hundred and thirty-five in South Carolina: among clergymen there is one leath in sixty-nine for the United States, one in forty-two for South Carolina; among laborers, one in seventy-seven in the United States, and one in ninety-seven in South Carolina; among lawyers, one in sixty-six in the United States, and one in one hundred and sixty in Sonth Carolina; among physicians, one in sixty-three in the United States, and one in serenty-eight in South Carolina; among teachers, one in one hundred and twenty-two, in the United States, one in two hundred and twenty-two in South Carolina. The number of persons in South Carolina having

\section{NO OCCLPATION}

because they belong to the defective and delinquent classes, is 5,726. Table $\mathrm{B}$ presents the data regarding these classes. 
Number of defective, dependent, and detimenent pesons in ecech 100 , onon of the population of sonth Camolimen and of the Unitul stutes, acomaling to the Seventh, Eighth, Ninth and Tonth L. S. Cinsus.

F.

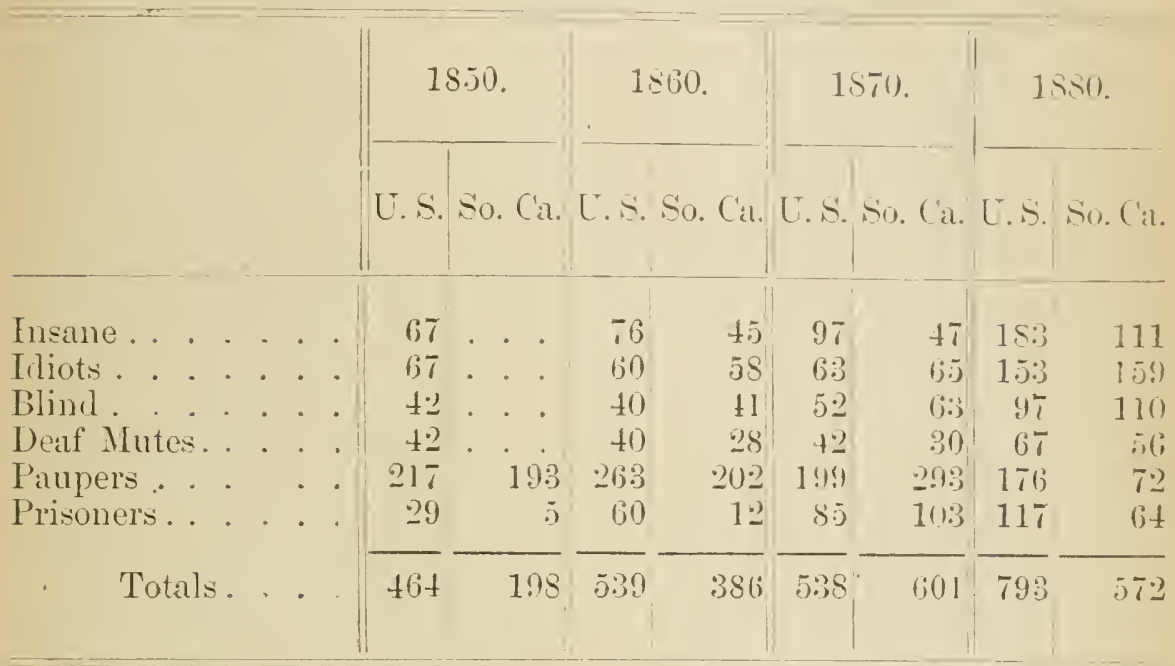

It will be observed from these totals that the burlen of these classes lats always been less in Fouth Carolina than in the country at large, except. for the decarle embracing the period of war and reconstruction. The linmane and enlightened treatment of

\section{THE INSALE}

is of modern origin, and takes date from the efforts of Dr. Pinel, in Paris, in 1791, and of William Tuke, of Jork, England, in 1796. Tirwinial was the first State in the Lnion to grant aid to this charity, and sontl Carolina was the third. In 1S2S the Sonth Carolina Lunatic A-rhum, with accommolations for 1:0 patients, was opened at Columbia. It wals a handsome fire-proof building, with extensive grounds, costing something less than $\$ 100,000$. Fince this tate extensive arlditions and infrovements lave been male. On November 1st, 187, 310 patients were accommodated. L'nder the able surerintendence of Dr. P. E. Grithin a number of large and commorlious buildings hare been adrled. and in the year 1SS2, 75j patients were unler treatment. The Institution is sulported by an anmual appropriation from the state of $8.70,(16)$ or $850.0(1)$, and during the last few years of $\$ 20.000$ or $\$ 30,000$ in addition for buildings and improvements. There are also accommodations for the insine in 
the Roper IJuspital. in Charleston, a charity founcled by a bequest from Nr. Thomas lioper, in 185t, and aiderl since by the City and State. The lesults of the treatment in 1582 are as follows: Deaths, 10 per cent ; "rured, s per ecent.; discharged, improved, or on trial, 6 per cent.; dis-

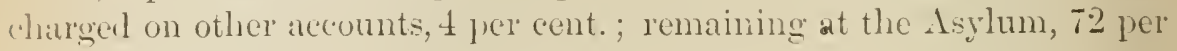
cent.

The great apparent increase in the number of the insane since the (census of 1570 is not attributed by those who have studied the sulject most closely to any "sucten and surprising increase in the number of unfortunates" themselves, but to the more careful and accurate methods irloper in their enumeration. Owing to the very defective manner in which data regarding this matter have hitherto been collected, it is doultful if there is anywhere positive evidence that this class of diseases is on the increase, much less as to the rate of such increment, if any.

As regards the number of the insane in hospitals, especially for their treatment, it appears, from the tenth census, that 44 per cent. of those in the country at large were found in such institutions, while only 37 per wnt. of the insane of South Carolina were found in such institutions. It is prossible that the enmmeration of these defectives was more thorough in this state than elsewhere; on the above showing it must at least have been as thorough. But, making no count of this, the figures of the tenth wensus fall far short of showing the actual state of the ease in South Carolina at the present time. The number of the insane in hospitals on the first day of June, 1S50, is given at 416 by the census. By Dr. Griffin's report it appears that, on the 31st of October, 1Ss2, there were in the Ayrum at Columbia 550 patients, besides 255 others under treatment, lluring the year. So that, allowing that the 1,112 insane enumerated in 1,5 is had increased to 1,200 , and making no account for those in the lioper Hospital, or for such insane of the State as were under treatment cutsile of its limits it appears that more than 60 per cent. of these mfortunates were receiving treatment at the State Asylum at Columbia, nor will the character of this charity be lessened by stating that only 2.7 (1) this number were pay patients. In this connection it is to be noted that Dr. Griffin has practiced the system of release on probation to a Ereater extent than has been done in any other asylum. Giving the results of his experiments in this line in 1582, he siys: "There were sent home 93. Of those who were afterwards discharged as cured, 35; al improved, 13 ; as unimproved, but able to be cared for at home, 6 ; dierl, $5 ; 18$, who were recently released, are still absent, and only 16 have returned. It is gratifying to state that, so far, there has been no instance of violence on the part of those released." Should this plan prove equally sucessful in future, it will largely increase the number of those who may 
enjoy the charity of the State. The insune belong not only to the rlefective, but also to the dangerous classes, and if the opinion now growing among jurists is well founded, that the delinquent classes are largely recruited from these defectives when neglecterl, the State, taking the greatest care of its insane, may hope, in a measure, to be freed from the incalculably greater burlens of criminals. In 1.580 , while there were 3.50 criminals in the insane asylums of the Union, there were none of this class in the State Asylum at Columbia.

By the tenth census, only 2.) per eent. of the colored insane of the United Siates were receiving treatment, while $\% 2$ per cent. of this class in South Carolina were the recipients of State charity. This pereentage is doubtless very largely increased since, as of the increase at the State Asylum, in 1S92, the whites were 27 an 1 the colorel 33 ; and while the census makes only 132) colored at the Columbia Asylum on the 1-t of June, 1S30, Dr. Griffin reports 220 colored patients present on the 31 st of U.tober, 1S52. Thus the numerous charges brought against the people of this state, of the ill-treatment of this race, is not sustainerl by the care of these helpless unfortunates.

The increase in the number of

IDIOTS,

in consequence of the more acsurate enumeration made by the tenth census, is about the same in South Carolina as in the Unitel States. Of the 1,5 ; $S$ in the State, 7 are foreigners, and 792 are colored, including 2 Indians. There are no training schools for idiots in South Carolina, but $5 t$ of these unfortunates aro charitably maintained in the State asylums and alms houses.

\section{THE BLIND AND DEAF MUTES}

Of the 1,100 blind in South Carolina, 669, or a little more than 60 per cent., are colored. Of the $56 t$ deaf mutes, the larger proportion are whites, there being only 263 , or about 46 per cent., negroes. The South Carolina Institution for the Exlucation of the Blind, Deaf and Dumb, at Colar Springs, Spartanburg County, was educating, in 1S.80, 16 blind and 50 deaf mutes. The institution is maintained by the State, and prior to its foundation, as early as 1831 , the Legislature made an mmual appropriation for sending deaf and dumb children to the Hartiord school.

\section{PAUPERISM}

is an evil so slightly developed in South Carolina as to be of small concern. The comparative status of the State is most truly shown in this regard by the census of 1980 , in which the number of panpers in alms 
houses is alone given. For the other years the number of persons receiving support on the 1st June in cach year, is chosen as the most accurate upon which to base the comparison offered in table $\mathrm{F}$. This number in South Carolina agrees very nearly with the number of paupers estimated to have been supported during each census year. This is far from being the case with the figures given for the country at large. There the aggregate number of paupers supported during the year exceeds those cnumerated on the 1st of June of each year by from 52 per cent. in 1870 , to 293 per cent. in 1560 , and 168 per cent. in $15 \% 0$. While the superintendent of the census state's, as his opinion, that these figures are of little value for purposes of comparison, nevertheless, in the absence of all other lata, so far as they may be relied on, they show that there has been from ome-half to one-fourth the proportion of pauperism among the population of South Carolina that there has been in the country at large, saring only during the period of military rule and reconstruction, as shown by the census of $15 \%$. Of the inmates of alms houses in 1SS0, 277 were whites and 242 were colored.

\section{THE CRIMINAL POPULATION}

of South Carolina has never been large, as will be seen by reference to table F. It has always been less than that of the country at large, except in the dark days of misrule, during reconstruction in 1570-days nerer to return, unless some social upheaval, of which no symptoms now appear, should occur. Of the 642 prisoners enumerated in this State in 1S50, 586, or 91 per cent., were colored, and were confined chiefly for thefts. During slavery such offences were prevented or punished by home discipline, and when emancipation imposed the burden of their correction upon the public, the number of delinquents largely exceeded any accommodations arailable for them. As a consequence, South Carolina, in common with other Southern States, was forced to lease out her convicts. Measures have been taken to remedy this. Industrial establishments are being erected at the Penitentiary. Early in 1SS3, the Board of Directors of the State Penitentiary announced that, on the expiration of the leases now in foree, no more convicts would be let out; and that hereafter all persons condemned to labor would be worked either within the Penitentiary itself, or upon State works, under the supervision of State officers. 


\section{CHA P T E R VI.}

\section{MANUFAC'TURES.}

The occupation of the inhabitants of Sonth Carolina has been more cxclusively agriculture than that of most cirilized communitics. One great cause of this is, that the soil and climate here render agriculture more profitable than in most places. A brief comparison of South Carolina with the country at large, as regards the relative values of farm productions and farm expenditures, will make this clear. The following dati are taken from the compendium of the Tenth U. S. Census; the latest authority on the subject.

\section{UNITED STATES.}

OUTLAY.

Value of farms, including land, fenees, and buildings . . \$10,197,096,7t6 Value of farming implements and machinery . . . . . 406,520,05.5 Value of live stock on farms, 1st June, 1850 . . . . . 1,500,464,609 Cost of building and repairing fences, in 1579 . . . $77,763,473$ Cost of fertilizers purchased in $1879 \ldots . . .2 . .25,586,397$

Total outlay . . . . . . . . . . . . . . . $\$ 12,210,431,310$

Value of all farm productions in 1879 . . $\$ 2,213,402,564$

Percentage of value of productions on outlay . . . 1s

\section{SOUTH CAROLINA.}

OLTLA:.

Value of farms, including land, fences, and buildings . . . \$ \$ $68,67 T, 482$ Value of farming implements and machinery . . . . . 3,202,710 Value of live stock on farms 1st June, 1850 . . . . . . . . 12,279,412 Cost of building and repairing fences in $1879 \ldots . . .917,000$ Cost of fertilizers purchased in 1579 . . . . . . . 2,659,9099

$$
\text { Total outlay . . . . . . . . . . . . . . } 857,736,573
$$

Value of all farm productions in $1879 \ldots . . . \$ 11,969,7+9$

Percentage of value of productions on outlay . . . . . . 47 
Severtheless, from an carly period numerous processes were invented and practiced by the people of Carolina in renelering raw material suitalle for business uses. Such was the extraction of indigo, in the mirldle of the last contury, and notably the inventions for threshing and cleaning rice. Power mills accomplishing the latter purpose were first invented in this State, and have since served as models in this important industry for the rest of the world. South Carolina was also the first State to pay Eli Whitney for the use of his invention in cleaning seed cotton. The tirst water gin was erected by Captain Kincaid, on Mill Creck, near Monticello, Fairficld county, in 1795, and for many years, dating from 1801 , the Bontwrights, of Columbia, were the great manufacturers of cotton wins for the South. Before and during the Revolution the families of planters and their slares were clothed in cotton homespuns made in the State. A factory, weaving these goods for the supply of the arljacent country, was established some years previous to 1790 , by the ScotchIrish settlers, at Murray's Ferry, Williamsburg county, and Mr. Benjamin Waring established, in the latter part of the last century, a cotton factory, near Statesburg, for spinning and weaving "Manchester cotton stuff.:" It this time there were in York, Greenville, Spartanburg, and Anderson, seven iron works for extracting the metal from the ore, and working it. The one in York possesses a forge, a furnace, a rolling mill, and a nail manufactory, and was operated by an improved water blast, the invention of Mr. Hill, one of the proprietors. There were five fulling mills in the upper country, and three excellent wheat merchant mills on Pine Tree Creek, Camden county, one of which, thought to be equal to any in the Lnited States, produced fifty barrels of superfine flour per lay. By the census returns of 1810 , the Carolinas, Georgia, and Tirginia manufactured greatly more in quantity and in value than the whole of New England together. These facts, at least, make it plain that neither the original character and activities of the people, or their natural surroundings, such as the climatic or physical features of the country, were hindrances to manufacturing pursuits.

That manufacturing has not held a more prominent position among the occupations of the people is by no means wholly due to the great profits accruing to agricultural pursuits. The improvements in spinning and weaving, the invention of the power loom, the development of great iron ore and coal resources, and the consequent activity in the manufacture of machinery of all sorts, which took place in Great Britain in the carlier part of the century, distanced competition in othel cointries, making English goods far cheaper than any produced elsewhere. But the chicf obstacle to manufactures in South Carolina was the institution of slavery. The large land holders had a monopoly of labor, which, in 
common with all other monopolies, was alverse to the development of manufactures. More than this, the sentiment against slavery. whin spread about this time throughout (Christemlom, isolated the industrial institutions of the South. Forcerl by the necescity of the "ase to stanul by the institution with which, against her protest, she had been burdened, she faced single-handed the public opinion of the civilized worlul. Feeling that every man's hand was against her, she became suspiciou: of strangers. Immigration ceaserl almost entirely, and the ellow-touch with the great industrial adrance of the age was lost; resigning herself almost as exclusively, as she was elsewhere exclucted, to agricultural pursuits, South Carolina satisfied herself with such profits as were gaincel in the eulture of cotton, and produced the largest amount of the raw material ever offered in the markets of the world. Even then, South Carolinit was not ummindful of the great advantages to be obtained from diversifierl pursuits, and the development of manufactures. Propositions for empluring slave labor in cotton factories were discussed, and ninety-eight negro slaves as operatives, under a single white overseer, were successfully worked at the Saluda Factory, near Columbia, in 1StS, and in this same factory, destroyed during the war, and rebuilt since, mixed operatives have been employed, and the negro has been found as capable of learning, within certain limits, as the white.

-When at length the obstacle of slavery was forever removed, as a result of the war of secession, step by step with the reccrery of the penple from the ruin then wrought, the interest in manufactures has advancerl. To-day there is perhaps, no community more anxious to diversify their pursuits, and to engage in manufactures, than the people of South Carolina. Abundant evidence of this is given in the exemption, by statute for ten years, from taxation of all capital invested in manufactures. by the encouragement that has been given to immigration, and particularly by the growth of manufacturing industries.

This will appear more clearly by an inspection of Tables A, B, and (', on the following page. 


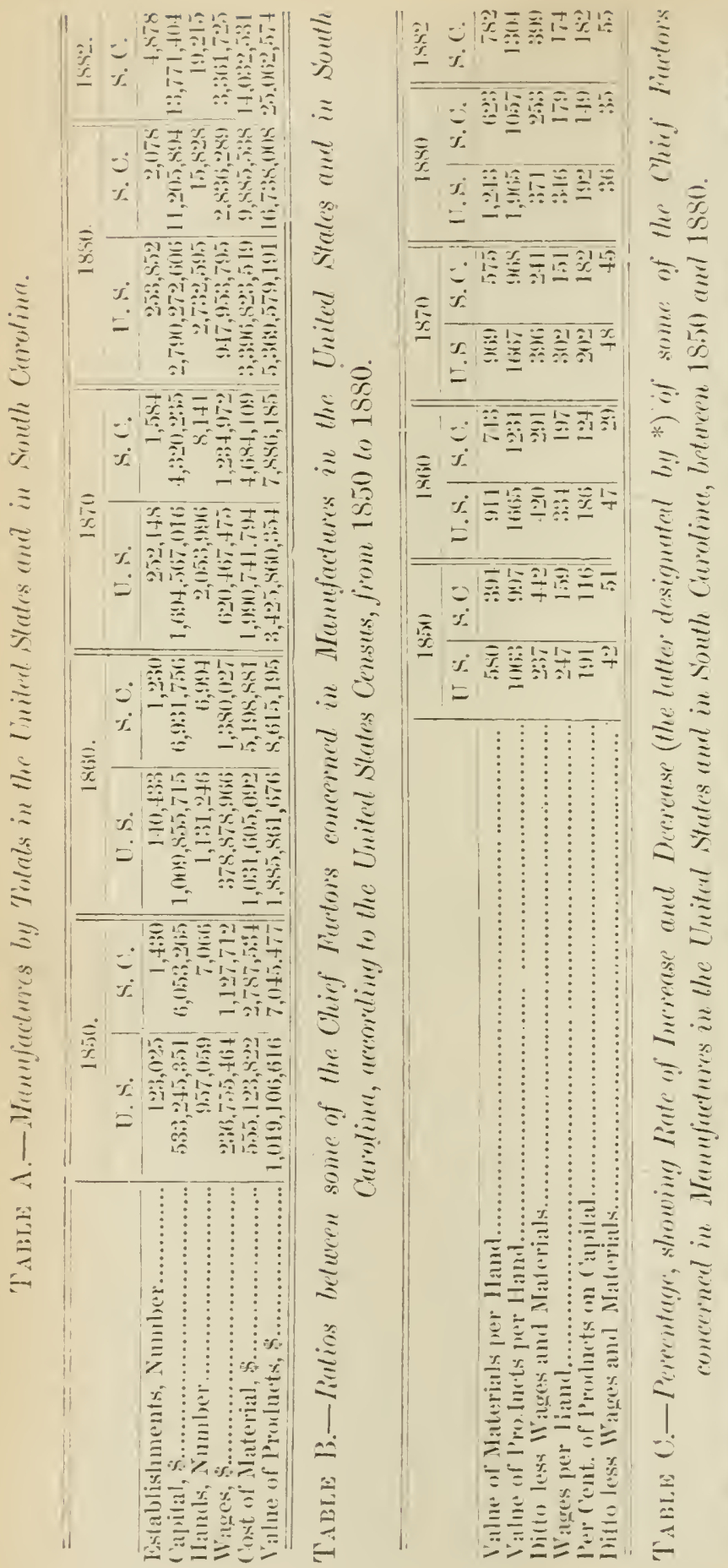


The growth of manufactures has been gigantic. In less than one generation there is an increase more than fire-fold of the capital sceking investment in these industries; three times as many hands are employed, and six times the value of raw material is converted to human uses. In spite of the much greater cheapness of all manufactured articles, the aggregate value of the products has increased five-fold. The amount of raw material that each hand manufactures is nearly (loubled in South Carolina, as well as in the United States, indicating the great adrance in skill and efficiency, together with the improvements in machinery. If on the whole the percentage of the nett products on capital show a decline, this is in accordance with a general tendency of calpital, where there are large accumulations, to accept lower rates of interest and of profits, while the steady improvement of wages is a sulject for gratulation, the greater remuneration of labor,.moving parallel with it: greater productiveness, and pointing to that great goal of all industrial systems, when each laborer shall be paid in accordance with the work he does.

It will be seen that the history of South Carolina for this period does not conform with that of the country at large. The asterisks in Table $C^{\prime}$ will show that during the first two decades there was an actual decrease in some regards, and no where rery marked gains in her manufacturing industries. This decline may in reality be said to have continued until the close of 1876 , as it was not until the restoration of civil government at that date, that the wonderful recuperation exhibited in these tables set in. As has been remarked, social institutions-now passed awayunfarorable to manufactures, checked their growth in Carolina during the decade 1850 to 1860 , immediately anterior to the war, notwithstanding it was otherwise a period of great material prosperity in Carolina, as it was elsewhere in the country. The war, as usually happens, was a great incentive to the development of manufactures in the Lnited States, and to some extent, in South Carolina. But here the destruction of property was ton great, and the pressure of the contest, and subsequently of military government, bore too heavily on every interest to admit of any decided material progress. With a remoral of this pressure the census of 1850 shows a remarkable change. Manufacturing establishments are increasing in numbers at a rate five times greater in South Carolina than they are in the country at large; in fact, the 494 new establishments in South Carolina represent nearly one-third of the total increase throughout the country. While such an increase does not inclicate the higher development of manufactures, where the tendency is to the consolidation of establishments, it is common to their early and vigorous growth, and shows plainly the direction which the activities of the population are 
taking. The rate of increase in capital and hands is nearly three times as great as in the whole eountry. The amount of material userl has more than doubled in South Carolina, while it lias only increased serenty per (ent. in the Cnited states, and this disparity would be greater if either the value- jrer $8140,000,000$ - of grain converted into flour and grist in the United States wer deducted from the materials used in manufactures, or the value $-\$ 2.5,000,000$ - of seed cotton conrerted into lint and seed lyy the gins of Carolina, were credited. The rate of increase in manfactured products of South Caroliua doubles that for the Lnited States, and the rate of increase in net products, that is, in products after deducting the cost of materials, is nearly three times as great. The impressions thus derived from the data furniwher by the L. S. Census will be strengthened by a consideration of those giren for 1852. The statement for this data is based for the most part upon the L. S. Census returns of 1850 , most of the items being taken directly from it. Other items have been added in consequence of the development of new industries not in operation at that date. And a careful renumeration of cotton mills and fertilizer factories has necessitated important adritions. These will be treated of in detail when the respective items are considered, and the following statement of manufactures in South Carolina in 1552, is given.

T.Able D.-Manufacturing Industries in Sonth Carolina in 1SS2.

\begin{tabular}{|c|c|c|c|c|c|c|}
\hline & 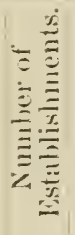 & 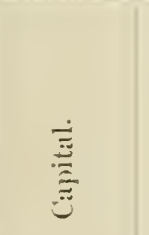 & 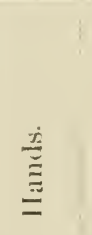 & 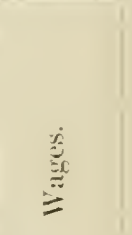 & 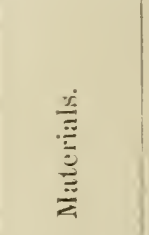 & 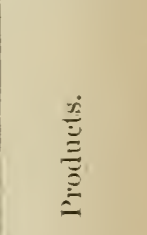 \\
\hline 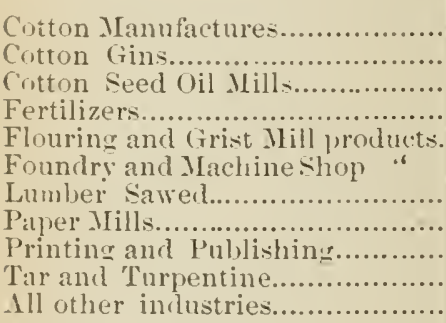 & 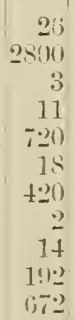 & 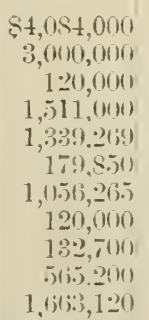 & 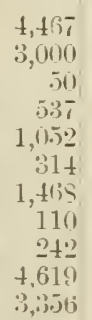 & 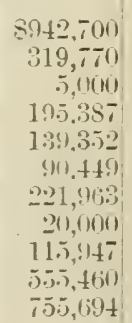 & 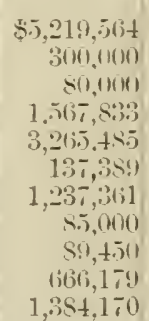 & 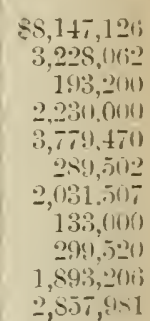 \\
\hline Total.. & 4 & $3,7-1,404$ & 9,21 & $3111,7.25$ & $14,1132,531$ & $825,06 \div, 574$ \\
\hline
\end{tabular}

In the Uniterl States the number of establishments engaged in

THE MANEFACTURE OF COTTON GOODS

constitute less than one-half per cent. of the manufacturing establishments. The capital employed is a little orer seren per cent. of the ag- 
gregate capital engaged in manufactures, the iron and sted business alone being larger. The number of hands is a little more than five fere cent. of all hands employed in manufactures, and somewhat larger than in any other manufacturing inclustry. The wages are four per cent. of the aggregate of wages paid in manufacturing, and about equal to the amount clisbursed for picking the cotton crop. The materials are three per cent. of all materials converted by manufacturing, and seren other industrics, to wit: flour and grist mill products, slaughtering and meat packiner. Iron and steel, lumber, sugar and molases, and men's dothing, consume more. The products are three per cent. of the aggregate products of manufactures; five industries, to wit: flour and grist ninills, shumghtering and meat packing, iron and steel, lumber, and foundry supplics, produce more. But cotton manufactures form the chief manufacturing industry in South Carolina, and their condition and growth from 1850 to 18S(), as shown by Cnited States Census returns, are given in the following table:

\section{TABLE E.}

\begin{tabular}{|c|c|c|c|c|c|c|c|c|}
\hline & 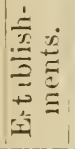 & $\begin{array}{l}\text { SPINDLES. } \\
\text { No. }\end{array}$ & $\begin{array}{c}\text { CAPITIL. } \\
8\end{array}$ & $\begin{array}{c}\text { Haxdos } \\
\text { No. }\end{array}$ & $\begin{array}{c}\text { W AGES. } \\
\&\end{array}$ & $\begin{array}{c}\text { Cotton } \\
\text { Consuned } \\
\text { Les. }\end{array}$ & $\begin{array}{c}\text { COST } \\
\text { OF } \\
\text { MITE'AL } \\
\$\end{array}$ & $\begin{array}{c}\text { Valte } \\
\text { of } \\
\text { Proncts. } \\
8\end{array}$ \\
\hline 1850. & .1094 & & $74,500,931$ & 92,286 & & $\begin{array}{r}288,5,58,000 \\
+t 65,0.50\end{array}$ & $34,83.5,(1.56$ & $65,501,65-10$ \\
\hline $\begin{array}{l}\text { so. Cal... } \\
1860 .\end{array}$ & & & & & & & & \\
\hline U.S.A. & 1091 & $5,25,-207$ & $98,58.5,269$ & 122,028 & $2:, 940,108$ & $42 \cdot 704,975$ & $57,24,5,594$ & $115,681, \pi i 4$ \\
\hline $\begin{array}{l}\text { so. Ca... } \\
* 1870 .\end{array}$ & - $I_{6}$ & 30.890 & $801,8 \div 0$ & & 123,900 & $5,9 / 8,061$ & & \\
\hline $\begin{array}{l}U \\
\text { S A A. }\end{array}$ & . 41.36 & $7,132,+15$ & $112,5+$ & - 135,360 & $31,23 \pi, 307$ & 409,1 & $89,3 ?$ & $141, \$ 91,7 \times 1$ \\
\hline $\begin{array}{c}\text { So. Ca... } \\
18 s 0 .\end{array}$ & - 12 & 10 & $1,069,600$ & 1,123 & 43 & & iio & 49 \\
\hline $\begin{array}{l}\text { U.S. A. } \\
\text { So (Cil... } \\
+18 s^{\circ} .\end{array}$ & $\begin{array}{r}756 \\
14 \\
14\end{array}$ & $\begin{array}{r}10,6.58,43.5 \\
82.334\end{array}$ & $\begin{array}{r}208,280,346 \\
2,776,100\end{array}$ & $\left\{\begin{array}{r}174,659 \\
2,053\end{array}\right.$ & $\begin{array}{r}42,040,510 \\
380,844\end{array}$ & $\begin{array}{r}750,34.3,981 \\
15,601,001.5\end{array}$ & $\begin{array}{r}102,206,3,34 \overline{7} \\
1,808,300\end{array}$ & $\begin{array}{r}192,0910,110 \\
2,845,-669\end{array}$ \\
\hline So. Ca... & 26 & $181,7+3$ & $4,084,000$ & 4,467 & 942,700 & $47,924,2,33$ & $5,219,564$ & $8,14 i, 126$ \\
\hline
\end{tabular}

Note.- The fignres given in the United States Census are stated in currency for the year 1870 ; they are here rednced to gold, which was at an average premium in that year of 2.5 .8 per cent.

tThese totals are from an enmmeration made by the Department of Agriculture of South Carolina in November, $18 s^{*}$, which is given in detail further on.

The marked and continuous decrease during this entire period in the number of establishments throughout the country at large indicates that the old established centres of this industry had already before its commencement attained their widest extension, and that thereafter the development of these enterprises depended rather on consolidating and enlarging existing mills, than on erecting new ones. Such a degree of 
maturity is not apparent in South Carolina, and the large increase in the number of cotton mills here since 1570 shows that there remains much suitable territory still unoccupied, and that the competition between the larger and the smaller mills is not yet so sharp, but that all may surrive and prosper.

Between 1550 and 1S60, while the capital and hands employed in cotton mills throughout the country show an increase, each of about 32 per cent., and the products an increase of 76 per cent., there was a marked decrease in all these regards in South Carolina, making it plain that, during that period of exceptional prosperity, there was no tendency in the State towarls the development of cotton mills.

During the decade of war and reconstruction, $1860-70$, there is a marked change. The percentage of increase, except only as regards the number of spindles, is notably greater in South Carolina than elsewhere. The capital employed in cotton manufactures increased $3: 3$ per cent., while in the United States the increase was only 14 per cent. ; the number of hands increased 26 per cent., against only 10 per cent. throughout the country at large. South Carolina consumed 19 per cent. more cotton in 1870 than in 1850 , while there was an actual diminution in the amount used in the Uniter States of 3 per cent.; the value of the products of the mills in reased 23 per cent. for the whole country, but in South Carolina this rate was nearly trebled, being 62 per cent.; the gain in the number of spindles was 36 per cent. for the whole United States, but only 13 per cent. in South Carolina. The mill owners here still lack the capital necessary to purchase a full supply of machinery, but they make no mean showing with what they have.

In the deade ending $18 S 0$ the gains are great everywere, and in erery particular, but in every particular the rate of increase is very much greater in South Carolina than in the country at large. The United States have 52 per cent, more spindles, but South Carolina has more than double, the increase being 133 per cent. The capital employed in cotton manufactures in the country at large is $S t$ per cent. more than it was in 1570 ; in South Carolina this increase rises to 159 per cent. The United States employ 28 per cent. more hands, while South Carolina furnishes work for 82 per cent. more. The value of the products of the cotton mills of the United States is greater than it was in 1870 by 35 per cent., but the value of the products of the Carolina mills has nearly quadrupled this rate of increase, showing a gain of $13 \bar{t}$ per cent. As to the raw material, the country at large consumer 183 pounds in 1850 , where it consumed 100 pounds in 1870, and for every 100 pounds manufactured in Carolina in 1870 there was, according to Mr. Atkinson, 328 pounds manufactured in 18s0. The fifteen and a half millions pounds of raw 
cotton manufactured in South Carolina in 1850 was more than four tines as much as the entire amount used by the eighty-seren cotton mills of the United States in 1S10, according to Mr. Alluert Ciallatin's report to Congress in that year. It is interesting to note that this greater work performed in $1 S S 0$ in Carolina engaged but little more than half the capital, half the number of hands, and only about three per cent. more spindles than are shown in 1810 by the enumeration of Mr. Gallatin.

Owing to the decline of manufactures in South Carolina between 15j0 and $1 S 60$, if the comparison were made between their condition in the last namerl year and in 1SS0, their progress would be more clearly marked. But, taking the whole period under consideration, the following results are exhibited. The United States has increased its spindles by 102 per cent., South Carolina by 166 per cent.; the capital engaged in cotton manufactures in the whole country has increased 179 per cent., in South Carolina the gain is 222 per cent.; the number of hands finding work in the mills is greater for the United States by SS per cent., in South Carolina by 101 per cent.; the value of the products of the cotton mills of the whole country is greater by 191 per cent. in 1850 than it was in 1550 , in South Carolina this increase is 246 per cent.; the increase in the annual consumption of raw material is 160 per cent. for the United States, and for South Carolina it is 215 per cent. Rapid as the derelopment of this industry thus appears for the country at large, the rate of progress is shown to be greater in each particular in South Carolina. Nor does this complete the statement.

In the fall of 18s2, the Department of Agriculture of South Carolina undertook an enumeration of the cotton mills of the State. The data obtained are exhibited in detail in the following table: 


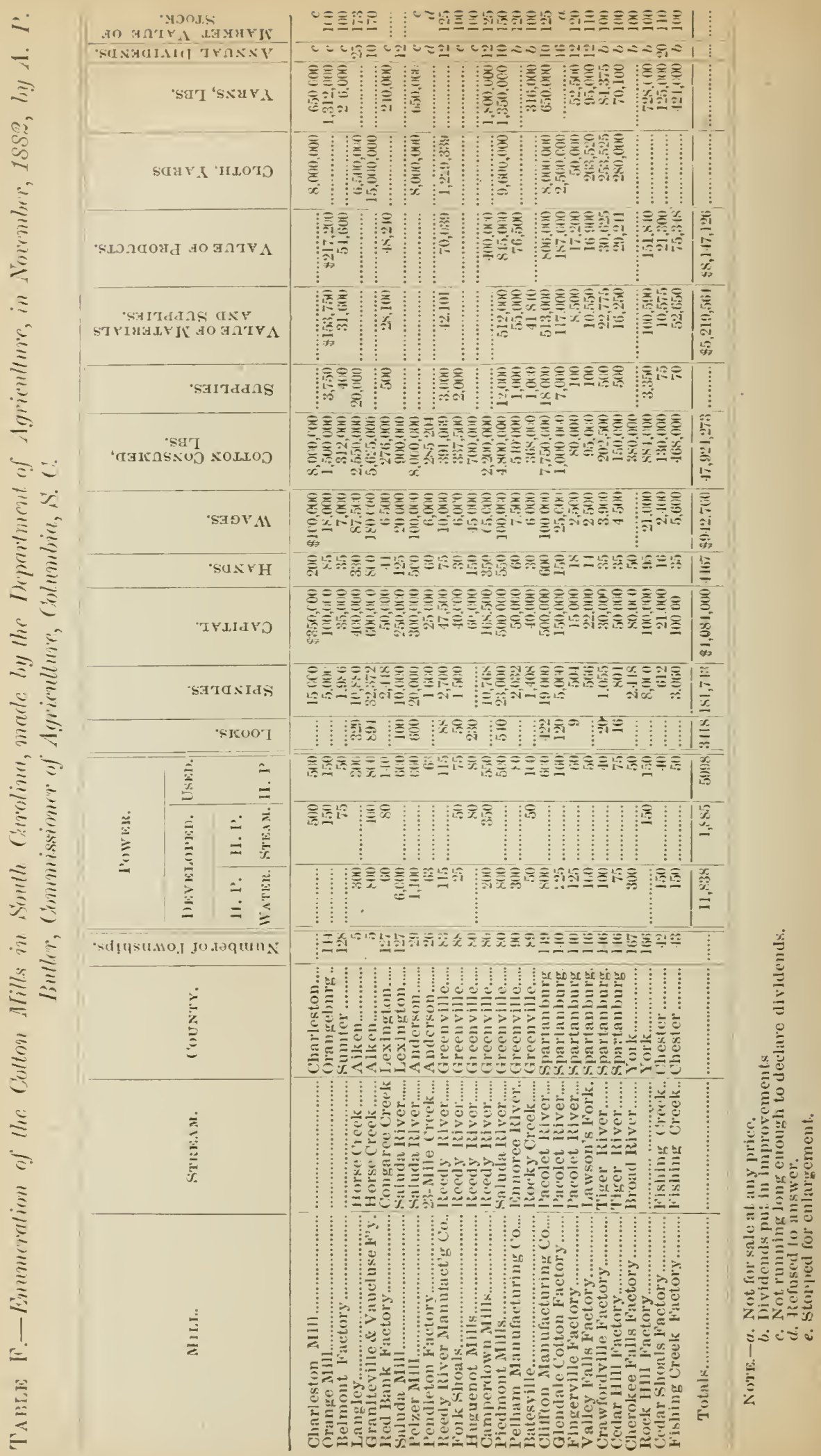


The returns are only partially complete, and it was found impracticahle to obtain answers in full, unless there were some law compelling the mill owner's to make them. No returns whaterer could be obtained from the Pendleton Factory, and those pullished some years since were used. The first nine columns are very nearly complete, and furnish important information. The aggregate of the other columms is given ly estinutes liased, in part, upon Mr. Edward Atkinson's statements regarding the mills in Sonth Carolina in 1580, and in part on deductions from the clata furnished by such mills as made complete returns to the Department of Agriculture. Looking from this enumeration in 1SS2, backwards to the condition of the cotton manufactures in South Carolina in 1550, it will he seen that the number of mills has increased forty-four per cent.; the number of spindles is nearly six-fold greater, showing an increase of four hnudred and eighty-eight per cent.; the capital employed is nearly firc times as much, showing an increase of three hundred and seventy-six per cent. ; there are more than four times as many hands, their increase being three hundred and thirty-nine per cent.; the ralue of the products has increased eight hundred and sixty-seven per cent., and the amount of raw material annually consumed, nine hundred and seventy-four per cent. Nor loes this movement seem as yet to have approached a limit. There is scarcely a town above the lower Pine Belt, that is, in the upper twothirds of the State, in which the erection of one or more cotton mills is not being actircly agitated; at the last session of the Legislature, in December, 1582, nine new companies for the manufacture of cotton were incorporated, and several of these will commence operations on the present cotton crop. It would seem that this State, which was a pioneer in the cultivation of cotton, is about to assume the position of a cotton manufacturing State on a large scale. Already the forty-seren millions of pounds of raw cotton required by the spindles in operation in this State, in 1983. is more than the average consumption of the whole United States from 1525 to 1530 , which is placed at 129,954 bales per anmum, averaging less than four hundred pounds. Alrearly also, the value of the proincts of the mills in this state exceeds the cost of the cotton goods consumed ammually within its borlers, assuming this to be about the arerage consumption per capita of the whole country. For if the value of the products of cotton manufactures in the United States $(\$ 192,0.00 .110)$ be athed to the vilue of the yearly imports of cotton stuff; $(\$ 29,922,000)$ and from this sum the ralue of the rearly exports $(\$ 9,981,000)$ be deducted, the remainder will represent the domestic consumption, and will be about \$ 4.2.2 to each inhabitant of the country. On this basis the consumption o. cotton gools in Curolina would ba less than $\$ 5,000,000$ per annum, and the mills ruming in 1533 are expected to yield a proluet excesding 
હ९,000,000. Again, the amount of raw cotton mannfactured in Carolina in 1953 is about equal to the total quantity of that material imported into Great Britain in the year 1800 , the import for 17 se being given as forty-three millions pounds, and for 1801 as fifty-six millions pounds. The rapid development taking place in the cotton manufactures of south Cirolina is not exceptional. It is almost entirely within the present century that this industry has had its growth, and "taking into consideration the capital invested, the labor employed, the genius it has waked, and the honol's with which that genius has been crowned, the endless stam marine, the number of merehants, bankers, elerks, and sailors engagerl in its world-wide distribution, it may be said that the cotton manufacturing industry fills a larger space in the commercial activity and greatness of to-rlay than any other, perhaps, than all the other manuficturing industries of the world combined." "The value of the products of the cotton manufactures of the world for $18 \$ 0$, are estimated at $\$ 1,3+5,310.000$. Of this enormous product furty-one per cent. comes from the United Kingdom of Great Britain, serenteen per cent. from the United States (which ranks next by more than double the quantity produced by any other nation), and forty-two per cent. from all the other countries of the world. And yet, if the natural and reasonable wants of mankind in the matter of cotton goods are to be supplied, this industry is only in its infancy. Learing ont of view all the numerous and important human uses that cotton goods subserve, and the new purposes (such as roofing, de., (tc.,) to which they are being daily applied, if the matter of underwear alone be considered, it is computed that the eleanliness, comfort and health of a human being will be increased by an anmual consumption of cotton cloth up to $\$ 20$ at eurrent prices. But the greatest consumption of cotton goods in 1850 in Great Britain and Ireland was only $\$ .5 .71$ per capita, having risen from $\$ 3.47$, in 1853 . In the United States it is twenty-one per cent. less. Taking the population of Europe, including Russia and Turkey, and of North and South America, the ammal product of the world would supply only 8.2 .95 per eapita. China and India chiefly supply themselves with cotton goods, manufactured by hand looms. The former country produces annually by this primitive and costly method, 7,300,000,000 yarks, an amount almost equal to twice the total annual export of cotton piece goods from Great Britain. If their population be inclurled, the present products of the cotton mills of the world would only furmish goods to the value of $\$ 1.20$ per capita. If finally, the populations of the rest, of Asial, of Africa, and the islands of the sea be included, and the entire product of the world's cotton manufactures were divided out to its inlabitants, there would be only a value of ninety-three cente for each. IIow far and how fidst the civilization of 
this age will open up markets for these products is one of the great questions of the day, and one of paramount importance to the Southern States which produce seventy-six per cent. of the raw material on which this stupendous industry is based, a supremacy they are likeh to maintain in the future, as they have in the past, whatever the course of crents may be. It would seem to follow from these facts that the apprehonsions. sometimes expressed that cotton minufactures and cotton culture are being overdone is idle and without foundation, "in view of the hundreds of millions of people, with an increased ability to purchase, which every new invention makes, who are awaiting the advent of civilization to arail themselves of more perfect appliances for their daily wear."

What is of immediate interest here, is to ascertain the facilities offered by the character of our manufacturing operations, and the conditions that surround them for their successul competition in the markets of the world with those of other countries. Some of the more important of these details in cotton manufacture in South Carolina and in the Tniter States, as deduced from the U.S. Census returns, are exhibited in the following table:

\section{TABLE G.}

\begin{tabular}{|c|c|c|c|c|c|c|c|c|c|}
\hline & & \multicolumn{2}{|c|}{1880.} & \multicolumn{2}{|c|}{1570.} & \multicolumn{2}{|c|}{1860.} & \multicolumn{2}{|c|}{1850} \\
\hline & & $\begin{array}{l}\dot{u} \\
\dot{v} \\
\dot{0}\end{array}$ & $\begin{array}{l}\dot{\Delta} \\
\dot{0}\end{array}$ & $\begin{array}{l}\dot{4} \\
\dot{j} \\
\dot{\Xi}\end{array}$ & $\begin{array}{l}\dot{\varepsilon} \\
\dot{\vec{x}}\end{array}$ & $\begin{array}{l}\dot{j} \\
\dot{0} \\
\dot{0}\end{array}$ & $\begin{array}{l}\dot{3} \\
\dot{\mathscr{J}}\end{array}$ & $\begin{array}{l}\dot{1} \\
\dot{2} \\
\dot{2}\end{array}$ & $\begin{array}{l}\dot{0} \\
\dot{0} \\
\dot{\delta}\end{array}$ \\
\hline Spindles per hand............................ & No. & 61 & 40 & 50 & 30 & 42 & 34 & & \\
\hline Pounds cotton consumed per liand..... & Lbs. & +29.5 & $760+2$ & $30: 0$ & 4324 & $2+(i i)$ & $4+64$ & $: 310: 2$ & $448 ;$ \\
\hline Pouncls cotton consmmed per spindle... & Llis. & & 177 & 57 & $13: 3$ & So & 125 & & $\ldots \ldots$ \\
\hline Yalue of products per hand ............... & $\$$ & $109: 3$ & $1+10$ & $10+0$ & $10 \$ 9$ & $9+8$ & 800 & $7(1 !)$ & S:2:3 \\
\hline 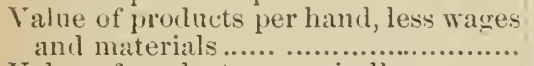 & 8 & 273 & 344 & 157 & 274 & 283 & 188 & & \\
\hline Yalue of products per spindle ............ & 8 & 18 & 35 & 19 & 35 & 22 & 20 & & .... \\
\hline $\begin{array}{l}\text { Talue of products per cent. on capital.. } \\
\text { Value of products per cent. on capital, }\end{array}$ & p.c. & 92 & 104 & $1: 6$ & 114 & 117 & Sy & $8 \overrightarrow{7}$ & 约 \\
\hline less waves and materials................ & p. c. & 22 & 25 & is & 28 & 34 & 19 & & \\
\hline $\begin{array}{l}\text { Talue of products per pound cotton } \\
\text { used .......................................... }\end{array}$ & ets. & 25 & 18 & 34 & 25 & 27 & 17 & 202 & 18 \\
\hline 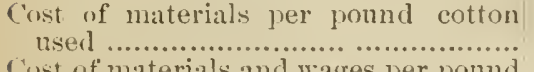 & cts. & 13.7 & 11.6 & 21.7 & 12.8 & 13.5 & 10.8 & 12 & 6.6 \\
\hline $\begin{array}{l}\text { Cost of materials and warges per pound } \\
\text { cotton used................................. }\end{array}$ & ('ts. & 19.2 & 14. & 29.4 & 17.1 & 19.2 & 18.9 & & \\
\hline Wates per liand ............................. & 8 & 240 & 18.5 & 230 & $1 \mathrm{si}$ & 114 & 1 is & & … \\
\hline
\end{tabular}

If the number of spindles run per hand be considered, it would appear that the effectiveness of the operatives in Carolina was not so great as in the country at large. In this particular, if the comparison be made in 1590, it will be more farorable than if made in 1580 . The reason for 
this is quite simple, in the great increase in the number of hands emploved, drawn almost entirely from the immediate neighborliood of the new mills, many inexperienced ones have been brought in, and are being taught. Nevertheless, South Carolina shows forty spindles to the hand, while in Ciermany there are only thirty-nine, in France twenty-four, and in Russia, ninetecn. Great Britain boasts, it is to ue, of eighty-three spindles to the operative, and in this respect she is further ahead of the United states than the latter is of South Carolina.

It all times South Carolina exhibits a marked superiority in the numher of pounds of raw material manufactured per hand, while the cheaper products of her mills do not compare with the more delicate and costly fabrics of England and the North, they are suited to a far wider market, and, therefore, furnish a safer and more stable basis of operations. This view gathers force when it is observed that the gross value of the products per hand in Carolina is greater than eleewhere, even than it is in Great Britain, where it is only \$1,169 per hand. (See Cotton Goods Trade of the World, Govermment printing press, Washington, D. C., 18s1.) It will be strengthened also by noting that the value of the net products per haud, that is of the products less the cost of materials and wages, is greater in Carolina ; and further, that these products, both gross and net, give a larger percentage on the capital employed in Carolina than in the country at large.

The most striking advantage exhibited by the census in the mamufacturing operations of Carolina over those of the country at large is in the much lower cost here of materials, a difference in faror of the Carolina manufactures of from eight and nine-tenths cents per pound of cotton consumed in 1570 , to two and one-tenth cents per pound, according to the (arefully prepared statements of Mr. Edward Atkinson, of Boston, in 1880. Computed from the data furnished by the report of the Cotton Goods Trade, above referred to, each pound of cotton consumed by the English manufacturers in 1850 , cost 14.8 cents, or 3.2 cents per pound more than in Carolina. These differences in the cost of raw material between the Carolina cotton fields and other places may need some qualifications in view of the fact that manufactured material, as yarns, more costly than raw cotton, may be included among the materials consumed in other places. For England, at least, such corrections must be very small, as the total value of the yarns imported in 1850 only exceeded by a small fraction one per cent. of the cost of the imports of raw cotton, and are probably more than offset by the cheaper, though poorer materials obtained from India. It is not easy to form even an approximate estimate of the actual diflerence between the cost of raw cotton to the manuficturer in Carolina and to the manufacturer in Enrope. The rates of 
freight and insurance are probably far from being the largest items. There are the commissions for buying and selling, often more than once; the charges for hauling, weighing, storage, drayage, wharfage, conpressing, mending; the loss by shrinkage of rarious sorts, by sampling, by damage from dirt and damp during transportation, by injury in compressing, by stealage, by the deduction of a heary tare, which is hearily discounted by the foreign purchaser, and which, fall as it may at first on the producer, is paid finally by the consumer of cotton goods. Then there is other tribute paid in various forms to the vast army of middlemen who exact every iota the material will bear during its passage between the planter and the manufacturer. And above all these, the robber hordes of speculators, increasing daily in numbers, hover over the trarle for the opportunity to plunder it affords. To illustrate the confusion worse confounded with which this last named class involve those transactions, it is sufficient to, mention that the speculations in 1S\$1-\$2 caused the price of American cotton to be lower during the whole year in Liverpool than it was to American spinners, and that with a nearly uniform supply and demand the price was forced up three cents per pound, or thirty per cent., in the summer of 1852 . Water can not be made to run up hill without much work, and this reversal of the natural order of things in the cotton market could have been effected only at immense cost. And this much is certain, that whoever might pay for it, or gain by it in the first instance, ultimately it must all be charged in the cost of cotton goods, and operate as an obstacle in the development of this trade. The cotton mills in Carolina find it largely to their interest to purchase directly from the farmers, and several find it profitable to have gins for cleaning the seed cotton, which they afterwards purchase for their own consumption.

In the matter of wages the advantage is once more with South Carolina. And this arises partly from the very nature of things, for in a genial and healthful climate like this, human life being easier, must, under other like conditions, be more abundant. The labor, too, has many admirable characteristics in ardition to its cheapness. The Anglo-Saxon population here, anxious to escape from field labor, possesses all the intelligence and good qualities exhibited by that race whererer it has been Americanized, beside being, as yet at least, unaffected by those Communistic notions that have interfered so profoundly with the effectiveness of such labor in many places. If a greater extension of manufacturing operations should make larger demands for labor than the native white population of the State could supply, besides the inducements such a state of things would hold out to immigrants, there is the negro population, which, as the whites passed on to the higher operations 
requiring greater skill, might be brought in for the simpler kinds of work. The experience of the Saluda Mills with colored operatives, already referred to, shows what may be done in this line. At any rate, things will change very much in South Carolina before manufacturers here will ask for a tariff of 40 per cent. on their products to protect them from the eheap labor of other countries, or cease to demand its remoral in order that they may avail themselves of the new inventions and cheaper machinery of other lands.

The other natural conditions which surround manufactures, such as the available water powers, and cheap land and building material of stone, brick and wood in South Carolina, have been referred to in detail in the preceding chapters of this book. It only remains to mention that, with the opening up of the great coal and iron fields of Alabama, now in rapicl progress, these materials will also be supplied here at low rates. Mr. MeCaughrin, President of the National Bank of Neyberry, and late President of the Columbia and Greenville Railroad, says that when the Atlanta and Birmingham Railway is opened this fall, coal from that point will be delivered in this State for $\$ 4.50$ or less per ton.

With cheaper land and with cheaper and better raw material than ean be had elsewhere, and with cheaper and, as it would appear, more reliable and effective labor, and with every advantage in the other natural conditions of the environment, it follows that the future derelopment of cotton manufactures in South Carolina will be limited alone by the amount of capital seeking investment in them. Although the laws which regulate the movements of capital are perhaps as little understood as those which compel the migrations of men and animals, they are doubtless as absolute as those whieh govern the diffusion of gases. And it may be assumed that when the tendency of production, prevalent everywhere, in opulent countries, and especially in old established centres of manufacturers, to reach a minimum rate of profits, is no longer checked by the importation of cheaper raw material and food supplies, or by new inventions, cheapening still more the cost of production, or by commercial revulsions, to all of which there is a limit, but one resource will be left to capitalemigration. This must come in the eycle of events, and, with the amazing rapidity with which history reaches maturity in these clays, it may, in the matter of cotton manufactures, come soon. In view of the adrantages offered by South Carolina, above detailed, a comparison of the value of factory stocks and the rate of dividends exhibited by the mills in Carolina, as shown in the enumeration furnished by the State Department of Agriculture, with those of other eountries, would indicate that (ven now some such morement would be profitable. Take for example this statement from the United States Consul at Manchester. Englund, 
January 12th, 1SS1: "Out of 12.j cotton spinning and manufucturing companies, mentioned in the Oldham C'hronicle, one paid a dividend for the last quarter of 2 per cent., one of $2 \frac{1}{2}$ per cent., two of 4 per cent., six of five per cent, one of $5 \frac{1}{2}$ per eent., two of $S$ per cent., five of 10 per cent., while 104 paid no dividends, and, in a great majority of cases, made losses, more or less serious." If these 104 mills were remored to the healthy hills of granite along the Catawba, the Broad, and the Salurla rivers and their tributaries in this State, they would escape the close competition which threatens their destruction. Such an increase of numbers here would facilitate manufacturing operations, and it would be long years hence, if ever, before their productions would reduce their profits in the wide markets of the world. Always there, would rest with them the vantage that first comers hold, which is now held against then.

COTTON GINNING

is one of the most important industries in South Carolina, Lut it has never received separate mention in the returns of the United States Census. Its omission in the list of manufacturing industries, which includes the grinding of wheat and corn into flour and grist, depends rather upon some arbitrary definition of nanufactures than upon any essential difference in the industries themselves. In the absence of a general enumeration of the gin houses of the State, the following estimate, based on partial enumeration, is offered as an approximate statement in regard to this industry :

\begin{tabular}{|c|c|c|c|c|c|c|c|c|c|c|}
\hline \multirow[b]{2}{*}{ 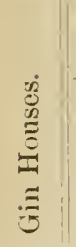 } & \multicolumn{4}{|c|}{ Power Eirloyed. } & \multirow[b]{2}{*}{ Capital. } & \multirow[b]{2}{*}{ Hands. } & \multicolumn{2}{|c|}{ Expenses. } & \multicolumn{2}{|c|}{ Prodect. } \\
\hline & $\underset{\Xi}{\ddot{\Xi}}$ & 峁 & 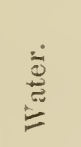 & ت્்ّ & & & Warges. & $\begin{array}{l}\text { Repairs, } \\
\text { supplies, } \\
\text { Insurance. }\end{array}$ & $\begin{array}{l}\text { Bales } \\
\text { Cotton. }\end{array}$ & $\begin{array}{l}\text { T'ins } \\
\text { seed. }\end{array}$ \\
\hline $2 S 00$ & 5967 & 5661 & 2295 & 13,923 & $\$ 8,000,000$ & 3000 & $\$ 319, \pi 70$ & $\$: 303,369$ & $.716,498$ & 258,245 \\
\hline
\end{tabular}

Before the subdivision of the large plantations into the numerous small farms of the present day, nearly every cotton planter had a gin house of his own. Now, however, there is not more than one gin house to each thirty-two farms growing cotton. From this it has resulted that cotton ginning has become a business, in a large measure, separate and distinct from cotton growing. In the reorganization of Southern industries on 
the new basis, it was first thought that movable ginneries would mect the necessities of the case, and for a year or two traction engines with ginning equipments went through the country for this purpose. It was found, however, that they would not answer. The small cotton famers did not have the facilities for storing their cotton until the whole or eren a large portion of their crop was gathered; the exigencies also of their financial condition made it necessary for them to put their cotton in the market without delay after it was gathered. For these reasons the portable gins were obliged to change their location for nearly every bale they ginned, which was so expensive that, after a fair trial, they were abandoned as unsuitable. Immediately, in addition to the gin houses established of old upon the plantations, new ones were erected by country merchants and others as toll gins, expressly for the purpose of supplying the wants of the new growth of small cotton producers. The competition for custom among these new establishments greatly reduced the charges for ginning; formerly the seed was given for the ginning, now bagging and ties are supplied in addition where the seed is taken. The moner charges for ginning were at first $\$ 1.00$ per cwt. of lint ginned, or $\$ 5.00$ a bale, now it has been reduced to $\$ 3.00$, and even as low as $\$ 2.00$ a bale, the average price being about $\$ 2.50$ per bale.

Unfortunately, with the reduction of the charges for ginning, there has been a great falling off in the quality of the work done. There is usually a cheap steam engine of five to eight horse power, the gins average forty to forty-five saws, and the object is to prepare the cotton as rapidly as possible for their customers, to take the lint from the seed as close as practicable, and not to reduce the weight of the product by separating too much the dust and motes from the lint. The consequence is that the quality of the staple is much poorer, not only on account of the motes and dust not removerl, and of the short fibres which the close ginning of the seed mixes with the longer ones, but also by the knotting, and even breaking of the fibres, owing to the high speed with which these small gins are run, in order to turn off each customer's work with the least delay to him possible. As a rule, a forty saw gin is made to give ten to twelve bales, or about 5,000 pounds of lint per day, whereas to separate the fibres, without injury, from the seed, four bales, or 2,000 pounds lint per day, is the most that was done when horse power's were used before the introduction of steam engines.

The deterioration of American cotton, which has recently-been much complained of, both at home and in England, is partly due to the causes alove mentioned. Other causes co-operate to promote this evil. The small and decreasing size of the farms learls more and more to the intermixture of cotton of different qualities. First, because where less than 
one bale is produced on the farm it must necesarily be mixed with eotton grown elsewhere, and most likely of different quality. Second, if the farm produces as much as one bale, this is gathered at successive jickings, which effect a differenee of quality. And third, the necessities of the small farms compel them to dispose of much of their cotton in the seed, to country storekeepers, which is, perhaps, the most frequent cause of mixture. In these regards the situation approaches that which has occasioned the inferiority of India cotton. Dr. Watson Forbes, in his elahorate report on cotton gins, published by order of the Secretary of State, for India. 1879 , states the chief sources of difficulty as follows: "Tlie smallness of the farms in India, as compared with the American cotton plantations, is at the root of the eril. In India there are but few ryots who could produce, at a single picking, as much eren as one bale of cotton; each bale being made up of cotton produced by several ryots. It is clear that under such circumstances the difficulty of producing cotton of uniform quality must be immensely increased." The gravity of this evil will be appreciated from Dr. Watson Forbes' statement that formerly" "the lows of cleaning the impurities from India cotton was four times as great as for American uplands." Nor is the crop so well handled now as formerly in picking. The laborers being paid by the hundred weight, find it to their advantage not to separate the dirt and trash from the cotton; indeed, it is not uncommon for them to add water and sand to increase the weight, a practice very apt to escape detection where the baskets and sheets are weighed in the twilight, at the close of the day's work. The sheets on which the cotton is emptied during the day by the pickers were formerly kept open and exposed to the sun's rays, so that the dews on cotton gathered early in the morning might be thoroughly dried out; now the sheets are kept carefully covered, so that the laborer may escape loss from evaporation. The loss resulting is not only in the loss of weight, but in the injury to the staple consequent upon the storing and ginning of damp cotton. The waste of cotton incurred in preparing it for spinning averages thirteen per cent., aind raries from five to twenty per cent. Although this loss apparently falls on the manufacturer, such is by no means the case, for they discount it, adding thereto a large margin, in the price paid to the producer. Mr. Edward Atkinson, a practical manufacturer, estimates that careful preparation of cotton would advance its price one cent per pound. This woukl amount, in South Carolina, to a clear gain of more than two and one-half millions of dollars. annually, a sum nearly sufficient to replace, with molem conveniences, all the gin houses in the State.

It therefore becomes a matter of much importance to determine how in the present transition state of the industrial organization of the State, so considerable a saving in this one inclustry may be effected. 
The loss or waste sustained in spinning ginned cotton arises from the presence in the lint of foreign substances, such as sand, dust, and leaf, or of motes (which are light immature seed), of sliort fibres, of fibres erimped (1) knotted, termed nips, and of fibres that have been strained and weakoned by buing pulled with too great or surdden a force from the seed.

The adventitious impurities, such as sand, lust, and leaf, are to be remedied by careful handling in picking and storing, and they may be in large measure removed by passing the cotton, before ginning, through machines known as openers, whippers and threshers, where the cotton, while violently agitated, is exposed to a current of air. At an early period this was accomplished by subjecting the cotton to the vibration of cord fastened to a large wooden bow, and cotton known as "bowed cotton," or "Georgia bows," enjoyed a high reputaticn in the market. Formerly these machines were to be found in nearly every gin house, and although several excellent patterns of these machines are still offered by the makers of agricultural implements, their use has been almost entirely abandoned. The plea being the loss in weight, which is of the same shortsighter character as the notion that the out-turn increased by the use of the heaviest bagging and ties, not reflecting that all this tare is estimated and overestimated by the purchaser, and deductions made therefor in the price.

Motes are separated by their greater specifie gravity from the lint. The volume of air passing to the gin brush, which sweeps the lint through to the lint room, is regulated by a movable mote board. In most gins the proper arrangement of the mote board effeetually separates the motes from the lint. Many of the patrons of toll gins, however, object to the loss in weight oceasioned by the removal of these impurities, a loss which, owing to the bulk of the loose motes, is more apparent than real.

Short fibres are, to some extent, a necessity, as both short and long fibres oecur on every seed, The remedy is a careful seleetion of planting seel having the most uniform length of tibre. Mr. Ephraim Clark, a distinguished selector and perfector of long staple seeds, pays special attention to this, using a comb to straighten out the fibres on the seed, so as to ascertain aceurately the degree of uniformity before selecting them for planting. Gimning first for the long, and a second time for the short fibres mitigates the evil, as did the old-fishioned lint room in use before the introduction of condensers, where the different lengths of fibres were separated by being blown greater or less distances as they fell into a large room. The prolifie source of the trouble is, however, the mixing of different lots of cotton, those grown from different seed, or on different soils, or even opening at different periods of the same scason, all which 
circumstances would materially modify the eharacter of the fibre. This cause depending on the small and lessening size of cotton farms might be counteracted by diminishing the size of the cotton bales, as uniformity could be more easily obtainerl with packages of one hundred pounds than with those of five hundred pounds. The tendeney, however, is towards making the packages larger.

Cotton samplers are in the habit of speaking of "gin eut" cotton, but except with wet cotton, or where very great speed is employed, the cutting or breaking of the fibres is not a frequent occurrence. The saw gin does not saw or cut the fibre from the seed, and in so far is misnamed. The teetl of the so-called sars are in reality small hooks, which, in passing through the seed cotton, eatch the lint and pull it through the bars or ribs of the feed hopper, placed so close to each other as to prevent the passage of the seed. These teeth, or hooks, pass through a rapidly revolving brush, that cleans them of the lint and casts it out by the draft of air its rotation causes, on the other side of the gin. In Whitney's first gin these hooks were made of wire, which, there being no wire at hand, Whitney, then a law student, drew out for himself. The idea of a notehed iron plate, or so-called saw, Whitney is thought to have borrowed from a Mr. Bull, of Georgia, who was experimenting there at the same time in devices for separating the lint from seed cotton. The hooks, if properly formed, never cut a fibre, nor if moving at the proper speed, are they likely to break one. The fibre is spindle shaped, being largest and strongest in the middle, and tapering towards the ends, so that when canght by the hook it gives way at this smaller and weaker point of attachment to the seed, and is separated from it without being broken.

Crimped and knotted fibres, or nips, are avoided in all good gins by regulating the speed at which the teeth strike the fibre, and the relative speed of the brush to that of the saws. The same remark regarding speed applies to the weakening and straining of the fibres while they are being detached from the seed. Of the two classes of gins in use, those which pinch and beat the seed from the lint, as the various forms of roller gins do, and those which simply pull the lint from the seed, as the saw gins do, the former are much more liable to produce the class of injuries here referred to than the latter. The loss in the best samples of roller ginned long staple, as tested by the Willimantic comber, at the Atlanta exposi. tion, was frequently as much as twenty per cent., due to injury of the fibre, exclusive of motes, seed, dust and other foreign matters.

It remains to mention another hindrance to the better handling of eotton. This is a more intelligent demand on the part of purchasers and consumers for the best article to be harl. Such a demand, if made in definite terms, would do much towards creating the supply. That it is 
nt ma le if llue larg ?y, peria ss, to the remotenzs; of munfarturers from the producers of cotton, and to the large intervening class of buycrs, sellers, and speculators, and middlemen, who prosper more by "rendering darkness visible" than by revealing the interest of these two mreat classes of laborers, in their true light. 'The following extract from a letter of a large manufacturer of cotton goods will illustrate this. speaking of his former experience of sixteen years in selling Florida long staple cotton, he says: "Some of it was saw ginned and some of it was roller gimned. The roller gin retained all of the trash, and a good many of the seed. The saw ginned was free of seed, and in every way cleaner than that ginned on the roller gin. Still that ginned on the roller gin sold for five cents to six cents per pound the highest. I argued the point with the buyers, affirming that the saw ginned was not cut, and was really the most valuable, on account of the freedom from seed and trash, and proved it to them. Treir only reply was, "I think you are right, but my orders are to pay so much for that ginned on the roller,' and they acted as per orders. I wrote to my customers these facts. Their objection to the roller was that it was too slow, and they fell on the plan of usingthe saw gin, and after ginning to pass the lint through a whipper. The whipper gave it the appearance of having been ginned on the roller gin (except the seed and trash), and buyers took it as roller ginned, and paid a ligher price for it."

The statement above given in the table regarding the gin houses in South Carolina includes buildings, gins, feeders and condensers, and the presses used for baling the cotton. These are mostly hand lever presses. 'They are not so powerful as the old wooden pin serew, moved by horses attached to levers thirty feet in length. 'The result is that, while the average weight of the bale has increased from 350 pounds to 450 pounds and 500 pounds, it has increased also in size in about the same proportion. So that the arerage bale now occupies about thirty-seren cubic feet of space. At the shipping ports the size is reduced by placing it under a powerful and costly hydraulic compress, which crushes it into about seven cubic feet, an operation that by no means improves the quality of the staple: removed from the repress the bale swells up, becoming rounded in form, so that when packed in layers above each other they actually occupy, counting the spaces botween the rounded sides, nearly twenty cubic feet each. The Dederick perpetual press in use at a few gin houses apparently removes all these difficultics. It compresses the original package, with the power in use and less hand labor, into square bales of such density that from twelve to fourteen tons, according to the powrer of the press used, may be put into a grain car. The bales are compressed in sections, a section at a time, so that no portion is sub- 
jected to undue pressure, as must always be the case where the pressure is applied at one time to the whole bulk of the bale. That the staple thus treated is notinjured may be inferred from a statement made by the Willimantic Company regarding high-priced sca island eotton, which it has always been thought could not, without great loss, be packed in any press yet devised. The treasurer writes of a bale compressed by this method tested in this mill: "The cott'n so eompressed makes less waste at the pieker, in the eards, and in the combing machine."

From these facts it appears that ino new inventions are essential to overcome meehanical difficulties in the proper handling of cotton to secure the best quality of staple, if the methods already devised are employed with intelligence and skill. The old gin houses, with their laborers skilled by a lifetime of careful training under intelligent direction, have passed away with the plantation system. Portable ginneries, with skilled labor, have been tried and have been found unsuitable. Numerous small toll gins, where the quantity, without consideration as to the quality, of the work done, is the object, now occupy this fielc. The improvement and development possible and demanded for this important industry can only be looked for in the consolidation and enlargement of gin houses. This raises the question whether the conditicn; are farorable for the enlargement of these establishments. The most important of these conditions is the production of a sufficient amount of cotton to afford full work within such a distance as would admit of hauling seed cotton by wagon to the gin. In the partial enumerations on which the estimates as to the statistics of gin houses is here based, the average distance that eotton was hauled was 1.4 miles; the maxinum distance seed eotton was hauled was eight miles, and for the largest purely toll gin the distanced areraged four miles. It may be therefore considered that, if sufficient inducements were offered, an improved gin house might eommand the ginning within a radius of four miles. The production of cotton for the whole State is about seventeen bales per square mile, which for an area having a radius of four miles, would be about eleven hundred and seven bales. But if the three principal cotton regions, the Upper Pine Belt, the Red Hill, and the Piedmont Region, which produce ninety per cent. of the eotton crop of the State, be taken, the average is found to be about twenty-seven bales per square mile, which gives seventeen hundred and ninety-five bales for the area indicated. The arerage size of the enumeration districts for the census of 1880 , for the regions above specified, was about sixty square miles. Of these two hundred and seventy districts, seventy-two, or more than onefourth, produced between two thousand and three thousand bales of cotton each, and twanty between three thousand and four thousand. It 
follows, therefore, that there are at least seventy locations where more than two thousand bales of cotton are grown: within a maximum distance not exceeding four miles. A two-horse wagon would transport at least four bales of cotton in the day over this distance, so that the propinquity would suffice. The buildings proper for a ginnery, turning out in the three ginning months two thousand bales of cotton, would not cost $\$ 2,000$. Three fifty saw gins, with feeders and condensers, would cost \$650. A Dederick cotton press, $\$ 1,000$; shafting, elevators and belting, \$3.50; for the power, whether water or steam, $\$ 1,000$ would suffice. In all, an investment of $\$ 5,000$, against an average cost of $\$ 1,074$ for the gin houses actually enumerated, having an average capacity of six bales a day. The expenses of running such an establishment would be: for supplies, including wood, if a steam power were used, $\$ 100$; for wages, one mechanic at $\$ 2.00$ a day, $\$ 200$; a firemen at $\$ 1.00$ per diem, $\$ 100$; two boys and two grown laborers for the season, $\$ 120$-total, $\$ 120$. At the minimum clarges for ginning, viz: $\$ 2.00$ per bale, the proceeds would be $\$ 4,000$ for the season, and deducting rumning expenses, there would be left $\$ 3,180$, or sixty-three per cent. on the capital invested. It will naturally be asked what inducements over and above the minimum charges would be offered to draw custom. To the present gin house the small producer delivers his seed cotton without knowing exactly what it weighs, it is stored in close proximity to other heaps of cotton, which are to be ginned first, and there is always more or less doubt, uncertainty, and suspicion as to the out-turn. Besides, for the most part, the cotton has to be carried up stairs to the second story, a laborious process, and almost always there is a delay of one or two days.

With the enlarged gin house the cotton might be weighed on platform scales, in the wagon, it could be quickly and easily thrown into a hopper, and thence carried, by an elevator, immediately to the platform from which it would be raked into the feeders. In twenty minutes, or almost as soon as the wagon could be unloaded, the ginning would be completed, the seed delivered, and the bale packed, weighed and thrown on the wagon. The whole process would be completed under the immediate inspection of the producer, and to his satisfaction. This method is pursued at a gimnery connected with the Glendale cotton factory, in Spartamburg, which, in consequence, recoives the patronage of the neighborhood, seed cotton being hauled there from a distance of eleven miles. To these inducements are to be added the increased value of the cotton from better handling, the cost of repressing at the shipping port would be saved, and there would be a reduction of freight on inland transportation for the compressed bales. Where these gimneries were on a line of railway the cotton might be delivered at reduced rates in any market town 
specified by the producer, at a great saring of expense in labor to him, as otherwise he must haul his crop home, store it, and again haul it to market. The seed, too, could be shipped without delay to the nearest oil mill, and the prorlucer might return home with a railroad receipt for his cotton and cotton seed meal preparerl to feed his stock, or fertilize lis land, accomplishing by one step what it now requires several tedious ones to compass.

The ralue of cotton seed and of its manufacture into oil and cake is just receiring a development which is likely to make great changes. In 1850 the price of upland cotton seed in South Carolina was ten to twelve cents per bushel, and it was used almost entirely as a manure. There was no oil mill in the State, and only one in Georgia. Before the working season of 18S2, at least five new oil mills were established in Georgia, and three in South Carolina. Those in Carolina were the Charleston Oil Mill, capital $\$ 60,000$, having three twenty box presses, with a cajucity of working fifty tons of seed a day; two other mills, one in Greenrille and one in Chester, having together about the capacity of the former, so that now of the 250,000 tons of cotton seed annually produced in the State, about 20,000 tons, or less than ten per cent., can be worked up into oil and cake. As a consequence of these enterprises, cotton seed is selling at eighteen cents per bushel, or at an adrance of eighty per cent. in two years. So that this crop, worth $\$ 1,721,000$ in 1880 , may, in 1852 , be sold for $\$ 3,097,000$. Nor is there anything of a merely speculative character in these advances. Cotton seed oil is to-day the cheapest edible oil in the world. Up to January 1st, 1851, none of this oil, as such, was sold for consumption in South Carolina. In the summer of $18 S 2$ it was to be found in nearly all of the country grocery stores along the lines of railroad, and in all the principal towns; about one hundred barrels a month are sold from Charleston, and the consumption in the State was not less than 2,000 barrels. Such is the faror with which it has been received that the dealers estimate that more than 5,000 barrels will be required to supply the demand during the present year. Considering the excellent qualities of this oil as a salad oil, or for cooking, and the present wide margin betreen its price and that of lard and olive oils, together with the growing population, and the increasing demand for food stuffs all over the world, nothing seems more certain than that it must arlvance in ralue rapidly as soon as its use becomes generally tested and known. The cotton seed cake, or meal, now sclls for $\$ 2 t$ per ton at the oil mill; twothirels of it is exported, and about ten per cent. is used as a fertilizer, being considered by the manufacturers of commercial manures as the cheapest supply of nitrogenous material; the balance is used for stock feed, chiefly by Northern famers and dairymen, a single broker, in Boston, dispos- 
ing last year of more than 15,000 tons for consumption there. Mr. Thos. liose (see Dr. Wratson Forbes' Report on Cotton Giins, Vol. II., p. 415) gives the value of that cake in England as $£ 10$ per ton, which would be $\$ 1 \$ .50$. The following table gives the comparative value of cotton seed meal and corn meal, from the German fodder tables :

\begin{tabular}{c|c|c|c|c}
\hline & $\begin{array}{c}\text { Proteine } \\
\text { Matter. } \\
\text { Per cent. }\end{array}$ & $\begin{array}{c}\text { Carbo- } \\
\text { hydrates. } \\
\text { Per cent. }\end{array}$ & Per cent. & $\begin{array}{c}\text { Comparative } \\
\text { Money Talue. }\end{array}$ \\
\hline Cotton seed meal . & 41.5 & 24.4 & 18.0 & $\$ 3.60$ per cwt. \\
Corn meal . . . . & 8.9 & 70.6 & 4.1 & 1.62 per cwt. \\
\hline
\end{tabular}

Here the proteine matter and fats, which go to form flesh, fat, milk, butter, and cheese, are valued at four and one-eighth cents per pound, and the carbohydrates, which support respiration, at nine-tenths of a cent per pound. From this estimate it appears that when corn meal is worth serenty-seven and three-quarter cents per bushel for stock feed, cotton seed meal is worth $\$ 72$ per ton, or just three times its price at the oil mill in South Carolina.

The product of a ton of cotton seed is stated as follows:

Thirty-five gallons of oil, value forty cents per gallon . . \$14.00

Seven hundred and fifty pounds cake, at $\$ 24$ per ton . . 9.00

Twenty-four pounds lint, at six cents per pound . . . . $1.4 t$

$\$ 24.44$

No count is made of the 1,000 pounds of hulls; they furnish fuel needed in the process of manufacture. From this estimate, the value of the products of the manufacture of the cotton seed crop of South Carolina would be $\$ 6,295,000$. If the English value for the cake was instituted, this amount would be $\$ \$, 643,000$, or by the German estimate of the value of the cake, it would be $\$ 10,552,000$.

Heretofore the chief obstacle to the successful operation of cotton seed oil mills has been the difficulty of procuring a supply of seed. The increasing facilities of railroad transportation will, to some extent, remove this difficulty. The diffusion of more accurate information among the cotton growers and ginners must convince them that they will gain enormously by disposing of their seed at present prices, and buying back the meal as stock feed, or to be employed directly as a fertilizer. Nothing heats and rots more rapidly than cotton seed, especially when fresh 
ginned and heaped in bulk. The sced are now kept in this manner by gimners and cotton growers until the month of February, when they are composted or drilled in the furrow for manure. A recent examination in the month of January of a number of such heaps, aggregating thousands of tons, revealed the fact that at least three-fourths of the seed, that is, all but those on the top of the heaps, were heated until the kemels were black, and they were entirely valueless for the manufacture of oil. The seed so examined were under shelter, and had received far above average attention. Unfortunately, no chemical analysis has been made to determine the exact deterioration as regards fertilizing constituents resulting from this heating process. It has, however, long been known practically to farmers that fresh green seed were far more valuable for fertilizing purposes than those which laad been heated or fermented. Leaving chemical considerations aside, the mere loss in weight by evaporation is enormous, and it is probable that of the seed cleaned by the gins during the fall months barely one-half to one-third in weight remains to be hauled out into the fields the ensuing spring, so that it would be economy for the ginner to turn his fresh seed over without delay to the oil manufacturer, being sure to receive in return cotton seed meal, nearly equal in weight to what his seed would be reduced to if he kept them himself, while the former contains nearly three times the fertilizing constituents of the latter.

The true basis, however, for the development of this remunerative industry would seem to be the establishment of gimneries in comnection with oil mills. The following estimates of the cost of such a combined establishment is taken from the statements of Richard Macdonald, of Charleston, who has had thirty years' experience in England and America in the manufacture of cotton seed oil. A mill to work fifteen tons a day will cost as follows:

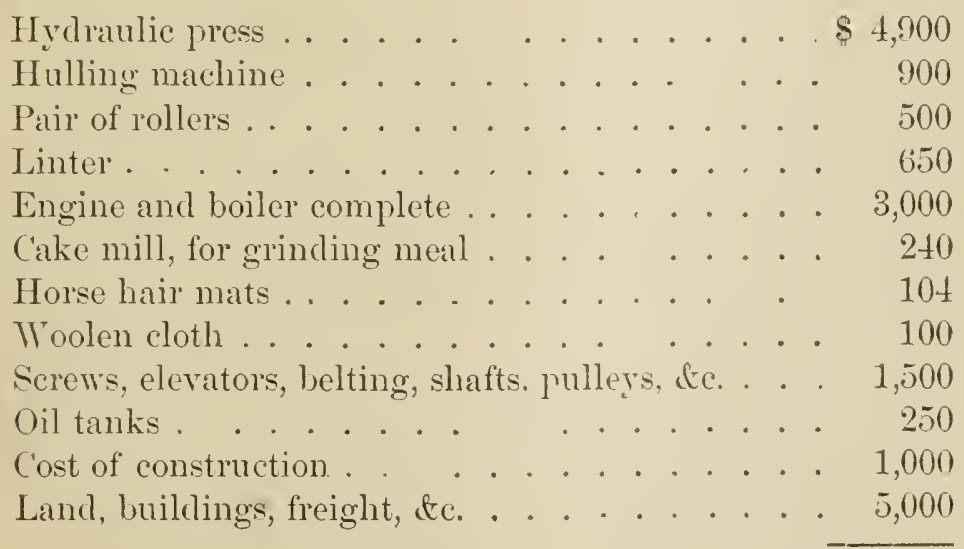


Allowing that only a custom work of 2,000 bales could be counted on at a gimmery, it would require four such establishments to furnish sect for one fifteen-ton oil mill. Their total cost, as above estimated, would be $\$ 20,000$, making in all $\$ 3 \$, 1+4$, say $\$+0,000$. The oil mill would yield say :

4,000 tons of seed, yielding 35 gallons oil per ton, (ri 40 cts. per gallon

4.000 tons of seed, yielling 750 pounds cake per ton, (a s2t per ton. $\$ 5,0001$ 4,000 tons of seed, yielding $2 t$ pounds lint jer ton, (ai, 6 cents per jound

Total product

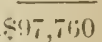

If from the above expenses be deducterl, als follows:

Cost of 4,000 tons of seed, (11 $\$ 12$ per ton.

Expense of working ditto, \$2 per ton. $\$ 4 \$, 000$

Freight, $\$ 2.50$ per tou

Total expenses

$\$ 66,000$

Net product $. .5,7,760$

This would be 175 per eent. on the investment in the mill. If the capital invested in the ginneries be inchuded, and their net prorluct of $\$ 3,180$ for each of the four, as above estimated, be added, in all, $\$ 12,720$, it makes a total net product of $\$+4,480$. This will amount to one hundred and eleven per cent. on the combined capital $(\$+0,000)$ of the ginneries and oil mill. The cost, especially of the gins, is here given at the highest figure. The use of water power would be a saring of $\$ 1,200$ per annum. On the other hand, the minimum rates for ginning are taken, and no allowance is made for the profits accruing from handling $\$, 000$ bales of cotton, from the improred staple of these bales, representing itself a net gain of $\$ 40,000$ per annum, at one cent per pound, and from the saving in waste and in cost of transportation by the easier handled packages. These gains would, in part, be shared with the farmer as an inducement to secure his patronage. But it must be remembered that such establishments, while immediately surrounded by the producers, would also be in direct contact with the consumers. Cotton would be sold on samples taken during the ginning, and contracts with manufacturers might be filled directly from the gin house at a great saving to both parties.

The numerous water powers in the middle and up-country would furnish suitable and healthful locations for such establishments. Those convenient to both railroad and river transportation would offer the greatest advantages, and would alway's hold a leading position. The expenses and repairs attending steam would be obriated, and cheap land and abundant labor could be commanded, Such ginneries and oil mills would at once become the centres round which the leading industries connected with cotton growing would organize themselves, and the 
present supremacy of the cross-road grocery would be transferred to it. The cotton seed, now little better than a waste of the farm, would he transformed into staple articles of food for man and bast, to which all the markets of the world are open. The growing deterioration in the prejaration of the great staple of the country for market would be arrected. and it would be furnished to the manufacturer in its cleanest and best form. 'The various qualities of cotton could be kept separate by the substitution of small, compact packiges for the present unwieldly bales, such packages might be carried on the shoulder instead of being pulled through the mud with hooks, as at present. There would be a rast siring in the labor of transportation to the farmer, and in the reduction of freight to the manufacturer. Such establishments would, while infusing fresh strength into agricultural pursuits by rendering its entire product available and valuable at the least cost, form a connecting link betwou the field laborer and the manufacturer, cleaning up the enormous waste and changes that now cumber the space between them. Here is the point where a reorganization and renewal of the agricultural and manufacturing industries of the South may join hands and take a new departure.

While this paper is passing through the press three new cotton seed oil mills are being erected in the state. In giring the aggregate for the

\section{FERTILIZEF FACTORIES}

in South Cirolina, only those establishments have been considered which employed machinery in preparing their products; the changes tffected in the materials by merely mixing by hand the different constituents of a fertilizer not being considered of sufficient importance to entitle the parties engaged in it to be regarded as manufacturers. But even if all these latter were included, it is not apparent how twenty-five fertilizr factories ever employed 2,679 hands, as stated in the compendium of the Tenth U. S. Census. It is probable that the number of hands emplored during the short shipping season in sacking and handling the phosphate was taken in the census returns, in place of the arerige of the force annually employed. The lattor is liere given from returns nade by cach conpany. The material used by these companies consists chiefly of the phosphate rock mined in the vicinity. "This is ground and used in this. state, or treated with sulphuric acid and sold as a soluble superphosphate, to which other materials, containing nitrogen and potash, or both, are sometimes added. The ground rock is reduced to extreme fincness, known in commelce as "floats," and it is thought that the subdirision of the particles is sufficient to enable the roots of plants to appropriate the 
phosphoric acid it contains as food. Measurements with the micrometer show that the size of the particles obtained by grinding vary from the 1), 1003 inch to the 0,00003 inch. By chemical tests it was estimaterl that at much astwenty-five per cent. of the phosphoric acirl present in this dust was dissolved by the ammonium citrate solution used in laboratories to represent the soil water, plant-root juices and other solvents in the wil ; from which it was inferred that this percentage was available by l) lants. The best results were oltained from the finest powder, that is, where eighty-fire per cent. of the particles were fincr than 0,0003 inch. Improvements in machinery to rerluce the phospluate rock to an impalpal. le powder are being much sought, since the great expense necessitater ly chemical processes in rendering it soluble would be avoided if this could be accomplished by mechanical means. Analysis shows that the percentage of phosphloric acid in "floats" varies from 24.2 to 27.8 . The fullowing table shows the average of the analysis of fertilizers manufactured in South Carolina, being the mean of analysis made for the Department of Agriculture of South and of North Carolina, together with the estimated value per ton of 2,000 pounds, based on the current prices of the phosphoric acid, ammonia, and potash they contain.

\begin{tabular}{|c|c|c|c|c|}
\hline & 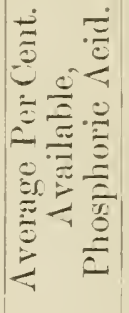 & 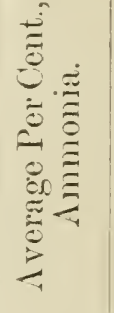 & 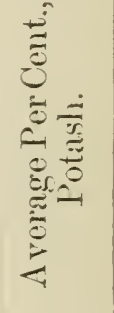 & 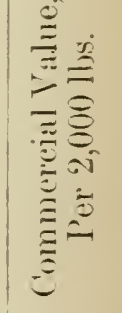 \\
\hline Simple Superphosphates. . . . . . . . . & 11.7 & . . & . . . & 828.57 \\
\hline Simple Superphosphates, with Potash. . & 10.55 & . & 1.29 & $\$ 26.66$ \\
\hline Ammoniated Superp'phates, without Potasls. & 9.61 & 2.96 & . & 835.41 \\
\hline Ammoniated Superphosphates, with Potash. & 8.95 & 2.70 & 1.73 & \\
\hline
\end{tabular}

The prorluct of these factories exceeds 110,000 tons yearly, the average estimated value of the product at the factory is placed at $\$ 20$ per ton. By the Tenth U. S. Census, South Carolina stood fifth among the States in the manufacture of manures. The product for the State was estimated at that date at 64,794 tons, and it is probable that the increase in the 
product, as above shown, makes South Carolina at this time the largest producer, except, perhaps, the State of Maryland alone. In 1870 there were but two fertilizer factories in Carolina, and the value of their products was less than one-fifth that of the present product, which is greater than the product of the entire United States in 1860 , by 148 per cent.

FLOURING AND GRIST MILL PRODUCTS,

while greater in value than those of any other single manufacturing industry in the United States, form only about nine per cent. of the aggregate products of manufactures. In South Carolina they amount to twenty-two per cent. of the products of all manufactures. The figures of the U.S. Census relating to this industry in the Uniter States, and in South Carolina, from 1860 to 1870 , are given in the following table:

Table of Flouring and Grist Mill Products.

\begin{tabular}{|c|c|c|c|c|c|c|c|}
\hline & Perions & $\begin{array}{l}\text { ESTAB- } \\
\text { LISH- } \\
\text { MENTS. }\end{array}$ & $\begin{array}{c}\text { C.APItal. } \\
\$\end{array}$ & HAXDS. & $\begin{array}{c}\text { WAGES. } \\
\$\end{array}$ & $\begin{array}{c}\text { Materials } \\
\$\end{array}$ & $\begin{array}{c}\text { Products. } \\
\$\end{array}$ \\
\hline \multirow[t]{2}{*}{1880} & U.S. & 24,338 & $177,361,878$ & 52,407 & $17,+20,316$ & $441,545,2.25$ & $505,185,712$ \\
\hline & S. C... & 720 & $1,330,262$ & 1,052 & $139,3.52$ & $3,26.5,485$ & $3,779,+70$ \\
\hline \multirow{2}{*}{${ }^{*} 18 \overline{0} 0$} & $\int \mathrm{U} . \mathrm{S}$. & 22,573 & $121,252,361$ & 58,448 & $11,672,067$ & $293,913,698$ & $355,988,14 \pi$ \\
\hline & $\{$ S. C... & 624 & 668,652 & 1,138 & 87,509 & $2,130,759$ & $2,4 \pm 4,99 \mathrm{~S}$ \\
\hline \multirow{2}{*}{1860} & S U.S. & 13,578 & $S 4,485,964$ & 27,692 & $8,729,390$ & $208,499,309$ & $248,580,36.5$ \\
\hline & (S. C. & 270 & 639,525 & 35.5 & $66,+24$ & $1,517,366$ & $1,757,174$ \\
\hline
\end{tabular}

*Here and elsewhere the currency values of 1870 are reduced to gold.

The rate of increase and decrease in this industry during the period under consideration will be most readily seen by consulting the following table, deduced from the above. 
Table showing Percentage Rate of Increase and Decrease (the latter marked lyy *) in Flour and Grist Mill Prorlucts in South Carolina and in the United States, drering the two decades cmlraced in the periorl from $1 S 60$ to 1850.

\begin{tabular}{|c|c|c|c|c|c|c|c|c|c|c|c|c|}
\hline & \multicolumn{2}{|c|}{$\begin{array}{l}\text { Establisil- } \\
\text { MENTs. }\end{array}$} & \multicolumn{2}{|c|}{ Capital. } & \multicolumn{2}{|c|}{ HAXDs. } & \multicolumn{2}{|c|}{ W } & \multicolumn{2}{|c|}{ Matfirils. } & \multicolumn{2}{|c|}{ Prodicts. } \\
\hline & U.S. & S.C. & U.S. & $\therefore C$ & U.S.S & S C. & U.S. & $\therefore$ C. & U.S. & S. C. & U.S. & S.C. \\
\hline 1860 to $1870 \ldots$. & 62 & 120 & $4: ;$ & 4 & 111 & $2: 20$ & 33 & 31 & 40 & 41 & 43 & 39 \\
\hline 18.0 to $1850 \ldots$. & 7 & 15 & 43 & 98 & $* 10$ & $* \tau$ & 49 & 59 & 41 & 53 & 41 & 54 \\
\hline
\end{tabular}

The impetus this industry received during the decade of war and reconstruction will be noticed. The rate of increase appears greater in South Carolina than in the country at large in every particular, except two. The increase of capital is markedly less and is explained by the losses of war; the increase in prodncts is naturally somewhat less also. In the subsequent decade, 1570 to 1850 , the rate of inerease lessens, but to a less degree in Carolina than in the country at large, and her rate of increase in capital and in products is large. Notable features in this decade are the lower rates of increase in the number of establishments, and the actual decrease in the number of hands employed, and were it not accompanied in a marked rate of increase of wages, in which Carolina leads, it would almost seem that improved machinery and enlarged eapital were assuming entire control of this industry.

SAWING LUMBER

ranks, as to value of products, third among the manufacturing industries of the country, the iron and steel industry and meat packing alone exceeding it in this regard. It produces four per cent. of the aggregate products of manufactures in the United States, and twelve per cent. of these products in South Carolina. The following table exhibits the condition of this industry in the United States and in South Carolina, as given in the L.S. Census returns from 1860 to 1850 : 


\begin{tabular}{|c|c|c|c|c|c|c|c|}
\hline & Periods. & $\begin{array}{r}\text { EstaB } \\
\text { LISII- } \\
\text { MENTS. }\end{array}$ & $\begin{array}{c}\text { Capital. } \\
\$\end{array}$ & HanDS. & $\begin{array}{l}\text { WAGES. } \\
\$\end{array}$ & $\begin{array}{c}\text { Materiai.s. } \\
\$\end{array}$ & $\begin{array}{c}\text { Products. } \\
\qquad 8\end{array}$ \\
\hline \multirow{2}{*}{1880} & (U.S... & 25,708 & $181,186,122$ & $147,9,56$ & $31,845,99+$ & $146,155,385$ & $233.268,729$ \\
\hline & S. C & 420 & $1,056,265$ & 1,478 & $221,96: 3$ & $1,237,361$ & $2,031,507$ \\
\hline \multirow{2}{*}{1870} & (U.S... & 25,832 & $114,794,586$ & 149,997 & $32,007,380$ & $8^{2}, 668,986$ & $178,1 \cdot \bar{\tau}, 462$ \\
\hline & S. C... & 227 & 436,730 & 1,212 & $167,8+2$ & $46.5,400$ & $9 \overline{5} \pi, 604$ \\
\hline \multirow{2}{*}{1860} & (U.S.. & $20,6.57$ & $74,530,090$ & 75,862 & $21,702,2(65)$ & $44,551,763$ & $96,715,554$ \\
\hline & (s. C.. & 361 & $1,145,116$ & 1,263 & 219,361 & 498,290 & $1,125,640$ \\
\hline
\end{tabular}

The following table, deduced from the above, will make the changes that have occurred plainer:

Table showing the Percentage Rate of Inerease and Decrease (the latter marlicd by *) in the Lamber Industry in South Carolina and in the United States, in the two Census decades embraced between 1860 and 1880.

\begin{tabular}{|c|c|c|c|c|c|c|c|c|c|c|c|c|}
\hline & \multicolumn{2}{|c|}{$\begin{array}{l}\text { EstabLISII- } \\
\text { MENTS. }\end{array}$} & \multicolumn{2}{|c|}{ Capital. } & \multicolumn{2}{|c|}{ HANDS. } & \multicolumn{2}{|c|}{ WAGES. } & \multicolumn{2}{|c|}{ Materials. } & \multicolumn{2}{|c|}{ Products. } \\
\hline & U.S. & S.C. & U.S. & S. C. & U.S. & $\therefore C$. & U.S. & S.C. & U.S. & S.C. & U.S. & s $\mathrm{C}$. \\
\hline 1860 to $1870 \ldots .$. & \multirow[t]{2}{*}{20} & $* 37$ & 54 & $* 61$ & 98 & $* 4$ & 47 & 23 & 85 & $\because 6$ & 83 & 14 \\
\hline 1870 to $1880 \ldots .$. & & 88 & 57 & 139 & $* 1$ & 20 & $* 5$ & 32 & 76 & 187 & 30 & 10.5 \\
\hline
\end{tabular}

The decade of war and reconstruction does not seem to have promoted the lumber business as it did manufactures in general, and it was actually disastrous to this industry in South Carolina, as shown by the decrease during this period in the number of mills and in the capital, hands, materials and products of the industry.

In the last decade, 1870 to 1880 , however, the losses are much more than recovered, and the rate of increase is much greater in each particular in Carolina than it is in the country at large. Next to the pine forests, which cover 20,000 square miles in the lower part of the State, and furnish the very best quality of yellow pine, the cypress is, perhaps, the most important timber tree in Carolina. The lumber is light and durable, especially for outside work. The tree is of rapid growth, and attains a great size, occupying swamps and waste places. Whenever the timber supply is reduced to the 
extent of necessitating the culture of trees, as in the older countrics of the world, the eypress will be among the most available here. Before that time howerer arrives, there are thousands of scuare miles in Carolina to be denuded of their pine forests. The live oak, for ship building, and many other hard woods, as the persimmon, for cogs of motive wheels, the logwoor, for shuttles, and white oaks, for staves, abound in this State. 'The only other manufacturing industry in Soutl (arolina whose annual prorlucts, according to the U. S. Census, exceed one million of dollars, is the manufacture of

TAR AND TURPENTINE.

The data furnished by the U. S. Census regarding this industry in Soutl Carolina for the years $1 S 60-70-S 0$ are given in the following table:

\begin{tabular}{|c|c|c|c|c|c|c|}
\hline $\begin{array}{l}\text { Census } \\
\text { YEAR. }\end{array}$ & $\begin{array}{c}\text { EsTAB- } \\
\text { LISHMENTS }\end{array}$ & CAPITAL. & Haxds & WAGES & $\begin{array}{c}\text { MA- } \\
\text { TERIALS }\end{array}$ & Products \\
\hline $1 S 60 \ldots$ & 95 & $\$ 931,270$ & 1,432 & $\$ 150,124$ & $\$ 691,555$ & $\$ 1,096,974$ \\
\hline $1 S 70 \ldots$ & 54 & 205,425 & 876 & 123,645 & 422,378 & 774,077 \\
\hline $18 S 0 \ldots$ & 192 & 565,200 & 4,619 & 555,460 & 666,170 & $1, \$ 93,206$ \\
\hline
\end{tabular}

The product of South Carolina in $18 S 0$ is over one-third of the aggregate products of this class in the whole United States.

In the thinly peopled lower third of the State, where lumber, turpentine and phosphate rock are the chief products of industry, the lands from which these bounties of nature have been gathered are esteemed of little value. And yet, if the physical and chemical constitution of these soils be considered (see Lower Pine Belt), or the erops they vield, there is no reason why they should not make to agriculture returns as raluable as any lauds in the State. If the State, or capitalists, would arrange for their thorough drainage, this would become a certainty, and a large region, now almost waste, would be opened for the colonization of a pemanent and thriving population. This would be facilitated by a number of private railroads five to twenty miles in length, built here by lumburmen and phosphate miners, rendering points formerly remote easily accessible. 
Space does not here admit of mention of the

\section{OTHER MANUFACTLRING INDUTTRIES}

of South Carolina. The five leading industries, according to the census of 1850 furnish seventy-eight per cent. of the aggregate products of manufactures in the State, The case is widely different in the country at large; there the five largest manufacturing industries only furnish twenty-eight per cent. of the aggregate products. It is this apparent lack of development of the minor manufacturing pursuits in this State which has sustained a very general belief that the people possessed little aptitude for manufacturing. It has been pointedly charged that they had little skill for small aftairs; there was no change anong then for a nickel, and in all their transactions they preferred wholesale methods to retail. Granting that there is some force in this charge, it obviously needs qualification when applied to a comprarison of the industries of one State with the diversification of pursuits rendered practicable by the diversity of conditions obtaining over the country at large. Doubtless also, the accurate enumeration of these minor pursuits anong a population largely rural, while it was much more difficult, was necessarily less complete. Nevertheless, after making every allowance, the want of the minor mechanical industries in Carolina is much felt, and nowhere ro the resources of the country or the necessities of the people offer greater promise of suceess to artizans of this description.

MINING.

The gold product of South Carolina was, by the U. S. Census, $\$ 13,040$ in 1SS0, which puts the State fifteenth in point of production of this metal among the other States. By the report of the director of the U. S. Mint this production increased in 1882 to $\$ 25,000$, which would place the State fourtecnth in point of production. (See page 13t.)

The commercial value of the numerous deposits of

\section{PHOSPHATE ROCKS}

along the coast of Carolina was established in 1868. The river mining yielded from 1870 , when the product wals 1,957 tons, to the close of 1852 , when the yield was $140,7-2$ tons, an aggregate of 945,552 tons, paying a royalty into the State treasury of one dollar per ton. In 1566 , the total product of the river and land mining companies was 132,625 tons; in 1883 it is given as 355,333 tons. The aggregate prorluct for this period 
of eight rears is $1,8,00,40$ tons. The market price of the rock has varied from 85.50 to $\$ 9.50$ per ton; a cireular dated 1st June, 1883 , states that "the two laresest mining companies (producing over forty per cent. of all the rock raised) hate sold all they ean produce for the remainder of the vear."

The following statement will give a general view of this inclustry in 1.883 :

\begin{tabular}{|c|c|c|c|c|c|}
\hline COMPANIES. & No. & Capital. & HANUS. & WAGES. & Prodects. \\
\hline River Mining.. & 11 & $\$ 525,000$ & 649 & 8259,300 & $\$ 90 \pi, 170$ \\
\hline Land Mining.. & 14 & $1,980,600$ & 1,28i & 363,360 & $1,283,830$ \\
\hline Total. & 25 & $\$ 2,50, ;, 000$ & 1,935 & 8622,860 & $82.190,000$ \\
\hline
\end{tabular}

KAOLIN CLAY.

There are, in the neighborhood of Aiken, Graniteville and Beech Island, some large deposits of kaolin clay of excellent quality. Several of these deposits are being worked. The capital employed is stated at $\$ 6,5,000$, and the average annual product for some years past has been about $\$ S S$,000. Other deposits of this material in Lexington, Kershaw and other counties have been mentioned in describing the localities where they oc'ur, but they have not been developed.

\section{GRANITE.}

Thomas IV. Woodward's Rock City quarries, four miles southwest of Winnsboro, the county seat of Fairfield, cover several square miles, furnishes the finest quality of blue and white granite, and compares favorably with any quarry in the world as to the quantity, quality and accessibility of the material. A steam tramway connecting these quarries with the Charlotte, Columbia and Augusta Railroad, is being constructed. The U. S. Postoffices and Courthouses of Columbia, S. C., and of Nashville, Temn., are built of granite from this point. These sales of this rock with those to the asylum in Columbia and others, aggregate up to this time about \$135,000. The white granite is the finest, and has been in use only since 1877. It is fine grained, free from impurities, works easily, las fine finish from the hammer and polishes well. Buildings constructed of it do not assume the sombre hues common to stone houses, it whitens with age, and approaches marble in apjearance. 
The Granby quarry, two miles below the eity, furnished the material of which the State House is built. It has not been worked since the war.

The Green quarry, one mile north of Granby, is worked by the Columbia Granite Company, making blocks for the parements of Charleston. The company have a large capital, employ about twenty block makers and fifty driller's and laborer's; the product is at the rate of one million of paying blocks annually.

Colonel F. W. MeMaster has a quarry of fine granite on the Greenville Railroad, one mile north of Columbia; it is also within one hundred feet of the State canal that is being constructed here.

Professor Woodrow, of the University of Sonth Carolina, who has examined these rocks in the vicinity of Columbia, says: "As to quantity they are practically inexhaustible. The rock is of a light gray color, the feldspar being light colored and the mica dark brown or black. It is fine grained, compact, and of uniform texture, and is comparatively free from seams and injurious veins, so that solid blocks of any desired size may be attained. Its durability might be inferred directly from the condition of its constituent material, and it is attested not only by blocks long exposed to the weather in the oldest buildings in the vicinity, but better still by the condition of the blocks that have been lying upon the surface for untold ages.". For numerous other quarries see chapter on the Piedmont region, and the accompanying map.

\section{FISHERIES.}

South Carolina comes twentieth in the fish producing States, with 1,005 fishermen, and products valued at $\$ 212,4 \$ 2$. She is, however, noted for her shrimp fisheries, these being more extensive than those of any other State, and nearly equal to those of all other State: combined. In 1850 her fishermen secured 18,000 bushels, valued at $\$ 37.500$. The principal fisheries are about Charleston, where several hundred negroes, with an occasional Spaniard, are engaged in fishing with hand-lines from vessels and small boats, to supply the city with whiting, blackfish and other species. A limited fishery occurs in the sounds about Beaufort, from which point a few fish are shipped to interior eities. Beyond the places mentioned no sea fishery of importance occurs, though there is more or less fishing for local supply along all portions of the coast. About 400,000 pounds of alewives, 207,600 pounds of shad, and 261,250 pounds of sturgeon, with considerable quantities of other species, were taken by the river fishermen, the largest fisheries being in the Edisto river and in the tributaries of Winyah Bay. 
The following is from U. S. Census of 1850 :

Persons employed . . . . . . . . . . 1,005

Capital dependent on fishery industries . . . . \$166,275

Pounds of sea products taken, including oysters . .,099,400

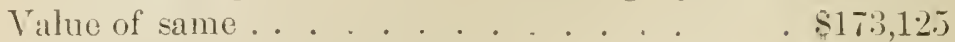

Pounds of river products taken . . . . . 1,043,850

Talue of same. . . . . . . . . . . . \$39,357

Total value of fishery products....... . . . 212,482

It may be here mentioned that in 1892 six whales were taken off Port Royal.

In $1 S 7 S$ a fish commission was appointed by the State government. Many eggs have been taken and the young fry hatched, and released in the streams of the State. In 1852 the commission released 166,000 well formed salmon, and 1,945,000 shad, besides a number of black bass and some salmon trout in the waters of the State. I State pond for the artificial propagation and culture of carp is established at Columbia, and has furnished these fish to $\$ 94$ private ponds in the different sections of the State. 


\title{
CHAPTER VIII.
}

\section{THE HISTORY AND PRESENT CONDITION}

$\mathrm{OF}^{\mathrm{F}}$

\section{TRANSPORTATION IN SOUTH CAROLINA.}

\author{
BY W. L. TRENHOLM.
}

The area of the State is about 30,000 square miles, and its topography creates three natural divisions, ealled the upper, middle and lower, of which the dividing lines are nearly parallel with the general line of the const.

Its frontage on the Atlantie, in a straight line from Little River Inlet to the mouth of the Savanuah river, is one hundred and ninety miles, and towards this line the eomntry descends in long undulations until it runs into the ocean, where it's flat edge is frayed out into eapes and points and spits, or rent into islands, which present to the sea sloping beaches of white sand, backed by dunes eovered with myrtle and studded with palmettos.

Between and behind these insulated fragments of the continent the sea water extends in bays, sounds and harbors, bordered with vast areas of marsh-covered mud flats, which, like the islands and the main land in rear of them, are pierced by innumerable inlets, creeks and passages, where twice a day the tides sweep through in endless ebb and flow.

Here the large rivers from the upper and middle eountry mingle their fresh waters with the brine, and lose their way to the sea amidst a labyrinth of tortuous passages.

On a belt varying in width from ten to thirty miles and stretching along the whole eoast, these features repeat themselves with endless variation of detail, presenting to sloop and steamboat narigation aecess to full five thousand miles of shore line and to rivers, up which these vessels may ascend for hundreds of miles.

In the old days before railroads, half the area of the State enjoyed uninterrupted water communication with Charleston, and if we go back to 
the first permanent European settlements, in 1670, we shall find that these characteristics of the comntry influenced materially the course of colonial revelopment.

In the first place it was probably owing to the sub-division of the land by these water courses that the Indians in lower South Carolina were found in detached tribes, of only a few hundred each, which were too weak to contend singly against the whites, and too much separated from each other by physical barriers and old feuds to combine successfully.

In the next place the first settlers found the Indians well supplierl with boats, but without roads, bridges, or domestic animals of burden, hence all the earlier needs of the colonists, in the way of transportation, were supplied by using the vessels they brought with them and the Indian boats.

These Indian boats were of the same sort as were found along the whole coast from the Delaware capes to Florida, where they had been seen by Verazzani, in 1.22t, nearly a century and a half before the settlement of Charlestown. His description of them is thus translated by Hackluyt :

"We saw many of their boats made of one tree, twenty foote long and four foote broad, which are not made with iron or stone, or any other kind of metall; ******* they help themselves with fire burning so much of the tree as is sufficient for the hollownesse of the boat, the like they doe in making the stern and fore part untill it be fit to sail upon the sea."

This sort of boat, constructed however with tools, continued in use by the colonists for a long time, under the names of Perriaguer, Pettiauger', and Dug-ont. In 1696, the Colonial Legislature passed an Act to punish "any person who should steal, take away, or let loose any boat, perriaguer, or canoe," and from the earliest dates the statutes are full of the provisions male for opening and keeping open navigable waters.

It happened, too, that rice soon became the chief product of the country; it was grown in the swamps extending between the oozy water courses near the coast, and, being a heavy grain, is peculiarly dependent upon water transportation. The row boats and sloops that brought the rice to "town" belonged to the planters, and were manned by slaves; they carried back the family and plantation supplies, and at a later period were used in the annual moving to and from the city, in spring and autumu, which came into vogue. The rice was conveyed from the plantation to the landing in flats upon canals, or, when that was not practicable, it was hauled by oxen, on sleds.

Lumber, the next most important product of the country, was rafted to Charlestown, anrl on the rafts came also the wood to supply the eity demand for fucl. 
Among the exports, beef and pork occupy positions next in importance to lumber; the cattle and hogs, we know, were driven through the woods, for among the early Statutes is one prolibiting the slaughtering of animals within a certain time after they had been driven to "town."

A thirl consequence of the character of the country was, that when the colonists, who at first were planted only at Charleston and its immediate vicinity, began to push their settlements into the surrounding territory, their movements and location were determined by the directions and navigability of the water courses.

Georgetomn, Beaufort, Goose Creek, Dorchester, Coosawhatchie, Saltketeher and Pocotaligo, were early occupied by traders with the Indians, and became, afterwards, rallying points of the colonists who took up the lands around them.

It was only after some settlements had been thus made that the colonists seemed to turn their attention to communications by land. In 16S2, there is mention of a hundred and fifty mares and some horses that had been brought into the Province from New York and Rhode Island; and in the same year, on the 26th May, the Colonial Assembly passed the first law to provide for the making of roads.

Unfortunately, the text of the statute is lost, but the title has been preserved. It is "An Act for Highways." This Act was followed by many others of a special character, $i$. $e$, relating to particular localities, or providing for some particular work, all, however, conforming to a general plan which placed the construction and maintenance of roads and bridges, as well as the conservation of navigable water courses, in the hands of prominent resirlents of the ricinity. Two or three of the leading planters in each neighborhood constituted the board of commissioners for that load district, and the confines of their territory were precisely defined.

Erery male inhabitant between sixteen and sixty years of age was compelled by law to work on the roads of the district in which he lived; and all the timber required for bridges and causeways could be taken by the commissioners without compensation to the owner.

The location of roads and bridges, during the early days of the colony, was obviously governed by military considerations, rather than br those relating to trade and peaceful travel. The colonists were never free from attacks by the Spaniards and Indians until after 1715, and both before and after that time the apprehension of servile insurrection seemed always present to their minds.

To secure the public safety was, therefore, necessarily a prime consideration, and since the roads were at first regarded chicfly as lines of communication by which the scattered colonists could concentrate for defence, it is not surprising that the whole labor of the community should 
have been rentered available for their construction and maintenance. The roul law was only parallel to the militia law, which placal in scrice every white man capable of bearing arms, and settled, by the place of his residence, to what division, brigale, regiment, battalion and company he should belong.

'The facilities for water transportation were so good, and the colonists had bocome so habituated to their use, that the trade with the distant tribes of Indians probably occasioned the only land traffic of any importance up to the middle of the eightoenth century. It was in allusion to this that Governor Archdale, in 1707, wrote: "Charlestown trades near one thousand miles into the continent." Muskets, powder, lead, woolen cloth, tools, and iron ware were the principal articles supplied to the Indians; frontier trading stations were established at Savana Town and old Apalachicola Town, both on Savannah river; at Wincau, near the Wascamaw Indians; at Congaree Fort, in South Carolina; Altamaha Fort, in Gaorgia, and Forts Palochuclas, Moore, and Charlotte, on the S.rvanuh river. Later, in 1762, was established the station at Keowee, Fort Prince George, for trading with the Cherokee Indians. Beyond the frontiers, the transportation of the "goods, wares and merchandises" into the Indian country was effected by means of pack horses and Indian "burthener's," and these brought back the skins and furs which, with Indian slaves, constituted the returns in the trade. There was water transportation between Charleston and all the trading posts except Keowee, and from the latter to Fort Charlotte was not a long way. It appears, however, that at intervals trains of pack horses and some vehicles passed directly between Charleston and Keowee, but by what route is not certain.

The magnitude and growth of the Indian trade are partly shown by the export of deer skins, which, according to official records were,

In 1710, 70,000 deer skins.

In 1731, 250,000 deer skins.

In $1748,600,000$ deer skins.

These 600,000 deer skins were valued at $£ 36,000$ sterling, about $\$ 180,000$ grold, or thirty cents each.

The Indian trade was encouraged by the Provincial government, but it was, also, strictly regulated, with a view always to preserving the confidence and friendship of the tribes surrounding the colony. Among the restrictions imposed upon traders was one that they should employ no negros;, even in rowing the "perriagos" between Charleston and the traling stations; and another, that they should bring no free Indians into the settlements.

The "burtheners," therefore, could not be used within the frontier, 
nor could negroes be employed in their place, and hence arose an additional influence tending to restriet Indian traders to the use of water transportation for their goods between Charleston and the several trading. posts, while they and their agents passed on horseback by the trails through the woods.

Until after 1730 , no settlement had been made above the tirle-water line, and there was hittle occasion, near the coast, for any but short roads.

The early history of the roads, bridges and ferries of the State can bo tracerl in the statutes of the Colonial Legislature. There it appears that, during fifty years, these public works were confined to the strip of land along the coast, about twenty miles wide, and to the settlements along the navigable rivers and watercourses; but,

In 1737, An $\Lambda$ et was passed which refers to the settlements lately made by several families in Orangeburg township, and directs a road to be made to them from the "head of the path that leads from Dorchester to Captain Izard's cow pen."

In 1739, A ferry for "passengers, horses and cattle," was authorized across the Savannah river, from Fort Moore, in South Carolina, to the Sand Bar, in Georgia, but it appears not to have been established, even in 1747 , when another $A$ ct was passed for the purpose.

In 1742 , An Act provides for a ferry across the Santee, and a road to be made in connection with it, "to facilitate the passage of travelers from Charlestown to Williamsburg and other, the northwest parts of this Province."

Up to 1750 , all the white inhabitants of South Carolina were Europeans, who reached the provinee by sea, and passed to their destination in the interior by boat; hence the interior settlements of that day were at or near river landings. These settlements were no where far from the coast, exeept at Windsor (near Hamburg), on the Savammah river, the "Congarees" (near Columbia), on the Congaree river, Camden, on the Wateree, and Cheraw, on the Pee Dee, these places being respectively at the head of sehooner navigation on each of the four great rivers of the State.

By reference to the map, it will be found that a line drawn from Hamburg, through Columbia and Camden, to Cheraw, will be nearly straight, nearly parallel to the coast, and will about diride the State in half. The upper country which lay beyond this line began to be peopled about 1750 , by settlers from Pennsylvania and Virginia, whose numbers were afterwards greatly increased by the effects of Braddock's defeat, in 1755 . The few immigran ts who made their way there from the coast were absorbed 
into the mass of these overland immigrants, who were an enterprising and progressive people, prepared, by several generations of frontier life to concuner suceess under difficult eonditions, and accustomed to depend wholly upon themselves in all the exigeneies of their surroundings. They knew neither the benefits nor the burlens of government, nor, if they had known, were they of the temper to assume the burdens for the sake of the benefits. Afterwards, their descendants, acpuiring property, took a short cut towards government through the "Regulation."

Between the upper Carolinians and the colonists of the low country, the patient subjects of the Jords Proprietors, and afterwards of the King, there were no ties of consanguinity, no identity of history, traditions or experience, no religious affinities, no personal acquaintance, no commercial relations. It is natural to suppose that the upper Carolinians maintained sone intercourse with their own people, both those at their old homes in Pennsylvania and Tirginia, and their kinsfolk and acquaintances settled in Ohio, Tennessee and North Carolina, and this intercourse would naturally take the form of tracle as soon as the new settlers had any surplus produce to exchange for the articles of consumption which they had been accustomed to obtain from Philadelphia, Baltimore and Richmond. As these immigrants had come with wagons and teams, there must have been practicable routes for a wagon trade; indeed, for a part of the way, they. would have the same roads that served other offshoots from the Pennsylvania and Virginia stock, and, no doubt, some families were sattered all along the route from the Alleghanies to the southern slopes of the Saluda momntains. It was not only more natural for them to maintain intercourse with the northern suttlem ints than with those on the coast, but was less difficult, for the whole middle country of South Carolina was a wilderness in 1750 , and there ware 10 rouds through it practicable for wagons. There were, as yet, few ferries, except vary near the coast, the rivers were not fordable, and approach to them was obstructed by swamps, which are more formidable even than rivers to highland people with wagons.

'There were, as has been said, four points in the middle country enjoying water communication with Charleston, but they do not appear to have been attractive or even practicable as markets for the upper country, and it is probable that they had little or no trade, besides that with the Indians, until after the Revolution.

In the absence of definite information on the subject, I am strongly of opinion that, until the Revolution had knit them together, the upper and lower Carolinians had rery little intercourse with each other, and that, (n) the other land, a constant overland trade was maintained by the former with the northern settlements. In corroboration of this opinion, 
I am informed that, only two or three generations ago, cotton was sent by wagon to Philadelphia from the neighborhood of Hanburg ; and if from a point in constant water communication with charleston, why not more probibly from points not so advantageously situated in that respect? In Gregg's History of the old ('heraws, page 110, it is saill: "The stock was driven to Charlestown and other places on the coant, an well an to more distant markets. Large numbers of cattle were sent from Peedere to Philarlelphia." Also, at page 112, in a note, we find the following: "Gen. IIarrington sent three four-horse wagon loads of indigo to Virginia, and with the proceeds bought $15(1200$ negroes."

It may be a mere coincidence, but it is singular that, to-rlay, when railroads dominate trade, the only railroads in the State which are arowcdly ancillary to the trade of Charleston, are those which teminate at Hamburg, Columbia, Camden and (heraw; precisely the four points which, a century and a half ago, were outposts of European colonization; while all the railroads traversing upper South Carolina are controlled either by the Pennsylvania Railroad, or by the Richmond and Danville, of Virginia :

Is it the persistence of some occult natural law of trade, is it fate, or is it simply accident, that has wrester from Charleston the control she once had of the Greenville and Columbia, the Blue Ridge, ant the Laurens railroads, and thrust them into the hands of Pennsylyania and Virginia? Howerer this may be now, there is evidence that, as soon as the settlement of the upper country dereloped itself, the Provincial Legislature, at Charleston, were diligent in pasing Acts for the establishment of ferries and the construction of roads to connect the new settlements with the capital. It appears, from a careful comprarion of these Acts, that many of them failed of their purpose, for the same roads and the same bridges were over and over again ordered to be eonstructed, and frequently new commissioners were appointed at each repetition of the logrislation.

The principal roads (omitting those connecting the coast settlement: and one from Charleston to the "Congarees") were projecterl as follows:

1753. From Eutaw Springs, on the "Congarees" road, lyy Burd's ferry, across the Santec, through II inchester, Camden and Lancaster C. H., "to the upper settlement; on the northeast of the Wateree river, near the Catawba nation," about 120 miles.

(This Act also provided for opening out the narigation of the Wateree river.) 
176). From near liort Motte, by McCord's ferry, orer the Congaree, just above the point of its confluence with the I'ateree, along the west sicle of the Wateree to Fishing Creek, "so far as the Province extends," about 110 miles.

1766. From near Fort Motte, up the rest bank of the Congaree, across this stream at Howell's ferry, "through the Forks of the Wateree to Lee's Fort," about $\$ 0$ miles probably.

176S. In conjunction with a ferry across Peedee, near Society Hill, two roads, one on mortheast side of Peedee, connecting Bennettsville, Marion and Conwayboro with Georgetown, and so with Charleston, about 150 miles of new road. The other, from Cedar Creek, through Society Hill, Darlington and Kingstree, to Fort Motte roal, albout 90 miles.

1768. Fron Orangeburg, across the Saluda, near Rocky Creek, through Newberry, to Laurensville, about 110 miles.

1770. From Orangeburg, across the Elisto, through Ninety-Six, across the Saluda, through Abberille to Pendleton and beyond, about 170 miles.

1770. From Augusta, through Edgefield, across Saluda river, near Ninety-Six, across Enoree river to Broad river, at Fishdam Ford, about 100 miles.

The highways were ordered to be constructed by the personal labor of the inhabitants of the country through which they respectively passed, which seems certainly to have been a hardship upon those thus burdened.

The road laws then in force in England required personal labor on local roads, but the main highways were maintained at the expense of the whole public. The Colonial Legislature, as we have seen, had at first only local roals to make, and these were sanctioned by military exigencies, hence it was quite appropriate to have them built and kept up by the neighborhood, according to the English system, but when the time came to build highways so as to connect the capital with the distant parts of the Province, then only recently settled, the law-makers seem not to have recurred to English precedents ; they simply applicd to these highways the laws in force for the construction and maintenance of the roaks previously built, which were wholly local.

Besides this hardship of making the dwellers along a highway keep it up for the convenience of a tratfic in which they have no interest, there were special dircumstances which made the road law more onerous in the uper country tinan in the low country.

In the first place, in the low country the large number of slares rendered the burden of road duty in that section comparatively light on the 
whites, whereas in the upper country at first, there were no slaves, and their number's remained small until after the heaviest work on the roads must have been already finished, so that there both road duty and military duty fell on the same individuals.

In the second place, in the low country each person could see the importance to his individual safety and convenience of every road on which he had to work, either in person or with his slaves, and these roads were used exclusively by those who made and kept them up; but in the upper country the highways were intended principally to promote a traffic between distant points, which brought with it no advantages to the great majority of those whose time and labor were consumed in constructing and mending them, while this demand upon their time and labor preventcd, retarded, or at least rendered more onerous, the making of such shorter roads as were needed and would have sufficed for the convenience of each neighborhood. After the highways were built and the cultivation of indigo, tobacco and cotton spread throughout the upper country, the benefit of having good roads to Charleston became apparent, and their existence was found to be essential to the material prosperity of the country.

During the Revolution the people of South Carolina seemed to realize, for the first time, that they were all bound together by common interests and had all a common destiny. Both Whigs and Tories recognized the unity of the State and acted upon it, and when the struggle was over, the patriotic enthusiasm it had excited manifested itself in efforts to render. intercourse betwcen all parts of the State easy and agreeable.

Roads, bridges, ferries and water courses were improved, new routes. were established, and there was evidently a desire to improve, too, the methods previonsly relied upon for making and mending the roads.

The legislation of this period contains the following Acts of interest or: importance.

1778. To render navigable the Wateree river, by an assessment upon the inhabitants, and upon owners of uninhabited lands, within a certain distance on both sides the river.

This Act seems to have been an effort to break away from the. principle by which for more more than a century all work of that sort in the State had been exacted of the people in kind, but it still elung to the idea that the locality, and not the whole State, should pay for such public works. Unfortunately this timid endeavor after a better method seems to have been abortive, and having been tried again and again, during the next decade, was abandoned.

178t. The road duty age was changed from between sixteen and sixty to between sixteen and fifty. 
1785. To clear the navigation of several rivers, by roluntary subscriptions and hy arsessments upon the lants in the ricinity, and upon the male inhabitants between sixteen and fifty. (Another weak and rain innovation.)

17S6. To establish a company for the inland navigation from Santee to (ooper river. (Santee Canal Company.)

17S6. To make, inter alias, a roall from Frilay's ferry, on Congarec, to Augusta.

(N. B. On the same day, 22, March, was passed the Act to establish the seat of government at a place near Friday's ferry-to lay out a town there and to call it Colmmbia.)

1757. To establish a company to improve the navigation of Edisto and Ashley rivers, and to make a. canal between the two rivers.

17S7. To establish a company to open the navigation of the Catarba and IVateree rivers. from the North Carolina line to Camden.

Among the corporators were John Rutledge, Thomas Sumter, John Gaillard, Benjamin Waring and Joseph Atkinson.

The company was to construct canals, dams and locks, or otherwise to render the river navigable; whereupon it was to acquire perpetual control of the stream, with power to lery upon the traffic whaterer tolls the directors thought proper, not exceeding. in any annual aggregate, twenty-five per cent. of the whole outlay of the company down to that date. The company had also the power to open roads through any private lands, so as to connect the river landings with the existing highways; it might take up and acquire title to any land, not already granted, within two miles of the river bank on either side. The shares were to be forever exempt from taxation, \&c. The company might import negroes, not exceeding three hundred, and have credit for five years for the duty on such as they should import.

17S7. Lynches creck. Clarke's creek and Black creek to be opened by labor of inlabitants in the noighborhood of each respectively.

17SS. A general road law. Term of commisioners, three years; limit of road duty, twelve dars in the rear; penalty for non-attendance, two dollars for each white man, and one dollar for each slave per dicm. Bridges may be built by contract. and cost assessed on male inlabitants between sixteen and fifty years of age.

17SS. To establish a company for opening the navigation of Broarl and Pacolet rivers. This charter was almost the same as that given for opening the Wateree and Catawba. 
1789. General roal and ferry law. Tests in road commisioners the granting of licenses for tarerns and billiard tables, the proceeds to be expended in repairing bridges and roads within the parisl or district to which the license applies. This new departure, like that of 1778 , seems to have been unsuccessful.

The dawn of the nineteenth century found the people of South Carolina at peace, united and prosperous. The years which had elapserl since the Revolution had been well employed in securing these material benefits. Industry and frugality had been elevated into the rank of patriotic and fashionable virtues by the spirit of republican simplicity which then pervaded all parts of the State. The eultivation of cotton had spread rapidly and was very profitable, and the roads, bridges, ferries and water courses were kept in as good order as circumstances allowed. Drayton's "View of South Carolina," published in 1502, contains, at page 15s, the following sketch of the roads of that day: "The roads in the State are well adapted to transportation and traveling, even to the mountains; and hence, wagons find no difficulty in eoming from the upper counties, bringing with them the commodities of that distant region. Cross roads to and from each court house are made throughout the State, and a wagon road has lately been made from the north fork of Saluda river, over the mountains to Knoxville, in the State of Tennessee, by which wagons have passed, earrying loads of twenty-five hundred pounds weight. This opens a new source of wealth to this State, and speeds a happy intercourse between the countries east and west of the Apalachian mountains.

"In the upper country, the water courses are mostly fordable, and when they are not, like other parts of the State, they are erossed by bridges and ferries. These roads are made and kept in repair-under the direction of commissioners-in the lower country by negroes, and in the middle and upper country by a suitable number of the resilents in the county or parish through which they lead; otherwise there is little or no expense attending them, and at this time a carriage and four may be driven from any part of this State to the other, and from the sea shore to the mountains, without any other difficulty than such at naturally arise in long journeys. Some few toll bridges are erected, but the spirit of the people is not yet favorable to these taxes on traveling. It is hoped, however, that the clay will come when bridges which are of too great magnitude to be built and kept in repair by individuals, will be taken under the direction of government. This is one of the good purposes for which public moneys may be reserred in the public treasury, and for which they may be drawn out in the public serrice." 
The rehicles used upon these roads for heary traffic were of three kinds. In the low country, they were mostly ox carts, marle with large whecls, four to six inclees tread, drawn by three or four yoke of oxen, and capable of carrying three to four barrels rice-about two thousand pounds. In the midrlle and upper country, sleds were therl for short distances on the furms and cross roads, while for long distances, four and six horse wagons were employed, capable of carrying two to three tons. These wagons had narrow wheels, and cut up the roads in winter, especially where the ground was clayey. Besides these ordinary conveyances, several novel methods were employed of moving produce to market. It is said that cotton was sent to Hamburg from the country near the upper Sarannah by throwing the bales into the stream and letting them float with the current. When produce had to be hauled to market from a locality requiring no return in goods, it was sometimes the practice to put it on a sled drawn by oxen, so that, at the end of the journey, not only the produce, but the oxen and even the material of the sled could be sold. Persons now living remember hogsheads of tobaeco arriving in Charleston, having been hauled by oxen or horses attached to a shaft run through the axis of the hogshead, from head to hear, so that the package might roll freely. Barrels of rosin were sometimes secured together, and floated in rafts to Georgetown from the Cheraw section.

The efforts which after the Revolution had been so earnestly directed towards facilitating communication between Charleston and the middle and upper parts of the State reached their climax in the conception and construction of the Santee Canal. By referring to the map it will be seen that the Santee river unites the-waters of the Wateree and the Congaree, and these, in turn, trace their sources to the head waters of the Catawba, the Broad, and the Saluda, all beyond the northern limit of the State. Had the improvements then contemplated proved practicable, those streams, and some of their tributaries, would have been rendered navigable to the State line, and then, by means of the Santee Canal, connecting the Santee and Cooper rivers, Charleston would have received by water the products of all Clarendon, Sumter, Kershaw, Laneaster, York, Chester, Fairfield, Richland, Lexington, Newberry, Laurens, Lnion, Spartanburg and Greenville, with those of a part of each of the counties of Oconee, Anderson, Abbeville, Edgefield and Ormgebnrg. So patriotic and magnificent a project deserved the success which, alas, it did not obtain. The corporators named in the Act of 1786 , chartering the "Company for the inland navigation from Santee to Cooper river," are John Rutledge, John Faucherenar Grimké, Theorlore Gaillard, George Haig, James Kennedy, Graham, Thomas Sumter, Benjamin Waring, Thomas Walker, John Vanderhorst, James Nitehell, Elanus Burke, 
Peter Fayssoux, Richard Champion, Aaron Lnocock, - Pearson, John James, Francis Marion, Joln Dawson, Alexander (rillon, Samuel Midwood, John Richardson, Ephraim Mitchell, William Bull, Duncan MeRae, Nathaniel Russell, Philip Gadsden, Peter Belin, Ifenry Laurens, Jr., Edward Rutledge, Ralph Izard, John Budd, Robert Beatty, William Smith, Minor Winn, William Clarkson, William Hill, James Theus, Joseph Atkinson, Thomas Jones and Daniel Bourdeaux. This was the grandest work of internal improvement that had been attempted in all America (although it was soon afterwards surpassed by similar schemes in other States), and nothing can show more (onclusively the devotion and resolute spirit of its promoters than the fact that after the eharter was obtained six years were consumed in making up the company. At length, in 1792, work was commenced, and in July, 1800, at a cost of $\$ 750,000$, the canal was finished and a boat loaded with salt went from Charleston to Granby.* The Santec Canal, twenty-two miles long, thirtyfive feet wide at the surface of the water, with a minimum depth of four feet (the same as the Erie (anal), and thirteen locks, all built of stone or brick, was a work of which the State may well be proud. It was no light misfortune either to the generation which built the eanal or to those which witnessed its gradual disuse and final abandonment, that so much publie spirit, so much faith and energy, should have failed to yicld a rich return. Although the Santee Canal never realized the expeetations of its projectors, it served a useful purpose, and was for thirty-orld years an important highway, serving to keep down the rates of land carriage between Charleston and an extensive and important region. The defect in the canal was its location across a ridge, and consequently the want of a supply of water at its summit, sixty-nine feet above tide level.

The facilities for water transportation in South Carolina probably reacher their highest development just before the epoch of railroadsthey are thus described in Mills' Statistics, published in 1826 , page 156 , et ser.: "The Savannah river divides this State from Georgia. It has a ship navigation eighteen miles, from the oeean to the city of Savannah, and good steamboat navigation 140 miles further, to Hamburg and Augusta. Above these places, 100 miles, to Andersonville, the river has thirty-three miles of rapids, with a fall of about eight feet to the mile, on a regular inclined plane; the other sixty-seven miles is smooth, deep'

*In this same year, 1792, the "Western Inland Navigation Company" Was incorporated by the State of New York, for the purpose of making a lock navigation from the Hudson river to Lake Ontario, but it accomplished very little, and after great expenditures, abandoned its work, which extended from the Molawk to Oneicla Lake. Nothing more was done until 1817, when the New York Legislature appointed a commission to build what has been since known as the Erie Camal. This was finished in $1825-a$ quarter of a century after the Santee canal was opened. 
water. Boats descend from Aniersonville with seventy bales of cotton, or ten tons. The Thgaloo is navigable for similar boats twenty-five miles, to Pulaski, and the Seneca trenty-six miles, or six miles above Pendleton ('ourt House. At the junction of Twelve Mile ('reck the Sencea changes its name to Keowee, which is eapable of being made navigable entirely within the mountains by merely sluicing. The 'Tugaloo branch of the Savannah rises in the mountains, a short distance from the Hiwassee, a mavigable branch of the Temnessee river. By means of these streams it is believed the Sonthern Atantic may be connected with the Western States by a narigable canal. The general govermment have ordered survers to be made to ascertain its practicability.

The santee river enters the ocean by two mouths. There is a goor steamboat navigation on this stream to the junction of the Congaree and Wateree, and up both these rivers to Camden and Columbia. (The Wateree changes its name to Catawba at the W'ateree creek). This river, above Camden to the North ('arolina line, is interrupted by four principal falls, around which canals have been cut, except at Rocky Mount, where the work is now going on. The first fall is at the Wateree Canal, which is five miles long, with a width of fifty-two feet, and having six locks; the second is at Rocky Mount, where there is a fall of 121 feet, requiring thirteen locks. The canal here is cut the greatest part of the distance. The third fall is at the Catawba canal, where there is a fall of fifty-six fet in three miles. The canal and seven lucks here are finished. The fourth fall is at Landsford, where a canal two miles long, with five locks, completes the navigation. Above this the river has rapids, but the small boat narigation can be extended with care within the Alleghany mountains. The Congaree is formed by the confluence of the Broad and Saluda rivers, where there is a fall of thirty-four feet, which is overcome by a canal three miles long, and five locks. On the Broad river, the navigation for small boats extends to King's creek, with the aid of Lockhart's Canal, which overcomes a fall of fifty-one feet by seven locks in two miles. Above King's creek there are sereral rapids and extensive falls; locks would be requisite to make good navigation hore, and when these are once passed, the navigation to the foot of the mountains is only obstmeter by a few rapids. Green river, a main branch of Broad river, extends to a point in the Bhe Ridge (properly the Alleghany) whore this momntain is very low and narrow; on the opposite side of the mountain rises the French Broad, a large branch of the Tennessee. It is confilently presmmed that the Atlantic and II estern waters may be united here by a navigahle canal with great comparative ease.

The saluda river is navigable 120 miles above Columbia. There are three canals on it: 
1st. The Saluda Canal, two miles and a lualf long, with fire locks, overcoming a fall of thirty-four feet.

2u. Drehr's C'anal, one mile long, and with four locks, orercoming a fall of twenty-one feet.

31.d. Lonck's Canal, which has a single lock of six feet lift.

The Pee Dee river rises in North Carolina (where it is called the Yadkin), and enters Winyaw Bay, above Georgetown. To Cheraw, above 120 miles from the ocean, it has a good stcamboat navigation; from Cheraw to the North Carolina line, nine miles, there is a fall, on a regular inclined plane, of eighteen feet, and above that line the rapich extend to the narrows, about seven miles by water, where the fall is very great. Above the narrows to the mountains this river is represented as farroralue for small boat navigation. It heads near New river, one of the main branches of the Great Kenawha.

The Little Pee Dee rises in the sand hills in North Carolina, and is navigable from Lumberton.

The Black river is navigable to the line of Sumter district, about sixty miles from its entrance into Winyah bay.

Lynch's ereek is navigable eighty miles, and Black creek thirty miles from their junction with the Big Pee Dee:

The Edisto discharges into the ocean by two mouths, called Torth and South Edisto inlets. It rises in the region of sand hills in two branches, which unite below Orangeburg; both branches and the main river are navigable, having no shoals. It has been contemplated to unite this river with the Ashley, by a canal fourteen miles, extending from near Gweham's ferry to Dorchester. The Edisto will form the feeder; the ridge between the two streams is only thirteen feet high, and les than a half mile through. This canal will sare eighty miles of diflicult, and, in some places, dangerous narigation between the upper Edisto and C'harleston.

The Combahee has a schooner navigation to Saltcatcher bridge, and the main Saltcatcher is navigable for boats ten miles higher. It may be made navigable to Barnwell Court House by merely removing logs which now obstruct it.

The Waccamaw river rises in Waccamaw lake, near the Cape Fear river. From this lake it is navigable for boats to Commayorough, and from that place to Winyah bay it is navigable for schooners. From Winyah bay to Santee river the Winyah Canal, six miles long, has been partly executed, and from the Santee to the head of the Owendaw there is good schooner navigation. From the head of the Owendaw to schooner navigation on the ITando, the distance is about eight miles, a canal here would require only eight feet depth of digging to be fed with tide 
water. Wanclo river enters Charleston harbor. From C'harleston to Savanuah there is a steamboat narigation between the islands and the main, with the exception of about half a mile between the Broad and the Savannali livers, where a canal is now cutting. Ilonce it will be seen that with fourteen miles of canaling, a good steamboat navigation, entirely inland, and parallel to the coast, may le effected from the North Carolina to the Georgia lines. It is supposed that five locks will be all that are necessary. 'This work has been estimated at less than \$2,50,000. It would appear to fall within the system of internal improvement contemplated by the general govermment.

The Ashepoo has a schooner navigation to the Ashepoo ferry.

The Ashley river enters Charleston harbor on the southwest of the city, and is navigable for schooners to Dorchester, twenty miles.

The Cooper river is a good navigable stream to the entrance of Biggin ereek, thirty-four miles by land from charleston. From this point to the Santee river, the Santee canal, twenty-two miles long, has been constructed, passing a summit sixty-nine fect above tide waters in Cooper river, and thirty-four feet above the Santee. There are on this canal thirteen locks. A great part of the produce from the upper Santee, Congaree, Broad, Saluda, Wateree and Catawba rivers pass this canal in boats carrying one hundred and twenty bales of cotton or twenty-five tons of merchandise.

It is sair that upwards of three million dollars was expended in the internal improvements thus described, without estimating the ralue of the labor assessed upon the localities adjacent to the works. In spite, howerer, of State expenditures, in spite of roads, bridges and ferries, in spite of canals, companies and steamboats, in spite of patriotism and State pride, the trade of upper Carolina could not be permanently retained by Charleston.

In Judge O'Teal's Annals of Newberry it is mentioned that, in 1S13, the late Hon. Ker Boyce, then keeping a store at Newberry, "began to trade overland with Philadelphia. Cotton was hauled from Newberry to Philadelphia, and goods brought back, by wagons. He and the late Thos. Pratt annually mounted their inorses and rode to Philadelplia, purchased their goods, and thus laid the foundations of their respective fortumes. In 1S15, they visited Amelia * island on horseback, purchased a stock of goods which they understool was there for sale, and transported it to Newberry by wagons." These opgrations ceaserl with the peace of 181.5 , and they were, perhaps, rendered possible only by the war and the fidelity of Charleston to the National cause, and to the em-

\footnotetext{
* Amelia Island, in Florida, was then lately taken from the spaniarda, and a noted place for contraband trade.
} 
bargo laid by Congress; but they serve to show how frail were the commercial ties binding the richest portion of the State to her own emuorium, and how habituated the people of the upper country were to secking markets in distant Stater. After 1815, steamboats and teamboats were added to the appliances for utilizing the rivers and canals of the State; and, for a time, they served to increase the volume of trade between Charleston and the interior, and to rencler it apparently more stable.

In Mills' Statistics, published in 1826, page 42S, it is stated that there were, at that time, ten steamboats plying between Charleston and the towns of Savannah, Augusta, Hamburg, Georgetown, Cheraw and Columbia. The average eapacity of these was six hundred bales of cotton, of three hundred and twenty pounds each, but some boats carried up to one thousand bales.

The morement of cotton to Charleston by water, between

1st October, 1S26, and 1st October, 1S27, was, through

the Columbia canal.

Shipped down the Congaree from Granby, about. . . .

Total quantity from above Columbia ....

Total quantity from Camden . .

45,612 bales. 10,000 bales.

Total quantity shipped at the various landings on the Congaree, Wateree and Santee, above Vance's Ferry . .

Total quantity from above Vance's Ferry. . . Total quantity from IIamburg and Augusta.

55,600 bales. 40,000 bales.

15,000 bales. Total cuantity from other sources and wagons . . . . .

Total Cotton Receipts (320 Ibs. per bale) . . 200,000 bales.

Flatboats, bringing cotton from Columbia, \&c., passed through the Santce canal. They were manned, generally, by a "patroon" and five hands, carried 110 bales of 320 lbs. each, and consumed twenty-four days in the round trip, from Columbia or Canden to Charleston and back. The tolls on the Santee canal were $\$ 40$ on each boat each round trip, The freight was $\$ 1$ per bale, or $\$ \tau$ per ton. Cotton was brought from Augusta and Hamburg to Charleston by steamboats; freight average, about $\$ 1.50$ per bale, insurance, $25 \mathrm{c}$., equal to $\$ 1.75$ on $320 \mathrm{lbs}$, or $\$ 12.25$ per ton. The up-freights were 50e. per $100 \mathrm{lbs}$., or $\$ 10$ per ton, and insurance one per cent. The delays on this route from various causes were very great, and, at times, the Savannalh river was so low as to stop all navigation. Travel was slow, difficult and expensive, and the mails only 
pasicel thrice a week between Charleston and Angusta, two days and nights being consunerl in the journey by the mail stages. 'The only legular lines of stages rumning out of Charleston were those to Savannal, Angusta, Columbia and Georgetown. Travelers who could not make use of these or the steamboats, harl to resort to private conveyances.*

The natural advantages of the country for water communication, and the enterprise with which ther were improver and utilized, the money and labor expended upon roads, bridges and ferries, failed to meet the neects of the country, and to maintain the trarle of the city. A magazine writer in 1831 says: "The rich inhabitants of the back country of South Carolina, and of those parts of North Carolina and Georgia which trade with Charleston, are obliged, at great expense, to transport their produce and receive. in return, their supplies; weeks, and not unfrequently months, have elapsed before places not more distant, in a direct line, than one hundred and twenty miles, could effect their communications, and then, and at all times, with great expense, and at no time without great risk of loss and great delay.

The profits of the planter, or what ought to be his profits, are but too often consumed in the expense of transportation; and the merchant fincls it impossible to calculate, with that certainty which his operations require, the time he may expect arrivals or hear of his shipments having reached their points of destination. Capital which would otherwise be active, is thus dormant a large portion of the time, and, consequently, more of it is required than would suffice with more certain, rapid and safe communication for the same amount of business.

Our climate presents an obstacle of no small magnitude to transportation, either for goods or for persons, at least during three months in the year. The rivers are unhealthy, and often too low, the roads are sandy, heary and hot; the laborers and the animals engaged in transportation are with difficulty brought to perform their task, and too often sink beneath it.

The exports of Charleston amount to ten millions of dollars per annum, whilst the direct foreign imports are searcely more than a tenth of that amount. 'The merchants in the interior' cannot postpone until the fall their supplies for the season, and as they cannot risk the approach to the city, as early as is required in the summer to purchase them and have them transported to their respectire homes by the present tedious and expen-

*On the 15th May, 1815, Gen.Thos. Pinckney, with two ladies of his fanily, set ont from their plantation on the Santee, in their own carriage, and traveled to Boston. A diary of the journey, in $11 \mathrm{~S}$. , is still extant. They reached I'hiladelphia on the 15th Jnua, havine traveled i9:2 miles in 31 days, inchuding stoppares, to that point. The traveling expenses, including two weeks' stay in Philadelphia, amounted tu \$42?. 
sive modes, they prefer sailing to New York, and laying them in at that place."

Mr. Elias Horry, in his address upon the completion of the railroad to Hamburg, in 1833, thus refers to the inception of that work, five years earlier. "In Sonth Carolina, partieularly in Charleston, a respectable portion of our citizens wisely determined that railroarls would be eminently beneficial to the State; that they would revive the diminished commeree of our city, and tend to bring back the depreciated value of property to its former standard. In fact, it became necessary that some efficient measures, some great enterprise, should be resorted to. Real estate in and near Charleston had sunk to half its former value, and in some instances to less; and this depreciation had extended also to country property.

Industry and talent had lost encouragement and met not their merited rewards. These erils had commenced and accumulated within a few years, and were still progressing, and during the same period the Northern and Eastern States and cities had attained to great and increasing affluence and prosperity, while those of the South were gradually falling into decay. To improve, therefore, the welfare of Charleston, and forward as much as possible her prosperity, and that of the State, our best merchants and most intelligent men decided in faror of the adoption of the railroad system.

The plan was that a railroad be located from Charleston to Hamburg, on the Sirannal river, and that a branch should be extended from the main line, when completed, to Columbia, and afterwards to Camden. The project was grand, and required knowledge and experience to have devised it."

The first charter was obtained 19th December, 1827, but being unsatisfactory, another was granted by the Legislature on 30th January, 1828, providing for a corporation, to be called "The South Carolina Canal and Railroad Company."

The Chamber of Commerce, on th February, 182S, appointed a committee of ten of its members to "inquire into the effect likely to result to the trarle and general interests of the city of Charleston by the establishment of a railroad communication between the said city and Hamburg," also to collect information about railroads, and report the probable cost of such a road, and the revenue likely to be obtained from it.

Mr. Alexander Black, the chairman of this committee, on 3d March, 1828 , submitted a very lucid account of all that was then known about railroads, and added the committee's opinion as to the probable effect of the contemplated railroad upon the prosperity of Charleston. Among other things, we learn from this report that "the trade of charleston is 
supported by about 200,000 bales of cotton and 100,000 barrels of clean and rough rice annually," and that a bale of cotton was worth about $\$ 2.5$.

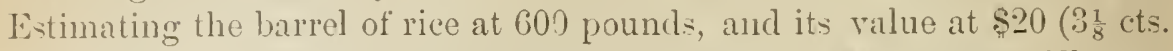
per pound) the whole trade of Charleston was only $\$ 7,000,000$. The report concludes, "Charleston * * * has for sereral years past retrograrled with a rapidity unprecedented. Her landed estate has, within ciglit year's, depreciated in value one-half. Industry and business talent driven by necessity, have sought employment elsewhere. Many of her houses are tenantless, and the grass grows uninterrupted in some of her chief business streets."

While Mr. Black's committee were at work collecting information from a distance, some public spirited citizens furnisher the means to have a preliminary survey made of the proposed route, and obtained a report of that surver on the 15th March.

These reports were published, and on the 17th March, 1S:S, books of subscription to the capital stock of the company were opened at Charleston, Columbia, Camden and Hamburg.

When the time expired and the books were closed, the subscriptions taken at Charleston amounted to 3,500 shares, the minimum required by the charter, but at the three other places not one share was taken.

On the 12th of May, 1S2S, the company was formally organized at a meeting of the stockholders, at the City Hall, Charleston, and officers were elected as follows:

President.-William Aiken.

Directors-Alexander Black, Thomas Bennett, Joseph Johnson, John Gadsclen, A. S. Willington, E. L. Miller, T. Tupper, William Bell, John Robinson, Thomas Napier, Henry F. Faber, James Holmes.

Secretaries.-Edwin P. Starr, John T. Robertson.

Exploring Surveyors.-Col. J. B. Pettival, Mr. C. E. Detmold, Mr. R. K. Payne.

United States Engineers.-Dr. ITm. Howard, and Messrs. Harrison, Swift, Guion, Anderson and Belin.

In time, Engincer Corps were organized as follows :

Chief Engineer.-Horatio Allen.

Is sistruts.-J. B. Pettival, C. E. Detmold, E. Watts, P. Martineau, W. B. Thumpson, James Clarke, C. O. Pascallis, A. A. Dexter.

Alexander Black may be regarled as the father of the enterprise. He got the first charter in 1827 , supplicd the information which attracted and satisficd others, and became commissioner, that is, fac totum, of the company during the whole period of construction. 
President Tupper, in lis farewell address in $18+3$, says it was an $u n-$ popular undertaking. Mr. Black and Mr. Allen, in the several reports made by them, from time to time, mention the opposition of the land owners between the Ashley and Edisto to the location of the roarl through that section, which was wealthy and populous, and the Board of Directors in their annual reports refer to the obstacles thrown in the way of bringing the road below Line street.

As late as 1S37, the use of locomotires south of Line street was made the basis of an indictment of the company as a public nuisance.

IIre can not, therefore, do too much honor to the men who risked reputation and the public favor, as well as their private means, in carrying the Charleston and Hamburg railroad through to completion.

It required courage as well as skill and labor, and when success was attained, when the public confidence was conquered and public support was ready to attach to an extension of what was quaintly called "The Railroad System," these heroic men resigned to others the leadership and prominence in the enlarged projects that followed.

The Louisville, Cincimmati and Charleston Railroad, the South Carolina Railroad, and the Southwestern Railroad and Banking Company, were great conceptions, and were eagerly championed by the orators and statesmen of the day; but in no case were the practical results in any degree comparable with those achieved by Mr. Black, Mr. Horry, Mr. Tupper, and their associates.

Mr. Wm. Aiken, the first president, died on the 5th March, 1S:31, and was succeeded by Mr. Elias Horry, who brought to the support of the already flagging enterprise a noble spirit, and the financial force of his large private fortune.

"The mode of construetion adopted for the railroad," says a writer in the Southem lievieu, of May, 1831, "is to frive piles every six feet apart in parallel lines, the heads of these piles are bound together by transverse sleepers; ${ }^{*}$ these are surmounted $\phi y$ the longitudinal wooden rail, about nine inches square, in various lehgths, from fifteen to thirty-five feet, on the top of which, on the imney side, the flat bar-iron is nailed. The tracks are about five feet apart."

Mr. Horry, the president, says, in one of his letters, that "the timlser" was varnished."

To do justice to those who conceived and executed the building of the Charleston and Hamburg railroad, we must fully realize the lack of information on such subjects generally, and, above all, the utter newness of such an undertaking in the sort of country to be traversed by this road.

* Hence probably the term "cross-tie," which still adheres to the transverse piece of timber underlying the rails, though the piles which they tied across are no longer used. 
It was the first effort in America to build a lailroad expressly for locomotive power, and in England the railroals were short straight lines, built at enormons expense.

The Baltimore and Olio, begun bafore the Charleston and Hamburg, was intended for horse-power, it being then supposed to be impracticable to use locomotives on short curres.

Mr. Peter Copor pratically refuted this notion, in August, 1S30, but some months before his experiment at Baltimore, viz: on the 14 th Januarr, 18:30, five days after the commencement of work on the road, the Boird of Directors of the Charleston and Hamburg railroad adopted the report of Mr. Bennett, containing this memorable sentence :

"The locomotive shall alone be used. The perfection of this porer in its anplication to railroads is fast maturing, and will certainly reach, within the period of constructing our road, a degree of excellence which will render the application of animal power a gross abuse of the gifts of genius and science"

George Stephenson's "Rocket" made its trial trip at Liverpool, on the (ith October, 1S29, so that there was barely time for the news of it to have reached Charleston, in Jaunary, 1S:30.

On the 2 Sth of December, 1529 , the contracts were given out, and on the 9th of January, 1830, the railroad was actually begun, by the driving of piles at "Lines" street."

Mr. E. L. Miller, one of the directors, undertook, at his prirate risk, to provicle a locomotive that should draw three times her own weight at a "need of ten miles an hour, and the contract was accepted by the Board of Directors on the Ist March, 1830. The locomotive was built in New York, under Mr. Miller's direction, and was the first constructed in the United states for actual service on a railroad. It weighed four tons, had fonr wheels, made with spokes, was called the "Best Friend," arrived in Charle-ton on the $23 \mathrm{~d}$ October, 1830 , and made one trip on $2 \mathrm{~d}$ November, when the wheels proved of insufficient strength. Others had to be got from New York, and finally, on the 14th and 15th December, 1530 , trial trips were made, when the "Best Friend" accomplished from sixteen to twenty-one miles per hour, drawing four or five cars with forty or fifty passengers. Without the cars the locomotive run thirty-five miles an hour, to the amazement of the community.

This achievement will be considered all the greater when we remember that the roadway was formed by stringers set on posts, with only a strip of iron spiked along one edge of the surfice of the stringers.

In 1S:0 six miles of roal were built. In 1531 the whole line was placer under contract. On the 7 th November, $193 \cdot 2$, the road was opened to Branchiville, sixty-two miles; on the Tth February, 1S33, to Midway, 
ninety-two miles, and in October, 1833, the whole roal was completed* and opened to the public from Line street, near Charleston, to Hamburg. Cost $\$ 951,148.39$. It was then the longest continuous line of railroad track in the world, 136 miles, and continued to be the longest until 1840 . It was built entirely on piles. In February, 1S32, the first United States mail ever carried on a railroad was transported over the twelve miles then in operation nearest the city. Stages to and from Columbia and Augusta completed those routes.

The Charleston and Hamburg railroad demonstrated both the practicability and convenience of this mode of transportation, and the unwise deflection via Kingville of the Columbia branch of the South Carolina railroad shows how completely the previous apathy of the interior communities had given place to an ardent desire to share in the benefits of the accomplished enterprise.

When the railroad from Columbia to Greenville was projected, the first surveys showed a straight and practicable line via Laurens, but so eager had grown the desire for the new accommodation that influences arose strong enongh to fasten upon the undertaking an egregious and costly route, which exhausted the resources of the corporation, and forced it to build up a territory it could not command, and to occupy a line inviting competition. It is umecessary to trace in detail the various railroad projects that have from time to time been set on foot. Some failed that should have succeeded, and some were carried out that should have failed. Following the completion of the railroads to Greenville and Charlotte came the great abortive effort to penetrate the Blue Ridge at Rabun Gap. This was rightly regarded as a public work, and on that ground both the State and city of Charleston contributed liberally to its accomplishment, but the war of secession came on and nothing of importance has been done since to utilize the great outlay made, beyond Walhalla.

The period between 1834 and 1860 was marked by the gradual development of railroads, and by many changes within the State, resulting from that development, which deserve careful consideration, as showing the effects of physical conditions upon society and politics.

Before considering these, however, it should be observed that no effective opposition was ever made to any project for building railroads within or across the territory of the State, but on the contrary, the Legislature freely chartered, and in some cases substantially aided railroads which diverted business from our own centres and tended to benefit cities beyond our borders at the expense of those within the State.

Augusta, Charlotte, and Wilmington profited largely by the uncalcu-

*The Liverpool and Manchester railroad, thirty miles long, was begun in June, 1826 , and finished 15 th September, 1830 , at a cost of $£ \$ 20,000$, abo'st $\$ 4,000,000$. 
lating liberality of South Carolina in this respect, and although Charleston was necessarily the chief sufferer, and exercised at that time an almost parmount influence in the State, she never sought to monopolize the trade of the interior by obstructing the charters of railroads leading to rival cities.

It is due to a high-minded and generous, community to record this fact, and to point out that it was the consequence of consistent adherence to principle, and not attributable to either weakness or indifference.

The effects produced by railroads, above referrerl to, are these:

1st. The railroads were built, for the most part, on the ridges between the rivers, and thus tended to produce a new distribution of population in those parts of the State which they traversed.

The carliest settlements in the low country, as we have seen, followed the rivers, and in 1817 , Col. A. Blanding stated in a published address, that "two-thirds of all the market products of the State are raised within five miles, and most of the other third within ten miles of a navigable stream ;" one of the consequences, no doubt, of the work done in improving internal navigation, and of the insufficient means prorided for making and keeping up the roads. It will be seen from this why the earlier railroads were so coldly received by the persons then most prominent as representatives of the agriculturalists of the interior, and why they were taken up and carried to completion only by men who, like Mr. Aiken, Mr. Horry, Mr. 'Tupper and Judge O'Neale, looked beyond the interests and prejudices of a class, and sought to promote the prosperity of the masses.

The richer lands bordering the rivers were held in large tracts by wealthy proprietors, who had water carriage for their crops and horses and carriages for themselves, but the small farmers, scattered over the less fruitful lands upon the ridges, were without facilities for trarel and for marketing their produce. To them the railroads were a great boon, but to the land owners on the rivers they were an annoyance. The Charleston and Hamburg railroad was prevented from passing through St. George's, Dorehester, and up the valley of the Edisto, by the opposition of the planters, but was welcomed and aiderl with gifts of land by the seattered settlers in the pine barrens, between the Ashley and Cooper.

21. The railroads created towns, and the country town became at once a new and important element in the development of the interior of the State. These towns were the centres of trade; churehes and schools arose there, some acquired colleges, and each town attracted to itself the enterprise, talent, and mechanical skill of the vicinity, and lawyers, clergymen, doetors, and merchants united, gave the towns that leadership in local affairs, social and political, which had been before enjoyed by 
certain large "settlements." Since towns represent the thoughts and interests of communities, while the "settlements" had represented chiefly" family influences, the significance of the changes is obvious. Railroads made upper South Carolina even more strongly democratic than it had been before.

3rd. The railroads facilitated negro deportations from the State and thus tended to reduce the wealth of the low country, whence the chief movement took place, while, by cheapening transportation, they vastly augmented that of the upper and middle country. As a consequence, the low country gradually lost the social and political ascendency in the State, which, acquired in colonial days, had been retained until the advent of railroads took it away. Thus it happened that in building tho Charleston and Hamburg railway, Charleston unconsciously initiated a movement which ultimately subverted her influence in the State, and deflected the course of social and political development in the Commonwealth, away from the aristocratic modes, which its origin and history had fixed upon the low country, and towards those principles which underlay the development of upper South Carolina, and which are the exponents of popular institutions both in government and society.

4th. The railroads stimulated the extension of cotton culture and made Western provisions so cheap that the farmers neglected the production of food at home. By cheapening the transportation of corn and bacon to the cotton lands, and cheapening the carriage of cotton to the seaboard, an unaccustomed adjustment of prices came about, which misled the farmers into that vicious semblance of economy of which the evil effects are still seen and felt throughout the State, whereby the independence and the substantial comforts of farm life are sacrificed to the pursuit of money returns from a large cotton crop.

5th. After the railroads were finished, the highways, which had been so early located, and which were built and maintained by so costly, and even oppressive a system of personal road service, were of little use as main arteries for trade and travel, but the former cross-roads, connecting the new towns and the railroad stations with the country around them, became important thoroughfares. Owing to the peculiar topography of the country, and to the course of the railroads along the ridges, these old cross-roads were ill adapted to such requirements, while the road laws were not elastic enough to remedy the inconvenience by applying to them the means used in building the former highways. Hence to this day some towns and many important railroad stations are almost inaccessible in bad weather This affects even the prosperity of the railroads, for good common roads are essential as feeders to the railroads.

6th. No precautions have been at any time taken to obtain for the Legis- 
lature, or the public, trustworthy information as to what railroads should be encouraged and what obstructed, nor as to the judicious location of such roads as may be desirable in a general way. Upon every occasion on which the State was asked to grant a charter and to confer the "right of way" along a given route for a railroad, even in cases where the State was asked to aid the enterprise, the field of discussion has been left solely to volunteers. Thus the public interests involved in the undertaking were rarely if ever adequately represented, and as a general thing only that side of the ease which was urged by the advocates of the enterprise ever had a hearing either in the Legislature or the newspapers. Any roice raised in dissent was weak and ineffectual against the clamor of the interested, while arguments in opposition were too often answered only by charges of unworthy motives on the part of those who ventured to make them public.

It has been an unfortunate thing that the State abolished the Board of Public Works just at the time when in the building of its railroads such an institution would have been most useful. If the board had been retained, and had been charged with the duty of laying out a systematic and comprehensive scheme of railroads for the whole State, leaving each route to be taken up by a private corporation as soon as it proved to be attractive, we should now be far better off than we are in respect to railroad accommodations. Our railroads, in that case, would hare been less costly, and therefore might have remained in the hands of the original stockholders; whatever extensions might have been required to meet the demands of increased population and production, could have been made in accordance with a carefully considered and definitely settled plan, aroiding injury to previously rested interests of the same character. It is not yet too late for the State to provide in some way for supplying the public and the Legislature with the advice of a disinterested engineer of high professional standing, whose views, under the sanction of official responsibility, should be obtained upon every project of public improvement which may be hereafter brought forward. It is now obvious that such an official, regarding matters from the stand-point of the general interest of the people; apart from local interests, would have been eminently useful in the past, and on that ground alone, even if there were no others, it is likely that in the future there will be equal need of a State engineer. There are, however, other reasons why the State should have in its serrice engineering talent and skill. Our road laws are of the worst form of the antique, they were not good when made, and are entirely unsuited to present uses. Certain neighborhood roads may perhaps be adrantageously and economically kept up by this antiquated method of personal service, but certainly every highway should be maintained in good 
order by the State, and the work should be done upon seientifie principles, as respects grading and drainage. Since navigable rivers and railroads are channels of public travel and traffic every road leading from a highway to a frequented landing, or to a railroad station, should be regarded as a part of the highway.

A Board of Works, with a competent engineer at its head, and the convict labor of the State at its disposal, would soon demonstrate its value and would take its place in public estimation as an indispensable part of the machinery of good government.

The war, terminating in 186.5 , had made excessive demands upon the transportation institutions of the State, and left the railroads in an exhausted condition, both as to motive-power and car resourees, while miles of track and trestle had been destroyed. The water transportation had been early broken up, and towards the end many important bridges had been destroyed. The common roads and the eauseways, from neglect and unusual traffie, were in bad order; almost the only vehicles of any sort in the country fit for use were a few army wagons and ambulanees; horses and mules were scarce and dear, while horse-feed and forage were equally so.

The recuperation of the railroads proved to be very costly, owing to the high prices which prevailed up to 1873 , and when the exceptional tariffs of that period were no longer practicable, corporation after corporation succumbed under the burden of their augmented debts.

From 1873 to 1880 was the period of reeeiverships and reorganization, and of legislative action direeted towards the regulation of railroads in their relations to the public. These matters can not be discussed here.

The reorganization of the railroads on a lower basis of capital and debt excited new hopes as to their profitableness, and encouraged expenditures and a system of management, producing marked improvement in rails, bridges, and station accommodation, and quite a new order of things in the speed and frequency of trains.

According to the report of the Railroad Commissioner for 18S2, there are in operation in South Carolina about 1,600 miles of railroads, which transported in that year 961,313 passengers over distances which make the total passenger traffic equivalent to the carriage of $48,661,470$ persons one mile.

The amount of freight earried over these roads in that year is $1,323,36 t$ tons, and taking this vast quantity in connection with the distance traversed, it is equal to the transportation of $122,043,275$ tons one mile.

Accorling to the same report, the average amounts paid by the public: were 3.42 eents per passenger per mile, and 2.47 eents per ton of freight per mile. 
In 1821, Mr. Roleert Mills, who was both an ardent patriot and an accomplished and accurate statistician, published through "The Telescopic Press," at Columbia, a pamphlet, advocating certain internal improvements for the facilitating of trade and travel, and from this authentic source we gather the following facts:

1st. That the bales of cotton then weighed about 320 pounds, and were reckoned as rumning seven bales to the ton (page 28 ).

Ind. That the freight on cotton from Columbia to Charleston by the steamboats which descended the Congaree and Santee, was $\$ 1.50$ per bale, equal to $\$ 10.50$ per ton, but this route was so long and hazardous that shippers preferred to send their cotton by wagons at a cost of $\$ 3.00$ per bale, equal to $\$ 21.00$ per ton (page 19 and seq).

3rd. That the "merchandize, salt, liquors," \&c., carried back to Columbia, cost for transportation from $\$ 15.00$ to $\$ 30.00$ per ton, both by steamers and wagons. The water route being 500 miles, and the road 110 miles.

4th. That " there are annually brought to Charleston from the country watered by the Santee and its branches, 50,000 bales of cotton, at a cost for transportation of $\$ 115,000 . "$ This is equal to $\$ 2.30$ per bale of 320 pounds, or $\$ 16.10$ per ton.

5th. Cotton carried from Chatham (now Cheraw) and Society Hill to Georgetown by steam and team-boats, cost, before the improvement of the Peedee, $\$ 1.25$ per bale, and afterwards 75 cents per bale. The carriage by land cost $\$ 2.00$ per bale, of 320 pounds, to Georgetown.

The whole quantity carried in one year was put down at 6,000 bales. A team-boat, carrrying 300 bales, required eight mules to propel it, five men to manage it, and took fifteen days to descend the stream from Society Hill to Georgetown. The freight from Georgetown to Charleston is not given.

It is impossible to compute how much the public gains in time and convenience by having railroads, but considering only the gain in economy, calculated upon the data thus furnished, we shall find the following results :

Cost of wagon transportation between Columbia and Charleston in 1\$21, 110 miles: To Charleston, $\$ 10.50$ to $\$ 21$ per ton; average, $\$ 15.75$. To Columbia, $\$ 15$ to $\$ 30$ per ton; average, $\$ 22.50$. Average both ways, a little over $\$ 19$ per ton-17 $\underset{100}{22}$ cents per mile. The route between Charleston and Columbia being the main artery of travel, rates were probably lower on that route than on any other in the State; hence we might safely assume a higher rate per ton per mile for the cost of carriage wrer the less frequented routes. The present cost, by arerage, on all the railroads in the State is, according to the Railroad Commissioners, 2.7 
cents per ton per mile. Between this rate and that of 17.27 cents there is a difference of 14.57 cents, which represents the minimum saving to the public on the transportation of merchandise. Without railroads, or some equivalent convenience, the freight traffic could never have attained its present dimensions, because the public could never have paid to move so much material at the old rates. But it may be instructive to observe that the tomnage figures for 1852, given by the Railroarl Commissioner, show that, if paid for at the old rates, the excess of cost on the transportation of freight alone, would have amounted to $(122,043,275 \times 14.57) \$ 17,781,705.16$. The data for estimating the saving in traveling expenses are not as precise as those we have for calculating the saving in the carriage of freight, but we may, perhaps, safely assume it to be in proportion to the ratio of the number of passengers to the tons of freight carried one mile by the railroads in 1882 , $i$. e., as $48,000,000$ is to $122,000,000$. We shall thus have:

Gain on freight $\$ 17,7 \$ 1,705$ $(122: 48:: 17,781,705:)$ Gain on passengers . $7,000,000$

Annual gain in cost of transportation by railroad

$\$ 24,781,705$

which is equal to seven per cent. per annum on $\$ 354,000,000$, and to nearly seventeen per cent. per annum on $\$ 145,442,292$, which is the total value of all property in the State, real and personal, including railroar property to the amount of $\$ 14, \$ 77,250$, as stated in the Report of the Comptroller General for 1582.

The cost of all the railroads in South Carolina may be estimated at about fifty million dollars, so that the public is now annually receiving an equivalent of about fifty per cent. on their cost, over and above all interest and dividends paid by the railroads to their creditors and shareholders. This should be remembered when complaint is made of insufficient accommodations and high charges by the railroads, especially since these great public works have, in nearly every case, proved unremunerative to their builders.

Another point of gain is, that the railroads are built and kept in order by the corporations owning and operating them, the ammal outlay being taken out of the earnings at even 2.7 cents per ton per mile, whereas the wagons of 1S20-34 made no contributions even to the repair of the roads which they incessantly lacerated, and, besides paying enormous rates of freight, the public was obliged to keep up the roads and rivers.

While the extension of railroads has been taking place, there has also been an expansion in the freight traftic of some of the rivers, notably, the Santee and Pee Dee. 
The greater volume and activity imparted to the currents of trade by the more numerous and more rapid processes of transportation causes more tratfic upon the common roads, which are really extensions of railroarl and steamboat routes. These common roads should be put in good order and kept so by the State, because the benefits to be derived from their improvement is diffused over the whole State. If the roads leading to a given town are good or bad, not only the interests of that town, but the convenience and economy of the whole surrounding region are affected, and even, in some cases, the effects extend to distant points haring only railroad connection with the town concerned. To this purpose the State may well appropriate all its convict labor and such funds as may be necessary to the efficient and sustained employment of the convicts. Such appropriations would soon appear to be in the nature of remunerative investments, raising the value of lands and augmenting the emoluments of labor wherever the road improvements extend. 


\section{CHAPTEP IX.}

\section{TAXATION AND DEB'T.}

The fiscal history of South Carolina presents many remarkable vicissitudes. Periods of great financial embarassments and depression have not been wanting, but they have never discredited the industry, economy or integrity of her people, and the recurrence of eras of great prosperity illustrate the recuperative powers with which the manifold resources of the country have endowed it.

The first tax, for the sum of $£ 400$, was imposed in 1682 , twelve years after the settlement of the colony. During the twenty succeeding years the taxes aggregated $£ 2,320$, and the largest amount raised in one year was $£ 800$.

Between 1702 and 1720, wars with the Spaniards, the Indians, and the pirates caused an angmentation of taxes, and during this period they amounted to $£ 215,000$. A tax of ten per cent. was laid on skins* and furs, and a duty imposed on goods and merchandise imported into, and exported out of the province. The custom duties were a source of income until 1790, when their collection was transferred to the Federal government. Specific duties were laid at this time on the importation of negroes; real and personal property was taxed, and a tax was apportioned among the merchants and inhabitants of Charleston. The Assembly also issued bills of credit to the amount of $£ 33,000$. A land bank was established to promote the rapidly increasing and successful culture of rice. It emitted paper bills to the amount of $£ 52,000$. The depreciation of this paper currency quickly ensued, exchange and the value of produce rose two hundred per cent. in two years, and in 1722 the ralue of this paper money was fixed at four for one of sterling

Under the Royal government warm disputes between the different branches of the Legislature for and against the issue of bills of credit occurred. The King's council refused to sanction the paper money, and the provincial House of Commons declined to concur in passing any legis-

*In the early settlements (as in Newberry) leer and beaver skins were used as currency, and were a tender in law in payment of lebts, being rated at certain valuations for the different sorts, as snmmer and winter dressed, or undressed skins, provided they weighed one pound or upirards. 
lative act whatever, and none were passed from 1727 to 1731 . But the Lower House prevailed in 1736, not, however, without a strong protest from Arthur Midlleton, James Kinloch and Joseph Wragg, in passing an Act to emit $\$ 210,000$ in bills of credit, declared in the Act itself to be equal to about $\$ 30,000$ sterling. In 1746 a second sum of $£ 210,000$ was issued by the same anthority, and loaned out at eight per cent., as the first had been. During this period the provincial currency was sometimes as low as ten for one, and averaged seven for one of sterling. "Proclamation money," which was an aggregate of the depreciation established by Queen Anne's proclamation of 170s, determining the value of coin in the provinces at one-quarter advance on sterling, and the depreciation of provincial currency fixed at four for one in 1722 , passed at the rate of five for one of sterling.

During the French and English wars South Carolina paid in taxes, from the year 1755 to 1765 , the enormous sum of $\$ 2.020,652$, of which $£ 535,303$ were raised in the year 1760 . The last emission of provincial paper currency was in 1770 , amounting to the sum of $£ 70,000$, and valued at about $£ 10,000$ sterling. The total amount of paper money issued by the province during these sixty-eight years was $£ 605,000$, of which more than two-thirds was secured by mortgage, and this sum greatly exceeded the amount in circulation at any one time, as the earlier issues were called in before the later ones were thrown into circulation. The conclusion of the early legislators, after a long experience, and a full discussion of the advantages and disadvantages of an irredeemable paper currency was, that, "while under proper restrictions it might be useful to a certain extent, proper restrictions were seldom imposed, and seldomer observed." (Ramsey.)

The last colonial tax raised in South Carolina was in 1769 , for about $£ 9,600$ sterling, or twenty-four timas as much as the first tax levied eighty-seven years before; as both periods "were times of peace, requiring no extraordinary expenditure, this fact is a strong proof of the progressive improvement of the country." (Ramsey.)

For five years previous to the Revolution there was great scarcity of money in South Carolina. The importation of about 5,000 negroes annually by Great Britain cansed the balance of trade to be against the colony. Gold and silver were very scarce. No tax bills had been passed, and there was no emission of paper currency by the Assembly for several years. The clerk of the House of Commons merely issued certificates to the public creditors, that their demands should be provided for in the next tax bill. This stringency was temporarily mitigated by certain gentlemen, men of large estate, who, in 1775 , issued their joint and several notes, in convenient sums, payable to bearer, to the amount of 
$£ 128,000$. They passed freely from hand to hand, but in a short while the war came on, a flood of paper money was issued, depreciation followed, and this project turned out both unprofitable and vexatious.

In the Revolutionary war, as in the wars in which Carolina had been previously engaged, recourse was again had to the emission of paper bills of credit. Between 1775 and 1779 no less than $£ 7,817,553$ was thrown into circulation. For the space of one year and nine months the enthusiasm of a people struggling for liberty maintained, undiminished, the value of this paper, but in April, 1777, a destructive depreciation set in, and the circulation of these bills was wholly arrested by the fall of Charleston, in 1780 . Their total value at the dates when the several issues were made, was estimated at $£ 4 \$ 1,065$. At the date of the extinction of this circulating medium, there was literally no currency in the State, for about that time also the Continental paper, "like an aged man, expiring by the decays of nature, without a sigh or a groan, fell gently asleep in the hands of its last possessors." The Spanish and French loans, which were of such vital assistance to the Federal government in the prosecution of the war at this critical juncture, furnished little or no relief to the people of Carolina. The war, however, was carried on with the same vigor. There was no money. Plate, rings, keepsakes, old coin and such like articles, were brought into use by those who had them. Buying and selling for the most part ceased, those having the necessaries of life divided them freely with the destitute. Simply to live, was the aim of most, and this was done to the astonishment of many, who could scarcely tell how it har been effected.

When at length the war was over, the State liquidated its war debts by giving to its creditors an acknowledgment of the sums due them in the form of an indent. For five years the interest on these indents was paid by issuing special indents, made receivable in taxes, which were annually imposed for their redemption. And thus every year two to three hundred thousand dollars was furnished, which obtained considerable circulation.

In 1785 , the State again issued bills of credit to the amount of $£ 100,000$, loaning them in small amounts on mortgages of land or deposit of plate, at seven per cent. interest. Of this loan £5\$,067 was outstanding in 1802 , yielding a revenue of $\$ 17,420$ to the State. The merchants came forward in a body and agreed to take these bills at par with gold and silver. No second issue was made, and the depreciation of the bills was inconsiderable. The South Carolina Bank received this paper medium on deposit and made repayment in specie or in its own bills.

In 1790 , the United States, to consolidate the finances of the country and to equalize the condition of the several States, assumed the debts of 
the thirteen original States, contracted in the prosecution of the war. That of south Carolina was the largest and amounted to $\$ 3,999,651$. In the further adjustnent of the war accounts of the several States with the United States, on the showing of Simeon 'Theus, it appeared to the satisfaction of the commissioners appointed on behalf of the United States, that the latter were indebted to. South Carolina, for advances made by her, in the further sum of $\$ 1,447,173$, and certificates of funded stock were given to the State for that sum.

These settlements, and the general prosperity which ensued with the establishment of the independence of the country, gave a stable foundation to the finances of South Carolina. A branch bank of the National Bank was established in Charleston, in 1792, and others followed soon after, and the inconveniences which had afflieted South Carolina in every preceding period of her history from the want of a circulating medium passed away, and the country rose to a high pitch of prosperity.

Nevertheless, in 1799, it appeared that no man in or out of office in the State, was able to tell the amount of the debts or of the credits of the State. In consequence, the office of Comptroller-General was established, and Paul Hamilton, the first incumbent, stated in his final report, in 1804 , that the balance due to the State was $\$ 754,555$.

This flourishing condition of the finances induced the Legislature to subscribe $\$ 300,000$ to the State Bank, and to establish and endow the South Carolina College at Columbia.

The war between England and France, causing the imposition of the embargo, and the non-intercourse acts, of 1807 and 1809, and finally the declaration of war against Great Britain, in 1812, bore heavily on the agricultural interests of South Carolina. From December, 1807, foreign trade was almost entirely cut off. Agricultural productions accumulated in the hands of the planters, becoming well-nigh unsalable. Money almost ceased to circulate among the people, and business came to a standstill. To relieve this distress, the Legislature, in 1812, chartered the Bank of the State, vesting in it the eash in hand and the funds belonging to the State, with power to loan on real security and personal, at an interest of seven per cent., the interest being paid in advance annually, and renewable for years. All stocks, bonds, shares and claims belonging to the State, the unexpended money in the treasury, and all taxes to be thereafter eollected, were deposited in the bank, and vested in the President and Directors, and the faith of the State pledged to support the bank, and to make good all losses. The bank was to pay the interest on the State debt. This debt consisted of three per cent. Revolutionary stock, and was estimated by the Legislature for redemption at fifty-five cents on the dollar, making it, by this valuation, $\$ 332,870$. The bank 
was directed to redeem and extinguish the same by the 31st of December, 1824. The bank was chartered until May, 1836 .

With the return of peace another period of great prosperity commenced. The assets of the State were gradually realized by the bank, and its effective capital amounted, in 1819 , to $\$ 1,372,500$. In this year also Stephen Elliott, the learned and distinguished president of the bank, placed the value of property in South Carolina, at $\$ 200,000,000$.

The subject of internal improvements was discussed in South Carolina as early as 1687, but it was ninety-nine years later before the Santee Canal Company was incorporated, and this work was completed in 1800 , at a cost of $£ 150,000$ sterling. Other private companies, for the improvement of the Wateree, Catawba and Edisto rivers, were incorporated in 1787. It was not, however, until the year 1816 that the office of civil and military engineer to the State was established, and aid given by the State to these improvements, at the rate of $\$ 50,000$ a year. This expenditure was soon much increased, and by the year 1826, the State had paid out more than $\$ 2,000,000$ in internal improvements, chiefly for canals and turmpikes, and of tiıis sum, $\$ 1,550,000$ remained as a debt.

Thus it happened that the extravagant expenditures indulged in by many of the States on account of internal improvements, which threatened them with bankruptcy, and culminated in the financial crisis of 1836-42, occurred some years earlier in Carolina than elsewhere. So that in 1827, when the Charleston and Hamburg railroad-the first railroad built in the world with a view to its operation by locomotive steam power-was projected, the already. depleted treasury only aided the private company, who obtained the charter, by a loan of $\$ 100,000$, secured by mortgage, payable in seven years, and bearing five per cent. interest.

In 1830, the Bank of the State was rechartered until 1856. It had discharged $\$ 215,931$ of the principal of the State debt. This burden, however, had been increased, by the expenditures for internal improvements, to $\$ 1,892,880$, leaving about $\$ 1,676,949$ still due. The available assets of the bank at this date amounted to $\$ 3,768,292$. During the succeeding decade, the debt of the State and assets of the bank were both largely increased, as will appear from the following statements:

When the South Carolina Railroad, one hundred and thirty-seven miles in length, was completed, in 1834 , the most brilliant anticipations of its success were entertained. The State had once again become prosperous; cotton rose from eight to fifteen cents per pound, and thence, in 1836 , to twenty cents. The idea of developing great interior routes of communication occupied the public mind throughout the entire United States, and seized for a second time upon South Carolina.

The Charleston, Louisville and Cincinnati Railroad and Banking Com- 
pany, to have a capital of $\$ 36,000,000$, was chartered. The State took $\$ \$ 00,000$ of the stock, advanced $\$ 200,000 \mathrm{incash}$, and endorsed the bonds of the company for $\$ 2,000,000$. This magnificent project, with many similar ones undertaken at this date, failed; accomplishing, some years later, of its great promise, only the Columbia branch of the Soutl Carolina railroad, sixty-seven miles in length.

Meanwhile, the enormous increase of the debts of many of the States of the Union, on account of their expenditures for internal improvements, threatened to assume the proportions of a great national evil. These debts aggregated $\$ 174,306,994$, and the Federal Government, free from debt, and with a large amount of surplus revenue in its treasury, was appealed to on all hands for help. $\$ 36,000,000$ of this surplus revenue was ordered to be distributed among the States in four quarterly instalments, commencing January, 1837. The pro rata assigned to South Carolina was about $\$ 1,350,000$, and of this amount $\$ 1,051,422.09$ was actually deposited with the State in July, 1S37, being the first three instalments. The financial distress, which culminated in the panic of 1837 , prevented the payment of the fourth and last instalment.

In 1S3S, a great fire destroyed a large portion of the city of Charleston, and an extra session of the Legislature authorized a loan of $\$ 2,000,000$ to aid the sufferers. 'The Bank of the State negotiated this loan, bor'rowing the money in England and loaning it on mortgages to the people of Charleston.

The result of these events was that, in 1St0, the State debt had increased to $\$ 3,676,949$ (not counting the surplus revenue deposited by the United States with the State until otherwise ordered by Congress). 'The assets of the bank had also increased, from the sources abore cited, to \$.5, 420,809 .

Although the decade, 1540 to 1850 , does not appear as one of unusual prosperity, it was marked by great economy in the management of the financial affairs of South Carolina. A strong anti-debt feeling was aroused among the people. No new loans were made, and, in 1850 , the return of the Comptroller-General shows the debt of the State, less the surplus revenue, to be $\$ 2,105,920$, funded in three, five and six per cent. stocks and bonds. The assets of the Bank of the State amounted to $\$ 3,633,718$, and other assets of the State in railroad stocks and bonds amounted to $\$ 1,320,156$. In all, $\$ 4,953, \$ 74$.

This prosperous condition of the treasury again induced a recurrence to unusual expenditures, a tendency which was fostered by the rapid increase in wealth of the people during the decade, 1850 to 1860 . In 15.52, the charter of the Bank of the State was a second time extended until 1S71. For the third time the project of a great highway to the 
Northwest obtained control of the Legislature, and the State issued six per cent. bonds, to the amount of $\$ 1,310,000$, in aid of the Blue Ridge railroad. The great increase in State expenditures which prevailed, adding largely to the burden of taxation, as for example, in the State of New York, increasing its amount three hundred per cent, found a parallel in South Carolina, in the sums expended in erecting a new State House of cyclopean blocks of granite. For this enterprise, if it may be termed so, the State issued at this time six per cent. bonds to the amount of $\$ 1, \$ 22,210$.

Nerertheless, the assets of the State were ample to meet all liabilities. The report of the joint eommittee of the General Assembly, in December, 1859 , showed that the bank was in a prosperous condition; that it had paid debts of the State in excess of the interest and prineipal of the funds with which it had been intrusted by the State (excepting a portion of the fire loan); that, deducting all the liabilities of the bank for issues, deposits, balances due to other banks, \&c., from the $\$ 7,779,337$ representing its assets, there remained $\$ 3,085,397$ of net assets, the fruit of its management. This sum, with $\$ 2,652,300$ held by the State in railroad shares-in all, $\$ 5,737,597$-represented the fiseal resources of the State available to meet its public debt, which (subtracting the fire loan stoeks and bonds already deducted from the assets of the bank) amounted to $\$ 2,47,796$, as stated by the Comptroller-General in his report for that year.

Such was materially the condition of the finances of South Carolina at the commencement of the war between the States.

In 1867 , the Comptroller General stated the funded public debt of the State, interest and principal, as $\$ \$, 375,255$, and the assets of the State, consisting chiefly of assets held by the Bank of the State and shares in rail. road companies, as $\$ 8,709,1 \$ 9$.

Of this increased indebtedness, $\$ 2,241,840$ was for principal of bonds issued during the war for the military defence of the State; $\$ 729,200$ reduced interest on bonds and stocks; $\$ 136,600$ State capitol bonds, \&c., issued during and after the war; thus leaving $\$ 4,975,615$ to represent the ante-bellum debt increased in the interval by interest.

Doubtless a considerable portion of the assets of the bank, with which these liabilities were to be met, would eventually have proved valueless, as did the results of many of the financial transactions during the war. Time, however, to test this matter was not allowed

In 1S68, the Federal military authorities summoned a convention to "Reconstruct" the State of South Carolina. From this convention the former citizens of South Carolina were virtually excluded, and it was placed by the military authorities, as the State government, for eight 
years. Subsequently it was in the hands of the newly emancipated negro slaves.

The convention declared the $\$ 2,241,340$ of war debt wholly and forever invalid. The first negro Legislature that met passed an act, in the fall of 1568 , to close the operations of the Bank of the State. Thereafter, the assets of this venerable institution added nothing to the revenues of the State. In 1870, it was placed in the hands of receivers, under whose administration its funds have gradually diminished.

Thus passed away a powerful institution, which, for more than half a century had exercised exclusive control of the fiscal affairs of the State. Its friends claimed that it had saved, consolidated and made profitable the funds of the State; that it had furnished relief to many citizens, added to the general revenues of the State, improring and developing the towns of the interior; its profits were employed in paying the interest and in reducing the principal of the public debt; it preserved its capital entire and its funds safe, maintaining the character and credit of the State in Europe and at home without blot or suspicion. Its most violent opponents admitted the ability and integrity displayed in its management, and declared that the abiding confidence of the people in it was a high but dangerous compliment to the purity of the public characters of the State.

This was but the prelude to the wreck which the negro government made of the finances of the State. Its policy was of extreme simplicity. It consisted in raising money by every means available, and at any cost, to be squandered in profligate and corrupt extravagances upon the plunderers in power. Space does not allow here even a brief summary of the numerous and devious methods adopted for these purposes. Of the high assessments placed on the remnants of property spared by the ravages of war; of the equally high rate of taxation; of the issues of bonds and stocks of the State by the Legislature, by the Governors, Treasurers Speakers of the House of Representatives, and financial agents; of their sale and hypothecation; of the army of clerks, messengers, porters, \&c., aggregating 2,505, employed by the Legislature; of the legislative accounts for services, including wines, groceries and dry goods, amounting. to $\$ 543,232$; and of much more, concerning which statements made by their own witnesses, will be found in the reports on legislative frauds during the years $1871,72,73,74$.

The average of the annual State taxes for the ten years preceding the war -a time of great prosperity and large expenditure-was $\$ 442,589$. From 1869 to $187 \%$, they averaged $\$ 1, \$ 22,007$. During this latter period, the assets of the State disappeared. The interest on the publie debt remained unpaid, large deficiencies occurred, no public works were undertaken. 
The sequel is briefly stated in the language of the Financial Investigating Committee of the negro Legislature of 1871-2: "We find ourselves facing a total debt of $\$ 28,977,608$. This sum represents the present actual and contingent liabilities of the State as the committee find them." The credit of the State was entirely destroyed. "It was with the greatest difficulty that the officers of the Statc Lunatic Asylum could purchase four thousand dollars worth of provisions on credit, although appropriations had been made to be payable out of the revenues which were then about to become due" (Statistics Public Indebtedness, 10th U. S. Census). The appalling spectacle was presented of a State struggling in the slough of debt, with Labor resting on her rusted implements, Commerce folding her wings, Trade in prison garments, and the Genius of Liberty weeping over her people, prostrate, bankrupt and disgraced.

Extreme measures were of urgent necessity. A constitutional amendment was ratified forbidding the General Assembly to create any further debt without first submitting the question to the people at a general State election, and unless two-thirds of the qualified roters cast their votes in favor of it. The negro Legislature, by act of the $22 \mathrm{~d}$ December, 1873 , declared as absolutely null and void bonds recently issued to the amount of $\$ 5,965,000$. By the same act, known as the "Consolidation Act," the State "Treasurer was authorized and required to receive from their holders certain specified certificates of stock and bonds, and to give in exchange therefor, other certificates of stock or bonds equal in amount to fifty per centum of the face value of the bonds and certificates of stock surrendered. Interest was no longer to be paid on the old bonds and stocks unless exchanged, and then at the rate of six per cent. per annum. The bonds and stocks thus specified were:

Bonds and Stocks issued by the State from the year 1794 to the year 1861 , amounting to .......

Bonds and Stocks issued during the war, from 1861 to 1866 ,

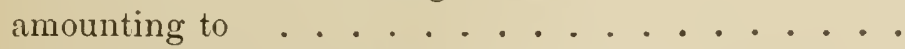

Bonds and Stocks issued after the war, before the Reconstruction Convention of 1868 , amounting to . . . . . .

Bonds and Stocks issued by the negroes from 1868 to 1870 , amounting to . . . . . . . . 5, . 535,100

This sum was to be paid at fifty per cent. discount, in consolidation bonds. It would have amounted to $\$ 4,904,321$, to which the past due interest was to be added. 
Even these measures failed to secure an honest administration of the debt. The Comptroller-Ceneral of the negro government reported, in 1875 , that the volume of consolidation bonds had been much increased by the funding of a "large amount of coupons, although the records of the treasury prove that they had been previously pairl."

This was the state of affairs in January, 1877 , when the Lnited States troops were withdrawn from the State House; the negro government allowed to fall to pieces, and the white citizens permitted once more to take part in the administration of affairs.

On October 31st, $187 \tau$, the State Treasurer reported that

The principal funded under the Act of December, 1573, amounted to . . .

. $\$ 4,396,290$ The principal then still fundable under the Act amounted to $\$ 2,704,551$, which, at the rate established by the Act, amounted to .

Total principal .

$\$ 5,7 \pm \$, 566$

It was found necessary to appoint a commission to investigate the indebtedness of the State, under the Consolidation Act. The irregularities discovered by this commission were so numerous and important that the Legislature, in 1S7S, created a court, known as the "Court of Claims," with jurisdietion to hear and determine cases testing the validity of the consolidated bonds, coupons, and certificates of stoek. A number of cases involving issues of law and of fact were determined by this court, and on appeal, by the Supreme court. In 1579 , the Legislature appointed a special commissioner to ascertain, in accordance with the decisions of the courts mentioned, and to establish the validity or the percentage of validity of each consol bond, certificate of stock, or of the unpaid interest thereon. The holders of these consols to have the right to surrender the same for cancellation, and to receive new eonsols from the State Treasurer, bearing interest at six per cent., for the exact amount reported ralid in the consols surrendered. These new consols, issued after February, 1Ss0, are engraved from the same plates as the green consols issued under prior Acts, but are distinguished by their color, being brown.

The "deficiencies," or floating indebtedness, left by the negro government, was atdjusted by a "Court of Claims" established in 1S7S. "Deficiency" bonds and stocks, bearing six per cent. interest, and payable in ten years, were issued in settlement of such portion of these claims as the sourt adjudged valid.

By these means the final adjustment of the debt of the State has been 
nearly completed. The interest on it is being paid regularly as it falls due. The State credit has been restored. The bonds and stocks which had been sold as low as sixty cents on the dollar, under the Republican administration, now commands from $\$ 1.04$ to $\$ 1.06$ in the money market.

Statement of the Public Debt, 31st October, 1882.

Total consols (valid) . . . . . . . . $\$ 5,429,92854$ Total deficiencies. . . . . . . . . . 501,992 24 State scrip Agricultural College . . . . . . 191,800 00 To be funded for ante bellum principal and interest-say. . . . . . . . . . . 168,924 47

To be funded for post bellum principal and interest 一 say (all valid) . . . . . . . . $\$ 5,23750$

To be funded for post bellum principal and interest

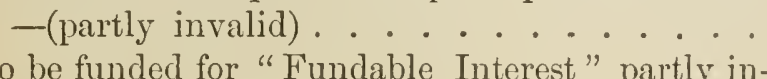

To be funded for "Fundable Interest" partly invalid-say . . . . . . . . 105,28968 To be funded for bills of the Bank of the State. . $\quad 37800$

Total bonded debt . . . . . \$6,571,\$25 43 


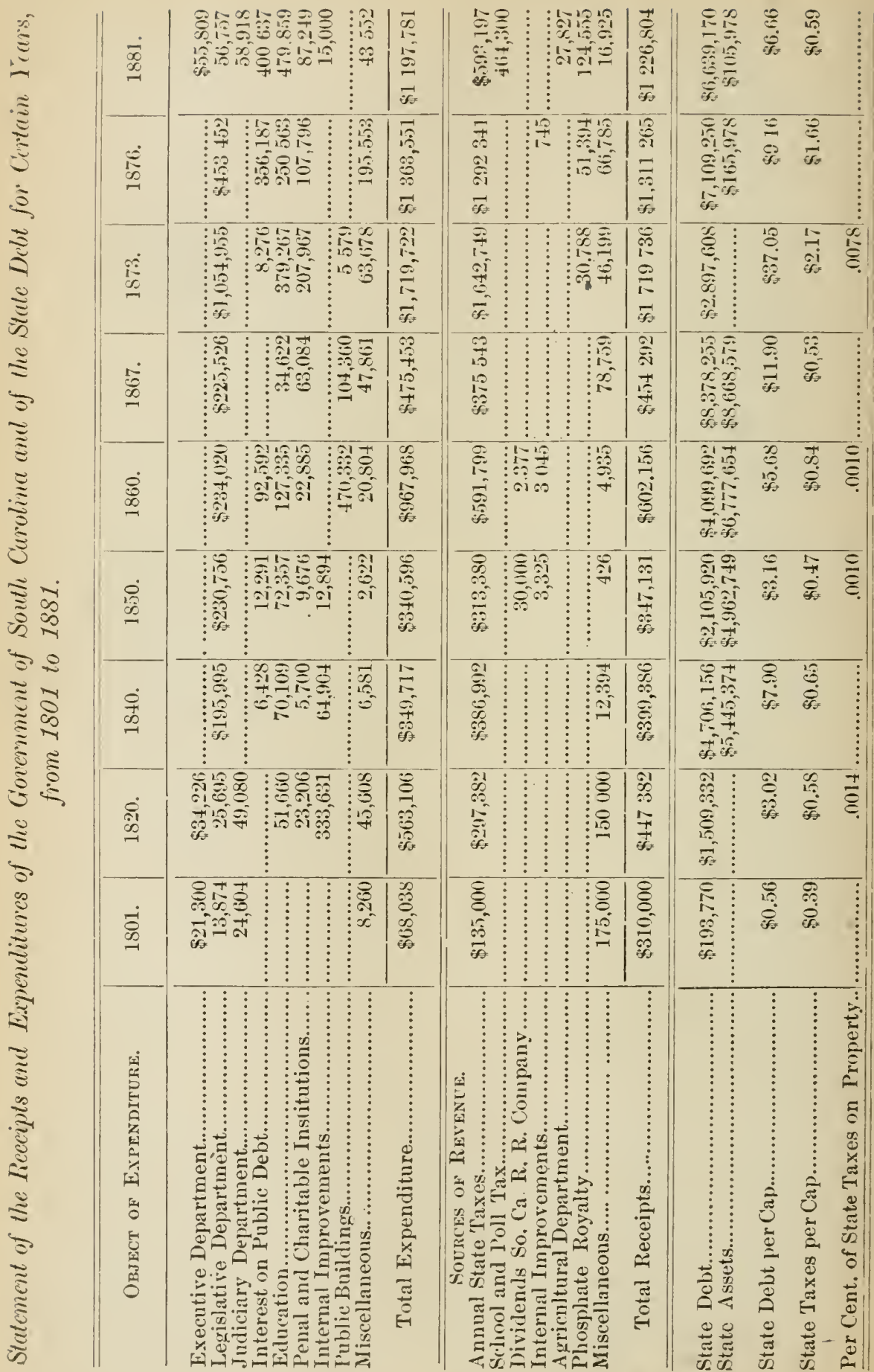


It will be noticed in 1881 that there is an item of $\$ 164,300$, under the head of "poll and school tax," not treated with the annual State taxes. It is derived from the poll tax and a tax of two mills on all property in the State, and is not imposed by the General Assembly, nor subject to appropriations made by it. A perpetual tax of this sort is levied by a constitutional provision, ratified in 1877 , and its proceeds are devoted exclusively to educational purposes.

In addition to the regular State taxes, South Carolina, in common with the other States of the Union, allows the citizens of the minor civil divisions, and of the towns and cities, to impose, under certain restrictions, such local county and municipal taxes as they may think necessary. The counties and municipalities may also create county and municipal debts, distinct from the State debt. This local taxation was in South Carolina for the year $1880, \$ 554,164$ for the counties; and $\$ 542.109$ for the minor civil divisions and municipalities. Of the latter the larger part was levied in Charleston and Columbia. Outside of the counties in which these cities are situated, the total township, town and village taxes of the State aggregated only $\$ 62,514$. Distributed according to population, the sum of this local taxation amounted to $\$ 1.10$ per capita; distributed according to area, it was $\$ 36.33$ to each square mile. Throughout the country at large the weight of these burdens is much greater, the average for the United States being $\$ 5.09$ per capita, and $\$ 94.49$ per square mile. The indebtedness of counties, townships, school districts, cities, towns and vịllages in South Carolina amounted, in 1880 , to $\$ 6,706$,767; outside of Richland and Charleston counties, this total amounted to only $\$ 1,498,437$. This amounted to $\$ 6.72$ for each one of the population, and $\$ 222$ to each square mile. The aggregate of this species of indebtedness for the country at large averages $\$ 16.67$ for each one of the population, and $\$ 276$ for each square mile of territory.

FEDERAL TAXATION.

In common with the citizens of the other States, the citizens of South Carolina pay taxes for the support of the Federal Government. These are of two sorts, the customs duties on articles imported, and the

\section{INTERNAL REVENUE TAXES.}

The United States Collection District of South Carolina paid for the fiscal year 1881, internal revenue taxes to the amount of $\$ 135,907$. This is a little more than one-tenth per cent. of the entire collections of internal revenue in the whole United States. It is notable that the cost of making these collections in South Carolina-compensation of collectors, office expenses, per diem of store-keepers, fees and travelling ex- 
penses of gaugers-amount to $\$ 45,332$, or 33.35 per cent. of the amount collecterl, while for the whole United States the cost of collections imounterl to only 37-10 per cent. During the period of the tax on cotton the collections in South Carolina were much larger, amounting in 1866 to $34-100$ per cent.; in 1867 to $73-100$ per cent., and in 1865 to $1 \frac{1}{2}$ per cent. on the collections for the whole United States, and aggregating, in the year last named, $\$ 2,634, S 00$.

The collections made in the State are not, however, the criterion of the amount paid on account of the tax within its limit. For if no collections whatever were made in the State by revenue officers, the citizens consuming the articles taxed rould pay the tax thereon. If the amount of taxed articles consumed could be ascertained, the chief factor in the amount of tax paid would be determined. This can be done only approximately. It is perhaps safe to assume that retail dealers in the articles taxed make about the same average amount of sales everywhere. The leading articles subject to the internal revenue tax are distilled liquors and tobacco. Liquor dealers are less numerous in South Carolina, where they are only about one to one thousand of the population, than in the rest of the United States, where they average a little more than three to the thousand. In special taxes on pursuits there is collected:

In South Carolina, from retail liquor dealers . . . . . . \$ 27,119

In the United States . . . . . . . . . . . . . . . 4 4,265,992

In South Carolina, from dealers of manufactured tobacco . . 29,367

In the United States . . . . . . . . . . . . . . . 1,827,495

This would make the percentage of the liquor trade .0066 of that of the United States, and the retail tobacco business .016 per cent. of that of the United States. Assuming, as above that these percentages represent the percentages of these taxed articles consumed in South Carolina, and that the tax is paid in proportion to their consumption, the statement would be :

Tax from distilled liquors collected in the whole United States for the whole period Internal Revenue taxes have been in force, $\$ 707,209,362$, of which .0066 per cent. is paid by South Carolina . . . . . . . . . . . . $\$ 4,667,581$

Likewise of the $\$ 524,240,114$ collected on tobacco, of which .016 paid by South Carolina . . . . . . . . . . .

These items form S0 per cent. of the Internal Revenue collections, and at the same ratio, 20 per cent. should be added to express the amount paid by South Carolina .. . . . To these items add the direct collections in South Carolina for the whole period. S,3S7,S 11

$\ldots \ldots \ldots, 743,331$

Making total revenue tax paid in South Carolina . . . . \$2 $\$, 062,610$ 
This would make the tax paid in South Carolina to a verage about one and a half millions of dollars for each year of the sixteen during which the tax has been collected. The aggregate amount is .00S5 of the $\$ 2,807$,153,628 collected as internal revenue in all the States. Taking the population of $1 S S 0$, the average for the whole United States is \$.j̃ per capita; for South Carolina it is $\$ 2 \pm$ per capita.

\section{THE CLSTOMS TAX}

of South Carolina is still more difficult to compute. It is a strong point in faror of these indirect taxes that, while as other taxes they are as certain to come as death, they more resemble this dread visitor in coming unawares. The collections made of eustoms in South Carolina offer no basis whatever for an estimate. Estimating the amount of the $\$ 1 S 6$,$522,06 \pm$ of customs collected in 1SSO, in the ratio of the population of South Carolina to that of the United States, the share paid by this State would be about $\$ 3,700,000$. This is probably more than what is really paid, but it is estimated much higher by many. From this it will appear that, granting that South Carolina pays less in Federal taxes than the average elsewhere in the Union, nerertheless, she pays, annually, $\$ 5,200,000$ in such taxes, or more than double all her other taxes, State, county and municipal together.

SUMMARY.

To estimate even approximately the burden that taxation and debt are to any community, it is essential to form some idea of the relation they bear to the wealth of the community. Unfortunately, the assessment valuation for purposes of taxation furnish no data from which to judge of the true values of property. Thus, in 1870 , the assessed value of property in Vermont was only 43 per cent. of the true valuation, and in $1 S 60$ it was 67 per cent.; in New York, in 1870 , it was 30 per cent., and in 1860 it was 70 per cent.; in Illinois, in 1870 , it was 22 per cent., and in 1860 it was 70 per cent. : and in all the States the percentage of true valuations returned for taxes in 1870 was 47 ; for 1860 it was 70 . The true valuations of property for the year $18 S 0$ are in course of preparation in the census office, but will not be completed for some months to come. The census valuations of property in South Carolina placed it at \$2.SS,257,694 in 1850 ; in 1860 it was given at $\$ 545,135,754$. This increase of 90 per cent. was rather remarkable, when it is remembered that, during these ten years, the State not only gained little by immigration, but that she spared largely of her population and wealth in opening up new set- 
tlements in the Southwest, and it is to be attributed altogether to an intelligent and careful husbandry which developed the natural resources of the State. For 1870, the census valuation, reduced to a gold basis for comparison, amounted to only $\$ 166,416,582$, showing that nearly 70 per cent. of the accumulations of 1860 had been sunk by the war. The facts furnished by these pages show how great in many regards the recuperation has been since this date, and especially since 1876 . No estimate of the aggregate gains will be here attempted, as without an elaborate study of the values in each of the States, such as is being now conducted by the census office, it would furnish no basis of comparison with other sections. It is safer to compare the relations of debt and taxation with certain comparatively well ascertained factors of wealth. Of the three factors of wealth, land, labor and capital, it may be assumed in communities so homogeneous, in most respects, as the States of the Union, that land and labor correspond, to a considerable extent, with population and area, and therefore a comparison of the debt and taxation per capita and per square mile of one community with another, if not decisive, is at least dealing with tolerably well "known elements baring a most important bearing on the problem. 
The following table, taken from the United States Census returns gives the figures, in accordance with which diagrams $\mathrm{A}, \mathrm{B}$ and $\mathrm{C}$ were constructed:

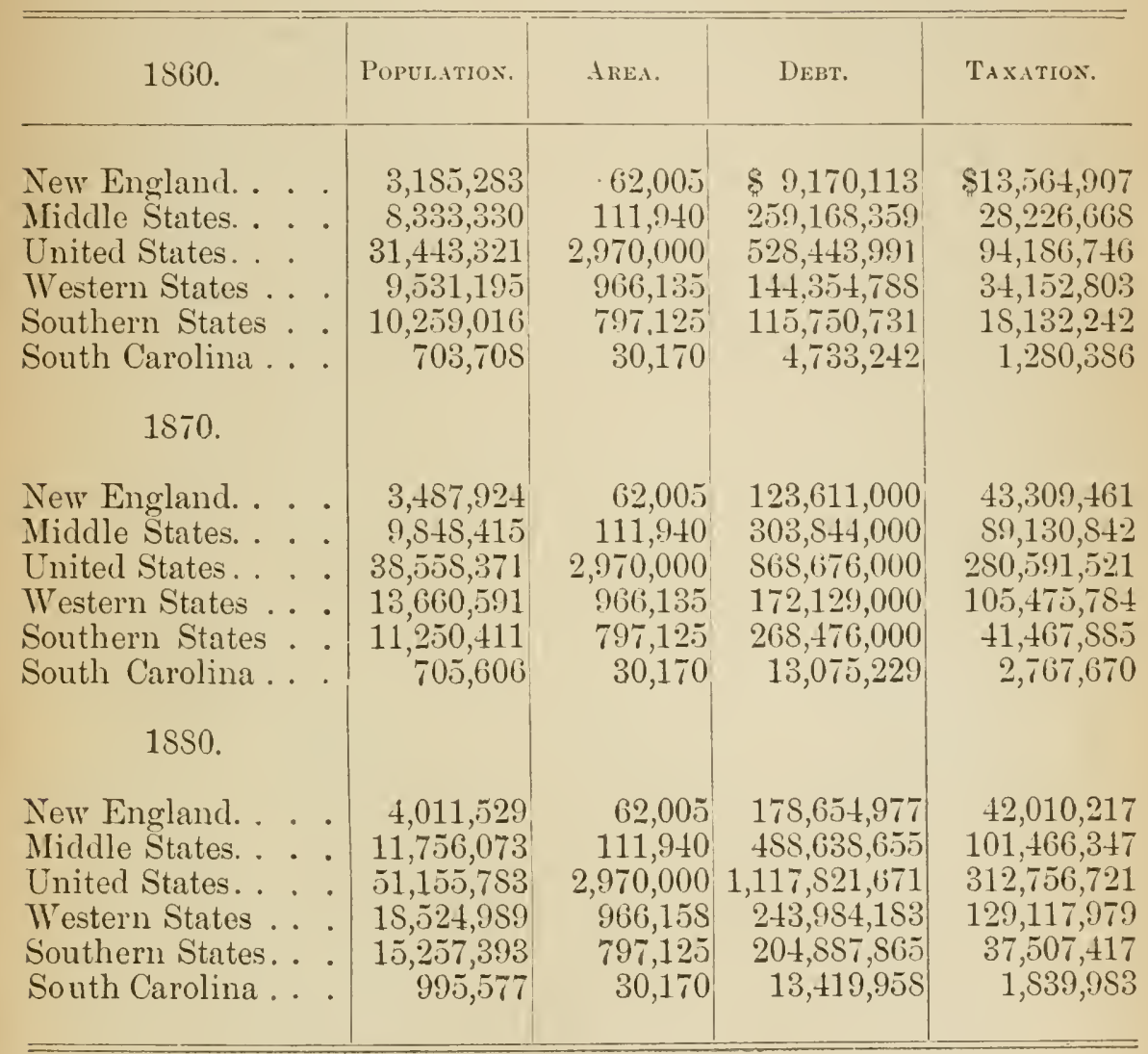


Plate $A$ cxhibits the relation of debt and taxation to population in South Carolina, and for the prineipal geographical divisions of the United States during the thirty years represented by the United States census returns of $1860,1870,1850$. National debt and taxation are not considered, but only State and local indebtedness and taxation, the latter including county, township and municipal debt and taxes. It appears that the ratio of debt and taxation to population has greatly increased since 1860 , and that these burdens become larger in passing from South Carolina and the Southern States to the Western, Mirldle, and New England States. The increase in 1570 is in part attributable to the premium on gold at that date, but in South Carolina it was due in a still greater degree to the corrupt character of the State government, maintained by military authority during "reconstruction." "The gradation of taxation from New England to South Carolina is more striking even than that of indebtedness, and while it shows the frugality with which the State gorermment is administered, shows also how unjust the general and sweeping charges of repudiation are, inasmuch as the load of clebt imposed by the "reconstruction" government is still being borne.

Plate $\mathrm{B}$ exhibits the ratio of State and local taxation and indebtedness to area, and agrees in its general features with plate $A$. The State and local indebtedness per capita of South Carolina is less than one-third that of the Middle and New England States. Per square mile, it is only one-eighth that of the former, and one-tenth that of the latter.

Plate C exhibits the total burlen of debt and taxation, Federal, State and local, chargeable on the State of South Carolina, per capita and per square mile, for the periods of 1860 and 1850 . The national debt and taxes are here assumed to be equally distributed according to population and area, and the portion assigned South Carolina is estimated on this basis. Of course the Federal debt and taxes are not actually distributed in this manner. As it is certain that no estimate, as to where and by whom these indirect taxes are actually and ultimately paid, would pass unchallenged, the above is given to show the relative magnitude of the changes which have oceurred since 1860 in State and Federal taxation and indebtedness. The Federal debt was:
In 1860
$\$ 64, \$ 00,000$

In 1880

$\$ 2,120,415,370$

The Federal taxes were:

In $1860 \ldots$.
In 1880

One thing is at least clear, that however and by whomsoever the portion of Ferleral taxes paid by South Carolina be estinated, they will be found to be largely in excess of all taxes, State and local, collected within her borders. 
Plate A.

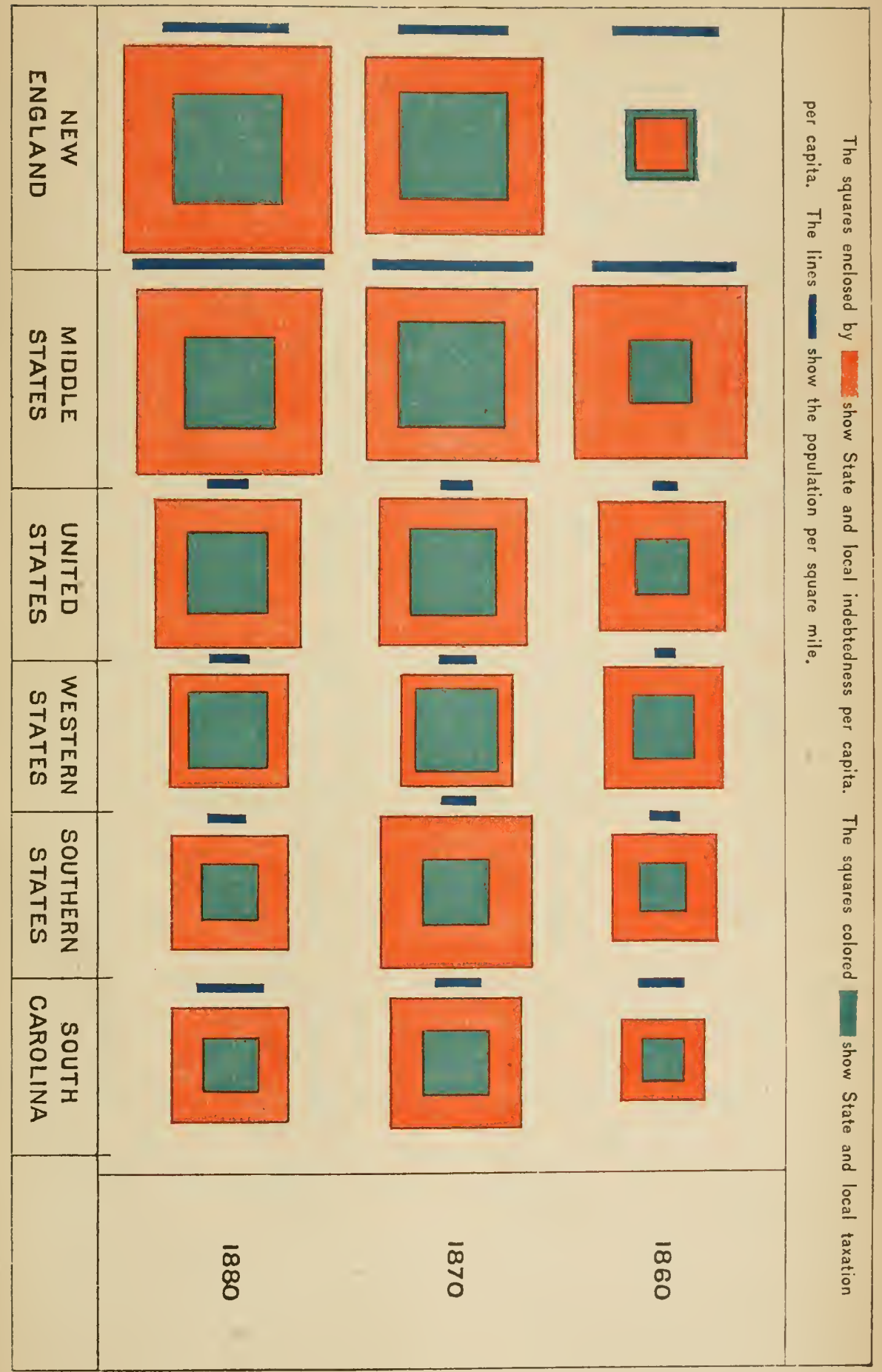



Plate B

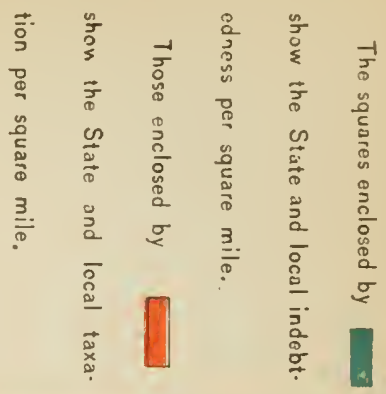
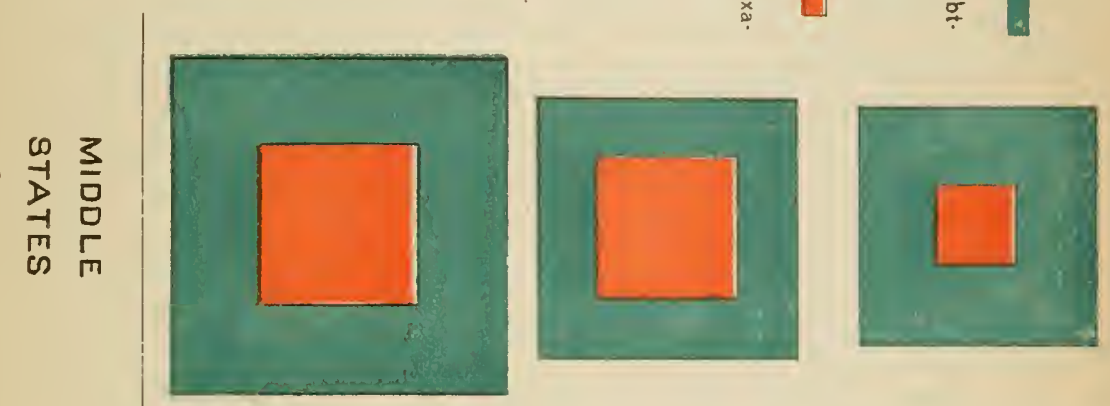

$$
\begin{array}{ll}
m & \\
z & z \\
0 & m \\
D & z \\
z &
\end{array}
$$

$\begin{array}{ll}0 & c \\ -1 & \underline{Z} \\ -1 & =1 \\ 0 & 0 \\ 0 & 0\end{array}$
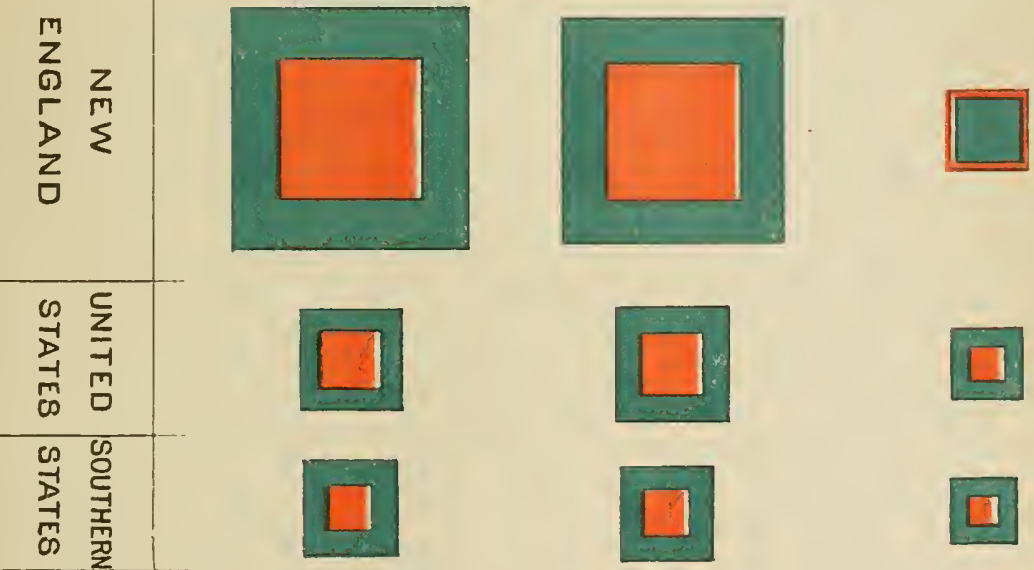

c)

焉 黄

S $\infty$

烦
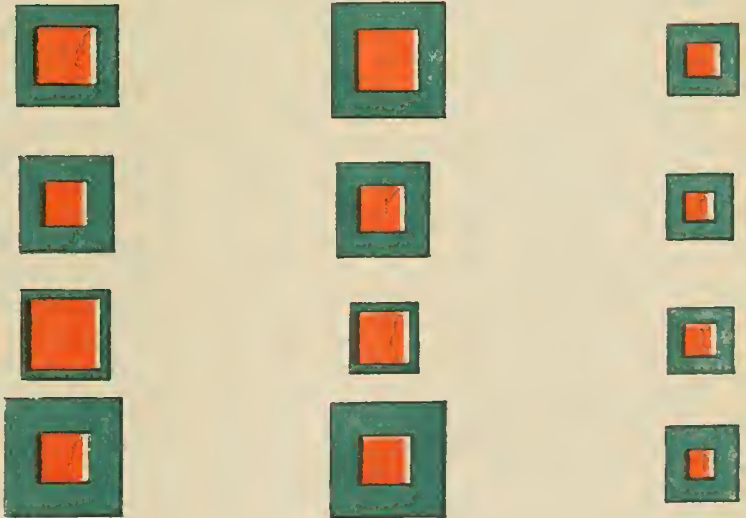

$\bar{\infty}$
$\infty$
0

ฐ্

$\bar{\infty}$
o 



\section{PER CAPITA}

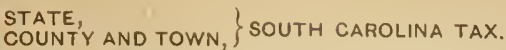

STATE,
COUNTY AND, TOWN,

6

DEBT.

INTERNAL REVENUE FEDERAL TAX
CUSTOMS,

" DEBT

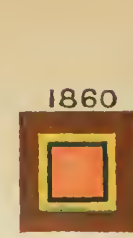

1880

PER SQUARE MILE

FEDERAL DEBT.

STATE,
COUNTY AND TOWN, $\}$ SOUTH CAROLINA DEBT.

INTERNAL REVENUE
CUSTOMS, FEDERAI. TAX.

STATE,
COUNTY AND TOWN, , SOUTH CAROLINA TAX

1880
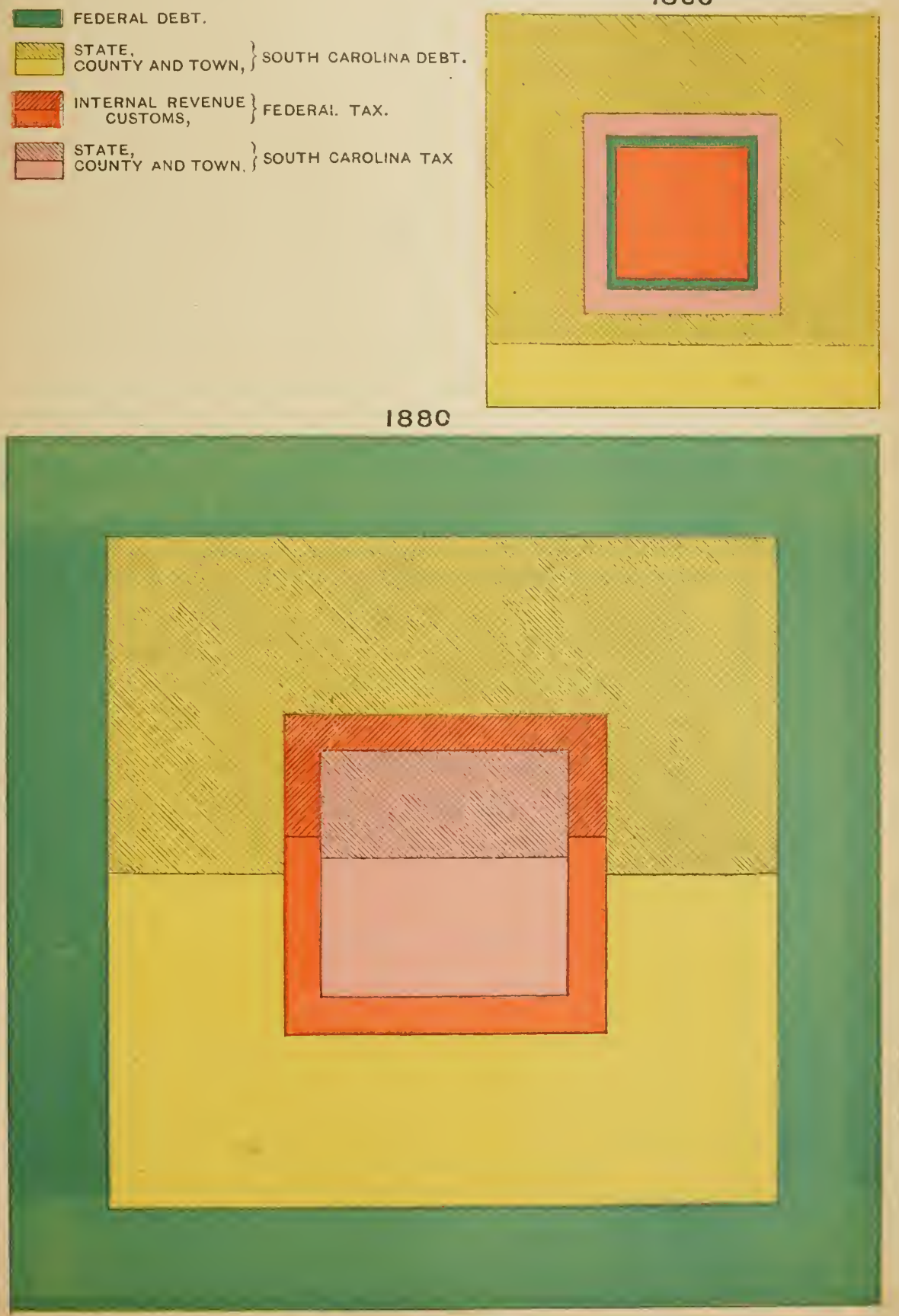



\section{CHAPTER X.}

\section{TOWNS OF SOU'IH CAROLINA.}

The urban population of the Lnited States was 3.5 per cent. of the aggregate population in 1790. By the last census it has risen to 2.2 .5 per cent. The facilities offered to trade and manufactures during the present century by the introduction of the use of steam, by improvements in machinery, by the telegraph and cheaper and better postal arrangements, has promoted everywhere this increase in city populations. In South Carolina this tendency has been less obvious than in most countries similarly located. Nevertheless, with the abolition of slavery, the barriers which isolated the State have been removed, and it is plain that she is making haste to take part in this as well as in the other great morements of the age.

Governor Drayton enumerates forty-two towns and villages in Sonth Carolina in 1800 , the population of which may be estimated at not exceeding 30,000 , or twelve per cent. of the inhabitants of the State. Mills, in 1520 , makes the number of towns and villages sixty-one, with a population of near 45,000 , being eight per cent. on the enumeration of the census for that year. William Gilmore Simms counts, in $18+0$, of towns, villages and hamlets, some seventy-five, with a population not far from $6.5,000$, being ten per cent. of the people in the State. The census of $1 S S 0$ counts one hundred and five towns in the State. This count, however, includes only a small proportion of the lesser villages and trading settlements, which are increasing with great rapidity, and are effecting: marker changes in the social and industrial condition of the population. The growth of the larger towns has been set back by the destruction and losses attendant upon the war, and by the radical rerolution it affected in the industries of the State, disturbing all the established methods of trade. But along the lines of railways, and every where in the rural districts, there has been a remarkable increase in the number of establishments engaged in trade. The cross-road store has become an important factor in the organization of labor and in the distribution of wealth. Established in the first instance as an arljunct to other industries, as commissariats for farm hands, or those employed in saw mills, turpen- 
tine or phosphate works, they have gained a foothold of their own, drawin round them small but growing communities, which find such locations eligible for the diversified industries and pursuits demanded by civilized life. Originally, the Indian traders, following the trail of the lunters and trappers, opened the interior of the State for settlement. Graziers and stock raisers, known as "cowpen keepers," were the first to follow them. In their wake, and to supplement for their uses the short-comings of the scasons, came the tiller's of the soil. These throve and prospered until in the fullness of time they became large planters and great landlords, supplanting and overshadowing all others. Then came the war, and the destruction of the plantation system. The thirty-three thousand plantations of 1860 are divided out among ninety-three thousand small farmers in 1SS0. Wholly occupied by their struggle with the soil and the seasons, these small farmers, of necessity, intrust their trading interests to the care of the country storekeeper. And thus the crossroads store stands again, as stood formerly the Indian trading post, a pioneer in a new industrial departure. The blacksmith, the wheelwright, and the trial justice settle near them, and when two or three stores are gathered together, churches and schools are opened, and a town which, from its very commencement, has instantaneous communication through the telegraph with every quarter of the globe, is admitted into the great fellowship of cities, and takes its growth.

The attempt is here made to express numerically the character and distribution of these towns and trading points. As in some sort, a first attempt, it is necessarily defective. The defects are, however, those of omission, and these can be supplied by more accurate enumerations in future.

In the following statements, trading settlements alone are considered. Health, educational or social resorts, as such, are not included, nor are mills or manufactories entered unless stores are connected with them. 
TOWNS OF SOUTH CAROLINA.

Towns, Trading Points, Stores \&c. in South Carolina.

\begin{tabular}{|c|c|c|c|c|c|c|c|c|c|c|c|c|c|}
\hline \multirow[b]{3}{*}{ Regions. } & \multicolumn{4}{|c|}{$\begin{array}{c}\text { Towns axd Trading } \\
\text { PoINTs. }\end{array}$} & \multicolumn{9}{|c|}{ Stores. } \\
\hline & & & & $\stackrel{\dot{1}}{=} \dot{1}$ & & $\cong$ in & & & HARAC & CTER & OF & & \\
\hline & $\underset{\Xi}{\stackrel{\Xi}{\Xi}}$ & 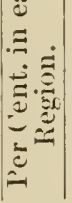 & 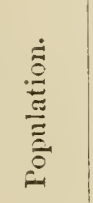 & 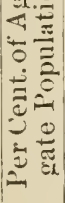 & $\frac{\dot{D}}{\Xi}$ & 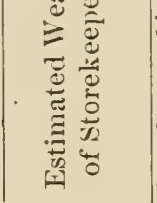 & 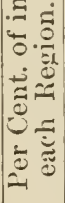 & 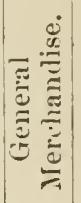 & 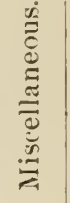 & $\mid \begin{array}{c}\dot{n} \\
\tilde{Z} \\
0 \\
\tilde{D} \\
\vec{D} \\
\vec{D}\end{array}$ & 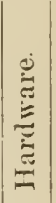 & $\frac{1}{0}$ & 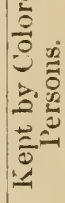 \\
\hline I. Coast........... & 34 & 7 & 58,756 & 52 & 1,169 & $\$ 20,322,000$ & 51 & 187 & 680 & 162 & 90 & 70 & 25 \\
\hline $\left.\begin{array}{l}\text { II. Lower Pine } \\
\text { Belt. }\end{array}\right\}$ & 78 & 16 & 9,095 & 6 & 330 & $1,473,000$ & 4 & 295 & 23 & 3 & 1 & 8 & 5 \\
\hline $\left.\begin{array}{l}\text { III. Upper Pine } \\
\text { Belt. }\end{array}\right\}$ & 99 & 20 & 21,538 & 9 & 1,009 & $5,630,000$ & 14 & 693 & 215 & 33 & 13 & 55 & 16 \\
\hline 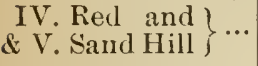 & 30 & 6 & 7,403 & 10 & 221 & $1,816,000$ & 4 & 143 & 62 & $\ldots . .$. & 3 & 13 & . \\
\hline VI. Piedmont...... & 244 & 49 & 50,788 & 12 & 1,750 & $10,546,000$ & 26 & 973 & 506 & 114 & 71 & 86 & 3 \\
\hline VII. Alpine ......... & 8 & 2 & $3,08 t$ & 33 & 166 & 369,000 & 1 & 99 & 58 & 4 & 6 & 4 & ....... \\
\hline Totals.... & 493 & 100 & 150,664 & 15 & $4,6+5$ & $\$ 40,156,000$ & 100 & 2,390 & 1,519 & 316 & 184 & 286 & 49 \\
\hline
\end{tabular}

It may be roughly estimated that the annual sales are about one hundred and fifty millions of dollars. In this connection, a general view of the condition of the

\section{BANKS}

in South Carolina, in the present and also in the past, is exhibited on the following page. 


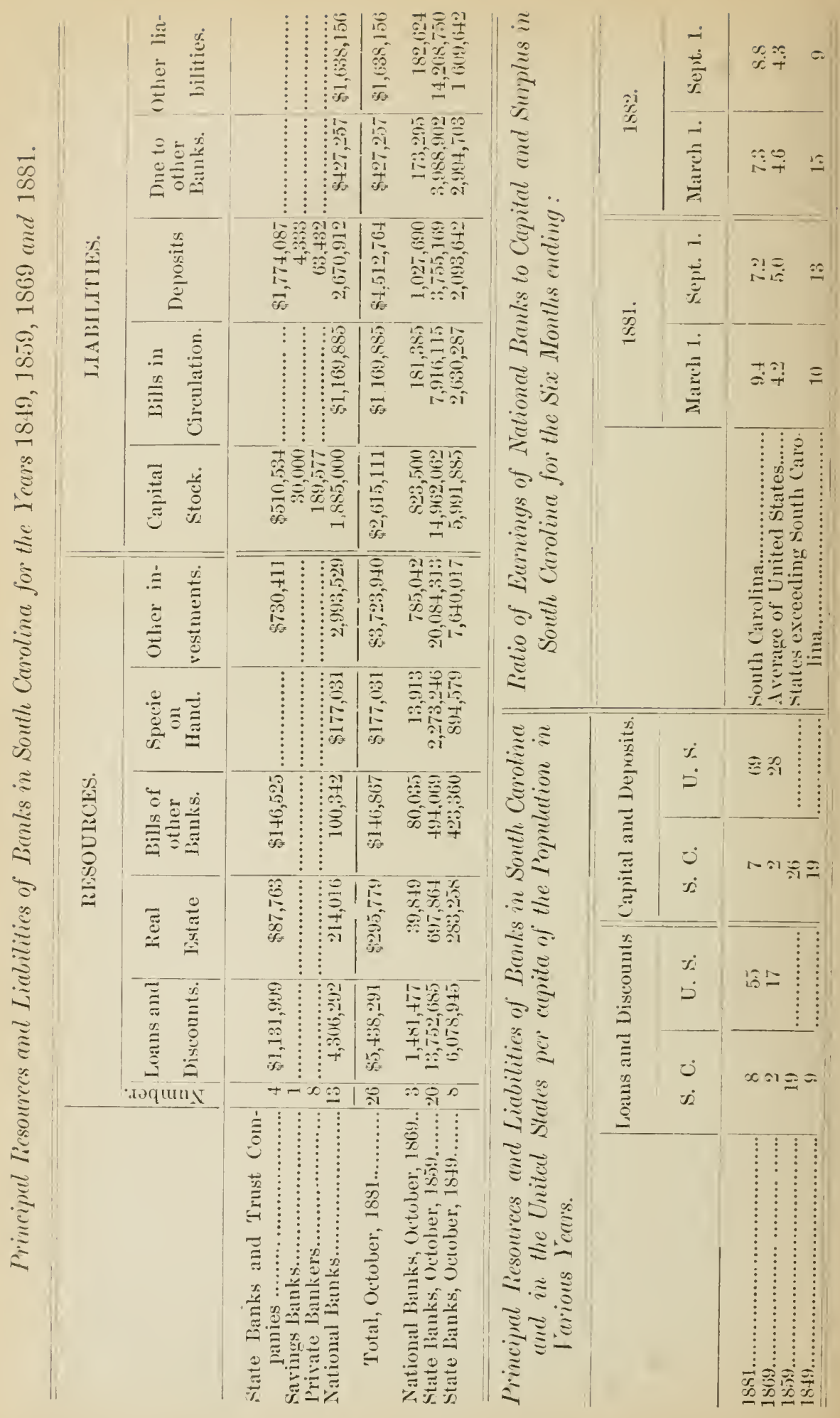




\section{COAST REGION.}

On the Coast Region of South Carolina there are 1,111 stores. Of these, four hundred and fifty keep general merchandise and groceries; one hundred and sixty-four, dry goods; eighty-five, hardware, and three hundred and ninety-seven are classed as miscellaneous. Notwithstanding the preponderance of the colored race, only twenty-two stores of this whole number are conducted by them. There are serenty-three stores or saloons where liquors are sold. In

\section{BEAUFORT COUNTY}

there are $9 t$ stores, to wit: Beaufort, forty-three; Port Poyal, seven; Bluffton, three; Hardeeville, four; Yemassee, four ; Sheldon, eight ; St. Helena Island, seven ; Ladies' Island, one; Pocotaligo, one; Coosaw, two; Grahamville, eight; Ferebeeville, two; Chisolm's Landing, two; Combahee, two; and doubtless some others which have escaped enumeration. Nine are kept by colored persons, and the aggregate wealth of the storckeepers is estimated at $\$ 5 \$ \$, 000$. The lines of trade are represented as follows: sixty-nine groceries and general merchandise, twelve dry goods, five hardware, and three miscellaneous. There are eight stores or saloons selling liquors.

PORT ROYAL,

the terminus of the Port Royal and Augusta railroad, is a striking instance of great natural advantages long known and neglected. It is the nearest point on the Atlantic ocean to the great centres of travel and production in the Northwest. It has the deepest entrance, and the deepest, safest and most commodious roadstead from Portland to Pensacola. It is the nearest port on the Atlantic coast to the W'est Indies and South America. Surrounded on all sides by large bodies of salt water, it is troubled by none of the malarial influences usually affecting fresh water estuaries. Dr. Spear, Surgeon U. S. N., gives the average annual death. rate of the U.S. naval forces in Port Royal waters as 5.6 per 1,000 men. The range lights erected on Hilton and Paris Islands enable vessels without a pilot to come in during blowing weather, with perfect safety by day or night. Capt. Jas. E. Jouett, U. S. N., writes that he has passed in and out several times at night, and never with less than twenty-nine feet of water. There are two distinct channels, so situated that sailing ressels may enter with the wind in any direction, and, passing up Broad and 
Port Royal rivers, they may enter Battery creek and reach the present wharves under full sail, where there is a stretch of anchorage five miles in length, with twenty-eight feet depth of water.

The net-work of broad and deep rivers, the beautiful islands resting in their midst, the verdure of the forests, the immense live oaks, venerable with the growth of centuries, the glistening fronds of the palmetto trees, the orange trees, the vines, laden with grapes, climbing everywhere, the abundance of wild fowl, and the fragrance of flowers that perfumed the air of this healthful and genial climate, attracted the early explorers and settlers to this locality. Here, in 1520, the Senator and Judge, De Ayllon, was the first European to land on Carolina soil. Here, in 1562, the Huguenots, under Jean Ribault, made the first settlement on the North American continent. Coveted and fought for by Spaniards and Frenchmen, the remains of the forts they built are still to be seen here. It was to this point, called then "the beauty and the envy of North America," that the English colony, led by William Sayle, which afterwards settled permanently at Charleston in 1670, first came.* And here, in 1682, Lord Cardross and his Scotch colony were dislodged and driven off by the Spaniards. In 1742, the headquarters of the British squadron on this coast was located here. More recently, this port was selected as the rendezvous of the United States naval force during the late war, as a depot of supplies and for repairs, and as a sanitarium for the troops. 'The records of the Navy Department bear ample testimony to its many natural advantages. The railroad was projected and built to this port under the idea that it was the most accessible from the interior, that it was the legitimate shipping point for Western produce, and that, in time, it would be the terminus of the great Southern lines of railway to the Pacific. That these hopes and plans have not been realized and accomplished has in no instance been attributed to anything wanting in the place itself, its surroundings, or its geographical relations to other places. The first settlements were abandoned in consequence of the inroads of Spaniards and pirates. To-day, it is said that hostile railroad combinations and the ill-advised jealousies of neighboring towns have checked the growth of this great seaport. As an illustration of this, it may be mentioned that, in 1875 , the city authorities of Savannah presented a memorial to Congress, expressing the fear that the "establishment of a naval station at Port Royal may result in the establishment of a growing commerce at that point, to the serious and lasting detriment of the commerce of the city of Savannah."

The present town of Port Royal is built on the southwestern point of

* This colony report seeing, on St. Helena Island, many peach trees. 
Port Royal island, * on a high sandy bluff, near the junction of Battery and Port Royal rivers, eighteen miles from Port Royal bar. There are three thousand feet of wharf room fronting Battery river, and the track of the Port Royal railroad terminating here, runs along the wharves within twenty feet of the vessels' berths. 'There is a large railroad warehouse across the railroad track on the wharves, with a storage capacity of 13,000 bales of cotton, uncompressed, 55,000 tons of fertilizer, and 2.50 tons of merchandise. The steam cotton compress in this warehouse is located within sixty feet of the wharf, where the deepest draft steamships may lie, and is one of the most powerful compresses in the South, and has a capacity of 500 bales per lay; the grain elevator, arljacent, has a capacity of 90,000 bushels. Five pilot boats attend Port Royal and st. Helena bars, with an average of three full branch pilots to each boat. Tessels requiring water, coal or wood, can obtain them here. Towing facilities ample. Towage rates the same as in Saramnah and C'harleston.

The town has a population of $3 S 7$; three ehurches and a sehool ; two hotels, and two boarding houses. The taxable raluation of real and personal property is $\$ 390,000$. Town taxes are fifty cents on $\$ 100$. Stores rent for $\$ \$$ to $\$ 25$, and dwellings from $\$ 6$ to $\$ 15$ per month. The connections by rail are, with Augusta, one hundred and twelve miles: Y'emassee, on the Charleston and Savannah railroad, twenty-five miles, this point being sixty and a half miles from Charleston, and fifty-fire and a half miles from Sarannah. There is an inland passage among the sea islands, between Charleston and Savannah, and two steamers are on the line, and touch at this point. A line of sea-going steamers run to New York. The number of ressels arriving during 1582 was 429 , tonnage, 219,050 ; ships of deep draft, with heary freights, as railroad iron, cotton ties, salt and fertilizers, find it convenient to deliver their loads here. The shipments are, of upland cottons, about 22,000 bales (in 1580, 48,000 bales were shipped), yellow pine lumber, manganese ore, cotton seed meal and Kaolin clay. The value of the exports from this port and Beaufort for the year $18 \$ 1$ are stated as $\$ 1,461, \$ 07$, against $\$ 2,678,893$ for the year previous. Customs receipts in $1579, \$ 13,294$. Port Royal has seven stores, and the yearly sales are giren as $\$ 45,000$ provisions, $\$ 15,1000 \mathrm{dry}$ goods, $\$ 10,000$ hardware. Phosphate rock of the finest quality is found in Battery creek and the Port Royal Fertilizing Company has extensive works here.

\section{BEALFORT,}

the county seat, settled about 1717 , has a population of 2,549. It is built on rising ground, on Port Royal island, about sixteen miles from the sea

*In the Statutes of State, 1795, this island is called Port-Republican island. 
and one hundred and eight miles a little east of south from Columbia. It corers an area of one thousand acres. The southern front of the town is on a bluff over the deep and wide waters of the Port Foyal river; along it is a fine broad drive, laid with shell, a mile in length, and a turf-corured promenade, shaded by a growth of massive live oaks. The street. are twenty-seven miles in length, and forty to sixty feet wide. They are regularly laid out, rumning east and west and north and south, dividing the town into one hundred and thirty-seven blocks. The sidewalks are neatly curbed and raised above the roadways, which are laid with shell, well kept, and shaded by avenues of fine trees. A number of small parks, open squares planted in shade trees and furnished with seats, are interspersed through the town. Wells twenty feet in depth furnish an abundant supply of excellent water, and cisterns for rain water are also used to some extent. The porous, sandy soil absorbs the rains so rapidly that there is little cause for drainage. The sewerage collected by surface and under ground drains is delivered into two large brick sewers, one a thousand, and the other six hundred feet in length, which empty into the river north and south of the town at low water mark. East of the promenade is the business portion of the town, and the wharres, which havenineteen feet depth of water at low tide. The Sea Island hotel is well located on the promenade, and is large and well kept; there are a number of good boarding houses. The private houses are well bnilt. and having been erected as residences for the wealthy planters of the sea islands, are much larger and handsomer than those usually met with in towns of this size. The public buildings are the Arsenal, now used as a Court House, the Town Hall, the Steam Fire Engine House and Hall, and two hand fire engine houses. Building material consists chiefly of choice yellow pine lumber, which costs $\$ 10$ to $\$ 15$ per thousand feet; tabby, a mixture of shell lime and gravel, was formerly much $\mathrm{u}$ *ed for walls and foundations, but is now superseded by the use of brick. The shell road, stretching across the island, furnishes a fine drive, and the facilities for transportation are good, carriages for pleasure drives hiring from seventy-five cents to one dollar per hour. The National cemetery, just beyond the town limits, covers thirty acres. It is handsomely laid out, and contains the graves of 10,000 Federal soldiers and sailor: who lost their lives in the civil war. There are six other small cemeteries attached to the churches in the town, and a number of burying places ontside, now used by the colored people. The St. Helena Episcopal ('hurch, built of tabby and brick, dates from 1720. There is als, a Baptist church for the whites and a Roman Catholic chureh. The colorel propte have two Baptist, two Methodist and one Reformed Episcopalian church. The whites have a Masonic lodge, and the colored 
population has a number of eharital)le organizations for the care of their sick and the burial of the dead. Some of these are, the Benevolent Society of the First Baptist Church, the Workers of Charity, the Shekinah Society, the Sons and Daughter's of Zion, the Rising Sons and Daughters of Zion, the Rising Sons and Daughters of Benevolence, the Rising Sons and Danghters of Charity, the Mary and Martha Society, the Olive Branch, the Sisters of Zion, the Knights of Wise Men, and an Independent Order of Odd Fellows. These societies have an aggregate membership exceeding one thousand, and own eleven buildings and lots, valued at over $\$ 12,000$. There is a white school, attendance sixty, and al colored school, attendance one hundred. The market is excellent, and living is cheap, fish, oysters, clams, shrimp, sea turtle and terrapin, with game, including partridges, water fowl, wild turkeys and deer, are abundant; the cost of beef on the foot is four cents to six cents, and of mutton three cents to five cents. The stores on the Bay rent for $\$ 300$ to $\$ 1,200$, and dwelling houses from $\$ 180$ to $\$ 600$ per annum; the Sea Island hotel rents for $\$ 2,500$. The indebtedness of the town is $\$ 5,000$, bearing seven per cent. interest, and represents the unpaid balance of the sums expended for the purchase of the steam fire engine, in building the house for it, and in laying the brick sewers. The taxable property is valued at $\$ 500,(100$ for the real estate, and $\$ 200,000$ for the personal property. The taxes are one per cent, and the sale of licenses yield $\$ 1,500$ more per annum. The government of the town is invested in an intendant and six aldermen. elected annually by the citizens. The police force consists of a chief marshal and two assistants. The town is remarkable for quiet and good order; for twenty years past, not a single individual has been killed or seriously injured in any disturbance within the corporate limits. There are forty-three stores, and the yearly sales are estimated at $\$ 300,000$ for provisions and groceries, $\$ 200,000$ for diy goods, $\$ 1.5,000$ for hard ware, $\$ 20,000$ miscellaneous; total, $\$ 535,000$. Trade and the mechanical and manufacturing industries engaged the attention of the old residents of Beaufort to a very limited extent. It was the home of the large landorners of the adjacent sea islands. Those whose time was not fully occupied with the care of their estates, devoted themselves to the professions, to politics, or to literature. In addition to the amusements incident to a refined and cultivaterl society, their chief pastime was in boating, fishing and lumting, and Elliott's volume on the Field Sports of Carolina is csteemed a classic in such literature, as well for the scholarly elegance of its style, the vivid interest it excites in the adventures and scenes it describes, occurring in this immediate vicinity, as for the pleasant pictures of rural life it portrays. Recently, three large steam eustom gins have been es- 
tablisherl, two large saw mills, and three large manufacturing mills for the manufacture of phosp hate rock into fertilizers.

\section{BERKELEY COUNTY.}

On the coast of Berkeley County there are twenty-nine stores, to wit: Edisto Island, nine; Rockville, one; Enterprise, seven ; Mount Pleasant, nine; Cainhoy, three. These are all groceries, or stores kepping general merchandise. The estimated wealth of the storekeepers is placed at $\$ 104,500$, and one of them is a colored person.

\section{MOUNT PLEASANT,}

the cointy seat, is on the north shore of Charleston harbor, three and a half miles from the city. Its front beach extends one and a half miles along the harbor, of which it commands a fine view, its width varies from four hundred to one thousand rards. Population, 783. Location high, dry and remarkably healthy. Excellent water is obtained from wells thirty feet in depth. About four miles of streets are laid with shell and well kept. The place has long been a pleasure and health resort for the planters of Christ Church parish and the people of Charleston. The Alhambra Hall, surrounded by a grove of live oak, is used for public entertainments, and there are two other halls, St. George's and the British Masonic. A park of ten acres has been laid out, and the county buildings will shortly be erected. The whites have an Episcopal and a Presbyterian church, and the colored people have a Methodist, Baptist, Presbyterian, and free cluurch. There is also a two-story school house, and an orphan asylum for colored children--private charities. Stores and dwellings rent for $\$ 10$ to $\$ 20$ a month. The tax assessment values the property at $\$ 182,275$ for real estate, and $\$ 12,000$ for personal, on which a tax of one-half cent is levied. Truck farming is largely and profitably engaged in ; as an instance, the cabbages alone from one farm of cleren acres sold for $\$ 10,500$ in 1881 . Near by is a large saw-mill, and an cxtensive brick and tile factory. There are nine stores, owned chiefly by Germans. A steam ferry plies regularly to Charleston, and the town will be the terminus of a railway, the stock for which has been recently subscribed, to extend along the coast to the Santee river, and beyond it to Little river, which will develop a region hitherto untouched.

\section{CHARLESTON COUNTY}

lies entirely along the coast, and besicles the City of Charleston, has two small towns. Moultrieville, on Sullivan's Island, is five miles across the 
bay from Charleston, and is comnected with it by a steam ferry. It is a pleasure and health resort for Charlestonians and people from the upluer country, who resort here in summer to enjoy the sea air and bathing its fine beach affords; it contains many handsome cottages and some attractive drives. It derives its name from Fort Moultrie, which beat off the British fleet of Sir Peter Parker, June 2Sth, 1776, and which, with Fort Sumter, a mile distant across the north chamnel, guards the entrance to the port. There are six stores.

McClellansville has ten stores, and is some thirty miles to the northeast. The city of

\section{CHARLESTON}

is built on a peninsula, formed by the confluence of the Ashley and Cooper rivers, that has an average elevation of eight to ten fect above high tide. Its safe and spacious harbor, forty feet deep at the city, and three miles wide, opens to the sea at a point about six miles to the southeast. The soil is loose, quartzose sand for a depth of trenty feet, resting on a tenacious and impervious clay. The city is three miles long, and varies in width from half a mile to two miles. "The first site of the town (on the western bank of the Ashley) had been chosen without regard to commerce. The point between the two rivers, to which the names (Ashley and Cooper) of Lord Shaftesbury were given, soon attracted attention; those who had purchased grants there, desirous of obtaining neighbors, willingly offered to surrender one-half their land as commons of pasture. The neck of land, then called Oyster Point, soon to become a village named from the reigning king, immediately gained a few inhabitants; and on the spot where opulence now crowds the wharver of the most prosperous mart on our Southern seaboard, among the grove: that swept down to the river's brink, and were covered with the yellow jesamine, which burdened the rernal zephyrs with its perfumes, the cabins of graziers began the city. Long afterwards the splendid regetation, which environs Charleston, especially the live oak, palmetto and cypress trees along the broad road which is now Meeting street, delighted the observer by its perpetual veriure. The settlement steadily increased: and to its influence is in some legree to be attributed the love of letter's. and that desire of institutions of learning for which South Carolina was afterwards distinguished." (Bancroft.)

Notwithstanding the provisions of the fundamental constitutions of the great John Locke, devised expressly for this colony, Charleston was not governed by a mayor or aldermen. Nor was there any township' organization, or "select-men," no merchant or craft guilus, or unions, taking part in local politics. The affairs of the town were administered directly 
by the Provincial Gorernor and Assembly; the regulation of many things, especially such as relaterl to education and the care of the poor, being left with the church. Through the leading part taken by the vestry, the parish system, long a feature in the State government, was developed, and thus it happened when, more than a century afterwards, in 1753, Charleston was incorporated by Act of the Legislature, the church wardens were deputed to conduct the first election for intendant and city wardens.

In 15:36, the titles intendant and wardens were clianged to those of mayor and aldermen. They were to be elected by citizens qualified to rote for members of the Legislature, were declared to be the City Council of Charleston, and were vested with the power to establish such by-law;, rules and ordinances respecting the harbor, streets and public buildings, and, in general, every other by-law and regulation that should to them appear requisite for the welfare and security of the city, or for the preservation of peace and good order, and to make assessments on the inhabitants of Charleston for the convenience and benefit of the city, and to fix, levy and recover fines for all offenees against their by-laws, and to appoint officers to carry their by-laws and regulations into effectual execution. Such was and has since been the form of government for the eity of Charleston, except when it was temporarily suspended in 1867 and 1868 , by order of the military authorities in charge of the military district of South Carolina.

The cost of the city govermment of Charleston reached its maximum in 1870 , when it was $\$ \$ 20,306$. For the decade including this year and the succeeding nine, the average annual cost was $\$ 794,255$. From this rate a more economical actministration of the city finances ensued, and for the last three years the arerage cost of the city government has been reduced to $\$ 853,136$. The increased expenditure in 1852 was oecasioned by the establishment of the paid Fire Department and the Fire Alarm Telegraph, costing $\$ 70,000$. The following statements gire the receipts and expenditures in detail : 
Statement of Receipts and Expenditures for the years 1S\%0, 1SSO, 1SS1, 188:

\section{RECEIPTS.}

Casl Balance lst January.

Licenses

Mirliets.

Taxes, current year.

Taxes, other y eal's

\section{OTHER SOURCES.}

Interest Acenunt.

Pulice Department...

Orplian House.......

Fire Department

Riailroad Bunds...

Rents

Real Estate

Bonus Receivable

Health Lepartment

Powler Magazine.

\begin{tabular}{|c|c|c|c|}
\hline 1870. & 1880. & 1581. & $1 \times 52$. \\
\hline $\begin{array}{r}50.54391 \\
12+1,2309\end{array}$ & 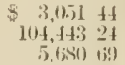 & 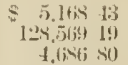 & 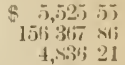 \\
\hline $\begin{array}{r}581.6169 \\
43,750 \\
08\end{array}$ & 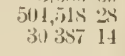 & $\begin{array}{r}1.311 .5 \\
31,662 \text { 7s }\end{array}$ & $\begin{array}{r}4 \times 1,313,75 \\
15,396,2.5\end{array}$ \\
\hline 68133 & $\ldots \ldots$ & 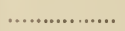 & 2.951 \\
\hline $7,3.1096$ & r. & …….... & .. \\
\hline $26 .(m)$ & $\ldots$ & $\ldots \ldots \ldots$ & $\cdot \cdots \cdots$ \\
\hline $3,0 \times 50$ & "61 1 1 & …............... & 321 \\
\hline$\ldots \ldots \ldots \ldots$ & $2.1116)$ (9!) & ...... & (1) TN!) fis \\
\hline ..................... & 4.5000 & 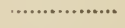 & IStist (t)! \\
\hline 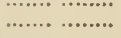 & ……….... & 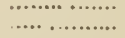 & 53131 \\
\hline 8815,972 & $\$ 651,14259$ & $\$ 640.2 \times 3 \quad 13$ & 709,578 (5) \\
\hline
\end{tabular}

EXPENDITURES.

Agriculturul Sinciety

Aiken Hospital.

Alims House.

Appraiser's Uflice.

Bathing House..

City Officers.

City Comrt.

City $\mathrm{Hill}$

Iity Hospilal

Clerk of council.

C'ollege.

Commissioners of Public Land

Citadel siquare

Conzmissioners of Election.

Colonial Common.

Destitute Orphans

Enston Home.

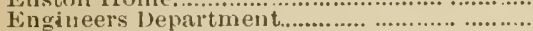

Fire Departiment.

Gas Lights.

Health Department

High School.

Harbor if aster...

Incidental Expenses.

Interest A conunt....

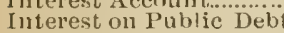

Lumatic Asylum

Linzaretto.

Iiscellaneous appropiations.

Mayor's Office.

Maps for Assessor.

News and Comrier Co

Notes Payable...

Ordinances. Lity

Orplian House.

Police l)eparlment.

Printing and Stationery

Putilic Buildings.

sinklng Fund

street Department

St. M ichrel's Clock.

Tidal Drains

'Transportation.

Treasurer"s ()flice.

Unpaid Bill 1879.

Vaults for Treasury

Water Works

widows' IIome.
$2+6 i 2$ 4)

$8,5,5,515$

. $15 . \ldots . . .3$

$1,4 \$ 683$

1,78100

2,125

$109(10) 013$

19,10713

6,100000

$\because 98 \div 90$

32.1919 .5

2xis 010

29, $9.5 \div 5: 5$

2.57100

$1+429$

1198200

33421961

7,168 4.5

4i) 00

31.91214

3,07225

.................

2500900

32,86960

$7 \pm 0115$

1,59180

105,34031

$277+77$

11, 29656

5 , (i)7 50

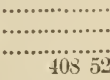

58:0,306 s 1,00000

क 5,0000

198000

13,00000

$+1) 0000$

$3,95+60$

51 tis

6,00000

60000

26.1900000

$25,112+57$

$15+90 \quad 96$

275000

$714)$

217.00400

11.0695

(........

19 sin $_{24}$

(6.5. (0)(11) (II)

3 (inti) (x)

$4,0(n) 00$
00

72,00000

4,720 si

129,502 os

...............

560077

21,50000

19,49984

2.000 (i)

3.96109

G00 0

2) (0)

is, 193 is

13,000000

2,98691

$3+5.5$

$249,3930$.

14,00000

(1), तो

10i0)

10., (u) (n)

101,500 vo
$\$ 1,00000$

8,24572

$2000(y)$

$24210(\mathrm{~m})$

14,999 (i:

20010 (0)

3,99964

(j.981 91

(i.0)(II) (x)

To(n) on

(6)10) (1)

15

18. 3066 6:

3.4560
,+ 00060

2.50000

$1 \times 3,4+4$ i)

$16,2 \mathrm{Ni}$

500 013

39) 1 in

225000

1.50ii (ii)

$20(0) 13)(1)$

$73,022)$ at

3.191) 31

25,17129

100,00000

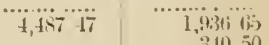

31050

$10,5(k)(b !)$

$8609,623.52$

8698,80480 
The rate of taxes for 1850 was two and one-half per cent., and for the following two ycars it was two and one-quarter per cent. In this period the taxable values in the city had advanced two and one-half millions of dullar's, or nearly twelve per cent. At the same time it was found by comparison of the sums actually realised on the sale of a number of pieces of property, with their assessment valuations, that the actual ralue was considerably in adrance of the assessed value. In 1881 this advance was stated at twenty-two and one-half per cent., and in 1882 it was still greater, being thirty-four per cent.

CITY DEBT.

There has been no growth in America greater or more remarkable than the growth of town and city debts. Previous to 1860 the entire municipal indebtedness of the country aggregated only $\$ 51,222,558$, being about $\$ 10$ per capita for the urban population. In 1870 these debts had reached $\$ 211,119,688$, and stood at $\$ 26$ per capita. In 1880 , the enormous indebtedness of $\$ 710,555,924$ is attained, exceeding $\$ 51$ for each citizen; in twenty-two cities it exceeds $\$ 85$ per capita, and reaches a maximum of $\$ 216$ per capita. The history of the debt of Charleston is in some degree similar. Prior to 1850 this debt amounted to only $\$ 3 \$ 5,252$, or about $\$ 9$ per capita. By 1856, however, it had reached $\$ 3,161,695$, and was $\$ 7 S$ per capita. Its maximum was reached between 1872 and 1850 , and amounted to $\$ 5,643,534$, being $\$ 115$ per capita. Alarmed at this rapid growth, and at the almost unlimited power granted by the city charter to the Council for contracting debts, the city gorernment elected in December, 1879, obtained from the State Legislature the passage of an Act restraining the exercise of this dangerous power. By this Act the City Council was prohibited from creating or endorsing any obligation beyond the municipal income of the current year, except when a proposition, specifying the object and amount of the indebtedness it was proposed to incur, should, by a two-thirds rote of the Council, have been submitted to a vote of the citizens, and having received the votes of twothirds of the qualified voters roting at the preceding municipal election, should then have been submitted to and approved by the State Legislature. The spirit of economy thus expressed has made itself practically manifest by a reduction of the city debt to the amount of nearly one and one-half millions of dollars, as will be seen from the following statement: 
The debt of the City of Charleston on the first day of January 1870 , was . . . . . .

It was increased by the issue of six per cent. stock, for past due interest . . . . . . . \$ 5,725

Five per ecnt. stock College and High School 22,000 Seven per cent. Fire Loan Bonds . . . . . . 324,000

Four per cent. bonds issued in settlement of case Fraser \& Dill vs. City . . . . . . . 50,100

401,82500

Sุก,,$(0+3,53+77$

Amount decreased by the eancellation and retirement of Fire Loan Bonds. . . . . . . \$250,100 00 Six per eent. stock... . . . . 743,983 79 Five per cent. stock. . . . . . . . . 47,60000 Four per' cent. stock (cancelled in 'S1 and 'S2) 372,10000 Six per cent. stock, old issue....... . $500 \quad 00 \quad 1,414,293 \quad 79$

Leaving public debt 1st January, 18s3 . . Which is made up of Bonds, four per cent. . . . . . . . . $\$ 3,413,30000$ Bonds, six per cent. . . . . . . . . . 1600,50000 Bonds, seven per cent. . . . . . . . . 500,00000 Bonds, seren per cent., Fire Loan . . . . . $103,40000 \quad 4,177,20000$

Stock, six per cent. . . . . . . . . . $\$ 29,0,50$ 98 Stock, five per cent. . . . . . . . 23,000 $00 \quad 52,05098$

The burden of this debt has becn still further and greatly relieved by a reduction in the rate of interest, which a wisc policy of promptly meeting all claims at maturity has enabled the present administration in a large measure to effect. Prior to 1880 , the annual interest charges on the city debt amounted to $\$ 314,557$, being $\$ 6.41$ per capita. In 1883 , this charge has been reduced to $\$ 1 \$ 8,000$, or about $\$ 3.65$ per capita. If the present plan of paying at maturity the debt bearing six and seven per cent. interest is persisted in, the city will, at an annual outlay of $\$ 23,000$, clear off the whole of this debt in eight years, and have remaining nothing but the four per cent. bonds maturing in 1909, with an annual interest charge of only $\$ 140,000$. Notwithstanding the risasters through which it has passed, swept as it has been by fire and sword, the 
crulit of the City of Charleston las once more gained the high rank it formerly hele. While only one-eighteenth of the aggregate municipal indebterhess of the Lnited States bears so low a rate of interest as four per cent., more than three-fourths of the debt of Charleston is placerl at that figure.

\section{STREETS.}

Charleston has seventy miles of streets. Cobblestone roarlways extend nine and one-eighth miles, and there is a shell road for one and threeeighth miles. There were fire and one-eighth miles of plank roadway, but this has been reduced, and will be entirely done away with. The remainder of the streets are much in the condition in which they were two hundred years ago, a state of things that would have been impossible but for the dry and porous nature of the soil: For the thirteen years previous to 1880 , about $\$ 100,000$ were amually expended by the city on the streets; in that year, two and one-eighth miles of stone roadway was laid, at a cost of $\$ 70,000$; in $18 \$ 1$, of stone roadway, cobblestone, and Macarlam roadway, about 1.4 miles was laid. The city is also charged with the sidewalks. The cost of paving with flagstone is estimated at two dollar's, and with brick at one dollar per square yard. In 1s\$1, besides resetting and repairs, 4,257 square yards of flagstone, and 3,811 square rards of brick pavement were laid, together with 2,534 feet of curbstone. Charleston has five miles of street railway. The early settlers obtained an abundant supply of excellent

\section{WATER}

by sinking wells, twelve to fifteen feet in depth, through the loose sands: with the growth of the city this water lost its purity, and recourse was had to eisterns supplied by rains. Many plans were proposed to remedy this evil. As early as $1803, \mathrm{Mr}$. Longstreet attempted to bore an artesian well, but did not succeed. From time to time other similar attempts were made, with like results. At length, in $1876, \mathrm{Mr}$. Spangler bored a well on Citadel Green, to the depth of 1,970 feet, and obtained an abundant supply of water. The delivery, tested at four feet above the surface of the earth, was found to be 250 gallons a minute, or 360,000 gallons a day. The water has a temperature of $99.5^{\circ}$ Fahr. It is pleasant and healthful for drinking and culinary purposes, it is delightful for bathing, and superior eren to eistern water for washing. This demonstrates the practicability of furnishing an unlimited supply of excellent water for the city. Mr. Spangler is working at another well, and others will be constructed ats occasion requires. 
DRAINAGE AND SEWERAGE.

There are five and one-quarter miles of tidal drains, built at twenty inches abore mean low tide. These drains would be a complete and effective scarenger, but being built with plank floors on loose sands, the planks have in some places rotted, and in others the sand has washed out, lowering the levels to such a degree as to render thorough draninge impracticable. They are to be replaced with concrete or other hard floors. The numerous street drains, ljuilt at different times, do not constitute a uniform system, and are defeetive as to levels, the rital necessity of which is not so conspicuons in tidal drain localities, where the water runs up hill half the time. In 18s1, there were laid 11,320 feet of twelveinch vitrified ironstone pipes, at a cost of eighty-seven and one-half cents a foot, in substitution of brick and wooden drains, and $b, 10, j$ feet of eight-inch pipe-drains. The scavengering has been transferred from the Street Department to the

\section{BOARD OF HEALTH,}

with rery satisfactory results. It is also proposed to concentrate the slaughtering louses at a public abattoir under their supervision. 'The administration of quarantine too has been transferrerl to this Board. The City Registrar is Secretary of the Board, and there is in operation a very effective system for the registration of rital statistics.

In consequence of the high rate of mortality prevailing among the colored race since emancipation, due to their disregard of the laws of hygiene. especially as regards children, it is necessary, to form a fair estimate of the healthfulness of Charleston, that the mortuary statistics of the races be eonsidered separatelr. The ratio of deaths among the colored population of the city was, in $18.30,24.85$ per 1,000 , in 1840 it was 27.60 , in 1850 it was 20.95, or an average of 24.47. In 1870 it had risen to 41.05 , and in $18 S 0$ to $41.0 S$. In $18 S 0$ the ratio of death per 1,000 of the colored population was as follows, for some of the Southern cities: Nashrille, 35.23; Norfolk, 37.06; New Orleans, 44.49; Savannah, 45.47. The following table exhibits the mortality among the white race in Charleston, as compared with that of some Northern cities during the last lialf century : 
C'mparative Murtality. Ratio per 1,000 Whites in the City of Charleston, S. C. and in other Cities.

\begin{tabular}{|c|c|c|c|c|c|c|c|c|}
\hline & 1830. & 1840. & 1550. & 1860. & 1870. & $1 S S 0$. & $\begin{array}{l}\text { AGiRe- } \\
\text { G.ATE. }\end{array}$ & $\begin{array}{l}\text { Ratio } \\
\text { DECADES }\end{array}$ \\
\hline Philadelphia & 20.90 & 17.78 & 19.63 & 19.15 & 2.2 .72 & 20.91 & 121.12 & $20.1 S$ \\
\hline Charleston. & 25.65 & 18.94 & 18.68 & 17.70 & 23.69 & 22.01 & 126.67 & 21.11 \\
\hline lioston. . & 20.00 & 22.19 & 24.79 & 24.68 & 24.30 & 23.53 & $13 !) .29$ & 23.21 \\
\hline Baltimore. & 2.2 .82 & 20.04 & 24.91 & 22.91 & 27.09 & 27.16 & 144.94 & 24.15 \\
\hline New Iork. & 25.66 & 25.16 & 30.70 & 28.19 & $2 S .84$ & 26.47 & 165.02 & 27.50 \\
\hline
\end{tabular}

FIRE DEPARTMENT.

In the Fire Department of the city there was a substitution, in 1881, of paid for rolunteer service. The service is performed under the direction of a Board of Firemasters. There are six steam fire engines, two reserve steam fire engines, and two hook and ladder trucks, with one hundred men and a sufficient force of officers, horses, fuel, wagons, itc. The fire alarm telegraph has thirty miles of wire, and ninety-three signal boxes, in six separate and distinct metallic circuits, connected only through a repeater at the central office.

\section{PUBLIC GROUNDS.}

On the extreme southeastern front of the city a massive stone wall, ten feet in width and fifteen hundred feet in length, rises immerliately from the waters of the bay; a broad, smooth drive separates it from the handsome private residences of the city that, with their gardens, occupy this quarter. The riew corers the spacious harbor, with its shipping, forts and islands, stretching seaward to the southeast, where the unbounded ocean terminates the horizon. It is known as the Battery, and forms a seaside promenade searcely surpassed anywhere. From the southern terminus of this promenade a walk, twenty-five feet broad, extends for eight hundred feet along the southern shore line of the eity. Opening on this walk are the entrances to the White Point gardens, corering eight acres of ground, beyond which is again the broad, smooth drive, with the handsome private residences and beautiful gardens. Washington Square, adjoining the City Hall, centrally located, covers one and a quarter acres, with its shade trees. Marion Square, in front of the Citarlel, is a well kept parade ground, of nine and a half acres. Hampstead, Wragg, and Liken Mialls, are lands belonging to the city, making 
for the whole fifty-three acres, susceptible of being greatly improved for the pleasure and comfort of the citizens. The public buildings, State and Federal, the numerous churches, to some of which historic as well as architectural interest attaches; the Academy of Music, one of the finest theatres in the South; the colleges, the library, the edifices devoted to charity, and many other fine buildings, including the imposing Charleston Hotel, and the Market, famous for its fruits, fish, game and vegetables, can not find place in this brief account. Charleston has always been generous in its

\section{CHARITIES.}

Mills enumerates fifty-one benevolent and missionary societies in operation prior to 1S24; of these fourteen were established in the eighteenth century. He ascribes to Charleston the honor of establishing the first religious charitable society in America. The Fellowship Society, formed in 1762 , for the succor of the insane, was doubtless one of the first of these humane institutions in modern times. The first library was a donation from Dr. Bray, in the year 1700, and the first free school was opened in 1712. At present the city maintains its charitable institutions at a cost of about ten per cent. on its gross income. Their management is in the hands of boards of commissioners, who serve gratuitously. deeming it a privilege to be intrusted with the duties of administering hospitals and bestowing relief on pauperisn; a surviral perhaps of the spontaneous charity cultivated by the old vestry influence. 'The Orphan House was established in 1790, and has accommodations for three hundred children; it is maintained at an annual cost of $\$ 20,000$. The Alms House, founded in 1712, has an annual average of seventy-eight inmates, besides its outdoor relief to two hundred and eighty-nine others. The Ashley River Asylum, for colored persons, averages sixty-eight inmates. The Roper and City Hospitals, and the Shirra's Dispensary, with four physicians employed permanently by the city, give relief to the sick poor, and by arrangement between the city and the Faculty of the Medical College, "the best medical and surgical skill is at all times available to the humblest person at a nominal cost, without regard to race or creed." 
I'ropulation of the City of Charleston, as shown by the Cuiter States C'cnsus fiom 1790 to 1880 , with the Decennial Rate of Increase compared with that of the Stute, and the Niember of Ducllings.

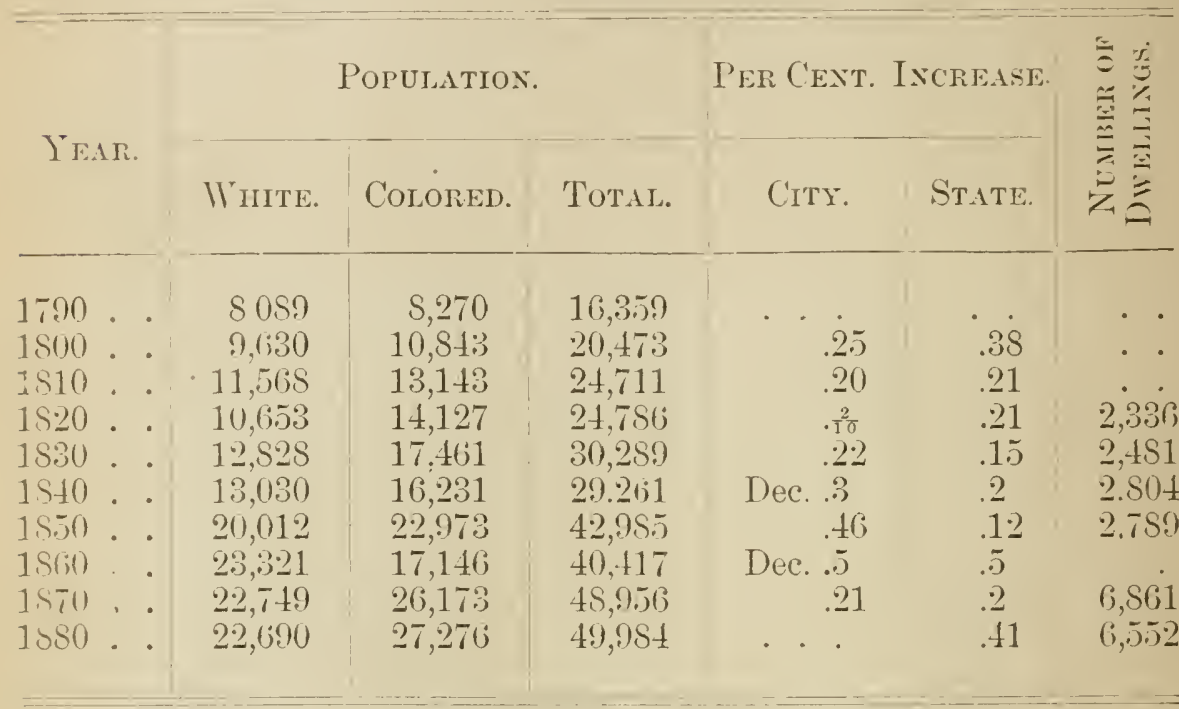

In 1870 , Charleston ranked twenty-sixth among the cities of the Uniterl States as to population; in 1980 it ranks thirty-sixth. In 1570 it rankel twenty-sixth as to the number of persons engared m useful and remunerative occupations, in $1 S S 0$ it ranks as thirty-fifth in this regard. In 1970 it was twenty-eighth as to the number of families, in 1850 it is twentyninth in this respect. In 1870 it was twenty-ninth as to the number of dwellings, in 1850 it is forty-fourth in this respect. In 1570 eighty-eight per cent. of the population were natives of the State, nine per cent. foreign and three per cent. were born in other States of the Union. In 1850, eighty-eight per cent remain natives, eight per cent. are forcign and four per cent. are froin other States.

\section{TIIE HARTOR}

is deep, spacious, land-locked, and perfectly safe. The deep water beyond the bar is only six miles from the city. The present wharves, furnishing as much as forty fect depth of water, have accommodations for about two hundred ressels, and the wide and deep waters of the Ashley (Kicamah, Indian name) and Cooper (Étiuan) rirers cxtend for six miles along the peninsula on which the city stands. The depth of water on the bar is at present about eighteen* feet. Since 18,8 the United States govern-

* Mills gives the depth, in 182T, as twenty to twenty-two feet. 
ment has been engaged in extensive works for increasing the deptly of the entrance. A stone jetty from Sullivan's Island, rumning southeast and seaward, and another from Norris Island, bearing northeast and toward the first, are being built. There will be an opening of 2,000 or 2,600 feet in width at their point of convergence, and it is estimated that the concentrated force of the currents and tides will scour out and kecp open, through this funnel-shaped aperture, a permanent channel twentysix feet in depth. Foundation courses 15,000 feet in length, for the north jetty, and 12,757 feet for the south jetty, in all 27,757 feet, have been laid, varying in width from forty-three feet to one hundred and eighteen feet, and height from two and a half feet to fourteen feet from the bottom, exclusive of spur jetties at certain points. The expenditure has been $\$ 1,045,000$, and it is estimated that it will require $\$ 755,000$ to complete the work, which can be accomplished by the 30th of June, 1 Sst.

In 1SS1, the entire management and control of the aflairs of Charleston harbor was vested by the State Legislature in a Board of Harbor Commissioners. The mayor of the city is, ex officio, chairman of this board, which includes among its members, the President of the Chamber of Commerce, a member of the Board of Health, and ten others, appointerl by the Goremor, one of them a full branch pilot. The board apjoints amnually, with power to remove at discretion, the Ifarbor Master and Port Wardens, and defines and assigns their duty. Formerly there were $n$ port charges; at present the support of the officers and other port expenses $\mathrm{i}$ : borne by a fee bill of five cents to ten cents per foot of length orer all, charged upon ressels ariving. The Harbor Commissioners have charge of all matters pertaining to pilotage and quarantine. The pilot gromel for Charleston is thirty miles in any direction from the port. The service is performed by eleven pilot boats and thirty-five authorized pilots; the rate of charges varying from fifteen dollars for six feet to one hundrecl and eighty dollars for eighteen feet, with four dollars per day detention money. Every care is taken to insure the faithful and efficient discharge of these responsible duties. It is proposed to establish a marine signal station, with telegraphie communication from the Charleston light-house to the eity, so that on arrival, masters of ressels will be at once in communication with the commercial world. Charleston is nearer to the grain fiels s of the great West than any Atlantic port lying to the north of it. The distance from Havana to Cincinnati, via Charleston, is three hundred miles less than by Baltimore, and fire hundred miles less than by Boston. For the European trade, this, the largest seaport on the South Atlantic coast, is nearer than the Gulf ports, and offers to immigrants the safest and most eomfortable royage at all seasons of the year, with facilitie for their distribution on landing as cheap and convenient as 
those at any port on the continent. Nearly two hundred years ago the transportation charges for immigrants from Europe to Challeston were twenty dollars apiece. The following statement shows the foreign tonnage entered at the port of Charleston, for the years named:

$\begin{array}{llll}1801 \ldots 59,880 & 1843 \ldots 21,148 & 1859 \ldots 129,764 & 1881 \ldots 156,500 \\ 1802 \ldots 67,914 & 1853 \ldots 94,475 & 1570 \ldots 36,332 & \end{array}$

The following statement shows the value of the exports and imports of merchandise at Charleston for the years given, and also the percentarge of such ralue on the value of the total exports and imports for the colonics, and for the United States:

\begin{tabular}{|c|c|c|c|c|c|c|c|c|}
\hline Tear. & Exports. & 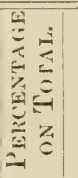 & IMPORTS. & 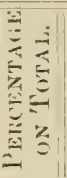 & YEAR & Exports, & 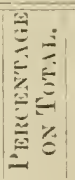 & IMPORTS. \\
\hline 1700. & $£ 14,158$ & 4 & $£ 10,003$ & 3 & 1810. & $85,290,614$ & 11 & \\
\hline 1710 & 20,793 & 9 & 19,613 & 6 & 18 & $7,200,511$ & 14 & $3: 3,007,+14$ \\
\hline $17 \%$ & 62,736 & 13 & 18,290 & 5 & 18: & $7,6.27,1.51$ & 13 & $1,0.7,01 !$ \\
\hline 1731 & 151,739 & 26 & 64,785 & 11 & 18 & $10,(1) 36,769$ & 9 & $3,0.5,870$ \\
\hline 174 & 265,560 & 37 & 181,821 & 22 & 18 & $8,890,648$ & 8 & $1,143,158$ \\
\hline 17 & 191,607 & 23 & 134,037 & 20 & 181 & $8,081,417$ & 6 & $1,+55,2 ! ! 6$ \\
\hline 17 & 162,769 & 21 & 218,181 & -8 & 1856. & $17,3: 28,503$ & 5 & $1,105,2,234$ \\
\hline & 278,107 & 27 & 146,273 & & & $21,170,273$ & & 1.5001 .570 \\
\hline 1775. & (2)79, 349 & 30 & $£ 378116$ & 14 & 1870. & $10,772,071$ & 2 & 505,6019 \\
\hline 779 & $82,61), 2(4)$ & 11 & $\$ 1,520,000$ & 11 & 1880. & $19,5 !) 0,(627$ & 2 & $2(1) 2,7 ! n$ \\
\hline 179 & $7.620,049$ & 17 & ? &.. & $1881 .$. & $26,498,8=7$ & $\ldots$ & 440,240 \\
\hline 1800 & 14,$304 ; 045$ & 42 & & & $1882 \ldots$ & $17,617,483$ & $\ldots \ldots$ & 586800 \\
\hline
\end{tabular}

In 1769 , the exports from Charleston were valued at $£ 508,108$, and were greater than from any of the other English colonies; in the same year her imports amounted to $£ 306,600$, and were greater than those of New York and Penusylvania added together. It was not until 1816 that the value of exports from New York equalled those made from Charleston in the first year of the century, and as late as 1724 the value of the domestic exports from ('harleston was greater than that of any city in the Uniterl States. The largest value of imports after the revival of prosperity, about 1850, was in the year 1858, and amounted to $8.2,070,249$. The lowest ebb in this regard, after the war and reconstruction, was reacher in 1879 , when the value of the imports amounted to only $\$ 131$,1S2. Here, as elsewhere, it will be obserred that there was great development from 1850 to 1860 , a disastrous falling away from that date, with a fair promise of a restoration of prosperity since 1S50. From 1791 to 1825 the Federal customs revenues collected in Charleston aggregated 
$\$ 22,337,381$ (more than the assessed value of the real and personal property of the city in 1S50), with a minimum, in 1796 , of $\$ 52,443$, and a maximum, 1817 , of $\$ 1,616,460$. In 1879 , the receipts from customs in Charleston was $\$ 53,727$.

The Leading Articles Received at and Shipped from Charleston in 1883.

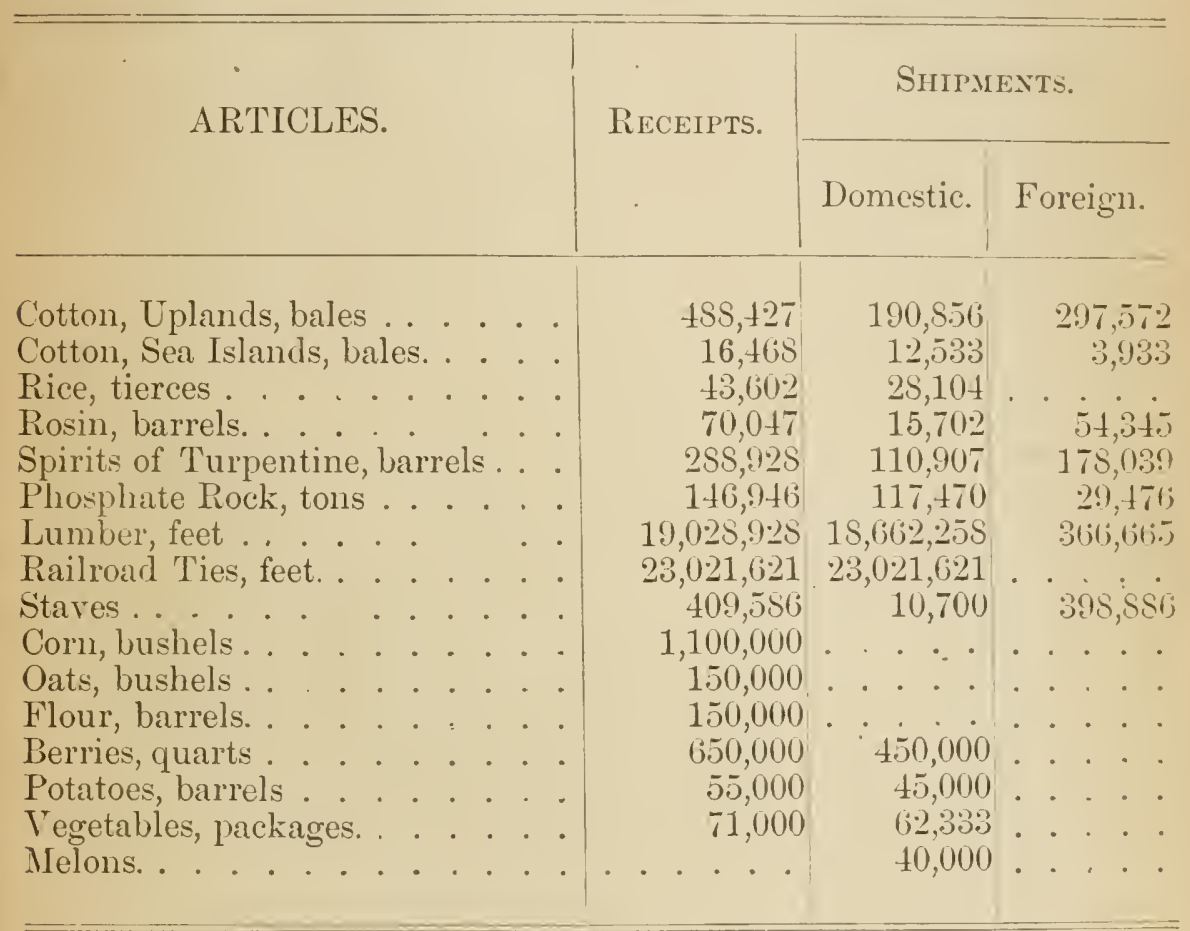


Hechanical and Manufacturing Industries of the City of Charleston, 1882.

\begin{tabular}{|c|c|c|c|c|c|c|}
\hline INDLSTRIES. & 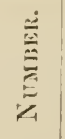 & CaPital. & HANDS & W ${ }_{\text {AGES. }}$ & MLTERIAL. & トRODLCT. \\
\hline Axle Grease.. & 2 & $\$ .5,800$ & 4 & & & 89,000 \\
\hline Batgrging Factories... & 1 & $245,(1000$ & 28(\} & & & 400,01100 \\
\hline liakeries............................... & 13 & $30,(000$ & 90 & & & 200,0110 \\
\hline Batsket and Willowware........... & 2 & 2,500 & 5 & & & $\therefore,(! 00)$ \\
\hline Beer and Breweries,................ & 1 & 50,000 & 25 & & & $80,0(11)$ \\
\hline Blacksmithing........................ & 6 & $10,0,50$ & $1 \bar{n}$ & siti,(1.) S & $\$ 3.855$ & 13,727 \\
\hline Boots and -hoes...................... & 9 & 1,120 & 13 & 4,256 & 4,160 & 13,191 \\
\hline Dentistry, Mechanical.............. & 7 & $2,81) 0$ & & (........ & 3,785 & 9,680 \\
\hline Candy Factories..................... & 4 & 8,000 & $5 \overline{1}$ & ..... & .......... & 70.0110 \\
\hline ( arpentering.. ..................... & 15 & 140,000 & 475 & & & $300,000)$ \\
\hline Carriages and Wagons............. & $s$ & 30,000 & (i.j) & & & $7(1,0) 00$ \\
\hline Cigars.................................. & 13 & 30,000 & $11: 0$ & & & 145,000 \\
\hline Clothing, Men's..... & 6 & 60,0100 & 50 & & & $7(0,0) .0$ \\
\hline Concrete Piping.... & 2 & 12,000 & 10 & & & 50,000 \\
\hline Cotton Factory...................... & 1 & 500,000 & 200 & 62,9100 & & $600,0 \times 0$ \\
\hline Cotton Compresses................. & 4 & 5311,000 & 230 & 62,900 & 65.000 & 174,900 \\
\hline Cotton seed Oiı Mill................ & 1 & $10(1,000)$ & 60 & n........ & 84,000 & 135,000 \\
\hline Engraving. ........................... & 2 & 6,000 & 5 & & .......... & 4,500 \\
\hline Flouring and Grist Mill Products & 4 & 15,000 & 60 & & & $80,(100)$ \\
\hline Fertilizers............................ & 11 & $2,386,000$ & 920 & ....... & $\ldots \ldots$ & $2,562,(1,00$ \\
\hline Furniture.............................. & 3 & 20,000 & () & & ............ & 8,900 \\
\hline Gas .................................... & 1 & 375,000 & 50 & & & 206,1000 \\
\hline Harness................................. & 11 & 45,000 & 60 & & ..... & $(60), 000$ \\
\hline Iron Fonnderies and Wurks..... & 17 & 390,000 & $4.5(1)$ & ........... & ................ & $75,(1) 00$ \\
\hline Lock and Gunsmithing........... & 7 & 23,300 & 8 & 2,708 & 2,000 & 11,413 \\
\hline Marble and Stone Works,......... & i) & 25,000 & 6i1 & ......... & & 80,0010 \\
\hline Mineril and Soda Water........... & 3 & 4.500 & 13 & 4,159 & 7,800 & 201.250 \\
\hline Painting and Palper Hanging..... & 7 & $5, \pi,()$ & $\$ 4$ & 9,629 & 10,208 & 25,450 \\
\hline Photographing...................... & 4 & 8,600 & 7 & & & 7,000 \\
\hline Plumbing and Gas-Fitting......... & 7 & 30,000 & $1: 3$ & & & $4: 2,000$ \\
\hline Printing. .............................. & $1 \pm^{\prime}$ & 240,000 & 215 & & & 290,000 \\
\hline Rice Mills.......................... & 4 & $\$ 50,000$ & $2: 26$ & & & $1,202,01110$ \\
\hline Saddiery .............................. & (;) & $2: 2,0001$ & in & & & 50,0110 \\
\hline Saw Mills............................ & 12 & 325,000 & 415 & & & son, 000 \\
\hline Ship-Building....................... & 11 & $44,3,50$ & 8.5 & $5:, 810$ & 53,350 . & $1: 8,0(1)$ \\
\hline Shirt and Underwear................ & 1 & $7,00(i$ & $6 \overline{5}$ & .............. & .......... & $1.5,000$ \\
\hline Street Car Repairs.................. & 2 & $5,110()$ & !) & & & 15,000 \\
\hline Tin, Copper and slieet I $\%$ n......... & $101^{\prime}$ & $3.5,000$ & $4: 2$ & & & $48.00(0)$ \\
\hline 'Tobateco ............................... & 8 & $11),(100)$ & 56 & ......... & & $53,0(0)$ \\
\hline Upholstering ................ & + & 4,700 & 15 & 6,000 & $3(0,4 \div 2)$ & $49,(i)$ \\
\hline IVoud and saw Mills.......... & 8 & $20(0,000)$ & 8811 & ............. & n............. & $6(i),(0)(1)$ \\
\hline II atch and clock Reparir......... & 9 & $15,(1000)$ & 18 & & & $\because 0,060$ \\
\hline \multirow[t]{2}{*}{ Miscellaneous......................... } & $\bar{T}_{1}$ & $16(1),(0)(0)$ & 210 & $\cdots$ & & $1.50,010(1$ \\
\hline & $27: 3$ & $56,6: 28,470$ & 5167 & & & $89,010,7: 31$ \\
\hline
\end{tabular}

These figures inchude those of several large industries which have gone into operation since the enumeration for the Tenth U. S. Census was marle. Had they been in operation at that date, Charleston would have lanked as twentieth among the cities of the United States in regard to the amount of capital invested in manufactures. 
The number of firms engaged in the

\section{WHOLESALE AND RETAIL TRADE}

of the City of Charleston is given, in January, 1853, as 924. They are cre:litad with an aggregate wealth of $\$ 18,755,100$. Of their number 302 were engaged in the grocery and provision trade; 148 in selling dry goods, clothing, boots and shoes; eighty dealing in hardware; miscellaneous, 394. There were reported fifty-eight establishments where liquor was sold. Of the whole number twelve were under the direction and management of colored persons. The sales for 1852 were given as follows:

\begin{tabular}{|c|c|c|c|}
\hline \multirow[t]{3}{*}{ Provisions } & Groceries . & $\$ 15,700,000$ & \\
\hline & Grain and hay . & 945,000 & \\
\hline & Ice, fish and oysters. & 60,000 & 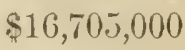 \\
\hline \multirow[t]{4}{*}{ Dry Goods } & Dry goods... & $4,320,000$ & \\
\hline & Boots and shoes. & $1,255,000$ & \\
\hline & Hats and caps . & 175,000 & \\
\hline & Clothing . . . & 375,000 & $6,125,000$ \\
\hline Hardware & .... . & & $1,525,000$ \\
\hline Miscellaneous. & . . . . & & $4,600,000$ \\
\hline Total & . . . & & $\$ 28,955,000$ \\
\hline
\end{tabular}

The aggregate values of the annual trade of the city may be summarized as follows:

Talue of staple products received . . . . . \$31,\$10,132

Value of local manufactures . . . . . . 9,010,731

Value of wholesale and retail trade . . . . . 25,955,500

Total ................. . . $\$ 73,806,363$

Banks of Charleston.

\begin{tabular}{|c|c|c|c|}
\hline & $18+8$. & 1860. & 1853. \\
\hline Number of Banks. . & 7 & 9 & 6 \\
\hline Capital & $\$ 9,152,5 \dot{3} 2$ & $\$ 11,129,637$ & $\$ 1,120,000$ \\
\hline Dividends . & 5.03 to 7,44 & 6. to 10 & 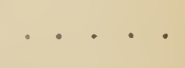 \\
\hline Surplus . . . . . . & . . & . . & 637,000 \\
\hline
\end{tabular}


There is a large business in foreign and domestic exchange and in discounts carried on by merchants in the city, employing a capital three to four times as great as that of the banks.

The most recent improvement in the railroad facilities offered by Charleston is the extension since July, 1582, of the South Carolina Railway track to deep water on the Cooper river, in the northeastern portion of the city. The railroad company has built here, on creosoted piling, a wharf 931 feet long and 100 feet wide, with two slips for loading lighters, and a slip on the north for loading lumber. Besides a number of sheds on this wharf, there are two storage sheds for fertilizers, each 400 feet by 60 feet. The wharf is furnished with ten electric lights. West of the wharf, and separated from it by double rows of railway tracks, are two warehouses, 410 by 60 feet each. There is a hoisting engine, and an automatic bucket and dump car, two automatic railways, with switch and chute to facilitate the handling of heavy freights. Immediately west of the southern scction of the wharf is the freight depot, 400 feet long, and two business offices. Other wharves are being constructer. They will consist of a number of piers, with docks from 200 feet to $30 n$ feet long. Railroad tracks will run to the head of the piers, enabling vessels to load directly into the cars.

\section{GEORGETOWN COUNTY.}

Georgetown, the county seat, the only seaport on the South Carolina coast north of Charleston, is situated at the hear of Winyaw bay, on a slightly undulating sandy and clay loam, on the north bank of the Sampit river. Immediately above the town, the Black, the Pee Dee and the Waccamaw rivers enter Winyaw bay. The Santee river was also formerly connected with Winyaw bay by a canal six miles long. To aroid the shoals af the mouth of this river and to render it more accessible, the United States government has made an appropriation to reopen a canal here. When this is completed, Georgetown will be at the outflow into the sea of a system of rivers having a drainage area of 31,000 square miles. These streams are now navigable by steamboats for a distance of 799 miles. Surveys and appropriations for perfecting their navigation have been made by the general government. The status of this work, up to the 1st July, 1SS1, may be briefly summarized as follows: 


\begin{tabular}{|c|c|c|c|c|c|}
\hline Name of River and part Nayigable. & 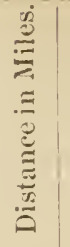 & 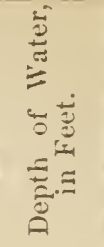 & 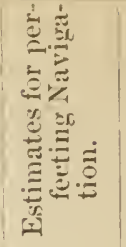 & 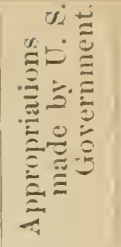 & 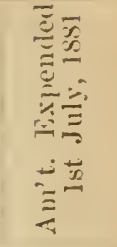 \\
\hline 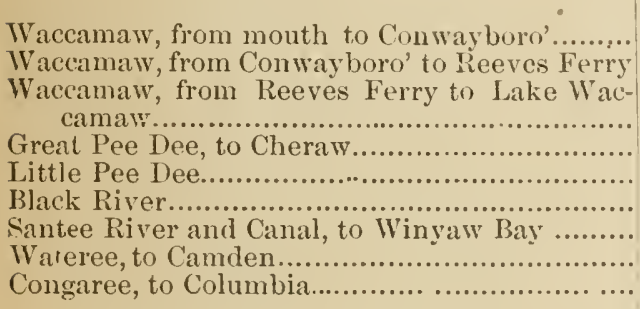 & $\begin{array}{r}66 \\
12: 3 \\
55 \\
14 ! \\
50 \\
60 \\
184 \\
64 \\
48\end{array}$ & 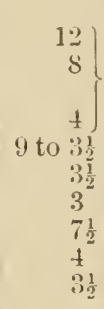 & $\begin{array}{r}\$ 29,370 \\
25,250\end{array}$ & $\begin{array}{r}2,2,1000 \\
8,(1000\end{array}$ & $=9-4$ \\
\hline Tota & 799 & & $\$ 205,038$ & $\$ 68,000$ & \\
\hline
\end{tabular}

These great highways, through the most fertile and perhaps the least developed portions of the State, could thus be permanently opened for transportation, which would be cheapened to the lowest rates by the competition consequent on the free admission of all carriers. The cost being estimated at only $\$ 257 \mathrm{per}$ mile.

The improvement in the Waccamaw river, which has its course parallel to the Atlantic coast, will make it a link in the great interior line of water communication along the seacoast, uniting at the Cape Fear with the inland water routes leading to Norfolk, Va. The estimates of the amounts necessary to complete the whole line of interior narigation from Georgetown to Norfolk is stated by the United States engineer corps as $\$ 6,225,805$; the distance being 539 miles, the cost would be less than half of that for a railway.

Looking southwestward, the Winyaw canal, uniting the Santee with the waters about Georgetown, opens an inland route for steamboats to Savamnah, requiring for its completion, according to Robert Mills, one or two short canals, aggregating in length eight and a half miles. Beyond Savannah there is the long contemplated inland route across the peninsula of Florida, and thence, by interior salt water rivers, to New Orleans, an improvement, the cost of which has been estimated at less than half the original outlay for the Erie canal, besides being always free from the obstacles of ice. Such a route would allow fleets of steam tugs and barges to transport in bulk, safely and cheaply, along the Gulf and Atlantic coast, all the products of the great West, from the liead water's of the Missouri and the Mississippi. 
Terscls drawing twelve feet are sometimes detained at Georgetown, because the bar of Sampit river affords only nine feet at low water. Calpt. Phillips, United States Engineers, reports that this obstacle may be removed at a cost of a trifle over $\$ 14,000$.

In the year 1700 , a ressel that was detained by low tide at Charleston har, had previously made its way, without a pilot, to the present site of ficorgetown. At that very time, however, a great storm occurred which oprened the inlet through North Island, known as North Inlet. The pressure of the vast flood of waters descending the rivers in Winyaw bay was thus no longer confined to a single channel, and as a consequence the entrance has filled up to a considerable degree. Capt. Marcou, United Sitates Corps of Engineers, estimates that it would require the outlay of one and a half millions of dollars to establish a depth of nineteen to twenty-two feet at low water on the Georgetown bar.

The railroad connecting Georgetown with the Northeastern railroad is nearly completed. When this is done, Georgetown will have the shortest railroad connection with Columbia of any seaport in the State.

Georgetown was founded early in the eighteenth century by the Rer. Mr. Screven, the first Baptist minister in South Carolina. It covers an area a mile square. In 1820 , the population was 2,000 ; in 1840 , it was 1,500 ; in 1850 , it was $1,62 \mathrm{~S}$; in 1860 , it was 1,720 ; in 1870 , it was 2,080 ; in $18 S 0$ it was 2,557 .

It is regularly laid out, and has fourteen miles of streets, pared with stone, brick or wood. Transportation through the streets is performed by drays or carts, at fifteen cents a load. Buggies and carriages may be hired at $\$ 2.50$ to $\$ 4.00$ a day. Wells and cisterns afford an abundant supply of water. Four main drains, with a number of lateral drains. empty into Sampit river, and constitute an excellent system of drainage. There are three boarding-houses; charges, from $\$ 1.00$ to $\$ 2.00$ a day for transient boarders. The court house, jail, and market house are of brick, and were erected at a cost of $\$ 50,000$. The hall of the Winyaw Indigo Society is also of brick; it is two stories, and cost $\$ 18,000$. 'The lower story is used as a school, the upper story has a library, and is used as a public liall; fees for exhibitions, $\$ .5 .00$. There are five churches, three for whites, Episcopal, Methodist, and Baptist, and two for the colored population, Methodist and Baptist. They have an aggregate seating capacity of over three thousand, and cost about $\$ 30,000$. The pupils of the Winyaw Indigo Society school are prepared to enter West Point and the colleges and universities of the United States. There are two public schools, one white and one colored, and, in addition, a number of private schools. The Winyaw Indigo Society, one of the oldest charitable institutions in the South, was incorporated in 1756 ; its funds have been chiefly 
devoted to the education of orphan children, many hundreds of whom have enjoyed its bounty. There is, also, a lodge of Masons. The choiccst game, fish and oysters are abundant and cheap. Beef and mutton sell at ten to twelve cents per pound; eggs, twelve to fifteen cents per dozen; fowls, twenty to twenty-five cents. Stores rent from $\$ 100$ to $\$ 500$, and dwellings from $\$ 60$ to $\$ 300$ per year. The building materials are heart pine and brick; the latter are manufactures in any quantity called for. on Port's creek, eight miles from the town. The total value of all property, real and personal, is stated at $\$ \$ 00,000$, and the annual taxes are about $\$ \pi, 000$. The town has no debt.

One hundred and seventy-five sail of vessels, of from fifty to five hundred tons burthen, and drawing six to thirteen feet of water, cross Georgetown bar annually. There is regular communication with Charleston and Cheraw by steamboat, and a line of eight three-masted schooners ply regularly between this port and the coast towns. The annual shipments are given as follows:

1,500 bales cotton, valued at . . . . . . . \$ $\$ 75,000$ 30,000 bbls. spirits turpentine . . . . . . . . 540,000 170,000 bbls. rosin . . . . . . . . . . . . . 510,000 $6,590,000$ feet lumber, shingles and other stuff . . . . . 300,000 16,000 tierces of rice . . . . . . . . . . . 560,000

\section{Total}

$\$ 1, S S 5,000$

The ycarly sales of goods is estimated as follows:

Groceries and provisions

$\$ 700,000$

Dry goods

300.000

Hardware and miscellaneous

300,000

Total

$\$ 1,300,000$

There are three saw mills, capacity of 20,000 feet per day ; a shingle mill, capacity 15,000 to 20,000 shingles per day; an inexhaustible supply of the finest eypress timber is at hand; it is furnished in blocks three feet to five feet diameter, clear of knots, at five cents to seven cents per cubie foot. A large rice-pounding mill has recently been establisherl, and the direct shipment of this grain to Northerm ports is increasing. Other manufactures are the preparation of naval stores, and of corn in rarious forms, oak staves, \&c. The average wages paid to laborers is twenty-five cents to seventy-five cents a day, and for skilled labor, one dollar to two dollars a day. 
The roads learling from the town are fine and well shaded, offering inducements for pleasure riding and driving, and there are delightful walks along the Sampit and Black or Wynee rivers. Winyaw bay is a beautiful sheet of water, and North island, on the seaward side of it, has a fine beach, and affords, with the adjacent sea islands, cool and salubrious summer resorts. "Here," says Robert Mills, "besides the refreshing sea breeze, the good things of this life, the treasures of the ocean and the land, are offered in great abundance to the inhabitants."

\section{LOWER PINE BELT REGION.}

The ten thousand square miles in lower South Carolina, described as the lower pine belt region, contains, according to the census of 1550 , only sixteen villages, with an aggregate population of 4,722 . Of these $\mathrm{Wal}$ terloro is the largest, with a population of six hundred and ninety-one. If, however, all the small settlements and trading points in this region be counted, they will, with addition of those mentioned in the census, amount in all to seventy-eight. The following account will make them appear still larger, as the settlements in each county will be named, for convenience, under the county, whereas since some of these counties extend into the adjoining regions, towns outside of the lower pine belt will be necessarily mentioned.

\section{HAMPTON COUNTY}

contains fifteen towns and trading settlements, with eighty-five stores, to-wit: Brumson, nineteen stores; Varnville, fourteen stores; Lawtonville, nine stores; Hampton Court House, Brighton, and Matthews Bluff, eight stores each; Gillisonville, six stores; Stafford, three stores; Robertsville, Tillman's, Early Branch and McNeil's, two stores each, and Peeplesville, Wagon Branch, and McCoy's Bluff, one store each. Of this number, five sell liquor, two are drug stores, two millinery, and the balance deal in general merchandise. One is kept by a colored person, and the estimated wealth of the storekeepers is $\$ 435,000$.

Hampton Court House (Township 120) was established in 1876 . It has a brick court house and jail, and a population now of three liundred. It is situated in the centre of the county, on the Augusta and Port Royal railroad.

Varnville, on the same railroad, has a town hall and high-school building. 'There are three churches, one of which is for colored persons, and has a seating capacity of 1,200 . 'The churches were built at a cost of about $\$ 1,000$ cach. There are two schools, one for white, and one for 
colored, pupils. Several thousand bales of cotton, a considerable quantity of rice, naval stores, hides and wax are shipped to Charleston and Savannah by rail. The Varnville Messenger is edited by E. W. Peeples. The buildings are of brick and wood, and the population and trade are increasing.

Peeplesville (Township 117) was settled in 1865, and has now about three hundred inhabitants. It has a hall seventy by thirty-five feet, and there are three churches, and one school, with forty pupils, in the neighborhood. The value of the real and personal property is given as $\$ 150$,000 . One thousand bales of cotton are shipped to Savannah. The yearly sales are, provisions, $\$ 30,000$; dry goods, $\$ 20,000$; hardware, $\$ 2,000$. There is a boarding-house, blacksmith shop, and livery stable, and several saw and grist mills, and naval stores manufactories. Planting, lumber, and naval stores are the chief pursuits.

Brighton (Township 119). At the close of the war there was one dwelling and one store, with a capital of one hundred dollars, here. There are now eight stores, fifty dwellings, a population of three hundred, two churches and a school. Two barrel makers, who came here ten years ago without capital, are the owners of a steam saw mill, and a gin and grist mill, with a turpentine and rosin still, as the result of their industry. There is weekly communication with Savannah by, steamboat.

Gillisonville (Township 116) was formerly the county seat of Beaufort. The public buildings were burnt during the last war. It has a church and two schools.

\section{COLLETON COUNTY}

contains twenty-two towns and trading settlements, having in all one hundred and twenty stores, to-wit: White Hall, eighteen stores; Walterboro, thirteen stores; Jacksonboro and St. George's, eleven stores each; Ridgeville, nine stores; Saltkehatchie, eight stores; Rantowles, Smokes' and Green Pond, seven stores each; Reevesville, five stores; Ashepoo and Combahec, four stores each; Bell's, Ross', and Folk's, three stores each; Ravenel's, Byrds, Cottageville, Rumphtown, Twenty-six Mile, Parker's Ferry, and Maple Cane, one store each. There is one drug store, the remainder dealing in general merchandise. Three out of the whole number are kept by colored persons. The estimated wealth of the storckeeper's is placed at $\$ 3 \$ 3,000$.

Walterboro, the county scat, is located in the centre of the county and has a handsome brick court house and jail. The population in 1880 was six hundred and ninety-one. There is an Episcopalian, a Presbyterian, a Methodist, a Baptist and a Roman Catholic church in the town, with three other churches for colored persons. A school house for colored 
children has a capacity for one hundred pupils. The white schools are private. The Collcton Piess is published weekly. There is a daily mail by stage line to Green Pond, twelve miles distant, on the Charleston and Savannah Railroad. A railroad from Walterboro to this point is graded, and when completed it is proposed to extend it to Branchrille, which will make it the shortest line from the capital to the seaboard. Walterboro is in a region devoted formerly to rice culture, and no cotton was sold here before the war; in 1881 one thonsand bales were sold in the torn. The yearly sales are stated (probably underestimated) as follows; Provisions, $\$ 75,000$; dry goods, $\$ 25,000$; hardware, $\$ 10,000$; miscellaneous, $\$ 45,000$.

St. George's, on the South Carolina Raihroad, has a population of three hundred. There is here a hotel, two school houses and a chureh. About 4,000 bales of cotton are shipped annually to Charleston. The estimate of yearly sales is, provisions, $\$ 75,000$; dry goods, $\$ 30,000$; hardware, $\$ 6,000$; miscellaneous, $\$ 50,000$. There are two steam saw mills and a grist mill.

\section{BERKELEY COUNTY,}

exelusive of the places on the seacoast already noticed, has ten villagcs and trading settlements, with sixty-five stores, to wit: Summerrille, twenty-four stores; St. Stephen's and Moneks Corner, twelve stores each ; Bonneau's, eleven stores; Oakley, three stores; Ladson's, two stores, and Pineville, one store. Of this number there is one liquor store, four drug stores, the remainder dealing in general merchandise. Four are kept by colored persons. The estimated wealth of the storekeeper's is given at $\$ 200,000$. Summerville, in the pine woods on the South Carolina railroad, is a health and pleasure resort for the citizens of Charleston. There are two hotels, two livery stables, several boarding houses, and ehurches of the leading religious denominations. The population is given by the last census as 636 . But during the season there are as many as 2,500 persons living here.

\section{WILLIAMSBURG COUNTY}

has thirteen towns and trading settlements, containing one hundred and thirteen stores, to wit: Kingstree, thirty-one stores; Graham's Cross Road, eighteen stores; Scranton, twelve stores; Black Mingo, ten stores; Salters and Cambridge, nine stores each ; Gourdin's, seven stores; Indiantown and Johnsonville, six stores each; Lane's, two stores; Greeleyville, Lyneh's Lake, and Pine Bluff, one each. Among these two liquor stores and one rlrug store are enumerated, the remainder keep general merchandise; one is kept by a colored person. The wealth of the storekeepers is estimated at $\$ 47,000$. 
Kingstree, the county seat, has a population of about 300 . It is situated at the head of navigation on the Black, more properly the II ynce river, and on the North Eastern railroar. The court house and jail are hanelsome brick buildings. There is a Presbyterian, a Baptist, and a Methodist church, besides a church for colored persons. 'The Kingstree Stert, a weekly paper, is published here. About two thousand bales of cotton are shipped annually. The name is derived from a large white or short leaf pine tree that stood on the banks of the Wynee, which was called the King's tree, after William III., of England.

Scranton, on the same railroad, has a hotel and church, and about two thousand bales of cotton are shipped annually, besides lumber and naval stores.

\section{CLARENDON COUNTY}

has ten towns and trading settlements, with fifty-one stores, to wit: Manning, twenty-four stores; Summerton, nine stores; Forreston, eight stores; Fulton, five stores; McFadden, two stores; Dudley, Enterprise, Jordan, Panola and Packsville, one store each. Of this number there are two liquor stores, three drug stores and one millinery; the balance deal in general merchandise. The wealth of the storekeepers is estimated at $\$ 217,000$. Mamning, the county seat, is on the Central Railroad, near where it erosses Pocotaligo river. The Methodists, Baptists, and Preslyyterians have each a church in the town. There is an academy, and one newspaper, the Clarendon Press.

Forreston, ten miles south of Manning on the railroad, has a Baptist church and two schools. Besides a considerable amount of lumber and naval stores, about four thousand bales of cotton are shipped to Charleston.

\section{HORRY COUNTY}

has thirteen towns and trading settlements, with forty-five stores, to wit: Conwayboro, twelve stores; Board Landing and Port Harrelson, seven stores each; Hickman's, five stores; Red Bluff and Bucksville, three stores each; Bayton, two stores; Dogwood Neck, Gallivant's, Hickman's, Wampee, and Round Swamp, one store each. The wealth of the storekeepers is estimated at $\$ 2 \$ 1,000$.

\section{THE UPPER PINE BELT}

is credited, in the census of 1880 , with twenty-one towns, having a population of 14,715 . Including some omitted by the above mentioned enumeration, and the various trading settlements, they actually numbered, 
January, 1883, ninety-nine, with 1,009 stores and a population of over 20,000. The wealth of the storekeepers is given at between five and six millions of dollars. Their distribution among the counties lying chicfly or wholly in this region is as follows:

\section{BARNWEIL COUNTY,}

traversed in a north and south direction by two railroads, the Port Royal and the Charleston and Augusta, has twenty-two towns and trading settlements, to wit: Blackville, thirty-three stores; Allendale, thirty-one stores; Bamberg, twenty-six stores; Williston, twenty-two stores; Barnwell Court House, seventeen stores; Midway, eleven stores; Campbellton and Graham, eight stores each; Elko, five stores; Appleton, Beldoc, Dunbarton and Martin's, four stores each ; Buford's Bridge, Cohen's Bluff, Lee's, Robbins', two stores each; Erwinton, Fiddle Pond, Hattieville, Millett, Tarn, one store each. Of these one hundred and ninety-one establishments, fifteen sell liquors, thirty-three miscellaneous articles, and the remainder general merchandise. The wealth of the proprietors is estimated at $\$ 1,250,000$.

Barnwell Court House has a high and healthy situation on Turkey Creek, in the centre of the county. The public buildings and threefourths of the town were burned by Sherman's troops, in 1S64, and after the war the county seat was removed for some years to Blackville. In 1876, the old court honse was rebuilt and a railroad, twelve miles in length, opened to Blackville. The town is rapidly increasing in size since this date. The Presbyterians, Baptists, Methodists, Episcopalians, and Catholics have churches here. Town lots and lands in the surrounding country are rapidly advancing in price. A company is formed to build a cotton factory on Turkey Creek, near by. There are two newspapers, the Barmuell People and the Barnwell Sentinel.

Blackville, on the South Carolina Railroad, has now upwards of 1,000 inhabitants, four churches, four schools, a carriage factory, several gins, saw and grist mills, and ships annually about 4,000 bales of cotton.

Allendale is a thriving and rapidly growing town on the Port Royal railroad, of orer six hundred inhabitants; the leading religious denominations have churches, and there is one public and one private school.

Bamberg, on the South Carolina railroad, has two churches, a high school, three private schools, a newspaper, a banking establishment, a planing mill, three wagon and wood shops, a saw mill, several cotton gins and grist mills, and ships about 5,000 bales of cotton annually. The population, in 1Ss0, was 648 . 


\section{ORANGEHURG COLNTY}

has eleven towns and trading settlements, with one hundred and thirtyfive stores, to wit: Orangeburg Court House, seventy-five stores; Branchville, twenty-six stores; St. Matthew's, serenteen stores; Fort Motte, seven stores; Rowesville, three stores; Elloree and Jamison, two stores each; Edisto, Felderville, Knott's Mills, one store each. Of this number, eight sell liquors, and eight are druggists, thirty-eight deal in miscellaneous articles, and seventy-six in general merehandise. One is kept by a colored person.

Orangəburg Court House is situated on high, level land, rising above the clear waters of North Edisto river, at the head of raft navigation, and on the Charleston and Columbia railroad. It was first settled in 1730, by German subjects of the Prince of Orange, whence its name. In 1825, the population was 152 , in 1840,350 . The public buildings and most of the town was burnt by Sherman's troops. It has been rebuilt, and the population in 1580 , was 2,140, and probably exceeds 3,000 at this time. It has a cireular area two miles in diameter, with the court house and public square as the centre. The business portion of the town, ineluding many handsome brick buildings, is built about the public square. Between.this point and the railway station is a fine drive, on each side of which are handsome private residences, with well kept grounds. The town government consists of a mayor and two aldermen, a chief of police, and four patrolmen. The sidewalks have a wool curbing, and the roads are well kept. The town is lighted by kerosene street lamps. Water is abundant and good; the drainage is into the Edisto river, sixty to one liundred feet below the town. The court house is a fine brick building, costing $\$ 35,000$. The Claflin University, a large three-story brick building, with mansard roof, is surrounded by fine grounds, and has accommodations for three hundred colored students. The Bolirer and May's halls are large and handsome halls, fitted with stage, seats, de., for public entertainments. Charges, $\$ 10$ to $\$ 15$ per night. There is a Presbyterian, an Episcopal, a Methodist, a Baptist and a Lutheran church. There are two public schools for whites, and three private schools, with one public school for colored pupils; number of pupils about six hundred. Five room cottages, with garden, rent for $\$ 12$ a month. Stores rent at from $\$ 10$ to $\$ 10$ per month. Brieks, for building, cost $\$ 7.50$ per thousand. Pine lumber, $\$ 10$ per thousand; shingles, $\$ 3.50$ per thousand. The value of real and personal property is estimated at $\$ \$ 00,000$; there is no town debt, and the annual town tax on property is about onehalf of one per cent. The average yearly sales are given as follows: provisions, $\$ 700,000$; dry goods, $\$ 125,000$; hardware, $\$ 25,000$; miscel- 
lancous, $\$ 50,000$. The manufacturing industries consist of a cotton mill, a rice mill, and two wagon factories, employing about one hundred lands, at wages of $\$ 1$ to $\$ 2$ a day. There is a weekly newspaper. The ammual shipments of cotton average 10,000 bales, to Charleston and New York.

\section{SUMTER COUNTY}

lias eighteen towns and trading settlements, with one hundred and sixtytwo stores, to wit: Sumterville, seventy-five stores; Maysville, twenty-one stores; Bishoprille, twelve stores; Magnolia, seven stores; Providence, Wedgefield, and Lynchburg, six stores each; Mannville and Shiloh, five stores each; Spring Hill and Statesburg, four stores each; Sanders' and Boykin's, two stores each ; Bossards, Claremont, Durant, Mechanicsville, one store each. Of this number seven deal in liquor, one in hardware, eight in dry goods, twenty-nine miscellaneous, and one hundred and serenteen in general merchandise. Seren are kept by colored persons. The estimated wealth of the storekeepers is $\$ \$ 12,000$.

Sumterville, on the Columbia and Wilmington railroad, near the headwaters of the Wynee river, was founded in 1800 . It occupies a lerel site on sandy soil, three-fourths of a mile in each direction from the count house square as a centre. There is an intendant and four wardens, with a chief of police, an assistant, and three regular policemen. There are ten miles of streets, with elerated sidewalks of rammed clay. Besides a fine court house building, there is a music hall fitted for public amusement; charges per night, including rent, license and lights, $\$ 20.00$. There are fire churches for the whites: one Episcopal, one Methodist, one Baptist, one Presbyterian, one Catholic. The colored population have three churches: tro Methodist and one Baptist. The educational establishments are the Sumter Institute, the St. Joseph's Academy (Catholic), the Sumter public s'hool for whites, cost $\$ 1,200$, pupils 200 ; the Lincoln public school, colored, cost $\$ 1,200$, pupils, 250 , and several private schools. Stores rent from $\$ 12.50$ to $\$ 60.00$ a month; dwelling houses from $\$ 5.00$ to $\$ 20.00$. The town taxes are four-tenths per cent. on real, and twotenths per cent. on personal property, realizing on the assessments about $\$ 2,000$ per annum. The indebtedness of the town is $\$ 12,000$ for the music hall, fire engines and floating indebtedness from 1872 to $187 \mathrm{~S}$, interest, seven and eight per cent. Sumterville was only a small village until the railroad was built from Columbia to Wilmington, in 1854 . Besides these connections, it is the present terminus of the Central railroad to Charleston, and has connection with Camden. About 12,000 bales of cotton are shipped annually. The yearly sales are estimated at, provisions, $\$ 250,000$; dry goods, $\$ 200,000$; hardware, $\$ 150,000$; niscel- 
laneous, $\$ 100,000$. The Bellemonte cotton factory, reently erected, is in successful operation. There are three weekly newspapers, and the town is growing rapidly.

\section{DARLINGTON COUNTY}

has sixteen towns and trading settlements, with one hundred and seventysix stores, distributed as follows: Darlington Court House, fifty-three stores.; Florence, forty-six stores; Timmonsville, twenty-two stores; Society Hill, fifteen stores; Dovesville, thirteen stores; Lydia, four stores; Ebenezer, Hartsville, Palmetto, Parrotts, and Stokes, two stores each; Cypress, Leavenworth and Oats, one store each. Of this number, ten sell liquors, eight, dry goods, five, hardware, thirty-eight, miscellaneous, and one hundred and fifteen, general merchandise. Two are kept by colored persons. The estimated wealth of the storekeepers is $\$ 93 \$, 000$.

Darlington Court House, emborered in a majestic grove of evergreen oaks, and washed on two sides by the clear waters of Swift creek, is the county seat. It ships about 7,000 bales of cotton annually. It contains two carriage and wagon factories and a furniture manufactory. The school privileges are good, and there are churches of the leading dcnominations. The Darlington National Bank lias a paid up capital of $\$ 50,000$; surplus, $\$ 5,193$. The fair grounds of the Agricultural Society are well laid ott, and have a commodious house. There are two weekly newspapers.

Florence, on the Columbia and Wilmington railroad, and at the terminus of the Northeastern and the Cheraw and Darlington railroads, had a population, in 1866 , of 600 ; in 1850 , of 1,940 ; now estimated at 2,500 . There are fourteen miles of streets, constructed at a cost of $\$ 75.00$ per mile. There are two hotels, a two-story town hall, costing $\$ 5,000$, seven churches, built at a cost of $\$ 19,000$, and four schools. Dwellings rent from $\$ 7.00$ to $\$ 17.00$ a month, and stores from $\$ 15.00$ to $\$ 10.00$ a month. Excellent bricks are burned in the ricinity, and lumber is abundant and cheap. The town taxes are one-half of one per cent. on property, and there is a town debt of $\$ 3,000$, at seven per cent. interest, for the purchase of a steam fire engine. About 4,000 bales of cotton are shipped annually. The Florence Times is published weekly. There is a carriage factory, four steam and two water gins and grist mills, three steam saw mills, and the railroad shops located here employ about one hundred and fifty lands.

Society Hill is an early settlement made by the planters of this section. It is on the Cheraw and Darlington railroad, and has weekly communication with Georgetown by steamboat on the Great Pee Dee river, which is one mile distant from the town. 


\section{MARLBORO COUNTY}

las eight towns and trading settlements, with fifty-five stores, distributed as follow; : Bennettsville, forty stores, Clio, seven stores, Brightsville and Brownsville, two stores each, Hunt's Bluff, Parnassus, Red IIill, and Three Creeks, one store each. Liquors are not sold in the county, and of the stores enumerated, six deal in miscellaneous articles, and fortynine in general merchandise. The estimated wealth of the storekeepers is $\$ 524,000$. Bennettsville is the county seat.

\section{MARION COUNTY}

has sixteen towns and trading settlements, with one hundred and thirtysix stores, distributed as follows: Marion Court House, fifty-eight stores; Mullens, seventeen stores; Little Rock, thirteen stores; Mars Bluff, ten stores; Forestville, nine stores; Effingham, Lynches Creek, seven stores each ; Oak Grove, four stores; Jeffreys' Creek, three stores; Little Bluff, two stores; Brick Swamp, Campobella, Cranesville, Donohoe, Free State and Hyman, one store each. Of this number, five sell liquors, three, dry goods, twenty-seven, miscellaneous, and one hundred and one, general merchandise; two are kept by colored persons. The estimated wealth of the storekeepers is placed at $\$ 633,000$.

The town of Marion, first called Gilesborough, is on the Wilmington and Columbia railroad. The population was given, in 1850 , at $\$ 24$; it is now thought to exceed 1,500 . It has eight churches and fire schools. There are three weekly newspapers and an agricultural paper. Avenues of stately trees offer an attractive promenade. About $S, 000$ bales of cotton are shipped annually from this point.

\section{THE RED HILI, REGION}

requires no separate mention as regards its towns. Being a long and rather narrow region, running northeast and sonthwest, the railroads crossing it only traverse it for a short distance, except the Columbia and Augusta road. As the towns along this road are actually on the granite formation, or the sand hills, they will be mentioned when treating of the towns in these regions. Actually the two small towns of Wedgefield and Stateburg, with St. Matthew's, in Orangeburg, are about the only towns in this region, and this will account for the fact that the region itself has never heretofore been recognized, notwithstanding its very characteristic features, as one of the physical subdivisions of the State. The 


\section{SAND HILL REGION}

proper, though thinly settled has a larger per cent. of its population collected into villages than either of the regions last treated of, as will be seen by reference to the table. For convenience, the five counties traversed by this region, to wit: Aiken, Lexington, Richland, Kershaw and Chesterfield, will now be considered, and as some of their most considerable towns are situated on intrusions, as it were, of the Piedmont and Lower Pine Belt Regions into these counties, the aggregate of towns will appear greater than strictly belongs to the region.

\section{AIKEN COUNTY}

has sixteen towns and trading settlements, with one hundred and four stores, distributed as follows: Aiken Court House, forty-fuur stores; Graniterille, seventeen stores; Hamburg, nine stores; Beech Island, six stores; Langley, Windsor and Ellenton, five stores each; Montmorenci, three stores; Bath and Vaucluse, two stores each; Hammond, Jolnnston. Kitching Mills, Merritt's, Sumnyside and White Ponrl, one store each. Of this number eight sell liquors, three hardware, thirty-seren miscellaneous articles, and fifty-six general merchandise. Two are kept by colored persons. The estimated wealth of the storekeepers is stated at $\$ 712,000$.

Aiken, the county seat, was settled in 1833, when the South Carolina railroad, then the longest in the world, was built. The first settlers were persons from the lower country in search of a healthy and invigorating climate duling summer. Since it has become a famous health resort for those from Northern latitudes seeking a warm dry winter air and sumshine. It has an elevation of about six hundred feet above the sea level, and the soil is coarse quatzose sand to the depth of ninety to one hundred and fifty feet, sanitary conditions reinforced by the balsamic odors of the great pine forest that surrounds it. In addition to numerous excellent boarding houses, the Highland Park Hotel, open during the spring and winter months for Northern visitors, is one of the largest and, in many respects, one of the best hotels in the South. There is a private bank in the town. The population in 1980 was 1,817. The streets of diken are wide. The sidewalks are raised and corered with clay. This clay, resting on a bed of deep sand, is kept well drained, and forms a smooth, liard, elastic surface. A broad drive of the same material has been similarly construeted from the Highland Park Hotel to the freight depot, three-quarters of a mile, at a cost of $\$ 600$. It forms an excellent roadway, orer which even heavily laden cotton wagons are in the habit of 
moring at a trot. It is claimed that six to eight inches of such clay, shread ovel these sand beds, will make a durable road of this character, asily kept in repair. As bodies of this clay are met with in nearly every locality throughout the sandy lower two-thirds of the State, the abore experiments suggest the material and methods suitable for construeting good and cheap dirt roads in this section. Graniterille, on Horse Creek, where the Columbia road approaches the Charleston and Augusta railroad, is a thriving manufacturing village of 1,669 inhabitants. Taucluse, a few miles above, and Langley and Bath, a short distance below, are similar villages, situated in the valley of this stream. Hamburg, oplosite Augusta, has now only about 455 inhabitants. Fifty years ago it was a prosperous rillage, of 1,200 inhabitants. Besides flour, corn, tolacco and other productions, there was then shipped hence by steamboat to Sarannah and Charleston as many as twenty-six thousand bales of cotton in one season. Fifteen steamboats, capable of transporting six liundred to one thousand bales at a load, once plied regularly, making weekly trips between this town and the cities of Charleston and Savannah.

\section{LEXINGTON COUNTY}

has eleven towns and trading settlements, with sixty-three stores, distributed as follows: Batesburg, nineteen stores; Leesville, sixteen stores; Court House, twelve stores; Gilbert Hollow, six stores; Countsrille, three stores; Rish's, two stores; Bars, Keisleĩ, Pine Ridge, Rishston and Sinclair, one store each. Of this number four sell liquors, twelve miscellaneous articles, and forty-seven general merchandise. The estimated wealth of the storekeepers is $\$ 350,000$.

Leesville, on the Columbia and Augusta railroad, has a population of 177. The situation is high and level. Soil sandy, with clay sub-soil. There are two hotels, a Methodist and a Lutheran church. The Leesville English and Classical Institute accommolates one hundred and twentyfive pupils. The real and personal property is valued at $\$ 100,000$. The town taxes aggregate $\$ 112.50$ yearly. Four thousand bales of cotton are shipped anmually, with fruit to the value of $\$ 15,000$, lumber, oats and other products. 'The yearly sales are, provisions, $\$ 112,000$; dry goods, $\$ 2,000$; hardware, $\$ 2,000$; mi-cellaneous, $\$ 10,000$. The place is growing latidly.

PICHLAND COCNTY

has seren towns and trading settlements, with one hundred and sixtynine stores, distributed as follows: Columbia, one hunded and fifty-four stores; Eastover and Gadsilen, five stores each; Shand's, two stores; 
Kingrille and Acton, one store each. Of this number thirty-two keep liquors, seventeen hardware, seventeen dry goods, eighty-three miscellaneous articles, and thirty general merchandise; three are kept by cclored persons. The estimated wealth of the storekeepers is given at $\$ 1,308,000$.

Columbia, the county seat of Richland, and the capital of South Carolina, is situated in lat. $33^{\circ} 59^{\prime} 58^{\prime \prime} \mathrm{N}$. Long. $81^{\circ} 2^{\prime} 3^{\prime \prime} \mathrm{W}$. It has a level site clevated some two hundred feet above the east bank of the Congaree, at the confluence of the Broad and Saluda rivers, and three hundred and thirtysix feet above the sea. It stands upon a promontory of granite, which extends from the crystalline rocks of the Piedmont Region along and between the Broad and Saluda rivers, and at their union juts out into the Sand Hill Region of the State.

Thie great falls of the Congaree begin at the upper end of the town, and terminate a little below the lower end. The fall in this distance is thirtysix feet, and the greatest width of the river is eighteen hundred feet.

Originally these lands were covered with a magnificent growth of immense oaks, hickories and pines. Colonel Thomas Taylor, whose descendants still reside here, was their first owner. The eity was laid out and incorporated in 1787 , and the Legislature met here for the first time in 1789. The town is two miles square, regularly laid out in streets one hundred and one hundred and fifty feet in width, most of them planted with beautiful shade trees. The streets aggregate sixty miles in length, and are neatly kept. The roadways of the main thoroughfares are Macadamized, the sidewalks paved. They are maintained, including lamps, at a cost of $\$ 8,000$ annually. Facilities for transportation of all kinds are ample and cheap. Natural springs, issuing from a valley between the town and river, afford an ample supply of excellent water, which is raised one hundred and twenty feet by steam power, for use, at the rate of one million gallons a day. 'The soil is porous, and its eleration abore the river offers every facility for thorough drainage. There are eight hotcls and first-class boarding houses, with moderate charges, and the place is much frequented by invalids from the North during winter. The public buildings are the State House, built of enormous blocks of granite, quarried in the vicinity, and to cost five millions of dollars when completed. The U. S. Court House and Postoffice is built of Fairfield granite, which at a distance might be mistaken for marble. The large and extensive fire-proof buildings of the Insane Asylum. The numerous buildings of the State University, and those of the Presbyterian Theological seminary. A large and handsome City Hall and Opera House ( 800 seats; rent and license fee $\$ 40$ a night). The Court House and Penitentiary, with some fine blocks of business houses, banks, \&c. The aggregate cost of the public buildings exceeds six millions of dollars. Co- 
lumbia is noted for the beauty of its public and private grounds, and for its beatutiful Hower gardens. Sydney Park covers twenty acres, furnishing attractive promenades. The Agricultural Socicty of the State has extensive fair grounds, with numerous buildings, and during fair week, in Norember, as many as twenty thousand persons assemble here from all parts of the State. There are two handsome ceneteries. There are fourtecu churches, three free and fifteen private schools. Stores rent for $\$ 20.00$ to $\$ 50.00$ a month, dwellings from $\$ 50.00$ to $\$ 500.00$ per annum. The assessed value of real and personal property is $\$ 3,000,000$, and the estimated true value is given as $\$ 5.000,000$. The taxes aggregate $\$ 45,000$ yearly, of which $\$ 33,000$ are levied on property, and $\$ 12,000$ come from licenses. The city debt, ineurred for permanent improvements, water works, streets, \&c., aggregates $\$ \$ 50,000$. Interest payable halfyearly, and the capital in three installments, running ten, twenty and thirty years. Railroads radiating from Columbia terminate at the following points: Charleston, one hundred and thirty miles; Augusta, eighty-fire miles; Greenville, one hundred and forty-four miles; Walhalla, one hundred and forty-seven miles; Laurens C. H., seventy-two miles; Spartanburg, ninety-four miles; Charlotte, one hundred and ten miles; Camden, sixty miles; Wilmington, one hundred and ninety miles. The Congaree river is navigable for steamboats from the southwest end of the city to the Santee river, which is navigable to its month, a waterway more than one hundred and seventy-five miles in length. For many years this highway has been neglected, but as long ago as 1825 , two steamboats, besides a number of tugs and canal boats, plied regularly on these streams and the Santee canal, transporting amnually not less than 30,000 bales of cotton from Columbia to Charleston, with full return freights. The receipts of cotton in Columbia in 1876 were 12,257 bales ; in 1882 they were 24,660 bales; and in 1853 they amount to this date already to more than 38,000 bales. They will overrun 40,000 bales for the whole year, not counting large amounts purchased by factors here from points more or less distant on the railroads, and shipped thence directly. Charleston and Norfolk are the competing points to which produce is shipped.

The Carolina National Bank has a capital of $\$ 100,000$, surplus $\$ 15,000$. and the Central National Bank has a capital of $\$ 100,000$, with a surplus of $\$ 20,000$.

The annual yearly sales are given as follows: provisions, $\$ 500,000$; dry goods, $\$ 500,000$; hardware, $\$ 500,000$; miscellaneous, $\$ 1,000,000$. 'This is, probably, a good deal short of the actual figures. The manufactures of Columbia are thus stated in the Tenth U. S. Census: 
TOWNS OF SOUTH CAROLINA.

Mcchanical and Manufacturing Industrics of Columbia, S. C., in $18 S 0$.

\begin{tabular}{|c|c|c|c|c|c|c|}
\hline - & 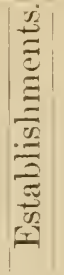 & Capital. & 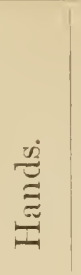 & Wages. & Materials. & Products. \\
\hline Blacksmithing. .. . . . & 5 & $\$ 3,815$ & 17 & $\$ 4,875$ & $\$ 6,250$ & $\$ 15,300$ \\
\hline Boots and shoes . . . & 3 & 2.650 & 6 & 1,760 & 2,200 & 4,700 \\
\hline Bread and baking products & 5 & 7,700 & 15 & 4,350 & 23,232 & 31,450 \\
\hline 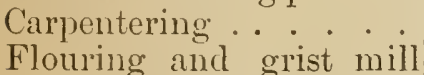 & 5 & 3,450 & 32 & 8,550 & 14,900 & 28,825 \\
\hline produets .............. & 4 & $\$, 680$ & 16 & 2,154 & 53,$29 ;$ & 61,049 \\
\hline $\begin{array}{l}\text { Foundry and machine } \\
\text { shop products. . . } \\
\text { Painting and paper hang- }\end{array}$ & 5 & 58,000 & $S 5$ & $22,35 \pm$ & $30,83: 39$ & $\$ 9,202$ \\
\hline $\operatorname{ing} . .$. & 3 & 1,260 & 7 & 2,165 & 4,526 & $\$, 915$ \\
\hline Photographing : . . & 3 & 3,200 & 4 & 750 & 1,400 & 5,300 \\
\hline $\begin{array}{l}\text { Printing and publishing . } \\
\text { Tin, copper and sheet-iron }\end{array}$ & 4 & 16,000 & 56 & 27,175 & 9,300 & 50,200 \\
\hline walle. . . . . & 3 & 16,050 & 9 & 1,510 & $2, S 00$ & 6,050 \\
\hline All other industries . . & 12 & 20,050 & 46 & 9,190 & 18,212 & 41,741 \\
\hline Total. . . . . • & 52 & $\$ 140, \$ 55$ & 293 & $\$ \$ 4,833$ & $\$ 166,754$ & $\$ 842,732$ \\
\hline
\end{tabular}

This statement does not include the products of the manufacture of gas, nor of quarrying, or the statistics of establishments owned and operated by the railroad companies and by the State. The large railroad shops located in Columbia, the gas works, the manufacturing operations carrier on in the penitentiary shops, would augment greatly the above figures. Even without these, the thirty hands of the two quarries, those of the brewery, ice factory, and the five hundred bricklayers and carpenters constantly employed in the town, would swell the number of skilled workmen to be found here, A cotton seed oil mill* is being erected, and when the work on the canal, which is being done by the State, is completed, and power for several large factories furnished, Columbia will be a manufacturing centre of considerable importance.

The population in 1820 was 4,000 , and it was about the same in 1840 .

* Before 1802 Mr. Benjamin Warng established an oil mill here, and obtained half a gallon of oil from one bushel of eotton seed. Mr. Stephen Brown had at that time : valuable rope walk here. Mr. Waring, and subsequently Mr. Herbemont, engaged here successfully in grape culture. 
In 18,50 it was 6,060 . In 1860 it was 8,052 . In 1870 it was 9,298 . In 1850 it was 10,0:36. Since the latter date the population has inereased ahout 1,500 , and since 1876 the returns of taxable property have increaser $\$ 750,000$. The growth which set in in 1850 was much increased during the war, to be swept off during the single night which Sherman occupien the town, by the great fire which destroyed it almost as completely as it was possible to destroy a town at one effort. During reconstruction an unhealthy growth was stimulated by the corrupt politicians Who congregated here. 'This has passed away, and the city has entered a promising period of normal and substantial progress.

\section{KERSHAW COUNTY}

has three towns and trading settlements, with eighty-four stores, to-wit: Camden, seventy-eight stores; Flat Rock, five stores; Welche's, one store. Of this number six sell liquors, two hardware, six dry goods, twenty-one miscellaneous artieles, and forty-nine general merehandise. Four are kept by colored persons. The estimated wealth of the store keepers is 8350,000 .

Camden, the county seat, is on the east bank of the Wateree river, a mile from the stream, and at an elevation of one hundred feet above it. The river is navigable to this point, and the town is one of the termini of the South Carolina Railroad. Pine Tree creek and Belton's branch wash it on three sides, giving it a position almost insular. It is the oldest inland town in the State, being settled by Quakers in 1750 ; it was laid out into regular squares in 1760, and chartered in 1769. In 1825 the population was 2,000; in 1840 it was 2,300; in 1850 it was 1,133: in 1860 it was 1,621 ; in 1870 it was 1,007 ; in 1880 it was 1,780. There are four large churches for the whites-Episcopal, Niethodist, Presbyterian, and Baptist. Two large colored congregations-Baptist and Methodist. Two weekly newspapers. About 20,000 bales of cotton are shipped here anmually, besicles large amounts of naval stores and rice, the production of the latter article is becoming very consiclerable and profitable in the ricinage. A private bank in the town affords facilities for the transaction of business.

\section{CHESTERFIELD COUNTY}

has six towns and trading settlements, with sixty-seren stores, to-wit: Cheraw, fifty-six stores; Chesterfield Court House, five stores; Hornsboro and Jefferson, two stores each, and Irvington and Old Store, one each. Of this number four sell liquors, twenty-one miscellaneous articles, and forty-two general merchandise. 
Cheraw, at the junation of the Cheraw and Darlington Railrourl with the railroad to Salisbury, North Carolina, is one mile from the head of narigation on the Great Pee Dae river. Thare is a population of 1,000 within the corporate limits, and about the same number on the outskirts of the town. In 1825 the population was 1,200 , and 20,000 bales of cotton were shipper by steamboat on the Pee Dee river from this point; in 1840 the population was 400 ; in 1860 it was 960 . It is regularly laid off. The streets are one hundred feet wide and have an aggregate length of fifteen miles, three lines of handsome full grown sharle trees, one on each side, and one in the middle, render them delightful drives and walks. A handsome two-story town hall has the upper story occupied as a Masonic lodge, the lower story is supplied with seats and scenery, and is used for public entertainments (charges, including license and lights, five to ten dollars). There is a skating rink, and the river, several streams and two beautiful lakes near by afford good fishing. There is a race-course near the town. There is a Methodist, Baptist, Presbyterian, Episcopal, and Catholic church for the whites. The cemetery of st. Ditvid's ehurch has been used for more than one hundred vears, and a number of British soldiers were buried there during the Revolution. There are also several churches for the colored population. Stores rent for one hundred dollars to four hundred dollars per annum, and dwelling houses about the same. The real estate is estimated at $\$ 500,000$, and the personal property at $\$ 250,000$. Taxes are restricted by the town charter to one-half of one per cent., and it has been found necessary to call for only half of this amount. Personal property is not taxed, excent t'le bar-rooms. There is no town debt. The Chester and Cheraw railroad is completed to Lancaster, and partially graded between that point and Cheraw. A gap of eighteen miles from Cheraw to Hamlet, North Carolina, remains to be built to complete what is considered the shortest line from Augusta, Georgia, to Richmond, Virginia. There is steamboat communication with Charleston, via Georgetown, by the Pee Dee river. Besides considerable shipments of lumber, naval stores, leather, hides, \&c., about 10,000 bales of cotton are shipped annually. There is a tannery, a tin-ware, a wagon, and a fertilizer manufactory in the town, besides two steam grist mills, and gins, and one steam saw mill. Abundant water powers in the neighborhood are little utilized. Cheraw is one of the oldest settlements in the State, and has been longr noted for the wealth and culture of its citizens. 


\section{THE TOWNS IN THE PIEDMONT REGION}

of South Carolina are given in the census of 1850 as thirty-six in number, with a population of 30,999 . A closer count, however, shows that, including towns, villages, and trading points, this region numbers nearly two hundred and fifty (two hundred and forty-four), with a population exceeding fifty thousand. So that half the towns of the whole State, and one-third of the town population is in the rillages of the upper country. $A$ count of the stores give 1,750 , and the estimated wealth of the store keepers exceeds ten millions of dollars. The enumeration is marle here by the counties lying wholly, or in part, in this region, taken in their alphabetical order.

\section{ABBEVILLE COTNTY}

has twenty-five towns and trading settlements, with one hundred and sixty-three stores, distributed as follows: Abbeville Court House, thirtynine stores; Greenwood, twenty-one stores; Ninety-Six, nineteen stores; Hodges, fifteen stores; Due West, twelve stores; Troy, ten stores; Donaldsville and McCormick, seven stores each; Antreville, four stores; Calhoun's Mills, Cokesbury, Lowndesville, Mapleton, and New Market, three stores each; Broadway, Simm's, and Verdery, two stores each; Bold Branch, Bordeaux, Lulah, Millway, Mountain View, Phœnix, and Sawney, one store each. Of this number nine sell liquors, one hardware, five dry goods, fifty-one miscellaneous articles, and ninety-seren general merchandise. The estimated wealth of the store keepers is $\$ 6 \$ 1,000$.

Abbeville Court House, the county seat, in Lat. $34^{\circ}, 13^{\prime}$, $S^{\prime \prime}$; Long. IT. from Columbia, $1^{\circ}, 5^{\prime}, 15^{\prime \prime}$; on a hill among the head-waters of Long Cane, is the terminus of a branch from the Greenville and Columbia railroad, twelve miles long. In 1840 the population was five hundred; in 1850 it was 1,252 ; in 1860 it was five hundred and ninety-two; in 1880 it was 1,543. There are two hotels, six churches, and a large graided school. The value of real and personal property is given at $\$ 100,1000$. The town taxes are two mills. There is no debt. Stores, buitt chiefly of brick, rent for from one hundred dollar's to five hundred dollars a year. The yearly sales are given as $\$ .500,000$, and ten thousand to fifteen thousand bales of cotton are shipped amually to Charleston and Baltimore. 'There is a carriage manufactory, and two large weekly newspapers. Property has increased in value twenty per cent. within three years.

Greenwood, at the junction of the Augusta and Knoxville railroad 
with the Columbia and Greenrille railroad, had a population, in 1570, of seven hundred; in 1S50, of seven hundred and forty-five, and is estimated now at twelve hundred. There are three churches, and two schools. Four thousand bales of cotton are shipped annually.

Ninety-Six, a colonial name, indicating the distance of this point from the old frontier fort of Prince George, is on the Columbia and Greenville railroad. It has a hotel, three elnurches and a school, with a population of five hundred and fifty. The property is ralued at $\$ 150,000$. Six thousand bales of cotton shipped annually. One hundred and twentyfive thousand bushels of oats were shipped in 1852 .

\section{ANDERSON COUNTY}

has eighteen towns and trading settlements, with one hundred and thirtyseren stores, distributed as follows: Anderson Court House, sixty-six stores; Williamston, eighteen stores; Pendleton, thirteen stores; Honea Path, twelve stores; Belton, seven stores; Andersonville and Pelzer, three stores each; Equality, Piercetown, Storeville, and Townville, two stores each; Broyle's, Holland's, Mountain Creek, Newell, Robert, Rock Mills, and Shallow Ford, one store each. Of this number two sell liquor's, five hardware, thirteen dry goods, fifty-two miscellaneous articles, and sixty-five general merchandise. The estimaterl wealth of the store keepers is placed at $\$ 1,0 \$ 6,000$.

Anderson, the county seat, is on the Columbia, Greenville and Blue Ridge railroad, and is the terminus of the Savamnah River Valley railroad, which is being built. The population in 1860 was six lhundred and twenty-five; in 1870 it was 1,432 ; in 1850 it was 1,850 , and has much increased since. There are two hotels, three halls for public entertainment owned by private individuals; license fee, ten dollars per day. The whites have fire ehurches-Presbyterian, Baptist, Methodist, Episcopal, and Catholic; colored persons, two churehes-Baptist and Methodist. There are three public and a number of prirate schools, and two weekly newspapers. Stores rent for from one hundred dollar's to six liundred dollars, and dwellings for one hundred dollars to three hundred dollars a year. Personal property is estimated at $\$ 350,000$. Real estate $\$ 400,000$. Town tax serenty cents on the one hundred dollars; no town debt. The yearly sales aggregate $\$ 750,000$. The national bank has a paid in eapital of $\$ 50,000$; surplus $\$ 50,000$. The State Saving and Insurance Bank a paid in capital of $\$ 25,000$. About 20,000 bales of cotton are shipped annually to Charleston, Philadelphia and New York.

Pendleton, on the Blue Ridge railroad, near Eighteen Mile Creek, had a population, in 1St0, of three hundred; in 1860, of eight hundred and 
fifty-four: in 1870, of nine hundred and eighty-five, and in 1850 , of six hunderel and seventy-two. 'There is a hotel, and four boarding houses. The Farmer's Hall is a two-story building. There are seven churches and five schools. No town tax or debt. About fourteen hundred bales of cotton are shipped to Charleston, and eight hundred to New York and Philarlelphia; six hundred go to the Pendleton, and four hundrerl to the Piedmont factories in this vicinity. There is a tin, a wagon, a shoc, and a blacksmith shop.

Belton, at the intersection of the Blue Ridge with the Columbia and Greenville railroad, had a population of three hundred and fourteen in 1S50. A large hall, belonging to the Sons of Temperance, is used for public exhibitions (license five dollars). There are five churches. The high school is a large new building; there is also a prirate school, and a colored free school. Brick stores rent for three hundred dollars to four hundred dollars a rear; wooden ones, from one hundred dollars to two hundred dollars. The Atlantic and French Broad Talley railroad is to pass this point. About five thousand bales of cotton are shipped anuually, ehiefly to Charleston, but in part to Norfolk and New York. The rearly sales are, provisions, $\$ 75,000$; dry goods, $\$ 15,000$; hardware, $\$ 5,000$; miscellaneous, $\$ 25,000$. There is a wood and blacksmith shop, and a brick-yard. A chureh, fire brick stores, and sereral residences have been built within eighteen months.

\section{CHESTER COUNTY}

has sixteen towns and trading settlements, with one hundred and twentyfire stores, as follows: Chesterville, eighty-seven stores; Blackstock, nine stores; Richburg, seven stores; Fort Lawn, four stores; Bascomville, Chestnut Grove, Hazlewood, Loweryville, and Crosbrville, two stores each; Carmel, Camwell, Landsford, Rossville, and ITrylie's, one store each. Of this number five sell liquor, two hardware, twelve dry gools, forty-seren miscellaneous articles, and fifty-nine general merchandise. The wealth of the storekeepers is estimated at $\$ 904,000$.

Chesterville, the comnty seat, is in Lat. $34^{\circ} 3 \gamma^{\prime} 4 S^{\prime \prime}$, Long. $0^{\circ} 21^{\prime}$, W' est of Columbia, from which it is distant forty-eight miles, in an air line. It is built on a rlyke of aphanitic porphyry, which slopes upward from all sides, in the manner of a glacis, recalling the toms of the middle ages, built about the castle of some feudal potentate. It has three hotels, and a large hall for public exhibitions is let for $\$ .5$ to $\$ 10$ a night. Nine churches, with accommorlations to seat 3,000 persons, were built at a cost of $\$ 35,000$. There are two graded schools; the buildings cost $\$ 9,0(10$, with a capacity for five hundred pupils, a female academy, and a Metho- 
dist Institute exclusively for colored pupils. Stores rent at $\$ 200$ to $\$ 250$ per annum, and dwellings at $\$ 100$ to $\$ 250$. Taxes are two and one-half mills, with a street tax of $\$ 2.50$ on all able-bodied males. There is an indebtedness of $\$ 3,000$, the balance due on the cost of constructing five water tanks for fire supply, with a capacity of 100,000 gallons. Three railroads unite here, the Charlotte and Columbia, and two narrow gauge roads, the Chester and Lenoir, tapping the Atlanta and Air Line railroad, and the Chester and Cheraw, completed to Lancaster. The National Bank has a paid up capital of $\$ 150,000$, surplus $\$ \$ 0,000$. Besides fruits, hides, \&c., about 30,000 bales of cotton are shipped annually to Charleston, New York, Baltimore, and Philadelphia. The yearly sales are given as follows: provisions, $\$ 300,000$; dry goods, $\$ 150,000$; hardware, $\$ 50,000$; miscellaneous, $\$ 20,000$. Among the industries of the town is a large wagon and earriage manufactory, the Chester agricultural works and machine shops, a saddlery, and a cotton seerl oil mill. Much attention has been bestowed here on grape eulture. Two newspapers are published in the town, and the County Agrieultural Society has extensive fair grounds. In 1840 the population was 250, in 1880 it was 1,S99.

\section{EDGEFIELD COUNTY}

has twenty-nine towns and trading settlements, with one hundred and ten stores, distributed as follows: Johnston's, thirty-one stores; Edgefield Court House, fifteen stores; Trenton, twelve stores; Ridge Springs, nine stores; Parksville, five stores; Kirksey's, four stores; Clintonward, Elmwood, and Pleasant Lane, three stores each; Big Creck, Butler, Clarkskill, Duntonsville, Meeting Street, two stores each; Bouknight, Caughman, Celestia, Cold Spring, Denny's, Ethridge, Fruit Hill, Garrin's, Longmires, MeKee's, Mine E'reek, Modoe, Pleasant Cross, Rehohoth, and Havirdsville, one store each. Of this number fire sell liquor, one dry goods, twelve miscellaneous articles, and ninety-two general merchandise. The estimated wealth of the storekeepers is placed at $\$ 549,000$.

\section{FAIRFIELD COLNTY}

has screnteen towns and trading settlements with ninety-one stores, distributed as follows: Winnsboro, forty-nine stores; Ridgeway, ten stores; Strother's, six stores; Shelton, five stores; Blythewood, Wallaceville, and White Oak, three stores each; Lylesford and Woodwark, two stores each : Blair, Buckhead, Gladden's, Horeb, Long Run, Monticello, and Poplar Spring, one store each. Of this number five sell liquors, five hardware, five dry goods, nineteen miscellaneous articles, and fifty-seren general merchandise. The estimated wealth of the storekeepers is $\$ 675,000$. 
Winnshoro, the county seat, is on the Charlotte and Columbia railroad, thirty miles from the latter place. The depot has an elevation of five hundred and forty-five foet above the sea level. It is situated on a rilge diviling the water shed of the Wateree from that of Broad river. The soil is a rich, stiff, dark red clay loam. Granite and trap rocks are found. Twenty feet below the surface the earth becomes friable, somewhat resembling quicksand, being perfectly white in some places. The town is regularly laid out; the streets of good wilth, aggregate six miles in length, have broad pavements, curbed with split granite, and are well shaded by handsome trees. The Court House, Jail, Town Hall, Market, Steam Fire Engine Halls, and Mt. Zion Collegiate Institute are all handsome brick buildings. The Thespian Hall, fitted for exhibitions, is eighty by thirty-five feet. Many of the private residences are beautifully located and are fine buildings. The water supply is excellent and abundant from wells and springs. There are five large fire wells and cisterns, a steam fire engine, a hand fire engine, and a hook and ladder company. Of the five churches for whites, the Presbyterian cost $\$ 35,000$; the Associate Reformed Presbyterian seats 300 ; the Episcopal Church seats 400; The Methodist 300; the Baptist, 300. The colored people have an African Methodist Church, seating 600, and Baptist Church, seating 200. The colored Presbyterian Mission School, built of wood, cost $\$ 2,000$, and accommodates 200 pupils. Stores and dwellings rent for $\$ 100$ to $\$ 500$, or about ten per cent. of their value; for the latter the demand is greater than the supply, a considerable portion of the town having been burned by Sherman's army, which has much retarded its growth. Excellent brick are made in the vicinity, and four miles distant, on Col. Thos. J. Wroodward's land, is a quarry of the finest granite, to which a railroad is being built. The yearly shipments are 14,000 to 15,000 bales of cotton to Charleston and New York, and 3,000 bales to Baltimore and Richmond. The Wimsboro National Bank has a paid in capital of $\$ 75,000$, and a surplus of $\$ 15,000$. The yearly sales are given as, provisions, $\$ 350,000$; dry goods, $\$ 150,000$; hardware, $\$ 50,000$; miscellaneous, $\$ 100,000$. Property is valued at $\$ 500,000$. There is a debt of $\$ 3,000$, balançe due on purchase of steam fire engine, interest seren per cent. Town taxes are restricted to two and one-half mills on the dollar by statute. In 1810 the population was 500 , in 1550 it was 355 , in 1860 it was 1,124 , in 1870 about the same, and in 1880 it was 1,500.

\section{GREENVILLE COUNTY}

has twenty-six towns and trading settlements, distributed as follows: Greenville Court House, one lnundred and forty-nine stores; Greer's, 
fourteen stores; Piedmont, six stores; Fairvicw, five stores; Ituntersville, Narietta, Merrittsville, and Sandy Flat, three stores each; Bellevue, Fork Shoals, Lima, O'Neal, Plain, Sterling Grove, Taylor's, Highland Grove, two stores each; Alba, Batesville, Chick Springs, Fountain Inn, Gowansville, Lickville, Mush Creek, Pelham's, Pliny, and Hart's, one store each. Of this number thirteen sell liquors, twelve hardware, twenty-seven dry goods, sixty-nine miscellaneous articles, and ninety-one general merchandise. The estimated wealth of the storekeepers is $\$ 1,298,000$.

Greenville, the county seat, long noted for the salubrity of its climate and the beauty of its situation, at the foot of the Blue Ridge mountains, and in full view of them, is located on Reedy river, at the junction of the Columbia and Greenville railroad with the Atlanta and Charlotte AirLine railroad. In 1820 the population was 500 , in 1840 it was $\$ 50$, in 1850 it was 1,305, in 1860 it was 1,518 , in 1870 it was $2,75 \pi$, in 1880 it was 6,160 . A careful enumeration by the Inter-State Directory Company, in 1883 , shows the population to be 8,355 . It appeared on the same date that there were in course of erection sixteen residences, seven stores, one warehouse, one stable, one large church, and a musieal conservatory three stories high, and including twenty-one rooms.

It has an elevation of ten hundred and fifty feet above the sea level. It has six hundred yards of granite pavement, twelve hundred yards of other rock pavement, and twelve hundred yards of brick parement. There are two miles of street railway in the town. Reedy river, with two falls of orer thirty feet each, traverses the town, which has in addition twenty-five street eisterns, eapacity, fifteen thousand gallons each. Rock eulverts and drains, with side drains of terra cotta, make a good system of drainage and sewerage. There are six hotels and three livery stables in the town. The handsome brick Court House cost $\$ 25,000$, and an opera hall, costing $\$ 15,000$, has seven hundred seats. The University grounds are handsomely kept, and the agrieultural fair grounds cover thirty acres, having some fine buildings. There are ten churches, with a seating capacity of three hundred to one thousand each, and costing, in the aggregate, $\$ 75,000$. There are two colleges, a military institute, a public school, and a number of other schools. Building materials are brick and granite, obtained in the vicinity. The value of real and personal property is stated at $\$ 2,500,000$, of which $\$ 1, \$ 00,000$ is insured. The taxes are six and a half mills on the dollar, yiclding $\$ 11,500$ per annum. There is a debt of $\$ 55,000$ in aid of the Air-Line railroad. Forty thousand bales of cotton, it is stated, have been shipped in one year to New York, Baltimore, Philadelphia and Boston, and yarn. to the value of $\$ 200,000$, to Boston. Bcfore the war no cotton was shiplped 
from this point. The yearly sales are approximately given as: provisions, $\$ 800,000$; dry goods, $\$ 800,000$; hardware, $\$ 300,000$; miscellaneous, $\$ 100,000$. The National Bank of Greenville has a capital of $\$ 100,000$; surplus, $\$ 20,000$, and there is a private bank also. Besides the Huguenot and Camperdown cotton mills, there is a carriage factory, a furniture factory, an iron foundry, a cotton seed oil mill, a mattress factory, three saddle and harness shops, a flour mill, a terra cotta factory, three brick yards, and a mill turning out pearl grits. There are three printing offices, two newspapers and a religious paper. The town is lighted with gas; the mills have electric lights.

Piedmont is a flourishing manufacturing town, eleven miles south of Greenville, where the railroad crosses the Saluda. The population is 1150 . There is a hotel, a two-story school house, capacity, one hundred pupils; the upper story used as a town and society hall; one church, capacity, four hundred persons, built at a cost of $\$ 1,800$. The value of the property is estimated at $\$ 1,000,000$. The shipmients are confined to the products of the mills of the Piedmont Manufacturing Company, estimated at $\$ 900,000$; by the last report of the president, "the net profits during the year amounted to $21 \frac{1}{3}$ per cent. on the capital stock of $\$ 500,000$, or over $\$ 105,000$. The yearly sales are: provisions, $\$ 10,000$; dry goods, $\$ 10.000$; miscellaneous $\$ 20,000$. This village was commenced in 1874-5.

\section{LANCASTER COUNTY}

has nine towns and trading settlements, with fifty stores, as follows: Laneaster Court House, thirty stores; Flat Creek, five stores; Pleasant Hill and Taxahaw, four stores each; Cureton's and Pleasant Valley, two stores each ; Craigsville, Gum and Hail's, one store each. Of this number eight sell miscellaneous articles, and forty-two general merchandise. The estimated wealth of the storekeepers is $\$ 272,000$.

\section{IAURENS COUNTY}

has cighteen towns and trading settlements, with one hundred and twenty-three stores, to wit: Laurens Court House, fifty-three stores; Clinton, twenty-seven stores; Martin's, eight stores; Line Creek and C'ross Hill, six stores ach ; Power's Shop and Waterloo, four stores each ; Brewerton, Roseborough, Tumbling Shoals, and Tylersville, two stores cach; Cedar Grove, Mountain Shoal, Mount Gallaghar, Pleasant Mound, Scuffletorn, Young's and Eden, one store each Of this number five sell liquor's, five dry goods, eight hardware, twenty-six miscellaneous articles, and serenty-nine general merchandise. The estimated wealth of the storekecpers aggregates $\$ 772,000$. 
Clinton, on the Laurens branch of the Columbia and Greenville railroarl, is a rapidly growing village. In 1870 the population was 200 , in 1880 it was 450 , and it now exceeds 600 . There are nine miles of streets, a hotel, several boarding houses, and a livery stable. There are no taxes, or town debt, and the sale of liquor being prohibited within three miles of the depot, it is not thought necessary to have a police. 'There are six churches, with a membership of four hundred, costing $\$ 7,000$, and able to seat serenteen hundred and fifty persons; a library society, three lodges of Masons, Good Templars, and Kniglts of Honor. The edueational establishments are, the Thornwell Orphanage, the Clinton College and preparatory school, a military school, and a private school. Among the manufacturing establishments are three steam mills, one carriage shop, one tin shop, one printing office, one gin factory, one steam brick factory, one steam planing mill, one firm of timners, two shoemakers, six firms of carpenters engaged in house-building. Dwelling houses rent on an average at $\$ 100$, stores at $\$ 100$ to $\$ 250$ per annum. Building materials are lumber, brick and stone, obtained in the vicinity, and a concrete of granite, sand and lime is also being used for buildings. Cotton shipments are about six thousand bales annually. The raluation of property is given as $\$ 185,000$.

\section{NEWBERRY COUNTY}

has fifteen towns and trading settlements, with one hundred and twentyone stores, distributed as follows: Newberry Court House, eighty stores; Prosperity, ten stores; Chappel's and Saluda, five stores each; Liberty Hall, four stores; Kinard's, Silver street and Jalapa, three stores each; Pomaria, two stores; Belmont, Boston, Helena, Phifer's, Walton and Whitemire's, one store each. Of this number nine sell liquors, eleven hardware, six dry goods, forty-seven miscellaneous articles, and fortyeight general merchandice. The estimated wealth of the storekeepers is $\$ 760,000$.

Newberry, the county seat, is in Lat. $34^{\circ} 16^{\prime} 37^{\prime \prime}$, and Long. $0^{\circ} 41^{\prime} \mathrm{W}^{\circ}$ est of Columbia, from which it bears N. $60 \mathrm{~W}$ est, $36 \frac{1}{ \pm}$ miles. It is situated on the Columbia and Greenville railroad, on the ridge between the Broad river (the Es-waw-pud-de-nah, or line river, dividing the Indian tribes), and the Saluda (Salutah or Corn river), and has an elevation of 502 feet abore the sea level. In 1840 , the population was 300 ; in 1850 it was 509 ; in $1 S 70$, it was 1,891 ; in 1850 , it was 2,342 . The streets have an aggregate length of twenty-four miles. Two small creeks traverse the town, which, with springs and wells, furnish an abundant supply of excellent water. Two large brick hotels, costing $\$ 15,000$, are open. The court 
house cost $\$ \$, 000$, the jail $\$ 6,000$, the market $\$ 2,100$ A new brick opera house cost $\$ 25,000$, seats 1,000 persons, and rents for $\$ 40$ a night. The whites have six churches, Presbyterian, Methodist, Baptist, Lutheran, the Associate Reformed and the Episcopal, built at an aggregate cost of $\$ 18,000$, capacity, 4,000 seats, and three colored churches, costing $\$ 4,500$. There are flourishing organizations of Masons, Odd Fellows, Knights of Honor, and Sons of 'Temperance. The Newberry College buildings cost $\$ 20,000$, the Female Academy $\$ 2,500$, the Male Academy $\$ 1,000$, the Hoge School (colored) $\$ 1,500$. The average rental of stores is $\$ 350.00$; of dwellings, $\$ 200.00$. Building materials are brick and pine lumber from the vicinity, and granite, great quantities of which of the finest quality are found in three to five miles of the town. The mayor and aldermen serve without pay. The town tax is two mills on the dollar, and a revenue, in addition, of $\$ 2,400$ from licenses. There is a debt of $\$ 22,000$, incurred in 1S\$1, for building the opera house; interest, seven per cent. The Newberry National Bank has a paid in capital of $\$ 150,000$; stiplus, s39,278. Twenty thousand bales of cotton areshipped annually to New York and Norfolk. The yearly sales are given as, provisions, $\$ 450,(100$; dry gcods, $\$ 200,000$; hardware, $\$ 75,000 ;$ miscellaneous, $\$ 125,000$. A large cotton mill is about being built.

\section{SPARTANBURG COUNTY}

has twenty-three towns and trading settlements, with one hundred and sixty-six stores, distributed as follows: Spartanburg C. H., seventy-four stores; Gaffney, thirty-two stores; Woodruff, eight stores; Pacolet and Wellford, six stores each; Cowpens and Landrum, five stores each; Cross Anchor and Reidville, four stores each; Dumans, New Prospect and Inman, three storés each ; Campobello, Damascus, Hobbyville and Martinville, two stores each; Compton, Crawfordsville, Fingerville, Glenn Springs, Hills Factory and Rich Hill, one store each. Of this number, seren sell hardware, fourteen dry goods, thirty-one miscellaneous articles, and one hundred and fourteen general merchandise. The estimated wealth of the storekeepers is $\$ 1,242,000$.

Spartanburg, the county seat, is situated at the junction of the Spartanburg, Union and Columbia railroad, and the Spartanburg and Asheville railroad with the Atlanta and Charlotte Air Line railroad. The population, in 1820 , was 800 ; in 1840 , it was 1,000 ; in 1850 , it was 1,176 ; in 1860 , it was 1,216 ; in 1870 , it was 1,080 ; it 1880 it was 3,253 . It has an elevation abore the sea level of seven hundred and eighty-seren feet. Besicles the court house and jail, there is an opera house costing $\$ 11,000$, and three large and handsome brick hotels, one of which has one hun- 
dred rooms. There are four churches for the whites, and three for colored persons. The Wrofford College is under the direction of the Methodist Church. There is also a male seminary, a female scminary, six public and private schools, and an orphan house. The National Bank has a paid in capital of $\$ 100,000$; surplus, $\$ 30,000$. Proprerty is valued at one and one-quarter million dollars. There is a city delut of $\$ 1.50,000$ for sulsceription to railroads, and $\$ 20,000)$ for Macadamizing the streets. Twenty-fire to thirty thousand bales of cotton are shipped annually to Nerr York and Charleston. There is a mineral spring in the town, and several in the vicinity. The town is lighted with gas.

Gaffiney, on the Air Line railioad, east of Spartanburg twenty-one miles, was founded in 1S73. The population, in 18s0, numbered $f(0)$, and is now estimated at 1,000. There is a hotel, and brick town hall eighty-five feet by fifty-four feet; four churches, costing 8.5,000, and two wchools. Stores and dwellings rent for ten dollars to twenty-five dollars a month. The property valuation is 8500,000 . There is mo town debt or taxes. The yearly sales are about $\$ 315,000$. Eight to ten thonsand bales of cotton are shipped to New York and Baltimore. There is a brick yard, lime kiln and two blacksmith forges in the rillage. One mile distant are the Limestone Springs, formerly a noted summer resort, now a female academy. Near here is the Magnetic Iron Manufacturing Company, with a magnificent water power. Iron ore. lead, colper, gold, flexible sundstone (ita columite or dimond rock), blue limestone, white and streaked marbles, fire-proof sand, and soapstone, are all found in this neighborhood. There is a weekly newspaper.

Clifton, on the Pacolet river, two-thirds of a mile from the dir Line railroarl, is a manufacturing village, of one thousand inhabitants, built up within two years. The village is the property of the Cotton Manufacturing Company, which employs six hundred hands. There is a church and school. Sales, about seventy thousand dollars per amnum. shipment of factory goods, $\$(600,000$ per annum.

II oodruff, on the proposed line of the Greenwood and Spartanburg railroarl, is eighteen miles south of the Court Hon-e. It has a population of thre hundred. There are four churches, one colored, and three schools. Wagon making and saw milling are local industries. Mail by prirate conveyance.

Reirlville, twelve miles sonthwest of the Court House, and five miles from Ternonville, on the Atlanta and Charlotte Air Line railroad, is a village of three hundred inhahitants, that has grown up around edueational institutions located there. These are a female college, one hundred and fifty pupils, and a male high school, one hundrerl pupils. Board costs ten dollars to twelve dollars a month; the buildings are of 
brick manufactured there. Dwelling houses rent from six dollars to (right dollars a month. Town taxes, one mill on the dollar. In the neighborhood are two mineral springs, containing sulphur, iron and magnesia.

Wellford, ten miles west of Spartanburg, on the railroad, has an Epis(opal Church and the Wellford High School. Rate of tuition, board and wasling, $\$ 12.50$ per month. The school-room accommodates one hundred and twenty-fire pupils.

Glemn Springs, twelre miles south of Spartanburg, is a summer resort noted for its mineral waters and healthful climate. There are two churches, a white and a colored school. Large numbers of visitors come during the summer. Dwellings rent for seventy-five dollars to one humdred dollars a year, cottages for thirty dollars during the summer. The mineral waters are bottled and shipped.

\section{ExION COUNT,}

traversed by the Union, Spartanburg and Columbia railroad, has eightcen towns and trading settlements with eighty-four stores, as follows: Union Court House, forty-eight stores; Santuc, eight stores: Jonesville, five stores; Cross Keys and Skull Shoals, four stores each; Mountjor, three stores; Fish Dam, Mount Tabor, and Smithford, two stores each; Asbury, Colerain, Goshen Hill, Gurdysvill, Meador, Pinegrove, Sedalia, Wrest Spring, and Wilkinsrille, one store each. Of this number fire sell liquors, three dry goods, twenty-five miscellaneous articles, and thirtyone general merchandise. The estimated wealth of the storekeepers is $\$ 755,000$.

\section{TORK COUNTY}

has twenty-one towns and trading settlements, with one hundred and thirty-seren stores, distributed as follows: Yorkville, forty-five stores; Rock Hill, twenty-seven stores; Black's, eleven stores; Fort Mills, cleren stores; Whitaker and Clover, seren stores each; Bullock's Creek, four stores; Clay Hill and Smith's, three stores each; Blairsville, Bowling (ireen, Clark's Fork, Guthriessille, Sandersyille, Zeno and Bethel, two stores each; Corncob, Hickory Grore, Tirzall, Bethany, and McConnellsville, one store each. Of this number four sell liquors, two hardware, six dry goods, forty-tluee miscellaneous articles, and eighty-two gencral merchandise. The estimated wealth of the storekeepers is $\$ 920,000$.

Yorkville, on the Chester and Lenoir narrow-gauge railway, is the county seat. In 1523 it had a population of 441 , being fifty-two me- 
chanics, eight lawyers, two physicians, and one clergyman; there was then eight stores, five taverns, a male and female academy, and two weekly papers, one devoted to agriculture. In 1840 the population was 600 ; in 1860 it was 1,360 ; in $1880,1,339$. There are ten miles of street, pared at a cost of twenty-five cents to one dollar per yard. The Court House is a venerable and handsome building, costing originally $\$ 5,000$. The King's Mountain Military Academy and the Female Academy are fine buildings, costing about $\$ 20.000$ ench; there are several other schools, and a newspaper. The churches are the Episcopal, Methodist, Presbyterian, Baptist and Associate Reformed. Building materials are chiefly stone and brick from the vicinity. Taxes are four mills on the dollar, two of which go to pay the balance due on paring the streets, which is nearly paid up. Six to ten thousand bales of cotton are shipped to New York. 'The yearly sales are stated as, provisions, $\$ 200,000$; dry goods, $\$ 150,000$; miscellaneous, $\$ 50,000$.

Rock Hill, on the Charlotte and Columbia railroad, has an elevation of six hundred and sixty-eight feet above sea-level. In 1850 the population was 500 , almost all of whom had settled there after the war. There are three hotels, a town hall, engine house, and two public halls, with a capacity for seating six hundred persons; has stage, scenery, \&c., for theatrical exhibitions (license fee, \$5). The whites have three brick churches, and there are three wooden churches belonging to the colored people. The best stores rent for $\$ 100$; cottage dwellings, from $\$ 100$ to $\$ 150$. Excellent brick are manufactured in the town. The value of property is estimated at $\$ 500,000$, of which $\$ 200,000$ is insured. Taxes are three mills on the dollar. Fifteen thousand bales of cotton are shipped to New York, Baltimore and Charleston. 'The yearly sales of goods aggregate $\$ 500,000$. A cotton factory, two carriage factories, a tin manufactory, two shoe shops, and two saddlery and harness shops, employing one hundred and twenty-five hands in manufactures. There is a private banking establishment in the town. The

\section{ALPINE REGION,}

of South Carolina, occupies the larger portions of Oconee and Pickens counties, although it extends through the northern portions of Greenville, Spartanburg and York counties, whose towns have been already treated of. Taken as a whole, it will be seen, on reference to the table, that the percentage of the population living in towns is greater for the Alpine Region than for any region in South Carolina, except imme- 
diately on the coast. 'This is due to the wide stretches of mountain sides that are but sparsely settled.

\section{OCONEE COLNTY}

las nine towns and trading settlements, with one hundred and nine stores, as follows: Wallalla, forty-nine stores: Seneca City, twentr-six stores; Westminster, sixteen stores; Fair Play, seven stores; Oakwar, six stores; Fort Madison, two stores; High Fall, Long Creek, and Whetstone, one store each. Of this number three sell liquors, fire hardware, four dry goods, thirty-seren miscellaneous articles, and sixty general merchandise. The estimated wealth of the storekeepers is $\$ 1415,000$.

Walhalla, the terminus of the Blue Ridge railroad, is the county seat, and had, in $18 S 0$, a population of $7 S 9$. There are four churches and two colleges, the Adger and the Walhalla; a newspaper, three saw-mills, fire grist mills, three gimneries, and two coach factories.

\section{PICKEXS COLNTY}

has eleven towns and trading settlements, with fifty-seren stores, as follows: Easeley, sixteen stores: Central, fifteen stores; Pickens Court. House and Liberty, six stores each; Briggs, four stores; Rock, three stores; Dacusrille, and Six Mile, two stores each; Ninetimes, Stuart, and Table Mountain, one store each. Of this number, one sells liquor's, one hardware, sixteen miscellaneons articles, and thirty-nine general merchandise. The estimated wealth of the storekeepers is $\$ 223,000$. 


\section{N D E X .}

ABBEVIILT CO., PIEDMONT REGION : The Metamorplic rocks on Savannah river, 127; Mica Slate, orerlying belts of Hornblende upon Gneiss in the northern portion of, 1:32; Talc and Clay silates of, $1: 32$; Trap rock grives rise through the disintegration of Felsitic and Dioritic Porphyries to the "Flat Woods" of, 134; Grold mines open in tree Talc Slates-above tlie IIet:morphic rocks the streams generally contain Gold in their sands, ib. ; Silver in Galena, Iron Ores, Feldspar, Steatite, Zircons found in 137; Analysis of the "Flat Woods," Soil, 143 ; Original Growth Hickory, Oak and ('hestnnt. with no underbrusl. only a dense growth everywlere of Cane, (irasses, and the Wild Pea, grazed on hy herds of Deer and Buflalo-the Chestnut has nearly disappeared, but the long extinct Wild Pea is said to be re-appearing since the passace of the Stock Liaw, 1t6; Hemp, Tobacer, Silk and lline produced by the early French settlers who gave its name to, 147 ; Wriren Grape cuttings shipperl to France from, ib. ; Field Labor and IV ages in, 15.5; Share system preferred in, 1.jt; Quality, Price of Land, Crops, Wrater-power Mines, de, in, 16t-166; IV acklell's relebrated Willington A ad(my in, $t^{4}$ ?) ; Erskine College, 4$)^{2}$; Due Wrist Female College, 517 ; Schools of, 4.8 ; 'Towns and Trading Points of, 704 .

AGIiICULTTLE: The Department of, in the State fovermment, $4 t 1$; Agricultural and Mechamical Colleges of the state Triversity, 48s.

AGRI' 'ULTURAL REGIONS OF SOTTH (AROLINA : I. Coast Region. 14-43; II. Lower Pine Belt, $t 4-70$; III. Lppel P'ine Belt, $71-109$; IV'. Reel Ilill Kerrion, 110-116; V. Sand Hill Region, 117-12.; TI. Piermont Region, 126-18:2 ; TH. Alpine Region, 18:3-2(18.

AGRICUITLRAL RETROSPECT: Early Culonial Exports, Skins, Lumber, Tar, Oranges, \&e., 9) Indien, Indian Corn, 10; (otton, 11: Sea Island ditto, 12; Diagram showing the fluctuations of all the staple Crope from $1670-1$ s $80,13$.

AIKFN ('U.: In the Sand rills ; Limite, immense beds of fine Buhr-stone, 11:3; Boiling springs, Blowing Wells, 119;
Franites, 110-131; Kaolin Quarries, 120; Soil Analysis-liaplit live in the Price of Lands in, 121; Peannts, Watermelons, it.; Flower Ciardens, Peach Orehards, 122; diken Town, a Famous Health Resort. 1:2:) ; Factories of, 118, 582; Towns and Trading Points in, 6!)7.

ALPIXE REGION: Location and Phrsi(al Features of, 18:3; Geulogy of the. 155; Soils and Climate, 186; Ginsenw and other Medicinal II rerls in wreat abundance fomml in the, 18s; Fold, Iron, Lime, Kaolin, Silver, C'opper, I.and, Cormudum, Mi(a), Mineral Springs, 185 : Statistirs of Farms, Prodinets, \&e., 189-19.). See reports from Pickens and Oconee. In climbing the mountains the following trees mark the steps of ascent: Rock Cliestmut, Monntain Oak, Cn'umber Tree, Momntain Lanrel, White Pine, Hemlock or sipruce Pine, $18 S$.

ALMOND. 115

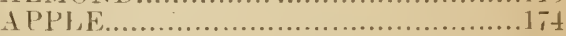

ANATTSLA OH SOILA: Coist Region. 14; Lower Pine Belt, 5.:; [T]er Pine Jielt, 74; River Swamp Lands, 7t, $\mathbf{s}$; Red Hill Region, 11:; Sand Hill Region, 121); Piedmont, 139); Grar sandy and Red Clay Loam, 1:39; Hormblentic Soils, 1ti); Clay slate, 141 ; Trappean, 142; Black-jack, 14:3.

ANDERAON CO.. PIEDJIONT: Manganese, Graphite, Feluspar, slcutite, Asbestos, Tourmaline, Zircon, ('orumdum in, 137; Quality, and price of lands, (rowth, Mill sites, Prolncts, Factories, Gold, silver, spinel Rubies, of, $166-5$; Water Courses, $2(14$; Schools, tis, 481; Towns and Tradine I'oints, 70.5 .

ANTMALA, VERTEBRATE: of South Carolina, 20:1-262.

AREA: Of South Carolina, 3 ; of Sea Islands. $\bar{T}$; Rice Launds, $7, \overline{7}$; Salt IIarshes, 7,$5 ; 3$; Swamp isands, $7,8,52$. 5:3; Impured Land of coast Region, 24 ; of [rylands in Lower l'ine. Tielt, 5.2; Nwamp Lands in ditto, 5.:; Tilled Land in clitto, 55; of [nuserl Land arlapted to Rice Culture in litto, 5i: River stwamps of the I'per Pine Belt.

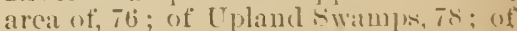
the sand Hill Region, 11s; of Bottorn 
Lamis on Crecks in the Sand Hills, 115; lierl Hills, 115; l'ierlumnt. 126; Alpine liegion, 183. Sce Table II. for areas of the recrions, 362 .

A. STERTOSOS

ASIILIEY FISII liED 137

PAfGING : Charleston Factory of

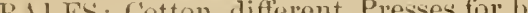
inc, Weight of, (33, 91; Charges for 'l'ransportation of, on Steamboats and Railroads, !2? other ('harges on, 9?; Tables showing the Numbers in different hegions and Connties made in $187(1-801$ of, 36.$)$; Size of, 594 .

B. $\mathrm{N}+\mathrm{N}$. $24,11 t$

BAXKs, 643 ; Brancl of the National Bank Established in South Carolina, bitt; bink of the State Chartered in 181:183.., il.; re-chartered in 1830 nutil 15.56, 645; again in 1852 to 1871,646 ; Farorable Report of Joint Committee of General Assembly on the Bank in 1s 7 1, 647; Closed by Reconstruction in 1870, fits; other Banks, $66^{\circ}$.

BAXK OF YEITBERRY, good plan for a Farmer's Bank, 15t.

BAPTIST': Institutions of Learning of the, 497,528 ; First Establishment and Early History of the, 5.); Chmr'hes, Sittings and Property of the, 55.5.

B.IRLEY : bushels nade in $1850-' 60-70-$ ' $80,362$.

BARIWELT, CO. UPPER PINE BELT Srstem of Labor in, 84; Quality and Price of Lancls, Marl, Swansps, Growth, Products of, 99. Towns and Trading Prints, 69:2.

BARTTES 137,182

BEAUFOR' CO. COAsT REGION: Immense Grape Vine in, 25; the First Settlement in South Carolina marle in; Long Staple Cotton First Planted in, 27; Labor Contracts, 30; Marsh Grass, Tegro Farmers, Scliools, Phospliate Rock, Port Royal Harbor and Railroad, 31, 1;6.); 'Towns and stores, 663.

BERKELEY CO., (OAST REGION : Statistic's of, in 1880, Table $Y ., 362$; Towns and stores, 668.

BERAUUA GRASS..................25, 87

BET I L.....................................137

BIRD'S MOUNTAIN....................... 18t

BIRJS: Of south Carolina, 217-33; few Fossil liemains of, 49.

BIR'TIS.........................................

BIS.MUTH ...................................

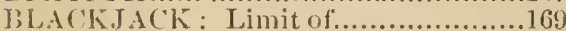

BLINI, DEAF AND DUMB, scluool for, 5.57

BL(NSOMIS, COTTON : First Appearance of $3 ., 90$

BLOMING IYELLS

BLOII LYG SANDS

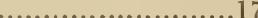

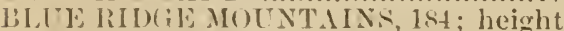
of different l'eaks of the, 185.
BOLNDARIES : Of Sonth Carolina..3, 184

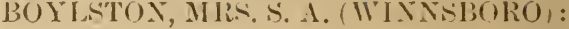
Fine Water Power on tle C'atawba of, 205.

BROOMISEDGE............................

BUFF\LO ...........................

BUHR STONE: 46, 73; Mill Stunes, 111, 112.

BLILDING II'TERIALS ...........t7, 398

CAEAR'S HEAD IT .185 CALHOUN, JAME F............... 186,189 CAMDEN: Joseph Kershaw's Flouring Mills, near, 9; Tracle in 18:6, 6:-7.

CANAL: Act Establishing the Catawba, 620 ; Santee, 6233 ; Salucla, 6:5.

CANE: Wild, 146, 170; Sngar, 25, 66, 114

CATHOLICS, ROMAN....................5.

CATTLE ...........................................

CHAITBEATE SPRING................

CHARGES ON COTTON ...............?

CHARLESTON CO., LOWFR PINE BELT : Ashley and Cooper Marls, 46 ; Quality. Price of Land; St ' liomas and St. Denis, once wealthy and populous, now abandoned-Growth, Inclustries, Wando Phosphate, 66; Towns and Stores of, 609

CHARLESTON : Health of, 21, 23, 67t; First Appearance of Tellow Fever in, 2.2; Settlement and Early History of, $422,66 \%$; siclinols of, $461-7$; Charitable and Literary Institutions of, 469) ; College of, 440 ; Cotton Mill, 582 ; Water Communication with the Back Conntry, 611; Early Trarle with the Indians, 61t; Receipts and Expenditures for 1879-80-1-2 and Debt of, 672 ; Water Supply, Streets of, $67 \pm$; Drainage, Board of Health of, 675 ; Fire Department, Public Gromnds, 676; Charities, 677; Popnlation at different periods-Harbor of, 678 ; former Pre-eminence among the Cities of the [nion of, 680; Leading Artic]es of Tracle of $6 S 1$; Industries of, (is?.

CHARLESTON ATD HAIBURG RAILROAD : History of the. 630.

CIESTER CO., J'IEDMONT : Iron, Steatite, Flagring and Whetstones in, 137; Gold, Granite, Blackjack Lind-, limestone Sinjing, Quality and Price of Lancls, Catawba Canal in, 109? ; Cotton Mills, 58:2; Towns and Trarling Points in, 706.

CHESTERFIED CO, IN THE SAND HIILS: Berls of Litnite in, 11:; Brewer Gold Mine, Bismutl, 137; Schools of, 482 ; Towns and Trading Posts, 70:?

CHTRCHES: The "Church Act," $170 \mathrm{t}$, devaring the Clumel of England the (hurch of South rarolina, 5i)(1) the Parochial System of Gorernment, 5.51 ; Early Colonial, ibid; Neoroes first Baptized, 533; Numbers, Sittings and 
Property of different, 5.5. ; Present Condition and Distribution of the most important. 5.$) 6$.

CLAFLIN UNIVERSITY

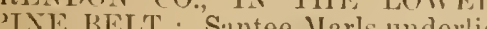
tle whole of 47 ; size of Farms. Labor Contracts, Liens, Quality and Price of Lands, 60,67 ; Stone resembling Menelite, found in, 112; Towns and stores of, 691 .

CLA I SLATES

CLIMATE: (If sea Islands, on) of Low Pine Belt, 5t; of Tuper ditto, 79; Red Hills, 114; Sand Hills, 12.2 ; Piedmont. 144 ; Alpine Region, 155 ; Meteoroloni(al Table, 360 .

CLOVER 147,181

COLLEGE A YD [NIVER-ITIES: The South Carolina Collecre, 486 ; Charleston, 490 ; Erskine, 492 ; Woftor $4,4 ! 5$; Furman, 497; Newberry, 494; Aderer, 501 : C'laftin, 525; Allen, 52- ; Medical College, 505 ; Female, $51+-52.2$.

COLLETON CO., IN THF LOWFR PINT BELT : Sea Jsland Cotton, first grown in, 27; Quality and Price of Lands, Labor System, Water-Powers, Nwamp H:nmmocks, Products of, (6.5) Towns and stores of, $6 \$$ ?

COLONY OF SOU'TH CAROLINA : Early History of the...9, 3s1, $421,5.00,5 i t,(31:$

COLLIIBIA : Congaree Tribe and River, 3tit; Act of 2:1 March, 1786, to found, 6:0); Incorporated 1787, First Legislative Session at, (i99; 'Trade, Debt, P(1)ulation, Industries of, 69()-702.

CONCIRTE FOR BUILDING STUNE, 20, 111

SATITUTION : Locke's Fundamental. 4:3i3; the Second in 1729 modeled after the English, 425; the Provisional, 1776 , the Frumth, 1, 90 , modeled after that of the United Sitates, 427 ; the Fifth, made by the Convention summoned by Congress in 1868,409 ; Leading Principles of the said, $f_{-2}^{*}(-4+2$.

OPPER.............................. CORALIINE BED OF THE CHARLETON B.ASIX. 47 .

COST OF MAKING COTTON: In the ('oast Region, per acre and pomm, 4'2 : in Lower Pinc Belt, 6t; in Lpper ditto, 9.).

COST OF PICKING COTTON........36, 42.

COTRON : SEA ISLAND, derivation of the name, 2t; A ppearance of the Plant, $29,35,79$; First Crop Maximm Product, Excellent Quality aud Himh Prices of, 12; Introluction and Early History of, 27; Color, Length and strengtl of the Fibre of, :-8; Labor and sistem of Planting, 29; Tillage and improvement of, $32-34$; Disenses amd Enemies of, 36, ] 60 ; Preparation for Market, 37 ; Gins, Roller and Toll,
35; Seed. 29; Santees and Mainswestern limit of, ibirl: ('ost in greneral of prolucing, fli; Table of Itemized Cost pere arre t: ; per pound, 4:3.

COTTON: ['Jaxis, Jower l'ine belt, sis; Systen of Labor, 5!); Cultivation of, (itl-tie; I'reparation for Market, 0 is: (ist of problucinge, lit.

COTTON: TPLAxis, Upyer Pine Belt, Tillage, sti ; Mannel of l'lanting, s8; (iinning, Baling, Shipping, (10); Diseasces aud Enemies of the l'lant,!2: ('haran on Felling, 93 ; Cost of, ilin : Itemized. ditto, 4.$)$; seed and l.jint, $y$;.

COTTOS: Number of lales macle in rlifferent liegrions of sumth carolinil. Tables II., III.; Number male in [nited states and sontl Carolina in

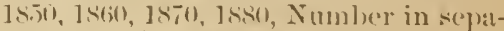
rate Counties, TubleV . :3(i0-i;(j;:).

COTTON: Manufictures of, 57ti-597; of kaw Cotton in South ('arolina, j.:.? Slape of the fibre, 5y:3; Cimneries in (ommection with Factories. it!).

COTTON SEED: Hrloridization of, 30 ; Oil and Meal made from the, ons-(;0).

COUNTIE- Township report of (kee names of $)$, Table T......................

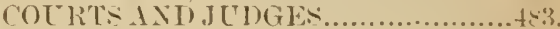

('OII PFA.................................., (i1, s1

CRAB GRASS ...............................

CREKK.

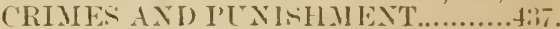

CYCLE OF TRAI)E, $y$; and of Transportation, 617 .

DARLINGTON CO., TPPER PINE PEI,T : sistem of Farming in, 8.r; Ta])] showing Yield of Cotton in lint Liens per bale, Size of Farms and I'orrentage of Owners, s6; Expenses and Production of Plantation in, !) : Win Making, Quality of Lamols, Crops in 11:3; Towns and Trarling Points in. (6!).

DE $\perp$ THS : In Charlestom, $1877-81,2: 3,40.3$ Percentace of ac'orcling to 1 cre, sex anl Colur, tos; in Claarleston, ls:30 to $1 \leqslant 50,676,54$.

DEAF DUMB AND BIIND: Institutes for the, 5ot: Numbers of, ixis).

DEBTs: Remedies for the lievovery of, 443 ; State, Liquidated hy Indínts, 643 ; Assumption of by General tims ermment, btt; Amomit disclaarered los the bink of the state in $15: 3\left(0,1 ; .0^{\circ}\right.$ : tmomt in 1940 of the, 1 it6; In 1 s. $) !$

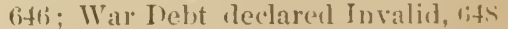
State Debt 187 I-7: Repmliated by Nogro (ioverument, 649 ; Condition of in 15i7, when the People of South Carolina recovered the (invernment of the state, (ijo): Adjustment hr Comrt uf

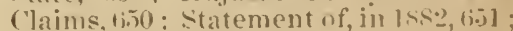
Tabular Statement of heceipts, Expen- 
ditures and Indebterlness in South (arolina, 1801-1sist, (i,i) : State and Lo(all of Country, (ion); Plate's A. B and

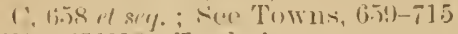

1)FliskNS: Trarle in PlRTSIR, CITCUL.TR, IN THE

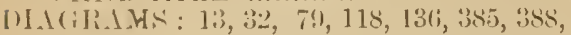
t(1). tiis.

() 1 1 II () $\mathrm{VI}$ 133

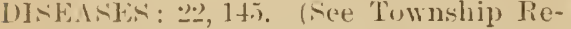
ports), 401, 407 to 420 .

[ISINTEGRATIUN UF ROCKS ; 138, 197, $2(12$.

I)I OTRCT

J)RN, (

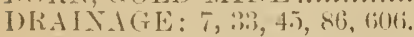

1) HOL ( $\mathrm{YHT}$ : 76 !) ; Jemarcation of areas of, by sinclinal Axis, 14.5 .

DTELLINA:

4.8

1) $\mathrm{E}$ WEST Female (illeare at ...........517

DWILLINGS' A YD FAIILIES: .398

EARTHENTWARE: Clay, 171.

EARTIIQUAKES : Felt during Drought, $1+5$.

EDGEFIELD C(): The Gneiss Rock dips vertically, 1:\%; Clay slate faces alternately N. E. and S. W. in, 1:33; frold Mines, 134: Silver. Manganese, Whetstones, Flagstones, Beryl, spinel Rubies, foum in, 137; soil tualysis, 140, 144; Lamels, Qnarries, Water-powers, 170-72; Towns and Tracling Points, 707.

FISTO ISLAND : ....................... 30,41

EIT CATION IN SOUTH CAROJINA Ilistorical sketch of 446 ; Free school System, 4.0) ; Fxpenditures in 18.50 for,

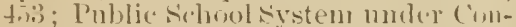
stitution of $18(88,45)$; state and Comty Oflicials, t56; school Districts and Shools by Counties in 1\$s1, 4.8 ; Grate. en Schools and Local Taxation, 4.5!) ; sthools in ('harlestom, t61-thi ; in (o)lumbia, 4hs; ('haritable, Edhcational and literary Institutions, 46!-48] ; l'rivate Sehools, 4.81-8.5; south Carolina (ollege, its t)rigin and IIistory, its Esefulness; Presidents and Ijistinmished Almmi, 4Nii-ss; Roopened as al University, 4S\&; Present Fan'ulty and ('omrses of Study, 4s'); College of ("larleston, fin); Erskine College, Clark and Erskine Seminary, 4!2?; Wollind (ollege, fin); Furman University, f!r ; Newberry ('ol'ere, f!!!; dilger Collowe, inl ; Theologinal Semimary at ('olumbia, stoz; Deaf, Jumb and lilind Institution, sut; Medial

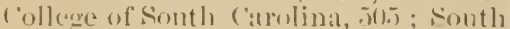
(alrolina Military Acalemy, its bril-

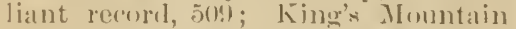
Military siloool, i12; (ireenville Military dralemy, s1:; Greenville Fimale college, 311; lme Wrest Females collere, 517: Wallhall'al Female Col- leare, Б̈18; Williamston Female Colluge, 51!) ; ('uper limestone Fomale Insti-

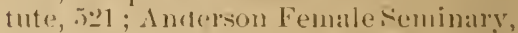

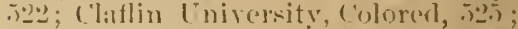
Allen liniversits for ditto, ne- Ilistory of the P'ress of the rtate, 5.2! ; Newspapers and l'erioliouls, extinct and extant, 5:oll-ist ; Comparative Il-

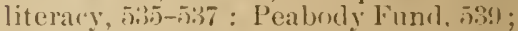
symotical Talbles referring to, j) $41-4 ! 4$.

ELEVATION OF SEA ISLANDS, $s, 1 S$; of Lewer Pine Belt, 4.), 7̈-; Hypsometrical Jiagram of Sand Hill kemion, 11S; of liver Banks, 127; of l'icrlmont Rexion, 127; of Alpine Regrion, 183; Highest Point in the state, 18.). (sees Section on Map.)

ELK 212

ELLIUTT, WM. : Fisst Long Staple Cotton Planter, 27: "Field Sports of ('alolit a," written by, 667 ; Stephen Elliott, (it.)

EOCENE FORMATION : $14,46,49,73,111$, $11 !$.

EPISCOPAI, CHURCH: Rengnized for seventy vears as the state Church, .5 .51 .

EROSION ............................. 128

ERSKIXE ( $\left.{ }^{\circ}\right)$ ILEGE.................t?

FIECLTIVE DEPARTIIENT..........433

FACTORIES: Comparative Cost of Power, 20s; Enmmenation of in South Carolina, in $188:$, by Department of Agricolture, 5s2; sec Manufactures.

FAIRFIELD CO., IN PJEDJONT RE(iION: On second line of Granite Guterop, 131 ; Building Granite, of, 131, tils: sioapstones. Whetstones, Flatestones, 137; Lord Cormwallis' opinion of, 146: Compared with Blue Grinss liegion. immiense crop of lucerme maite in, 148; see Township Revorts, 17:-3; Towns and Trading Points, $70 \%$.

FALLA () THE liVERS....... ......2(0)

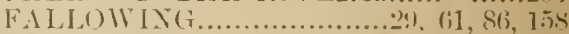
FAMILIEN A NI) JWELIINGS.......3!s FARMS: On Coast liegion, :-4.); Lower Pine Belt, jitiz; Tpper l'ine lielt, S.2-!) : Red Hill Region, 115; Sand llill Rerion, 12::; Tabular Statement of Values and Prorluctions, 152: Pienlmont Region, 15.5-6: Alpine Rexion, 1!):3 see Reports, Towsship, Cirvespondents, and Tables II., III., IV., V.

FAt I'l . .................................

F.ILX.1: of l'hosphate Works, 48: found hy Early settlers of sontl carolina, $146: 2(1)$ to 311 .

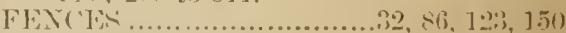

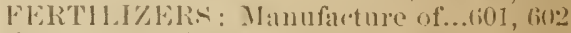

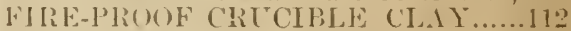
FI(i..................................? FIsIIES, 20, lis, ts so; Fish Pomils, (i10) of Funth Carolina: 350 ) Species of, 248 (1) 20.6 
FIsIlEriEs, of the World; Value of the, 243 ; of South (amolina, (it)!

FLAGSTONES

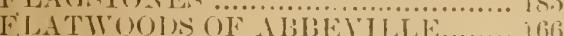

FLOTR MILIS; OF JOSEPH KERSil. $1 W^{\circ}$, in 1760,4 ; Tabular Statement of, (illt.

FLOW ()F RITERS 2112

Foli.l一i:

E( )Plis

.).

F]RESIITS ..................... $41,77,78$

FlRENCH C(OLONISTS' settlement in South Carolina, of, 3\$1, 125.

F]R().Ts: Table.

FlRUITs: of the Coast Region, "yt fift. Note; Sand IIill Region, 11+, 32.2; Best Regions for, $14 t, 1 s 0$.

G $11, \mathrm{E}, \mathrm{Y}$ 186

G.IIE: Bircls. 206

(i) IRIENS.

G F(0) in sontlı Carolima, $5,6,16$.

GEOLOCiY: Of' South Carolina Lpper and I.ower Country, 4 ; of Coant Region 14; of Lower Pine Belt, 7.5 ; of Red Ilill Region. 111; of Sand Hill Region, 119; of Pierlmont Recrion, 130; Eras of. $131 ;$; of $A$ lpine Rerion, 18.5 .

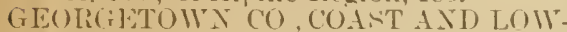
ER PINE BELT RETIOX: Quality amel Price of Lamd, 70 ; Exemption from stock Law of, H3; Towns and 'T'rading l'oints, 6st; Kiver 'Transpor' tatiom, 685.

GFIRIINS.

GIN : Cotton. Eli Whitney's. Iobler iriu. :37 Toll (iins, as ; dillerent kinds of (ii: !10; Steam and Water, 90; Lonl staple on saw Gin, 59:3-4.

UIXIIit Cotion in the Lpper Pine Belt, 90 ; in Piedmont Rerrion, 16il Alpune Region, 1!l:; as an Inpontant Industry, Ts?; Number of Gin-luouse. in foutl (arolina, .si!); Enlarod (rinmeries. jom(i.

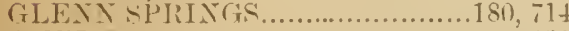

(iNEIST .............

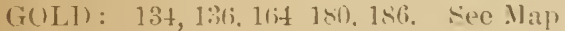

(iR.IIN, 13, 24, $56,81,115,121,150,18$ ? sce Tables II, III., IV.. V.

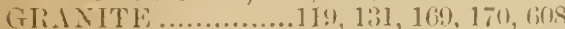

Gi.JPF VINF.

(iR.1P'HITE: 1:7, 168, 1sit. see Map.

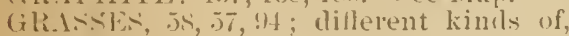
(1) :34\%.

GLEFNLIND .1:in

(iREEN SINT)....................t. it, 111

GREENVILLE (O.. IN PIEIMUNT AND

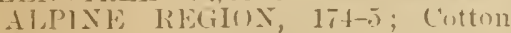
Mills of, 58*3; Towns and Trading Puints, 70s.

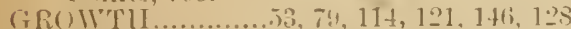

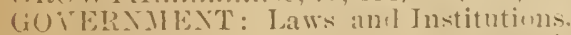
Original ('harter, f.2.); Locke's ('onsti- tution, 42., Organization wf, fott; lifferent f'mstitutioms of, $4 \pm(;-42 !) ; D_{k-}$ jartmentsof, 4:) ; sutlrace, 4:34; Taxation, Ellu(ation. Militia, fios); Statutory 1.aws, t:3, !) ; Jublic Instruction. thii: llew, of ter $4+1$.

GLLF STREAII

H.lFOOI), GOTlERAOR: Soil Alalysis, 7.; ; Rermudal Gelss. 14x.

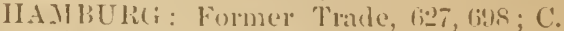
\& H. Railruarl, (i2)!

IIAMIMOXI), J. II., vieli of Fottom Land, 77 ; Tab)le of Frosts, 79: ]'. l'. : ('ost of Produc:ing Cotton, : 4 ; Soil Analy-is, $7 t$

IIAIIJUNDITE .ST

11.APTOS, WA DEE, [Thland Cotten Plantaltion, 11

IIAJPTON (O., LOWER PINE RELT, (j.), 8t, !n, 9S; Towns and Trading Points, liss.

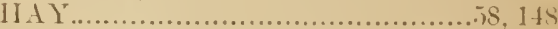

HEA1,TH, :1, :31, 7!), 114, 18.5: liesorts, it, $114,1: 3 ;$ : Mineral Springs for, 16s, 1si

IIEII A'TITE...............

HEMP..................................... 1

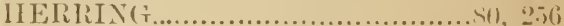

HIGHIS Ys: Colonial dets Relatiner to, 613, (i15, (i17; Materials fur, (i)

HISTORL ()F SOUTII ('AROIIX.A : C'hrouolngi(al Table, 381 ; Early, 4.2.).

HOMLAPT ${ }^{\top}$ : ('otton and Woolen, formelly used, Mnrmats Ferry, 5it.

HOMENTE D L $111^{\circ}$

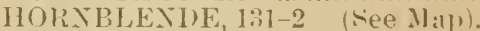

IIORSES: Aet of Legislature aqrinst inferior, $1+7$.

HORSE CIEEK..................., 11, 206

IC'E A.TD SNO

ILLITERACY IN SOLTH C'AROLINA, S:?.).

IXI)

IXIMINK: Nitions and Tribes formerly

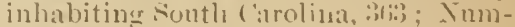
ber, :bs; Former Trade with Charlest(i) $),(i] 4$.

IXJIA Y CORA: Value of early Expnt. 10: J'arker's erop of. 11; White Flint, 2.); swamp ('rops, 77; 1 mount of 11 aste

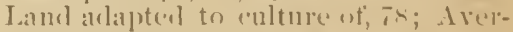
ace product in Find Ilills, 12t. see Tilbles $1 V^{*}$.and $\mathbf{r}^{\circ}$

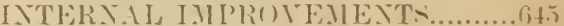

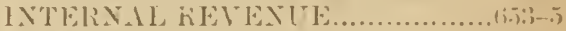

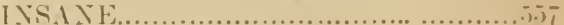

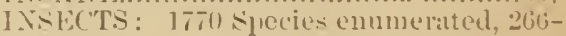
:11.

IRINII SETTI,ER:

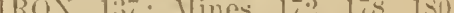
ilorks, jit; Prrites, 1:3.;

ISLAXI): Folmation of, 15; Elevation of. is

ITAR(HE.MTTE, (IR DIAMUND BEARING ROC'L, 13:3, IS.). 
I. MES' ISLA ND

.29

I. M Jifor W WED for Nut Grass.

.87

I(IIIN'S ISI A NI)..........................30

IOHNAOX, (JI A NCELIAR: Tenant kystem of, 84 ; Soil of Donolioe, 75 ; Cost of Cotton Production sti.

JUJICIAI, DEPARTIENT OF SOUTH CAROIANA.

433

K.AITIT .42

K $f(1) L I N \ldots \ldots \ldots \ldots \ldots 112,120,171,175,608$. KIIRSH I W ( ()., SA ND HILL A ND PIEDMONT REGION: Steatite found in, 11:; Porplovitic (iranite in, 131; 'Township Ieports, 12:3 Early Flour Mills, 574; Towns and Trading Points, 702.

FIVCIID: First Gin made by .11

KING MOUNTAN.: Heinht, 185 ; Military School, 512.

LABOR: Sea Islands. 29; Lower Pine Belt, 59. Upper ditto, $8 *$; Pierlmont. 15!)-164, 199, 58s.

LABOREISS: Proportion of White and Colored in Tpper Pine Belt, 83 ; (See Town-hip Reports), 5tit.

LANCASTER CO., PIEDMONT REGION, 175 ; Schools, 483; Towns and Trading Points, 710 .

LANDS: Former Prices of, 29, 57 ; Present Talue in Hampton, 6.5, !s; Colleton. Clarleston, Clajendon, 67; WilliamsJurg, 68; Marion, 69, 104; Barnwell, (99; Orangeburg, 100; Sumter, 101; Darlington, 103 ; Marlboro', 107 ; Red Hills, 115 ; Sand Hills, I23; Abbevilie, 164; Anderson, 166; Chester, 168; Elgefield, 170; Fairfield, 172; Greenville, 174; Lancaster, 175 ; Laurens, 176; Newberry, 178: Spartanburg, 179; Union, 181; Ýork. 182: General View of Values of, $150-157$.

LAURENS CO., PIEDMONT REGION: Limestone, Manganese, Graphite, Feldspar, Asbestos, Tommaline, Jieryl. Corundum, 137; Gray and Blue Granite, Gold. Copper, Lead, Quality and Price of Iands, Sugar Maples. Water Powers, 176; Towns and Trading Points, 710 .

I. FAd D foil Analyses, 121 ; Flowers and Fruits, 1202; Statistios, Stock and (rops, 123; 'Towns and 'Tradiue Points, 698.

1.IBRAR T : Charleston

479

l.IENS: Number and average amomnt in Iprer Pine Belt, 8:2; I'iedmont Region, 154; Laws concerning, 439.

I.ICNITE . ..............................165

LI.ME: Jrom Marls, Tt; Kilns, j85, 194.

1.IMEToN $1:$, 1:7. (See Map.)

L.I.MESINKS

IIXIVIATIONOF SOILE
LUCERNE: J. H. Rion's Crop of......148 LUTHERA IS: College of, 4:99, jut; First C'hureh of, 5.52 .

LUTBER ............................... 51,5

LUXATIC ASYLU II ..................... (;)

MACHINERY: Talue of Farming in Uniterl States and Sonth C'arulina. Tabie IV

IIA LARIA ............ $4,79,145,415,411 ;, 417$

MAMMALS OF SOUTH CAROIANA...?

MANGA NESE ..................1:5, 1(i.), $181 ;$ MAGNOLIA ANDGRAY MOSS: Limit of the ................................

MINNING, J. L. : Curions siliceous Rolk near resirlenre of.......................11:

MANUFACTURES: Laws to Encourace, 443; Numbers enuaged in, 56t; of Indigo; Machinery for Cleaning Pice and Ginning Cotton invented and first used in South Carolina ; Early Cotton Factories in Williamsburg and simter, Iron Works in Iork, 574; Increase since 15.50 of, 576 ; Manufacturing Industries in South Carolina in 1S5.2, 578 ; great Increase in last Decale, is1; Names and Locations of chief Cotton Vills, \&re, in South (arolina, 58:; Magnitude of Cotton Manufactures. 58t; Prorlucts per Spindle, E(., 5.5; Proximity of Cotton, 587 ; other arlvantages of South Carolina, 58s; Cotton Ginning, 589; Fertilizer Factories, (i01 ; Flour Jills, (60)3.

MANUAL LABOR ACHOOLA ......473, 47 MANURES IN COAST RE(IION, 20, :H; Phosphates, Potash Salts, (i1; (Dow Pea, Cotton Seed Meal, Ss; the Marlboru Plan, 88, 89; Taylor's Method, ibid. in Pierlmont Region, 159.

MAPs, 3 ; of Popu?ation, 38 .

MARLS ......................20; $45,46,47.7: 3$ MARION CO., UPPER AND LOWER PINE BLLT, 69.85 .87 ; S'chools of, 483; Towns and Tradine Points, (iil:;.

MARLBORO', UPPER PINE BEL'T : Maximum Product of Cotton male in, 81 ; System of Farming, 8.5; 11" I Lindoned Lands, S7; Prnduct per alcre, 8s, 107 ; Sohools of, 484 ; Towns and Trading Points in, 696 .

MARRIAGEs, 40:3-4. Divore, 442 .

MEDICAL COLLEGE OF SOUTH CARO. LINA ............ META IORPHIC ROCKS, 4,119 , l:30, et seg. See Map.

METEOROLOG : Table I..............3130 METHODISTS: First appearance in South Carolina, 553 ; Institutions of Learning, 495; Female Collegre, Columbin, $516 ;$ Allen University, 527; Sumbers, 5.j.

MICA SLATE....132, 186, 199. See Map.

MILTARY A (ADEMY, 5UR; King's Mt. 512; Greenville, 513 ; Agre, de., 3!!).

MILI'TIA..................................4t 
MILLS $.201,582$ MINES, 135. See Gold, Iron, Phospliates. MIYING ............................13t, 607

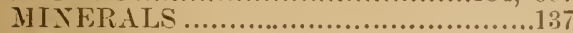
MINER.IL SPRI YGS.................132, 16 is MIOCENE

MOUNTAIXS

MULES: Tables $\mathrm{IT}$. and $\mathrm{Y}$ ..t, 73 360

NATIGA'TION. Extent of Inland, 6 ; Vrater Courses suited to, 7.2; Navigable Rivers, 129 ; Bays, Sounds, Harbor's, Rivers, (601, 63.).

NEGROES, 31 ; First Imported, 3ti9; by whom and number of, 1714-186.5, 371; Free Negroes, 372; Intermixture of Races, 373; Distribution according to Elevation and Temperature, 379 ; Percentage in different Regions, 379 ; Character of the, 374; First Almission to Christian Churcll, 5.53; Religions Character of, 55t; Trades, 1860 , of, 568 ; Insame, 574; Criminals, 572. See Township Reports for Negro Labor, Wanes, dic., de.

NEWBERRY CO., PIEDMONT : Quality and Price of Land, ('rops, Growth, Grasses, Granite, Gold, Water-powers, $178-79$; Bank of, 154; College, 499; schonls, tis; Towns and Trading Points, 710

NUTGRASS; ......................... 148

OATS :

OAKS: $50 ; 30$ Varieties of, 340.

OCCUPATIONS OF THE PEOPLE OF SOLIH CAROLINA, IN 1880: Farmers, 93.550; Farm Laborers, 1!S,147 ; Fatcory Operatives, 2, 31t; Clergyuen, 1. 16. ; Physicians, 919 ; Lawvers, 614 Tearhers, 2, 170, since 1870 the number of those engaged in Agrienlture has decreased $t$ per cent. ; the number of Law yers has decreaserl 46 pel cent, Clerirmen have increased 110 per cent.; $564-6.5$.

OCONEE'C()., ALPINE REGION : 'Tourmaline, Lead, Gold, silver, Copper. Graphite, Mlica. Corundum, 137, 186 ; Soils, Water Falls, Winds, Springs, Climate, 18, (College at Walhalla, .xil Tomnship Reports, 378 ; see Title Alpine Region; Towns and Trading Stations, (6)

OIL: Of Cotton Seed and Meal ; the Manufacture and Value of, 597 .

OLI) FIELIS :

158

OLIVES

. .24

ORATGES: A Colonial Export, 9, 24, 317.

OR.ATGEBLRG CO., TPPER PINE BELT: Quality and Price of Lands, Growth, Crups, Labor System, Abundant Supply of Mall (Iroin Ore), WaterPnwers, 110: College, 525; Cotton Mill, 58: ; Towns and Trading Stations 693.
ORCHARDS $, \ldots \ldots \ldots . .80,122,144,179,180$

ORES AND MINERAIA ................. 1:;

OXEN ..........................................

PACOLET: A Remarkable Frnit Region in Fairforest and l'acolet 'Townslipes, Spartanburg Co. lying in the Thermal Belt, not Liable to Frost. 14,180 .

PALA EOZOIC ROCKS OF SOUTH CAROLITI

PALMETTO: 18 ; Varieties of, 34 .

PARlSGREEN : For Cotton Caterpillat, 37 PAUPERS .......................................

PEACH................................ 1 22, 144

PEA NCTS ................................. $1: 1$

PEA, As a Fertilizer......................til

PEE DEE: Herring in the ,................

PIEDMONT REGION : Water Comrses of the, 129 ; Geological Furmation of the, 130-136; Ores and Minerils, 137 ; Soils, 139-143; Climate, 1t4; Growtl and Productions, 146 ; Sratistics of Farms, Crops. Stock, 149 ; Systems of labor and Farmino in the, 15:3-160; See Counties of Alberille, Anderson. Chester, Edgefield, Frirfield, Greenville, Lancaster, Laurens, Newberry, Spartanbury, York.

PICKENS CO., ALPINE REGION: Adbetos, Copper, Feldspar, Iron, Mica, Iiuse stone, spinel Rubies. Steatite, 137,186 ; Towns and Trading Stations, 716 .

PINNACLE, IIOUTAIN: 'The Highest Point of Sonth Carolina, 1s.),

PINCKNEY, GEX. C. 'C.: Water Culture for Pice introduced $\mathrm{b} v, ?$

PINES: Short and Lom Leaf, 114, 121 ; 1s Varieties of in sonth Carolina, : if PINE BELT, THE LOWER: Phrsical and Geoloxical Features of, $\dot{t}+-4 \bar{t}$. Phospliate Rock, ib. ; Soils, J.2; Growth, 53 ; Climate, 54; Area of, 55; Rice Culture, Dry and Wet-Cieneral statisties, 56 ; Area of Fertile swamp Lands in, 57 ; systems of Labor and Farming in, 59. Housing Crops in, (ii). See Charleston, Clarenilon, Colleton, Georgetoun, Hampton, Horry, Marion, IVilliomeshurg.

PINE BELT, 'TIE UPPER: Geological and Physical Features of, 71,73 ; 1 ater $^{\circ}$ Conrses, 72 ; Soil Analyes of, $7 t-1 ;$; Climate, Growth, 79 ; Prollnctions, Statistics of Farms, (irain, Cottom, Live Stock, 81 ; Nistems of Farminer, Contracts, Wages, Jiens, $\mathrm{K}^{\circ}-1 ;$; I'lanting, Honsing and shipping ( $r o j$ s in, 50. Sce Barmell, Durlington, Marion, Marlboro, Orangetming sumter.

PHOSPHATE ROCK: Theories concerning the Formation of, 4 ! ; the Location and Extent of the Formation-the Companies now engagcd in minimy the, $47-52$.

PLANTS: Native and Naturalized, of Soutli Carolina, $31:-3.5 \%$. 
I'LANTIXY AYD CLITIVATION: see Cottous.

PLEJUCEN ANT POST-I'LEIOCFNE FOlR.M.ATIONS. 1t. 20,

J'UUIYIXI; : 3i:, $31,(30,80$; Steam Plow for Rice, 5i

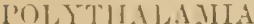

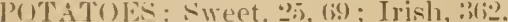

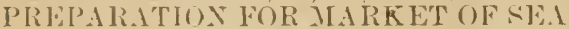
ISLANI) (OTTON, 37 ; Uplands, 63.

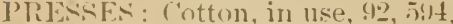

l'IRESTTERIA N- : Institutions of learning fonmuled by ; Erskine College, 492; Aderer C'ollege, 501; Columbia Theological Scminary, 50 ; Due West Female Collece, 517; Brainard, Fairfield Normal Institute. 5) s; Early ('hurch of the .5.) ; Relative Standing in $18.50-$ '(30-'T0: uf the Chureh of the, 55.).

PRES OF SOUTH CAROLINA: Papers, Iieligious, Political ; Periodicals, Lxtinct and Extant; Printing, Publishince and Bindine Establishments, 5:yint.

PROIERTY : Laws of......................

I'UPLLATION: Indians, 364; Negroes, 36. 371: Free Jenroes, 372; Inerease of the Black, it ; Distribution of the, 37.); Perrentage of Colored, 379; Chronological and ('ensus Tables from 17!)0-1sho of the different Pursuits of the, : :!1; as to Sexes and Ages, C'mparative Tables, 3!)-(i; Lwellings and Families, 3!) ; ('omparative Mortality in south Carolina to that of other States nuon the augregate and classifiel, $401-408$; Diseases of the, 412 .

QCAliRIE: Of Kaolin, 120: of cranite, $1(i 4,172,180,19 \%, 608$; of Building Rock, 16 t.

QUARTZ

.138

R.AIIR()ADS 629,634

IidIX FALl: In Piedmont, 14t, 1si; in the State, Average, 199.

R.ATTJESTIKES: Four varieties of, 23.5 IiECLA IUED LA JIS ............. 78 REGIONSUFSOUTH CAROLIXA, seven: I. Corlst, 1t; II. Juwer l'ine belt, $f t$; I11. ['pres' Pine Belt, $71 ; I^{\top}$. Red Hiil, I10; Y'. Sand Hill, 11T; T'I. Pierlmont, 126; VII Npine, 183.

RED JIILL REGION: The trend of this narow belt, which embraces the "Miilue "and the "IIigl Hills of Santee "below the sand Hills, whose protrusion oreasionally interrmits it, follows that of the other recrions, 110) fioslogical Features of the, 111 ; soils, 112: ('limate, (irowtl, 11t; and Statistis's of the, 115; Wedrefield, Ilimh I'ricell Lamis of, 116.

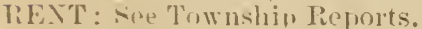

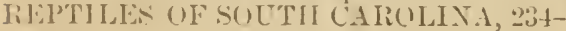
240 .
RION. J. II., Great Crop of Lucerne marle by, $1+4$.

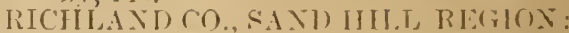
Lies on the dividing line between the rerent and very ancient formations: Growth, Produrtions, Climate and Statistjos of. 121-1i ; see Colmmlia, (j)s ; and other Trowns and Tradling stabtions, $69 y-701$

RICE: Early Export of, 9; Water-Culture introdnced in 17st; Mills for C'leaning Rice invented by Lucas, it, ; Exports

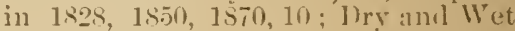
Culture in Lower I'ine Belit. ofi; Area Adanterl to Water-('ulture. Process of Cultivation, Price of Lamel and Product of, $5 i$; Protective Tariff on, s.s.

RIVERS ATD CREFLS OF SOLTH CAROLINA, affording Inland Coast Navigation, 4-6; Navigable Streams in the Jower Pine Beit, 4.5 ; in the Find Hill Region, 115; svnoptical Table of all the Rivers and Creeks in the state, 12 !); witl the Irater.Powers aflorted by each of them, 204.

ROTATION OF CROPS.....(i1, 8T, 158, 191

SALT MLARSHES

SAGO PAL.II ................................11t

SAND HILL REGION: See diken, chesterfield, Kersham, Lraington, Richland, Elevation of the, 11s: Geologicul Features, 119; Kaolin, 120: Suil Analyses, Corn, Watermelons, 1:1 : Peach Crehards. 12.2; Salubrity of Climate, 12.); Statisties of Farming, 12:3.

SAITEE MARLA ........................

SANTEES AND MAINS ................?

SCHOOLS: Grarled. 45.) : in Charleston, 461 ; Colmubia, 468 ; Private, 481 ; Colored, 527: Mannal Labor, $47 \pm-7$.

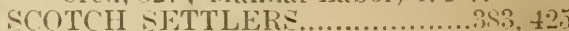

SEA ISLANDS: Formation of, 15; Character of, $18,19$.

SFAL: In Cluarleston Harbor..............211

SECESIOD ORDINANCE in $1500 . . . .479$

sECTIONS: Geological, see IIap.

SIRTA NTE Statistice in relation to ...44i,

SHEEP: Tables IV.and T.................. SHIPPJ AG ANT) SALE OF COTTUN, 6:3,

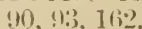

SHIP CHA NNELS: How lvine............17 SHAD, STLRGEON ALI) "ROCK FISH 80,1310 .

SHRIYIPS ...........................29?; 609

SIIALE SISTEM IN L(JWER PISE BELT. 5!. (6) ; [puer dittu. \$4; Picelmont Region, 156.

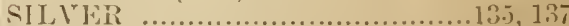

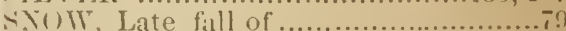

- UCIFTIEA, Cinaritable, Eluational and Literary, $4(i 9-4 \mathrm{t}(1)$.

SOINDINGS: Depth of...................... SOIL- Analysis of Promlurine longe sta-

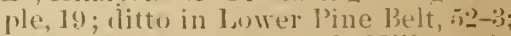
River sw:tmul, 76 ; Reil IJills, 113 
Sand Hills, 120 ; Pirdmont, 139; Hornblenile. 140 : ('lay slate, $1+1$; 'T'an), $1+$ ". SOLTH ('ARULIXA: Urigin of the name, $4 \cdot 21$.

SPIIELA: : 28.5 speries of, 242.

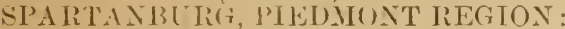
Ores and Jlinerals, $1: 37,180$; Towns and Traline l'uints, $71: 2$.

SPRINGs, Ijoiling. 11s; Temperature of ('ertain, 12:3; Jineral, 16s, 1so.

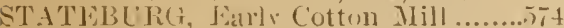
s'TRIKL................................ 195

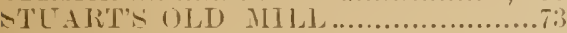

S'TACKHOL:SE, E. 'I.: Cost of Cotton (ro), 96.

STE.1MBOATs: Charges for Transportation of citton, 92.

S'TE.ITITF, UR SU.ISTONE, 119, 137, $167,174,156$.

S'TOCK LAII: Comnties Exempted from the, 4 ti:

SToC'l, Live, on Cuast, 2t; Lower J'ine Be]t, 万.); [pres ditto, s?; Real Hill, 111 ; simd liisls, 1:2t; Piednumt, 150; Alpine, 190. See Tables II., III., IV., I" STORIL

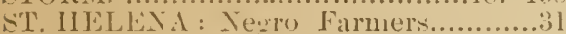
STR.TTA: Order of Superpusition in South Carolina, $t$.

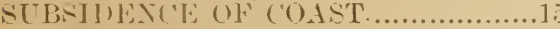

STEMEIRCit:TCE

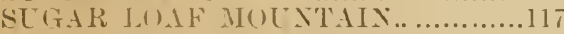

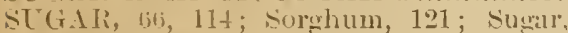
Miple, $17 t$.

SUMTEI: (U., TPPER PINE BELT: Flevation of: 71: Miotene Marls, 7:. see lownship liejorts, 102: 'I owns and 'i'rubliner l'oints, (iet.

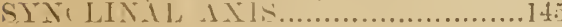

SYNAfOCiLE: The first in south carolina. 5.'.

SIVIYE: Fee Tables IV. and T.

TABLES, between First and Second Part. TALU sLATL ............................... TiRlFF: (On Rjee, 58 ; on Manufactures 5 sis.

TASK IT HOEING

T.LATIO)

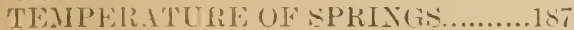

THOגIP() of Evlncatton; /etal and ability of, 4.56 ; Urganization of state Nomal silnool by, 4:-).

TORAC ( ( $)$ sit)

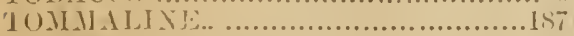
TUWNSIII liEIURTS, 65 to 6 ; ys to $10 ! 1 ; 16+$ to 1 14.2.

Toll is: Table of...... biil

TRAT'Ro('k $.1: 34$

TRA NSIOPRATION: History of in Sonth Carolinal, (i11-(j+0); Cuast Region, Inland Water Communication, 611 ; Is- dian Boats and Early Exports, 612 ; Imlian Trable of C'larleston, 1707, extemeled 1u(u) Miles Inlaud, (ilt; Jarly Road and Ferry A(ts, (il.); Two inines of Traflic till 17\%5; Epler Comntry Trates with Viruminial and the Low Country through Clualestou, Later Fuarl and Ferry dets to connert Twor Distinct leoples of sonth (anolina, 1517-21 ; (anal system, 6:;-6; steallboat Silvigation, (i2); Charleston anel Hamburar liailroad, (ies), I'ublic syirit and Enterprise of Charleston, ib.: 1)evelopment of Railroads results in renewing old divergenco of Tracle liontes, (0:3):34; Cost of 11 agon, steamboat and Railway Tramsportation, (jis.

[NION (O., PIETAION'T REGION : Thim Jine of Granite Outerop and second Line of 'Trat, Rocks, giviner lise to the Ileadow Lands, 1:it; (1)es, 137 ; Itarolumite, 1:3: see Twwmship lieports, 181 ; Soloouls, 45.) ; Towns and 'Trading Points, i1t.

[NIVERITIEs: The Sonth Carolina, tis ; Furman, 4!7 ; Clalllin, 52.); Allen, $5 \cdot 27$.

LP-CUENTRY AND LOH COLNTRY : Distinction of ................... $124,38 \mathrm{~S}$

VEriETABLE REMIAY.': Fossil, .....112 IELTEBRATES OF SU['T]I (:AR()LI-

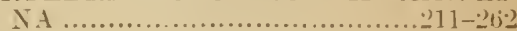

TINE VITAL STITISTIC

WAGES.....................? 65, $83,98,764$ IVAG(ON TRA TSI'OR'IATION (') IIPAREI IVITH STEA I..................tis

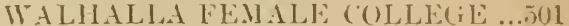
WATER CLLTERE O) ISTC E........... 万o W ATERMELONS ....................... 1

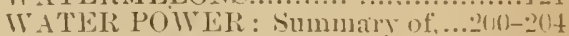
WATER SHEDS: of the liver sistems of south Carolina, 12?!

WA RS UF THE REVULCTION: () Wexico and secession; Tromps fumished by South Carolina cluring the, :i:s.

WILL- : $19,73,114$; Irtesiall, 1itt.

IIEIAH AND SIISS SETWLELS IN SOLTH CAROLIXA; :36.

IVH. LEs...........................21:3, 610

II llE.AT: $3\left(0^{2}\right.$; Mills for Grincling, (6)3.

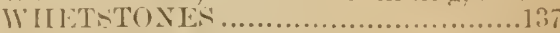

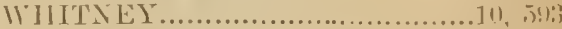

WILLI.MSBUR(T (') L T'T), I.1)WER PINE BELT: Farms, s! ; Abandoned Lanals. 60. Exempted from stork Law, t4ii; First Cotton Fatetury of the state Establisherl in. $5 \pi+$ Towns and Trading Points, (ivo. See Tuwnship hejorts, (is and 69 . 
INDEX.

WIXDS ..................4,17,144, 187, 202 YORK COUNTY, PIEDMONT REGION; WOFFORD COLLEGE ..................495 Black Jack Lands, 134, Ores and MlinWOODWARD, T. W.: Granite Quarry...60S erals, 137; Large trees, 147. See

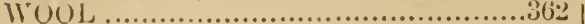
Township Reports, 182; Towns and Trading Points, 714 .

YAZOO FRESHET

5, 46 ZIRCONS

IELLOW FEVER 


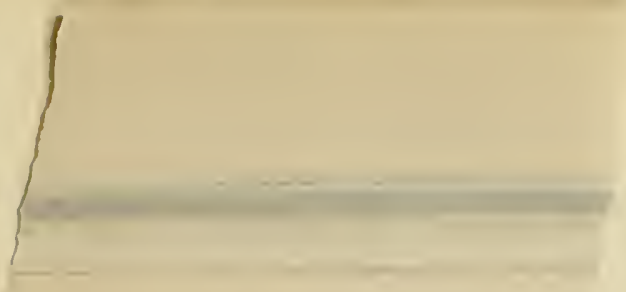

\section{다구의}

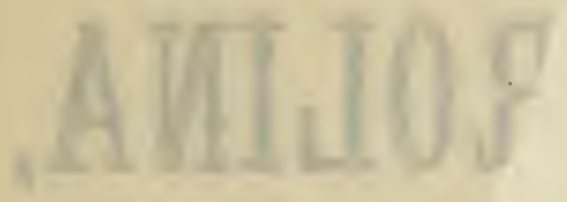

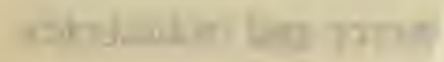

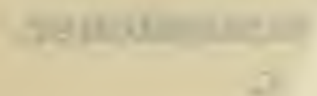

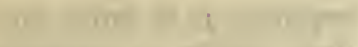

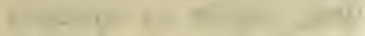

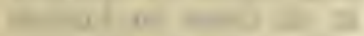

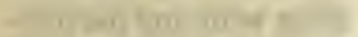

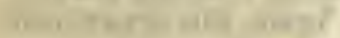

$$
\begin{aligned}
& +2+2+2
\end{aligned}
$$

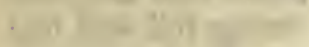

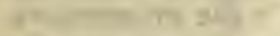

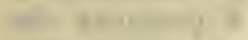

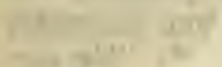

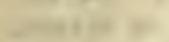

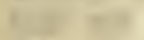

$$
\begin{aligned}
& \pi \\
& \sqrt{7} \\
& +
\end{aligned}
$$




\section{MAP}

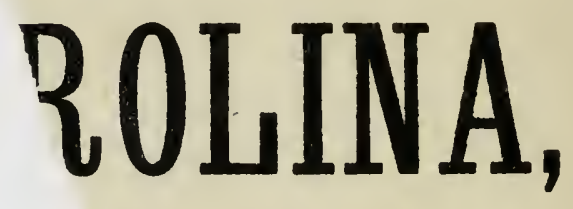

merce and Industries

\section{mmissioner,}

c.

inquiries as to lands and ding settler or investor at all times to furnish aling with any particuIgain, this department should visit the State owing full well that i the prospectors. if products the son, Secretary 't: "No secir diversifor that in this

r the d a ial I 



\section{UNIVERSITY OF CALIFORNIA LIBRARY \\ Los Angeles}

This book is DUE on the last date stamped below.

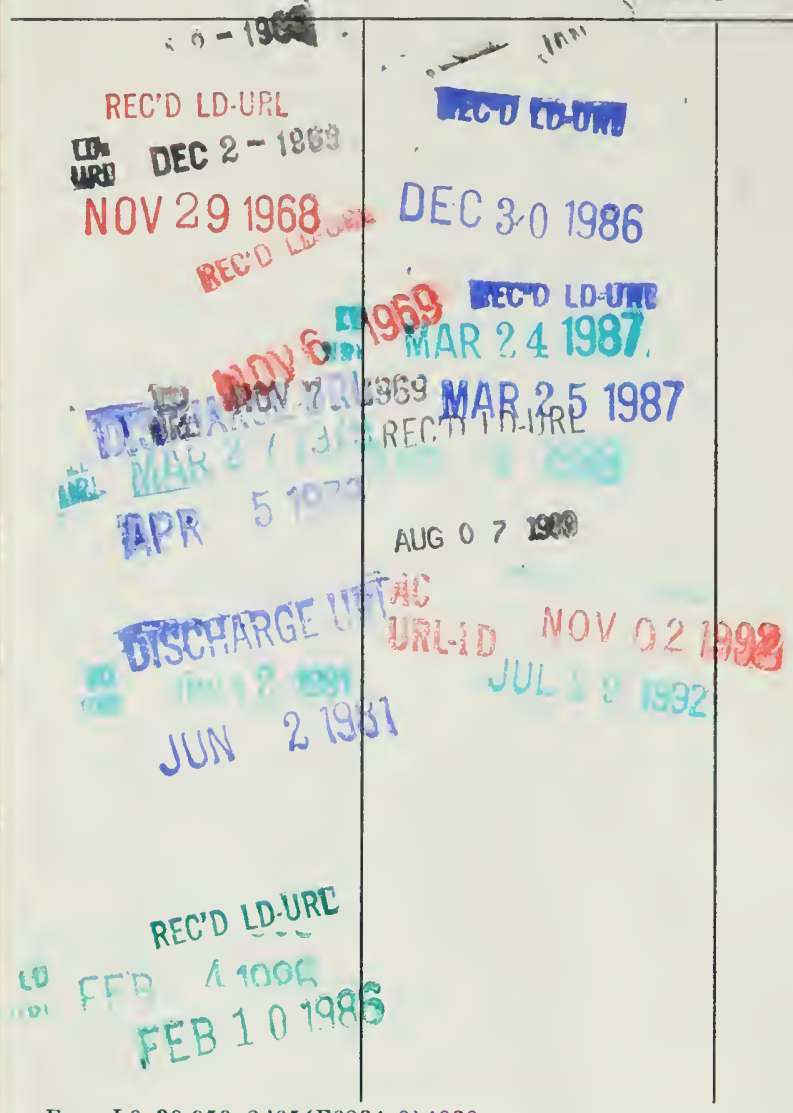

Form L9-39,050-8,'65 (F6234s8) 4939 


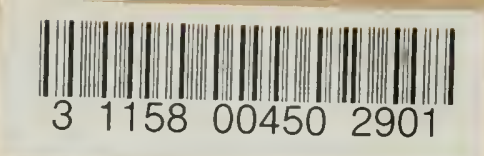

quar 
2.

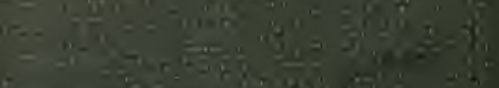

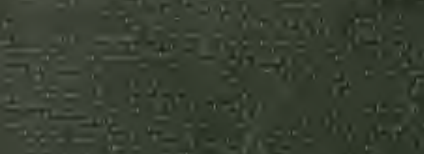

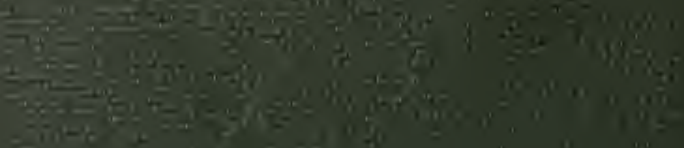

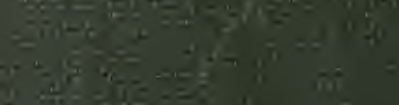

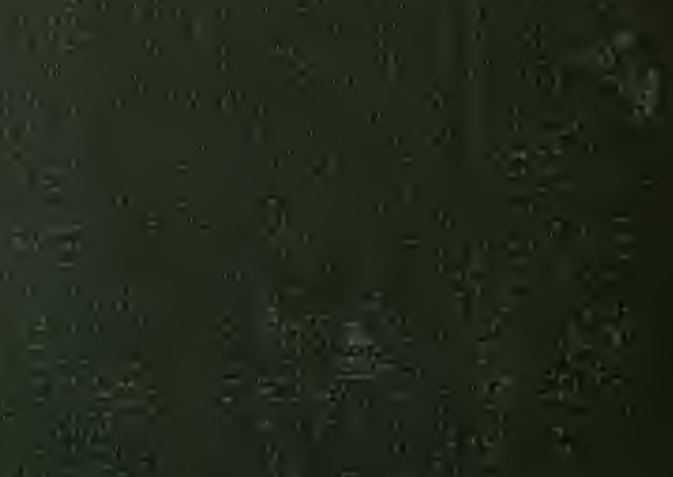
-

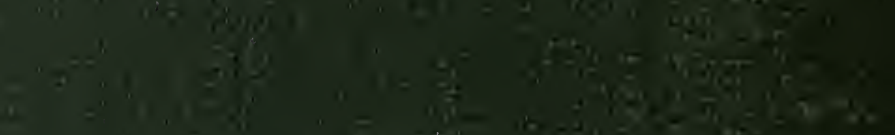

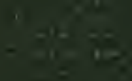

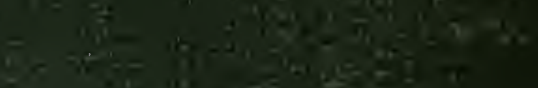

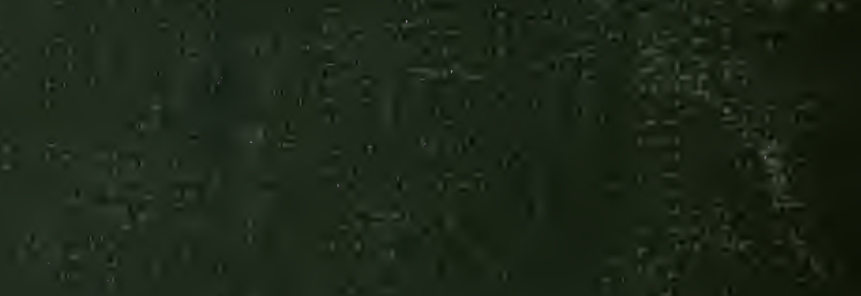

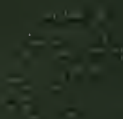

$$
\begin{aligned}
& 3
\end{aligned}
$$

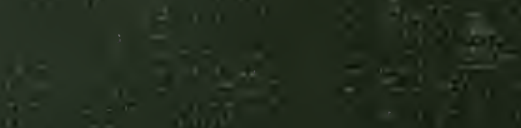

